\title{
The ART \& PRACTICE of TYPOGRAPHY $B_{y}$ EDMUND G. GRESS
}




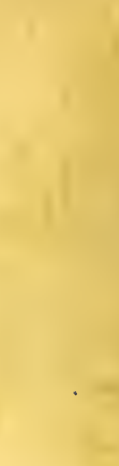



The ART \& PRACTICE of TYPOGRAPHY 


\section{IN GENERAL CONGRESS ASSEM BLED.}

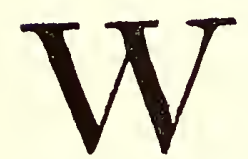

II $\mathrm{N}$ in the Courfe of human Events, It becomes neccfiury for onc People to difiolve the Political Bands wlich have connected them with another, and to affume among the Powers of the Eurth, the. Scparate and equal Station to which the Laws of Nature. and of Nature's God entitle them, a decent Refpect to the Opinions of Maikind requircs that they llould declare the caufes which impel them to tle Suparation.

We ltold thefe Truths to be felf-evijent, that all Mcn are creatcd equal, that they arc endowed by their Creator with certain unalienable Rights, that among thefe are Life, Libcrty, and the Purfuit of Happrnefs--'That to fecure thefe Rights, Governments are infitituted among Men, deriving their juft l'owers from the Confent of the Geverned, that whehcver any liorm of Government becomes deftructive of thefe Ends, it is the, Right of the People to alter or to abolin it, and to infitute new. Government, laying its Foundation on fuch Principles, and organizing its. Powers in füch Form, as to them Giall fecm moft likely to effect their Safety and Happinefs. Prudence, indeed, 'will dictate that Governments long ef. t.bilined hould not be clanged for light and tranfient Cedufes; and accordingly all Expericnce hath mewn, thst Mnnkind are more difpofed to fuffer, whilo Fivils ar fuffertble, than to right theinfelves by abolikhing the Forms to which they are accuftomed. But when 2 long Train of Abufes and Ufurpations, purfuFils are fufferible, than the right evilices a Defign to reduce them under abfolute Defpotifin, it is their Right, it is their Duty, to throw off fuch Government, jig invariably the fame Ohjed, their future Security. Such has been the patient Sulferance of thefe Colonies; and fuch is now the Necellity which conftrains shem to alter their former Syltems of Government. The Hiftory of the prefent King of Grcat-Britain is a Hiftory of repeated lnjuries and Ufurpations, all shem to alter their former Sytablinment of an ablolute Tyranny over thefe States. To prove this, lct Facts be fubmitted to a candid World.

having in direct Object the Eitablifhment of an ablolute Tyranny over thefe States. To prove this,

He has refufed his Alient to Laws, the moft wholefome and neceffary for the public Good. He has forbiden his Governorterly neglected to attend to them.

HE has refufed to pafs other Laws for the Accoinmodation of large Difriets of Pcople, unlefs thofe People would relinquißs tha Right of Reprefentation in the Lecillature, a Kiglit ineflimable to them, and formidable to Tyrants only.

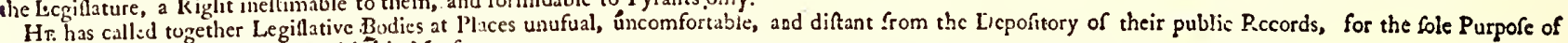
furisuin them into Compliance with his. Meafures.

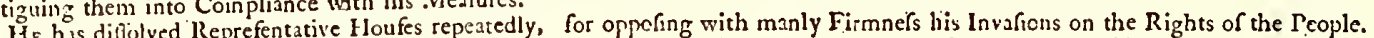

He has dillolved Reprefentative Hloufes repeatedly, for ofpening with manly Firmners his Invafions on the Rights of the People.
Hr. has refufed for a long Time, after fuch Diffolutions, to caufe others to be elected; whercby the Legiflative Powers, incapable of Andihilation, have returned to the People at large for their exercife, the State remaining in the mean time cxpofed to all the Dangers of Invafion from without, and Convnlifons withis.

$\mathrm{H}_{6}$, has endeavoured to prevent the Population of thefe States; for that Purpofe obftrueting the Latis for Naturalization of Foreiguers; refufing to pare others to encourage the: Migrations hither, and raifing the Conditions of new Approprations of Lands.

to encomrage the: $\mathrm{Migrations}$ hither, and raftice, by refufing his Afent to Laws for cftablifhing Judicialy Powers.

He has obi? ructed the Adminitration of Will alone, for the Tenure of their Offices, and the Amount and Payment of their Salaries.

II has made ered a Mulitude of new Offices, and lent hither Swarms of Othcers to harrafs our People, and eat out their Subftance.

$11 \mathrm{c}$ has erected a Mulitude of new Of Peace, Standing Armies, without the confent of our Legillatures.

Ile has kept anong us, in Times of Peace, Standing Armies, without the confent of

He has affected to render the Military independent of and fupcrior to the Civil Power. vietended Legiflation:

Fon quartering large Bodics of Armed Troops among us :

Fux prorectiug them, by a mock Trial, fror. Punihment for any Murders which they mould connit on the luthabitants of thefe States :

For cutting of un Trade with all Parts of the World

For cutting off uur Trade with all Parts of the

FOR depriving us, in many Cafes, of the Bencfits of Trial by Jury:

For depriving us, in many Cafes, of the Benchits of Trial by Jury:

For tranfporting us bcyond Scas to be tried for pretcrded Offences:

Fos abolithing the frce Syitem of Englith Laws in a ncighbouring rovince, eftablifhing therein an arbitrary :

For taking away our Chartcrs, abolifining uur molt valuable Laws, and altcring fundatnent.llly the Forins of our Governments:

FOR fufpending our own Legifatures, and declaring themfelves inverted with l'ower to lcgillate for us in all Cales what foever.

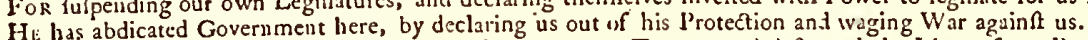

Hi: has abdicated Government here, by declating us out our Tuwns, and deftroyed the Lives of our l'ople.

II has plundered our Seas, ravaged our Coats, of forcion Mercenaries to complcat the Works of De.tll, Defolation, and Tyranny, already begun with cir$\mathrm{H}_{\mathrm{E}}$ is; at this Time, tranforting large Armies of forction

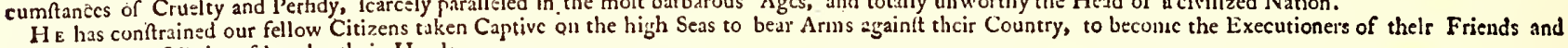
Diet!men, or to fall themfelves by their Hands.

It $x$ h.s cxcited domeftic Infurrections amongt us, and has endenvourcd to bring on the lubabitanis of our Fronticrs, the mercilers Indian Savages, whofe hnown Rulc of Warfare, is an undiftinguifhed Deftruction, of all Ages, Sexes and Conditions.

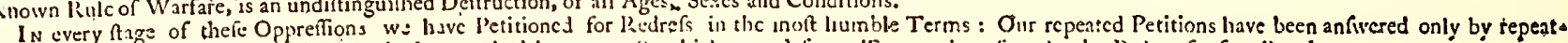

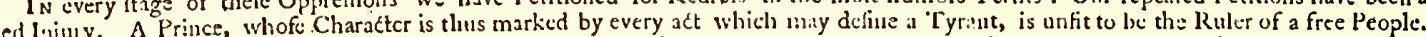

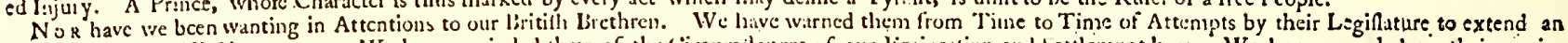

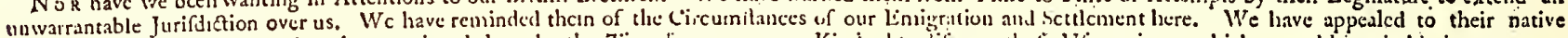

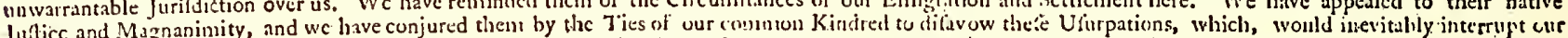
Juflice and Magnanimity, and we have conjured them by the They too have been deaf to the Voice of Juftice and of Con1:ntyuinity. We mult, thereforc, acquiclec in the Neceflity, whicis denounces our Separition, and hold theun, as we bold the reft of Mankind, Encunies i:ı War. in f'usce, Fricuds.

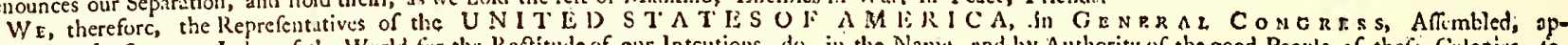
pealing to the Suprcme Judge of tixe World for the Rectitude of our lntcutions, do, in the Nams, and by Authority of the good People of thefe Colonies, foe

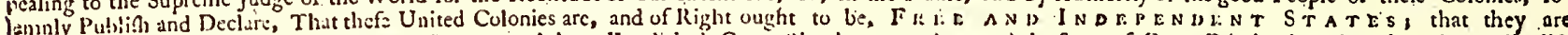
- biolved from all Allegiarce to the Brition Crown, and that all prolitical Cunncition betiveen them and the State of Great-Britain, is and ought to be totally dif-

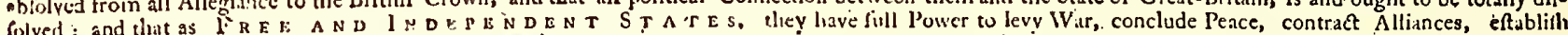

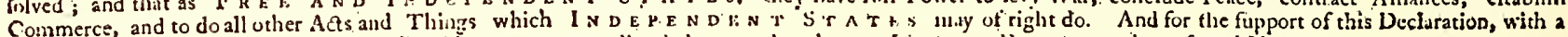
firm Relinnese on the Pratection of divior l'rovidence, we inutually pledire to each other our Lives, cour liurtusies, and uur facred Honor.

\section{Signell by ORDER and in BEUALr of thig CONGRESS,}

\section{JOHN H A NCOCK, PRESIDENT.}

A TTEST.

CHARLIIS THOMSON, SECRETARY.

$$
\text { PHILADELPUAA: PRTETED EE JOHN DENLAP. }
$$

\section{THE FIRST PRINTED DECLARATION}

Fac-simile in reduced size (original type form about twelve by seventeen inches) of the Declaration of Independence officially printed about July 5, 1776. It was this setting of the Declaration that was read before Washington's army. Reproduced direet from the original in the Congressional minute book of July 4, 1776 


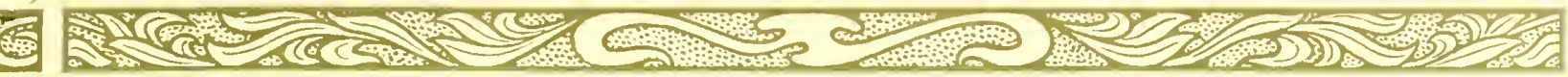

The ART \& PRACTICE of
TYPOGRAPHY

\section{A Manual}

of American Printing

INCLUDING A BRIEF HISTORY UP TO THE TWENTIETH CENTURY, WITH REPRODUCTIONS OF THE WORK OF EARLY MASTERS OF THE CRAFT, AND A PRACTICAL DISCUSSION AND AN EXTENSIVE DEMONSTRATION OF THE MODERN USE OF TYPE-FACES AND METHODS OF ARRANGEMENT

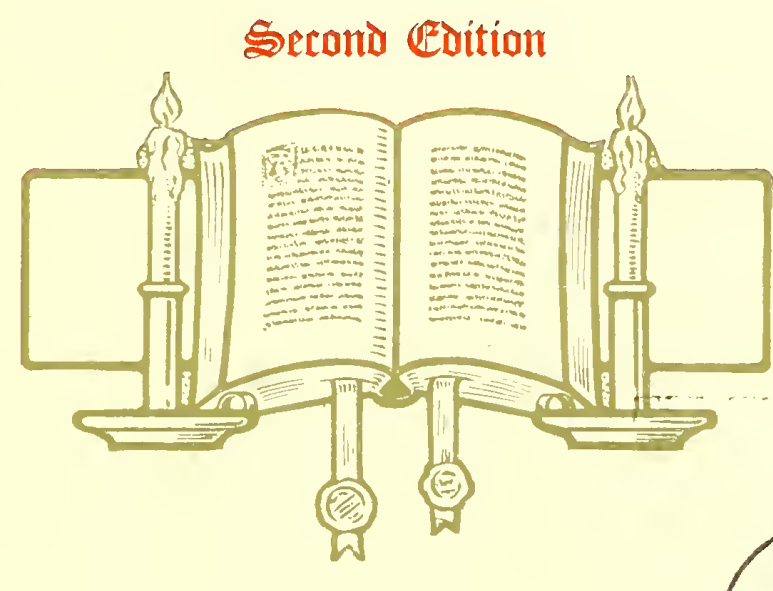

By

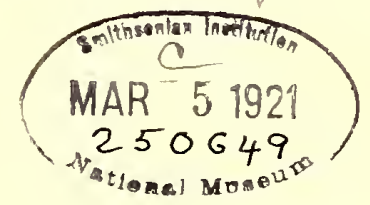

EDMUND G. GRESS

EDITOR THE AMERICAN PRINTER

AUTHOR THE AMERICAN HANDBOOK OF PRINTING

NEW YORK $\cdot$ OSWALD PUBLISHING COMPANY 1917 
Copyright, 1917, by the Oswald Publishing Company 


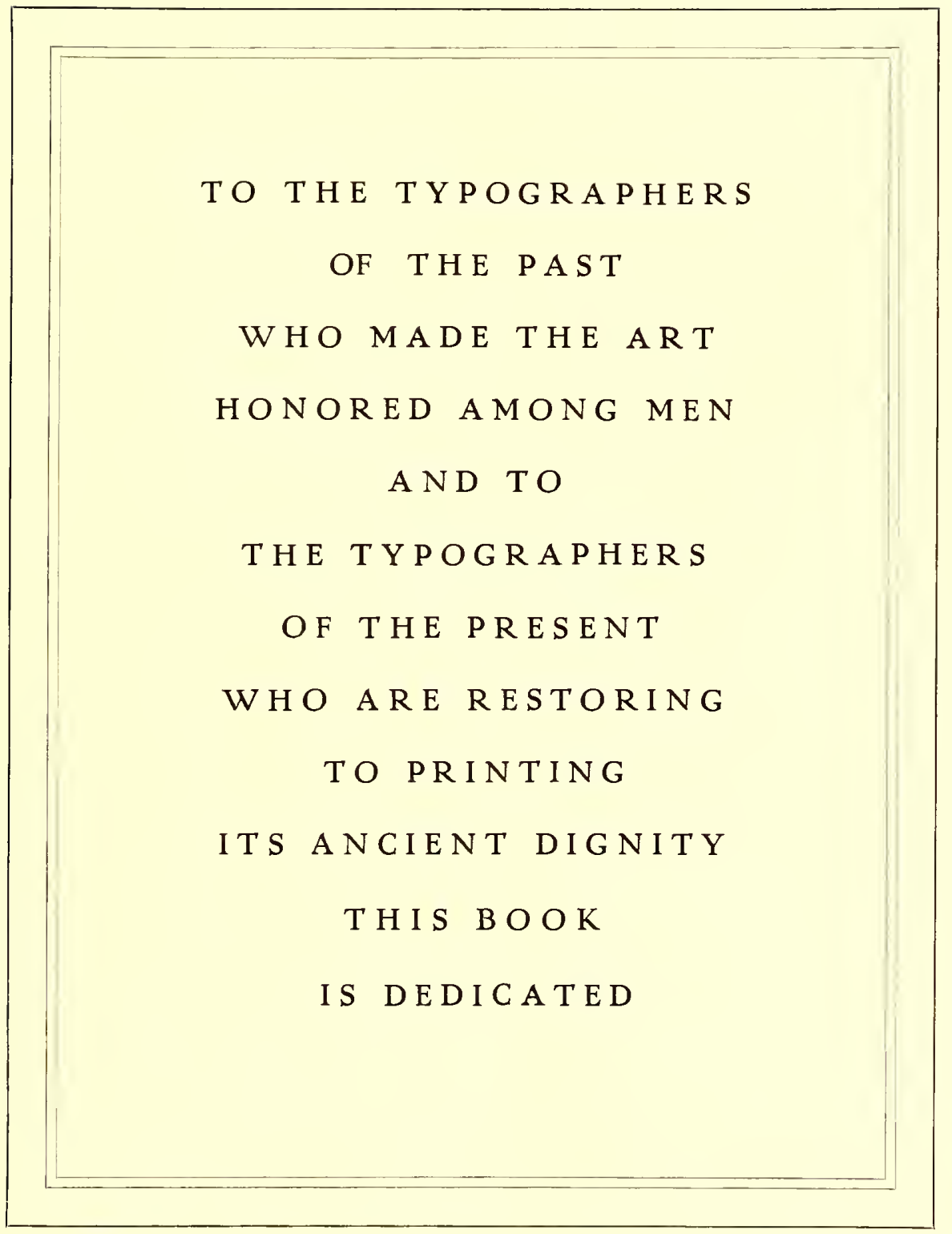




\section{TABLE OF CONTENTS}

Author's Preface ... . . . . . . . . . . . . . . . . . . . . vii

Synopsis of Contents . . . . . . . . . . . . . . . . . . . . ix ix

List of Reproductions . . . . . . . . . . . . . . . . . . . . xvi

List of Designers . . . . . . . . . . . . . . . . . . . . . $\mathrm{xx}$

WHEN BOOKS WERE WRITTEN . . . . . . . . . . . . 1

THE ORIGIN OF TYPOGRAPHY . . . . . . . . . . . . . . 7

THE SPREAD OF TYPOGRAPHY . . . . . . . . . . . . . . . 13

TYPOGRAPHY IN COLONIAL DAYS . . . . . . . . . . . . . 19

TYPOGRAPHY IN THE 19ti CENTURY . . . . . . . . . . . . . 27

THE "LAYOUT" MAN . . . . . . . . . . . . . . . . . . . 35

HARMONY AND APPROPRIATENESS . . . . . . . . . . . . . 41

TONE AND CONTRAST . . . . . . . . . . . . . . . . . . . 47

PROPORTION, BALANCE AND SPACING . . . . . . . . . . . . 53

ORNAMENTATION . . . . . . . . . . . . . . . . . . . . . 59

THE TYPOGRAPHY OF BOOKS . . . . . . . . . . . . . . . 67

BOOKLETS, PAMPHLETS, BROCHURES, LEAFLE'S . . . . . . . . 75

CATAlogs . . . . . . . . . . . . . . . . . . . . . . 83

PROGRAMS . . . . . . . . . . . . . . . . . . . . . . . 91

ANNOUNCEMENTS . . . . . . . . . . . . . . . . . . . . 99

TICKETS . . . . . . . . . . . . . . . . . . . . . . . . 107

LETTERHEADS AND ENVELOPS . . . . . . . . . . . . . . . 111

BILLHEADS AND STATEMENTS . . . . . . . . . . . . . . . 119

PACKAGE LABELS . . . . . . . . . . . . . . . . . . 123

BUSINESS CARDS . . . . . . . . . . . . . . . . . . . . . 127

THE BLOTTER . . . . . . . . . . . . . . . . . . . . . . 131

POSTERS, CAR CARDS, WINDOW CARDS . . . . . . . . . . 135

ADVERTISEMENTS . . . . . . . . . . . . . . . . . . . . 139

NEWSPAPERS . . . . . . . . . . . . . . . . . . . . . . 147

PERIODICALS . . . . . . . . . . . . . . . . . . . . 151

HOUSE-ORGANS . . . . . . . . . . . . . . . . . . . . . 161

TYPE-FACES . . . . . . . . . . . . . . . . . . . . . . 169

IMPRINTS . . . . . . . . . . . . . . . . . . . . . . . 195

APPENDIX - GREETING CARDS 



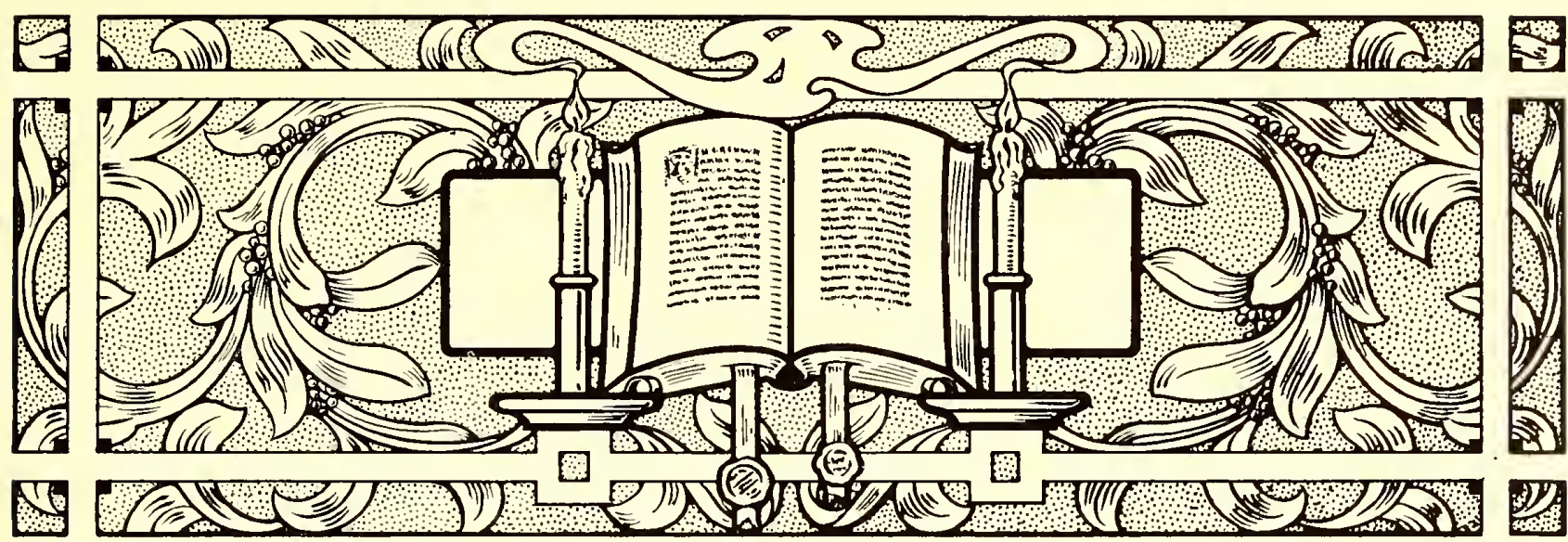

\section{AUTHOR'S PREFACE}

IN the preface to the first edition of "The Art and Praetiee of 'Typography," the author stated that he did not "antieipate again having the pleasure of produeing a book as elaborate as this one," but the favor with whieh the volume was reeeived made another edition advisable, and in eonsequenee he has had the additional pleasure of enlarging and revising it and of produeing a volume even more elaborate and with a better seleetion of examples.

The task of rewriting and replanning the second edition was near eompletion when Ameriea entered the war against Germany, and now, a few months later, the book is presented to the publie. The first edition was published in February, 1910. Work on the new edition was begun by the author in the latter part of 1913, and so great has been the task, in addition to his eustomary editorial labors, that almost four years have passed.

The extent of the work will be eomprehended when it is mentioned that there are twenty-eight ehapters, in whieh the illustrations or typographie arrangements, numbering six hundred and fifteen, inelude forty full-page speeially-printed inserts. Most of these illustrations or typographie arrangements are in eolor. The text matter, whieh makes direet referenee to the examples, totals nearly one hundred thousand words.

That these examples are mostly high-elass and by many of the best typographers in Ameriea (Europe also being represented), is due to the faet that the author during his eonneetion with The American Printer has reeeived several thousand pieees of printing, from whieh seleetions were made for this work.

Great eare was exereised in the ehoiee of examples in order that the book would not beeome obsolete, and it is believed that most of the type arrangements shown will be eonsidered good for a hundred years to eome. That this is possible is proved by the Whittingham titles on page 32 , one of which is sixty-eight and the other seventythree years old at this writing. These titles were set up when most typography was poor, yet few other type arrangements of that time would meet approval today; whieh indieates that it is not when printing is done, but how it is done that makes it good or bad.
Attention should be ealled to the plan of this volume There are two parts, the first having to do with typography of the past and the seeond with typography of the present. Good printing of the present has a basic eonneetion with that of the past, and for this reason one part is ineomplete without the other.

The entire first part should be studied before any of the ideas in the seeond part are applied to present-day problems, and espeeially should the ehapter on 'TypeFaees be patiently read and studied. The printer should first know type-faees and then learn how to use them.

In the ehapters on Harmony, Tone, Proportion, Ornamentation and other art prineiples the author does not intend to advoeate that his readers shall make pietures with type or build pages that are merely beautiful. The first requirement of typography is that it shall be easy to read; the second is that it shall be good to look at. The effieient typographer studies the eopy and arranges it so that the reader's task is an easy and pleasant one.

In planning the second edition the general style of the first edition was retained. However, an effort was made to ehange the style, espeeially of the binding, but so satisfaetory was the original that it was again adopted.

The historieal chapters in the first part have been revised and slightly altered, but they are praetieally as before. Extensive ehanges have been made in the seeond part. The text has been thoroly revised, and better typographie examples substituted in many cases. These ehapters espeeially have been greatly altered: Booklets, Catalogs, Announeements, Letterheads, Billheads, Business Cards, Posters, Advertisements, Imprints.

The ehapter on Type-Faces is all new and has been enlarged from ten to twenty-four pages. New ehapters on the following subjeets have been added: Package Labels, Blotters, Newspapers, Periodieals, House-Organs. In plaee of the medley of contest speeimens in the appendix of the first edition, there are halftone reproduetions of more than one hundred attraetive holiday greetings.

No one realizes more than does the author the minor defeets in typography, presswork and other details that 
are present in this volume, yet the effort of a Hereules and the patience of a $\mathrm{Job}$ have been expended in making everything as eorrect as possible. As the book now stands, it is a reaehing after the ideal, with human inability to attain perfection. It is needless to point out imperfeetions; the reader will discover them.

In his sclection of examples and recommendation of type-faces the author has been entirely free from pressure from any source. If certain type-faces are favored, it is because the author believes he is doing something for the cause of good printing by favoring them. What has been written has been written with sincerity.

It is well to mention that the "Pilgrim's Progress" title on page 21 is not genuine. Having seen the book on exhibition at the New York Pullic Library, the author arranged to have it photographed and included in this work. The sequel to this is interesting and rather humorous. When the chapter on Type-Faces was being written and Caslon types were being studied, the author was startled to find that the types used on the "Pilgrim's Progress" page were the same as those William Caslon was supposed to have designed forty-four ycars later. Greatly puzzled, the author made a trip to the library and examined the original. He immediately saw that the type-face used on the body of the book differed from that on the title. Discovering a note on the fly-leaf signed by William Pickering, the explanation dawned on him. The book was probably owned by Pickering in the middle of the last eentury and the title-page being missing a new one was set up, printed and inserted when the book was rebound. It was Whittingliam, Pickering's printer, who revived the Caslon types about that time, and he naturally used these types as the nearest approach to the Englisli types of the period, 1678 , when "Pilgrim's Progress" was first published.

It is impossible to mention by name all of those who have in one way or another assisted and encouraged the author in the production of this volume. A list of acknowledgments would include typographers of international note and typographers-to-be whose prentice hands need guidanee. It would include office associates and those of the workrooms whose interest and attention to teehnical details helped much in the effort to make the work worthy.

There is one, however, were such a list printed, whose name would lead all the rest, the man who, back in 1903 , conceived the idea of this book; without whose business support this elaborate and costly work would have been impossible; whose idcals liave been an inspiration; whose confidence and encouragement generated the energy and enthusiasm that have attended the author during the fourteen years in which this work has been building. It is a privilege to pay this tribute to Jolnn Clydè Oswald.

New York, July, 1917. 


\section{SYNOPSIS OF CONTENTS}

\section{PART ONE}

\section{WHEN BOOKS WERE WRITTEN Page 1}

The printer and typography-Definitions and derivations of trade wordsPrinting with separate types practiced between 1450-1455 - Books previonsly written by hand or printed from woodThe Middle and Dark Ages-Latin in written books kept knowledge aliveMeaning of "manuscript"-Writing materials-Arrow-shaped writing of the Chaldeans-Papyrus rolls of the Egyptians-Ink, paper and block-printing supposedly invented by the Chinese-Dressed skins and palm leaves used by IIindoosThe Hebrews wrote upon stones and animal skins-We owe the present Roman alphabet to the Phonicians-The word "alphabet" derived from the first two letters of the Greek alphabet, Alpha and Beta-The bards of Greece-Manuscripts written by slaves-Papyrus imported from Egypt-Development of parehment, and what it is-The great $\Lambda$ lexandrian library-Length of rolls-Story of "Septuagint"-Destruction of the Alexandrian library-Rome supersedes Alexandria as an intellectual center-Cæsar credited as the founder of the first newspaper"Short-hand" writing-The period of Emperor Augustus a memorable one in literature-Producing large editions of manuscript rolls-Books were plentiful and eheap-Elaborate parchment rolls-Origin of flat-sheet books-Ilinged waxed tablets-Destruction of the library at Constantinople-Drift of literature toward the East-Transcribing and decorating holy writings in the monasteries of Europe-Monopoly of learning gave power to Church of Rome-Sinee the seventh century monastery manuscripts in Latin, the official language of that church -Translation of Bible into "Vulgar tongue" forbidden-William Tyndale's English translation-Martin Luther's German translation-Making of manuscript books in the Middle $\Lambda$ ges-St. Benedict sets the monks to work copying manuscripts-Popularity of cloistersThe scriptorium and the rmles roverning scribe or copyist-Tools and materialsRubries-Illuminating-The copyist at work-A beautiful Irish book-Illuminators' colors and binding of manuscript books-Missal, Psalter, Book of IIoursDonatus, books associated with the Middle $\Lambda$ ges-First types were initations of eurrent Gothic lettering-'Types cut in style of Roman lettering- $A$ ncient Roman writing all eapitals-Evolution of Roman capitals into small or lower-case lettersThe uncial and half-uncial-Minuscule and majuscule-Development of writing toward both heavy pointed Gothie and the Roman style used by Niclolas Jenson -Cursive, a "seript" letter.

\section{THE ORIGIN OF TYPOGRAPHY Page 7}

The invention of typography marked the beginning of a new eivilization-The beginning and end of the Middle AgesPrinting with separate metal types an evolution-Demand for playing cards and saered pictures-Engraved wood blocks -Block books, and method of printing them-Coloring cards and pictures by means of stencils-The oldest dated specimen of printing-The first block books probably Latin granmars-The " $\Lambda \mathrm{rt}$ of Dying," the "Bible of the Poor," and the "Mirror of Human Salvation"-When, where and by whom was typography invented?-The inventor failed to print his name on his product-Almost every European country claimed the honor- $-\Lambda 1$ claims disproved excepting those of Germany and Holland-Weight of evidence is with Germany-Typography was practiced by Gutenberg at Mainz some time during 1450-1455-Claims of priority for Coster of Haarlem-Story of the invention by Ulrieh Zell the earliest testimony on the subject-Dierick Coornhert's version-The unfaithful servant-Dignified gray heads point out the house of "the first printer"-Hadrian Junius and his "Coster Legend"-Fashioning the bark of a beech tree in the form of lettersChanging the letters to lead and then to tin-Old wine flagons melted into type$\Lambda$ workman, John Faust, steals the typemaking instruments-Cornelis, an old book binder-The story dissected-Peter Scriverius has another version-A clap of thunder-Confusion of dates-A statue erected to Coster in Haarlem-"True and rational account" by one Leiz-Gerard Meerman's story-The sheriff who printed with wooken types - Robbed by a brother of Johann Gutenberg-Jaeob Koning awarded a prize for his essay on the invention-Makes researches in IIarlem archives - Corroborates some details in preceding stories-For many years Coster given equal honor with Gutenberg-Investigations by Dr. Anton Van der Linde -Forgeries and misrepresentations revealed-Haarlem practically surrenders its claim and alters its school booksRecords of Louwerijs Janszoon and Lanrens Janszoon Coster-Van der linde goes to Germany, alters his name and writes a book-Hessels translates the book into English, and afterward becomes a Haarlem advocate-Coster proofs are wcak-1Iaarlem claimants unable to agree as to Coster's identity-Gutenberg a tangible human being, and probable inventor of the art-Parentage of Gutenberg-The family removes from Mainz presumably to Strassburg-Was the new art practiced at Strassburg?-Records of a lawsuit-Gutenberg agreed to teach Andrew Dritzehen certain trade secrets-Fust lends money to Gutenberg and takes a mortgage on his printing office-Fust seizes all types, presses and books-Records of this suit evidenee of Gutenberg's invention-The famous Forty-two tine Bible-Gutenberg again estahlishes himself as a printer-An appointment from the Bishop of Mainz-Dies about 1468H. Noel IIumphrey's tribute-Peter Sehoffer-Copies books at the University of Paris-Becomes Gutenherg's assistant - Assumes charge after his master's death -Marries Fust's daughter-The new firm publishes a Psalter-First hook with a printed date-Features of the book.

\section{THE SPREAD OF TYPOGRAPHY} Page 13

The city of Mainz $-\Lambda$ conflict between two archbishops-The city is set afireFust and Schoffer's printing office burned -The workmen flee to various parts of Europe-A table of the spread of typography from Mainz-In Germany-John Mentel at Strasshurg-Albrecht Pfister at Bamberg-Ulrich Zell at Cologne never printed a book in the German languageArnold Ter Hoorne first to use Arabic numerals-Gunther Zainer at Augsburg first in Gernany to print with Roman eharacters-Heinrich Keffer at Nuremberg-John Sensenschnidt at Nuremberg and Bamberg-The Bumberg NissalAnthony Kobnrger at Nuremberg had twenty-four presses in operation-In Italy -First type printing done in the monastery at Subiaco-Conrad Schweinheim and Arnold Pannartz bronght from Germany-Ulrich IJahn first printer in city of Rone proper-John de Spira first typographer at Veniee and had exchusive right-Nicholas Jenson comes to Venice and uses a new lioman type-face-Story of his introduction to the art-The first page of displayed type composition- $J$, $U$ and $W$ not in books printed by Jenson -Ilis office passes to $\Lambda$ ldus ManutiusItalic introduced-Aldus reduces the size of looks and suggests the printing of a polyglot Bible-Works of Peter Paul Porrus and Augnstin Justinian-Aldus 
assisted by scholar-refugees from Constantinople-His complete name-Venetian printing offiees and their productBernardo Cennini at Florence-Johann Numeister at Foligno-In SwitzerlandBertold Ruppel at Basel-This city gave France its first typographers-Joln Froben at Basel-Erasmus has him print his books-In France-Ulrich Gering, Martin Crantz and Michel Friburger at Paris -Gering becomes rielı-Sectional wood border on book printed by Philip Pigouehet for Simon Vostre-IIenry Estienne at Paris-First of illustrions family of typographers-Robert Estienne best known and most scholarly-Flees to Geneva, Switzerland, for safety-Dies there after a labor of love-In the Netherlands-A press erected at Utrecht-Colard Mansion and William Caxton at Bruges produce the first book printed in linglishVan der Goes at Antwerp-Christopher Plantin at Antwerp gave renown to that city-IIs printing office now a museumA polyglot Bible his greatest work-Louis Elzevir, founder of a family of learned printers, at Leyden-The seeond Louis Elzevir at Amsterdan-Johannes Andriesson at Iraarlem-In England-William Caxton the first to set type in that country $-\Lambda_{\text {pprenticed to a merchant and }}$ goes to Bruges-Becomes Governor-Enters the serviee of the Duchess of Burgundy-Translates a "IIistorie of Troye" and learns how to print it-Returns to England and sets up a press at Westminster Ablicy-Peculiarities of Caxton's work -Wynken de Worde sneceeds to Caxton's business-Introduced the Roman letter into England-Richard Pynson at London-Richard Grafton as a printer of English Bibles translated by William Tyndale and Miles Coverdile-Tyndale suffers death-Grafton imprisoned for printing the "Great Bible"-Edward Whitechurelı his partner-John Daye also imprisoned-Fox's "Acts and Monuments"-In Scotland-Androw Myllar and Walter Chepman at Edinburgh-In Ireland-H Humplirey Powell at DublinIn North Ameriea-John Cromberger at Mexico City-In the Inited StatesStephen Dayc at Cambridge, Mass.

\section{TYPOGRAPIYY IN COI,ONIAL DAYS Page 19}

Martyrs in typographic history-Ecclesiastical and political conditions in Europe from the sixteenth to eighteenth centuries-A book of treaties on the intended marriage of Queen ElizabethOliver Cromwell encourages printing and literature-First edition of Milton's "Paradise Lost"-Thomas Royeroft prints Brian Walton's Polyglot Bible-The first book published in England by subscription-Paper for the work allowed to come in duty free-Cardinal Mazarin discovers a copy of Gutenberg's Forty-two Line Bible-Chap-books and something about
them-Poor representatives of the art of typography - Woodcuts and type battered and worn-Peddled by chapmen-Dicey books-Broadsides-Puritans land at Charlestown and begin to settle Canbridge and Boston-Rev. Jesse Glover solicits money for press and types-Contracts with Stephen Daye to come to new country-Rev. Glover dies-Daye reaches Cambridge with outfit-Begins printing in 1639-'The first work-The first bookPoorly printed-President Dunster of Harvard College appoints Samuel Green to succeed Daye-Another press and types added-An inventory-The printing office discontinued-Printing in the eolonies of Massachusetts and VirginiaPennsylvania second English colony to have typograply - William Bradford prints an almanac-13rad ford arrested in Philadelphia for printing an addressType pages as evidence-"Pied" ly a juryman-Bradford goes to New YorkFirst printshop there-Official printerPullishes the first New York newspaper -Benjamin Franklin-Indentured to his brother James-'The New England "Courant"-James is imprisoned-Benjanin becomes the publisher-'The brother's disagree-Benjamin ships to New YorkMects William Bradford and goes to Philadelphia-Secures employment with Samuel Keimer-Leaves for England to buy printing equipment - Goes to work in London-Returns to Philadelphia and starts a printing offiee-One of the first jobs-Publishes "Poor Richard's Ahnanack"-Proverbs widely quoted-Sells his shop to David IIall-Quaintness of Colonial typography-Comments on reproductions-Page from a Caslon specimen book of 1764-'The work of Bodoni.

\section{TYPOGRAPHY IN THE NINE-} TEENTH CENTURY

\section{Page 27}

William Morris's declaration-The first printed book a testimony to genius-The first cylinder press and first linotype were crudely constructed-Typography at its highest point-Italian and German styles contrasted-These styles blended into the Colonial-Franklin as a typographer compared to Aldus and Plantin-Beginning of the nineteenth century-Utility and art-William Nicholson plans a cylinder press-Dr. Kinsley constructs a model$A$ new roman type-face designed-Ornaments and borders discarded-Style of typograply becoming uninterestingTransition illustrated by four title-pages -Charles Whittingham and William Pickering-Artistic qualities introduced -Punches of Caslon Oldstyle recovered - A page in Colonial style-Punctuation marks omitted-Fifty years ahead of their time-Job printing of modern development-Newspaper, book and job work-Typography should be based upon art foundations-A Book of Common
Prayer-Title-pages without ornamentation-Job printers take to fancy typography-Imitations of copperplate engravers' work $-A$ business card and a bill of fare-Changing styles applicd to commercial headings-MacKellar, Smiths \& Jordan-A card with apologies-A longing for pictures, color and decorationBrass rule and tint blocks-Rcmarkable skill exhibited-The "Modern Renaissance"-Machinery led typography away from art-Printers thought they were doing artistic work-Inspiration wrongly interpreted-Forming of a curious ehain of events-The Kelmseott Press-William Morris, artist, poet, designer and craftsman-Franklin and the Franklin stoveMorris and the Morris chair-The influence of Morris on house furmishing and typography-His home-Learned to print and to make paper-Designs type-faces"Golden"—"Troy"—Draws decorative initials and borders-Additional designs by Burne-Jones-Morris criticised-Revolutionizes typography- $\Lambda$ ubrey Beardsley-Will Bradley-A country printerStudies art in Chicago-The "Wayside Press"- "Bradley: His Book"-Inspired by both past and present- $\boldsymbol{A}$ new typograply-Combines with the University Press-Beeon $s$ an interesting subject for discussion-An opinion by George French-Attempts another new style of typography - Profuse ornamentation Works rapidly-Bradley and his clientsHis personality-Influence upon the American style of typography-Other influences-Thcodore L. De Vinne-IIas a college degree- $\Lambda$ pprentice in a country printshop- $\mathbf{J}_{\text {ol }}$ eompositor with Francis Hart-Takes charge of the business-A writer on printing subjects-Exponent of the conservative and dignified in typography-Should be no confliet between the styles of Morris, De Vinne and BradleyFor different purposes-The compositor must decide-De Vinne a leader in perfecting modern methods-Designs a typeface-Persuades printers to group wording-Charles 'T. Jacobi-Has done much for typograply in England-Responsibilities of the modern typographer-Underrating the value of history-All knowledge is valuable.

[The chapters following are devoted to the consideration of typography as practiced in the twentieth century.]

\section{PART TWO}

\section{THE "LAYOUT" MAN Page 35}

Typography in the twentieth centuryCompared with the past-Perfection not attainable-The spirit of the master craftsman-Inspired work-The necessity of careful preparation-Every printshop should have a layout man-when a building is erected-Quality printing is 
not accidental-Shop style-Layout men in large and small shops-Please the customer-Typography essentially a business vocation-Orders obtained thr" "dummies" submitted-Selecting a layout man -Type equipment should be appropriate and sufficient-A working outfit for the layout man-Portfolio of sample sheetsLaying out a small booklet-Paper, margins, type page and size of type-Words to a square inch-Arrangement of titlepage-Specimen pages in available body type-Use of crayon and pencil-Dummy submitted to customer-Duplicating it in the workrooms-Dummy sheets for periodicals and large catalogs-Incorporating illustrations in the text matter-Marking copy for machine composition-The average stationery job-A patchwork of typographic styles-Different results if handled by a layout man-Studying color harmony-Determining color combinations-The colder color should predominate-Indicating the finished resultProofs in the colors and on the stock to be used-Blending paper stock-laying out advertisenents.

\section{HARMONY AND APPRO- PRIATENESS \\ Page 41}

"Leit-motif"-The central idea in composition-Harmony and appropriateness -Undervaluing their importance-What is appropriate?-Discriminating judgment required-Discreet sclection of type, ink and paper-It makes a differenceAs to type-faces-As to inks-As to papers-Simplicity synonymous with good typography-The ideal printshop-Ilarmonious type-faces, ink colors and paper stock-Certain amount of contrast desirable-All capitals or all lower-case-Harmony of type-faces and borders illustrated-Typographic sins-In typography there should be a motive-"Is it appropriate?"-An architectural motive-In which strength is the motive-Design suggested by an old lock-plate-Typographic motive found in woodcut borders and initials of early printers-A millinery booklet cover-A page severely plain and non-sentimental-A program for a church service appropriate to the environmentA page in keeping with a festive spiritTypographers should give support to artists-The Colonial arch and a titlepage-'The better the typographer, the more restraint will he exercise.

\section{TONE AND CON'TRAST}

Page 47

A story of white and black-A combination popular with writers, printers and readers-Uniformity of tone or depth of color-A mixture of irregular gray and black tones inexcusable-Art principles too often ignored-Contrast neeessary, but uniformity should not be sacrificed-
Art makes concession to utility-A right way and a wrong way-Unjust blaming of the customer- $\Lambda$ German example of uniform tone-Practical demonstration of uniform tone-Four ornaments, upon which four pages are constructed-Contrast, from the viewpoints of art and utility-I.essening the contrast between print and paper- $\Lambda$ compromise- Impressing the print firmly on antique paper -Sctting the print daintily upon glossy paper-l ack of artistic feeling responsible for unpleasant contrasts-Great contrast is ecoentricity-Mark Twain and contrasts -Cover-page should be darker than titlepage-The tone of a massed page-Controlled by spacing-Duplicating the tone of a pen-and-ink illustration-A spotted black tone-Equalizing the tone by using lighter ink-Spaced capitals and openline illustration $-\boldsymbol{A}$ classic interpretation of uniform tone-Characteristies and tone superbly blended-Initial and headpiece should approach the tone of the type page -Uniform tone between display line and border-Catalog illustrations should stand out in relief-Outline type-faces to obtain gray tone on newspaper page-Ictterspacing-AH lines should be similarly spaced-An unusual heading.

\section{PROPORTION, BALANCE AND SPACING \\ Page 53}

Symmetry is necessary to beautyWhat has art to do with printing?-Two views-The book printer and the job printer-I'leasing the few or being all things to all men-Printing as a business and as an art- $\Lambda r^{t}$ is essential to printing-Study of art arouses ambition-Unfolds a new world-Proportion-Book pages - The width and length of a pagePosition of the page-Margins-The job printer and proportion-Relation of shape of type-face to page-Condensed types for narrow pages-Extended types for widc pages-Architecture as an example -Vertical and horizontal lines-The relation of lines to proportion-A page with ornament, type-face and page design in proportion-Irregularity and when it may be introduced-A type line large or small by contrast-The happy medium-Balance, an important subject-Type lines horizontally centered-Safety from blunders - Out-of-the-center balance - The point of vertical balance above centerTesting balance to the limit-Diagonal arrangements show lack of imagination -Spacing-Its proper apportionmentAn important feature when letters are designed-The capital L-Emphasis by means of spacing-The effeet of separate lines-Should be an even page tone-Distributing display lines over the entire page-Grouping them at the point of balance-Spaced words in narrow measures -A good sign when one recognizes imperfections.

\section{ORNAMENTATION}

Page 59

The human race has a liking for ornamentation-Natural and artificial beauty -Nature furnishes motives for man's work-The average man giving thought to art-Ieautiful things all about-Privileges of musemins and art galleries available to printers-Take less thought of food and raiment and these things shall be added-Is ornamentation necessary to art typography?-Paper as embellishment -Covering poor stock with decorationOrnaments under lock and key-Revising ideas of art-Abstinence-Using ornaments with discrimination-Study of significance and appropriateness-Motive or reason in ornamentation-Italian and German influences-Ilarmony because of sympathy betwcen arts and crafts-Inharmonious ideas of several persons-Relation of typography to architecture shown in alphabets-Roman and Gothic -Ornamentation both inventive and imitative-Conventionalized ornament-With or without perspective-Things which have inspired the decorator-Artists' work full of meaning-Leaves, mythieal heings, sacred animals- $\Lambda$ rchitectural designs on title-pages-Egg-and-dart and bead ornaments-Results of olservation -Designs thousands of years old-Typographic borders-Triple division of taste - The severely plain, Doric-The slightly ornamental, Ionic - The elaborately ornamental, Corinthian-Sturdiness and grace -Difference in ideals and preferencesSome delight in magnificence, others in plainness-The three divisions of taste applied to typography-The style of architecture and home furnishings influence typography-The "mission" style and straight lines-The frivolous rococo style and curved lines-Rococo type ornamentation not successful-A style to please those who like neither the severely plain nor the elaborately ornamental-Ornament secondary-Should not distract attention-Excess of embellishment-Chippendale first made furniture serviceable, then added ornament-Regularity and variety in repetition-Four classes of ornament-Based upon geometrical lines, upon foliage, upon the inanimate, and upon the animate-Initials as means of ornamentation-Corner ornaments-Decoration with a motive-Reversing half of a design-A page with but a single ornament-Present-day preferences are for Gothic rather than for Italian type ornaments-The reason-Ornamentation.

\section{THE TYPOGRAPHY OF BOOKS Page 67}

Good taste important in production of books-Judgment perfect in one respect and erratic in others-Good taste and conservatism-Catering to fashion leaves unsalable stock-Conservatives are few- 
Printed things that please for the moment-Art reasons in book typography applicable to job typography-The job compositor drawing closer to his book brother-The book typographer governed by precedent-The conservative man constructive-The radical destructive-Masterpieces discarded for frivolous thingsMorris set out to change book typography -He offered the good things of the old masters-Age not proof of merit-Good typograplyy always good-Book industry in America tremendous-Carnegie at first ridiculed, now acknowledged a benefactor -The need of good books well printedMajority of books poorly printed-Rarely do reading pages, title-page and cover harmonizc-Cover only part given artistic attention-Should be honestly what it seems-A book model in its way-Not a line in capitals-Only two sizes of type on title-page-Chapter headings cling to type page-Margins-Surface coveredProportion - Bruce liogers - Designs books for the Riverside Press-Regard for the appropriatc-'The literary motive the cue-Suggesting a product of the middle nineteenth century-Two pages with faults-Inlaarmonious typographyThe cost of an appropriate title-page ridiculously small-Provide display faces to match machine letters-Artist and typographer and the literary motive-Composite Colonial and modern-Unfinished effect-Books that lend themselves to decoration-Serious hooks-Typographic results exceptionally good-General use of border-Title page an excellent example-Reading matter close to borderOne margin-Style of the modern novelModern book composition set on the linotype-An unconventional page-Page from a book written and illustrated by will Bradley-llarmony between type-face and decoration-Effeetiveness of a plain initial-Title-page of classic designDignified beauty-Classic feeling in a modern title-paze-A serious effort by the Roycrofters-Page from a book by De Vinne-An ecclesiastical book by $\mathrm{UP}_{\mathrm{p}}$ dike-Inproving typography in America -A book with a French motive-Avoiding commonplace types-Fonts from old matrices-Specially designed faces-Arrangement of a book-Fly leaf, sub-title, title-page, copyright notice, imprint, table of contents and illustrations, preface, frontispiece, dedication, index-Numbering the pages-The space under running titles-Lowering of the chapter headings -The space around initials-Position of a book page-Em-quad or en-quad between sentences?

\section{BOOKLETS, PAMPHLETS, BRO-} CHURES, I.EAFLETS

\section{Page 75}

Misuse of the word "booklet"-Definitions of booklet, pamphlet, brochure, leaflet-Chap-books-The booklet's mission
educational-Users-Ideas of writer and artist should be blended-Harmonious and complete-Printers have many artists to select from-The connecting link between job typography and book typography-Blending the typography with a lettered title-page-Pure typographical effects-Approved faces-Three series only-A page one likes to read-Reluctance to explore the past-Understanding of typography-Type alone can be effective-Good typography to be preferred to poor art work-Distinctive featuresSpace betwcen sentenees-Dignity in lettering and decoration-Title labels-A small amount of reading matter-Placing an illustration that is out of proportionCare in the details of typesetting-Results of careless typography-Buyers slaves to conventionality-Newness and bright coloring that gets attentionLower-case letters for capitals-Interesting decorative headings-The initial furnishes a spot of black-No decoration of any kind-Depending on type-faces and paper for results-Swash italic capitals and letterspaced capitals-Chapter heading not sunk-Suggestions from lettered designs-A standard type for old-style effects-Iettering in Caslon style on blueprints-A memorial volume-Strict typographic harmony-Suggesting such volumes-Japanesc paper printed on one side-Simple typography-Living in an artistic atmosphere-Printing journalsSpecimen booklets for study purposesPrinters depend too much on artistsPossibilities of type arrangement never exhausted-Working together.

\section{CATALOGS \\ Page 83}

Three branches of architcetural virtue applied to the cataloy-Act well, speak well, look well-The diys when the cata$\log$ was a heterogeneous collection of woodcuts and type-faces-Now care and taste shown-The catalog a portable show case-Proper display of goods makes selling easier-Playing $\mathrm{up}$ the ordinary-A block of marble, rough and carvedStandardizing the dimensions of catalogs -Engineers recommend standard sizesOther suggestions-Overlapping coversTitles on exposed backs-Date-Index card inclosed-Copy should be legibleA duminy should be passed on-Decoration supplemental-Expressing personality-The penalty of being an average typographer-The envy of master printers of old-Horizontal position of illustration-Brass rule well used-A design full of character-Description facing illustration-Small amount of reading matter-Red borders-Variety and interest by simple means-Cover-page built on an illustration-Modern German typographic ideas-Bold type desirable when color is to be shown-An art museum catalogSecuring value from background-Tech- nical details kept orderly- $\mathbf{A}$ book-catalog page-Rule border adds decorative quality-Typography seldom receives the attention it deserves-An uncommon catalog page-Tabular treatment for a highclass wine list-The stone rejected by the builder-A dainty German page-A legible ornamental letter- $\mathrm{Absence}$ of roman lower-case-Appropriate woodcutMarginal distrilution-Realistic pictures -Gloves well shown-Usual method of selling-Tabular matter.

\section{PROGRAMS}

\section{Page 91}

"Let all things be done decently and in order"-Four classes of programs-Programs of sacred services-Offer opportunity for artistic treatment-Significance an important element-The key to ecclesiastical printing-Rubrics-A modern interpretation of the historic-Pointed Gothic type-face-Uncial rubricated initials-Red lines- $A$ significant devicePrejudices annong clergymen-A churchly aspect by rubrication-Arranging numerous small titles-Economizing spaceAn almost perfect specimen of church program printing-A specialist on church typography-Program of lenten services - A small program, with a page for each event-Arranging a program with little matter-The dance program-Should be dainty-Stock folders-Must "look like a dance program"-A typographic dance card-Centered dots in place of periodsUniform border treatment on an outing program-An unconventional dance program-Banquet programs and varied treatments possible-Value of the decorative border-A rrangement of type matter -A background in olive-The menu program in small booklet form-Menu dishes in the form of checks-"Iasls" and "Rehasls" $-\Lambda$ bit of fun $-\Lambda$ classic menu-page -A style appropriatcly humorous-Eating in a foreign language-Side hits-Artistic treatment simulating woodcut decoration-A simply constructed menu page -Unicjue arrangement-Titles at the left -Symmetrical arrangement-Plograms for entertainments and exercises-The commonplace prograun a disappointment -Artistic programs--A refined page by Updike-Features of interest in a page by Rogers-Admirable treatment of a brief progran-Appropriate decoration overprinted by type $-\Lambda$ page dominated by the Gothic style-List of characters unusually displayed-A neat page in Caslon type-The program containing small advertisements-Theater programs exert influence on public taste.

\section{ANNOUNCEMENTS}

Page 99

Publicity essential to success-Announcements the modern representative of the public crier-Not confined to any 


\section{SYNOPSIS OF CONTENTS}

size or shape-Often eonsists of only one page-mithe most personal of printed mediuns of publicity-The printer depended on for suggestions and adviee-Confidence of the customer an asset-Imitation engraved announcement the most common-Allows of no original or decorative treatment - The cobbler and tinker-Satisfaction from work well done -The uncommon typographer not governed by usual wanings- $A$ n announcement folder of a quality seldom attained - Points of interest in a Caslon pageBlack text letter and a generous size of sheet-Sturdy masculine lettering-The human quality of imperfection-A eartoonist's task-Broad strokes make a liberal showing of color possible-Classic dignity-Ornaments as eye-attractors- $\mathrm{A}$ postal-card announeement - One-tenth manual labor and nine-tenths brain exereise-Mistake to make type-face very large or very small-Obtaining variety and emphasis by use of italic and small capitals-Spacing of lower-case-One size of type only-Division into two type groups-A study in tone values-Harmony of type-face and decoration-A brief announcement-Colonial effectsAppropriate typography based on an early newspaper-Lack of margins and absence of print-Heavy- and light-faced rule-Greater legibility when lines are separated-A misplaced initial-A blotter announcement-Printers" own announcements.

\section{TICK ETS}

\section{Page $10 \%$}

Good results by accident-A good job of printing should be an every-day occurrence-Lack of interest reason for nondevelopment-Any man not interested in his vocation to be pitied-Thought concentrated on typography-Efficiency a guarantee-Accept responsibilities-'The first observations of a student-“None perfect, no not one"-Tickets afford practice of art printing-Many themes and styles in typography-Resourcefulness a valuable characteristic-Ticket forms especially designed-One based upon a classic motive-An idea from ancient Rome-Capitals slightly spaced-The historic Gothic or church style-Contrast by the use of color-A modern conception with a masculine motive-The margins of two styles-An odd and striking effect-Modern treatment based upon the Colonial-A bookish effect-An idea for a lecture course-White or colored stock? -A ticket of peculiar interest to women -The geometric or secession style-Enthusiasm over new styles-Building a house in the sands-Square-faeed type and square ornaments- $A$ n adaptation of the missal style-Inspiration from William Morris and Italian printers-For educational and art functions $-\Lambda$ motive from the art workers of the Middle Ages -A modern application of classie type
effects-A purely Colonial effect-Dainty, refined treatment and symbolic decoration-Typography that is distinctly masculine-Orange is lighter than black in tone-An arrangement dictated by an ornament-A tieket not easily duplicatedColor background-Corner decoration in keeping with the subject-A motive from early French books-Typographers should go thru the world with eyes open.

\section{LETTERHEADS AND ENVELOPS Page 111}

Standard sizes-Single leaves and the folded note sheet-Official envelops-Folding the sheets-Printing on fourth page - Society stationery-Ruled sheets seldom called for-Paper and typographical treatment of letterhead and envelops should have relation-Style of professional stationery seldom changes-Simple, neat, refined typography-Color seldom well used-Styles furnished by lithographers and steel-die printers-Work along standardized lines-A letterhead one form of advertising-Two tones of type-face for much copy-Elaborate treatment seldom advisable-All matter in one group-Blank space a factorBrief copy-Use of a decorative device$A$ harmonizing border-A meeting announcement-Suggesting an architectural panel-Appropriate to the businessAll lines of same length-For a general store-Resetting of a "brick" letterhead -Too literal-Injection of individuality -Something different-Attractive club stationery - Typographic neatness - A copperplate letterhead - Two distinct groups-Italic on a heading-Inclosing type matter in a panel-A line border finishing off the edges of a letter sheetA spot of decorative color-'The cross-line panel-German treatment-Notehead by a book typographer-Humor-Envelops a convenience-Its purpose and use-Advertising possibilities-"After five days return to"-Medieval character-Bringing out the business-An envelop corner that is artistic-Elaborate treatment.

\section{BIILHEADS AND STATEMENTS} Page 119

Suitable and dignified type composition-Should correspond in style to that of letterhead-Standard sizes-Allowance for head portion-Window envelopsChange in arrangement-Billheads of a quarter of a century ago-Features of the average billhead or invoice-Composition of a billhead-Transforming a letterhead into a bilthead-Classic typographyTypographic art and good taste on a billhead-Stationery of a book dealerPrinting on colored stock-Lower part divided into columns-A decorator's stationery-Business stated in firm nameCredit bills-Use of the statement-Other forms used in business.

\section{PACKAGE LABELS \\ Page 123}

Effectiveness of an attractive package label-Good clothes and the paekageSelection of wrapping stock $\rightarrow \Lambda$ ppreciation of neat wrapping-Druggists excelThe art of making a good impression'Twine, gummed-paper tape, corrugated board-The printed label as a spot of attraction-The wrapping paper as a background-Two labels of contrasting treatment-Stronger label striking-Labels not usually seen at close range- No standard size-Stock that pastes easilyHand lettered labels as studies-Italic with a decorative quality-A label design with no border-Suggestion of Italian art-Closely-spaced black-toned lettering-Artistic quality and interest by means of typography-A study in blaek and white-The Aldinc eombinationBorder, decorative device and lettering in the same key-A label design that could be improved-A Goudy type arrangemen-Label with address printed inStock labels should be studicd.

\section{BUSINESS CARDS}

Page 197

Courtesies of business-The business card as an introduction-Sizes of cardsWhite cards predominate-An attempt at standardization in arrangement- $\mathrm{A}$ model of dignity-Featuring the individual's name-Contrast in tone-A specimen of hand lettering $-A$ design of strength and interest-An attractive black monogram -Decorative device in color-An interesting contrast-High-hat and frock-coat treatment in French style-Arrangement in blocked Caslon capitals-Decorative device in tint-Roman capitals with italic -A depresentative German card-The word "deeorators" furnishes the eueItalic for dainty effects-A strong, simple arrangement-Classic arrangement in one size of type-Much information on a card-Decorative treatment that could be merged with the stock-Horizontal rule lines-A card in Bodoni-More than one right way-Styles available for all likes and dislikes-Character and personality expressed typographically-More individuality now permissible-Copperplate engravers set the style for mueh businesscard printing-I Iow to obtain results.

\section{THE BLOT'TER}

Page 131

Business cards and blotters-Less restraint and dignity-Coarseness should be avoided-No longer an experimentAdvertising values-The size-Fnameled surfaces $-\Lambda$ model typographic blotter with calendar-Treatment shonld be simple-One design of type-face-Blank space liberally distributed-Natural freedom-Most blotters contain too much 
type matter-Relief from sledge-hammer advertising-Blotter for personal checkbook-Good taste-For a conventionPleasing factors - Strong contrasts Reading the message as the signature is blotted-Masculine treatment-The character of an architectural panel-Pleasure in using-Material that is used and material that is not used-A model of good taste in blotter typography-The test of time-A neat, refined arrangement - The use of large type-The narrow way - Gray features-A touch of appropriateness-Other features.

\section{POSTERS, CAR CARDS, WINDOW CARDS}

Page 135

Poster printing a specialty in large cities-Type equipment well selected, but not elaborate-Blend of type-facesStandard job faces duplicated-Sizes of posters, car cards and window cardsColor and lettering-What the poster slould be-Vicwed at closer range-Typographic effects in poster printing-A poster that measures up-A study of composition-Contrast of color-Card in conversational style-Using types in a sane, simple manner-Strong simplicity -Refinement in theatrical printing-A strong poster in gothie and "secession" border-Making the typography appropriate-Shakespearcan ty pography-Decoration reproduced from original sources - Usefulness of a library of books-A hanger in one size of type-The Colonial style of type arrangement-Why cardhoard is used-Suggested arrangement for excursion card-Printers and poster printing-The best sale-bill compositor in the country-Work should be donc profitahly-Poster printing on a large scale.

\section{ADVERTISEMENTS}

Page 139

Advertisements, business men and printers - Blame for ineffectivencss - Treating the advertisement typographicallyStudy of good type work, advice and judgment-Oratory-A good speaker and a good typographic advertisement-Print too small or too large-Bluntness and forcefulness - Decorative attractiveness -Emphasizing significant parts-The difference between setting type with a stick and setting it with the head-Assuming a new formation-A multiplication of small advertisements-Easily read, conversational style of advertisements-Not much to say-Popularizing zinc-A well-treated signature-One of many clever advertisements-A peculiar department-store advertisement - Problems of the country newspaper-Typography influenced by the article advertised -Text types in advertisements-Harmonious suggestion-A long list of cities and agents-Selling costly automobiles-
Suggesting Roman architecture-Text group in upper right corner-Little display-Blank space well used-Interesting country-newspaper advertisement-Classified advertisements well displayed.

\section{NEWSPAPERS}

$$
\text { Page 147 }
$$

Neutral gray-Building suitable and harmonious typographic form-Problem simpler in early days-The ideal newspaper-The title-Distinctive in designText letters-Using the ends of titlesSlogans and quotations-Date lines-The text - Small type-Narrow columns Lengthy excerpts indented-The headings -First newspaper a letter and not set off by headings-Side headings-Wars developed display-Advertising the contentsCondensed type necessary-Harmonious type lines-Italic to overcome monotony -Paneled headings-A four-deck singlecolumn heading-The make-up-A goodlooking newspaper-Alternating large and small headings-No advertisements on front page-Position of article of most importance-Paneled news-EditorialsUsual position-The sporting pageBuilding advertisements from the lower right colner of the page.

\section{PERIODICALS

Page 151

Making publications attractive-Letterer and decorator-Circus poster type -The poor always with you-Many periodicals good to look at and casy to read -The dimensions-Nine by twelve inches a favorite with teclnical publicationsThree groups for magazines-Growing larger-Pocket magazincs - The front cover-Paintings-Decorative designsPaid advertisements on the front coverAppropriate views in half tone-Columns - Number decided by size of type-Wide columns strain the eyes-Gutenberg used two columns-Small type in very wide measures-The margins-Proportions as in good books-Good margins spoiled in bindings-Type-faces for thetext-Chosen for legibility in small sizes-Separation with one-point leads because of lack of descenders - Difference in type-faces printed on coated and antique-finished paper-Lines need to be separated by leads-Should be well-formed as well as readable-Thin lines should be cut a trifle stronger-Type-faces for the headingsSame design as type for text matterDesirable, but not always possible-An instance-Large, black headings should be avoided-Slightly decorative panelsEditorial headings and titles-Make-up of the illustrations-A background of gray -Well balanced-Text matter between illustrations-Same style on facing pages -Arrangement of headings-They sell the contents-A well-advertised storyThe captions-Centered under illustra-
tions-In two parts-Lines of same length -The editorial pages-No standard style -Unlike other reading pages-Features - Verse in italic-Restraint necessaryThe advertisements-Bold types overshadow text pages-Good taste-Not to be mingled with text matter-Treatment need not be timid or blustering-When advertisers are best served.

\section{HOUSE-ORGANS}

Page 161

Little brother of the periodical and newspaper-Smallest and largest dimensions - Favorite sizes - Self-covers and covers that are separate-Not many pages -Published regularly-Titles-Number of columns - Margins - Type-facesHeadings-House advertising-Illustrations, descriptions and prices-Mistake to use dark types with illustrations-Ideal typographic treatment-UsefuI and informative-Light matter to maintain interest-Features-Borders and initialsAlmanacs-House-organs on blotter stock -In newspaper style-A western printer's expression-Specimens of actual work -Too much copy-Loose inclosures should not prove a nuisance-Return post cards -Postal regulations.

\section{TYPE-FACES \\ Page 169}

Type-faces not easily rememberedNaming and numbering-Six representative standard Roman type-faces-Legible and good-looking and possessing character-Caslon Oldstyle-Scotch RomanCheltenham Oldstyle-Cloister OldstyleBodoni Book-French Oldstyle-Private type-faces not considered-Permanency and investment-Cloister Oldstyle based on Jenson's Roman letter-Not the first Roman type-Caslon Oldstyle-A historic American type-face-Approved by good printers as the best and most useful Roman face available-Difficulties in machine composition-Not an entirely ncw Roman letter-Story of its designingIll-treated by modern founders-The revival-Bodoni Book-Refined and legible-Its history-Modern ideas of improvement-Scotch Roman-The link connecting the graceful old-style and the severe modern Roman-French OldstyleCapitals especially pleasing-Cadmus, the Mayeur letter - Cheltenham Oldstyle Designed in America and developed into a numerous family-The space above the line emphasized by long ascenders-Used for narrow booklets-Capitals awkwardly large-Development of the Roman typeface-In the beginning Roman letters were in capitals only-Lower-case letters in formation-Black Letter and White Letter-Jenson fortunate in the selection of a model-Comparisons-A change in form-Moxon's drawings of the alphabet-Made into type-Basker- 
ville's types rival Caslon's in beauty-Bodoni threw typography out of gear-His types not so dressed up and finished as at the present time-Modernized Oldstyle - Characteristics of Roman type-facesThe serifs-Has a decorative qualityOldstyles and Moderns distinguished by serifs-Thick and thin strokes-Makes lettering intcresting-Their distribution - Characteristics of pen-made lettersAscenders and descenders-Beauty in the strokes-False logic-Proportion of letters-Old Roman capitals as modelsUnifornity in width revealed in typewriter type-Legibility of type-facesType matter should be easy to readTests for legibility-Printing on a hardfinished paper and a soft-finished paperDecided contrasts tire the eye-Iowercase more legible than capitals-Space between lines necessary-Space between words- $\Lambda$ dvantage of close spacingPossible in machine composition-Words more easily read than letters-Group of words almost as easily read as one word - Length of line - Recommendations Size and kind of type should be considered-Measuring one and a half alphabet -Technical and optical reasons-Testing newspaper types-Approved typc sizes and leading-Dr. Cohn's measurementsItalic types-The mate of Roman typesWas first cut by Francia for Aldus-Not merely an inclined Roman-Moxon's Italic letters, including Swash capitals-Text faces-Fashioned after Black I etter writing-Other names-Block types- $\Lambda \mathrm{n}$ unfinished Roman letter-Poster rendering in black tones-Bold types-Many could be dispensed with-Ornanental types'Types for special purposes-The influence of Frederic W. Goudy on typography.

\section{IMPRIN'TS \\ Page 195}

The printer should regularly use his name and device-Neglect and foar of customer's condemnation-Should mark his product as other craftsmen and manufacturers do-A guarantee of qualityHow the innovation could be introduced -A precaution-Imprint should be unassuming and inconspicuously placedVarious uses-First use of a printers' decorative device-Historical uses of distinguishing marks-Emblems of hospitality-The sign of the Cross-Printers should select a device and attempt to live up to it-The Gutenberg Bible contained neither device nor printed name-Fust and Schoffer's Psalter first book with imprint-The colophon-A decorative device-Its significance-Imitated-As used by a descendant-The classic Aldus device-Pickering uses it-Others adopt it-
Bruce Rogers's interpretation-'The imprint-device of the Venetian Society of Printers-Its significance--Finllen of authority-The most popular of old imprints-Iubbard adopts it-Used on biscuit packages-Other adaptations-Caxton's imprint device-Resembles a rugCharacters cause discussion- $A$ trade device used by the merchants of BrugesA merchant's memorial plate-De Worde atlapts the device-Morris's device resembles De Worde's-The device of the German master printers - Typothet $-A$ modern adaptation-The British printer and the pun-Daye and Myllar-Frolsen's imprint-Devices of Bebel, Plantin, the Elzevirs, Tory, Dolet and Estienne-Devices very large in the old days-Ancient motives in two modern devices-The winged Lion of St. Mark-Recent adaptationsStory of the device-A colophon-imprint -Designs with ancient motives-The unique mark of the De Vinne Press-Imprint-devices based upon architectural motives-Initials in monogram formRepresentative devices used by commercial printers-Decorative imprints with typefounders' material-IIarmony of type, rule and ormament-Small type imprints-Where should an imprint be placed-On books-On small commercial work-A legitimate opportunity for publicity that should be. 


\section{LIST OF REPRODUCTIONS}

The first printed Declaration of Independence, frontispiece

\section{PART ONE}

\section{WHEN BOOKS WERE WRITTEN}

\section{Page 1}

The scribe at work, opp. p. 1

Assyrian clay tablet, p. 1

Ancient Roman reading manuscript, p. 2

Roman waxed tablet, p. 3

The Egyptian "Book of the Dead," p. 3

Evolution of the alphabet, p. 4

Capital letters of the ancient Romans, p. 4

Uncial letters of the sixth century, p. 5

Half-uncial letters, p. 5

Gothic letter's of the fiftl century, p. 5

Page from the "Book of Kelts," p. 6

\section{THE ORIGIN OF TYPOGRAPHY}

\section{Page 7}

Portion from Fust and Schoeffer's Psalter of 1457 , opp. p. 7

French playing card, a block print, p. 7

Image print of 1423, p. 7

Bible of the Poor, from block book, p. 8

'Text page from the block book "Ars $\mathrm{NIO}$ riendi," p. 8

Pagc from an engraved wood block, p. 9

Pagc from separate metal types, p. 9

Two pages from the Iluntington copy of Gutenlerg's Bible, p. 12

Decorated page from Cintenberg's fanous Bible of Forty-two lines, opp. p. 12

\section{THE SPREAD OF TYPOGRAPIY}

\section{puspe 18}

The Venetian style of typography and decoration, opp. p. 13

The spread of typography (table), P. 13

Page printed by Koburger, p. 14

The first displayed composition, p. 14

A page from the famous Bamberg Missal, opp. p. 14

'The first italic, a page by Aldus, p. 15

Specimens from Plantin's l'olyglot Bible of 1569, p P. 16,17

Gothic ornamental pieces, from a "Book of Hours," p. 16

Page by England's first printer, p. 17

Page in English by John Daye, p. 18

The first Psalter in English, p. 18

\section{TYPOGRAPHY IN COLONIAL DAYS Puge 19}

A title-page of 1655 , with much type display, opp. p. 19

First book printed in English America,p. 19 Title-page of a Shakespeare book, p. 20
First edition of "Pilgrim's Progress," (reset by Whittingham), p. 21

First issue of the London "Times," p. 21

Page from a chap-book, p. 22

Page from "Description of Trades," p. 22

Frencl specimen of 1742 , p. 23

Caslon types and ornaments, p. 23

First edition of "Paradise Lost," p. 24

Two pages from "Poor Richard's Almanack," p. 25

Italian specimen of 1776, p. 26

Pages from Bodoni books of 1789 and 1806, p. 26

\section{TYPOGRAPIYY IN TIIE NINE- 'TEENTH CEN'TURY \\ Page gry}

A Morris title-page and text page, opp. p. 27

Page from a "Book of Common Prayer," p. 27

A design of the rule-curving period, p. 28 Title-page of 1810, p. 28

Title-page of $1817, \mathrm{p} .28$

Title-page of 1872, p. 28

Title-page of Mackellar's "American Printer," p. 29

A banquet program of 1865, p. 29

From a type-foundry specimen look of 1885, p. 30

A business card of 1865, p. 30

$A$ business card of 1889, p. 31

Stationery composition of 1870, p. 31

The panel as used in 1893 , p. 31

A neat letterhead of 1897 , p. 31

Title-pages by Clarles Whittingham, p. 32 Bradley's adaptation of the Colonial style, opp. p. 32

A Jacobi page of 1892 , p. 33

A Bradley page in lower-case, p. 33

A Bradley page in Caslon capitals, p. 34

A De Vinne page, p. 34

\section{PART TWO}

(The index figures refer to the number of the example)

\section{THE "LAYOUT" MAN Page 35}

Booklet cover-page laid out with pencil and crayon, 1

Anticipating the appearance of the printed page, $\mathbf{2}, \mathbf{3}$

A scertaining color combination with crayons, 5,6

Laying out copy for machine composition, 4-a, 4-b

Table for ascertaining the number of words to square inch, 7

Notehead set without instructions, 8

Business card set without instructions, 9
Label set without instructions, 10

Notehead laid out for compositor, 11

Business card laid out, 12

Label laid out, 13

Layout of a cover-page, 14

Cover-page as set from instructions, 15

I ayout sketch for a cover, 16 (insert)

The cover printed as indicated, 17 (insert)

\section{HARMONY AND APPROPRIATE-} NESS

Page 41

Harmony by the use of lower-case, 18 Harmony of type-faces and borders, 19 An architectural subject treated appropriately, 20 (insert)

A booklet cover suggestive of the subject, 21 (insert)

Cover suggested by old lock-plate, 22

An old lock-plate, 23

Inscription on a Roman arch, $\mathbf{2 4}$

Cover-page for a catalog of books, 25

A plain page for a plain purpose, 26

Treatment appropriatc for a church program, 27-a

Portion of a page of an old manuscript missal, 27-b

Cover-page for a catalog of decorative materials, 28

The Colonial areh, 29

Title-page in semi-Colonial style, 30

\section{TONE AND CONTRAST}

$$
\text { Page } 47
$$

Contrast in color and tone, $\mathbf{3 1}$

Uniform tone and contrast of black and white, 32

Four ornaments, each of a different depth of tone, used in the construction of four pages, $33,34,35,36,37$

Extremes of tone on book pages, 38,39

Blending of illustration and text, 40

Spotted black tone of border and text, 4.1

Blending of illustration and type-face, 42

Uniform tone in classic typography, 43 (insert)

A study in uniform tone, 44 (insert)

Tone-blending of initial, headpiece and text, 45

Emphasis of parts to be printed in light color, 46, 47

Display lines should match the border in tone, 48

Uniform tone by equal spacing, 49

PROPORTION, BALANCE AND

\section{SPACING}

Page 53

One method of determining the page length, 50

Another method, 51 
Three widths of type-faces, 52

Iype page in which vertical lines predominate, 53

An architectural comparison, 54

'The conventional page shape, 55

'Type page in which horizontal lines predominate, 56

An architectural comparison, 57

Page in which ornament, bordrer and typeface are in proportion, 58 (insert)

Pages in which the type-fite is not in proportion, 59, 60

Mismated type-faees and borders, 61

Vertical lines proper, 62 (insert)

Horizontal lines not suitable, $6: 3$

A display line surrounded by otleer type lines must be larger, 64, 65

Type proportionately too large, 66

'Type proportionately too small, 67

$\Lambda$ proportion that is about right, 68

Out-of-center balance on a card, 69

'Type grouped unusually high, 70

Exact center is too low, 71

The point of vertical balance, 72

An architectural example of out-of-eenter balance, 73

A disorderly arrangement, 74

An ornament that balances with the design, 75

Out-of-center balance on an announcement, 76

The effect of horizontal lines in a type page, and how it is avoided, 77,78

Spacing letters to obtain cren tone, 79

Emphasis obtained by letterspacing, 80

The obsolete practice of sprcading the lines over the page, 81

'The modern practice of grouping the typc lines, 82

\section{ORNAMEN'IA'TION}

\section{Page 59}

'The egg-and-dart ornament, 83

'The bead ornament, 8.4

The egg-and-dart ornament as a typographic border, 85

'The bead ornament as a typographic border, 86

Conventionalized papyrus plant, 87

The winged ball, 88

The acanthus leaf, 89

Palm-like Greek ornament, 90

The Doric pillar, 91

'The Ionic pillar, 92

The Corinthian pillar, $\mathbf{9 3}$

Ornamentation on an cntablature, 91

Square-lined, ornamentless furniture, 95

Square-lined, ornamentless ty pography, 96

Dainty, elaborate rococo ornament applied to furniture, 97

Similar treatment of a program titlc-page, 98 (insert)

Slightly ornamental furniturc, 99

Slightly ornamental typography, 100

Monotony and variety in strokes and shapes, 101, 102, 103, 104, 105

Roman architectural border and roman type-face, 106

Gothie pointed ornament and Gothic typeface, 107
Natural and conventionalized ornament, 108

Extravagant wall border ormamentation, 109

Roman scroll ornament cut in stone, 110

'Type ornament based upon geomctric lines, 111

'Type ornament based upon foliage, 112

Ornament based upon the inanimate, 113

Ornament based mpon the animate, 114

Ornamental hand-lettered effect, 115

Corner ornaments, from bolts on inscription plates, 116

Decoratoin from a manuscript book, 117

Filling blanks with ornamentation, 118

Semi-oruamental ceclesiastic style, 119

Initials of various kinds, 120

Simple ormamentation applied to letterhead, 121

Appropriate omamentation on a modern booklet, 122

Effect of alternating colors, 123

An omament based upon the animate, 121

'The significance of ornanentation applice, 125 (insert)

\section{THE TYPOGRAPHY OF BOOKS Page 6ry}

Two model specimens of book typography, 126,127 (insert)

'Title-page of a book of classic poems, 128

'Title-page with a ninetcenth-century motive, 129

'I'wo book pages inharmonionsly treated, 130,131

'Two pages, composite Colonial and modern, 132, 133

'Two pages constructed with care for detail, 13.4, 135

A text-pagc in modern roman, 136

$\Lambda$ text-page in old-style type-faces, 137

Title-page with an Italian motive, 138

Page from a children's book, 139

Ilarmony in tone of type-face and decoration, 140

A title-page of classic design, 111

Classic feeling in a modern title-page, 142 (insert)

'Text-page of a Royeroft volume, 14.3

'Text-page from a book by De Vinne, 141

'Two pages from a small ecclesiastical book, 145, 146

Gothic treatment of a book of poctry, 147

Title-page with a French motive, 148

BOOKIETS, PAMPIIETS, BROCIIURES, IEAFLETS

$$
\text { Page } 75
$$

'Title-page by Gondy, 119

'Two pages from leaflet in simple typography, 150, 151

'Ihrce casily-read pages by Sherbow, 152, 153,154

Two typographic leaflet pages, 155, 156

'Three pages in which rules are factors, $157,158,159$

I abel on a brilliant cover, 160

Admirable treatment for small anount of matter, 161
Adopting a photograph of wrong proportions, 162

'Two artistic pages frou type and rule, 163,164

Rear and front cover designs of unconventional booklet, 165,166

$\Lambda$ prospectus page by Bradley, 167

Dignified typographic beanty, 168, Iti9

I Iand-lettered cover page, 170

Representative page trom a commenturattion book, 171

Unconventional arrangcment of a booklet page, 172

\section{CATAIOGS}

Page 83

Page from an automobile catalog by cleland, 175

Unusual tratment of a page, 176

Architectural title treatment, $17 \%$

Effcetive results obtaincd in a simple way, 178,179

Inside page and cover of a publication catalog, 180,181

German poster type on a catalog, 182

Title-page and inside page of a museum catalog, 183, 181

Rules on a book catalog, 185

'Type matter prominently treated, 186

Unusual automobile catalog page, 187

Tabular rules in a wine list, 188

German wine-list treatment, 189

Title-page of an exhibit catalog, 190

Capitals and italic for deseriptions, 191

Page from a sewing-machine catalog, 192

An attractive background, 193

Artistic catalog treatment, 19.

'Tabular matter in a eatalog page, 195

\section{PROGRAMS}

Prige 91

Progratu cover-page in ecclesiastical style, 200 (insert)

Economizing space on a plogram, 201

Missal style of church program, 202

Classic treatment of a church program page, 203

Program page in semi-missal style, 204

Generous margins on a program, 205

A dance card, 206

Page from a booklet progran, 207

Unconventional treatment of a dance program, 208

Tle decorative border on a banquet program, 209

A halftone decorative background on a program, 210

A booklet progran, 211

'The banquet program in the form of a check book, 212

Inmorous treatment of titles and odd arrangement, 213

Suggestion for a menu page, introducing a bit of fun, 214 (insert)

A classic menu pagc, 215

Program used by master printers, 216

Dignificd style for menu page, 217

Treatment simulating woodcut decoration, 218 


\section{LIST OF REPRODUCTIONS}

The missal style adapted to a menu program, 219

Unique arrangement of a menu page, 220 Excellent typographic treatment, 221

Refined entertainment program page, 222 Two pages from an entertainment program, 223, 224

Program page in lower-case, 225

The decoration was in color, 226

Program in Gothic style, 227

A well-arranged page, 228

\section{ANNOUNCEMENTS} Page 99

Classic capitals combined with rules, 229 (insert)

Two pages from an announcement folder, 230, 231

Announcement in Colonial style, 232

Odd treatment of an announcement, 233

Announcement in poster art, 234, 235

Invitation based on inscription plate, 236

Ornaments as eye-attracters, 237

Postal-card announcement, 238

Good advertising typography, 239

An announcement, 240 (insert)

Announcement in two groups, 211

Study in tone values and margins, 212

Harmony of type and deeoration, 243

A brief announcement, $24 \mathrm{t}$

Colonial style of treatment, 245

Literal treatment in Colonial style, 246

Two pages froul an announcement cireu-

lar, $217,248$.

From a convention announcement, 249

Liberal leading of type lines, 250

I I r rmony in graty tones, 251

Blotter in rugged style, 25\%

\section{'I'ICKETS}

Page 10\%

Classic, refined treatment for art and litcrary purposes, 256

'The historic Gothic, or pointed style, 257 (inscrt)

Strong treatment, the motive of modern origin, 258 (insert)

A striking effect for the college student, 259 (insert)

Modern treatment based upon the Colonial, 260

Suggestion for course tickets, 261

Daintily appropriate in type-face and illustration, 262

The mission style applied to ticket composition, 263

The ecclesiastical or missal style well adapted, 264

Perhaps Morris would have set a ticket this way, 265

The medieval art worker furnished this motive, 266

Modern application of classic type effects, 267

Patterned after Colonial treatment of title-pages, 268

A dainty, refined effect suited to many occasions, 269

Robust treatment of an outing ticket, 270
The cab ornament dietated the type formation, 271

Treatment that should prevent easy counterfeiting, 272

Decoration suitable for the subject, 273

Arrangement with French motive, 274

\section{LETTERIEADS AND ENVELOPS}

\section{Page 111}

A large amount of copy conventionally treated, 275 (insert)

Small type for professional stationery, 276 (insert)

Church stationery of the conventional kind, 277 (insert)

A change in style of professional stationery, 278 (insert)

Elaborate border around letter sheet, 279

Symmetrical arrangement, 280

Squared effects, 281

Simple treatment of little copy, 282

Character in letterhead design, 283

Colonial rule border panel, 284

Advertising a meeting, 285

A woll-treated panel heading, 286

Suggestion of the ecclesiastic, 287

Three lines of equal length, 288

For the general store, 289

Treatment suggesting the business, 290

Novel and dignificd treatment, 291

A distinctive heading, 292

Decorative initials in heading, 293

Just a neat typographic arrangement, 294

Dignity in letterhead designing, 295

$A$ heading in two groups, 296

Uncommon distribution of color, 297

Double-panel treatinent, 298

Distinction in letterhead design, 299

An ornament with a touch of color, 300

A cross-lined panel, 301

A German idea, 302

Note-sheet typography, 303

Humor in a notchead, 304

Conventional treatment of an envelop corner, 305

Artistic envelop treatment, 306

Envelop eorner in text lettcr, 307

Harmony of device and typography treatinent, 308

Elaborate envelop eorner, 309

\section{BH.LIEADS AND STATEMENTS Paye 119}

Features of the average invoice, 310

Converting letterhead into billhead, 311

'The non-stock-ruled type of billhead, 312 (insert)

Italie lower-case and Roman capitals, 313 (insert)

Bilhead suggesting early printing, 314

Good taste on billheads, 315

Interesting border treatment, $\mathbf{3 1 6}$

Large setting of a billhead, $\mathbf{3 1 7}$

Invoice with many columns, 318

Decorative type treatment that is suitable, 319

An uncommon arrangement, 320

Credit bill made from billhead, 321

Professional bills, 322
PACKAGE LABELS

Page 123

Catching attention at a distance, 323 (insert)

Emphasizing daintiness and delicacy, 324 (insert)

Lettering for typographic study, 325

A label rich in suggestion, 326

Ruled line for the address, 327

Black lettering with contrasts, 328

Artistic quality thru typography, 329

Study in black and white, 330

A Caslon specimen, 331

Harmony of border and lettering, 332

Possible of typographic improvement, 333

Frecdom of treatinent, 334

Label used for a speeial list, 335

\section{BUSINESS CARDS}

Page 127

Standardizing the arrangement, 336

Dignified treatment for a well-known house, 337

Forceful card treatment, 338 (insert)

An unconventional effect, 339 (insert)

$A$ blaek monogram that is attractive, 340

(insert)

The monogram in color, 34

An uncommon typographic effect, 342

I igh-hat-ind-frock-eoat treatment, 343

Business card in bloeked capitals, $\mathbf{3 4 4}$

An underprinting decorative device, 315

Roman capitals with italic lower-case, 346

Modern German card treatment, 347

Decorative style suited to business, 318

ltalie is sometimes pleasing, 349

A strong design for special purposes, 350

Classic arrangement in one size, 351

A large amount of copy, 352

Highly deeorative, 353

Horizontal lines well employed, 354

For gencral purposes, 355

\section{THE BLOTTER}

Page 131

A model blotter, 356 (insert)

Modest amount of copy, 357

A convention-hall blotter, 358

Strong but pleasing contrasts, 359

Suggestive of an architectural panel, 360

Treatment that survives the test, 361

Neat, refined arrangement, 362

Type matter that fills the blotter, $\mathbf{3 6 3}$

A blotter arranged the narrow way, $\mathbf{3 6 4}$

Harmonizing typography, 365

\section{POSTERS, CAR CARDS, WINDOW CARDS}

Page 135

Typographic poster in Roman capitals, 366 (insert)

Lettered poster worthy of study, 367

A car card that has suggestion, 368

Little copy and strong contrasts, 369

Unique insurance advertising, 370

Simplicity worthy of adaptation, 371

Refined theatrical printing, $\mathbf{3 7 2}$ (insert) 
$\Lambda$ strong poster on plain lines, 373 (insert) Type treatment that suggests Franklin's time, 374.

Poster in Shakespearean typography, 375

Simple typographic treatment, $\mathbf{3 7 6}$

Colonial style on a window card, 377

Suggestion for an excursion card, 378

\section{ADVERTISEMENTS}

\section{Page 139}

Newspaper advertisement arranged without thought, 379

Easier to read and more pleasing to look at, 380

$\Lambda$ city department-store advertisement, 381 (insert)

The conversational style, $\mathbf{3 8 2}$

Name and trademark sell the goods, $\mathbf{3 8 3}$

One word thoroly advertised, 384

Interesting use of white space, 385

$\Lambda$ bordered advertisement, 386

Study in advertising values, $\mathbf{3 8}$ ?

Pictorial store advertisement, 388

The store name docs not appear, 389

Four country-newspaper advertisements, 390 (insert)

$\Lambda$ good-looking advertisement, 391

Suggested by building arehitecture, 392

$\Lambda$ long list of agents, 393

Planned to sell high-prieed cars, 39.

Roman lettering and architecture, 395

Uncommon plaeing of blank space, 396

Modest display of a magazine advertisement, 397

Blank space emphasizes illustration, 398

$\Lambda$ country-ncwspaper advertisement, 399

Classified advertisements, 400

\section{NEWSPAPERS}

\section{Page 147}

First number of America's first newspaper, 401

The first newspaper issued regularly, 402

Make-up of a suburban newspaper, 403 (insert)

Front-page make-up of a Hearst newspaper, 404

Same news story by the "Times," 405

A four-deck heading, 406

Sporting-page make-rp, 407

Pyramid make-up of advertisements, 408

\section{PERIODICALS

$$
\text { Page } 151
$$

Decorative treatment of a Thanksgiving number, 409 (insert)

Dignity in make-up and typography, 410

Samples of actual type matter, $410-\Lambda$, 422- $\Lambda, 421-\Lambda$

Typographieal harmony of heading and text, 411

Advertising the story to the readers, 412 Inserted feature panel, 4.13

Illustration separated from heading, 414

Headings and text in same face, 415

Use of a small illustration, 416

Box headings on editorial pages, 417

$\Lambda$ nother way to feature editorials, 418
Excellent editorial typography, 419

Use of rules on editorial page, 420

News photograph on front page, 421

Fine typographie make-up, 422

$\Lambda$ ttractive first text page, 423

Running around illustration, 424

Feature page of a Christınas number, 425

Convention feature of a trade journal, 426

News headings and make-up, 427

Conservative, readable editorial page, 428

Caslon headings and old-style text, 429

Caslon typography on a magazine, 430

Typography of a pocket magazinc, 431

\section{HOUSE-ORGANS}

$$
\text { Page } 161
$$

Two pages in Kennerley typography, 432 (insert)

Three pages from a quaintly-treated houseorgan, 433, 434, 435

Distinctive lettering and typography, 436

Interpolated paragraphs in italic, 437

$\Lambda$ house-organ in miniature, 438

Another on the same plan, 4.39

Attraetive rule treatment of headings, 4.10

Contents outlined on cover, 441

Simple, effective typography, 1.12

Dark-toned typography, 443

Suitable treatment for silverware, 4.4

Rubrieated typography on a house-organ, 445,446

Easily read and pleasingly illustrated, 447

A typographic house-organ, 448

Editorial page typographically neat, 449

Attractive use of rules and italic, 450

Elaborate house-organ title-page, 451

$\Lambda$ page in Cloister type, 452

Use of paragraph marks, 453

Good specimen of house-organ cover, 451

Blank space used to good advantage, 455

Cover of the "Philistine," 456

An "almanaek" feature, 457

Bodoni typography, 458

Cover of a small house-organ, 459

Suggestions for return post cards, 460, 461,462

\section{TYPE-F $\Lambda$ CES \\ Page 169}

Comparison of the same type forms on two finishes of paper, 463 (insert)

Roman alphabet from Trajan column, 464- $\Lambda$

Proportions of Roman capitals, 464-B

Fvolution of Roman lower-ease, $\mathbf{4 6 5}$

Two standard legible type-faces, 466

Six standard representative Roman typefaces, 467

'Types of Sweinheim and Pannartz, 468

Roman types of John and Wendelin of Spires, 469

Roman type-face of Nicholas Jenson, 470

Manuscript of the fifteenth century, 471

Type-face used by Paul Manutius, 472

Cloister Oldstyle as a Jenson title, 473

Type-faee nsed by National Printing Offiee, 474

Comparison of oldstyles, 475

Cheltenham Oldstyle in Plantin typography, 476
Type-faces used by Daniel Elzevir, 477

Roman types of Fournier, 478

Capital alphabet drawn by Moxon, 479

Moxon's lower-ease alphabet, 480

Moxon's alphabets inked in and reduced,

479- $A, 480-\Lambda$

Farliest Caslon specimen sheet, 481

Two slightly different faces to Caslon fonts, 482

Baskerville types, 483

Possible descent of Scotch Roman, 484

$\Lambda$ study in French Oldstyle, 485

Resetting in Bodoni Book, 486

Comparison of original Bodoni with present types, 487

Modern Roman of the ninetcenth century in three tones, 488

Modern Roman as used on newspapers, 489

Optical changes by adding serifs, 491

Differenees in serif construction, 492

Oldstyle ehanged to modern, 493

Modern changed to oldstyle, 494

Comparison of strokes, 495

Thiek and thin strokes in the alphabet, 490

Serifs and stroke contrasts, 497

Vertical thick strokes, 498

Diagonal thick strokes, $\mathbf{4 9 9}$

Heavy strokes in the letter "O," 500, 501

Letters with ascending and descending strokes, 502

Descending strokes long in lettering, 503

Cramped descenders and compressed ends, 504

Deseending and ascending numerals, 50.5

The space between words in good lettering, 506

Lower-case letters grouped according to formation, 507

Legibility and other qualities, 508

Sizes of type set to proper lengths, 509

$\Lambda$ seertaining the proper optical length,510

Moxon's Italie capitals of 1676,511

Italie lower-case of Moxon, 512

Resetting in Cloister types, 513

Decorated capitals or Swash letters, 514

Roman and Italic compared, 515

$\Lambda$ few representative Italic type-faees, 516

Complete Roman and Italic Caslon alphabets, 517

Text capitals of Moxon, 518

Text lower-case of Moxon, 519

Two standard German type-faces, 520

$\Lambda$ half-Gothic and half-Roman type, 521

Several represeutative Text types, 522

Block types, serifless and of one thickness of stroke, 523

Modern art poster type, $\mathbf{5 2 1}$

A bold-faee from French Oldstyle, 525

A few representative bold types, 526

Eightecnth-eentury ornamental types of Fournier, 527-A

Early nineteenth-century ornamental types of English founders, 527-B

liecent Anicrican types of the ornamental kind, 527-C

\section{IMPLI N'TS}

Page 195

The first "imprint," as found on Fust and Schoeffer's Psalter, 1457, 528-A (insert) 
Colophon and imprint by Peter Schwffer, I476, 528-B (insert)

The first inprint-device, and three adaptations, 529

Aldus's anchor and dolphin device, and adaptations by modern printers, 530

The most popular imprint-device as early used by printers, and modern intcrpretations, 531

Arms supposedly granted the Typothetx, German master printers, 532

The imprint-device of England's first printer, its probable derivation, and two notable deviecs evolved from it, 533

Two designs with ancient motifs, 534

The pun, as found in two ancient printers' marks, 535

Devices used by notable printers of the sixteenth and seventeenth ecnturies, 536
A printer's device and imprint that monopolizes two-thirds of the title-page, $536-\Lambda$

Colophon-imprint by D. B. Updike, 537

The Lion of St. Mark adapted to a book on Venetian life, 538

The Lion of St. Mark and its use by the Oswald Press, 5:39- $\Lambda$, 539-B

Robert Estienne's mark and Bruce Rogers's adaptation, 540

An appropriate mark for a printer, 5 k1

Use of oval shape in the designing of printers' marks, 512

Modcrn imprints suggested by ancient forms, 5.3

Printers' marks based upon architcetural Inotifs, 5.44

An imprint that has to do with mythology, 545
The monogram is an attractive form for printers' devices, $\mathbf{5 4 6}$

Representative of the large variety of devices in use by printers, 547

Decorative imprints constructed with typefounders' ornantents and suitable type-faces, $\mathbf{5 4 8}$

Type imprints and the various effects possible with them, 549

Quaint book-encling as used by Elbert Hubbard, 550

\section{APPENDIX HOLIDAY GREETINGS}

Reproductions of more than a hundred greetings, in various forms, received by the cditols of "Ihe American Printer."

\section{LIST OF DESIGNERS}

\section{PART ONE}

Aldus Manutius, 1.15

Barker, Christopher, p. 18

Bodoni, John Baptist, p. 26

Bradley, Will, "pp. p. 32, 33, 31

Caxton, Willian, p. 17

Daye, John, P. 18

Daye, Stephen, 1. 19

De Vinne, Theodore I.., p. 31

Franklin, Benjamin, p. 25

Fust and Schoffer, opp. p. 7

Gutenlerg, Johann, p. 12, opp. p. 12

Jacobi, Charles 'T., p. 33

Jenson, Nicholas, p. 14

Koburger, Anthony, p. 11

Mackellar, 'Thomas, p. 29

Morris, Williau, opp. p. 27

Newcomb, Thonas, opp. p. 19

Parker, Peter, p. :21

Plantin, Christopher, p. 16, 17

Rand, George C., and Avery, p. 29,30

Robcrts, James, p. 20

Scnsenschmidt, J., opp. p. 11

Thomas, Isaiah, 1. 28

Whittingham, Charles, p. 21, 32

\section{PART TWO \\ (Figures refor to the example numbers)}

Adams-Brander Company, 301

Advertisers Press, 300

Anger, Harry A., 121, 292, 296

Baker, William Henry, 155, 156, 239, 340, 457, 458, 462

Bartlctt-Orr Press, 335

Becker, August, 362

Beran, C. R., 207

Blanchard Press, 170

Bradley, Will, 62, $76,100,139,167,211$, $219,237,339,409,425,430$

Bradley, Willian Aspenwall, 141
Cadillac Printing Company, 187

Calkins \& Holden, 381

Cahumet Press, 211, 215

Capon, Charles R., 283, 311, 326, 454

Carr, Horace, 252, 361

Chasmar-Winchell Press, 195

Cleland, T. M., 49, 160, $175,176,188,233$, 250,39.4

Colonial Press, 136, 137

Cook Printing Company, 121

Cuoper, Frederick G., 338

Cooper, Oswald, 234, 235, 328

Corday \& Gross, 172, 295

Crittenden, Lce I., 204, 35

Currier, Everitt R., 230, 23I, 448

De Vinne Press, 217

De Vinne, Theodore I.., 11

Donglas, I ester, 1:23

Dunn, H. HI, 367

Dwiggins, Will, $17 \%, 435$

Fell Company, William F., 289, 325

Fleming \& Carnrick, 96

French, Gcorge, 126, 127, 291

Frommader, E. $\Lambda ., 363$

Gilliss, Watter, 183, 181, 410, 411

Glover, John, 304

Goudy, Frederic W., 112, 149, 170, 331, 366

Government Printshop, Berlin, 118

Gress, Fdinund G., 1, 2, 3, 1, 5, 6, 11, 12, $13,14,15,16,1 \%, 18,20,21,22,25,26$, $27-\Lambda, 28,30,31,35,36,37,38,39,46,18$, $58,64,65,68,69,82,85,86,106,107,115$, $116,119,168,169,171,200,205,208,214$, $218,220,240,242,243,246,256,257,258$, $259,260,261,262,263,261,265,266,267$, $268,269,270,271,272,273,274,276,277$, $278,282,285,287,289,291,307,310,313$, $316,317,319,322,323,324,329,330,336$, $337,343,345,348,352,355,356,357,358$, $361,365,372,373,374,375,376,377,378$, $391,393,399,400,415,416,426,427,428$, 438,439
Greenleaf, Ray, 308

Gress, Walter B., 346

Griffith-Stillings Press, 210, 213, 443

Haime, Harry, 221

Hall-'Taylor Company, 193, 393

lleintzemann Press, 45, 281

Jacobson, E. G., 165, 166

Kehler, J, HI., 40

Kleukens, F. W., 32

Lang, Fred S., 226

Leader, Lcon I., 288, 297

Lewis, Barnard J., 157, 158, 159

Mackay, $\Lambda$. F., 232, 244

Marchbanks Press, 150, 151, 331, 460, 461

Matthews-Northrup Works, 125, 178, 179, 192

Munder-Thomson Company, I22

Nasli, J. H., 131, 135, 147, 185, 279, 442, $450,1.51$

Neal Press, 306

Nelson, Arthur, 138, 249, 281, 28i, 290, 440 Peahody, Charles Edward, 342

Radcliffe, B. Walter, 360

Rogers, Bruce, 43, 128, 129, 148, 223, 224, 4.9-B, 451

Roycroft Shop, 14:3, 456

Sehool of Printing, Boston, 42, 75, 335

Seaver-Howland Press, 4:33, 434.

Sherbow, Ben jamin, 152, 153, 236, 238, 247, $248,380,412,413,414,420$

Snith Company, Eugene, 452

Stetson Press, 225, 228

Stillson Company, Robert L., 186

Stutes, Edward W., 206, 350

Taft, Henry D., 353

'Tapley Company, J. F., 344

Taylor \& Taylor, 16:3, 164, 194, 445, 446

'Trow Press, 140

University Press, 41

Updike, D. B., 70, 145, 146, 180, 181, 190, 191, 203, 215, 222, 227, 303, 314, 315

Warde Press, 447

Winchell, Edward Everett, 161, 162, 209 
PART ONE 



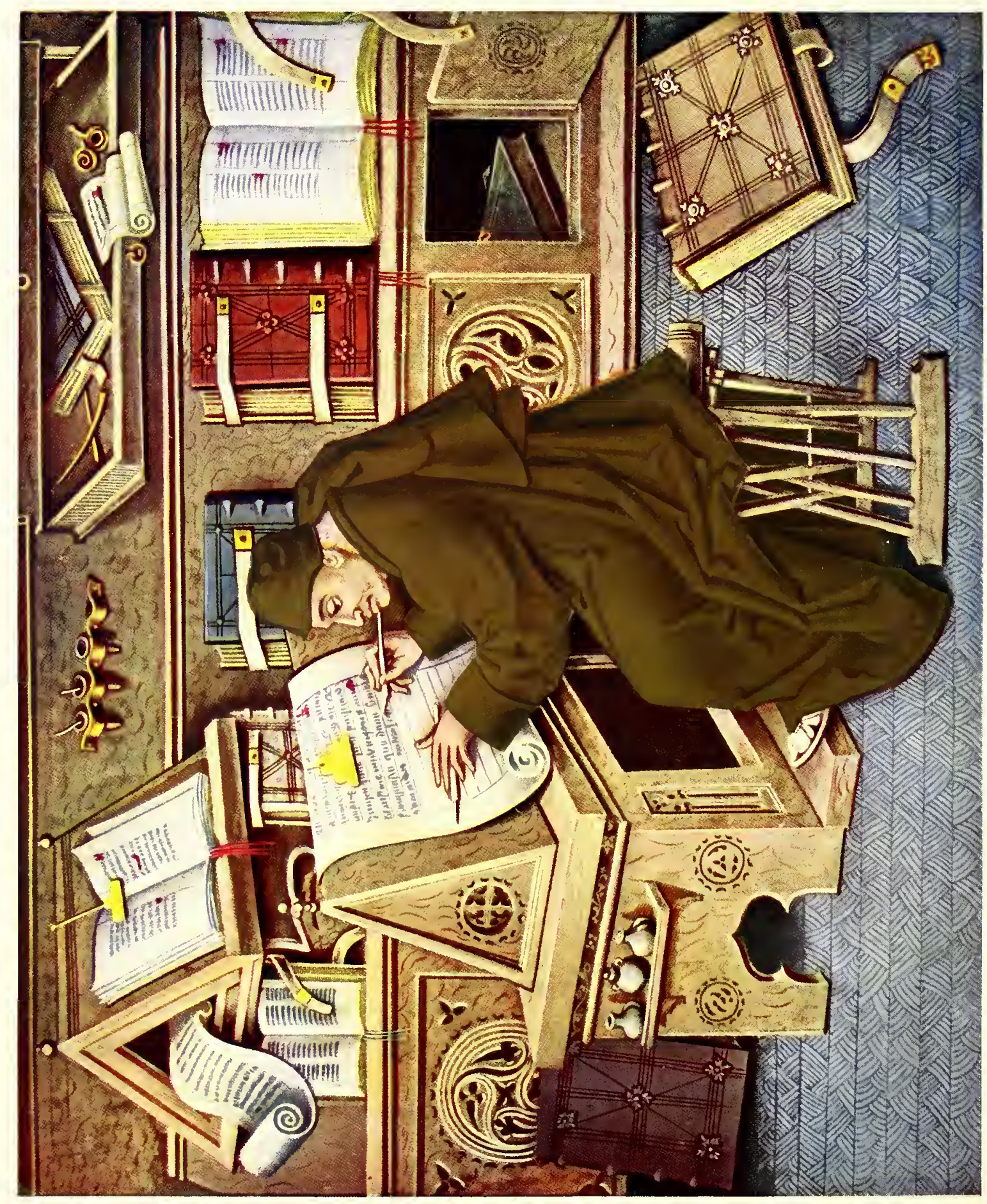

$r$ 


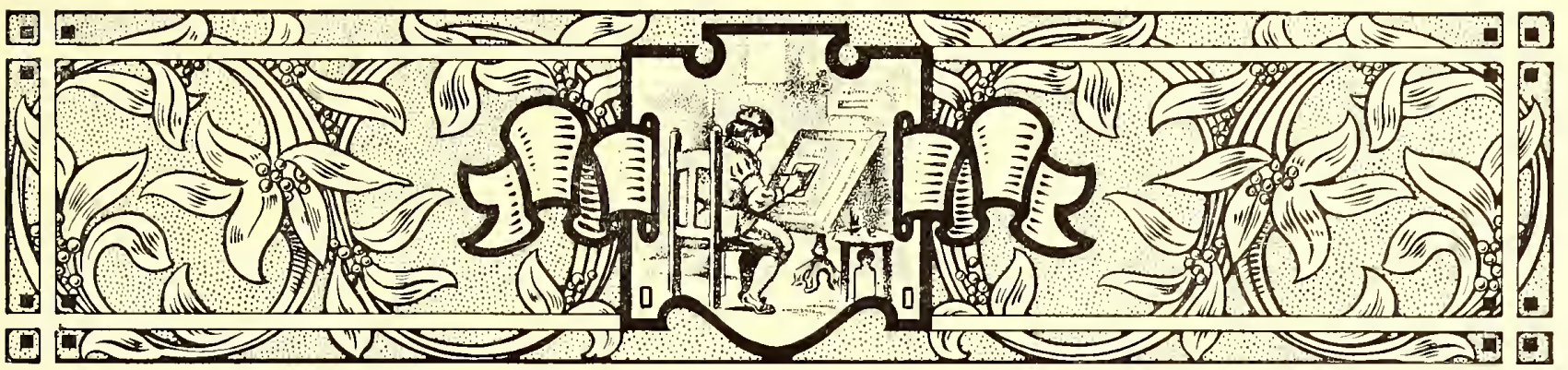

\section{WHEN BOOKS WERE WRITTEN}

TO MANY persons the words "Printing" and "Typography" are synonymous. The Standard dictionary, in its leading definition of the word "Printer," says: "One engaged in the trade of typographical printing; one who sets type or runs a printing press; specifically a compositor."

But in these days there are so many kinds of printers (lithographic printers, steel- and copper-plate printers, linotype printers, textile printers, etc.) that to define the sort of printer who does lis work witli type the use of the adjective "typographic" is necessary.

The word "typography" is derived from the Greek typos, or type; and graphe, or writing-type-writing. Typography, then, as I shall use it, means printing from movable, or separate, types.

The origin of typography may be open to dispute, but it is an undeniable fact that the art of printing with separate types was practiced at Mainz, Germany, during the years 1450-1455, and from there spread over Europe.

Before that period books were written by hand or printed from crudely engraved blocks of wood.

The thousand years preceding the invention of printing (the fifth to the fifteenth century) are known in history as the Middle Ages, and the first six centuries of this period (the fifth to the eleventh) are called the Dark Ages, because during those years civilization in Europe relapsed into semi-barbarism, and scientific, artistic and literary pursuits were almost entirely abandoned.

Latin had been the language of intellectual Europe up to the time of the fall of Rome $(476$ A.D. $)$ and one of the influences that led up to this benighted period was that Southern Europe was overrun by so-called barbarians from Germania in the north-the Angles and Saxons, who settled in Britain; the Franks, Burgundians and Goths, who settled in Gaul (now France) and Germany; the Vandals who settled in Spain, and the Lombards, who settled in Italy.

In Italy, Spain and Gaul the Latin-speaking natives far outnumbered the invaders, and the Germanic conquerors were forced to learn something of Latin. The present languages of those countries are the result of that attempt. The language of the Germanic Angles and Saxons was used in Britain after their invasion of that country, but was modified by the French-speaking Normans who conquered England in the eleventh century. Thus Latin as a common language died.

Altho dead to most of the population of Europe, Latin was made the oflicial language of the Christian church, and, during that period of the Middle Ages when French, Spanish, Italian and English were in a state of evolution, it afforded a means of keeping alive in written books the knowledge the world had gained before the dark curtain of ignorance was rung down.
Manuscript books are so-called from the Latin words mamu scripti, meaning "written by hand," and the initials of these two Latin words are frequently used for the word manuscript, i.e., "MS."

The materials upon which books were written liave at various times been clay, stone, wood, lead, skin, papyrus and paper.

Looking back six thousand years to the beginning of recorded time we find the Chaldeans (Babylonians and Assyrians) writing arrow-shaped claracters with a sharp

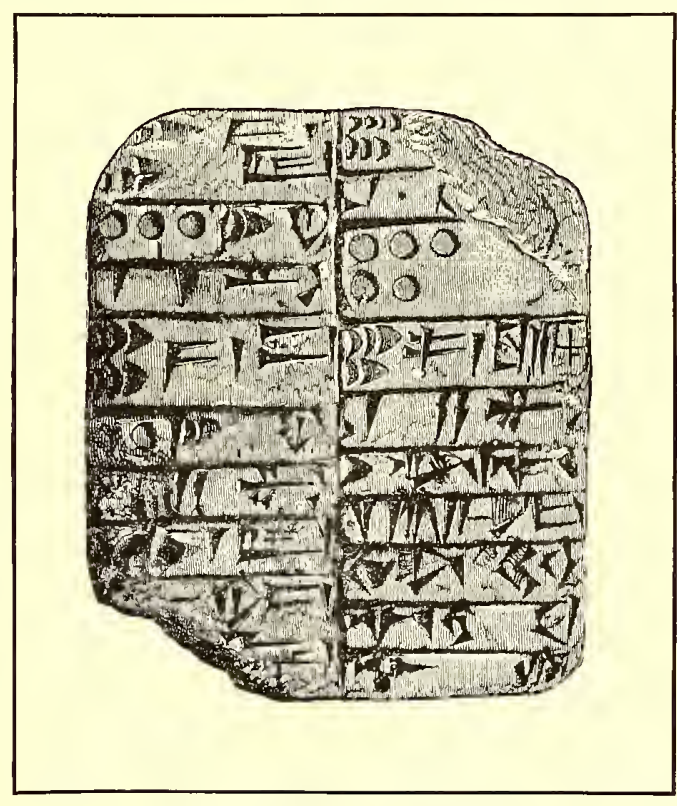

ASSYRIAN CLAY TABLET

Showing the cuneiform (arrow-shaped) writing

tri-pointed instrument upon damp clay, which was then made permanent by baking. In 1845 a library of baked clay tablets was discovered among the ruins of Nineveh. Thousands of these tablets have been collected in the British Museum, the most interesting of which is one which had been broken in eighteen pieces, containing an account of the Flood.

Twenty-five hundred years before the Christian era, when the great pyramids were being built, the Egyptians wrote upon papyrus, a plant growing on the banks of the Nile. The inner portion of the plant was stripped, the strips laid across each other, pressed and dried. The squares of material thus made were then joined together to form a long strip which was rolled around a rod

Upon papyrus is written one of the oldest "books" in the world, "The Book of the Dead," now in the British Museum. This is a literary work of a semi-sacred character, and copies were placed in the tombs with deceased 
Egyptians, whence its name. A reproduction of a portion of this book is given on page three.

Supposedly under the patronage of the Egyptian ruler, Rameses II., about thirteen hundred years before Christ, many books on religion, law, medicine and other subjects were written, and a great library was accumulated.

The Chinese wrote with a stylus or brush upon tablets of bamboo fiber. It is impossible accurately to determine the antiquity of Chinese methods, as the extravagant and often unsubstantiated claims of historians ant edate those of modern discovery. Ink, paper, and printing from blocks were all supposedly invented by the Chinese early in the Christian era, and even the first use of separate types is credited to $\mathrm{Pi}$-Shing, a Chinese blacksmith. It may be relevant to suggest that the old-time "blacksmith" joke and the printing-term " $\mathrm{pi}^{\mathrm{i}}$ " are derived from this source.

Dressed skins and palm leaves were used by the Hindoos, and writings in Sanscrit were probably done in the temples by the Brahmins, the priests and philosophers of early India. The Vedas, sacred writings as old as 2000 B. C., formed a big portion of the Hindoo literature.

The Hebrews wrote upon stones and animal skins. In this manner they preserved the Old Testament portion of the Bible, and gave to posterity one of the most wonderful books ever written.

The ancient Phønicians were commercial people, and being such did very little in producing literature; yet it is to them that we owe the present Roman alphabet. The illustration on a following page shows how this transition probably came about. There is a slight resemblance between some of the twenty-one characters in the Phonician alphabet and certain picture writings of the Egyptians, whose hieroglyphic alphabet consisted of several hundred characters and was as cumbersome as is the Chinese alphabet with its several thousand characters.

The Greeks received their alphabet directly from the Phœnicians, there being a tradition that one Cadmus introduced it into Greece. Some writers claim that "Cadmus" merely sionifies "the Last" and does not refer to an individual. The names of the first two letters of the Greek alphabet, Alpha and Beta, are similar to these of many other languages, and the word "alphabet" is derived from these two words.

In Greece, especially at Athens, before manuscripts became numerous, lectures and public readings were important features of intellectual life.

'The poems of Homer, supposed to have been composed about 880 B.c., were not put into writing until 560 в.c., and during this period of more than three hundred years they were retained in the memory of bards, by whom they were sung or recited.

"Plutarch's Lives," one of the best known Greek literary works, was written in the second century, A.D.

The Greek nation is generally acknowledged to have been one of the most intellectual of ancient times, yet it is a peculiar fact that only the boys were given an education, the intellectual development of women being considered unnecessary.

Copying of manuscripts was often a labor of love. Demosthenes, the great philosopher, is said to have transcribed with his own hands the eight books of Thucydides on the history of the Feloponnesian War.

Many of the Greek manuscripts were written by scribes and copyists who were slaves, and some of these slaves developed much talent of a literary kind.

The Greeks imported papyrus as a writing material, until one of the Ptolemies, in the interests of the Alexandrian library, decreed that no papyrus should go out of Egypt. This led to the development of parchment, so named from the city of Pergamus, where it was first made. Parchment is the skin of calves, goats or sheep, cleaned and smootlied.

In the days of militant Greece, Alexander the Great conquered Egypt, and in the year 332 B.c. founded Alexandria. When at his death Alexander's empire was di ided among his generals, Eigypt fell to the lot of Ptolemy, surnamed Soter. Thus began a dynasty of Egyptian kings known as Ptolemies, ending in 30 B.c. with the death of Cleopatra, the last of the line. The second Ptolemy, surnamed Philadelphus, founded the great Alexandrian library, which accumulated over five hundred thousand rolls of manuscript, mostly brought from Greece. The length of the rolls varied from small ones of two hundred lines to massive scrolls of one hundred and fifty feet when unwound.

There is a legend that Ptolemy Philadelphus was so impressed with the appearance of a roll of parchment containing in gold letters the sacred scriptures of the $\mathrm{He}$ brews, that, about 270 B.c., he caused their translation to be made into Greek. This, it is said, was done in Alexandria in seventy-two days by seventy-two learned

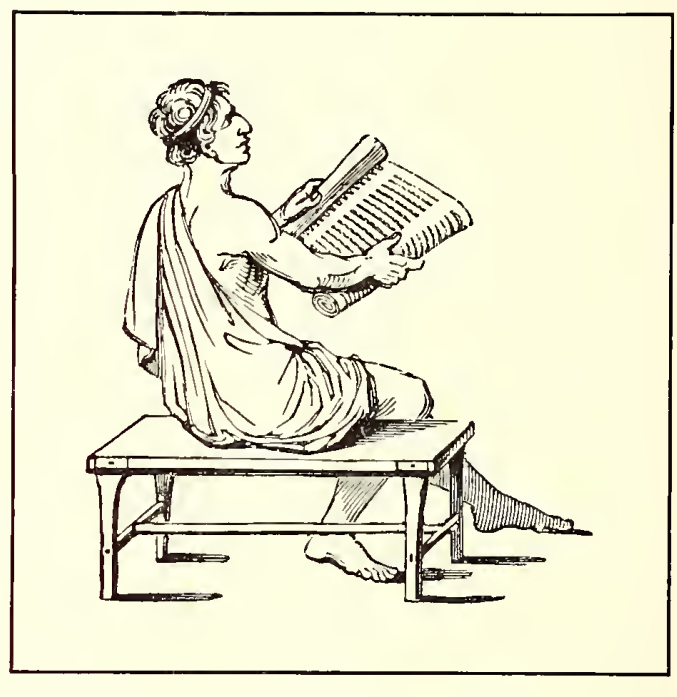

ANCIENT ROMAN READING A MANUSCRIPT ROLL From a painting found at Pompeii

Jews from Jerusalem. Hence the name "Septuagint," which has alwars been applied to that Greek version of the Old Testament.

Julius Cesar, the Roman conqueror, whom Shakespeare designated "the foremost man of all this world," about the year 30 в.c. visited the city of Alexandria and became interested in Cleopatra, the Egyptian queen. This led to a war with King Ptolemy, and during a fierce battle Cæsar set fire to the Egyptian fleet. Unfortunately the flames extended to the Alexandrian library and destroyed the greater part of its magnificent collection of manuseripts.

Gradually after that, Rome superseded Alexandria as an intellectual center, as Alexandria had previously superseded Athens. The conquest of Greece, over a hundred years before, had been the cause of many Greek scholars and philosophers taking up their abode in Rome. This, with the fact that a great number of scribes and copyists had involuntarily come to the Eternal City because of the fortunes of war, helped to develop in the Romans an interest in literature.

During the period of Roman history identified with Julius Cæsar there were customs in manuscript making that are interesting in their suggestion of modern newspaper methods. In fact, Cæsar is credited with having been the founder of the newspaper. 
He introduced the daily publication of the news of the Roman Senate and People, a radical change from the previous custom of issuing yearly news-letters known as the Annals. The acts of the senate were reported by trained writers known as tabularii, or inscribers of tablets, and were revised and edited before publication by a senator appointed to that duty. Abbreviated forms of writing were used in "reporting," a sort of short-hand which enabled the scribe to write as rapidly as a man could speak. Cæsar himself wrote his letters in characters which prevented them being read by his enemies.

The "Acts of the Senate" grew into a diary of general news, known as the "Acts of the City," and it is likely

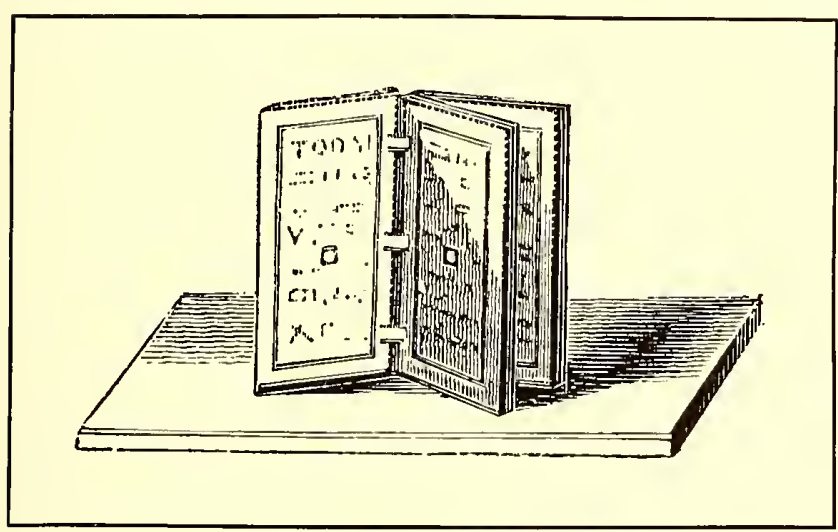

\begin{abstract}
ROMAN WAXED TABLET
The present method of binding flat books might have originated with these old tablets
\end{abstract}

that the educated slaves in the families of public men were called into service to duplicate copies for circulation.

Altho the Emperor Augustus, who reigned in Rome at the beginning of the Christian era, discontinued publishing the Acts of the Senate, he encouraged the writing and copying of books to such extent that the period is a memorable one in literature. The classic authors, Virgil and Horace, wrote at that time, and many other important manuscripts were produced.

Slave labor was utilized for copying, and large editions of manuscript rolls were produced with an ease that rivaled the later method of the printing press. In such instances it was the custom for a reader to read aloud, to, say, one hundred trained writers. The possibilities of this process may be imagined. Horace allowed his slaves rations which were so meager that the entire cost of production, including papyrus and binding, of a small book was equivalent to about twelve cents in United States coin.

Thus it will be seen that in the days of the Roman Empire books were plentiful and cheap because of slave labor, just as they are cheap in modern times because of machinery.

For most of their books the Romans, as had the Egyptians and Greeks before them, used rolls of papyrus wound about rods. Ordinarily these rods were made of wood, but for highly-prized manuscripts, rods made of ivory with gold balls at the ends were used, and the writing in such cases was on purple-colored parchment, elaborately decorated with gold or red ink.

The present style of flat sheet books might have originated with the use by the Romans of tablets of wood or metal, wax- coated, on which memoranda were scratched with the stylus. Several tablets were hinged together and the wax surface was protected by raised edges in the manner of the modern school slates (see illustration). This led to the use of several leaves of vellum fastened together and enclosed by richly carved ivory covers, a form that came into use about 300 A.D., shortly before Constantine removed the Roman capital to Constantinople. Constantinople naturally became the center of civilization, and the work of transcribing manuscripts was taken up in that city. In the eighth century the reigning emperor, in order to punish the transcribers for insubordination, caused the library at Constantinople to be "surrounded by vast piles of fagots, which being fired at a given signal, the whole building was totally destroyed, along with its twelve scribes and chief librarian and more than thirty thousand volumes of precious manuscripts." It seems to have been a favorite method of punishment during the Middle Ages for those in authority to destroy valuable manuscripts.

While, as we have seen, with the fall of the Western Empire of Rome, the drift of literature was toward the East, there remained in the West a dim light that was kept burning thru the six hundred years so fittingly called the Dark Ages. This light came from the monasteries of Europe, in which little bands of devoted men were transcribing and decorating the holy writings used by the Christian church.

The Christian church as an organization became powerful after the Roman Empire declined, and the monopoly of learning which the church possessed during the Dark Ages gave it such a superior knowledge and power that the Church of Rome granted authority to kings, and took it away, at its pleasure. A memorable instance of this power took place in the eleventh century, when Hildebrand, who as head of the church was known as Pope Gregory VIf., forced Henry IV. of Germany, who had

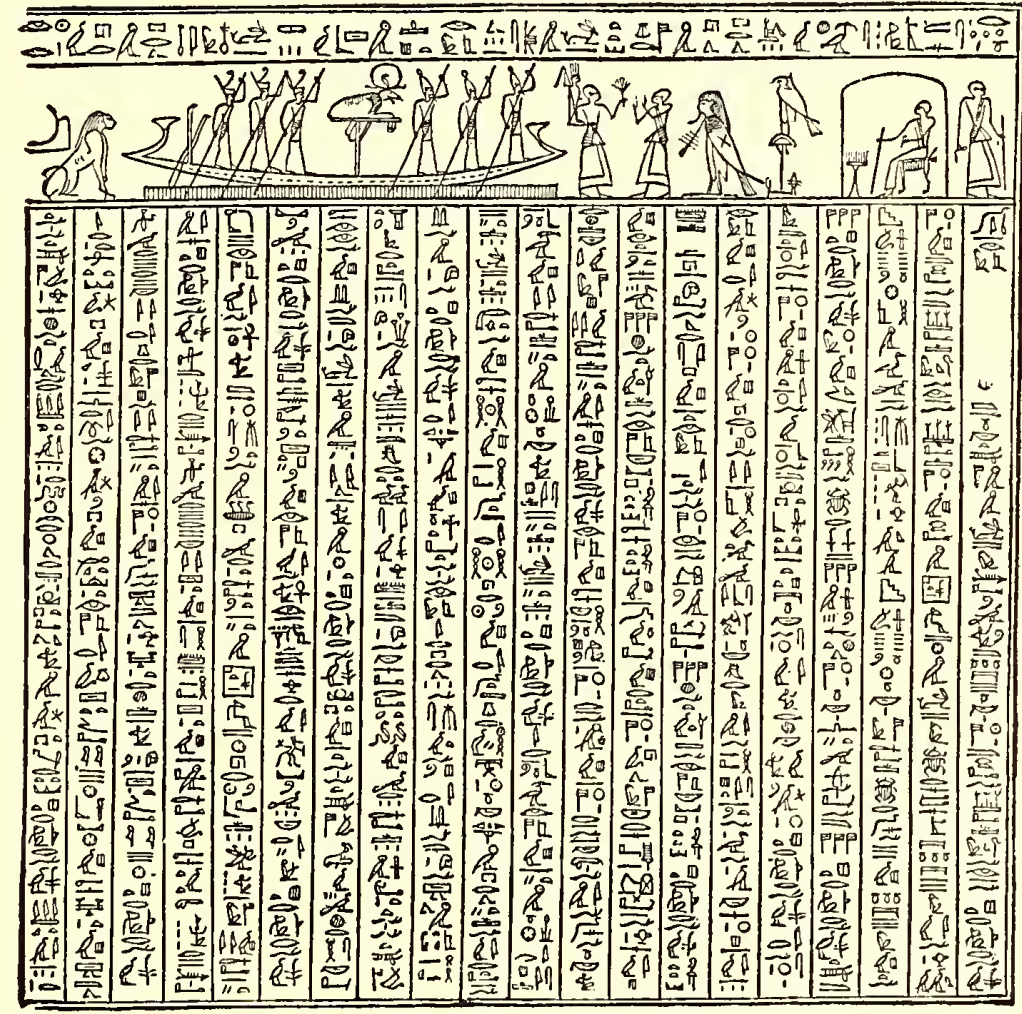

THE FAMOUS "BOOK OF THE DEAD"

Part of the seventeenth chapter of the "Book of the Dead," showing hieroglyphics and illustrations. This book was written upon papyrus, and copies were placed by ancient Egyptians in tombs with their dead 
offended him, to seek pardon in a most humiliating manner. Henry stood barefoot in the snow for three days, before Hildebrand would pardon him.

On one occasion previous to the event mentioned above, Charlemagne (Charles the Great), king of the Franks, who was crowned by Pope Leo III. and saluted as Emperor of the West, was so mistakenly zealous in

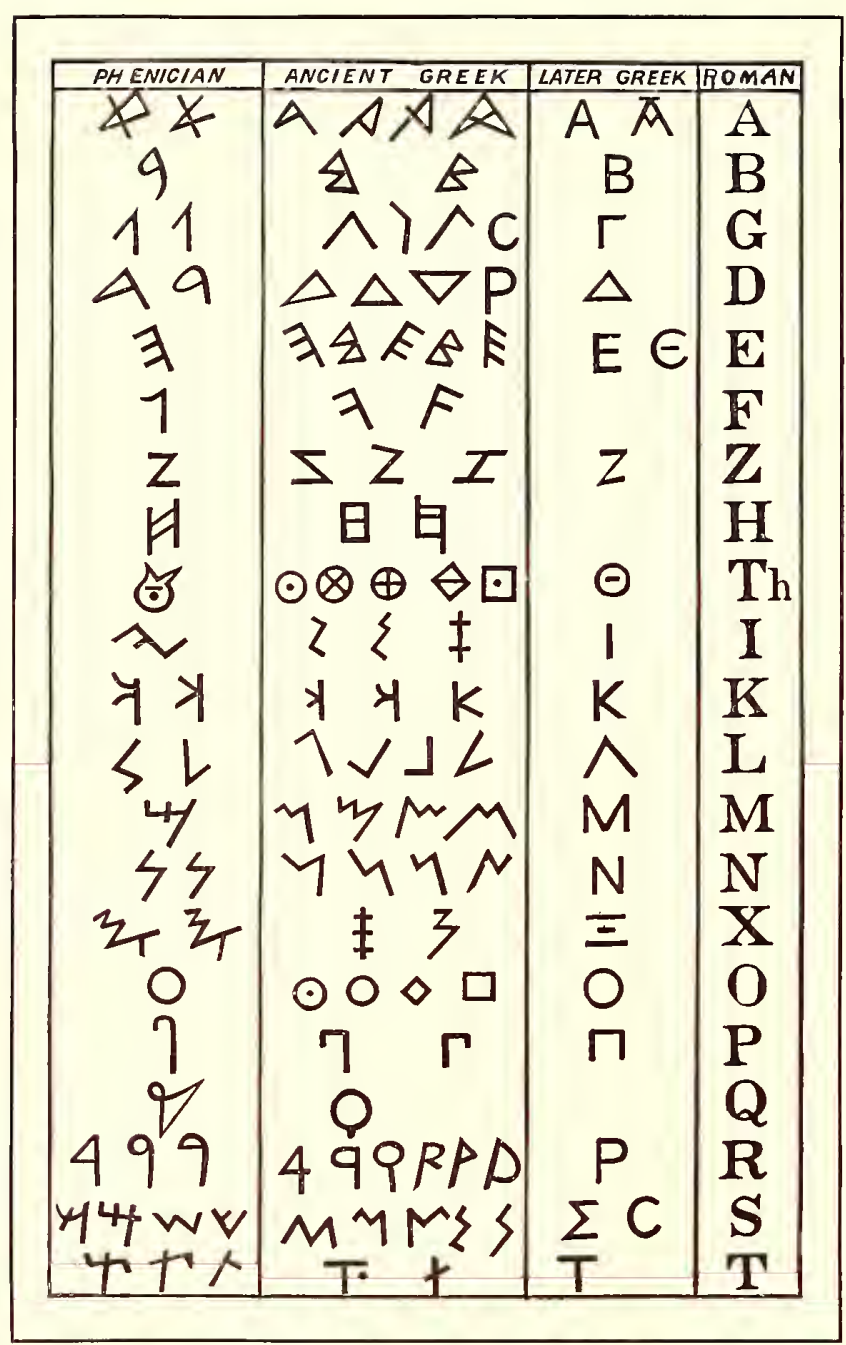

EVOLUTION OF THE ALPHABET

This table shows how the present-day Roman

alphabet came to us from the ancient Phoenicians

extending along with hisown kingdom that of the Lowly Nazarene, that he ordered the hanging of more than four thousand prisoners before the Saxons would consent to be baptized and conquered.

Latin as a language is dead, so far as the secular world is concerned, but since the seventh century it has been the official language of the Church of Rome. All manuscripts produced by monks after that time, whether written in Britain, Germany or Italy, are in Latin, and the services of the Roman Catholic Church are conducted in that language even today. In the year 1080, the King of Bohemia asked Hildebrand, the Papal head of the church, for permission to have the services performed in the language of the people. This request Hildebrand refused, saying: "It is the will of God that his word should be hidden, lest it should be despised if read by every one."

In 1229 a council of the church published a decree whicle not only strictly forbade the translation of the Bible into a "vulgar tongue," but also forbade all but the clergy to have copies in their possession.

In spite of these mandates, translations of various portions of the Bible were made into common tongues, but at great risk. William Ty ndale set about to translate the Bible into English, vowing that ere many years he would cause the plough-boy to know more of the Scriptures than did the priests. By 1526 he had completed the New Testament, but his books were burned in the public squares as soon as completed. Ten years later Tyndale was burned, as had been his books.

In 1534 Martin Luther completed his wonderful translation into German of the entire Bible, and gave to the people what had previously been denied them.

We will now consider the making of manuscript books in the Middle Ages. In the early days of the Christian church, persecution was so severe that Christians lived in hiding, or secluded themselves from the outer world to worship. This condition led to the existence of a class of men known as monks (from a Greek word monos, meaning "alone"). At the beginning of the sixth century, an earnest, conscientious Christian, now called Saint Benedict, set out to reform the evils then prevalent in monastic life. One of his theories was that the monks should spend their time, not in idleness, but in manual labor, in teaching the youth, and in copying manuscripts. The Benedictine monks, as the followers of Benedict are known, were the main agents in spreading Christianity and keeping learning alive during the Dark Ages. Their mode of living became so popular that, it is said, there were at one time thirty-seven thousand monasteries or cloisters in existence.

One of the occupations of the Benedictine monks was that of copying manuscripts, and in some monasteries a room known as the scriptorium was set apart for such work. The office of scribe or copyist was one of great importance, and stringent rules governed the work. No

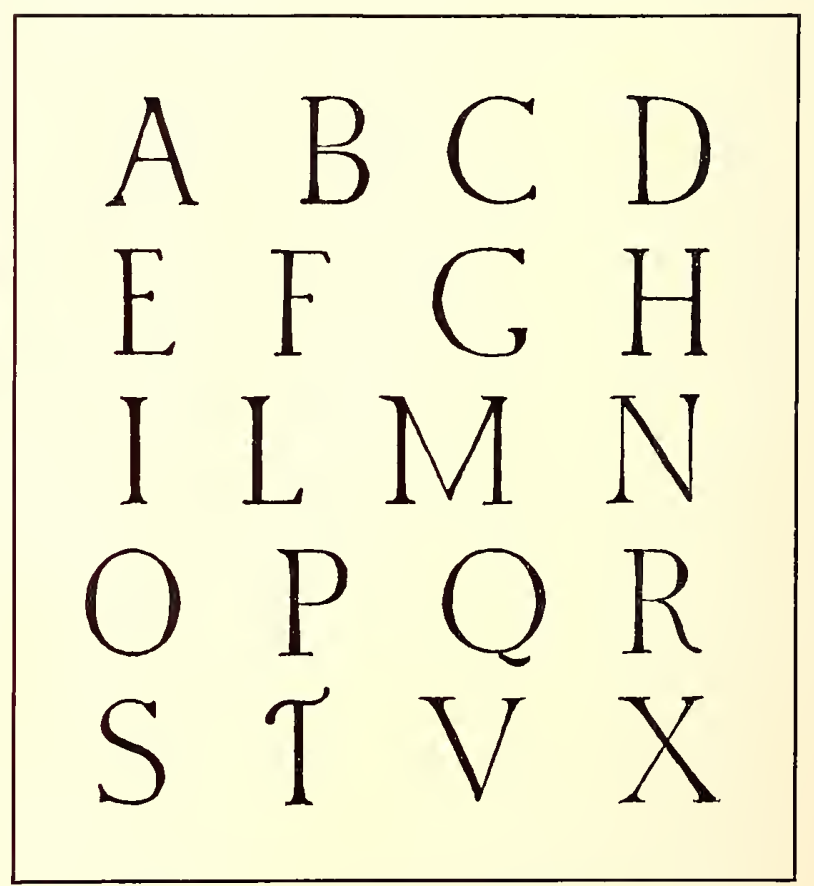

CAPITAL LETTERS OF THE ANCIENT ROMANS From inscriptions carved in stone

writing was done by artificial light, talking was prohibited, and none but the scribes was allowed in the room. The tools were quill pens, knives to cut the quills, pumice stone to smooth the surface of the parchment, awls and rulers with which to make guide-lines, and weights to keep down the pages. Parchment and vellum, the former made of the skins of calves, goats or sheep, the 
latter of the skins of unborn lambs and kids, were the materials written upon. Black ink was commonly used for the text of books; and vermilion, an orange-red ink made of red clay, was used for titles and important parts of the text. The portions in red were known as rubrics, from rubrica (red earth.)

llluminating was done to some extent in the monasteries, but illuminators other than monks were often called upon to assist in this work. This practice led to queer combinations, as sacred writings were frequently

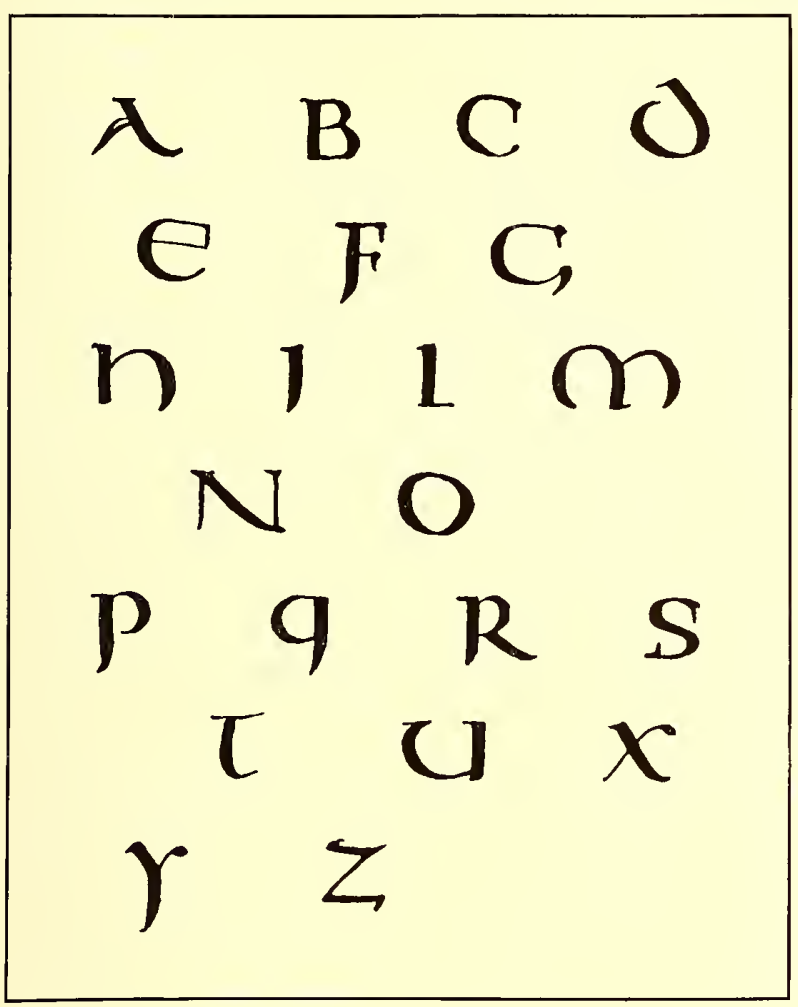

UNCIAL LETTERS OF THE SIXTH CENTURY

These letters show the Roman capitals assuming the shape of the later Gothic, or text, letters

decorated with monkeys and other animals and birds, which might have afforded appropriate decoration for an account of the Flood.

After the parchment was prepared and before beginning to write the scribe would scratch his guide-lines upon it with an awl. The position of the page and the lines of lettering were thus indicated, the page guide-lines extending to the edge of the parchment. The scribe's work was principally that of copying (setting reprint, printers would say) from a book on the reading desk at his side. He was supposed strictly to "follow copy," and his work was compared occasionally by a person known as a corrector. The black writing finished, the skins were passed to the rubricator or illuminator, if the manuscript was to be elaborately treated.

The colored plate shown as a frontispiece is from an old print and pictures a scribe at work. He is writing the text on a sheet of parchment held in place by a weight. The book from which he is copying is in front of him, above his writing desk, and his copy is indicated by a guide such as printers still use. Ink pots and pens are in place and an elaborate library is evidently at his disposal. The picture

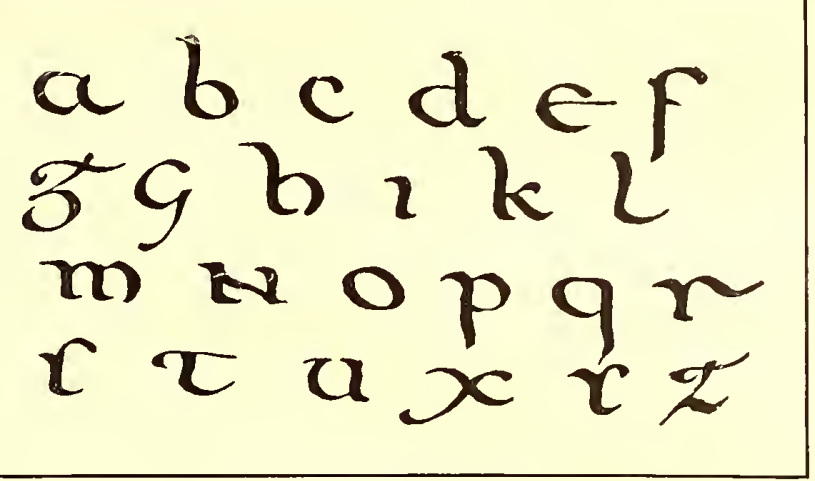

HALF-UNCIAL LETTERS
Demonstrating the transition of Roman
capitals into small, or lower-case, letters

is defective in perspective but is withal rather interesting.

The most beautiful and elaborate specimen of the illuminator's art now in existence is the famous "Book of Kells," a copy of the Gospels written about the seventh century. 1t is notable because of the excellence of its decoration, the endless variety of initial letters it contains, and the careful lettering. The scribes and illuminators of Ireland have a lasting monument in this book, as it is supposed to have been produced in the monastery of Kells, founded by St. Colombo.

Gold, red and blue were tavorites with the illuminators, the burnished gold leat' adding richness to the brilliancy of the effect.

Manuscript books were ordinarily bound in thick wooden boards, covered with leather, but there are books yet preserved the boards of which are of carved ivory, and others that are inlaid with precious stones.

The books associated with the Middle Ages most familiar to us are the Missal (mass-book), containing the services of the celebration of the mass; the Psalter (book of psalms), containing the psalms used in church services: the Book of Hours, containing prayers and offices for the several hours of the day, and the Donatus, a short Latin grammar, the work of Elius Donatus, a Roman grammarian of the fourth century.

When printing was invented the first types used were imitations of the current Gothic lettering, known to us as Black Letter, Old English, etc. A few years later, when typography was introduced into Italy, the types

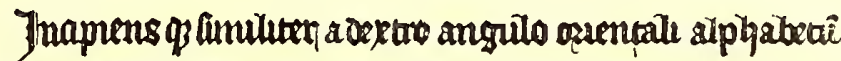

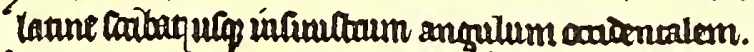

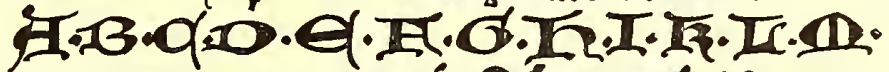

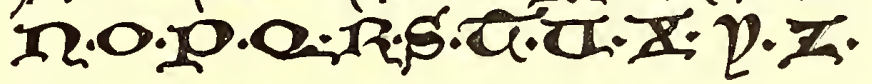

\section{Ythud pontricale feat carlbi on is laurentus Epitropus amtufiopozentis ozounis fratum

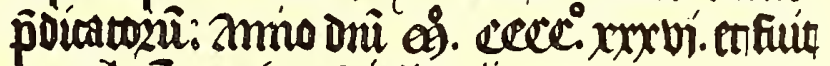 completầ quinta dié Junì:}

GOTHIC LETTERS OF THE FIFTH CENTURY

Also showing the decorative uncial-like initials used on manuscript Missals 
were cut in imitation of the lettering selected for use by the scribes of the Italian Renaissance, which lettering is familiarly known in our time as Roman. The capitals of this Roman lettering are fashioned after those used in ancient Rome, and the small or lower-case letters are after the Roman writing known as minuscule, of the twelfth century.

The ancient Roman writing was all capitals, and as found on stamps and coins was of the character of the modern so-called "gothic" (plain strokes, without the small cross strokes known as serifs). The more carefully made Roman capitals, as carved on monuments and buildings, are not unlike the present type-faces known as Caslon and French old style.

The evolution of Roman capitals into the small or lower-case letters of the present day is traced in the writing called uncial, in which the letters A, D, E, H, $\mathrm{M}, \mathrm{Q}$ are rounded and altered in appearance. More changes developed the writing known as half-uncial, in which only the $\mathrm{N}$ and $\mathrm{F}$ retain the appearance of
Roman capitals. The small (lower-case) letters became known as minuscule, as contrasted with majuscule, or capital letters. (See reproductions on preceding pages.)

From this point book writing developed in two directions: one toward the heavy pointed stroke of the churchly Gothic style, and the other, guided by Charlemagne in the eighth century, to the style of Roman letter used by Jenson and other printers of Venice, Italy, in their classic printing of the fifteenth century. Our old-style Roman types are from this source.

Another style, called cursive, was the carelessly ex ecuted handwriting used for ordinary purposes, and in that respect may be likened to our own business seript.

Thus as the fifteenth century dawned upon Europe we find literature and learning locked in the cells of the monks, while outside, the hosts of people who for ten centuries wandered in semi-darkness had reached an elevation which showed them a new existence coming with the intellectual awakening that was then already upon them.

GaIR Jokgodhaguoo nominccurr.

colluarioce-loous

Doclerunc eibibare unumag

nolur bibere $\rightarrow$ :

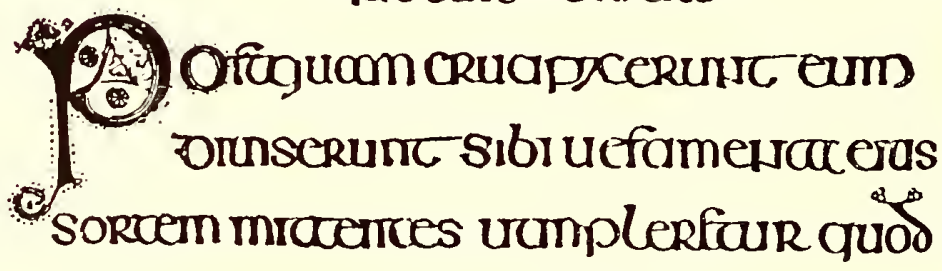
chcaum esc perpororftam chicertcem Orunseruruc sibr uefameqrac meac.; Qbsuperuescem meam misserup sorcom t a sedesces seruabourcegf

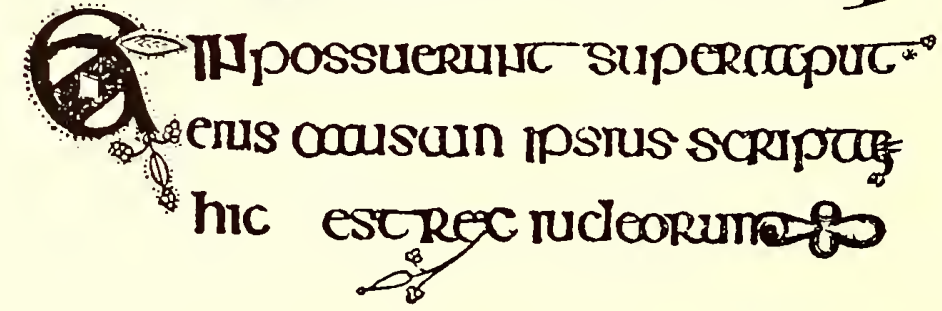



8)

$\infty$

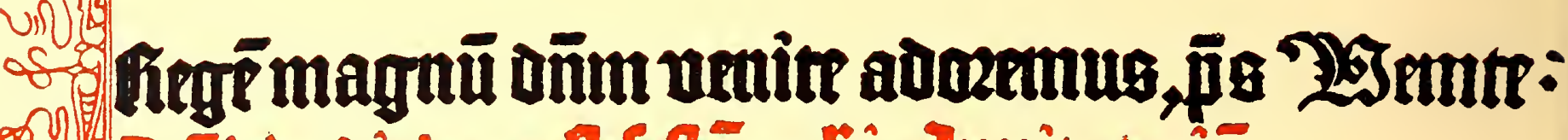

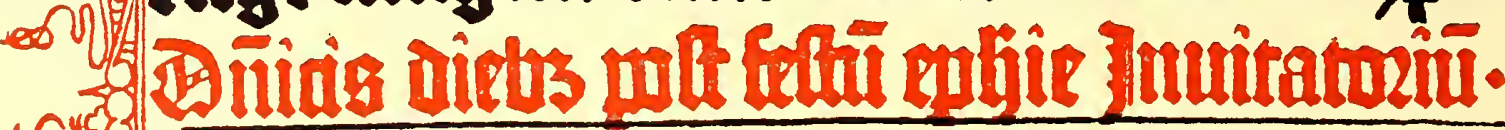

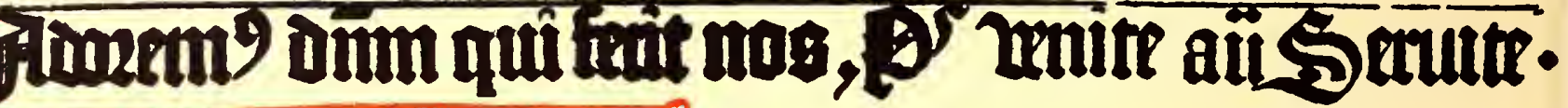

(i)

1. W

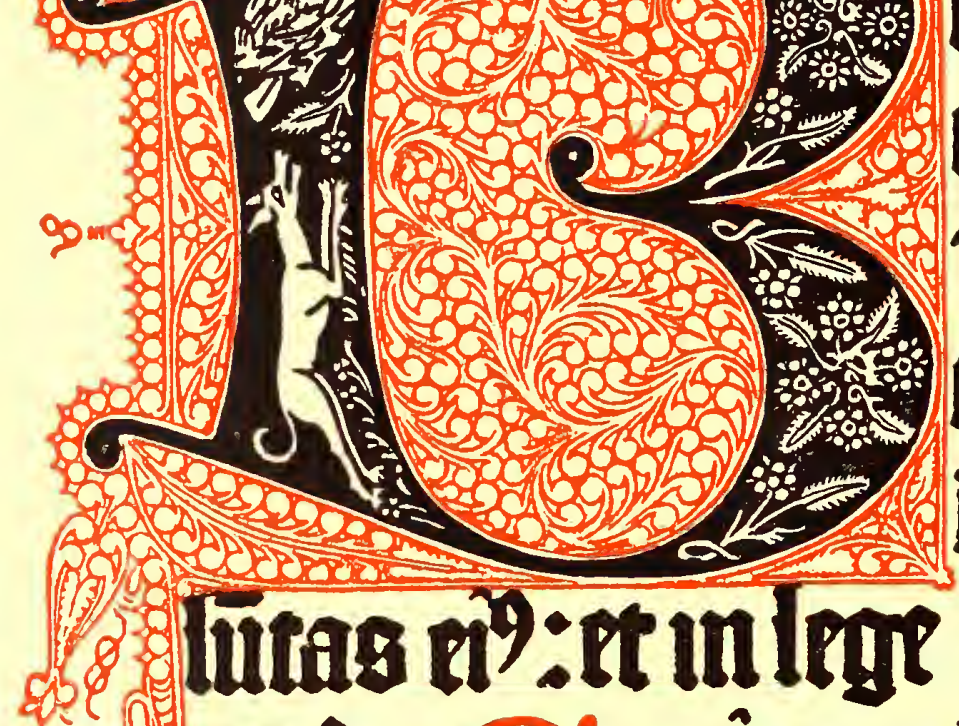

Eatugvir qui nomabijtin 站ovar. confilio impiozî it in viaptrōz nō Itetit:zì

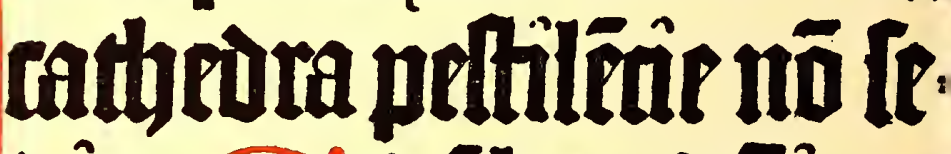
dit, STè îleut dñivo

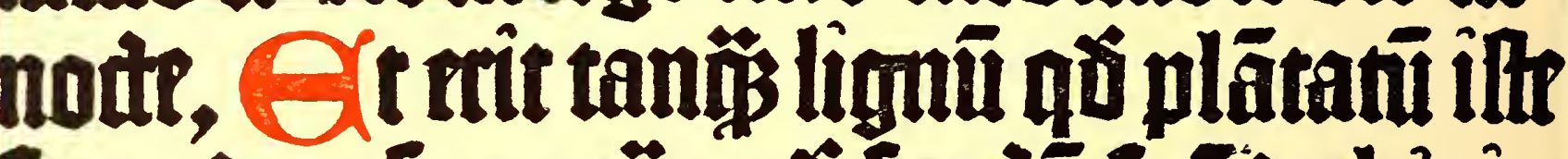

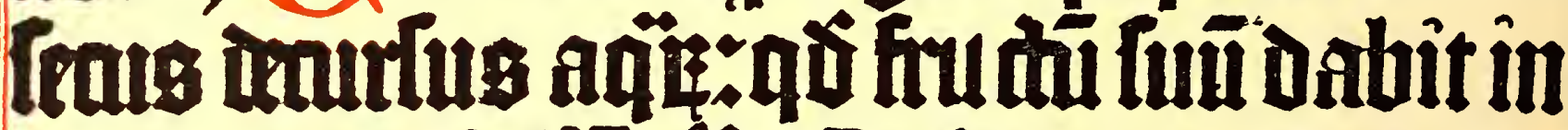
on o 7 ra

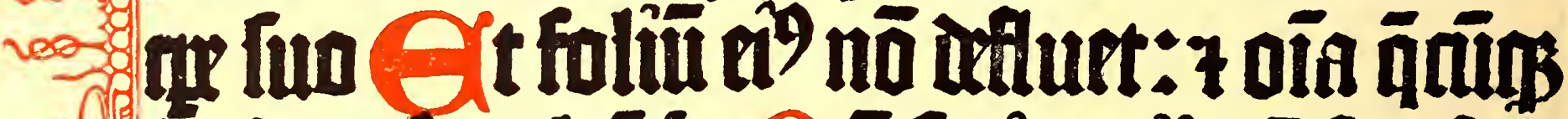

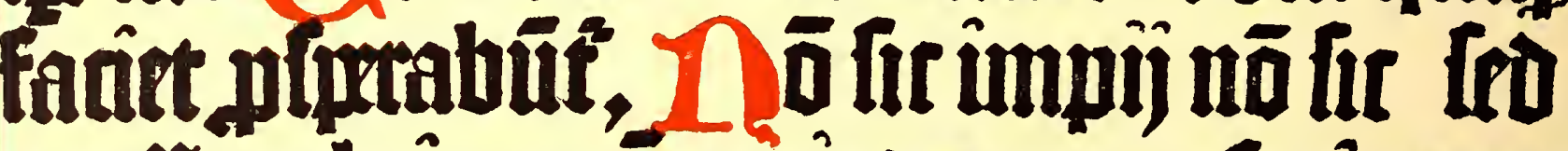

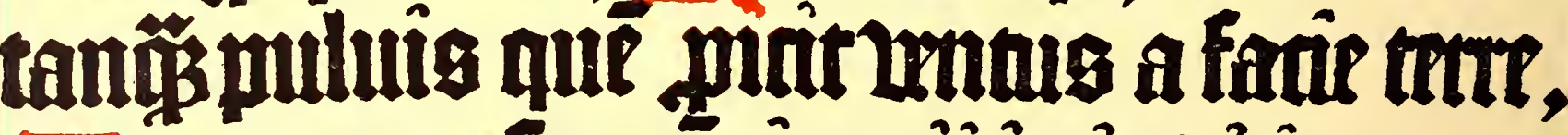

-

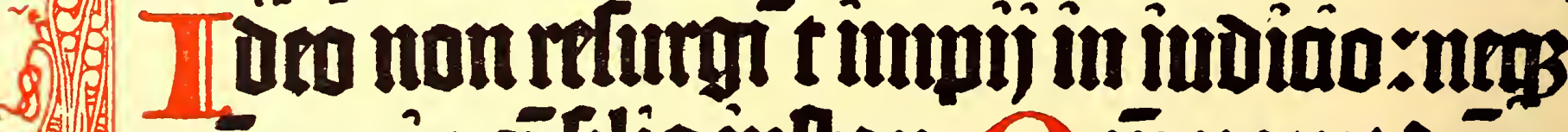

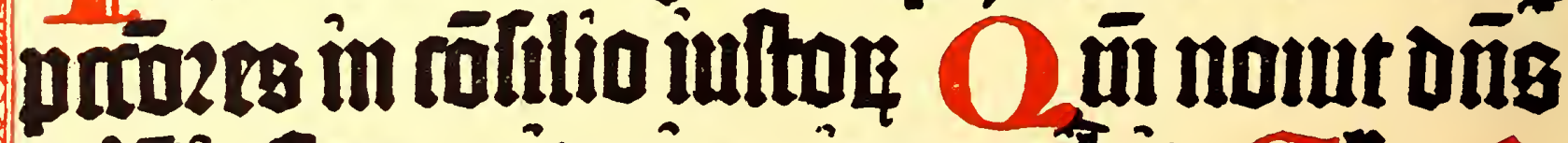

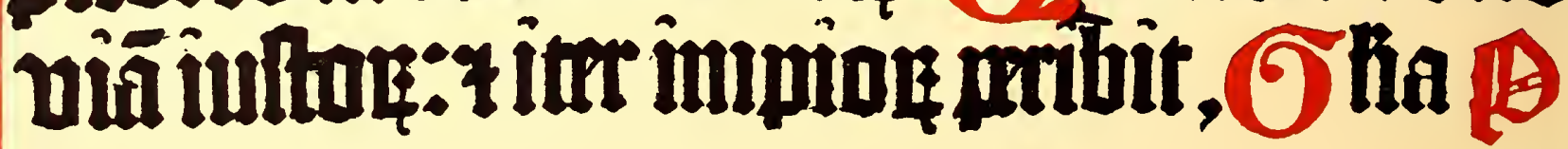




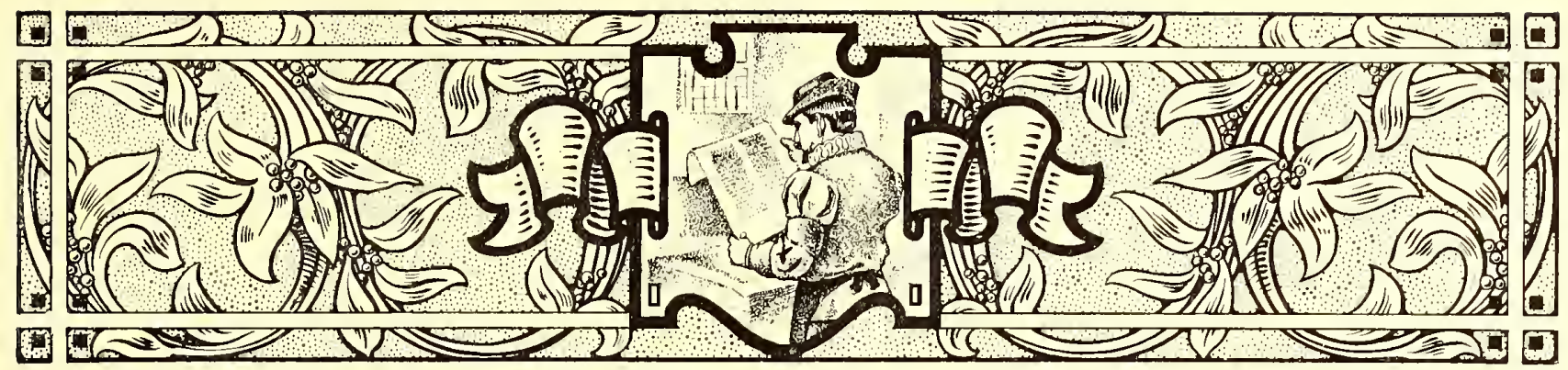

\section{THE ORIGIN OF TYPOGRAPHY}

THE invention of typography in the fifteenth century marked the beginning of a new civilization and the end of the medieval thousand years. The Middle Ages may be said to have begun with the capture of Rome by the Vandals in 455 A.D., and to have ended with the production of what is considered the first printed book in 1455 .

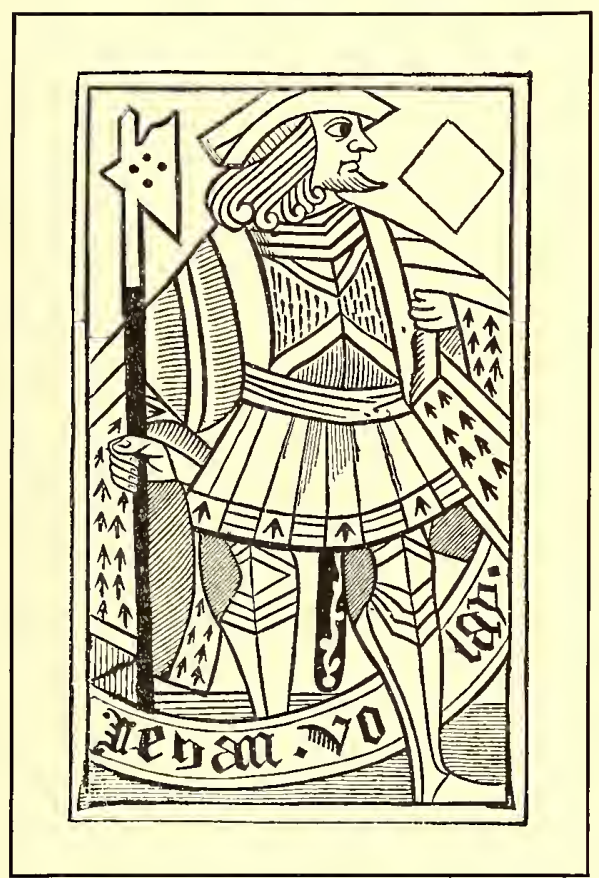

FRENCH PLAYING CARD

A block print of the fifteenth century

As has been shown, during most of the thousand years preceding the invention of typography, ignorance and superstition reigned thruout Europe, despite the efforts of Charlemagne and others to revive learning and encourage interest in books. The popular mind had become so perverted that ability to read and write and love for art were considered proofs of effeminacy.

As the medieval period neared its close, the brain of man became more active; he began to reason and to understand much that before had been mystery. Interest was manifested in the problems of science and religion, and notable things were accomplished by artists and craftsmen. It seemed as if the intellect of mankind was awakening from a long sleep, and civilization was being born again.

As the light of the new intelligence shone upon the earth and Europe rubbed its dazzled eyes, 'TYpography, the star that was to light the way to modern knowledge and achievement, appeared.
Printing with separate metal types, while involving a new principle, was to some extent a development of other methods. The evolution from manuscript books to block books, and from block books to books printed from types occurred quietly in the natural course of events ; so quietly, indeed, that there is mystery surrounding each change of method.

In the carly part of the fifteenth century, when writing was the only agency used for making books, the demand for playing cards and sacred pictures necessitated a method of reproduction more rapid than the old; and thus engraved wood blocks were introduced.

As the desire for knowledge outgrew the productive resources of the russet-gowned scribes, men with a mechanical turn of mind began to engrave pages of books on wooden blocks, a process which, tho extremely tedious, afforded a means of partly satisfying the need, and which became the stepping stone to the invention of printing with separate types. The block books, as they were

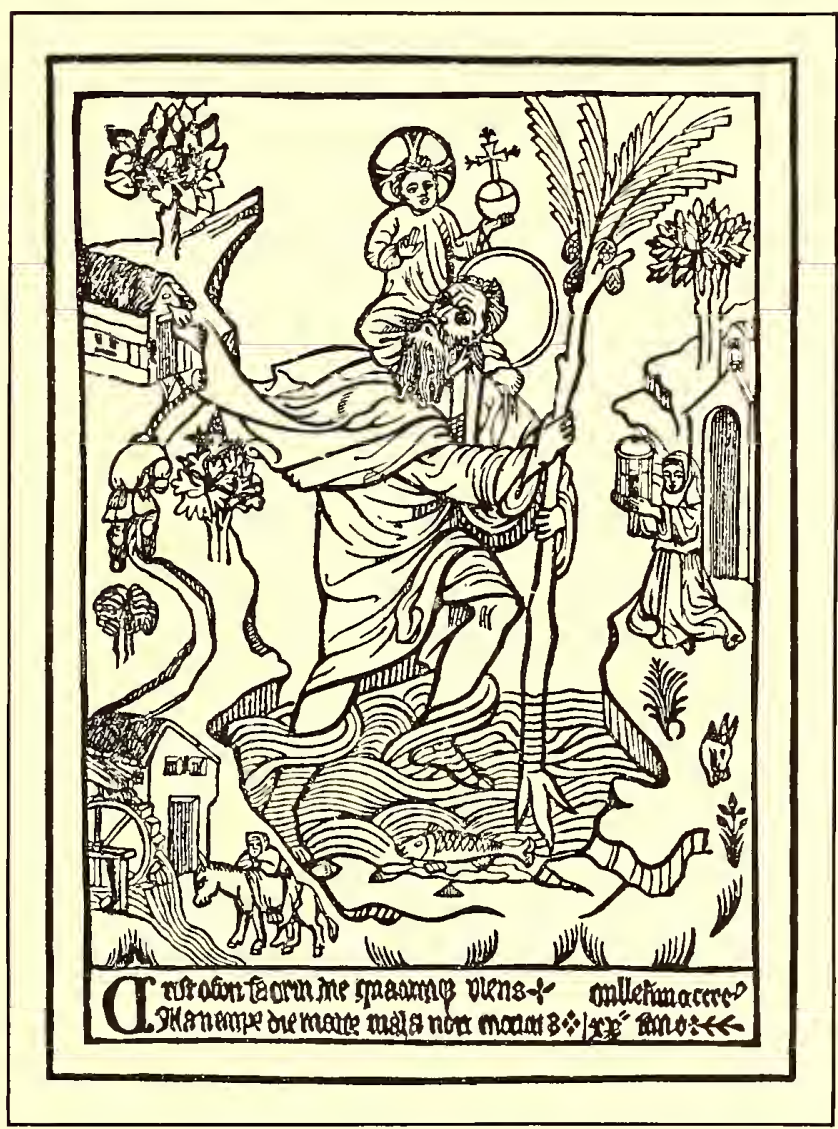

IMAGE PRINT OF 1423

The first block print with a date 
called, sometimes contained whole pages of reading matter, each letter cut in relief on the face of the wood, and frequently the page included a large illustration carelessly drawn and crudely engraved. The early method of printing bluck books was by placing the paper on the inked surface and rubbing the back. Only one side was printed and a brown distemper ink (a kind of watercolor) was used. Simply constructed presses, prototypes of the modern hand press, were employed by block-book makers in later years. Playing cards and image prints were popular products of the block-book period, and after being printed were colored by means of stencils. A French playing card of the fifteenth century is reproduced on the preceding page, as well as a print illustrating the old legend of St. Christopher carrying the infant Jesus across a river. This last-mentioned print is dated 1423 , is $8 \frac{1}{8} \times 11 \frac{1}{4}$ inches in size, and is the oldest dated specimen of printing.

The invention of printing really dates from the time books were printed from wooden blocks, altho the more important invention, that of typography (printing with separate types), is also known by the general word "printing." The first block books, probably Donatuses, may lave been printed in Holland. The "Donatus" is a Latin grammar, and received its name from its author, Ælius Donatus, a Roman grammarian of the fourth century. It is a small book of not more than thirty-four pages printed on parchment, and had a large sale.

There is a morbid side to human nature, and it has been with us since the beginning. Today it finds delight in perusing in the sensational newspapers detailed descriptions of murders, train wrecks, and other happenings in which blood is spilled. During the Middle Ages it prevailed, and is reflected in the pictures that have come down to us in the block books. A doleful atmosphere is present in the block book, "Ars Moriendi" (Art of Dy-

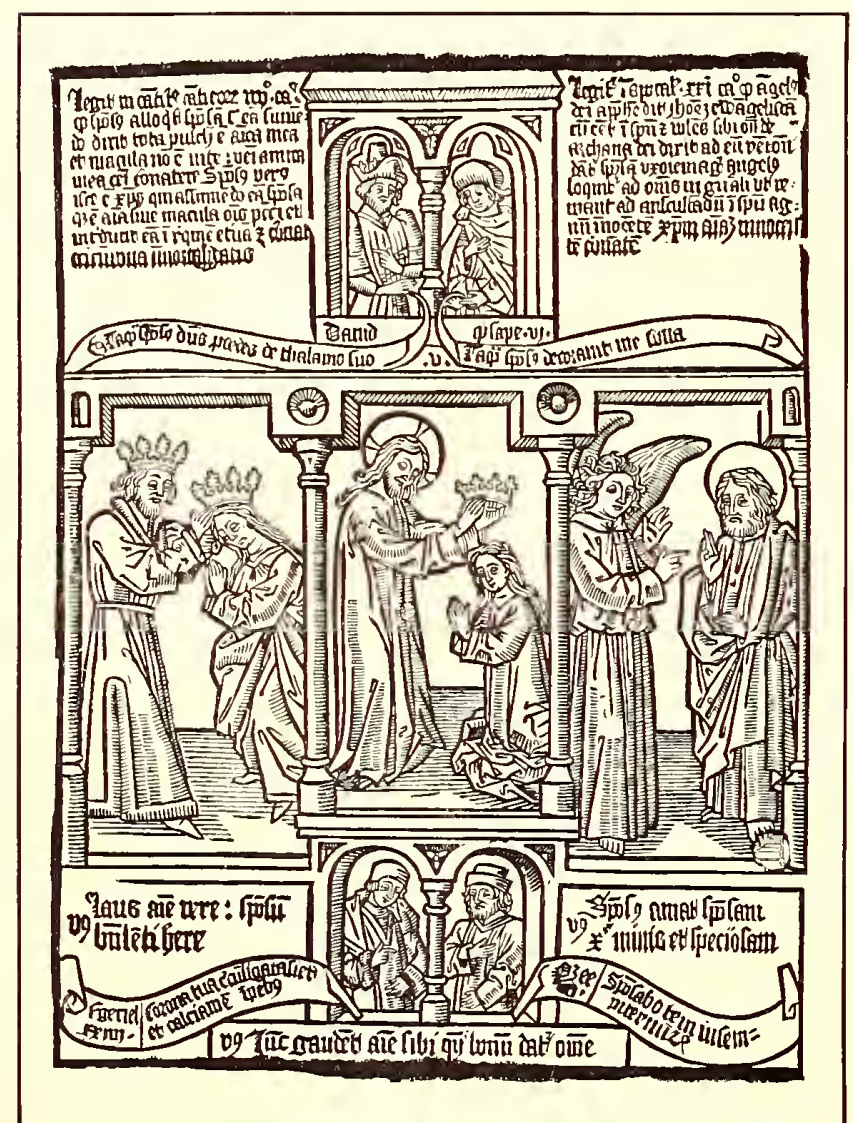

BIBLE OF THE POOR

Famous block book of the fifteenth century

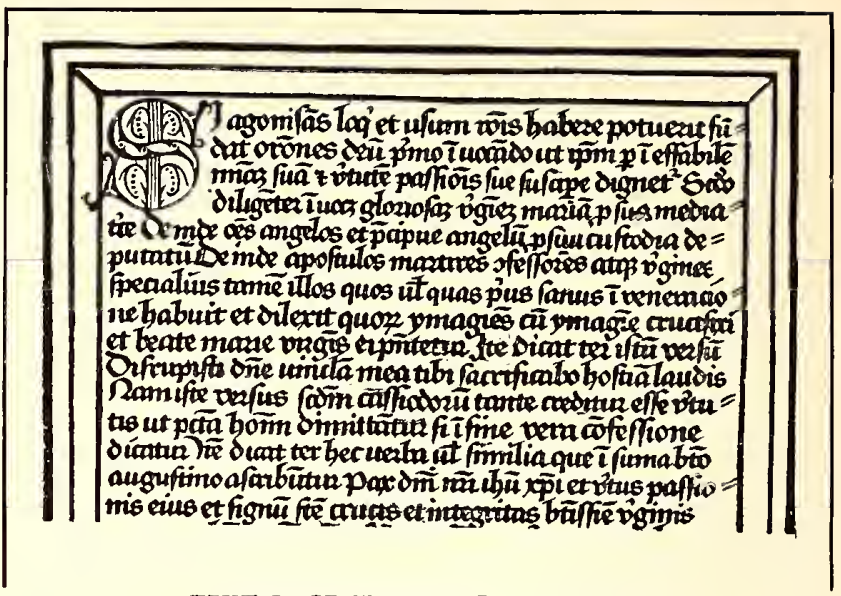

TEXT PAGE FROM A BLOCK BOOK

"Ars Moriendi," printed in the fifteenth century

ing), whose illustrations show weeping angels and leering demons, weird settings that are magnitied by the crudeness of the engravings.

The "Biblia Pauperum" (Bible of the Poor) is another block book very popular in the days preceding the invention of typography. It is a book of about forty pages, consisting principally of illustrations of the important happenings as told in the Scriptures. The book was for the use of illiterate monks and those that did not have access to the elaborate manuscript Bibles.

A book of similar purpose, but more complete than the Bible of the Poor, is called "Speculum Humanæ Salvationis" (Mirror of Human Salvation). This book literally presents the transition from block books to typeprinted books, for of the sixty-three pages in one edition twenty are printed from wood blocks and forty-three from separate types (see reproductions herewith). The printed page of the "Nirror" is a trifle larger than the page that is now being real. Almost every monastery in Europe contained copies of the "Speculum."

When, where and by whom was typography invented? It is surprising that there should be any real uncertainty about the facts comnected with the invention of typograply, but some uncertainty does exist, and various opinions and conclusions are set forth in books on the subject. The new method of printing was invented in the midst of indifference and ignorance, and for many years but few cared that it had come among them.

The inventor of typography, whether Coster or Gutenberg, was too modest to claim the credit in a substantial way, as he failed to print his name on the first books done by the new method.

This modesty, or whatever else it may lave been, opened the way for almost every European country to claim the honor of having been the home of the invention. However, all claims have been disproved excepting those of Germany and Holland, and as the argument now stands the weight of the evidence is with Germany.

C. H. Timperley, in his "Dictionary of Printing" (1839) says that of those who had written on the subject up to his time, one hundred and nine favored Mainz and twentyfour favored Haarlem as the birthplace of typography.

There is indisputable evidence to prove that typography was practiced by Gutenberg at Mainz, Germany, from 1450 to 1455 , and that the art spread from that city to all parts of Europe. There is no doubt about that. The only thing which can lose to Gutenberg and Germany the credit of the invention is proof that another man printed from separate types in another country previous to 1450 . Certain investigators have attempted to supply this proof, as we shall see. 


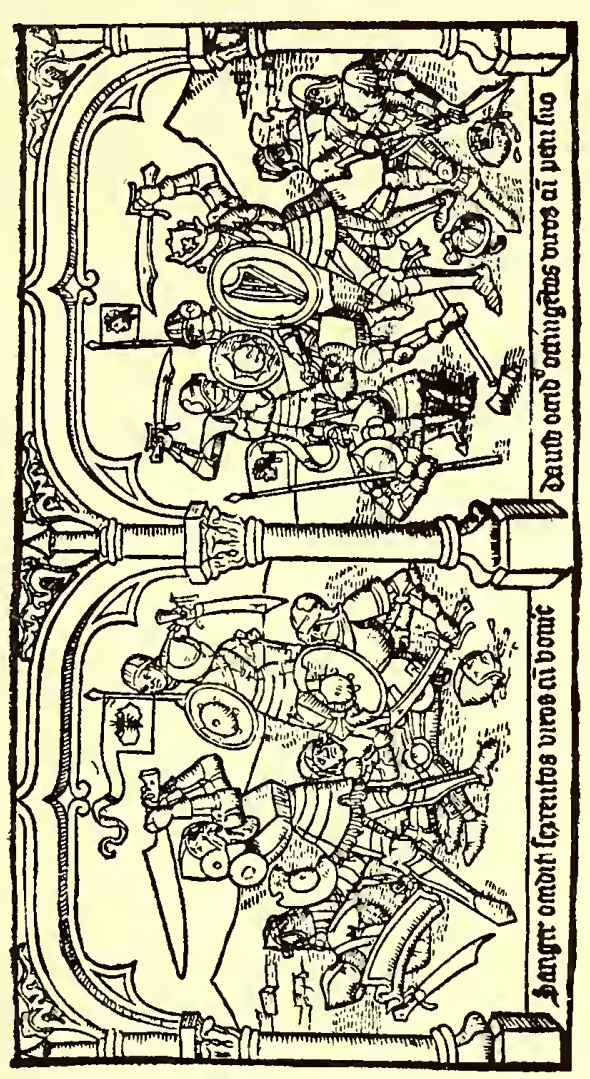

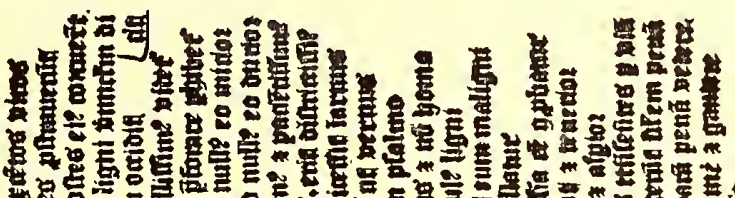

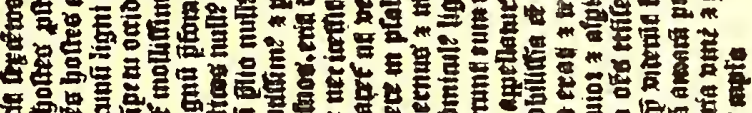

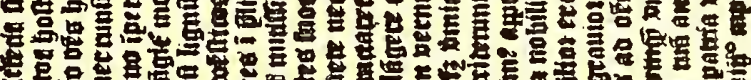

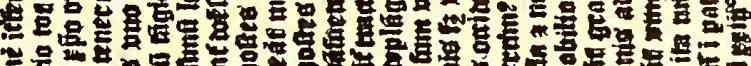

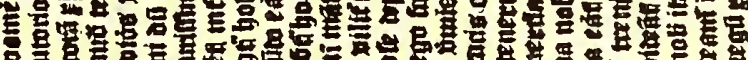

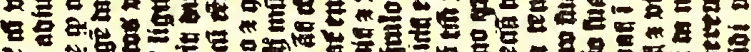

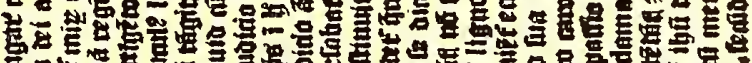

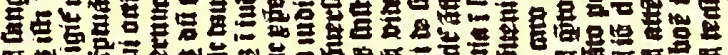

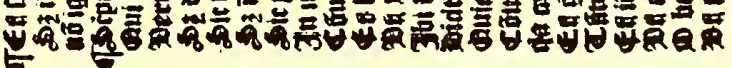

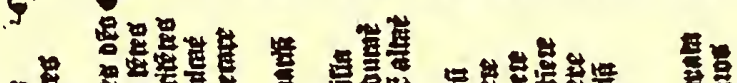

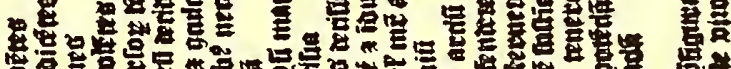

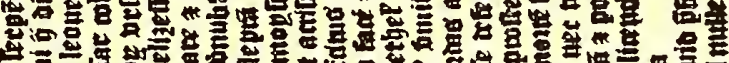

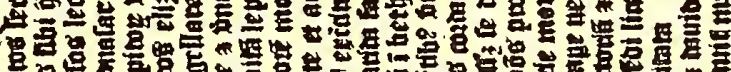

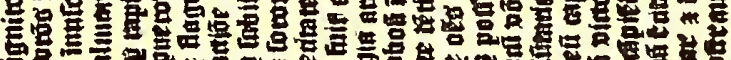

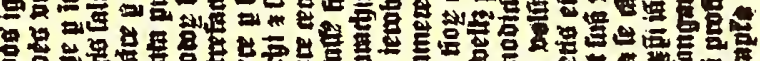

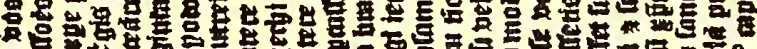

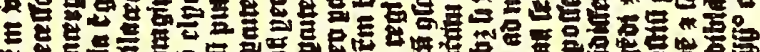

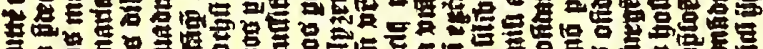

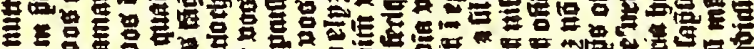

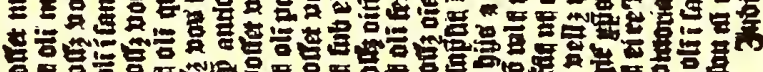

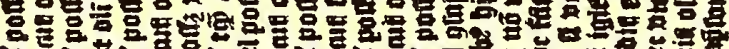

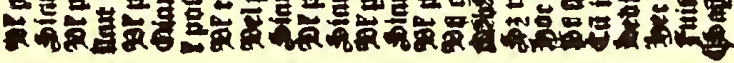

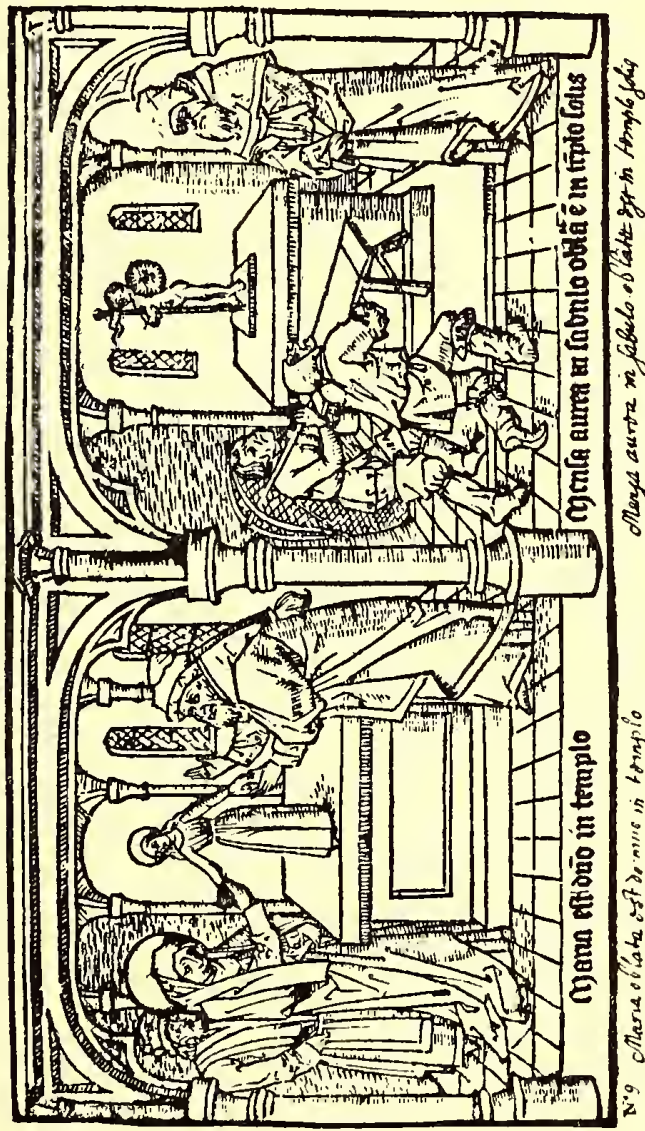

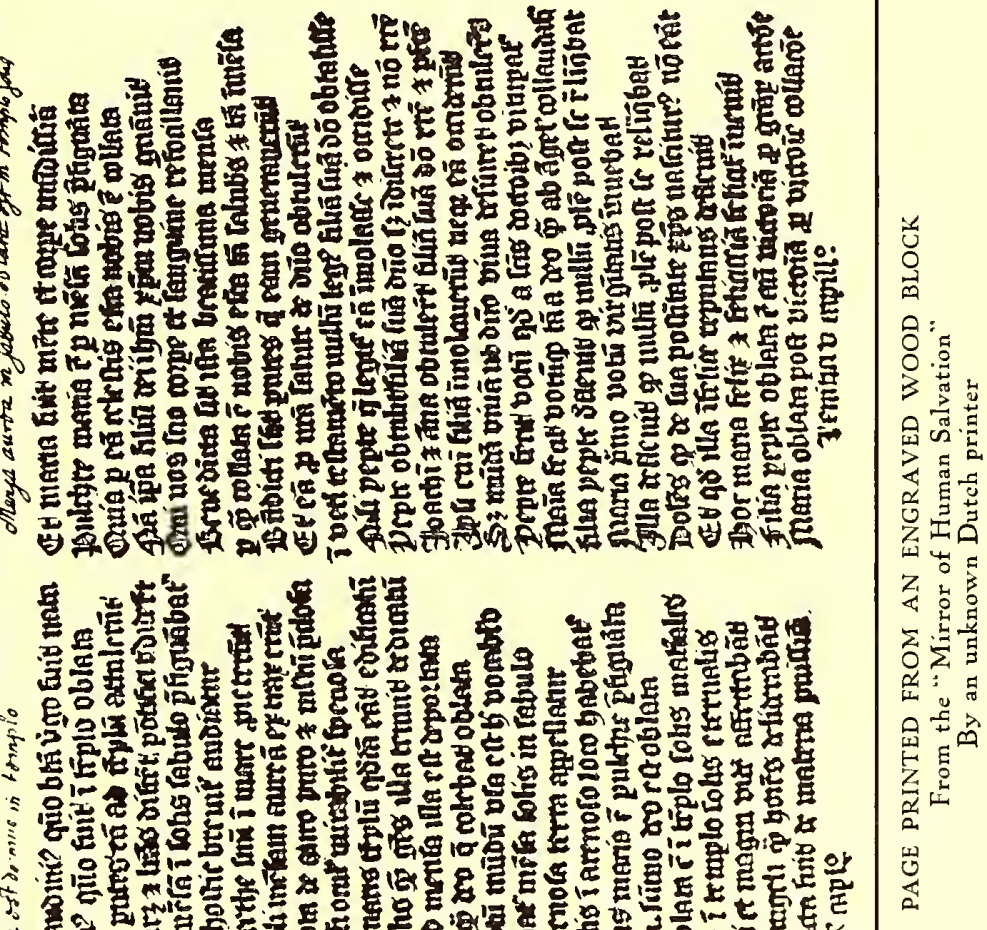

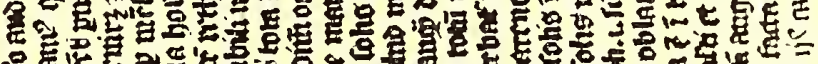

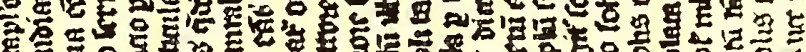

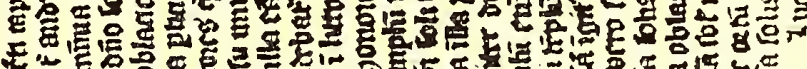

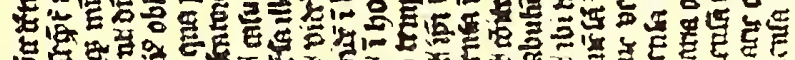

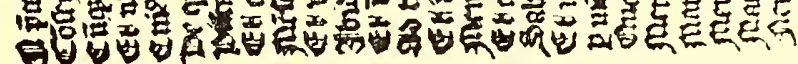


The pretensions of Holland are that one Laurens Janszoon Coster (Lawrence, son of John, the sexton or sheriff) printed with separate types about the year 1430 at Haarlem.

The earliest testimony on the subject is a chapter in the "Chronicle of Cologne" (1499) wherein the author speaks of information about the invention of typography received by him from Ulrich Zell, who printed books at Cologne, Germany, as early as 1464 . He states that the "art was discovered first of all in Germany, at Mainz on the Rhine," and that "the first inventor of printing was a citizen . . . named Junker Johann Gutenberg." 'This statement is added to by the assertion that the new art "found its first prefiguration in Holland in the Donatuses which were printed there before that time." It has been argued that the last assertion refers to block books.

An extract from the Cologne-Chronicle account may be of interest :

This highly valuable art was discovered first of all in Germany, at Mainz on the Rhine. And it is a great honor to the German nation that such ingenious men are found among them. And it took place about the year of our Lord 1440, and from this time until the year 14.50, the art, and what is connected with it, was being investigated. And in the year of our Lord 1450, it was a golden year, they began to print, and the first book they printed was the Bible in Latin; it was printed in a large letter resembling the letter with which at present missals are printed. Altho the art was discovered at Mainz, in the manner as it is now generally used, yet the prefiguration was found in Holland, in the Donatuses, which were printed there before that time. And from these, the beginning of the said art was taken, and it was invented in a manner much more masterly and subtle than this, and became more and more ingenious. . . . But the first inventor of printing was a citizen of Mainz, born at Strassburg, and named Junker Johann Gutenberg. From Mainz the art was introduced first of all into Cologne, then into Strassburg, and afterwards into Venice. The origin and progress of the art was told me verbally by the honorable master Ulrich Zell, of Hanan, still printer at Cologne, anno 1499 , by whom the said art came to Cologne.

There was printed in the year 1561 an address to the town oflicers at Haarlem by Dierick Coornhert, an engraver, in which he stated that he was

often told in good faith that the useful art of printing books was invented, first of all, here in Haarlem, altho in a crude way, as it is easier to improve on an invention than to invent; which art having been brought to Mainz by an unfaithful servant, was very much improved there, whereby this town, on account of its first having spread it, gained such a reputation for the invention of the art, that our fellow-citizens find very little credence when they aseribe this honor to the true inventor. . . . And because I implicitly believe what I have said before, on account of the trustworthy evidence of very old, dignified and gray heads, who often told me not only the family of the inventor, but also his name and surname, and explained the first crude way of printing, and pointed with their finger the house of the first prmter out to me.

It will be noticed that Coornhert fails to mention the name of the alleged inventor, the location of his house, or the date of the invention. The claim that "the useful art of printing books was invented, first of all, here at Haarlem, attho in a crude way," may refer to the printing of block books and not to typography.

The claims of Holland were first presented definitely about 1566 in a history of the Netherlands called "Batavia," the author of which was known in his own tongue as Adrian de Jonghe; in English as Adrian the Younger, and in Latin as Hadrian Junius. The story as written by Junius has been dubbed the "Coster Legend" and it reads in part as follows :

About one hundred and twenty-eight years ago there dwelt in a house of some magnificance (as may be verified by inspection, for it stands intact to this day) in Haarlem, near to the market, and opposite the royal palace, Laurentius Joannes, surnamed Æditus, or Custos, by reason of this lucrative and honorable office, which by hereditary right appertained to the distinguished family of that name. . . When strolling in the woods near the city, as citizens who enjoyed ease were accustomed to do after dinner and on holidays, it happened that he undertook as an experiment to fashion the bark of a beech tree in the form of letters. The letters so made, he impressed the reverse way, consecutively, upon a leaf of paper, in little lines of one kind and another. . . Thereupon he made, by the addition of letters, explanations for pictures on engraved wood. Of this kind of printing, I myself have seen some stamped block books, the first essays of the art, printed on one side only, with the printed pages facing each other, and not upon both sides of the leaf. Among them was a book in the vernacular written by an unknown author, bearing the title "Spieghel onzer Behoudenis" [Dutch edition of the "Mirror of Salvation," two pages of the Latin edition of which are here shown]. . . . He subsequently changed the beech-wood letters for those of lead, and these again for letters of tin, because tin was a less flexible material, harder and more durable. To this day may be seen in the very house itself . . . some very old wine flagons, which were made from the melting down of the remnants of these very types. The new invention met with favor from the public and . . attracted purchasers from every direction. . . . He added assistants to his band of workmen, and here may be found the cause of his troubles. Among these workmen was a certain John. Whether or not, as suspicion alleges, he was Faust . . or another of the same name I shall not trouble myself to ascertain. This man, altho bound by oath to the typographic art, when he knew himself to be perfectly skilled in the operation of type setting, in the knowledge of type founding, and in every other detail appertaining to the work, seized the first favorable opportunity . . and flew into the closet of the types, and packed up the instruments used in making them that belonged to his master, and · $\cdot$ immediately after slunk away from the house with the thief. He went first to Amsterdam, thence to Cologne and finally regained Mainz. . . . Within the space of a year, or about 1442 , it is well known that he published, by the aid of the same types which Laurentius had used in Haarlem, the "Doctrinal" of Alexander Gallus . . . and also the "Treatises" of Peter, of Spain . . . I remember that Nicholas Gallius, the preceptor of my boyhood, a man of tenacious memory, and venerable with gray hairs, narrated these circumstances to me. He, when a boy, had more than once heard Cornelis, an old bookbinder and an underworkman in the same printing office when not an octogenarian and bowed down with years, recite all these details as he had received them from his master.

This is the strongest proof the friends of Coster can present, and it has been thoroughly dissected by investigators representing both sides of the controversy. The weak points of the document appear to be:

(1) The date of the experiment with wood letters in the garden (about 1440) does not leave enough time for completion of the invention of separate metal types and the equipment of a large printing office until the theft which Junius says occurred in 1441 .

(2) The date of the theft of 1441 does not reconcile itself with the fact that Gutenberg in 1436 was probably experimenting with lis invention at Strassburg.

(3) The claim that a Dutch edition of the "Mirror of Salvation" was printed with separate types cut from wood seems doubtful, because even the best modern machinery has not demonstrated that wood type can be made as accurately as is necessary for arrangement of snall types in a massed page. When it is considered that the size of types used on the edition mentioned was about fourteen point, and the lines were printed in alignment, the modern printer is sure to question the accuracy of the assertion.

Four editions, two in Latin and two in Dutch, of the "Mirror of Salvation," are known to exist, all printed from types except twenty pages of the second edition, which are printed from engraved blocks. They are the work of some early printer of Holland; whether his name was Coster or whether the books were printed before or after 1450 will probably never be ascertained.

One Peter Scriverius in 1628 wrote a new version of the invention in which he says that "In the year 1428, Laurens Coster, then a sheriff of Haarlem, strolled into the Haarlem woods. He took up the branch of an oaktree, cut a few letters in relief on the wood, and after awhile wrapped them up in paper. He then fell asleep, but while he slept, rain descended and soaked the paper. 
Awakened by a clap of thunder, he took up the sheet, and to his astonishment discovered that the rain had transferred to it the impress of the letters," etc.

Junius had placed the date of Coster's invention at about 1440; Scriverius put it at 1428 . The date was again changed, this time to 1420 , by Marcus Boxhorn, who wrote on the subject in 1640 .

In 1722 a statue of Coster was erected in Haarlem, but no date was placed upon it.

A "true and rational account of the invention" was published at Haarlem by one Leiz in 1742 , which gives in detail the supposed events of Coster"s life as a printer, from the cutting of the wood letters on the tree bark in 1428 to his death in 1467 , but does not reveal the source of information.

Gerard Meerman, a learned but impractical writer of Rotterdam, in 1765 published a book, "Origines 'Typographical,' and comes to the conclusion that typography was invented by Louwerijs Janszoon, known as Laurens Coster, who was sheriff at various times between 1422 and 1434 , and who died between 1434 and 1440 ; he used separate wooden types about 1428 or 1430 , and did not (as Junius had claimed) use lead or tin types; he was robbed on Christnas night 1440 by Johann GensHeisch (elder brother of Johann Gutenberg), who carried the art to Mainz; he printed one edition of the "Mirror" from wooden types.

In the early part of the nineteenth century a scientific society of Holland offered a prize for the best treatise on the subject of the invention and in 1816 Jacob Koning was given the award for his essay, "The Origin, Invention and Development of Printing." Koning was the first writer on the subject to make researches in the Haarlem archives and in his book he claimed to have carefully collected from the registers, account books, and other official data all the entries that could throw light on the subject, and to have got together all the documentary evidence to be found.

The investigations of Koning, as reported by himself, corroborated some of the details of the stories of those who preceded him, and he found that Louwerijs Janszoon lived at Haarlem from 1370 to 1439 , when he died.

For many years the discussion stood as Koning had left it and Coster was universally given equal honors with Gutenberg as the inventor of typography; but for several years previous to 1869 rumors of errors and defects in the Haarlem claim were in circulation in Holland.

Dr. Anton Van der Linde took up the task of investigating these rumors and the results of his labors were given in a series of articles in the Dutch Spectator during 1870. These articles were revised and issued in book form under the title, "The Haarlem Legend of the Invention of Printing."

Van der Linde showed how Coster's cause had been bolstered by Koning and others with misrepresentations, evasions and even forgeries, and Holland practically surrendered its claims and altered its school books to meet the new conditions.

The town records revealed no mention of printing in connection with Louwerijs Janszoon, the sheriff, who died in 1439 , or with Laurens Janszoon Coster.

Van der Linde went to Germany as librarian of the royal library at Wiesbaden, became $V$ on der Linde and in 1878 published an enlarged edition of his former book under the title "Gutenberg," in which he argued that Gutenberg was the inventor of typography.

In $1879 \mathrm{~J} . \mathrm{H}$. Hessels, who had translated into English Van der Linde's first book, was asked to write a review of the new book, "Gutenberg,"' and in doing this lie became so interested in the subject that lie began a careful investigation into the question. He afterward declared in the preface of his book, "Gutenberg" (1882). "Had I myself been able to realize beforehand the time, the trouble, and the expense that this Gutenberg study would cost me, I should have abandoned the subject at the outset." But the work was so infatuating that in 1887 he published another book: "Haarlem, the Birthplace of Printing; not Mentz."

To demonstrate the fickle workings of the human mind it may be interesting to note that in his book of 1882 Mr. Hessels wrote,"I have never made any thoro examination of the Haarlem question, but such inquiries as I have made have led me to believe that the Haarlem claim cannot be maintained." Contrast this with the title of his book of 1887: "Haarlem, not Mentz," and notice his change of base.

While Mr. Hessels had come to believe in Haarlem, Van der Linde's faith in the cause of Gutenberg was so strong he forsook his native land, and in America Theodore L. De Vinne in his book "The. Invention of Printing" (1876) had reasoned out the tangle in a way to satisfy himself and many others that Gutenberg, and not Coster, was the inveutor of typography.

It is impossible here to go into detailed discussion of the points at issue, and only because the burden of proof is upon the Holland advocates has so much space been given to Coster.

While there may be some truth in the Coster story, the proofs are weak, and Haarlem claimants do not seem able to agree as to the identity of the man Coster.

Gutenberg, on the contrary, is shown by records too numerous to here mention separately, to have been a real, tangible human being, one who printed with separate metal types, and the probable inventor of the art.

It is believed that Gutenberg was born at Mainz, Germany, about the year 1399. His parents were Frielo Gensfleisch (goose-flesh) and Else Gutenberg (good-hill). The boy Johann took the last name of his mother, in accordance with the German custom of perpetuating a name.

Because of civil strife in Mainz, the Gensfleisch family left that city about 1420 and took up residence presumably at Strassburg.

There is a possibility that typography spent its infant days at Strassburg. Gutenberg lived there in 1439 and was practicing a secret art, which resulted in a lawsuit. The records of the case had lain, with other records of the time, in an old tower, and were not found until about 1740. They were removed to the Library of Strassburg, remaining there until the Franco-Prussian War (1870), when they were destroyed by soldiers.

This suit against Gutenberg was brought by the relatives of Andrew Dritzehen, one of his workmen, whom Gutenberg had agreed to teach certain things connected with the business in which he was engaged. The testimony of the several witnesses includes references to secrets which Gutenberg would not impart to his associates: four pieces lying in a press (which De Vinne claims was a type-mould); lead, melted forms, work connected with printing, etc.

It is argued that Gutenberg could not have printed in such a perfect manner at Mainz in 14.55 if he had not devoted many of the years before to perfecting the new art, and for this reason Strassburg may reasoliably claim to be the birthplace of typography.

Gutenberg's greatest misfortune, the seizure by Fust of his printing office and the just completed edition of the famous Forty-Two-Line Bible, furnishes a strong link in the chain of evidence that goes to prove him the inventor of printing.

The story has been often told how Johann Gutenberg, in need of cash to finance his invention, went to Johann Fust, a citizen of Mainz, and obtained a sum of money for which he mortgaged his printing office. This was in 
1450. Five years later we find Fust appearing before a public notary in the convent of the Bare-Footed Friars to enforce his claim. Fust evidently caught Gutenberg unawares, for the courts decided against the inventor, and all types, presses and books in the possession of Gutenberg were taken to the louse of Johann Fust.

The records of the agreement and lawsuit just mentioned are proof that Johann Gutenbero printed witl separate metal types at Mainz, Germany, during the years 1450-1455. While le did not print his name on any of the products of his printing office, there are specimens of Mainz printing such as Indulgences, Donatuses, etc., which corroborative evidence shows to have been done before 1455 .

The greatest achievement of Gutenberg, the culmination of his efforts in the new art, was the famous FortyTwo-Line Bible. There are a number of copies of this book in existence, some printed on vellum, some on paper. It consists of almost thirteen hundred pages, about twelve by sixteen inches, two columns to the page, the columns containing for the most part forty-two lines, wlience the name by which the book is known. The types in size are equivalent to the present-day twentypoint, and in style are a copy of the book-Gothic letters of the fifteentl century.

The reproduction of an illuminated page of the Bible herewith is less than one-half the size of the original, which is in the British Museum, but will give an idea of the style of treatment accorded what is probably the first type-printed book. The text portion was printed in black ink only. The illuminators put a dab of red on the initial beginning each sentence, and filled all blank spaces with decoration, with which the initials I and P are cleverly blended. The smaller reproduction sliows two pages from the copy that was sold for fifty thousand dollars in 1911 .

Johann Gutenberg, after his printing outfit was taken by Fust, did not entirely lose heart, but again establislied himself as a printer, altho he never afterward produced the equal of his great work, the Forty-Two-Line Bible. In 1465 he was appointed a gentleman of the court of the Bishop of Mainz, as a reward either for his invention or for political activity.

Gutenberg died about 1468 and his printing material and equipment went to one Conrad Humery, who had some rights of ownership in them.

Among Gutenberg's workmen in 1455 was a young man about twenty-five years of age named Peter Schoeffer, who previously had copied books while a student at the University of Paris. He was a valued assistant to Gutenberg, and when Fust took over the equipment forfeited by the inventor, Schoffer assumed charge, married Fust's daughter and became a partner in the business.

Two years later the new firm published a Psalter, which has become, along with Gutenberg's Bible, one of the great books of historic printerdom. Seven copies are known to exist. The Psalter consists of one hundred and seventy-five vellum leaves nearly square. The Psalms are in types of about forty-point body, $t$ wice the size of those used on Gutenberg's Bible and of a similar style. The features of the Psalter are the large printed two-color initials, generally credited to Schoeffer, altho some authorit ies havedeclared that they originated with Gutenberg.

This Psalter was the first book with a printed date, the colophon at the end containing "August 14, 1457."

The portion of a page shown in this connection, being full size and in colors, should convey an idea of the appearance of the Psalter. The four cross lines are for the music notes, which were inserted by hand.

Fust died about 1466 from the plague while at Paris arranging for the sale of books. Schoeffer continued to print, and many books came from his presses. The last book he printed, just before his death (about 1502), was a fourtlı edition of his Psalter.

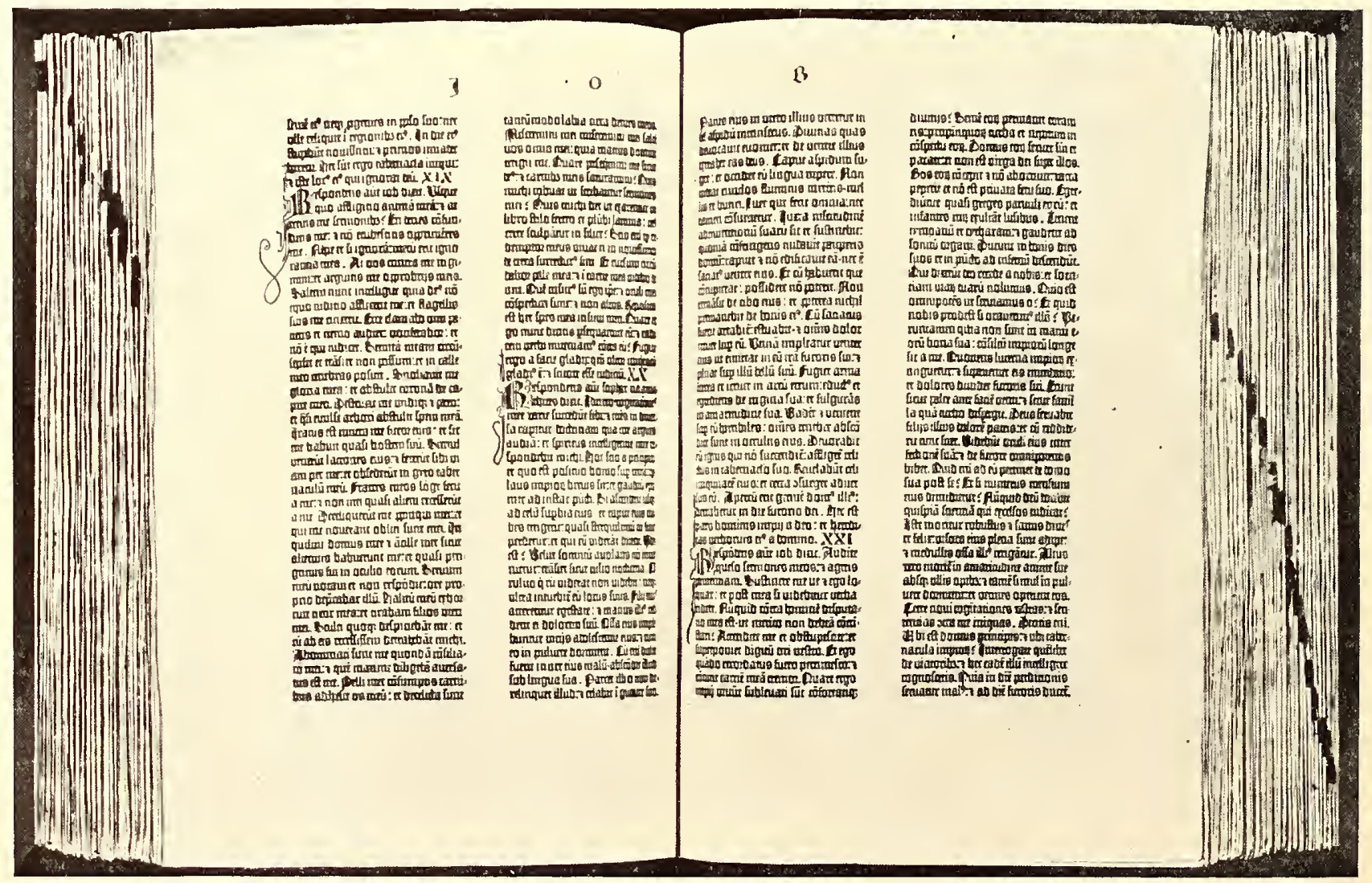

THE GUTENBERG BIBLE OF FORTY-TWO LINES

Photographed by Walter Gilliss from the copy for which Henry E. Huntington paid fifty thousand dollars at the sale of Robert Hoe's library in 1911 


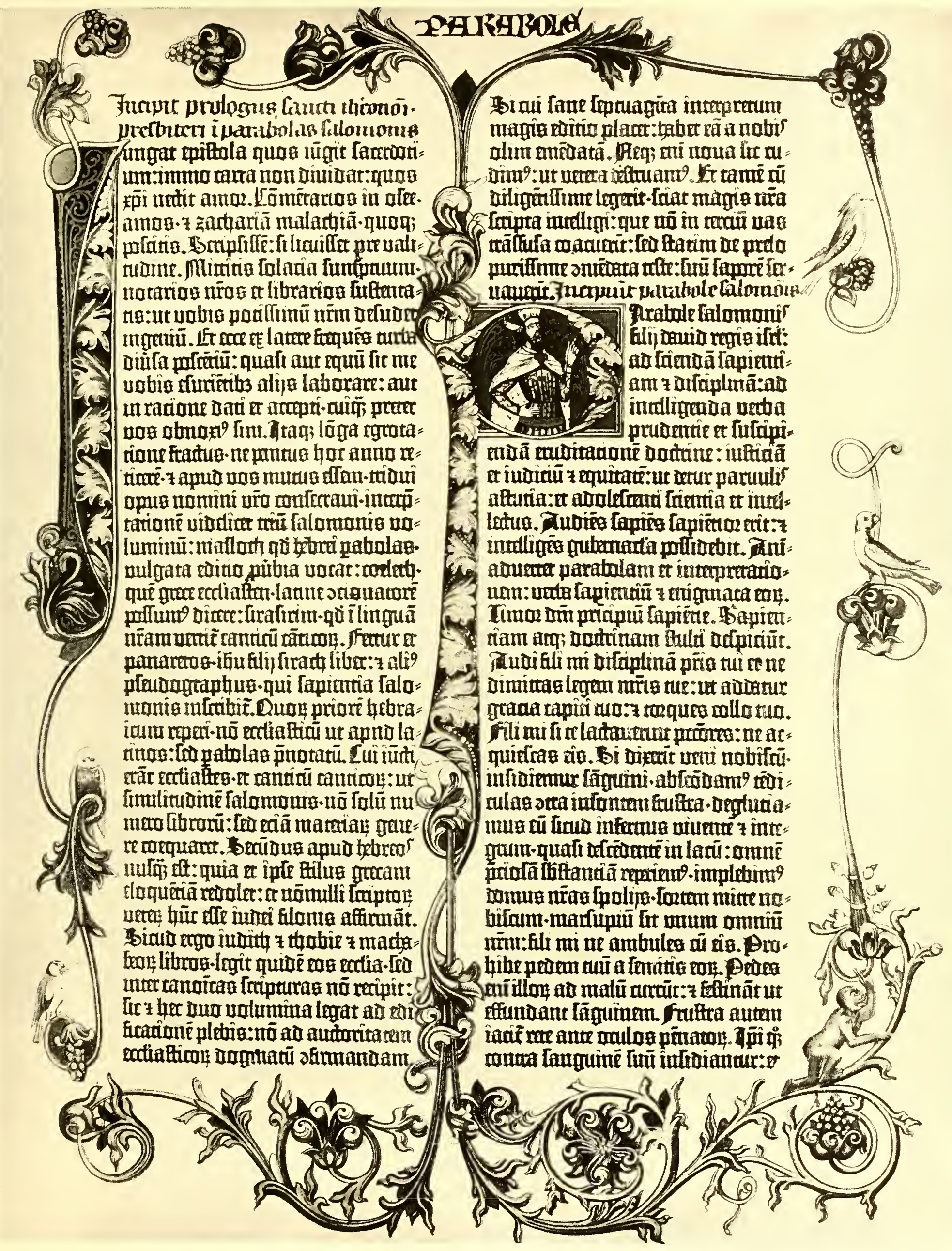

THE GUTENBERG BIBLE, ILLUMINATED

Less than half the size of the original which is in the British Museum. Not all pages in the book were decorated like this, and copies in other collections are illuminated in a different style. From Humphrey 




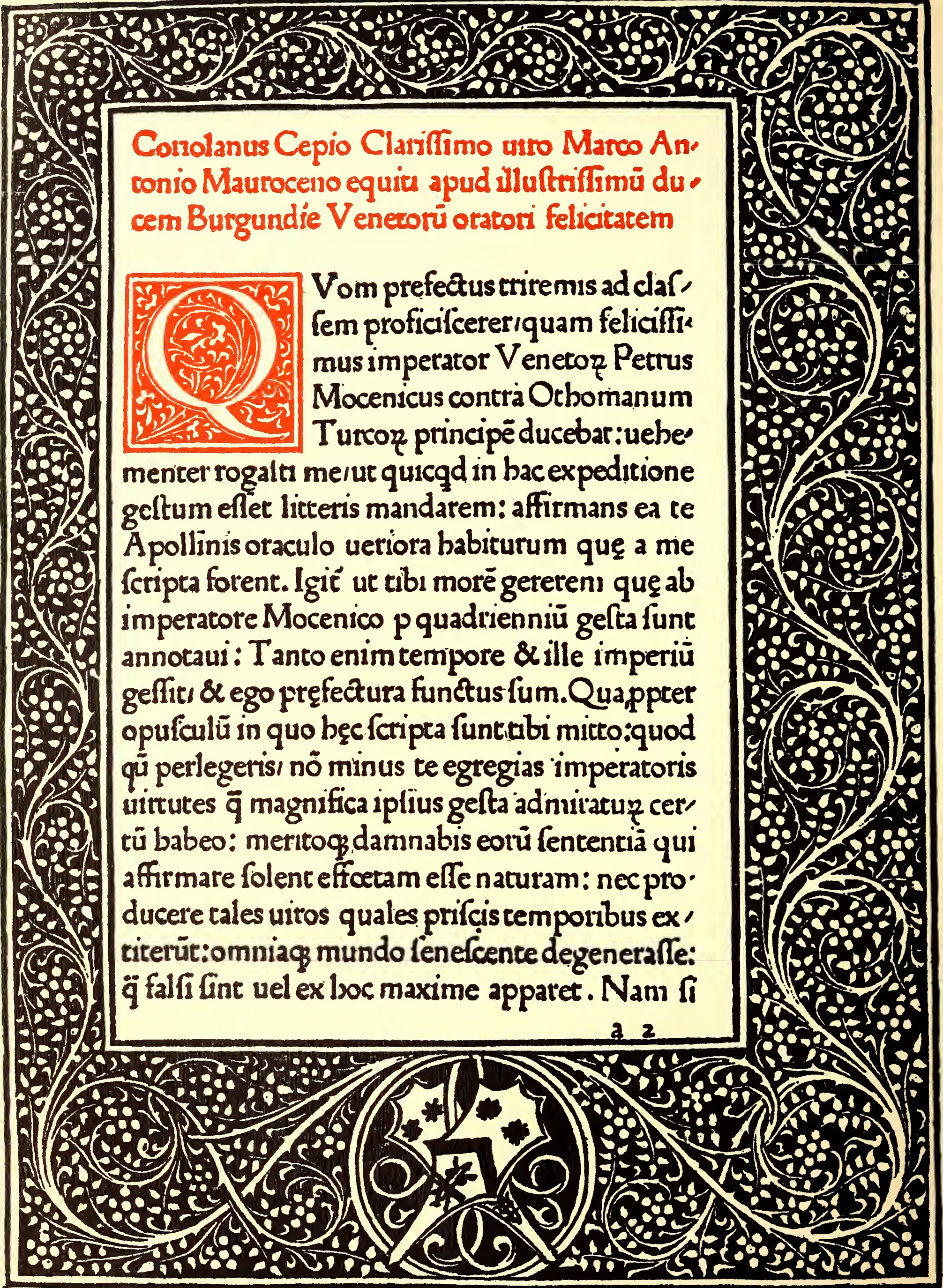




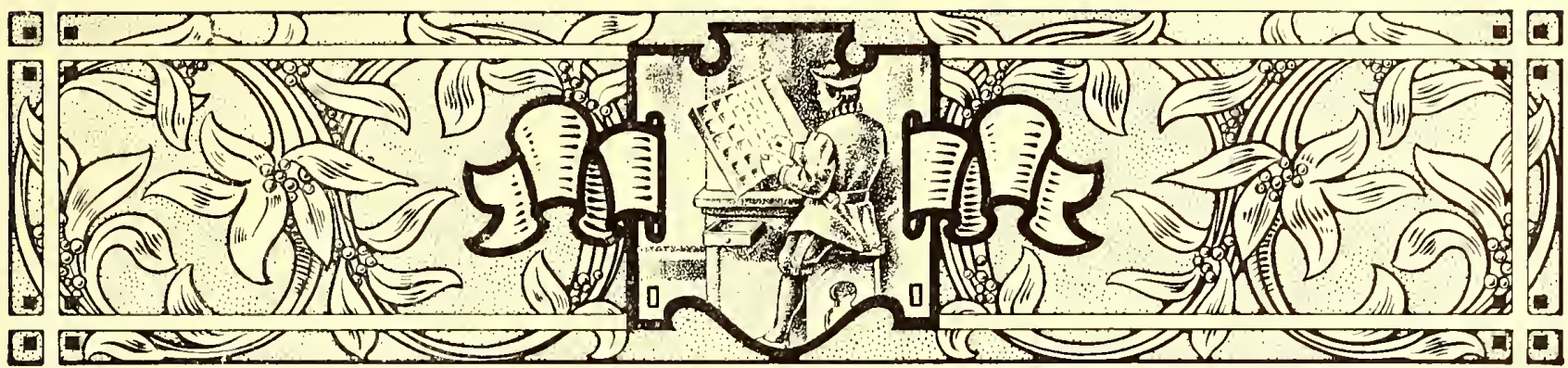

\section{THE SPREAD OF TYPOGRAPHY}

THE CITY of Mainz is in the western part of Germany, on the banks of the river Rhinc, and even at the present time is heavily fortified. In the year 146\%, seven years after Gutenberg's first Bible was completed, it was the scene of a terrible conflict between two archbishops, Diether and Adolph II., who contended for the office of elector. The elector had a vote in the selection of the king or emperor, and Mainz was one of seven principalities entitled to such an officer.

Diether was the cloice of a majority of the citizens of Mainz, but Adolph had the support of the pope in his claims and made war to establish himself in the office. One night in October, 1462 , there was an uprising of the followers of $A$ dolph within the city and hundreds of the inhabitants were murdered. The soldiers of Adolph then entered Mainz and set it afire. Most of the citizens fled, and industry and business were paralyzed.

Gutenberg was not affected by these events, as his new shop was outside of the city proper, in the village of Eltville, a short distance away.

The printing office of Fust and Schoffer, however, was burned, and the workmen, fleeing for safety from the distressed city, took up residence in various parts of Europe. Thus was the new art of typography spread and its secrets made common property.

As an introduction to the consideration of the spread of typography, the accompanying table may be of value. The information is as accurate as can be given after carefully consulting numerous authoritative books on the subject. Most writers disagree as to the years in which typography was introduced into many of the cities of Europe, and for that reason in cases where such doubt exists one of the later dates has been chosen for the purpose of this table.
In Germany, before the capture of Mainz, John Mentel at Strassburg and Albrecht P'fister at Bamberg, were printing books by the new process. With this fact as a basis, both Mentel and Pfister were once proclaimed inventors of typography by over-enthusiastic students of printing history.

Of the printers driven from Mainz by the sacking of the city, Ulrich Zell is probably the best known, because of his comnection with the Coster-Gut enberg controversy. Zell became rich as a printer and publisher at Cologne, conducting an office there for more than forty years. During all that time he never printed a book in the German language. He had as business competitors twentyone other master printers, one of whom, Arnold Ter Hoorne, was the first to make use of Arabic numerals.

Gunther Zainer began to practice typography at Augsburg in 1468 and was the first printer in Germany to print a book in Roman characters. He was alo one of the first printers to encounter restrictions by 1 abor unions. Zainer illustrated his books with woodcuts, and this the block-printers' guild objected to. They induced the magistrates to pass a law against typographers using woodcuts, but this law was afterward modified to allow the use of woodcuts when made by regular engravers.

Heinrich Keffer printed at Nuremberg about 1450 under the direction of John Sensenschmidt, who in 1481 , at Bamberg, pub. lished his famous Missal, printed with large Gotlic types of about sixty-point body. Keffer had been a witness for Gutenberg in his law suit of 1455 .

Anthony Koburger opened a printing office at Nuremberg in 1173 , and later also conducted offices at Basel in Switzerland, and at Lyons in 
France. Koburger was one of the most successful of the early printers; he had twenty-four presses in operation at Nuremberg alone and is said to have printed twelve editions of the Bible in Latin and one in German.

In Italy the first printing done with separate types was in the year 1465 in the monastery at Subiaco, a village

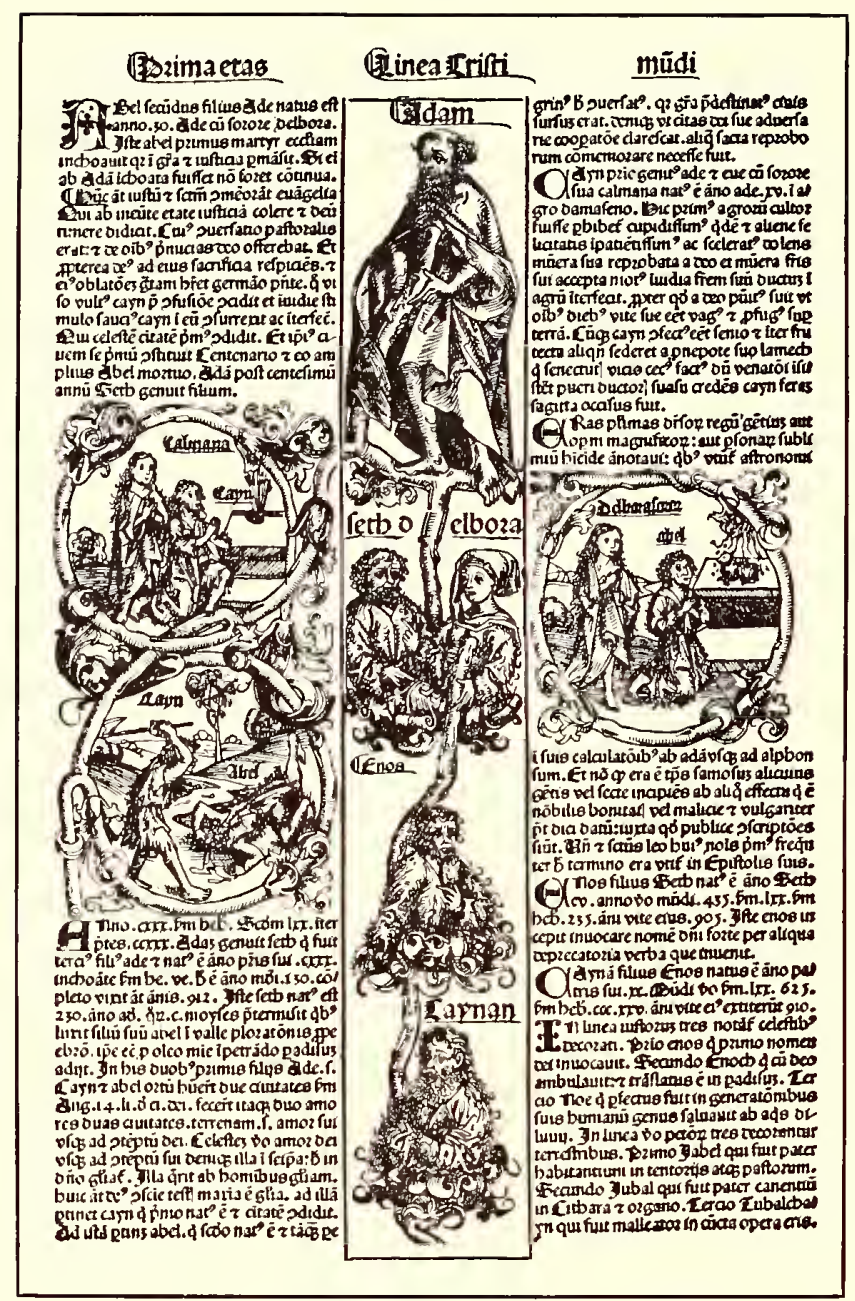

PAGE PRINTED BY KOBURGER

Combination of woodcuts and typography in a book of 1493

on the outskirts of Rome. The cardinal in charge of the monastery, impressed with the importance of the new art and anxious to have it introduced into ltaly, persuaded Conrad Schweinheim and Arnold Pannartz to come from Germany for the purpose. In 1467 these two printers removed to the city proper and there printed more extensively. Many classical works were produced, but five years later they complained that a large portion of the product had not been sold and that ther were in distress.

Utrich Hahn was the first printer in the eity of Rome proper, having opened an office there soon after Schweinheim and Pannartz began work at Subiaco.

John de Spira (born in Spire, Germany) was the first typographer at Venice, the Italian city famous for the excellence of its printed books. Setting up a press in 1469 , his work was of such quality as to obtain for him exclusive right to print by the new process at Venice. De Spira died in 1470 and the privilege was forfeited.

Nicholas Jenson, who came to Venice in 1470 , is known as the originator of the Roman type-face. Schweinheim, Pannartz, Hahn and De Spira, all had used type-faces based upon the letters of Italian scribes, but the types had Gothic characteristics. Nearly all Roman type-faces of the present day trace lineage, as it were, to the types of Jenson.

With the exception of Gutenberg, Fust and Schceffer, and perhaps Aldus, who succeeded him, Jenson is the most conspicuous figure among the early printers. The story of his introduction to the art is interesting: Charles VII., King of France, in the year 1458 decided to send an emissary to Mainz to learn the new art, which was supposed to be a secret, and Jenson, then an engraver and master of the royal inint at Tours, was selected for the mission. Three years later he returned to Paris with a full knowledge of typography, but found the king had died and that his successor was not interested in the matter. This condition of affairs seems to have discouraged Jenson, for he did not begin to print until 1470, and then at Venice, Italy. (A typographical error in a printed date of one of his books makes it read 1461 instead of 1471 , and encourages some writers to claim that Jenson was the first Venetian printer.) The death of John de Spira opened the firld for other printers in Venice, and Jenson was one of the first to take advantage of it.

Jenson cut but one set of punches for his Roman typeface, the cutting being done so accurately that no changes were afterward necessary. The Roman types, being less decorative and more legible than the Gothic letters of the Germans, allowed the use of capitals for headings. A colophon, the forerunner of the modern title-page, was set by Jenson entirely in capitals with the lines opened up by liberal space. This colophon, which was probably the first page of displayed type composition, is reproduced below.

It is an interesting fact that the books of Jenson do not contain the letters $\mathrm{J}, \mathrm{U}$ and $\mathrm{W}$, these characters

PROBI AEMILII DE VIRORVM EXCELLEN

TIVM VITA PER.M.NICOLAVM IENSON

VENETIIS OPVS FOELICITER IMPRESSVM

EST ANNO A CHRISTI INCARNATIONE.

M.CCCC.LXXI. VIII.IDVS MARTIAS.

THE FIRST PAGE OF DISPLAYED TYPE COMPOSITION Arranged by Jenson at Venice in 1471

not having been added to the alphabet until some years later. To satisfy a demand he also cut and used a round Gothic face. The product of Jenson's presses represents the highest attainment in the art of printing. His types were perfect, the print clear and sharp, paper carefully selected, and margins nicely proportioned.

Jenson died in 1481 , honored and wealthy. His printing office passed first to an association and then to one whose fame as a printer perhaps surpasses that of Jenson

Aldus Manutius was a learned Roman, attracted to printing about 1489 by the pleasures it afforded in the publishing of books. He introduced the slanting style of type known as italic, so named in honor of Italy and fashioned after the careful handwriting of Petrarch, an Italian poet. Italic at first consisted only of lower- 


\section{QXLII}
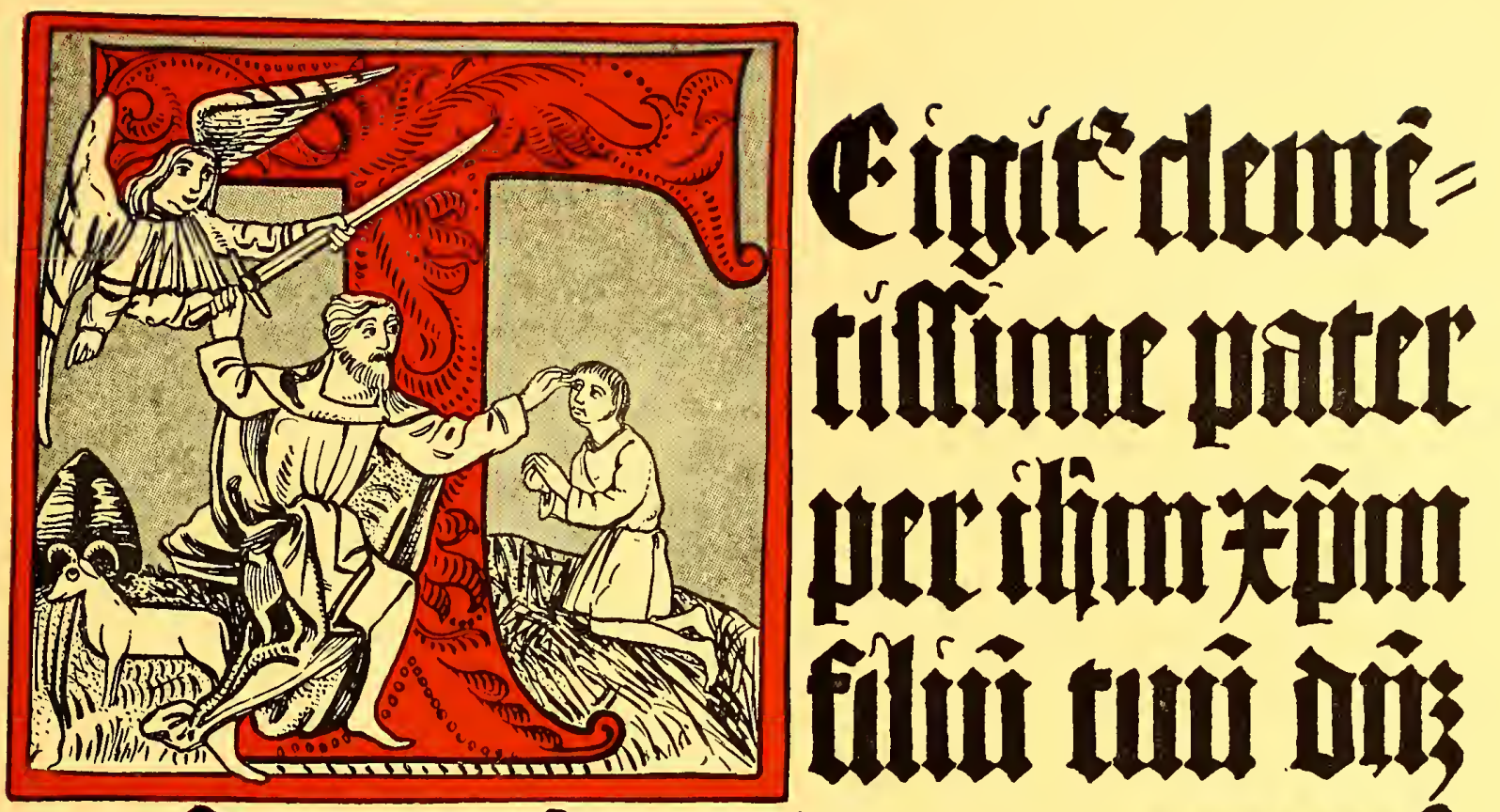

unftrum fupplires tomin!

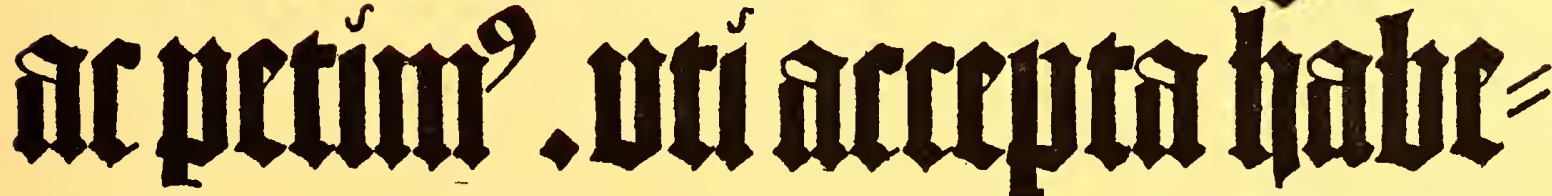

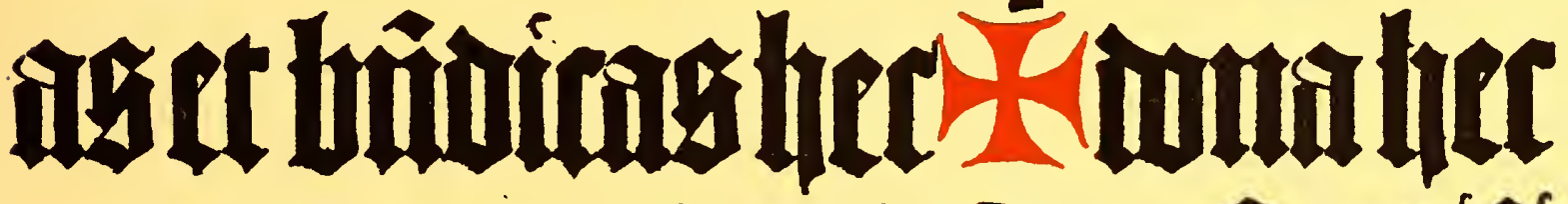

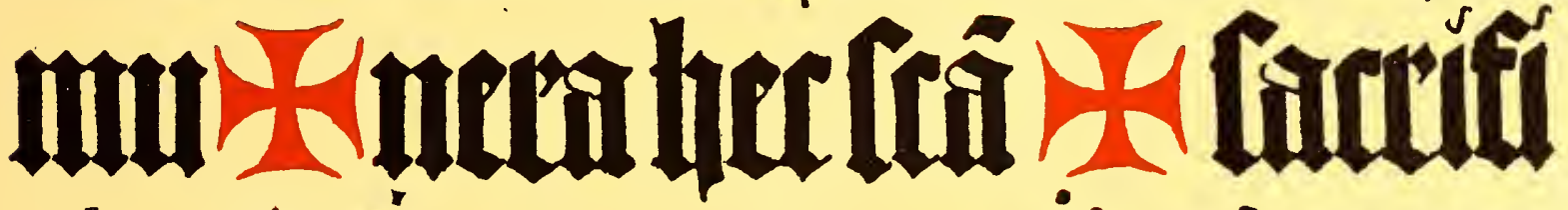

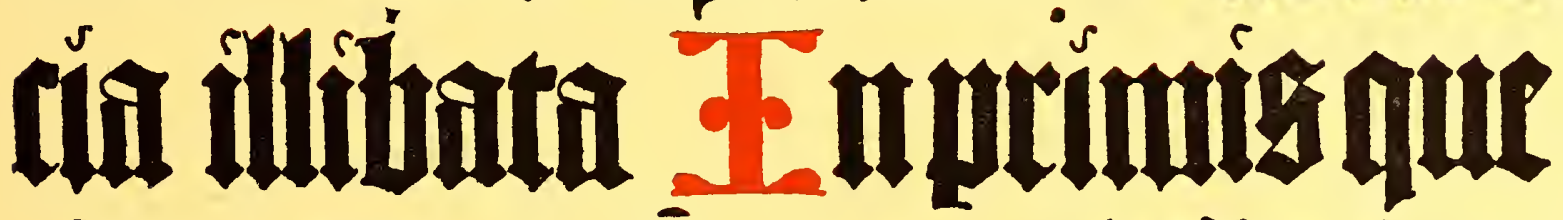

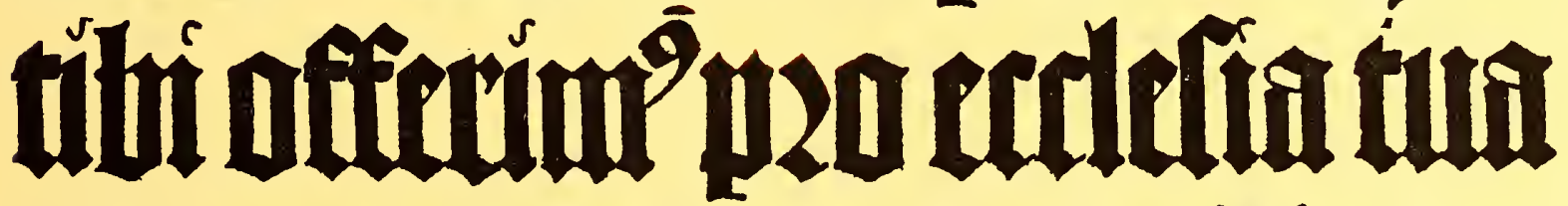

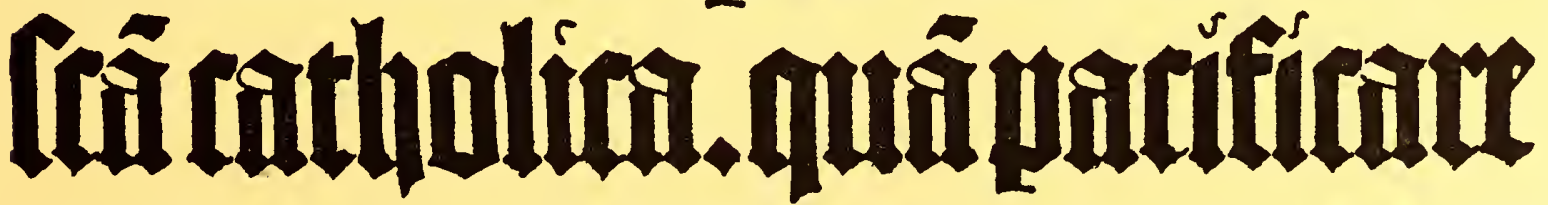

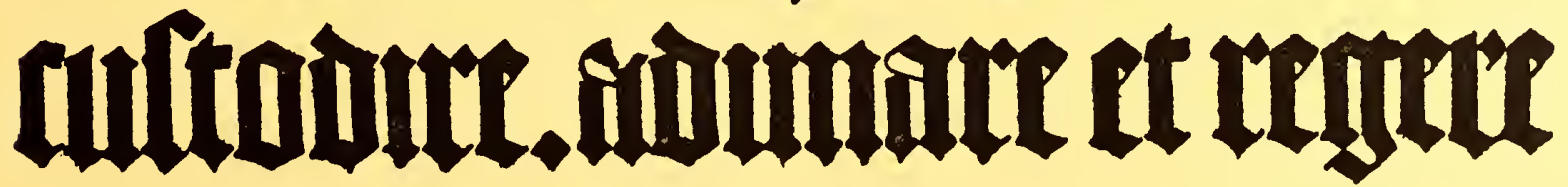

A page (actual size) from the famous Bamberg Missal 

case letters, small upright Roman capitals being used with them. The reproduction below shows this combination and also the peculiar style of inserting a space after the capital letter beginning each line.

Aldus also introduced the innovation of considerably reducing the size of books from the large folio to the convenient octavo. The size of a folio page is about twice that of this one, which is known as a quarto, and an octavo page is half the size of a quarto.

Aldus was the first to suggest the printing of a polyglot Bible. The word polyglot means "many tongues" and here refers to a book giving versions of the same text or subject matter in several languages. The polyglot Bible of Aldus was to have been in Hebrew, Greek and Latin, but got no further than a few specimen pages.

The first polyglot work ever printed was a Psalter of eight columns, each a different translation, from the press of Peter Paul Porrus, at Genoa, Italy, in 1516. This Psalter was the literary work of Augustin Justinian, a Corsican bislop, who later also arranged an entire Bible on similar plans.

Aldus is honored wherever books are known, not only on account of the excellence of his productions, but because of the sincerity of his purpose and his love of printing. In the first book printed by him at Venice he declares for himself and co-workers: "We have determined henceforth to devote all our lives to this good work, and call God to witness that our sincere desire is

\section{D.V.M.GEORGICON IIBER PRI- MVS AD MECOENATEM.}

\author{
vid faciat latas fegetes: quo fodere \\ torram \\ 9 Vertere meconds, ulmis'qi; adizm- \\ gerc sites. \\ Conweniat: quas cura boum, qui oul \\ tus habendo \\ s it pecori:atg apibes quanta experienta parcis. \\ H inc anere incipiam. vos o clarifima mundí \\ I umuna, labentem calo quie duitis annum: \\ $\boldsymbol{I}$ ibcr, ON alma Ceres, ucftro fi muncre tellus \\ C haoniam pingui glandem mutarit arifa: \\ P oculcíg; inuentis Acheloia mifosit usu: \\ E thos agrcfum profentia mumna Fauni, \\ F erte fimul, Fauniq; pedem, Dryades'q; puelle. \\ $M$ unera ueftra ano.tuig; o, xi prima frementem \\ $F$ udit equum magno rellus percuffe trident, \\ N eptune: or cultor nemorum, rui pingria Cace \\ I crentum niuci tondens dumetrimenci. \\ I pe nemus linquens patrium, faltus'́; Lycoi \\ p an owium cuftos, tua fi tibi Menala cure: \\ A dfis o Tegrae fausns:olecég; Minerua \\ I nucntrix:unóq; puer monftr afor at atri: \\ E teneramab radice frens syluane apre/firn: \\ D üq; dc $x$ 'q; omres, ftudium quibus cruá tucrns \\ Q yiqi; nou as altis nonnullo fermne fruges: \\ Quíf; fatus largum colo demetrins imbrem. \\ I H'qi adco, quem mox qux fins babstura deorums ।
}

$c$

THE FIRST ITALIC TYPE-FACE

Page printed by Aldus at Venice in 1514 to do good to mankind," In the production of classical works Aldus was assisted by many scholar-refugees from Constantinople, which city had been aptured by the 'lurks. Aldus's fame spread thruout Europe, and many visitors came to Venice to see him. This annoyed lim to such an extent that he had a notice placed above the entrance to his printing office which in part read: "Whoever you are that wish to see Aldus, be brief; and when business is finished, go away." It can thus be seen that the present-day motto cards popular in business offices are not a new idea.

Aldus's complete name was Aldus Pius Manutius Romanus, the first word of which is abbreviated from Theobaldus.

There were more than two hundred printing offices in Venice before the year 1500 and two million volumes were produced. 'These figures may surprise the average modern reader, who is not inclined to concede extensive production to the past.

Bernardo Cennini, a goldsmitl, introduced typography into Florence, Italy, in the year 1471. It is claimed that he made his tools, cast his types and printed without instruction from German typographers, depending upon verbal reports of the process and examination of printed books. Cennini produced only one book.

Johann Numeister, who had been a pupil of Gutenberg, after the death of his master journeyed toward Rome, but for some reason stopped at the little Italian city of Foligno and began to print there in 1470. He used both Roman and Gothic types.

In Sicitserland the new art was first practiced at Basel about 1468 by Bertold Ruppel or Rodt, who had been one of Gutenberg's workmen. Basel was an important printing center in the days when the art was young, and gave to France its first typographers.

John Froben, who set up a press at Basel in 1491, is perhaps the best known of the printers of that city, and because of his use of the then new italic letters was called the "German Aldus."

In those days lived the famous Dutch philosopher and theologian Erasmus, one of the brightest minds of Europe. Frasmus, having heard of Froben, came to Basel to arrange for the printing of his books, and thus began a friendship which lasted many years. Erasmus became a guest at the house of Froben, and his presence was a big factor in that printer's success. Erasmus once said of Froben that he benefited the public more than himself, and predicted that he would leave his heirs more fame than money. (A book of one of the works of Erasmus, printed by Hieronymus Froben, son of John, recently sold for fifteen hundred dollars at a sale in New York.)

In France typography might have been introduced as early as 1461 had not the death of Charles VII. interfered with the plans of Jenson and caused him to go to Venice. As it was, in the year 1470 Ulrich Gering, Martin Crantz and Michel Friburger, three German printers who had been working at Basel, Switzerland, settled at Paris and began to print under the patronage of two members of the University of Sorbonne. The early books of this press were printed from a Roman typeface. The quality of the work of these printers is said not to have been good. Types were defective and presswork deficient, many of the printed letters needing retouching by hand.

Gering became rich and upon his death left much of his fortune to the university within whose walls he had first printed upon coming to Paris.

In order to demonstrate the success of the early printers in decorating their books without the aid of illuminators, a page is reproduced, printed about 1486 by Philip Pigouchet for Simon Vostre, a bookseller of Paris. The decorations were printed from wood blocks, engraved 
GENESI S. Tranlat.B.Hierony. Creatio.

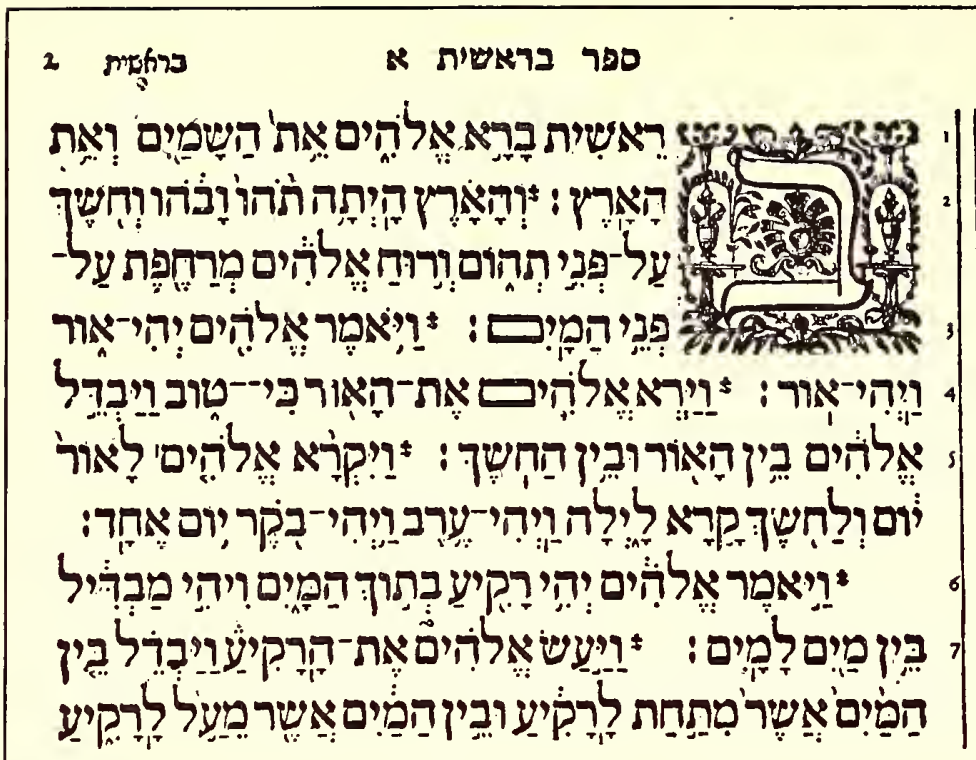

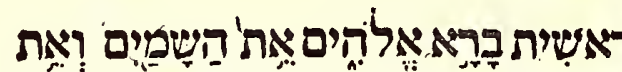

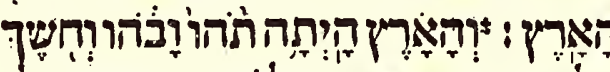

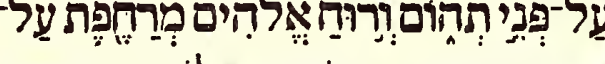

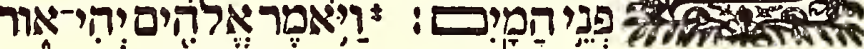

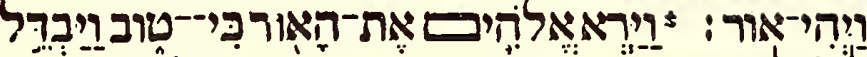

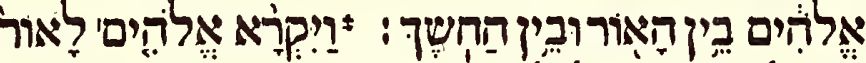

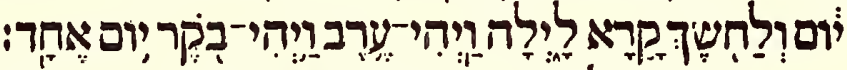

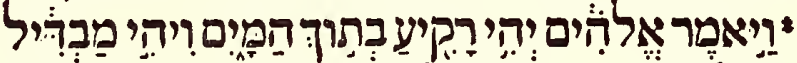

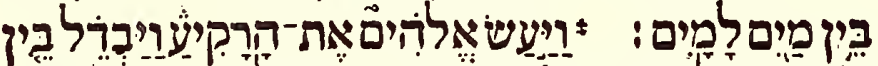

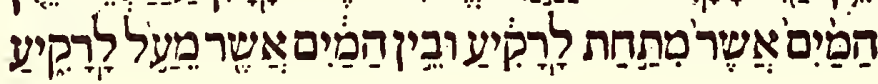

\section{CAPVt PRIMVM.} N principiocreauit Deus cæ.

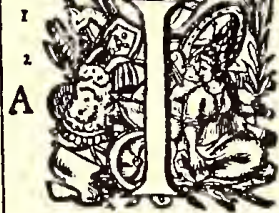
lum \& terrá. "'Terra autem erat inanis \& vacua : \& tenebræ erant fuper facié abyfsi: Meb.n., \& fpiritus Dei ferebatur fu - Hic..10.6 3 per aquas. " Dixitó, Deus, Fiat lux. Et facta elt ${ }_{4}$ lux. ${ }^{*}$ Et vidit Deus lucem quòd eflet bona: \& , diuifit lucem à tenebris. * Appellauitá, lucem diem;\& tenebras nocté. Factumq́; eft velpere 6 \& mane dies vnus. " Dixit quoque Deus, Fiat firmamentú in medio aquarum; \& diuidat.a7 quas ab aquis. ${ }^{\$}$ Et fecit Deus firmamentum, diuifitá; aquas qux erant fub firmamento, ab his qux erant fuper firmamentú. Et factumelt in the style of the Gothic period, with stippled backgrounds, and are interesting to the printer because they show early use of the pieced border, a method now familiar.

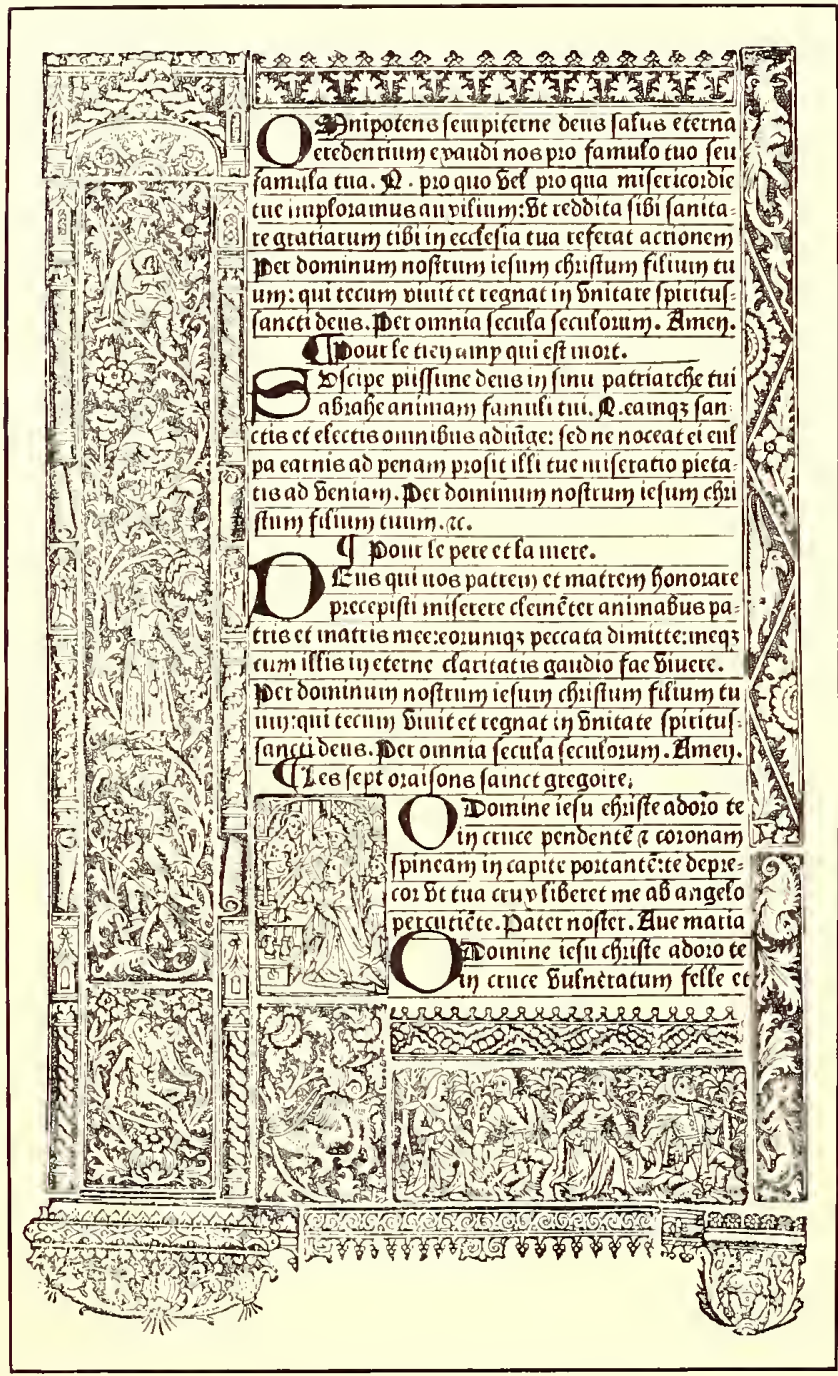

GOTHIC ORNAMENTAL PIECES

Book of Hours, printed for Simon Vostre at Paris in 1486
Henry Estienne settled in Paris in 1502 and was the first of an illustrious family of typographers. The Estiennes flourished until 166.4, during that time printing many remarkable books. A grandson of Henry Estienne was the first to apply the system of numbered verses to the entire Bible.

Robert Estienne, a son of Henry, was the best known and most scholarly of the Estiennes. He was patronized and favored by the King of France, and his press may be said to have been the beginning of the celebrated Greek Press of Paris.

Robert Estienne's ambition, the printing of de-luxe editions of the classics, was his undoing as well as his making. 'The priests of the Sorbonne, upon the appearance of a polyglot Bible in Hebrew and Greek from the Estienne press, became enraged and Robert had to flee to Geneva, Switzerland, for safety. There was little demand in that city for elaborate books, but Estienne patiently worked there until his death in 15.59. His life had been spent in a labor of love, for he had scorned money as a reward for litis work.

In the Netherlands typography was not practiced so far as is known until 14.73, when a press was erected at Utrecht. While it is supposed that printing was done before that time at Bruges, there is no direct evidence to support the supposition. It is known, however, that Colard Mansion printed at Bruges in 1474, and that he taught typography to William Caxton, with him producing the first book printed in the English language.

There is a book with the date 1472, printed at Antwerp by Van der Goes, but this date is supposed to be a misprint, as in the case of Jenson's book of 1471 .

Christopher Plantin, a Frencliman, who began to print at Antwerp in 1555, gave to that city the renown which it enjoys in the printing world. Plantin printed on a magnificent scale, his luxurious notions extending to the casting of silver types. His printing office was considered one of the ornaments of the city and is today used as a museum for the display of paintings and typographical work. Plantin retained a number of learned men as correctors of his copy and proofs, and the story is told that his proof sheets, after undergoing every possible degree of correction, were hung in some conspicuous place and a reward offered for the detection of errors Plantin's greatest work was his polyglot Bible of 1569, a portion of which is reproduced above. 
Interf.ex Grxc.lxx. GENESIS.

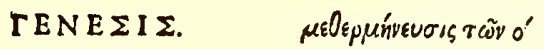

3

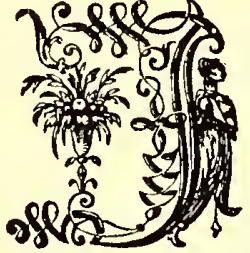

CAPVT PRIMVM. N pronctpiofecit Deus calum or terră. At terraerat inutibilis et incŏpofita, et tenebra SuperabysJum: 心 BirtusDeiferebatur fu per aquam. ${ }^{*}$ Et dixit Deus, Fiat lux, (t) factaeft liux." Et vidit Deuslucè,quòd bona: odisifit Deusinter lucem, \&s inter tenebrus. ${ }^{5}$ Et rocauit Deus lucĕ dië: 世) tenebras vocautt noclë: (t) factü eft pespere; o factü eft mane, dies vnus. ${ }^{\star}$ Et dixit Deus, Fiat firmament ü in medio aque: $\sigma$ fot diuidè's inter aquă, (t) aquă. Et fect Deus firma ment u, $\&$ diuifot Deus inter aquă; que erat Jub fir-

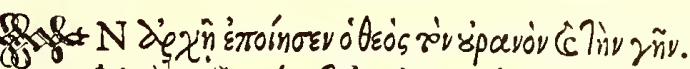

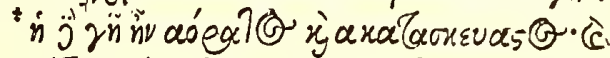

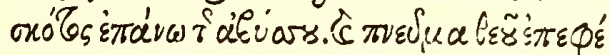

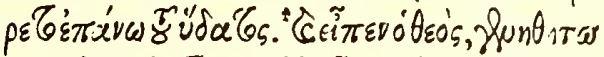

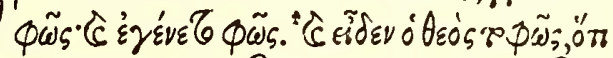

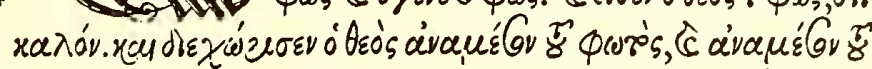

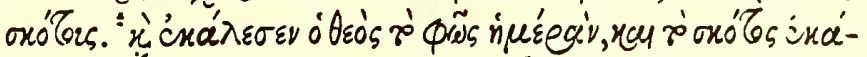

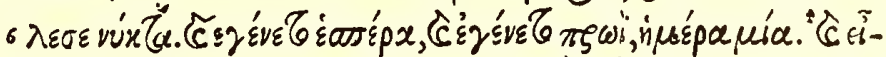

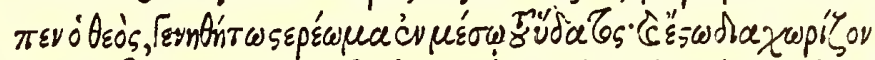

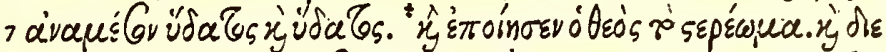

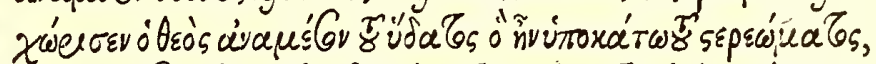

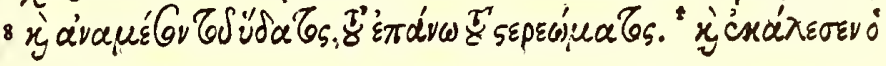

IN HEBREW, LATIN AND GREEK, PRINTED BY PLANTIN AT ANTWERP, ABOUT 1569

Louis Elzevir, founder of the family of learned printers of that name, first printed in 1595 at Leydell. The second Louis Elzevir opened an office at Amsterdam in 1640. The product of the Elzevirs was of such quality as to make them famous thruout Europe as printers of the classies, and their books were extensively imitated and counterfeited.

While Haarlem is claimed to have been the birthplace of typography, a book cannot be produced printed in that city with a date earlier than 1483 , when Johannes Andriesson had an office there.

In England the name of William Caxton is one to conjure with among typographers, for Caxton was the first to set type in that country, the event taking place about the year 1477. Perhaps the thing that endears Caxton to the hearts of English printers is that he was born in England. The first printers of Italy, Switzerland and France were Germans, but Caxton was Enghish; we have his own words to prove it: "I was born and lerned myn englissh in Kente in the weeld where I doubte not is spoken as brode and rude englissh as it is in ony place in englond."

Caxton had been apprenticed when a young man to a merchant, and after his master's death took up residence at Bruges in the Netherlands, with which city England did considerable trading. There he prospered and as governor of the Merchant Adventurers had control over all English and Scotch traders in the Low Countries. The device later used by Caxton for his imprint is supposed to have been copied from some trading mark of the Bruges merchants.

Caxton resigned as governor and entered the service of the Duchess of Burgundy, who encouraged him in literary work. Under her patronage he translated (14691471) a "Historie of Troye." The demand for this work was an incentive for Caxton to learn how to print it. This he did with the assistance of Colard Mansion who had started a printing office at Bruges.

Shortly afterward, Caxton returned to England and set up a press in the vicinity of Westminster Abbey, then on the outskirts of London. The first book with a date printed by him is "The Dictes and Sayinges of the Philosophers," completed in November, 1477. His typefaces are copies of those of Mansion, who in turn imitated the ketters of Dutch copyists. A type-face based on Caxton's letter is now made by an American foundry.
The product of Caxton's press during his life is estimated at eighteen thousand pages, nearly all of folio size. Caxton did not print de-luxe editions as dict other of the early printers of Europe, but his productions were no less interesting. On his first books the lines were

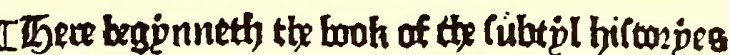
and ffables of Elope whitte wete tranclateid out of ffrendle in to Engliale bi wojllam Eaxton

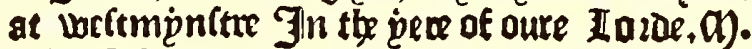
- EECE.1Extioj.
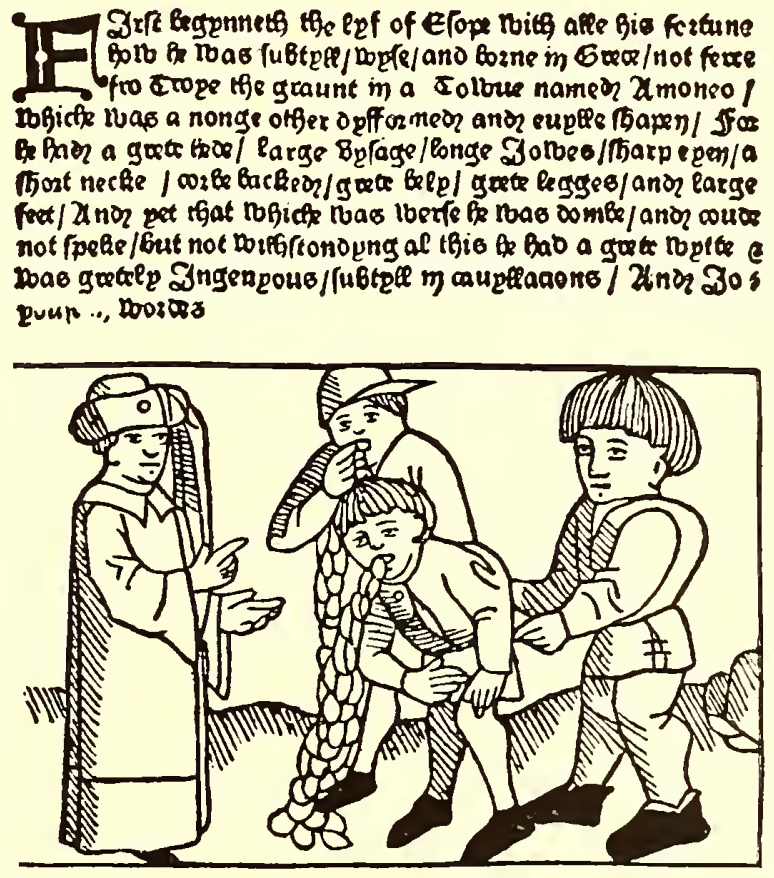

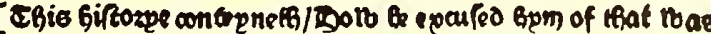

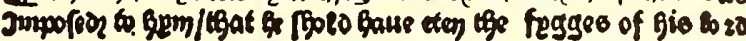

PAGE BY ENGLAND'S FIRST PRINTER How Caxton arranged a book title in $\mathbf{1 4 8 3}$ 
not spaced to the full length. This gave to the right side of the page a ragged appearance, as in modern typewritten letters.

Caxton did not devote a separate page to a book title until late in his life, when lie printed a title alone in the center of the first page. The reproduction (on the preceding page) of a part of Caxton's "Fables of Esope" shows how the title was arranged at the page hearl.

Wynken de Worde, a native of western Germany, was a workman under Caxton and upon the latter's death, about 1491, succeeded to the business of his master. He continued to print in Caxton's house for several years, afterward removing to "Fleet-street at the sygn of the Sonne," in London proper. Old English black-letter, which is now so popular, was used by De Worde to a great extent, and he was the first printer to introduce the Roman letter into England.

Richard Pynson, another of Caxton's workmen and friend of De Worde, set up a press in Temple Bar, London, about 1492 , and printed many useful books.

Richard Grafton is famous as a printer of English Bibles during the troublous times of the Reformation. The cluurch authorities believed it was not good for the people in general to read the Sacred Scriptures, and the Bible, translated into English by William Tyndale and Miles Coverdale, and printed anonymously by lichard Grafton at Antwerp, was the object of much concern to the ecclesiastics. The Bishop of London complained that "Some sons of iniquity have craftily translated the Holy Gospel of God into our vulgar English." After a long imprisonment 'Tyndale suffered death by

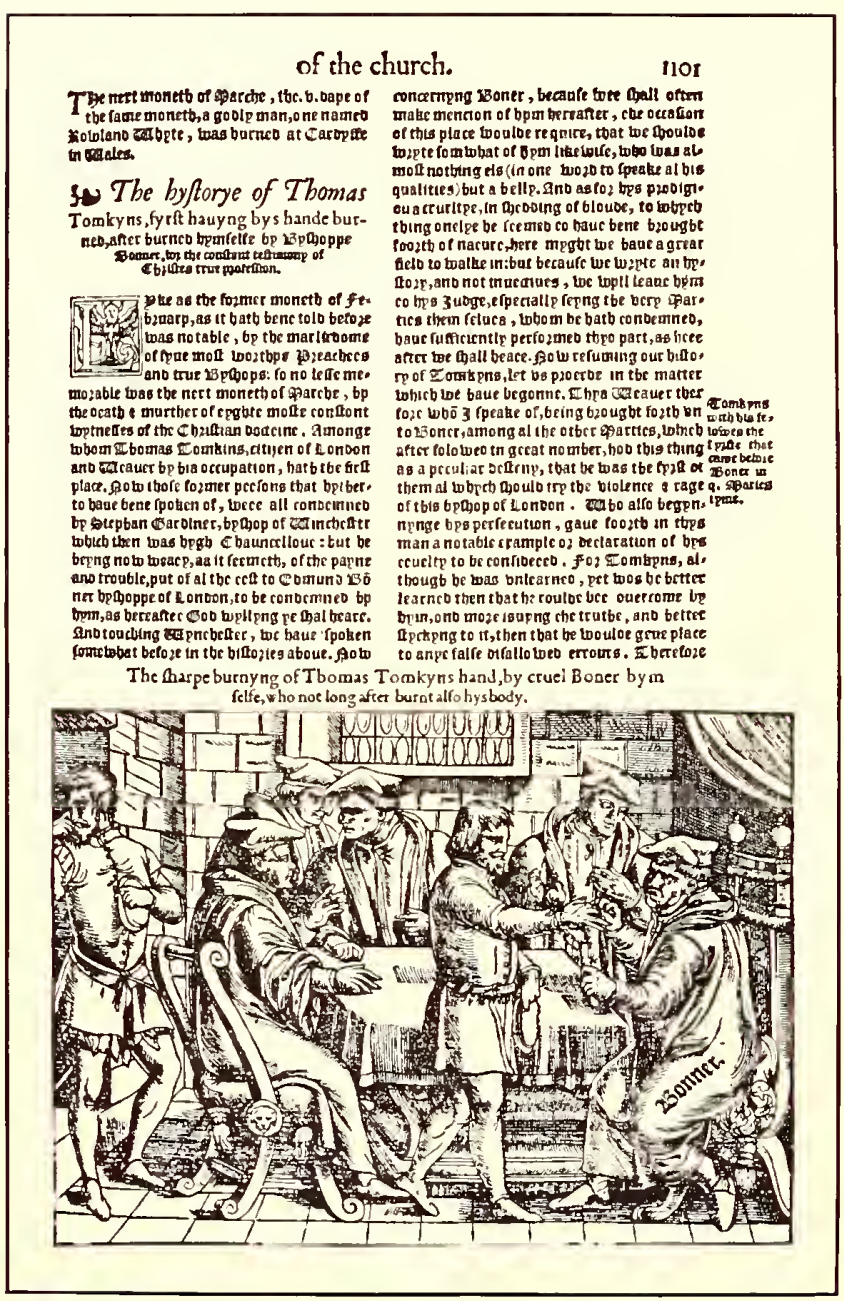

PAGE IN ENGLISH BY JOHN DAYE

From Fox's famous "Acts and Monuments," London, 1560 strangulation and burning. Grafton was imprisoned in 1540 for printing a large folio Old and New Testament known as the "Great Bible." This tremendous task of printing was accomplished by Grafton in partnership with Edward Whitechurch at l'aris and London.

Shortly after this the prejudice against an English translation was partly overcome, and in 1543 Parliament passed an act allowing the Bible to be read by certain

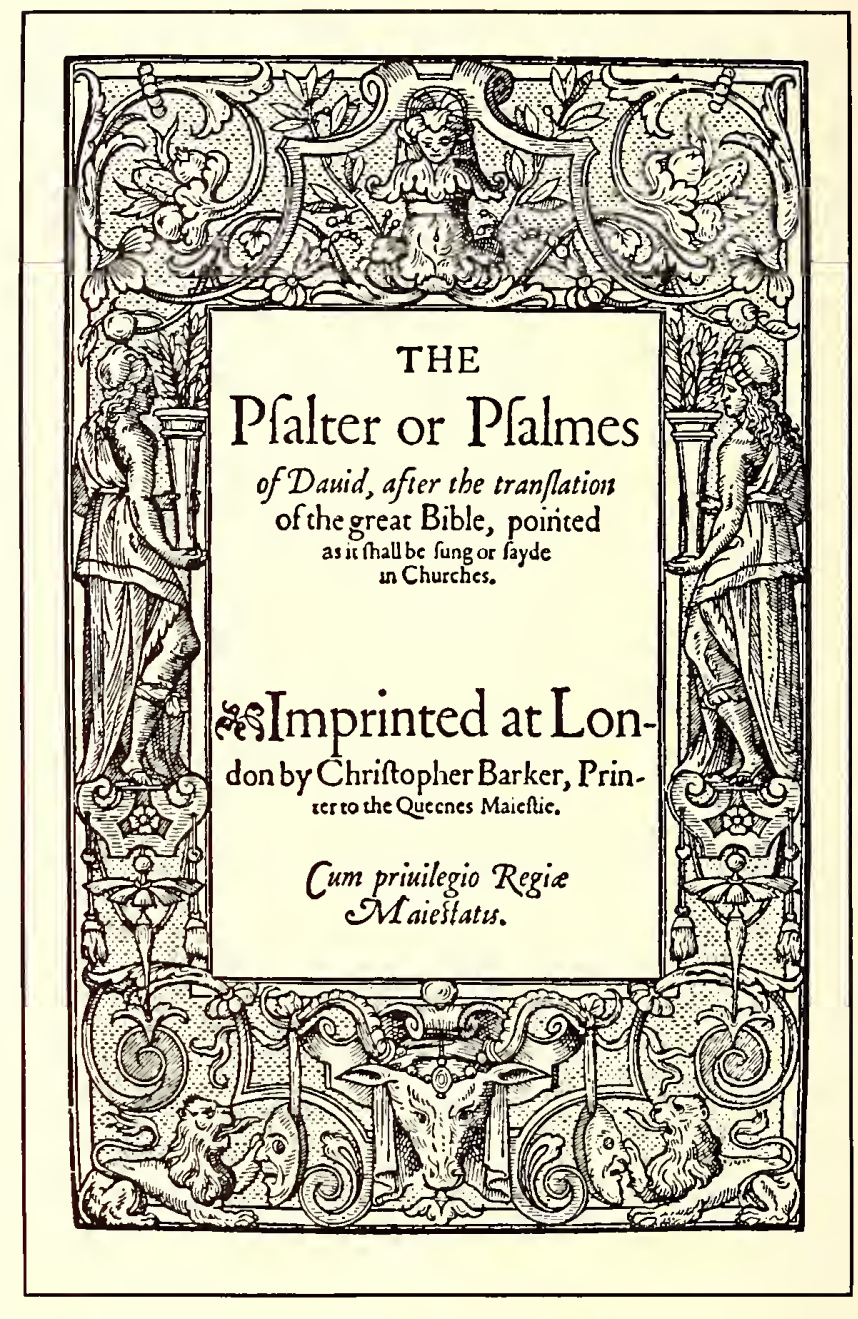

THE FIRST PSALTER IN ENGLISH

Printed at London about 1565 by Christopher Barker

clisses, but forbidding women, apprentices, journeymen, husbandmen or laborers to read it privately or openly.

John Daye, who first printed about 1546 , was another English typographer to suffer imprisonment on account of activity in the Protestant cause. Many important books were printed by Daye, and in character and accomplishments he has been likened to Plantin who printed during the same period at Antwerp.

The best known of the books printed by Daye is Fox's "Acts and Monuments," on the subject of wrongs and persecutions in the days of the Reformation. Dibden says it was "a work of prodigious bulk, expense and labor."

In. Scotland printing was introduced in 1507 at Edinburgh by Androw Myllar, in partnership with Walter Chepman, under a patent granted by King James IV.

In Ireland a prayer book was printed by the new process in 1551 at Dublin by Humphrey Powell.

In North America typography was first practiced in 1540 at Mexico City, Mexico, by John Cromberger.

In the United States, or rather the territory now included under that name, typography was introduced in 1639 at Cambridge, Massachusetts, by Stephen Daye. 

CompleatA mbaffador:

O R. T W O

\section{TR E A T IES}

OF THE

INTENDED MARRIAGE

O F

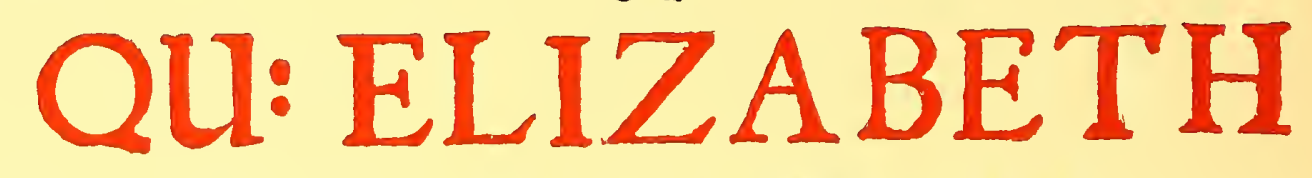

Of GLORIOU'S MAMORY;

Comprifed in
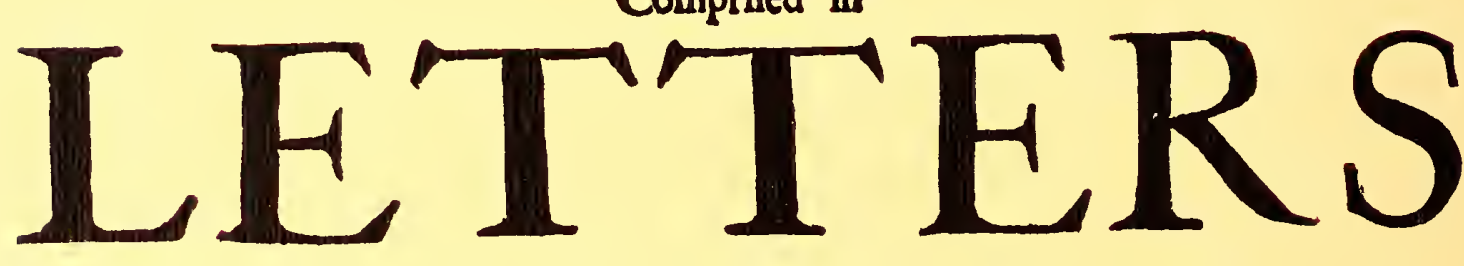

$$
\text { O F }
$$

NEGOTIATION

\section{O F}

Sir Francis Walfingbam, her Refident in France.

TOGETHER

With the Anfwers of the Lord BUR LEIGH, the Earl of LEICESTER, Sir T R O: SMITA, and others.

Wherem as in a clear Mirror, may be feen the Faces of the two TLourts of Ang land and France, as they then food, with many remarkable

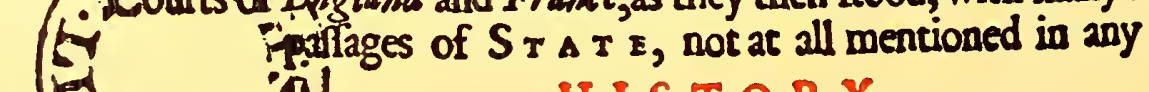

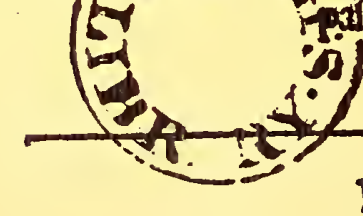

Faithfally Colleted by the traly Honourable, Sir D U D Y DIG G ES Knight, late Mafter of the Rolls.

\section{LONDON:}

Printed by Tbo: Nerweombl, for Gebriel Bedell and Thowses Collins, and are to be fold at their Shop at the Middle-Temple Gase in Fleetftreet,

I 653 . 


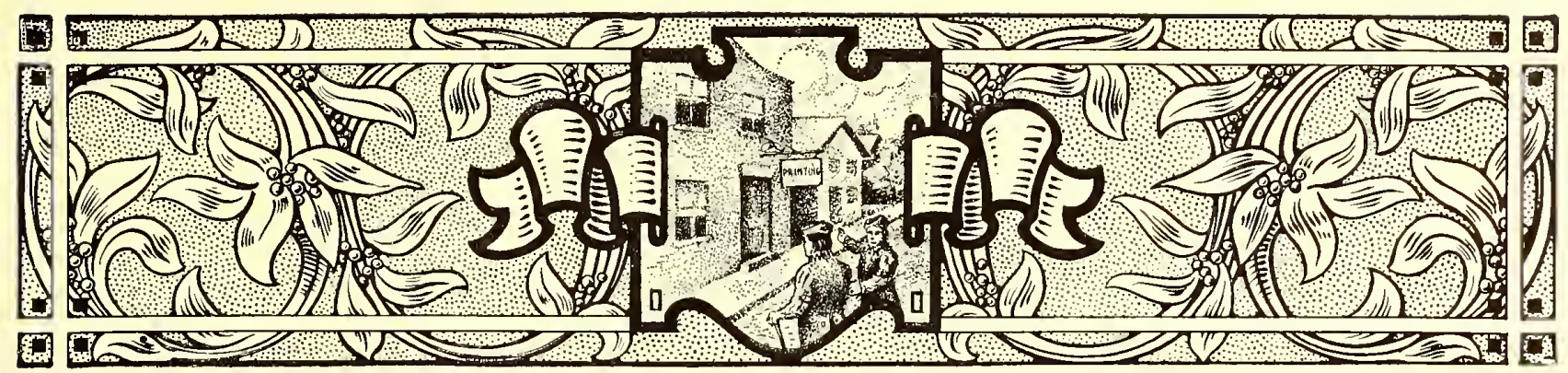

\section{TYPOGRAPHY IN COLONIAL DAYS}

TYPOGRAPHY has been an important factor in the development of modern civilization. In the battle for civil and religious liberty, in both Europe and America, the man with the pen and he of the composing-stick have been together on the firing line. With Paul they could well boast that they had been "in perils of waters, in perils of mine own countrymen, in perils in the city, in perils in the wilderness, in weariness and painfulness, in hunger and thirst." William Tyndale died at the stake, Richard Grafton and John Daye suffered imprisonment; Robert Estienne became an exile from his own country; Jesse Glover on his way to America found a grave in the waters of the Atlantic; Stephen Daye set type in a wilderness; James Franklin, William Bradford and John Peter Zenger were imprisoned, and Benjamin Franklin suffered hunger and privation.

As ecclesiastical and political conditions in Europe strongly influenced the practice of typography during the days of the American colonies, I will briefly review the events of the sixteenth, seventeenth and eighteenth centuries that the reader may better understand and appreciate the subject.

In the year 1521, when Luther appeared before the Diet of Wormsin Germany, the English people were ardent Roman Catholics. Henry VIII. was King of England and the great Cardinal Wolsey was in high authority. Henry, in the early part of his reign, was exceedingly loyal to the Catholic Church; he published a book in answer to the attacks of Luther, for which the pope gave him the title "Defender of the Faith." However, when Henry wished to divorce his wife that he could marry Anne Boleyn, the church authorities did not approve. This so angered the king that he took from Wolsey his office and possessions, denied the authority of the pope over the Church of England, and had himself declared the supreme head of that organization. The king was excommunicated by the pope and in return Catholics were persecuted and put to death, and their monasteries, colleges and hospitals broken up. Henry repeatedly changed his religious opinions, and for many years both Catholies and Protestants were put to death for differing with him.

For six years after Henry's death in 1547 , during the reign of his son Edward VI., the Protestants were in power. Then for five years under Mary the Catholics controlled the religious affairs of the country, and the flesh of "heresy" was toasted at the stake.

Elizabeth, who began to rule in 1558 , was proud of the appellation "Virgin Queen" and gave the name "Virginia" to the English colony in America. She never quit spinsterhood, but about the year 1570 considerable correspondence was carried on between the English and French THE FIRST BOOK PRINTED IN ENGLISH AMERICA By Stephen Daye at Cambridge, Mass., 1640. (Page slightly reduced) courts regarding her 


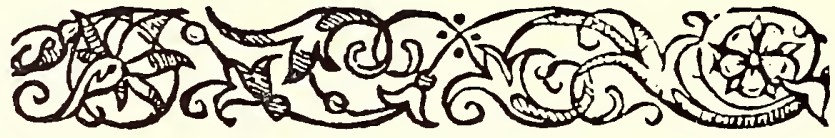

A

Midfommer nights dreame.

\section{As it bath beene fundry times pub- likely atted, by the Righe Honoura- ble, the Lord Chamberlaine his Seruasts.}

VVritten by VVilliam Sbakefpeare.

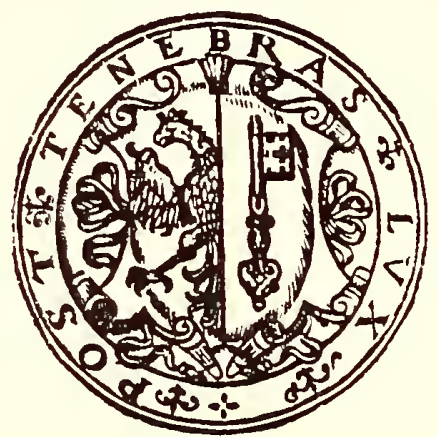

\section{Printed by Iames Roberts, 1600.}

printed in 1600, while Shakespeare was in the midst of his literary labors

Puritans that printing was introduced into English America. Elizabeth reigned until 1603 and was the last of the Tudor family of sovereigns. The first of the Stuart Kings, James I. (son of Mary Queen of Scots), then ruled until 1625, when he was succeeded by his son Charles I. Charles was a despot and claimed that the people had no right to any part of the government. A civil war resulted, Charles was beheaded (1649) and a form of government known as the Commonwealth was established. Oliver Cromwell shortly afterward became Lord Protector with more power than the king had possessed.

Cromwell was a Puritan, but of the radical element known as Independents, differing from another element of Puritans known as Presbyterians. The Independents have come to be known as Congregationalists. Under Cromwell's severe Puritanic rule, sculpture and painting were declared as savoring of idolatry and public amusements were sternly put down. However, Crom well encouraged printing and literature. $\mathrm{He}$ was an intimate friend of John Milton, the blind author of "Paradise Lost" (see title-page reproduced on a following page), which book was published in 1667 , the year following the Great Fire. Milton was Latin secretary to Cromwell, and published a book which argued against royalty, for which, on the accession of Charles 1I., he was arrested.

In 1657 (the year before Cromwell died) was published the sixth and last volume of the London Polyglot Bible, compiled by Brian Walton and printed by Thomas Roycroft. In this Bible there were used nine languages: Hebrew, Chaldee, Samaritan, Greek, Syriac, Arabic, Ethiopic, Persian and Latin. The work took

intended marriage. This resulted in the accumulation of over three hundred letters, which eighty-five years later were collected and printed as a 442-page quarto. (The title-page is reproduced full size as an insert in this chapter.) A poor Puritan named Stubbs and a poor bookseller named Page published a pamphlet against the marriage of Queen Elizabeth to the French king"s brother, and tho the queen herself had said she would never marry, these unfortunate subjects were punished for their audacity by having their right hands cut off.

Under Elizabeth, the "Protestant" religion was permanently established in England, but the enactment of severe laws, such as prohibiting any one attending the ministry of clergymen who were not of the established religion, gave rise to dissenters derisively called Puritans because they wished to establish a form of worship based on the "pure" word of God. It was by these so-called four years in printing, and was the first book ever published in England by subscription. Cromwell encouraged the undertaking by allowing paper to be imported into England duty free, and by contributing a thousand pounds out of the public money to begin the work.

In those days the Puritans presented a curious contrast to the Royalists. The Puritan, or "Roundhead" as he was also called, wore a cloak of subdued brown or black, a plain wide linen collar, and a cone-shaped hat over closelycut or long, straight hair. The Royalist, or "Cavalier," wore clothes of silk or satin, a lace collar, a short cloak over one shoulder, short boots, and a broad-brimmed beaver hat adorned with a plume of feathers.

The period designated as the Restoration, long celebrated by the Church of England, began soon after Cromwell's death, when in 1660 Charles II. ascended the throne. This period brought with it a reaction from 
the Puritanic conditions that previously existed and all sorts of excesses were practiced. Cromwell's body was taken out of its grave in Westminster Abbey, hanged on a gallows and belieaded.

It was during the rcign of Charles II. (1665) that the Great Plague killed one hundred thousand people in London, a terrible experience followed by one equally terrible the next year: the Great Fire, which consumed thirteen thousand houses.

In 1688 there was another revolution; the people passed a Bill of Rights, and set a new King (William III.) on the throne.

George I., the head of the dynasty now represented in England by King George V., came to the throne in 1714. He was a German, could not speak English, and was the grandfather of George III., the "villain" in the great drama of the American Revolution.

In France the Protestant Huguenots were persecuted by Cardinal Richelieu, whose strong personality dominated King Louis XIII. from 1622 to 1642 , and many of them left for America. In 1643 Louis XIV. became King of France and his long reign of seventy-two years is renowned because of the magnificence which found expression in sumptuous buildings, costly libraries, splendidly-bound books, and gorgeous dress.

Cardinal Mazarin, in whose library was later discovered a copy of Gutenberg's Forty-Two-Line Bible, acted as advisor while Louis XIV. was under age.

In the seventeenth and eighteenth centuries many mechanics in England worked for a shilling a day; their chief food was rye, barley and oats; and one-fifth of the people were paupers. Teachers taught their scholars principally by means of the lash, masters beat their servants and husbands their wives. Superstition was strong and children and grown folks were frightened with lugubrious tales into being "good." This spirit is especially noticeable in the chap-books that were sold during the seventeenth and eighteenth centuries. A title to one of these chap-books (dated 1721) reads :

A Timely Warning to Rash and Disobedient Children; being a strange and wonderful Relation of a young Gentleman in the Parish of Stepheny in the Suburbs of London, that sold himself to the Devil for twelve years to have the Power to be revenged on his Father and Mother, and how his Time being expired, he lay in a sad and deplorable Condition to the Amazement of all Spectators.

Children in those days were either devilishly bad or ridiculously good. Read this title-page:

The Children's Example; shewing how one Mrs. Johnson's Child of Barnet was tempted by the Devil to forsake God and

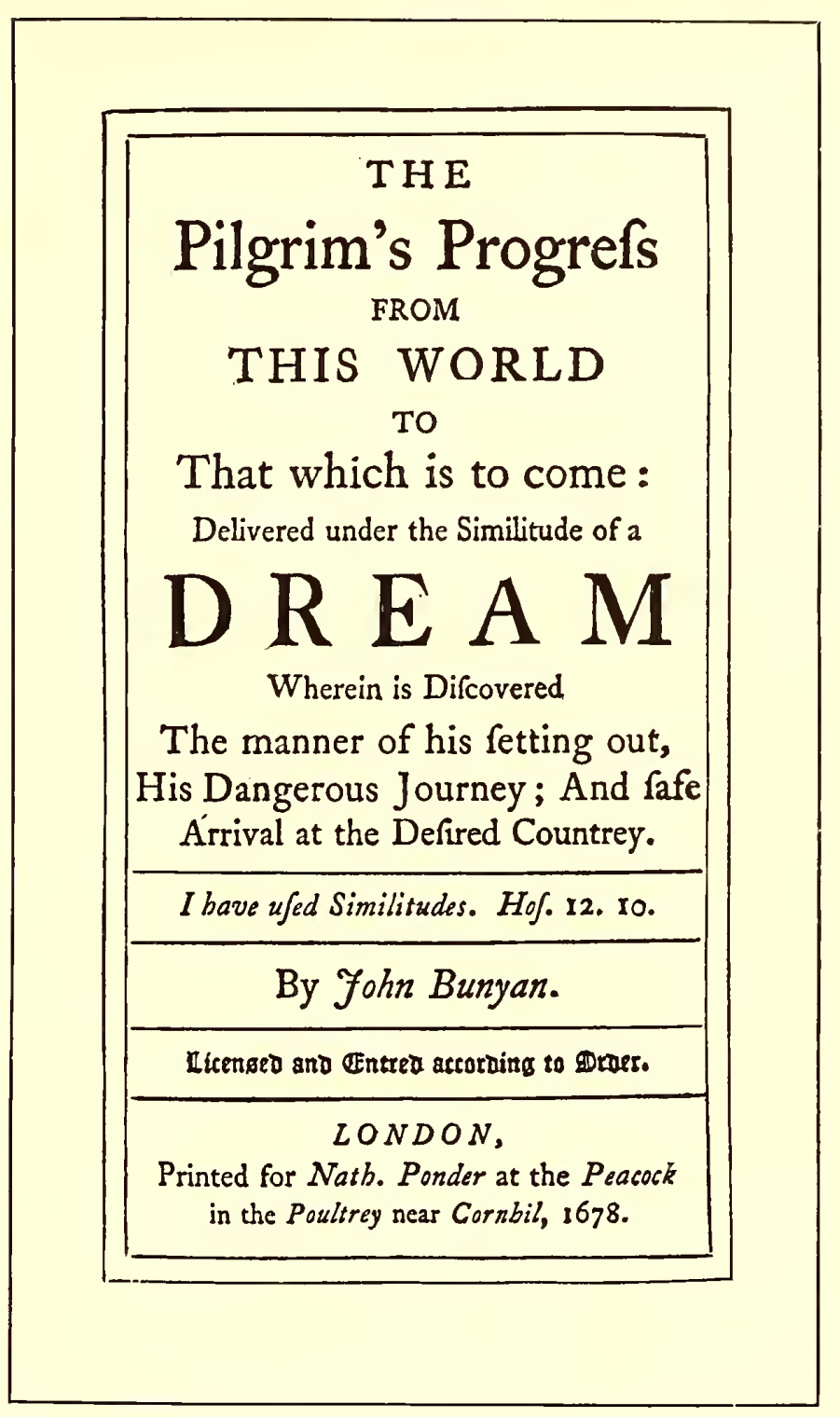

FIRST EDITION OF " PILGRIMS PROGRESS"

Title-page (actual size) of Bunyan's well-known book, London, 1678

follow the Ways of other Wicked Children, who us'd to Swear, tell lies, and disobey their larents; How this pretty innocent Child resisting Satan, was Comforted by an Angel from Heaven who warned her of her approaching Death; Together with her dying Speeches desiring young Children not to forsake God, lest Satan should gain a Power over them.

Jack the Giant Killer, the hero of our childhood diys, was a favorite subject for chapbook exploitation. There is shown on the following page the title of such a "history."

Chap-books are poor representatives of the art of typography in Colonial days because they were to the book industry then what reprint books are to the trade in our time. Todlay it is customary for some publishing houses to buy up old electrotype plates of obsolete editions of dictionaries and other popular books. The plates having already been put to extensive use, are battered 


\section{T H E}

\section{$\begin{array}{llllllllllllllll}H & I & S & T & O & R & Y\end{array}$ \\ O F}

\section{Jack and the Giants}

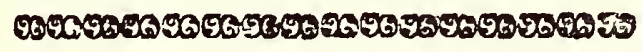

The F I R T PAR T.

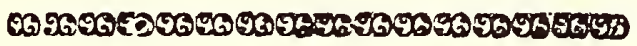

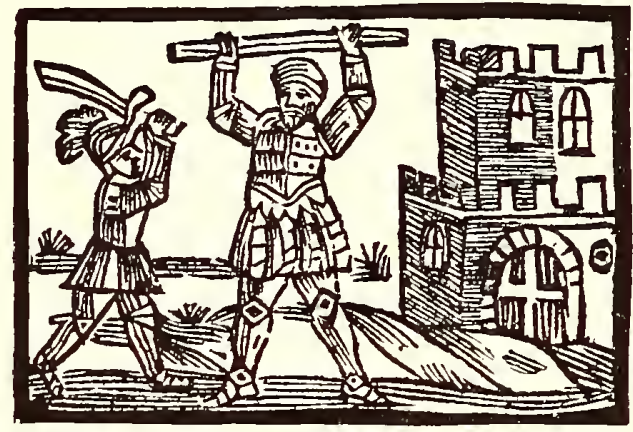

$4 y^{2}$ of of

Printed and Sold at the Printing-Office in Bow-Church-Kard, London.

PAGE FROM A "CHAP-BOOK"

Probably a Dicey product of the eighteenth century

and worn, and impressions from them cannot be accepted as criterions for determining the quality of modern printing. Neither are the chap-books true printing representatives of their times. The woolcuts, crudely drawn in the first place, were also worn and battered by repeated use.

In the early part of the seventeenth century chapbooks were 8 vos. (sixteen prages of about $5 \times 8$ inches), but later were reduced to 12 mos. ( $t$ welve or twenty-four pages of alout $4 \times 6^{1} \frac{1}{2}$ inches). The stories were condensed to fit these small penny books, which were peddled by chapmen. A chapman is described in a "Dictionarie" of 1611 as "A paultrie Pedlar, who in a long packe, which he carries for the most part open, and hanging from his necke before him hath Almanacks, Bookes of News, or other tritling ware to sell."

Many of the chap-books of the eighteenth century were printed and published at Aldermary-Church-Yard and Bow-Church-Yard, London, by William and Cluer Dicey, afterwarl C. Dicey only. The Dicey books were better productions than those of their imitators. It is not possible to determine the exact year in which the majority of chap-books were printed, as many title-pages merely read "Printed and sold in London," etc., or "Newcastle; printed in this present year," without the formality of the date.

There were also other cheap productions known as broadsides, single sheets about $12 \times 15$ inches, in most cases printed broadwise of the paper and on one side only.
On December 21, 1620, there landed at Plymouth Rock, in what was afterward the colony of Massachusetts, a band of Puritans from England. These non-conformists, unable conscientiously to obey the laws of their native country, had come to America to worship God in their own manner. Ten years later Governor Winthrop with one thousand Puritans landed at Charlestown, and in the following year these immigrants began to settle Cambridge and Boston. A building for an academy (now Harvard University) was erected at Cambridge in 1638, and in 1639 Stephen Daye began to print there.

For the establishment of this, the first printing office in what is now the Inited States, Rev. Jesse Glover, a l'uritan minister of some wealth, was chiefly responsible. Himself contributing liberally, he solicited in England and Holland sufficient money to purchase a press and types, and June 7, 1638, entered into a contract with Stephen Daye, a printer, to accompany him to the new country. Rev. Glover (with his family, Stephen Daye and the printing outfit) embarked on a vessel for New England, but on the voyage across the ocean he was taken ill and died.

The press and types having reached Cambridge were finally placed in charge of Stephen Daye and printing was begun in 1639. The first work produced was "The Freeman's Oath," probably a single sheet, and the first book (1640) was the "Booke of Psalmes," familiarly known as the "Bay Psalm Book." (The reproduction on the first page of this chapter is from one of these books

\section{$194 \quad A$ DESCRIPTION of}

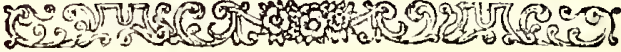

\section{S K R E E N-M A K E R S.}

THEIR Trade of late Years has been 1 greatly improved, not only as to curious Workmanhip, moft of which is now exceedingly rice, but as to the Variety of Sorts and the Materials of which they are compofed.

The Principal of them, though they are but few, are Shop-kecpers as well as Makers, whofe working Part is an eafy, clean Employ, to which they take with an Apprentice 15 or $20 \mathrm{l}$. whofe Hours in work mult be from fix to eight: They pay a Journeyman 12 or 15 s. a Week; $50 l$. will fet up whom as a Maker only; but if he ftocks a Shop with but common Sortments he will sequire $500 \%$.

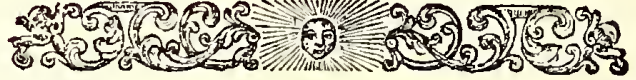

\section{$S \mathrm{~N} U \mathrm{~F} F-\mathrm{M}$ A K E R S.}

$T \mathrm{~T}$ is but a few Years fince their Trade made 1 any Figure in Shops, which now appear almoft every where, plainly thewing, that not only the Practice of taking Snuff is greatly increafed, but that the Making and Selling it muft be profitable.

The

PAGE FROM “DESCRIPTION OF TRADES." LONDON, 1747 Showing use of decorative bands to separate subjects 
preserved in the public library, Forty-Second Street, New York.) This book of Psalms is a revision of Ainsworth's version of 1612, and was in use in New England for upwards of a century, more than fifty editions laving been published. The size of the type-page of the first edition is $3 \frac{1 / 4}{\times 6} 6^{1 / 4}$ inches.

In quality of presswork this first book of Stephen Daye affords a decided contrast to the Bible of Gutenberg, near which it lies in the cases at the public library. The print on the pages of the Psalm Book is uneven in color and impression, while that on the pages of the Bible is denseblack and firmly and evenly impressed. The reproduction of the title-page of the Psalm Book does the original no injustice. It is difficult to determine whether the shoulders of the border printed the angular lines, or whether these are a part of the design. It is interesting to note how in the word "Whole," Daye furmed a W by combining two $\mathrm{Vs}$, his font of types being one evidently intended for Latin work only.

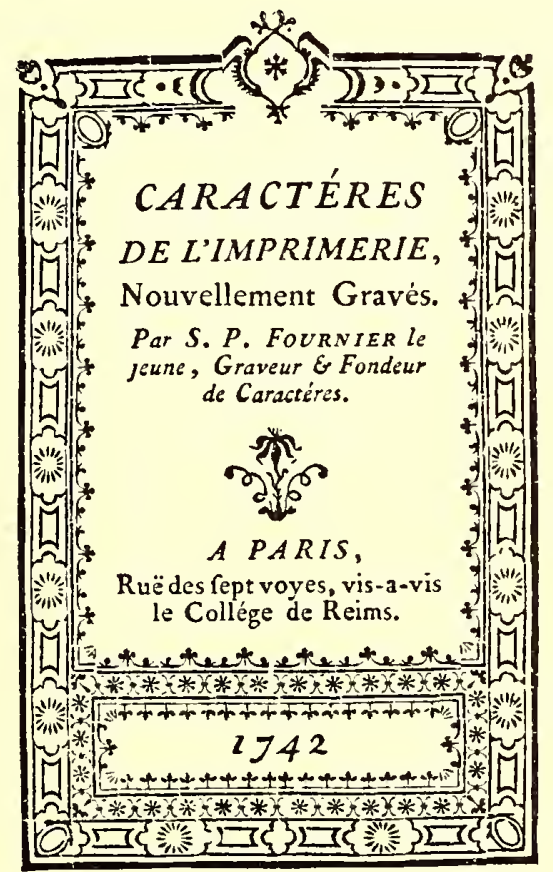

FRENCH SPECIMEN OF 1742

(Actual size)

Daye continued in charge of the printing office for about ten years. Jesse Glover's widow had married Henry Dunster, the first president of Harvard College, and Dunster, for his wife and as president of the college, managed the printing office and received such profits as were made. For some reason Daye in 1649 ceased to be master printer and Dunster appointed Samuel Green to the position. Green had come from England in 1630 with Governor Winthrop, but was not a printer at that time.

The commissioners of the united colonies, who had in charge the propagation of Christianity among the Indians, added another press to the one already at Cambridge, together with types, etc., for the purpose of printing the Bible and other books in the Indian language. In 1662 Green gave to the commissioners the following "account
ABCDEFGHIKLMN OPQRSTUVWXYZJ Quoufque tandem abutere, Catilina, patientia noftra? qu 2uoufque tandem abutere, $\mathrm{Ca}$ tilina, patientia noftra? quam-

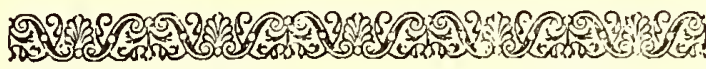

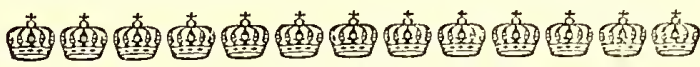

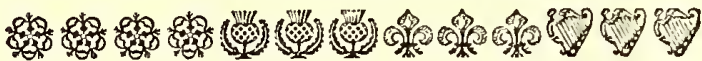

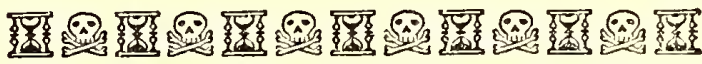

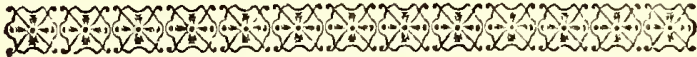
(a) $x^{25}$ (6)

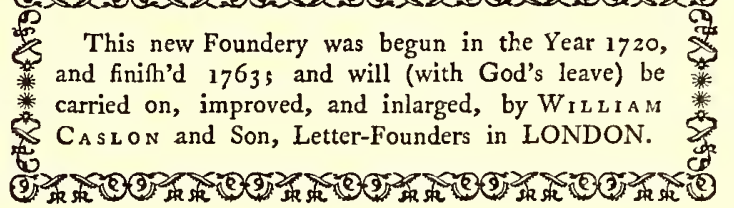

CASLON TYPES AND ORNAMENTS

From the specimen book of W. Caslon and Son, London, 1764

of utensils for Printing belonging to the Corporation:"

The presse with what belongs to it with one tinn pann and two frisketts.

Item two table of Cases of letters with one ode Case.

Item the ffont of Ietters together with Imperfections that came since.

Item one brasse bed, one Imposing Stone.

Item two barrells of Inke, 3 Chases, 2 composing stickes, one ley brush, 2 candlestickes one for the Case the other for the Presse.

Item the frame and box for the sesteren.

Item the Riglet brasse rules and scabbard the Sponge $\mathbf{1}$ galley 1 mallett 1 sheeting sticke and furniture for the chases.

Item the letters that came before that were mingled with the colledges.

In 1670 the commissioners presented this equipment to Harvard College. Green continued to print until he was very old, and upon his death in 1702 the printing office was discontinued.

Before 1740 more printing was done in Massachusetts than in all the other colonies. Printing was not introduced into the colony of Virginia until about 1727 , principally because the authorities deemed it best to keep the people in ignorance.

Pennsylvania was the second English colony in America in which typography was practiced. The charter of this colony was granted to William Penn in 1681 and in 1687 William Bradford at his printing office "near Philadelphia" printed an almanac. This was a sheet containing the calendar of twelve months (beginning with March and ending with February, as was customary in the seventeenth century). In England, Bradford had worked for a printer who was intimately acquainted with George Fox, founder of the Society of Friends (Quakers). This infuenced Bradford to adopt the principles of that sect and he was among the first to emigrate to Pennsylvania in 1682 


\section{Paradife loft.}

A

$\mathbf{P}$

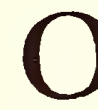

$\mathrm{E}$

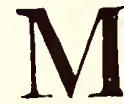

Written in

T E N B O O K S

By FOHN MILTON.

\section{Licenfed and Entred according to Order.}

\section{$L O O N D O N$}

Printed, and are to be fold by $P$ oter Parker under Creed Church neer Aldgate; And by Robert Bulier at the Turk, Head in Bilhoplgate-firset; And Martbia Walker, under St. Dumfons Church in Fleet.jtret, 1867 .

FIRST EDITION OF "PARADISE LOST"

Title-page (slightly reduced) of Milton's famous book, London, 1667

or a cutler, but love of books caused him finally to be indentured to his brother, James Franklin, who had opened a printing office in Boston. Benjamin was twelve years of age when indentured and was to serve as apprentice until his twenty-first birthday. Making an arrangement with his brother to be allowed to furnish his own board, Franklin provided himself with meals "often no more than a biscuit or a slice of bread, a handful of raisins, or a tart from the pastry cook's and a glass of water," using the money thus saved for the purchase of books. In 1721 James Franklin began to print a newspaper (the New England Courant) and Benjamin tells how some of his brother's friends tried to dissuade him from the undertaking, "one newspaper being, in their judgment, enough for America." Some articles in this newspaper giving offense to the Assembly, James Franklin was imprisoned for a month, and on his discharge was forbidden to publish the Courant. To evade this order Benjamin's name was substituted for that of James Franklin as publisher.

A short time afterward (1723) the brothers disagreed, and Benjamin left Boston, coming by ship to New York. Here Franklin offered his services to William Bradford, then the only printer in the city, but he could give him no work. However, he suggested that Franklin go to Philadelphia where Andrew Bradford, his son, had a shop. Franklin did not succeed in getting work with Andrew Bradford, but was more fortunate with Samuel Keimer. The printing house of Keimer, as described by Franklin, consisted of an old damaged press, a small worn-out font of types, and one pair of cases. Here Franklin worked until he left for England to select an equipment for a new printing office to be established

Bradford became involved in a quarrel among the Quakers of Philadelphia and in 1692 was arrested for printing a pamphlet. The sheriff seized a form of type pages to be used as evidence, and it is said that Bradford later secured his release because one of the jurymen in examining the form pushed his cane against it and the types fell to the floor, "pied" as it is technically expressed. The trouble into which Bradford found himself in Philadelphia very likely influenced him in 1693 to leave that city and establish a printing office in New York "at the sign of the Bible" (the site at 81 Pearl Street is now marked by a tablet), his being the first printshop in New York and the only one for thirty years. He was appointed in 1693 official printer to the government. In 1725, when Bradford was sixty-one years old, he began the publication of the first newspaper in $\mathrm{New}$ York (the Gasette).

No review of Colonial printing would be complete without an account of Benjamin Franklin, whose birthday (January 17) is each year widely celebrated. Franklin's father was an Englishman who came to New England about 1685, and Benjamin was born in Boston in 1706, the youngest but two of seventeen children. He came near being a minister, a seaman, a tallow-chandler by him in Philadelphia. At that time there was no type foundry or press manufactory in the United States. Franklin had been encouraged by Governor Keith with promises of financial assistance, but the trip to London proved a fool's errand and Franklin went to work in a printing office there as a journeyman, first at the press, later in the composing-room. (It is told that forty years afterward when Franklin was residing in Great Britain, he went into this printing office and with the men there drank "Success to printing.") He returned to Philadelphia, worked as a foreman for Keimer, and then with a partner, Hugh Meredith, opened a printing office.

One of the first jobs done by the new firm was forty sheets of the history of the Quakers, set in pica and long srimer. Franklin tells how he "composed a sheet a day and Meredith worked it off at press; it was often eleven at night, and sometimes later, before I had finished my distribution for the next day's work. But so determined I was to continue doing a sheet a day that one night, when, having imposed my forms, I thought my day's work over, one of them by accident was broken and two pages reduced to pi, I immediately distributed and composed it over again before I went to bed."

In 1732 (for the year 1733) Franklin first published 
"Poor Richard's Almanack." For this purpose he used the name of Richard Saunders, an English astrologer. This almanac continued to be published by Frankliu for twenty-five years, nearly ten thousand copies being sold annually. The two pages here reproduced are full size, and as it is likcly that Franklin gave close attention to the typography it will be interesting to study their arrangement. They are good examples of title-page and tabular composition of Colonial days.

Franklin considered this almanac a proper vehicle for spreading instruction among the common people, and filled the little spaces that occurred between the remarkable days in the calendar with proverbial sentences. These proverbs, which contained the wisdom of many ages and nations, were latter gathered together as a harangue of a wise old man under the title "The Way to Wealth," and the familiar plrase "As Poor Richard says" is often repeated therein.

In 1748 Franklin took as a partner David Hall, the firm name being Franklin \& Hall until 1766, when Hall became sole proprietor.

Quaintness is the chiet characteristic of Colonial typography. While the treatment lacks the artistic quality, the refinement, and the daint $y$ finish of the productions of Aldus,

\begin{tabular}{|c|c|}
\hline \multicolumn{2}{|c|}{ Mon. March hath xxxi days. } \\
\hline $\begin{array}{l}\text { My Love and I for } \\
\text { She would keep ftal } \\
\text { But when I won the } \\
\text { This made me ask h } \\
\text { Quoth the, fince you } \\
\text { Here me your Kiffes, }\end{array}$ & $\begin{array}{l}\text { Kiffes play'd, } \\
\text { kes, I was content, } \\
\text { e would he faid; } \\
\text { her what the meant: } \\
\text { are in this wrangling rein, } \\
\text { give me mine again. }\end{array}$ \\
\hline 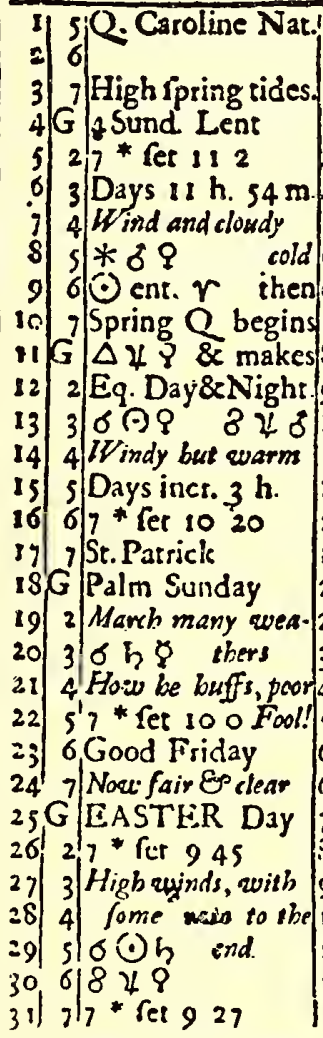 & 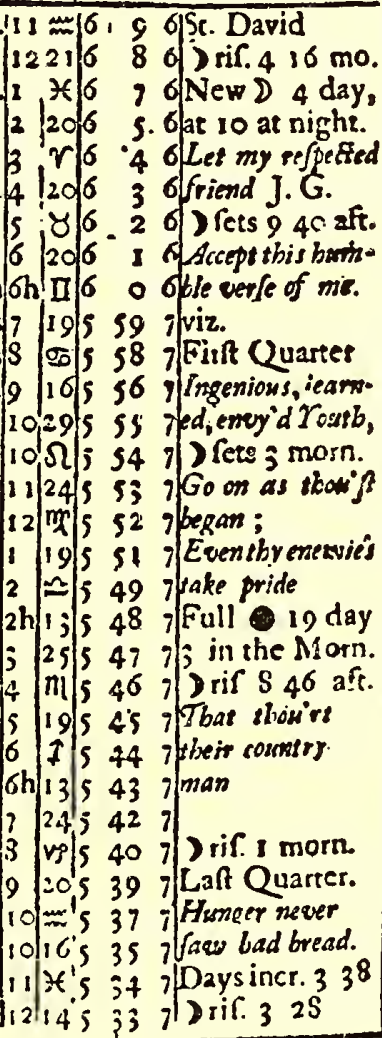 \\
\hline
\end{tabular}

\section{Poor Ricbard, 1733. \\ A N \\ Almanack}

For the Ycar of Chrift<smiles>[CH]1CC[Tl]1</smiles><smiles>[10BH]</smiles>

Being the Firft after I EAP YEAR:

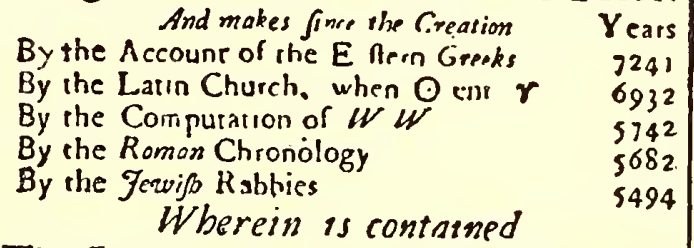
The Lunations, Eclipfes, Judgment of
the Weather, Spring Tides, Planets Morions \& murual A $\int_{\text {pear. }}$ Sun and Moon's Rifing and Setting. Length of Days, Time of High W'ate: Fairs, Courts, and obfervable Days

Fieted to the Laritude of Forr. Degrees, and a Mcridian of Five Hours W Weft from I ondon. but mav without fenfihle Error ferve all the adjaccut Places. even from Newfoundland ro SouthCarolina.

By RICHARD SAUNDERS, Philom.
PHI I A DE L P H I A :
Printed and fold by B FR ANKLIN, at the New
Priating Office near rhe Markct

TWO PAGES FROM " POOR RICHARD'S ALMANACK"

Printed by Benjamin Franklin in 1732

Froben and other printers of classics, it has natural simplicity, human interest, and an inexpressible something that makes it attractive to the average printer of today.

The title-page of the "Compleat Ambassador," showing the actual size of the original, is constructed in a severely plain manner, a style known as the "long and short line," with catchwords.

The "Midsommer Nights Dreame" title-page is one of the most artistic of Colonial pages, printed when Shakespeare was in the midst of his famous literary labors (1600). To get contrast the compositor alternated lines of roman with lines of italic. The spacing material could not have been accurate, and two capital $V^{*}$ s were used for a $W$, as in the Daye title-page.

The "Paradise Lost" title-page is a poor specimen of composition and presswork. It was common in Colonial days to surround the type-page with a double rule border, and in this specimen the rules are bent and battered. Printed in 1667 , it is a part of the first edition of Milton's famous book.

The London Times heading is interesting, representing as it does the first number, under the new name, of a newspaper which has since become world-famous. The 


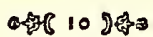

editionum collatione, multae eaeque infignes variantes leEtiones deprehendantur, quodque folio Lxxvi prior pagina etiam in utroque quod habeo, exemplari non reperiatur impreffa. Ea autem ex una typographorum ofcitantia praetervecta videtur; nec enim quicquam illic deficit ralbagiani commentarii .

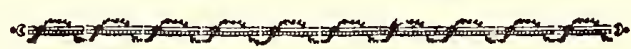

C A P U T III.

$D_{e}$ ceteris hebraicorum librorum ediuionibus ab hebraicae typographiae origine ufque ad annum $M C C C C L X X X$.

$$
0=0
$$

1. $P$ salterium hebraicum cum commentario Kimchii in-quarto codem anno minoris judaeorum fupputationis ccxxxvat, Chrift Mcccclxxv11. Alter hic eft hebraicae typographice foetus, paucis tantum menfibus gerfonidis commentario recentior. Hic enim editus eft, ut fupra animadvertimus, die iv

ITALIAN SPECIMEN OF 1776

Showing use of decoration

heading mentions that the Times was printed "logographically." Logotypes (two or three letters cast together) were being experimented with to facilitate type composition, but did not prove successful.

The printers "At the P'eacock in the Poultrey near Cornhil" surely were good workmen. The "Pilgrim's Progress" title-page is a finished bit of printing.

The custom of using decorative border units to make printed books attractive was seemingly practiced thruout Europe. The Italian page of 1776 is an example of this, as is also the French specimen of 1742.

The page from the Colonial book, "Description of Trades," exhibits the use of the decorative band for dividing subjects, which idea has possibilities in the direction of general job printing that make it worthy of experiment.

Because Caslon types and ornaments were extensively used by Colonial printers I have reproduced on a previous page specimens of types and ornaments from the typespecimen book of W. Caslon \& Son, printed in 1764. The Caslon type-face was original in the sense in which the type-face cut by Jenson was original; both had characteristics which identified them with their designers, but both also had a general resemblance to type-faces previously used. The lioman face cut by Caslon bears a marked similarity in its capitals to the type-faces used by Thomas Newcomb on the title-page of the "Compleat Ambassador" (see insert).

There are shown here two specimens of type-faces designed by Bodoni, which were the first of the so-called "modern" romans. The letters reveal a thinning of the lighter lines and a thickening of the heavier lines. The serifs are straight and sharp. The design of the letters was such as to afford the typefounders of the nineteenth century a model upon which to base their efforts at mechanical accuracy in the cutting of type-faces. As a result of the introduction of Bodoni's new type-face there was not a type foundry in the world in 1805 making the old-style roman type-faces. Giovan Battista (John Baptist) Bodoni was a printer-typefounder of Parma, Italy.

The illustrations in this chapter were in most instances photographed from originals in the New York Public Library, the library of the New York Typotheta, and the private library of The American Printer.

\section{$2 J$}

et attonito quodam silentio, quam ulla loquendi copia prosequendas censeo, quibus certe Aula Hispanica beneficentissime patuit, et in qua, tanquam in sua regia, sedem ipsae collocarunt. Et quidni eo confugerent mitissimae artes, ubi regium patrocinium, et liberalitas eas ab invidia, et inopia liberabat, totque extabant exempla propensae in doctos artifices CAROLI volunta. tis? Cujus rei monimenta erant locupletissima Academia Matritensis regiis aedibus aucta: Valentina excitata: Hispalensis, Caesaraugustana, Barcinonensis largiter amplificacae; erant Carmonae, Selmae, Balliesterii Parisios missi, lautissimis ad iter, et commorationem impensis subministratis, ut quam modo in ipsorum operibus admiramur, graphidis, et sculpturae praestantiam assequerentur; erant laxata compita, ornata fora, instaurata templa, singulaeque urbium par-

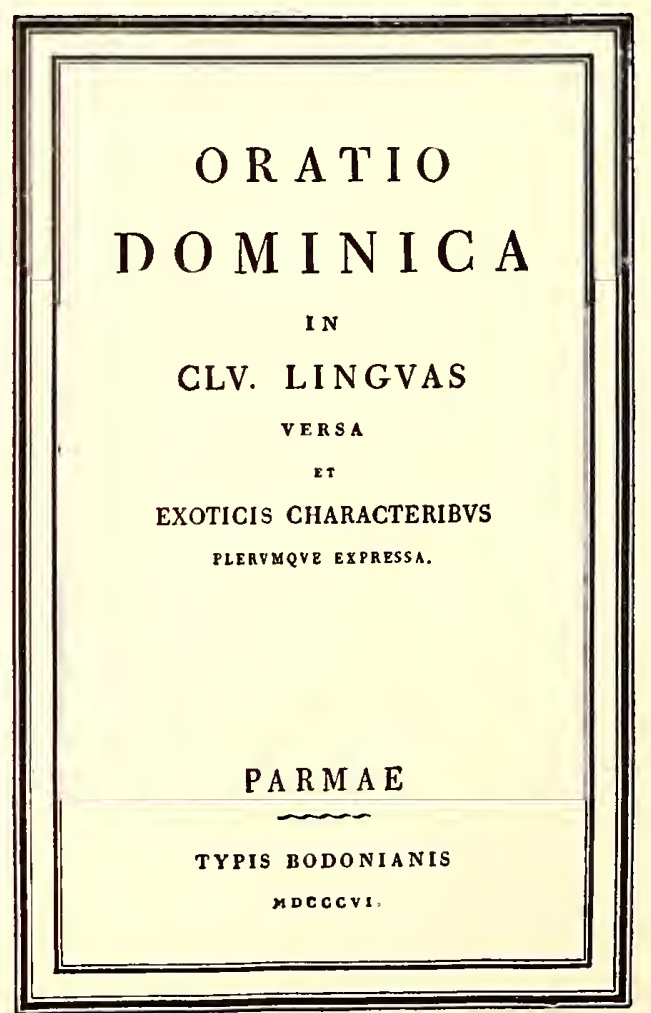





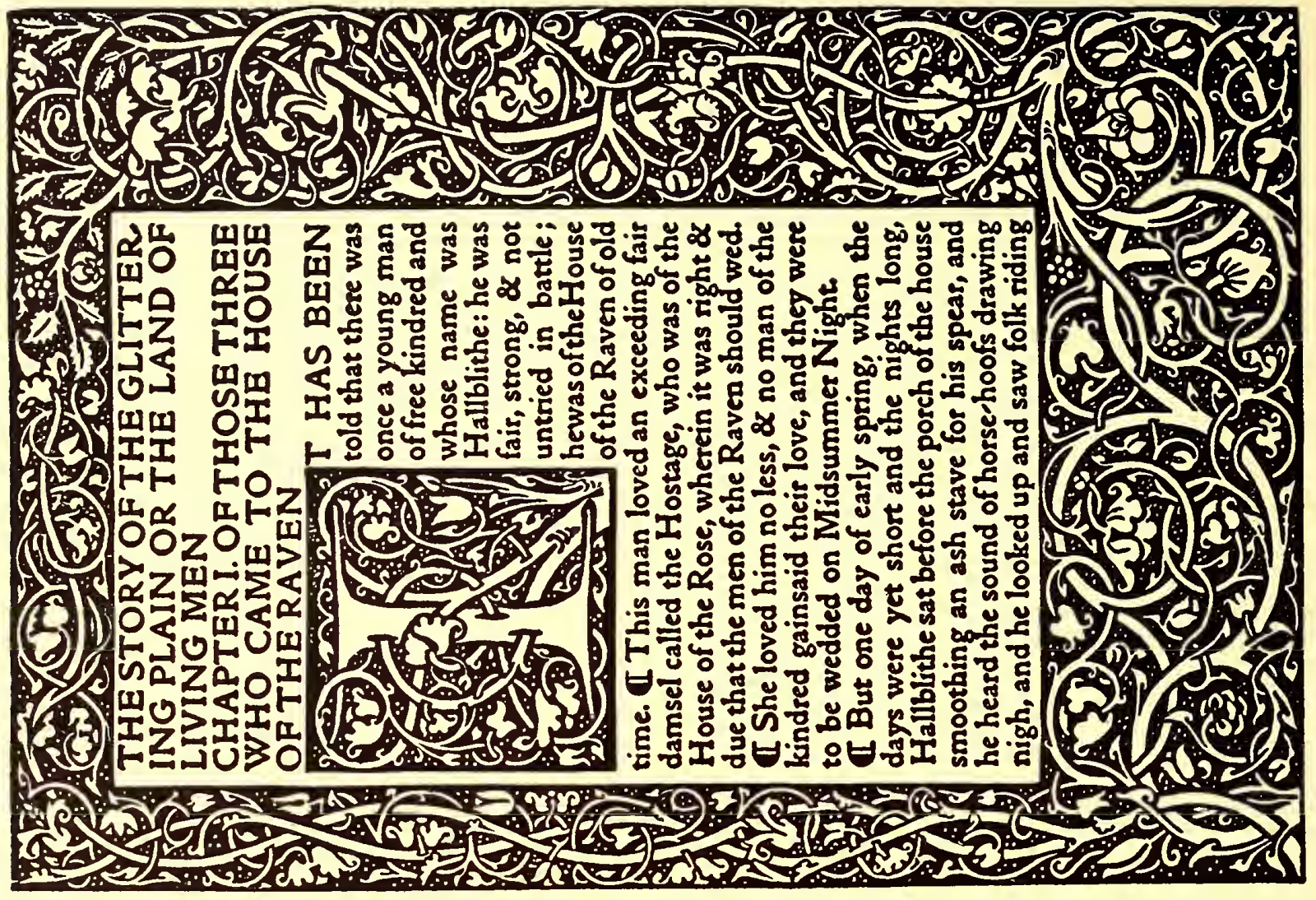

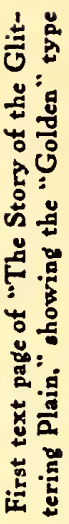

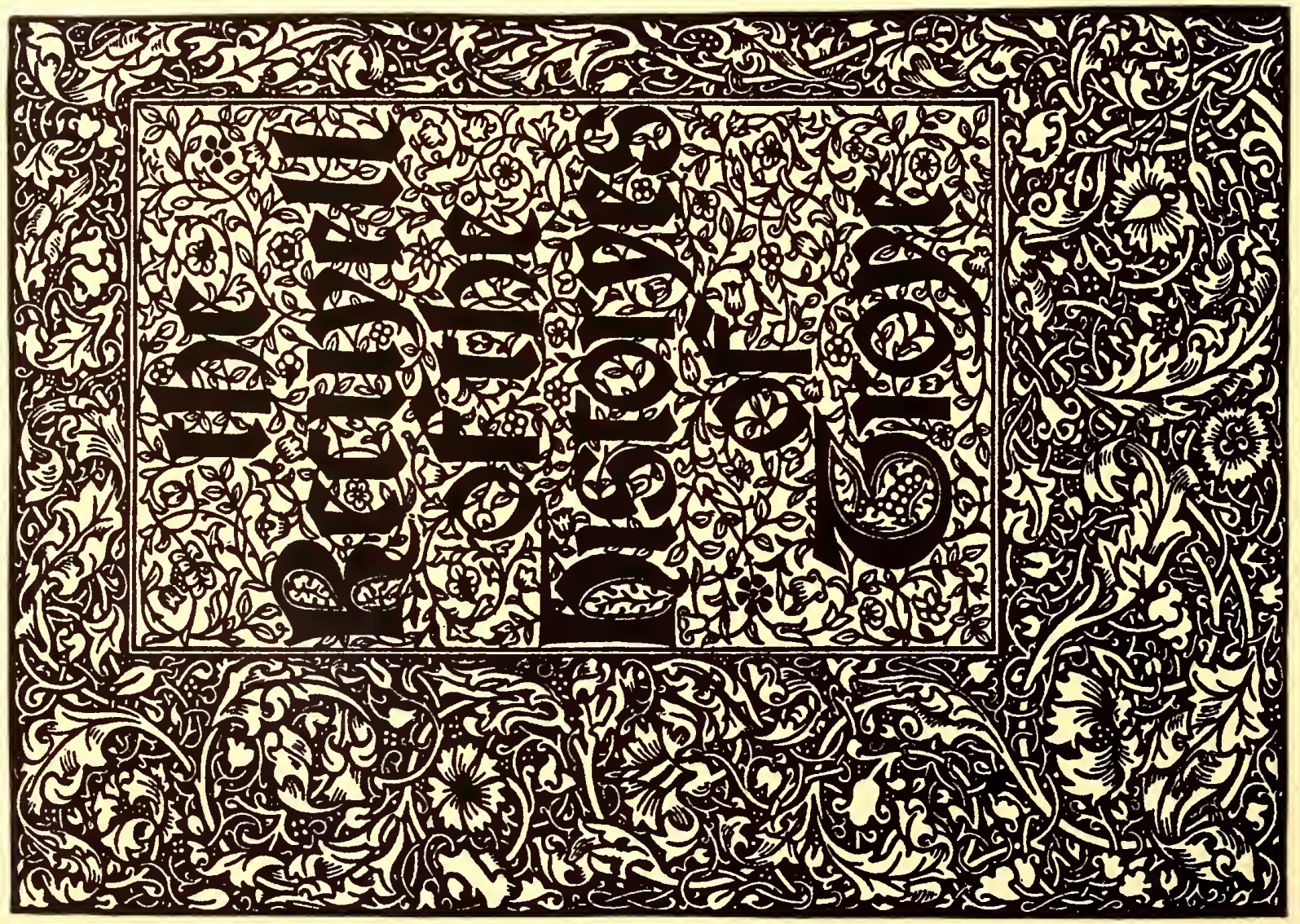

. 


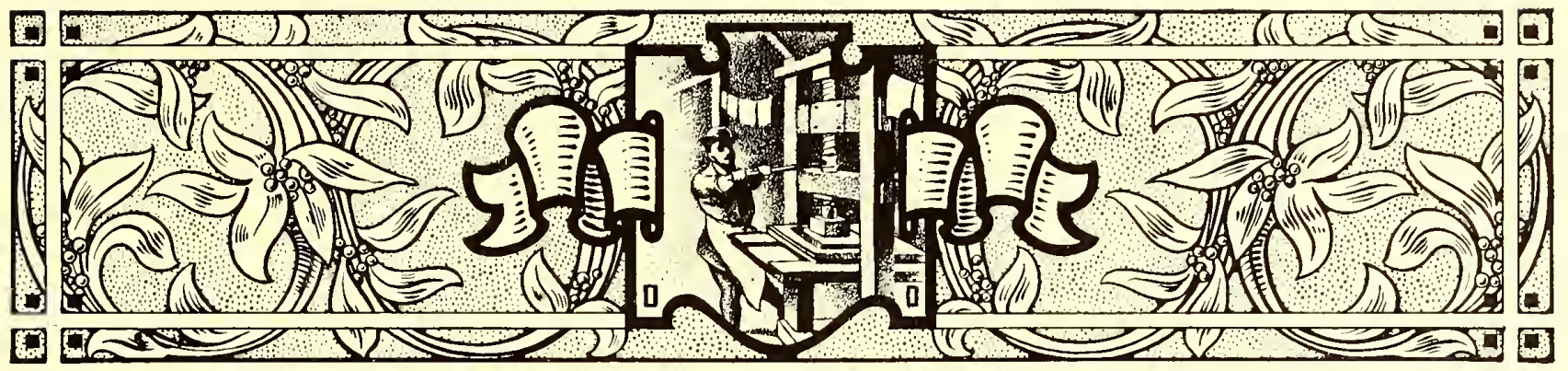

\section{TYPOGRAPHY IN THE 19Th CENTURY}

IT WAS near the close of the nineteenth century when William Morris, the distinguished exponent of strength and simplicity in art, declared that "no good printing has been done since 1550." According to this statement one hundred years after its invention typography forfeited its place among the esthetic arts, and then for three hundred years remained below the standard set by its inventor. By setting his date at 1550 Morris overlooked the achievements of such eminent printers as Plantin and the Elzevirs, but his arraignment probably had some justification.

Posterity had defaulted in its administration of the legacy left by Gutenberg.

The first book printed from separate types, as an example of artistic arrangement and careful workmanship, is a remarkable testimony to the genius of the inventor, especially when the completeness of theinvention is compared with theinitial productions of later inventors. The first cylinder press and the first linotype machine were both crudely constructed.

Typography attained its highest point toward perfection in Italy in the days of Jenson and Aldus. The Italian style of lettering and decoration differed greatly from the German. There were dignity, refinement, a dainty neatness, in the printed pages of the Venetians, and their type-faces were precise and of a darkgray tone. The German page, with its bold Gothic letters arranged in masses of black, was characteristic of the religious fidelity and sturdiness of the dwellers on the banks of the Rhine.

As the art of printing spread, the German and Italian styles became mingled, finally resulting during Colonial days in a style of typography which represented the Italian modified by the German just enough to make it interesting. But typography as an art was in a state of deterioration. Even Franklin, called by the printers of America their "Patron Saint," as a typograpler lacked the artistic perception of Aldus and Plantin, altho he was a superior mechanic and a shrewd business man.

The beginning of the nineteenth century found the practice of typography leaning more than ever toward utility and away from art. William Nicholson, an Englishman, had planned a cylinder printing press, and Dr. Kinsley, of Connecticut, had constructed a model of one. A roman typeface on severe, mechanical lines had been designed, and picturesque old romans such as the Caslon were going out of use. Ornaments and borders were being discarded, and the style of typography was getting uninteresting and losing the personal element.

To illustrate this transition there are reproduced four representative titlepage arrangements. The first is that of a book on printing published in 1810 , containing several lines of the then new romantype-face. In arrangement this page is similar to the
Letterpress imitation of the decoration of double-column pages on early books. From the "Book of Common Prayer," London, 1814 


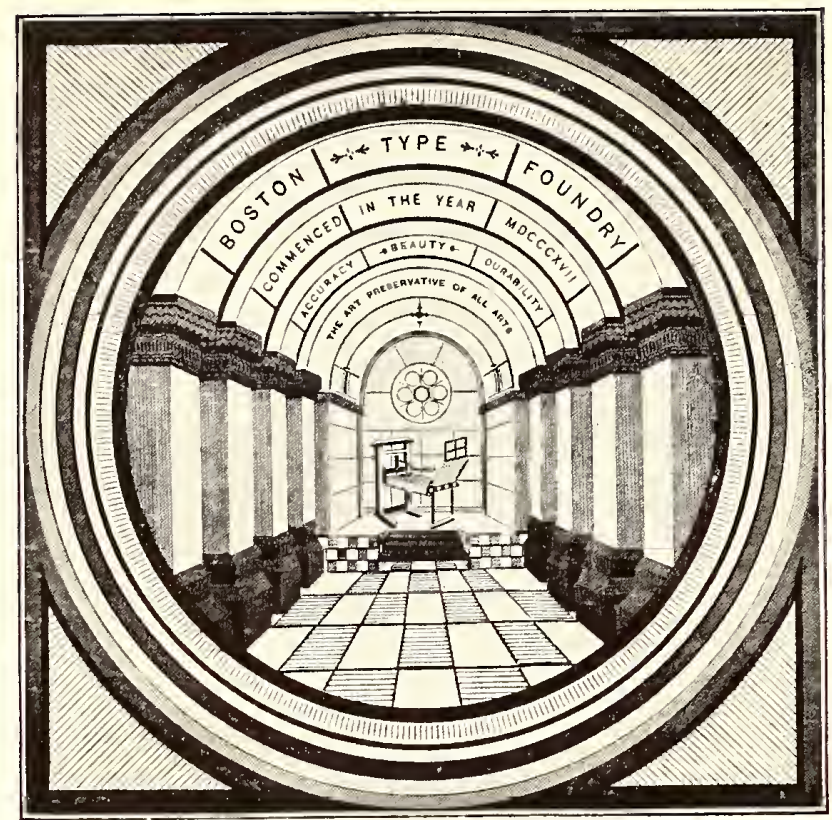

DESIGN MADE WITH BRASS RULE

Executed in 1879 , it is one of the best specimens of the rule-curving period

"Queen Elizabeth" page inserted in the chapter on Colonial typography which is perhaps the source from which came the "long-and-short-line" and "catch-word" style of the average title-page of the nineteenth century. The second example of the group shows a displayed page of 1847 similarly treated, and the third is a reproduction of the title-page of a printer's manual of 1872 . This lastmentioned example is the product of a prominent type foundry of that time and very likely was arranged in the style then accepted as good typography. A more uninteresting page could hardly be conceived, especially in a book intended for printers.

The fourth example is a reproduction of the title-page of Mackellar"s well-known manual, "The American Printer" (now out of print), and presents what to the head of the most prominent American type foundry was probably an ideal arrangement. While revealing the long-and-short-line characteristies of the previously mentioned pages, as a whole the effect is more interesting to printers. In this page may be noticed the trend toward delicate, characterless typography.

A printer, Charles Whittingham, of the Chiswick Press, and a publisher, William Pickering, of London, England, furnish an example of effort made in the middle of the nineteenth century to raise the practice of typography to a more artistic standard. These men, both lovers of books, and artists in temperament, had become intimate friends, and together endeavored to introduce into their publications simplicity, appropriateness, and other artistic qualities.

Desiring to use an old-style face on one of their books, Whittingham inquired of the Caslon type foundry if any of the punches cut by the first Willian Caslon were in existence. The original punches being recovered after y ears of disuse, fonts of type were cast and used on a book,

"The Diary of Lady Willoughby," printed in 1844. The title-page of this book is reproduced on a following page, and it will be seen that Whittingham arranged the typography in the Colonial style to harmonize with the literary motive of the book. So well was this done that one has to look twice at the date to satisfy himself it is not 1644. Other typography from these men is not quite so radically different from that of their contemporaries, but is more refined, artistic and tasteful, as may be seen by the "Friends in Council" page further on in this chapter. An innovation by Whittinglam was the omission of punctuation marks excepting where needed to make clear the significance of the wording.

Whittingham and Pickering, in the field of artistic typography, were fifty years ahead of their time, as printers in general were not ready to accept the good things offered them. The modern renaissance came later.

Job printing as a distinct department is of modern development. Typographers of old were primarily book and pamphlet printers, and in many cases interest was chiefly centered in publishing newspapers or almanacs; job printing was incidental. This caused similarity in the typography of newspaper, book and job work, a con-

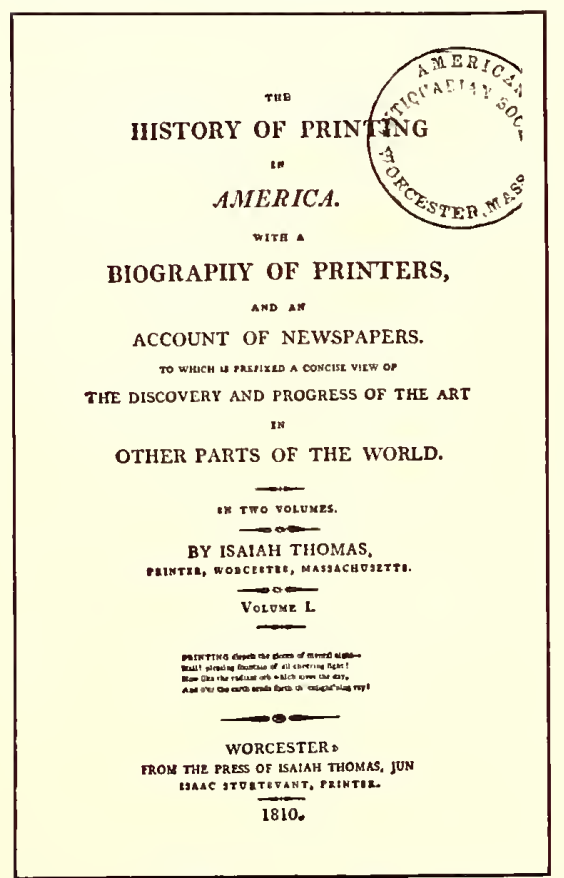

TITLE-PAGE OF 1810

TITLE-PAGE OF 1847

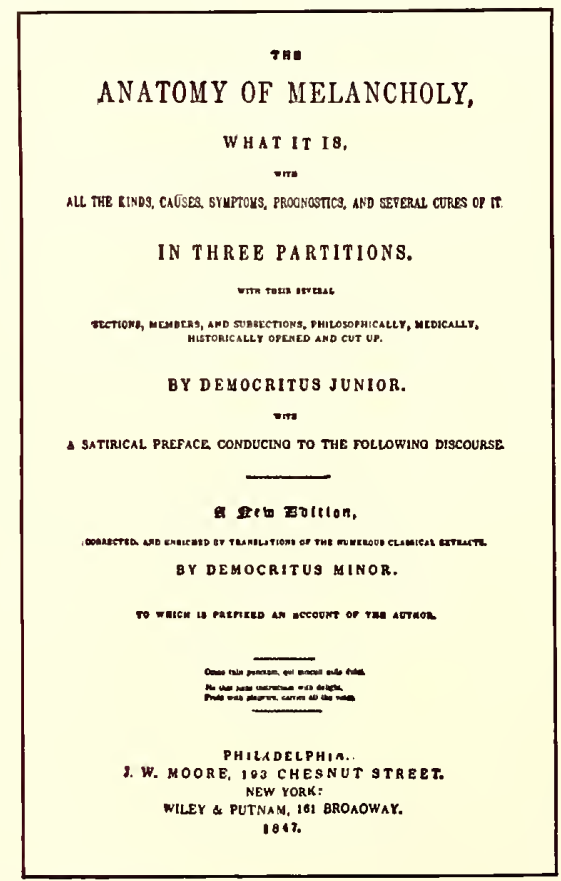

PRINTER'S MANUAL

a Practical guide

COMPOSITORS AND PRESSMEN

THOMAS LYYNOH

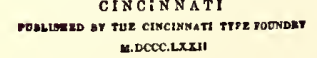

m. Decc.Lual

TLE-PAGE OF 1872 
dition that today exists only in a small degree. Now these three classes of work are generally separated into departments, each with its own rules, styles and practices, job composition being less restrained by customs and rules than any of the other departments.

Attractiveness is as necessary to the typography of the general job of printing as dignity and legibility are to a law brief, but, endeavoring to get attractiveness into their work, job printers often go astray. They wrongly labor under the impression that to have a job distinctive it must be made freakish. Typography is not good unless based upon art foundations.

Icleas in plenty could have been plucked by the printer of the nineteenth century from old books, especially from those printed for religious organizations, such as the "Book of Common Prayer." A handsome edition of a book of this kind was printed in London by John Murray in 1814. Each pair of pages is different in decoration and typography, the designs being by "Owen Jones, architect." The decorative treatment of the page of Psalms reproduced from this book is worthy of study and adaptation.

About the time of the Civil War the job printer was less fettered than ever by the customs of the book printer. While title-pages of books were being composed without ornamentation in severe-looking modern romans, the job printer, influenced by the typefounder, took a liking to fancy typography, for the production of which there were shaded, outlined, rimmed and ornamental letters, in imitation of the work of the copper-plate engraver. The business card on the next page, and the

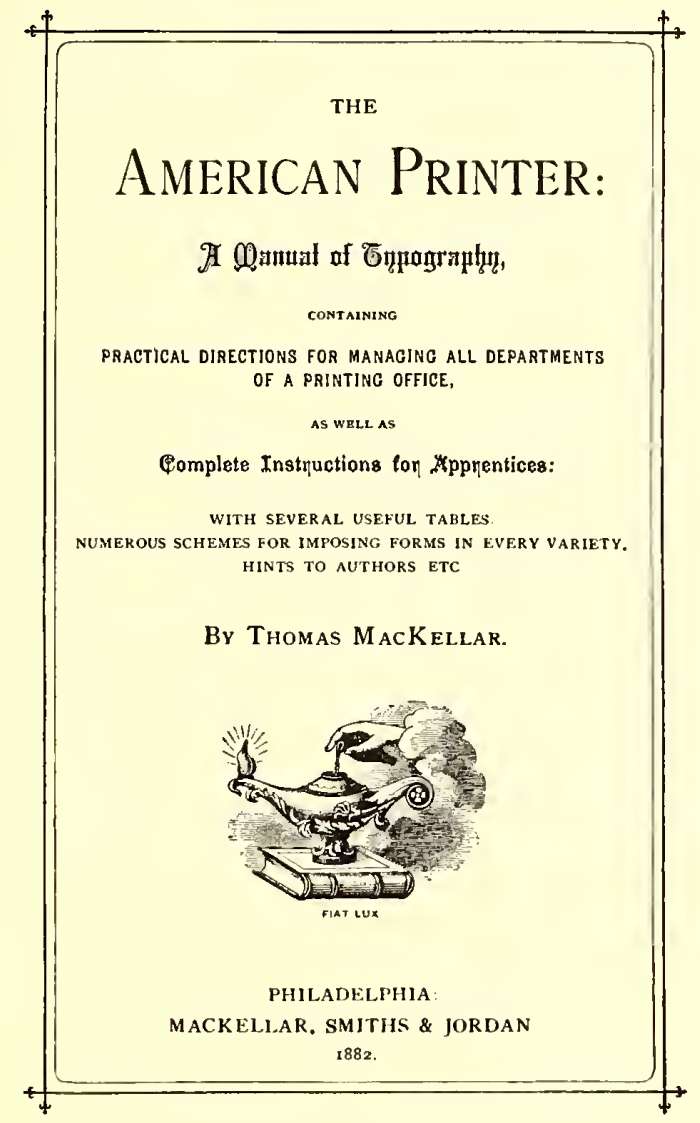

THE TREND TOWARD DAINTINESS

Title-page of MacKellar's manual, "The American Printer," 1882

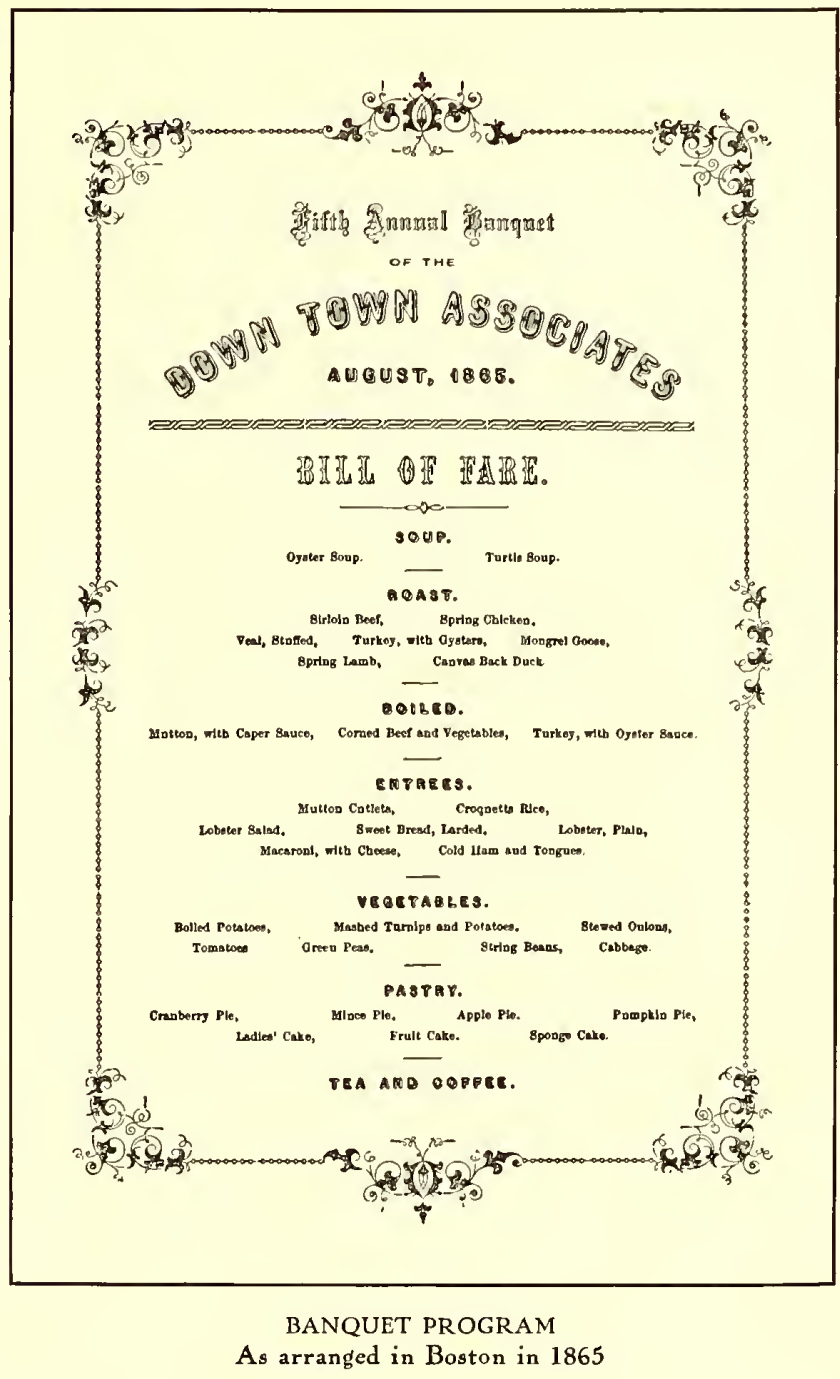

"bill of fare" here shown, are specimens of such work.

The changing styles of typography as applied to commercial headings are well set forth by the group on the fifth page of this chapter. The first specimen is a "plain" billhead of 1870 . The second is a billhead of 1893, when the compositor was taught to corral all excess wording in an enclosure of rules at the left side of the heading proper. In this specimen there is a touch of ornamentation and a showing of seven different typefaces, one of which is the then conventional script for the date line. The third specimen of the group, a letterhead which won first prize in a contest held in 1897 , reveals further development of simple typography. Only one face of type is used (Tudor black) and there is no ornamentation excepting a few periods on each side of the word "The."

During the nineteenth century no type foundry did more toward influencing the typography of the general job printer than the one known at the time of its absorption by the American Type Founders Company as MacKellar, Smiths \& Jorkan, of Philadelphia. 'The reproduction of a few clippings from its specimen book of 1885 may recall memories to the printer now of middle age.

The Free Press business card has peculiar interest to the author. It was set and printed by him during dull hours about the year 1889 , when his thinking apparatus was controlled by influences from the underworld of typographic practice.

There is another phase of late nineteenth-century typography which should be mentioned. It seents that printers had developed a longing for pictures, color and 


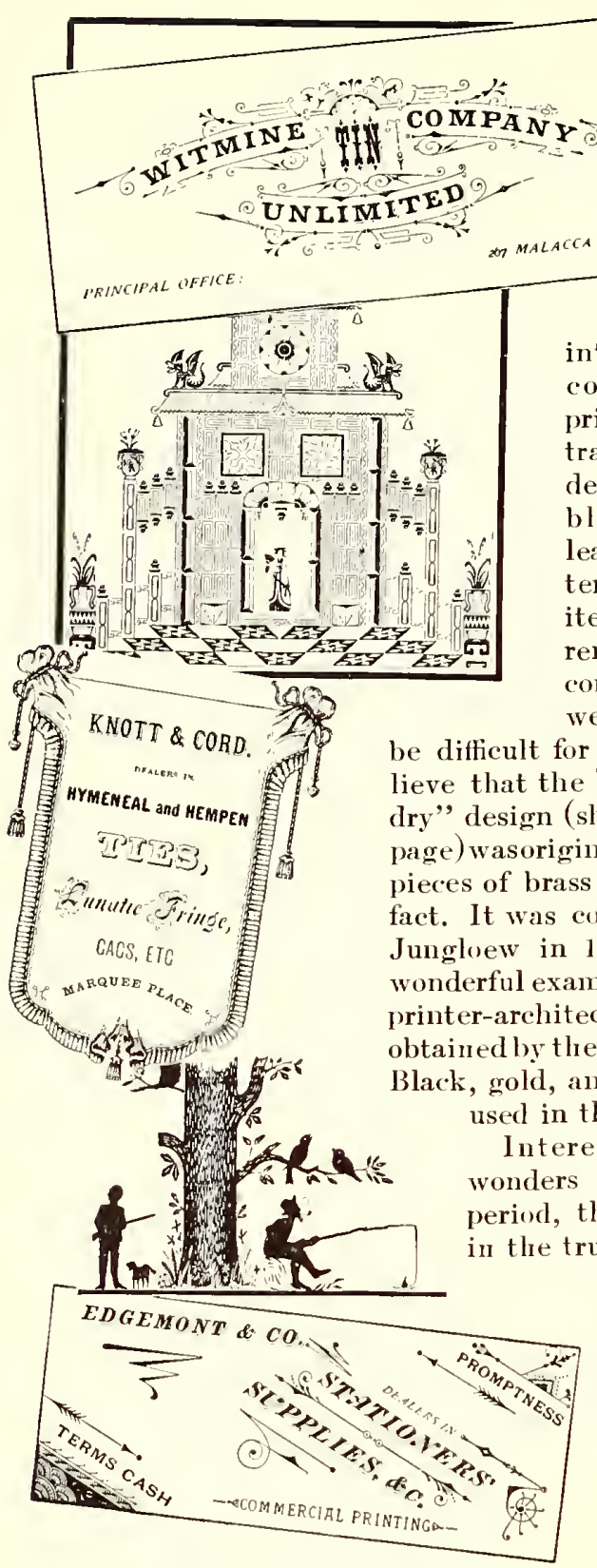

"IN THE GOOD OLD DAYS"

From a specimen book of 1885 decoration. The process of photoengraving not having been perfected, job printers s h a p ed brass rule into representations of composirg-sticks, printing presses, portraits and architectural designs, and cut tint blocks from patent leather and other material. The skill exhibited by many printers is remarkable; beautiful combinations of tints were produced. It will be difficult for many persons to be(shown on a preceding of of brass rule, but such is the Juew in 1879 , and is truly The perspective obtained by the designer is a feature. id, and several tints werc

thesting as are these of the curved-rule eriod, they are not artistic the true semse of the word; examples of skill indeed, but not art as it is today understood.

We now come to one of the most interesting periods in the history of printing, a period which may well be termed the

"Modern Renaissance." As was intimated earlier in this chapter, the invention of printing machinery served to lead typograply away from art. The printers of that time thought they were doing artistic work when they set their jobs in fancy type-faces, twisted brass rule, or printed in many colors. They did not know that art-printing was simplicity - and something else. The apprentice was taught to set type as was his journeyman instructor before him. Any inspiration he received came from the typefounders, and even that was often interpreted wrongly.

Ten years before the close of the nineteenth century display typography was in a chaotic state so far as art was concerned. Printers who before had not doubted the appropriateness and quality of their own typography, began to realize that it lacked something they were not able to supply, and were ready to follow a Moses who could lead them to better things. Then began to form a curious chain of events that was to have a revolutionary influence upon commercial typography as well as upon commercial art. The first link in this chain was the establishing of the Kelmscott Press in England by William Morris.
William Morris was an artist, a poet, a designer and a craftsman. Partiality for things medieval showed itself early in his life, and before he took up printing he manufactured artistic house furnishings in the ruins of an old abbey.

Years ago if the average American citizen were asked what great thing Benjamin Franklin did, his answer might have been, "He invented the Franklin stove." The average person of today would connect the name of Morris with the Morris chair. As the application of art principles to typography has caused the compositor to turn from rule curving, to set his lines straight, and to seek paper and ink without luster, so the influence of Morris led to a distaste for gilt and polish and trimmings, and created a demand for subdued colors and straight lines in home furnishings. He who can influence others to think and act in manner different and better than they liave done before, is truly great.

Morris lived in a picturesque old manor-house in Kelmscott on the Thames in England, and it was there at the age of fifty-seven years that he began to print. He was not a printer by trade, but before a type was set he studied the art from the beginning. He even learned to make a sheet of paper himself. Kelmscott Press paper was made by hand of fine white linen rags untouched by chemicals. Morris as a handicraftsman had an abhorrence for maclinery. It is doubtful if he would have used even a hand-press if results equally good could have been obtained without it.

Morris's idea seems to have been to take up good typography where the early printers left off. When he wanted types for the new printshop he had enlarged photograplis made of the type pages of Jenson, Koburger and other printers of the fifteenth century, and from these photographs designed his type-faces, arranging the details of the letters to conform to his own ideas.

His roman type-face he called "Golden," probably because of its use on the "Golden Legend." This typeface was afterward reproduced by foundries in America as Jenson, Kelmscott, and other type-names. Morris was wont to say that he considered the glory of the Roman alphabet was in its capitals, but the glory of the Gothic alphabet was in its lower-case letters. He also designed a type-face characteristic of the Gothic letters used by Koburger and other fifteenth-century printers, and, probably because of its use on the "Historyes of Troye," called it Troy. This type also was reproduced by type foundries, and printers knew it as Satanick and Tell Text.

The space ordinarily assigned to the page margins Morris covered with foliage decoration in the manner of the early Italian printers, large decorative initials blending with the borders. These initials and borders, with few exceptions, were drawn by himself and engraved upon wood by W. H. Hooper. Compare the right-hand page of the two pages here reproduced with the Venetian specimen in the chapter on "The Spread of Typography."

One of Morris's book, an edition of Chaucer, was additionally enriched by upward of a hundred illustrations by BurneJon es, a noted British artist.

In both

Eng 1 and and America Morris was the subject
Ceo. C. Pland \& Avery, PLAIN AND ORNAMENTAL

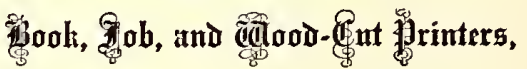
NO. 3 CORNHILL,

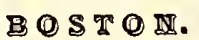

BUSINESS CARD

As displayed in 1865 


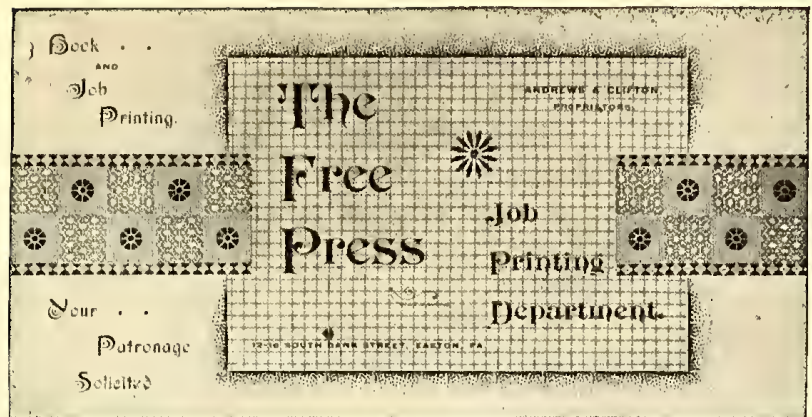

A BUSINESS CARD OF 1889

One of the author's early attempts at artistic (?) printing

of much criticism. Men who as art printers were not fit to touch the hem of his garment were loud in condemnation of his work. Others, more fair, pointed out the excellence of his printing, but claimed that neither his type-faces nor his style of typography would be used many years. This last prediction has proved partly true. The Jenson, or Kelmscott, type-face was used so frequently and so generally that despite its virtues it finally tired the public eye, and is now seldom seen. Satanick, the "Troy" type-face, as made by the American Type Founders Company, is not now displayed in that company's specimen book.

However, the work of William Morris, tho not accepted as the model for general use, was the cause of a revolution in modern typography. Instead of the delicate and inartistic type-faces and ornamentation of 1890 , the contents of type-foundry specimen books revealed strong, handsome, artistic letters and common-sense art borders and ornaments. Morris's experience as a printer did not cover five years, yet his name will always live because of the good he did typography in the nineteenth century.

Decorative artists were wielding a big influence in the revival taking place in the field of typography. Contemporary with Morris in England was a young artist, Aubrey Beardsley, prominent in a new school of art which saw merit in the flat masses of color as found in the seemingly grotesque designs of the Japanese.

Here in America the work of Morris and Beardsley found favor in the eyes of Will Bradley, who was destined to lead the forces in the typographic revolution on American soil. Bradley had been a country printer; as apprentice, journeyman and foreman he had tasted both the joys and sorrows of practical work in the printshop. However, Bradley was more than printer; he had artistic tendencies which finally influenced him to go to Chicago to study art. There he frequented the art galleries and public libraries, and developed into a poster artist of exceptional merit. There were those who called him the "American Beardsley."

The year 1896 found Bradley with a studio at Springfield, Mass., where his love of printing influenced him to open a printshop which he called the "Wayside Press." In May of the same year he issued the first number of "Bradley: His Book," a unique publication for artists and printers. The type-faces used were Jenson, Caslon and Bradley, and almost every page contained decoration. There were many odd color combinations and Bradley must have stood close to his presses when this first number was printed. Purple-brown and orange, olive-green and orangebrown, orange-yellow and chocolate-brown, purple-red and green-blue-these were some of the color harmonies.

'The Christmas number of "Bradley: His Book" was set entirely in Satanick, the American copy of Morris's "Troy" type, and bright vermilion was nicely contrasted with dense black print.

While Morris was a medievalist, and received his inspiration from the printed books of the fifteenth century, Bradley was inspired by both past and present. Printers know him particularly because of his adaptations of the styles of the seventeenth and eighteenth centuries. He demonstrated how Colonial printers could liave done their work better. In presenting the Colonial specimens which are here reproduced from the November, 1906, "Bradley: His Book," Bradley wrote:

Antique and deckle-edge papers enter so largely into the making of books today that printers cannot do better than to study the styles of type-composition that were in vogue when all books were printed upon hand-made papers. A knowledge thus rained should prove of great value, especially in the setting of title-pages. * * * The only face of Roman type which seems appropriate to antique paper is that which is known as Caslon. When types were fewer, and the craft of printing less abused than it is now, this was the only ty pe used in bookwork; and some of the title-pages in our earlier books are extremely interesting and suggest motifs which may well be carried out today. Taking suggestions from these books we have set a few pages, using as subjects the titles of some modern works. 'There seems to be an unwritten law which we are supposed to follow in this class of composition; and yet one should be a little brave and daring, purely for the joy of getting out of the old beaten track.

The type foundries helped the spread of the new typog-
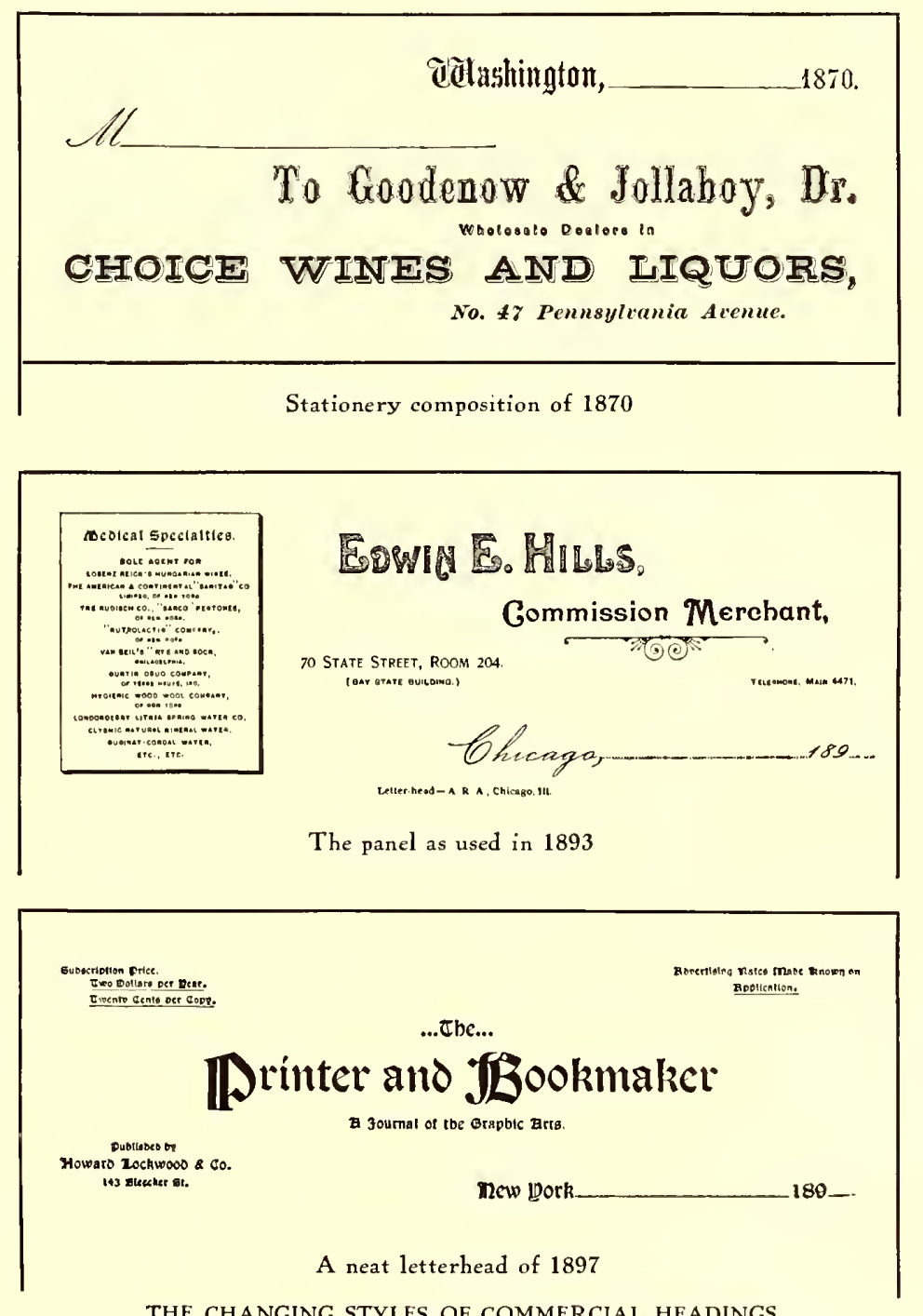

THE CHANGING STYLES OF COMMERCIAL HEADINGS 
raphy by supplying a series of Bradley's decorations, known as "Wayside Ornaments."

Bradley discontinued the Wayside Press in 1898 and combined his printshop with that of the University Press at Cambridge, Mass. There a battery of presses was kept busy during the continuance of the extraordinary interest in Bradley booklets.

In 1905 Bradley impaired the strength of his following by attempting for the American Type Founders Company the introduction of a new style of typography, the prominent feature of which was profuse ornamentation. While this effort supplied job printers with many valuable ideas in type arrangement and color treatment, happily the style as a whole was not adopted by printers generally or typographic conditions might have become as unfortunate as they were previous to 1890 .

Frank B. Berry, associated with Bradley during his engagement with the American Type Founders Company, tells in these words of the construction of a thirty-twopage pamphlet of specimens entitled "The Green Book of Spring": "Starting in on this about half-past ten one morning Bradley made up a dummy, prepared the copy and laid out the work-specifying the size and style of type to be used, the form of display and designating the exact position of each ornament with the required spacing. This was in effect practically furnishing reprint copy for the compositors. Then, to 'give good measure,' as he expressed it, copy was prepared for the cover, and the work was ready for the printers before half-past one."

In the few years succeeding the establishment of the Wayside Press, Bradley's style of typography was closely followed by many printers, and all the printshops of America were more or less influenced by it, but at this date his ideas and Morris's ideas are merged more or less

\section{FRIENDS IN COUNCIL:}

\section{A SERIES OF READINGS}

\section{AND DISCOURSE}

\section{THEREON}

หै

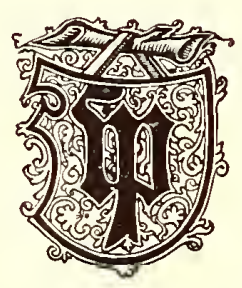

BOOK THE SECOND

\section{LONDON}

WILLIAM PICKERING

2849

AN INTERESTING TITLE-PAGE

By Charles Whittingham, London, 1849

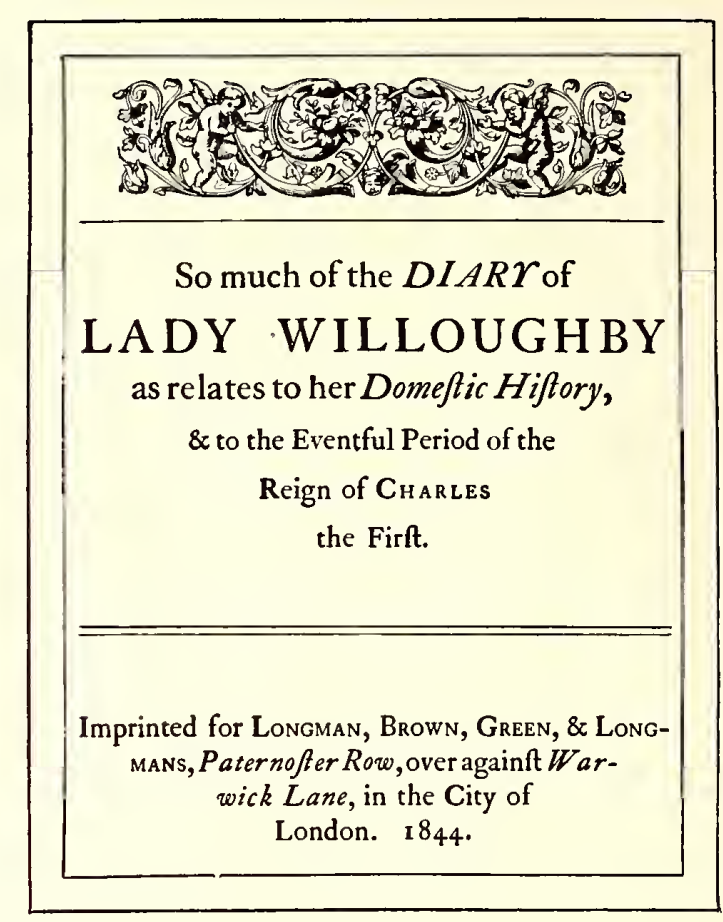

TITLE-PAGE IN THE COLONIAL STYLE

By Charles Whittingham, London, 1844. The first use in the nineteenth century of the Caslon type-face

with those of De Vinne, Jacobi, Updike, Rogers, Cleland, Benton, Kimball, Goudy, Goodhue, Winchell and others. From Germany, too, have lately come suggestions in decoration that are visibly influencing general typography.

In recent years Bradley devoted his talents to the makeup of magazine pages. His characteristic decoration has added interest to the text sections of several leading magazines. He dictated the makeup and drew the cover design and department headings for the twenty-fifth anniversary number of The American Printer issued July, 1910.

This versatile artist-printer also accomplished the unique task of applying business and industrial methods to the making and selling of art work. He had a staff of working artists, one of whom acted as foreman. Bradley had a book in which he pasted his sketches of decorative borders, ornaments and illustrations. These were classified and numbered, and when a design was to be drawn he gave instructions to the working artist indicating which sketches were to be worked up. In this manner he eliminated the manual labor so far as he was concerned and was able to accomplish much more than if he had attempted to do everything himself. He also planned a series of decorative units and illustrations and offered a quick art-service to advertisers and printers.

Fred W. Goudy, who designed such type-faces as Pabst, Powell, Forum, Kennerley and Goudy Old Style, has influenced printing styles in the direction of classic effects. Goudy as a student of Roman architecture and letter-carving has dignified the printing industry and enriched typographic art.

This lesson would not be complete without a tribute to the work of Theodore L. De Vinne, who had the distinction of being the only printer but one in America to receive a college degree for accomplishments as a printer.

De Vinne's introduction to typography was as an 


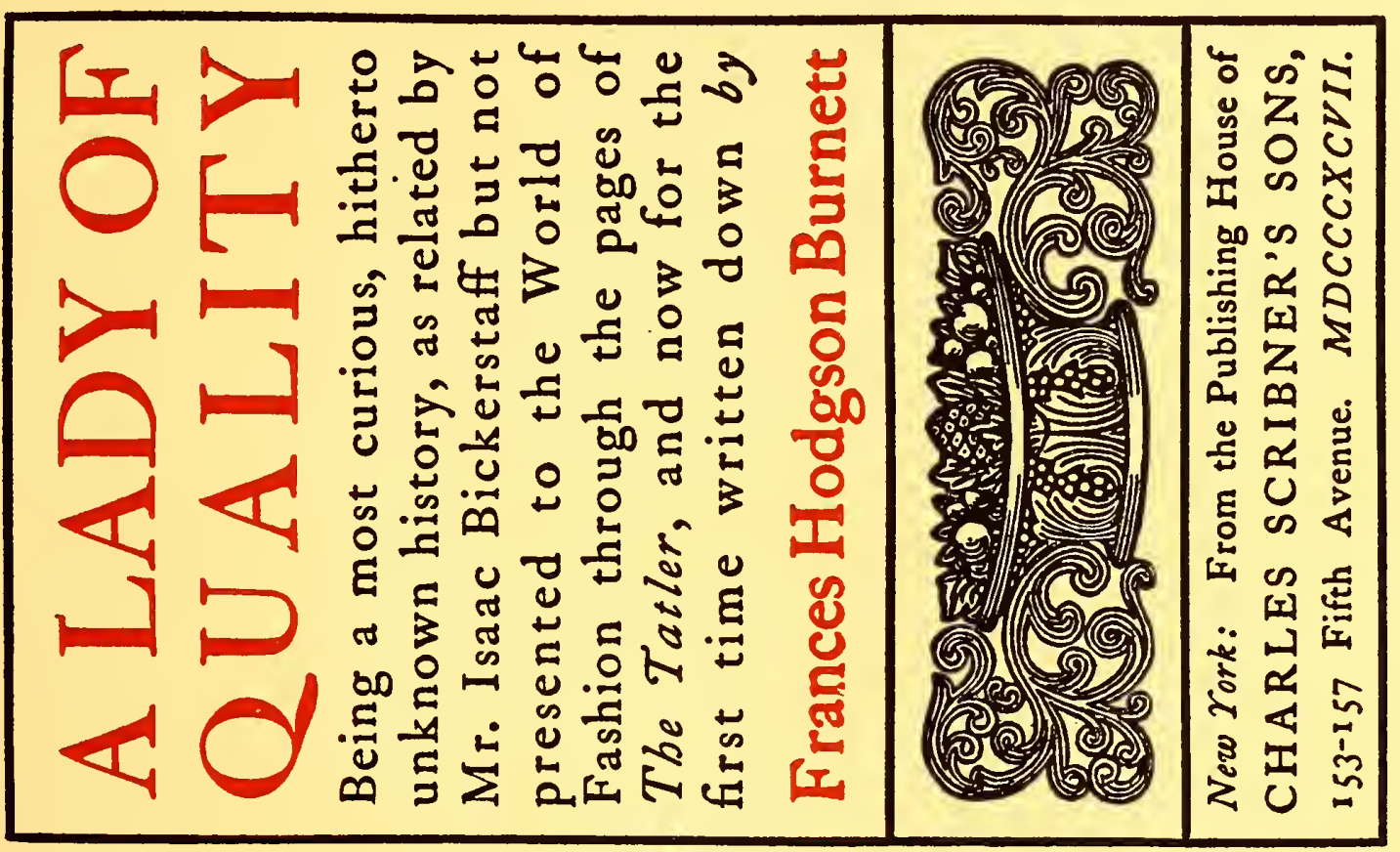

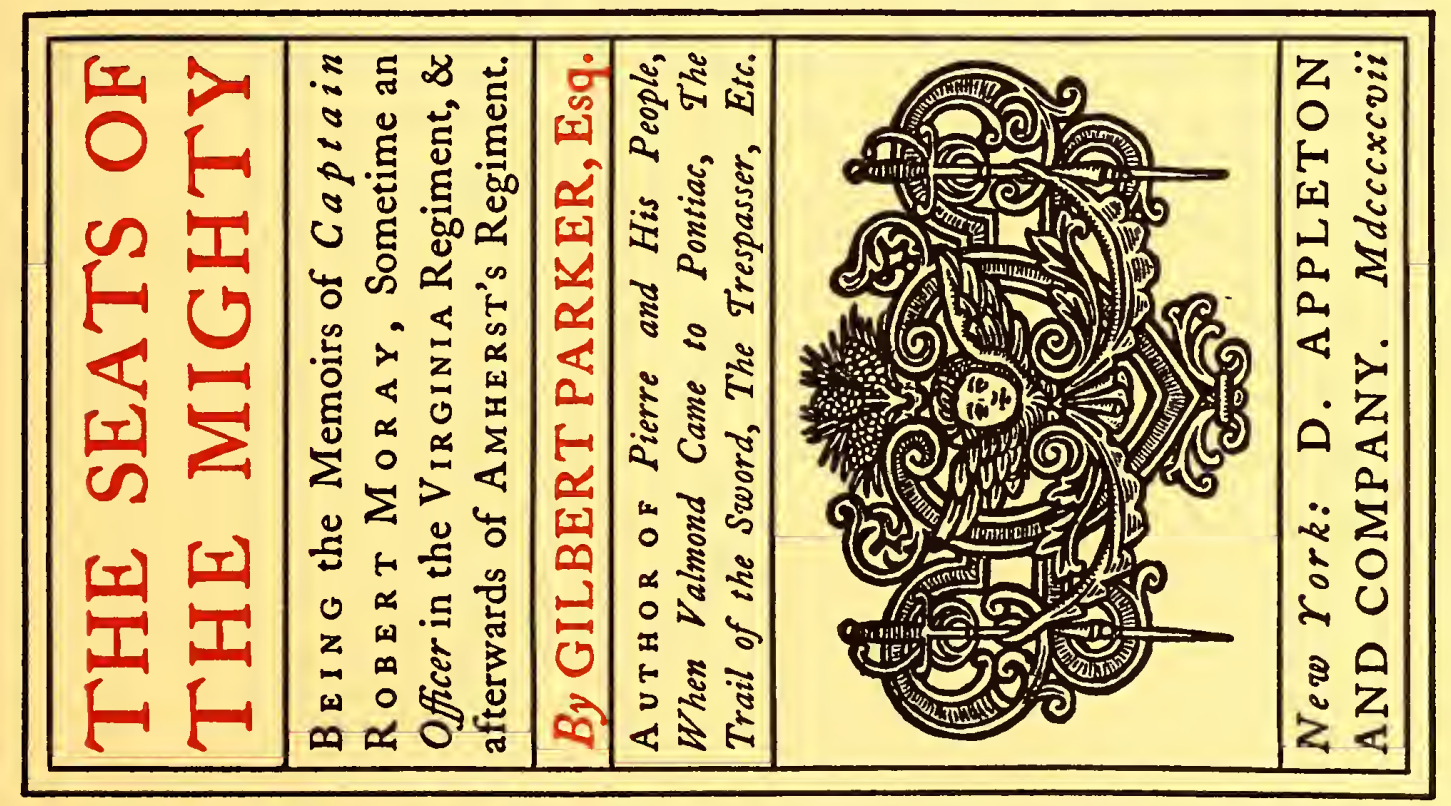



apprentice in a country printshop. He went to New York in 1847 and worked at the case and press in several offices before accepting a position as job compositor with Francis Hart. Upon the death of Mr. Hart in 1877, Mr. De Vinne took charge of the business, which is now known as the De Vinne Press.

As a writer on printing subjects, perhaps lis greatest work is "The Invention of Printing," published in 1876. I have examined and read most of the books on the subject of the invention, and De Vinne's book is the most reasonable, fair and understandable of all.

De Vinne had always been an exponent of the sane, conservative and dignitied in typography. The work of his shop was precise, exact and thoro. While giving credit to Morris and Bradley for their accomplishments, he had little sympathy for the styles of either. De Vinne properly claimed that a writer's words are of more importance than the decoration of a designer. Morris intended his books for the shelves of the book collector; De Vinne looked upon a book as something to be read. However, there need be no conflict between the styles of Morris, De Vinne and Bradley. The typographer should learn to discriminate, to choose wisely when selecting a style for a book or a piece of job work. For editions de luxe in limited numbers, and for booklets on art or literary subjects, the Morris style is appropriate. For books on scientific or legal subjects, and for booklets of conservative and dignified nature, there is nothing better than the De Vinne style. For booklets which are to attract attention and for job work that is to be distinctive, Bradley showsthe way.

With De Vinne beckoning to us from the point of con-

\section{COME NOTES ON BOOKS $S$ AND PRINTING. A GUIDE FOR AUTHORS AND OTHERS}

BY CHARLES T. JACOBI MANAGER OF THE CHISWICK PRESS AND EXAMINER IN TYPOGRAPHY TO THE CITY AND GUILDS OF LONDON INSTITUTE

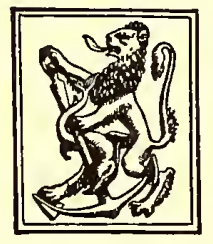

TONDON: PRINTED AT THE CHISWICK PRESS L BV CHARLES IVHITTINGHAM AND CO., XXI TOOKS COURT, CHANCERY LANE, E.C. MDCCCXCII

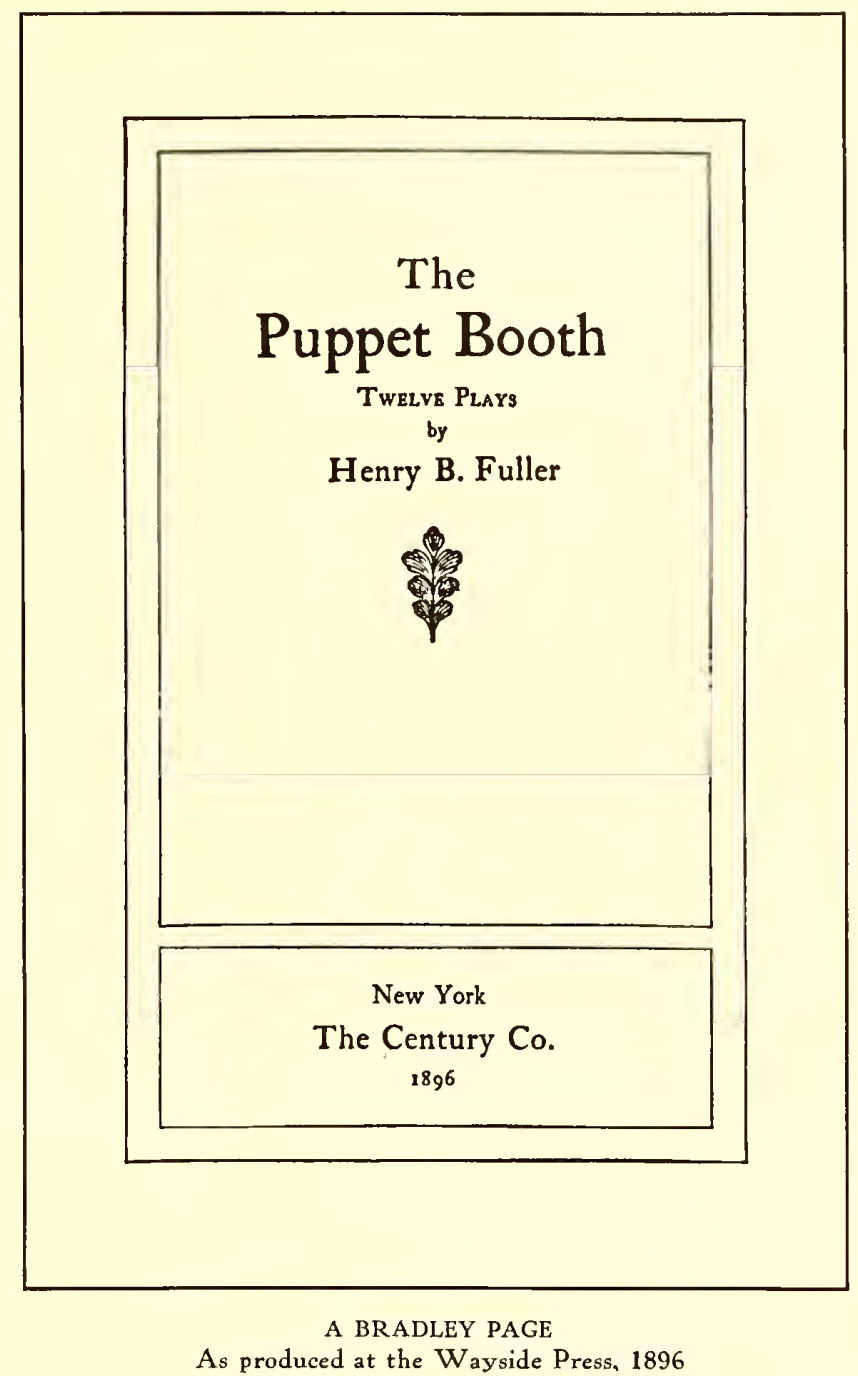

servatism and Bradley from the point of radicalism, the typographer anxious to do work properly must decide for himself how to treat it. I have seen a jeweler's booklet cover so filled with ornamentation by Bradley that it was almost impossible to read the wording, and I have also seen a children's Bible typographically treated by the De Vinne company in a style as severe as if it were a book of legislative acts.

De Vinne had always been a leader in the perfecting of modern methods. He was one of the pioneers in the use of dry paper and hard press-packing, and gave much thought to modern type-faces. The type-face known as Century was designed after his suggestions as a model roman letter.

De Vinne did much in persuading printers to group the wording of title-pages instead of equally separating the type lines as was done in the middle of the nineteenth century.

Charles 'T. Jacobi, of the Chiswick Press, London, as an instructor and writer on printing subjects has done much for typography in England. He is not wedded to a particular style of typography, but advocates the adaptation of any style that is good when by so doing clients are pleased and the principles of art are not violated. The title-page reproduced in this connection is unusual in arrangement. The type groups and the device are all squared and their angularity is enhanced by the exclusive use of capitals. Realizing that a page or design is defective if it presents the appearance of disjointed sections, Mr. Jacobi has avoided such results in this instance by arranging the page in the form of a letter $Z$. 
With this chapter the history of typography is brought down to the twentieth century. The modern typographer has great responsibilities. Upon him depends the solution of the problem whether or not our beloved calling is to be ranked with the esthetic arts. Shall the product of the village printer be only of the standard of that of the village blacksmith? Every typographer, regardless of the nature of the work that is his to do, shonld cultivate a love for the artistic and enlarge his knowledge of the things that make for good printing. The chapters that follow will help to this end.

Because printing as now practiced is in a great degree dependent upon principles and styles developed during the early days of the art, the student should not neglect carefully to read and digest the historical facts and reproductions that have been presented. Too many typographers underrate the value of a knowledge of history. "I do not care what printers of old did; I want to know what the printer of tomorrow is going to do." This is almost a literal quotation of the remark of a printer who prides himself on his progressiveness, and he is only one of many who imagine that to be up-to-date it is sufficient to use new type-faces, ornaments and borders, caring little if the resulting jobs lack appropriateness, harmony, color, tone, and other elements that are essential to perfect typography.

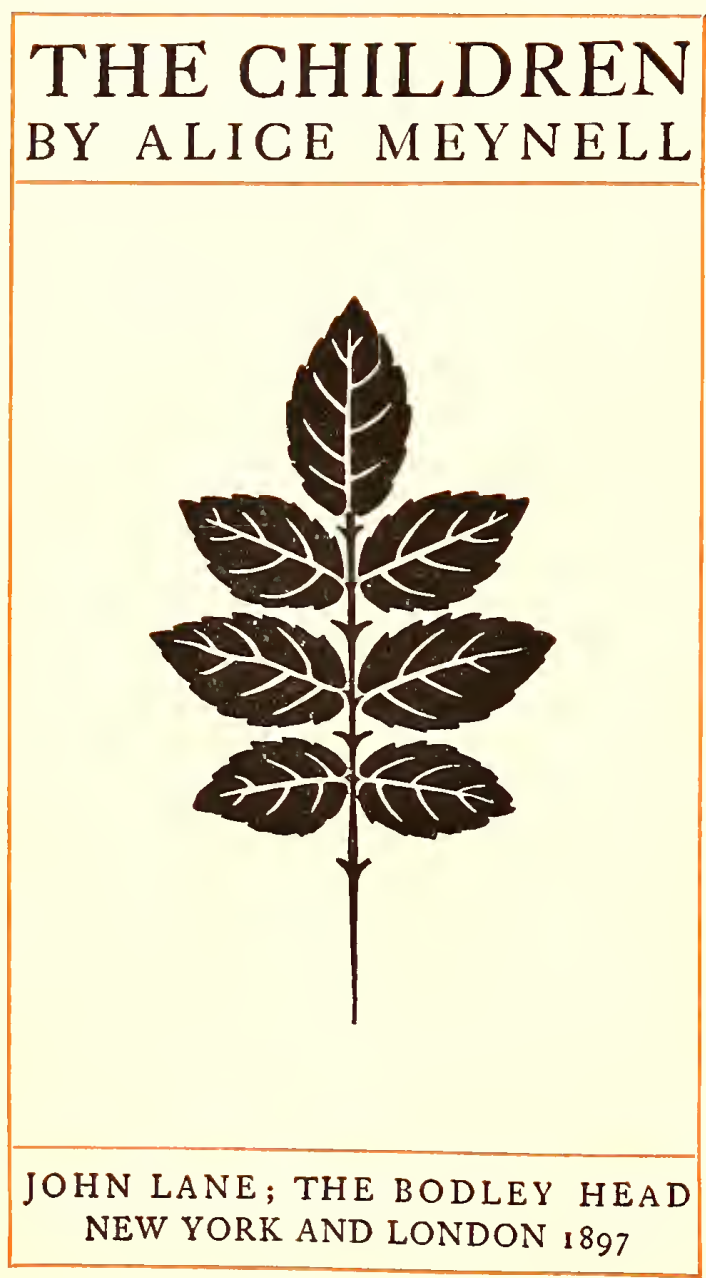

A BRADLEY PAGE

As produced at the Wayside Press, 1896

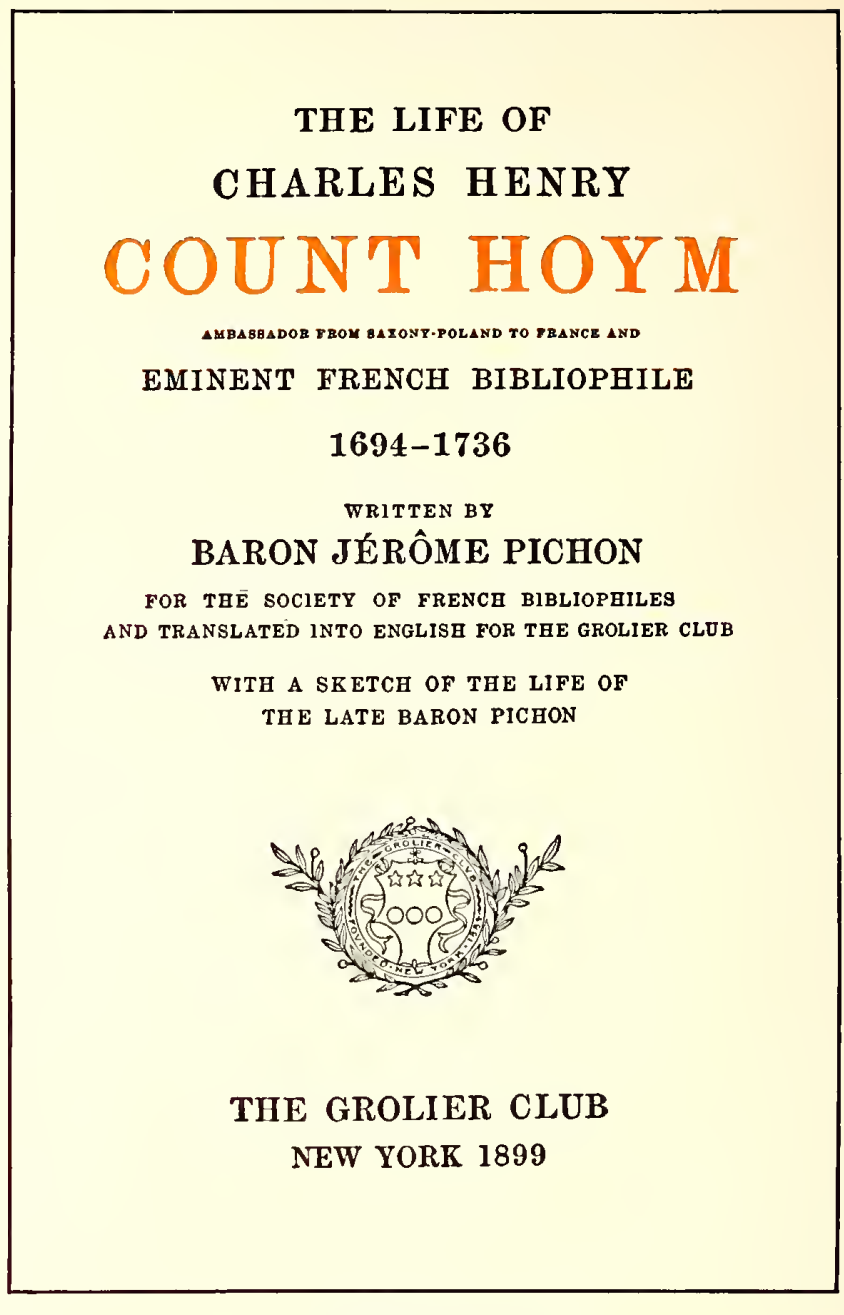

A DE VINNE PAGE

This probably presents De Vinne's idea of title-page arrangement

He who labors without a knowledge of history is much like the young man who started to work on a job press. He was allowed to make ready a form, and after a while the pressman went over and examined the work. On the back of the form he found something that looked like an underlay, but could discover no reason for its use. Mystified, he inquired what it was all about, and was told that the apprentice was doing only what he had seen the pressman often do before-cut out several pieces of paper and place them under the form. It had never occurred to the young man to ask why this was done. Thus it may be with the typographer. He arranges a job of type composition in the style of something good he has seen, but fails to get the quality of the original because he does not comprehend just what has served to produce that quality.

Morris was a student of ancient printing. His thoughts were back in the fifteenth century with Jenson, Aldus and Koburger, and when he began to print, he printed understandingly. There was a well-defined plan, and there was harmony in ornament, type, ink and paper. When the "up-to-date" printer began to imitate Morris he did it with the same degree of comprehension possessed by the young man who made the "underlay."

Will Bradley would not today be as famous as he is in printing circles if he had labored under the false idea that it was useless to know history. Bradley knows printing history and loves old books, and this knowledge and affection are expressed in his work. The printer who succeeds is the one who looks upon all knowledge as valuable and has a good reason for everything he does. 
PART TWO 


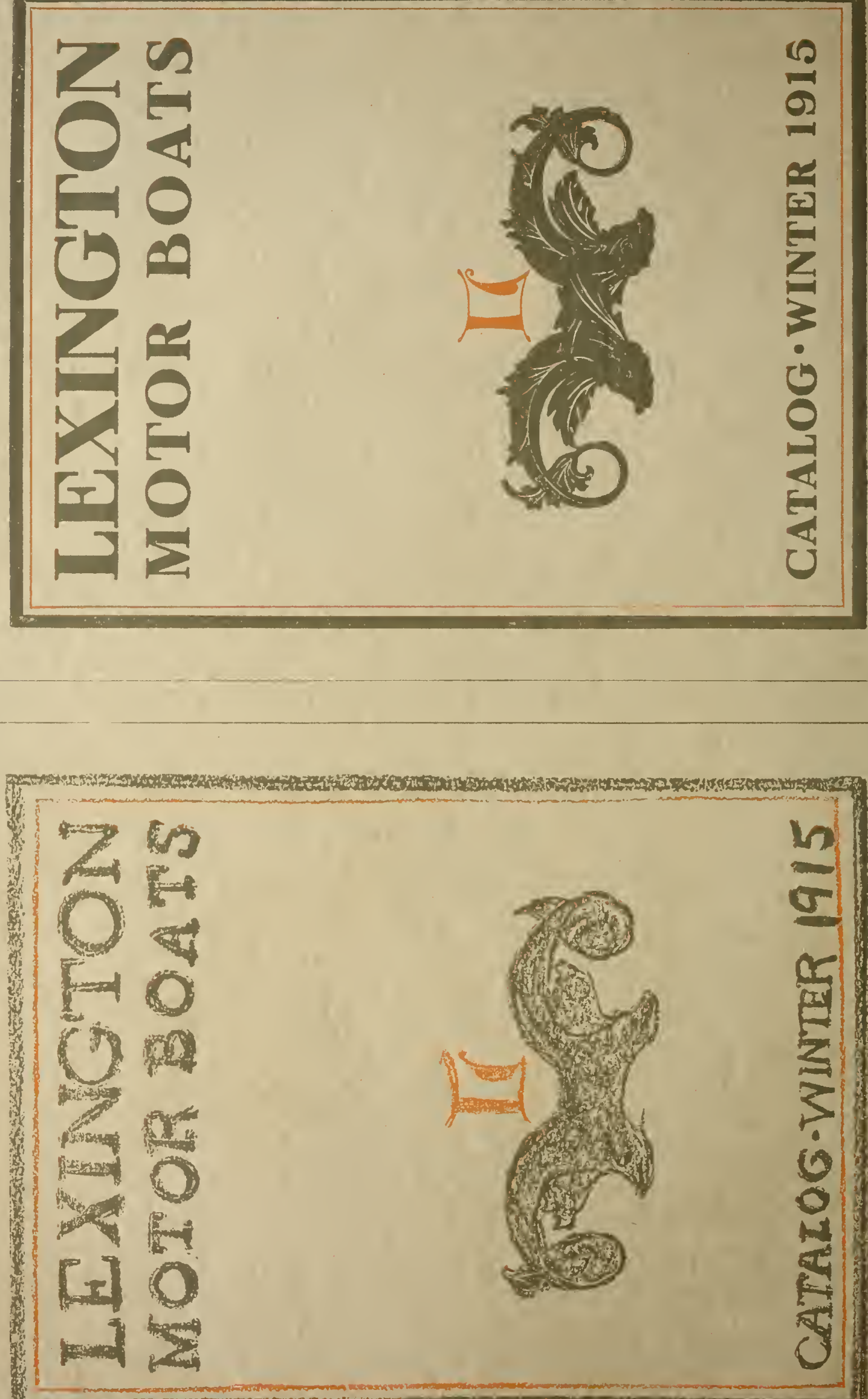

1. 


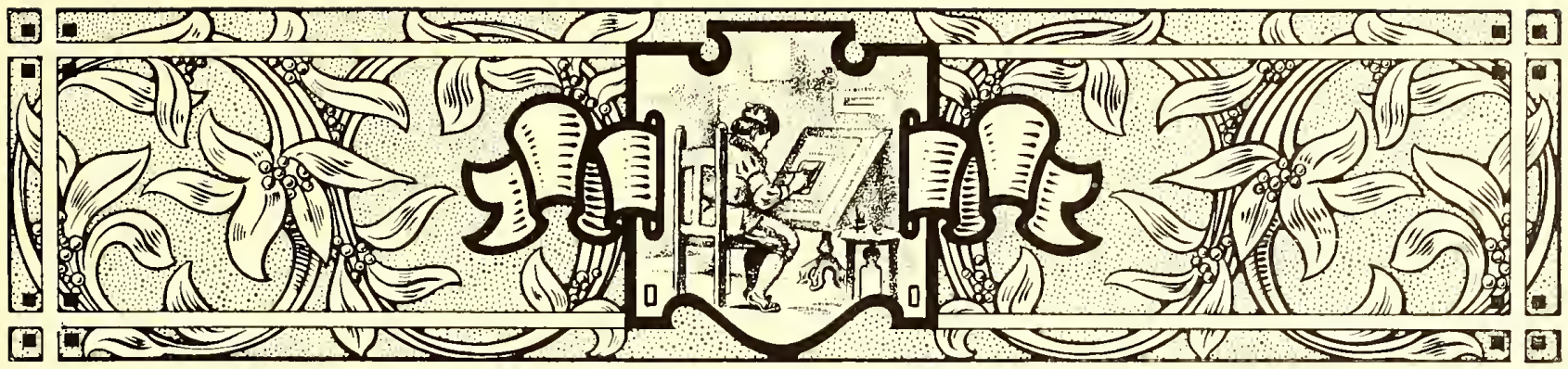

\section{THE "LAYOUT" MAN}

HOW does the work of the typographer of the twentieth century compare with productions of the past? In the belief of some the good typographer, like the good Indian, is dead. The truth is that much of the printing done during the first four hundred years was not well done. While the same proportionate result still prevails, the ancient did not have the excuse of the modernlack of time; nor has the modern the excuse of the ancient-lack of facilities. However, while poor work in any century or any industry is explainable, it is not excusable.

Someone said, "The man who attained his ambition did not aim high enough." Perfection is not attainable, but it should be the goal in our race. Many typographers are doing good work, altho each is doing it differently. No one is producing perfect typography; but when perfection is the pacemaker no result can be commonplace.

The good typographers of the past had the spirit of the master craftsman and their product was inspired. The modern printer to succeed needs only the inspiration that comes of study, hard work and love of his trade.

Inspired work, however, is generally the result of preparation.

Artists and advertising men realize the necessity of careful preparation for

the process of printing, but typograplers as a class evidently do not. If they did they would do even better work and make bigger profits possible. Every printshop should have a "layout" man.

In spite of the fact that much good printing is done today, fully nine-tenths of the product is partially unsatisfactory because of lack of preparation. When a business man decides to erect an office building he does not immediately go to a building contractor and tell him to build it. He first consults an architectural engineer, ex- amines drawings and exchanges opinions, and when the building cortractor starts his work everything las been planned and specified.

Should printing be done in a less thoro manner? Is not the making of a book, catalog or business card each proportionately as important and as well entitled to

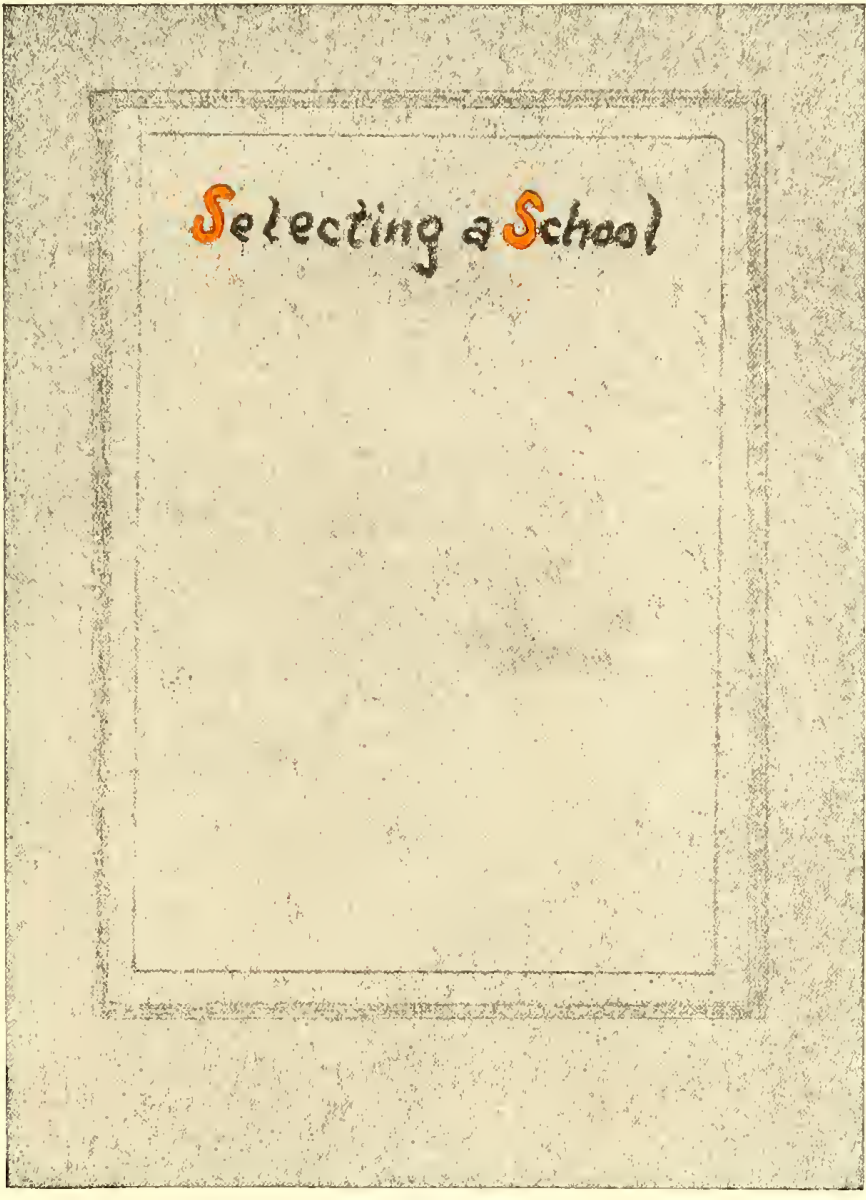

EXAMPLE 1

Booklet cover page laid out with pencil and crayon on gray stock proper attention as the larger undertaking? Good typography cannot be produced if preparation is slighted.

Quality printing is not accidental. Shops famed for the artistic excellence of their product have maintained their "shop" style" despite changes in the force of workmen and executives, and this individuality, or "shop style," as it is termed, has been obtained and retained only because the copy has been carefully prepared and the work has been intelligently laid out by some qualified person (artist, ad-writer or $t y-$ pographer) who understands shop preferences in the matter of style. It is the "institutional idea."

In printshops extensive enough to allow of the expense, one or more layout men should be employed, and in the smaller concerns the head job conpositor or foreman could do the work. Solicitors, when artistically fitted, could in special cases lay out their own jobs of printing, as personal contact with the customer peculiarly fits them to do it satisfactorily. The important thing, anyway, is to please the customer. While the art side of the practice of typography is important, it is not all important. Typography is also a business.

If the customer"s tastes and prejudices were ascertained beforehand, many of the changes now made after jobs are in type, frequently causing inharmonious arrangements, could be avoided. The average printer rarely parallels the experiences of a few fortunate printing concerns which, 


\section{Selecting a senool}

large and growing demand for office help. A at the teachers, courses of study, accomoda viromment should be the best in order to secu ctory results from study, another point in hich school to attend is the cost. Good teache and good salaries everywhere. The better ung men and women students is always foun e best instructors are employed. As we emp mpetent teachers we are compelled to charg te of tuition. If any school charges a lower tuit is because of cheaper teachers, less desirable ition, inferior courses of study, lack of influer ferior methods. A good article always comman ice, while a cheap article is sonctimes worth $t$ ice paid for it. There is therefore no need of ing deceived in selecting a school. Time ar udents have left other schools and enrolled wit e completion of their courses, whereas if they in their courses with us we would have sav eir time, money and sad experience. Success a zrapher or bookkeeper depends upon a good $t$ ilure is often the result of poor training. Our $\mathrm{g}$ icceed, as will be noticed by the letters present it this prospectus. Read what our students sa

Selecting a School

chers, courses of study, accomodatio
should be the best in order to secure ts from study, another point in de th school to attend is the cost. Good teachers d good salaries everywhere. The better gr Ig men and women students is always found best instructors are employed. As we emplo petent teachers we are compelled to charge of tuition. If any school charges a lower tuitio because of cheaper teachers, less desirable ac m, inferior courses of study, lack of influenc ior methods. A good article always command , while a cheap article is sometimes worth the a paid for it. There is therefore no need of an $g$ deceived in selecting a school. Time and ents have left other schools and enrolled with completion of their courses, whereas if they $h$ their courses with us we would have saved $r$ time, money and sad experience. Success as pher or hookkeeper depends upon a good tra $\therefore 3$ when receiving an order for a booklet or catalog, are told the amount of the appropriation and given carte blanche.

Orders for much of the better class of work are obtained thru "dummies" submitted by printers or solicitors. The customer advises a certain number of such persons that he is in the market for a booklet and would like to receive suggestions. Each competitor prepares a "dummy", on the stock and in the binding intended for the completed booklet. The cover desion is roughly sketched or otherwise indicated and the inside pages prepared to represent the finished job.

Let us imagine ourselves in a printshop of medium

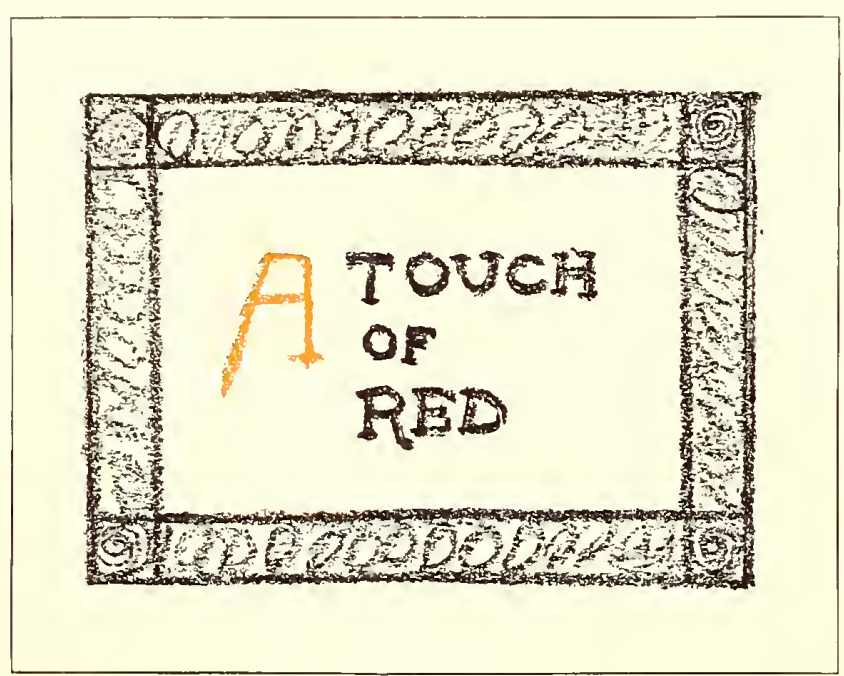

EXAMPLE 5 size, which cannot afford the regular services of an artist. From the composing-room force take the most artistic and practical job compositor and install him at a desk. If there is not sufficient desk work to occupy his full time, arrange with him to fill in spare time at the case. In selecting a man for the position it should be remembered that few typographers have qualifications combining artistic perception and thoro workmanship. It is in a great measure true that a nervous, artistic temperament unfits a typographer for thoro, finished work at the case or stone, while on the contrary, a calm, precise, methodical disposition is often accompanied by lack of imagina-

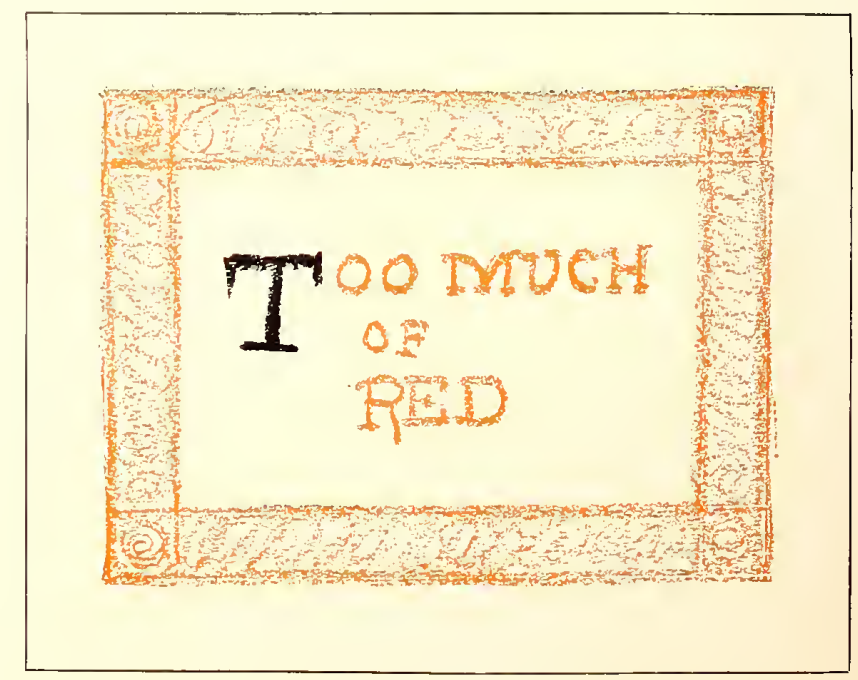

EXAMPLE 6 
selectingas sebary

actory results from study, another point in hich school to attend is the cost. Good teach and good salarics everywhere. The better oung men and women students is always four le best instructors are employed. As we em ompetent tcachers we arc compelled to char ate of tuition. If any school charges a lower tui is becausc of cheaper teachers, less desirable ation, inferior courses of study, lack of influe. iferior methods. A good article always comma rice, while a cheap article is sometimes worth rice paid for it. There is thcrefore no need of eing deceived in selecting a school. Time a udents have left other schools and enrolled wi

$1 / 14$ be complction of their courses, whercas if the

un their courses with us $\sqrt{\mathrm{e} \text { would ha }}$

$2 / 10$ heir time, money and sad exp" grapher or bogkk tilure is often tro acceed, as will b

$7 / 3$ ut this prospect usiness men have zphers and book :ollege, and ad a gese

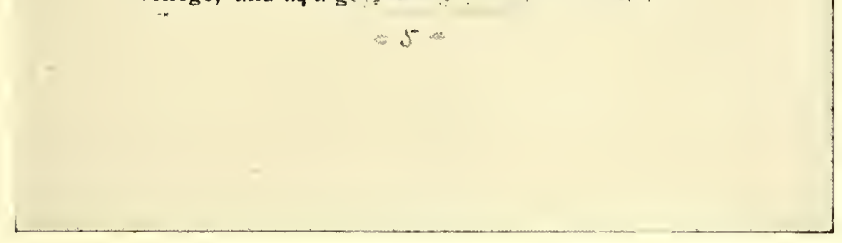

\section{EXAMPLE 4-a}

After pasting in illustration and eounting the lines for machine composition. Reduced from the original

tion. Each workman should have opportunity to do that which he can do best. He of the artistic temperament should lay out the jobs, and he of the mechanical turn of mind should construct them.

The proprietor or other person in authority should discuss with the layout man the subject of shop style in

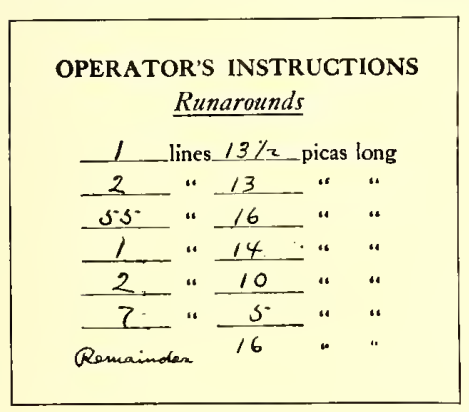

EXAMPLE 4-b

Instructions to operator typographical arrangement. The matter of type equipment should also be gone over, as nothing hinders the layout man so much as to be compelled to use type-faces selected by another having ideas widely different. It is important that the type equipment be appropriate and sufficient for the class of work done. An equipment of a half dozen harmonizing faces of type is far better than one of two dozen ill-assorted faces. Good typography is to a large extent dependent upon the type-faces used.

The layout man should make a study of the personality and tastes of a customer. He should meet all such that come into the office, and arrange to call once upon each of the regular customers. He must keep in close touch with conditions in the composing-room, so that in the discharge of his duties he does not call for type-faces already set out of the cases, or not a part of the equipment.

The mechanic and the artist, to do satisfactory work, must have a certain working outfit. The layout man is no exception; while he could perhaps manage with only a lead pencil and foot rule, it would be foolish to do so. His work will be expedited if lie has an assortment of good crayons; hard, medium and soft lead pencils; a pair of shears, a T-square, a gelatine triangle, a type-line gage, a table for giving the number of words to an inch in the various size type bodies; and a library of books and periodicals on printing, especially of those showing examples of type designs. To provide him also with a set of water colors, a jar of chinese white, a bottle of gold paint, a bottle of india ink and several brushes would not be extravagance.

It would be economical and wise if several sample sheets of each kind of stock were kept near his desk in a portfolio or convenient drawer. Book papers could be cut in quarters, cover papers in halves, and cardboard in various convenient sizes, all ready to be used at an instant's notice. Several each of ruled headings, cut cards and other standard goods sloould also be included. In laying out jobs, especially large runs, he should make them of such size as will cut from the sheet witl little or no waste. If an order is to be rushed, he should ascertain if the stock may be had without delay.

\section{WORDS TO THE SQUARE INCH}

\begin{tabular}{|c|c|c|c|c|c|c|c|c|}
\hline \multirow{2}{*}{$\begin{array}{l}\text { SQUARE } \\
\text { INCHES }\end{array}$} & \multicolumn{8}{|c|}{ Sizes of TyPE-SOLID } \\
\hline & $\begin{array}{c}5 \\
\text { PoINT }\end{array}$ & $\begin{array}{c}6 \\
\text { POIкт }\end{array}$ & $\begin{array}{c}7 \\
\text { POINT }\end{array}$ & $\begin{array}{c}8 \\
\text { PoINT }\end{array}$ & $\begin{array}{c}9 \\
\text { POINT }\end{array}$ & $\begin{array}{c}10 \\
\text { PoIvT }\end{array}$ & $\underset{\text { POINT }}{11}$ & $\underset{\text { PoINT }}{12}$ \\
\hline 1 & 69 & 47 & 38 & 32 & 28 & 21 & 17 & 14 \\
\hline 2 & 138 & 94 & 76 & 64 & 56 & 42 & 34 & 28 \\
\hline 4 & 276 & 188 & 152 & 128 & 112 & 84 & 68 & 56 \\
\hline 6 & 414 & 282 & 228 & 192 & 168 & 126 & 102 & 84 \\
\hline 8 & 552 & 376 & 304 & 256 & 224 & 168 & 136 & 112 \\
\hline 10 & 690 & 470 & 380 & 320 & 280 & 210 & 170 & 140 \\
\hline 12 & 828 & 564 & 456 & 384 & 336 & 252 & 204 & 168 \\
\hline 14 & 966 & 658 & 532 & 448 & 392 & 294 & 238 & 196 \\
\hline 16 & 1104 & 752 & 608 & 512 & 448 & 336 & 272 & 224 \\
\hline 18 & 1242 & 846 & 684 & 576 & 504 & 378 & 306 & 252 \\
\hline 20 & 1380 & 940 & 760 & 640 & 560 & 420 & 340 & 280 \\
\hline 22 & 1518 & 1034 & 836 & 704 & 616 & 462 & 374 & 308 \\
\hline 24 & 1656 & 1128 & 912 & 768 & 672 & 504 & 408 & 336 \\
\hline 26 & 1794 & 1222 & 988 & 832 & 728 & 546 & 442 & 364 \\
\hline 28 & 1932 & 1346 & 1064 & 896 & 784 & 588 & 476 & 392 \\
\hline 30 & 2070 & 1410 & 1140 & 960 & 840 & 630 & 510 & 420 \\
\hline 32 & 2208 & 1504 & 1216 & 1024 & 896 & 672 & 544 & 448 \\
\hline 34 & 2346 & 1598 & 1292 & 1088 & 952 & 714 & 578 & 476 \\
\hline 36 & 2484 & 1692 & 1368 & 11.52 & 1008 & 756 & 612 & 504 \\
\hline
\end{tabular}

\begin{tabular}{|c|c|c|c|c|c|c|c|c|}
\hline \multirow{2}{*}{$\begin{array}{l}\text { SQUARE } \\
\text { INCHFS }\end{array}$} & \multicolumn{8}{|c|}{ Sizes of TYPE-LEADED with 2-point leads } \\
\hline & $\begin{array}{c}5 \\
\text { POINT }\end{array}$ & $\begin{array}{c}6 \\
\text { POINT }\end{array}$ & $\begin{array}{c}7 \\
\text { POINT }\end{array}$ & $\begin{array}{c}8 \\
\text { POINT }\end{array}$ & $\begin{array}{c}9 \\
\text { PorNT }\end{array}$ & $\begin{array}{c}10 \\
\text { POINT }\end{array}$ & $\begin{array}{c}11 \\
\text { POINT }\end{array}$ & $\begin{array}{c}12 \\
\text { PoINT }\end{array}$ \\
\hline 1 & 50 & 34 & 27 & 23 & 21 & 16 & 14 & 11 \\
\hline 2 & 100 & 68 & 54 & 46 & 42 & 32 & 28 & 22 \\
\hline 4 & 200 & 136 & 108 & 92 & 84 & 64 & 56 & 44 \\
\hline 6 & 300 & 204 & 162 & 138 & 126 & 96 & 84 & 66 \\
\hline 8 & 400 & 272 & 216 & 184 & 168 & 128 & 112 & 88 \\
\hline 10 & 500 & 340 & 270 & 230 & 210 & 160 & 140 & 110 \\
\hline 12 & 600 & 408 & 324 & 276 & 252 & 192 & 168 & 132 \\
\hline 14 & 700 & 476 & 378 & 322 & 294 & 224 & 196 & 154 \\
\hline 16 & 800 & 544 & 432 & 368 & 336 & 256 & 224 & 176 \\
\hline 18 & 900 & 612 & 486 & 414 & 378 & 288 & 252 & 198 \\
\hline 20 & 1000 & 680 & 540 & 460 & 420 & 320 & 280 & 220 \\
\hline 22 & 1100 & 748 & 594 & 506 & 462 & 352 & 308 & 242 \\
\hline 24 & 1200 & 816 & 648 & 552 & 504 & 384 & 336 & 264 \\
\hline 26 & 1300 & 884 & 702 & 598 & 546 & 416 & 364 & 286 \\
\hline 28 & 1400 & 952 & 756 & 644 & 588 & 448 & 392 & 308 \\
\hline 30 & 1500 & 1020 & 810 & 690 & 630 & 480 & 420 & 330 \\
\hline 32 & 1600 & 1088 & 864 & 736 & 672 & 512 & 448 & 352 \\
\hline 34 & 1700 & 1156 & 918 & 782 & 714 & 544 & 476 & 374 \\
\hline 36 & 1800 & 1224 & 972 & 828 & 756 & 576 & 504 & 396 \\
\hline
\end{tabular}

EXAMPLE 7

Table for ascertaining the number of words to square inehes. Use of this table in laying out booklets and eatalogs will not only save time but will minimize the ehanee of a misealeulation 


\section{TALMOND STUDIOS \\ Artists' Allaterials}

1004 Fulton Street, Brooklyn

EXAMPLE 8

Notehead as set without instructions from layout man The three specimens on this page lack relation in design

covered by print. For cheap work it is generally necessary to crowd the matter into the least possible number of pages, and in such case narrow margins are allowed. For the better quality of work, liberal margins are necessary to proper results. A page should set toward the top and binding edges, the margins at these places being each about the same. The margin at the right edge should be a little more than at the top and back, and the margin at the bottom should be a little more than at the right edge. For the booklet now supposed

For an example of the workings of the layout system we will suppose that the principal of a local business col- $^{-}$ lege has brought in typewritten copy of about a thousand words to be made into a small booklet. A little questioning brings out the information that the customer desires something attractive, refined, and of good quality. He does not want a cheap job, and neither has he money to spend upon expensive de luxe booklets.

The layout man looks over his sample papers and finds that there is on hand a ten-cent white antique paper $25 \times 38$ inches in size. Taking a quarter sheet he folds it repeatedly until the leaf appears to be about the proper size. Measuring it he finds it to be $43 / 4 \times 6 \%$ inches. The leaf is then trimmed to $4 \% \times 5 \times 5$ inches (thus allowance should always be made for trimming the edges after binding).

For the cover the layout man selects from his samples a medium gray antique stock of good quality. The cover stork should harmonize in finish with the paper on the inside. In this instance an antique finished stock is selected to cover the antique finished paper on the inside. Many are the booklets that would have been improved by attention to this rule of hamony. However, a rough finished cover stock and a smooth inside paper is not as inartistic a combination as a smooth cover stock and a rough inside paper.

The cover stock selected in this instance is $20 \mathrm{x} 25$ inches in size, and an eighth of this sheet folded once gives a leaf $5 \times 6^{1 / 4}$ inches. Deciding to have the cover lap three-sixteenths of an inch over the edges of the insicle leaves, it is trimmed to $4 \% / 1 ; \times 6 \%$ inches.

On one of the inside leaves a page is penciled off, the layout man judging how much of the paper should be

\section{For}

FROM

\section{TALMOND STUDIOS Artists' Materials 1004 FULTON STREET \\ BROOKLYN}

to be in course of preparation, $2^{3 / 4} \times 4$ inches has been determined as the proper size of the type-page. Each page thus requires eleven square inches of type-matter. 'The layout man refers to the table (Example 7) which gives the number of words to a square inch and ascertains that eleven square inches of ten-point type, the lines separated by two-point leads, should accommodate one hundred and sevent $y$-six words. Multiplying this number by six, allowing two pages at the front of the booklet for

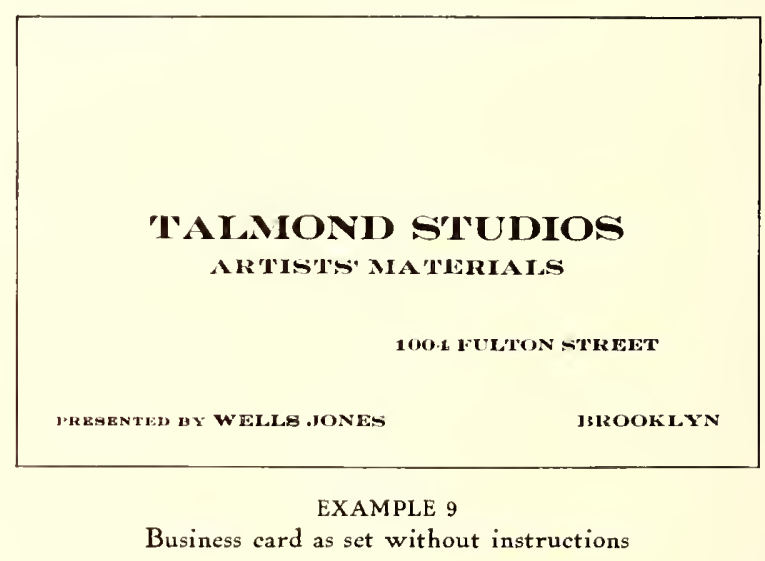

the title, etc., he finds the booklet will take 1,056 words, about the number of words in the copy supplied.

For a booklet of this kind the type should be no smaller than ten-point. Instead of stinting margins and sacrificing legibility, as is often done in endeavoring to force copy into a limited number of pages, additional leaves should be added.

The cover and inside papers having been prepared in the proper size and number of leaves, the dummy is stitched with wire or sewed with silk floss as may be desired. The arrangements of the title-page, the first text-page and a page entirely text matter are indicated in proper position by means of pencil and crayon; or for booklets of a large number of pages it is well to set the first text-page in type and paste a proof of it in the dummy, getting by this means the customer's approval of both type-face and general effect.

The appearance of the printed page may be anticipated by pasting in position a type-page cut from another booklet already printed. (Examples 2 and 3.) In a shop where much booklet work is done, it would be a convenience to the layout man if a number of specimen pages, set in the available body type (both solid and leaded), were printed for use in preparing dummies. These specimen pages should be about $5 \frac{1}{2} \times 7$ inches, a size that would make them usable for most purposes.

The cover arrangement was sketched on the gray stock 
(Example 1), the border being represented by the gray lines of a hard lead pencil. The type line was indicated by means of a soft black lead pencil and an orange crayon. Ornaments are not specified because they are better omitted on booklets where dignity is the principal feature.

The dummy booklet thus completed is submitted to the customer and when approved goes to the work-rooms with the copy. The compositor, makeup man, stockman, pressman and binder have no excuse for any misunderstanding, as, generally speaking, they have merely to duplicate the dummy. The labor of the estimate man, too, is lessened, as the dummy booklet affords a substantial basis upon which to figure the cost.

The plan of making a dummy booklet, just explained, can be adapted to many jobs, but of course it should be varied to suit special requirements.

In cases of periodicals and voluminous catalogs, dummy sheets should be printed with the outlines of the page

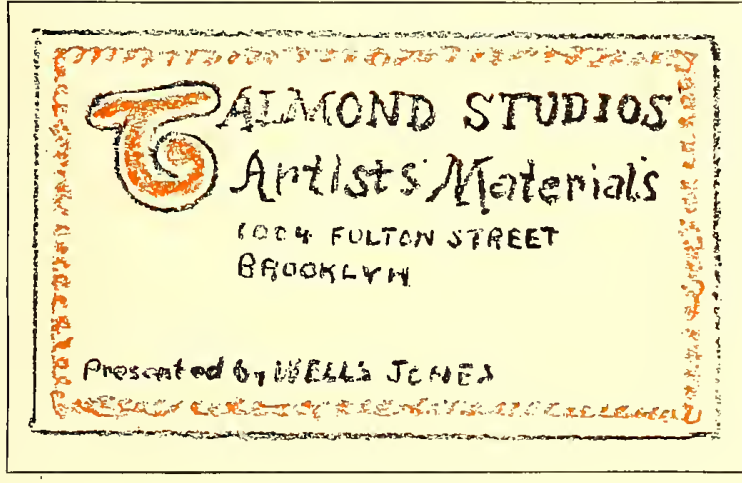

EXAMPLE 12

Business card as laid out

indicated by light-faced rule. With such sheets the layout man is enabled quickly to paste in position prints of the illustrations and text matter from the galley proofs. Getting his instructions in such methodical manner the make-up man can do his work without confusion of orders, and the proof-reader's task is made easy.

When illustrations are provided to be incorporated in the text matter there is more or less trouble in making up the pages. To center all illustrations so as to avoid changing the width of the type lines is easy but not always artistic. It is economical to have plates made the full width of type matter, but the printer is seldom consulted until after the plates are made. However, various sizes of illustrations may be attractively grouped on facing pages and the type-matter filled in around them. This method may appear difficult because the text matter is often composed on machines; but it is not difficult if prepared in this manner: Take the prepared body-type sheets, cut them to the required page size, paste them to the dummy sheets, and upon the pages of text matter thus presented fasten the prints of the illustrations in proper positions. The body-type sheets need not be used on pages for which there are no illustrations; in such instances merely the number of lines to a page is ascertained. Example 4-a demonstrates how the print of the illustration is placed over the body-type page, and the "step" shape of the pencil lines shows how the boundaries of the type ines are made to fit the outline of the illustration. The length of type lines should always be ascertained with the pica (twelve points) as the unit of measurement.

Supposing Examples 2, 3 and 4 to be clummies of pages, the composition of which is to be done on the linotype or monotype machine, the layout man with his pica measure starts at the initial letter $\mathrm{T}$ and measures and counts the lines, noting the results in the margins. (See Example 4-a. The page as shown is slightly reduced, hence the lines do not measure as set forth.) The figures are copied from the margins onto a slip and will then appear as shown in Example 4-b.

This plan emphasizes the necessity of a layout man as a member of the executive staff in the modern printshop. It may be a simple procedure to reset run-around matter at the moment it is needed by the make-up man, but it is an expensive habit.

The average stationery job is sometimes given scant attention in the larger printshops where long runs on cylinder presses overshadow it in importance. This condition leads to unsatisfactory results and the customer is the sufferer; his stationery as a whole is likely to be not only inartistic but a patch-work of typographic styles and arrangements. To illustrate this: A dealer in artists' materials orders at various times letterheads, business cards and package labels, and the copy is sent to the work-rooms with no instructions about style. Assuming that a different compositor gets each order, the jobs are composed as shown in Examples 8,9 and 10. These speci-

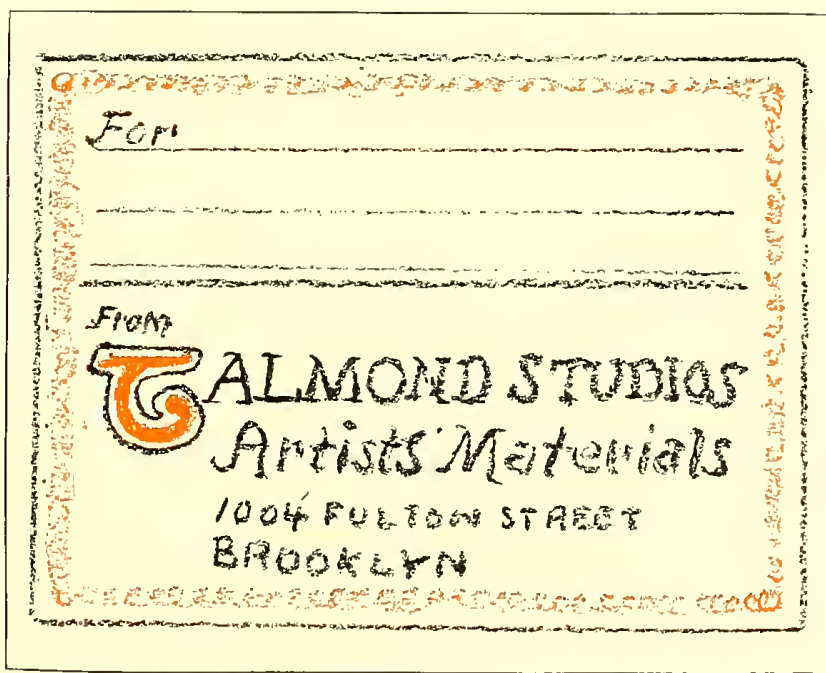

EXAMPLE 13

Label as laid out 


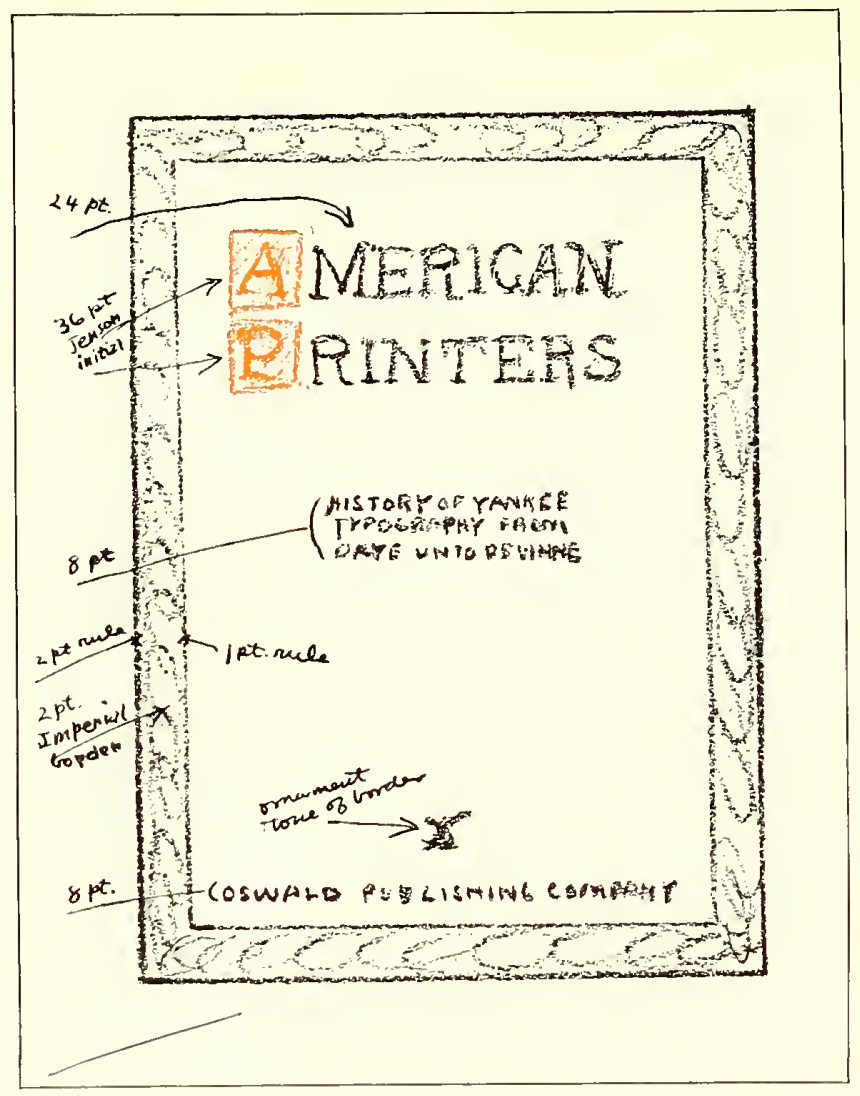

EXAMPLE 14

Layout of a cover-pade, with instructions in detail as to material to be used. Reduced from original mens are above the avcrage in arrangement, but are faulty in that they have no relation to each other in appearance; have nothing distinctive in their typography that identifies the business card with the letterhead or the label.

How different the results had an artistic layout man prepared each order before it was given to the compositor. Examples 11,12 and 13 , roughly sketched with pencil and crayon, demonstrate what could have been done. With stationery thus hamoniously treated a business house would be given credit for individuality and progressiveness.

In a printshop doing a good class of work (every printshop should endeavor to do that) the larout man ought to make a study of color harmony. Not that it is necessary for him to attend an art school or devote most of his time and attention to experimenting with prisms and light rays; charts and tables which help to solve the color problem are easily obtainable. After a little study and practice he will learn that while red, yellow and blue (the primary colors) harmonize with each other, mixtures of two or all three give shades that are more pleasing. Olive-green (an art shade) substituted for blue, in combination with orange, produces an artistic blend in place of the gaudiness which otherwise would prevail. This because olive-green is a mixture of blue and orange; a relationship in color composition is established and contrast lessened.

A black pagc increases in interest with the addition of a touch of red, and for this purpose vermilion is recommended. The vermilion shade of red is approximated by mixing white with orangc-red.

The colored crayons with which the layout man should be supplied are exceedingly useful in determining color combinations. The eye is a reliable guide in this matter, if it is carefully trained to recognize color harmonies. It

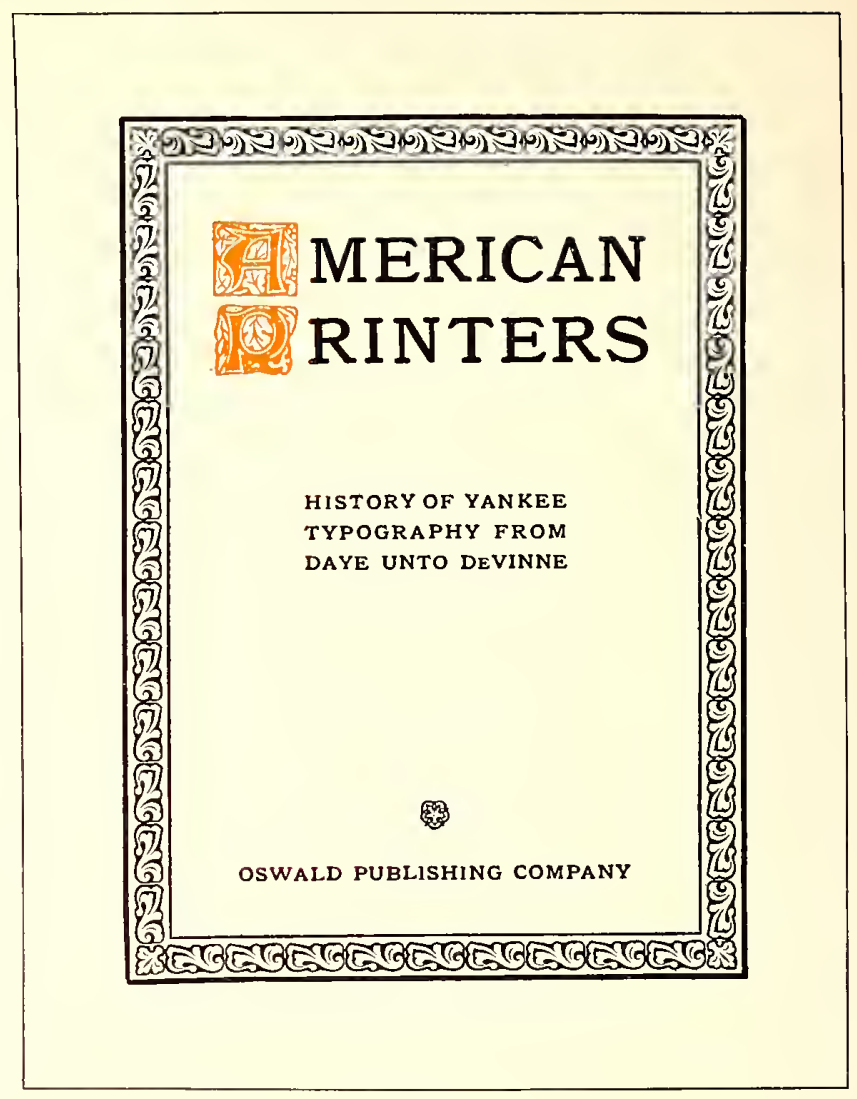

EXAMPLE 15
Cover-page as set from the in-
structions. Reduced from original

should be easy to distinguish the right from the wrong color treatment in Examples 5 and 6 . The colder color should always predominate; backgrounds of bright red and bright yellow are difficult to harmonize with any color of ink excepting black.

From the insert (Examples 16 and 17) will be seen how a color combination may be roughly sketched on the actual stock to be used and the finished result indicated without setting a line of type or inking a roller.

When the page is set in type it is well to have the proofs in the colors and on the stock to be used, but it is unnecessary to separate the design into several forms to do so. For a job such as Example 15, for instance, two proofs may be pulled, one in black and one in orange, and the initial cut out of the sheet printed in orange and pasted in position on the sheet printed in black. Another and a more satisfactory way is to ink the entire page with black, then clean the black from the initials, and ink them with orange by means of a finger. It may be relevant to suggest that the human skin is ideal for inking purposes, and that a printer's composition roller is an imitation of its qualities.

The layout man, in addition to the study of ink harmony, should learn to blend colors and tints of paper stock. He should know that a buff or cream inside paper reflects the color of a yellow-brown cover stock, and hence makes a prettier combination than white inside paper and brown cover stock. Another important point is the color blending of a tipped-on illustration and the stock acting as a back ground. The prevailing shade in a color illustration should be matched by the background or by a surrounding border, or by both.

When laying out advertisements or other display pages the size of the type-face should be written in the margin (Example 14). Practice will enable the layout man intuitively to approximate the size needed. 



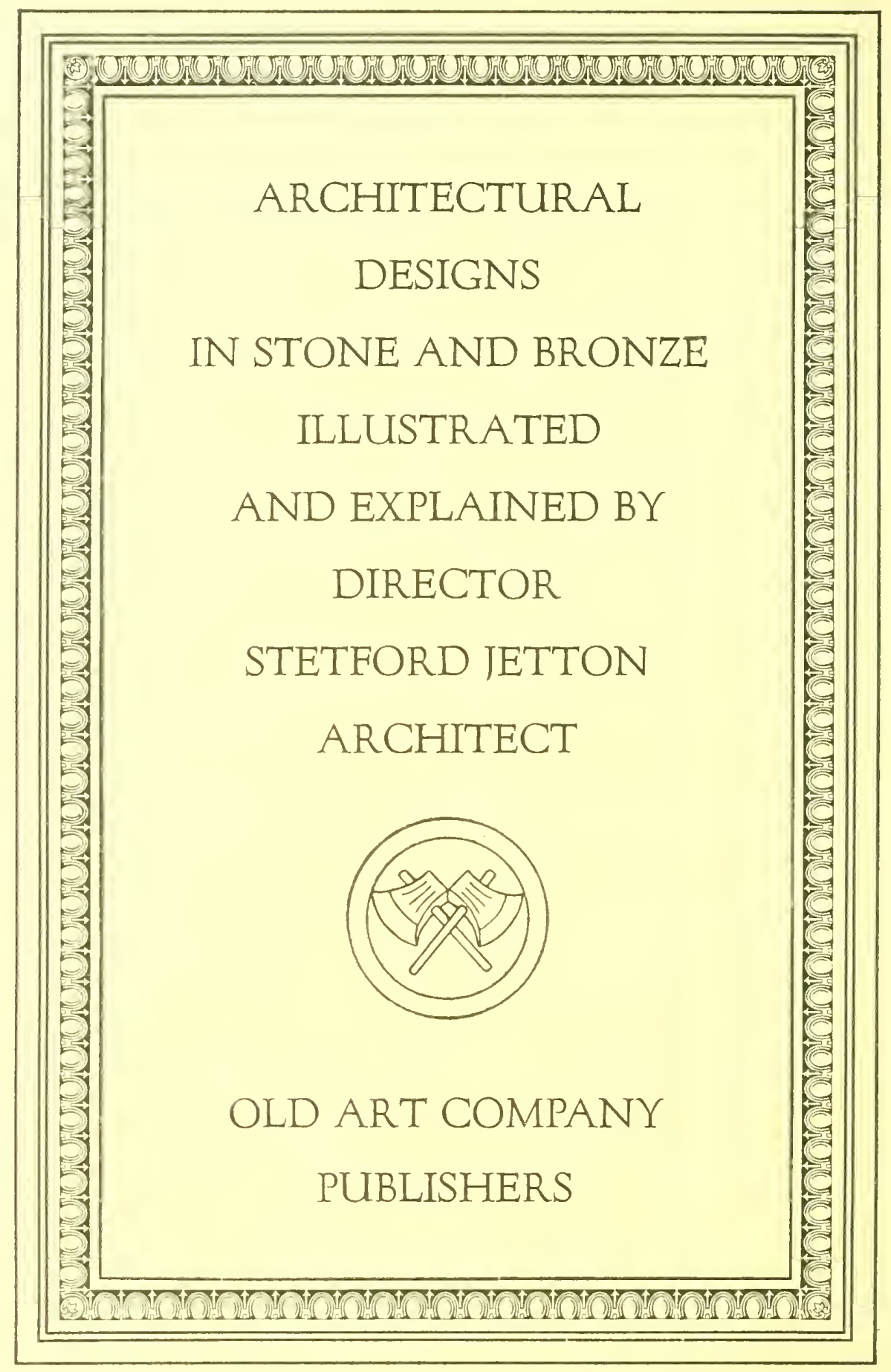

EXAMPLE 20

An architectural subject appropriately treated 


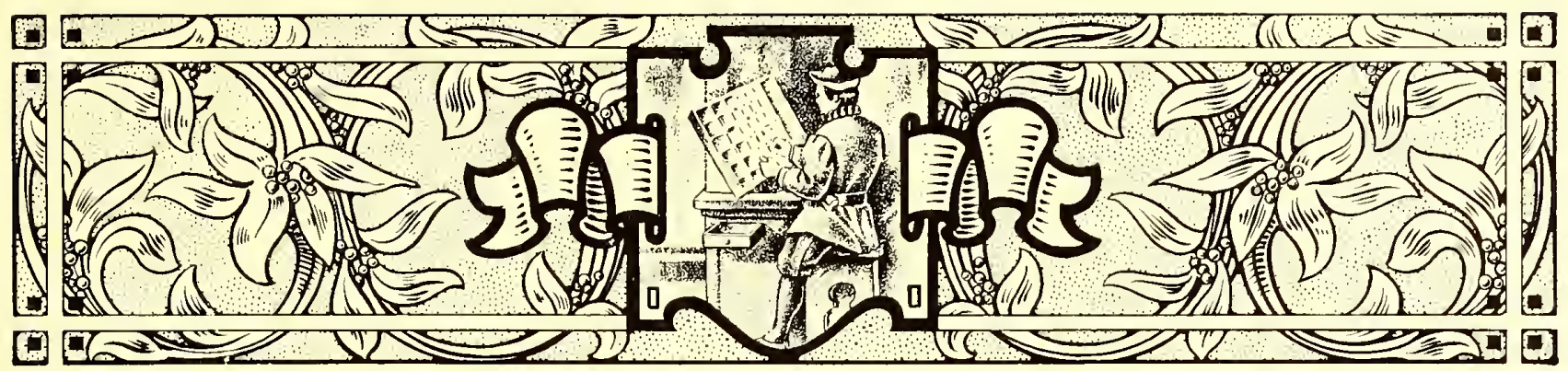

\section{HARMONY AND APPROPRIATENESS}

IN music there is that which the Germans call "Leitmotif" - the guiding theme in the construction or interpretation of musical compositions. The "Leit-motif" finds a parallel in the central idea or motive governing the composition of a building, a painting, a book or a job of printing. If Gothic is selected as the style of architecture for a building, every detail from the arches to the smallest bit of ornamentation is kept in harmony with the central idea of construction. If the building is to be Colonial, every detail is made appropriate to the Colonial motive.

The person is legion who undervalues the importance of harmony and appropriateness. Houses are furnished without regard to a general plan and furniture is added because it strikes the fancy at the moment of purchase. A Morris chair in dull-finished wood, a Louis $X V$ table with dainty curves and gilt luster, and a mahogany or ebony piano case are gathered in motly discord on an oriental rug. And when this same person has printing done, or does it himself, there is again revealed an utter disregard for the things that make for harmony.

What is appropriate? There are times when it is difficult to give an unprejudiced answer, especially when an idealistic art interpretation of the appropriate is combatted by the homely reasoning of a tiller of the soil. As a finishing touch

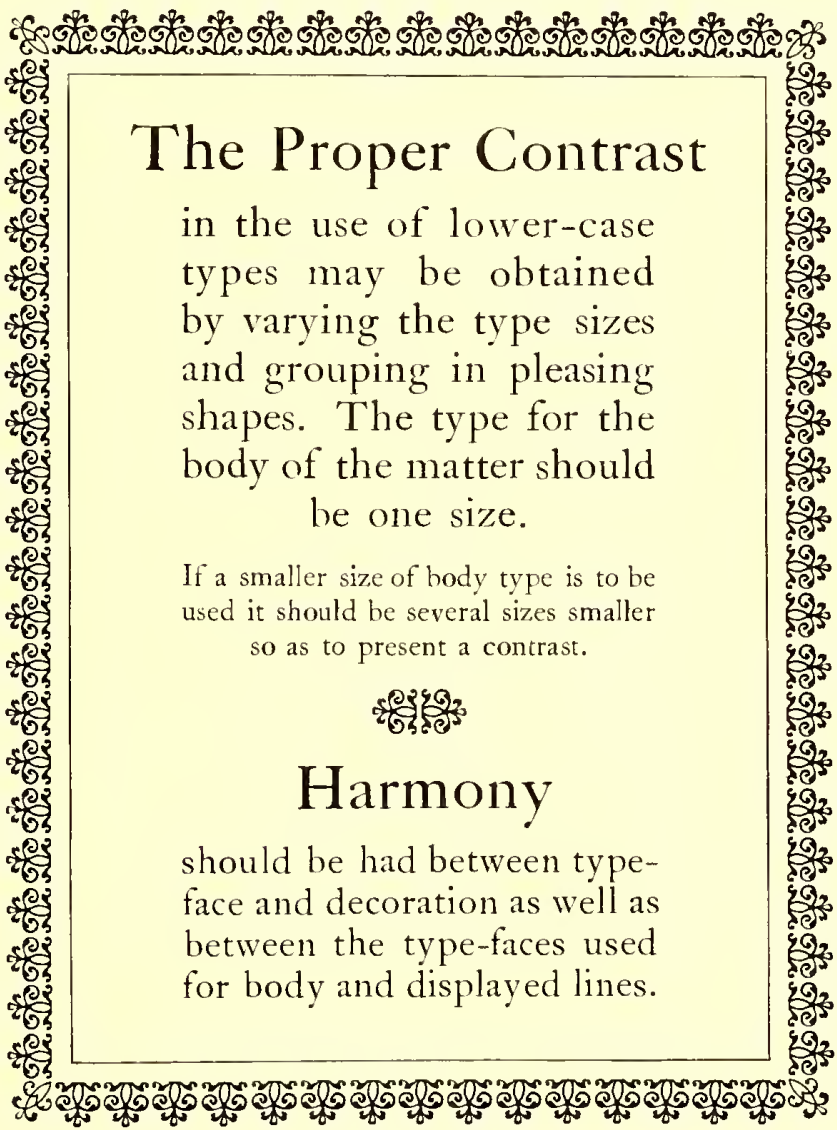

EXAMPLE 18

To obtain harmony it is frequently necessary to use but one series of type, and either all capitals or all lower-case necessary but are about as poetic as a page of stock quotations in a newspaper or a package of little pig sausages.

It requires a discriminating judgment to distinguish between the appropriate and inappropriate. 'T'he plain people of one of the new sections of New York City were astounded recently to find the street signs bearing such names as Socrates, Horatius, Poseidon, Aphrodite, Pericles and Seleucus. Names such as Wall Street, Broadway, Bowery and Fifth Avenue are unobjectionable, but Seleucus Street and Pericles Street -!

Typographers frequently go wrong in the use of the old Roman V. The $\mathrm{V}$ as part of the words PVBLIC LIBRARY on a stone building excites no comment; it seems appropriate and in rood taste; but as part of the words PVRE MILK on a grocer's letterhead it tempts the risibility in our natures. After all, good judgment is one of the most valuable assets a man can possess.

Harmonious and appropriate results in printing are brought about by discreet selection and use of these three elements: type, ink, paper. It is one thing to ink the type and pull an impression on paper, and it is another thing to do it properly. It makes a difference what type is used, what ink is used, and what paper is used. There are hundreds to the classic architecture of the agricultural building at Washington the words Fructus, Cereales, Forestes and Flores were carved in suitable places on the structure. The secretary of agriculture noticed the Latin words and forthwith ordered the architect to have them recarved in the English-Fruits, Grains, Woods and Flowers. Now there are those who say the words as modified suggest a sign on a country store. The architect probably reasons that the words as originally carved were purely decorative, and in their Fnglish form are not only un- of type-faces, many colors and qualities of inks, and a variety of finishes and qualities of papers.

As to type-faces: Printers of law briefs and legal blanks need the formal, legible modern romans. Printers making a specialty of commercial stationery, wedding invitations and calling cards need scripts and engravers' romans. Printers whose chief product is highclass announcements and booklets cannot do without oldstyle romans, italics and text faces. When everything in printing from the diminutive calling card to the massive 


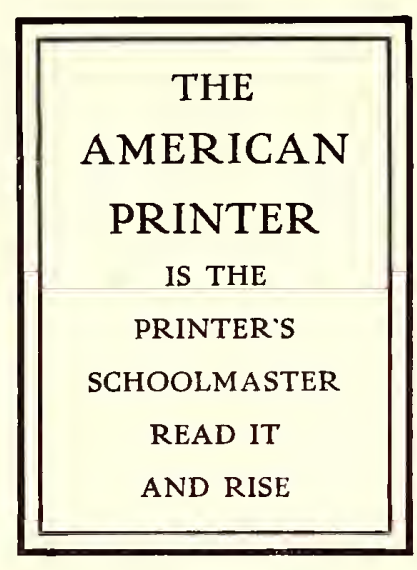

A

Harmony. The heavy line and the

light line are found in the construe-
tion of both border and type-face.

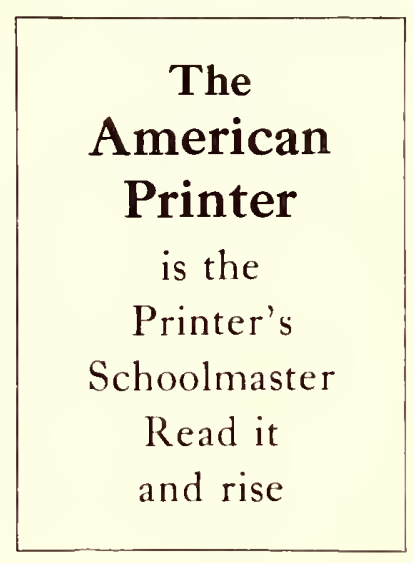

$\mathrm{D}$

Harmony. The two type-faces are Harmony. The two type-faces are
of the same design; one is stronger
iu tone.

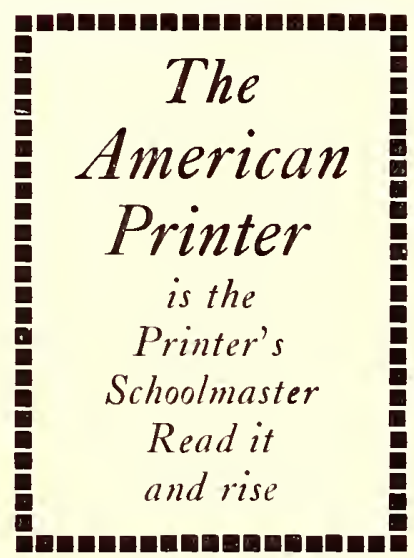

G

Incongruous. Border has no charthe italic type-face.

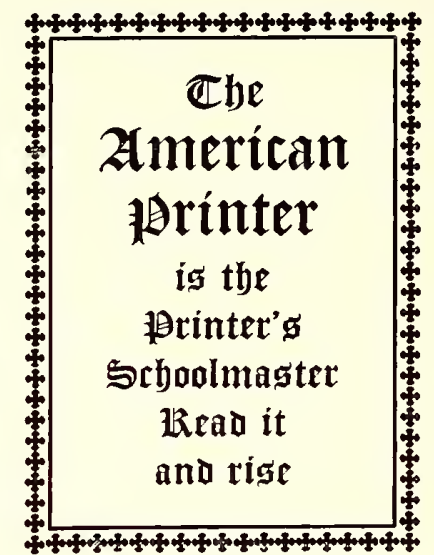

$B$

Harmony. The blaek, pointed ehar acteristic is a peeuliarity of both type-faec and border.

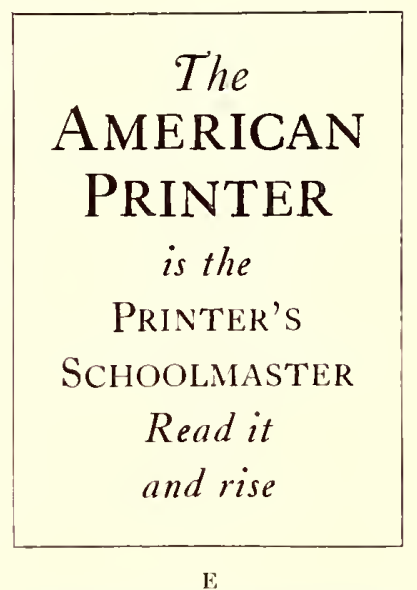

Harmony. The two type-faces are of similar desirn : one is slanted and
slightly altered to obtitin contrast.

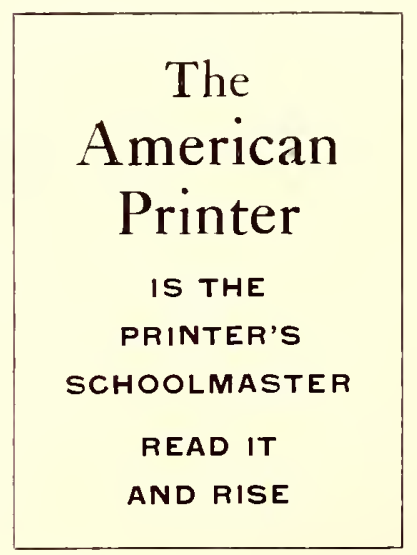

H Incongruous. There is no relation
in the style of these two type-faces; one las serifs, the other none.

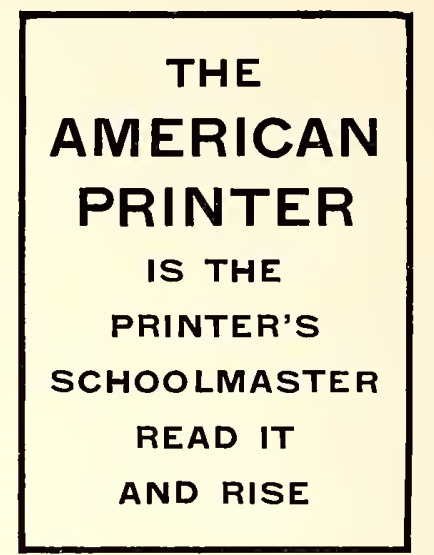

liarmony. Type-face is made of strokes of one width; border is eom-
posed of one line of similar width.

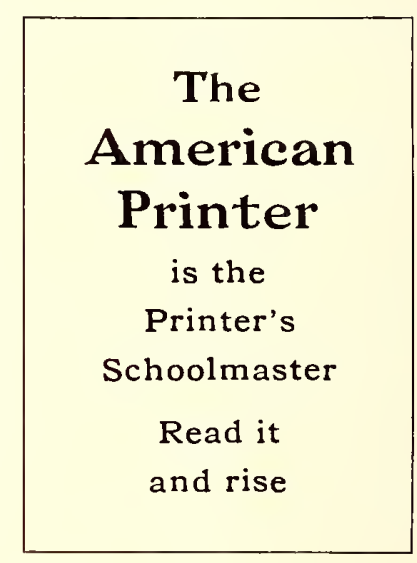

F

Near-harmony. Type-faces are suf fieiently similar in design to blend
if eontrasting sizes are used.

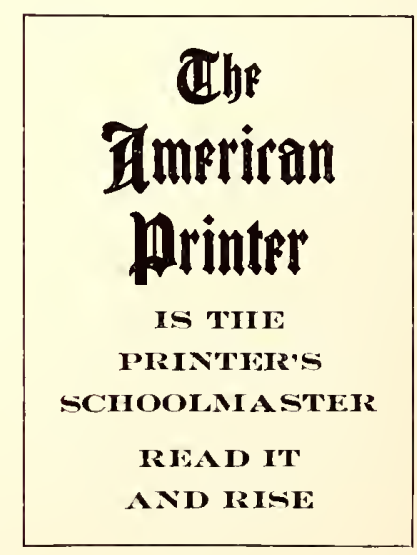

1

Incongruous. Letters not related in design; one is condensed, the other extended. 


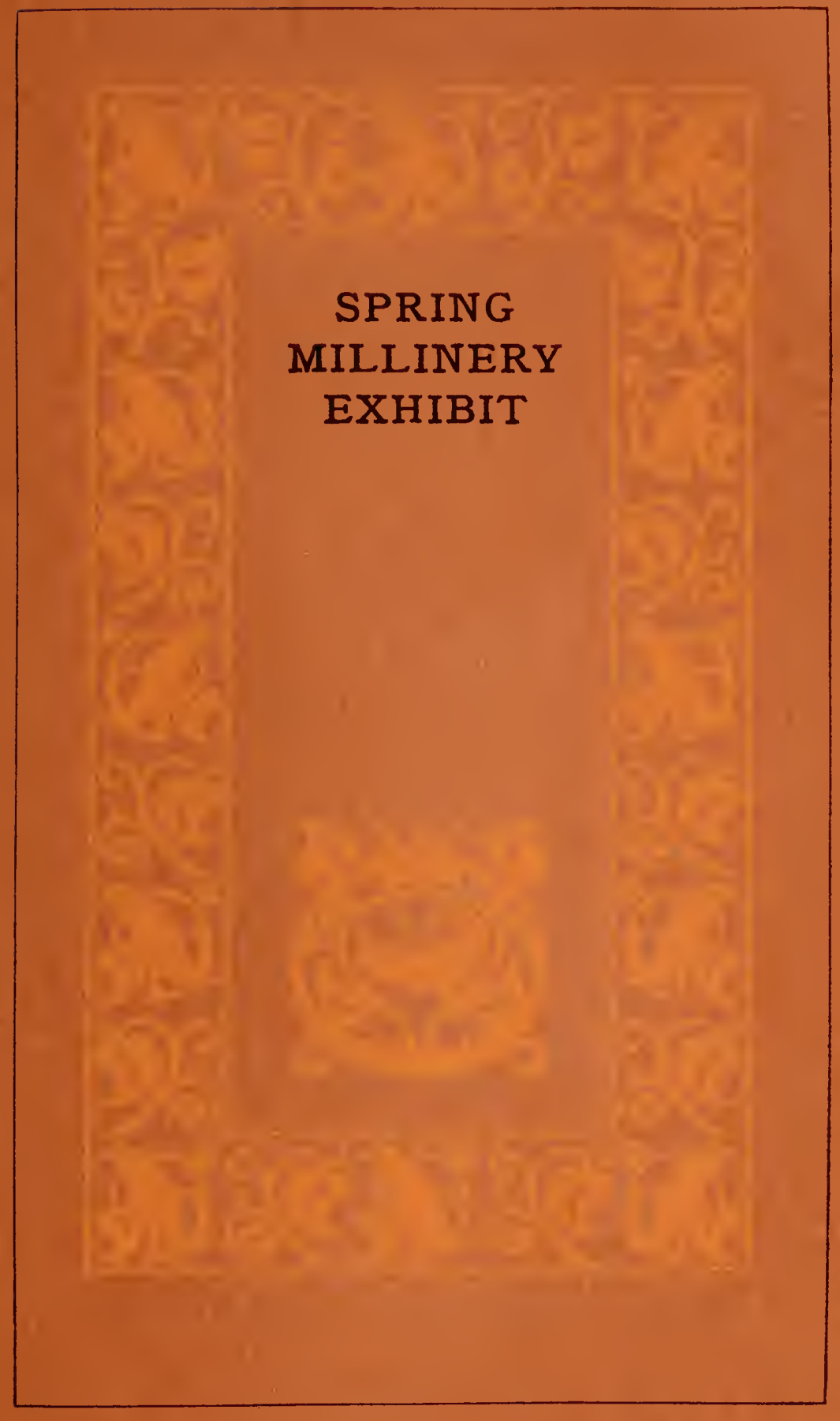

EXAMPLE 21

A booklet cover, the coloring and typography of which is suggestive of the subject 

catalog is solicited many styles of type-faces are needed.

As to inks: There are inks ground in strong varnish for bond papers, inks ground in soft varnish for coated papers, and heavy opaque inks for dark cover papers, and it makes a deal of difference if they are not used appropriately. And then, in the matter of harmony of colors there is a subject for much study. 'The wise printer will use good black inks and enliven his jobs with mere touches of orange or vermilion. Black and orange are always pleasing in combination and look well on most papers. There are pitfalls in the use of numerous colors, and until the subject of color harmony is understood by the printer he will wisely adhere to black and orange.

As to papers: Wove and laid antique papers, white and buff tinted, are appropriate for announcements and booklets in combination with old-style type-faces and black and orange inks. Dainty papers of linen finish in combination with delicate engravers' type-faces, are appropriate for milliners, florists, jewelers and others catering to the esthetic tastes of women. Dull-finished coated papers are considered more artistic than highly enameler ones, and there are those who prefer it as being more restful to the eyes.

It is a stupendous undertaking, in face of the multitudinous elements that are part of the production of printed work to point out a path that will lead to good typography. There are many printers doing good work and each of them has probably arrived at his point of attainment by a different route. 'There is no royal road to Jearning. The student may be assisted, but whether he succeeds depends to a great degree upon himself. $\mathrm{He}$ must have an open mind, good judgment, and a liking for simplicity.

Simplicity is synonymous with good typography and its path is a straight and narrow one.

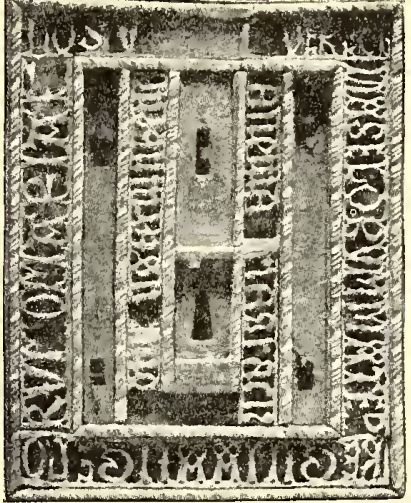

EXAMPLE 23 An old lock-plate

He who would do worth-while typography must decide wisely when accepting the good things offered by his friends, the paper man, type man and ink man. They are generous in their offerings and willingly assist the doubting one in deciding; but confidence in his own judgment is a necessary qualification for the typographer who would attain success.

The ideal printshop is that one which contains only harmonious type-faces, ink colors and paper stock. This ideal condition being impossible except in a small shop, the best alternative is to have all type-faces as nearly harmonious as possible. It would be wise to build upon

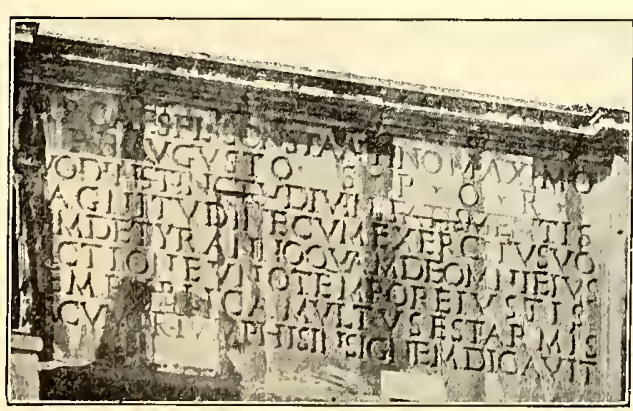

EXAMPLE 24

Inscription on a Roman arch the bo d $y$

ty $\mathrm{pe}$ as a foundation. Choose a body face that will be suitable for nost purposes, a nd then select a series or family of d i s p l a y types that harmonize

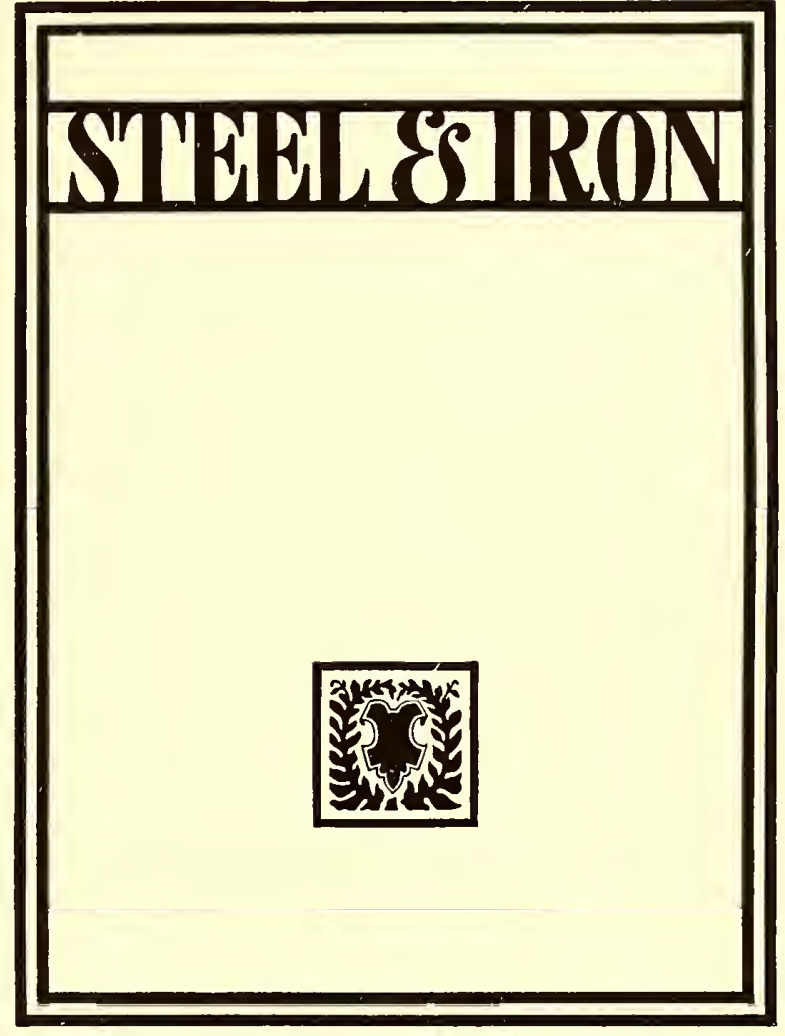

EXAMPLE 22

Type-design for catalog cover suggested by the old lock-plate

with it. If Caslon Old Style is chosen as the body letter, Caslon bold, Caslon italic and Caslon text will afford variety in display while retaining harmony. (Of course the large display sizes of the Caslon Old Style should be included.) The Cheltenham family probably provides the greatest variety of harmonizing faces. Scotch Roman is a dignified and legible letter, and supplemented by its italic and the larger display sizes is a satisfactory face for many purposes. Old Style Antique is a useful letter where a black tone is desired and is pleasing in its original form. There are many artistic letters now to be had that give the effect of hand-lettering, which are admirable for distinctive advertising literature.

While harmony of type-faces is essential, yet a certain amount of contrast is desirable. At one time it was customary to alternate a line of capitals with one of lowercase. This arrangement gave contrast, but not harmony. The best results are obtained by the use of either all capitals or all lower-case. As explained in the chapter "When Books Were Written," our alphabet in its original Roman form consisted of capital letters only. Lowercase letters, also known as minuscules, are the result of evolution, and in form differ materially from the capitals. Custom decrees that a capital letter be used to begin an important word otherwise in lower-case, but with this exception either kind is better used alone.

Example 19 illustrates harmonious combinations of type-faces and borders and also presents several incongruous features.

Section $\mathrm{A}$ is an all-capital scheme enclosed in a border of heavy and light rule. A border such as this owes its origin to the panels used by the Romans to surround inscriptions on stone, and as these inscriptions were in capital letters only, the appropriateness of the treatment is manifest. As the letter is also formed of heavy and light strokes the harmony is enhanced.

In section B there is harmony from both the historic 


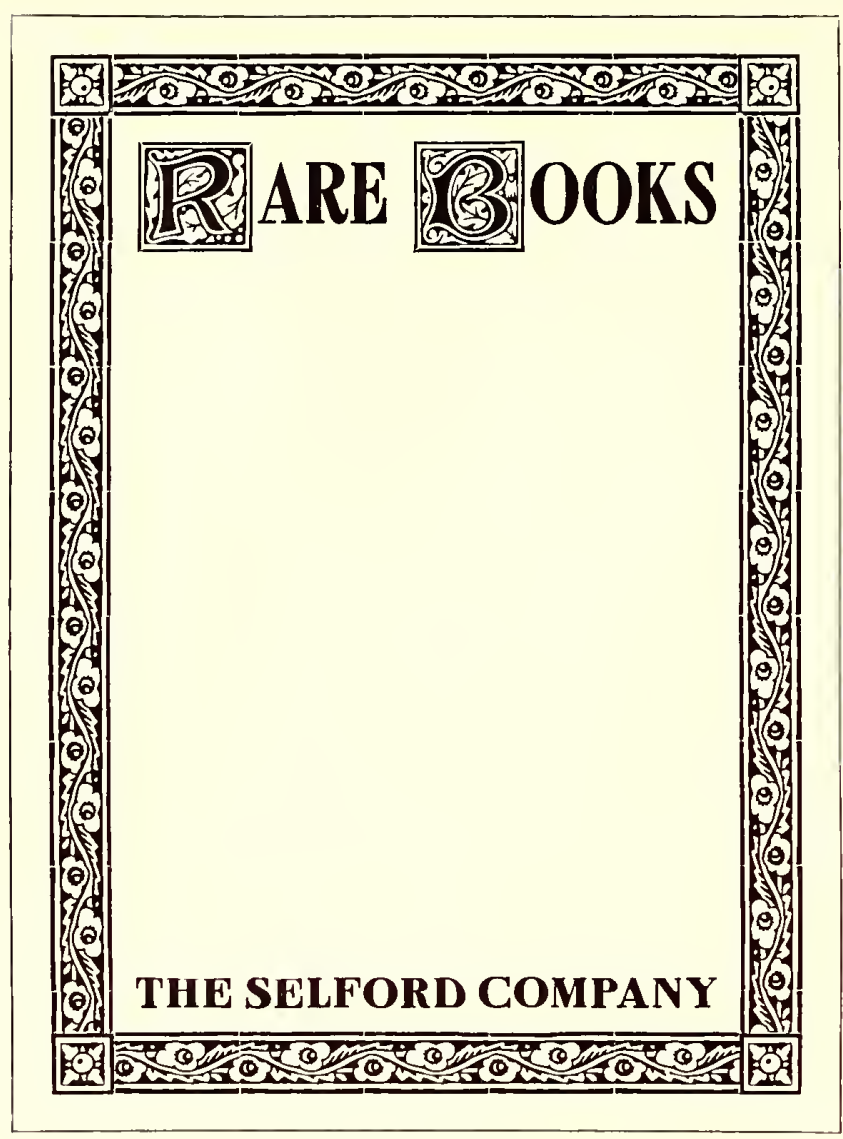

EXAMPLE 25

Cover-page for a catalog of books, using type imitations of woodeut initials and borders and artistic viewpoints. The black text face, representing as it does the direct result of the evolution from capital letters, is appropriately used only in its lower-case form. The use together of text capitals is objected to on tle ground of illegibility. 'This black text face (correctly called Gothic) is historically associated with ecclesiastical printing, and the burder, consisting of pointed crosses of black tone, blends with the pointed black letters of the typeface.

Section c shows a plain letter of modern cut known erroneously as gothic. Containing no serif's, it lacks a feature which has always been considered necessary to beauty in type-faces. As a harmonious border for this face there is nothing better than a plain rule of the width of the type strokes.

The next three panels demonstrate such harmony as may exist between type-faces of different series:

D. - This panel shows Caslon bold in combination with Caslon roman, and demonstrates the close harmony existing between type-faces of the same family.

E. - Another demonstration of the harmony of the family types.

F.- Harmonious, to a certain extent.

The type and rule in the next panel do not harmonize for these reasons:

G. - The border is too black and square in form. Italic, because of the slant of its letters, looks better not surrounded by a border, but when one is used it should be light and contain some of the characteristics of the italic.

In all cases where ornamental borders are used more finished results are obtained if a rule separates the border from the type, as in Section $\mathbf{B}$.

The next two panels present the "horrible examples," which are defective for these reasons:

н. - The type-face of the upper group has nothing in

\section{ANNUAI, REPORT}

\author{
OF THE
}

\section{BOARD OF SURVEY}

\author{
FOR 1913
}

CONTAINING DIAGRAMS OF

ALL IMPROVEMENTS DURING TIIE PAST YEARS TOGETHER WITII PLANS AND SPECIFICA. TIONS FOR THE COMING YEAR

\section{CITY OF PITTSBURGH} DEPARTMENT OF STREETS

\section{EXAMPLE 26}

A plain page without ornament or decorative types, for a plain purpose

common with that of the lower group. That of the upper group is a distinctive old-style roman, with serifs, and is set in lower-case, while that of the lower group is a plain black modern letter, without serifs, and is set in capitals. The main display should never be lighter in tone than the less important ty pe matter.

I fails to harmonize because the type-face of the lower group is slightly extended and the one of the upper group is condlensed. The shape of the letters of a type-face should conform to the shape of the page, and so far as possible to the shape of the companion letter, when one is used. Condensed letters should be avoided except for pages that are long and narrow, and an extended letter should not be used except on a wide page.

There are more typographic sins committed thru violation of the laws of appropriateness than in any other way. In this regard it would not be difficult to make out cases a grainst the best of typographers, whose sins are washed away by good work in other respects. As in architecture, where one part of a building bears relation to all other parts, so in typography there should be a motive that blends all elements in serving one well-defined purpose. The phrase "Is it appropriate?" prominently displayed above the type cabinets, over the presses, in the stock-room, and over the layout man's desk, would help to keep in mind this important requirement.

An archit ectural motive was suggested by the copy for Example 20, and type-face and decorative border were selected that the motive should be emphasized. The architecture of the Romans was frequently embellished with inscriptions (see Example 24), and in modern architecture the panel of Roman lettering is a feature; the lettering is generally all capitals of the same size, of a style near that of the ancient lettering; and the panel 


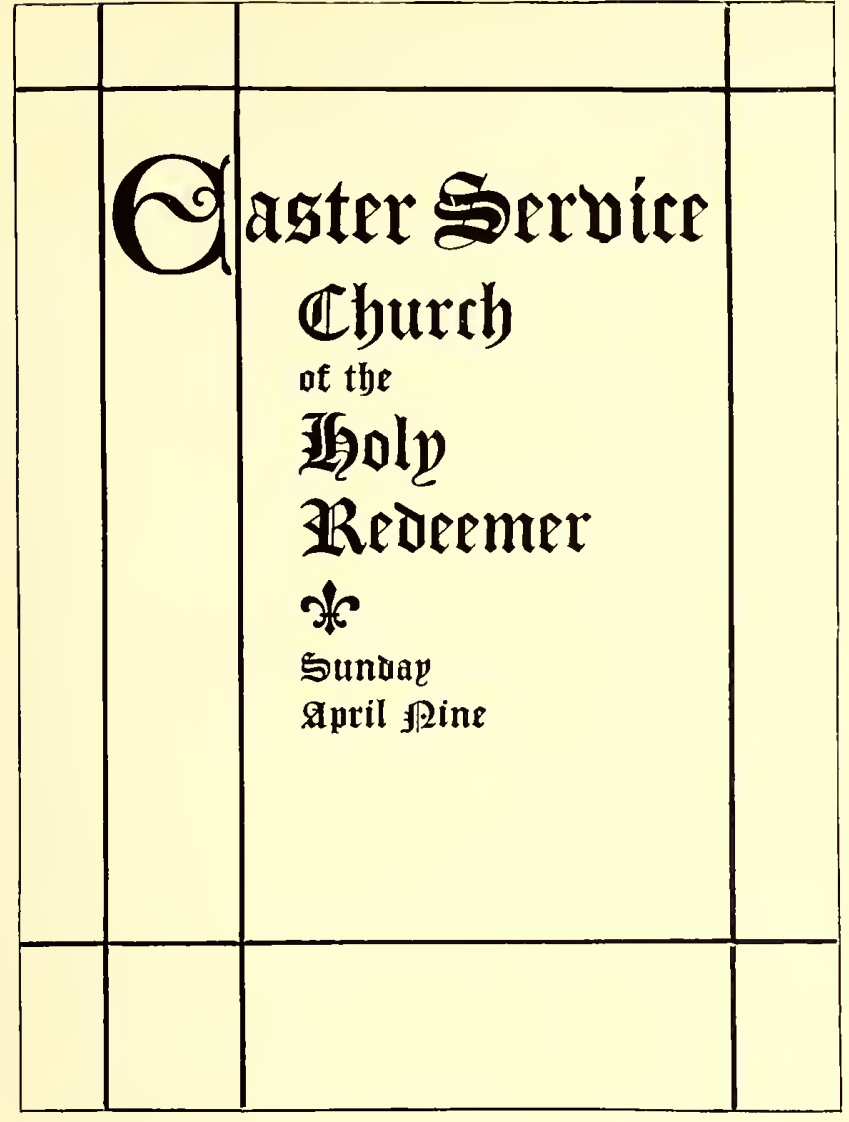

EXAMPLE 27-a

Treatment appropriate for a church program, in style based upon old ecclesiastical manuscript books. (See specimen below.)

is outlined with molding, plain or decorative. Serving a purpose equivalent to the architect's panel molding, the type or rule border is a valuable addition to a page of type. A page of display type or a halftone not surrounded by a border is like an oil painting without a frame. The egg-and-dart border around Example 20 is historically associated with architecture. The type-face is a Roman capital letter designed by Fred. W. Goudy from an inscription found in the ancient Forum at Rome.

Bismarck was called the "Iron Chancellor" because of his great strength of character and unbending will. Strength instantly associates itself with the mention of iron or steel, hence the motive for the construction of Example 22. It may be interesting to know that the design of this page was further suggested by the old lock-plate (Example 23). A printer with imagination can absorb ideas from many sources. The lock-plate is not literally reproduced in type, but a few of its features, including the key-hole, were borrowed and con-

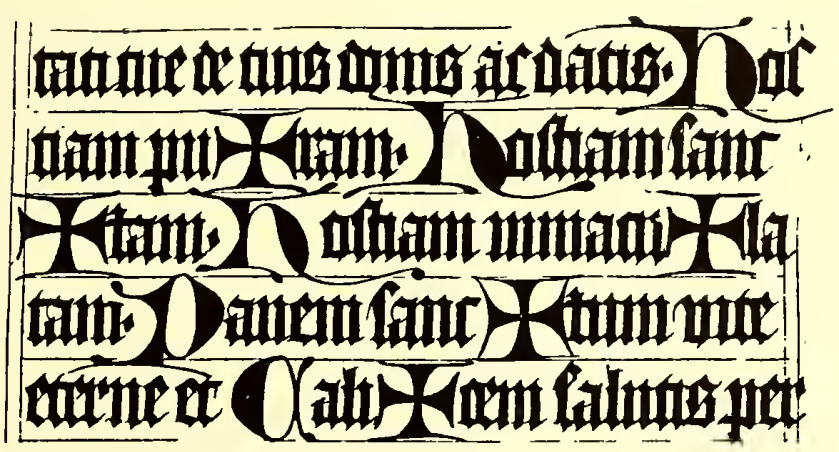

EXAMPLE 27-b

Portion of a page of an old manuscript missal

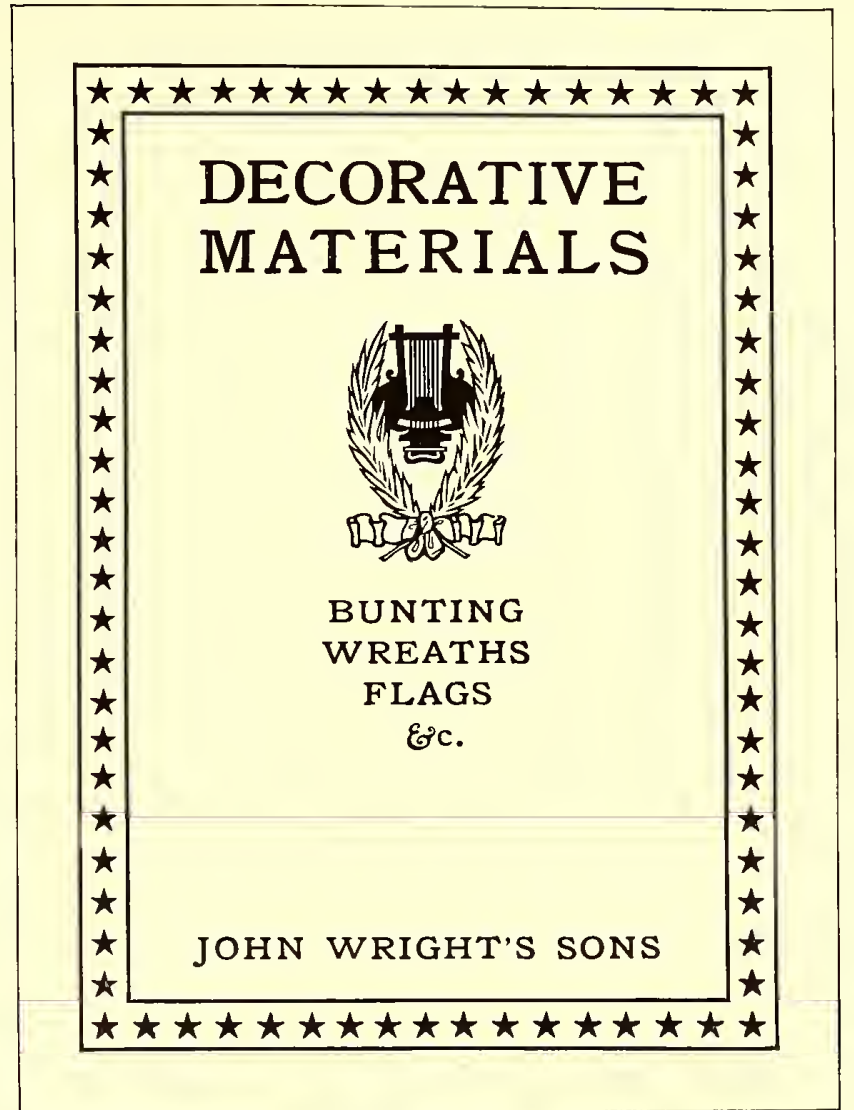

EXAMPLE 28

Cover-page for a catalog of decorative materials, suggesting festive gatherings, music and waving flags

ventionalized. An artist-designer does not copy his models closely; they serve the purpose of suggesting shape and treatment and his imagination does the rest.

For the cover of a small catalog listing rare books, a typographic motive is found in the woodeut borders and initials of the early printers. Example 25 shows what may be done with type-foundry material on such a cover. The border is of black tone and the type and initials are given the strength that harmonizes with it.

Old books suggest discolored leather, dusty shelves and plain men, and it is an abrupt change to the subject of millinery, with its bright colored feathers, ribbons and delicate finery. The milliner ornaments his sales-room with vines nd flowers and dainty colors, and the printer gets his ty ographic motive from such sources. Example 21 illustrates a booklet cover treated thus appropriately. The page size is unconventional, the coloring is dainty, and the type lines are neatly diminutive.

As a millinery store is unlike an office in which are maps and blue prints and legal documents, so typography for these two purposes should be unlike. Example 26 is a page severely plain and non-sentimental. The types are merely to tell something in a blunt manner. There is needed no touch of decoration or color to interest the reader, because those who read it would do so whatever the treatment. This is the only example in the present chapter in which the advertising element is unimportant. The page may be commonplace because it need not be anything else, altho it is well to do good work even here.

From the surveyor's office our journey of instruction takes us into a church during an elaborate Easter service. Light filtered of its brightness by stained glass windows; high-placed Gothic arches pointing toward the sky; soft organ-music-all these create an atmos- 


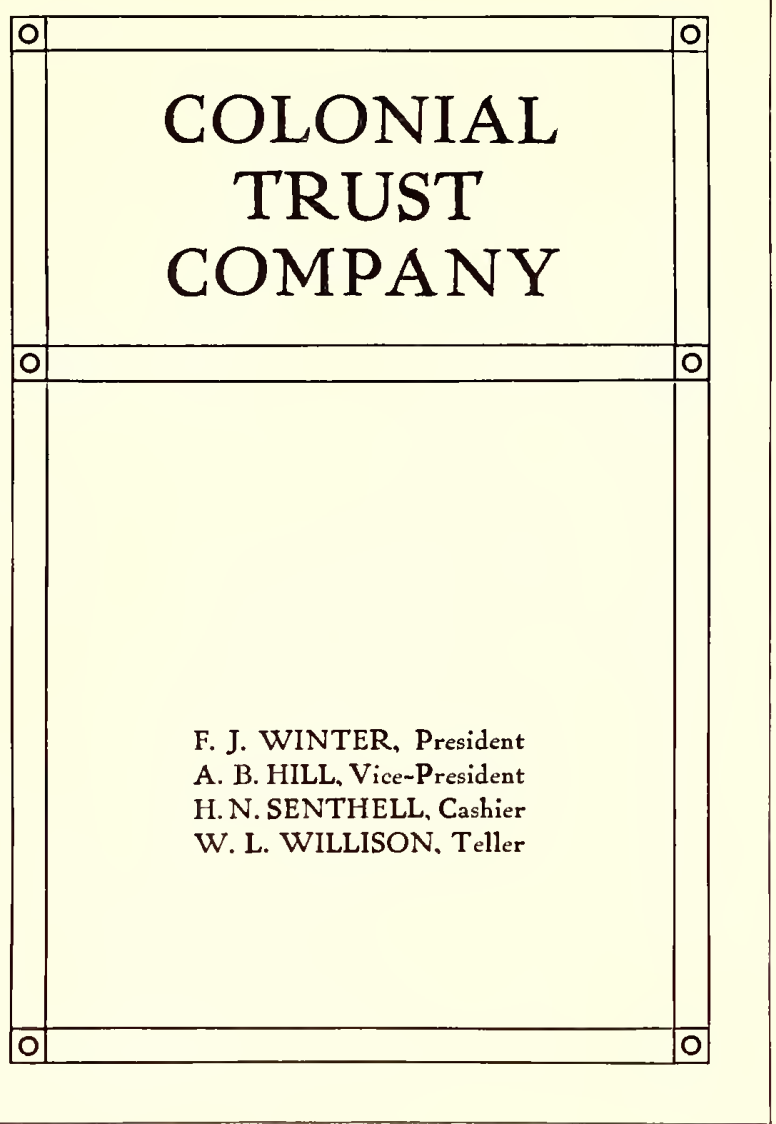

EXAMPLE 30

Title page in semi-Colonial style, appropriate for use with a cover design such as Example 29

phere of solemnity and harmony. A program or pamphlet for use during a church service should be as appropriate to the environment as a Book of Common Prayer or Bible. Typographic treatment good as shown in Examples 22,26 or 28 would be ridiculous for a church program. Example 27-a shows a page historically appropriate. The type-face is peculiarly fitting because of its pointed form, and also for the reason that a letter of similar design was used by medieval scribes on ecclesiastical books (see Example 27-b). The crossed rules, which should be printed in orange-red, are adapted from the guide lines as made by the scribes for marking the position of a page on the sheet.

When a holiday crowd is gathered, dignity is put aside and all enter into the festive spirit of the occasion. Here is the motive for the typographic treatment of a booklet or catalog of decorative materials as presented by $\mathbf{E x}_{\mathrm{x}}$ ample 28. It would be excessive emphasis of appropriateness to print such a page in a combination of bright red and blue. The colors should be softened. The page would look well printed in a deep blue with a flat blue tint overprinting the star border.

There is room for improvement in the support typographers give artists in the production of booklets and catalogs. In many cases title-pages are constructed with no regard to the motive suggested by the design on the cover. Bibliophiles judge a book not only by the excellence of its execution, but by the harmonious unity that may be expressed in every detail, from the literary contents to the last bit of tooling worked on the cover. The type, ornamentation, paper, ink, margins, leather, the arrangement of the title-page and the cover treatment, all must be selected and utilized in expression of a dom- inant central motive. The same rule presents the key to good typography in job work. Example 29 shows the Colonial arch adapted as the border of a booklet cover. The artist gives this treatment to the cover because of the motive suggested by the name "Colonial Trust Company," and when the title-page is set it would be a mistake not to use some Colonial arrangement. Example 30 blends with Example 29 and is modified from the old Colonial title-page treatment just enough to give it a modern appearance without sacrificing the old-time atmosphere. 'The border suggests both the widely-spaced rules of the Colonial printers and the architectural pillars of Example 29. No letter spacing is used, despite the temptation offered.

Discussion of the subject of harmony and appropriateness could be extended much further than is allowed by these limits. lages could be filled with descriptions of instances in which the compositor had erred in treating typography and ornamentation inharmoniously or with an unimaginative appropriateness. 'The use of angelic ormaments on Y. M. C. A. printing, where something more substantial is desirable; the double-meaning that may be read into the use of a horseshoe ornament on a printer's letterhead; the placing of illustrations of live

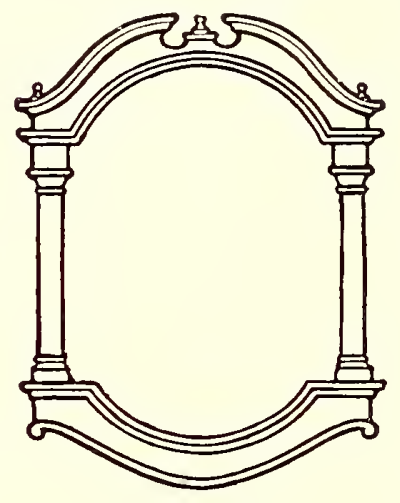

EXAMPLE 29

The Colonial arch fish, lobsters and animal food on banquet programs-these are a few of the things that might be mentioned.

High-class catalogs have been marred by the use of stock decorative initials which were at variance with the other decoration. In order to save a few cents both printer and customer are inclined to use stock decoration that happens to be on hand at the moment. Hundreds of dollars are spent on the work and then for the sake of saving thirty cents (the cost of a harmonious ini-

tial or ornament) many dollars in effectiveness are sacrificed. Another way of injuring the appearance of a book is to use a type-face on the title-page that does not harmonize with that used for the body matter and the subheadings. In order to secure complete harmony even the lettering on the cover should blend in style with that used for the title-page, sub-headings and text pages.

Altho strict adherence to the laws of harmony and appropriateness is necessary in the production of good work in any field of endeavor, Americans seem to be really proud when they violate such laws. We all know the person who dresses in a slouchy manner because he read somewhere that Horace Greeley dressed that way. And there is the modern politician who wears a slouch hat and constantly carries a quid of tobacco in his mouth because Henry Clay did so. There are also house-organ publishers who use inharmonious and inappropriate typefaces and decoration because Elbert Hubbard thus treats the cover of the Philistine.

It is not a question of the sort of clothes a person actually needs to go from one end of a street to anotherLady Godiva reached her destination with no clothes at all-yet we often admire a person dressed harmoniously and in good taste without knowing the reasons for our admiration. As there is art in tailoring and in the selection of clothes, there is also art in printing, and he who investigates will find that the great natural laws of beauty apply even to typography, which some by their work seem to think requires no more thought than ditch-digging. 


$$
\text { - }
$$




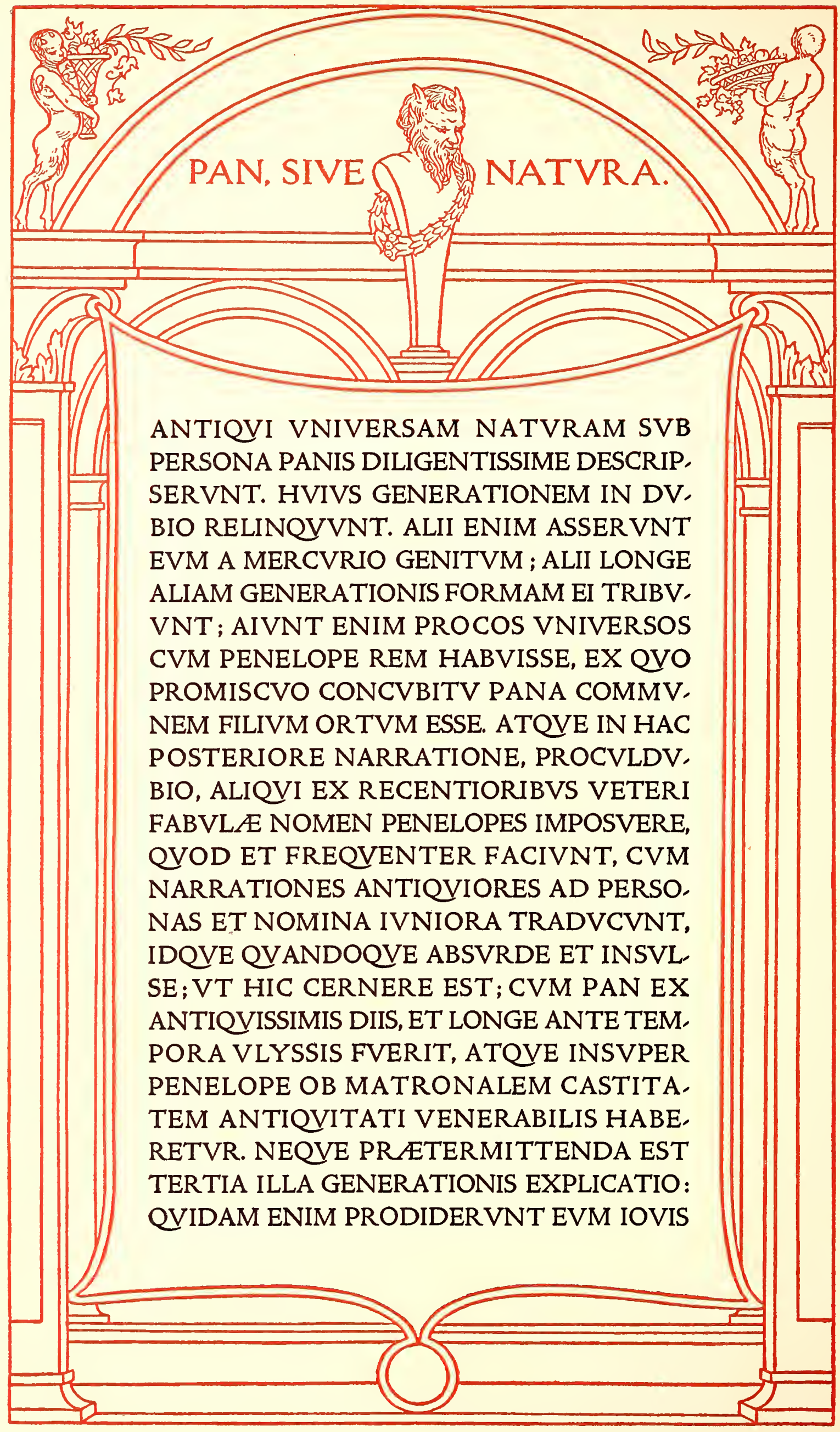




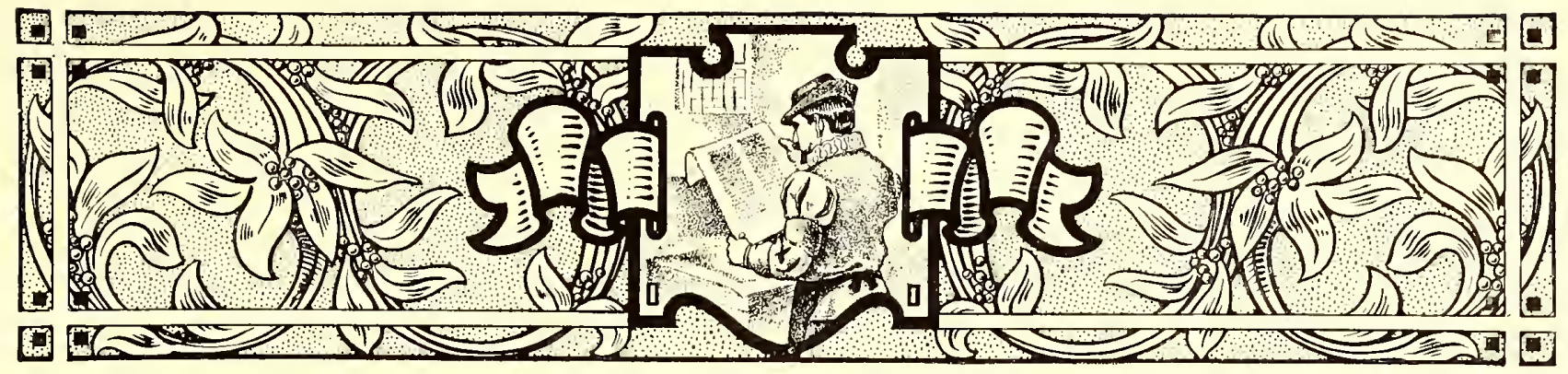

\section{TONE AND CONTRAST}

THIS chapter is a story of the alpha and omega of color - white and black. Since the creation of the world, when light first illumined the darkness, these two colors (if I may call them colors) have been emblematic of extremes-white, the symbol of purity and goodness, black of impurity and evil. White and black represent extremes in color. Mixing of all the color rays of the solar spectrum produces white, and mixing of all the colors in the solid form of printing ink produces black. From this contrast of white and black maybe drawn a lesson in color. (Example 31.) Light represents warmith, darkness cold. As the colors are toward light they are warm; as they are toward darkness they are cold. Red becomes warmer as it takes on an orange hue, and colder as it takes on a purple hue. A warm color should be contrasted with a cold color-as orange with black. The furtler in tone the color is from black the more it contrasts with the black. As an illustration: Orange is more pleasing than a deeper shade of red as a companion color for black. Blue, purple or green, selected to be used with black, must be lightened with white ink to get the desired contrast.

White and black as a combination are and ever have been popular with writers, printers and readers. Fully nine-tent hs of the newspapers, books, catalogs and other forms of reading matter are printed with black ink
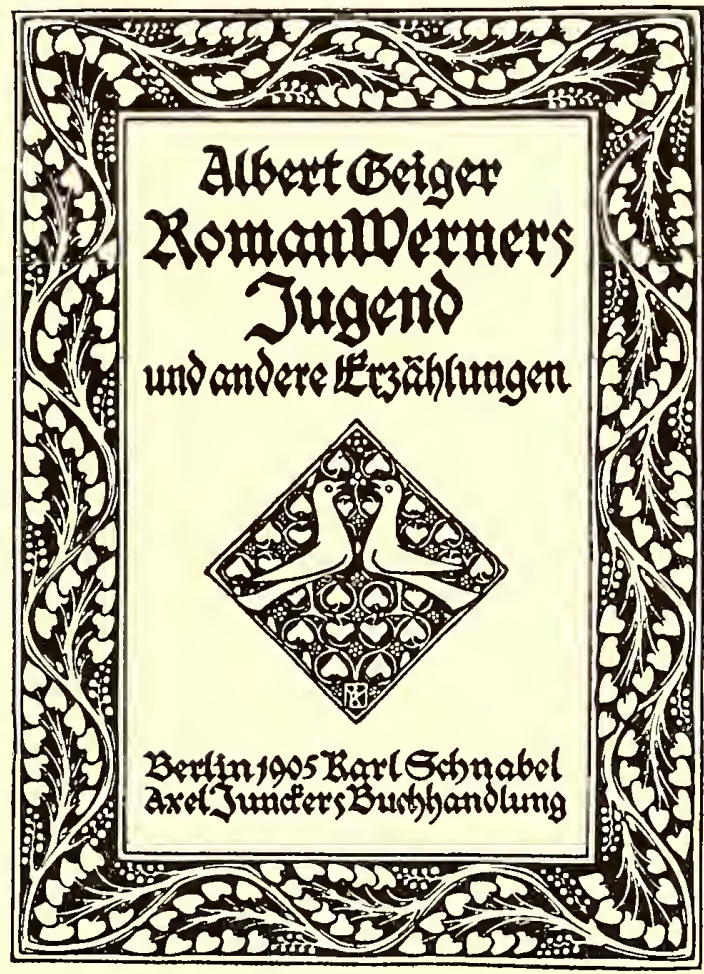

EXAMPLE 32

An example of uniform tone and contrast of black and white. Page by F. W. Kleukens, Darmstad

and functions of the day and night; theater choruses and the soldiery are living masses of uniform tone and color. As uniformity is important in these things, so is uniformity important in the tone of a page of printing. A typepage exhibiting a variegated mass of black and gray tones is not unlike a squad of recruits in different styles of elothing marching irregularly; whilc on the contrary a type-page of uniform tone and arrangement may be likened to a uniformly equipped regiment of soldiers marching with rhythmic tread.

A page of display typography composed of a mixture of irregular grey and black tones is inexcusable in the sight of the art-loving reader. As combinations of inharmonious type-faces are wrong, equally so are combinations of incongruous tones. For the sake of contrast and variety in typograplyy, art principles are too often ignored, the printer confessing to ignorance or lack of ingenuity. Contrast is necessary, but it may be had without sacrificing uniformity. A gain making use of a military simile: soldiers are marched in platoons, companies, battalions and regiments that the monotony of solid formation may be broken; type is arranged in groups and paragraphs for similar reasons. While an absolutely solid page of type may present a pleasing tone, a slight break in the regularity is desirable for reading purposes. Thus art makes concession to utility, but such concession should alon white stock. It is coincident that optical necessities require for best results in reading a black-and-white combination, and black ink and white paper are more cheaply and easily produced than other colors of ink and paper.

This chapter is also an illustrated sermon on uniformity of tone or depth of color, in which is pointed out the necessity of bringing many spots of black or gray into harmonious relation. The esthetic importance of uniformity of tone is universally recognized. Choirs are robed in white and black; fashion has its uniform clothing for the hours
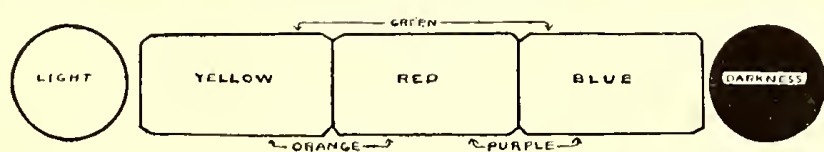

EXAMPLE 31

Contrast in color and tone ways be oranted reluctantly. There is classic authority for the arrangement of the type lines in Example 20 of the preceding chapter, but on the majority of printing jobs it is necessary to eompromise with utility and emphasize important words, as in Example 19-a of the same chapter. The secret of producing artistic typography in these practical times is to pilot the ideas of the customer into artistic channels; emphasize the words he wants enphasized, but do it in a way that will result in creditable typography. There is a right way and there is a wrong way 


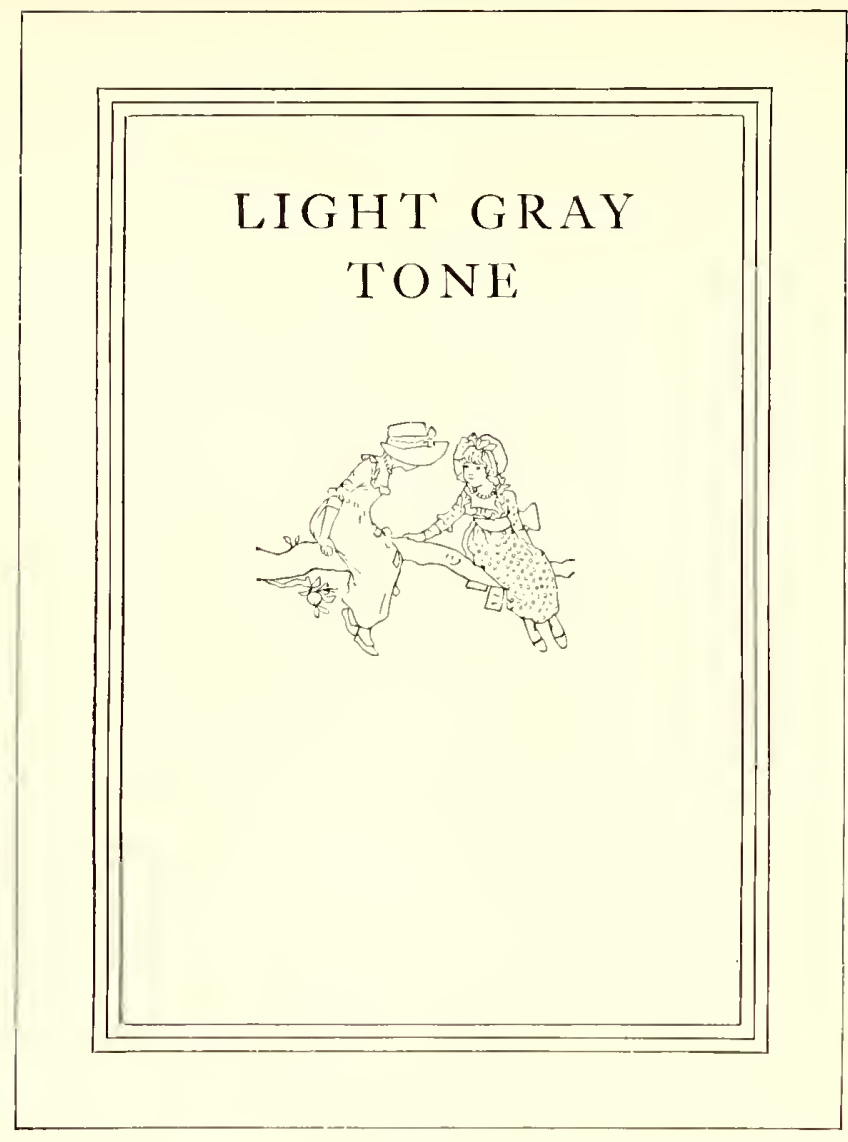

EXAMPLE 34

of arranging type, and too many typographers arrange type the wrong way and unjustly blane the customer for the result.

The effectiveness of uniformly black tone on a background of white is well illustrated on the beautiful book title shown as Example 32, in which even depth of color is consistently maintained. There is not a weak spot on the page; border, ornament and lettering are of equal tone, and the white background is reflected thru the black print in agreeable contrast. The Germans are masters in their treatment of contrast and uniform tone, and he who bewails the limitations of black and white printing should ponder over the results shown by this specimen from over the sea.

Here is a practical demonstration of the workings of the theory of uniform tone in typography. Example 33 displays four ornaments, each of a different tone or depth of color. One of the customs when constructing a booklet cover-page to be ornamented, is first to select

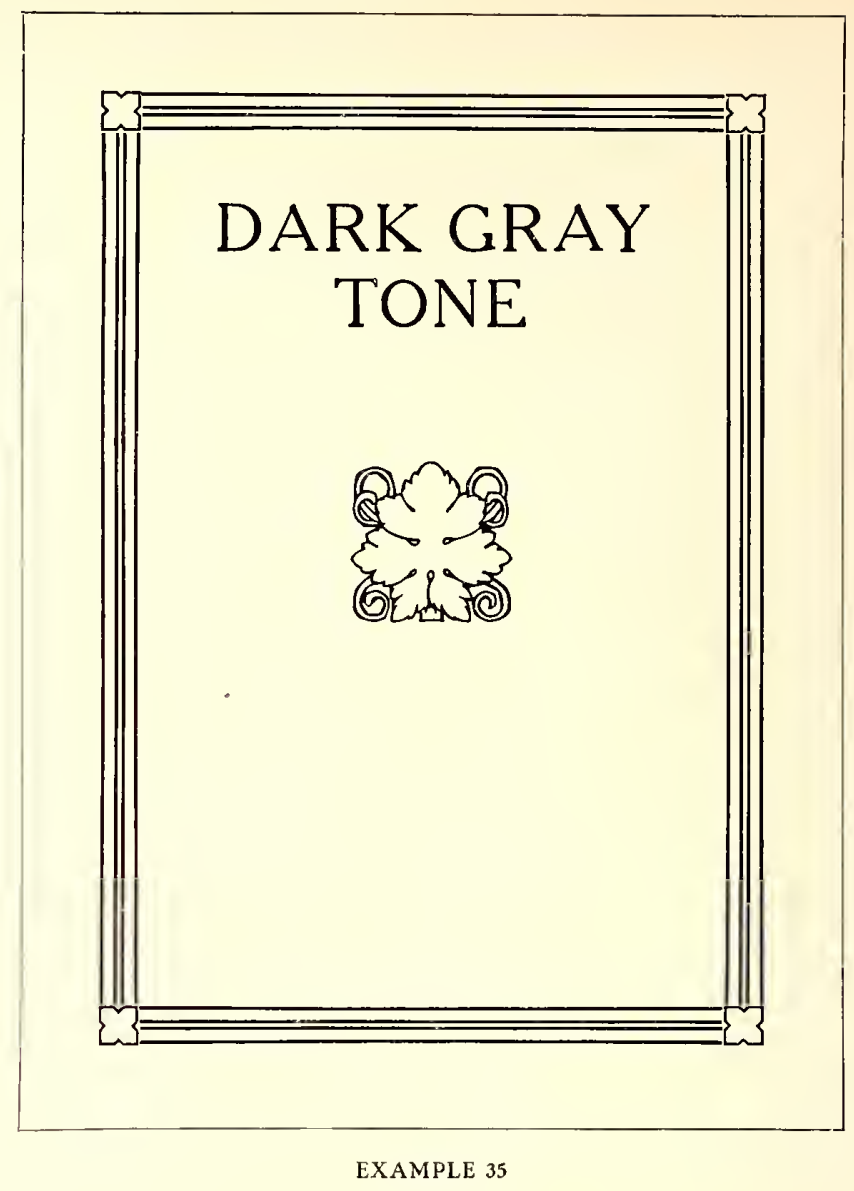

an ornament that is appropriate in design and of proper proportions. Upon this ornament the page is constructed, and it dictates the characteristies of the border and of the type-face; its tone determines the tone of the entire page. 'This is also true of a trade-mark furnished by the customer, altho such plates are frequently so inartistic that a compromise is necessary.

Assuming that a cover-page is to be designed and that ornament a has been selected for use on the page, a rule border is chosen with triple lines approximating the strength of those in the ornament. (Example 34.) The lines are very thin, and white space is a large factor in producing a tone that is light and dainty, in keeping with the subject of the illustration. A perfect result would be obtained with a type-face of very thin strokes, yet Caston capitals, slightly separated to let in white space, give good results.

The ornament shown as $\mathrm{B}$ has been formed of lines darker than those used in the first ornament, and a mass of 'white forms a spot of contrast. Rules of the proper

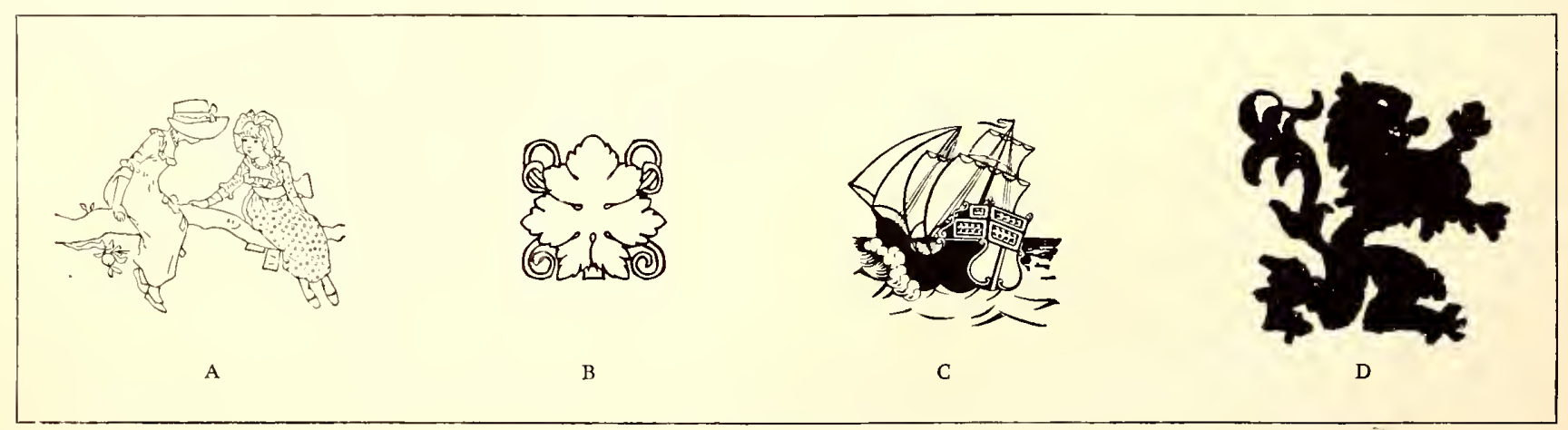

EXAMPLE 33

Four ornaments, each of a different depth of tone, used in the construction of the four pages shown as examples $34,35,36$ and 37 


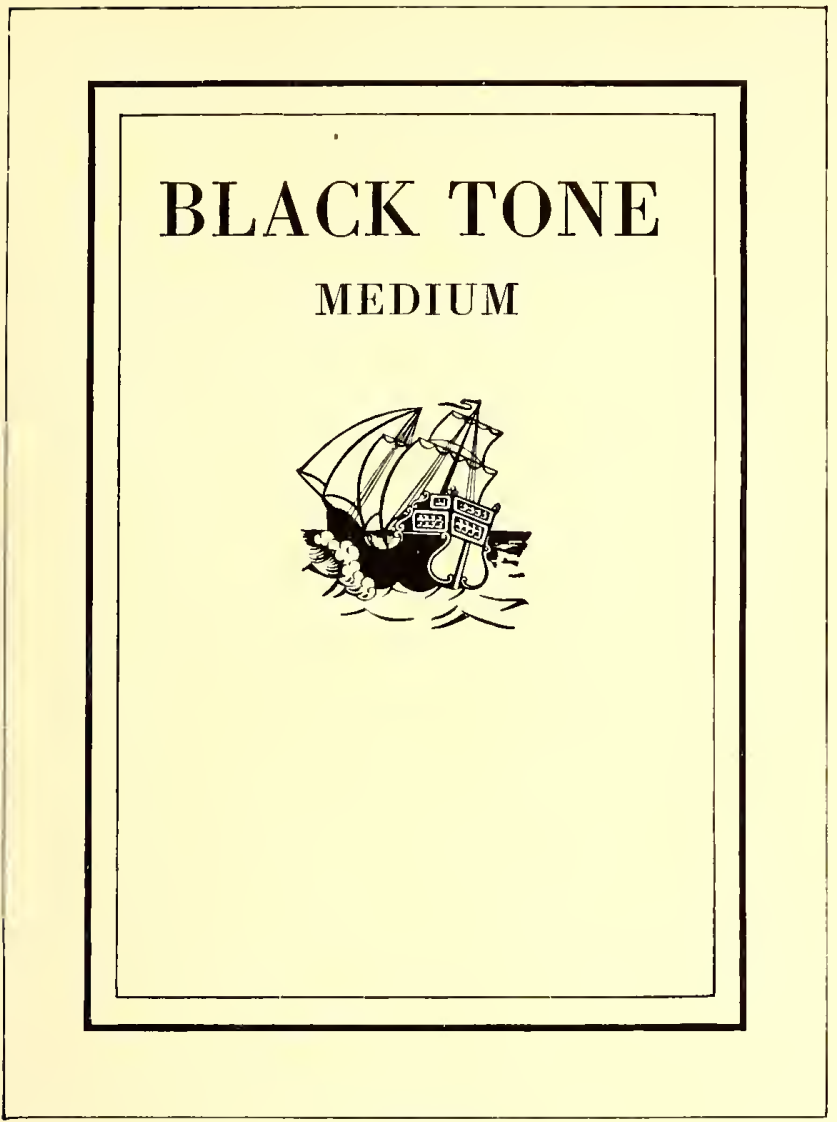

EXAMPLE 36

tone are selected and a border unit adopted that reflects the spot of white in the ornament. (Example 35.) Cht ltenham capitals maintain the tone scheme. In this case,

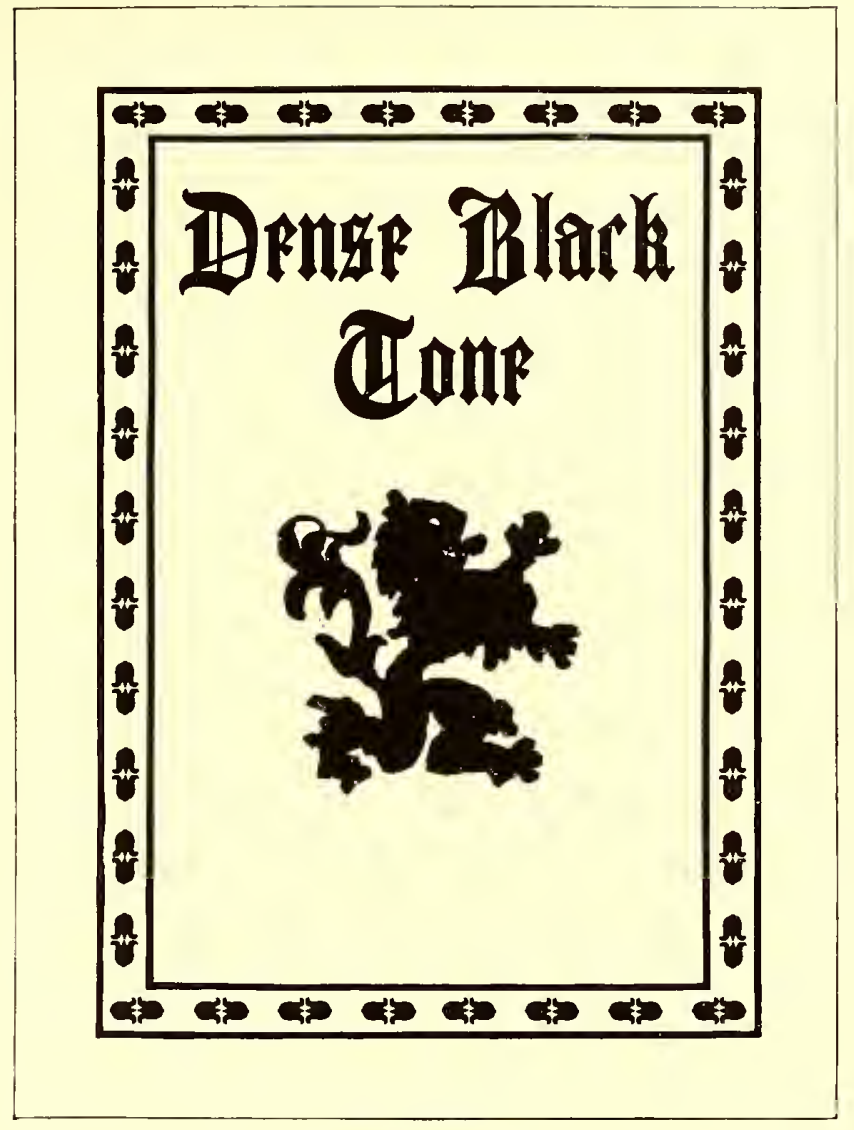

EXAMPLE 37

as in others, the type-face is a trifle stronger in tone than ornament and border. This is well. Type-lines on a cover are usually of more importance than the decoration. life is one of the most difficult and at the same time fascinating themes that engage the human intellect. Says John Fiske, The materialistic assumption that there is no such state of things and that the life of the soul accordingly ends with the life of the body, is perhaps the most colossal instance of baseless assumption that is known to the history of philosophy, for we cannot scientifically demonstrate the immortality of the soul, but the soul accepts its own immortality, which is to say it is relf-respecting and recognizes its fitness to live, hence its right to live. Immortality is more than continuous existence, an everlasting continuation of our preser life. Immortality is endless existence plus a great moral purpose, which contains a true and rational theodicy. From the initial dawning of life, we see all things working together toward one mighty goal, the evolution of the most spiritualqualities which characterize human effort.

'Tennyson's love refused to acknowledge the end of love. It reasons out of the depths of our own consciousness, and this has always been the strongest defense of the immortality of the soul. It indicates a supreme faith in the reasonableness of God's way of doing things, and it is the acceptance of this reasonableness that makes life is one of the most difficult and at the same time fascinating themes that engage the human mind. Says John Fiske, "The materialistic assumption that there is no such state of things and that the life of the soul accordingly ends with the life of the body, is perhaps the most colossal instance of baseless assumption that is known to the history of philosophy." We cannot scientifically demonstrate the immortality of the soul, but the soul accepts its own immortality, which is to say is self-respecting and recognizes its fitness to live, hence its right to live. Immortality is more than continuous existence, an everlasting continuation of our present life. Immortality is endless existence plus a great moral purpose, which contains a true and rational theodicy. "From the first dawning of life, we see all things working together toward one mighty goal, the evolution of the most spiritual qualities which characterize human 


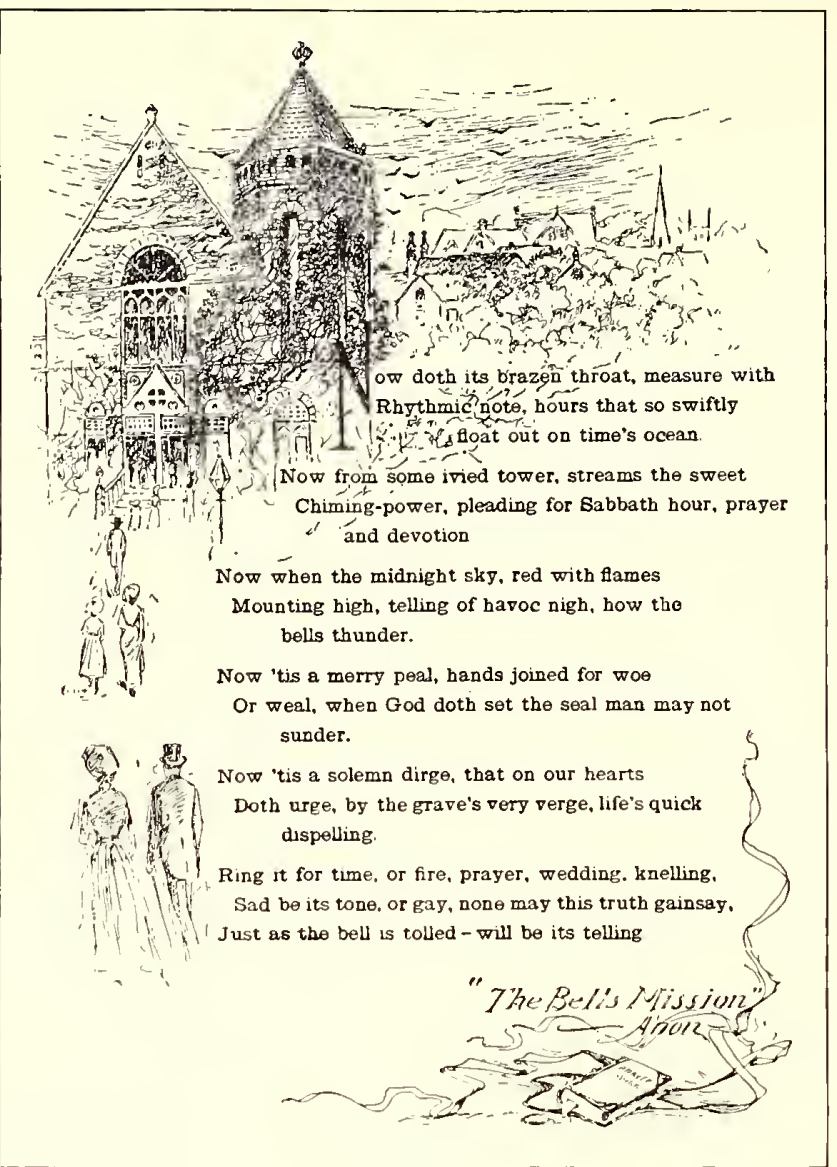

EXAMPLE 40

A page by J.H. Kehler, in which illustra-

tion and text are blended in uniform tone

Ornament $\mathbf{c}$ differs from ornament $\mathrm{A}$ in that it is composed of light lines contrasted with solid blacks. A border is made of a light line and a dark one, and the Bodoni type-face, containing light and heavy strokes in contrast with a white background, assists in producing a decidedly pleasing medium black tone (Example 36 ).

This combination of ornament, type and rule demonstrates there is considerable tone beauty in a well-selected contrast of light and dark lines when set off by liberal white space between lines and in the background.

'The dense black tone of ornament $\mathrm{D}$ is duplicated in the dark-line border filled with black decorative units (Example 37). The black-printing Chaucer Text reflects not only the tone but the decorative characteristics of ornament and border. The tone of this example apprcximates that of the Gernam page (Example 32).

These four examples afford an interesting study in uniform tone.

As the tone or depth of color increases from the light gray of Example 34 to the dense black of Example 37, it will be observed that the contrast between the print and the paper background also increases. This leads to the subject of contrast. What amount of contrast is needed on the ideal job of printing? There is conflict between art and utility on this question, but there need be none. Art demands that the print be a part of the paper upon which it is impressed, much as the plant is a part of the eartl in which it soots are buried, and utility demands that the print shall be strong and clear that reading may be made easy. The artist-printer lessens the contrast between print and paper by printing with gray ink on gray stock, brown ink on light brown stock, and so forth. The utility printer gets the maximum of contrast by printing with black ink on white stock. As print- ing is both art and business some compromise must be made, and it is this: On two-color printing have all reading matter in the stronger color and subdue the color of the decoration so that the contrast between the paper and the print of the reading portion of the page is softened by this intermediate tone. Black print on white paper is made artistic by impressing the print firmly on antique paper. This roots the print to the paper, and the result is more idealistic than that presented by the print daintily set upon the surface of glossy, enameled papers.

Lack of artistic feeling among typographers and customers is responsible for unpleasant contrasts in tone. A dense black illustration or initial will be set in a page of liglit gray reading matter, or type of black tone will be used on a page with an illustration of light lines. Great contrast in any detail of typography is not art but eccentricity; this statement may be made plain by a comparison. One winter's day when the conventional folk of New York were wearing clothing of a somber hue, they were startled by the appearance among them of Mark Twain in a suit of white. Six months later the humorist's garb would have excited no comment, but the black clothed mass of humanity around him emphasized the whiteness of his attire, and the conspicuonsness thus produced separated him from his surroundings and made him an object of curiosity. Such things are done by great men to show their disregard for custom and by others because they are foolish or are advertising something; but it is common-sense right from Cervantes to do when in Rome as the Romans do (meaning that printed work which both attracts and repels by its gaudy, unconventional appearance is not nearly so good or desirable as the more conventional printed work which

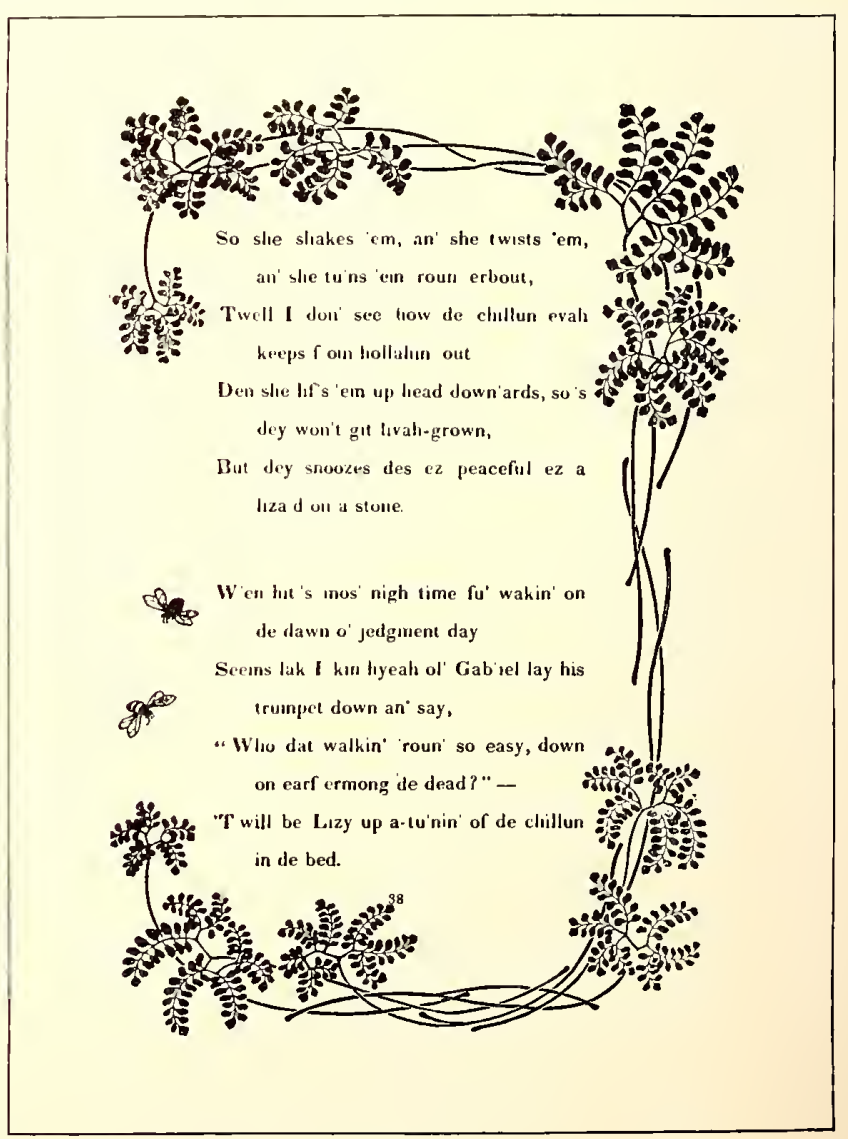

EXAMPLE 41

The spotted black tone of the border is reflected in the treatment of the text. The tone is made uniform by printing the border in a light color. Page by University Press, Cambridge 


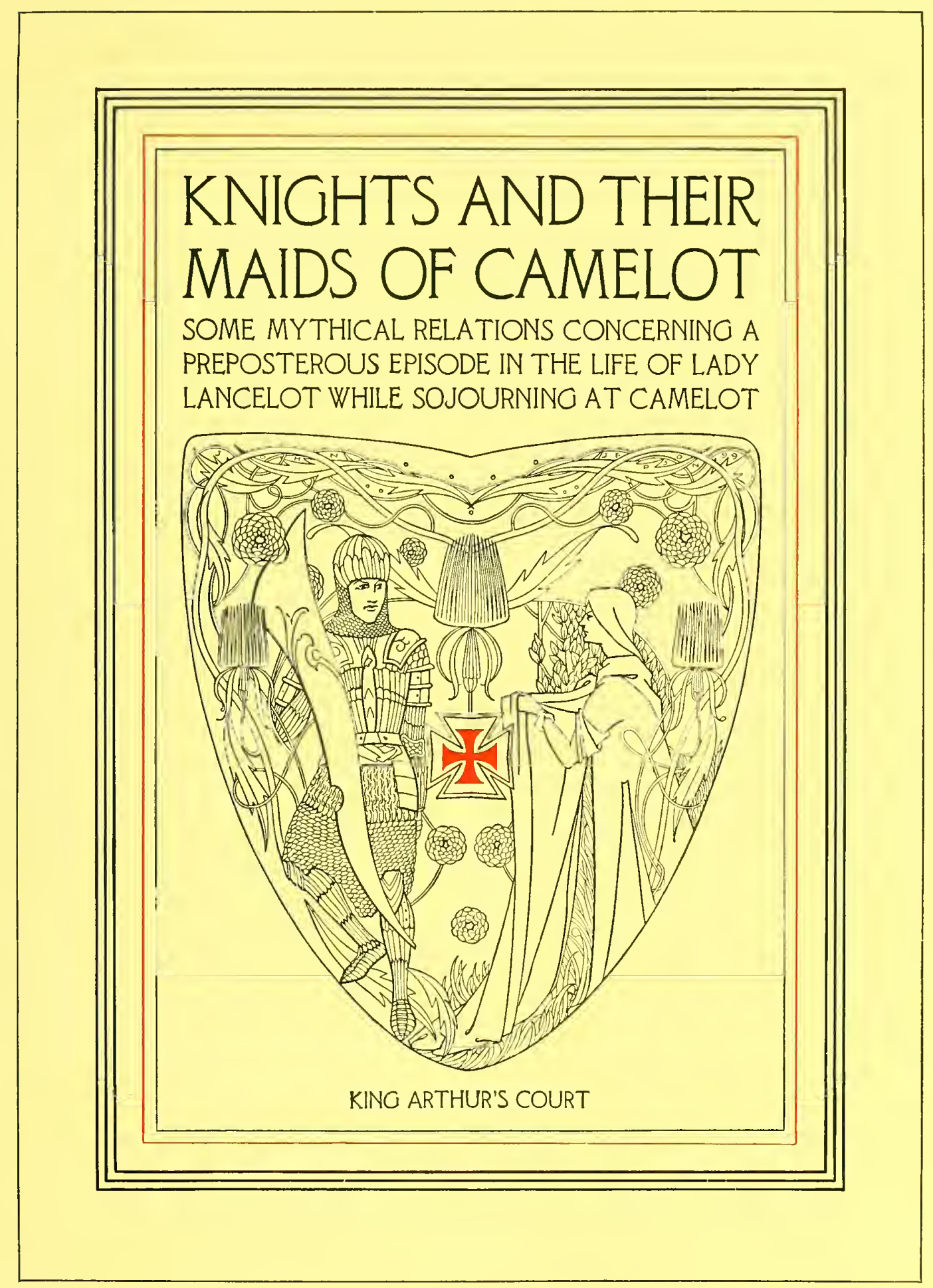

EXAMPLE 44

A study in uniformity of tone as found in combinations of type and decoration 



\section{CORBETT \& CROWLEY}

\section{PRINTERS AND BOOKBINDERS}

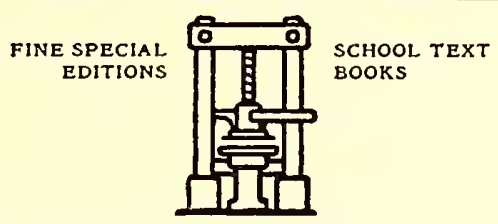

NOS. 24 AND 26 LOWELL AVENUE H Y D E P A R K, N E W Y O R K

EXAMPLE 42

The tone of the illustration and type-face is here blended. Card by School of Printing, Boston, Mass.

tastefully and quietly presents its message in subdued tones). One man will become widely known because he has dived from a big bridge or gone over Niagara Falls; another because he has painted a great picture or modeled a great statue. The one thrills, the other impresses. It may be easier to produce typography which attracts attention by contrast, but such results do not bring the lasting satisfaction that comes from typography thoughtfully and artistically designed.

Several other points are suggested by Examples 34 to 37. A page for a cover should be of darker tone than a page to be used as a title inside the book; this where the body-type of the inside pages is of the customary gray tone. A cover placed upon a book to protect it suggests strength, and the typography of the cover should conform to this suggestion. The reason for the uniform tone presented by each of the four examples above mentioned is another important point. Were the border darker than the ornament and type lines, the ornament darker than the border and type lines, or the type lines darker than the ornament and border, there would not be uniformity of tone, and a consequent loss in the effectiveness that comes from tone harmony.

The tone of a massed page is of vital importance in the typography of a book, and a happy medium is somewhere between the underspaced black type-page of Morris and the overspaced hair-line type-page against which the Morris page was a protest. Examples 38 and 39 show the manner in which the tone of a page may be controlled by spacing. In Example 38 the page is moderately spaced between words and lines and in Example 39 the page is liberally spaced, presenting two extremes and vividly picturing the manner in which spacing influences the page tone.

The tone of the pen-and-ink outline illustration in Example 40 is admirably duplicated in the typographical treatment accorded the page. The result would not have been so satisfactory if there had been no quad lines to break the solidity of the page.

The spotted black tone of the decorative border in Example 41 is reflected in the typography of the page, a result obtained by using a bold-faced body-type and separating the words with a liberal amount of space. However, the tone would not be equal printed in one color, but by printing the border in a lighter color the tones are equalized. Here is a suggestion for obtaining even tones. Where one portion of the page is bolder than the other, print it in a lighter shade of ink, or if any part of a type-page must be printed in a lighter color, set that part in a type-face of darker tone (Example 47).
Job printers should be interested in Example 42, as it is a good presentation of the theory of uniform tone. The effect of the open-line illustration is duplicated in the spaced Jenson capitals and cross lines. The result would have been even better had the small groups on both sides of the illustration been stightly letterspaced and the line at the bottom spaced less.

Example 43, on the insert, is a classic interpretation of uniform tone. The architectural design is formed of lines about the same strength as the strokes of the typeface and the massed capital letters admit sufficient light to give them a tone near to that of the open-spaced border.

Example 44 (insert) is a pleasing blend of tone and characteristics. The delicate light-gray tone of the Camelot type-face is closely matched in the decoration and border, and altogether this is an almost perfect exemplification of the subject of this chapter. It is seldom that an artist so car efully considers the charact erist ics of a ty peface and reproduces these characteristics in so admirable a manner as was done in this instance.

Initials and headpieces should approach closely the tone of the type-page of which they are parts. Example 45 shows such a combination, with the tone of the decoration just a trifle darker than that of the text portion. An initial has otlier duties to perform than merely to look pretty; it must direct the eye to the beginning of the reading matter. In the manuscript books of the Middle Ages, written without paragraphs, the starting point of a new thought was denoted by an initial more or less elaborate. The utilitarian purpose thus served by the initial

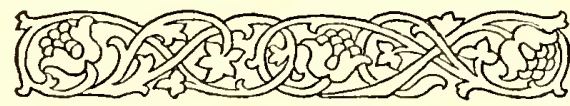

NOTE

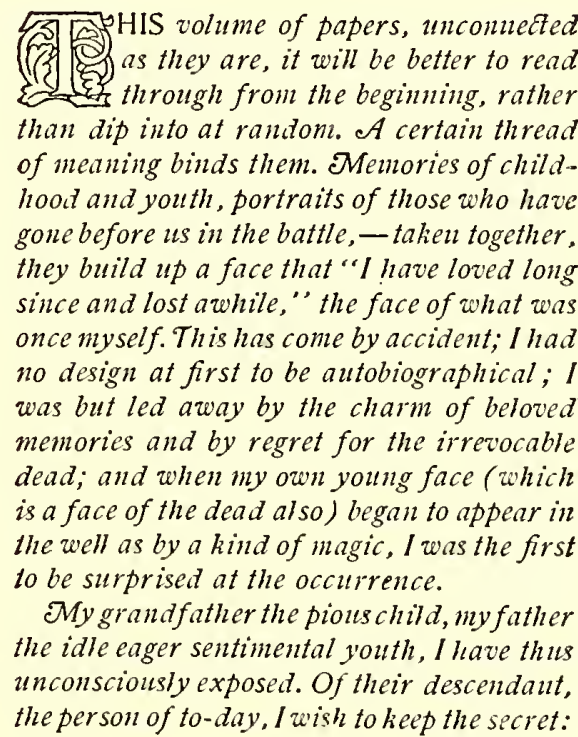

In which the tone of the initial and headpiece is lightened to near that of the text portion. Page by Heintzemann Press, Boston 


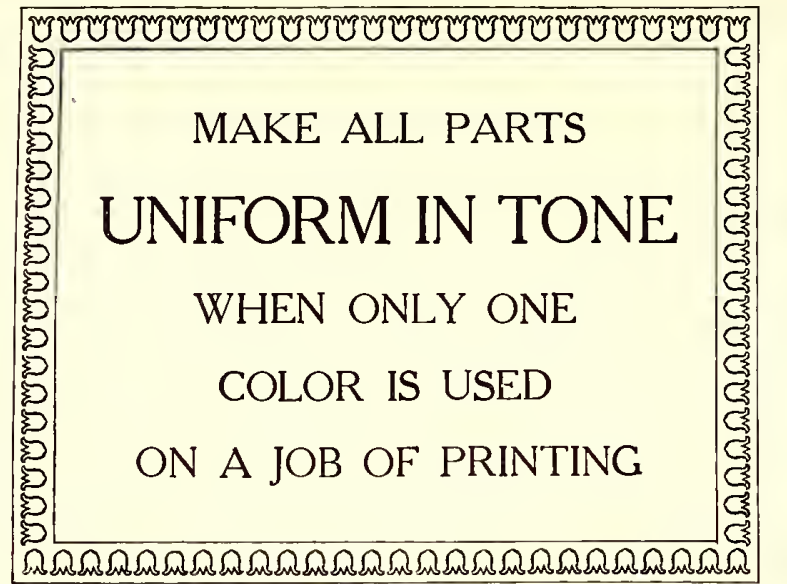

EXAMPLE 46

is reason for making it a trifle darker than the remainder of the page. However, if there is great contrast in tone, the page will be difticult to read because of the initial claining too much attention. The effect would be much like attempting to listen to one speaker while another is calling and beckoning.

Every rule has its exception and I wish to record one in the matter of uniform tone. On a page composed of display lines and a large amount of reading matter it is an offense against legibility to set the reading matter in a type-face of black tone to correspond with the display lines, considerable contrast being necessary in such cases to make reading easy. (Example 48.) Notwithstanding this exception in the case of reading matter, uniform tone should be retained between display lines and border.

\section{DISPLAY LINES}

IN TONE SHOULD MATCH THE TONE OF THE BORDER

Have no use for excuses for not doing a thing - there is no excuse for excuses. They weaken character; they make a person after a while a walking apology instead of a man who has a right to hold up his head and walk fearlessly and have his word count in council. The world has no use for a weakling, with a ready tongue for excuses, and unwilling hands for work. The best word of advice I could give to a young man starting out in any business is, avoid the necessity for the first excuse.

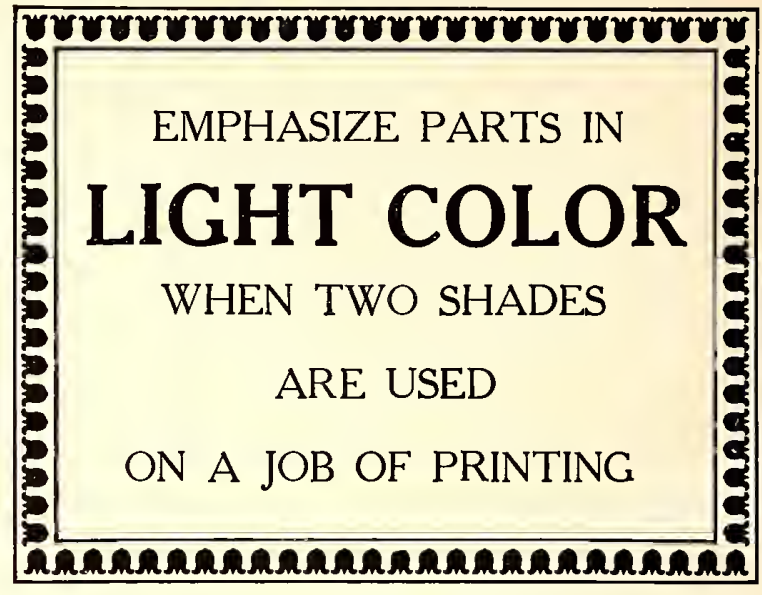

EXAMPLE $4 ?$

If a catalog is illustrated (and the majority are) it is important to have the illustrations prominent on the page, sacrificing tone to utility if necessary. Sometimes the illustrations are printed in dense black and the remainder of the page in gray or brown. While this causes the illustrations to stand out in relief-an important point when machinery is depicted-it should not be forgotten that the type matter must be read.

In advertising composition it is seldom possible to have an even tone on the entire page. The New York Herald advertising pages are unique in this respect. Outline type-faces are used, and all illustrations are redrawn in outline before they are published. This serves to give a uniformly gray tone to the pages, but the advertisers are not enthusiastic over the effects. While other newspapers may not be able to maintain uniform page tone, it is possible at least to have each advertisement present a tone uniform in its displayed parts and border, and the good typographer will secure such effects. The gray shaded type-faces now available should enable printers and publishers to obtain tone uniformity where gray effects are desired and large type sizes used.

Irregular letter-spacing has been the cause of many pages of unsatisfactory tone. In a displayed page where one line is spaced between letters, all lines should be similarly spaced. Example 49 presents a decidedly unconventional letterhead by reason of the letter-spacing, and it illustrates the point that all lines should be spaced equally. It may be well to warn job compositors inclined to imitate the style of this heading that there are few customers who would concede any merit to such an arrangement, and it should be used sparingly. Unconventional treatment, even tho good along the lines of the style chosen, is not always appreciated.

T H E

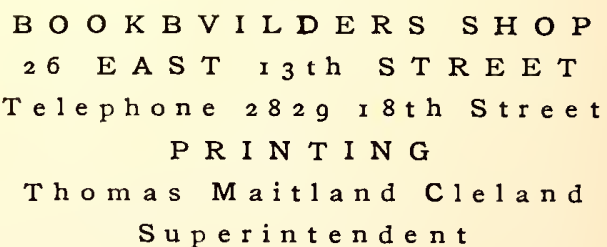

EXAMPLE 49

Equal spacing is necessary to obtain uniform tone 


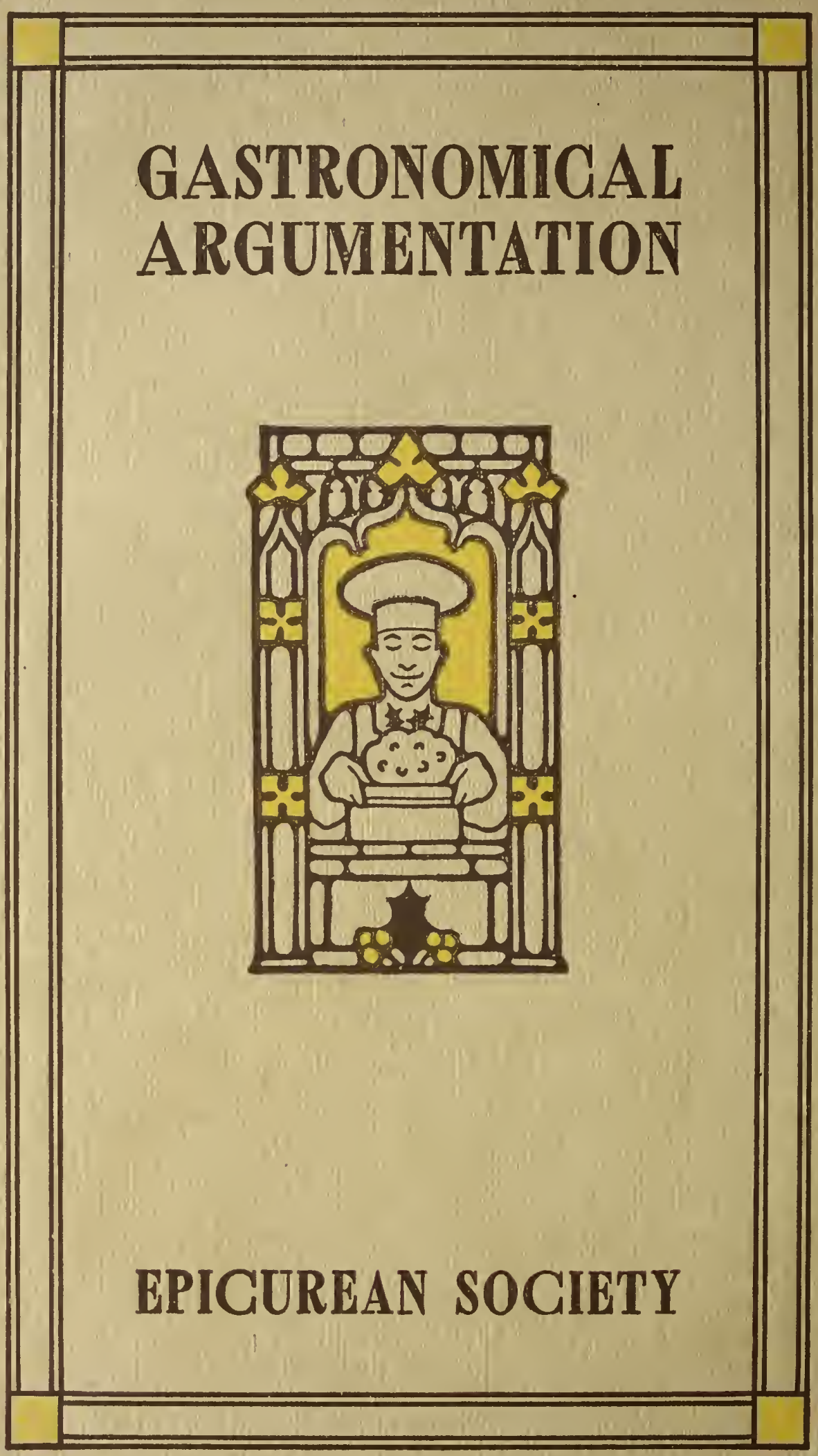

EXAMPLE 58

In which the ornament, the border and the type-face are in proportion 


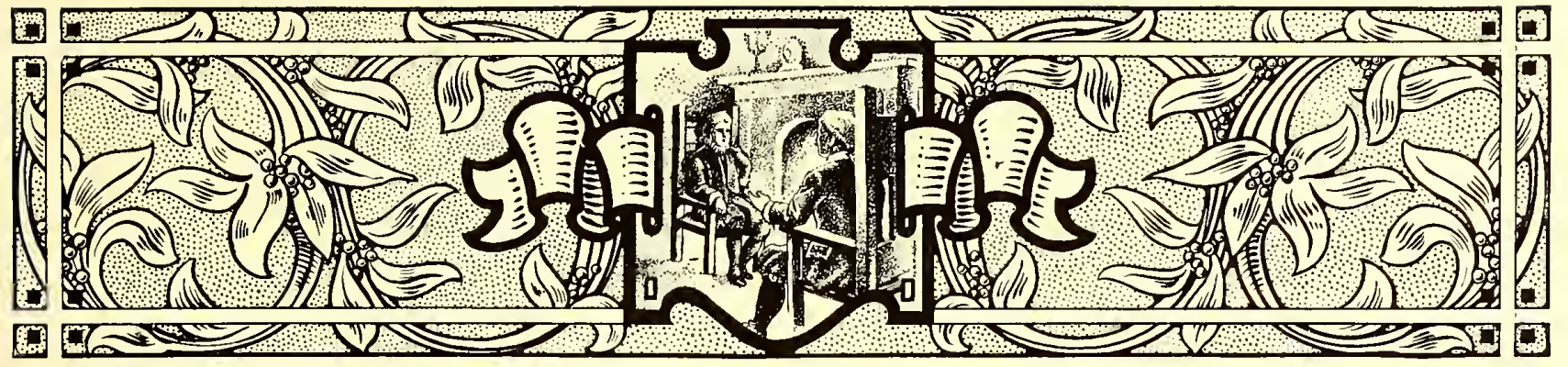

\section{PROPORTION, BALANCE AND SPACING}

SYMMETRY is necessary to beanty. This law of estheties is as applicable to typography as to sculpture and architecture. Proportion and balance-the things that make for symmetry in typography - are obtained only by giving the work more attention than seems necessary to the average producer and buyer of printing.

Why should the printer worry about esthetics - about symmetry? What has art to do with printing, anyway? Questions such as these find too frequent voice in the printing trade, coming from the employee wlose interest and ambitions end when he "gets the scale," and the employer who is satisfied merely to deliver so many pounds of paper and ounces of ink for so much money. Pity the man whose work is drudgery and who denies that art and beauty are meant for him. He has his antithesis in the man who, appreciating the higher blessings, neglects to give value to the more common and practical things.

There have always been two opposing classes-in religion, polities, art, music, business. On all questions one portion of humanity

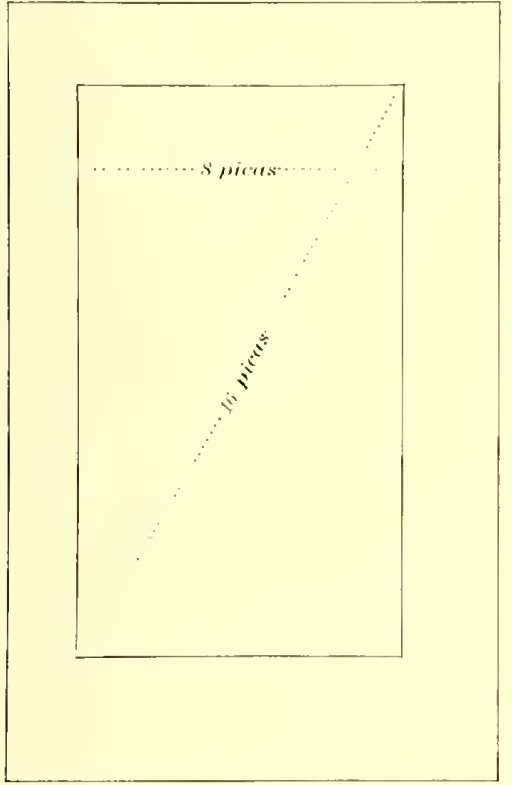

EXAMPLE 50

One method of determining the page length. The page should measure diagonally twice its width is "for" and the other "against," mostly because of the influence of environment upon tastes and interests. Mozart's and Beethoven's music charms and enthuses and also lulls to sleep. One class should try to understand the other. Each has good reasons for its preferences, but none at all for its prejudices. The painter Rubens, gathering inspiration in the courts of rovalty, portrayed luxury and magnificence. Millet, painting in a barn, pictured poverty, sorrow and dulled minds. What pleased one found little sympathy in the other. During the Middle Ages learned men talked, wrote and thought in Latin, and when it was proposed to translate the Scriptures into the language of the masses these men held up their hands in horror.

Not so many years ago the book printer looked upon the job printer as the Roman patrician looked upon the plebeian, but the job printer has absorbed dignity and typographic taste from the book printer. While the book printer's highest ideal is a volume with uncut leaves ornamenting the book shelves of the collector, the job printer's mission is to be all things to all men. He prints the refined announcements of art schools one day and another day finds him placing wood type to tell the story of a rural sale of articles "too numerous to mention."

There should be more sympathy between the book printer and the job printer, and also between the printer who regards his calling as a business and

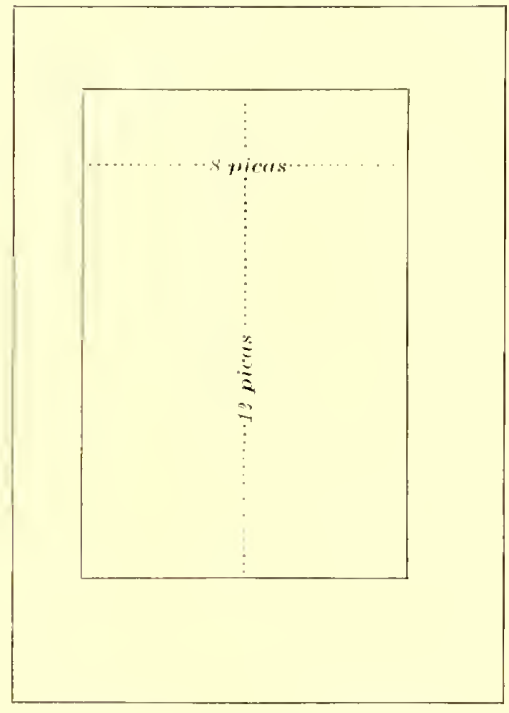

EXAMPLE 51

Another method of determining the page length. The length of the page should measure fifty per cent more than its width. These examples also present proportionate margins, the foot margin in each instance being the largest the printer who remirds it as an art. The employer and employee who consider printing only a means to an end and that end money, are as near right and as near wrong as they who produce art printing for art's sake and forget the pay envelop and the customer's check. The first starve their souls, the last their bodies.

The printer who does things artistically in an economical manner "strikes twelve", (in the slang of Elbert Hubbard). Printing need not be shorn of beauty to be profitable to botli printer and customer, tho beauty too conspicuous turns attention from the real purpose of the printed jobwhich, in the case of a booklet, is the message the words convey. An equestrian statue of Napoleon should feature the great conqueror, not the horse, but would be impossible with the horse left out.

Art is essential to printing; so are Uncle Sam's specimens of steel engraving. The nore art the printer absorbs the larger should grow his collection of these engravings. Study of art arouses ambition; ambition brings better and harder work. It reveals in the typographer the difference between mere lead-lifting and the artistic selection and arrangement of types. The boy who sweeps the floor and does his best is nearer art-heaven than he who sets type and cares not how he does it.

'The printer who determines to learn about art - who 


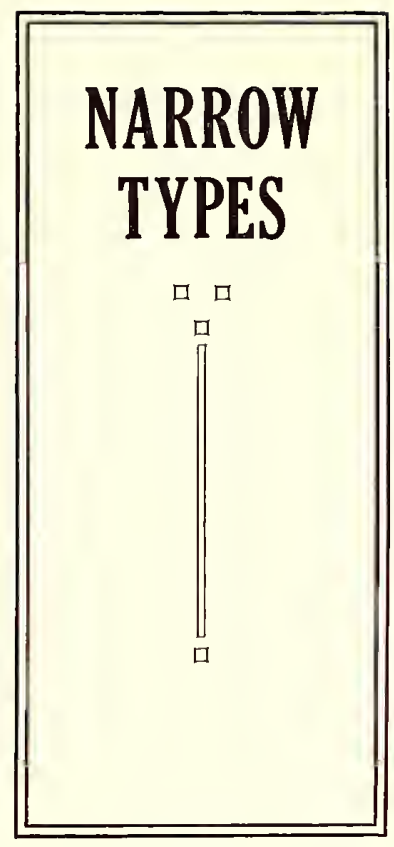

EXAMPLE 53

In which vertical

lines predominate makes continued effort to find the reason why one man's work is good and another's is not, will be surprised and gratified at the new world that unfolds itself as he studies. He will find that altho having eyes, he has really seen only as he has appreciated. There is no easy road to the appreciation of the beautiful. Art does not consist merely of a set of rules to be observed; there are few beacon lights placed by those who have trod the road. Beyond a certain point the novice must depend upon intuition or "feeling." Great painters have been asked their method of producing masterpieces, and have bcen unable to explain.

In introducing the subject of "Proportion" it is well first to dispose of book pages. In olden times the sizes of books were known by the number of folds to a sheet of paper about $18 \times 24$ inches. A book made from such sheets, folded once into two leaves, was known as a folio volume and measured about $12 \times 18$ inches. Folded twice into four leaves, a quarto, measuring $9 \times 12$ inches. Folded three times into eight leaves, an octavo, measuring $6 \times 9$ inches. Paper is now made in a variety of sizes, which allow of individual preferences being satisfied. For the sizes of catalogs $9 \times 12$ and $6 \times 9$ are becoming standard. The sizes do not depart far from the rule of proportion which holds that the width of the page should be two-thirds its length.

Examples 50 and 51 illustrate two widely-used methods of determining page lengths. By the first method (lixample 50) the page should measure diagonally twice its widtl. In this instance the width being cight picas, the diagonal measurement is sixteen picas. By the second method the length of the page should measure fifty per cent more than its width. Here the width being eight picas, the length is twelve picas. These measurements may or may not include the running titles or folios.

If only small margins are possible, the page (exclusive of running title) should be about centered, with a slight inclination toward the head and back. But when margins are reasonably ample the page should set liberally toward the head and back; the margins of the head and back (exclusive of the running title) should be about the same, the outer side margin should be fifty per cent more than the back margin, and the foot margin one hundred per cent more than the back inargin. Various explanations of this rule have been put forward, a few of which are: The old book-owner making marginal notations as he read, needed wide margins for the purpose. Early manuscript books were bound on wood, and this wood was extended at the foot and used to hold the book when reading. Two pages onepage, much as double columns are now treated. As book illuminators required room for their handiwork the margins may have thusoriginated. The principal reason why we should observe such margins is that the arrangement has the sanction of long usage and the approval of the best bookmakers since books were written.

The job printer, it is reasonable to suppose, is more interested in proportion $\varepsilon \mathrm{s}$ it refers to display typography. He asks: What relation has type, in the slape of its face, to the page of which it is a part? And the answer is: A type-face should conform in the proportion of its letters to the proportion of the page. Let us thoroly understand this. In Example $5 \mathcal{2}$ there are slown three widths of type-condensed, medium and extended. The type of medium width is more used than the condensed

\section{H H H}

EXAMPLE 52

Three widths of type-faces or extended kind, and most pages liave a proportion such as Example 55. From viewpoints of both economy and art, the type-face of medium width should be given preference when selecting type equipment. Condensed types are properly proportioned for use as headings in the narrow columns of newspapers and for narrow folders and booklets.

Many of the laws that are necessary to good typography also govern the other arts. As an instance, in architecture it is requisite that a tall and narrow building contain a preponderance of vertical lines, a feature most noticeable in church buildings of Gothic style (Example 54). Because the extent of vertical lines is greater than that of horizontal ones in a condensed typeface, such a face is proper for a long and narrow page (Example 53). The proportion of page shown by Example 55 is about that met with most frequently inprint. ing production. Here the vertical lines are in a slight majority, but it is interesting to observe that in Example 56 where the page is more wide than long, horizontal lines are more numerous than vertical ones.

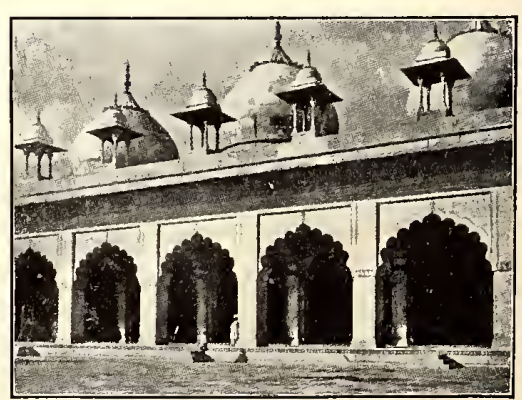

EXAMPLE 57

Compare with Example 56 


\section{EXTENDED TYPES}

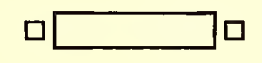

EXAMPLE 56

In which horizontal lines predominate

It is not always possible to follow out in every detail the requirements of proportion. Architects inust sacrifice much in the interests of utility and in deference to the wish es of their clients. Printers must do likewise, but as a rule they travel farther from true art principles than do architects. Consider the contrasting proportions of the structures in Examples 54 and 57. In Example 54 notice that the openings have been made to conform to the general proportions, and that vertical lines have been multiplied to emphasize narrowness and hight. As a contrast, in Example 57 observe the width of the openings; how it blends with the general proportion of this structure. Now to ascertain that typography parallels architecture compare Example 53 with 54 , and 56 with 57 .

An exiggerated idea of the relation of lines to proportion is furnished by $\mathrm{Ex}-$ amples 62 (see insert) and 63 . The vertical lines of Example 62 run with the length of the page as smoothly as a canoe floating down stream. The horizontal lines of Example 63 are irritating in their disregard of proportion. For

\section{MISFIT}

the eyc to takc in at a glance both the page lines running vertically and the rules running horizontally is as difficult as watching a three-ring circus. Examples 59 and 60 also illustrate this point.

I have prepared in Example 58 (see insert) a page in which not only are ornament, type-face and page-design in proportion, but the characteristics of the ornament are reflected in the border, and the tone is uniform.

Irregularity of form is valuable in breaking monotony, and in some forms of art may be essential, but as contained in Example $6 \mathrm{I}$ this feature is inharmonious. Before experimenting with variety or becoming agitated about monotony the typographer should perfect himself in the things that make for regularity. When he learns to set a page that is harmonious and in proportion then it may be well to introduce irregularity - in homeopathic doses.

There is much uncertainty manifested among typographers as to the proportionate strength of display lines on a page. A type line is proportionately large or small as it contrasts with its environment. Gulliver was a giant when among pigmies. The foremost citizen of a country town is considerably reduced in importance when he rubs elbows with the big men of the cities. The homely adage that "a big frog in a small puddle is a small frog in a big puddle,"' is applicable to typography. A display line surrounded by other type lines (Example 64) must be made larger or by strengthened strokes made bolder than when alone on the page (Example 65). The old City Hall in New York is claimed to be the most beautiful work of architecture in the city, but is ridiculously out of proportion with the towering office buildings surrounding it.

Examples 66, 67 and 68 are studies in the proportion of a type-face to the page of which it is a part. In Example 66 the page is largely covered with type, treatment that is necessary on poster, dodger and other printed matter that must force its presence upon the public. In Example 67 the page consists mostly of blank space, the type standing modestly

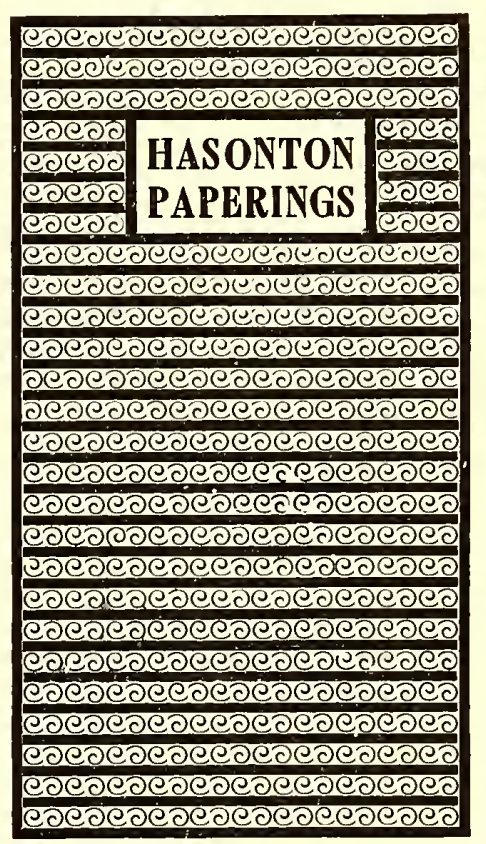

EXAMPLE 63

Horizontal lines are not suitable for a vertically narrow page (See Example 62, insert)

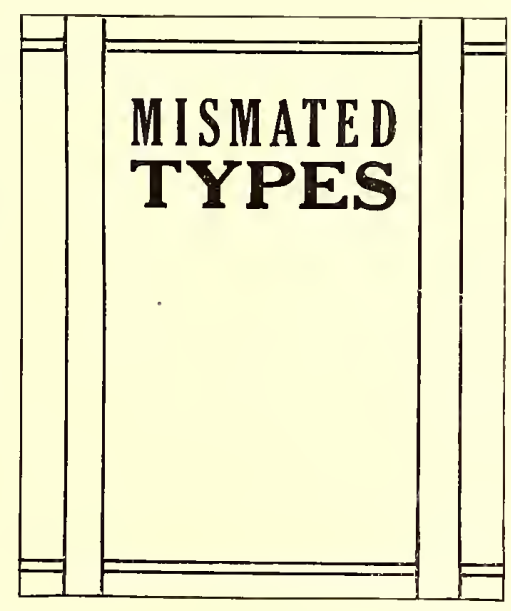

EXAMPLE 61

Type-faces and borders are mismated 
What is there to be done that the calling of Gutenberg, Aldus and Estienne may again resume its place among the fine arts?

\section{The American Printer}

finds the answer to this question in education - bringing knowledge to the apprentice, to the journeyman, to the executive, to the proprietor. It has been said that one should either play or work, but the truth is that art is work done as play, work done for the love of it, pleasure in accomplishment. Where a man's heart is, there is art. Love, effort, ambition, - all these have to do with art printing.

EXAMPLE 64

EXAMPLE 65

A display line surrounded by other type lines must be made larger than when alone on the page, to obtain proportionate emphasis

and apologetically in the midst of that space. This treatment is proper on dainty works of poetry or when the demands of extreme refinement are to be satisfied. Example 68 is the "happy medium," the compromise-a strength of display that will be satisfactory in almost every case. This method of arriving at correct treatment emphasizes the need in the typographer of a judicial as well as an artistic temperament. The wise judge knows that truth is about midway between the claims of opposing counsel.

Balance is another importint subject, as it has a big share in making typography good or bad. The builder works with plumb-line and spirit-level that his walls may be in perfect balance, tho sometimes he is tempted, as the printer is tenupted, to work away from the center of gravity. In Italy there is a building, an architectural curiosity - the leaning tower of Pisa (Example 73) in the construction of which gravity has been defied to the limit, and in Canada only recently a bridge in course of construction on this gravity-defying principle, fell in a mass into the river. In typography, safety from blunder lies in type lines horizontally centered. Typographic experts experimenting with out-of-the-center balance, both succeed and fail. Compositors imitating them generally firil. Example 76 is an out-of-the-center arrangement that is fairly successful. Balance is saved by the type-lines in the upper left corner and by the border surrounding the page. Examples 69 and 75 show out-of-center balance adapt ed to a business card and a booklet cover.

While horizontally the center is the point of perfect balance, vertically it is not. Stick a pin thru the very center of an oblong piece of cardboard and twirl the card; when movement ceases the card may not hang up$\mathrm{rig}$ h t l y.

Mark of $f$

the card in three equal sections and stick t li e pin thru the lorizontal center of tl e line separating the upper two thirds.

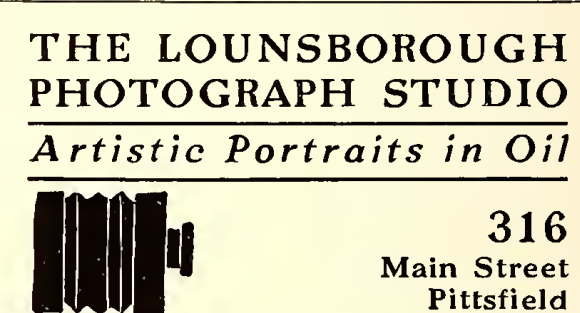

EXAMPLE 69

Out-of-center balance, adapted to a business card
After being

twirled the card will cease to move in a perfectly upright position. Fxample 71 shows a word placed in exact center, yet it appears to be low. Example 72 shows a line above center at the point of vertical balance. On a title-page, business card, and on most jobs of printing

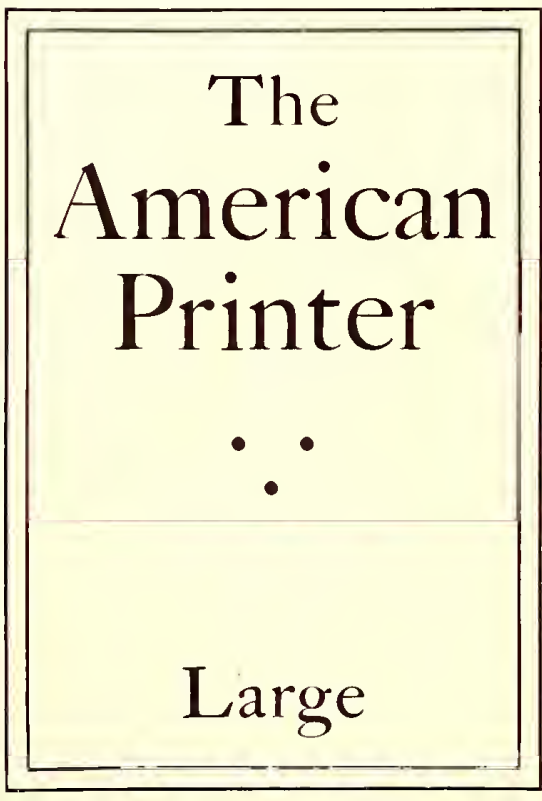

EXAMPLE 66

Type proportionately too large for the average page

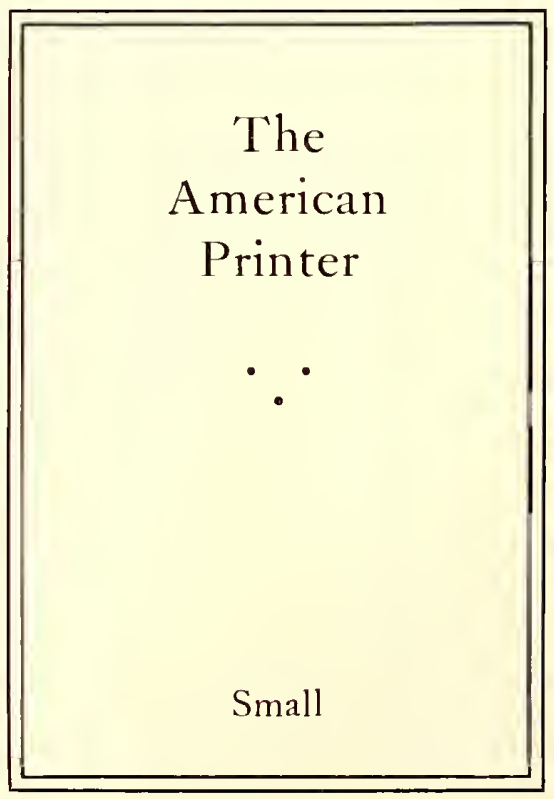

EXAMPLE 62

Type proportionately too small for the average page

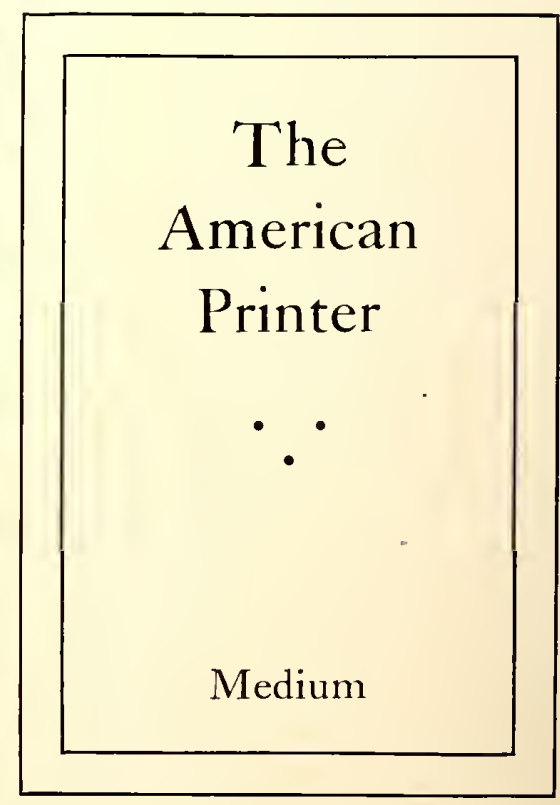

EXAMPLE 68

This proportion is about right for the average page 


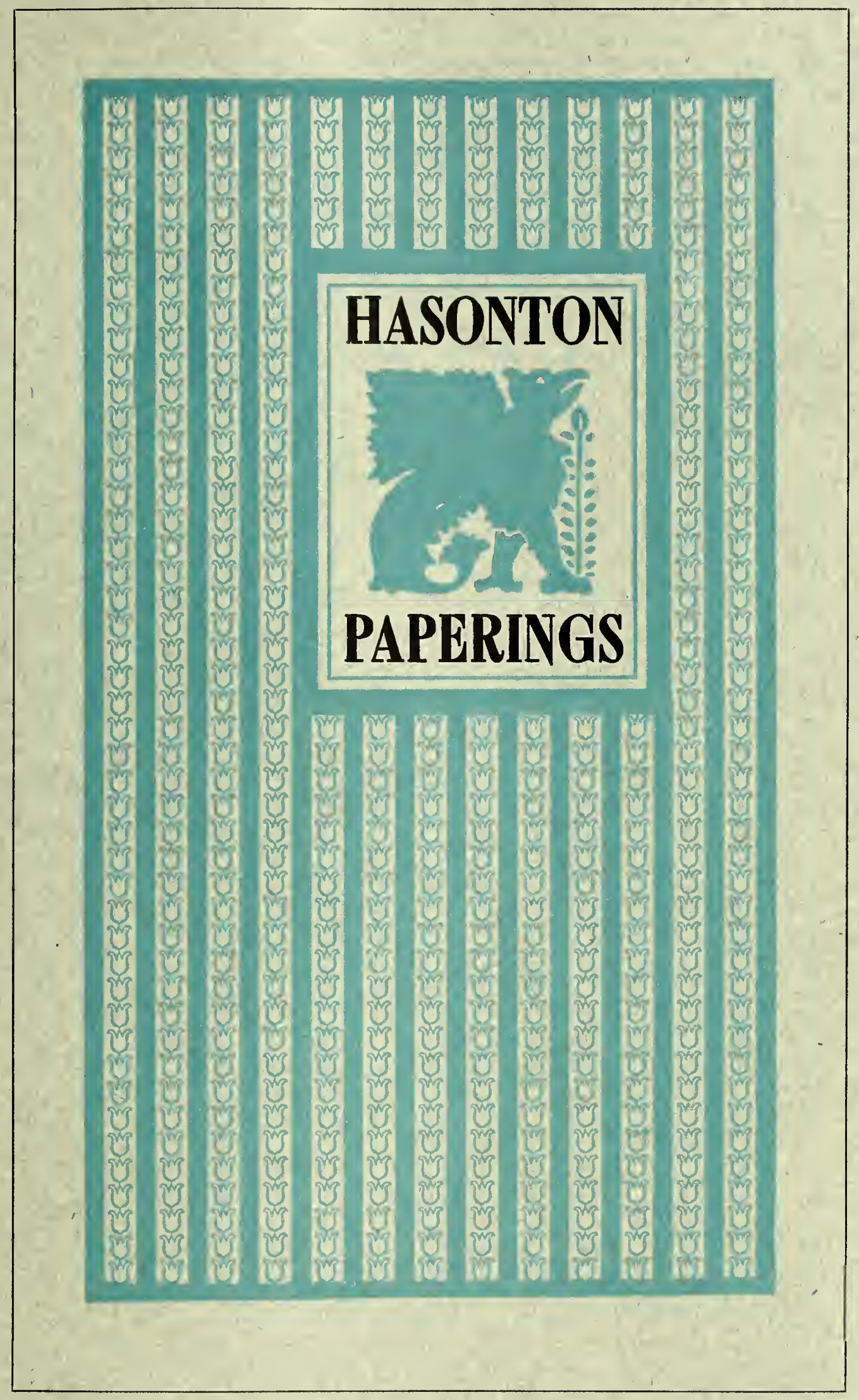

EXAMPLE 62

In which the lines of the design run in the proper direction. Arranged by Will Bradley 



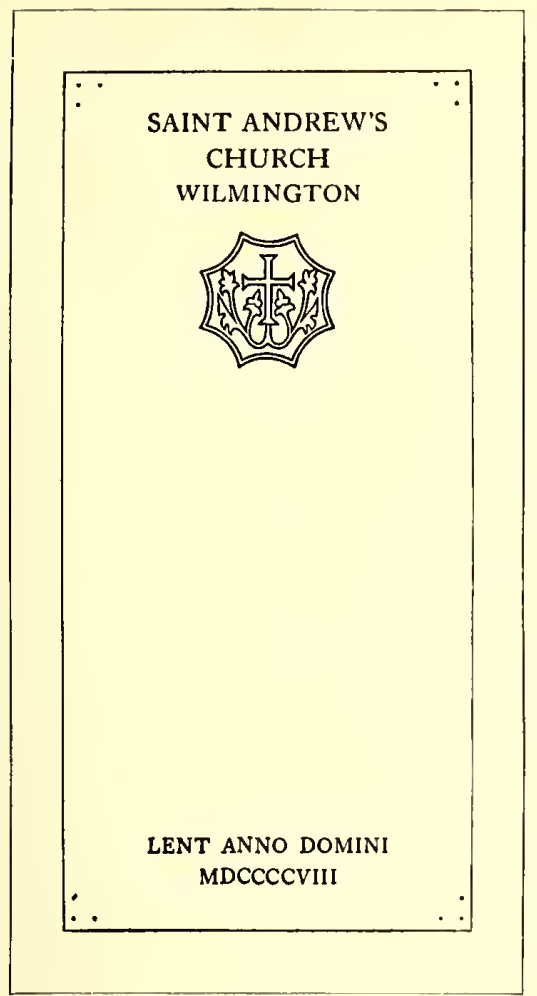

EXAMPLE 70

In which the upper type group is unusually high. Page by D. B. Updike the weight should come at this point. 'The principal line, or group, should provide strengtl necessary to give balance. Example 70 presents a page witl type group and orname nt placed unusually high. The typographer responsible was undoubtedly testing balance to the limit.

Sometines the customer gets a notion he wants a type-line placed diagonally across the page in a manner like Example 74. Such arrangements generally show lack of imagination and are crudely freakislı. There are so many orderly ways of arranging type tliat such poorly balanced specimens are deplorable.

Spacing is seemingly one of the little things-merely incidental to the mechanical practice of typography. When the apprentice compositor is told to divide his spaces evenly among all the words in a line; not to thin space one line and double-thick space another; to transpose a two-point lead, or make some other what to him may appear to be trivial alteration in spacing, he judges his instructor to be over-particular. Yet the proper apportionment of space oll a page determines the tone and the balance and aids in giving proportion and emphasis.

In type-making, when a font of type is designed, not only is each letter considered separately, but in combination with every other letter of the alphabet, that when the letters are assembled into words space may be evenly distributed. The designers of the best type-faces have given attention to this feature and have demonstrated that legibility

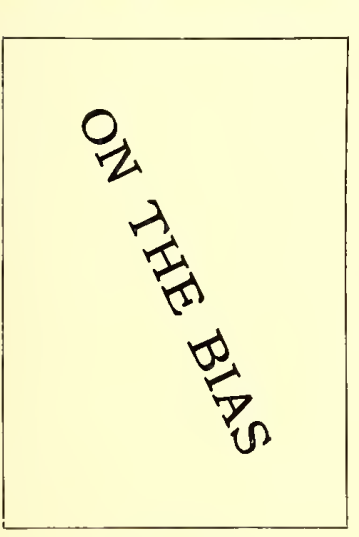

EXAMPLE 74

4 disorderly arrangement is increased with proper space distribution. Because of the e x cessive open space it contains, the capital $\mathrm{I}$. gives the most trouble of any letter used as an initial. As part of the word "Millinery" the irregularity

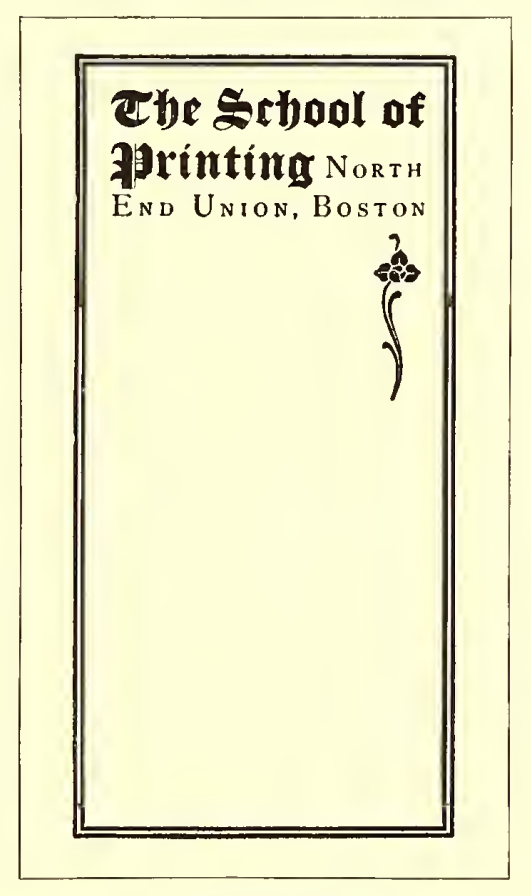

EXAMPLE 75

The ornament balances the design Page by School of Printing, Boston

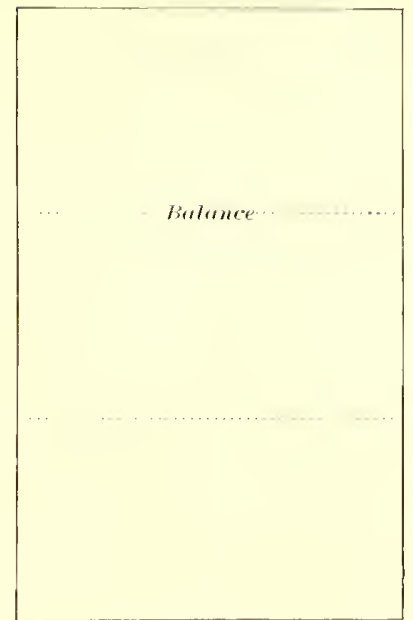

EXAMPLE 72

Showing the point of vertical balance of spacing is particularly promment ( $\mathrm{Ex}$ ample 79-a). Partly to overcome this irregularity the companion letters should be spaced as slow in 79-b. When the letters A T occur together, and the space between them should be decreased, it is necessary to file the metal in the upper right of the type $A$ and the netal in the lower left of the type T.

Witl roman type-faces, important words are usually empliasized by italies or small capitals. The Germans, using for body purposes a text letter which has no italic or snall capitals, space the letters to get emphasis (Example 80-a). Letter-spaced words thus used are perhaps as neat as italic, and the idea nnay well be arlapted to roman types ( $\mathrm{Ex}$ ample 80-b).

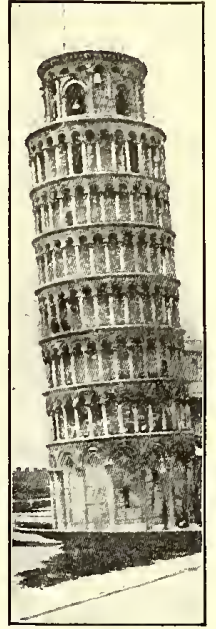

EXAMPLE 73
The relation of lines to proportion, Balance out of center

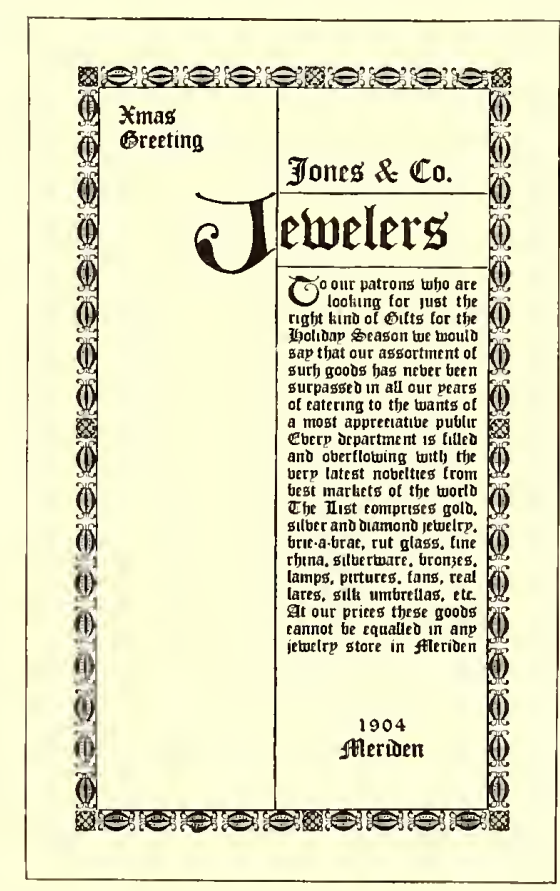

EXAMPLE 76

Out-of-center balance.

Page by Will Bradley 
And Noah was six hundred years old when the flood of waters was upon the earth. And Noah went in, and his sons, and his wife, and his sons' wives with him, into the ark, beeauseof the waters of the flood. Of elean beasts, and of beasts that are not clean, and of fowls, and of every thing that ereepeth upon the ground, there went in two and two unto Noalı into the ark, male and female, asGod had commanded Noah. And it came to pass after the seven days, that the waters of the flood were upon the earth. hu the six hundredth year of Noal's life, in the second month, on the seventeenth day of the month, on the same day were all the fountains of the greatdeepbroken up, and the windowsof

\section{EXAMPLE 77}

The effect of horizontal lines is given by narrow spacing between the words and wide spacing between the lines

ample 63 contrary to the principles of proportion. this may be overcome is illustrated in Example 78, which

\section{a MILLINERY ${ }^{b}$ MILLINERY}

\section{EXAMPLE 79}

Other letters must be spaced because of the open appearance of the letter " $L$ "

and 82 are enlightening. Example 81 shows the manner in which some years ago display lines were erroneously distributed over the entire pare, presenting in effect the fa ults of Example 7. The manner of rect if $y$ in $g$ these faults is demonstrated in Example $8 \mathcal{2}$, where main lines are grouped at the point in the upper part of the page.

The narrow meas uretowhich these words are set necessitates letter-spaci $n g$. T h e resulting appearance is far from The erroneous and obsolete practice of spreading the lines over the page of balance

satisfactory yet it enables illustrations to be grouped pleasingly and makes possible a squaring of the pages which could not be done otherwise.

It is not always that results are as perfect as we desire th e in. I n New England there is a printer who, in the opinion of those fortunate to have viewed his work, is producing typography classically perfect; yet this man goes from his work at the close of the day almost dis-

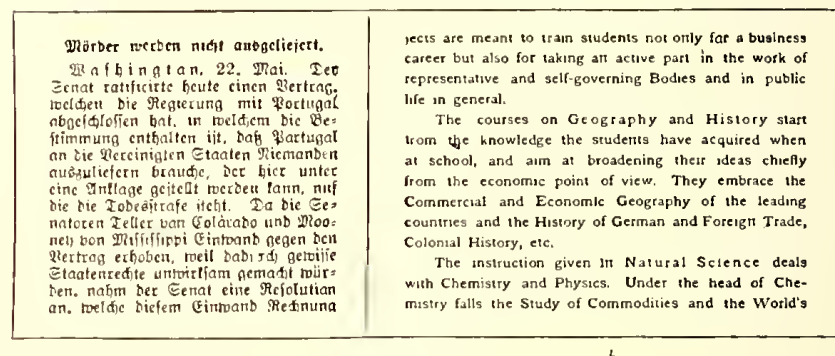

4

couraged because of the faults that areevident to his t r a i n e d ey e. The a $r$ t ist' $^{\circ}$ i d e a l a lways eludes him and the chase seems a ho p e less one, yet he continues on lest he lose sight of it altogether. It is a good sign when one recognizesimperfections: it means that he is gaining ground EXAMPLE 80

Emphasis obtained by letter-spacing, in lieu of italics and small capitals

And Noal was six hundred years old when the flood of waters was upon the earth. And Noah went in, and his sons, and his wife, and his sons' wives with him, into the ark, beenuse of the waters of the flood. of elean beasts, and of beasts that are not clean, and of fowls, and of every thing that creepeth upon the ground, there went in two and two unto Noah into the ark, male and female, as God had eommanded Noah. And it eame to pass after the seven days, that the waters of the flood were upon the earth. In the six hundredth year of Noah's life, in the second month, on the seventeenth day of the month, on the saine day were all the fountains of the great deep broken up, and the windows of heaven were opened. And the rain was upon the eirth forty days and forty nights. In the selfsame day entered Noah, and Shem, and llam and Japheth, the sons of Noah, and voah's wife, and the three wives of his sons

\section{EXAMPLE 78}

The effect of horizontal lines is avoided by having the space between the words approximate that between the lines

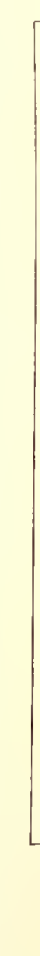

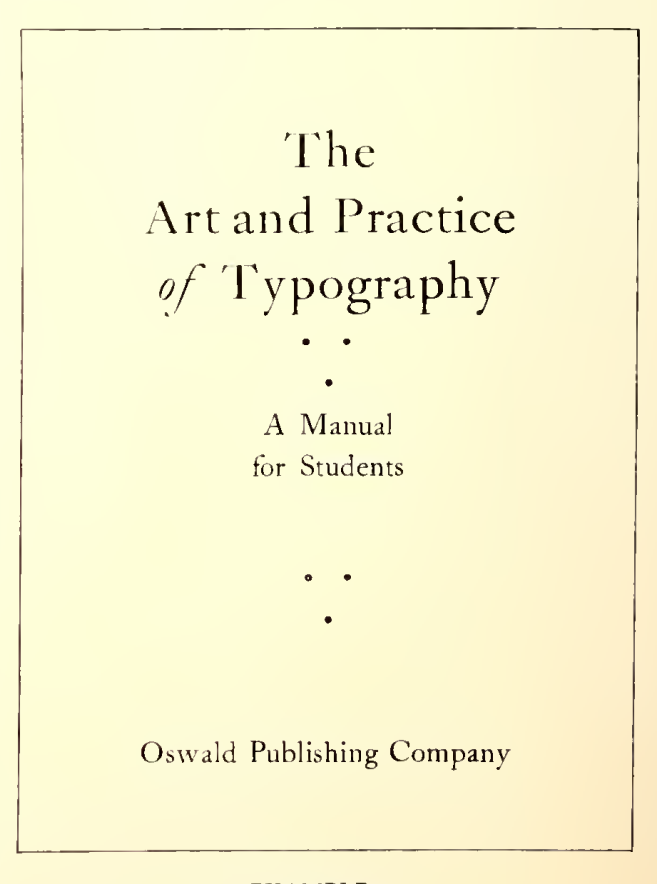

EXAMPLE 82
The correct modern practice of grouping the lines at the point of balance 

T less than a century, the confines of the city of Buffalo have changed from the camping and hunting ground of the Senecas to the city second in importance in the Empire State, eighth in size and population in the United States, and one of the leading commercial cities of the world. The growth and progress of Buffalo has been largely due to: (1) its geographical location, the benefits flowing from the commerce of the Great Lakes and of the Erie Canal, and latterly from the vast railroad systems which extended their lines to this point to secure their share of its enormous commerce; (2) to the enterprise, progressiveness and public spirit of its citizens reflected through its chief commercial organization first known as the "Board of Trade" and now celebrating its semi-centennial as the "Chamber of Commerce."

The first commercial organization was founded in 1814 soon after the destruction of the village of Buffalo by the British and their Indian allies; formed for their mutual protection, for the rebuilding of the village, and re-establishment of trade and commerce. This was the second commercial organization to be formed in the country, being preceded only by the Chamber of Commerce of New York, chartered by the King in 1768.

This organization, few in numbers, was largely responsible for securing the western terminus of the Erie Canal at Buffalo rather than at Black Rock, between which villages in those days a keen rivalry existed.

Early in the $40^{\prime}$ 's the organization having lapsed into a state of innocuous desuetude, Mr. Russel A. Heywood, in January, 1844, called together a number of the more influential and prominent citizens of Buffalo for the purpose of organizing a Board of Trade, and on January 16th of that year constituted the organization which has since been superseded by the Chamber of Commerce. The Board of Trade was incorporated March 7, 1857, and conducted its affairs in the rooms donated
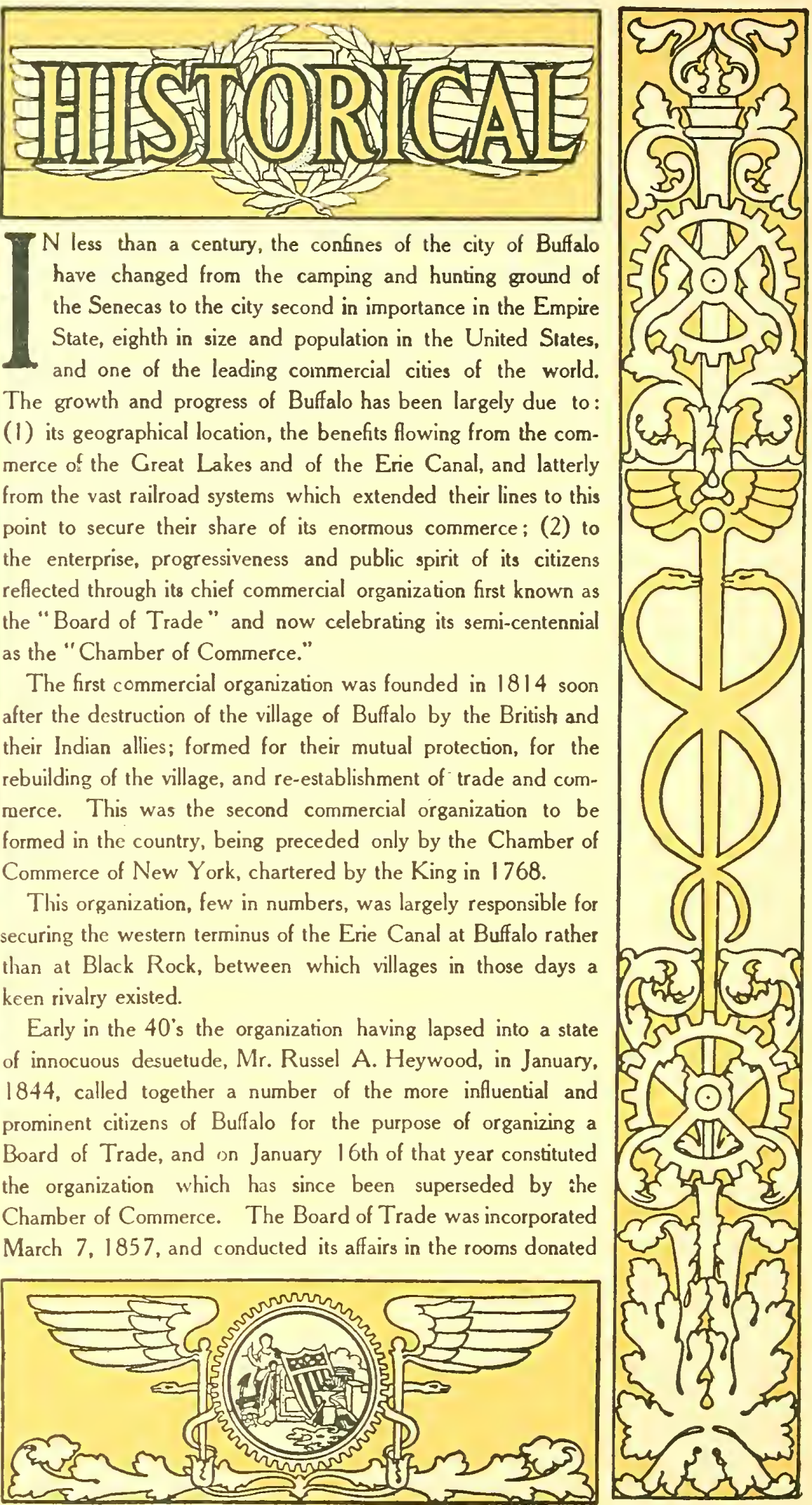

EXAMPLE 125

Illustrating the significance of ornamentation, as applied to a booklet. Design by the Matthews-Northrup Works, Buffalo, N. Y. 


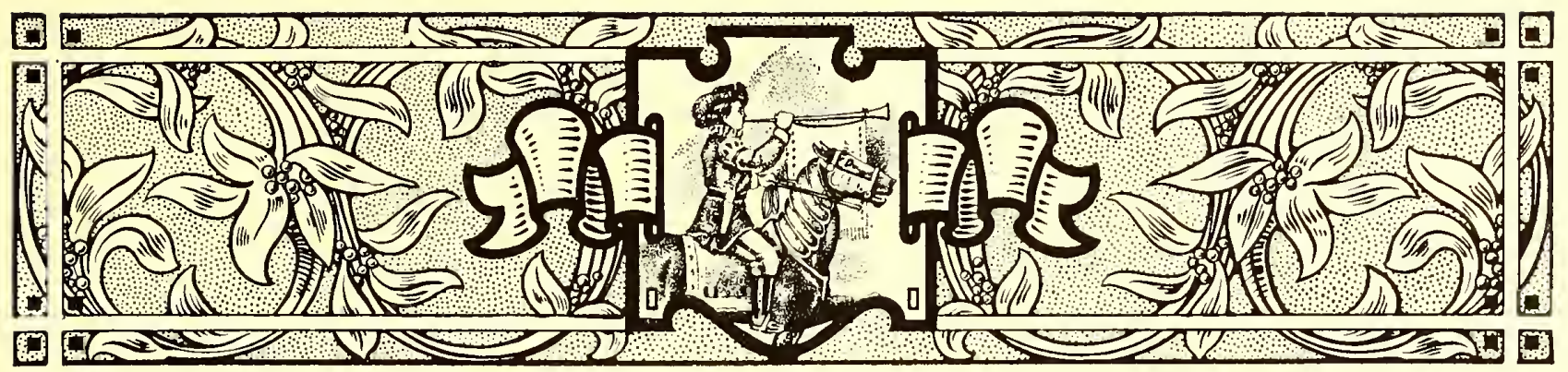

\section{ORNAMENTATION}

OFFER a child the choice of two toys, alike excepting that one has a flower painted upon it, and lie will doubtlessly select the ornamented onc; proving that the human race has a natural liking for ornamentation. When the oldtime trader visited savage countries, he took with lim colored glass and brought back gold. The glass soon after ornamented the somber bodies of the savages, and the gold became rings and bracelets worn by the whites. There are those in this day who love the trees and the flowers and hear music in the brooks, but more find pleasure in artificially ornamented ball-rooms with music blown and sawn and hammered from brass and catgut and sheepskin.

Man was created in a garden of flowers and trees pleasant to the sight, yet he has ever been yearning for a new Eden of pure gold, garnished with precious stones, forgetting that Solomon

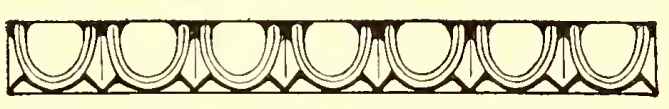

EXAMPLE 83

The egg-and-dart ornament

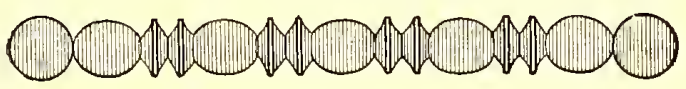

EXAMPLE 84

The bead ornament ence, and it has been only within recent years that the average man has given thought to art. Many a one has thrown off his lethargy to discover beautiful things all about which he had never before noticed.

Art galleries and libraries all over the United States are aiding greatly in the cultivation of taste for art, and the printer to whom these privileges are accessible, yet who does not avail himself of their advantages, is much like the man who was lost in the Adirondacks, not knowing he was but a half-mile from a railroad. China, who could conquer the world if she only knew her power, has been sleeping for centuries, while a little handful of intelligent people on a small island of Europe wields an influence that is felt wherever the sun shines.

The printer and he of an allied vocation should take less thought of food and raiment and devote in all his glory was not arrayed like the lily of the field. Nature is the great artist, and man's ornamentation at best is a poor imitation of nat ural things. The trees of the forest gave the motive for the stone columns and ornamental capitals of architecture, and the plant and animal world furnished themes for talented calligraphers in the days when books were literally written. The blue vault of the skies inspired Michelangelo to plan the great dome of St. Peter's at Rome, as the sun furnished a model for the Indian while decorating his tepee, and the flowers of the field have provided inexhaustible color harmonies.

In the early days of this country most of the inhabitants devoted their working hours to the struggle for exist-

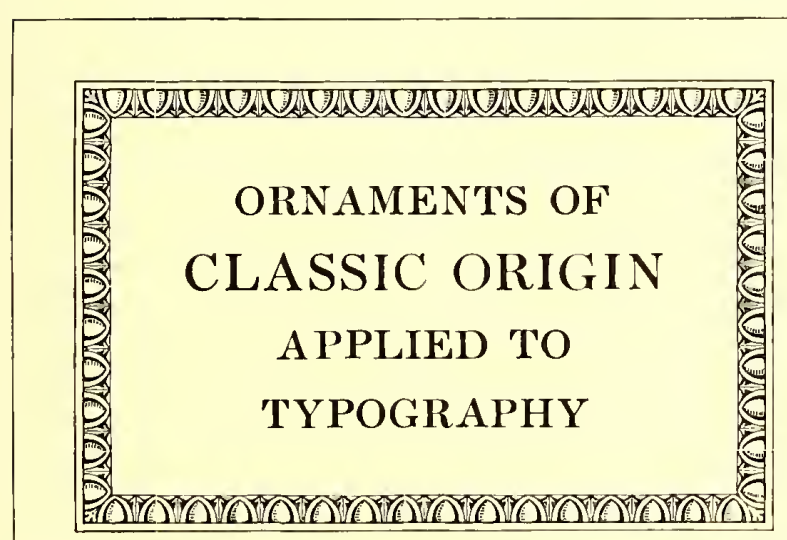

more thought to learning the things of todav and yesterday with which he may be but little acquainted. If one knows just enough to "nake a living" he will never make more than a living. A study of art, of history, of the larger things in the printing business, will result in the good things of the earth being added.

Is ornamentation necessary to art-typography? Ask one good printer and he will answer, yes. Ask another and he will answer, no. One of the meanings of ornament as given by the Standard dictionary is: "A part or an addition that contributes to the beauty or elegance of a thing." A paper may be so pleasing in texture as to give beauty or elegance to an otherwise plain page of

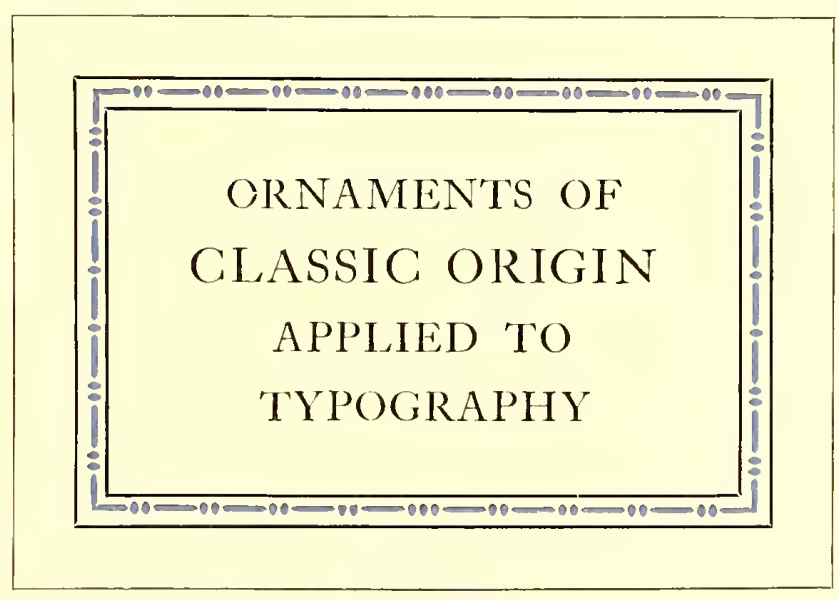

EXAMPLE 86

The bead ornament as a typographic border 


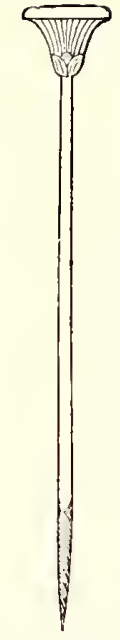

EXAMPLE 87 Conventionalized papyrus plant (Egyptian)

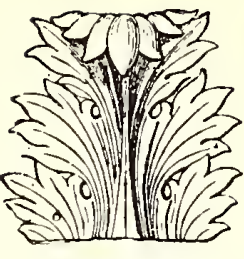

EXAMPLE 89

The acanthus leaf. much used by the Greeks and Romans in ornamentation tion from the paper.

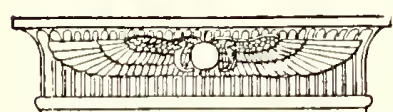

EXAMPLE 88

The winged ball, an ornament much used by the Egyptians years ago became possessed of a desire to do artistic printing and lrad a number of type ornaments purchased with which to express his ideas. When one prouf after another came from the customer with oninous blue marks mon the cherished ornaments, he realized the necessity of revising his irleas of art. For fully a ycar after that lie worked without voluntarily using an ornament, neanwhile devel-

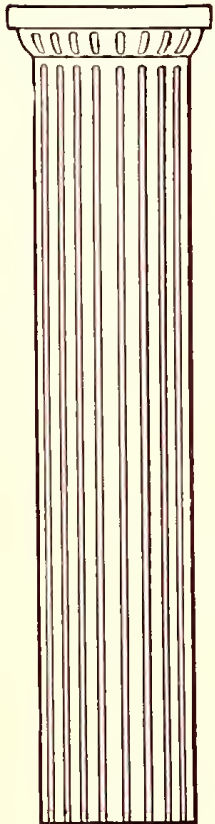

EXAMPLE 91

Plain and dignifice. The Doric pillar

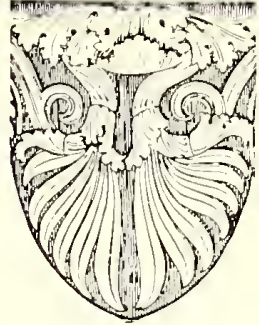

EXAMPLE 90

Palm-like ornament, Romans used by Greeks and

printing; in fact, it is sometimes a mistake to use type ornaments or other embellishment on a richly finished handmade paper. On the contrary, a stock poor in quality or color had better be covered witl decoration to divert atten-

There are printshops in which all ornaments are kept under lock and key; a compositor wisling to use decoration must present good reasons before he gets it. Customers have become suspicious of ty pe ornamentation because of the peculiar use to which printers sometimes put it. A young man some

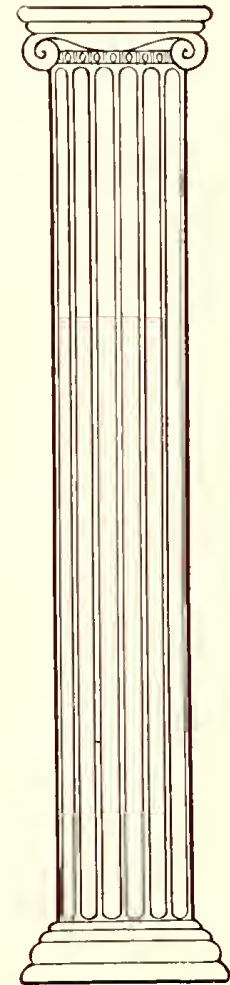

EXAMPLE 92 The Ionic pillar
Slightly ornamental.

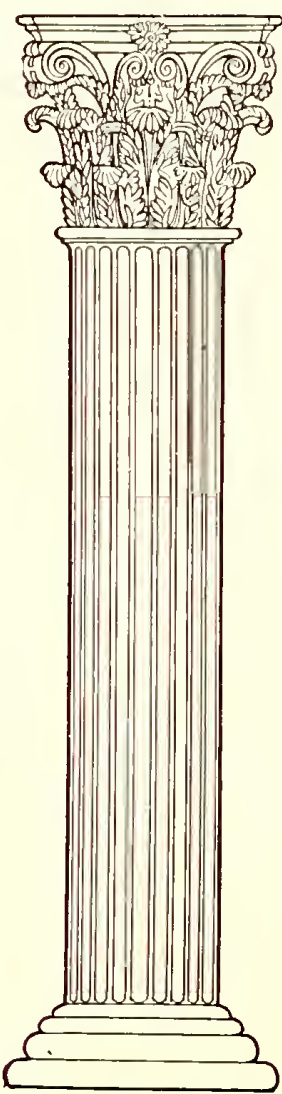

EXAMPLE 93

Elaborately ornamental. The Corinthian pillar oping all the possibilities of good typefaces and appropriat e paper stocks and color combinations. It has been claimed that fasting has a beneficial effect on the body; be that as it may, our friend certainly improved his artistic taste by his abstinence. When he again began using ornaments it was with discrimination and after study of their significanceand appropriateness.

This leads to the subject of motive or reason in ornamentation. The styles of typography may be generally divided into two classes, one dominated by Roman or Italian influence and the other by Gothic or German influence. During the Middle Ages the Gothic influence was felt clicely because the pointed style of architecture and embellishment was sanctioned by the Christian church. As

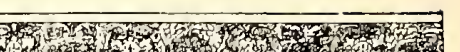

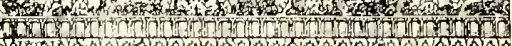
s.
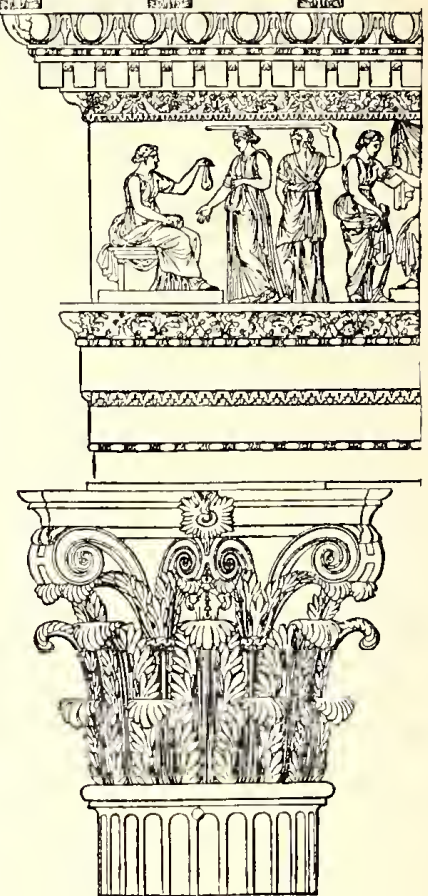

EXAMPLE 94

Ornamentation as used by the Romans on an entablature and a Corinthian pillar, showing edd-and-dart, bead. and acanthus ornaments art was practically dead outside the clurch, the art-workers absorbed the Gothic style.

When typography was invented Gutenberg's first book was based upon the Gothic stylethe type-face a pointed black letter, such as was then used on manuscript books, and the ornamentation pointed foliage (done by hand). It was some years after this that typography came under the influence of the Italian Renaissance, and both type-faces and decoration assumed the loman style. In the old days there was sympathy between the various arts and crafts, and it worked for harmony in effects. Building-decoration, metal-carving and wood-engraving were governed by the same artistic motive, and were often done by the same man, much as the printer at one time was compositor, pressman, binder, typefounder, ink-maker andpaper-maker, all inone. Now, many a piece of printing goes wrong because the ideas of several people, inharmonious from lack of relation, are injected into the work during the several stages necessary for its production.

The relation of typography to architecture is plainly shown in the formation of the Roman and Gothic alphabets. Theletters of the Roman alphabet, dignified in their straight strokes and symmetrical in their rounded lines, suggest features of Roman architecture (Example 106; also see Example 43 of a previous article). In the interesting picturesqueness of the pointed black Gothic letter may be seen reflections of the graceful arches of the cathedral pointing upward like hands in prayer-and of the pointed leaf ornamentation of the Gotlric period. (Example 107.) 



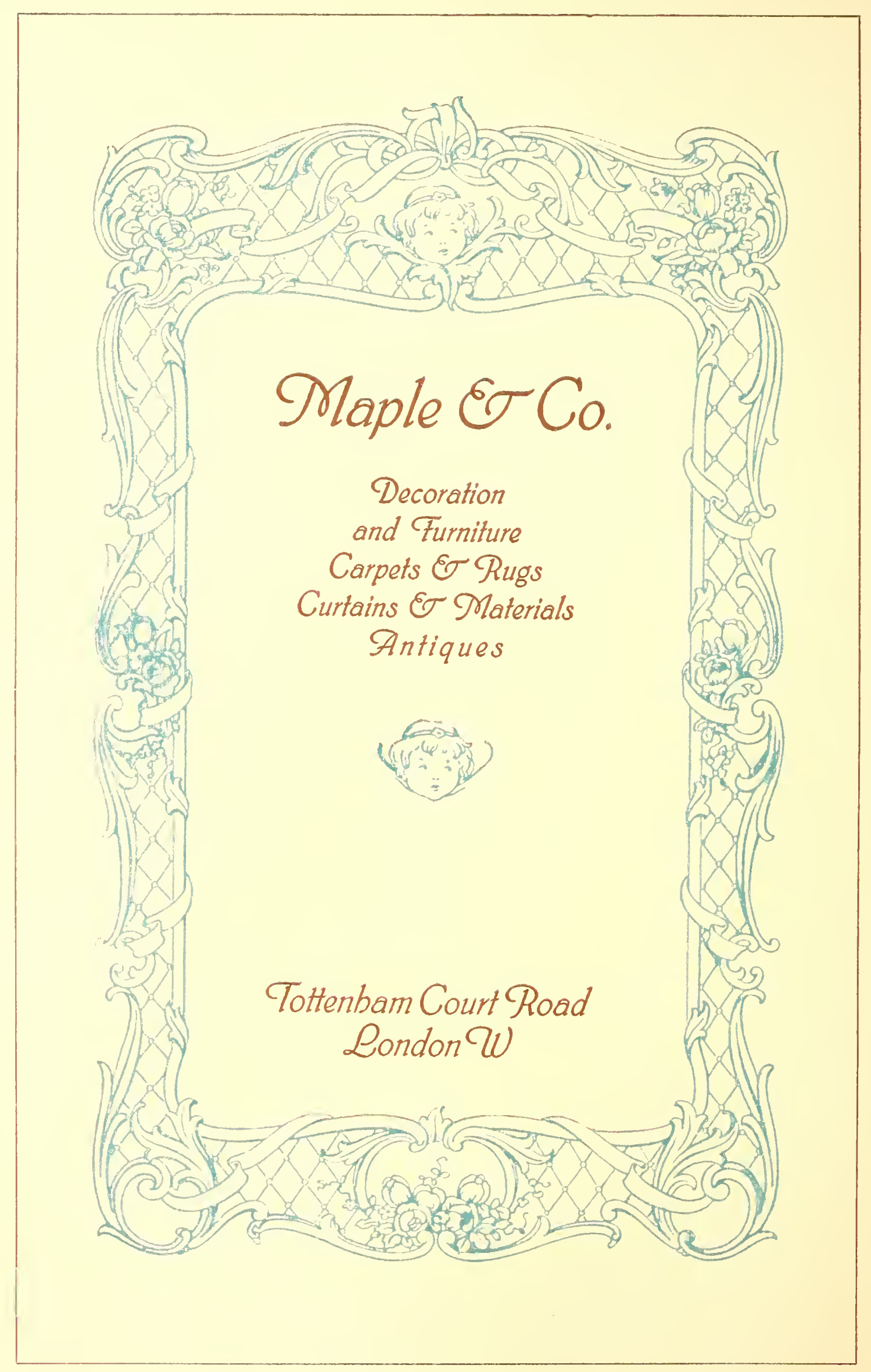

EXAMPLE 98

Dainty, elaborate rococo ornament, as applied to a program title-page. Compare with the chair. Example 97 
Ornamentation is both inventive and imitative. An ornament purely inventive or one purely imitative is seldom artistic. A child may make a jumble of lines that altho original means nothing; when it is older it may draw a flower so realistic and imitative that little is left to the imagination. When a flower or plant is used as a model in designing an ornament it is "conventionalized," that is, it is blended with its environment. A flower in a gardeu surrounded by other vegetation

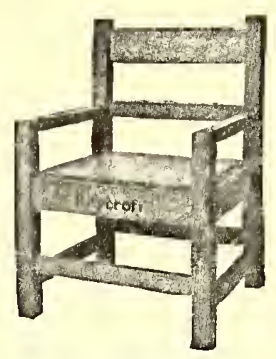

EXAMPLE 95 Square-lined, ornamentless furniture should be as the other Howers, but as an ornament on the

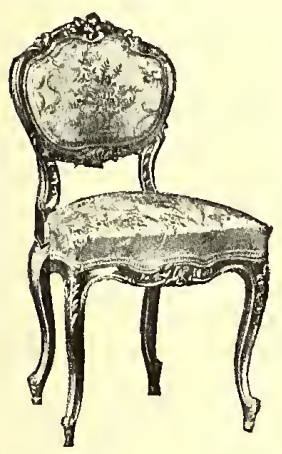

EXAMPLE 97

Dainty and elaborate rococo ornament, as applied to furniture. Compare Example 98 flat surface of paper it should be without perspective. Example 108-a shows how commonplace an ornament looks wlıen its details are carefully shaded in perspective. Examples 108-b and 108-c show how moredecorative an ornament is when either outlined or filled in. Sometimes shadows are merely suggested, as on the fruit basket and book ornaments in Example 113.

In the conventionalized decorative art of all ages may be found traces of the things which have inspired the decorator. The lotus leaf, and the papyrus plant (which once gave writing material to the world) thousands of years ago influenced

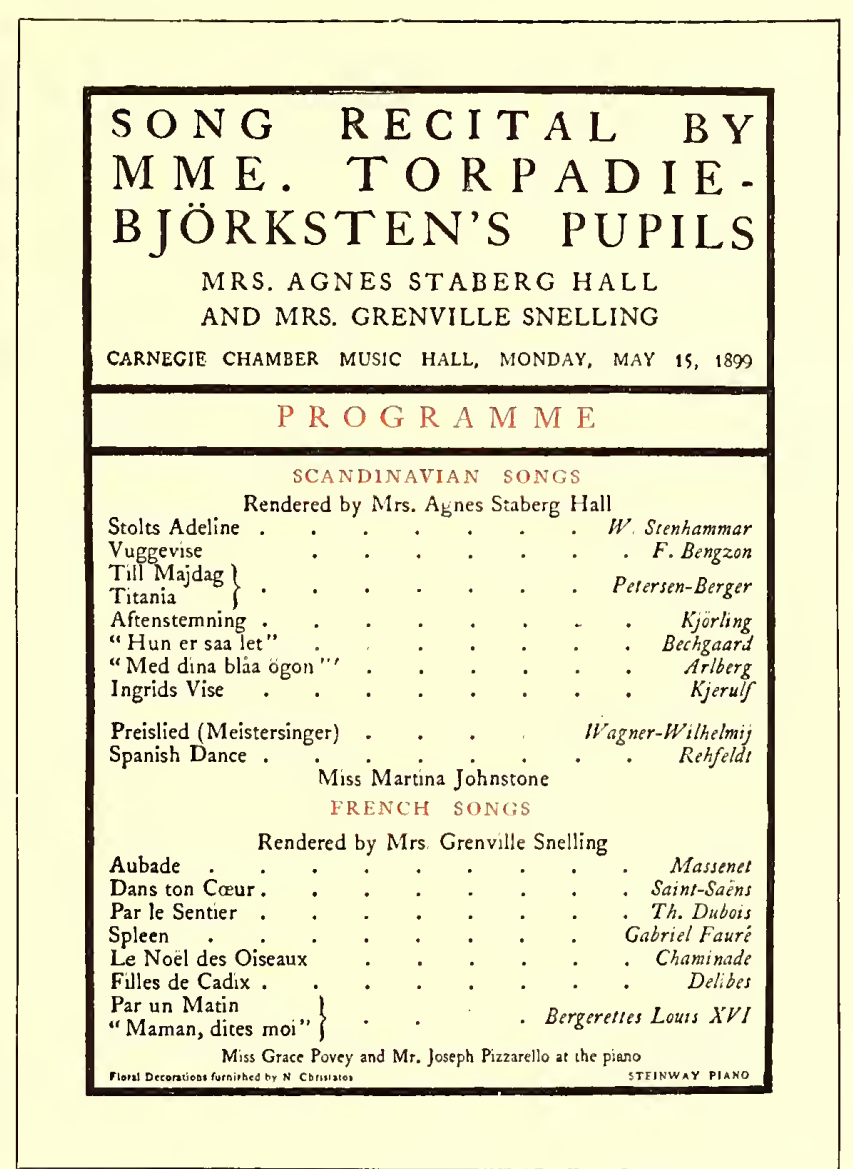

EXAMPLE 96

Square-lined, ornamentless typography. Compare with chair opposite. Design by Fleming Eै Carnrick, New York

Egyptian design (Example 87). Religion dictated many of the decorative forms in ancient art. The winged-balland-asps (Example 88) was a favorite device in Egyptian decoration and has come to us by way of Roman mythology as the winged staff of the herald Mercury, the ribbons on the staff supplanting the Egyptian asps, but later evolving into serpents as in the decorative border of Example 125. The work of the best artists is full of meaning. The Egyptians considered certain animals sacred, and they were reproduced numerously in the picturewriting and ornamentation of the time. The sacred beetle as conventionalized was much used. In Example 125 the cog-wheel of commerce is conventionalized as the rim of the ball, which also contains a seal. The anchor and rope, hour glass, wreath, torch, acanthus leaves, all are conventionalized and blended pleasingly in outline drawing. The tone of the border approximates that of the type matter it surrounds.

The acanthus leaf (Example 89) is the model for much

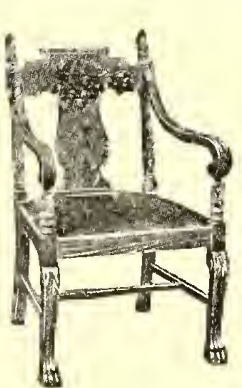

EXAMPLE 99

Slightly ornamental furniture of the elaborate leaf decoration found on the capitals of Corinthian columns and wherever rich imposing leaf ornament is desired. The anthemion (Example 90 ) is a palm-like ornament used by the Greeks and Romans, now frequently found in decorative work of an architectural nature.

It may not occur to the average printer that architecture is in any way allied with typography - that there is any conneetion between the ornamentation of a building and a job of printing. Fred W. Goudy, Bruce 


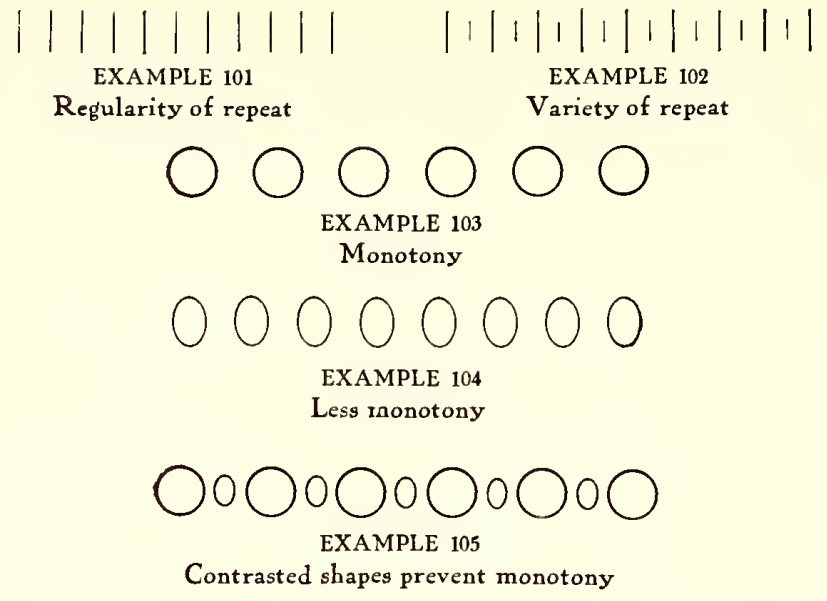

Rogers and D. B. Updike employ conventionalized architectural columns and arches to ornament title-pages of classic motives. The average typographer, tho, finds more inspiration in the ornamentation that is only an embellishment to architecture. There are several ornamental units that are used more frequently than others, and these are the egg-and-dart (Example 83) and the bead (Example 84). You, who are reading this, are invited to verify by observation this last statement. A printer who did so was astonished at the eggs, darts, and beads that were to be seen wherever lie looked. Cut into the stone of buildings, carved into the wood of furniture, used on molding about doors and windows, on office partitions, on library lamps, in the ceiling panels of restaurants, about the prosceniums in theaters, around the mirror in the barber shop-wherever he looked there were the ornaments. It is remarkable how non-observant the average printer is. The hands of artists-Greeks and Romans-wlo lived thousands of years ago made similar designs, and yet a knowledge of history is counted non-essential by printers and others!

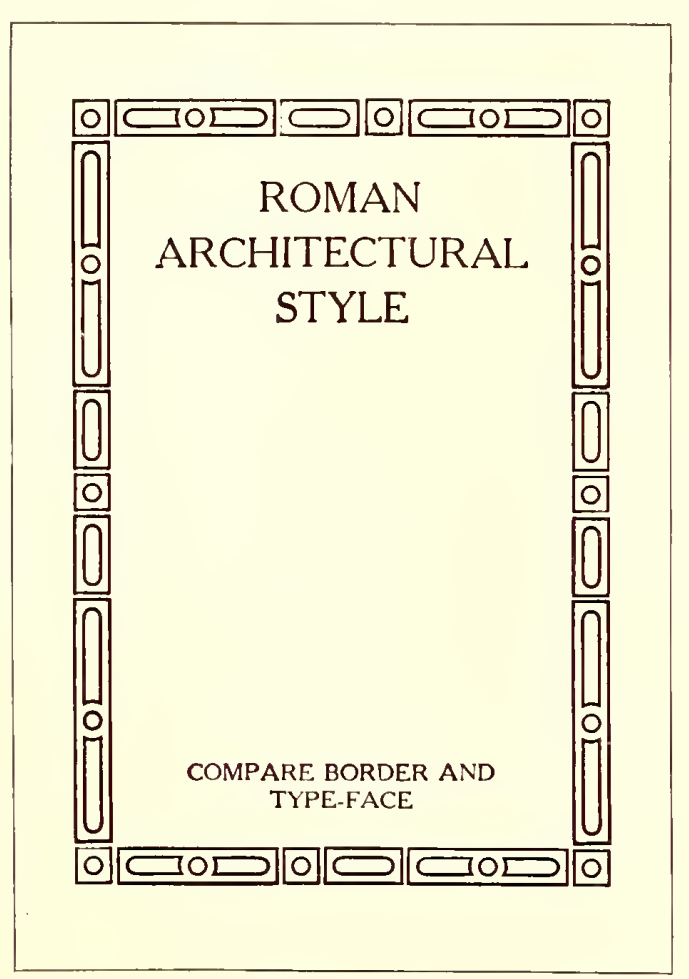

EXAMPLE 106

Type border of Roman architectural ornament. Compare the straight and curved lines with the Roman type-face

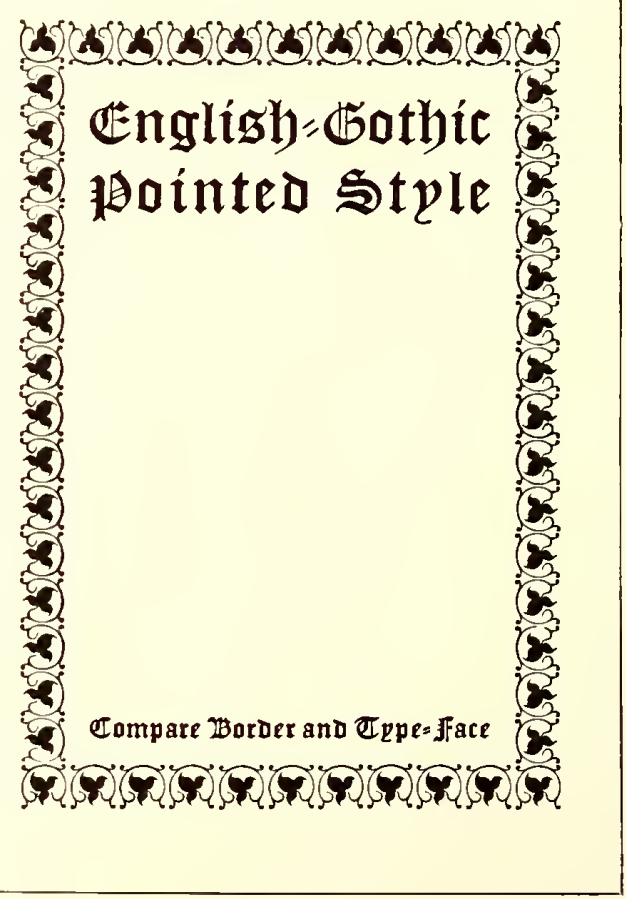

EXAMPLE 107

Type-border of English-Gothic pointed ornament. Compare the black pointed effects with the Gothic type-face
Let us apply the egg-and-dart and bead ornaments as borders in typography, and notice how admirably they serve the purpose. Example 85 sllows the egg-and-dart ornament perhaps too carefully drawn as to detail; and Example 86 demonstrates how the bead ornament may be adapted to panel work.

From early times there seems to have been a triple division of taste regarding ornament. In the days of Rome these divisions were given expression in the treatment of supporting columns, the three styles being known respectively as Doric, Ionic and Corinthian. The Doric column is severely plain, the Ionic slightly ornamental, and the Corint hian elaborately ornamental.

The Doric style (Example 91) is emblematic of dignity, simplicity and strength, and appeals to the man preferring these qualities in printing.

The Ionic style (Example 92) represents refinement in ornament, and pleases the man able to discriminate be$t$ ween the severely plain and the over-ornamented-a quality of judgment worth cultivating by every typographer.

The Corinthian style (Example 93) expresses the preference of many who delight in ostentation and elaboration in ornament. The elaborate, showy acanthus leaf
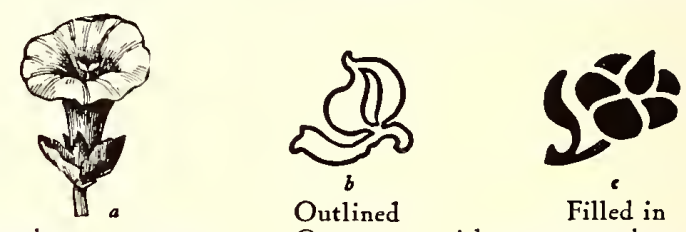

Ornaments without perspective EXAMPLE 108

usually forms the chief decoration for the capital surmounting the column, and the entablature (Example 94) is particularly rich in ornamentation.

The Doric pillar has been called masculine and the Ionic feminine, the sturdiness of the one and the grace of the other also being likened to the warlike Spartans who emphasized the development of the body and the artistic Athenians who especially developed the intellect.

This difference in ideals and preferences has come down the centuries to our time. A few years after Cromwell, plain, blunt, and even disapproving of sculpture and paintin $\mathrm{g}$, was ruling England, across the channel Louis XIV. strutted in corsets and on high red heels amid gilt and rlamour in the courts of France.

Monks and nuns lived plainly in the company of bare walls and squarely cut chairs, and dressed in subdued browns and blacks, while at Rome surrounded by the art works of Michelangelo and Raphael the higher dignita- 


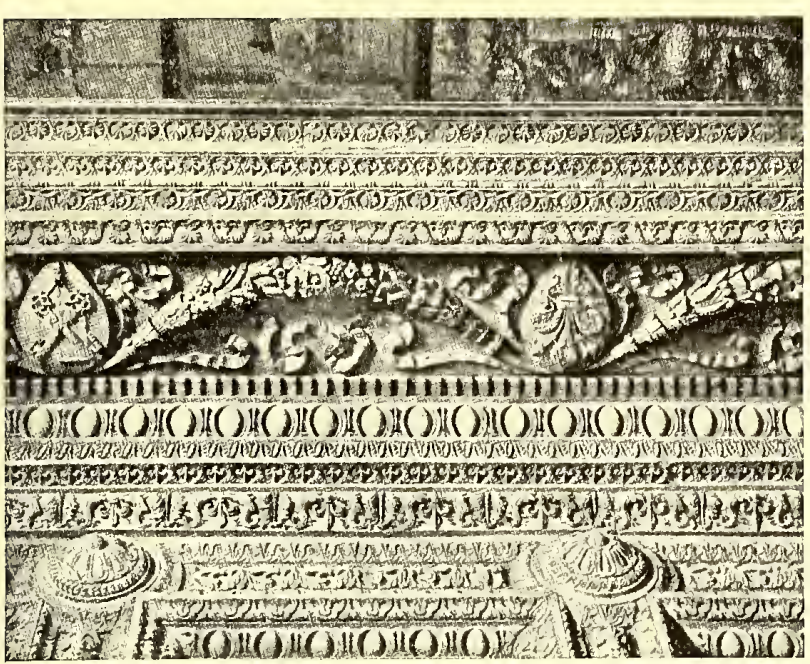

EXAMPLE 109

Extravadant wall border ornamentation,

designed during the Renaissance in Italy

ries were clothed in brilliant reds, and gold and white.

Morris loved an old worn-out house, squarely-cut furniture, burlap, and subdued colors; while the Newlyriches boast of the magnificence of their mansions, Louis Quinze ball-rooms and imported tapestry.

Only recently two church buildings were remodeled. In one were placed ornamental brass railings, lectern, pulpit and candelabra, and stained-glass pictorial windows; the walls were covered with gilt Heurs-de-lis on maroon backgrounds, and the entire effect was one of cheap magnificence. The other church had been an old Colonial structure of square proportions. Dignified mahogany furnishings were selected, the walls were ornamented in pure geometric designs, pale gold on tinted backgrounds, and the windows were made of small panes of glass subdued in color, in harmony with the architecture of the building, with a result that spoke good taste and refinement.

Examples 95, 96, 97, 98, 99, 100, present the three divisions of taste - the plain, ornamentless; the slightly ornamental, and the elaborately ornamental-applied to typography and reflected in furniture. The typographer should learn that the arts are related, that the styles of home-furnishings and architecture influence the styles of typography. A few years ago mission furniture was introduced and along with it came architecture that called for exposed roof supports, squarely-cut moldings, coarse fabric wall coverings, subdued green and brown tapestries. And before they knew the reason, printers were using heavy brass rules, rugged type-faces and printing on dark-liued antique papers. Example 96 is a program page produced under these influences. Compare

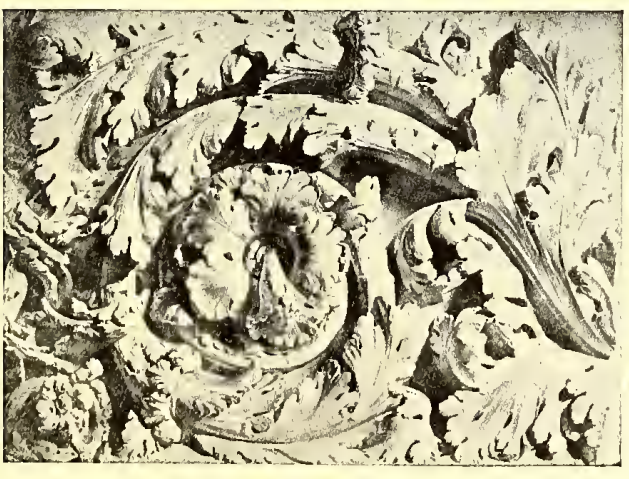

EXAMPLE 110

Roman scroll ornament cut in stone it with the so-called "mission" chair (Example 95) and note the resemblance of motive. Both are rug g e d, angular and plain.

Now for contrast, co m par e them with

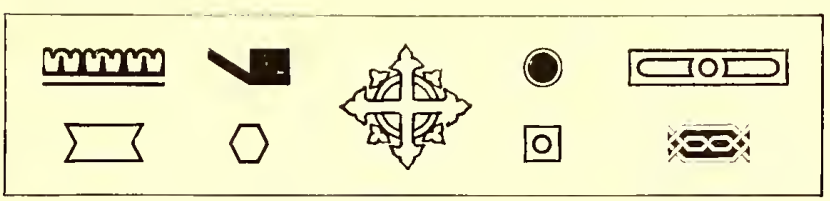

EXAMPLE 111

Type ornament based upon geometric lines

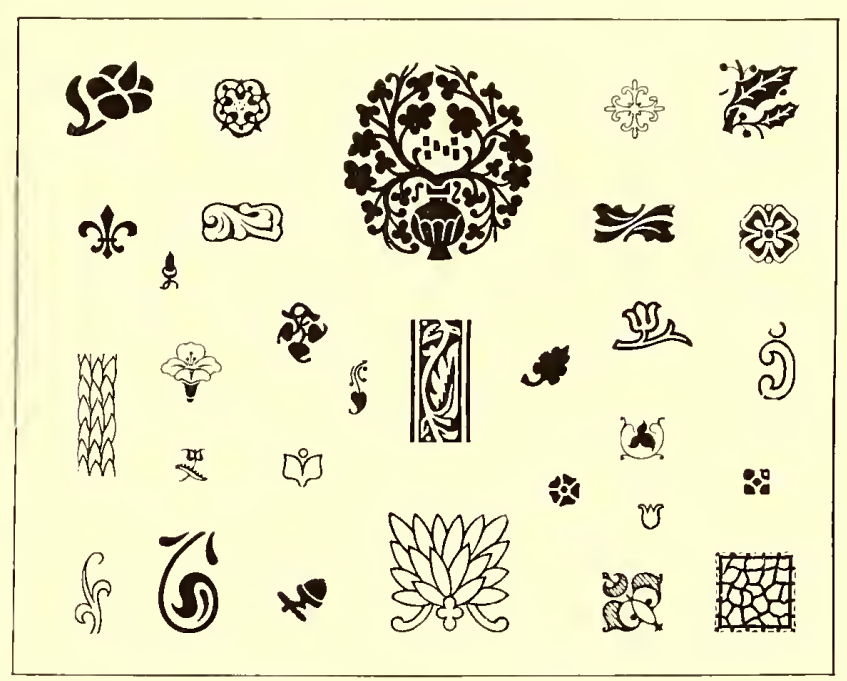

EXAMPLE 112

Type ornament based upon foliage
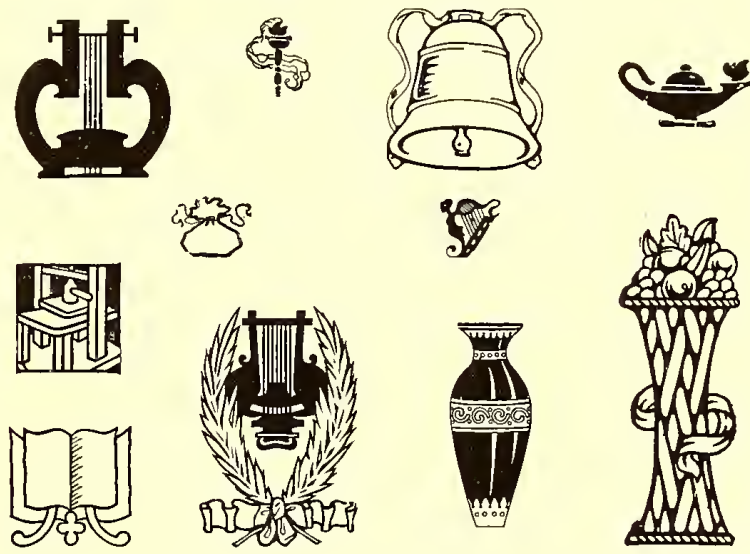

EXAMPLE 113

Type ornament based upon the inanimate

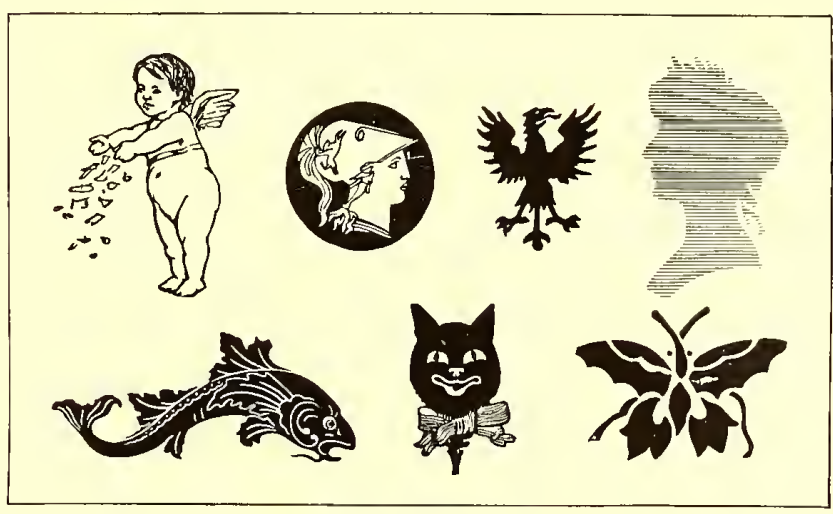

EXAMPLE 114

Type ornament based upon the animate 


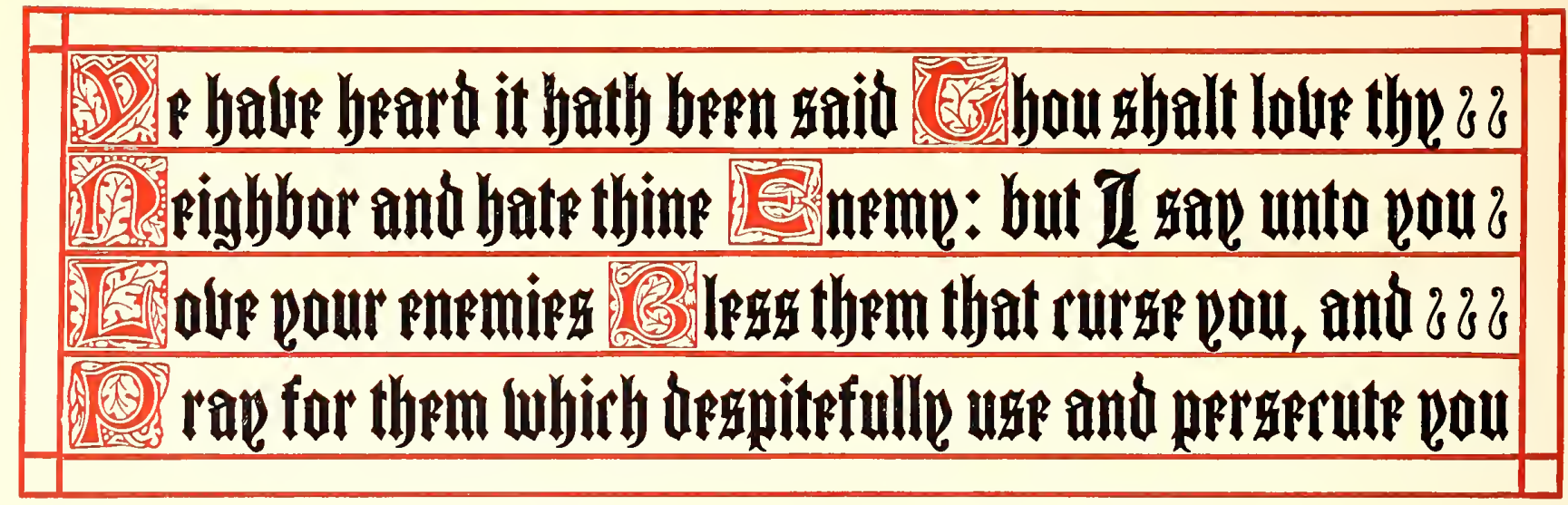

EXAMPLE 115. Ornamental hand-lettered effect; obtained by initials, text letter and rule

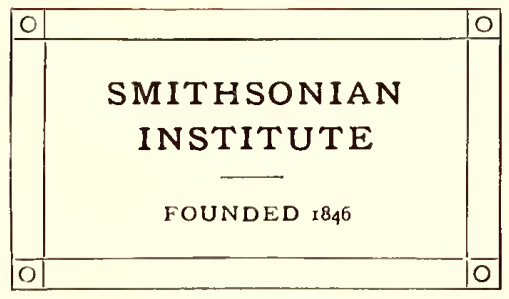

EXAMPLE 116

Corner ornaments may have been suggested by the bolts on inscription plates or by the cross lines on books the dainty, elaborately ornamental chair (lixample 97) and the title-page (Example 98). Both chair and title-page designs are based upon the frivolous rococos style of the period known as Louis XV. (or Louis Quinze). In that period, shells and leaves conventionalized into graceful, golden curves were blended with a profusion of roses and other flowers. Sitraight lines were avoided, and furniture and architecture took on curves even to the extent of causing structural weakness.

Because a majority of type-faces are built upon horizontal and vertical lines, rococo type ornamentation is seldom successful in typography. The pen-and-ink border design (Example 98) is a clever adaptation of the Louis $\mathrm{XV}$. rococo style. There is not an absolutely straight vertical or horizontal line in the border, and with the curves and Howers, ribbons, lattice-work and cupids it makes an appeal to women. The type-face combined witl the border has similar characteristics-a freedom of line and an abundance of curves.

Examples 99 and 100 show a chair and an announcement page, both slightly ornamented to please those folks who like neither the severely plain nor the elaborately ornamental.

Ornament is secondary to the real purpose of the thing it embellishes; it should not be so lavish as to distract attention from the more important object. A booklet is issued to convey a message, and should the reading matter be overshadowed by ornamentation, this purpose may not be accomplished. A "How ery" oration may entertain and please an audience, but it may not convince. In 1896 Bryan stampeded a convention by his ext emporaneous eloquence and metaphor, but when he came to the "enemy's country" and faced an audience which wanted facts, he read his address from carefully prepared manuscript.

During the Middle Ages, when nations were fighting for existence and necessities of life were barely obtainable, there was little ornamentation except in isolat ed instances, but when, about the fifteenth century, the Renaissance came, art received an enthusiastic reception. Ornamentation was indulged in to excess, the artists using all the classic forms and inventing new ones. Example 109 , showing wall border decoration.
Filling blank spaces with ornamentation, as was done on manuscript books. Page by Government Printshop, Berlin, Germany 
looks to the printer like a specimen sheet of type borders. This brings to mind that there is always the temptation to over-ornament when an artistic job is desired, and the necessity of advising printers to restrain themselves and save a few ornaments for other work. Our brethren of the cloth like to repeat the story of the theological student preaching his first sermon before the Seminary authorities. He began at Genesis and took his hearers thru the entire Bible to Revelation. When he had finished an old professor gravely asked what he would preach about the next Sunday.

The famous designer Chippendale, first made his furniture serviceable and then added ornament, from which fact the printer should profit. Have a printed job serve its purpose, and ornament it only so far as is consistent to this end. It is frequently advisable to omit decoration and let the type talk without interruption.

Ornamentation when used for border purposes has two features which may not be apparent to the superficial glance-regularity in repetition and variety in repetition. Example 101 shows repeated strokes of the same length. In Example 102 by alternating the length of the strokes the design is made more interesting. Examples 103, 10t and 105 illustrate this principle in rounded forms. In the first there is monotonous repetition, in the second there is less monotony because the oval form is less regular than the circle, and in Example 105 , by contrasting the forms in both size and shape the design acquires new decorative interest. This principle of contrast and variety is exemplified in most border designs. In Example 107 the light scroll lines contrast with the black leaves, and in Example 106 curves are contrasted with angles. Contrast is sometimes obtained with color, as shown in Example 123.

Ornament as used by the printer may be divided into four classes: Ornament based upon geometric lines

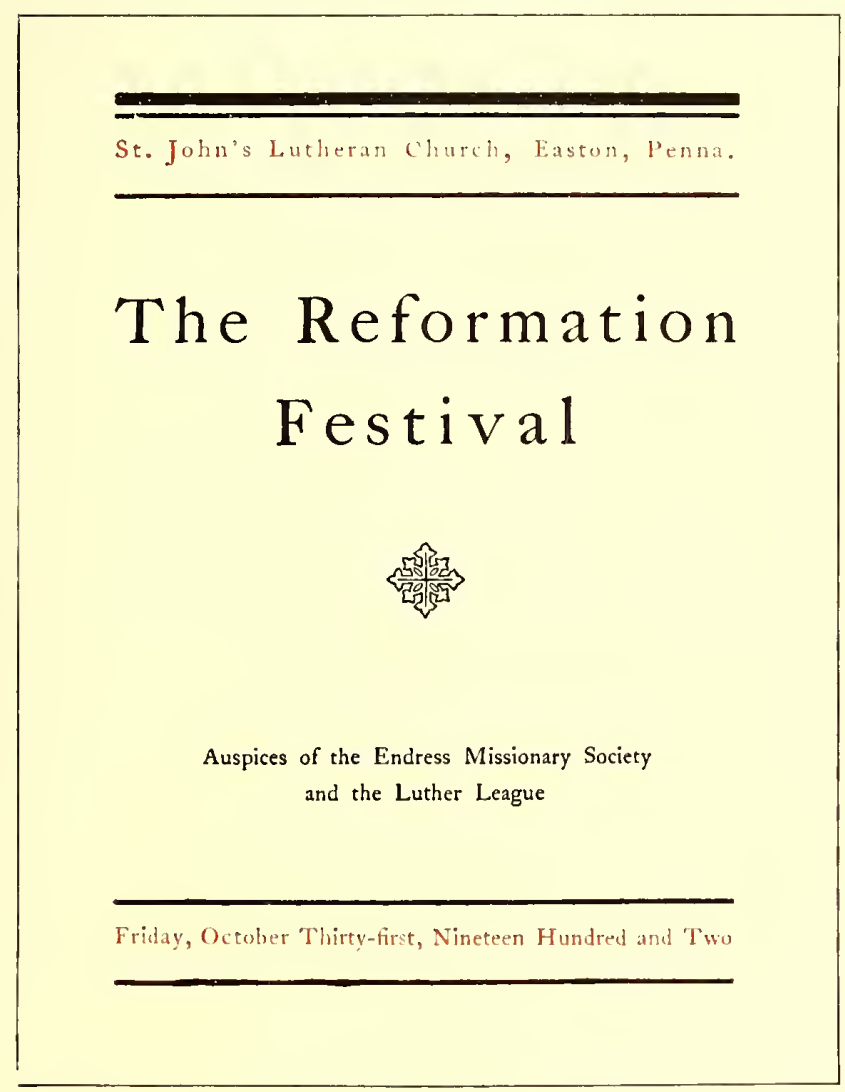

EXAMPLE 119

Semi-ornamental ecclesiastic style

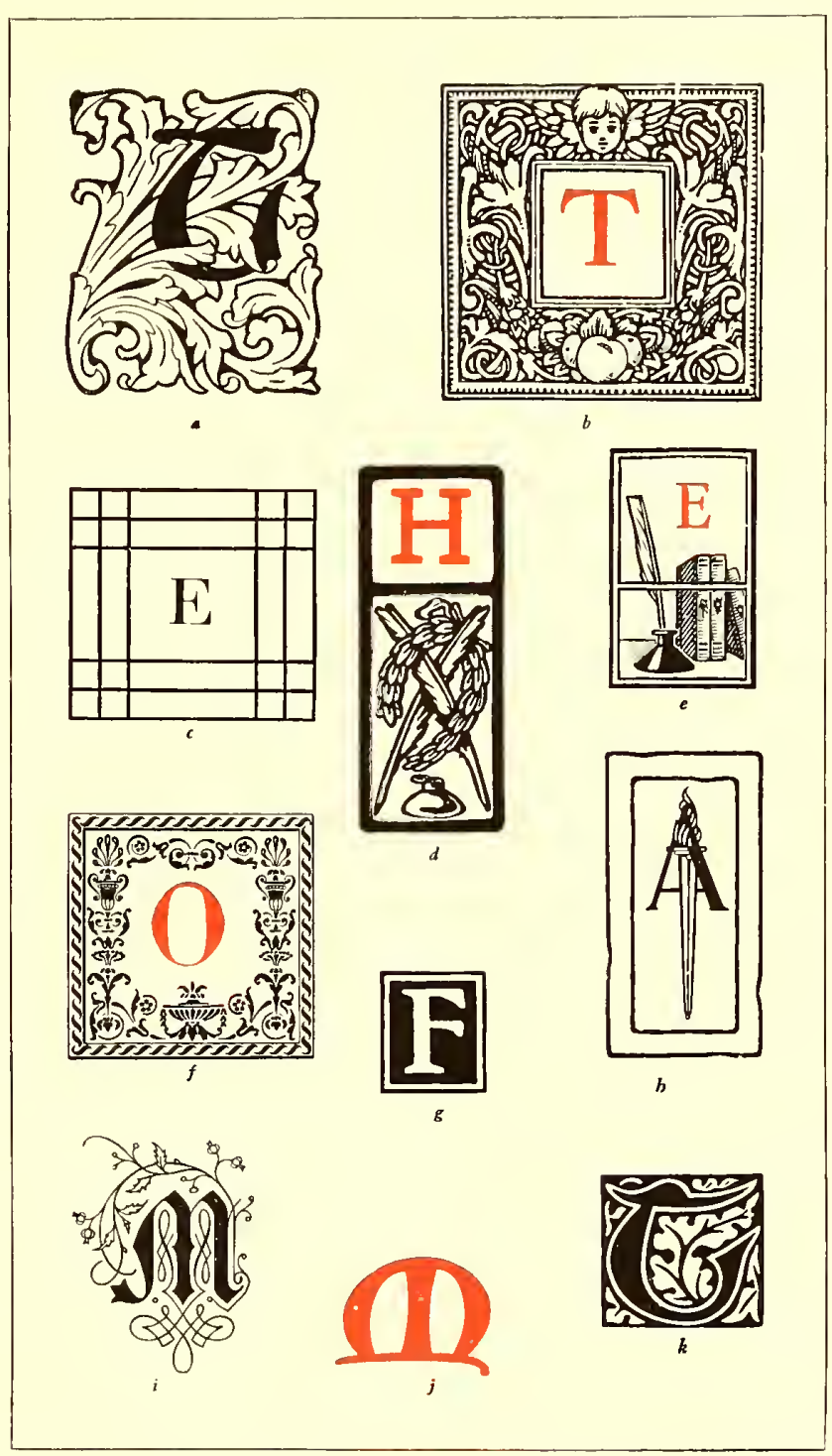

EXAMPLE 120. INITIALS

a-Foliage decoration based on the acanthus leaf

b-Imitation of mortised woodcut initials

c-Simple geometric treatment

d-Rugged Colonial style

e-Suggesting literary use

$f$ - Italian ornamentation

g-Plain black and white effect

h-Modern adaptation of Roman torch

i-German scroll decoration'

j- Based upon the uncial character

$\mathrm{k}$-Woodeut effect as used by Morris

(Example 111), ornament based upon foliage (Example 112), ornament based upon the inanimate (Example 113) and ornament based upon the animate (Example 114). The center ornament in Example 111 contains the cross and circle, ecclesiastic devices, and its conventionalized pointed leaves would atso admit it to the group shown as Example 112-ornament based upon foliage. Leaves and flowers from the beginning have been a prolific source of inspiration to artists. Before the invention of typography the decorator of manuscript books reveled in foliage, as will be seen by Example 117, and today when decoration is added by the process of printing the same liberal use of foliage is evidenced (Example 118). In both examples should be noticed the custom of filling blank spaces with decoration.

The inanimate (Example 113) lends itself better for ornamental purposes than does the animate (Example 114), and the less familiar the subject the better orna- 


\section{The IVY PRESS--Seattle's Printers \\ 쇼

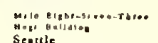

EXAMPLE 121

Simple ornamentation applied to letterhead.

Design by Harry A. Anger, Seattle, Wash.

ment it makes. An ornament based upon the animate is shown in Example 124, and as will be seen it is not as pleasing as the one in Example 121, which is based upon the inanimate.

Initials afford a convenient means of ornamentation (Example 120). An initial well chosen as to tone and appropriateness often satisfies all demands in this line. The mortised Colonial initial indicated by $b$ looks well with Caslon roman and printed on antique paper. Tlre acanthus design $a$ looks well with Washington 'Text; the Italian design $f$, with a letter such as Bodoni. Initials are used in a lriglily decorative manner in Example 115, after the style found in ecclesiastical manuscripts. The possibilities of type and rulc are here well set forth.

Sometines ornaments in the corners of a plain rule
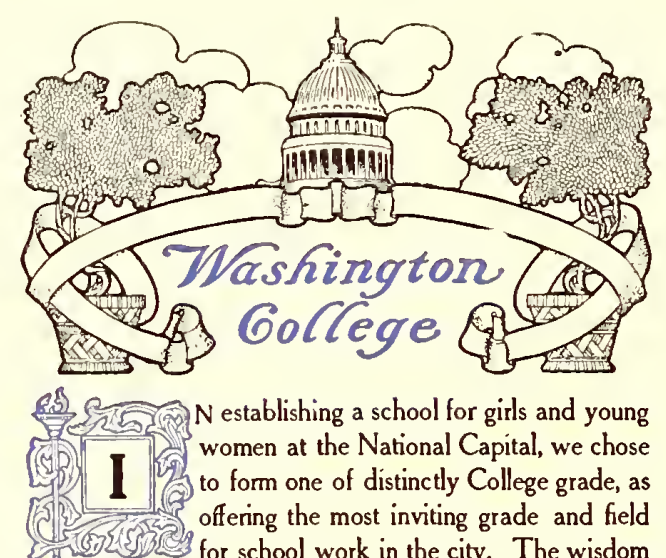

$\mathrm{N}$ establishing a school for girls and young women at the National Capital, we chose to form one of distinctly College grade, as offering the most inviting grade and field

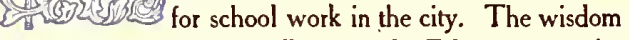
of such choice has been fully attested. Education may be distinguished as Primary, Academic, College, and University. The place of the College is between the Academy and the University. This place we occupy - offering also some years of Primary and Academic work in our Preparatóry School.

Every young lady, if possible, should have a College education, no matter what her work in life may be. Only a few women will, or can, enter the professions-except that of teaching, and for that the College may prepare. All who can, should first do the College work, and then, if a higher or a professional training is desired, go to the University for that.

The mission of the Young Ladies College is to fully prepare young women for their places in the home and in society. Its work is necessarily more extensive than the Academic and distinct from it; and, necessarily, less exten-

\section{EXAMPLE 122}

Appropriate ornamentation applied to the modern booklet. Page by the Munder-Thomsen Company, Baltimore, Md. border (Example 116) are sufficient decorat ion. The se effects may have been sugrested by the corner bolts with which brass plates are fastened to walls.

In the booklet decoration (Example 122) the artist has taken hismotive from the word "Washington", making the capit ol dome and its supports the central figure in the design, which is Colonial in character. Drawing a line down thru the center of the

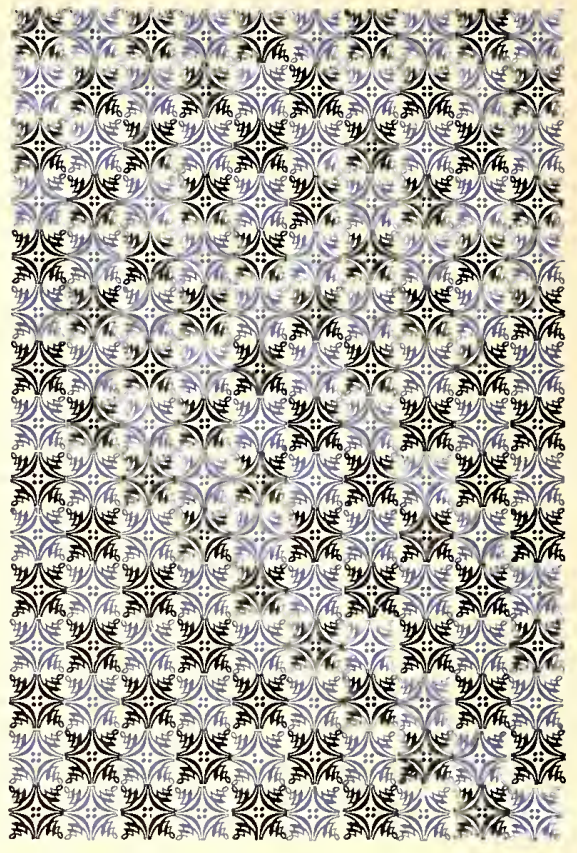

EXAMPLE 123

Effect of alternating colors, for covers and end-leaves of booklets and catalogs design it will be found that with a few minor exceptions the right half is a duplicate in reverse of the left half. The effect is frequently found in decorative work, as it gives balance and differentiates between illustration and decoration. An illustrative design, showing an actual scene, would not be effective.

Wall paper and linoleum designs are made in patterns that repeat at intervals and for this reason answer the purpose of decoration.

Example 119 presents a program page, which, while attractive, has but one ornament, an ecclesiastic design. The arrangement of bands above and below the main display assists in forming a decorative effect.

Type decoration in use today shows a preference for forms from Italian sources. Several years ago the Colonial spirit had influenced a preference for Gothic-English forms. The work of Goudy, Cleland and others has had a part in developing taste for the Italian.

In closing this chapter it may be well again to warn the printer not to over-ornament. The relation of ornament to typography is well covered in the caution of an experienced architect to a novice: "Ornament construction, but do not construct ornament."

The best art is that which is concealed, and which unobtrusively adds effectiveness to a piece of printing.

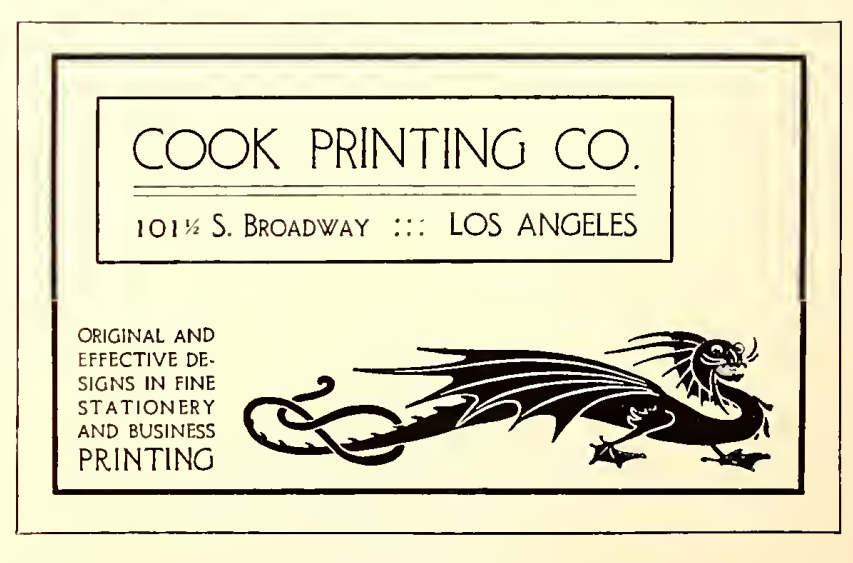

This ornament. based upon the animate. not well suited for business purposes 

ษัญ
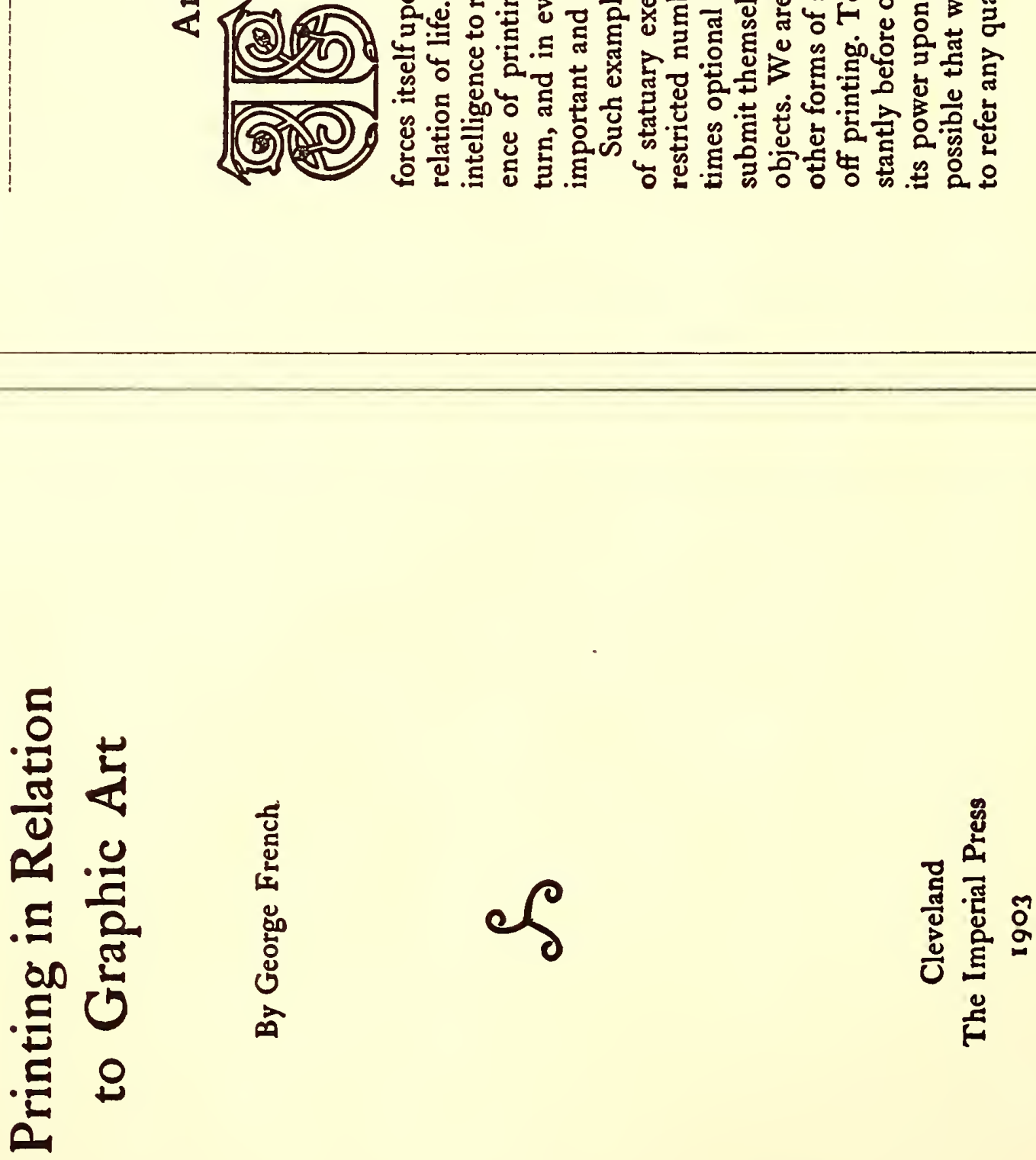


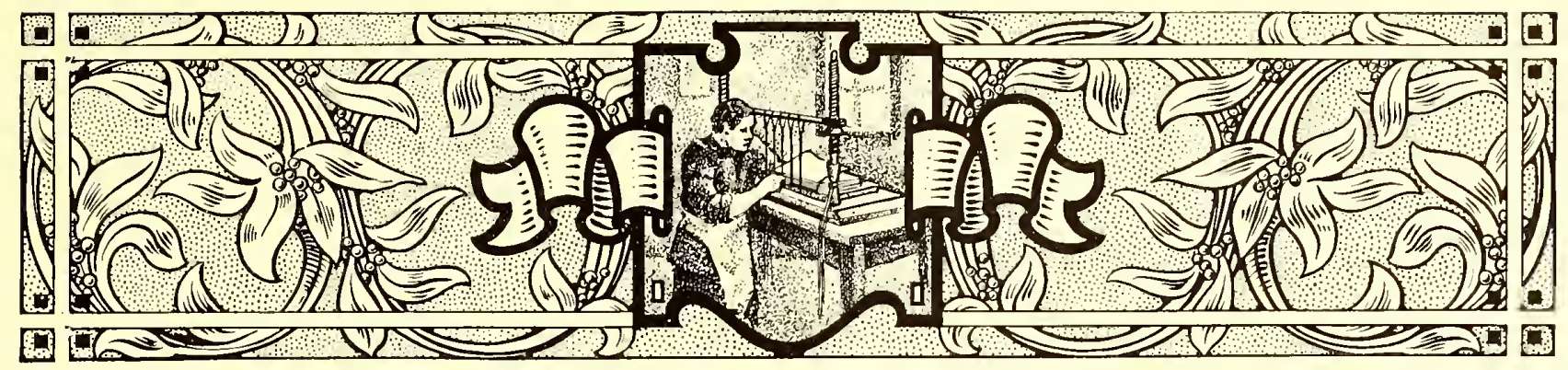

\section{THE TYPOGRAPHY OF BOOKS}

GOOD taste, a quality essential to the successful production of all kinds of printing, is of great importance in the typography of books. In the matter of good taste most of us are specialists - we perfect our judgment in some one respect and let it remain erratic in others. A musician or other artist may stand high in his class and yet, perhaps, show poor taste in dress and manners.

A person of good taste is usually conservative. He weighs all new things in the balance of judgment, and allows enthusiastic faddists to push him off the sidewalk rather than join the crowd and shout with it. He knows the fickleness of mobs and remembers that in a week hosannas have been changed to shouts of bitter invective. The merchant catering to the whims of fashion ever has unsalable stock on his shelves. In the days of militant

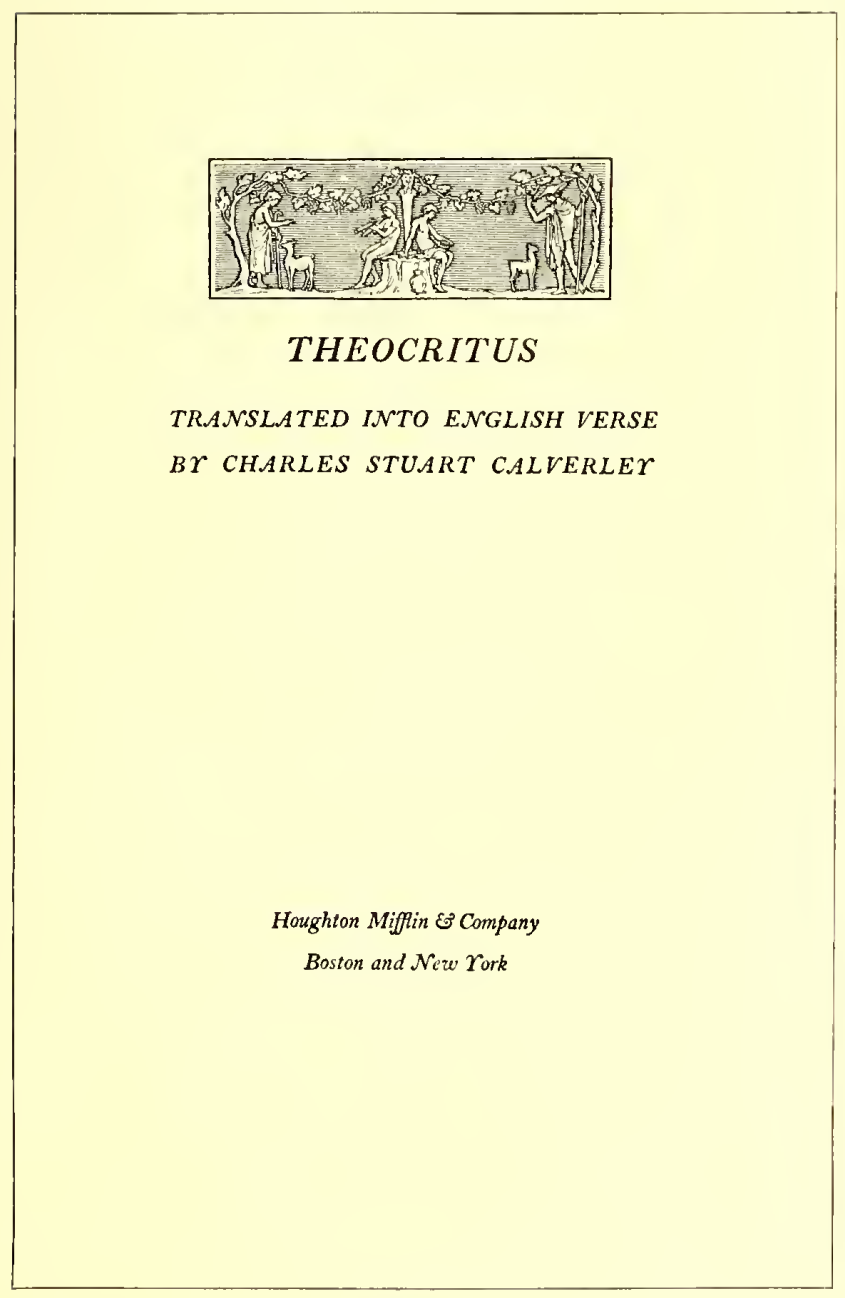

EXAMPLE 128

Appropriate title-page of a book of classic poems. By Bruce Rogers
Rome the crowd which one day cheered Sulla, the next day crowned Marius with laurel.

The natural tendency of humanity is radical. The conservatives are in the minority, yet their influence is great because their opinions are generally based upon sure foundations. Of course a person can be progressive and possess a present-day mind without being either radical or conservative. The natural tendency of job printers is radical. Left much to their own whims and fancies they produce printed things which may please only for the moment. The test of gold is not in its appearance when purchased, but in y ears of wear. Because a job of printing is made for short service is no reason why it should not be as well done as book composition is required to be. All the art-reasons in book typography

\section{JOHN GREENLEAF WHITTIER}

MEMOIR

AND SELECTED POEMS

BY BLISS PERRY

BOSTON AND NEW YORK HOUGHTON, MIFFLIN AND COMPANY MDCccevil
EXAMPLE 129

Title-page with a nineteenth century motive. By Bruce Rogers 
Memories of a Hundred

Years

BY

EDWARD EVERETT HALE

AUTHOR OF "THE MAX WithOUT A COUNTRY," EiC.

VOLUME II

New Hark

THE MACMILLAN COMPANY

LONDON MACMILLAN \& CO., LTD.

I902

All rights rescred
MEMORIES OF A HUNDRED YEARS

\section{CHAPTER I}

THE ORATORS

MODERN AMERICAN ORATORY

$\mathrm{T}$ HE cant phrase of conventional conversation says that the age of oratory is over. I do not believe this. The conditions are changed. The methods are changed. But it is as true as it ever was that if a man wants to lead men, he had better be able to tell men what he wants. And it will be well for hin and them if he can tell them this, so that they shall believe him and remember afterward what he has said to them.

William McElroy, who is himself no inean judge, told me that George William Curtis once said to him that the most remarkable passage in modern oratory, the passage, that is, that is best worth remembering, is the passage well known and often cited in Waldo Emcrson's oration at Dartmouth in 1838. Carlyle speaks of that address as lying on a counter in an Oxford book-

EXAMPLE 130

EXAMPLE 131

Poor examples of book typodraphy. Two pages which set forth the common practice of inharmonious type treatment, the title-page containing old-style type-faces and the text-page modern type-faces. The type-face should be of the same design

are equally applicable to jol typography. The two methods should not be judged by separate standards-a thing is good, or it is not. At the present time educational work is elevating the standard of job typography, and the designer of job composition, drawing closer to his book brother, is beginning to notice the faults and flaws in the latter`s work.

The book typographer, like the lawyer, is governed by precedent. When the legal man presents an argument he cites Doe v. Doe, and Smith v. Jones, and with each new discovery of precedent is increasingly happy. The common law under which we in America are governed originated in England centuries ago, and the radicals who would dispense with this law catalog themselves as anarchists. The right-thinking man is constructive. When a new thing has been proved good he believes in adding it to what has already been constructed. The radical is destructive in that he would destroy what has been constructed and without always setting some new thing in its place. Attics have been known to hold masterpieces which have been discarded for new, frivolous things that from an art viewpoint are worthless.

William Morris set out to change book typography, and in contrast to the typography of the day his ideas may have seemed radical. What he really offered was the good things found in the works of the old masters of Venice and Nuremberg-typography and decoration that had well stood the test of centuries. Book pages produced fifty years ago by Pickering and Whittingham look well today; not because they are old, but because they were in good taste then, and are in good taste now. Pages set by their contemporaries in condensed roman look abominable now, because they were contrary to true art principles then.

The book industry in America is tremendous-so much so that because of its magnitude quality in typography is likely to be lost sight of. In New York City in one year eight million books are read or consulted thru its public library system! Could the monk, with his mere score of books chained to shelves, have had a vision of this, what would have been his thoughts? Or, Benjamin Franklin, as he founded the first circulating library? Andrew Carnegie, ridiculed when announcing his intention to use his wealth in providing buildings for public libraries, lived to see liimself acknowledged a benefactor of mankind.

Next to providing books is the necessity of providing good books and of printing them according to the laws of art and good taste. Continual association develops a taste for the things associated with. If the majority of books are poorly composed or poorly printed, they will unconsciously be taken as standards of book style by the reading public. The style of book typography, averaged in this way, is today far from flattering. It is rarely that the reading pages, title-page and cover harmonize in style and motive. On the average volume the text-pages seem to have been set in any face that chanced to be on the composing machine at the time; the title-page is in some type foreign in style and design to the face used 


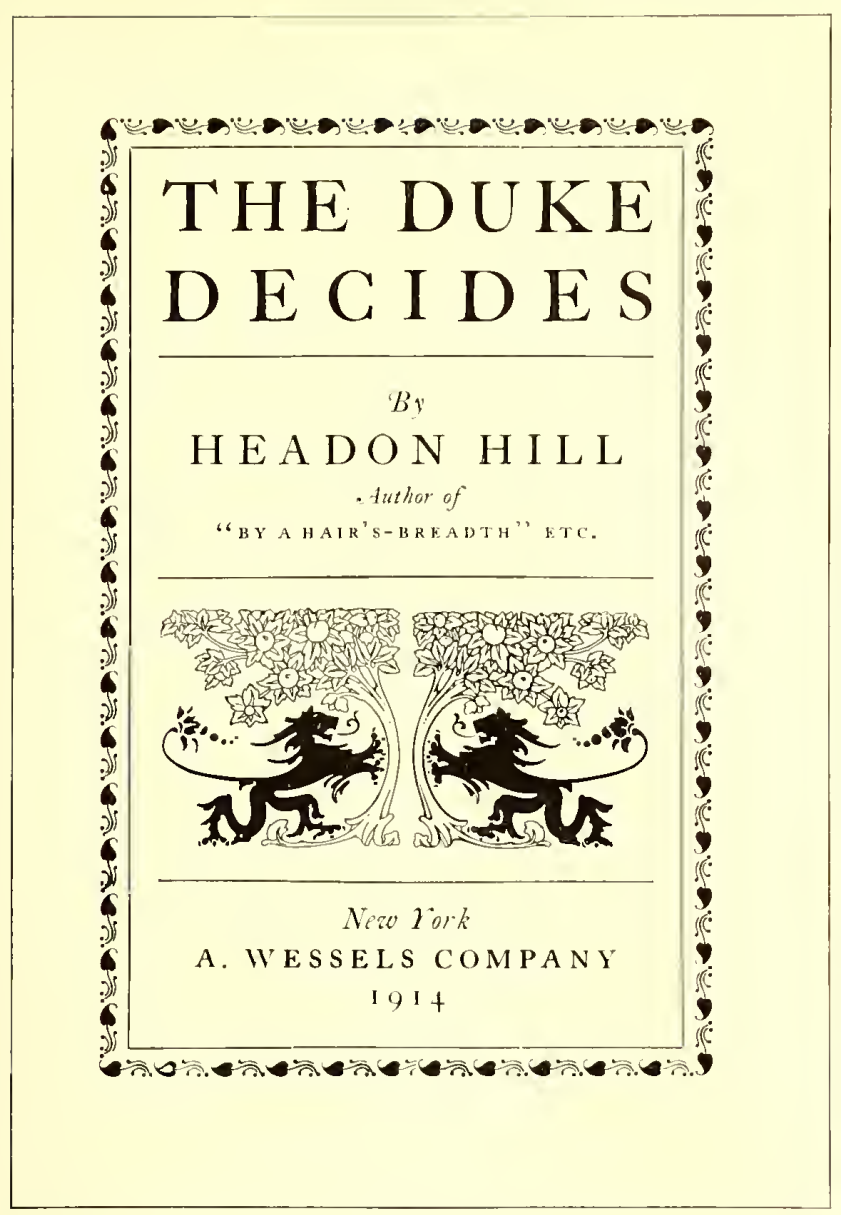

EXAMPLE 132

Two pages of composite Colonial and modern typography. Relation on the body of the book, and the cover (usually the only part of the work given artistic attention) is designed without regard to what is on the inside. The whole effect reminds one of a box of berries with only the healthy members of the family in view. Many a time I have picked up a book in artistic binding, only to lay it down disappointed at the typographical treatment of the inside pages. Even a book should be honestly what it seems, and not a wooden nutmeg.

The book-page reproductions used in connection with this chapter may prove more valuable if each is considered separately in the order of its appearance.

Examples 126 and 127 (Insert). - The title-page and an inside page of a book which in its way is a model. From the viewpoints of art, legibility, good taste, typography, printing, and binding, the book is very satisfactory. The classic restraint of the Italian school and the human interest of the Gothic are here blended harmoniously. These pages will please the lover of lower-case letters, as from the label-title on the cover to the last paragraph of this volume not a line has been set in capitals. 'The typeface is a handsome old-style roman based upon the Caslon model, and in the book itself is printed upon a hard hand-made paper in a dense and clear black ink. The only decoration used in the book is found in the chapter initials, attho decoration is suggested in the use of brackets on each side of the page numbers. Only two sizes of type are on the title-page, and the chapter headings cling to the type-page in a manner that helps the tone effect of the whole. The reproduced pages are shown in the actual positions of the originals. The margins of a full reading page measure five picas at the fold, six picas at the head, seven-and-a-half picas at the outer edge, and eleven picas at the foot. The type-page covers slightly more than one-third of the surface of the leaf upon which it is printed. The type-page in proportion measures diagonally twice its width, a point illustrated in Example 50 of a previous article.

Example 198. - A reduced facsimile of the title-page of a limited edition of classic poems, produced at the Riverside Press under the supervision of Bruce Rogers. This typographer stands among those in America who are giving themselves to the work of steering the printing craft back to the waters in which it sailed in the days of Aldus Manutius. Bruce Rogers came from Indiana with no technical knowledge of typography, but artistic talent soon enabled him to gather the details, and for a number of years he designed books for the liverside Press that brought him fame and helped to raise the standard of printing in America.

Example 199.- There is one feature of Bruce Rogers' work which stands out prominently, and that is his reard for the appropriate. The literary motive of a book gives the cue for its typographic treatment, and he prints as if he were living in the period so presented, and influenced by its tastes. The "John Greenleaf" Whittier" title-page suggests a product of the middle nineteenth century, when Whittier lived, and Example 128 is imbued with the spirit of the Greek Theocritus. But two sizes of type are used in the Whittier page, and these are apportioned according to the importance of the wording.

ExaMPLES 130 AND 131. - Two pages from a book issued by a prominent publishing house and printed by a prominent press. 'They are reproduced for the purpose of point- 


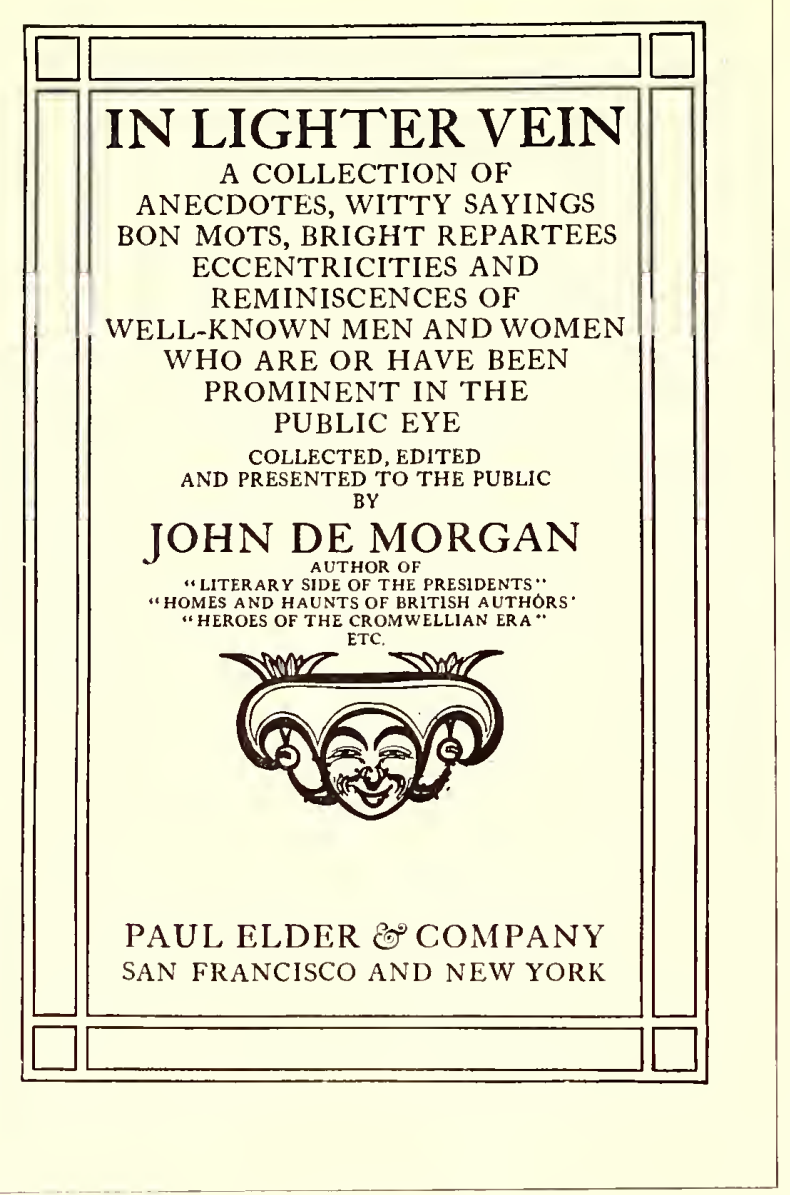

EXAMPLE 134

Two pages, the typography of which shows unusual care and consideration for detail. Typography by J.H. Nash
IN LIGHTER VEIN I 5 I

you're a daft idle body, who goes moaning about the hills, and has not wit enough to raise a field of oats." The child had heard the opinion so of ten that she was well able to repeat, even if she did not understand it.

Dlla Wheeler Wilcox is the $A$ author of an epigram which will live through the ages. It is bright, truthful and terse. She writes: "Divorce is a fire-escape from a domestic hell. But whoever uses it always smells of smoke afterward and usually bears scars and bruises for life."

The Emperor William of Germany got a sharp rebuff at a Court ball some little time since. At a review he had reprimanded the old General von Meerscheidt for losing his presence of mind at a critical moment. "If your Majesty thinks that I am getting too old, I beg of you to allow me to resign." "No, no," replied the kaiser, "you are too young to resign. lndeed, if your blood didn't course through your veins quite so fast, you would be a more useful army leader." On the evening of that day the kaiser met the general at a Court ball. The

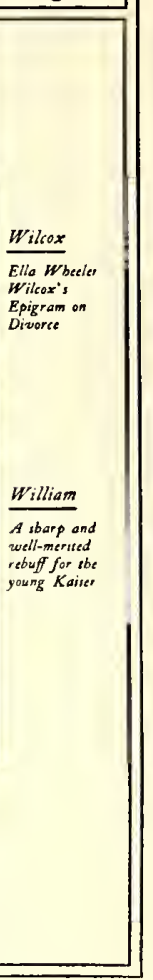

\section{T II E M I L L I O N A I R E'S S O N}

business for literature, but one could hardly marry on such a prospect, and with sueh a father as his in the baekground. Moreover, an engagement at this time would be more than likely to defeat its own ends; yet, after such a scene, his duty to Alexa became imperative. What was to be done?

He had gone no further than this question when her note came. So great was his confidence in her, his reliance in her judgment, that at onee he dashed off the reply, to assure her of this. In first receiving the note he had been relieved, erediting her with some of his own difficulties, and reading between the lines some such message as, "We have gone too fast; and if we see more of each other, it must be on a calmer footing."

It was as if Alexa herself had come to the rescue. But after he had re-read the note five or six times, doubt erept in, and doubt on a vital question. Perhaps, after all, she did not care. Perhaps the note was to say, "I was momentarily earried away, and showed more than I felt." This was horrible, and worse than separation. Yet how could he ask her if she loved him, and yet tell her in the same breath that cvery monition of prudence was against their engagement? Was ever man in more hideous dilemma?

Business was unendurable under these conditions. He left the office early, and made posthaste for Whistle's, delighting her hugely by a request for luneh. After he had caten, his energy rose again. 225

EXAMPLE 136

A text-page in modern roman. By Colonial Press

\section{Che Fainghip of Nature}

tion comes through achievement alone; that the building of character from habit is wrought out only through the play of the individual will. Stultify the will, prohibit its play, and you have at once destroyed its power of growth. The principle of life is movement, and stagnation is death. So that if a thing has no play, you may be sure it has no life.

So, too, if you will follow the trail of the word into meaning of playfulness and amusement; perhaps you will not be far wrong if you declare that play means health. Play is the fine flavour of the spirit, the expression of joy. Just as we gain freedom for the play of our powers, we gain enjoyment in the playfulness of spirit. The animals play, and man in a normal, healthy state takes the universe for his playroom. To be a doleful, puritanic, unsacial Pharisee is to be a degenerate. A sour visage means debauchery of the soul, as truly as other appearances indicate bodily intemperance. To keep the Ten Commandments is not the whole business of man, not his whole 244

EXAMPLE 137

A text-page in old-style type-faces. By Colonial Press 
ing out a fault common to a majority of books of the present day-inharmonious typography. While the text pages are consistent in the use of plain modern roman, the title-page with no regard for the face used on the text pages is composed in Caslon roman and modernized old-style. It would seem that, true to the title, the printer had aimed to present three representative type-faces used during a hundred years. And, to make matters worse, the cover contains an elaborate twentieth century design. Why do not publishers realize that these things are wrong? Why do not printers realize it? After the six liundred pages of this book had been set in modern roman, the cost of setting a title-page also in modern roman would have been ridiculously small. Printers doing work for publishers should provide display faces to match their machine letters, or else when buying matrices of a body face, assure themselves that display faces may also be had. Artists, too, should be cautioned to make their design not only after the motive suggested by the literary contents of the book, but also after the typography (which should of course be based upon the literary motive).

Examples 132 and 133. - Two pages in style composite Colonial and modern. Relation between the reading pages and the title-page is established thru use of type of the same series and also by adapting the flower decoration to the running head. Certain books lend themselves to decoration; this is one of them, because it is of the entertaining sort. Serious books, such as those on the subjects of law,

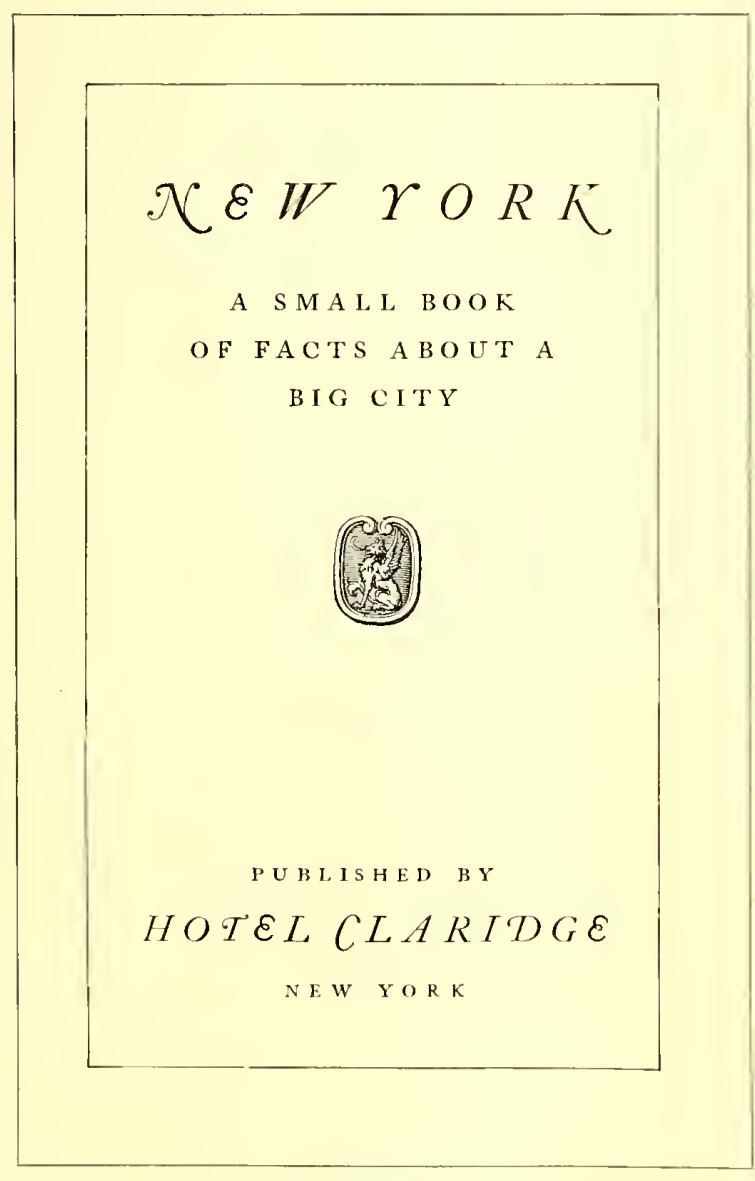

EXAMPLE 138

Title-page with an Italian motive. By Oswald Press, New York

\section{The Tenth Chanter.}

How Efree came to Play a Cune for the King 6 Queen. And of fow the King was not pleased with the Husic. Also more about Rolie Polie.
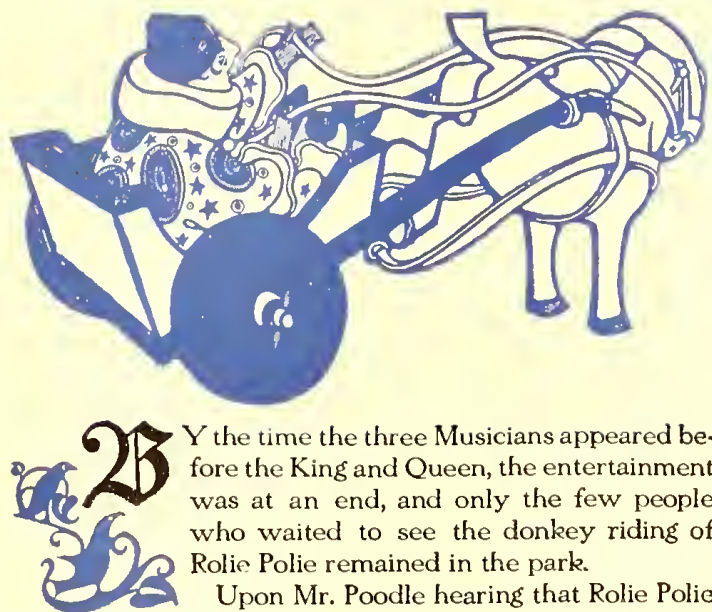

$Y$ the time the three Musicians appeared be fore the King and Queen, the entertainment was at an end, and only the few people who waited to see the donkey riding of Rolie Polie remained in the park.

Upon Mr. Poodle hearing that Rolie Polie proposed to give a performance, he hurried off to find the little clown, and put an end to his plans. "There is no telling, your Honor," he said to the Mayor, "what that little clown of mine may do; he is apt to be up to all kinds of tricks, and if he once gets astride his donkey and tries to perform in this park, something serious is sure to happen."

$$
75
$$

EXAMPLE 139

Page from a children's book, designed and written by Will Bradley

medicine and science, should have no decoration. The wise book typographer will not use decoration unless he comprehends just what he is doing.

Examples 134 and 135.-J. H. Nash, who designed the typography of the book of which these two pages are a part, produced results that are exceptionally good from a typographic point of view. The border as seen in Example 134 was used on the title, introduction and contents pages, and the border in Example 135 was used thruout the text pages. The crossed-line border effect was even adapted to the frontispiece. The title-page is an excellent example of consistent typography; not a line of lower-case is to be found on the page, and prominence is proportionately given the title of the book and the names of author and publishers. The reading matter is set within six points of the rule border, that the page should have but one margin. If the space between type and border were larger it would give the appearance of another margin. The initial letters assist the reader in locating the beginning of each story.

Example 136. - This page is in a style associated with the modern novel and was set on the linotype in eleven-point Scotch Roman; the lines twenty picas wide, leaded with twopoint leads. The running head is in capitals of the body letter, separated from the reading page by a half-point rule, and the page number is centered at the foot.

Exampe 137. - A good example of modern book composition, set on the linotype in twelve-point Caslon Old Style, the lines twenty picas wide, separated by four points. The running head is in a black text letter suited to a book of this kind. An amount of space equal to a line of type and the leading following it, has been placed between the ruming head and the reading page.

Example 138. - No style of typography is in such good taste as that which is based on the old Italian, in which but one 


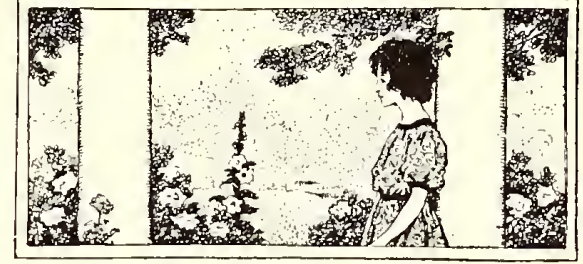

CHAPTER III

IN WHICH I SEE A NEW KIND OF FOG

$\mathbf{W}^{\mathrm{E}}$ had bread and milk and hot gingerbread for supper. I noticed with satisfaction that there was no cream on the milk. I did not like cream when I was a little girl.

"Fannie isn't a cream cow, is she, Cousin Sally?" said I, as I crumbed my bread.

"No, she's a red cow," answered Cousin Sally.

"Brown, you mean," Kitty corrected.

"She's what you call a red cow," her mother rejoined.

"I don't mean that," I said. "I mean, she doesn't have cream on her milk."

"Doesn't have cream on her milk!" exclaimed kitty. Cousin Sally's face turned red and she looked at me sharply; she thought that I was finding fault with the milk she had given me.

EXAMPLE 140

Harmony in tone of type-face and decoration.

Typography by the Trow Press, New York

style of type-face, usually the Caslon, is used, and the capitats letter-spaced a trifle. This style has been worked into a symmetrical page and an ornament included that because of its ltalian treatment blends neatly with the typography. It might be interesting to note that the illustrations in this book were in line, and where emphasis was needed in side headings small capitals were used and the letters separated by slight spacing.

liximpte 139. - A page from a book for children, written and illustrated by Will Bradley. The type-face is a wide, legible letter and was specially designed by Mr. Bradley. Each chapter is begun with a line of old English black letter, followed by several lines of highly decorative italic. The illustrations are interpreted in the grotesque decorative style that Bradley does so well. The running heads and page numbers are in the italic.

Example $140 .-A$ page notable for the harmony between the tone of the type-face and decoration. The illustration has been treated by Beatrice Stevens in a decorative spirit, and is very effective. The capitals of the body matter are used for the "Chapter 111 " line, and smaller capitals for the descriptive line under it. The plain initial is more effective than an ornamental one would have been.

Example 141.-A title-page of classic design in Scotch Roman type. The anchor and dolphin, originally the device of Aldus, as enlarged in outline has much to do with the effectiveness of the page. The dignified beauty of this page makes it worthy of close study.

Exanple 142.-A further demonstration of the beauty of classic typography. Fred. IV. Goudy has done many

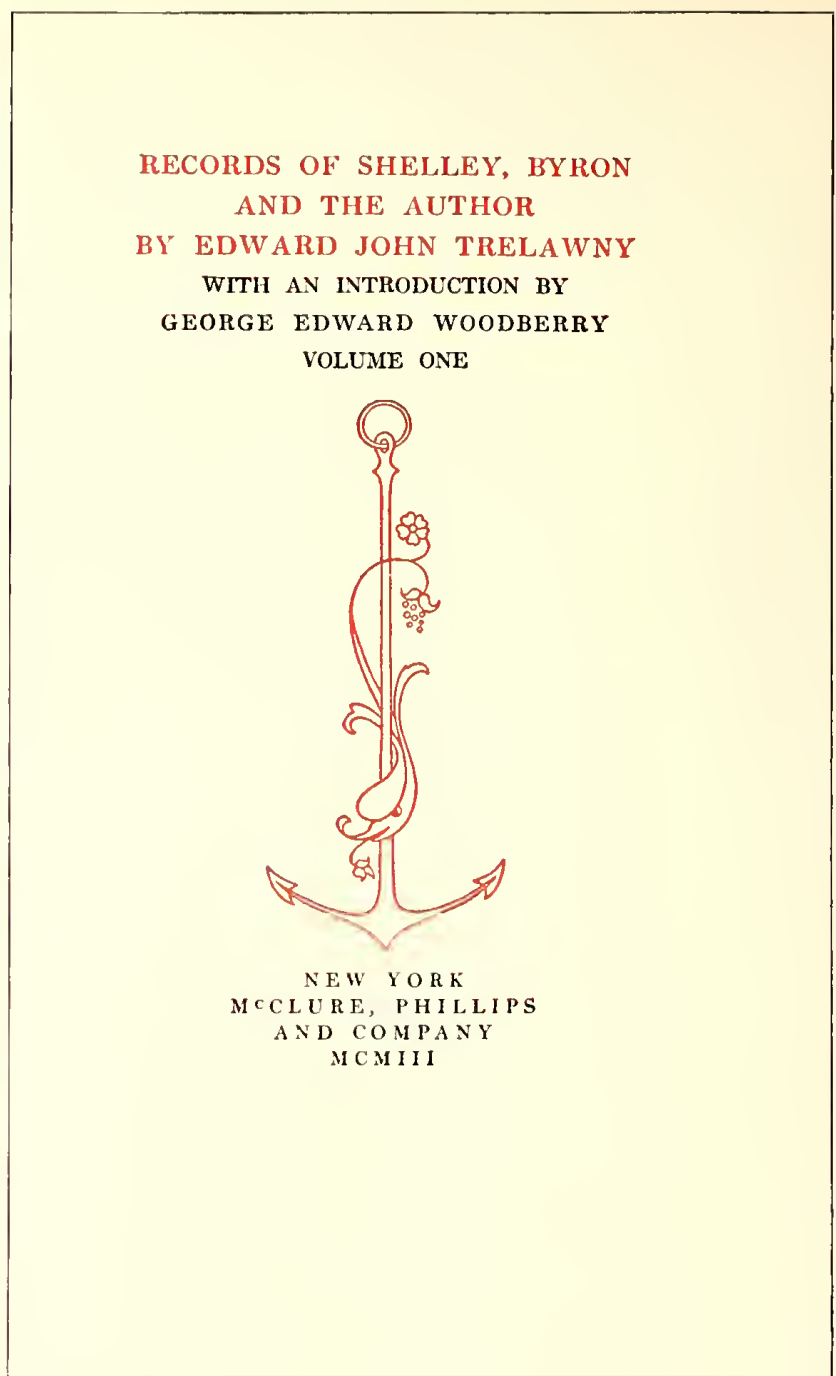

EXAMPLE 141

A title-page of classic design, with an Aldine anchor device. By William Aspenwall Bradley

things worth while, but none better than this. He not only designed the smaller type-faces and lettered the large lines in harmony, but arranged the page and, in its original form, printed it. American typography owes much to Mr. Goudy and it is a pleasure to include this page here.

Example 143. - This is a page from one of the Roycrofters' serious efforts in bookmaking. It was printed in dense black ink on white stock, the large text initials standing fortlı in pleasing contrast.

Example 14. - This is a page from a book by Theodore L. De Vinne, and probably presented his personal ideas in book typography. Notice the spacing around the subheading, and the treatment of footnotes. The first line under the subheading is not indented.

Examples 145 and 146.-D. B. Updike, of the Merrymount Press, is responsible for the typography of these pages, which are a portion of a book containing the ceremony of marriage as performed in the Protestant Episcopal Church. The type is a special letter based upon early forms. The book was printed in black and vermilion. Mr. Updike, with Rogers, Goudy and others, believes that the way to improve typography in America is to do typography as well as it can be done. He established the Merrymount Press in 1898, and has arranged and printed many fine volumes, in addition to much high-grade small work.

Exanple 147.-Books of poetry are usually treated in a typographic style that is light and dainty. The typog- 


\title{
THE DOOR IN THE WALL And Other Stories

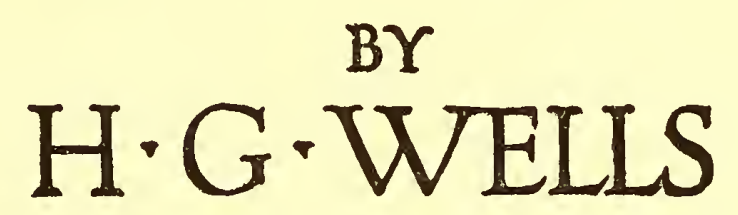 \\ ILLUSTRATED \\ WITH PHOTOGRAVURES FROM PHOTOGRAPHS BY \\ ALVIN LANGDON COBURN
}

NEW YORK \& LONDON MITCHELL KENNERLEY

\author{
MCMXI
}





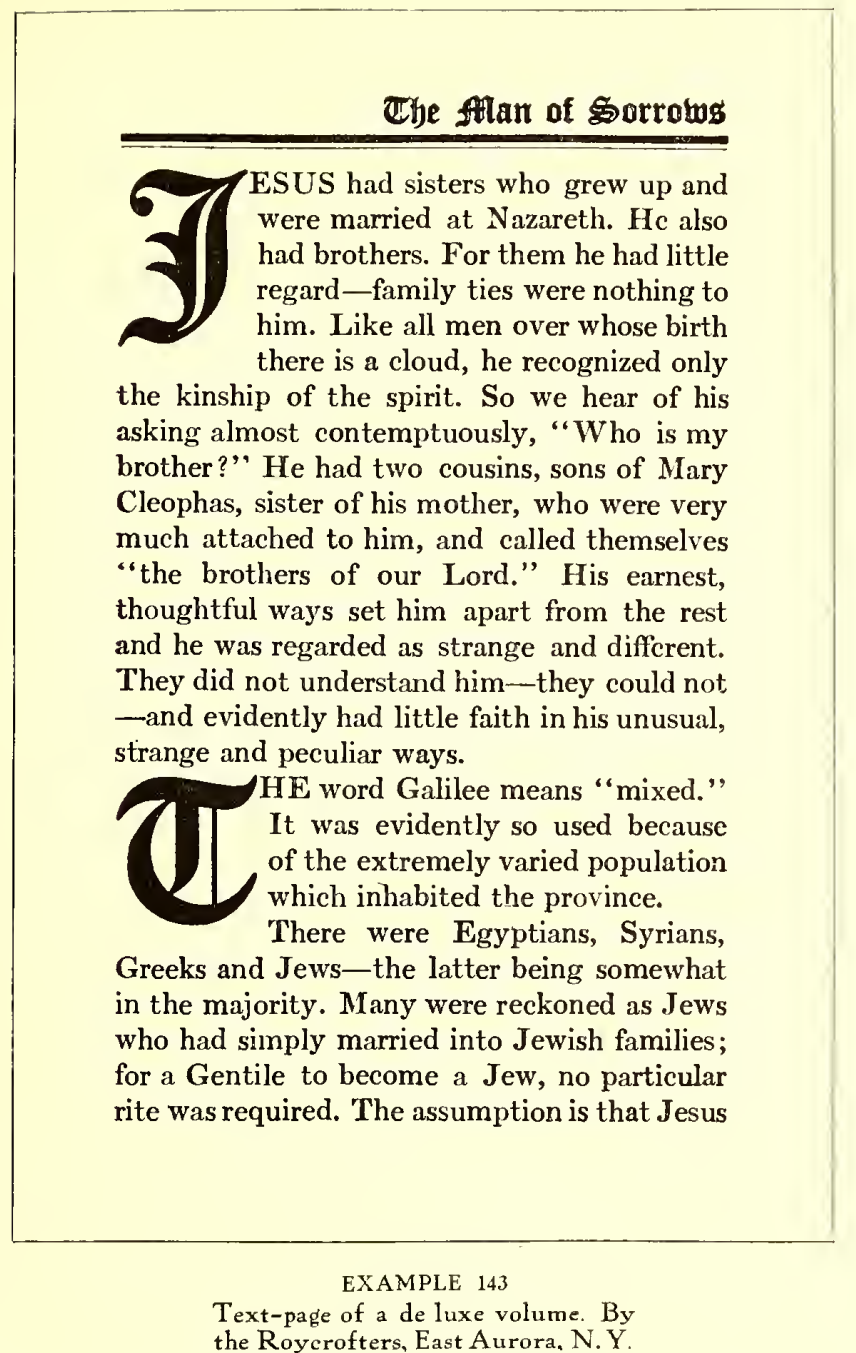

rapher who has the spirit of the artist in him puts more into a book than is required by the traditions of the craft and endeavors to express with type and decoration the spirit of the poet's message. The verses of Edgar Allan Poe, with their suggestion of dark shadows and pathos, make the book designer's task difficult, but in this example Mr. Nash has given the work a decorative treatment that in its dark tone helps to beautify the sad spirit of the great American poet. Washington Text shows forth admirably as a type for these pages and the decorative panel harmonizes with it in both tone and design. In its original form the book was printed in lull black and dull red inks on a toned handmade paper. The liberal margins assisted in giving that touch of exclusiveness and taste that is essential in good book-printing.

Example 148.-French

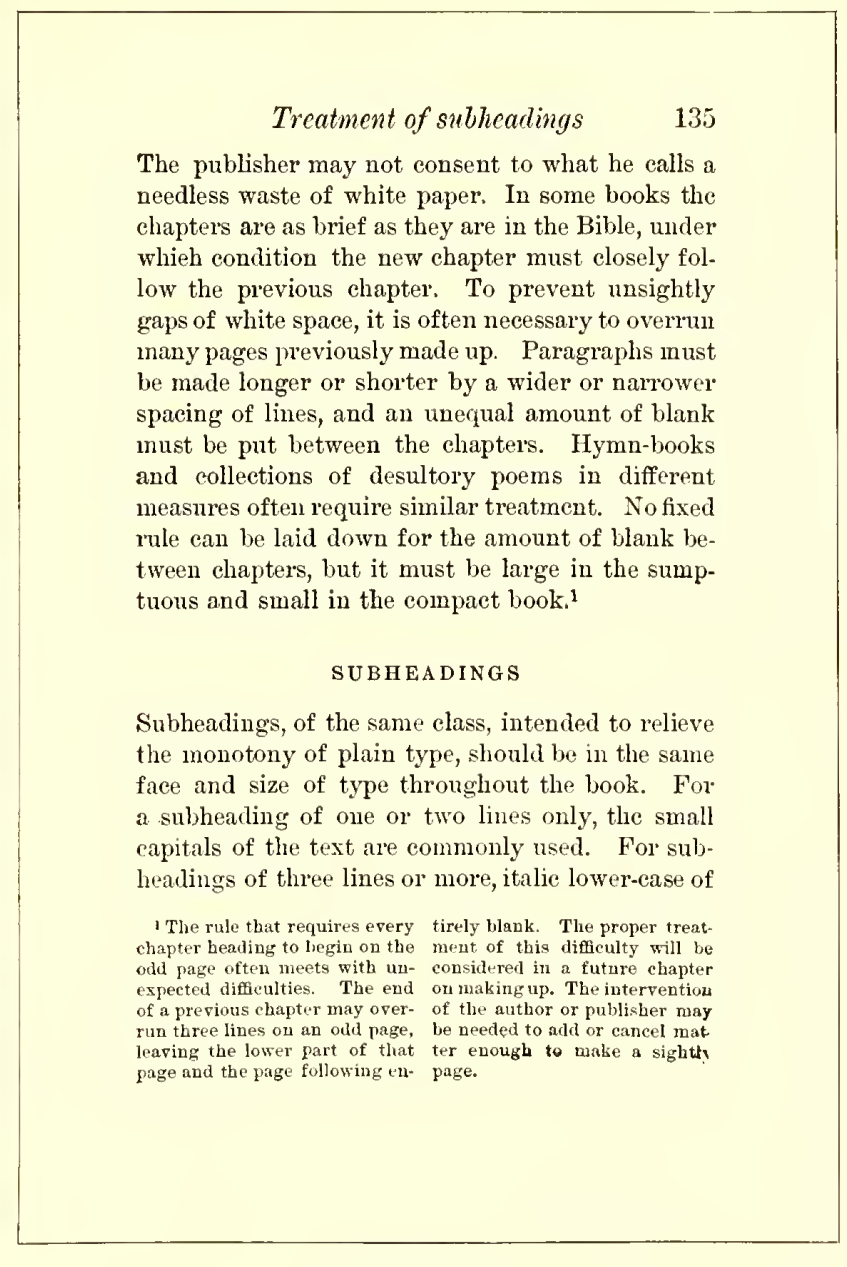

EXAMPLE 144

Text-page from a book by De Vinne. Note treatment of running titles, subheadings and footnotes

title-pages of the eighteenth century are furnishing motives for the desioning of cover and title-pages for the uses of
Crege form of Soleminization of (4)atrimony: Tosether with a fetrifuate of martiage

Mew 2ork: Eowin S. 1Boefan flouth Frenue and peii Steet

\section{(The form of Solemnization of (2)attimonp}

TFit the day and time appointed for Soleminization of (t)atris monp, the pere one to $6 e$ innerisd offapl coine into the body of the CGurch, or afate be readp in some proper Gouse, with their friendo and neigh ing togetfier, the (t) an on the right Gand, and the Woman on the feft, tịe (A) inister ohall a ap,

2 EAik $\mathbb{L}$ Gefoved, we are sathered together Gereinthe eight of tBos, and in the face of thice company, to join together this $\left(\begin{array}{c}\text { an } \\ \text { and }\end{array}\right.$ this Woman in hofp (t)atrimony; which io an honouta6le eotate, 


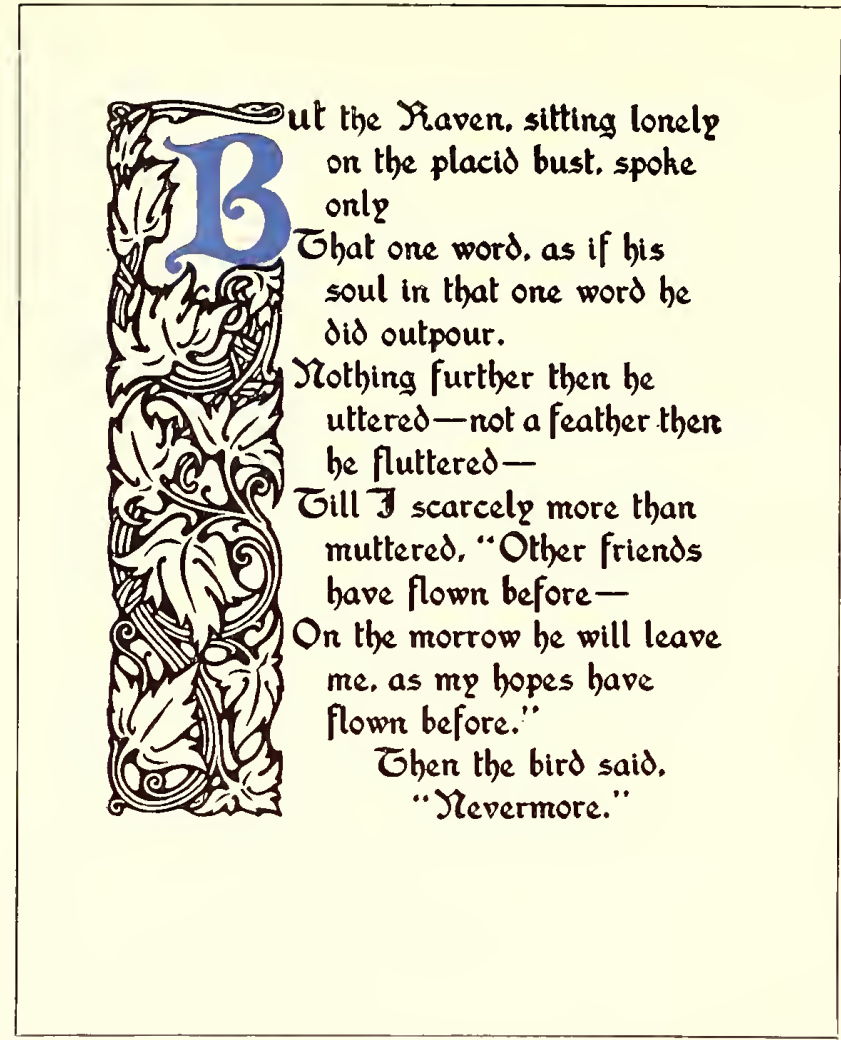

EXAMPLE 147

Gothic treatment of a book of poetry. Typography designed by J. H. Nash for Paul EIder E Company

publishing and advertising, and to many this page by Bruce Rogers will have considerable intercst. The design carries the spirit of an age when decoration was rampant and when architecture and books were festooned and adorned with cupids. The decorative lettering used in the main title shows such influence. This book in its first chition was printed in 1789 , and when recently reprinted the typographic spirit of the old volume was incorporated in it. It does not measure up to the recently accepted ideas of tone-harmony and shape-harmony, yet the clement of appropriateness is so strong that those shortcomings are not to be held against it.

Custom has developed a law for the arrangement of the several parts of a book. There is first a blank leaf known as the fy-leaf, followed by a leaf with the title of the volume in small type slightly above center or placed toward the upper right corner. The frontispiece, if one is used, is then inserted. The next leaf contains the title-page, which usually gives the titlc of the work, name of author or editor, place of origin, name of publisher and date of issue. On the back of this leaf, slightly above center, is the copyright notice, and in the lower center or right corner the imprint of the printer. The table of contents and the table of illustrations follow, taking as many pages as are necessary. The preface, or author's introduction, is next, after which another half-title may be inserted ahead of the first chapter. The dedication, at one time occupying a page in the fore part of the book, is occasionally used. The index is inserted in the rear of the book. This rear-index is not found in novels, but in books on technical subjects and those used for reference purposes.

It is customary to number book pages with Arabic numerals beginning with the first chapter, all pages in advance of the first chapter being numbered with lowercase lioman numerals. The page numbers, when at the foot, should be separated from the type-page by the same amount of space used between the lines. There is ten-

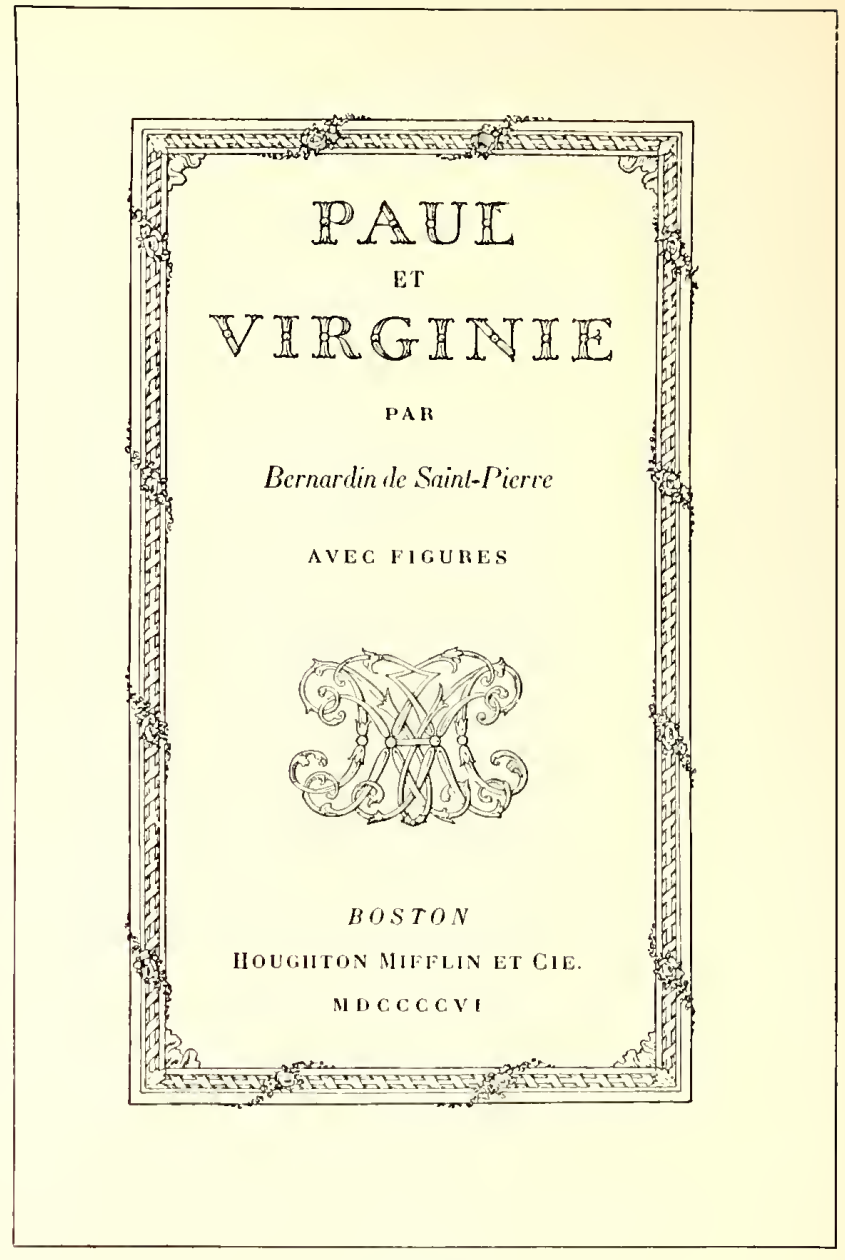

EXAMPLE 148

Where a French style of treatment is appropriate. Designed by Bruce Rogers

dency among inexperienced printers to place the numbers too far from the type-page.

There is a rule that the running title should be separated from the type-page by space equivalent to a quad line of the size of body-type used, altho the best typographers prefer only about half that amount of space.

Parges containing chapter headings are lowered at the head below the regular page hight. Example 127 shows a lowering of five picas space. Other books show more or less than this amount of space, but the space allowed in this example is pleasing.

When an initial is used the space between it and the type should be the same, botll at the right side and foot of the initial.

The position of a book page should be toward the binding and the head. In elaborate books of wide margins this inclination should be great, but in the conventional book of narrower margins it should be less noticeable-say six points toward the binding and eighteen points toward the head.

The use of an em-quad between sentences on a book page is encouraged by many printers, but the newthought compositor uses two three-to-em spaces or less. By referring to example 127 it will be found that the same amount of space separates all words in one line. The capital letter seems sufficient indication of the beginning of a sentence. In the first book printed from separate types (see reproduction of page from Gutenberg's Bible in the chapter on "The Origin of Typography") there was no space used between sentences, the period in the judgment of the printer separating the words sufficiently. 



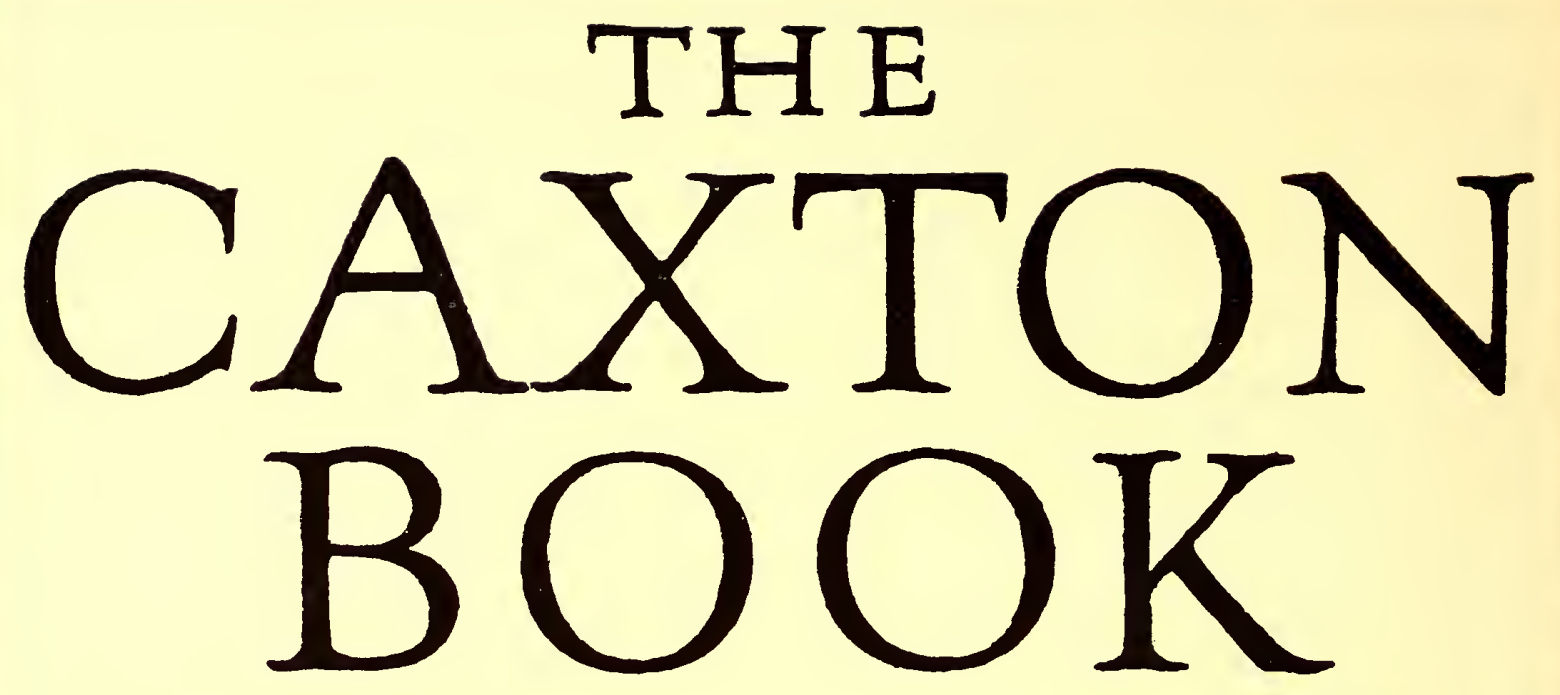

A FEW RECORDS OF THE PAST·BE' ING PROPHETIC OF THE FUTURE
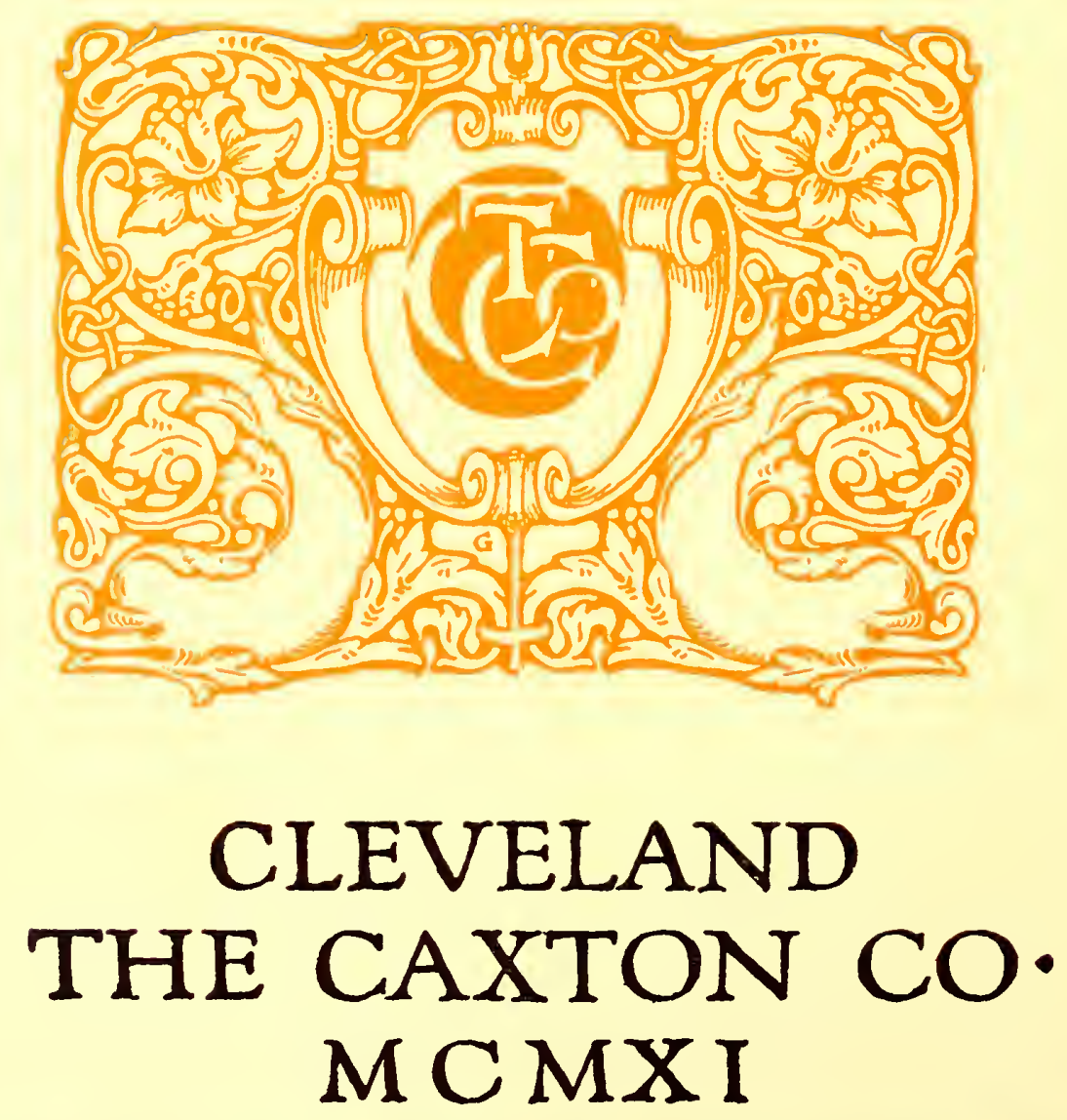

EXAMPLE 149

Title-page lettering and decoration by F. W. Goudy, for the Caxton Co., Cleveland, O. 


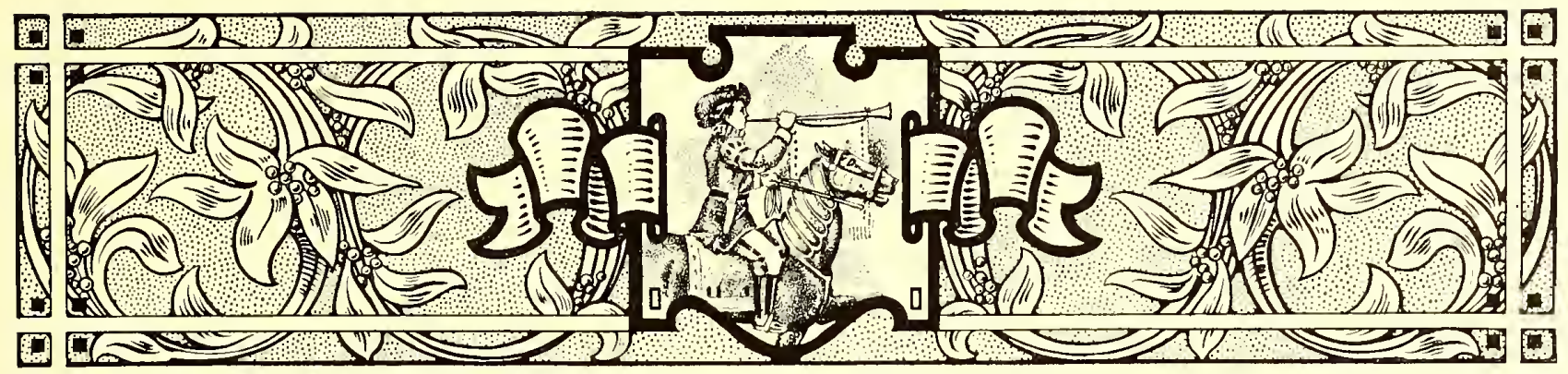

\section{BOOKLETS,PAMPHLETS,BROCHURES,LEAFLETS}

DID I wish to be flippant I would open this chapter by asking, "When is a booklet not a booklet?" and might even bc pardoned for doing so, for no other word has been so misused as lias "booklet."

A booklet, the dictionaries tell us, is just a little book, as is indicated by the suffix "-let," which termination forms diminutives from French and English nouns. Yet "booklet" has been used to designate not only little books, but big books, and has led to the rather tautological description, "a little booklet." When does a booklet cease to be little, and is its littleness in its dimensions, in the number of printed sheets, or in some other feature not recognized in a hurried consideration of the subject?

Going back to the lexicons-

A booklet, as has been said, is a little book.

A leaflet, according to the Standard Dictionary, is "a little leaf; also a tract." Webst er says it is " a sheet of small pages which are folded, but not stitched; a folder."

A pamphlet, we understand from the Standard, is "a printed work stitched or pasted, but notpermanentlybound; a brief treatise or essay.", Webster says it is "A book of a few sheets of printed matter, or formerly of manuscript, commonly with a paper cover; specifically, sometimes, any such work not in excess of eighty pages, and not bound." The word "pamphlet" was derived from a popular Latin poem, "Pamphilus," of the twelfth century.

"Brochure"" is a French word often used for "pamphlet." Webster gives its meaning as "a printed and stitched book containing only a few leaves; a pamphlet; a treatise or article publish ed in such form."

A circular is a letter or a note, usually printed.

However, for the purposes of this chapter, while I shall endeavor so far as possible to use one of the above approved terms in designating the various examples of printing, the word "booklet" in some instances may have a wider application than "a little book."

The chapbooks sold in the seventeenth cent ury, contain-

ing abbreviated stories, were, perhaps, prototypes of the booklet; but as now used the booklet is a modern conception. It is a result of development in asthetical knowledge among advertisers and the buying public, who have learned to discriminate and to demand artistic, tasteful work manship. When the "dodger" or liandbill ceased to be effective as a publicity auxiliary to the newspaper, the booklet was born. State laws consider a few placards or publication in one or two obscure newspapers sufficient notification to the public, but the advertiser knows the futility of such obsolete methods and gets his messa ge to tl e public in numerous ways - traveling salesmen, newspapers and magazines, trade, technical and class publications, houseorgans, catalogs, booklets, circulars, posters, novelties, car cards, electric signs, etc. To an extent the booklet's mission is educational; it introduces the business house, gives authoritative answers to questions that the prospective buyer would naturally ask, explains advantages and gives reasons for superiority. 'The booklet is best if writ-

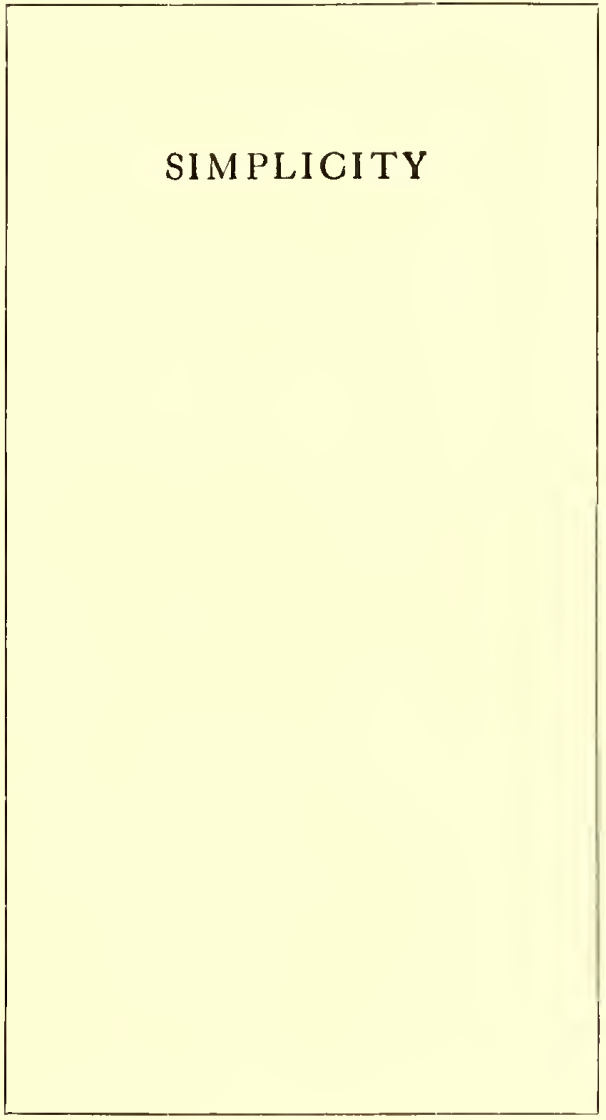

EXAMPLE 150
Simplicity in type arrangement is rare-good taste in the display of type is absent in most of the printed things one sees.

This shop is built on the idea of simple and direct type arrangement and designs that will carry a message easily and directly to the mind of the reader.

Note how pleasing a simple bit of type may be, when it is arranged in good taste and properly printed.

Simple directness is effective. This circular is simple and not unusual, but it's very legible. It shows how easily a printed thing may be read.

No one can ignore the 1mportance of the printed message.

We can help you.

The Marchbanks Press 114 East $13^{\text {th }}$ Street New York exponent of simplicity in typography. By the Marchbanks Press, New York 


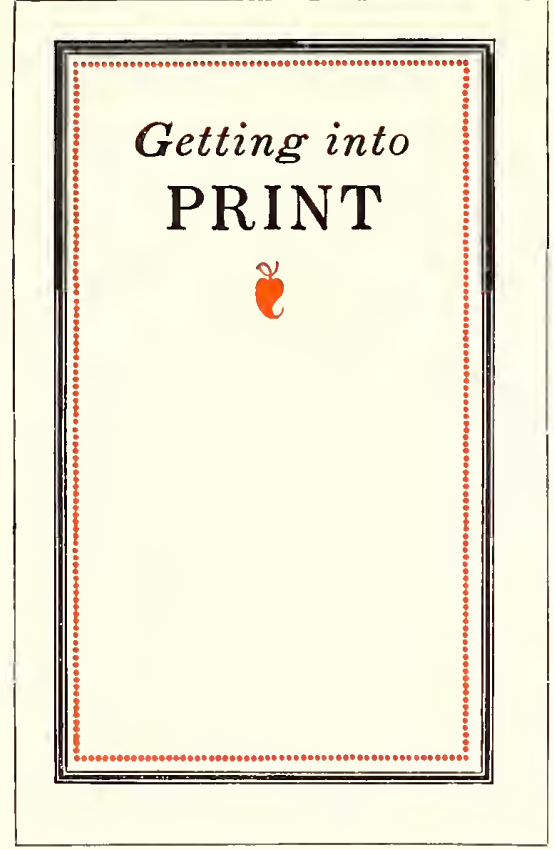

EXAMPLE 152

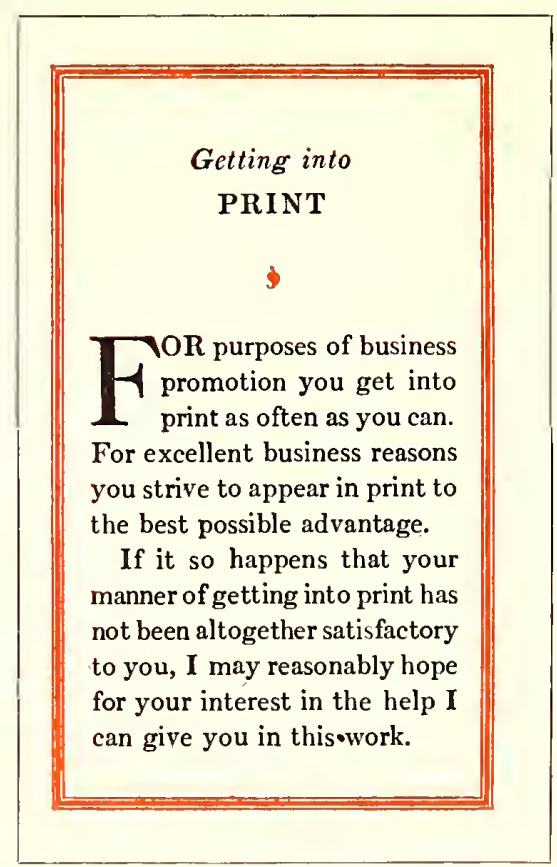

EXAMPLE 153

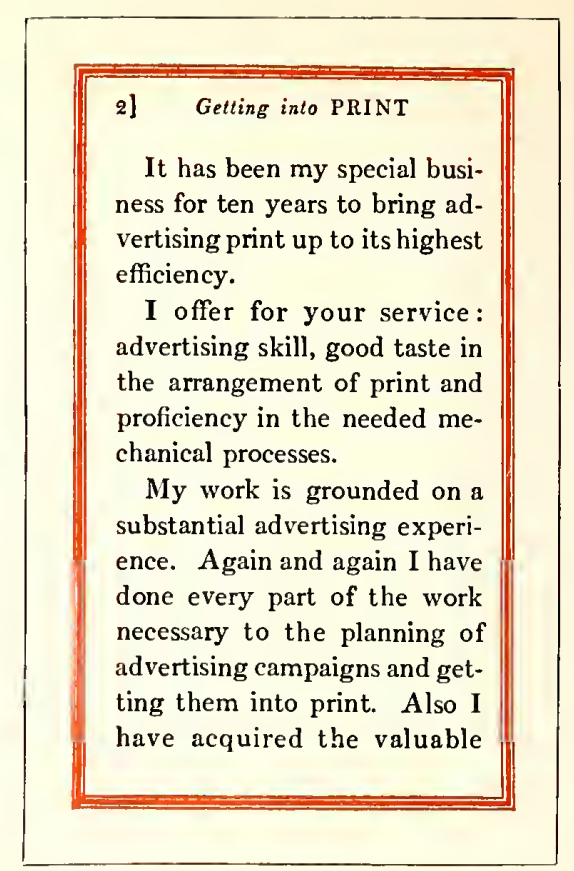

EXAMPLE 154

Three pages from an easily read booklet in Scotch Roman, showing the typographic style of Benjamin Sherbow, New York

ten in a style that is non-technical, and slould be treated by the artist and printer in a manner that will interest the recipient.

Among the users of the booklet as a publicity medium are railroads, cities, hotels, real-estate companies, banks, clothiers, educational institutions, printers, and manufacturers of automobiles, musical instruments, cameras, and tools and equipment of many kinds. If one wishes to purchase intelligently a piano or other expensive article he obtains a booklet on the subject, and whether he buys or not depends largely upon the impression obtained from the booklet; if it is well written, informative, carefully illustrated and handsomely printed, it will be likely to exert an influence in favor of a sale. The printer's share in producing such a booklet is large, altho he is called upon to work in conjunction witl the writer, the artist and the engraver.

Much of the booklet printing is planned by advertising writers and commercial artists. The best results are obtained when artist and writer blend their idleas harmoniously; this is possible only when the writer has artistic tastes and a definite understanding of typography. In many booklets the text matter does not fit the decoration. I have in mind an instance in which the artist laid out sixteen pages of marginal illustrative decoration, and the writer supplied only about half the copy necessary to fill the sixteen pages. To overcome the deficiency the printer set the text matter in an excessively large size of type, but even then the space left for the reading matter was only partly filled. If the writer was unable to fill the space, the artist should have decreased the number of decorative pages or else planned his decoration to cover more surface.

Those houses that have made a success of booklet printing produce a job that is harmoni-

Two pages from an eight-page leaflet, in which the typography was relied upon for results. The rule borders were printed close to the edges of the paper. By William Henry Baker, Cleveland, $O$. 


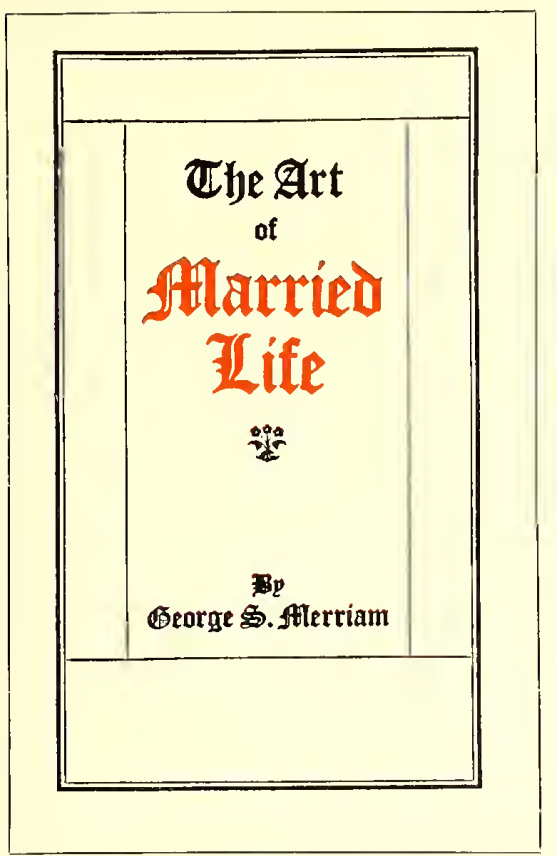

EXAMPLE 157

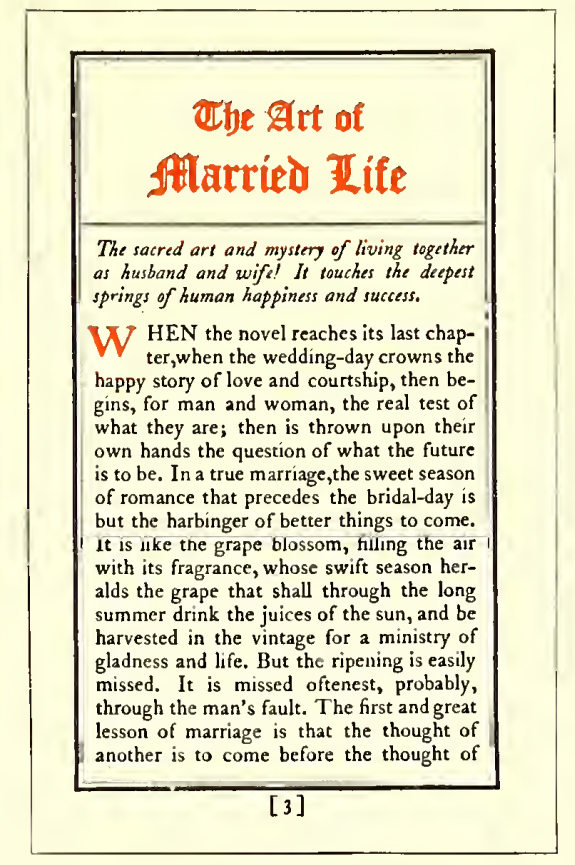

EXAMPLE 158

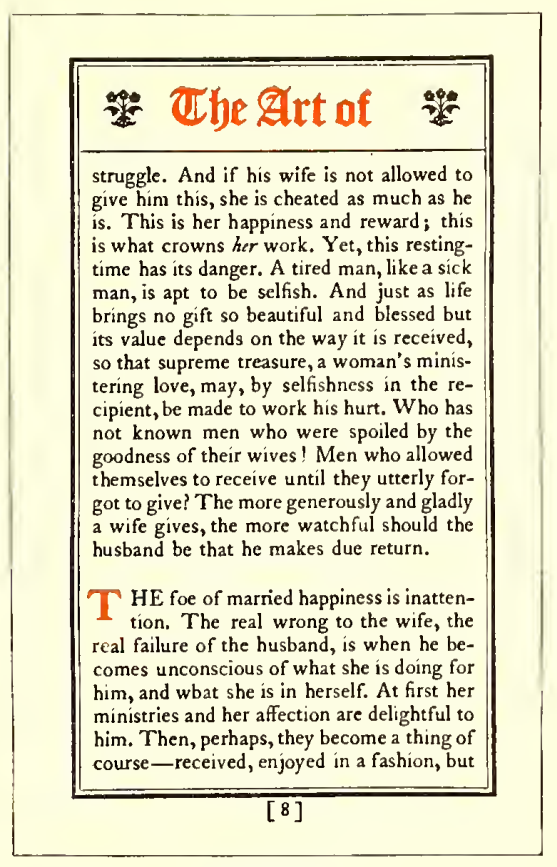

EXAMPLE 159

Three pages that demonstrate the possibilities of type and rule in obtaining effective results. By Barnard J. Lewis, Boston, Mass.

ous and complete. Reading matter, illustrations, decoration, paper, ink and color treatment, all blend on their booklets. There is a central motive around which all concerned in the make-up of the booklet weave their ideas.

Altho such a condition is ideal, it is not absolutely necessary, and it is not always profitable, for a printshop to have under its roof a complete equipment for producing every detail of a booklet. One of the successful producers of booklets - an artist witl associates able to interpret his ideas-had in liis artistic suite of offices a palm which he enjoyed showing to visitors who asked to see the "plant." On the other hand, there is the head of a large printing concern producing high-class booklets who has artistic ideas but who depends upon the open field of artists and engravers to develop and perfect his plans. He manages to meet a prospective customer and from conversation with him learns something of his tastes and preferences. This printer then selects an artist whose style of work will most likely appeal to the customer and be best for the purposes of the booklet. He assumes that the most successful artists are those who have specialized on some one kind of work-classic Roman lettering and decoration; seventeenth-century French decoration; Old English or American colonial effects; modern German coloring and decoration; art-nouveau creations, the serious and the humorous; illustrations of child life, or of the Civil War period. While there are versatile artists like Will Bradley who can do good work in many styles, they are not numerous.

Some printers retain typographic artists who serve clients by the hour. These artists sometimes are advertising writers who have studied the art side of printing and know that nuch depends upon tlie type-face used.

To plan a booklet properly the commercial printer must know something of the principles of art and advertising and of good book typography. Booklet printing is really the connecting link between job printing and book printing. The unconventionality of job typography and the dignity and conservatism of book typography can successfully be blended in the booklet.

Example 149 (Insert). - This style of title-page is appropriate for a booklet or brochure in which the typography plays an important part in the production. The printer having plates of this kind delivered to him should for the remaining pages endeavor to use a type-face which has some relation in style to the lettering found in this example. The page having been drawn by Frederick $W$. Goudy, one of his type-faces would, of course, be most harmonious, but other old-style letters such as Cloister Oldstyle, Caslon Oldstyle and Old-Style Antique would also be suitable. Some of the pages would possibly include initial letters drawn in the same style as the decoration, and thruout the work the motif established by the titlepage should be maintained. An antique-finished paper blends best with the general decorative plan, but if coated stock must be used it should be of a dull finish. Art work of the quality of this example cannot be procured from every artist. This example is expressive of the personal taste and talent of Goudy.

Examples 150 and 151. - The printer in the main must be his own artist, and he can best serve himself and his customers on such occasions by providing pure typographical effects. 'This is diffcult. The printer must have studied good typography. hemust know typography not only as a worker at the trade but as a student of the art. He must be thoroly acquainted with type-faces. His type equipment usually shows hisknowledge in this regard; if it consists of odds and ends of typefaces aimlessly selected, he is not in a position to give liis customer the proper service, but if his

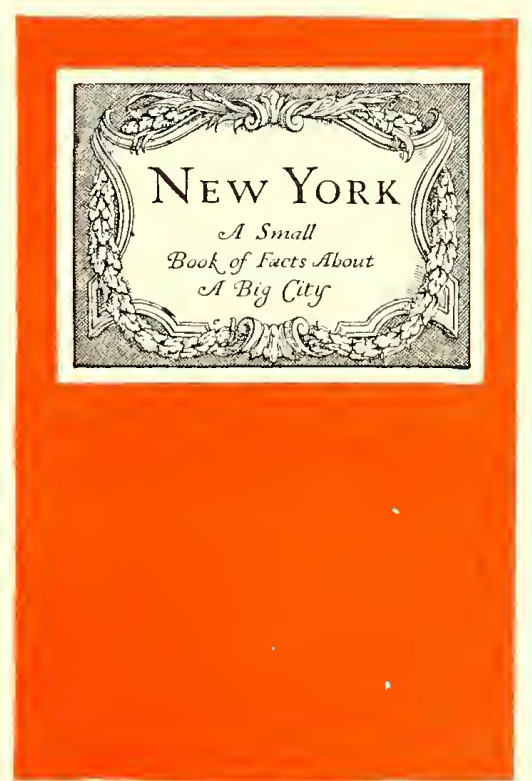

EXAMPLE 160

A label pasted on a brilliant cover stock is striking. Designed by Thomas Maitland Cleland for the Oswald Press, New York 


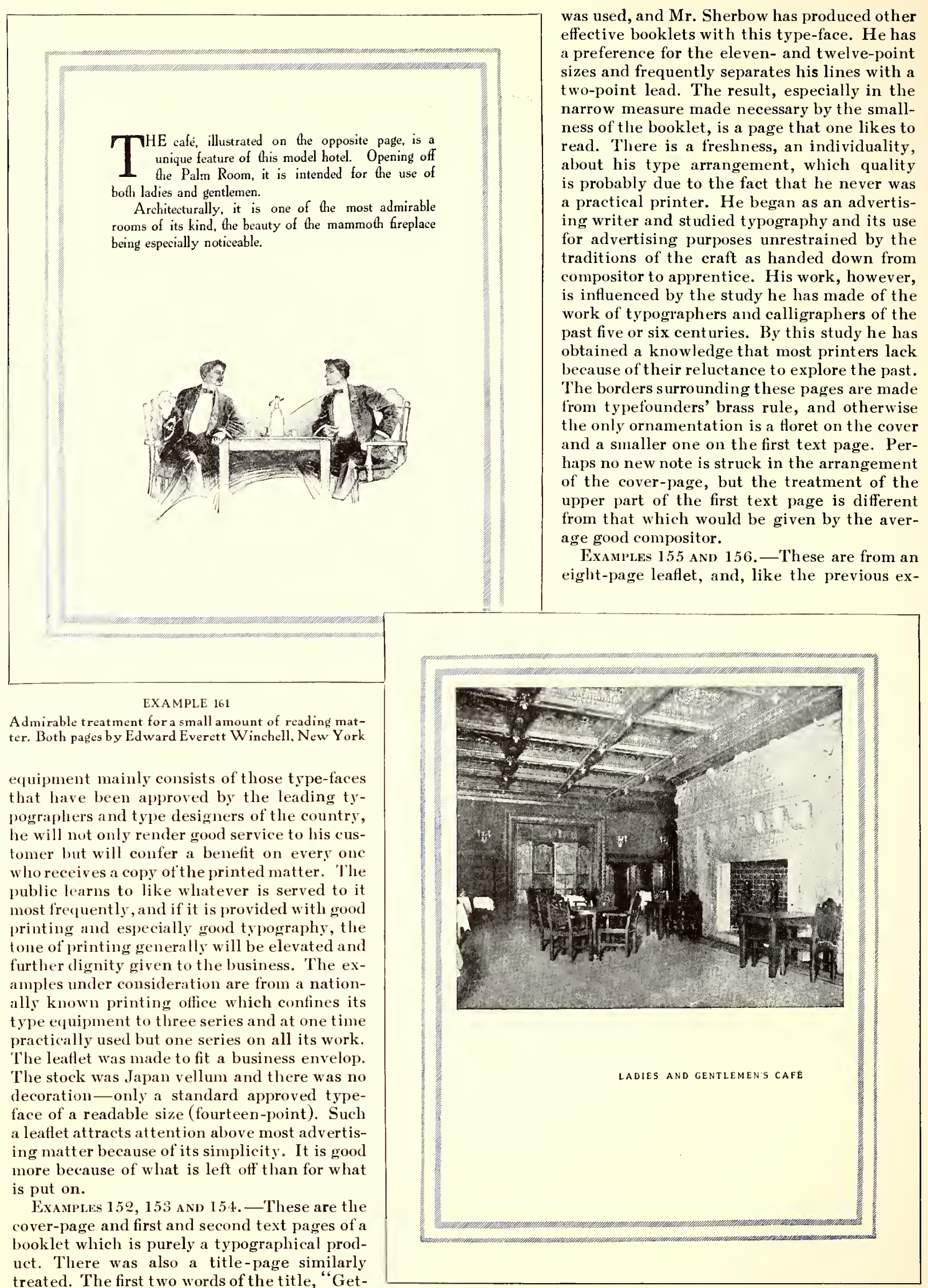
treated. The first two words of the title, "Getting into Print," were on each of the four pages set in italic lower-case, and the word "Print" was in roman capitals. Scotch Roman was used, and Mr. Sherbow has produced other effective booklets with this type-face. He has a preference for the eleven- and twelve-point two-point lead. The result, especially in the narrow measure made necessary by the smallness of the booklet, is a page that one likes to read. There is a freshness, an individuality, about his type arrangement, which quality is probably due to the fact that he never was a practical printer. He began as an advertising writer and studied typography and its use for advertising purposes unrestrained by the traditions of the craft as handed down from compositor to apprentice. His work, however, past five or six centuries. By this study he has obtained a knowledge that most printers lack because of their reluctance to explore the past. 'The borders surrounding these pages are made from typefounders' brass rule, and otherwise the only ornamentation is a floret on the cover of the cover-page, but the treatment of the upper part of the first text page is different from that which would be given by the averge good compositor.

Examples 155 and 156. - These are from an eight-page leaflet, and, like the previous ex-
Admirable treatment for a small amount of reading mat-

equipment mainly consists of those type-faces that have been approved by the leading tytomer but will confer a benefit on every onc who receives a copy of the printed matter. The printing and especially good typography, the tone of printing generally will be elevated and forther dionity given to the business. The exally known printing office which confines its type equipment to three series and at one time The stock was Japan vellum and there was no decoration-only a standard approved type(fourteen-point). Such ing matter because of its simplicity. It is good more because of what is left off than for what

cover-page and first and second text pages of a booklet which is purely a typographical prod-
EXAMPLE 162

A good way to arrange a page when the photograph is of proportions different from those of the booklet page. Note treatment of caption 


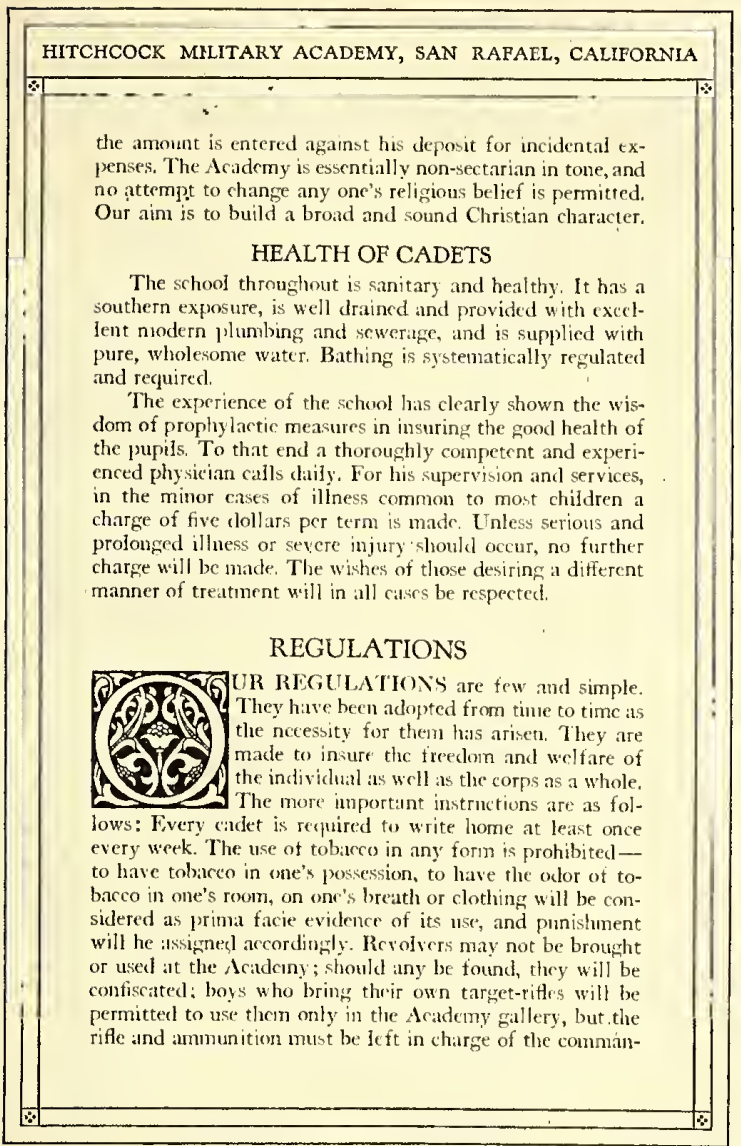

EXAMPLE 163

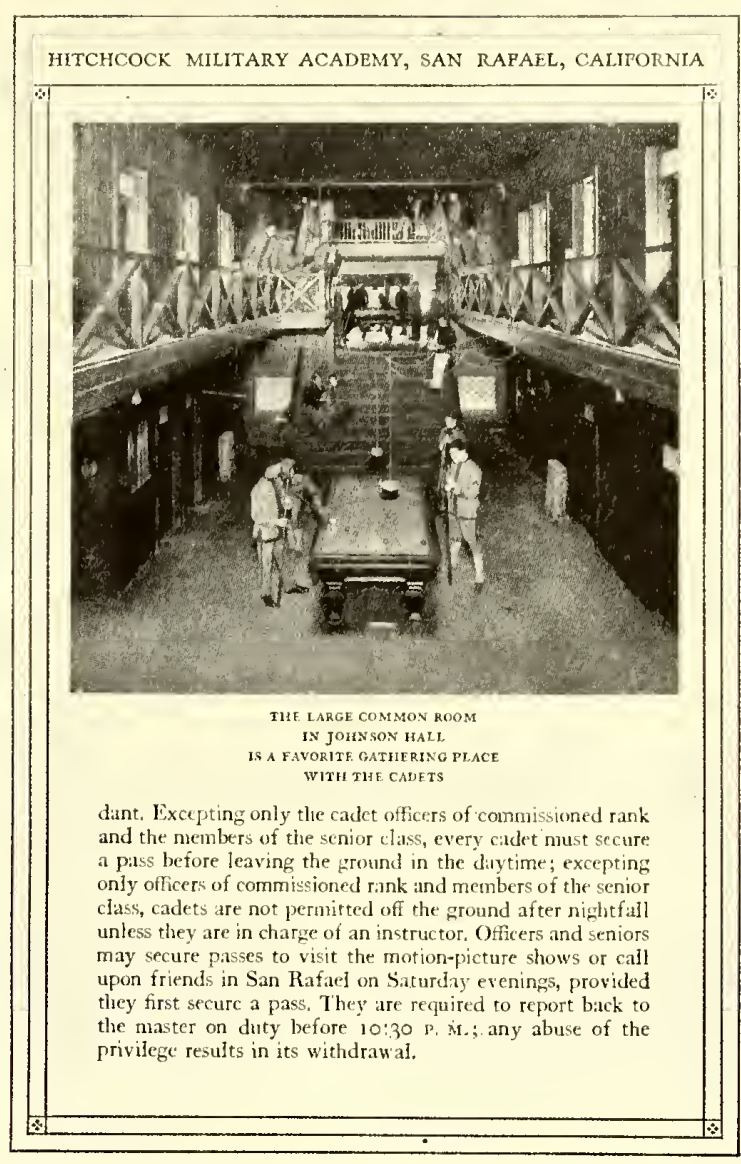

EXAMPLE 164

Two booklet pages in which typography was the chief dependence in securing artistic results. The borders were made with brass rule and the illustration was tipped on. By Taylor \& Taylor, San Francisco, Cal.

amples, they give evidence of an understanding of typography that comes from study of the subject. Mr. Baker in these pages provides practically no margins outside or inside the rule border. This border is merely a one-point rule which serves a good purpose without forcing itself upon the attention. The type-face is Old-Style Antique, which as the years go by does not seem to lose its "flavor." It is a readable type-face and one that is at its best when used on antique-finished paper, as in this case. The leaflet was printed in black ink on a greenish cream-tinted paper. Mr. Baker's personal device adds decorative value to the title-page. It will be noticed that the headings are set in a larger size of the body type and lined at the left. There is no indention excepting for the reprinted letters, which are set in a small size of the same type. These letters treated in this manner are only incidentally made a part of the advertising argument.

Examples 157,158 and 159. - Caslon Oldstyle and Caslon Text are factors in the effectiveness of the booklet of which these three pages are representative. These three examples are additional evidence that type alone when properly used is almost as effective from an advertising point of view as if supported by the best decoration and illustration. It might be said that good typography is to be preferred at all times to poor art work, altho really good art work properly subordinated will undoubtedly add attractiven ess and interest to a booklet otherwise well treated typographically. The border of contrasted heavy and light rule adds typographic value to the booklet under consideration, and the use of the liglit rule in other ways on the title-page and under the leadings in Exaniples 158 and
159 also has an influence for good. A two-line initial in color at the beginning of each paragraph and the setting off of one paragraph from another by blank space are distinctive features in the make-up of the pages. Ornaments are used in the running headings, and they are the same design as that used on the title-page. The size of this booklet was $3 \frac{1}{2} \times 5 \frac{1}{2}$ inches. It should be noticed that Mr. Lewis in these pages places no more space between sentences than bet ween the various words of the line, altho Mr. Sherbow and Mr. Baker on the preceding examples use more. There is difference of opinion among good printers as to the amount of space between sentences. Some of them prefer the em-quad, which has been used by the average printer for a great many years. Others believe with the ancient printers that the period and the capital are sufficient indication of the beginning of a new sentence without the insertion of a square of white space that affects the tone of the page. It should be noted in Mr. Lewis's pages that while he has allowed fair margins around the outside of the rule border, he has arranged for very little margin inside, and to this is due a certain compactness that is agreeable.

Example 160. - This is the cover of a small book of information. The cover stock was deep red in color and the title was printed on Japan vellum stock and pasted as a label on the cover. The label design is by 'Thomas Maitland Cleland, whose carefully formed lettering offers suggestions to good printers who know the value of dignity in lettering and decoration. A title label, especially when dark cover stock is used, makes it possible to include a typographic effect on the cover, thus insuring harmony 


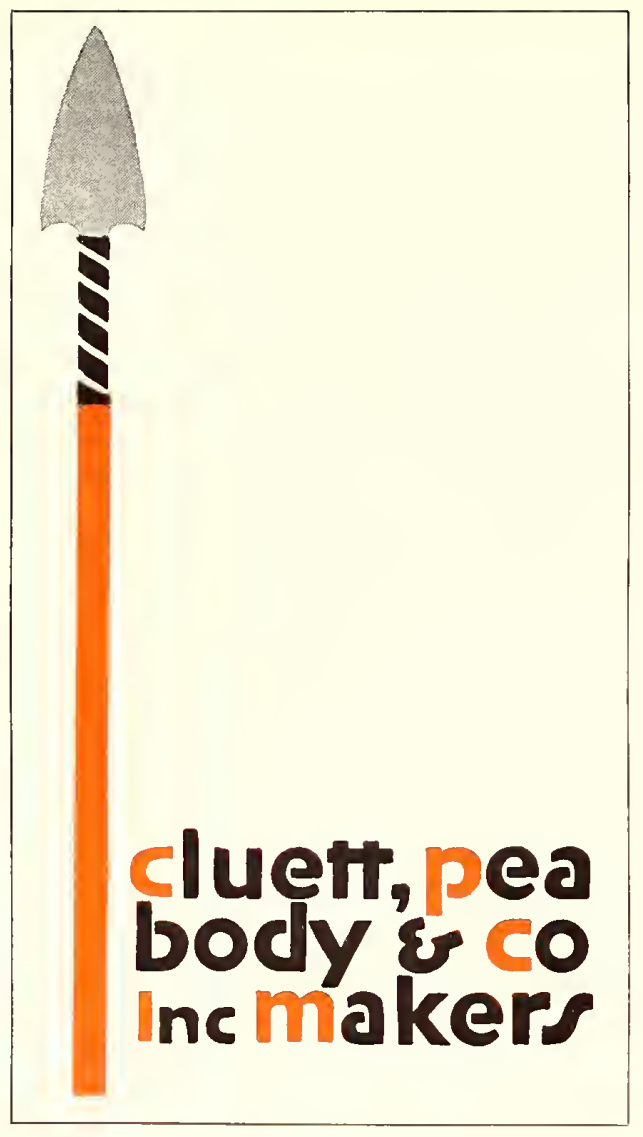

EXAMPLE 165

Attractive rear and front cover designs of an unconventional booklet. The arrowheads in the original were in emerald-green ink. By E. G. Jacobson, New York

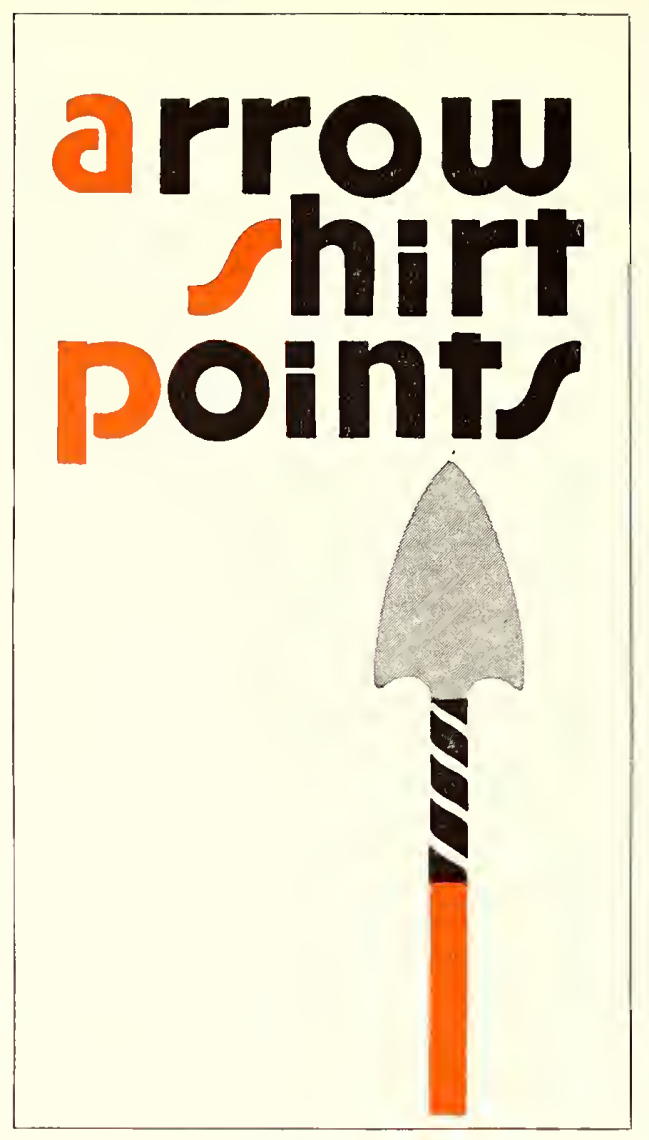

EXAMPLE 166

consistent with the typeface that may be used on the inside of a booklet. The title-page that was a part of this small book was shown as Example 138 of the chapter on books.

EXAMPLES 161 AND 162. - Two facing pages from a booklet designed by Edward Everett Winchell and presenting the attractive features of a large New York hotel. There is but a small anount of descriptive matter, confined mostly to two pages in the front of the book, yet the treatment is such that more words would have spoiled it. The plain rule border gives uniform shape to the pages and pleasingly contrastswith theliberalwhite space inside. In Example 161 the descriptive matter is grouped at the head of the page in Avil, an interesting old-style roman type-face. The fading of the vicrnetted edges of the half tone in to the surroundingwhite space is effective. Example 162 demonstrates how an illustration which is out of proportion to the page may be placed to get

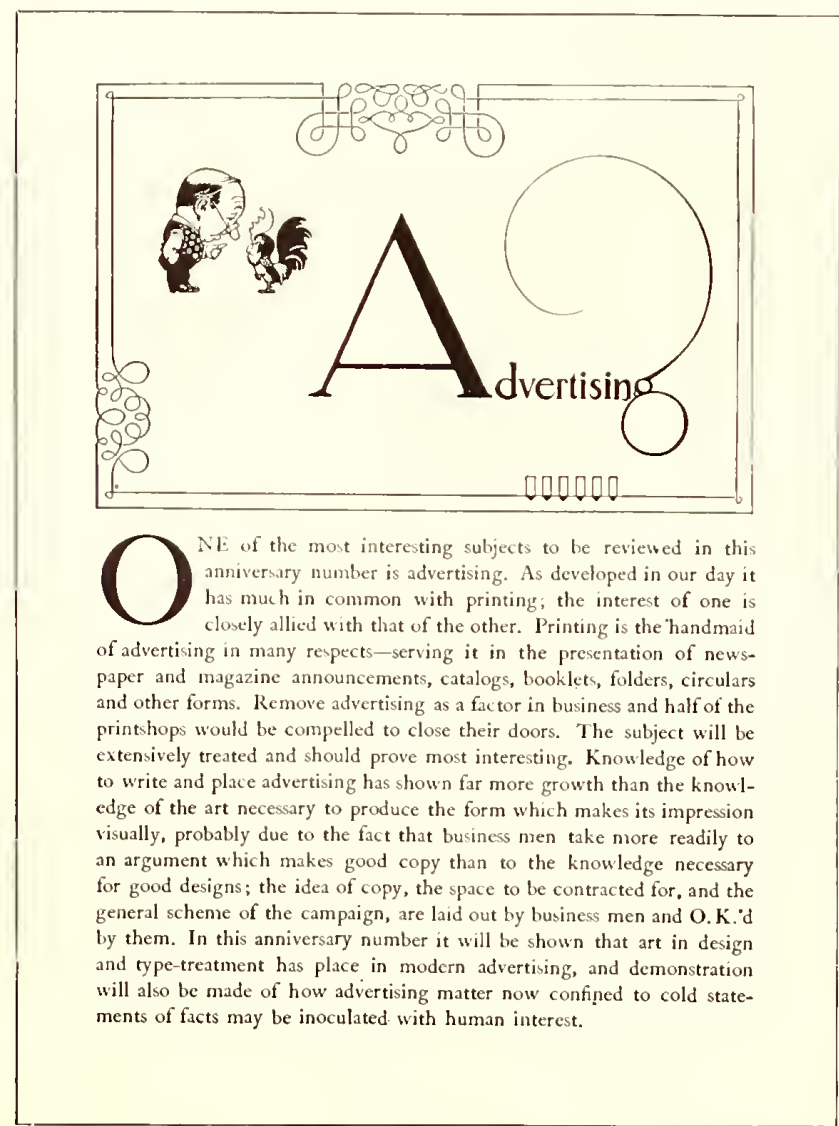

EXAMPLE 167

One of the eight pages of a prospectus for "The American printer." The initial "A" was in color. By Will Bradley good results. The caption, set in capital letters slightly spaced, is in keeping with the squared style of the page. Compositors should study the position of this caption. Many would be inclined to center it directly under the illustration; this would cause the lower part of the page to seem empty and unfinished. By moving the caption down, so as to break into the white space and divide it, the sense of vacancy is not experienced.

ExaMpLes 163 and 164. - These are two pages from a booklet in which typography was the chief dependence of the printer in securing artistic effects. The border is made of brass rules and four small ornaments; a decorative initial is introduced at frequent intervals thruout the booklet; otherwise, the effect is due to care in the details of typesetting. The space between sentences is the same as that between the words of a line, and widely spaced lines are not to be found. It should be kept in mind that the best typography is that in which the spacing between words is not excessive. Carelessness in typesetting and in the operation of composing machines is responsible for unpleasant effects produced by wide spacing and by "rivers", running thru the page. In Example 164t the illustration was tipped on. The paper used in this book was a buff antique, the tipped-on prints being on dull-coated stock. The dark-brown ink used for the text pages was also used for the prints, making a pleasing color harmony.

EXAMPLES 165 AND 166.-These are rear and front booklet covers, the design of which is striking because of the disregard for conventionality. No capital letters are used, an idea that should be adopted with reluctance by printers unless their customers approve of the innovation. Most buyers of printing are slaves to conventionality and hesitate to accept typography or especially drawn work which is bizarre or in any way a departure from the usual methods of treating printed work. The activity of German, 


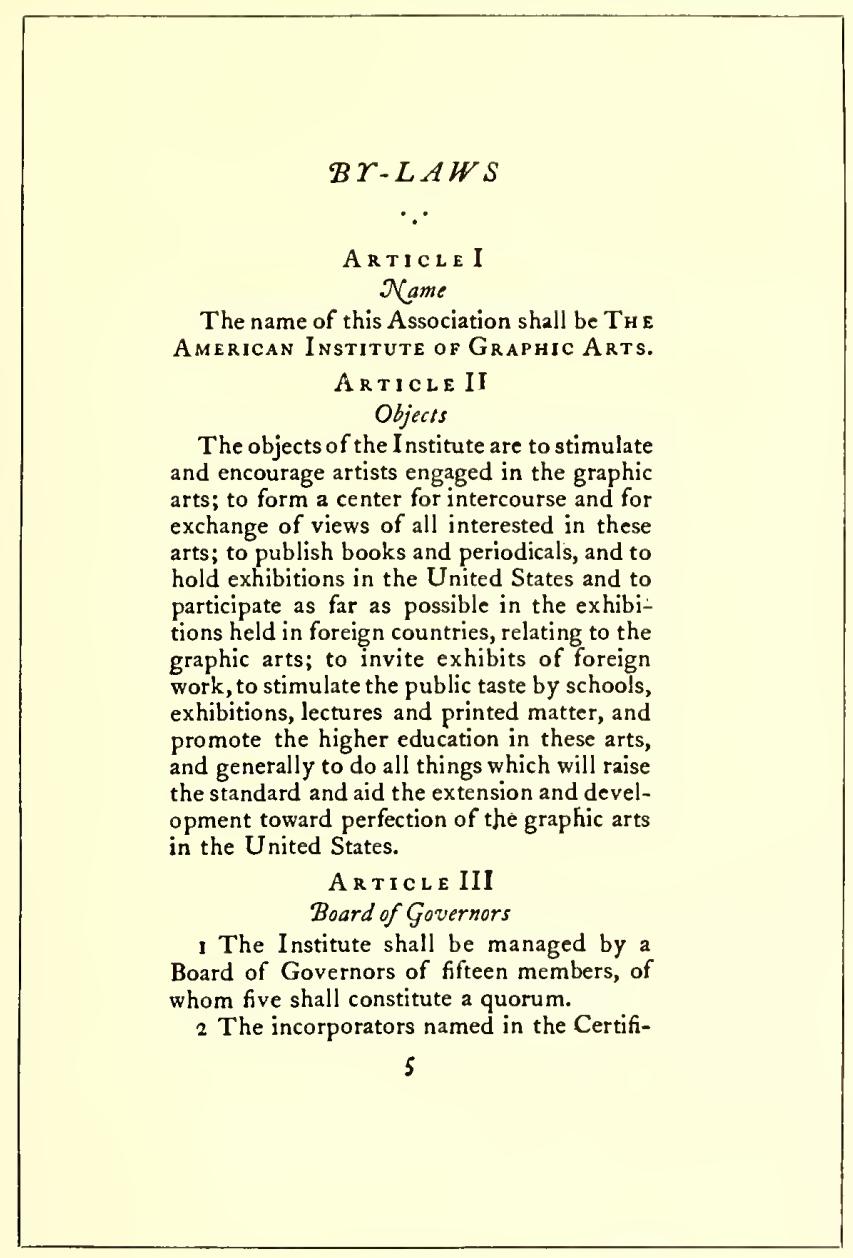

EXAMPLE 168

Two pages from a booklet in which no decoration was used, the decorative quality of the type-face impressed

on handmade paper having been depended on to provide a dignified beauty. By the Oswald Press. New York
THE AMERICAN INSTITUTE

OF GRAPHIC ARTS

IN CORPORATED

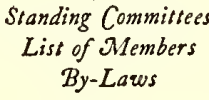

PUBzished BY THE INSTITUTE

15 Gramercy Park, New York

1914
Austrian and French artists in this country, however, has caused some business and advertising men to be more tolerant in these things, as the bright coloring, dashing decoration and the newness of it all seem to get attention where conventional effects fail. It might be said in reference to the lettering on these examples that the designer has not produced anything really new so far as the use of the socalled lower-case letters instead of capitals is concerned. There was a period in the development of the modern alphabet when its characters were neither "capitals" nor "lower-case" as we know them-a period in which the minuscules were being evolved from the ancient Roman capitals or majuscules. Altho modernized, the lettering here used can be traced historically to the uncial lettering of the days of manuscript books. The arrowheads were in emerald green.

Example 167.-This page, designed for the prospectus of the twenty-fifth anniversary number of The American Printer, in my opinion is among the best things that Will Bradley has done. There were eight pages and on all the decorative headings were similar, altho each had sufficient change in the treatment to give special inter- est to the page. The finc line decorative borders were in pleasing contrast to the dark-toned illustrations and the liberal apportionment of blank space. Fourteen-point Caslon Oldstyle, the kind with the long descenders, was used for the text matter. The large Caslon initial added another interesting spot of black. The decoration and type matter were printed in black ink on buff-tinted dull-coated paper, and the large drawn initial on each page was in sepia brown. The original size of this pamphlet was $6^{3 / 4} \times 9^{1 / 2}$ inches.

Examples I 68 and I69.-No decoration of any kind was used in this booklet, unless the period groups may be counted as such. The purpose was to produce artistic printing in good taste by depending upon the type-face and the paper for results. Decorative interest (usually welcome in a mild way) was supplied by the swash capitals of the italic and by letterspacing capitals and small capitals wherever they appeared. The chapter headings of all the pages in this book were aligned with one another and not "sunk" as is sometimes done. The pages are made interesting by the varied use of italic lower-case and roman capitals. The size of this book- 


\section{THE EXERCISES}

Held April 13, 1915, in commemoration of the Golden Anniversary of The Typothetae of the City of New York

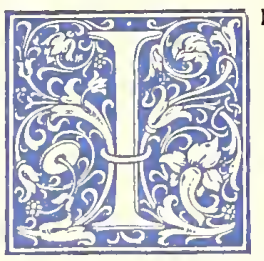

N RECOGNITION of the work of those employing printers who during the days of the Civil War met together and gave thought to the welfare of their beloved industry, Printing, and whose labors resulted years afierward in a great nationa organization and in inestimable good to the entire business, members of The Typothetae of the City of New York met the evening of Tuesday, April 13, 1915. The event was the fiftieth anniversary of the inauguration of The Typothetae, and the meeting was preceded by a dinner at Lüchow's, r ro East Fourteenth Street.

Historical souvenirs relating to The Typothetae were chronologically arranged in cases and frames at one end of the room, and a pamphlet in the typographic style of 1865 . was placed at each plate.

As this was also the regular monthly meeting of the organization, routine business was transacted that included an election of offucers. The new list of officers was announced as follows: President, Frederick Alfred; vice-president, R. W. Smith; vice-president, Gustav Zeese; secretary, R. H. Middleditch; treasurer, James $R$. Thomson; executive committee, James W. Bothwell, George B. Carter, William Green, John A. Hill, G. Frederick Kalkhoff, E. M. Lent, John Clyde Oswald, William E. Rudge, Frederick Triggs, Edmund Wolcort: crustees, L. H. Biglow, I. H. Blanchard, A.T. De La Mare, Charles Francis, Joseph Gantz, A. Stanley Graff, M. L. Griswold, Willis McDonald, Nelson Macy, William E. Rudge,

EXAMPLE 17

Page from a typographically treated commemoration book

let in the original was five by eight inches, and the margrins were made to conform to those used on good book composition, each margin increasing in this order: Head, inner side, outer side, foot.

Exampe 170.- Lettering, as has been pointed out, has an important place in booklet designing along with decoration, illustration and typography, and from well-lettered designs the printer can obtain valuable suggestions. This example was printed on handmade paper, and the deckle edges and rough surface of the paper blended with the freehand drawing of letters and border. There was a further blend of the hand-lettering and the Caslon type-face used on the inside pages. The lettering was based upon the same model as the Caslon, which is standard for oldstyle effects. Here is a hint for printers: Distinction will be added to booklets otlıerwise printed from Caslon or similar type-faces if the cover and the display headings are hand-lettered. This may be done with fair results by setting them first in Caslon type. After the type has been arranged satisfactorily, take a print in blue tint on paper suitable for drawing with ink. 'The letters may then be traced freehand with black india ink over the blue print and any desired ruggedness or variation introduced. As lightblue ink will not reproduce when a zinc etching is made, the blue proof need not be carefully adhered to. Italic and small capitals should be introduced in such lettered designs.

Example 171.-This is a page from a souvenir booklet containing an account of the exercises held in commemoration of the fiftieth anniversary of the New York Typothetre. Almost the entire book was sct in fourteen-point Cloister Oldstyle and I talic and printed inblack and orange ink on a white antique-finished paper of good quality. The cover was a domestic vellum-like paper which contained the words, "Golden Anniversary ot" the Typothetæ," set in Cloister Italic with swash initials, the two lines being deeply stamped into the paper on gold leaf. In this manner strict typographic harmony was maintained thruout the booklet. Large decorative initials were introduced in several instances and two-line initials of Cloister capitals were used in a minor way. This page should offer suggestions to printers who are called upon to print souvenir volumes; in fact, much work of this kind can be created by the printer suggesting the publishing of such volumes after historic or memorial meetings are held in his city.

Example 172.-This is the first inside page of a booklet, the stock of which consisted of a thin straw-colored Japanese paper, printed on one side only. The cover, a heavy, rough dark-green paper, contained only the wastebasket illustration printed on both front and rear in gold ink set into the stock by a heavy impression. The simplicity of the typography accords with the treatment as a whole.

Printers will accomplish the most in booklet printing, as in other branches of the craft, if they live in an artistic atmosphere. Sir Joshua Reynolds, the great English painter, said: "The more extensive your acquaintance is with the works of those who have excelled, the more extensive will be your powers of invention." That is the reason painters haunt Italy and other art centers where the works of the old masters are accessible. The printer should take journals such as The American Printer, devoted to the art of typography; for these journals bring to the great army of craftsmen specimens of the work of famous printers and of those who are contributing their mite to the cause of good typograply.

The helpful atmosphere of the trade papers can be supplemented by specimen booklets for study purposes. 'These booklets can be obtained by writing to the printers producing them, or to the advertiser; and many can be had from retail houses selling the articles advertised in the booklets.

The printer must learn more than he now knows about art or he will become only a caddie in the gane of booklet printing, with the artist and ad.-writer making all the puts. The printer is depending too much upon the artist and too little upon liimself. The possibilities of type arrangement have not been exhausted and never will be, $y$ et many workers at the printing trade act upon the assumption that good printing is impossible without the artist's initiative and co-operation. Many a good job of printing has been spoiled by inferior lettering or decoration, the work of a poor artist.

Withal, there is nothing more EXAMPLE 172

Unconventional arrangement of a booklet page. By Corday \& Gross, Cleveland, $\mathrm{O}$. ideal than a good printer and a good artist working together to produce perfect printing. 


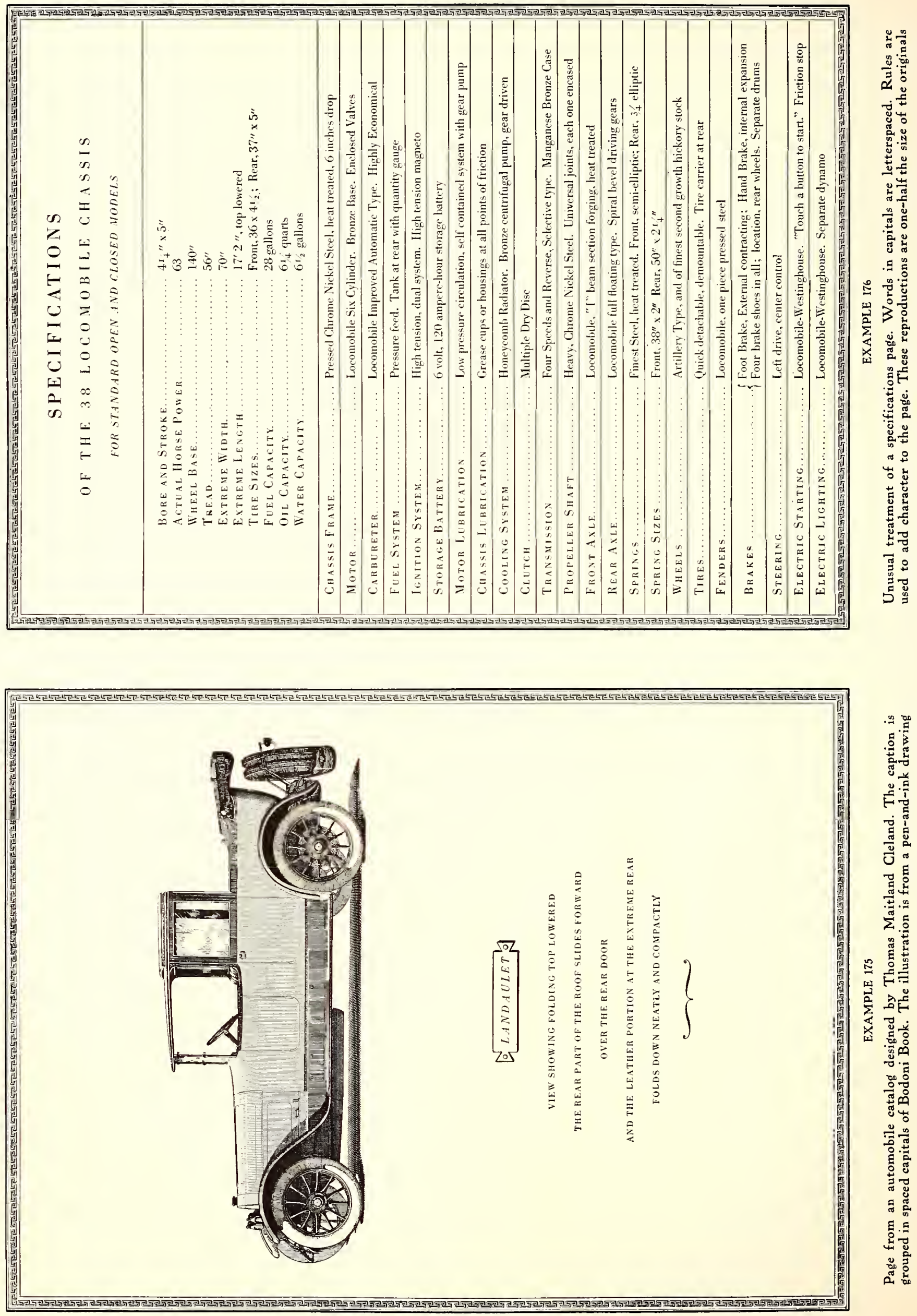

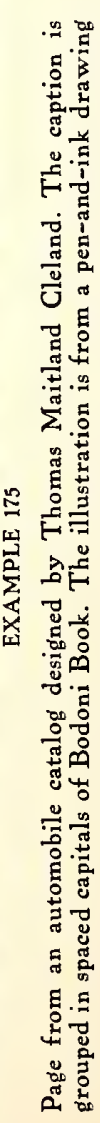




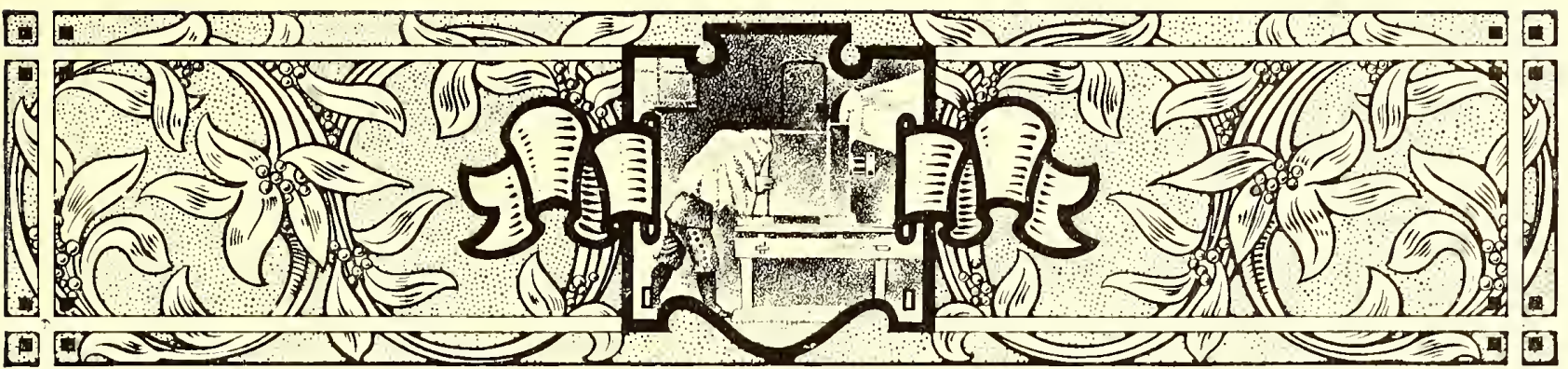

\section{CATALOGS}

RUSKIN, enumerating three branches of architectural virtue, requires of a building (1) that it act well, and do the things it was intended to do, in the best way; (q) that it speak well, and say the things it was intended to say, in the best words; (3) that it look well, and please us by its presence, whatever it has to do or say.

These three requirements, like many others that are important in the eyes of the architect, can be applied to the illustrated catalog, which most printers at one time or another are called upon to produce:

(1) The catalog should act well; it should be constructed in a manner fitting the purpose for which it is issued. If, say, it contains a list of plumbers' supplies, it should be bound in strong stock of a color that will not easily soil. If it contains a list of jewelry and is for retail purposes, it could be bound delicately in light stock.

(2) The catalog should speak well; the illustrations should be faithful presentations of the articles to be sold, and the descriptive matter should be well written, accurate and informative.

(3) The catalog should look well ; the type-faces, paper, ink, binding and other elements should be harmonious; the illustrations and descriptive matter should be arranged with regard to balance and proportion, and the treatment as a whole should be pleasing and interesting.

There was a time when catalogs were printed without attention to these things, or if the first two requirements were complied with the third was ignored. It will necessitate no effort for the reader to recall the days when merchants had no orderly plans for displaying their wares - when the average storeroom and window looked like a curiosity shop. Those were the days when the catalog was a heterogeneous collection of woodcuts and type-faces, packed on the pages to the very edge of the paper.

Now many show windows and salesrooms are delights to the eye, and similar care and taste are shown in the printing of the catalog.

The catalog is a portable showcase and from it the customer makes selection, often without seeing the article itseif.

These facts make it essential that goods be displayed invitingly and in good taste. An article well displayed requires few words to sell it.

Place a girl of plain features, but handsomely dressed, in the midst of beautiful colors and lights, and a dozen millionaires will want to marry her-an extreme illustration of the power of attractive display, emplasizing the necessity of "playing up" the ordinary to create the desire of possession. It is possible, also, to accomplish this purpose by different methods. It is told of Josephine that, wishing to gain the admiration of Napoleon, she appeared at a reception in a gown of pure white, without ornament. The contrast of her simple dress with the elaborate costumes of the other women and with the elegant furnishings of the room was such as to draw compliments from the emperor. It should be remembered, however, especially by the typographer, that mere plainness of dress did not win Josephine her triumph, but that artistic simplicity did. A block of marble rough-hewn from the quarry is plain, but, carved into statuary by a lodin, is far more than that.

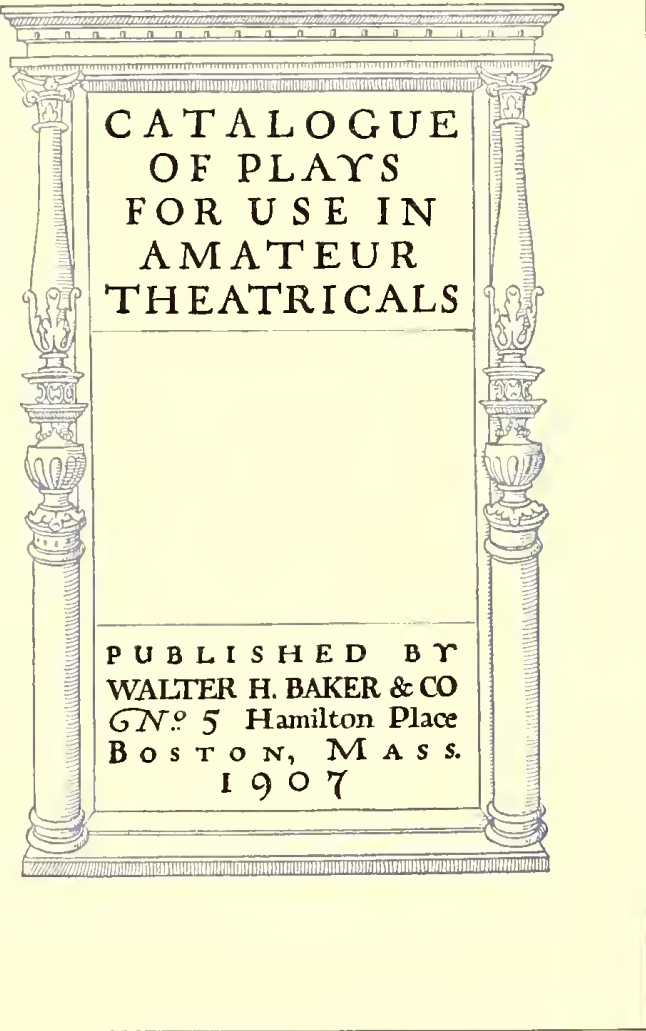

EXAMPLE 172

A rchitecturas title treat ment by Will Dwiggins. The lettering containg typographical suggestions
This point is worthy of meditation by all who wish to produce the effective and attractive catalog.

Efforts have been made to standardize the dimensions of catalogs; it would be well for printers and others to assist in accomplishing this purpose. A committee of the $\Lambda$ merican Society of Mechanial Engineers, after investigating the sizes of catalogs in common use, recommended that the standard size of catalogs be six by nine inches. The recommendation was also made that the size of bulletin and large catalogs be eight and a lialf by eleven inches.

Other suggestions by the committee were: Paper-covered catalogs intended to be permanently filed should be trimmed to exact size, cover and all, barring deckle edges. Overlapping covers are favored only when the covers are stiff enough to support the catalog's weight when standing on edge. Titles should be printed on the exposed backs of the catalogs, reading from top down ward. The date of publication should appear on the title- 


\section{TYPE B}

This instrument is designed for belt drive from horizontal shaft.

Approximate total height, 20".

Range of scale, according to purchaser's specifications.

EXAMPLE 178

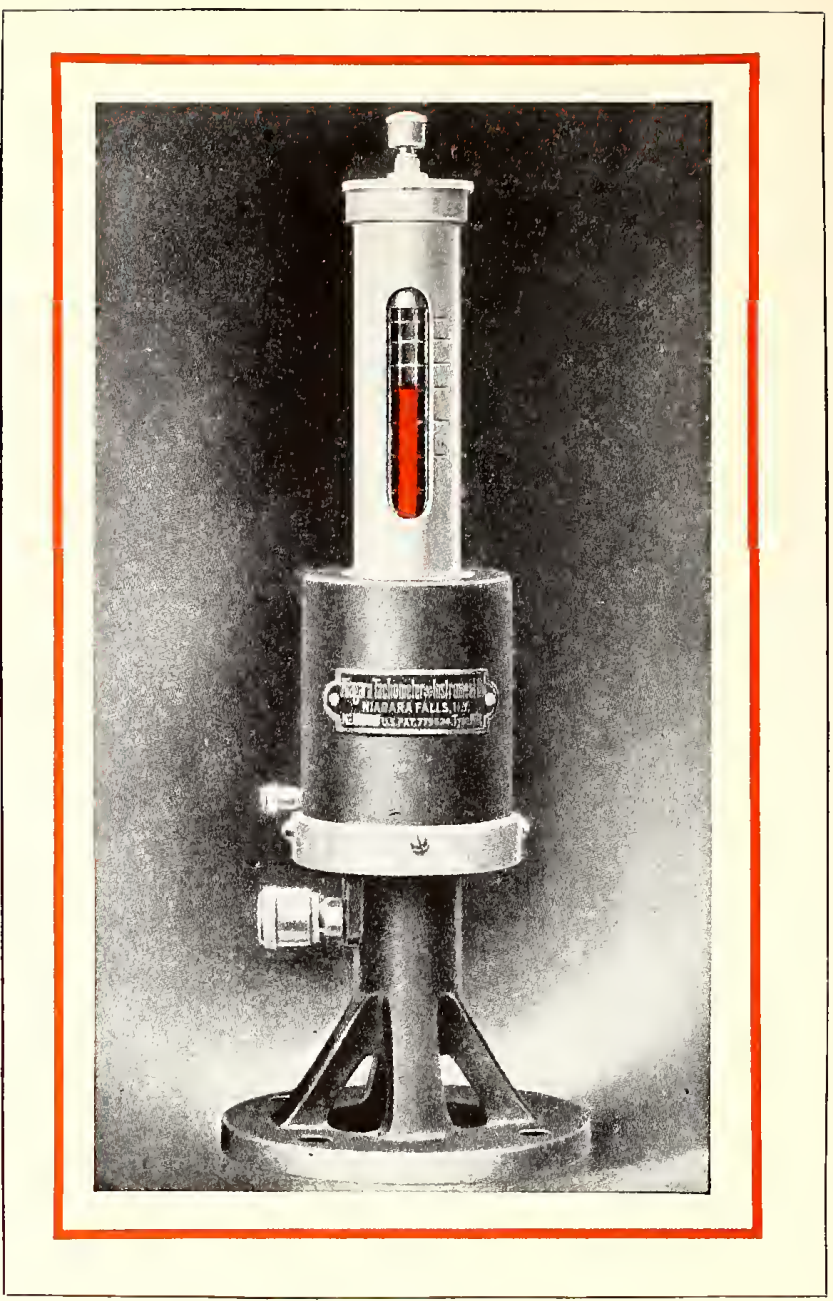

EXAMPLE 179

Facing pages that show effective results obtained in a simple way. The plain, legible typography ably supports the strong illustration and attractive border treatment. By the Matthews-Northrup Works, Buffalo, N. Y.

page. An index card of standard size (three by five inches), containing the title and character of the contents, should be inclosed in every catalog.

Before proceeding with the composition of a catalog the printer should insist that the copy be legible, orderly prepared, and all points settled as to type-face, headings and position of illustrations. A dummy page should be planned and set up, and it should be studied and discussed by customer and printer before work is begun on the catalog as a whole.

If the catalog is to be elaborately treated, all drawings should be approved and plates made before the type work is commenced. If the printer is assisting in the general preparation of the catalog, he should keep before the customer the fact that decoration is merely supplemental, and should urge first attention to the type matter and illustrations.

EXample 175.-This catalog is one of those productions which in style so closely express the personality of an individual that they are not a direct help in teaching typography or catalog planning to others. Most typographers must proceed according to defined requirements and plan their work with regard to set styles. Mr. Cleland and it few other typographic artists in this country carry out their ideas without the assistance of an advisory board. The average typographer or artist, on the other hand, must not only incorporate the suggestions of half a dozen persons, but nust submit to the deletion of most of the little things that to his way of thinking give his work character and make it worth while-the penalty of being merely an average typographer. Mr. Cleland is a student of the best printing of past centuries, and his refined taste and wonderful skill with the pen enable him to produce effects that would be envied by the master printers of old.

On this page he lias used Bodoni Book, slightly spacing the capital letters and grouping the matter so that it dominates the blank space in the lower portion of the page.

The cartouche, or panel, as here used for the car name was in favor in Bodoni's day, a hundred or more years ago. The horizontal position of the illustration adds to the pleasure in examining the catalog, for when an illustration runs the long way of such a page the necessary turning of the book is an annoyance.

Example 176.- Brass rules are seldom well applied in typographic work, but when they are, as in this instance, the results are pleasing. This page, because of its tabular nature, was doubtlessly difficult to arrange, and every compositor, appreciating that fact, will admire what Mr. Cleland has accomplished. It should be noticed that words of roman capitals have in every instance been letterspaced, while those in lower-case have not. This treatment gives effects that are unusual and well liked by persons of good taste.

Example 177. - This shows the cover of a catalog of plays. Will Dwiggins in his usual clever manner has made a design full of character, human in the absence of the mechanical. The lettering contains suggestions for effects that could be approximated with some well-designed type-face. It will probably be well to warn against 


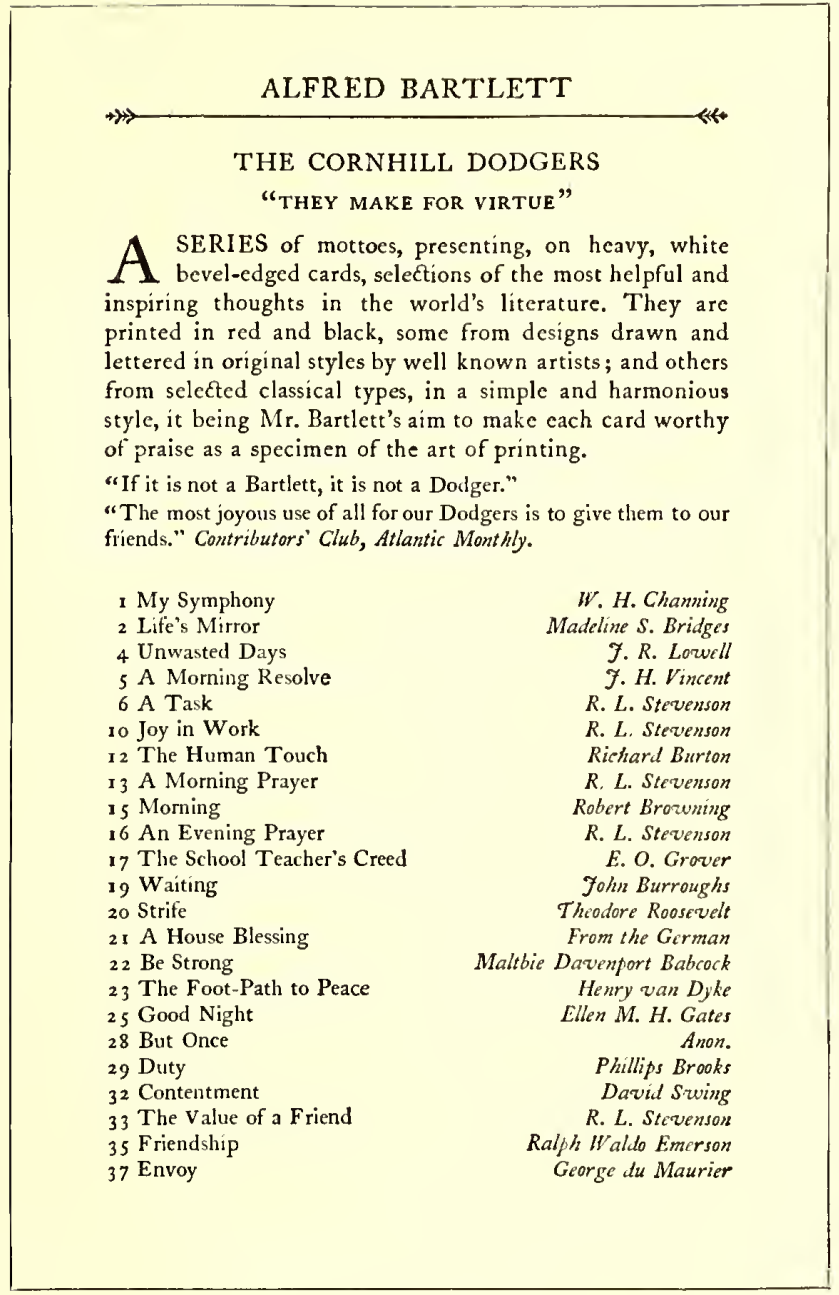

EXAMPLE 180

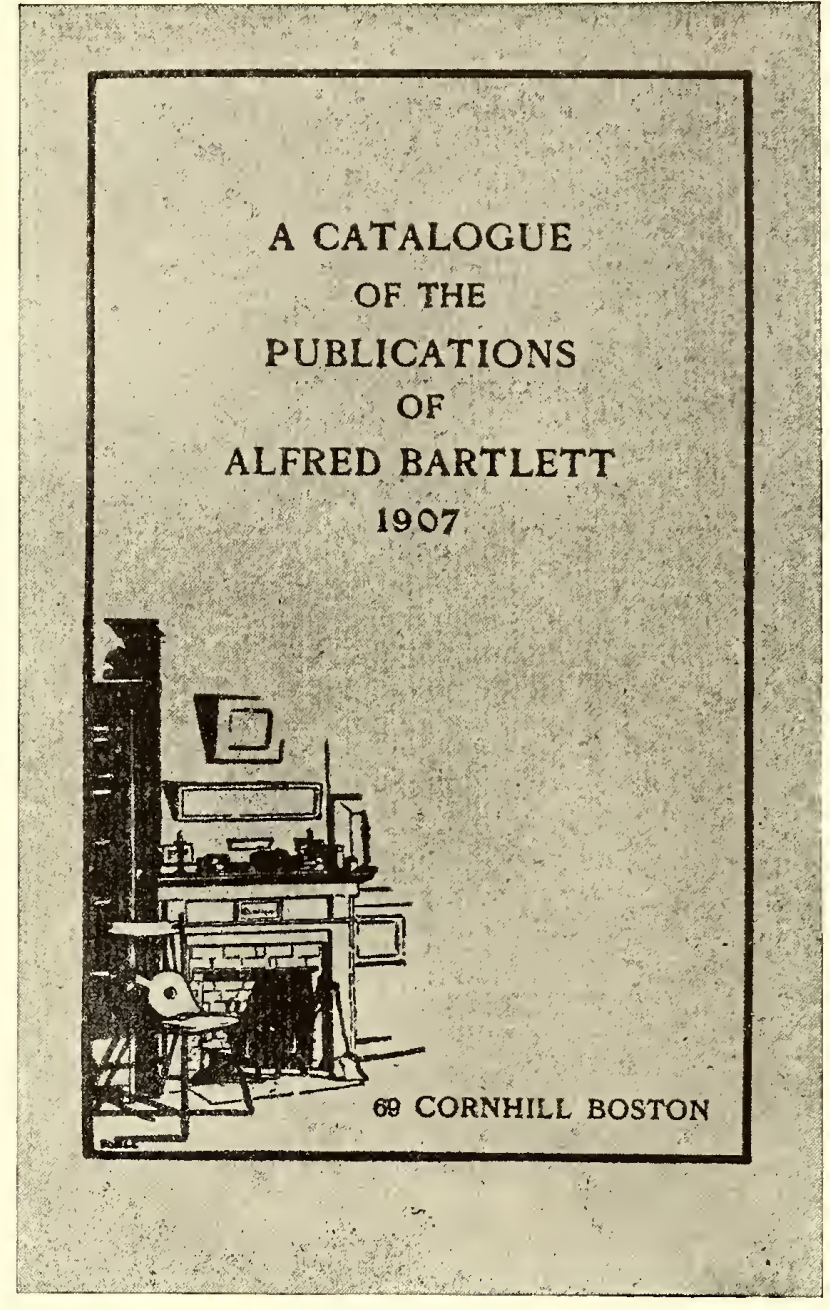

EXAMPLE 181

1nside page and cover of a publication catalog designed by D. B. Updike. The typographic treatment of these two pages is suitable and pleasing. The cover stock was green-gray of a rough antique finish

the careless use of typographic ornaments in any attempts that may be made to imitate the effect of this decorative border. Architectural designs formed witl the average printshop material seldom look well. Simple rule effects would be better.

ExAMPLes 178 AND 179 . - In many catalogs a page illustration is faced with a page of reading matter describing it. In this instance the descriptive matter is small in amount and for that reason presented a problem in typography. The printer, however, solved the difficulty by using a type-face fairly large in size, but of good design, and placing the group in the upper part of the page aligned with the top of the illustration. It is well to keep in mind that in booklets, catalogs and similar work good results are frequently obtained by aligning all pages at the liead. The effectiveness of these two pages is helped also by the fact that a red border surrounds each page and the lialftone has a dark background.

Example 180.- There is evidence in this specimen that it is possible to obtain variety and interest by simple means. The italic, especially with the decorative quality found in swash letters, is a factor, and the rule at the head, with bits of decoration at the ends, also helps. It will be noticed that no leaders have been used; their omission is sometimes advisable, at other times not. An antiquefinished white paper is best for old-style effects such as this.

Exampic 181. - This cover-page has been built on the small illustration. From the old fireplace the view of the room fades into the paper stock. After the border line is extended from the drawing, there remains a large amount

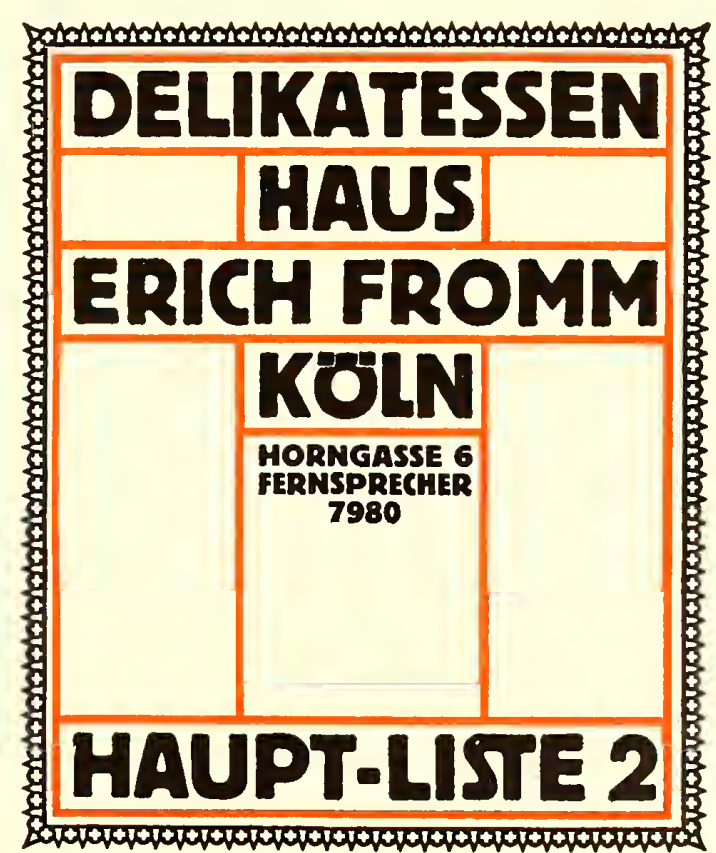

EXAMPLE 182

German poster type on a grocery catalog with characteristic block grouping 


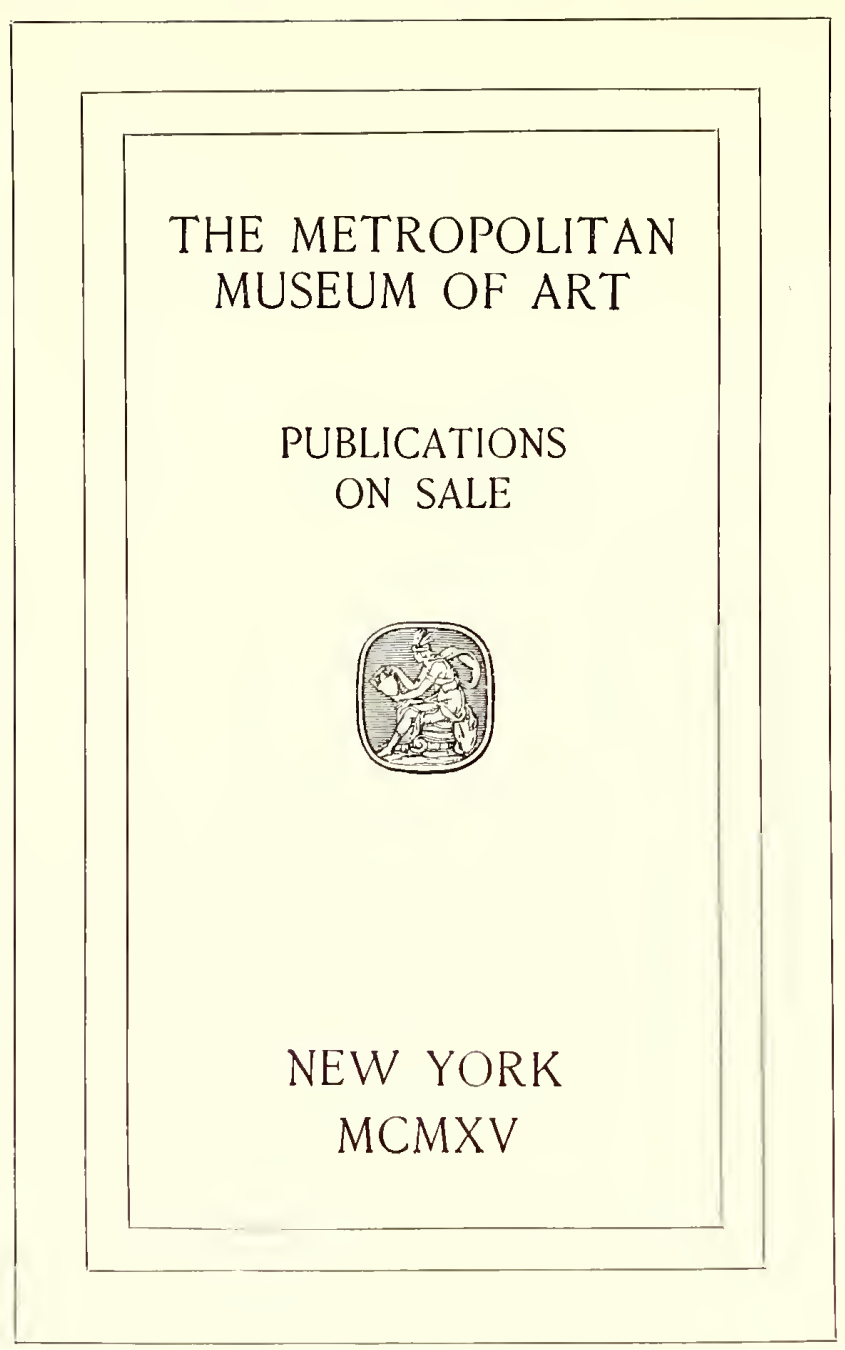

EXAMPLE 183

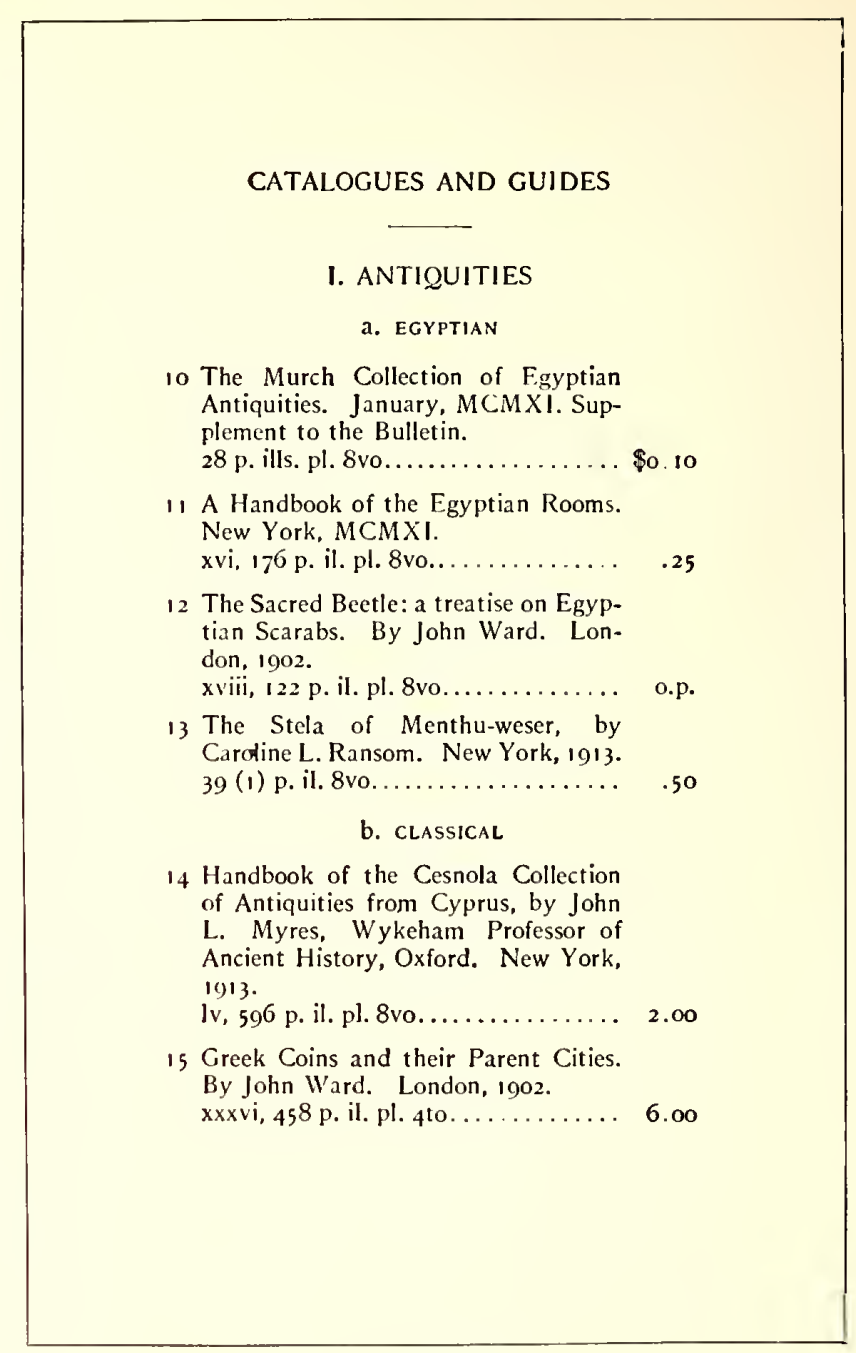

EXAMPLE 184

Typographic arrandement of the title-pace and one of the inside pages of a museum catalog. The proportions of this type-face blend harmoniously with the dimensions of the page. Example 184 shows some details of catalog eomposition

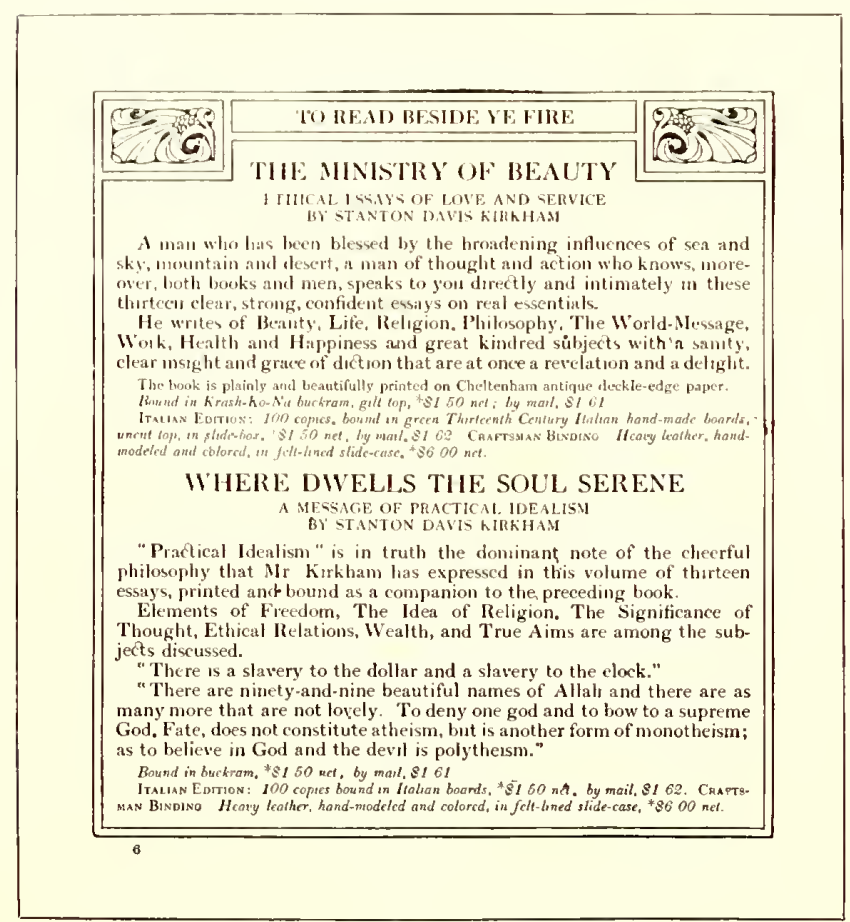

EXAMPLE 185

Rules add a decorative quality to this book catalog. By J. H. Nash of blank space, on which the title, in a well-balanced position, is arranged in type. The address neatly fitted in the space at the foot finishes the design at that point.

Example: 182.-Modern German typographical ideas have found expression in this grocery-catalog page. The lettering is type, the black tone and decorative form of which were probably inspired by strong lettering designed for poster purposes. Rules seem to have a place in the building of modern German art effects, as will be seen by this design. Bold type as used here is possibly unnecessarily forceful, but when color is to be shown in its true values it is desirable. Color never shows to advantage in thin lines, while broad lines bring out the color qualities of the ink. This is why colored inks printed from lightfaced types seem to lack the brilliancy of the prints from flat-surfaced plates in ink-makers' sample books.

Examples 183 and 184.-Every printer at some time is called on to produce catalogs in whicl books or other published articles are listed and priced, and on such occasions wishes to see what "the other fellow" has done in this line. For this reason the two pages are of interest. They show a title-page and a representative inside page from a catalog issued by the Metropolitan Museum of Art, New York. The type-face is of the class usually designated as French Oldstyle, and its proportions blend harmoniously with the dimensions of the page. The distribution of blank space on the title is pleasing; the type lines are so grouped as to secure value from the background of white. In Example 184 the heads and subheads are pleasingly contrasted by the use of capitals in some cases and small 


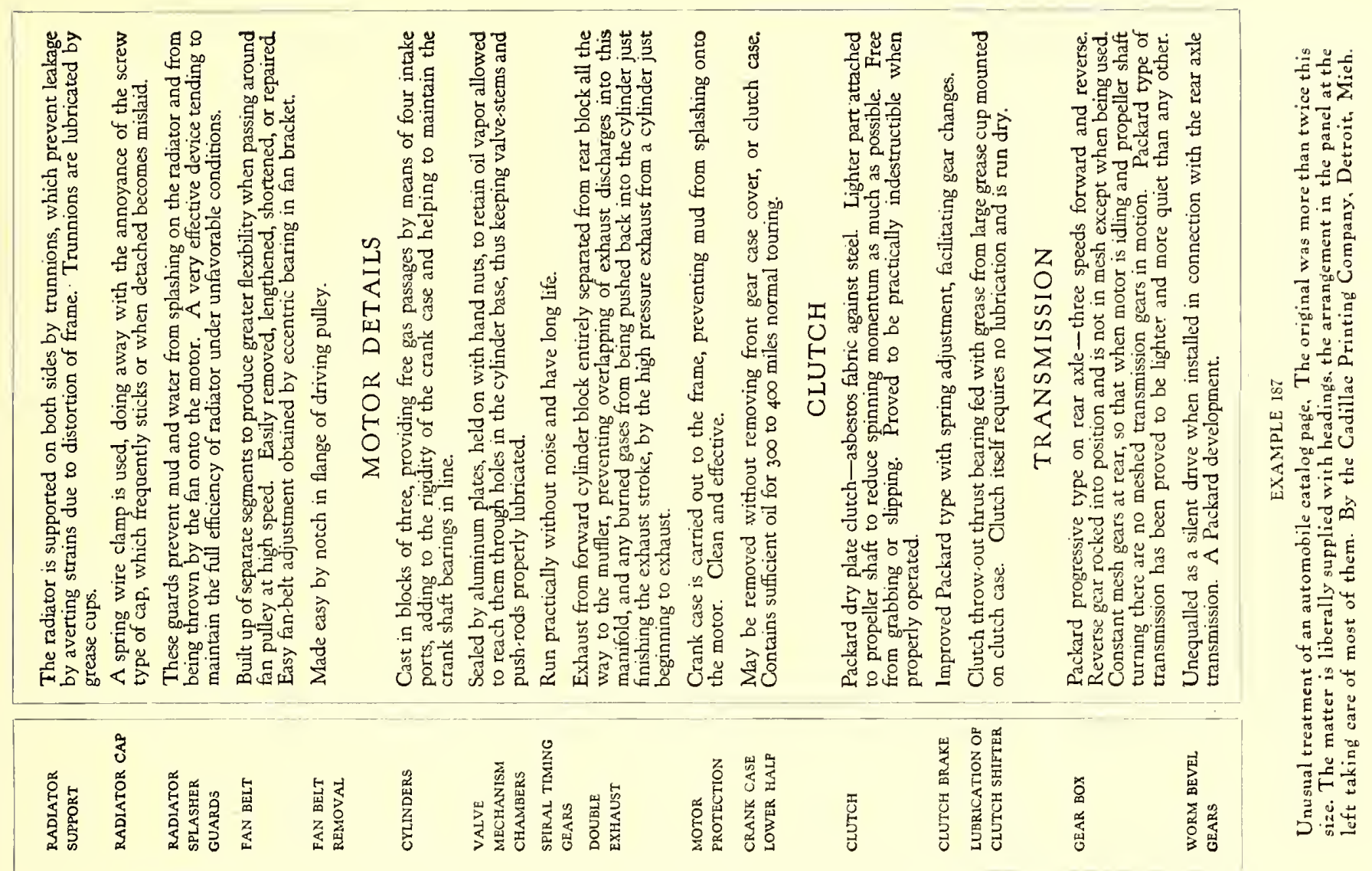

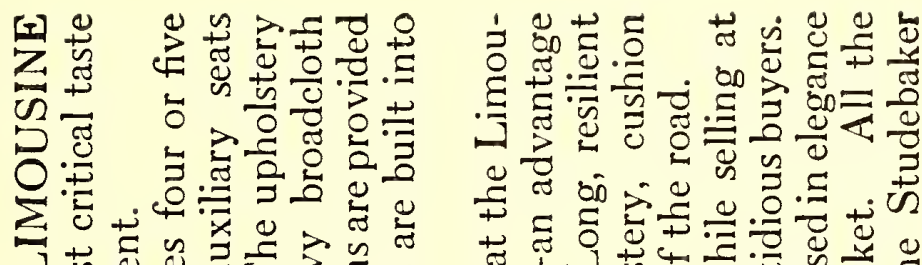

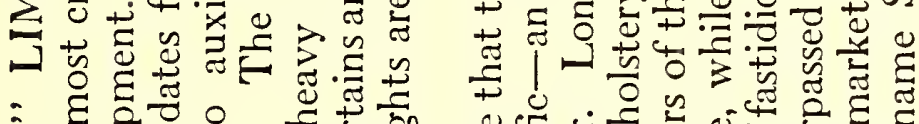

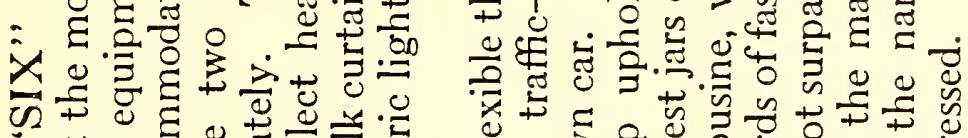

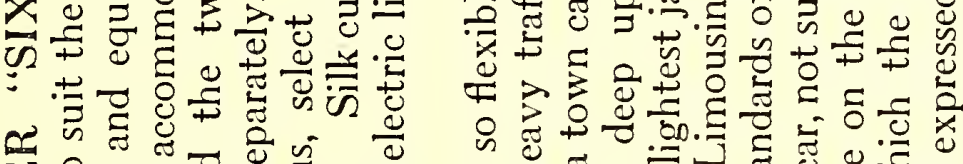

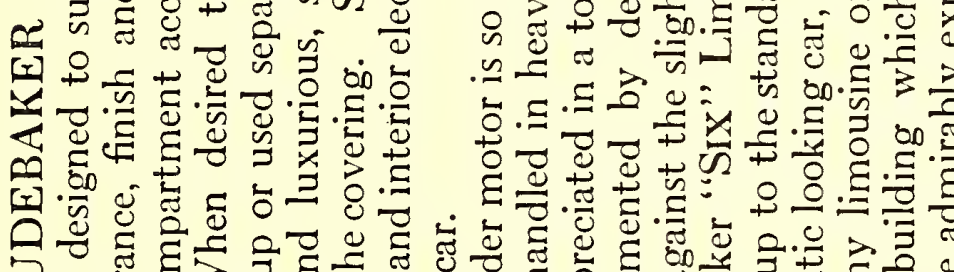

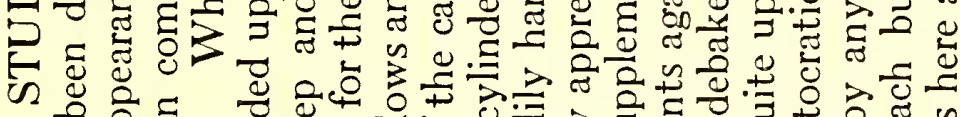

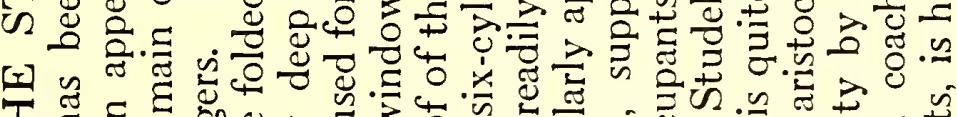
II.

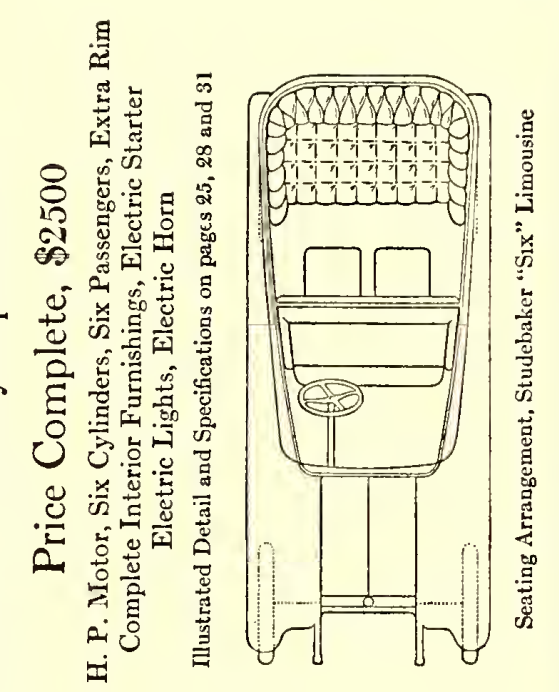

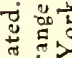

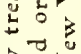
辛艺

焉

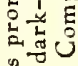
范.

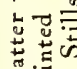

ن

造

西

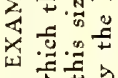

烈

.

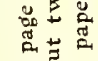

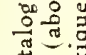

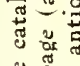

苟,

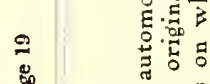

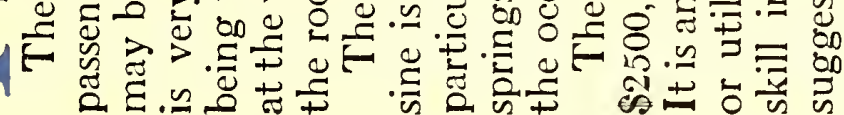


IMPORTED MINERAL WATERS DOMESTIC WATERS

\begin{tabular}{|c|c|c|c|c|c|}
\hline$x$ & & $1 / 2 \mathrm{G} a l$. & Splits & Bots. & $1 / 2$ Boss. \\
\hline 431 & WHITE Rock & & $\$ .15$ & $\$ .40$ & $\$ .25$ \\
\hline $43^{2}$ & Still Rock & $\$ .75$ & & .40 & .25 \\
\hline $43^{6}$ & LONDONDERRY & .75 & & & \\
\hline $43^{8}$ & Poland & .75 & & .40 & .25 \\
\hline 455 & APOLLINARIS & & .15 & .40 & .25 \\
\hline $45^{6}$ & MATTONI & & & .40 & .25 \\
\hline 457 & Celestins Vichy & & & .50 & .30 \\
\hline 459 & Perrier & & .15 & $.4 \circ$ & .25 \\
\hline 460 & German Seltzer & & & .40 & .25 \\
\hline $46 \mathrm{I}$ & St. GAlmier & & & .40 & \\
\hline & & & & & \\
\hline & & & & & \\
\hline
\end{tabular}

SPARKLING BEVERAGES

\begin{tabular}{|c|c|c|c|}
\hline $\begin{array}{l}x(0 . \\
290\end{array}$ & Paulding's Pippin Cider & $\begin{array}{c}\text { Bots. } \\
\$ 0.90\end{array}$ & $\begin{array}{l}1 / 2 . \text { Bots. } \\
\$ 0.50\end{array}$ \\
\hline 291 & Jericho Russett Cider & .90 & .50 \\
\hline 292 & GINGER BEER & & .25 \\
\hline 293 & Gincer Ale, Cantrell G Cochrane,Sweet E Dry & & .25 \\
\hline 294 & Ginger Ale, Ross' Belfast & & .25 \\
\hline 296 & SARSAPARILLA, SchWEPPE'S & & .25 \\
\hline 297 & $C_{L U B}$ SODA, SCHWEPPE'S & & .25 \\
\hline 298 & Club Soda, Carl H. Schultz's & & .15 \\
\hline 299 & DELATOUR & & .15 \\
\hline
\end{tabular}

[19] which it belongs. The effect was one of richness and suggestive of quality. Illustrations of the cars were of page size printed by the gravure process.

Example 188. - Few printers would use rules in tabular form for a high-class wine list; tabular work is supposed to offer no opportunity for art expression. We know of the stone rejected by the builder which became the headstone of the corner. We have also heard of Michelangelo carving a masterpiece from an ill-shaped block of stone that had been discarded by other sculptors. Mr. Cleland did an equally interesting thing when he selected rules to give decorative quality to this wine list, supplementing characteristically drawn head- and tail-pieces. Caslon Oldstyle was used and the paper was handmade. A pleasing effect was obtained by letterspacing the capitals in the headings.

Exнмple 189. - We usually expect strong, masculine effects from German typographers and decorators, and when we come across a wine list as dainty as this one we are surprised and pleased. There is remarkable harmony of type-face, decoration and illustration. The type-face is uncommonly legible for so ornamental a letter, and the light decorative lines of the illustration and border reflect the qualities of the type-face. In the original there was an additional border around the one here shown, and it was printed in a very light gray-brown tint. The tint also appeared in parts of the illustration.

Examples 190 and 191. - These pages are from an exhibition catalog. D. B. Updike is responsible for the typography, hence the pages afford an interesting study. The catalog is printed in four sizes of type, altho a cursory view of the pages would lead to the impression that a less number is used. There are three sizes of capitals and one

\section{EXAMPLE 188}

Page in reduced size from a wine list designed by T. M. Cleland for the Oswald Press. Interesting use of rules in tabular style

capitals in others. Each item is grouped, and the technical details are kept orderly by being placed in a line with the price. No period is used after the item number.

Example 1 85. - Scotch Roman type is used to excellent advantage in this book-catalog page. The title in each case is in large capitals, the sub-title and the name of the author are in smaller capitals, the explanatory matter in roman lower-case and the technical details in small italic. lt will be seen that the advertising points have been carefully considered. A rule border and two ornaments add decorative quality. The closeness of the border to the type matter merges it with the page in an attractive manner. As in this case, decorative treatment should be a part of the general design and not something separate.

Example 186. - On automobile catalogs typography seldlom receives the attention it deserves. Illustration and decoration are given great attention, and what type matter is used seems to be like a guest invited at the eleventh hour. However, this example is from a catalog in which type acts an important part. In its original form this page was about twice the size of the reproduction and was printed in dark gray and orange on white antique paper. It will be seen that beginning with a colored initial the reader can without effort or eyestrain read the descriptive matter, which is followed by technical details in smaller type and a line illustration of the car. Scotch Roman was used, and it was not found necessary to introduce italic.

EXAMPLE 187.- The treatment of this page is uncommon for catalog purposes. A Goudy type-face was printed in dark brown (border rules in light brown) on an Italian handmade paper. The size was more than twice that shown here. Sub-headings have all been grouped in the panel at the left, each so placed as to be opposite the paragraph to

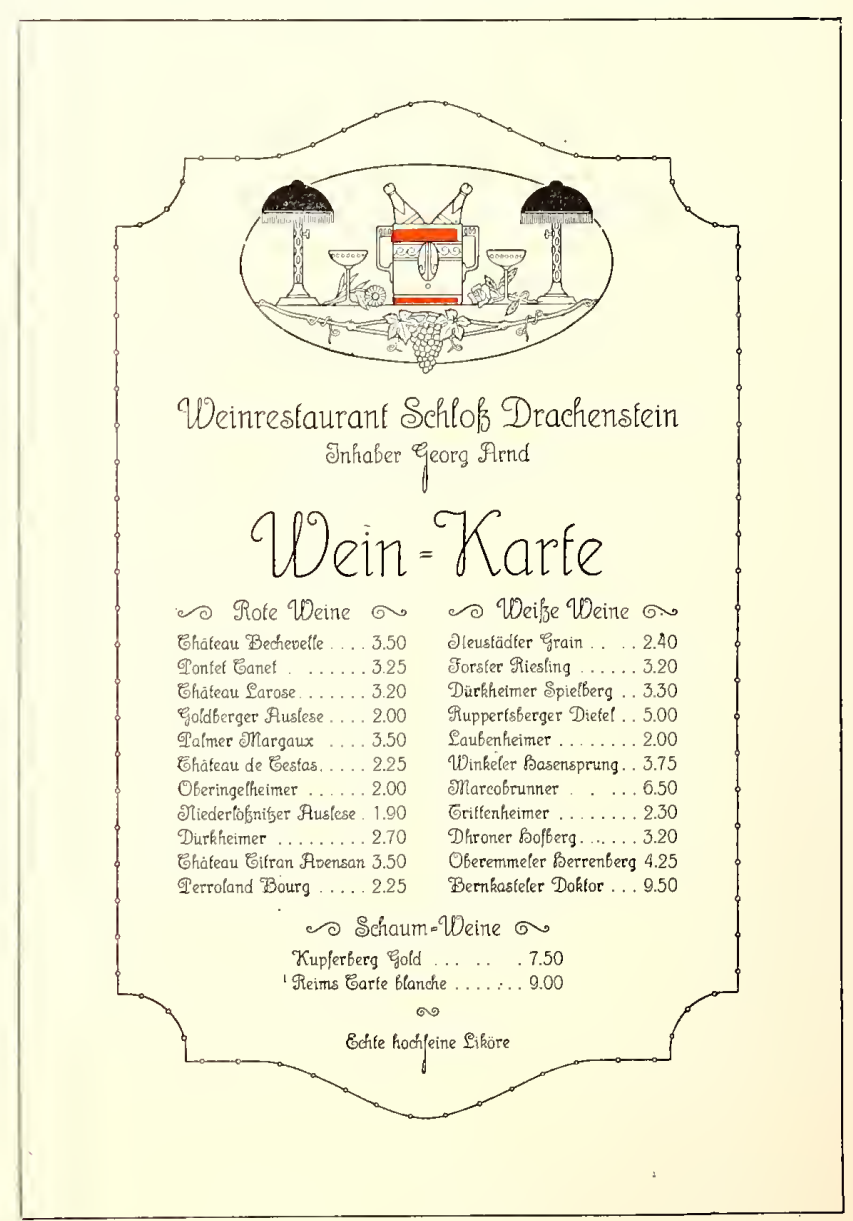

EXAMPLE 189

German treatment of a wine list, showing neat typography and attractive decoration 
THE METROPOLITAN MUSEUM OF ART

\section{CATALOGUE}

oF A

MEMORIAL EXHIBITION

OF THE WORKS

OF

AUGUSTUS SAINT.GAUDENS

NEW YORK : MDCCCCVIII
34

\section{CAT A LOG UE}

62

WASHINGTON MEDAL

Bronze medal, low relief, copyrighted 1889. D. $4^{1 / 2}$ in.

(Obverse) Bust of WVashington, side view, bead in profile, directed left; Continental costume. At the right, the fasces of magistracy. Forming a border about the edge, thirteen stars.

Signature

PHILIP MARTINY, MODELLER, DESIGN AND COPYRIGHT BY AUGUSTUS SAINTGAUDENS

Inscription

GEORE WASHINGTON. PATER PATRIAE. MDCCLXXXIX.

(Reverse) Upper balf, an American eagle, with wings spread, claws bolding arrows and olive branch bearing shield with lagend E PLVRIBVS branch bearing shield with lagend E PLVRIBVS
VN VM. Lower left, coat of arms of New York State. Thirty-eight stars forming border.

Inscription

TO COMMEMORATE THE INAVGVRATION OF GEORGE WASHINGTON AS FIRST PRESIDENT OF THE VNITED STATES OF AMERICA AT NEW YORK APRIL XXX MDCCLXXXIX. BY AVTHORITY OF THE COMMITTEE ON CELEBRATION WASHINGTON MEDAL NEW YORK APRIL XXX MDCCCLXXXIX.

Lent by Mr. Frederick S. Wait. size of italic. A fact that makes the catalog unique is the absence of roman lower-case. It is difficult to visualize an eighty-two-page book without roman lower-case, but here is one. The title-page (Example 190) is composed in three closely related sizes of capitals, corresponding to the sizes used on the inner pages. The important words, "Catalogue," "Memorial Exhibition" and "Augustus Saint-Gaudens," are set a size larger than the minor words "of a" and "of the works of," altho the difference is but a point. The small woodcut is an appropriate accompaniment of the classic style of the type composition, and the harmony is further enhanced by printing in a clear black ink on thin white antique paper. Example 191 slows a page from the body of the catalog, the features of which are worth noting. All lines excepting the exhibit number are set fush at the left, and the paragraphs or groups are separated by space. The title of the exhibit is set in the larger capitals, the descriptive matter in italic lower-case, and quoted words in the smaller capitals. Punctuation

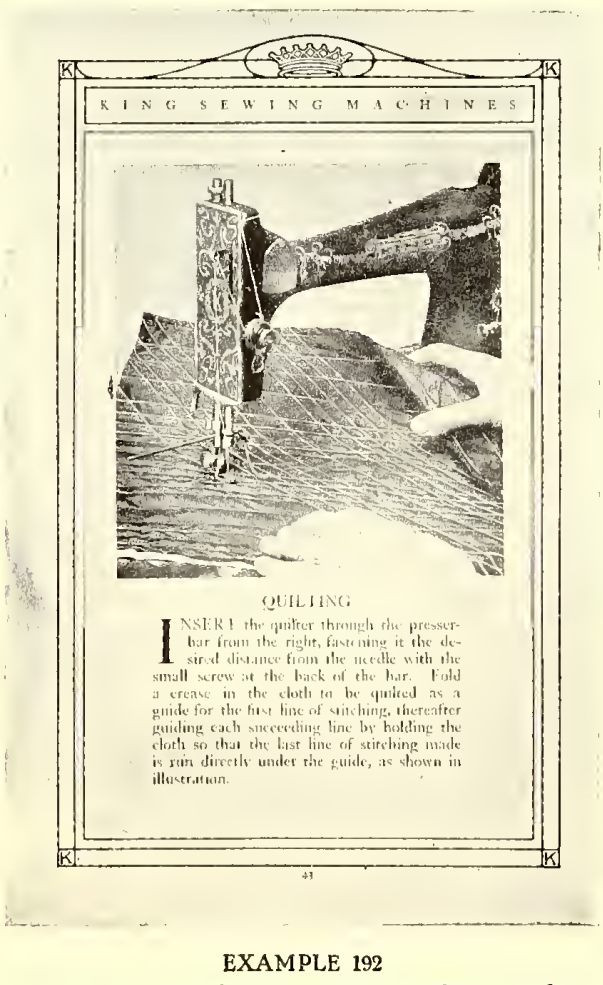

Interesting page from a sewing-machine catalog. By Matthews-Northrup Works, Buffalo, N. Y. at the ends of lines is sometimes omitted and sometimes used. The rule adopted by modern ty pograpleers - to omit punctuation points at the ends of display lines-leads to nice distinctions when a page such as this one is to be treated. As a help in deciding on proper marginal distribution on work of this sort, it is well to mention that the size of the leaf of this catalog was $43 / 4 \times 73 / 4$ inches, the type pages measuring $2 \frac{5}{8} \times 5^{1 / 2}$ inches or less, the type pages not being of regular lengtl. The margin at the head was $5 / 8$ inch; at the binding edge, $\pi / 8$ inch; at the outer edge, $1 \frac{1}{4}$ inches; at the foot, $1 \frac{5}{\mathrm{~s}}$ inches or more.

Example 192.- This shows a page from a catalog of sewing machines and sewing-machine parts. The workings of the machine were pictured in suclı a realistic manner tliat the effect was almost equivalent to a demonstration on the machine itself. The border did not force itself on the attention, yet furnished the decorative element to the page. The type matter, in Caslon roman, was stylishly arranged in harmony with 



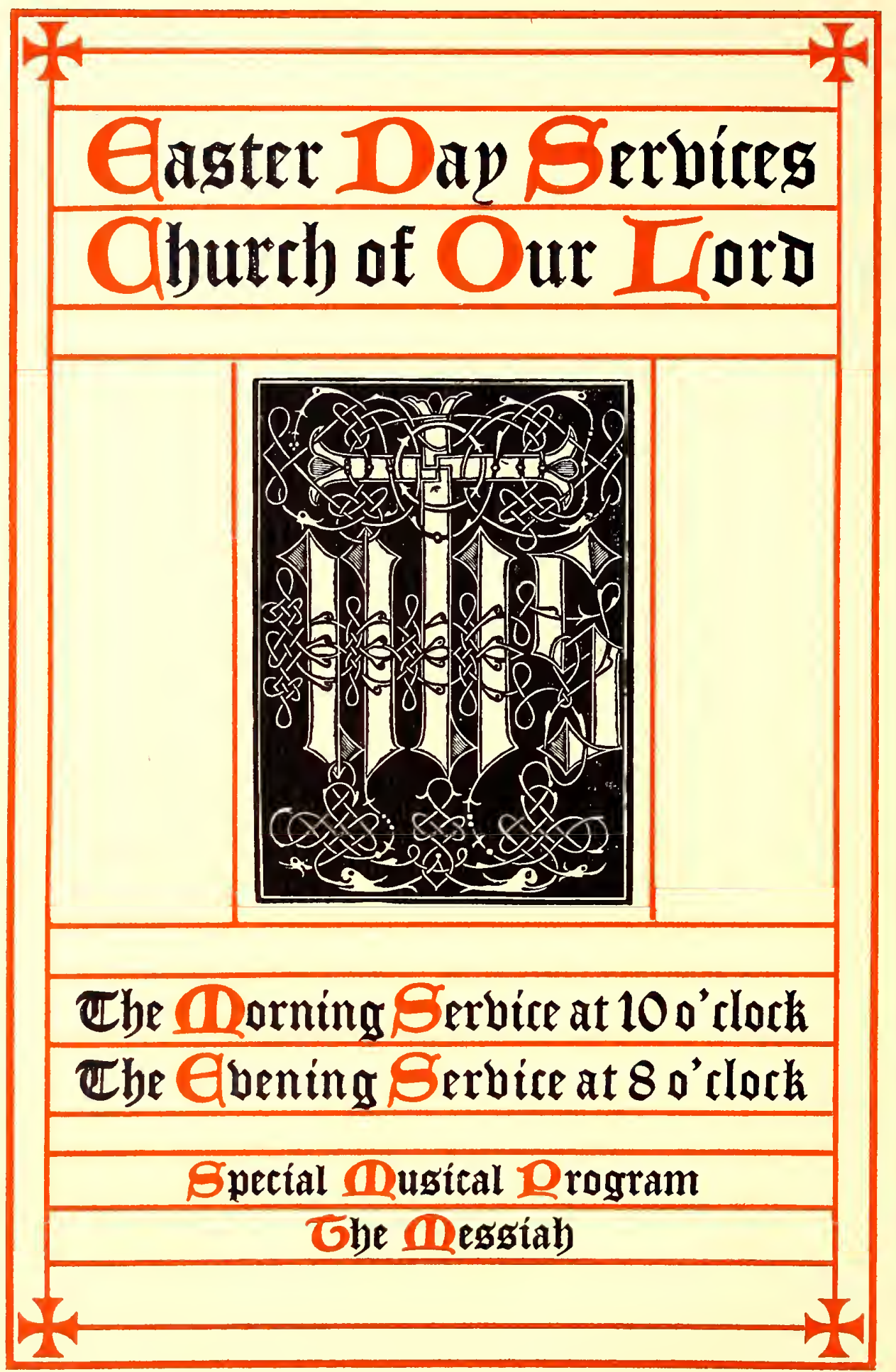

EXAMPLE 200

Program cover page in ecclesiastical style 


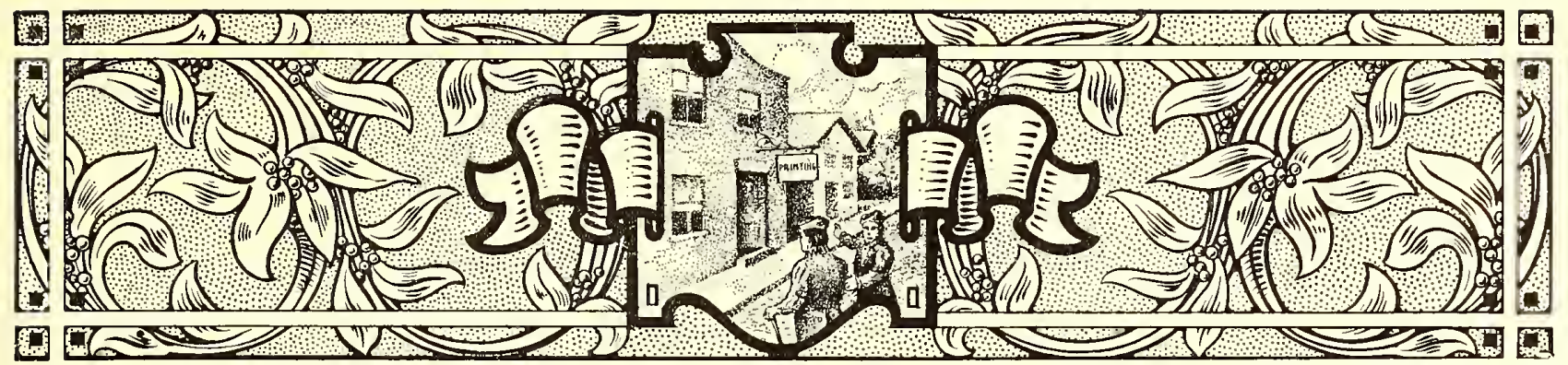

\section{PROGRAMS}

"LET all things be done decently and in order." These words of Paul, while possible of wide application, have peculiar significance applied to the program. The program exists because of recognition of the necessity of orderly procedure "where two or three are gathered together." Historically, the program has come to us from the early times, when all knowledge was transmitted by word of mouth. Church services are the result of evolution from ancient ceremonies, and other exercises for which programs are used originated in the far past.

Programs familiar to printers could be divided into four classes: Programs of sacred services, dance programs, banquet programs, and programs for various entertainments. In this order they will be considered.

The historical side of the program of sacred services should not be overlooked. It is a mistake for printers to produce church programs in the same style of typography employed on secular forms. Church programs, more than any other line of printing, offer opportunity for artistic treatment, and their production is pleasure to the artistprinter who believes significance is an important element in good typography.

The key to the proper treatment of ecclesiastical printing lies in the old manuscript books written in the monasteries. Black ink was commonly used for the main portion of books, and vermilion, a red earth (rubrica), for titles and important parts of the text. In the writing of Missals (containing services of the celebration of mass), of Psalters (containing the psalms), and of Books of Hours (containing prayers and offices for the several hours of the day), maltese crosses and uncial capitals were written in vermilion. Uncial capitals are now made by several type foundries as Missal initials, Caxton initials, Sylph initials, etc., and maltese crosses are easily procured. As black text letters were also used on these missals and psalters, the type-faces now known as Caslon Text,
Morning and Sermon

at elrann a'tleck

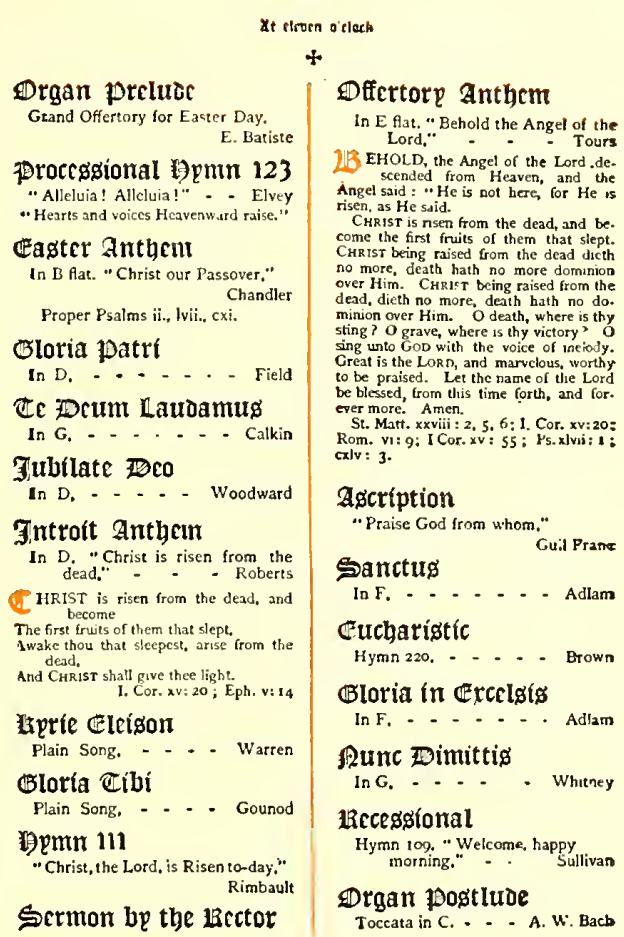

EXAMPLE 201

Excellent arrangement for economizing space on a program containing numerous small titles

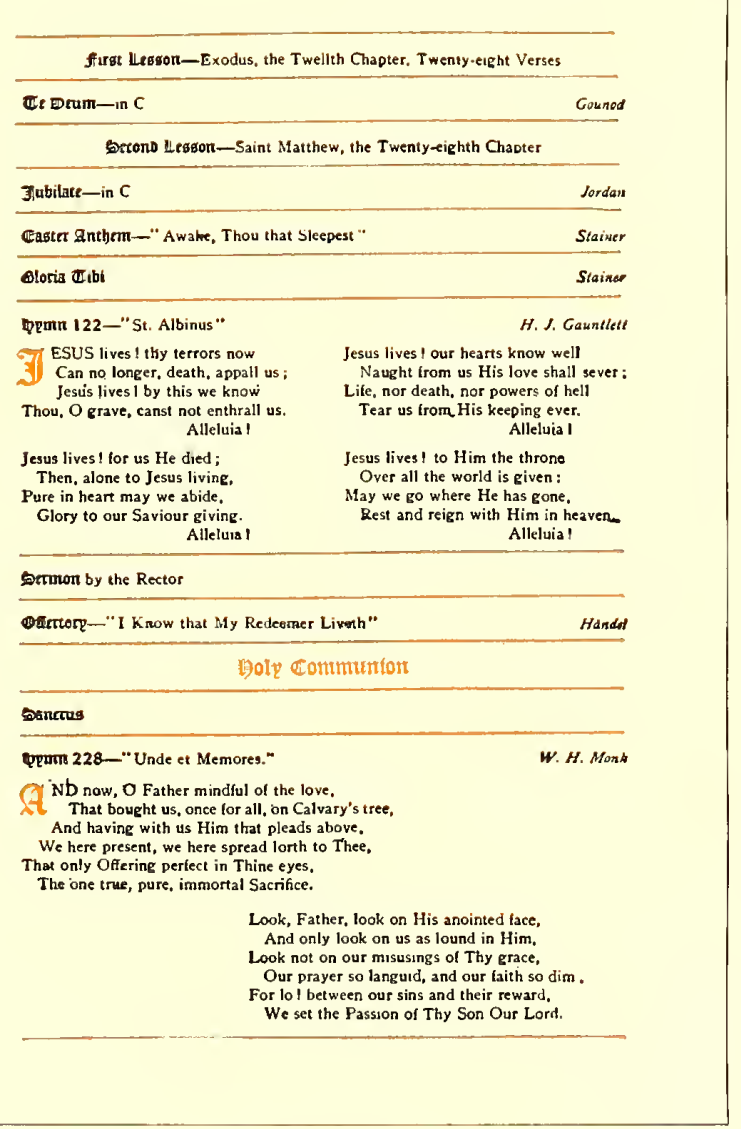

EXAMPLE 202

An almost perfect specimen of church-program printing, showing the missal style 


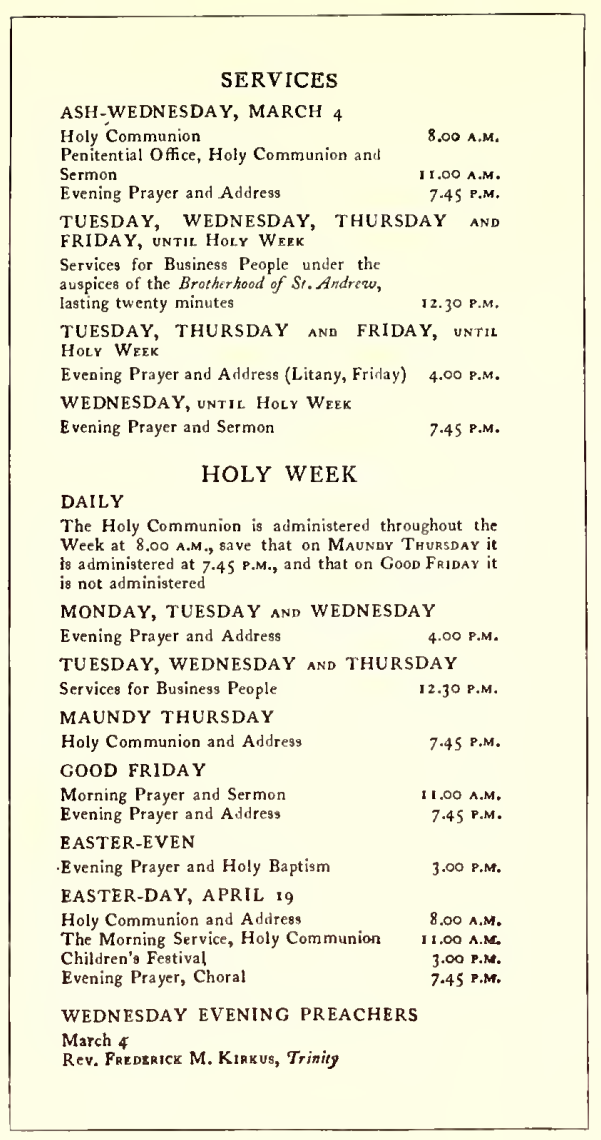

EXAMPLE 203

Classic treatment of church-program page. By D. B. Updike, Boston, Mass.
Cloister Black, Flemish Black, etc., be in $\mathrm{g}$ copies of these early text letters, are appropriate faces portions or church programs. Text letters were long ago discontinued for body purposes in $\mathrm{E} \mathbf{n g l i s h}$ printing, hence they have become unfamiliar to the general reader and it is not desirable to use them for such purposes. A roman letter such as Caslon is the best companion for these black text letters.

The Church of England, the American branch of which is known as the Protestant Episcopal Church, deserves much credit for the modern development of an ecclesiastical sty le of printing. Because of the custom of using red ink in forms of service, for the parts giving direction as to the conduct of the services, these parts have become known as "rubrics." It is necessary to mention to printers generally that when colors are used on programs or books of service the "rubrics" should be in red. This treatment is illustrated in the page from the marriage service shown as Example 146 in the chapter on "Books" which also shows an uncial initial. When only black is used it is customary to set the rubries in italic.

ExaMple 200(Insert).-This title-page presents a modern interpretation of the historic ecclesiastical treatment. The black type-face is Caslon Text, and is a copy of one of the early manuscript letters, as before mentioned. As pointed Gothic is usually accepted as the style of church architecture, so pointed Gothic type-faces have been adopted for church printing by typographers who know. Uncial rubricated initials as used on this title-page are known commercially as Caxton initials. The for display

red lines which are a prominent part of the page have historic significance. Now grown to possess decorative value, they originated thru the necessities of writers or manuscript books, and were originally guide lines for writ i n $\mathrm{g}$. They designated the position of the page and $t h$ e

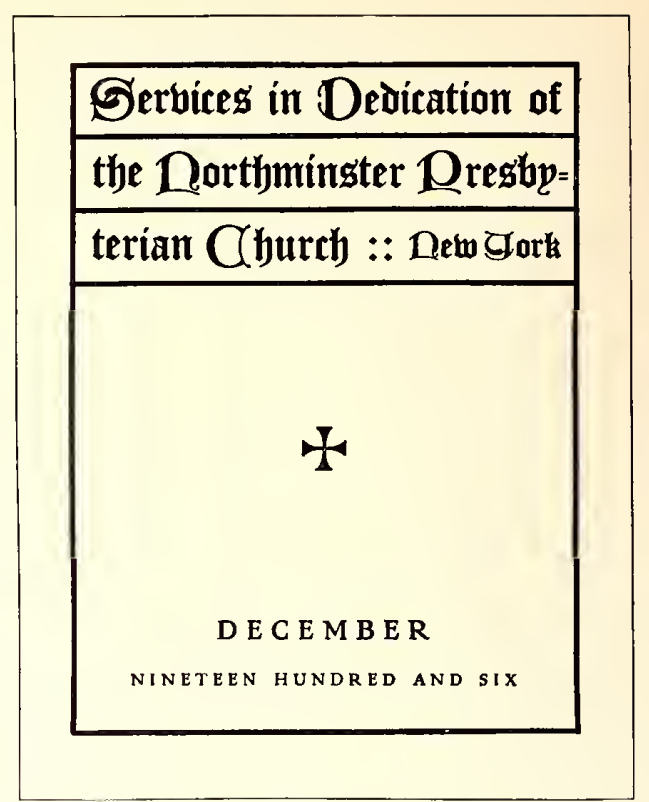
lines of let-

ters. With the ancient churchmen the maltese cross was the symbol of Christ, and today also these crosses have that significance, altho to a great extent they are now considered merely as ecclesiastical decoration. The square device in the center is in the Celtic style of ornament. The significance of the design lies in the decorative cross and the letters I. H. S. (Iesus Hominum Salvator, Latin, meaning "Jesus Saviour of Men"). It may be well to suggest that treatment of church printing should be varied sometimes with the denomination for which the work is done. The majority of clergymen will be pleased with printing treated in the accepted ecclesiastical style, yet there are some, prejudiced against "high church" liturgies and emblems, and others with individual ideas of what is appropriate, who must be considered. The writer recalls an instance in which the customer, an Episcopal clergyman, objected to what he called a "Latin" cross, used as an ornament on a title-page, and was satisfied when a maltese cross was substituted for the purpose. Many church programs which now appear commonplace would take on a churchly aspect if rubricated, even tho that be possible only on the title-page.

The example under consideration (No. 200), it will be noticed, is constructed on squared lines, a shape dictated by the large decorative device. While the page as arranged is interesting and fairly harmonious, the pointed letters in the type lines would blend better with a device of the pointed Gothic kind; or, again, the squared device would be in closer harmony with a squared type effect such as could be obtained with roman capitals.

Generous margins on a church program are pleasing
Example 201.-This page 


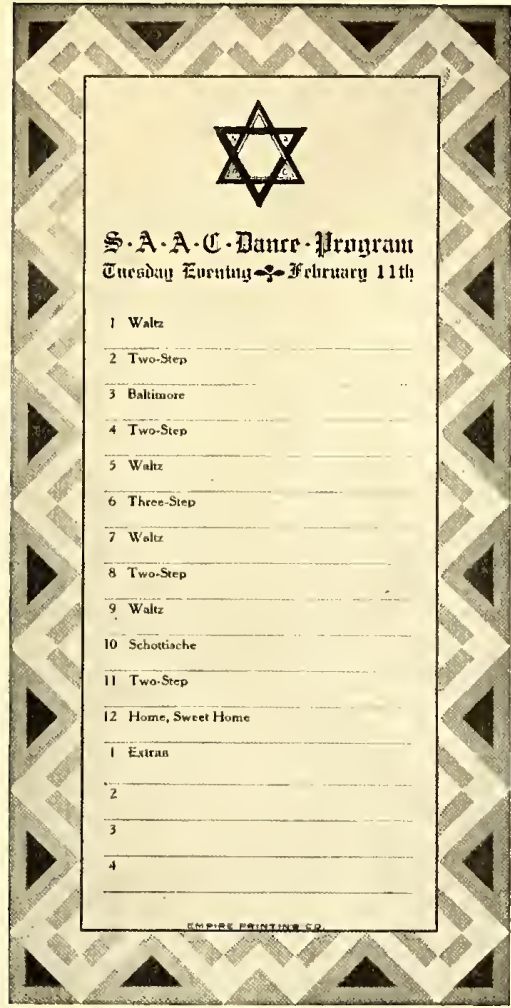

EXAMPLE 206

A dance card by Edward W. Stutes, Spokane, Wash. presents an excellent suggestion for the arrangement of a program in which numerous smatl titles appear. $1 f^{\circ}$ each title were set in a measure the full width of the type page, as is frequently done, the matter would not come into one page. 'The arrangement as shown not only economizes space but gives synimetry and tone, which otherwise would not be had. 'The portions in red are well selected for printing in that color. There is artistic value in the shape formed by the vertical dividing rule and the page heading.

Example 202.

This page has not the compactness of the preceding one, yet esthetically it is more pleasing. It is an almost perfect specimen of church-program printing. As already mentioned, the horizontal red lines and the black text letter used for titles have an ecclesiastical motive. Careful disposition of blank space has given a pleasing tone to the page, which is also helped by the position of the second stanza of the hymn at the foot. The type-faces are harmonious, the use of

black text,

old-style roman and italic affording a pleasing variety. By including in the color the initial letters and the title "Holy Co $\mathrm{mm} \mathrm{\textrm {m } \text { - }}$ nion," parts of the page are blended and related.

Example 203. - The printer may be nat urally curious to know how a typographer such as D. 13. Updike, who is known to specialize on ecclesi- astical typography, $\mathrm{t} r$ e a $\mathrm{t}$ c h u r c h programs. Here is an $\mathrm{U}$ p d i k e pacre, from a program of Lenten services, arranged in the simple, classic style of typographic treatment that he always renders so well. As will be noticed, the main portion of the type page is aligned at the left. The nianner of usingr capitals, small capitals, lowercase and italic is an interesting $s t u d y$. While exa $\mathrm{min} \mathrm{i} \mathrm{ng}$ the page it is enlightening to note that A. M. a $\mathrm{n} \mathrm{d}$

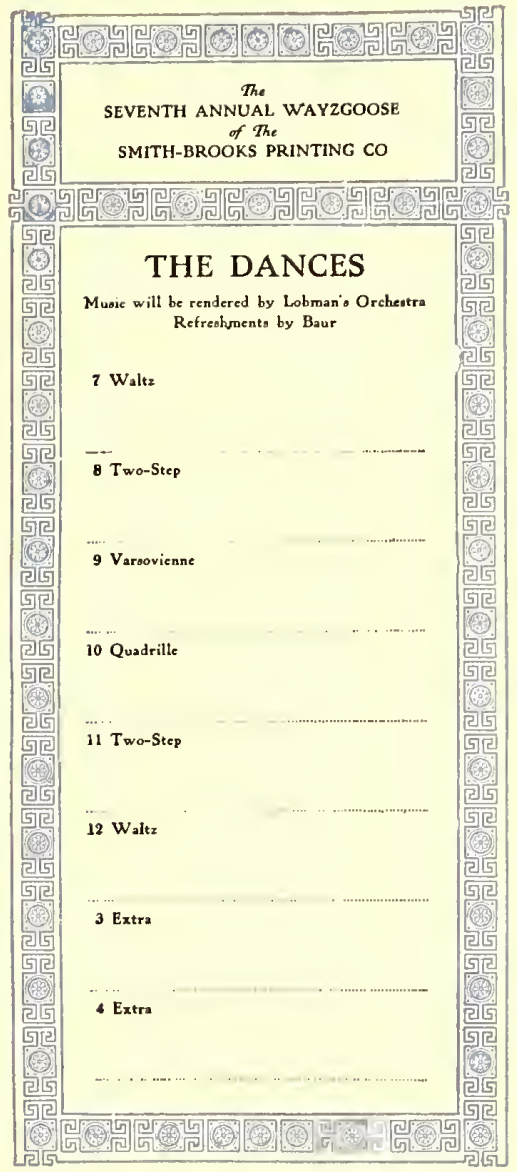

P.M. are in sman capitals, and that no space other than furnished by the period is placed between these abbreviations or the degrees D.D., Ph. D., etc.

Example 204. - This is the title-page of a sinall program which was in booklet form, a page being devoted to each event on the program. The title-page is in missal style, with cross rules and uncial initials. The spaced Pabst capitals at the foot are not sufficiently strong in tone to balance the upper part of the page. Perhaps the effect would be better had the missal style of treatment been extended to the lower portion of the page.

Example 205. - This is the second page of a small program used at the laying of the corner-stone of a new church building. It would have been possible to get all the type matter on one page, but crowding into small space is often done at the sacrifice of beauty, and this program profits by the liberal margins. The rule lines at the head were used to obtain uniformity of page width and hight. The outline type ornament gives ecclesiastic dignity to the program. The two-line initial at the beginning of each hymn adds style and finish to the typography.

The dance program is a far step from the church program. The contrast between the subdued and reverent atmospliere of the house of worship and the gayety and frivolity of the brilliantly lighted ball-room emphasizes the necessity of printers using their best powers of discrimination in treating the various programs that come to their shows. 


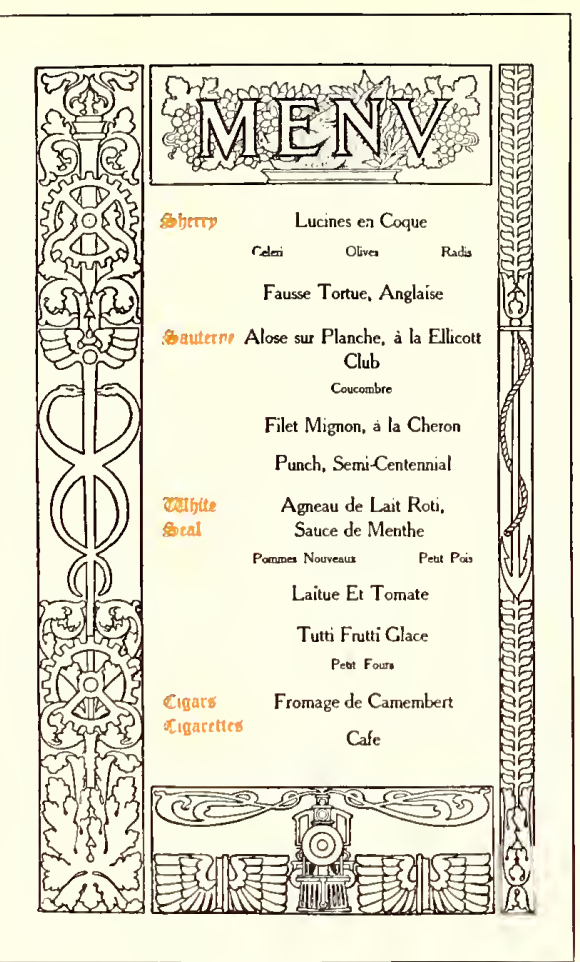

EXAMPLE 209

The decorative border on a banquet program. By Edward Everett Winchell, New York

The dance p r o g r a m should be dainty. White seems to be more acceptable than colored stock on which to print the order of dancing. The type and ink treat me n t should be neat and delicate. If a bold typeface be used, it should be printed in a light tint of ink, such as gra y, pale blue, pale green, and the like. It is possible for printers to produce attractive dance programs with the material generally found in

the shop, yet stuck folders may save wear of the thought machinery and probably be more satisfactory to the customer. Young people are imitative and may be suspicious of a dance program which does not resemble those they have seen before; it has got to "look like a dance pro-

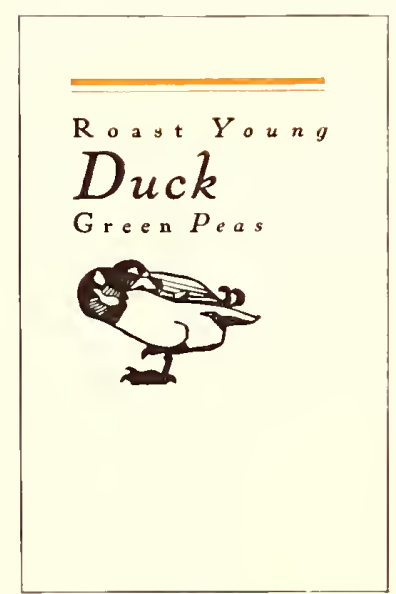

EXAMPLE 211 Page from a booklet program. By Will Bradley gram." For tifty years or more dance programs have consisted of folded cardboard with tassel and pencil dangling therefrom. The stock folder is to be had in a variety of designs printed or embossed on the first page, appropriate for many occasions. However, there are shown three typographic dance programs.

Example 206. - An lndian border was used around this dance card, but its strong lines were softened by printing in gray and red. White stuck was used. In the headline, instead of the customary periods, dots are centered decoratively. Artists often

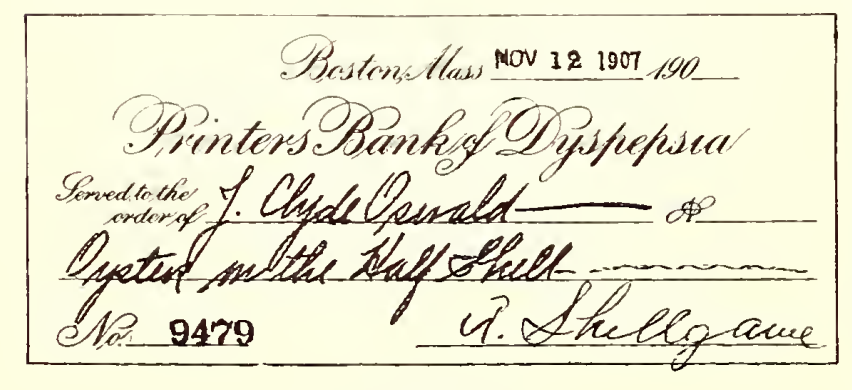

EXAMPLE 212

The banquet program in the form of a checkbook place a dot or s mall ornament between words of a lettered design for the purpose of benefiting the tone. More often practically no space at all is placed between words if in lowercase beginning with capital letters.

$\mathrm{E} \times$ A $M \mathrm{~L} D$ 207.-A part of an outing program, this page carries the style of all $\mathrm{the} o \mathrm{ther}$ pages as regards border a $n$ d h e a d panel. It il-

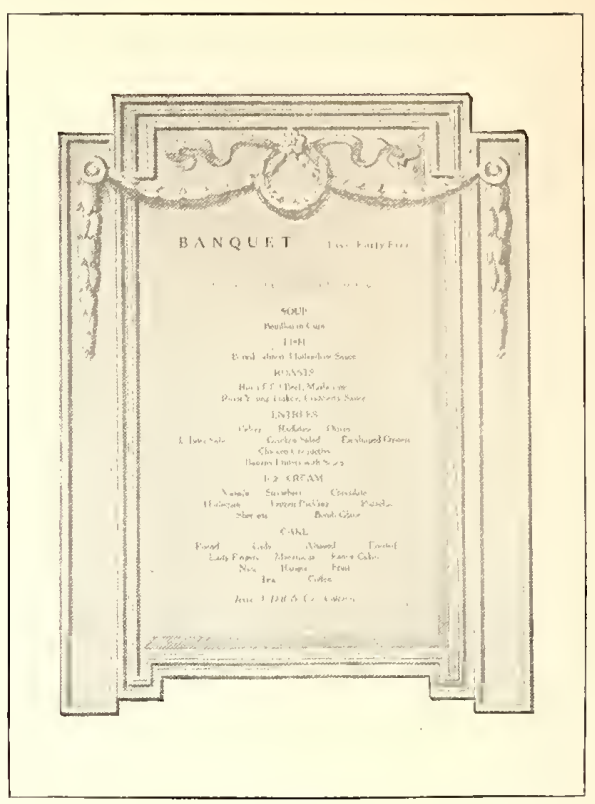

EXAMPLE 210

A halftone decorative background on a program. Design by Griffith-Stillings Press, Boston, Mass. lustrates the effectiveness and economy of uniform border treatment on a program. There are very few programs that would not be benefited by decorative borders in color. But one border need be set in type, duplicates being obtained by electrotyping. If there are to be only a few hundred programs, two borders may be set in type and printed on all the sheets, running only two pages on. If desired, a hand-drawn decorative border could be engraved and afterward duplicated by electrotyping.

FXAMPL 208. - There is nothing conventional in the design of this dance program. It is different from most others. 'The rule lines extend to the border, and the heading "Dances" sets slightly to the right of center, supported underneath by the graceful flower ornament. Punctuation is omitted. This page is recommended for dance cards, when the printer desires to have the job exclusively typographic.

The banquet program not so many years ago here in America aurl in England was commonly called a bill of fare. Now only the cross-roads hotel and the cheap city eating house have bills of fare. The polite title is now "menu," pronounced men-yu or mehnoo. Some writers claim the word came to us from "Manu," a mythical sage said to have sprung from the god Brahma. Yet the dictionary would seem to indicate that the word is French, meaning small, and was derived from the Latin minutus, little. It is possible that the small portions now served in many restaurants suggested the use of "menu" because of the contrast with the generous "helpings" of the oldfashioned meal. In 1512 a

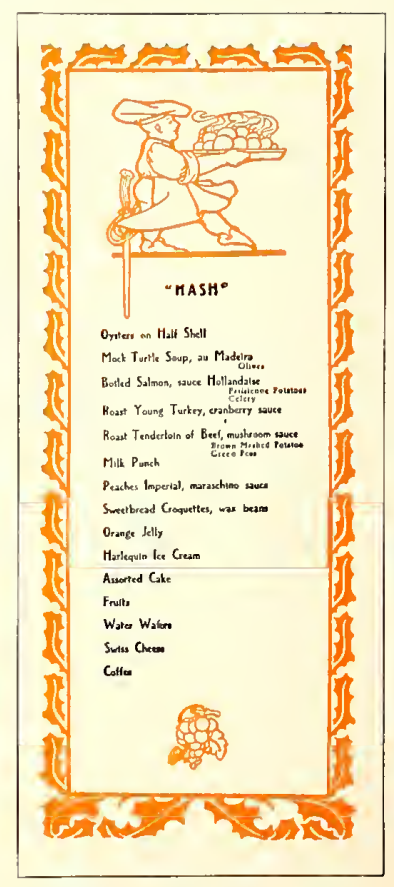

EXAMPLE 213

Humorous treatment of titles and odd menu arrangement. Design by the Griffith-Stillings Press, Boston, Mass. 


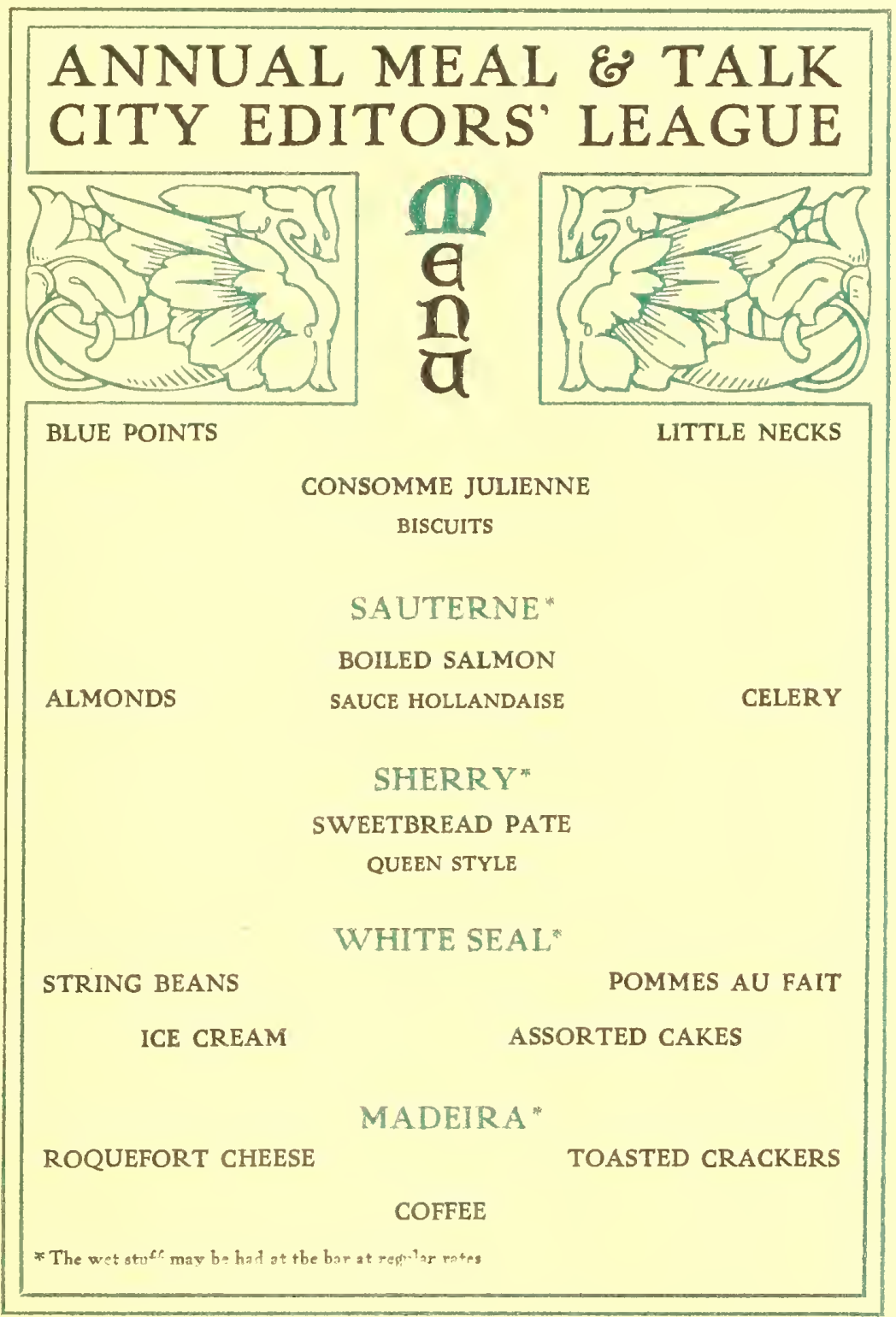

EXAMPLE 214

Suggestion for a menu page, introducing a bit of fun 
, 


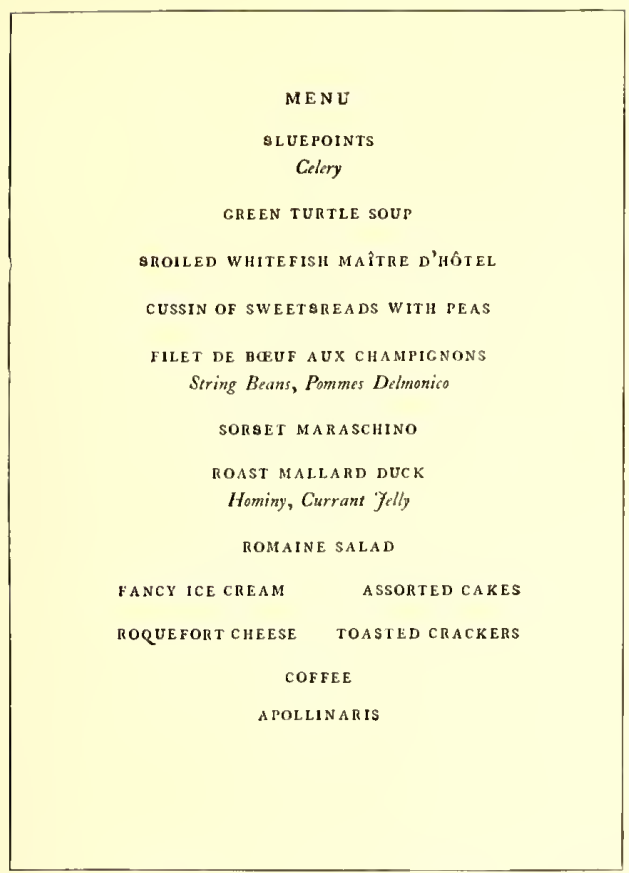

EXAMPLE 215

A classic menu page. Designed

by D. B. Updike, Boston, Mass. "shore dinner" for an individual consisted of "a quart of b c e r, a quart of wine, salt fish, red her ri $n g$, white herrings and a d i s h of sprats."

I $n$ the ba u a u e t p r o gra m the printer has great opportunity to make use of his inventive faculties. No other kind of program allows of such varied treatment. There is no limit to the shapes, the type arrangements and the color treatments that are suitable for banquet programs. An association of leather merchants holds a dinner and the members may find beside their plates a program bound in a miniature hide, the sheets of the program attaclied by a leather thong.

Bankers meet and the program may be in the form of a checkbook.

For an athletic association an oval-shaped program suggesting a football will "score."

Newspaper publishers will appreciate the menu list presented as a papier-mache matrix of the type form.

Commercial travelers would be pleased were their banquet programs designed in imitation of a mileage book.

A literary society dinner would be appropriately graced were the program printed on parchment and wound around

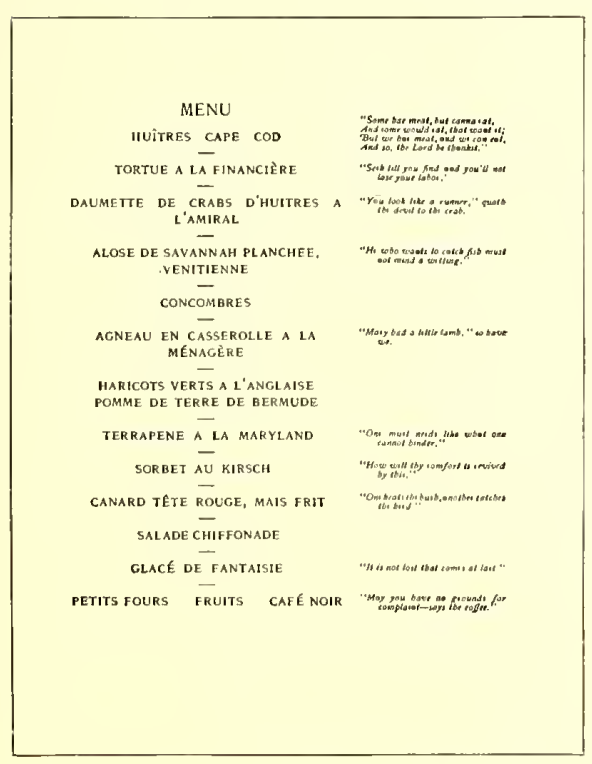

EXAMPLE 217

Dignified style for menu page. By the De Vinne Press, New York tive border around it. Type ornaments and borders could be printed on the wood as a guide for burning the designs.

Many effec-

tive menu forms could also be evolved with the assistance of the bookbinder. Pulp board covered with an artistic cover paper makes a handsome background for mounting the menu page, which should be printed on a harmonizing stock. Italian and Japanese h a nd $-\mathrm{m}$ ad $\mathrm{e}$
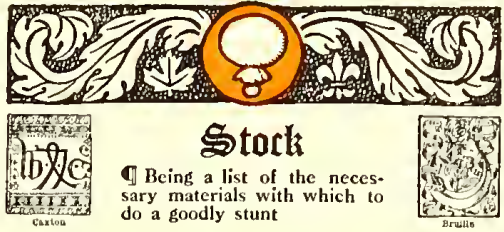

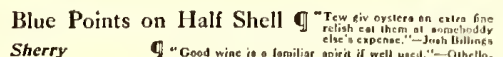

Cream of Fresh Mushrooms "He hash never led of the

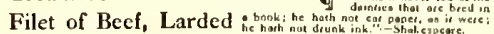

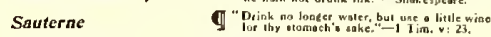

Sweetbreads en Casserole

Punch Cardinat

Roast Young Chieken "Ihig dith or meat is los good for any

Green Peas-Potatoes

Rye, Scotch and Soda

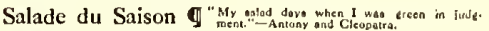

Potato Iees Fantasie

Assorted Faney Cakes and Pastries

Bon-bons-Salted Almonds

Black Coffee

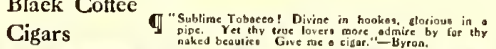

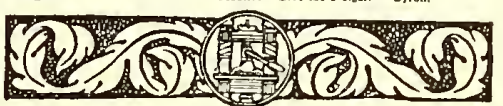

EXAMPLE 216

A menu program used by master printers.

By Charles Edward Peabody, Toronto, Ont. papers are particularly suitable for such work, and when the style of typography is made to blend with the stock the effect is rich. Domestic manufacturers, too, make a large line of artistic papers applicable to the purpose.

ExaMPLE 209.-This page is from a booklet program, and is companion to Example 125 inserted in a preceding chapter. It sets forth the value of the decorative border on programs. The arrangement of the type matter is the customary one. The minor dishes are set in small type, while the damp stuff from the wine cellar is represented at the left in rubricated text letters.

Example 210.-A halftoned decorative background in olive was a feature that lent value to this page, which is on e of a number of similarly tre at ed pages in a bo o klet program . The classic panel design makes a $\quad$ g background for a menu page. The idea is applicable in many other ways.

ExAMPLE 211. - This c li a p t e r would be incomplete w it hou t one or two Brad l e y specimens. Here is an

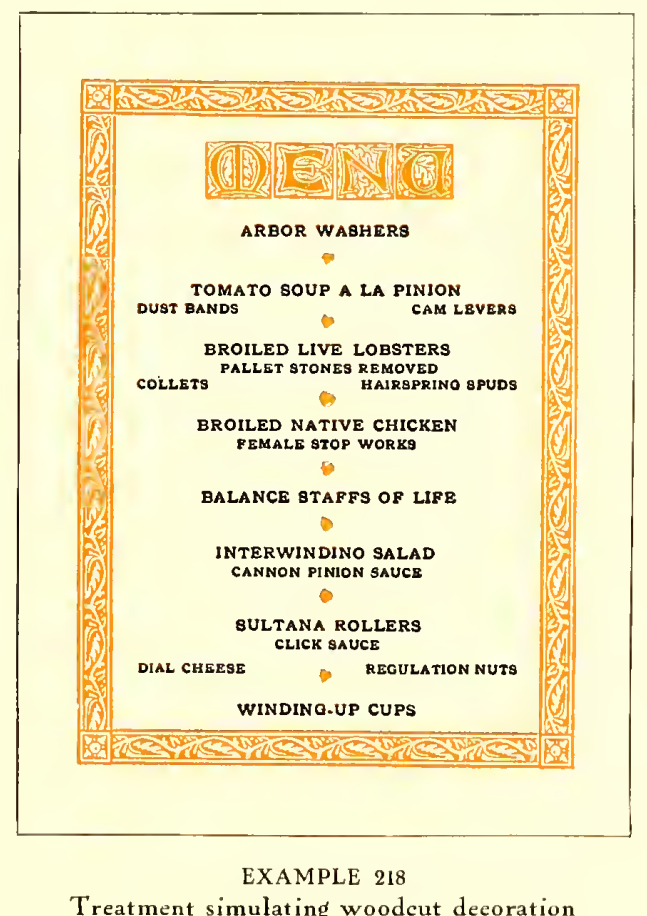

Treatment simulating woodcut decoration 


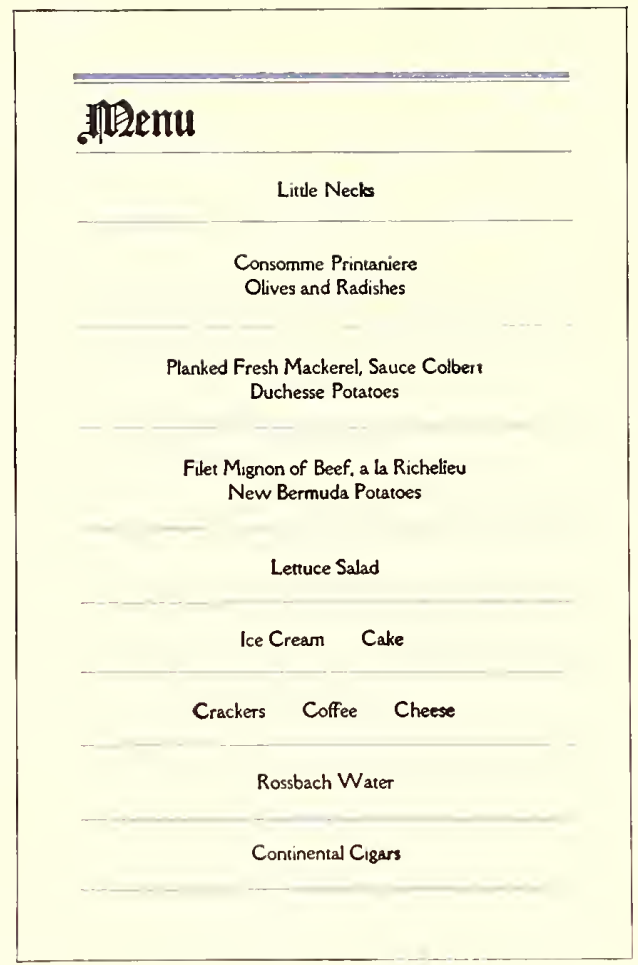

EXAMPLE 219
The missal style adapted to a
menu program. By Will Bradley

i d e a in menuprinting bor $n$ while he was with the American Type Founders Compan y in 1905 . It took the form of a small booklet $2 \frac{3}{4}$ by $43 / 4$ inches, eight pages and cover, and each page was devoted to one of the dishes on the menu. Below the n a me of the dis h was a chapbook ornament. Alt ho t h e small booklet has been little used as a form for menu purposes, it has possibilities for development that should not be overlooked by the printer.

EXAMple 212.- Here is a novel banquet program. Each disli on the menu was prosented in the form of a check on the "Printers" Bank of Dyspepsia," and the "bank" was ordered to pay to the order of the guest a portion of food or drink, in this instance oysters on the half-shell. The checks were signed by appropriate names," A. Shellgame" in this instance. The entire lot of checks was bound in the customary checkbook style.

Example 213.- In this program the menu is termed "Hash" and the toasts "Relıasl." "The treatment is

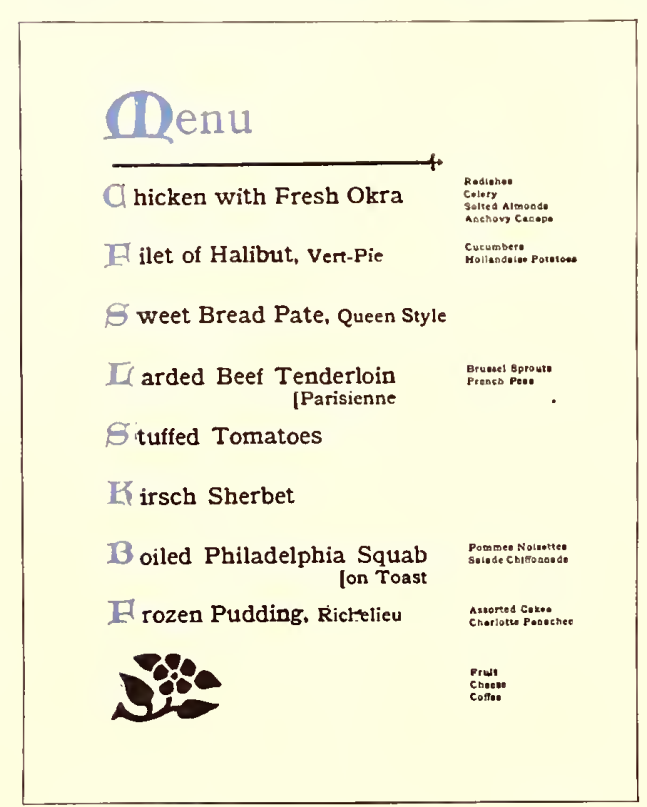

EXAMPLE 220

Unique treatment of a menu page in which the minor dishes are arranged at the right unique, especially in the a r rangement of the list of palate ticklers.

Fixam PLE 214 ( I n sert).-Suggested for a menu page in two colors. Banquets are occasions of gayety and enjoyment, and humor is appreciated. Disp 1 a $y$ i n $g$ c ho i c e d r i n k s prominent$1 y$, and then in a note at the foot
calling at-
tention to
the fact
tlat they
can be had
at the bar
at regular
rates, is a
bit of fun
that has not
been wide-
ly perpe-
trated. Ty-
pographi-
cally the
page is re-
fined, yet is
sufficiently
decorative
to appeal to
a large class
of custom-
els.

EXAMPLE

c 1 a s s i c menu page

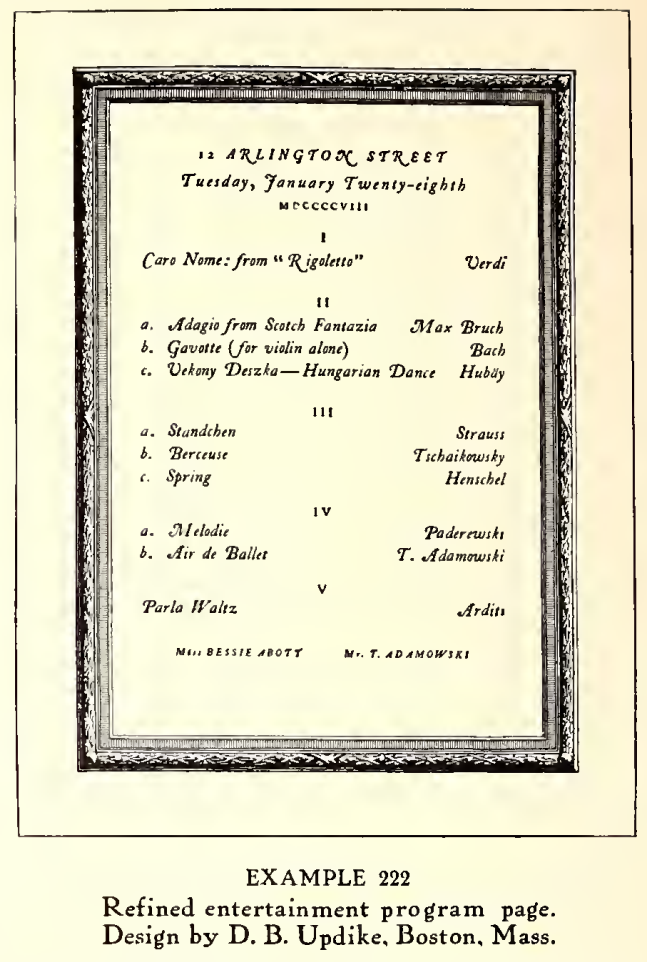

by Updike. Roman capitals and italic lower-case only are used. Perhaps this is the way Aldus would set the page were he alive today. The page as a mass is symmetrical.

Example 216. - This page is from a program used at a master printers' banquet, all pages being treated in a style appropriately humorous. The word "Stock" tops the page instead of the usual "Menu." "Make-up" heads the list of officers, and in this manner were the guests' funnybones agitated.

EXAMPLE 217.- Here is a program for those accustomed to eat in a foreign language. The typographic treatment is refined and dignified, the roman capitals and the italic blending classically. Little side hits such as those to the right are always appreciated, especially when care-

fully selected.

Example 218.-An artistic treatment simulating woodcut decoration suitable for many occasions is presented by $t h$ is page. The four initial letters give the appearance of a decorative h e a d i n g and blend well with the border. It is appropriate that c a pita $1 \mathrm{~s}$ should be used thru-

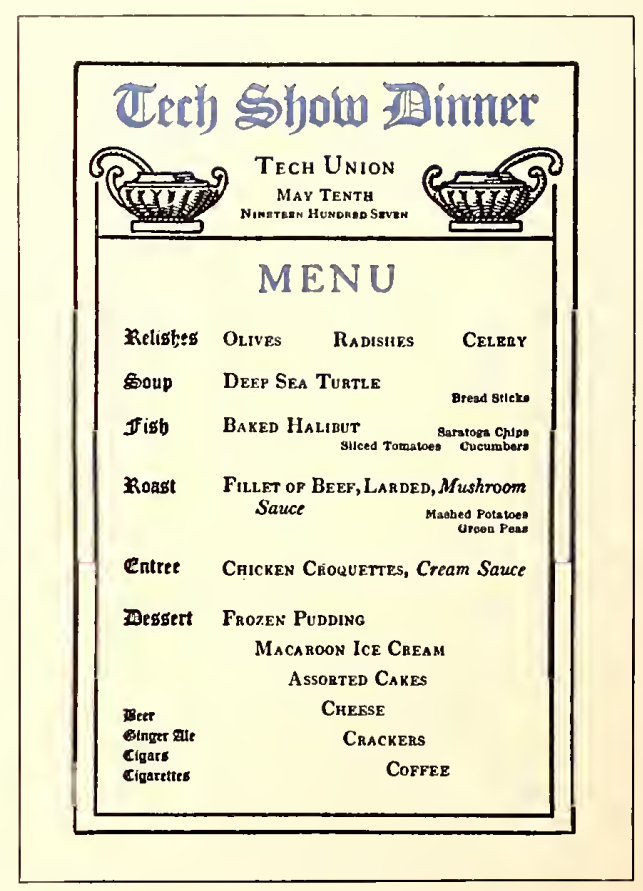

EXAMPLE 221

Excellent typographic treatment, By Harry Haime, Boston. Mass. 


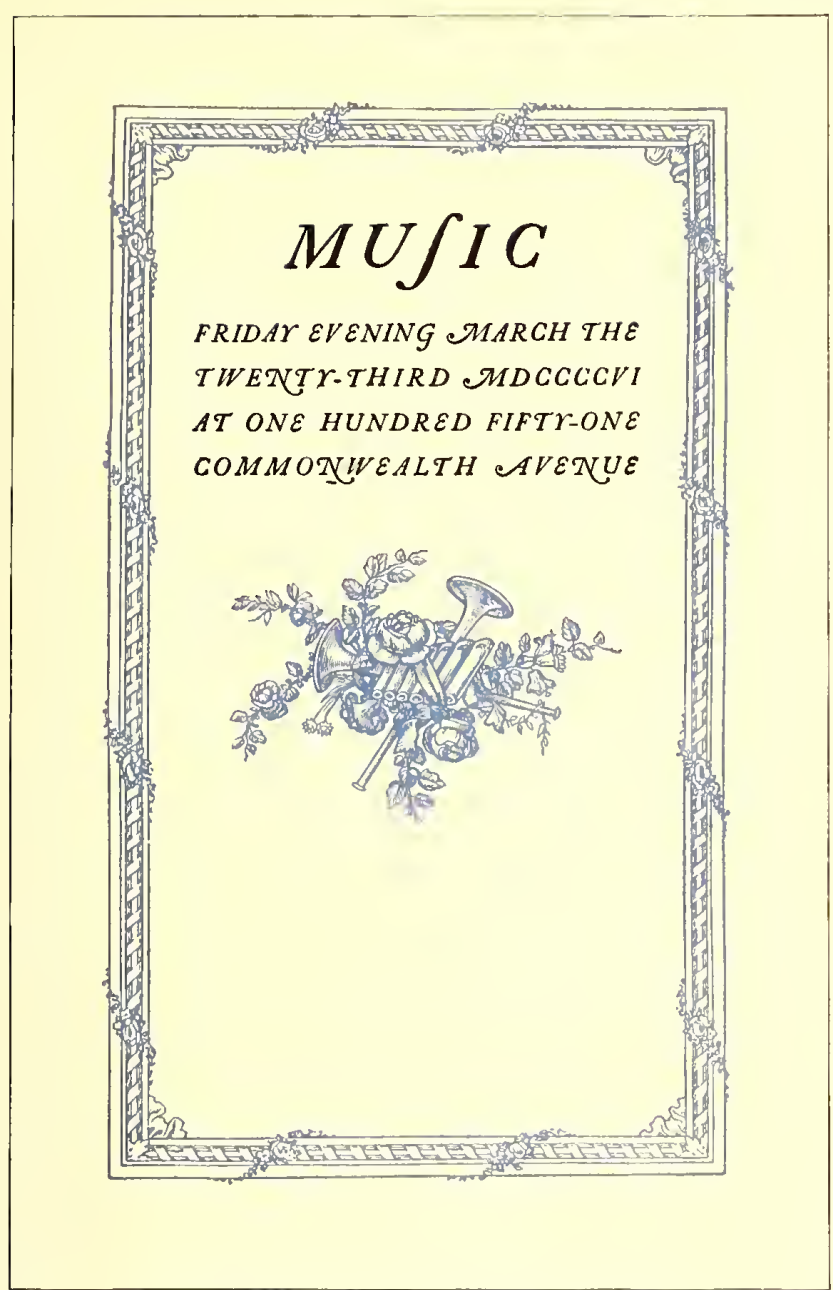

EXAMPLE 223

These two pages are from an entertainment program by Bruce Rogers, Cambridge, Mass., and furnish interesting material for study

\section{PROGRAMME}

QUARTET FOR TWO VIOLINS, VIOLA, AND VIOLONCELLO IN G-MINOR, OPUS 27 GRIEO

A Un poco Andante - Allegro molto ed agitato

B Romance-Andantino

c Intermezzo-Allegro molto marcato

D Finale-Lento, Presto al Saltarello

II

PIANO SOLO

BALLADE, A-FLAT

CHOPIN

MR. HEINRICH GEBHARD

III

VIOLIN SOLO

A ROMANCE, OPUS 20

- moto perpetuo, opus 34 PROFESSOR WILLT HESS

IV

QUINTET FOR PIANO, TWO VIOLINS, VIOLA, AND VIOLONCELLO IN A-MAJOR, OPUS 81

$$
\begin{aligned}
& \text { A Allegro ma non troppo } \\
& \text { B Dumka-Andante con moto } \\
& \text { c Scherzo-Molto vivace } \\
& \text { D Finale - Allegro }
\end{aligned}
$$

out the page and that the type-face should be Old-Style Antique. The florets dividing the dishes distribute the color pleasingly. The fact that this program was used by an organization of mechanical engineers explains the queer wording of the list of good things to be eaten.

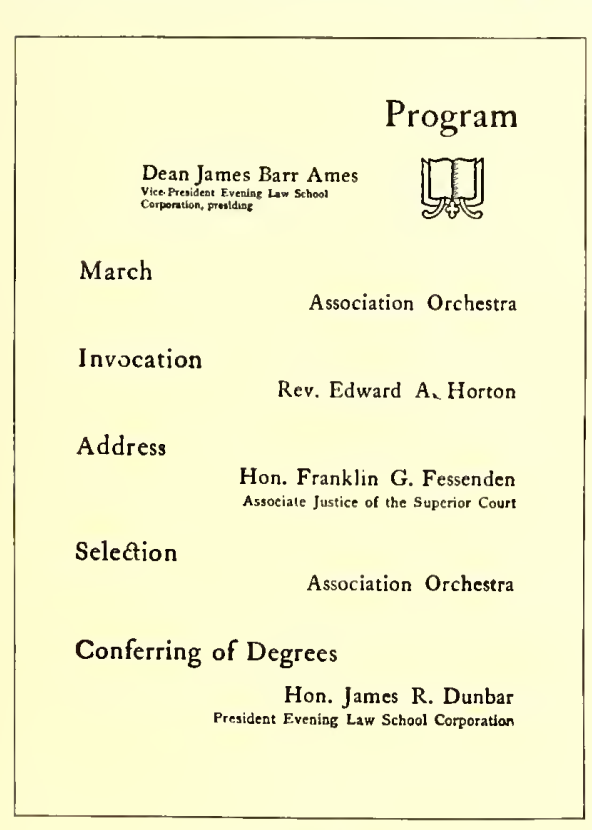

EXAMPLE 225

A program page in lower-case. By Stetson Press, Boston, Mass.
E X A M P I, F 219.-Bradley suggests another good arrangement in this page. It is simply constructed, y et possesses interest and style. The original was in b lack and light-brown inks on buff antique stock.

F $X$ A M I' L $\mathrm{E}$ $220 .-\mathrm{T} h$ is page has the merit of being unique while contain ing elements of the artistic. The important dishes are set forth promi- nently, the minor dishes appearing in small type grouped at the right. Uncial initials blend with the Old-Style Antique type. The horizontal rule and the large flower ormament play necessary parts in obtaining a balance.

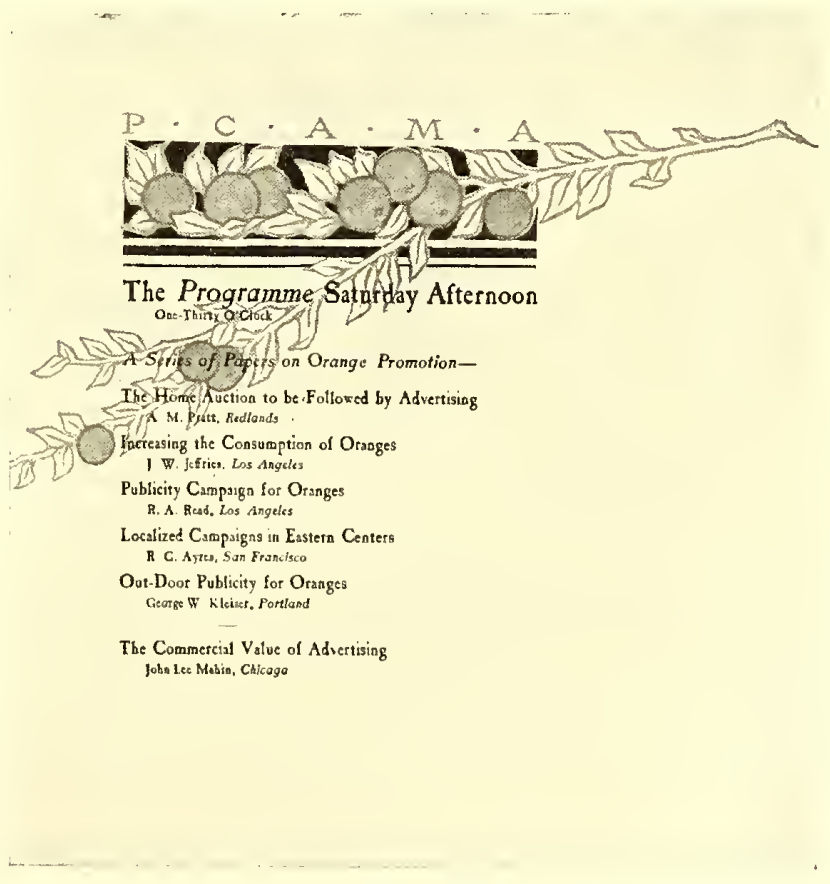

EXAMPLE 226

The decoration was in color. By Fred S. Lang, Los Angeles, Cal. 


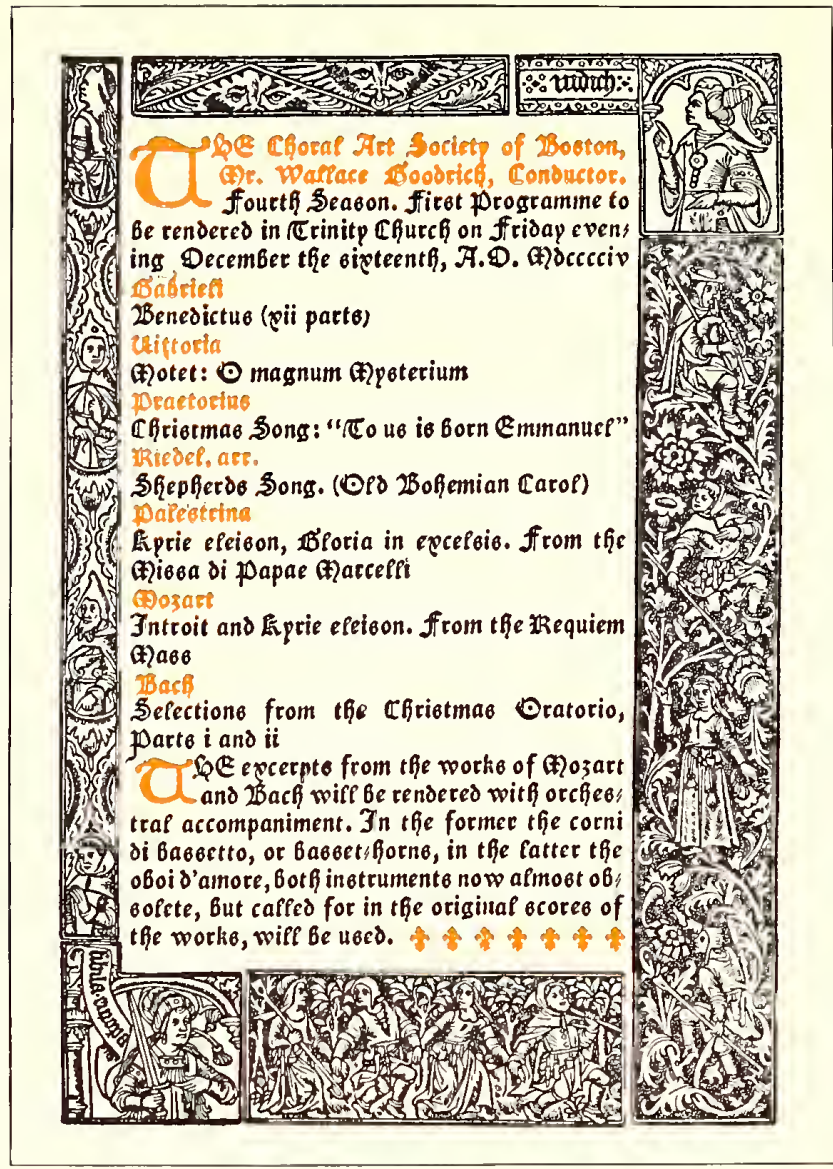

EXAMPLE 227
Prodram in the Gothic style. Designed
by Merrymount Press, Boston. Mass.

Example 221.-The treatment of the titles at the left side and the symmetrical arrangement at the foot of this example are highly commendable. The details of the entire page denote the finished typographer. The combination of capitals and small capitals is pleasing, and the manner in which variety las been secured in a design of orderly arrangement is commendable.

Programs for entertainments and exercises, while not allowing the unrestrained workings of the fancy that those for banquets do, are yet proper vehicles for carrying artistic ideas. The program should be artistic. The commonplace program is a disappointment to the intelligent auditor and an evil in that it influences the public taste towards mediocrity. The printer who cannot produce a good entertainment program has need to study art principles and observe the artistic programs being produced by others.

ExıMple 222. - A refined program page by Updike. In the original the border was printed from a copper intaglio plate on smooth-surfaced hand-made paper, the reading portion being printed clearly and sharply from type. Updike's work is noted for the clearness of the print. Just enough ink is carried to prevent the print being called gray. Of course the type must be clean and unaffected by wear, the ink well ground and the impression firm. This specimen is almost entirely in italic, with "swash" or decorative capitals that add interest to a page of dignified typography. Swash italic capitals properly used are valuable aids in securing attractive yet refined typographic effects.

Examples 223 and 224. - These two pages by Bruce Rogers should have interest for every printer who loves good typography. The zinc reproductions of these pages, also that of the preceding example, fail to present the sharp print of the originals. Roman lower-case is absent from this program. Rogers and Updike, with Aldus, liave demonstrated that roman lower-case is not essential to typography. Perhaps that is why their work has distinction-other printers set most of their type from the roman lower case.

On the title-page the features of particular interest are the long $s$ in the word "music," the swash italic capitals and the woodcut ornament.

The program page is interesting in its construction and its details should be studied closely. Unless suitable ornamentation is available, program pages had better be treated plainly as here, witl such attention to the details of the type arrangement as will obtain finished results. It is a test of typograplic ability in the production of a program page to compose work that, without the friendly aid of decoration, is pleasing to look upon.

Example 225.- This page shows admirable treatment of a brief program. The various sizes of type are well distributed, and the consistent use of roman lower-case is pleasing.

Example 226. - The type in this page overprinted the decoration which was in pale orange and pale green. The decoration was appropriate in that the program was for a meeting lield on the fruit-growing Pacific Coast.

Example 227.- The Gothic style dominates this page. Excepting the two uncial initials, only one size of type las been used. That fact alone is interesting, as the result is remarkably finished. Decoration of quality for similar effects can be obtained by having historic decorative borders from old books photographed and redrawn upon the plotograph with such alterations as are desired. The face of the photograph can then be washed away, leaving only the drawing, from which the plate is made.

Example 228. - The list of characters in a dramatic entertainment

is here displayed in an unusual inanner. It is so easy for conpositors to set copysuch as this in the conventional type-leadertype method, but this compositor has arranged it to conform to the proportion of the page.

The program containing small adver$\mathrm{t}$ i sements, especially the theater prooram, is possible of much improvement. Such typography should be given better attention, as theater programs exert large influence in form in $\mathrm{g}$ public taste.

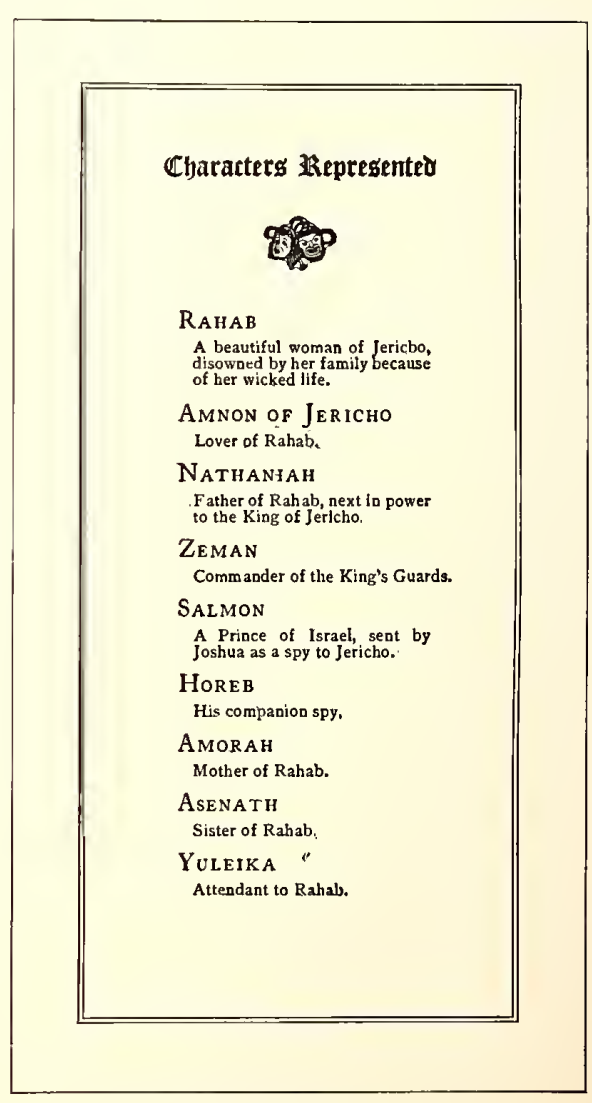

EXAMPLE 228

A well-arranged page. By Stetson Press, Boston, Mass. 


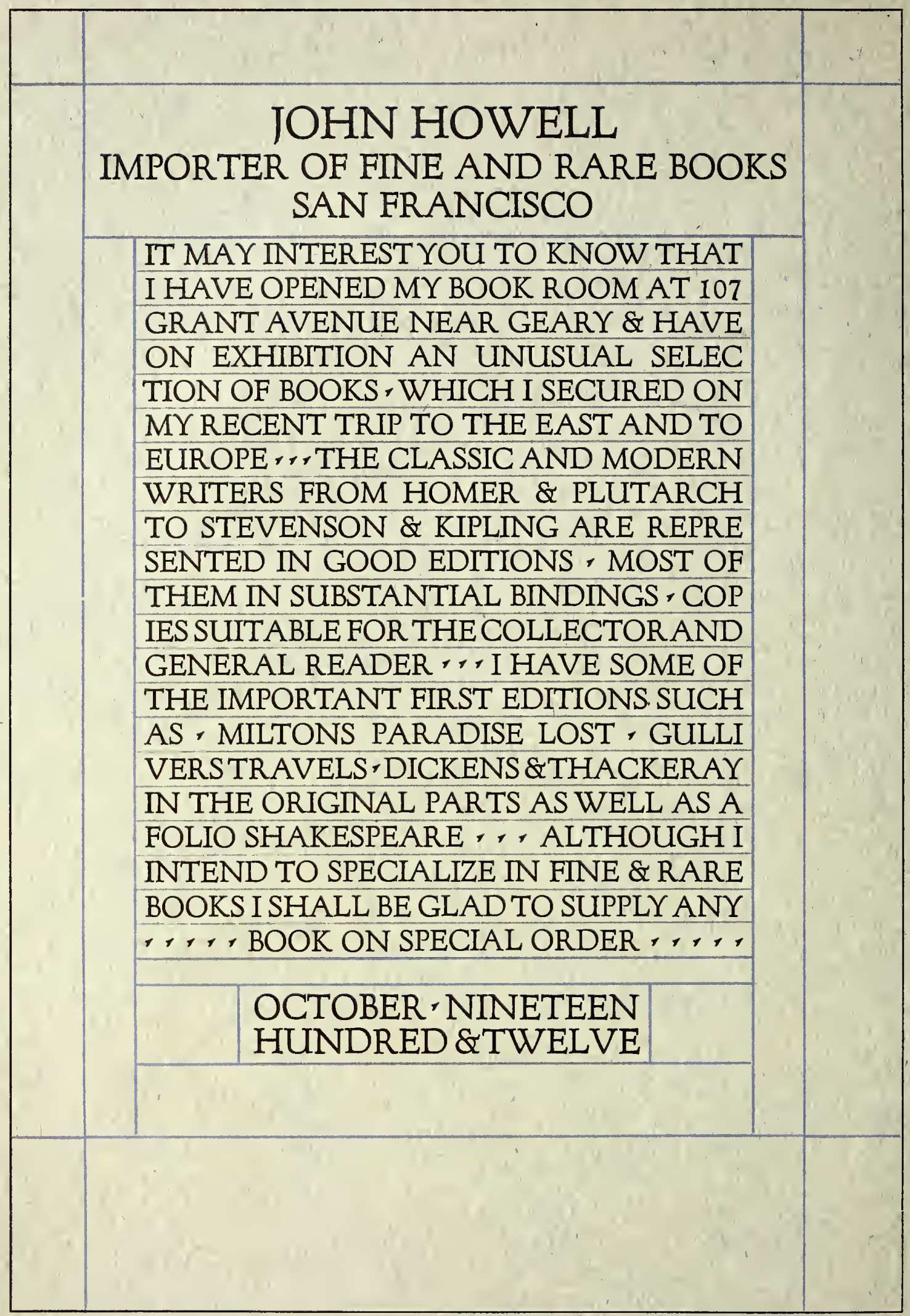

EXAMPLE 229

Classic capitals combined with rules. Suitable for announcements having to do with art, architecture, literature and music 


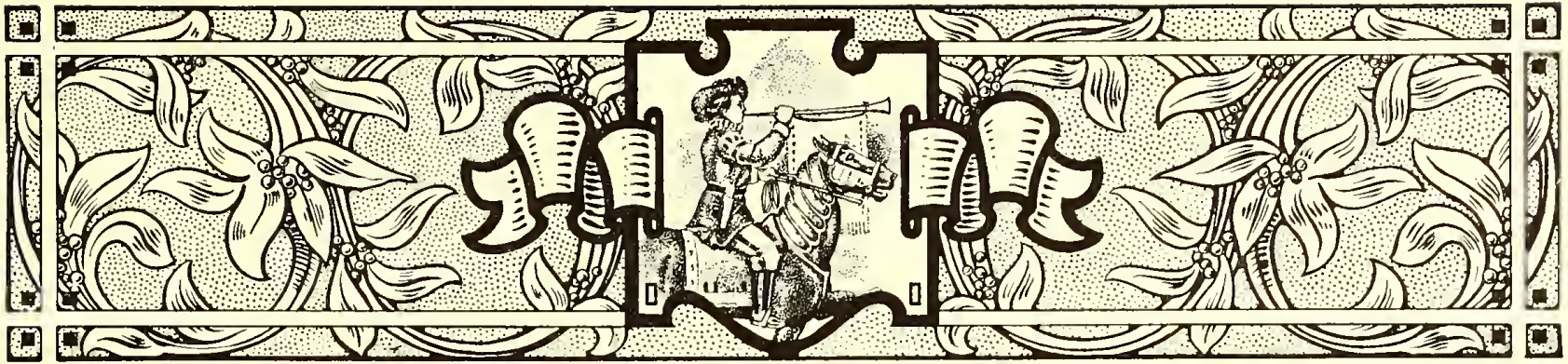

\section{ANNOUNCEMENTS}

PUBLICITY is doubtlessly essential to success in every business and profession. The public is interested in the man who does things, but this interest is obviously confined to the man who it knows does things. The great men are advertised men. The great deeds of history are those advertised by poets and historians. Shakespeare made famous many ancient characters, as did Plutarch before him, and the most famous acts of the American Revolution are those performed near the homes of poets and writers. We would not be familiar with the rides of Paul Revere and "Phil" Sheridan had they not been advertised by means of printers' ink.

Several years ago in New York an influential art society recognized the work of a mural painter by awarding him a medal. In accepting it the artist sadly renarked that the recognition came too late in life for him to "use it as a help to live with," which proves that in the heart of

AN ANNOUNCEMENT OF THE CURRIER PRESS NEW YORK

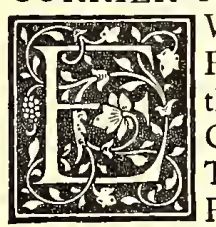
VERETT R. CURRIER and FREDW.Goudy announce the establishment of $\mathrm{THE}$ CURrier Prìss at I 14 East Twenty-eighth street. The Printers are men of long experience and training who have made a study of the history and uses of printing, and seek to apply to modern requirements some knowledge of the principles which made the work of the early mastersso preeminently satisfying and enduring. $M_{R}$. GouDY, as a designer of letters and book decorations, has a wide reputation. MR. CURRIER has been associated with leading master printers, notably, D. B. Updike of the Merrymount Press (Boston), and for the past two years with Bruce Rogers at the Riverside Press in Cambridge.

With a small but highly efficient equipment it is hoped to produce printing the the most proud and sensitive artist or professional man there is a feeling that he needs publicity-recognition, if that word is less offensive-in order that his life work may be successful.

It is fashionable for prominent persons to employ press agents, and goings and comings and doings are told to the public at every opportunity. In the days before the development of newspapers and other typographical mediums for advertising, the people depended upon the public crier to make all sorts of announcements. He would attract a crowd by sounding blasts with a horn or by ringing a bell, and then make known his message.

The modern representative of the crier is the printed announcement. It is not confined to any definite size or shape, often consisting of one page only, printed on card or paper stock.

The announcement form may be considered the most

ment, more especially, cburcb printing, music programmes, announcements for publishers and merchants, catalogues of art collections and private libraries, and similar work, in which quality and character are desired.

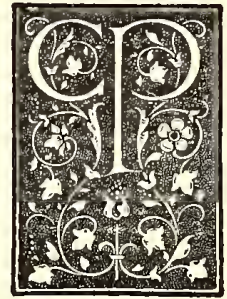

ROOM 306 : TEL. 466 I MAD. SQ. 114 EAST TWENTY-EIGHTH ST.

EXAMPLE 231

EXAMPLE 230

on brown-tinted hand-made paper 


\section{D

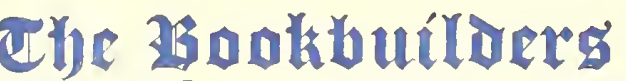 $A R$ I B : At the first general meeting of The Bookbuilders, Monday, February I 9 th, the annual sub- scription for membership was fixed at $\$ 5.00$, payable in advance, and exclusive of the present entrance fee of $\$ 1.00$. 7 At present the club numbers one hundred and ten mem- bers, and it is planned to add to the present quarters a large room for writing and lounging, and ultimately to take the whole floor. It is hoped that by this means The Bookbuilders will develop into a social club which will be representative of every branch of business now concerned in the practical art of book building. \\ 7 The luncheon room has been well decorated and comfort- ably furnished, and the club is indebted to two of its members, Mr. Alexander Drake, of The Century Co., and to Mr. Dan Beard for the loan of many antique utensils and pictures. isf The popularity and good fellowship of the lunch hour grows daily, and the rapidly incrcasing though carefully selected membership bids fair to put the club itself on a very sure foundation. \\ $\$$ The committce is anxious to print the club rules and list of members, and therefore asks you very kindly to send in your ap- proval of thc arrangements so far made, and to enclose your sub- scription (chcck is preferable) with the form herewith attached, payable to the treasurcr.}

Fraternally yours, The Commitse

\section{F. H. Hischrock \\ J. T. Headley Treasurer \\ W. S. Booth \\ W. A. Nosworthy \\ I. H. Offord}

little original or decorative treatment. If other forms or treatments are desired a standard type-face, such as Caslon or Cloister, should be used. Many compositors err in combining copperplate-engravers' faces with rules and borders, or in other ways misusing them; for such results are "neither flesh, fish nor fowl," as the saying goes.

If the customer requests an imitation copperplate effect, give it to him as closely as you can; that is good business policy, and is in accordance with the sound advice to "Do your best, no matter what the circumstances," reminding one of the old rhyme:

If I were a cobbler, it would be my pride The best of all cobblers to be;

If I were a tinker, no tinker beside Should mend an old kettle like me.

But, whenever possible, get on higher ground. If you must be a tinker, be a good one, but rather be a producer of new things than a builder of patches and something that is "as good as new." Printers should test their earnestness with tasks that develop their art instincts and, accompanied by proper financial return, bring that satisfaction which comes from work well done.

ExAMPLE 299 (Insert).-Usually the printer should not set an advertising page all in capitals, nor should he use many rules in its con-
EXAMPLE 232

Announcement in Colonial style. By A. F. Mackay

personal of the printed mediums of publicity. It presents a direct, individual appeal or invitation, and the recipient, influenced by this fact, is likely to give it more consideration than some other form of advertising. Recognition is flattering to all of us, and upon receipt of an announcement we are apt to feel pleased that our patronage or personality is thus recognized.

The printer is depended upon by most customers to furnish suggestions for the physical make-up of the announcement, and he is also frequently asked for advice in regard to the pluraseology. This places a responsibility upon him that he cannot well ignore, and he should be able to respond with proper suggestions. Being thus qualified to assist the customer has many times led to further and profitable business. The printer possessing the confidence of his customers has an asset of great value.

The most common form of typographic announcement is that printed from roman, text, gothic or script $t$ ype-faces in imitation of engraved intaglio printing. The styles of this form of announcement change slightly with the fashions in copperplate effects. Printers desiring to do such work would do well to obtain samples from one of the leading society stationers and follow them closely in arrangement, spacing of words and lines, and size and kind of stock. This class of work allows of

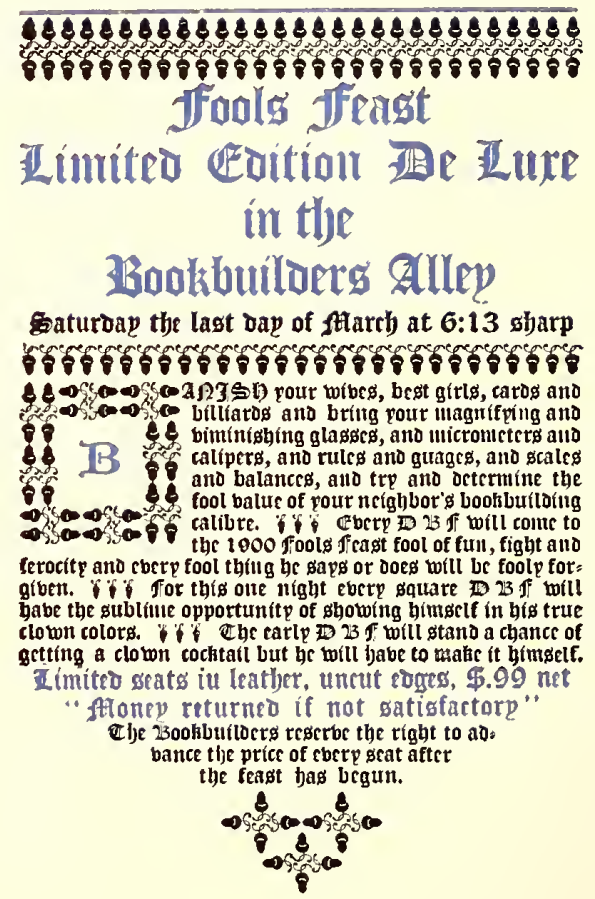

EXAMPLE 233

Odd treatment of an announcement. By T. M. Cleland 
position; but when the typographic designer has skill and artistic taste in addition to : developed sense of titness and refinement, thewarningsand"thoushalt-nots" that apply to most printers are not for him. Mr. Nash,with the use of Fred W.Goudy's Forum type-face and rules that suggest the guide lines of old manuseript books, has produced an announcement that is classic in composition, pleasant to look upon, and a page that carries the message in an especially effective and appropriate manner. The original was printed on hand-made paper. This type-face has been modeled on ancient Roman lettering and for that reason has a classic character that makes it suitable for announcements and other printing having to do with art, architecture, literature and music.

Examples 230 AND 231.--These are the first and third pages of an announcement originally printed in black ink on brown-tinted

hand-made paper. The type-face, Caslon, was sharply impressed into the stock. It may be advisable to state here that all Caslon romans are not alike. The face usually sold by typefounders has the descenders shortened, that the letters may conform to the system of alignment adopted some y ears ago in America. This shortening of descenders, seemingly a trivial matter, affects the general appearance of the type-face. Attempts to "improve" the Caslon face are apt to end disastrously to the effectiveness of the letter. It has characteristics that are essential to its beauty, and shorn of any of those characteristics it loses attractiveness proportionately. This announcement folder is of a quality seldom attained in printing, depending as it does upon detail in typesetting and presswork. The reproduction cannot present these points, because the finish of the paper, the clearness of the print, the spacing, the apportionment of margins, the tone, all counted in the finished result.

Example 232.-This circular announcement in its original form was $9 \frac{1}{2} \times 121 / 2$ inches in size, the paper upon which it was printed being gray-green laid hand-made. The positions of the groups of type matter and the sizes of margins are features worthy of study. Other points of interest are: the treatment of heading and initial, the use of florets at the beginning of each paragraph, and the committee signatures. The last-named lines are set in italic lower-case with roman capitals, Aldus style. The border was printed in dull red, close to the edge of the paper.

Example 233.-This meeting announcement is of the same series as the preceding example, but, set all in black text letter without border, the effect is totally different. The peculiar black and gray tones of the Caslon ornaments blend well with similar characteristics presented in the massed black letter. The page was printed in vermilion and black on buff laid hand-made stock. 'The effectiveness of this style of announcement is due not alone to the typography and stock, but to the generous size of the sheet used-good paper and plenty of it. This announcement was mailed without envelops, the double sheet being folded into thirds and the lower end inserted into the upper end.

Example 234.- This announcement page is lettered in a style that suggests the sturdy masculine character of

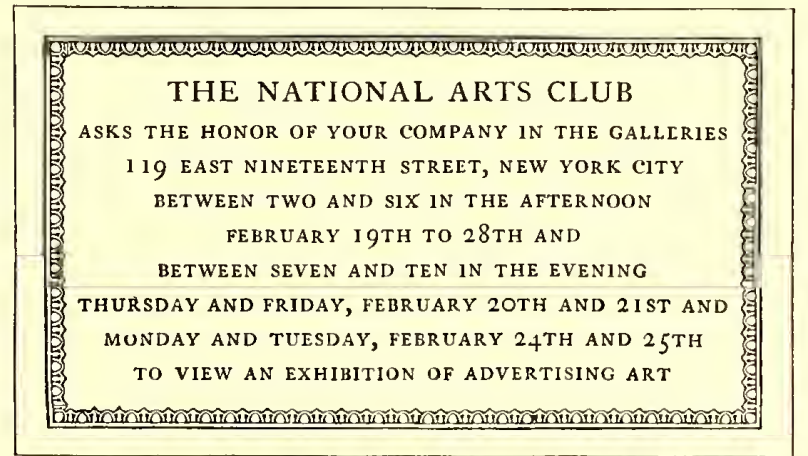

EXAMPLE 236

A classic arrangement based upon the architectural inseription plate. By Benjamin Sherbow, New York 


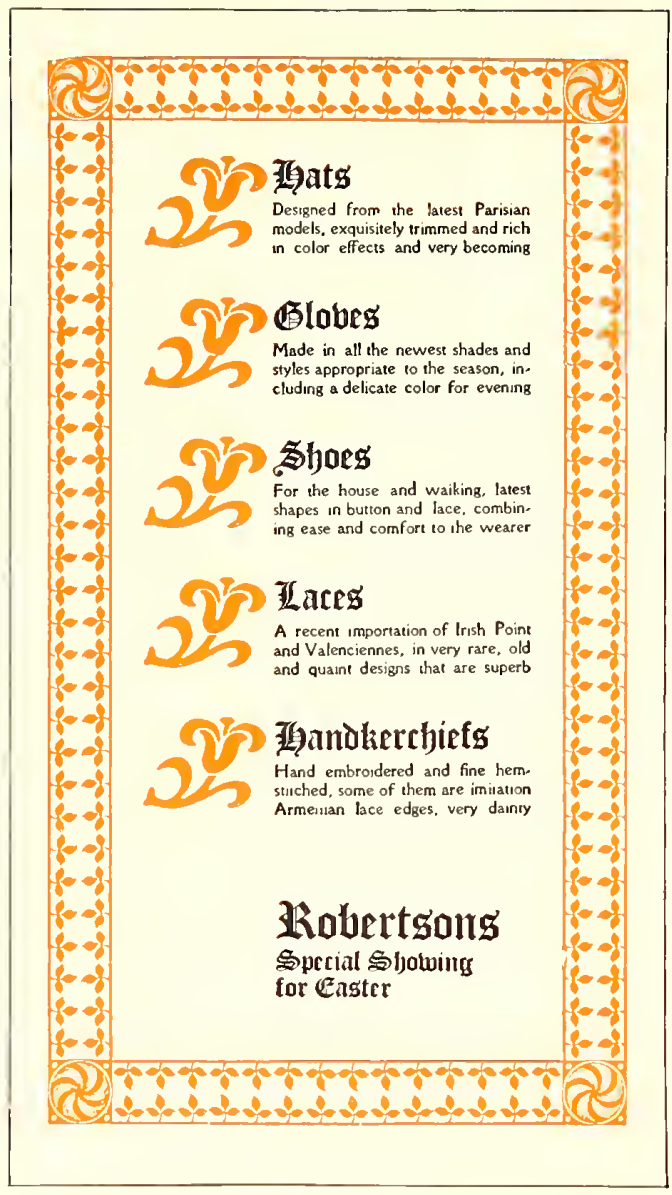

EXAMPLE 237

Ornaments as eye-attracters. An idea that could be adapted to many jobs of printing. Designed by Will Bradley

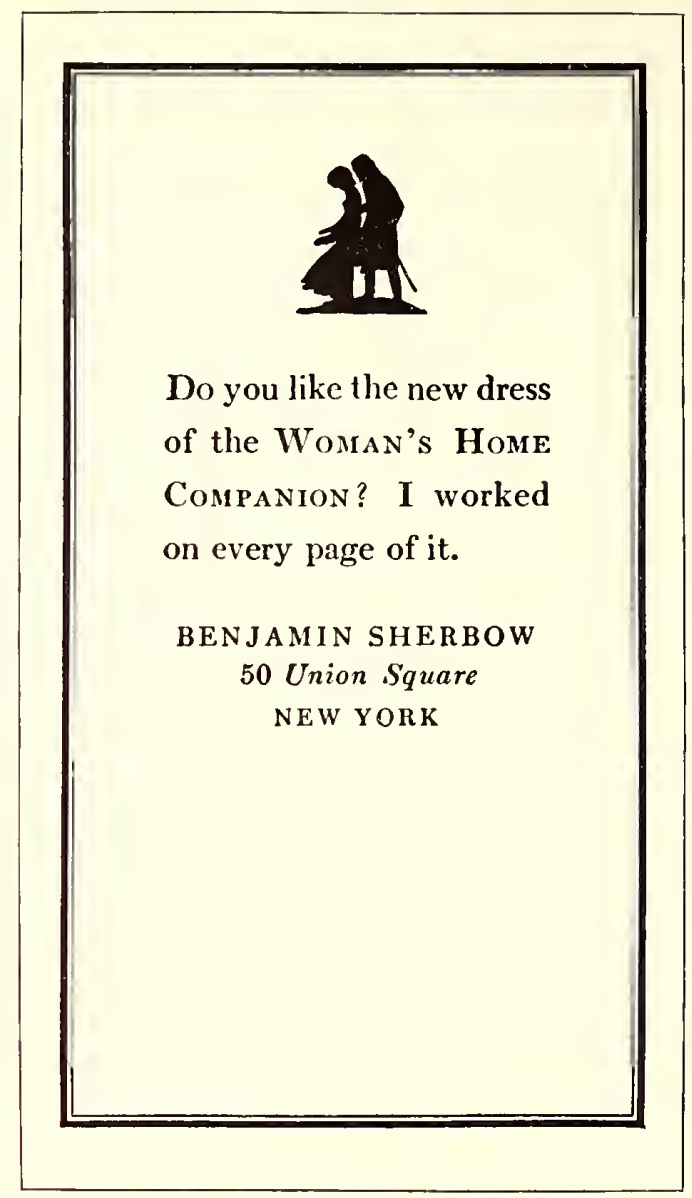

EXAMPLE 238

Postal-card announcement, the typography of which is attractive, not because of what is put on, but because of what is left off

asked him about it. With a smile, he stated that he had been working on the cartoon for several hours in order to make it look as if it liad been drawn in fifteen minutes. German typefounders liave made typefaces that carry the qualities of this poster style of lettering. The young printer should not infer from this that careless and unfinished typographic work is preferable to a careful, finished product. It will be found that the artist or printer who can best give this little touch of human nature to designs is one who first learned to do the work as perfectly as possible.

ExAMPLE 235.This design was the first page of a folder of which Example 234 was the third page. Oswald Cooper, who lettered this announcement, used the figure of a

the lettering that has been developed with the new German decorative art. Typographers should not make the mistake of assuming that a page set in the so-called gothic types of the typefounders would give this effect. While the letters are without serifs, as are the gothic types, yet they have not the mechanical perfection of those types. Type-faces, lettering and drawing of any kind seem to be better liked when they possess the human quality of imperfection. I once called on Boardman Robinson, then cartoonist of the New York Tribume, and found him at work on a cartoon for the day. I noticed that he had considerably altered the picture on which he was working, and I

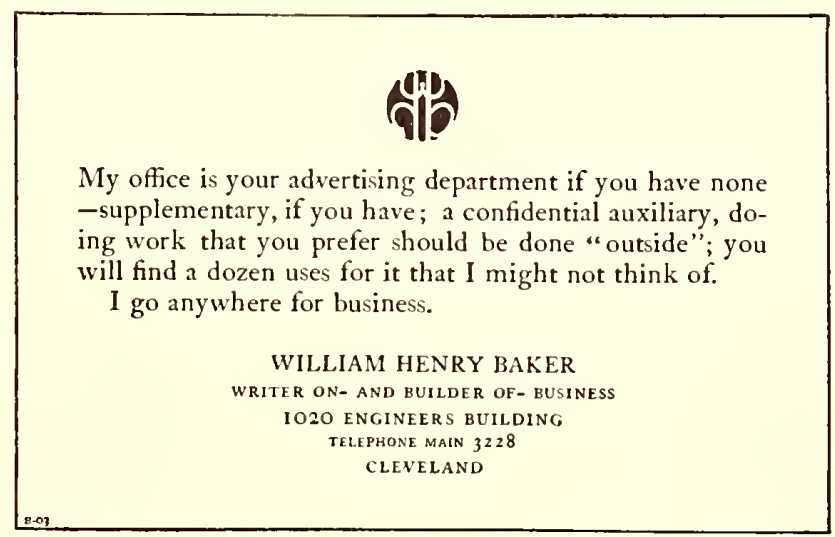

EXAMPLE 239

Good advertising typography. Type groups and blank space well proportioned, and an interesting decorative spot of color dog that had been drawn by the German poster artist Hohlwein, but gave him due credit in the upper left corner. This style of lettering, as has already been mentioned, is appropriate to the subject of German posters and in harmony with the poster illustration used. Heavy treatment of this kind offers a rich opportunity for the use of strong and harmonious colors. Light-faced type is very unsatisfactory as a carrier of color, but the broad strokes of this style of lettering make possible a liberal showing of color on the page. An extra color has been introduced, altho the original an nouncement was entirely in brown on a brown-tinted card.

Example 236. - From the viewpoints of art and dignity an announcement card such as this one is always in good taste. Its style is classic, being arranged along the lines of an architectural inscription plate. The border is the reliable egg-and-dart pattern and the type-face is Caslon. Capitals are essential to best results in this sort of design.

Example 237. - The idea suggested in this page, of using ornaments as eye-attracters, is a good one. While the design as a whole is decorative in character, the advertising element is not overlooked. The several articles of merchandise are prominently displayed, as is also the name of the store. In the series of type designs of which this was a part, the designer strongly emphasized ornamentation. There was a reason for his doing this, as he was engaged in introducing new typographic decorative material, but printers working for the commercial public are engaged in a different vocation. In attempting such designs as this, compositors should decrease the prominence of the ornaments and border and increase that of the reading portion of the page. 


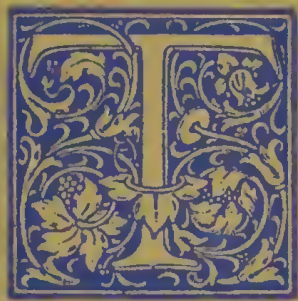

H E Annual Meeting of T H E AMERICAN INSTITUTE OF GRAPHIC ARTS will be held at the National Arts Club, 15 Gramercy Park, New York, Friday evening, December IIth, I9I4, at eight o'clock. It will be preceded by a D I N N E R at two dollars a plate at six thirty o'clock.

The guest of the evening will be

MR. ERNEST PEIXOTTO

traveler, and author and illustrator of "By Italian Seas," "Through the French Provinces," "Romantic California," "Pacific Shores from Panama," etc. Mr. Peixotto will deliver an informal talk on "Pen Draughtsmen" illustrated with stereopticon pictures. There will also be an Exнівіт of his drawings.

Preceding the address there will be a short business meeting for the election of six directors. Please return enclosed card.

PROGRAM COMMITTEE

Arthur S. Allen Joseph H. Chapin

Thomas Nast Fairbanks

John Clyde Oswald, Chairman

EXAMPLE 240

Showing the use of roman, italic and spaced small capitals on an organization announcement 
$=$ 
EXAMPLE 241

Unusual division into two groups, providing for fold. By the Calumet Press, New York

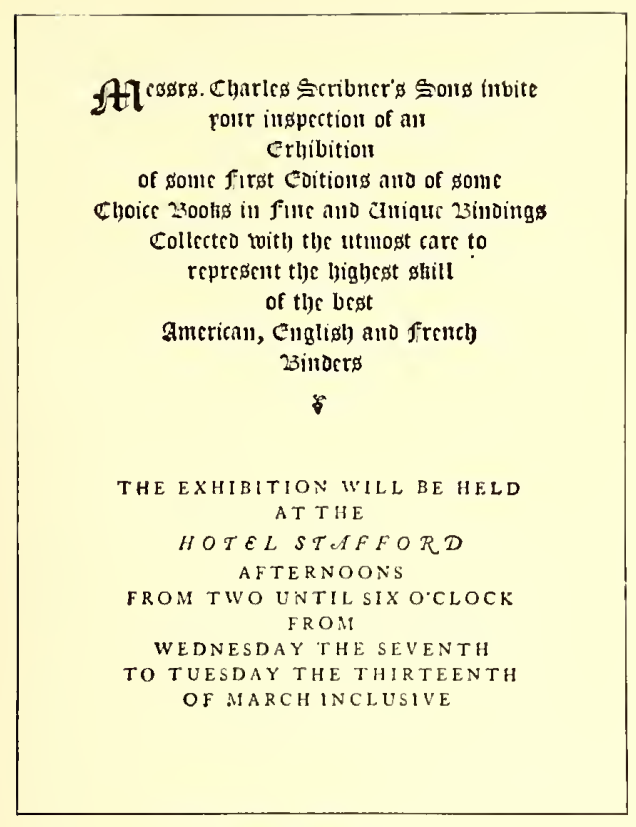

Example

238. - This announcement was printed in black inkon a Government postal card. The young compositor will, no doubt, recognize the small amount of actual typesetting necessary for this page; however, he should not overlook the fact that the results were really secured by one - tenth manual labor and nine-tentlis brain exercise. A specimen such as this is good not because of what is put on but because of what is left off. There are only a rule border, a sinall silhouette illustration and four lines of type exclusive of the signature, yet the busy man gets the message and experiences pleasure in getting it. The type in the original was no larger than was necessary to be easily read. Compositors frequently forget that announcements of this kind are read at a distance of only a foot from the eyes, and that twelve-point type is really large enough for the purpose. It is usually a mistake to make the type-face very large or very small. One is an unnecessary size and the other is an illegible size.

Exanple 239. - This is another announcement set in twelve-point type, with a liberal distribution of blank space. The personal mark of Mr. Baker adds a decorative touch of color that attracts attention and helps to make the page distinctive.

Exauple 240 (Insert). - This announcement has typographic interest in that it shows how variety and advertising emphasis can be obtained by the proper use of italic and small capitals with lower-case roman, especially with a type-face such as Cloister Oldstyle. The small capitals are letterspaced; they usually respond pleasingly to such treatment. Typographers who have studied the matter of

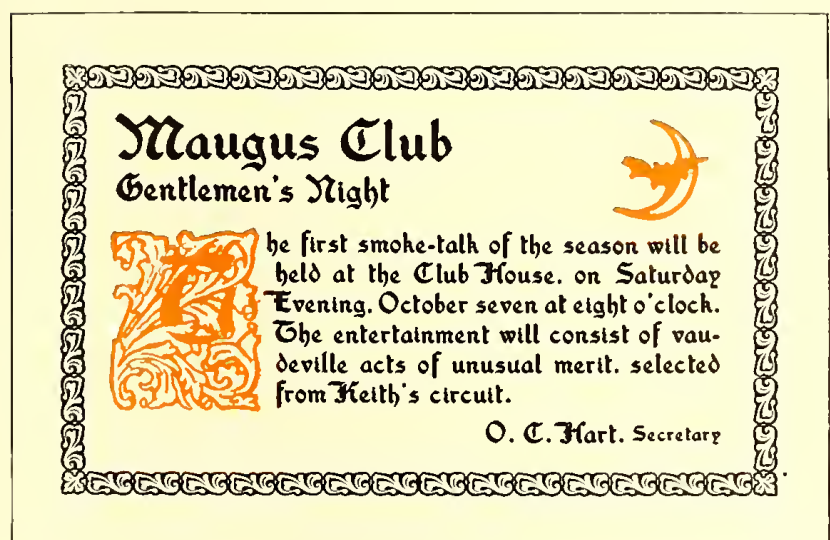

EXAMPLE 243

Harmony of type-face and decoration

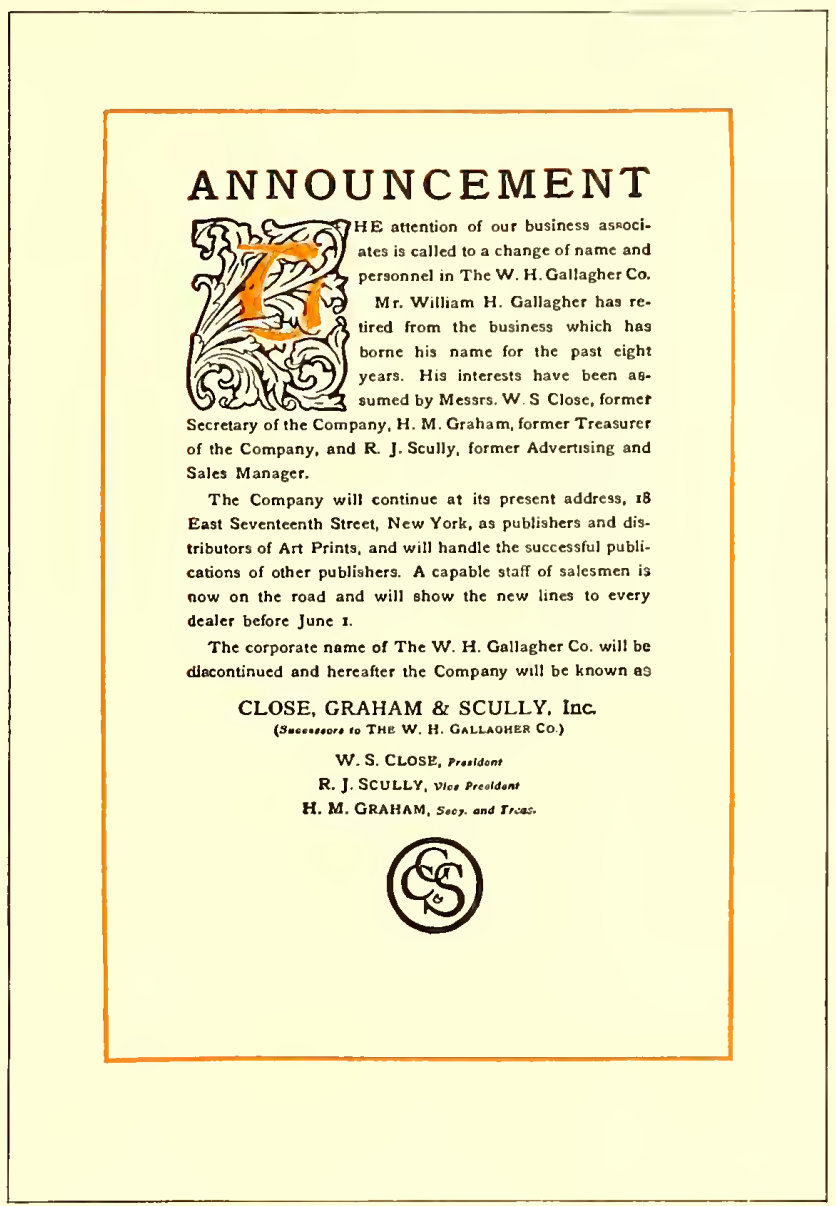

EXAMPLE 242

A study in tone values and margins

spacing have found that capitals and small capitals can be letterspaced with good results, and that roman and italic lower-case seldom look well if the letters are separated by spacing. It is probably an exaggeration to say that lower-case should never be spaced, as typographic artists such as Will Bradley have produced very effective results with letterspaced lower-case; but the average com. positor had better adhere to the rule of never letterspacing lower-case letters. It will be noticed that on this announcement the name of the organization, the words "Dinner" and "Ex-

hibit" and the name of the guest, are set in capitals and small capitals with letterspacing. The names of the books, the title of the talk, and the request to return a card, are in italic. Only one size of type has been used, excepting for the committee group at the foot. In order that the words "Program Committee" should not look exactly like the other lines in this group, they were letterspaced.

Example 241.This announcement form, like No. 240,

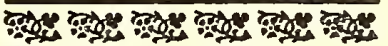
The Iookbuilares Gakip pleasure in extend: ing to Atlaster

the pribulleges of their rlub rooms durting the werk ending

\section{8.}

Artistic form for brief announcement. By A. F. Mackay, New York 


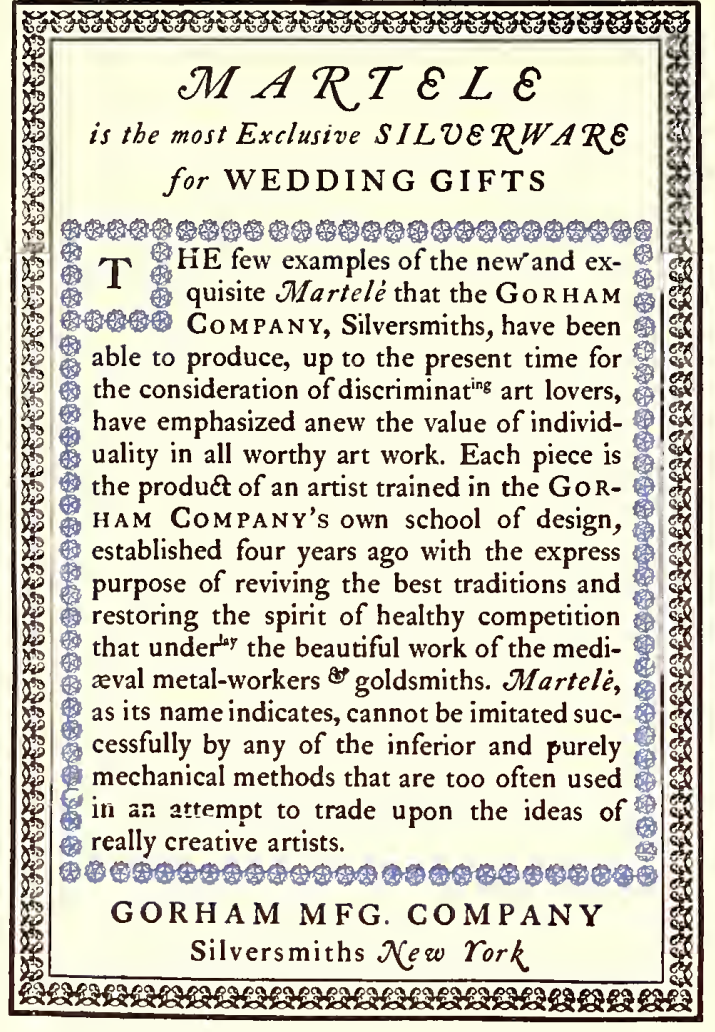

EXAMPLE 245

Colonial treatment of an announcement

page. By the Calumet Press, New York

is conventional in size, the paper upon which the original was printed measuring $5 \% \mathrm{x} 7$ inches. The arrangement of the type page was designed to provide for the fold which lorizontally crossed the center of the page. The division into two groups, each in a different type-face, is unusual, and the manner in which this has been accomplished is instructive to the student of typography. The use of a large initial gives distinction to the upper group, and spacing of the Caslon capitals in the lower group maintains a distinction there. This page illustrates two points recognized by good ty pographers-that the printed effect of old-style roman capitals is usually improved by a slight increase of space between letters, and that, on the other liand, the printed effect of text letters would be impaired by increased space between them. There is danger of too great contrast of tone in a page, and had this example been executed less skilfully, it would have failed in effect.

Example 242.--This announcement circular affords a study in tone values, especially in the original size, which was $9 \times 12 \%$ inches. The type, Old Style Antique, was twelve-point, with six-point slugs between lines. The black tone of the type-face and the liberal spacing found relationship in the black tone and open lines of the initial letter at the head. This harmony was carried out in the entire page, the black and white tones contrasting thruout. No gray lines were used; even the monogram at the foot was constructed of strong lines. In obtaining an effect like this it is necessary that the typeface be of medium black tone somewhere between the gray tone of the Caslon face and the heavy black tone of the John Hancock or other extra-black faces. It may be well to call attention to the margins inside the rule border. The artist avoids monotony in margins. In old books the four margins surrounding a type page differed. The foot margin was the largest, the others being smaller in this order: outer side, head, inner side. In this announcement page the foot margin is larger than the others, and the head presents the smallest amount of marginal space. The side margins were made equal because, unlike the paired book page, this page stands alone.

Example 243. - Harmony of type-face and decoration is the chief attraction of this announcement card. Some of the characteristics of Washington Text in tone and stroke are also found in the initial letter and border, and to this the harmony is due. Placing of the initial letter so low on the page was a bit of daring, yet balance is retained, due to the heading.

Example 244.-While only a little folder, $31 / 2 \times 4 \% \frac{1}{2}$ inches in size, this job was exceedingly effective. It was printed in black on white antique stock. Such a form could well be adapted to many brief announcements.

Example 245. - This form was set in type during the Colonial revival that interested good printers about the year 1900. Caslon type and Colonial decoration give an individual character to the page. Colonial effects are not so common just at this time, which fact is quietly digested by the wise typesetter as he recognizes his opportunity.

Example 246. - This announcement demonstrates the possibilities of typography along the lines of appropriateness. A Colonial organization wished to announce a meeting at which would be celebrated the founding of the first American newspaper, and desired something in Colonial style. The printer looked up a reproduction of an early newspaper and set the heading in a style such as was given the headings of newspapers in the early days. The society had an emblem or seal engraved in the serifless and characterless style of lettering that the aver-

\section{The Colonial NEWS LETTER} Containing the Ifrefieft Aobices from the COLON I A L S E C RETARY WEDNESDAY, March 24, 1915

$\mathrm{T}$ His Letter takes notice that on Thurfday the 15 th day of April, in this year of our Lord, 1915 , at 30 minutes after 12 by ye towne clock, ye Societie of yc Colonial Daughters of ye Seventeenth Century will have a Greate Feafte ferved by ye famous Marefi, at the Houfe of ye Women's Club, 114 Pierrepont Street, turning down from yc Borough Hall, nearly oppofite the Dutch Reformed Meeting Houfe.

This will be a celebration of the founding of the Bofton News Letter, the firft American newfpaper.

The author concludes it to be of intereft to this Societie to know that Mr. Willis Fletcher Johnfon, L.H.D., of the New York Tribune, will make a fpeech fetting forth the amazing advance of two centuries.

Mr. Charles Graham Baker, cartoonift of the Brooklyn Times, will entertain the members and guefts of ye Societie by making fome of his whimfical fketches.

Mifs Betty Lee will fing tunes of ye olden time.

Take notice and likewife obferve that Tickets for Colonial Daughters and their friends may be bought for the fum of ten fhillings, fix pence.

$\checkmark$ Write to

Miftrefs Samuel Bowne Duryea, 46 Remfen Street, Brooklyn, New York, before Saturday, the Ioth day of April.

\section{EXAMPLE 246}

An announcement literally treated in Colonial typography, even to the use of the long "f" 


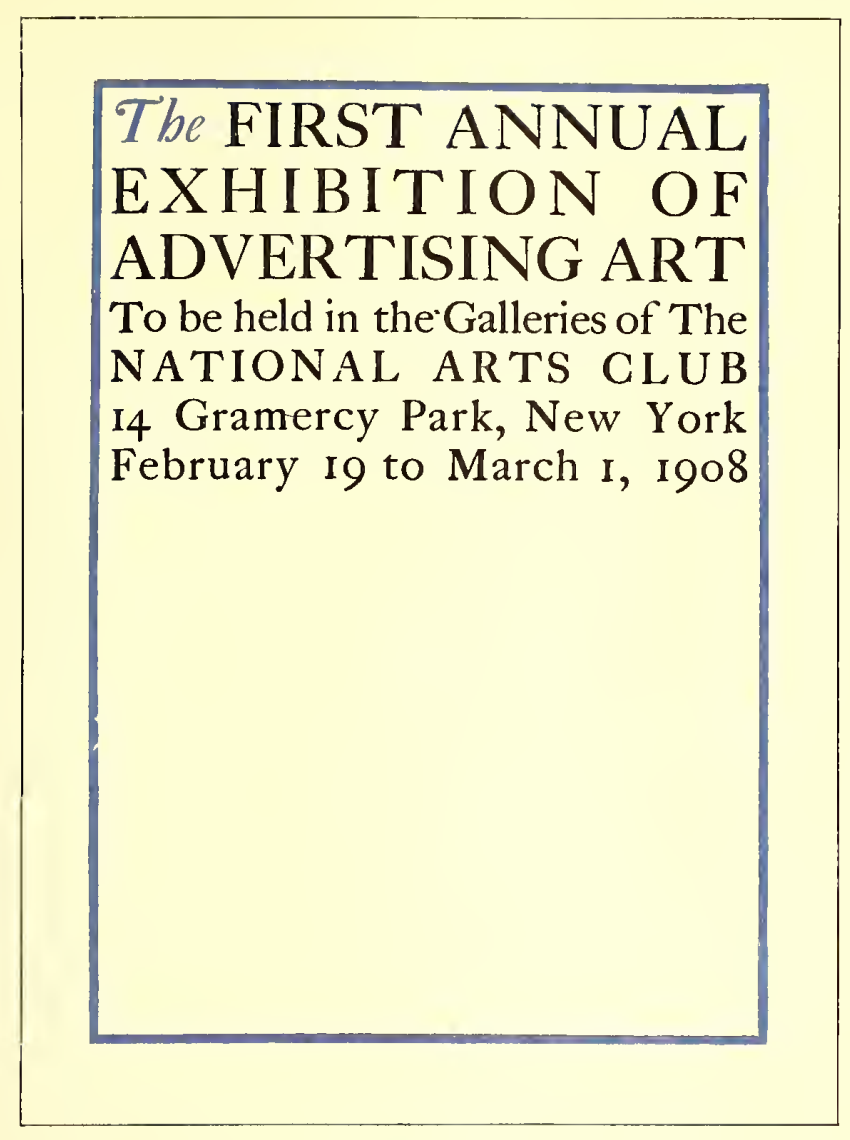

EXAMPLE 247

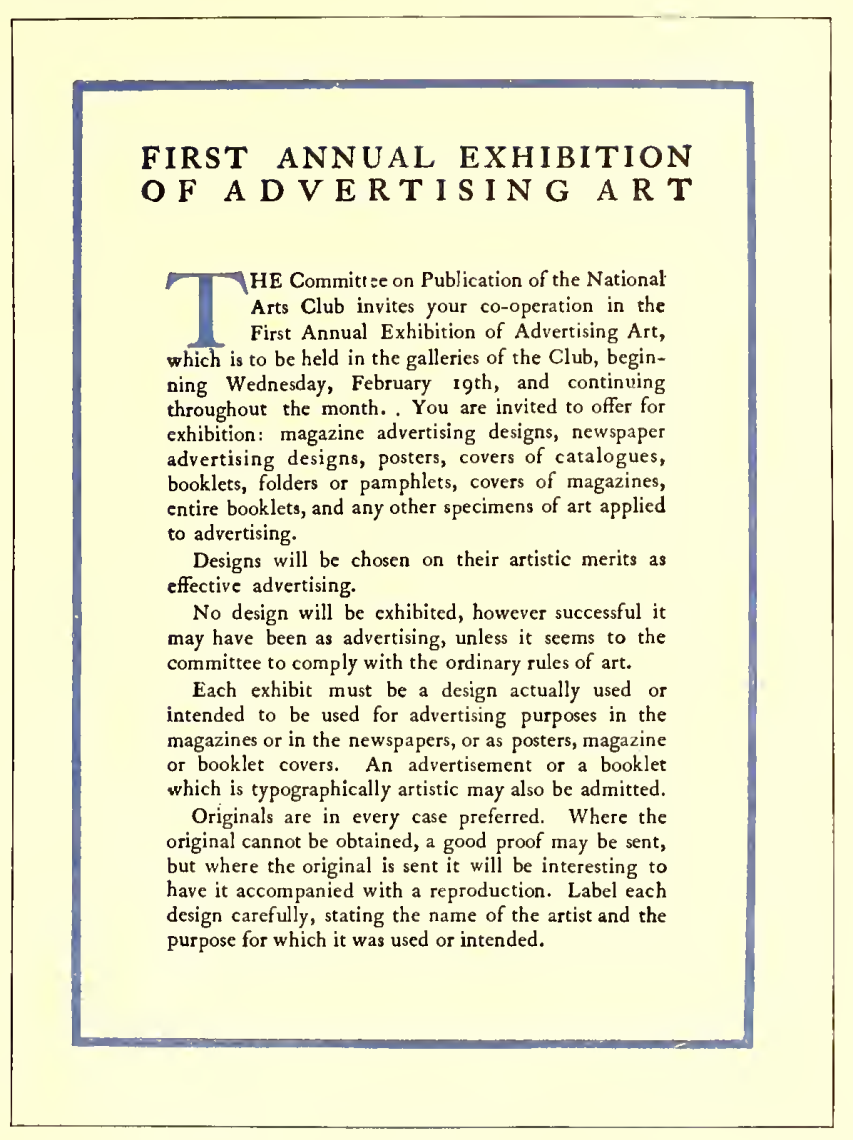

EXAMPLE 248

First and second page of an artistic, unembellished announcement circular. Designed by Benjamin Sherbow, New York

age engraver will give an organization. The printer had the emblem redrawn, giving instructions to the artist to draw the entire design in free-liand and to be careful that the lines and lettering be not too regular. Instructions were also issued to have serifs on the lettering and to have it contain the contrasted light and heavy strokes of the roman type-face of the Colonial period. As will be seen by the example herewith, the idea was well carried out by the artist. The society had appropriately phrased the announcement. The printer carried the idea along by using a small size of " $\mathrm{e}$ " in the word "ye," and a long "s," made by cutting a part of the cross from the "f." A suitable hand-made paper was selected and the paper was dampened before printing it. The announcement was then folded up and sealed in the style of Colonial times, without an envelop.

Examples 247 AND 248. - These are the first and second pages of a large circular announcement printed in black and light olive-brown on buff-tinted laid antique paper. No embellishment is used, nor is any needed, the treatment being sufficiently artistic. The arrangement of the first page is uncommon. The lack of margins around the type group and the absence of print on three-fifths of the page would be counted by some printers as mere eccentricities, yet to others these things spell art. Compositors interested in this arrangement should notice how the type lines fit the phraseology. The advertising element has been considered by the designer along with asthetic requirements. The double line of capitals at the head of the second page was duplicated on the third. The second page shows simplicity and legibility that are admirable, the liberal margins and the three-line initial being noteworthy features.

Example 249.-This is the second page of a convention announcement and is evidence of the success that is possible with the proper use of a well-designed type-face, an

\section{IMPORTANCE OF THE CONVENTION}

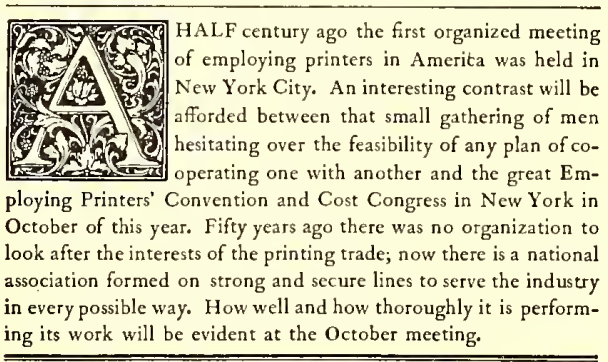

\section{THE PROGRAM}

AT the convention, reports will be made by the officers and the chairmen of the different committees showing what has been acchairmen of the different committees showing what has been ac-
complished during the past year. In addition, a remarkably fine list of addresses will be presented. The program covers practically every phase of the printing business. It deals with the problems of the office as well as of the plant. Business administration, salesmanship, cost systems, plant management, relations with employees, competitors and supply men, etc., the viewpoint of the buyer of printing itors and supply men, etc., the viewpoint of the buyer of printing
- all these topics and more will receive attention at the hands of experts. Geographically it is equally comprehensive. New York, New Orleans, Los Angeles, Sacramento, Chicago, indicate the widely distributed points from which the speakers will come. Owners and managers of printing plants, educators, men who have made successes in other lines outside of printing but closely connected with it, will be present to contribute the benefit of the knowledge that

EXAMPLE 249

One of four pages of a convention announcement, showing the attractiveness of rules when properly used with headings 
Mr. EDWARD A. KENDRICK

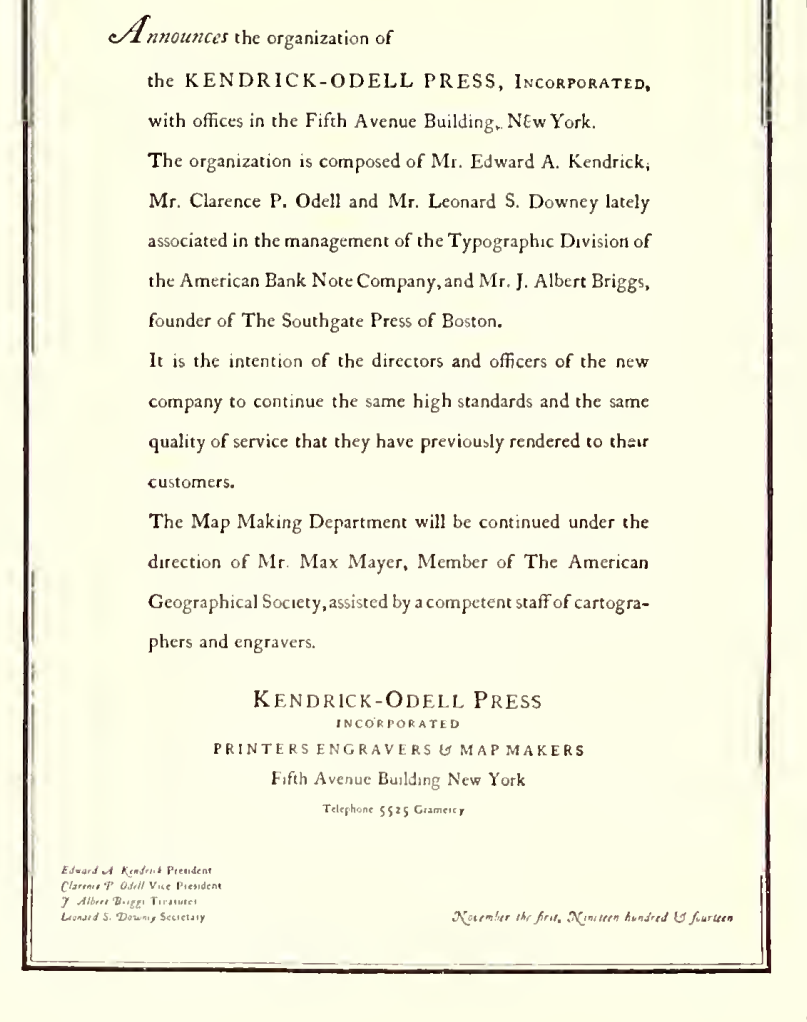

EXAMPLE 250

Announcement designed by an artist who believes in the liberal leading of type lines

appropriate initial, and rules to separate the headings. A combination of a heavy- and light-faced rule has always looked well with the Caslon style of type-face.

Example 250.- This announcement, originally printed on hand-made paper, all in black ink, was designed by a famous New York artist-typographer, who believes that thcre is greater legibility when the lines are separated by a libcral use of leads than when they are "set solid." The arrangement is unusual in several respects - the placing of the name in the far-off' upper corner, the use of the

\section{Marjorie Dork}

NNOUNCES the addition of a novelty

shop in connection with her beauty shop, situated at 16 West Allegan street.

The line comprises Gowns, Blouses, Negligee, Neckwear and Hosiery

Ladies of Lansing will appreciate this opportunity to buy useful and exclusive accessories such as are usually found only in the largest cities

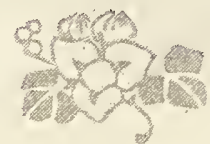

EXAMPLE 251

Announcement in black and gray on gray fabric-finished stock, illustrating harmony of type-face and decoration

initial " $A$ " in the midst of a sentence, the setting of the names of the officers in italic and their titles in roman, and the liberal leading previously referred to.

Example 251.- This specimen also has the feature of an initial in the midst of a sentence, and it may be well to suggest to young compositors that it is better not to use an initial in this manner. This page would probably be even more effective if the entire word "announces" were in lower-case. The announcement was printed in black and gray on a light-gray stock. The foundry that made this series of type also made ornaments that would harmonize witl it and thus enabled the printer to produce an artistically pleasing page. This letter is one of a few that closely suggest good hand-lettering. The selection of type sizes and the arrangement and apportionment of margins help to make a result that reflects credit on the printer's art.

EXAMPLE 252.-A blotter was the vehicle that carried this announcement, which is in the rugged Colonial style of typography of the year in which this piece of work was produced. The tone is pleasing, as is also the contrast of white and black. The ornament blends in shape and style with the accompanying typographical treatment.

In the production of his own announcement forms the printer is not hampered by the requirements of customers. He works with the unrestricted freedom of a Michelangelo and there is little reason why his work should not be of the best, if he will read and study books and trade magazines. 



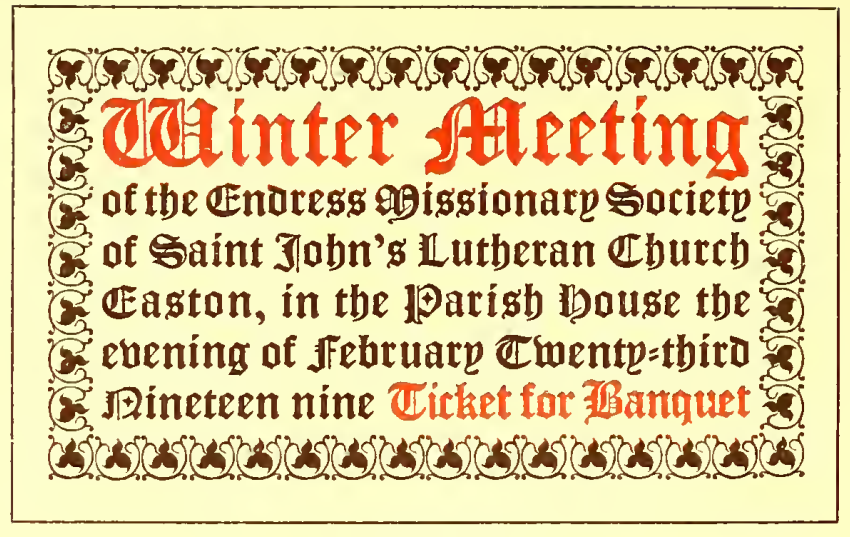

EXAMPLE 257

The bistoric Gothic, or pointed style

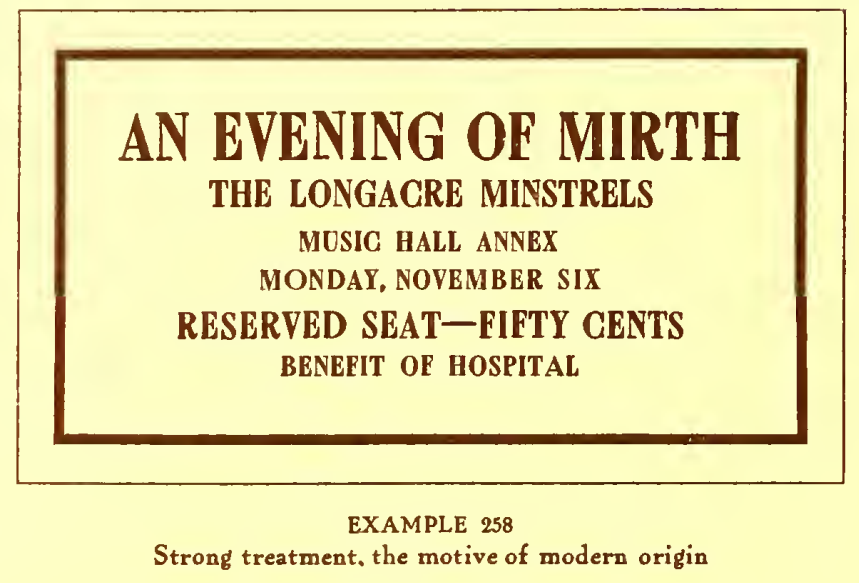

\section{College Theatrics}

Third Performance

Mrs.Trippings

March 29, 1909

Exchange this ticket at Box Office 


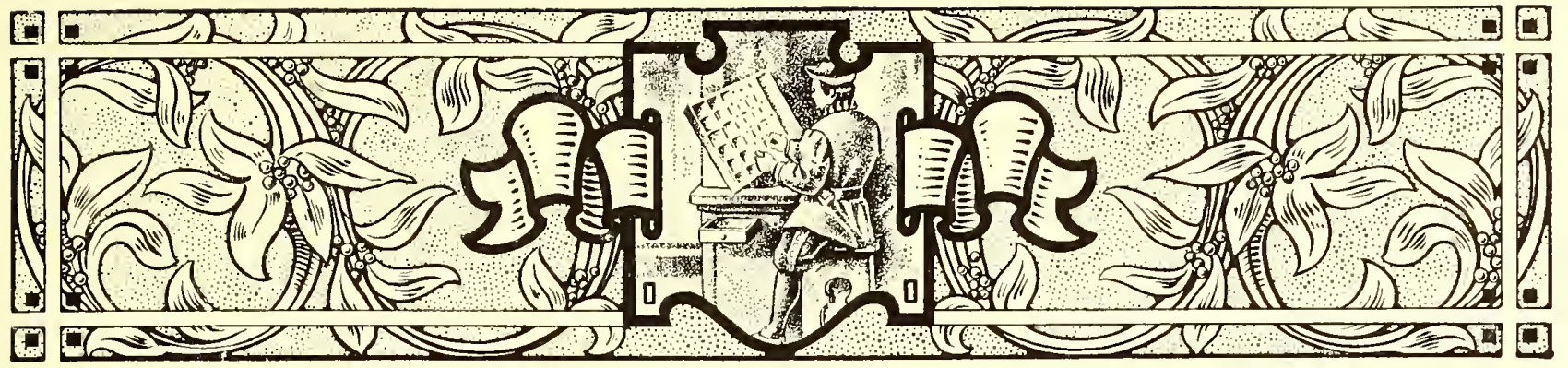

\section{TICKETS}

IT is said of printers who make no attempt to learn the principles governing art typography, that once or so in a lifetime they produce an artistic job of printing. They become much elated at the phenomenon, not realizing that it was brought on by the unconscious introduction into their product of art principles. The experience may be likened to that of a child who accidentally touches an electric button, causing the room suddenly to be illuminated. The child knows the light is there, but does not comprehend how it got there.

Now instead of being the cause of an oriental handshake, a good job of printing ought to be an everyday occurrence, and the stirring of the waters should be left for the bad job of printing when, unfortunately, it happens along.

Lack of interest is the reason for the non-development of many printers in the art side of typography. Because, to many compositors, printing is merely a means of making a living, only enough knowledge is acquired to enable them to "hold their jobs," or, in the cases of employers, to retain their customers. Time spent in the printshop is considered drudgery and the pleasures of life come after the whistle has blown.

There are young printers who know comparatively nothing about good typography, yet are authorities on the rules of pinocle, baseball, or other pastimes. And there are older printers, too, who could write a book about chickenraising, yet do not know when type-faces harmonize.

Any man who is not interested in his vocation is to be pitied. Unless his heart is in his work, a lawyer, preacher, editor, ad-writer, artist or printer will not be successful.

Interest may be developed. If the typographer will devote a portion of the time now spent on outside matters to the study of his craft, and especially the art side of printing, his work will become lighter and the hands on the clock will chase each other. The same concentration of thought now devoted to unimportant side interests would bring large dividends if invested in the study of typography. Efficiency is a guarantee of steady work and good pay to the employee, and an assurance of steady customers and better prices to the employer.

The typographer who prefers freedom from care, and the blissfulness of ignorance, is a poor member of socicty. He should line up among the world's workers and accept some of the responsibilities. The first things he observes, should he become a student, are the imperfections of his own product. Work that before looked good to him, now, viewed in a new light, is defective, and finally the old verdict is reached, "There is none perfect, no, not one." While to the experienced art-printer expectations of absolutely perfect results are known to be futile, he tries for one hundred per cent just the same. A man lacks something in his make-up when he is satisfied to be rated as a twenty-five or fifty per cent printer.

Tickets, altho only a minute part of the printing-office product, afford opportunity for the practice and development of art printing. In typography there are many themes and styles and their incorporation into typedesigns is an interesting and instructive study. The compositor or layout man should know and understand these various styles, that he may be able to adapt himself to any demand made for "something different." Resourcefulness is a valuable cliaracteristic for any printer to possess, and close examination of the nineteen ticket forms, and careful reading of what follows, should serve to develop that quality. These forms were designed by the author especially for this chapter.

Example 256.- It is fitting, in commencing a series of type arrangements, first to show one based upon a classic motive. The design is old to students of art, yet may be new to printers in general. The arrangement has been used for many years by leading architects on inscription tablets, and the idea itself comes from ancient Rome. 'The egg-and-dart border is a standard embellishment in architectural designing. The roman type-face is historically proper, especially the adherence to capitals, as originally there was uone but what we call capitals, the small "lower-case" or minuscule letters having been evolved during the Middle Ages. The letters of roman type-faces usually set very close together and to get certain results the capitals should be slightly spaced. One-point spaces have been used in this example. White cardboard is preferable to a colored one on which to print this design.

EXAMPLE 257 (Insert).-The historic Gothic or church style furnished the motive for the treat ment of this ticket. Both border and type-face possess characteristics peculiarly Gothic-notably the pointed form of the letters and floret. There is also blend of tone, and similar contrast of heavy and light strokes in letter and border. 


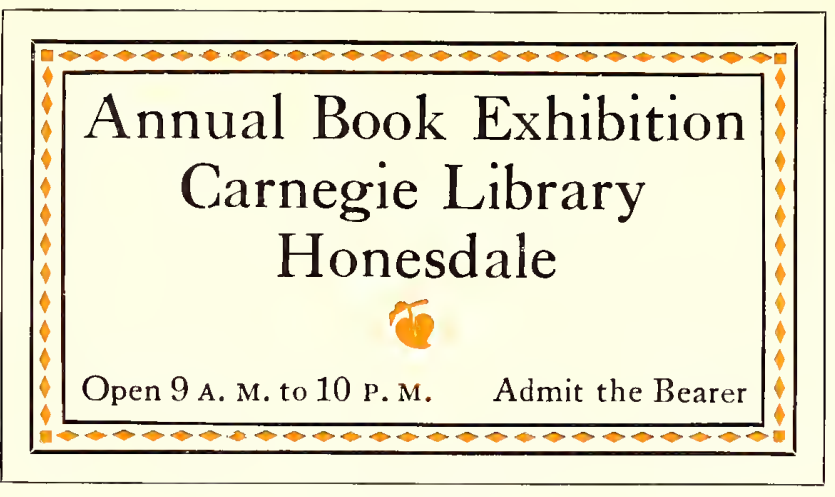

EXAMPLE 260

Modern treatment based upon the Colonial

Ancient features are consistently carried out in the arrangement. The lines are set close to the border and made full length. Contrast is obtained by the use of color and the emphasis in type size of two important phrases. This style of treatment is appropriate for tickets used by churches or kindred organizations.

Example 258 (lnsert). - The style of this ticket is a modern conception and originated in the art revival of the latter part of the last century. The motive is masculine and its features are contrast of tone, massing of lettering, and liberal blank space. It will be noticed that while in this specimen the margin inside of border is wide, on the previous specimen (Example 257) there is practically no space inside of the border. These features are necessary in the correct interpretation of the respective styles. The motive of the specimen under consideration is particularly applicable to tickets for minstrel performances, smokers, club outings, and other affairs in which men are interested.

Example 259 (Insert). - The color border on this specimen suggests a means of varying the treatment of tickets, the extension of the border into two of the corners adding distinction. Such a design as this is likely to meet approval among college students, as they welcome odd and striking effects. The strong italic lower-case is a relief from the many more familiar roman faces used on such tickets. Emphasis of important parts is obtained by increasing the type sizes until proper contrast is obtained.

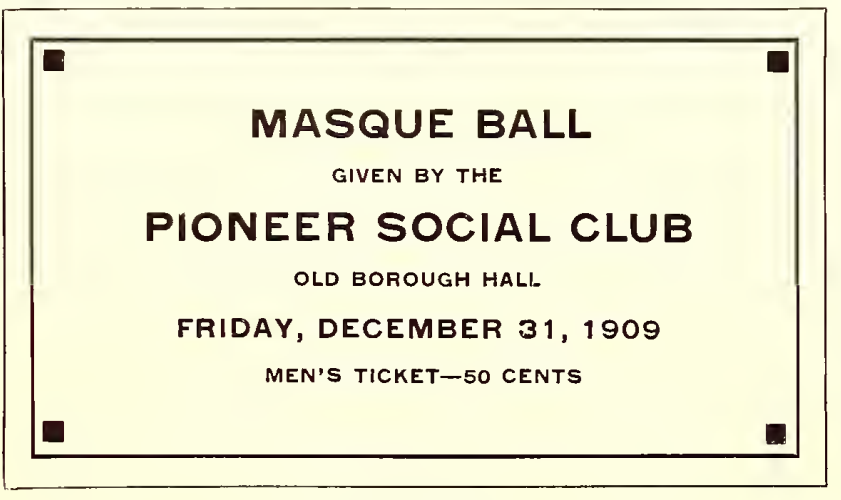

EXAMPLE 263

The secession or mission style applied to ticket composition

\section{COURSE OF TEN LEGTURES} IN THE HIGH SGHOOL ASSEMBLY ROOM

$\begin{array}{cc}\text { I. JULIUS CAESAR } & \text { VI. WASHINGTON } \\ \text { II. MAIK ANTONY } & \text { VII. JACKSON } \\ \text { III. ALEXANDER } & \text { VIII. LINCOLN } \\ \text { IV. CHARLEMAGNE } & \text { IX. GRANT } \\ \text { V. NAPOLEON } & \text { X. ROOSEVELT }\end{array}$

TICKETS FOR COURSE W TWO DOLLARS

EXAMPLE 261

Suggested for course tickets. Coupons should be attached

Example 260.-The treatment of this example may be described as modern based upon the Colonial. The Caslon type-face furnishes a Colonial atmosphere, and the border treatment of color inside surrounding rules blends with the type-face. Only two sizes of type are used and lowercase is consistently adhered to. The shape of the main group gives a pleasing symmetry to the arrangement, the floret serving well to complete this result. The effect as a whole is bookish, and may be adapted to various literary and art purposes. White or buff stock would be suitable, antique finish preferred.

Example 261.-There may be an idea here for course tickets in which a number of lectures are listed. The form as shown is not complete, the ideaincluding the attachment at one side of coupons containing the names and dates of the lectures. Only capitals are used and the three main lines are aligned at each end of the measure. The narrow border gives a finish to the general design, which is well suited for printing in black ink on white stock.

Example 262. - Here we have a ticket of peculiar interest to women and the treatment is daintily appropriate. Caslon italic is an admirable letter for the purpose, as it is graceful and neat. Bold treatment and large type have been avoided, the main portion of the copy being grouped in the center and surrounded by liberal blank space. The outline illustration underprinting the type group gives added interest to the ticket and may have

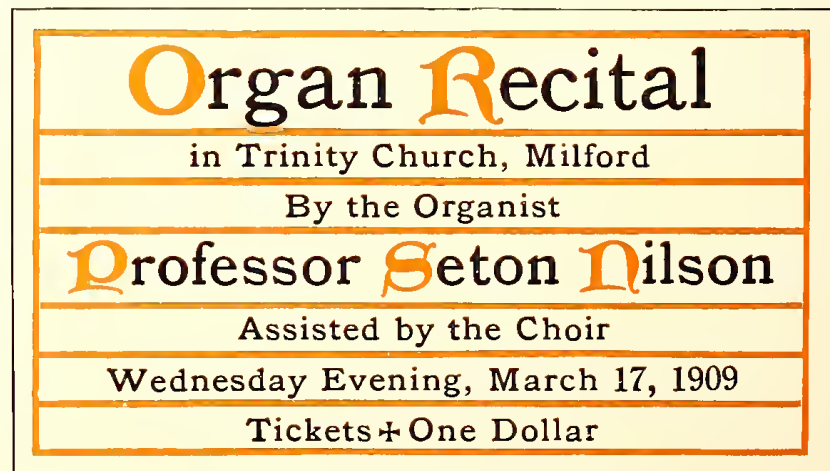

EXAMPLE 264

The ecelesiastical or missal style well adapted 


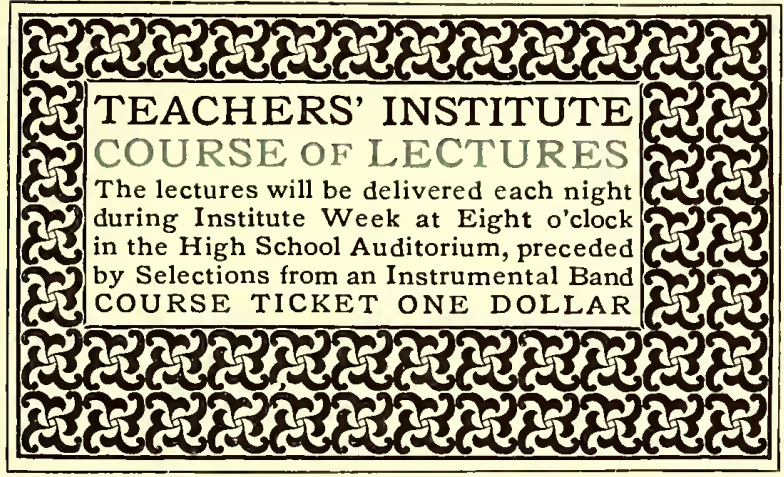

EXAMPLE 265

Perhaps Morris would have set a ticket this way

advertising value in the suggestion it presents of the evening's pleasure. White card would be proper, and a buff or gray-blue stock might also look well.

Example 263. - This ticket presents the geometric, or so-called secession style; a mild example, tho. Because straight lines form its motive, some call it the mission style. There are possibilities in it for the typographer looking for fresh ideas with which to vary his work. Right here it may be well to warn compositors against becoming enthusiastic over every new style of type arrangement that may come to his notice. There are men who in their endeavors to do something to win fame-something astonishing and entirely original-. set out on unknown seas without rudder or compass. The result usually is shipwreck. The printer who starts out to produce typography not founded on some proved and tried base builds a house in the sands that may come tumbling down at the first test of endurance.

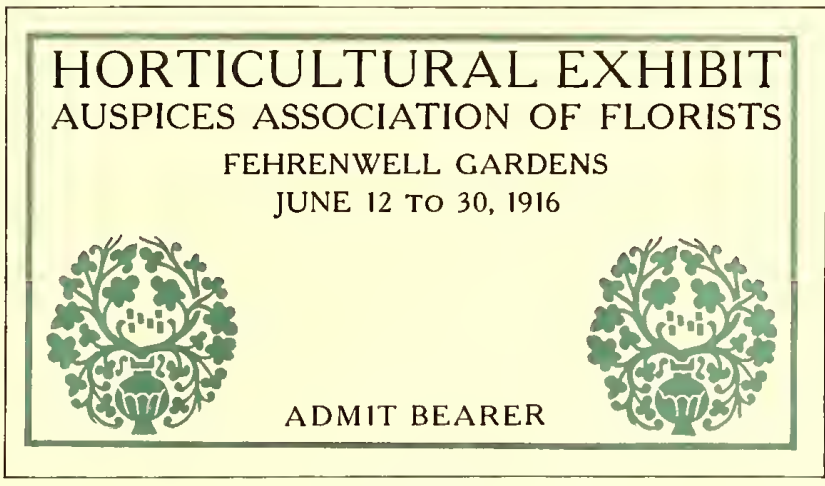

EXAMPLE 267

Modern application of classic type effects

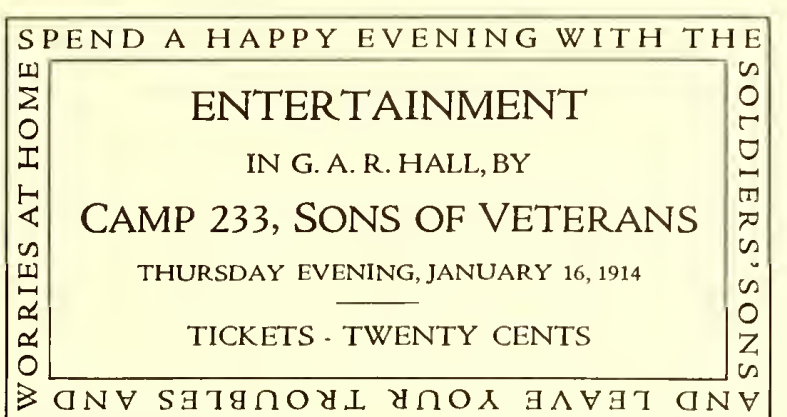

EXAMPLE 266

The medieval art worker furnished a motive for this ticket

color) may be had of typefounders in slight variations. White or buff card admirably supports missal treatment.

ExaMPLE 265.- Inspiration for ticket designs may even be drawn from the work of William Morris and the Italian printers who used the black-toned decorative border, altho this style should not be undertaken unless the proper border is available. The one here adapted carries out the idea fairly well. Old Style Antique set snugly to fill the panel gives the proper results, the capital lines also being necessary to this style. Tickets for educational and art functions especially lend themselves to this treatment and white card should be used.

Exanple 266. - The motive for this ticket form came from observing that art workers during the Middle Ages frequently engraved inscriptions around the margins or borders of plates, slabs, doors, and like objects. This suggested the adoption of the idea to carry a few pertinent words on an entertainment ticket.

Cardboard of almost any color could be used.

EXample 267. - Perhaps this arrangement could be described as a modern application of classic type effects. The display lines are in Cheltenham, a face that approximates some of the ancient Roman lettering, and the treatment of the ticket as a whole is chaste. The ornaments, surrounded as they are by blank space, emphasize the classic simplicity of the ticket. The type group is tapered to give proper symmetry.

Example 268. - This is purely a Colonial effect and as on a title-page. Uncial initials (as are here shown in

\section{EXHIBIT of PR INTS}

$\Gamma_{\text {HE directors of the Allentown Public Library have }}$ prepared an Exhibit of Prints, reproductions of the work of old masters, such as Raphael, Titian, Rubens, Michelangelo, Van Dyke, Rembrandt, Murillo, etc., exhibit to be open for examination every afternoon from

FEBRUARY TEN to MARCH TWO Present this Ticket at the Hamilton Street entrance

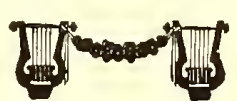

THE ORPHEUS ASSOCIATION ANNUAL CONCERT

ACADEMY OF MUSIC. BOSTON

DECEMBER 6, 1909

ADMISSION - FIFTY CENTS 


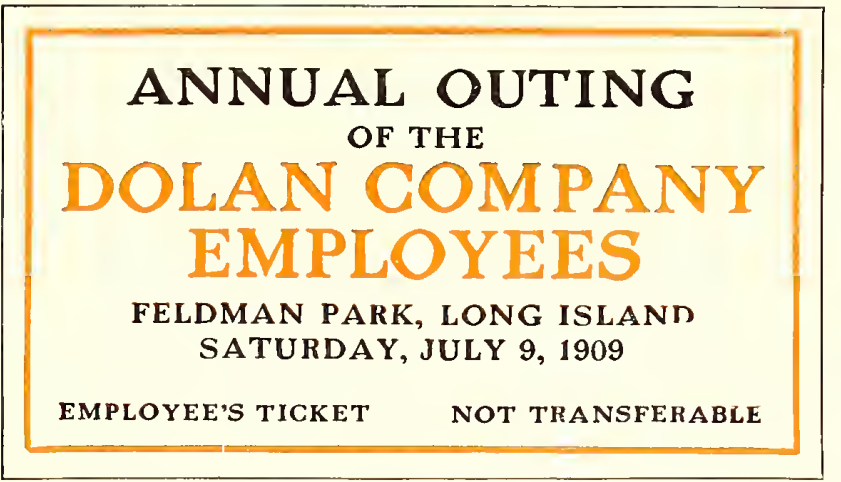

EXAMPLE 270

Robust treatment of an outing ticket

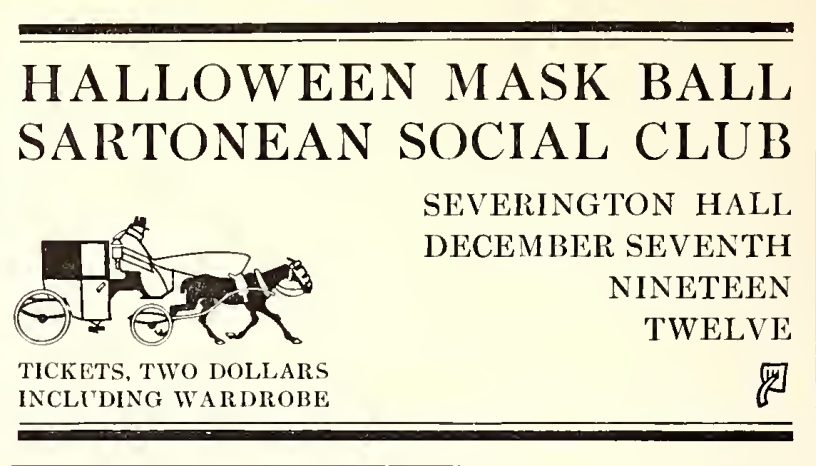

EXAMPLE 271

The cab ornament dictated the type formation

closely follows the arrangements found on title-pages of the seventeenth and eighteenth centuries. Hair-line rules well separated by space were common in those days. The type here used is Caslon, a letter cut in the eighteenth century, and one especially suited to Colonial typography. Antique-finished card in white and buff is appropriate.

Exanple 269. - Dainty, refined effects are demanded by certain customers. This specimen demonstrates the effectiveness of such treatment on a ticket. Two sizes of type (l'abst), all capitals and slightly spaced, give the proper results. The ornaments are used as symbolic decoration.

Example 270. - The typography of this ticket is distinctly masculine. This result has been obtained by the use of capitals of a robust type-face, so distributed in size as strongly to emphasize the important phrases. Had this form been printed in one color, the two type lines now in color should have been reduced a size. It is well for compositors to kcep in mind that

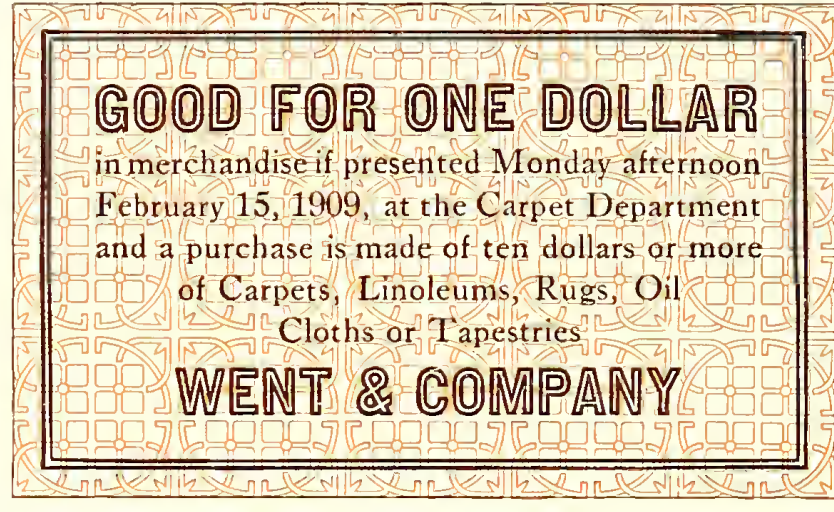

EXAMPLE 272

Treatment that should prevent easy counterfeiting

are social clubs of all kinds in every city, and balls are frequently held for which tickets are needed. An element of interest such as is given by the cab ornament would surely be appreciated by such customers.

ExanPLE 279. - Occasionally there comes to the printshop a customer wanting a ticket which cannot easily be duplicated by any one with a press and a few fonts of type. Instead of referring the customer to a lithographer the printer should ascertain if he is not in a position to produce such a ticket. The style of the one here shown is suggested for such emergencies. A type border printed in color forms the background. Over this print the reading matter, and for the display lines use a typeface that happens not to be possessed by other printers in the same city. In providing a border for this ticket a rule with double lines has bcen used, thus blending it with the double lines of the type-face. White stock should be selected for this ticket.

Example 273.- The corwhen orange is used in combination with black, the portion printed in orange will be lighter in tone than that in black, unless the difference is provided for by bolder or larger type-faces. Any color of stock excepting dainty tints would do for this ticket.

EXAMPLE 271.- This unusual arrangement was dictated by the nature of the cab ornament. The shapes of the type groups are built about it. Were the cab ornament not used, another arrangement would be necessary. There

ner decoration is in keeping with the subject of this ticket, and the arrangement as a whole is suggested for similar purposes. Any color of cardboard is suitable.

Example 274. - The decoration of early French books furnished the motive for the typographical treatment of this ticket. It is submitted simply to demonstrate that ideas for arrangement can be picked up in many quarters, and as a suggestion that typographers go thru the world with eyes open.

\section{Bushwick Photographers Club}

SEASON TICKET -1908 HOWARD BASE BALL CLUB

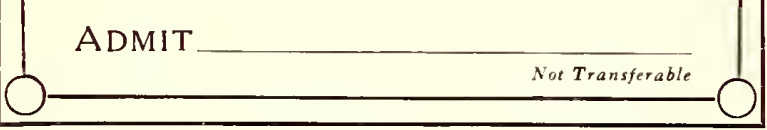

EXAMPLE 274

This arrangement has an old French motive
This ticket is good for one dozen best photographs if presented for the purpose of a sitting before March 30th, during mornings

Menton's Studio, 1164 Myrtle Avenue 


\section{BRONSON, LOCKART \& RANDALL}

WHOLESALE DEALERS IN

\section{DRY GOODS, WOMEN'S COATS AND SUITS}

EXCLUSIVE IMPORTERS

OF THE GENUINE GLABNEVIN LINENS

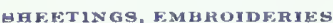
TABLE CLOTHE

\section{TELEPHONE 1768 CLAREMONT}

Cable ADTregsi Bronar
QELLING AGENTS THROUGHOUT THE UNITED STATE\& FOH THF WORLD-FAMOUS

\section{CLEVELAND, OHIO}

Neat. conventional treatment of a letterhead containing a large amount of copy. The bold-face type lends variety to the heading and brings out important points

OWEN L. BANNARD. M.D

OFFICE HOUAS

AB DOVER STREET. HILLSIDE

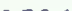




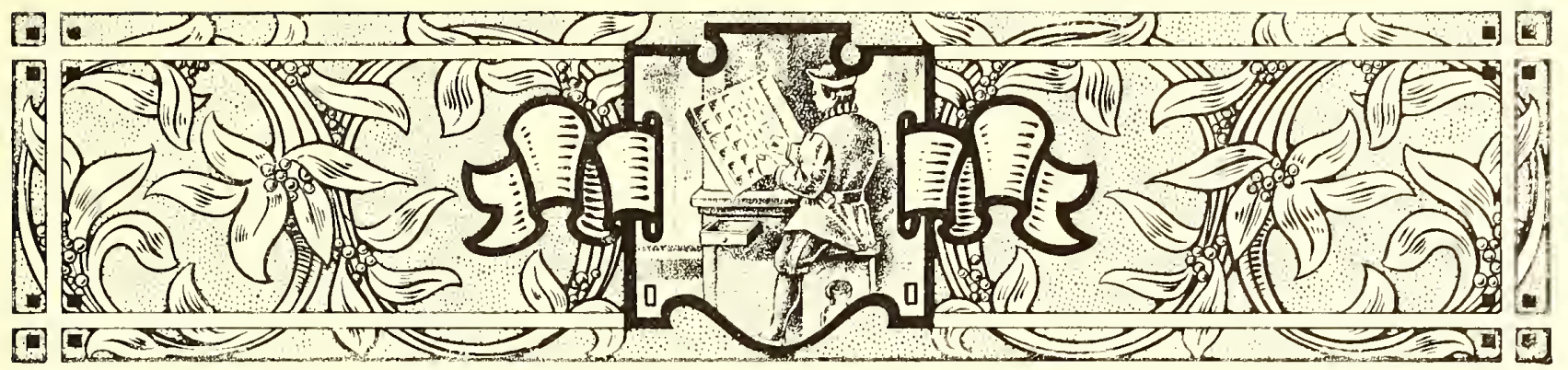

\section{LETTERHEADS \& ENVELOPS}

IS there a standard size of letter sheet and envelop for commercial correspondence? A look thru the letter files of any business house will reveal the interesting fact that most of the letters are on sheets measuring $8 \frac{1}{2} \times 11$ inches. Letter sheets of about this size lave been in use for many years. From DeVinne's Price List of $18 \pi 1$ we learn that $10 \times 16$ inches $(8 \times 10$ folded $)$ was the favorite size of letter sheet, and that for commercial letters the size $10 \% 4 \mathrm{x} 17$ inches $(8 \%$. $10 \% /$ folded $)$ was sometimes required.

Note sheets were then in two sizes: Commercial note, $8 \mathrm{x}$ 10 inches ( $5 \times 8$ folded); and packet note, $9 \times 11^{1 / 4}$ inches $(5 \%$ $\mathrm{x} 9$ folded).

Thetypewriterand modern commercial requirements have sincedeveloped use of the single leaf, altho for personal correspondence and certain refined business purposes the folded note sheet is proper.

In passingit might be noted that in the price list above mentioned the printer is urged to charge an increased price when

"brass or French flourishes are used in excess." The composition of "one plain lieading, of not more than four straight lines," was to be charged at seventy-five cents; "one ornamental heading with curved lines," twenty-five or fifty cents additional.

As has been stated, the standard size of the presentday commercial letterhead is $8 \frac{1}{2} \times 11$ inches. Strange to say, the standard size of envelop (known as No $6 \% / 4$ Government) used for the carrying of these letter sheets measures $6^{1 / 2} \times 3^{5 /} /$, tho if a snug fit were required the envelop would beabout $5 \%$ × 3 inches. The standard size, however, should usually be selected, as all sorts of enclosures are rnade to fit it.
The large "official", envelop is also used extensively for business purposes, the most common size (No. 10 Government) measuring $9^{1 / 2} \times 4^{1 / 8}$ inches. It takes a letter sheet of two parallel folds, and also provides for business and advertising enclosures larger than those planned for the standard envelop of smaller dimensions.

Distinction is given business stationery by folding the standard letter sheet twice so that, folded, it measures $5 \frac{1}{2} \times 4 \frac{1}{1}$ inches, and by using an envelop (Baronial) that measures an eighth or a quarter of an inch larger each way. For private or semi-private purposes this kind of envelop is preferred, especially if the letter sheet is used as a double note sheet. The heading is frequently printed on the fourth page of the double note sheet, so that when the message is written on the fourth and first pages and the sheet is opened, the letter appears as two pages in a book.

Another size of men's personal correspondence sheet measures 5 x 8 inches folded once. After being written upon the sheet is again folded, and it then measures $5 \times 4$. inches. When the customer is willing to pay a price for which the best quality of stationery may be furnished, the printer should secure from houses specializing in society stationery envelops that are made with a more st ylish flap than thosecommonly used for business purposes.

Anothersize of letter sheet, used for men's personal correspondence and for giving an exclusive appearance to commercial stationery, measures about $7 \frac{1}{4} \mathrm{x}$ $10 \%$ inches. The paper is given two parallel folds and fits in an envelop that measures about $7 \frac{1}{2} \mathrm{x}$ 4 inches. 


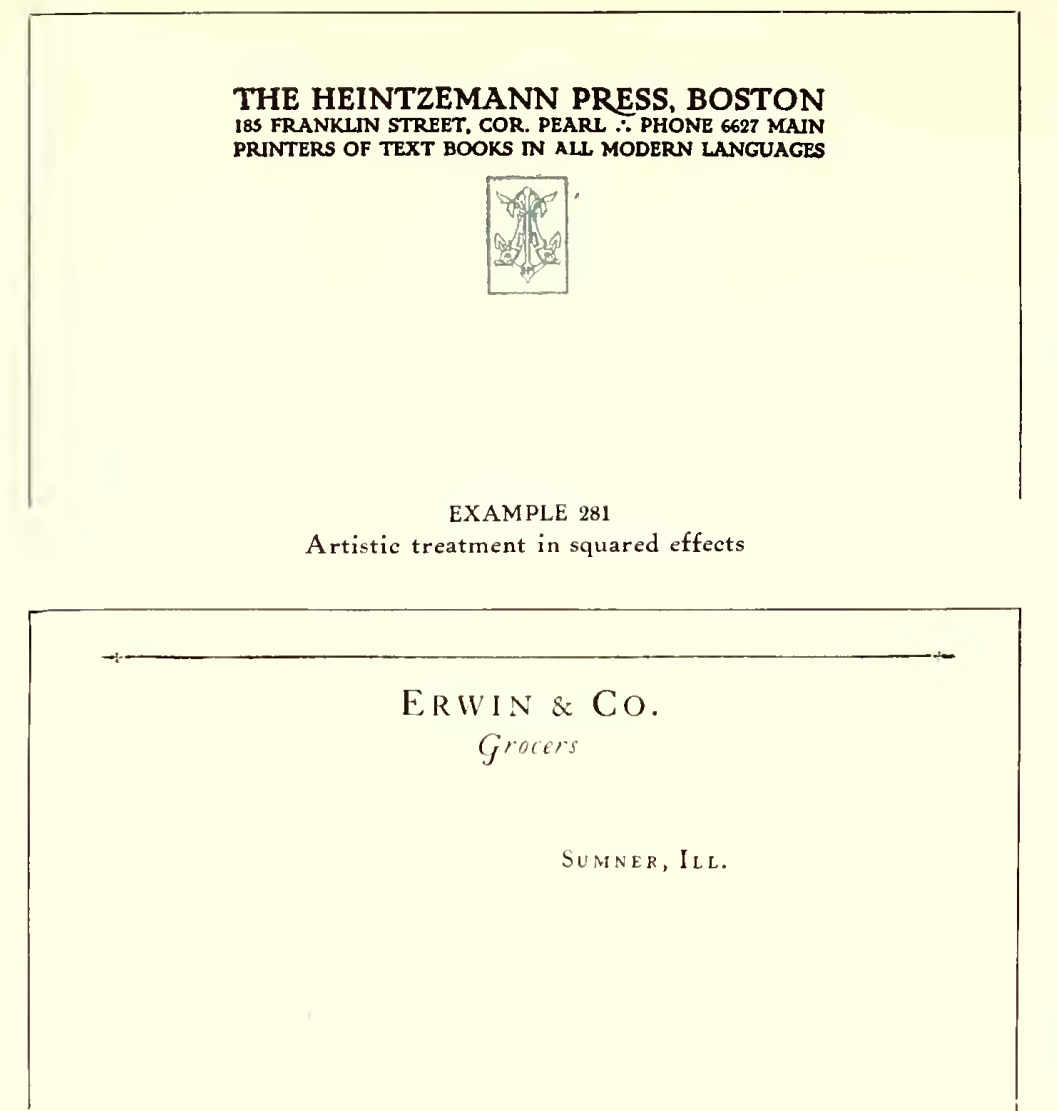

EXAMPLE 282
A simple treatment of a heading with little
copy. Capitals have been letterspaced a trifle preferable over a heavy-weight paper of a low grade. Quality isn't a matter of weight, altho if it can be afforded the heavier weight is not in the least objectionable. Twenty-pound folio (17 $\times 22)$ seems to be most easily obtained in the various papers.

As to the style of typographic treatment, the printer must in all cases consider the tastes of his customers, and especially the business or profession for which the stationery is to be used. As an instance, the style of typographic treatment of doctors' and lawyers' stationery seldom changes.

It should be kept in mind that simple, neat, refined typography is appropriate for almost every order of stationery, while elaborate typography in many cases is inappropriate.

Color is seldom well used on stationery. Most letterheads that the writer has seen which have been treated in three or four colors would have been more pleasing if given but one printing. A test of typographic skill is to design a letterhead that in one printing will look attractive and distinctive. The heading should usually be printed in black or some darkened color, and if another impression is desired a very small part of the design printed in orange or vermilion will add a touch of bright color.

All the reproductions shown are reduced in size, those on the inserts being only slightly smaller.

ExAM1'LE 275 (lnsert). - Lithographers and steel-die printers really furnish the styles for the conventional arrangement of letterheads.
Since the typewriter is in such general use, ruled letter sheets are seldom called for : in fact, ruled correspondence sheets of any kind are now in poor taste.

The old-time notehead is also little used, the half-letter sheet $\left(8^{1} \%\right.$ × $51 \%$ inches $)$, and the two-thirds letter sheet $\left(81 / 2 \times 7^{1} / 3\right.$ inches), printed the broad way, taking its place for brief business messages.

The typographical treatment of letterheads and envelops should have some relation, and it is now generally conceded that the paper should be the same in both cases. A good grade of paper is now considered essential for bona-fide correspondence, a cheaper grade being allowed for form letters. A light-weight paper of a high grade is

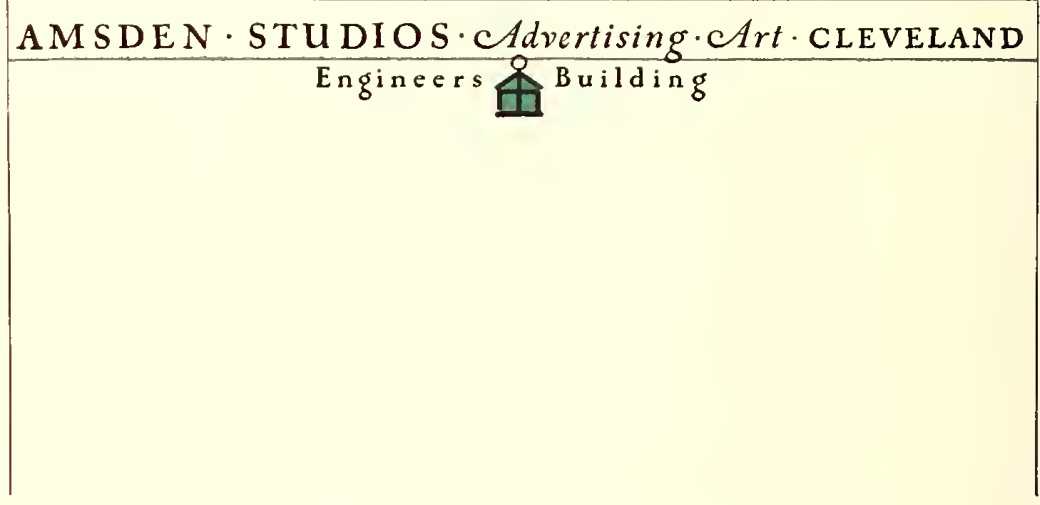

\section{EXAMPLE 283}

There is a great deal of character in this simple letterhead design. The lantern is really a monogram. By Charles $\mathrm{R}$. Capon

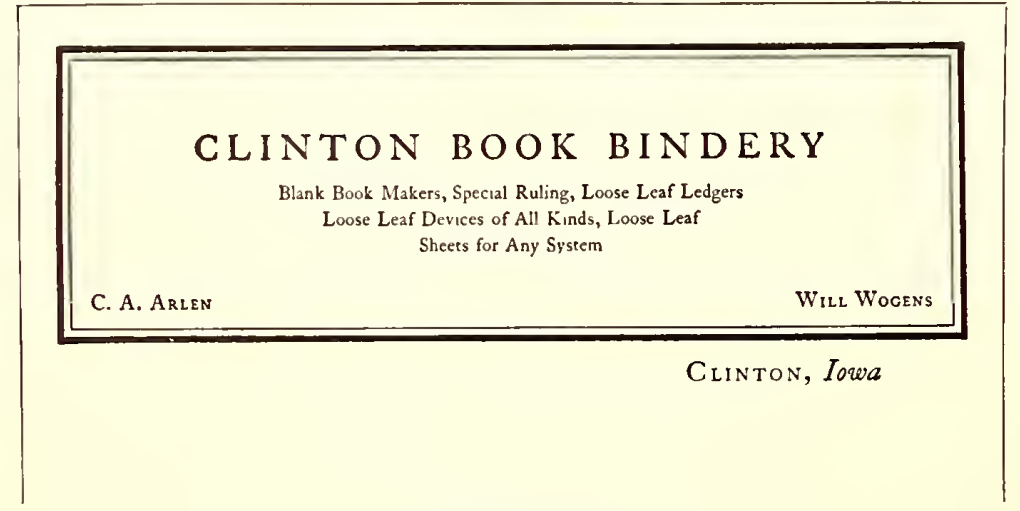

EXAMPLE 284

The heavy border effect of the Colonial style of typography gives character to this heading. By Arthur Nelson
They work along standardized lines and usually produce well-balanced, appropriate headings. Ty pographical printers should study stationery produced by these processes and observe how the parts of headings are grouped and the advertising points emphasized; for a letterhead is one form of advertising. There are limitations, however, in the copying of such letterhead arrangements. Only plain designs should be studied for this purpose. Imitations of shaded and ornamental lettering are seldom successful. Example 275 demonstrates how a good letterhead can be designed along lithographic lines. The effectiveness of this heading depends a great deal upon the use of both lightand dark-faced type. Where there is a great deal of matter, as in this instance, the heading 
would likely appear flat and uninteresting and would lose some of the advertising qualities it possesses if the light-faced type were used thruout. This is no argument for bold-faced type on stationery headings as a usual thing, but refers to the kind of heading here shown. The parts in the dark-faced type include the firm name, the nature of its business and the city in which the firm is located. The names of the officers are arranged in the upper part of the heading, and this position of the names seems to be satisfactory in most instances. The telephone number and cable address are in the center near the date line. The type used in this heading is Card Litho and Card Light Litho.

Example 276 (Insert). - Professional stationery must be treated with dignity and refinement, and the type should be small. Treatment such as this would undoubtedly meet with approval from the professional customer. It would be a mistake to apply to professional stationery the variety of attractive and interesting arrangements that are applicable to stationery used for many business and advertising purposes. The printer would save resetting of the work and more surely please his customers if, in filling orders for doctors, lawy ers, architects, engineers and other professional men, lie attempted nothing but the conventional dignified treatment illustrated by this example. The type is an imitation engravers' gothic slightly letterspaced to give the effect usually found on steel-die work.

Example 277 (Insert).—Ministers, included as they are in the professional class, like to

\section{The Ifouisiana State. Mental Societu}
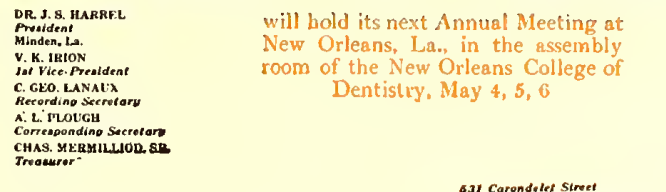

DR A G. FRIPDHichs

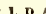
DR. .. A. DENBAR DR. D. R. STERE DR. PACL UE VERGES sil Moobera cuiliding
New Orleans, La.
EXAMPLE 285

On which a meeting is advertised

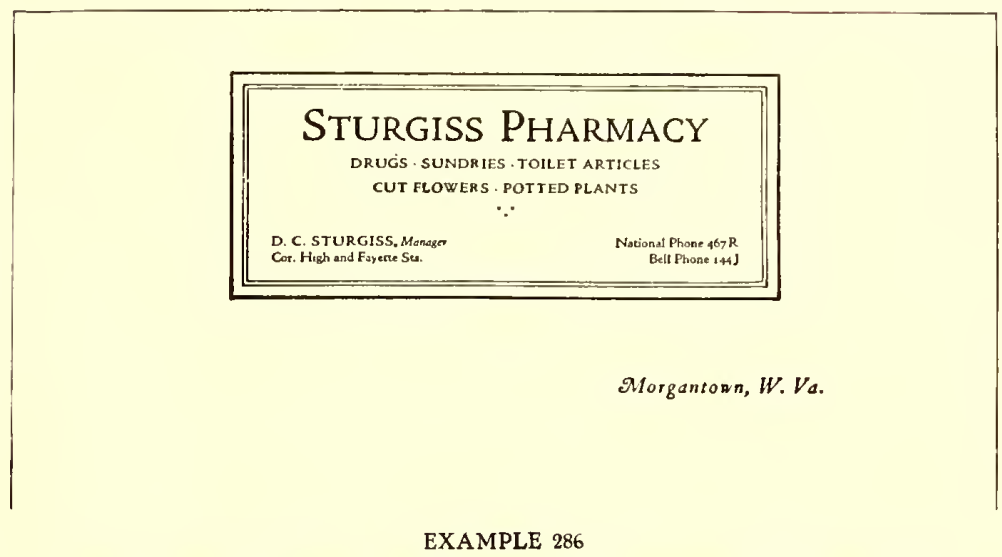

A panel, when well treated, gives distinction to stationery. By Arthur Nelson

COMPLETE FINANCIAL SYSTEMS FOR CHURCHES + NEEW AND NOVEL MONEY-RAISINO IDEAS + SPECIAL PRINTINO

\section{A. M. FARNSWORTH EBurch Printing 国}

'PAMDEN, N. Y.

\section{EXAMPLE 287}

Suggestion of the ecclesiastic in the design of a letterhead for a church printer letterhead be treated with the elaborateness of this one unless the customer expressly desires such treatment and is willing to pay for it, or the letterhead is the printer's own, as in this instance. The reproduction, unfortunately, does not present the rich qualities of the original, which was printed in green-gray and red-gray on a gray handmade paper. The typography was merged with the paper stock, and there was not the contrast found in the reproduced specimen.

Example 280.-Old-Style Antique, as this heading shows, is a good type-face for the letterhead of an art publication company. Capitals have been used thruout and grouped so as to form a symmetrical arrangement that harmonizes well with the decorative device placed have their stationery dignified and neat. At the same time they do not object to the use of text type, as it has a churchly suggestion. This type, too, must be snall, that used here being eight-point in size.

Example 278 (Insert).- Stationery for a lawyer, like that for a doctor, should be dignified and refined. It is well to give him the professional customer's style of typography such as that of the doctor's heading, but if a departure is to be made from the imitation steel-engraved lettering, it is possibly well to use a modern style of type such as the Bodoni, and letterspace the capitals, as was done in this example. But one size of type-face has been used here (eight-point), capitals, italic, and small capitals being utilized.

Example 279.-Practically never should a
HILES \& COGGSHALL. PRINTERS CATALOGUES, BOOKLETS, OFFICE STATIONERY AND BLANK BOOK'S LEGAL BLANKS AND DOCKETS 205 ST. CLAIR AVENUE, N.E. CLEVELAND

EXAMPLE 288

Artistic yet simple arrangement the feature of which are the three lines of equal length. By Leon I. Leader 


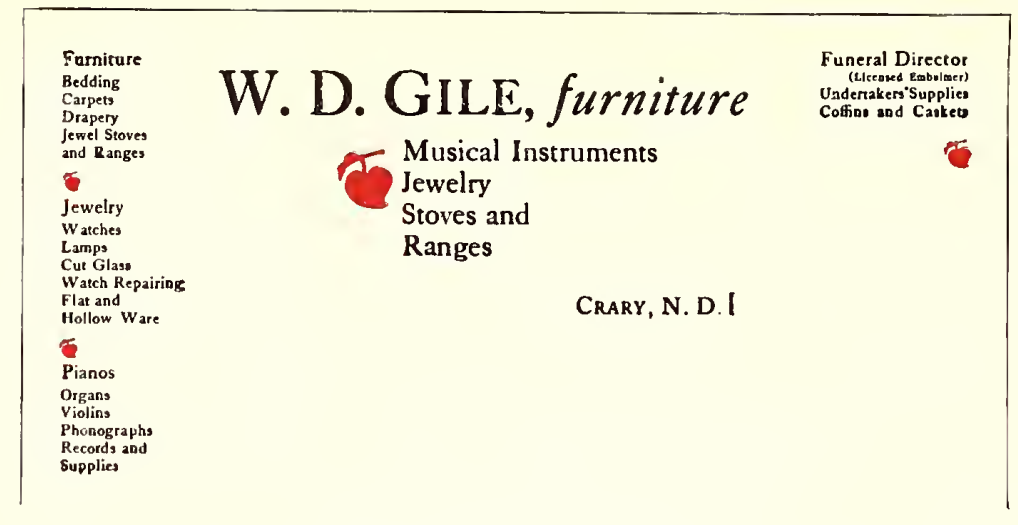

EXAMPLE 289

Letterhead for a storekeeper selling a general line of goods

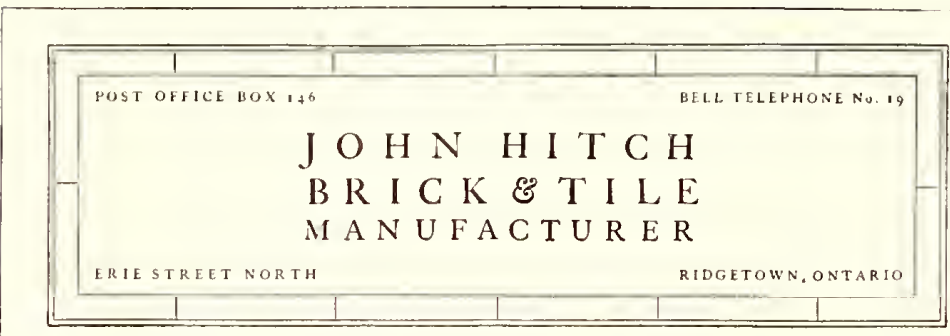

EXAMPLE 290

Panel treatment that suggests the business. By Arthur Nelson in its attractiveness. 'Tlue original was on brown paper.

Example 282.- When the printer receives copy as brief as that used for this letterhead he experiences difficulty in producing an effect that will be attractive. With the customary engravers' type-faces nothing very satisfactory is possible, but by using a type-face of character, sucl as Caslon Oldstyle in its original form, as was done here, artistic interest can be added. Two sizes of capitals, spaced, were used for the firm name. Italic was selected for the word "Grocers," with a swash or decorat ed capital that accompanies the old Caslon ty pe-face. Capitals and small capitals were utilized for the date line. A touch of decorative interest was added to the heading by the use of a rule, on each end of which was placed a dagger, such as is usually a part of book fonts. This treatment could be made even more effective by printing the letterhead on a white bond paper of good qualit. .

Example 283.- This letterhead is offered as a suggestion for artistic treatment when not much copy is furnished and it is possible to use a small decorative device. The type-face should have old-style qualities of an artistic nature and should be slightly letterspaced. The lantern device on this heading is really a monogram, cleverly designed. The original was in black and orange on buff-tinted paper, and as shown by the reproduction, the heading was placed very high on the sheet.

Example 284. - For some reason a border made of a heavy line and a light one har-

under it. A feature of this heading is that ali matter is included in the one group, excepting the name of the city, which is placed to receive the date line.

ExAMPLE 281.-Successful treatment of a heading like this depends upon the typographer's ability so to arrange the copy, without resorting to letterspacing, that all lines are the same length. It is necessary atso to use all capitals of an old-style face of dark tones in which the letters set fairly close together, a result such as can be had with Old-StyleAntique or Cloister Oldstyte. The decorative device in its shape harmonizes with the formation of the group of type tines above it. The liberat blank space that surrounds this heading is an important factor

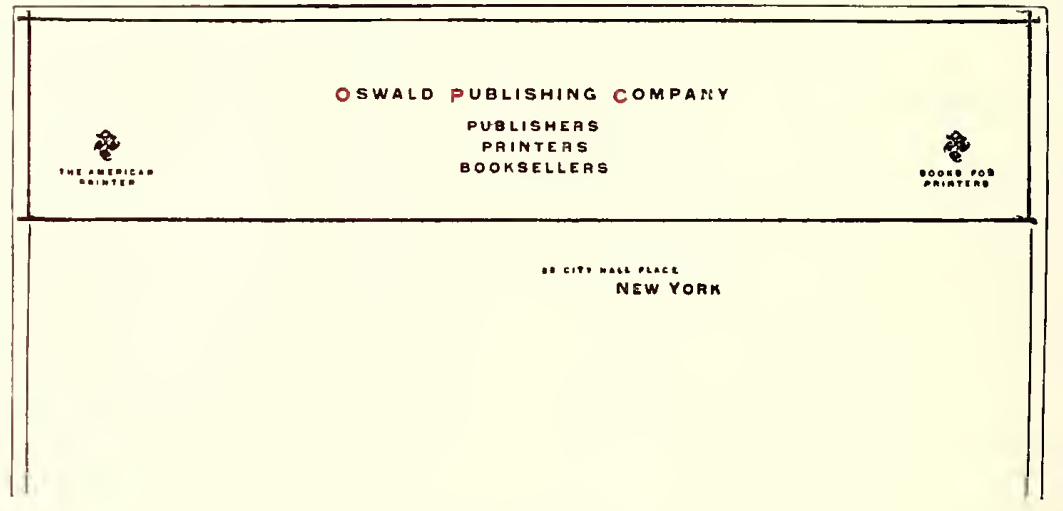

EXAMPLE 291

Dignified yet novel treatment

monizes with the type matter in Caslon Oldstyle, especially when liberal blank space separates the type and the border, as in this instance. It is well usually not to have the border darker in tone than the type matter, but on this heading it would be a mistake to lighten the border, which, however, would look well printed in vermilion or orange ink. A bufftinted paper of an antique finish would blend with the Caslon typography. It is a departure from conventional methods to place the names of the firm members in the lower part of the panel. This was probably done so that the name of the bindery would stand out without interference from type matter above it, but as a concession to conventionality it would probably be well to place the names in the upper part 
Example 285. - The printer is frequently called upon to arrange for an organization a letterhead which contains an announcement of the next meeting of the society. The example under consideration shows how this may be done; the meeting announcement is presented plainly, yet a letterhead appearance is retained. The name of the society crosses the letter sheet and is joined on each end by a group of officers. The reference to the meeting occupies the space directly under the name of the society. In the original the main part of the heading, which now stands out so strongly, was subdued by the use of gray ink.

Example 286.-There is suggestion of the architectural panel about the arrangement of this heading. The suggestion is continued by the use of a classic Roman type-face mainly in capitals. Panels are not as successful on letterheads as they would be if more judgment were used in forming them. This lieading should prove helpful in working out the panel idea. Its proportions could be smaller with good results. The original was printed with green-black ink on a primrose color of bond paper, but would also look well on white stock.

Example 287.-A letterhead is successful if by its treatment it suggests the line of business for which it is used. This one measures up in that respect. By the use of the old text type and Maltese crosses an ecclesiastical touch is given. The old church missal books of the manuscript days were brilliant in rubrication, a feature of which were ruled lines, crosses and initials in vermilion. The arrangement of this heading is also one that could be used for

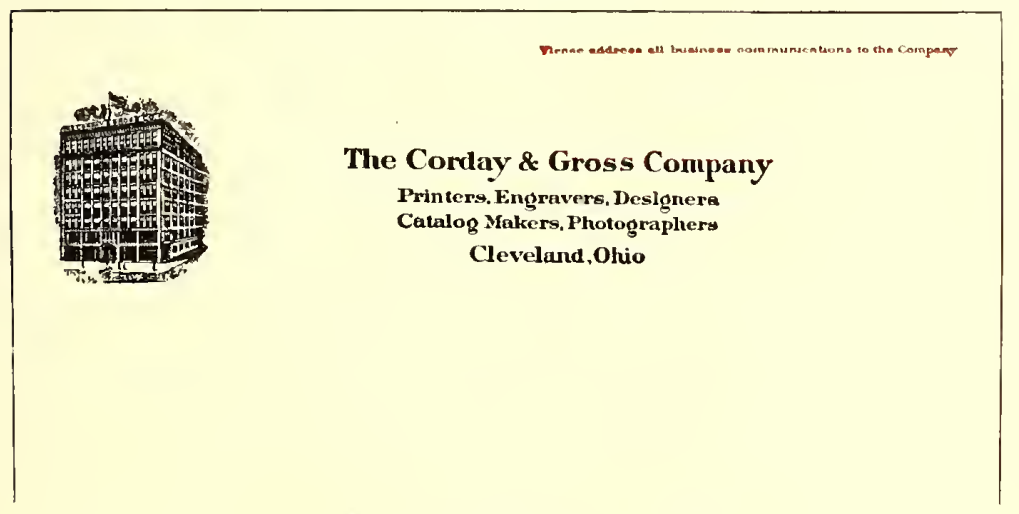

EXAMPLE 295

Neatness and dignity in letterhead designing

\section{(b) Orcester aledonian lub}

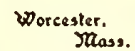

EXAMPLE 293

Individuality obtained by means of decorative initials

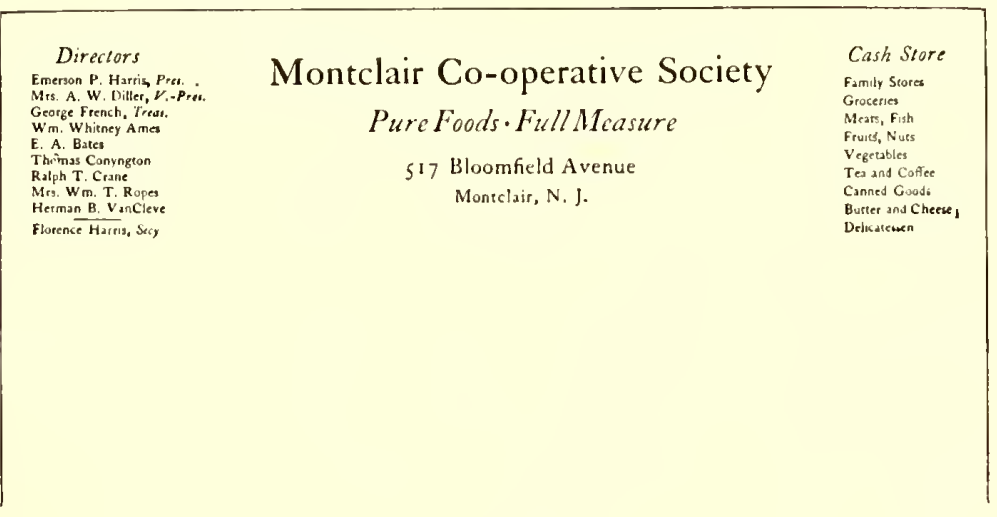

EXAMPLE 294

Just a neat typographical arrangement

and well-balanced lieading. It is difficult properly to display copy which includes such a variety of articles as furniture, jewelry, stoves and coffins. The typographer responsible for this letterhead set it in Caslon Oldstyle, grouped it as well as he could, and introduced decora tive value by means of florets printed in color. The name of the merchant was given tlie most prominence, and "Furniture" was featured for the reason that it seemed to constitute the principal part of the business. The printer who objects to this arrangement should try his hand at resetting it. As copy, this heading is in strong contrast to that supplied for Example 282.

EXAмPLE 290.-This example is a resetting of a letterhead on which the printer had imitated bricks by using oblong border units printed in many purposes. Some of the facts about the

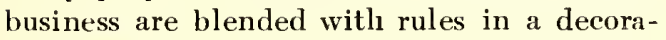
tive band that gives breadth to the heading.

ExaMPLE 288. - Letterheads arranged so that all lines are the same length, especially if such arrangement allows proper emphasis of the firm name, usually look well and have artistic interest. This heading is one such as almost any printer with a good old-style type-face could produce. Like Example 281, this treatment requires the use of capitals. Lower-case in square or block formation does not shape up harmoniously. Capitals exclusively slould be used when such effects are planned.

Example 289.-A letterhead for a general store invariably presents a problem to the printer who wishes to produce a harmonious

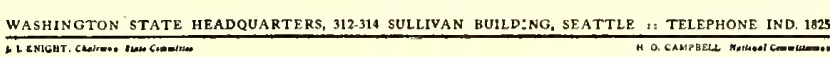

INDEPENDENCE PARTY THOMAS L HISGEN

EXAMPLE 296

A heading in two groups. By Harry A. Anger 


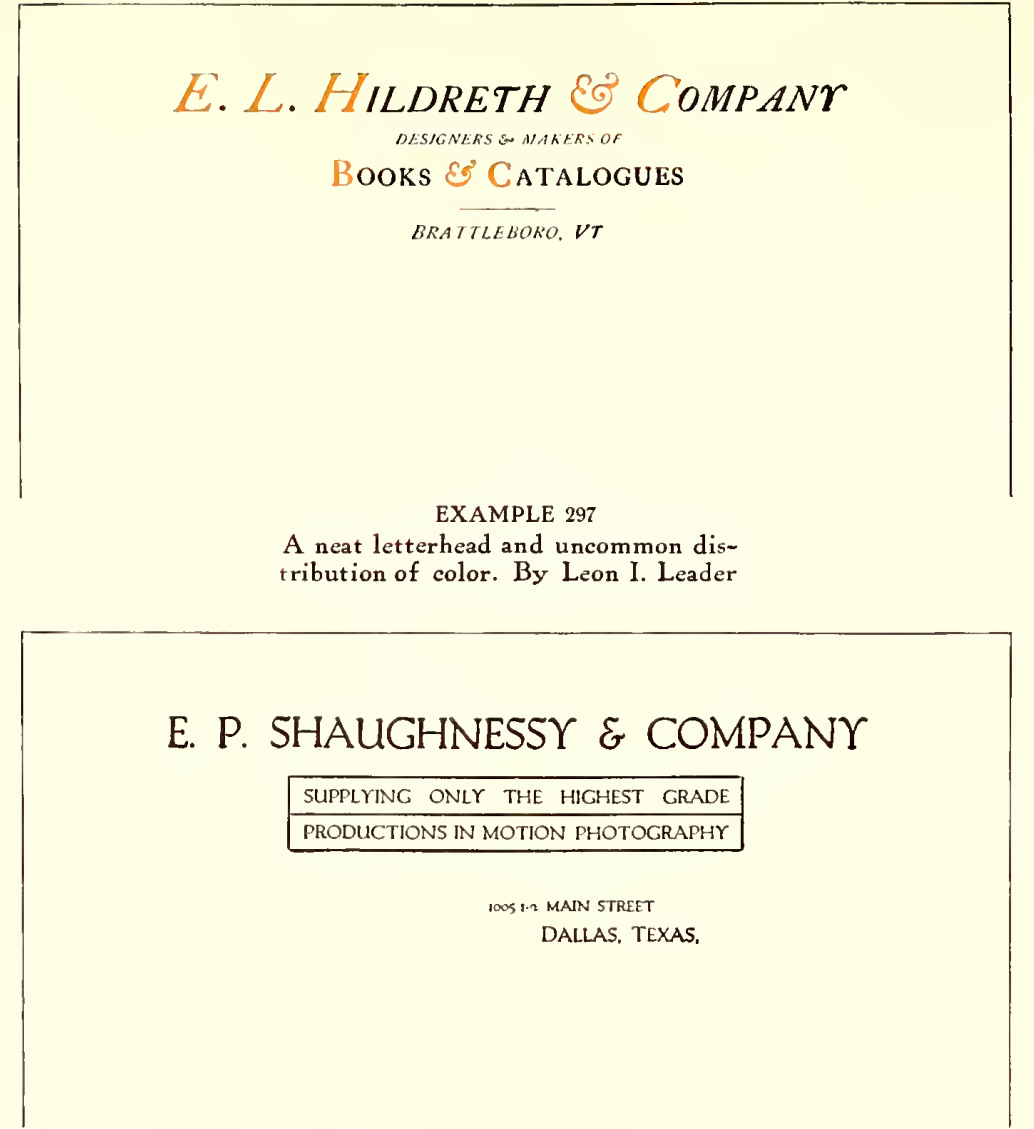

Double-panel treatment that is unusual succeeded. He did it, too, with the good old Caslon type-face. This type has proved its worth in commercial job work, and there seems to be no limit to its usefulness. By spacing the letters in this heading a peculiar tone has been obtained which gives the letterhead much of its character. The position of the lamp ormament is odd. Black and orange ink and white paper were used.

Fxampie 293.-While it is safer to print club stationery in the conventional style of professional stationery, there are clubs which will appreciate any individuality and attractiveness the printer may introduce on the letter sheet. This heading is a suggestion of what might be done in this direction. Washington Text has been combined with decorative initials.

Example 294.--The problem here was to produce a letterhead for men who appreciate typographic neatness, and the problem was met by setting the heading in Caslon lower-case and introducing italic in several places where it would be of the most value. As will be seen, the names of the officers were grouped on the left, and balanced on the right by a group that tells of the things the store has to sell. It is likely that copy such as this would meet with different treatment from the average compositor, who would be inclined to distribute the copy over all parts of the letterhead. The lesson to be learned is that the several parts of copy should be orderly apportioned to positions on the letter sheet, as in this instance.

ExampLe 295.-This is an excellent example of a good letterhead. originally produced by

red. His effort was too literal, and in rearranging the heading the purpose was merely to suggest bricks and tiles in a light-printing border. Spaced Caslon capitals completed an effect that is unusual and distinctive. The line "Brick and Tile" could be printed in color.

Example 291.-There is a dignified yet novel attractiveness about this heading. The light cross-rules give sliape, and individuality is injected by slightly spacing the letters and confining the color to three small initials. Gothic (sans-serif) type looks well treated in this manner. As will be seen, liberal blank space is necessary for a right effect. 'The original was printed in black and vermilion ink on gray bond paper.

Example 292.- The designer of this letterhead planned to get something different and

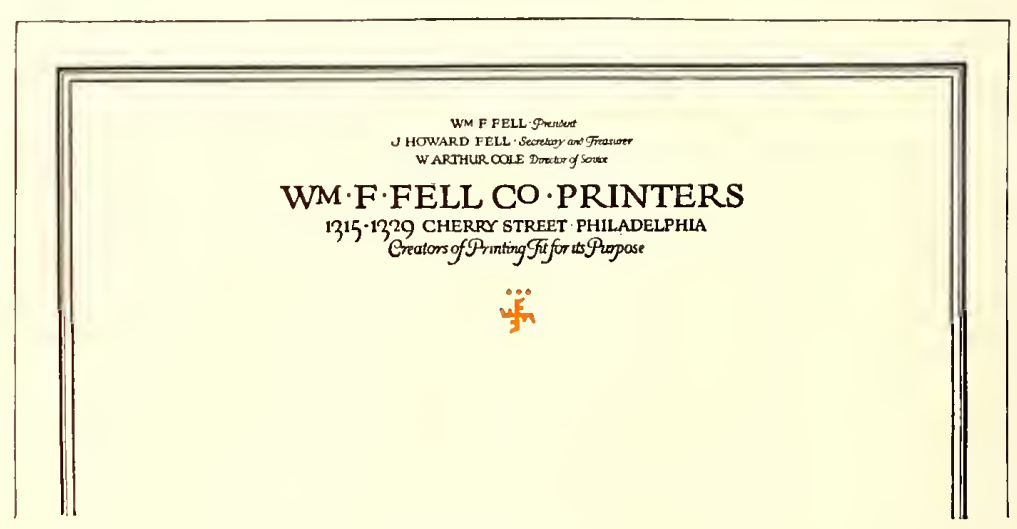

EXAMPLE 299

Distinction in letterhead design. The rule border, which extended around the entire sheet, was in a shade of ink lighter than that used for the type

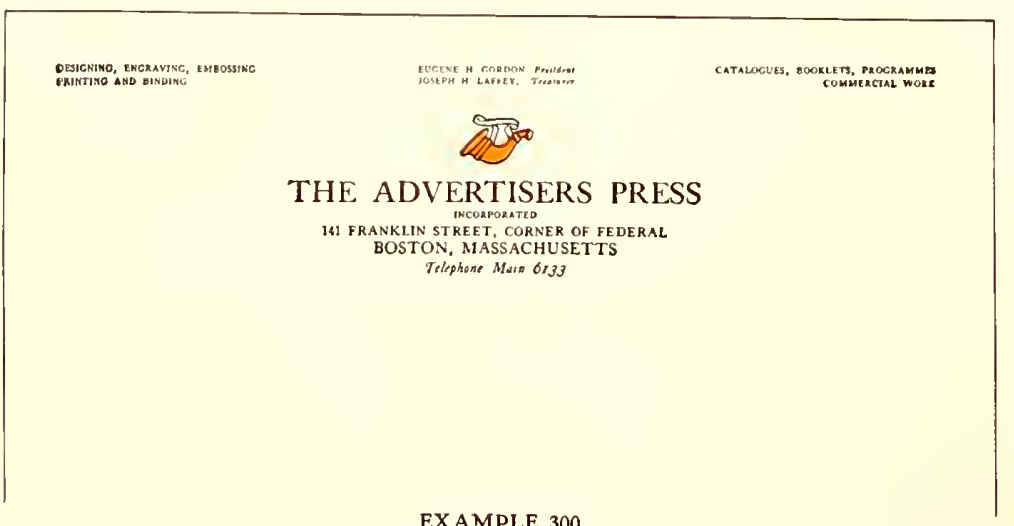

A letterhead in Caslon roman capitals and italic lowercase, with touch of color in the distinctive shop mark the incised copperplate method. Study of its details would benefit the typographic printer for the reason that, as mentioned in the beginning of this chapter, designers of letterheads produced by lithographic and intaglio processes have given much thought to letterhead arrangement. The main part of the heading is symmetrically arranged in a group in which attention has been given to spacing. The jllustration is disposed of at the left, and an added line has been placed in the upper right corner and printed in red. The neatness and dignity of this letterhead are an inspiration.

Example 296. - The copy of this letterhead presented a problem which was solved by making two distinct groups of the type matter. In the main group were placed the matters of na- 
tional importance, and in the upper group in smaller type such copy as refers to the state organization. Compositors should observe how the "Y" at the end of the main line has been extended into the margin so that the group alignment might be retained. The printing combination was black ink and white paper.

ExлmpLe 297.-Perhaps the use of italic capitals exclusively would have been more consistent, yet the one line of roman capitals does not detract from the pleasure the neatness of this heading affords the admirer of good printing. The distribution of color is uncommon. The italic short-and ( $\xi^{\circ}$ ) adds a touch of decoration to the heading. Typographers will find that these old-style italic short-ands look well in display lines substituted for the spelled-out "and." The roman short-and $(\&)$ is severe in character and is not so pleasing.

EXAmple 298.-Occasionally it is advisable to inclose type matter in a panel, altho in most instances the typographer will find that a letterhead is neater if no rule panel is used. However, there is something attractive and different about the panel treatment of this letterhead. Without the rules the heading would be neat, but would lose a distinction that is now given it by the rules. The type-face, Packard Oldstyle, possesses a quality found in handlettering and looks well on this heading.

Example 299.-A line border finishing off the edges of the letter sheet adds a quality to the appearance of the stationery that makes it worth while when the printer uses the idea on his own stationery or a customer is willing to pay the increased cost necessary for such an effect. On the Fell letterhead the border was

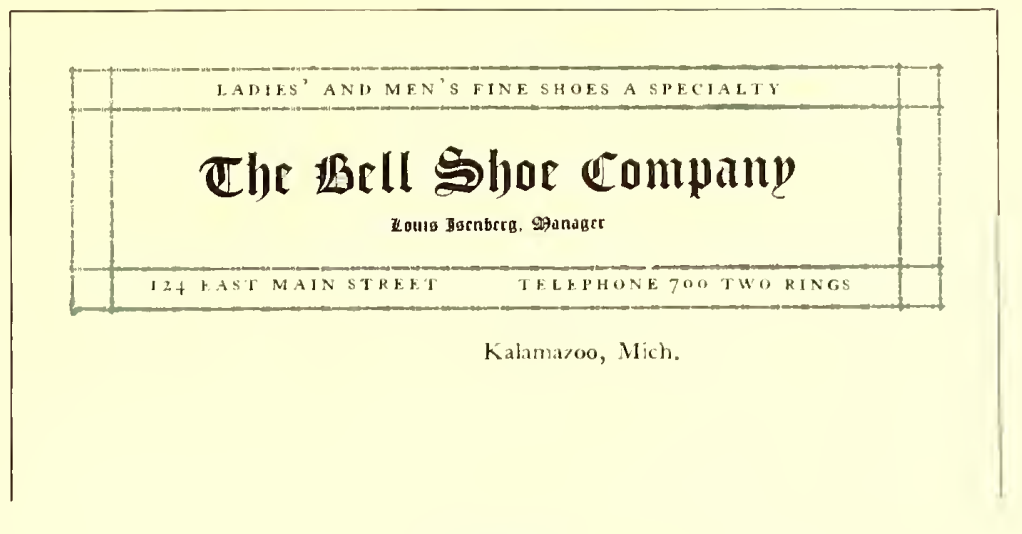

EXAMPLE 301

The crossed-line panel successfully adapted to letterhead purposes. By Adams-Brander Company

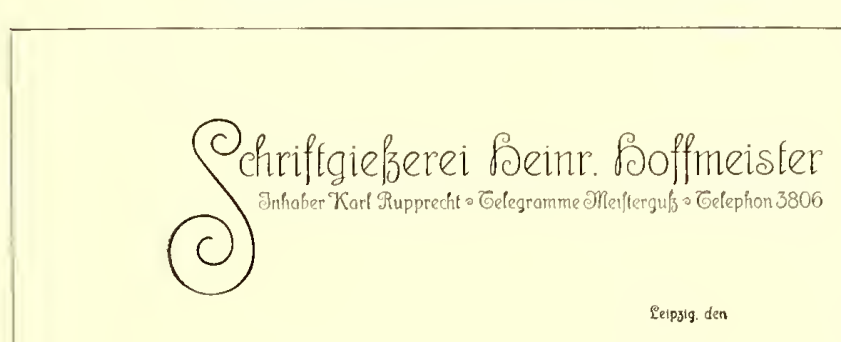

D. B. UPDIKE THE MERRYMOUNT PRESS No. 232 SUMMER ST. BOSTON

CABLE ADDRESS UPDIKE BOSTON TELEPHONE MAIN 922

EXAMPLE 303

Type arrangement as used by a noted typographer. Printed on the fourth page of a folded note sheet

in a shade of ink lighter than that used for the type. The arrangement of the heading is worthy of study, especially the disposition of the officers' names, which are placed one under another instead of being conventionally arranged in a line at the top of the sleet. While this heading is hand-lettered, it is suggestive of similar effects that could be produced with good type-faces of an old-style design.

Example 300.- Another letterhead in the Caslon typeface, roman capitals and italic lower-case being used. Much of the attractiveness of the heading is due to the spot of decorative color made by the shop device, which in design blends well with the type-face and because of its position brings the eye to the title of the press. The names of the officers are placed above the center, and the service rendered by the press is outlined in the end groups.

Exımpis 301.-The cross-line panel is here adapted to

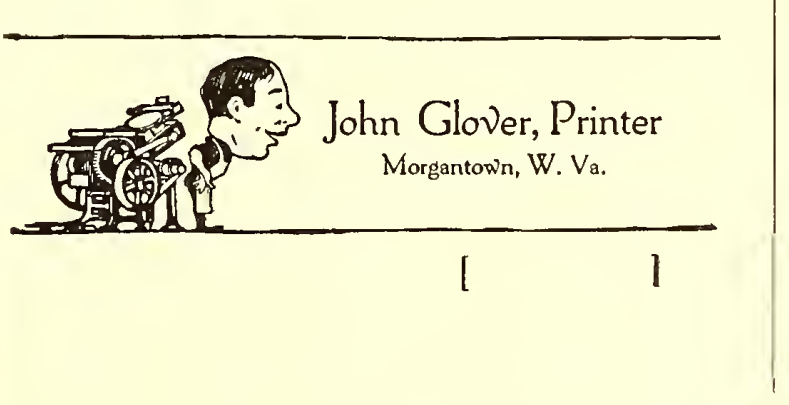

EXAMPLE 304

Humor in a notehead is exceptional 


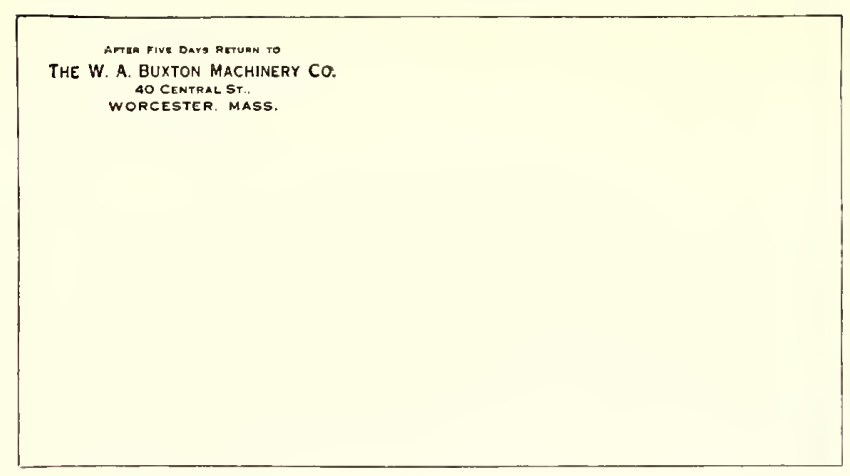

EXAMPLE 305

Conventional treatment of an envelop corner

adds a touch of decoration between groups. This notehead was printed on the fourth page of a folded sheet in dull-finished black ink on white bond paper.

Example 304.- Humor in a notehead is questionable and should be used only in exceptional cases. Mr. Glover, however, has used it to good advantage. l'rinting has always been such a serious business that customers may welcome a printer who can smile even on his note sheets.

The envelop is an acknowledged convenience in correspondence. It not only protects the letter from being

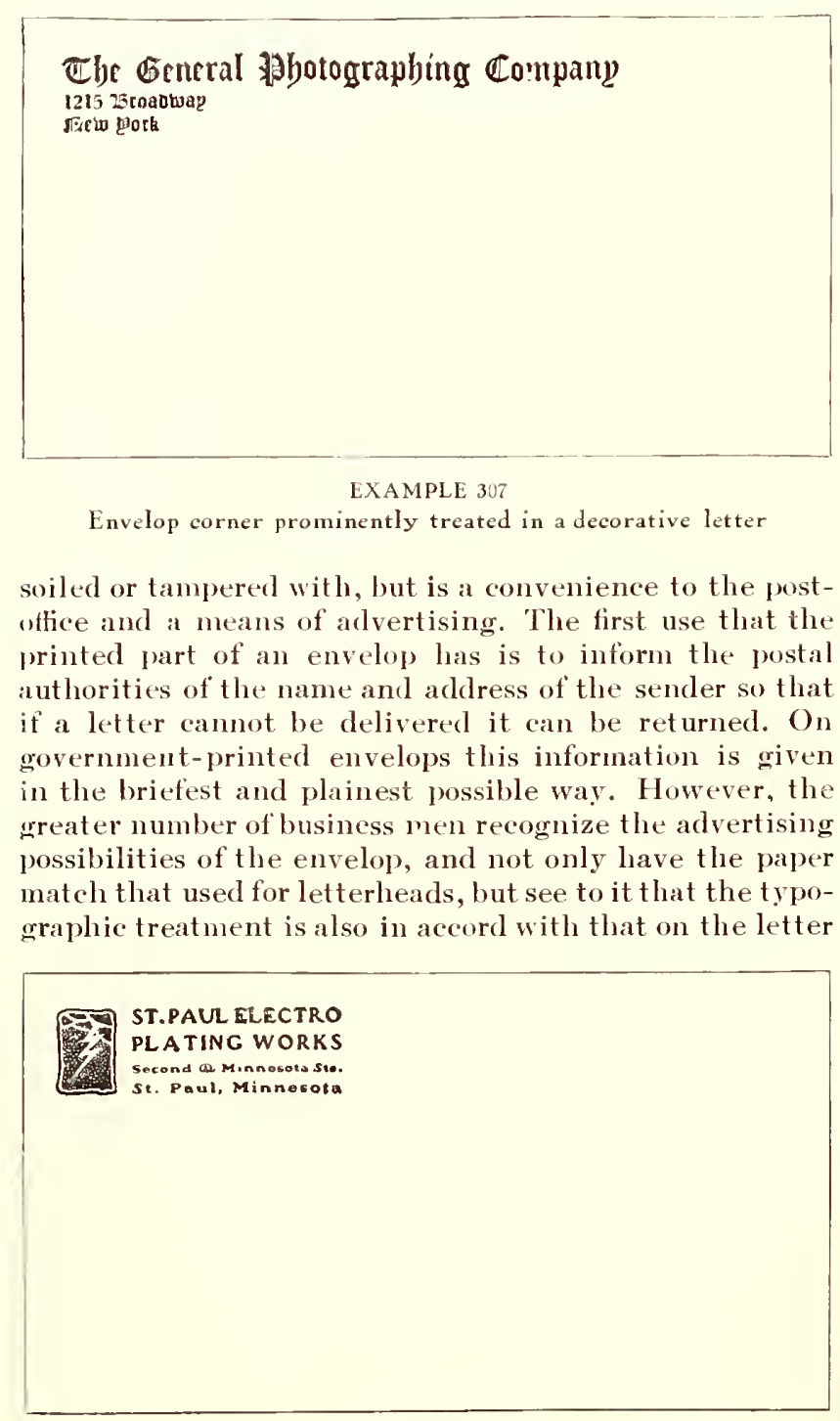

EXAMPLE 308

Harmony of device and type treatment. By Ray Greenleaf

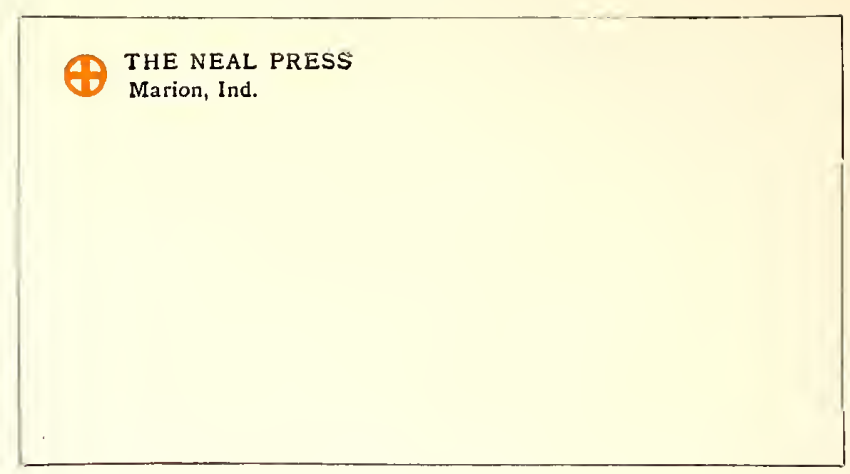

EXAMPLE 306

Distinctive and artistic treatment

sheet. The treatment of the face of the envelop should be neat. It is not only in poor taste to cover the envelop with printing, but is against the post-office regulations. There are those who prefer to print the type matter on the flap of the envelop, and others who print the type matter in the usual corner and the trademark on the flap.

Example 305.-This is a specimen of a conventionally treated envelop corner in imitation steel-engraved lettering. The old-tashioned "After five days return to" as here used is not much in vogue, and printers would do well to omit it unless the customer insists upon its inclusion. This envelop corner is in the same style of typography as the letterhead that accompanied it.

LXample 306. - Artistic interest of a medieval character has been given this envelop corner by the use of Old-Style Antique, and especially by the decorative device in color. The desion of this envelop is distinctive, and mail from this source would easily be recognized after one or two letters had been received.

EXAMPLE 307.-Occasionally it is good policy to bring out the llame of the business in a prominent way, especially if it can be treated in a decorative letter such as the one used in this instance. Not every business will allow of such prominent treatment, and in this matter the printer needs to use judrment. The type has been aligned at the left.

Exhmple 308. - It is seldom that an envelop corner is treated so harmoniously and artistically as the one under consideration. The general charactcr of the decorative device is miatched by the style of the type-faces used. The squaring of the type group also adds shape harmony. This corner card, designed some years ago, is proof of the fact that good work is always good.

Example 309.-Seldom should an envelop corner card be as elaborate as this one, but when such an arrangement is allowable, as in this case, the design shown is worthy of consideration. The type-face is Caslon with Caslon Text, and the bands are made by using square ornaments with alternating blank space inside of rules.

978000000

ILOY $\mathrm{B} B \mathrm{CK}$

Tlorist

FIFTY-ONE GRANBYSTREET

OOC.
EXAMPLE 309

An elaborate envelop corner 



\section{The A. E. Pike Company}

Practical Tailors

Ladies' and Gentlemen's

Garments Made and Cared For

The non-stock-ruled type of billhead, with a panel in which name, date and other items are recorded. Showing use of roman lower-case

Both Telephones Number 193

THE JOS. BETZ PRINTING COMPANY High-Grade Catalog, Commercial and Process P R I N T E R S

SOLd TO EAST LiVERPOOL

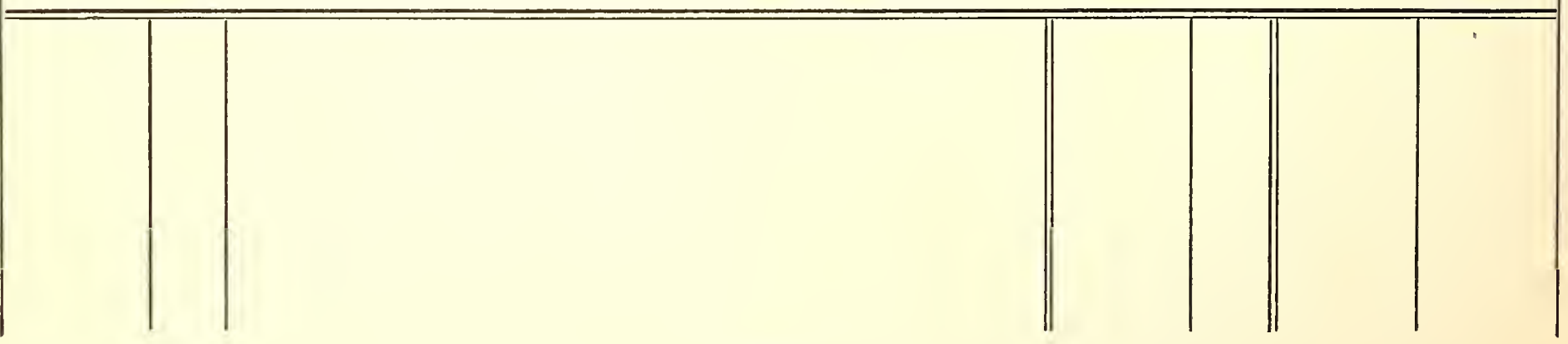




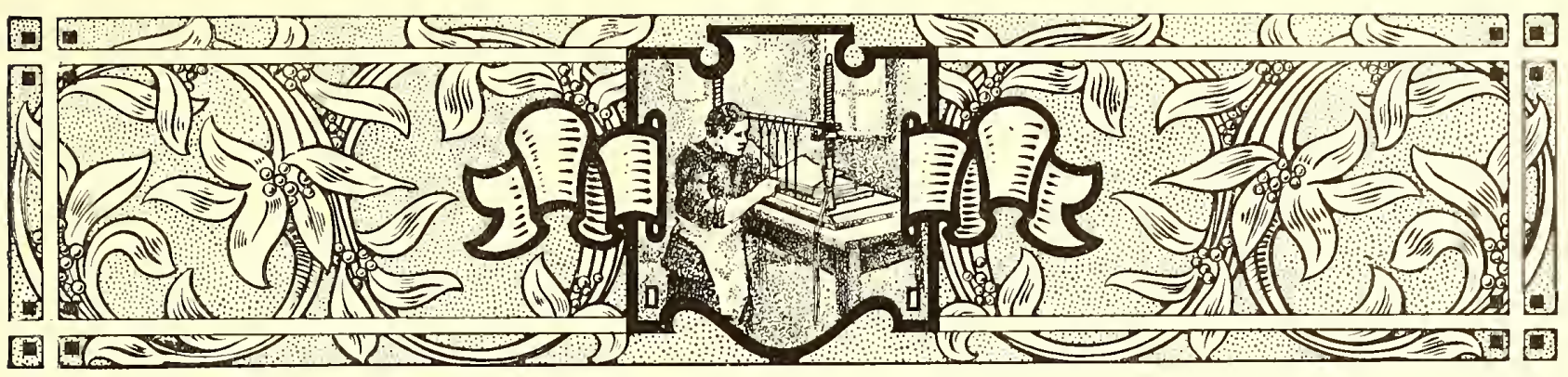

\section{BILLHEADS \& STATEMENTS}

THE printer called on to produce a billlead lias a responsibility seldom fully realized. He lias a duty to himself, to his customer and to those who come after, which is best carried out by suitable and dignified type composition. A business liouse has been known to use the same design of billhead for tifty years, and it is a fact that many merchants cannot be persuaded to change the style of the billhead, no matter how honely it may be.

Billheads and statements should correspond in style to that of letterheads and other forms of stationery, and in changing the design it must not be forgotten that these other forms should also be altered to harmonize. The paper slould be of the same finish and color, and the main features of type arrangement similar. The type-face must be the same on all.

The standard sizes of billheads for com mercial purposesare:

$81 / 2 \times 5 \%$ inches, 8 out of a sheet $17 \times 22$.

$8 \mathrm{~V} / 2 \times 7$ inches, 8 out of a sheet $17 \times 2 \mathrm{~s}$.

$81 / 2 \times 91 / 3$ inches, 6 out of a sheet $17 \times 28$.

$81 / 2 \times 14$ inches, 4 out of a sheet $17 \times 28$

Professional billheads are usually an inch or two smaller than thesmallestsize of commercial billheads.

There is a variety of sizes in statements. Popular sizes are those cut out of folio( $17 \times 22$ inches), which then measure $5 \frac{1}{2} \times 5 \frac{5}{8}$ inches, and $5 \frac{1}{2} \times 81 / 2$ inches.

Whether ruled or not, it is customary to allow about $23 / 4$ inches for the printed heading on both billhead and statement.
Because of the extensive use of "window" envelops, the heading should be so arranged that the name and address of customer can be placed in the lower left part of the billhead. The exact position can be ascertained by placing a billhead over such an envelop and jogging the two at the head and left side. When held to the light the opening in the face of the envelop can be traced on the billhead. The billhead is folded to fit the envelop and inserted so that the name and address can be seen.

Use of the typewriter and window envelopshasbrought a change in the arrangement of billheads, and printers, whenever they have opportunity, should alter the old billhead arrangement to conform to the new requirements.

Most billheads a quarter of a century ago contained in the upper right corner in script (usually) a date lime, and under it at the left was a dotted line beginning with a large script $M$. Immediately following came the firm name (usually rather large) flanked on the left by the word "To," and on the right by the abbreviation of debtor, "Dr." So the apprentice boy was taught, and he would then be further instructed to place the words "Dealers in" (or their equivalent) in small type, centered; then to display the words indicating the line of goods carried. In a small lineat the lower right corner was the street address, and aligned opposite were the mystic words "Terms Cish."
How a letterhead may be converted into a billhead. The upper portion is also shown as Example 283 in the chapter on letterheads 
F. A. SAUNDerson, Photographer, go Bromfield Stret, Boston, Massachuserts

In Account with

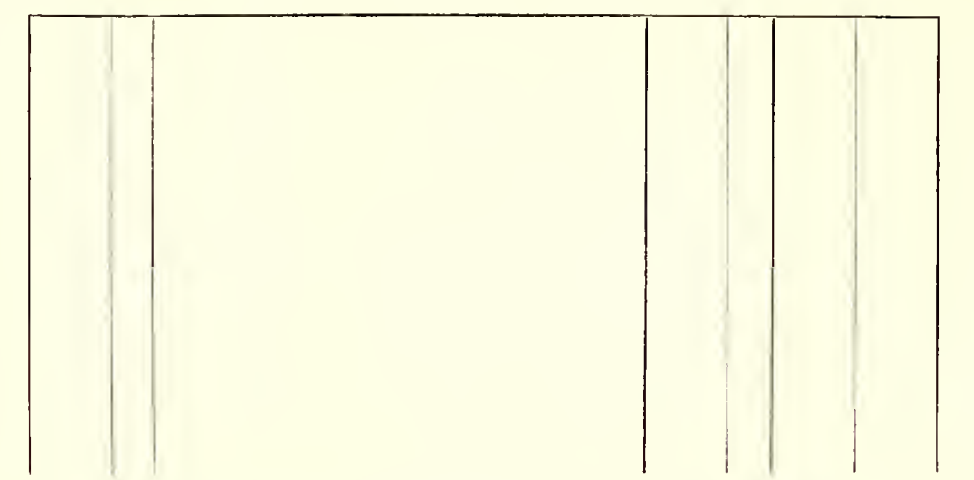

EXAMPLE 314

A billhead, or statement, in a classic non-display style of typography that suggests early printing. By D. B. Updike of sale which can be placed at the top of the heading with a rule underneath, altho they are sometimes arranged at the side or at the foot of the invoice. The name of the company is given most prominence, followed by mention of the commodity or product. The number, street and city naturally should be displayed so that the customer's location can be referred to quickly in correspondence. "Sold to" precedes the space left blank for the customer's name, and this, as has been explained, should be in the lower left corner. Blanks for the date, terms, invoice number, ledger number, customer's order number and other notations of record may be grouped in convenient open spaces.

Example 311.-The composition of a billhead really begins with the composition of a letterhead. It should be possible to take any letterhead and by adding a few lines convert it into a billhead. The specimen under consideration shows how this is done. The original of this billhead was exhibited as Example 283 in
Sometimes the words "Bought of" were substituted for "To" and "Dr." 'The older printers will remember the logotypes in various fancy designs of the phrase "Bought of" that the typefounders furnished in those days, which logotypes were set against type lines of double great primer caps. Now "Bought of" has been supplanted on billheads by "Sold to," which directs attention to the fact that John Smith has sold goods to 'Thomas Brown, rather than that Thomas Brown has bought goods of John Smith-a distinction without a differenee, one might say, yet there is interest in noting the change.

The propable reason for the "NI" being discarded in recent years on commercial billheads is that many business houses are now corporations, which fact makes "Mr." and "Messrs." no longer suitable as forms of address.

Example 310.-This specimen presents the main features of the average commercial inroice, or billhead. Usually there are conditions

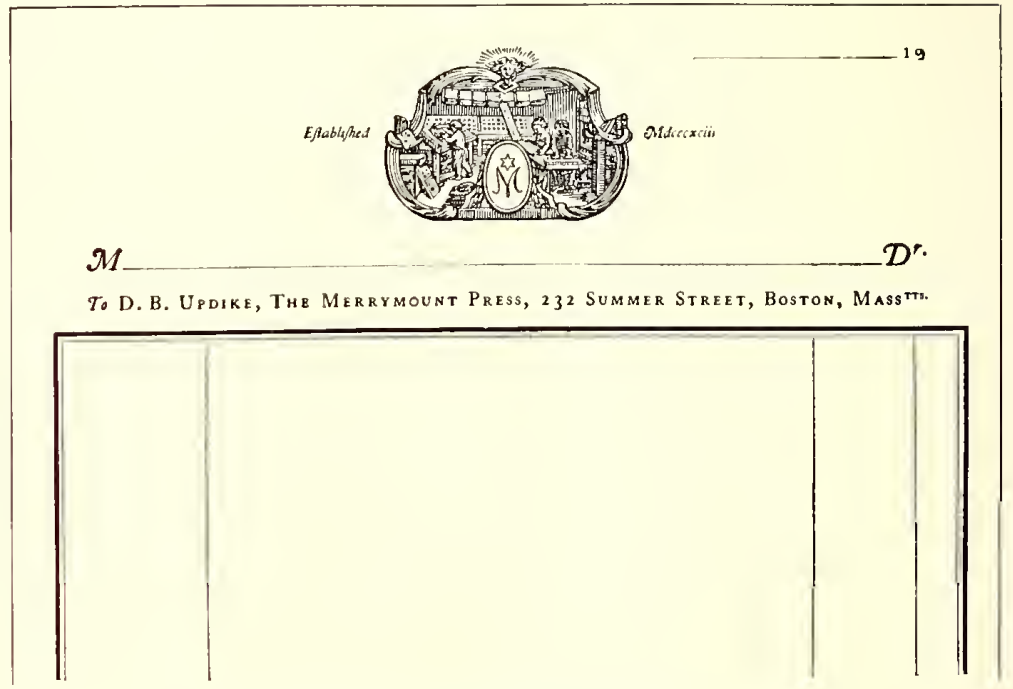

EXAMPLE 315

Typographic art and good taste, as demonstrated by this specimen, have a place on billheads as well as on books

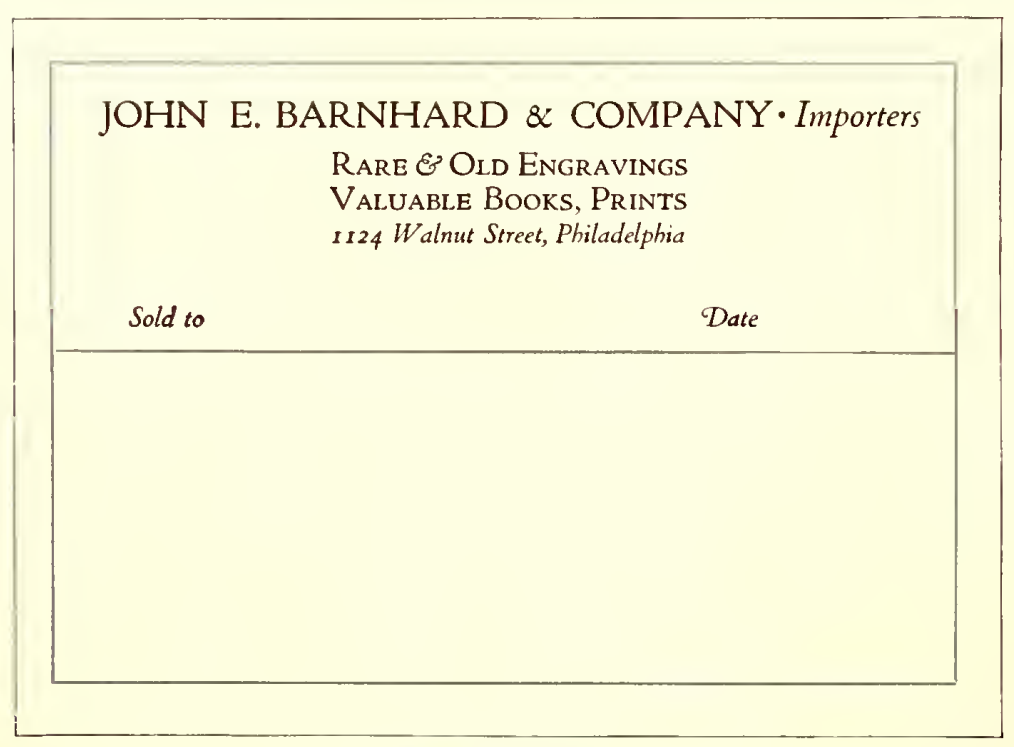

EXAMPLE 316

A suitable billhead with interesting border treatment. No guide lines have been used the preceding chapter. The conventional phrase "Sold to" is placed in its customary position and the other phrases added at suitable spots. Printers should keep this suggestion in mind and, when laying out a billhead, design the upper part as they would a letterhead.

Example 312 (Insert).-This is an interesting representative of the non-stock-ruled heading, and it also illustrates the changes the typewriter has wrought in billhead printing. When bills were written in by hand, script type and dotted rule prevailed, but because of the use of typewriters, script and horizontal guide lines are gradually disappearing from the face of billheads. The example under consideration also demonstrates the effectiveness of Caslon lower-case for billhead purposes. When every line is in roman lower-case there is harmony, but sometimes there is also monotony. In this instance, however, the introduction of italic and small caps would alter the plan of the heading and detract from its distinction. The rule border and the panel for the insertion of customer's name and address give distinction: 
Example 313 (Insert).-There is here another demonstration of the transformation of a letterhead into a billhead. Remove the words "Sold to" and the ruling at the foot and the form is ready for the letter sheet. Kennerley type, altho primarily a book face, is also usable on stationery where neat, distinctive effects are desired. Capitals arc spaced (as in the old books of Aldus), and italic is used with the capital lines, this use of italic also being suggested by the work of the Aldine Press. However, the specimen is not intended to be in the classic spirit of Aldus; it is mercly a modern commer cial suggestion.

Example 314 - - Here is a billhead, or sta'ement, in classic typography that suggests the style of the fifteenth century. The heading is practically in one size of type. Advertising distinction is obtained by using capitals for the name, capitals and small capitals for the business name and address, and italic for "In account with." There is not much that is striking about this billhead, yet, printed on a fine qual-

\section{THE IKENDALL PRINTING HOUSE RRLL PHONB HIGH-GRADE PRINTING ENGRAVING-STATIONERY}

[102 WEST ONTARIO STREET

Sold to PHILADELPHIA

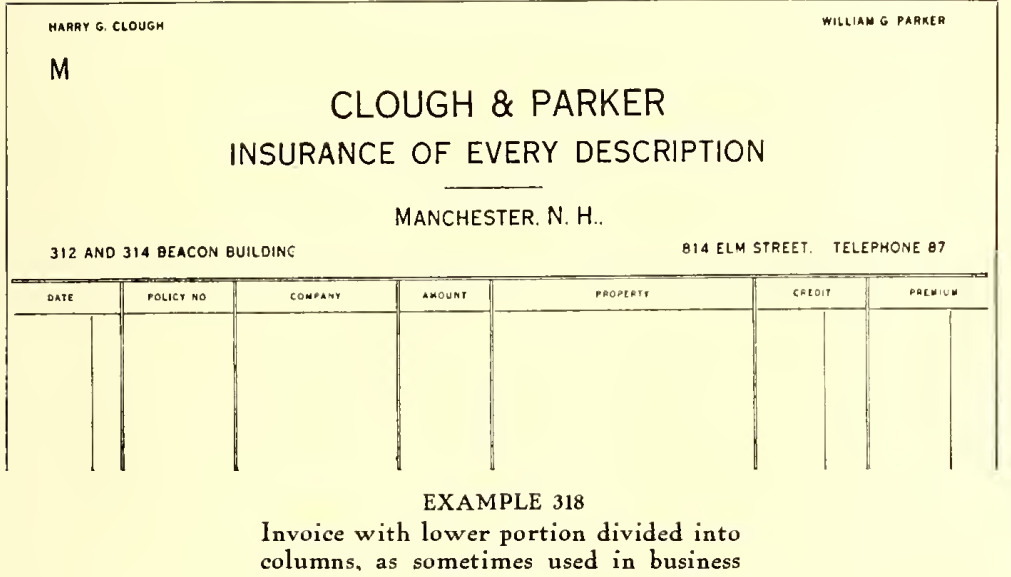

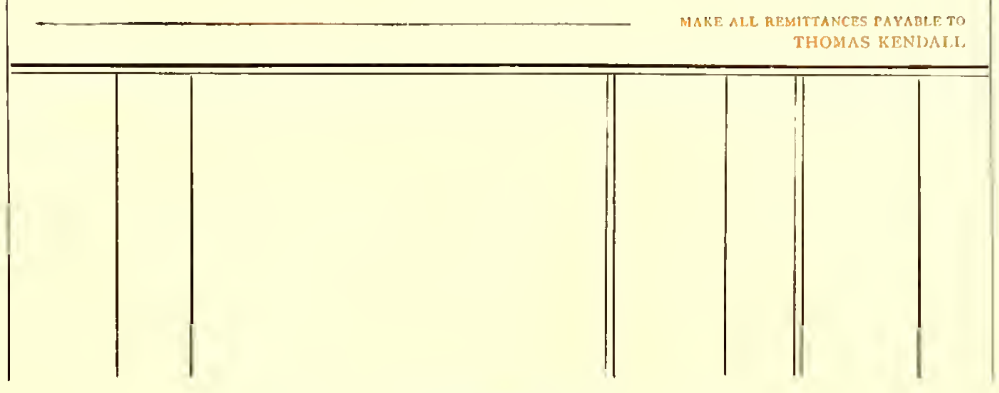

EXAMPLE 317

Large treatment that would look well in harmonious colors on colored paper ity of writing paper, it would make one really glad to receive a bill of this kind.

Example 315.-D. B. Updike makes plain by this specimen, as well as by the preceding one, that typographic art and good taste can be used in the designing of a billhead as well as in the designing of a book. The woodeut device has the same good quality as the typography. The old-fashioned "M" and "Dr." are used, and blend well with the old dignity of the heading. The ruling on the lower part of both of these headings was printed from rules. There are other good printers who prefer brass rule to the ruling machine for billhead purposes. Machine ruling is convenient, but is not in good taste for billheads, statements and letterheads of really fine quality.

Example 316. - The stationery of a book dealer slould have a bookish character-that is, the typography should be inspired by the same skill and taste evinecd in the treatment of a good book. A well-designed type-face should be selected, and there should not be a great contrast in the sizes used. When it is possible to have two printings, the extra impression could take the form of a simple rule border in color, as on this specimen. The first type line runs almost from border to border at the head, and another portion of the copy is arranged directly under it in three even lines. The "Sold to" occupies its approved position. No guide lines are provided for the accountant's part of the bill, as with a typewriter the various items can better be filled in without them, and a billhead really looks neater without the rules.
Example 317.-For printing on colored stock strong treatment is sometimes advisable - treatment such as has been given this heading. On white paper the type sizes should be kept small, as the light background illuminates the print. White and black form the greatest eontrast. There is not much contrast between blue ink and blue paper, for instance, and it is necessary to strengthen the print by the use of a larger or bolder type-face. The arrangement shown is unconventional. A full line has been made of the business title, the name itself being slightly emphasized by printing it in color and giving an initial eff ect to the first letter. Other parts of the copy are grouped at suitable points, "Sold to" occupying the usual lower left corner.

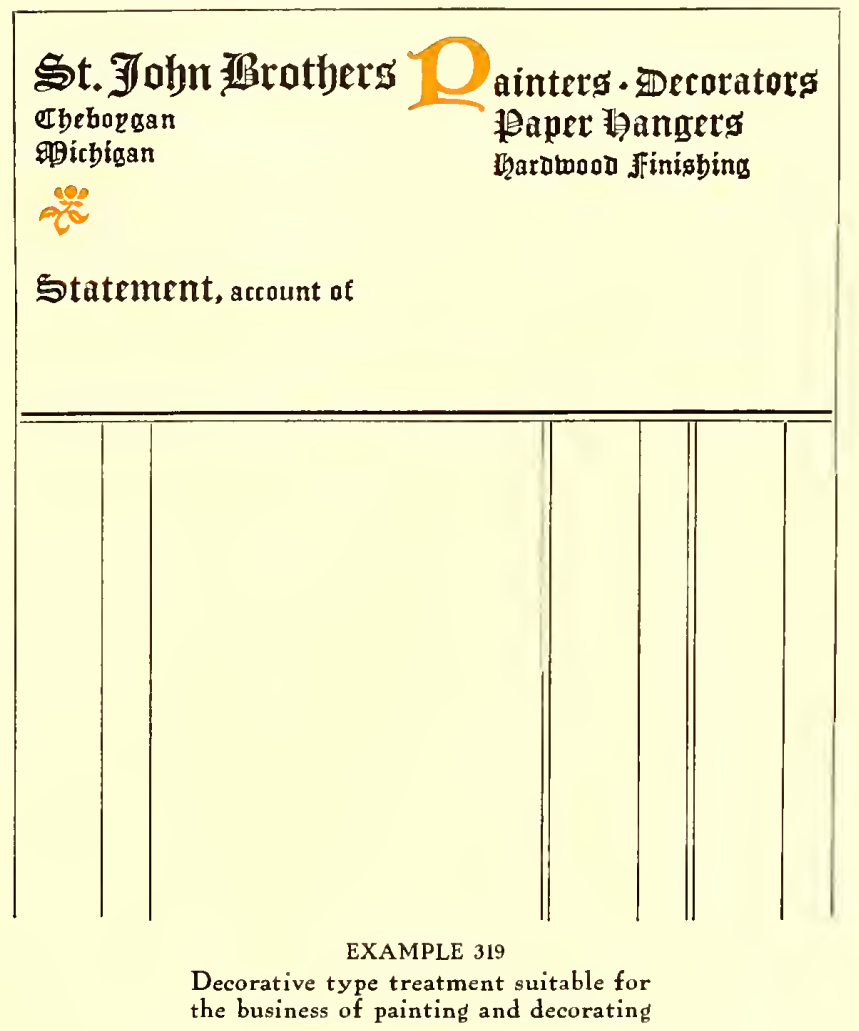




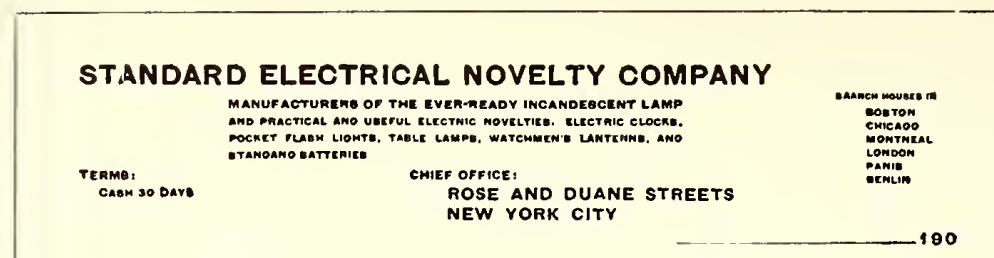

SOLD TO

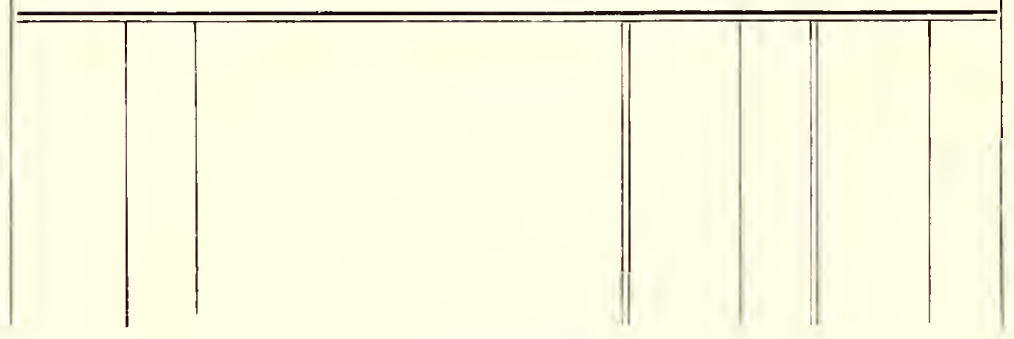

EXAMPLE 320

An uncommon arrangement. The main type line tells the story, as the company's title describes the business

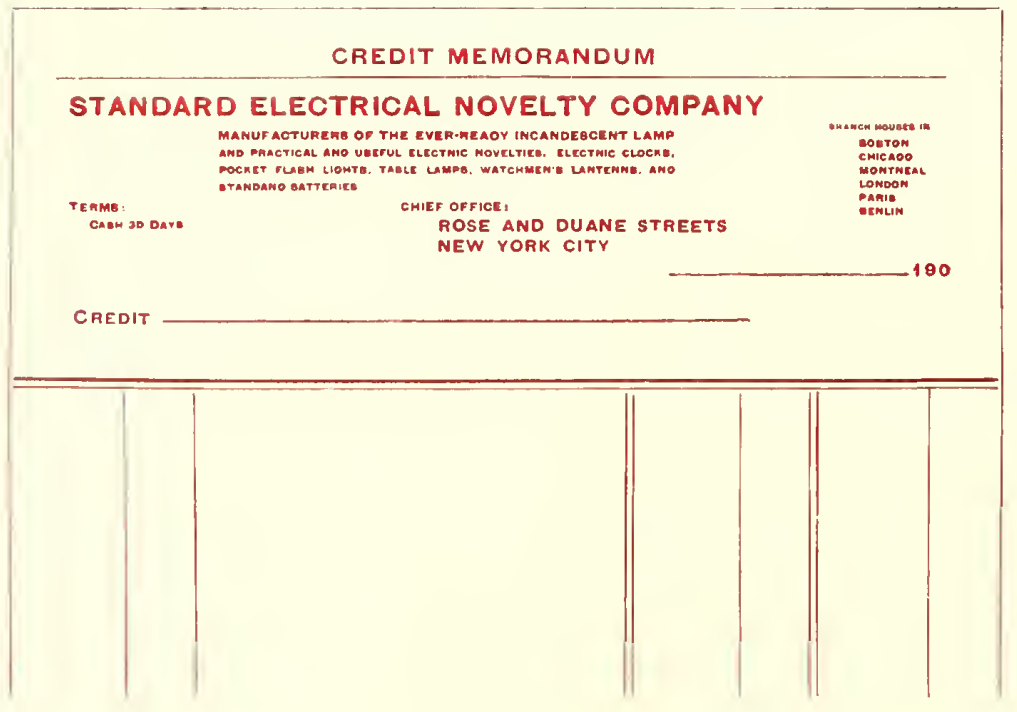

EXAMPLE 321

Credit bill made from the preceding billhead by adding a line at the head and changing "Sold to" to "Credit" this arrangement could be carried out in some other type-face, the serifless "block" letter as here used is not displeasing. The grouping of the branch houses is good, and other groups are also well placed.

Example 321.-Most business houses find need for credit bills, to be used when goods are returned or some error has been made in billing. Such forms are easily provided by using the billhead, adding the words "Credit Memorandum" at the head and changing "Sold to" to "Credit." In order that credit bills may look unlike regular bills, they should be printed in color as is here shown.

ExaMPLE 322.-All professional stationery should be refined. The sizes of paper and type should be small and the whole effect restrained and polite. Such work seldom changes in style, and consequently there is little variety. The form shown here would probably prove acceptable for many years to men of the medical and similar professions.

It may not be out of place to remind the reader that an invoice (or bill) is a list sent to a purchaser or consignee, containing the items and charges of merchandise that have been forwarded to him.

As to the statement: It is a common practice to send each customer at the first of the month a statement showing the debit balance of his account to date, whether it is due or not, enabling him to compare the statement with the ledger account. In order to call the attention of customers to the fact that payment is desired. many business houses send a statement whenever a bill is due (when goods are purchased on January 10 , as an instance, at ten days, a statement is sent January 20).

There are numerous other forms used in business, such as checks, deposit slips, drafts, promissory notes, bills of lading and the like, but there is not space to show them here.

Such forms, if possible, should be in harmony with the style of the letterheads, billheads and other stationery. The same type-face should be used and the arrangement of display parts should have similarity.
ExAMPLE 318.- Many invoices and billheads now have the lower part divided into columns for taking care of the various itcms peculiar to the business, as in this instance. The customer usually decides when he wishes to depart from the conventional ruled effect, and it is just as well for the printer not to suggest a change of this sort, as it means extra composition for which the customer may be disinclined to pay. The type-face on this well-arranged example is a good one for plain conmercial headings. It would be well, for convenience, to place the " $\mathrm{I}$ " in the lower left corner and move the building address to the right corner, over the street address.

Example 319.-A decorator's stationcry seems to offer opportunity for effects away from the customary plain treatment of the average heading. This statement, in the same style as a letterhead that accompanied it, shows a decorative type-face and an arrangement that could possibly be called decorative. The upper two type groups are joined by the uncial initial, and the two groups at the left are connected by the flower ornament.

EXAMPLE 320.-This is an unusual arrangement for a billhead. As the business is stated in the firm name, there is not the usual necessity for a second display line. While

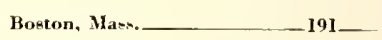

$M$

To JAMES DEWITT WOLFE, M.D., Ir.

For Professional Services

EXAMPLE 322

On professional bills the paper and type should be small and the treatment restrained and polite 


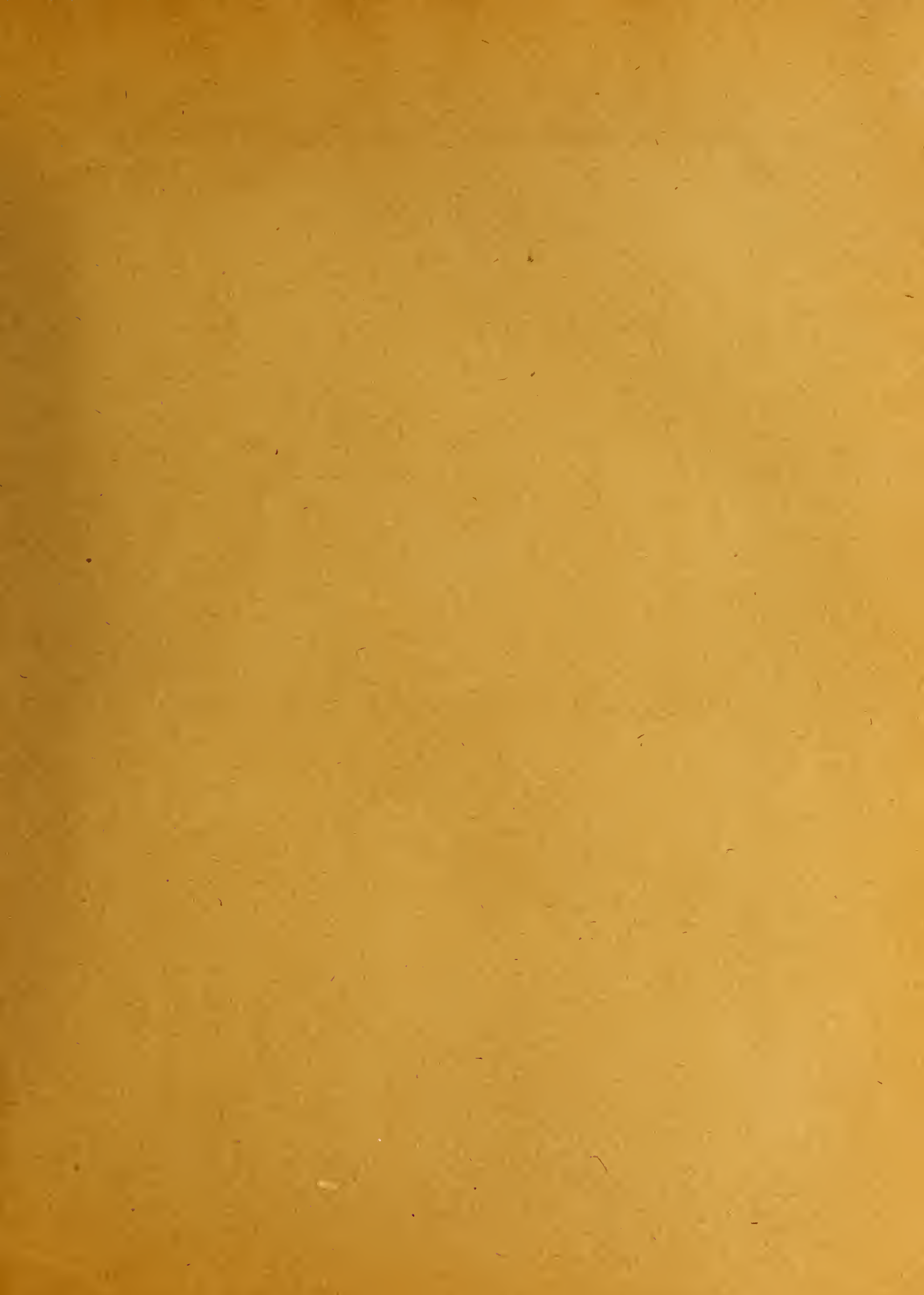




\section{HEAVY EFFECTS LABELS 416 BLACK AVENUE·REDINGTON·COLO}

EXAMPLE 323

A label that catches the attention at a distance and looks well on the background of wrapping paper

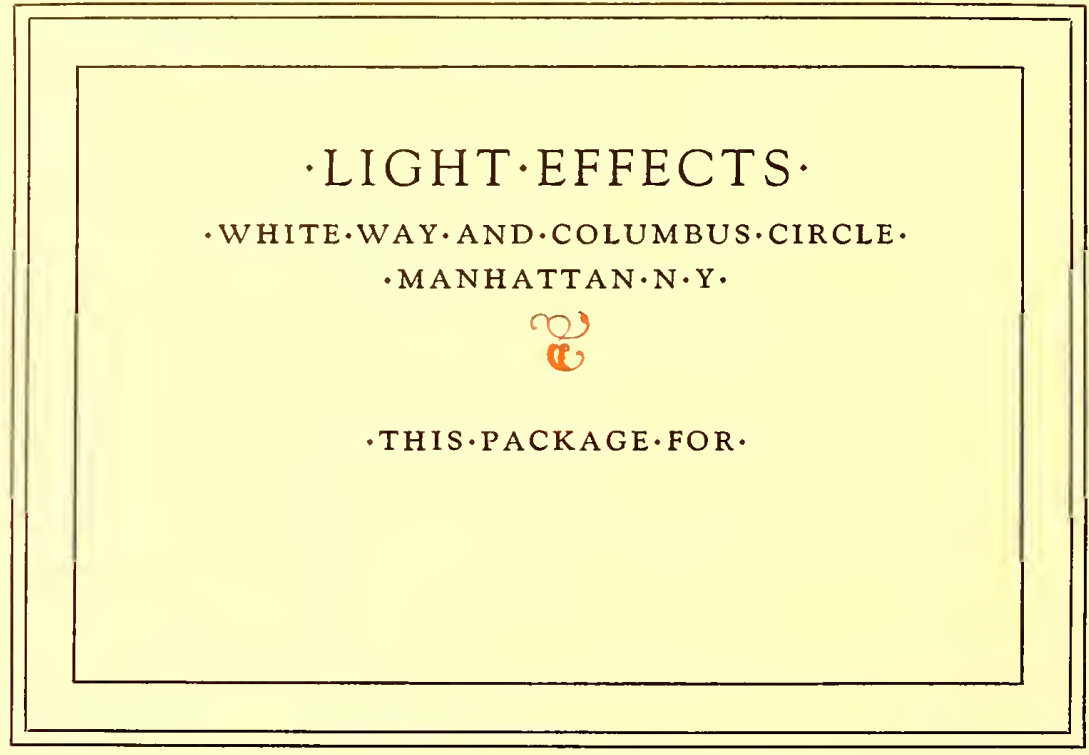

EXAMPLE 324

A label of classic simplicity for small packages and a business that emphasizes daintiness and delicacy 


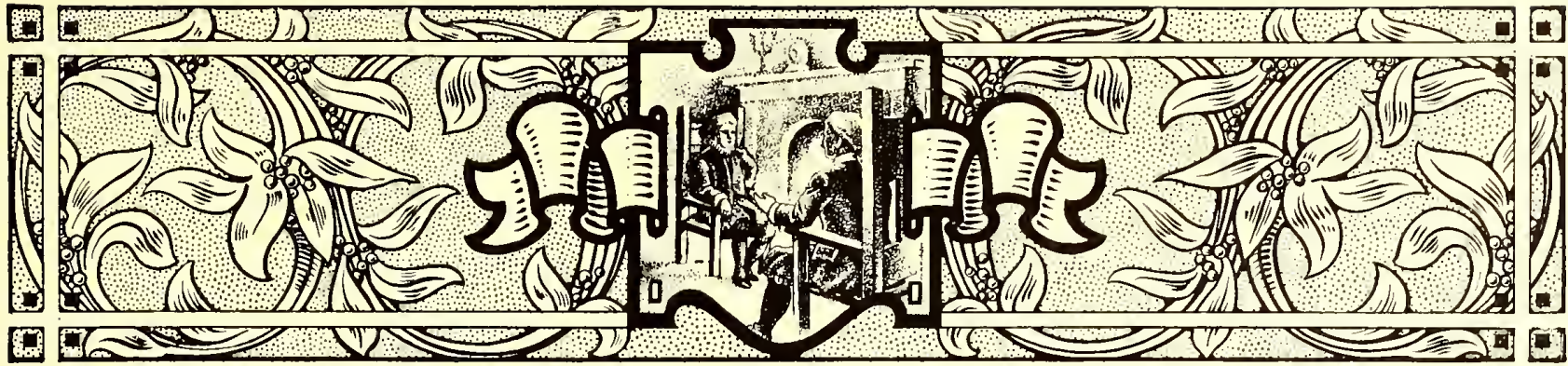

\section{PACKAGE LABELS}

THE effect of an attractive package is recognized to be of such importance that a widely known manufacturing concern recently sued a competitor for imitating the appearance of its packages and labels. However, not all business men feel this way about it.

After spending time and money in the production of merchandise of high quality, it is more than foolish to economize on the packing.

It is possible, with goodclothes wellselected, tomake an unattractive person attractive, and it is also possible to make an attractive person unattractive by poor clothes ill selected. Apply this.

The wrapping paper should be strong, and of color and finish suited to the article to be wrapped. Some stylish city dry-goods houses use paper with distinctive stripes or small monograms printed over its surface. A well-known haberdasher wraps his hats in soft black paper.

The selection of the wrapping stock should of course be governed by the character of the business and the class of customers, but as in similar instances, it is dangerous to underestimate the taste of one's customers. The persons who lack appreciation of a neatly wrapped and attrac. tive package are very few indeed.

Among merchants, druggists are known to wrap the neatest packages. This seems to be due in partto theirprofessional training. Not many printers give their product a similar attractiveness at the time of delivery.

The art of making

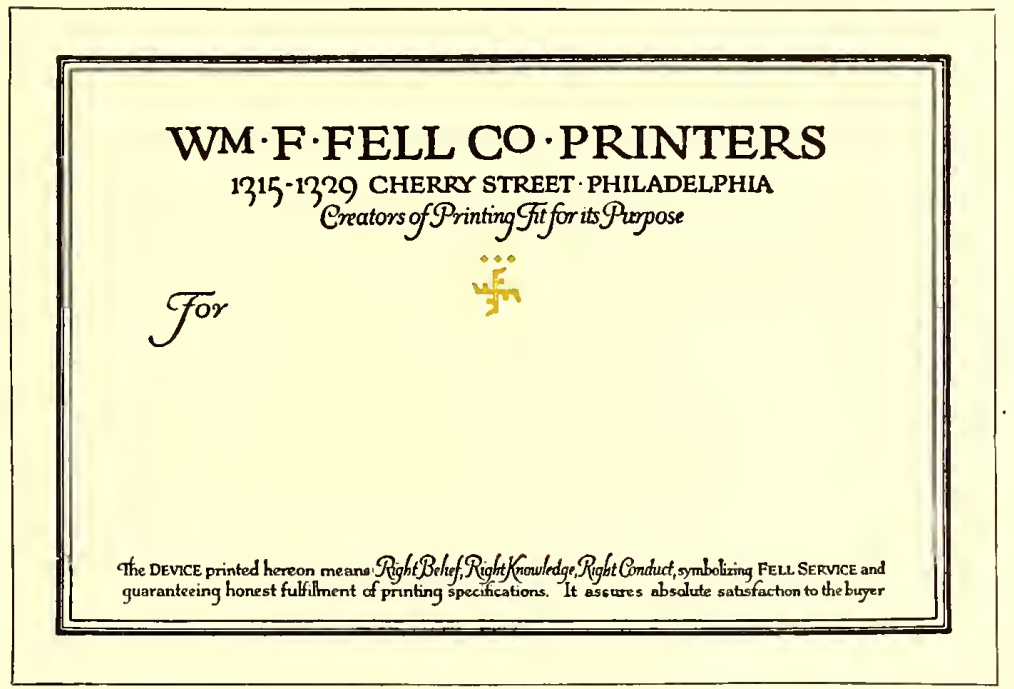

EXAMPLE 325

A hand-lettered design for typographic study

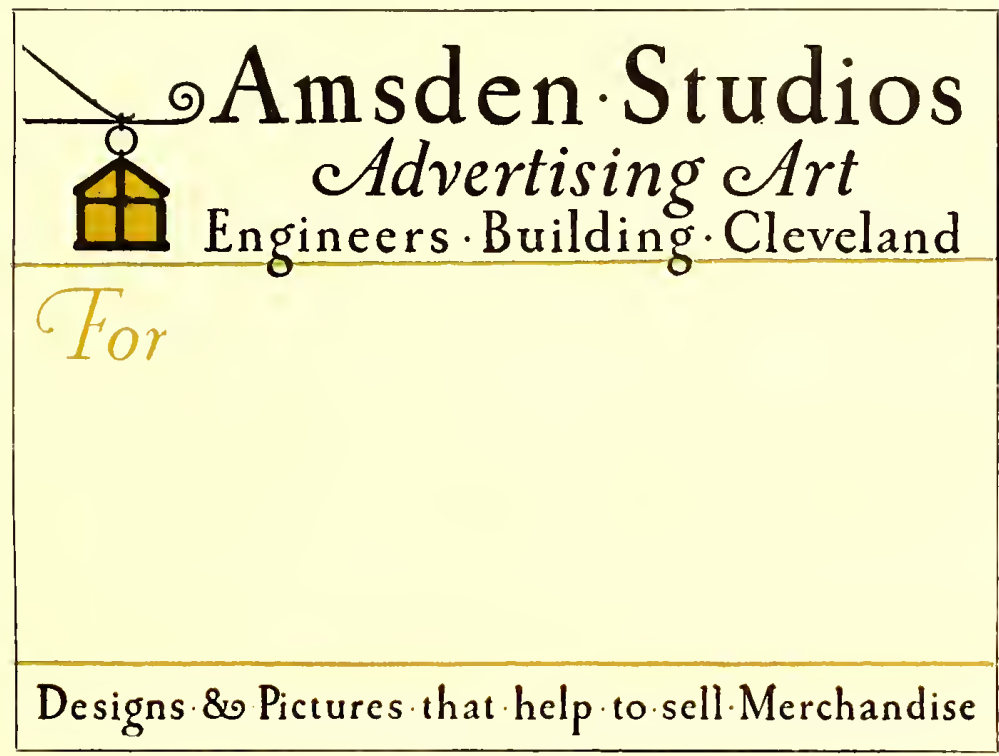

EXAMPLE 326

Another label rich in suggestion per. Cord and twine are commonly used, and interest is sometimes added by selecting appropriate colors. Linen ape for a business of an exclusive nature gives distinction.

Gummed-paper tape, while convenient, seldom looks ell, and when printed on looks worse.

Corrugated board when properly used adds both neatness and protection to the package. Some printers have cartons made from this board, in which their product is packed and delivered.

The printed label is of the most interest, as it affords a spot of attraction and furnishes information needed in the delivery of packages. All labels should be planned with the wrapping paper as a background. A label may look well alone, yet when placed on the package may appear weak and uninteresting.

In order to test this, two labels of contrasting treatment are pictured mounted on a sheet of conventional wrapping paper.

It will be admitted that the stronger label is more striking and catches tlie attention. There are tlose who will prefer the weaker label because of its neatness and beauty, yet we must not lose sight of the fact that labels, unlike business cards and letterheads, are not usually seen at close range when on packages. A business card is examined a few inches from the eyes, whilea label on a package is frequentlyview ed from a point sev eral feet away. 


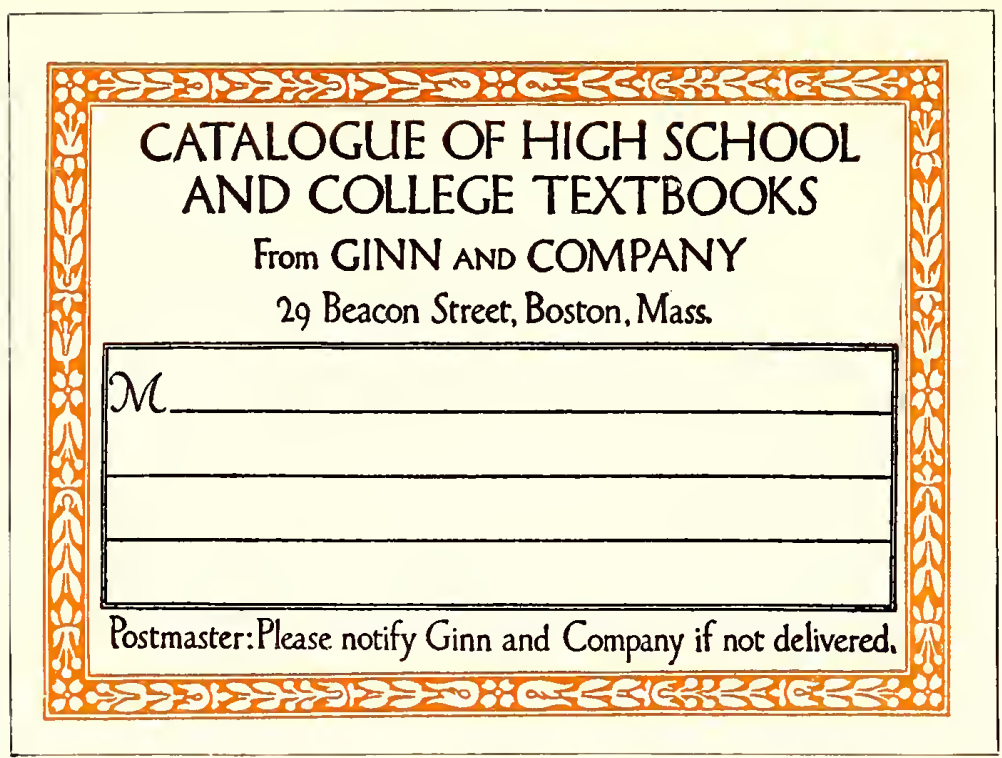

EXAMPLE 327

Ruled lines for the address, in panel

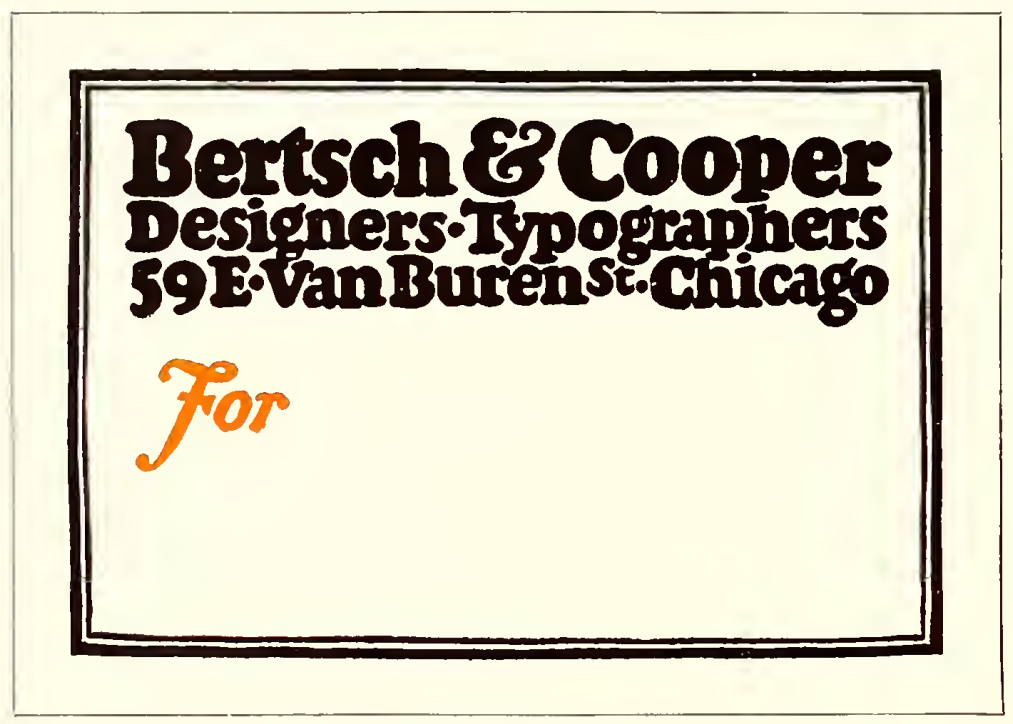

EXAMPLE 328

A mass of black lettering with contrasts

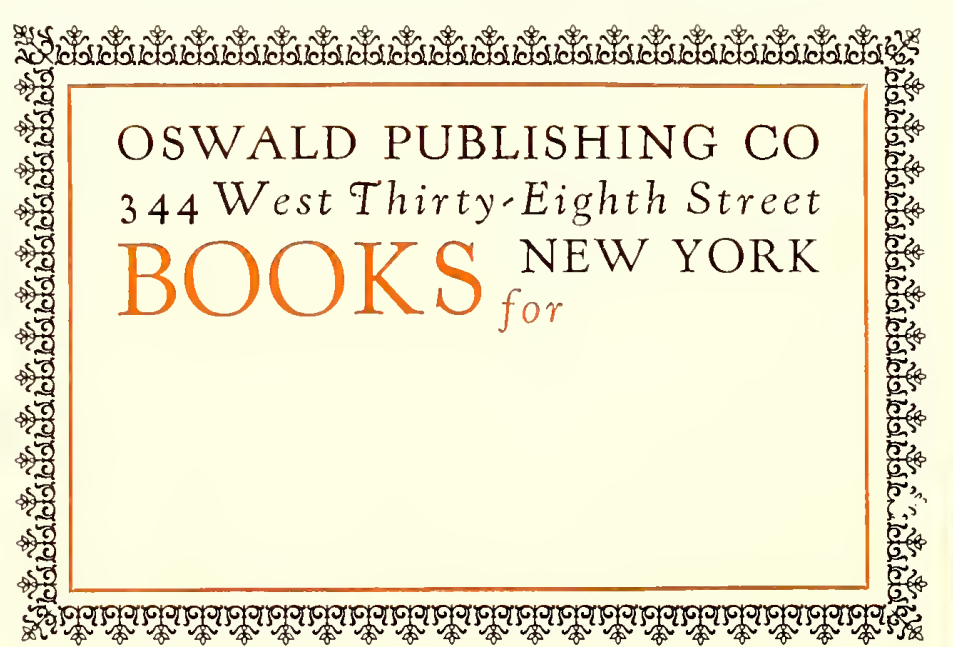

EXAMPLE 329

Artistic quality and interest through typography
There does not seem to be any standard size for labels. They vary from four, five and six inches wide to three, four and five inches high. When The American Printer conducted a label competition it specified the size as five by four inches, and this seems to be a good average size.

The paper on which the label is printed should be stock that pastes easily. White is used to the greatest extent, altho a creamtinted color such as comes in Japan vellum is preferred by some persons of good taste.

Example 323 (Insert).-As has been said, this label shows the effectiveness of heavy effects. A design such as this has advertising value. It can be seen and read at some distance, vet is not offensive in appearance. The red border is attractive, and merges the label with the wrapping background. The type-face has decorative quality. The combination of black, red and cream in strong contrasts is worthy of study. As will be noticed, all capitals have been used, and there is not much space between the lines or between border and type-face.

Example 324 (Insert).-For small packages and for a business that places emphasis on daintiness this label treatment would be just the thing. The classic simplicity of its design and the mere touch of color should appeal to many. The main line is set in fourteen-point capitals and the other three lines in twelvepoint small capitals. Letterspacing adds decorative interest and merges the letters with the background by allowing the paper to show thru. The type-face is Goudy Oldstyle. The dots between the words arc hyphens slightly eut. The border is arranged to suggest an architectural panel. This label and the preceding one have been composed merely to suggest possible effects. It would not be difficult to adapt most label copy to the styles shown.

ExAMPLE 325.-This and other hand-lettered labels included in this chapter are presented as studies for the typographer. Hand-lettered designs by good artists are usually arranged with much thought, and the details give many ideas to those who have trained themselves to grasp them. It will be noticed that the border of this label is composed of three lines, a heavy and light line close together and a light line a trifle rcmoved. At the head are two lines of roman capitals and one of italic. Do not overlook the smaller capitals " $\mathrm{s}$ " and "o," and the close spacing of the words in italic. The device is small and in color. The use of roman lowercase, capitals and small capitals and italic in the lower group should be examined carefully. While it is not possible to obtain exactly these same results with type, they can be approximated effectually. It is well, however, to emphasize at this point that in approximating the effects of any good piece of lettering it makes a difference what type-face is used. It will be noticed that the italic capitals in this specimen have a decorative quality. Such an effect can be imitated in a small way by the use of the swash letters that are furnished with some oldstyle italics.

Example 326.-This is another lettered design that is rich in suggestion. No border is used, and the lettering is arranged close to the 
edges of the paper. Contrary to the treatment of the preceding example, the lettering is all slightly spaced. While it is well for the young compositor not to letterspace lower-case, such practice is allowable when the results are good. The effect here is onc of antiquity, espccially since the letters are not perfectly formed (note the " $m$ " in the word "Amsden"). Caslon Oldstyle should be used in planning this style of work. An unusual feature is that a part of the copy is placed at the foot of the labcl so that the address is written between two groups of lettering. The same plan is found in the preceding example.

ExAMpLE 327.- There is suggestion of Italian art in this labcl. Similar effects could bc closely approximated with typefounders' material. Attention is called to the manner in which the letters are treatcd so as to avoid an excess of blank space in such groups as the "ATA" in "catalogue." Rule guide lines in a panel are provided for the address. This space is usually left blank on modern labels, altho conservative houses are inclined to retain the rules. In line with old ideas, the " $M$ " is included in the address portion. This letter is usually omitted on labels for the same reason that it is left off of billheads.

ExaMPLE 328.-Closely spaced black-toned lettering is still liked by some persons, and there is no use denying that when it is well rendered the effect is pleasing. This example presents a mass of black lettering in three lines of equal length, the lines merging with one another to preserve the mass effect. The border, formed of a heavy and a lighter line, is drawn with human irregularity that is in keeping with the character of the design as a whole. The "For" in italic affords contrast in both form and color. Also note the treatment of "St.," which is made small and placed in a position above the base of the other letters. This treatment is typical of antique typography.

ExAMPLE 329.-That artistic quality and interest may be put in a label form by means of typography is proved by this example. The lacelike border, the spaced Kennerley types and the words and rule in red blend attractively. Advertising value is present, yet it is so merged with the general composition and the label that it is not offensive. In fact, it adds decorative qualities. This label form would look well clearly printed on a rough-finished paper of good quality - a handmade paper if possible.

Example 330.-Another typographic label of character, a study in black and white. The border (a combination of a heavy and a light rule) was made intensely black to contrast with the white background, an effect as of color. A type-face (Bodoni Bold) with similar strong contrasts was then sclected, arranged with liberal margins in the upper part. A suitable ornament in dark tones added the picture elcment, and the words "Deliver to" were widely letterspaced, as they were used decoratively. This and the other typographic specimens indicate the possibilities that are present in the everyday tools of the printer and the material that is available. Many printers feel that they are not able to producc typographic

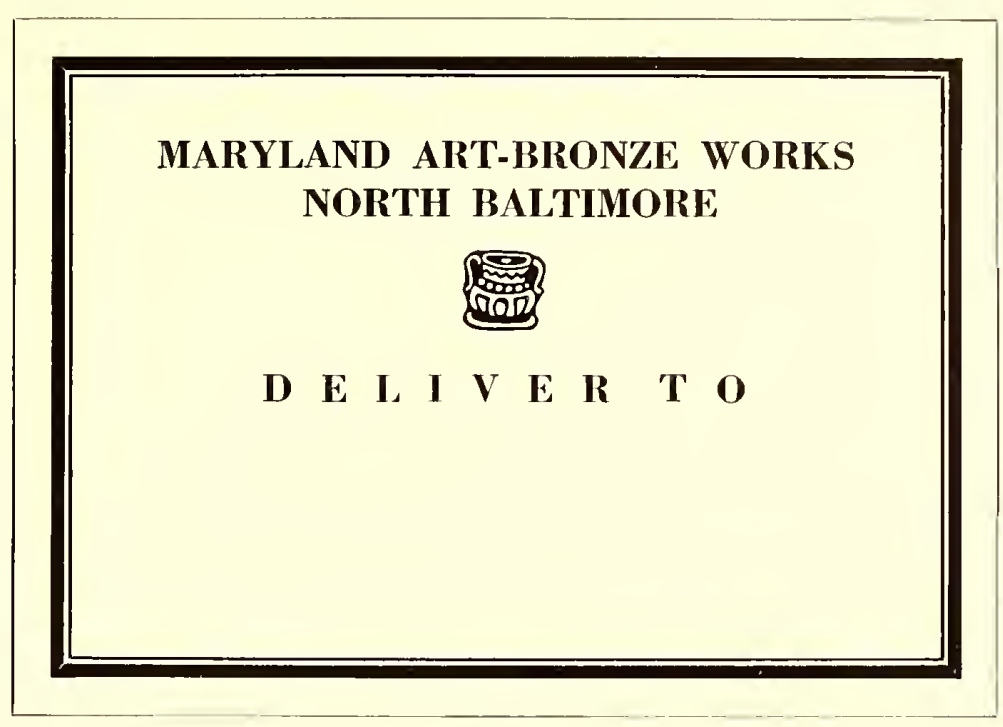

EXAMPLE 330

A typographic study in black and white

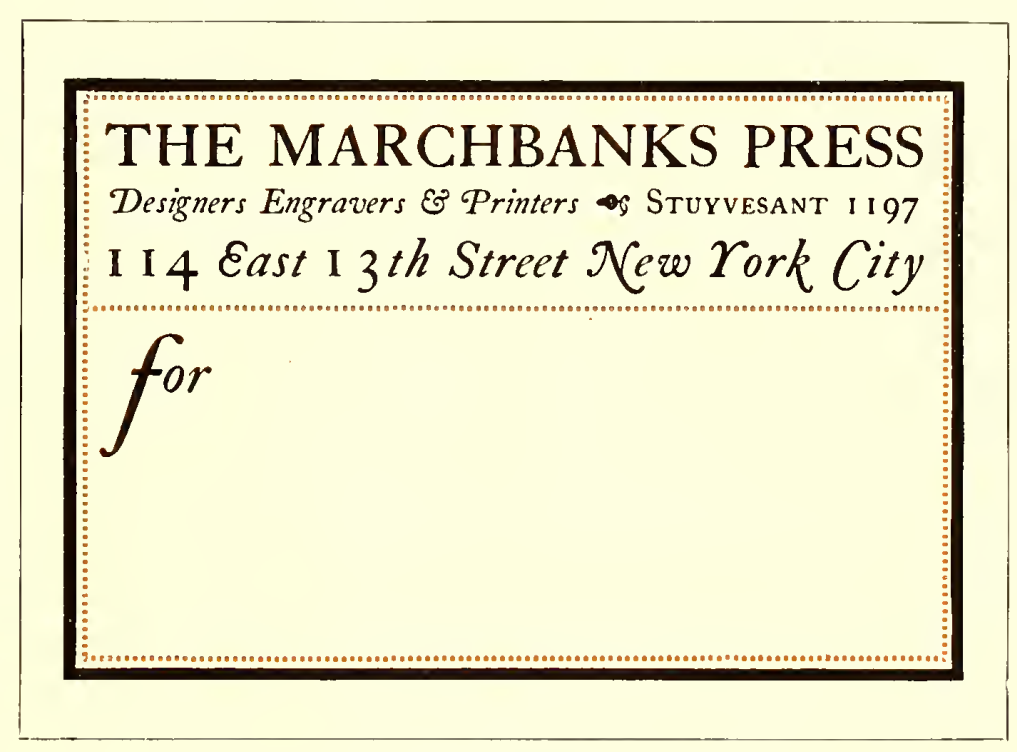

EXAMPLE 331

A Caslon specimen, with decorative interest

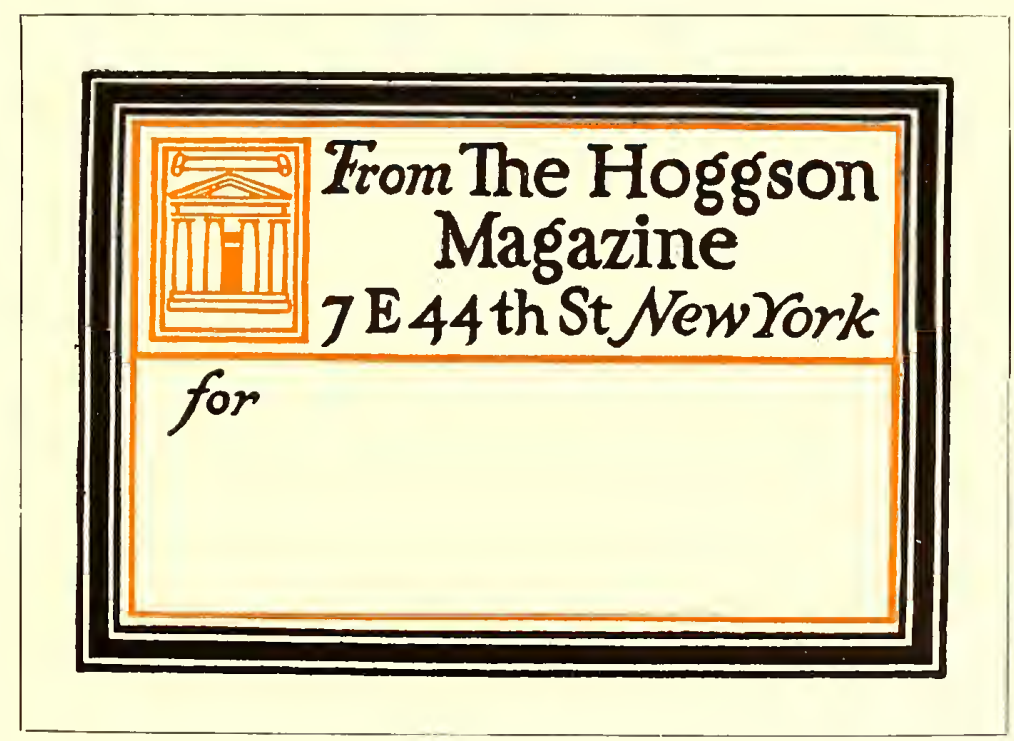

EXAMPLE 332

Harmony of border, decorative device and lettering 


\section{Publixhres Printma

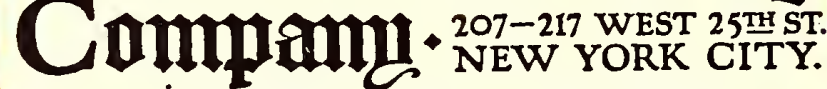 Designers, Engravers and Printers of high-grade illustrated catalogs.}

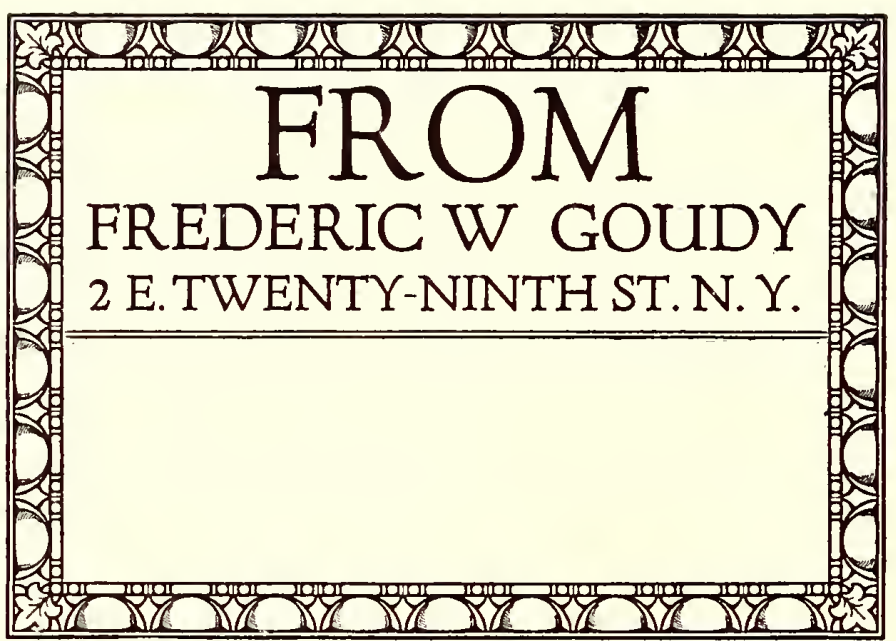

EXAMPLE 334

Freedom of treatment that is distinctive

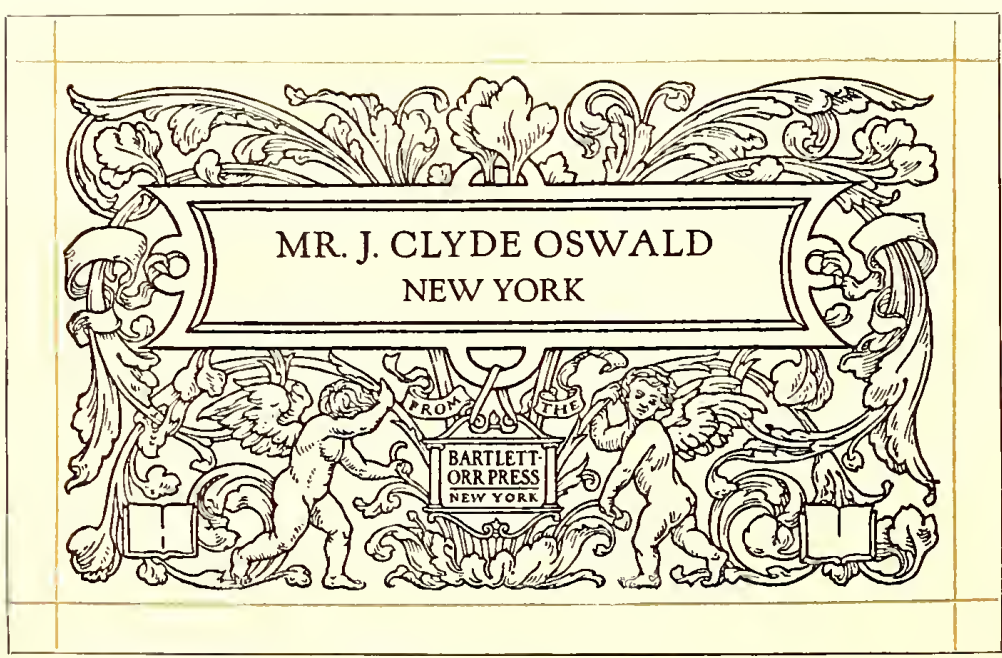

EXAMPLE 335

Label used for a special list work of real quality, assuming that special equipment is necded. The truth is that many are not able to produce good printing because their type equipment and decorative material have not been well selected. The fact that there is a lack of suitable type-faces usually reveals itself to them after they have learned that one type-facc is not so good as another. In the finished work there is nothing seen of the presses, of the imposing stones, or of the composing frames, but the print of the type-face is on every sheet.

Example 331.-A specimen in Caslon, in which roman capitals and italic lower-case (the Aldine combination) make up an interesting label. 'The swash italic capitals add a specific decorative quality. 'The large lowercase "f" gives a graceful touch to the "for." Dotted rule inside the black border is a change from the conventional continuous line. 'This form was printed on Japan vellum.

ExAMPLE 332.-This is another hand-drawn label with qualities that can be approximated in typography. Border, decorative device and lettering are in the same key, and the harmony is agreeable. There are those who thoughtlessly condemn black borders as funereal, a judgment that is based on prejudice and not on an understanding of their usc. It is well, however, to caution the young compositor against abuse of the black border; it would be well if he were to use no black borders until he had developed taste in the practice of typography.

Example 333. - An unusual label design that could probably be improved with careful typography. 'The initials of the text lettering are not exactly harmonious, and the space between words in the lower group is excessive. Printer's should practice on the improvement of the design.

Example 334.-A characteristic Goudy type arrangement, with a freedom of treatment that is distinctive. How many printers would give the prominence to "Froin" that it has here? This suggests the custom of printers of the sixteenth century in starting a title-page with a large size of type regardless of the importance of the word or words.

Exanple 335.- This label was used in mailing to a special list some fine pieces of printing. 'The name of each addressee was printed in with type as shown by the reproduction, and, needless to state, attracted attention. 'The treatment of this label is uncommon in another respcet-the modest inconspicuousness of the phrase, "From the Bartlett-Orr Press, New York."

It would do no harm if printers also studied the stock labels manufactured by certain stationery houses. They will find much that is poor and commonplace and little that should be directly copied, but there are many suggestions in label making that could be adapted. The "reverse-plate" idea is one. The label is set in type and a proof sent to the photo-engraver, who makes a plate in which the letters show white and the background black. This plate can then be printed in color on gummed paper and the paper trimmed so as to "bleed" the edges of the printed background. 


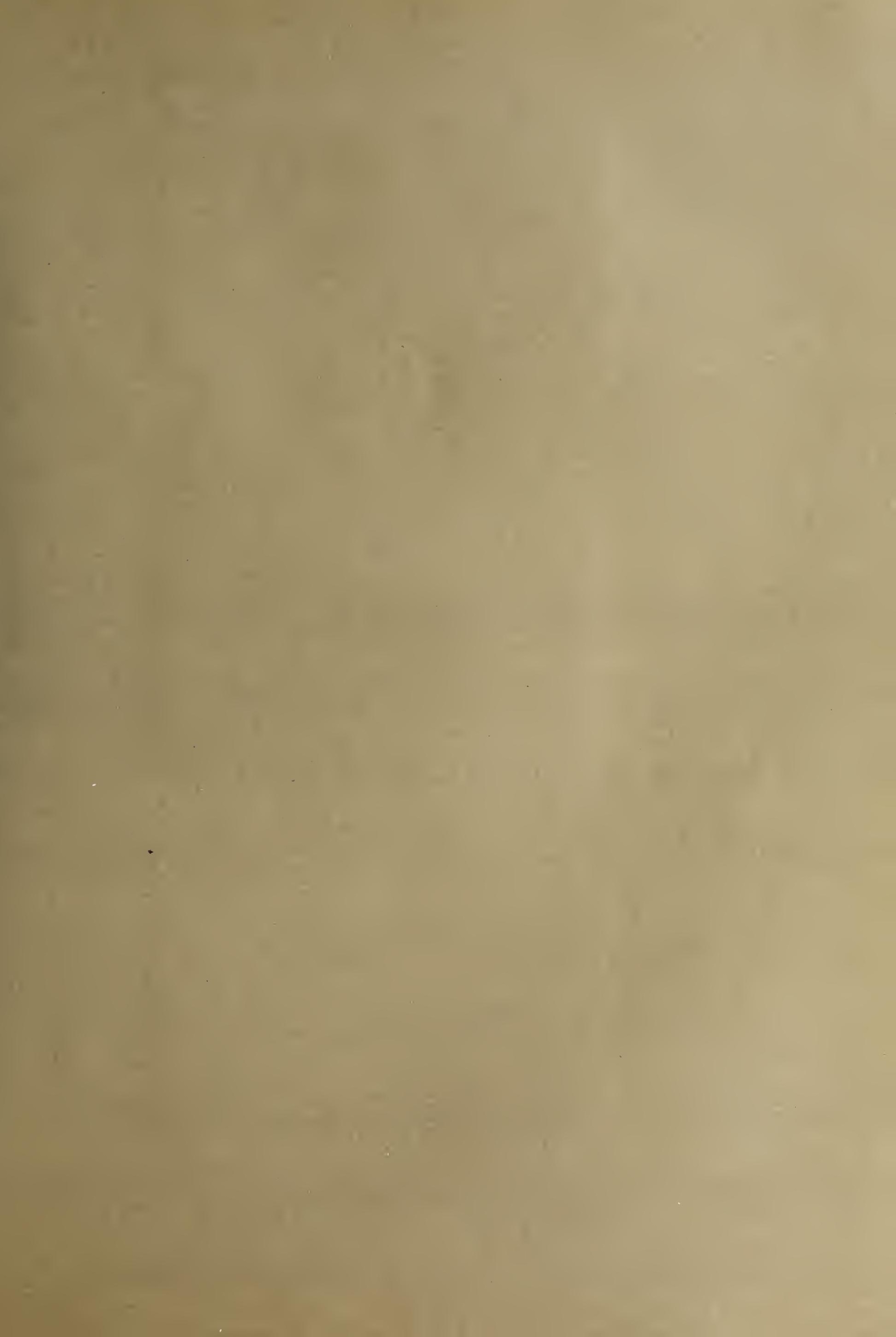




\section{The Marchbanks P1ess} 114 East 13th. New Yorkk

Forceful business-card treatment exemplified by hand-lettering

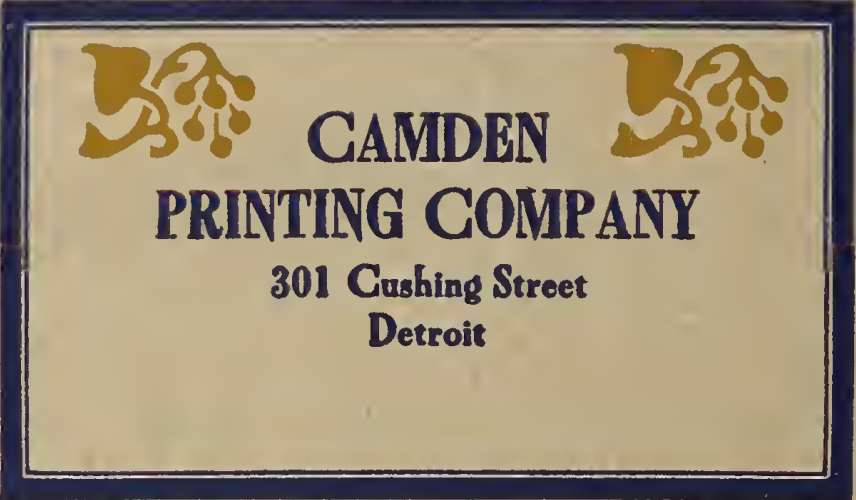

EXAMPLE 339

Gray-brown stock is suitable for unconventional effects of this kind

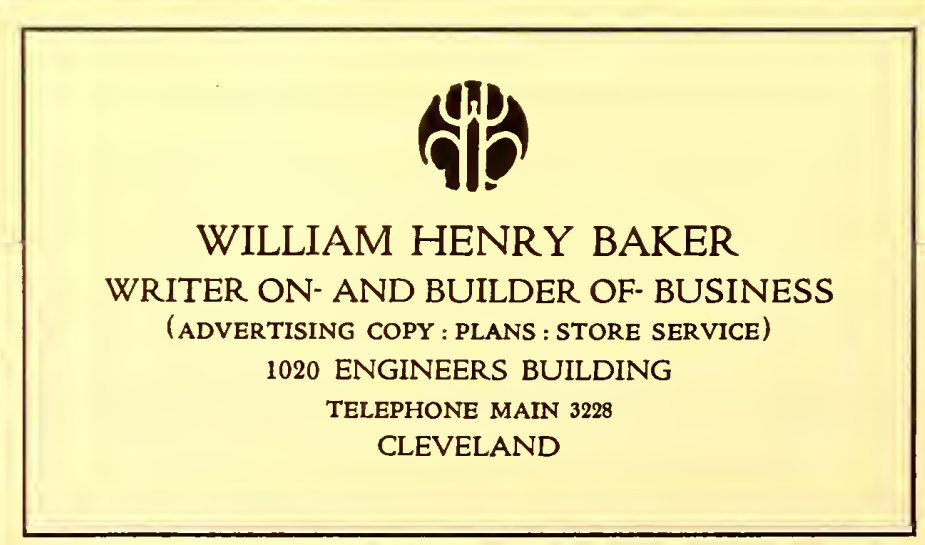

EXAMPLE 340

The black monogram has much to do with this card's attractiveness 


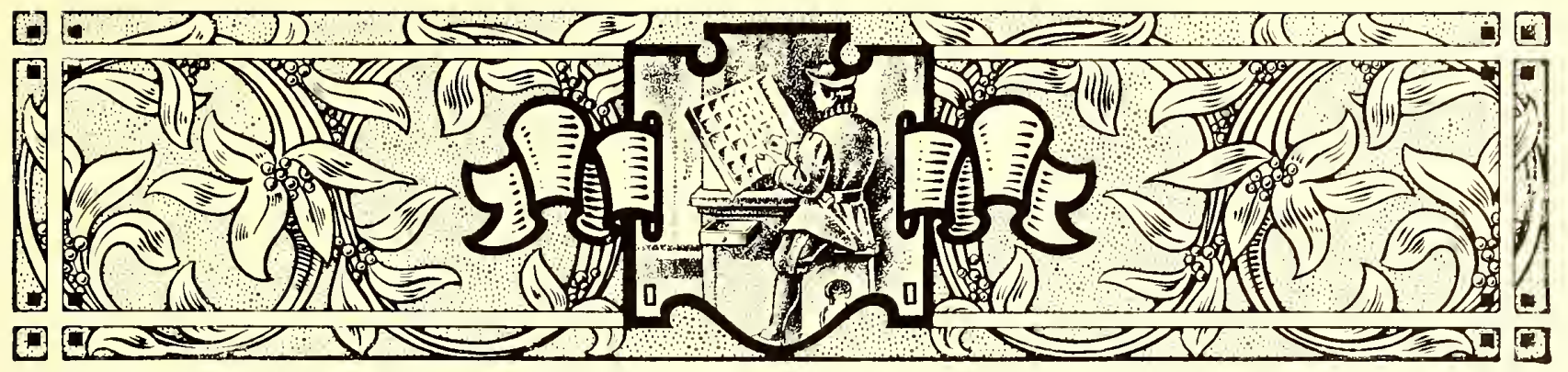

\section{BUSINESS CARDS}

POLITE society requires that a visitor shall be announced by a card bearing his or her name, and the courtesies of business call for this same formality. The man called on unexpectedly is placed at a disadvantage if he has not understood the visitor's name and has no idea of his business. A card thit clearly tells both name and business prevents embarrassment and misunderstanding.

The card makes it unnecessary for the caller to explain who he is. Without the printed information he would likely need to introduce himself thus: "I am James Johnson. I am president of the Johnson Manufacturing Company. We manufacture machinery for the making of paints. Our office is at 320 Broadway. Our telephone number is Worth 4653." But with all this neatly printed or engraved on a card, dignity is maintained and embarrassment avoided.

The sizes of business cards are far from being standardized. Examination of about one hundred business cards showed a range of sizes from $3 \times 11 / 2$ to $4 \times 21 \%$ inches. The size of which there were most and which gave an indication of standardization was $31 / 2 \times 2$ inches. Fully one-quarter of the cards were of that size. From this investigation it would seem logical for printers to use that size unless the customer orders otherwise.

White cards predominated in the lot examined, and this suggests that it is in good taste for the printer to use white stock on most of the busincss cards that he is called on to print.

Example 330.-If an effort were made to standardize the contents and arrangement of a business card, the plan presented by this example would probably result. The customer's name is placed at the point of greatest prominence, a trifle above the center of the card. The words describing the business are second in position under the customcr's name. 'The street and number are taken care of on the next line, and under the strect and number is the name of city or town. In the lower left corner is provision for the representative's name. The telephone number, for which a business card is frequently preserved, finds place in the upper part of the card. A variant for the position of the street and number and the name of the city or town is in the lower right corner.

EXAMPLE 337 .- Here is a card that is a model of dignity and of simple business-card treatment. A good word can be said in favor of using the individual's name in the center of the card and the firm name in a less prominent position. When a card is handed to a business man, he looks at it first for the purpose of finding out who it is that wishes to see him. A card of this kind tells him instantly. In many cases the individual's name alone would be sufficient. No business is mentioned, as it is one of those cases in which it is assumed that the name of the firm provides sufficient identity. In omitting mention of the business, one should make sure that the firm is as well known as he assumes it is. If the name is not familiar to the person receiv-

The probable result of an attempt to standardize the contents and arrangement of a business card ing it, he will be perplexed, not knowing if the visitor desires to sell him books, insure his life, or buy a bill of goods. In the typographic treatment of this card Cloister Oldstyle, capitals, has been used for the smaller line and Cloister Bold, capitals, for the larger line. This slight contrast in the strength of lettering in many instances gives quality and legibility to steel-engraved and lithographed business cards and stationery. The printer by having a well-designed typeface in two strengths will be able to introduce similar good qualities in his work. The spacing between words on this card is closer than that usually allowed by compositors. Close spacing between words is a quality found in good lettering and in good typography.

Example 338 (Insert).-
Dignified treatment for the card of a well-known house. The firm name and address are subordinated to the name of the person using the card. No business is mentioned, an omission open to discussion 


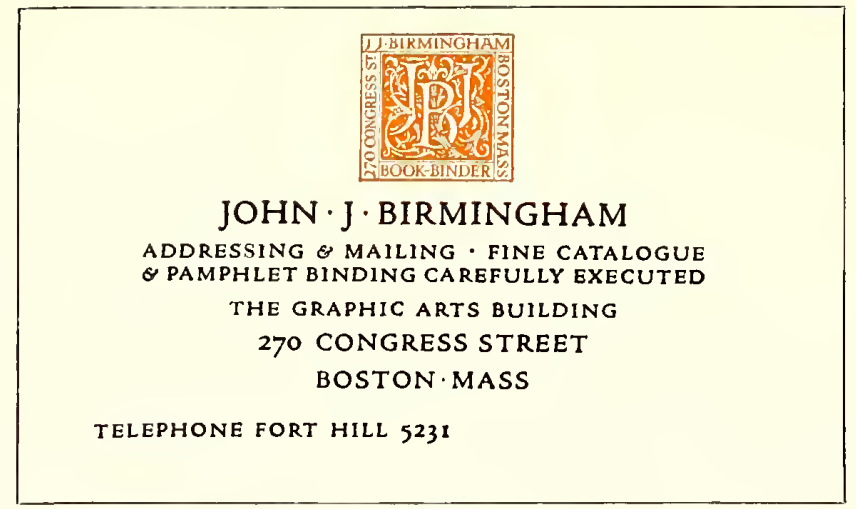

EXAMPLE 34

The monogram in color adds distinction

While the main purpose of this ehapter is to encourage the use of typography on business cards, a specimen of hand-lettering is used to point out forceful treatment that, aided by good printing, liberal blank space and high-class card stock, may sometimes be effective for business-card purposes. The printer using a card of this kind would see to it that it was not presented to a prospeetive customer who had a dislike for anything unconventional.

Example 339 (Insert).-Conceding that at eonventional arrangement on a white cardboard is best for most purposes, it eannot be denied that a design of the strength and interest of this one would often be received with pleasure by the man in the business office. It is not unlikely that the thought would occur to him that the printer who ean produee a card of this kind is qualified to design and print publicity matter equally attractive for other purposes. Bewick Roman is the decorative type-face shown. The border and ornaments used are essential to the good results in this design. The card wonld not be as pleasing with the ornaments or the border taken off. This eard, by the way, is one of the good things arranged by Will Bradley back in 1905 .

Example 340 (Insert).-Quality is added by an attraetive blaek monogram on a baekground of white supplemented by the gray formed by the type group. This is an interesting specimen of business-card typography, sug-

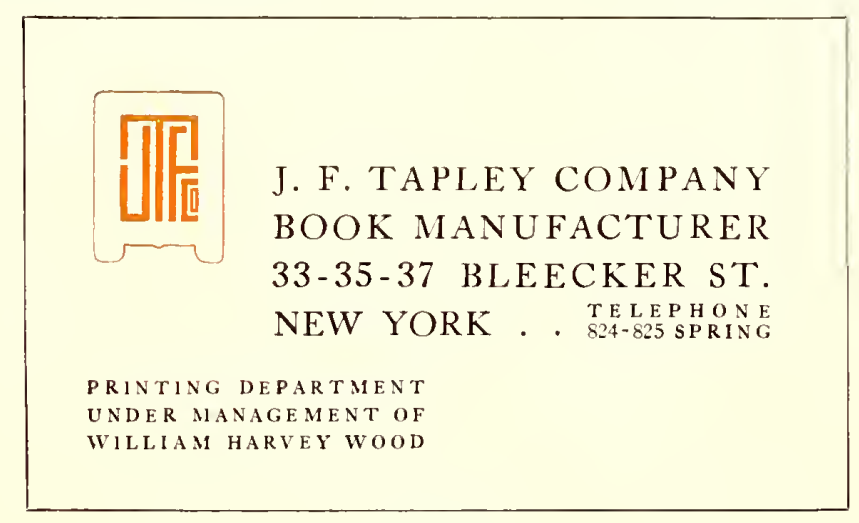

EXAMPLE 344

A business card in blocked capitals. with monogram of harmonious shape
BOOKLETS - CATALOGS - ADVERTISING LITERATURE

4ta

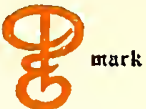

Charles Edward Peabody Advertising Specialist

Temple Building

Toronto

With THE HUNTER-ROSE COMPANY, LIMITED

EXAMPLE 342

An uncommon typographic effect

gestive of architectural panel treatment. The lines (in Cloister Title) are graded in size aecording to their importance, the telephone line oecupying an unusual position between the street address and the name of the eity. Bccause of its position, it also adds a bit of legibility and prominence to both of these lines.

Example 341.- This treatment is similar to the preceding example, with the decorative deviee in color.

ExAMPLE 3 12.- This card is an interesting eontrast to those that have just been considered.

Example 343.--Here is a eard French in motive and of a style that emits exelusiveness. It almost pictures the high hat and frock eoat of the man who would probably use it. All the formalities are observed, the abbreviation "Mr." preceding the name. The man who uses a card of this kind would no more think of mentioning his business on a card than he would of putting a business sign on his residence. The open-face type is College Title and the italic is Caslon.

ExAMPLE 314.-An unusual arrangement in bloeked Caslon capitals slightly letterspaced. Arrangements of this kind are difficult for the compositor and should not be attempted unless he is not hurried and can experiment with the details of the eomposition. The shape of the monogram lends itself to the general arrangement.

Example 345 . - This is a compaet arrangement built

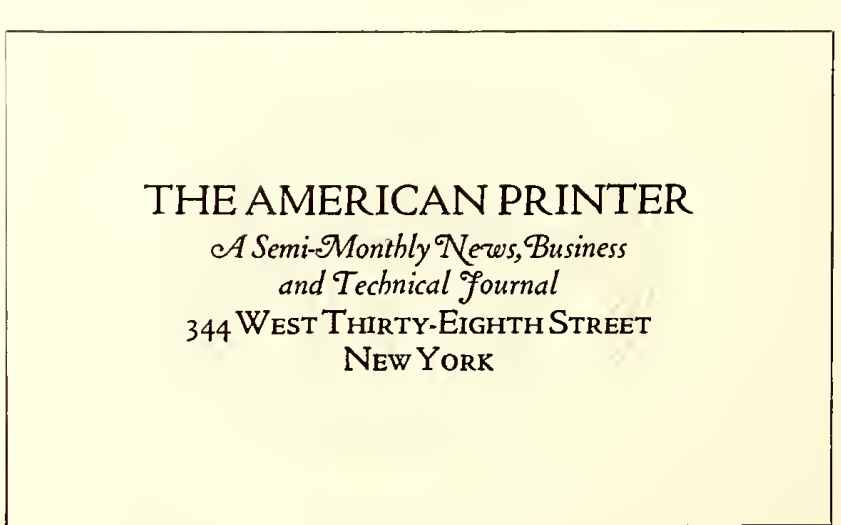

EXAMPLE 345

Arrangement as sugdested in Example 336 with an underprinting decorative device 
The American Printer

Buoks for Primers

wurite

\section{Ofwald Publifbing Company \\ Printers \\ Publifbers Bookfellers}

Reprefented by Jobn Caxberg

Twenty-five City Hall Place

New York

Roman capitals with italic lower-case

somewhat after the scheme outlined in Example 336. 'The decorative device in the original was printed in a tint so like the stock that it suggested a watermark.

Exampe 346.- This card would better please the average person if italie capitals were substituted for the roman. However, thcre was a historical motive for treating it in this manner. When Aldus Manutius introduced the slanting style of type we know as italic, only lower-case letters were cast, and roman eapitals were used with them.

Example 347.--The Germans in the designing of business cards seem to have abolished conventionality, as they endcavor to have each card in its design possess distinct advertising value. This example is representative of such effects.

Example 318.-The designer of this business card took his cue from the word "decorators" and endeavored to form a card with

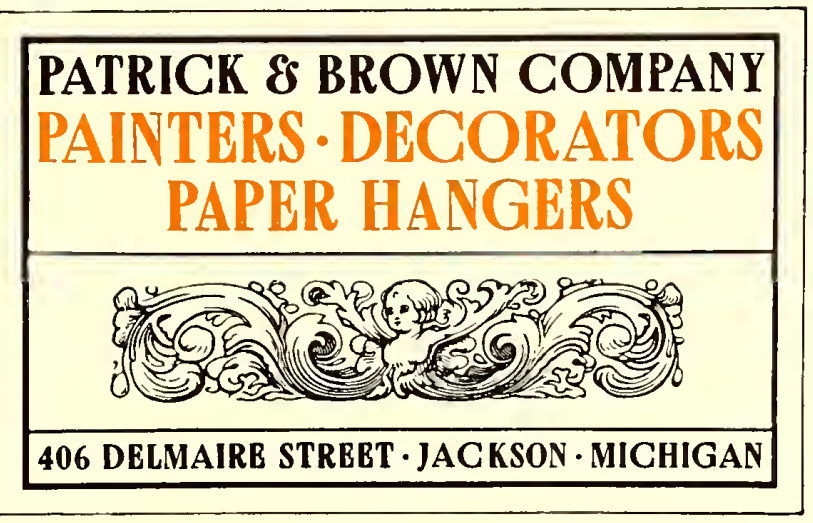

EXAMPLE 348

Decorative treatment suggested by the business

\section{Die \\ Etring Taube}

Etrich Flieyer-2Berte B.mbsy. Siebau Preufijiff Orflepten

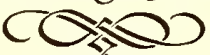

EXAMPLE 347

Modern German business-card treatment

would make a mistake to use it unless he was sure that the customer would care for it. The typographie treatment is simple and eompact and lacks nothing in legibility. The shape of the border eorners fits into the space left by the contour of the type group.

Example 351.-An arrangement that has a suggestion of the elassic. All lines are in one size and in capitals. 'This treatment should not be used excepting in special cases, as it would not meet the approval of most customers.

ExaMple 352.-In the amount of matter it contains this eard contrasts strongly with Example 343. Some small business men find it good advertising to give as much information on their cards as the size of the card will allow. This example shows how a great deal of copy was treated so that the general effect was not displeasing. In order to accommodate this amount of decorative values. This was the reason for the selection of Bewick Roman for the type-face and the Italian ornament to occupy space that is usually left blank on business cards.

ExampLe 319.- When dainty effects are desired, Caslon italie, as used on the greater portion of this card, almost always looks well.

Exampte 350.-A strong ornamental effect, such as appears on this card, is liked by some people, but the printer

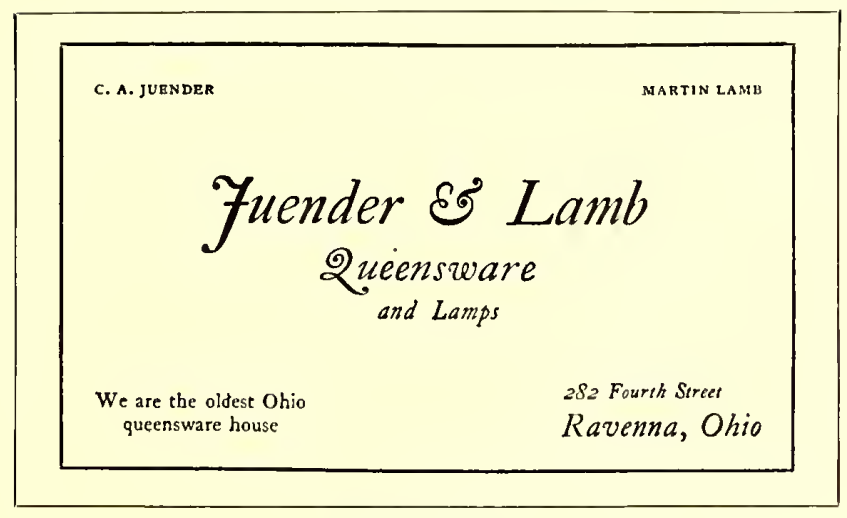

EXAMPLE 349

Italic is pleasing on some cards

copy, it is usually nccessary to enlarge the size of the card a trifle. Bodoni was used for all excepting two lines, the firm name and address, which were set in Bodoni Bold.

Example 353.-A deeorative eard that could be merged in color treatment with an antique-finished stock of some suitable tint.

Example 354.- Horizontal lines crossing the facc of a card are rarcly suecessful beeause they usually separate

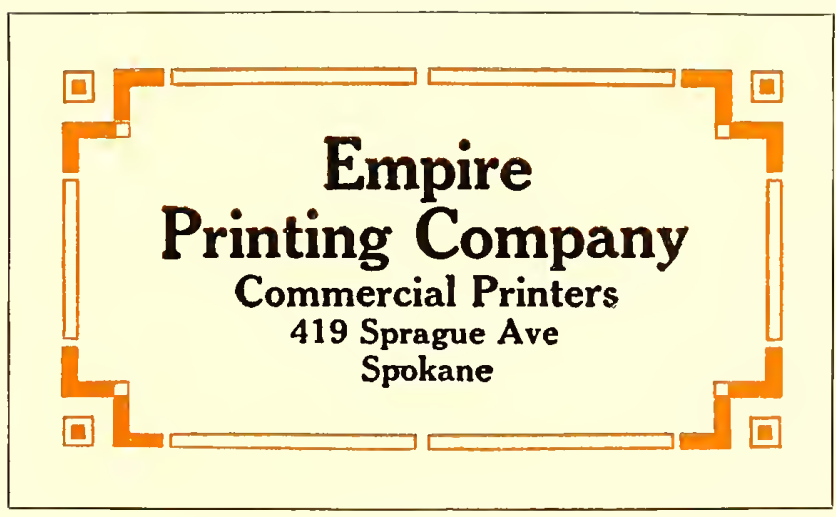

EXAMPLE 350

A strong design for special purposes 
LEE L. CRITTENDEN, REPRESENTING AMERICAN TYPE FOUNDERS COMPANY ROSE AND DUANE STREETS, NEW YORK

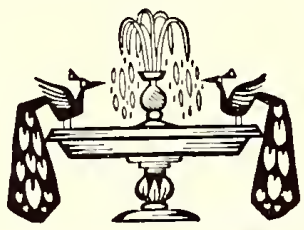

EXAMPLE 351

Classic arrangement in one size of type

connecting phrases, but in this instance the lines are a necessary part of the design and divide the type matter at a suitable place.

FxaMple 355.-This eard in Bodoni and Bodoni Bold capitals, letterspaced, with the use of a few rules, has distinction that could be suceessfully carried to other forms of stationery. The contrasting heavy and light rules blend with the heavy and light lines of the Bodoni Bold.

These specimens will convince both printer and user that there is more than "one right way" to design business cards. 'Typography is the interesting study that it is because, to paraphrase the words of Shakespeare, age eannot witlier nor custom stale its infinite variety. Some style of typographic treatment is available to meet the likes and dislikes, preferences and prejudices, of every one using business cards. The strictly conventional person ean be supplied with a strictly conrentional card, proper in

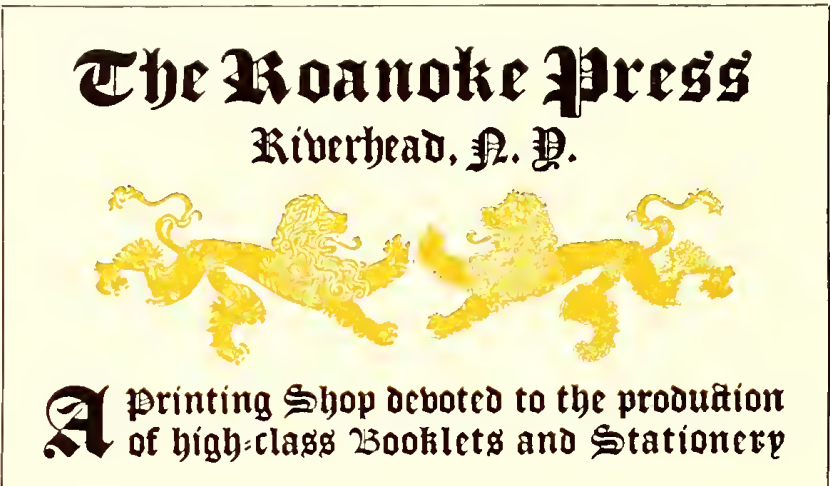

EXAMPLE 353

Highly decorative, with possibilities for harmonious color effects
FRALEY \& GARDNER Signs

Souvenirs, Novelties and Sundries for Advertiser

Maps and Atlas Books for

Commercial or General Advertising Gift Purposes

Telephone 4996 John

20 FIFTH AVENUE - NEW YORK
A business card with a large amount of copy

the cheap-looking, inharmonious cards that some owners of small shops on side streets seem pleased to use.

More than an ordinary amount of thought should be given to the physieal eonstruction of a business card. Because of the present great interest in all forms of advertising, more individuality is permissible than formerly. As typography ean give distinetion and attractiveness to business cards, printers should study the use of type on this class of printing, and give their customers the best possible service.

Printers are produeing eards in imitation of intaglio work to satisfy customers who do not consider that a truly typographic design "looks like a business eard." There is no use denying that eopperplate engravers set the style for mueh of the business-card printing. Shops doing this imitation work should have samples of the best card work done by engravers, so that their imitations may be as aceurate as possible, so far as all details. The artistic person, he of the flowing tie, ean obtain a card with sympathetie qualities. 'The noisy huckster ean be supplicd with a typographie effect that almost shouts the message it contains. In fact, character and personality can be expressed typographically on the business card, and the printer will find this matehing of typography with human nature an interesting study.

A large city wholesale house cannot afford to eirculate

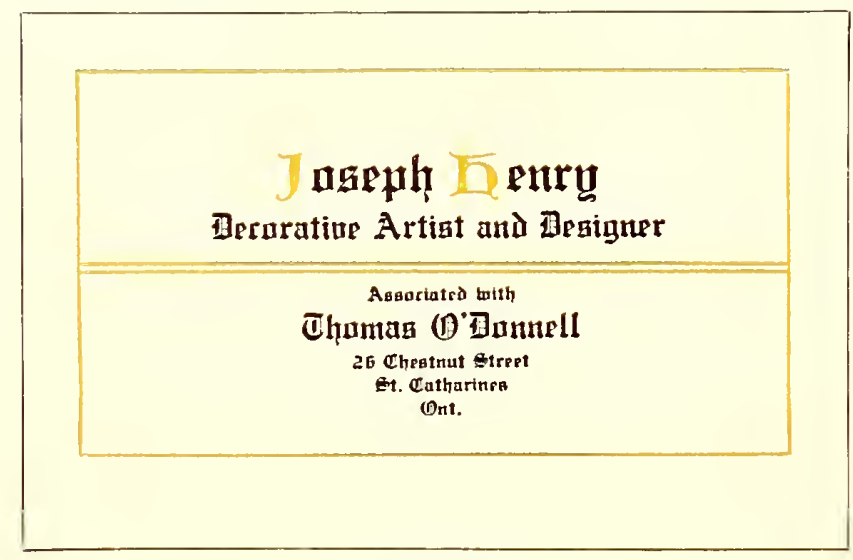

EXAMPLE 35

The horizontal lines are well employed coneerns style, faee and arrangement. There is little pleasure in being an imitator unless you are a good one, and here is opportunity to gain a reputation for the clever printing of imitation engraved work. Good stock, a dense-blaek ink and perfeet types are means to this end. Pleasing results have also been obtained by using green-black ink or dull gray-black ink, which assists in eonveying the soft, pleasing eff eets of lithography.

\section{ROBINSON \& WELLERS \\ FAIR OAKS AVENUE B E T H L E H E M}

\begin{tabular}{lll}
\hline BRIDLES & BLANKETS & FUR ROBES \\
\hline
\end{tabular}




$$
\text { . }
$$




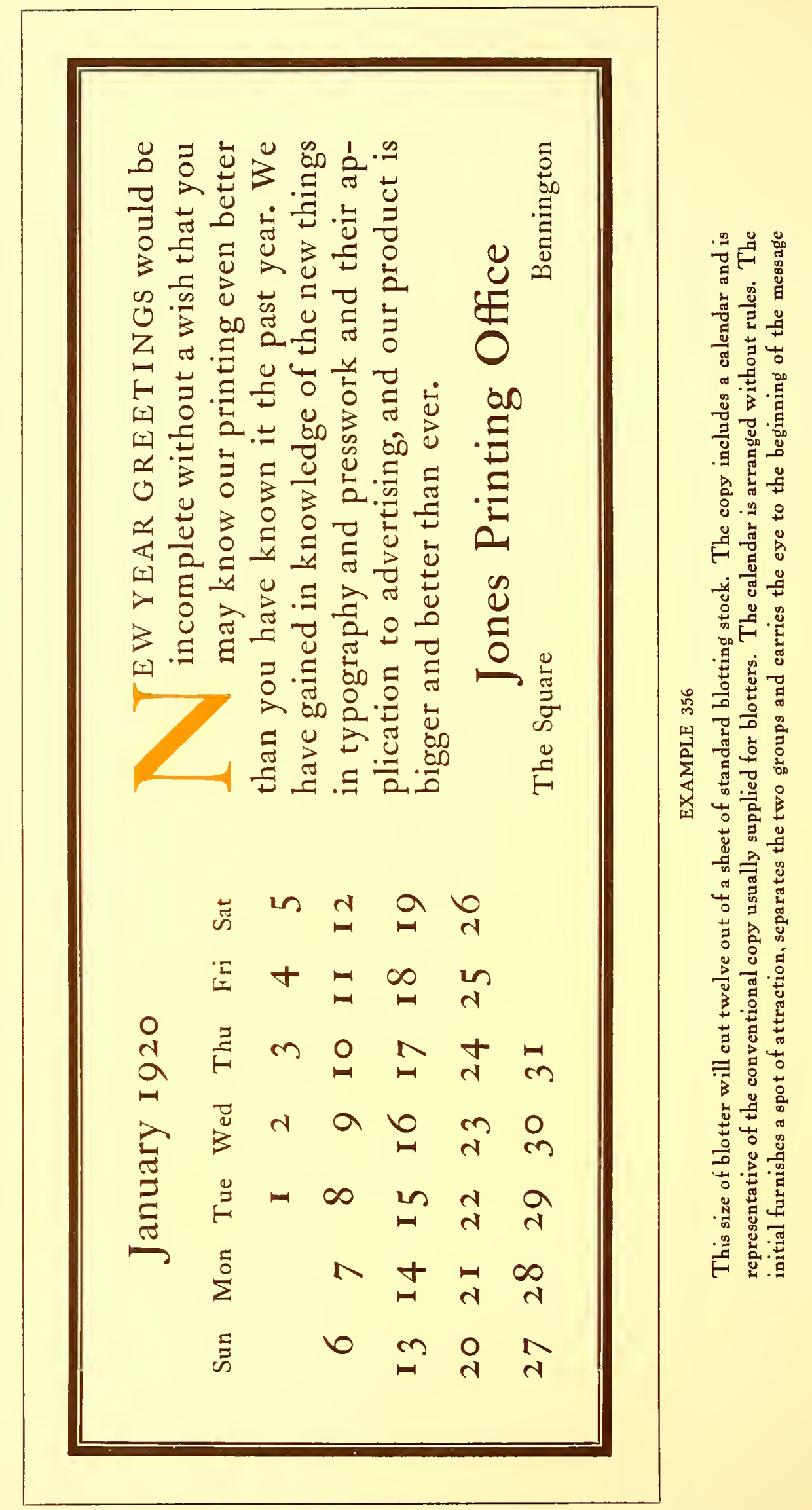




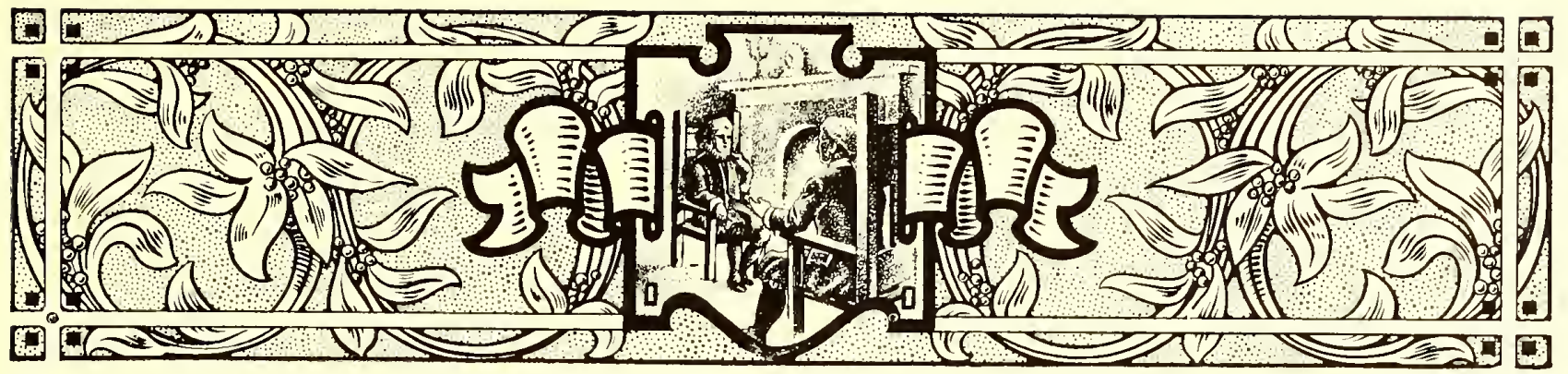

\section{THE BLO'TTER}

BLO'TTERS have a plaee in moderu business which, while not so important as that of business eards. is fairly well established.

Business eards are left with customers as reminders, and altho blotters are sent for the same purpose, they have should be as well thought out as that of a business card. In a sense the blotter represents the business house sending it, and while it may show less restraint and dignity than the business eard, eoarseness should be avoided in the handling of both type and illustration.

\section{Blotter \\ for your checkbook \\ with the compliments ot \\ The Oswald Press \\ 344 West 38th Street \\ New York} the added quality of usefulness. The treatment of a blotter

ures about (x) $31 / 1$, and fits in a No. $6 \% / 4$ Govermment envelop, whieh measures $61 / 2 \times 3 \%$. This size is most eonvenient for inclosing with everyday business mail. and it is possible that most of those aetually using blotters prefer the smaller size.

The blotter with an enameled surface on one side is probably the hest for use. A person naturally rubs his hand over the blotter to absorb the wet ink, and an enameled surface feels morc pleasant to the toueh. When not many blotters are on hand in a business offiee those with absorbent surfaees on both sides render the greater service, but usually advertisers keep offiees well supplied.

From a printing point of view the blotter stock with one side cnamel-finished is better for illustrations or small type, while roughfinished stock is suited to typographie treatments that require antique effeets.

Exampe 356 (Insert).-This blotter represents not only the size of a great many blotters but the contents, as it is customary to include a monthly ealendar. 'Too frequently forms of this eharacter are mitle inharmonious hecause stoek ealendar plates are utilized and are aceompanied by type-faces of another design. This laek of liamony is seldom neeessary, as the printer in his typography should mateh the style of type used for the stoek ealendar plate. Sometimes in addition to the ealendar A modest amount of copy and neat treatment

'The blotter as a means of publicity unteh used by advertiscers is no longer an experiment; it is a familial form in the printshop.

The advertising value of a blotter seem, to lie in its ability to do one of two things-strongly and favorably to attraet attention when reeeived, or thru attraetive simplieity to grow in favor during use. The former may be likened to a roeket whieh eompels attention and pleases for a moment, and the latter to a star whose beanty attraets forever.

In planning a blotter it is well to keep in mind its utilitarian charaeter and make it as useful as possible.

The size is determined by the sheet of stoek out of whieh blotters are cut. As the stock measures $19 \times 2+$ inehes, most printers eut blotters a trifle less than $91 / 2 x+$ inehes, thus seeuring twelve blotters to a sheet of stock. There are others who prefer the blotters not so wide and make them 8 or $81 / 2$ inches.

Another reason for the blotter size of a trifle less than $91 / 2 \times 1$ inehes is that it fits nieely in a standard No. 10 Government envelop, whieh measures $9^{1 / 2} \times 41 / 8$ inches.

A size of blotter that is also much used meas-

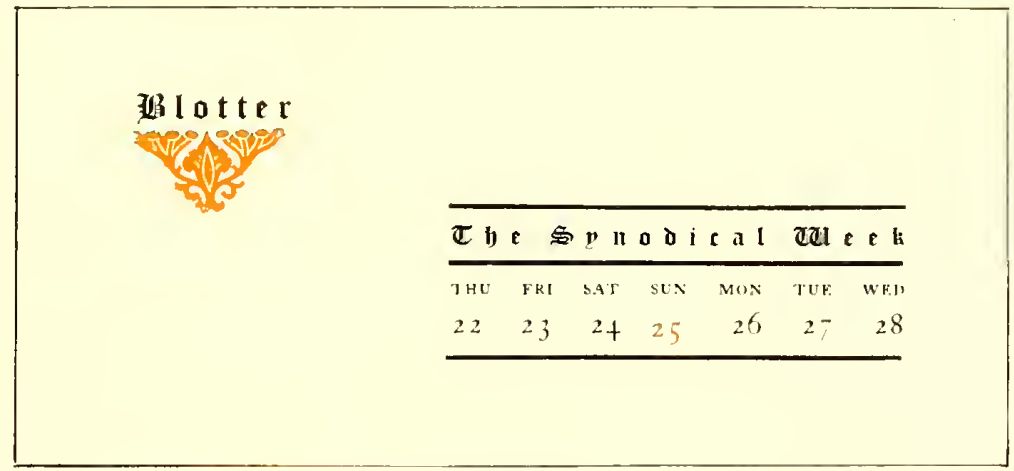

EXAMPLE 358
Blotter used in the writing room of a convention hall 


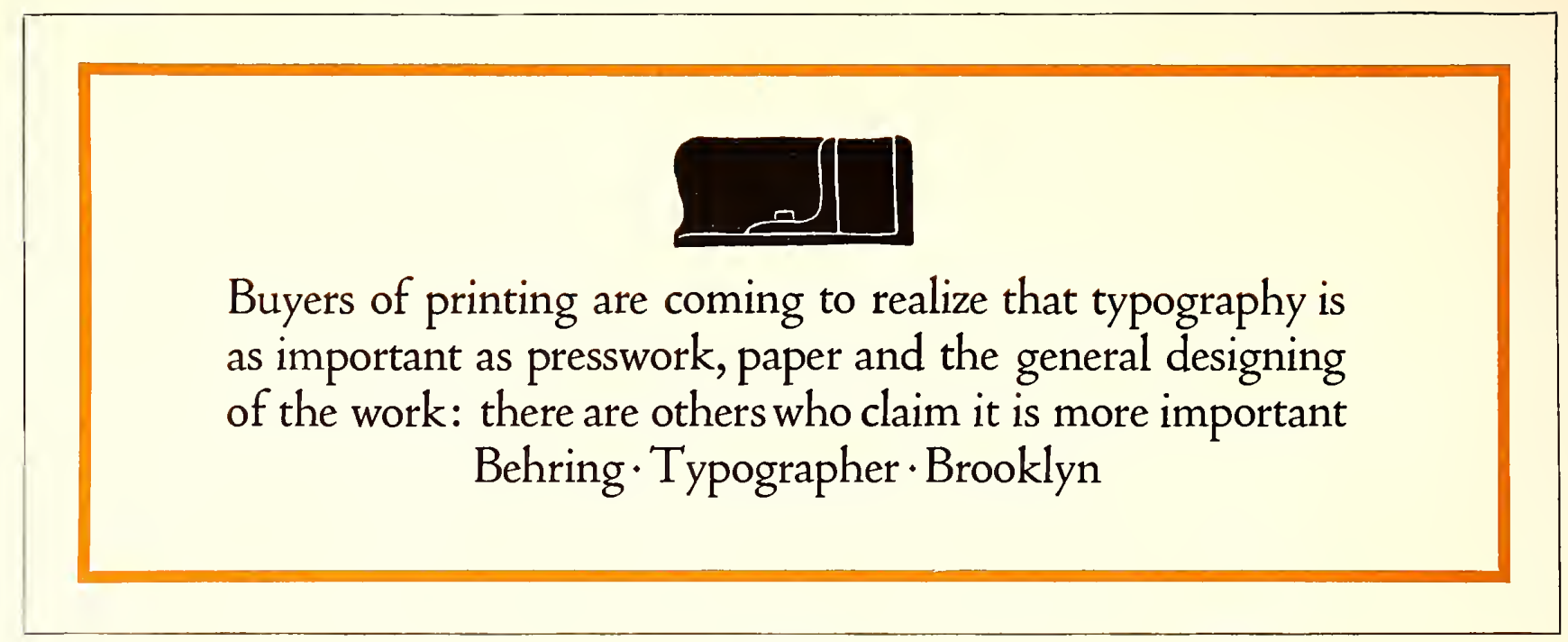

EXAMPLE 359

Simple typographic arrangement with strong but pleasing contrasts

roman, and mostly lower-case. This manner of handling the typography will give good results in almost every instance in which it is tried. The message of the advertiser is presented in a plain, legible paragraph introduced by an initial in color. The blank space liberally distributed is restful, and the dark-printing qualities of the heavy-andlight-line border contrast with the blank background, the rubricated initial and the mass of gray in the type matter. No rule lines appear in the calendar section, and the result is an appearance of natural freedom.

Eximple 357.- Most blotters contain too much type matter. The business man would probably appreciate a modest little announcement and consider it a relief from the sledge-hammer advertising that too often forces itself on his attention in an unwelcome way. As one rubs over the average blotter he finds it almost necessary to close his cyes because of the strong character of the design or color treatment. The arrangement of this example is a suggestion for a little blotter that would doubtless be welcomed by many. It could be of a size that would fit in the personal checkbook. Because of the intimate character of its use the typography should be confined to a simple paragraph or to a group arrangement as shown. Both the message and the treatment here given are in good taste for such a purpose, and, as has been suggested, it is likely that similar treatment on a larger blotter would win approval.

ExAMPLE 358.-This blotter was used in the writing room of a convention hall and was prepared for a state meeting of a church organization. It will be noticed that only the week of the convention is given in the calendar, and that it begins on Thursday and ends on Wednesday. Some of the factors that make this blotter pleasing are the liberal blank space, the black lines of the rules, and the ornament in color. Text type is used because of the rcligious cliaracter of the convention, and it is letterspaced. As a general rule it is well not to letterspace text type, but lrere in order to obtain a certain distinctive effect it has been done witl good results.

EXAMPLe 359.- Here is a suggestion for a simple typographic arrangement with strong but pleasing contrasts. The color of the rule border contrasts with the white of the background and the black of the illustration. The gray effect of the type group is a harmonizing factor that softens the contrasts. Only one face of type-Cloister Oldstyle - is used, and that of a size that makes it possible for the business man to read the message as he blots his

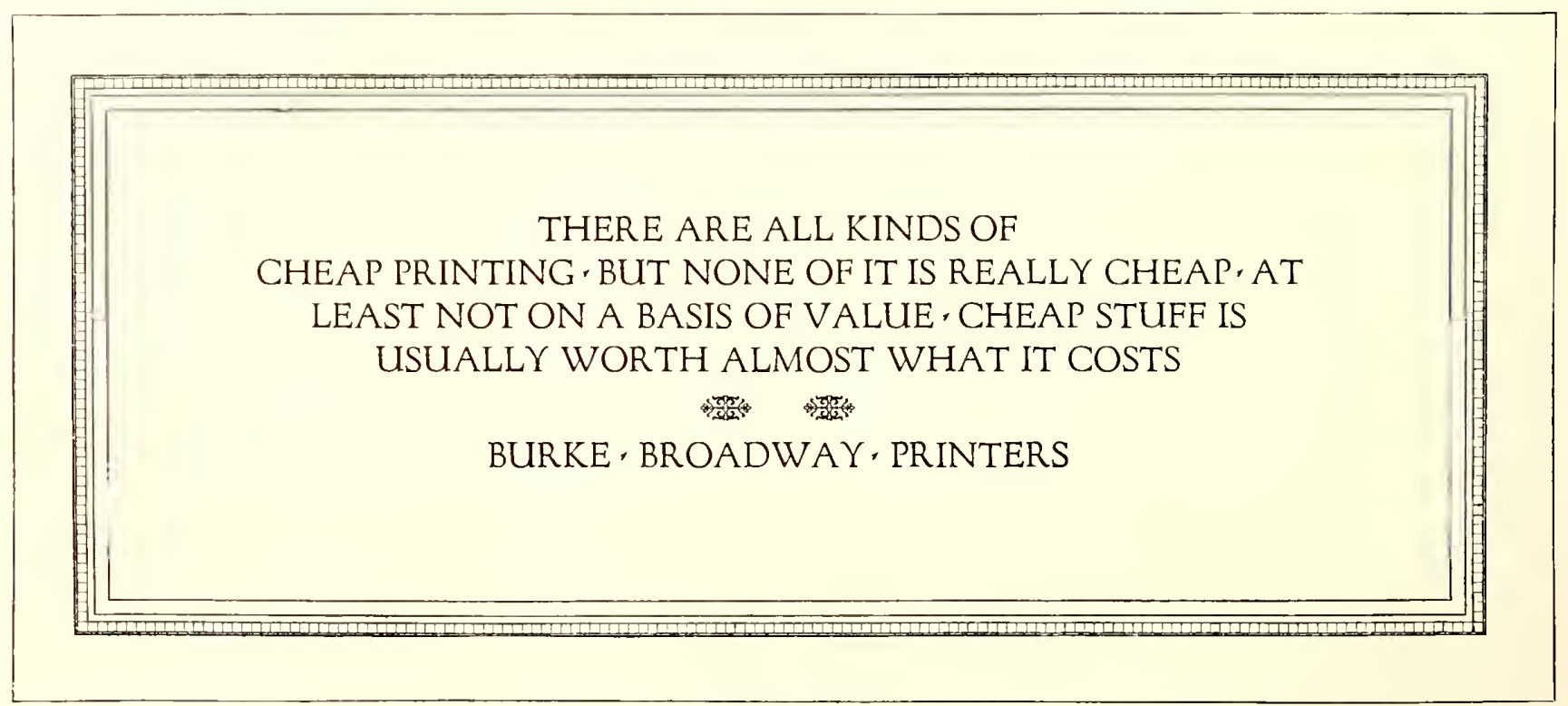

EXAMPLE 360

A blotter arrangement suggestive of an architectural panel 
HE ultımate result of shieldıng men from the effects of folly is to fill the world with fools -Herbert Spencer

Qth floor

8 Caxton Building
HORACE CARR

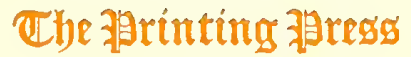

CLEVELAND

EXAMPLE 361

Blotter treatment that survives the test of time

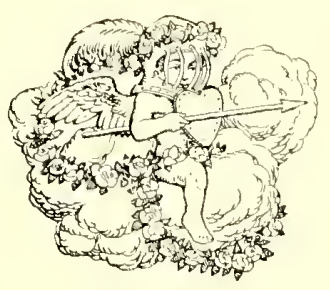

We propose that you allow us to submit specimens of our printing and explain what we can do for you. We are specialists in High Grade Catalogues and Commercial Printing and deliver all when wanted

August Becker Printing and Office Supplies 300 Graham Avenue Brooklyn N Y

Telephone Stagg 287

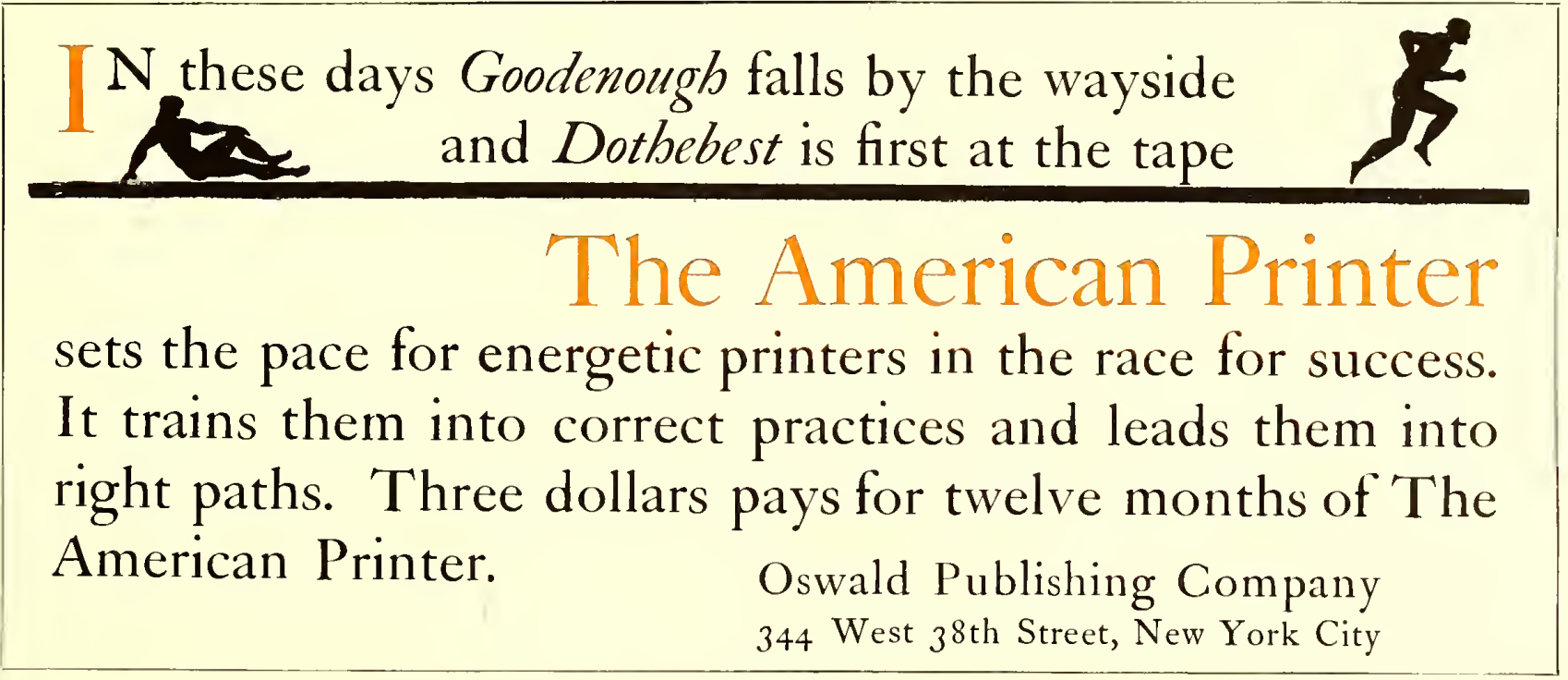




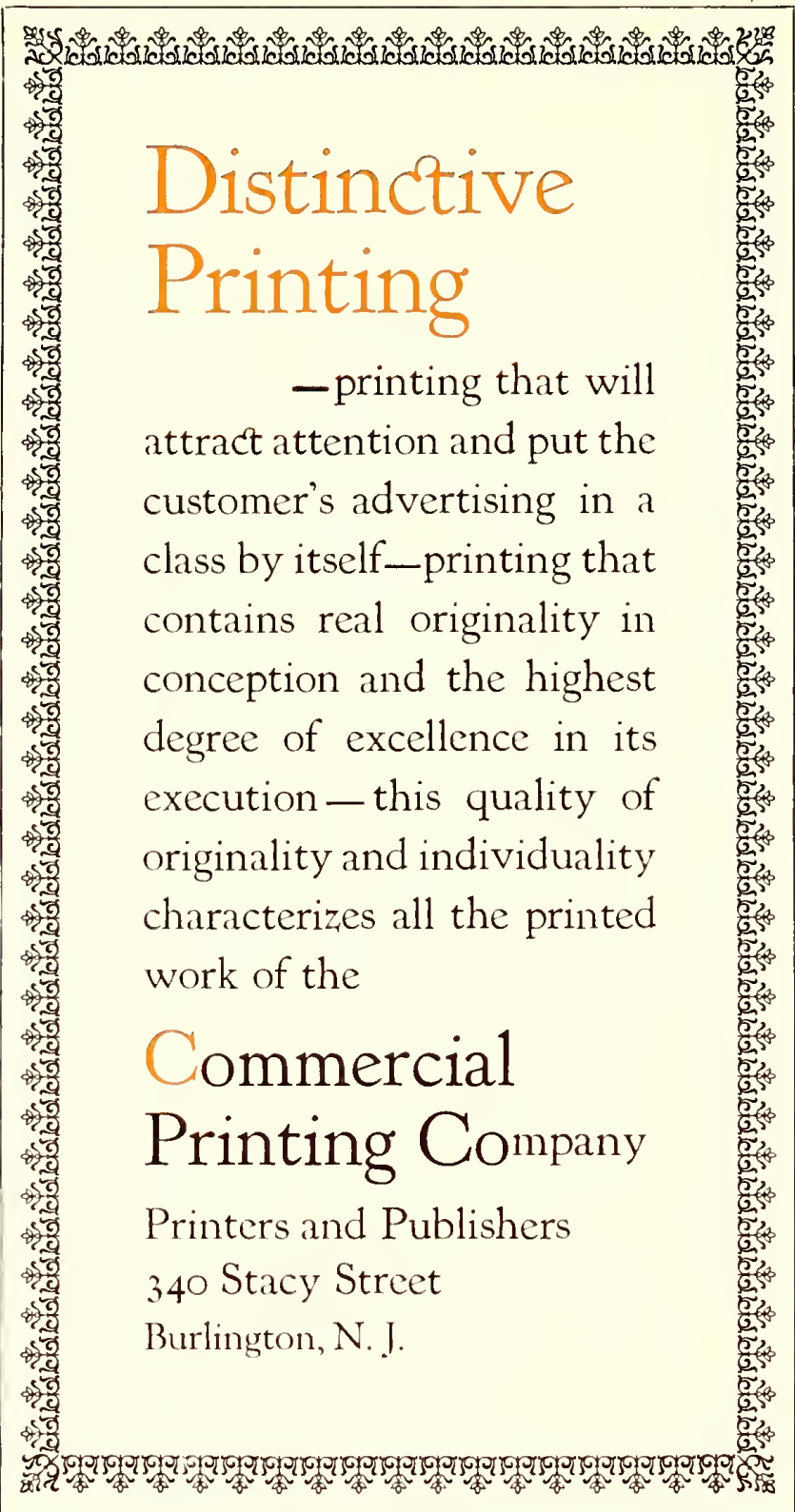

EXAMPLE 364

A decorative blotter arranged the narrow way

signature. The treatment is masculine and will please a great many because of its style.

ExaMPE 360.- This blotter has the character of an arehitectural panel, a motif that is adaptable to many torms of typography. The general gray effect of the Formm Title and the architectural border is satisfying, especially as the type group and border are separated by a liberal amount of blank space. The shape of the type group suggests a keystone. 'This is one of those blotters that the business man should find pleasure in using and looking at frequently. It will be noticed that the spacing between the words is less than the en-quad whinh the typographer would customarily use in capital lines. It would be a mistake to separate these Roman capitals with more space than that used here.

Example 361.- It has been said that two important factors in good typograply are the material that is used and the material that is not used. Horace Carr has done many good things with the Caslon type-face, but none more pleasing than this blotter. It is a model of good taste in blotter typography and the sort of treatment that has proved to be good blotter advertising. This particular example was received by the author some years ago and was then reproduced. 'Testing it with careful examination after all this time, it looks as well as ever.

ExaMPLE 362.- - Here is suggested a neat, refined arrangement, in which type group and illustration are placed practically in the center of the blotter and surrounded with blank spacc that accentuates its neatness.

EXAMPLE 363.-This blotter-one that was submitted several years ago in a blotter competition-shows treatment which calls for the use of large type that occupies almost the entire surface of the blotter. While an effect such as that of the previous example is preferable for most purposes, there are times when it is desirable to have the typography arranged on a large scale.

Example 364.- It is customary to design a blotter the broad way, but occasionally printers desire for the sake of novelty to arrange it the narrow way, as is done on this example. 'The blotter has decorative quality because of the use of the gray border and the lower-case of Kennerley Oldstyle. Lower-case properly used is usually attractive.

Example 365.- A touch of appropriateness is given to this blotter by the use of the scroll decorative piece, and the harmony is further carried out by the selection of Bodoni Book for the type portion.

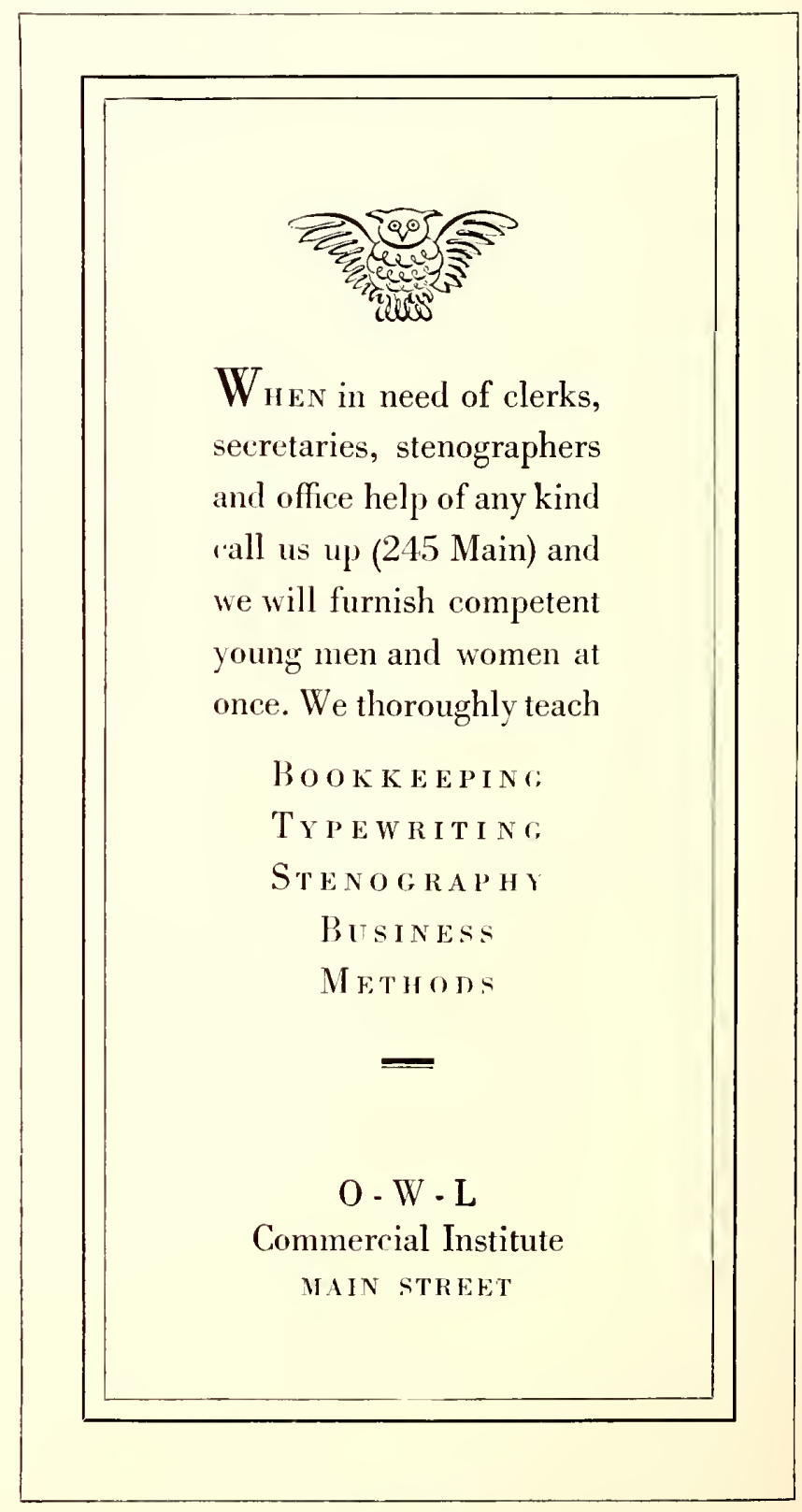

EXAMPLE 365

Appropriate trademark and harmonizing typography 

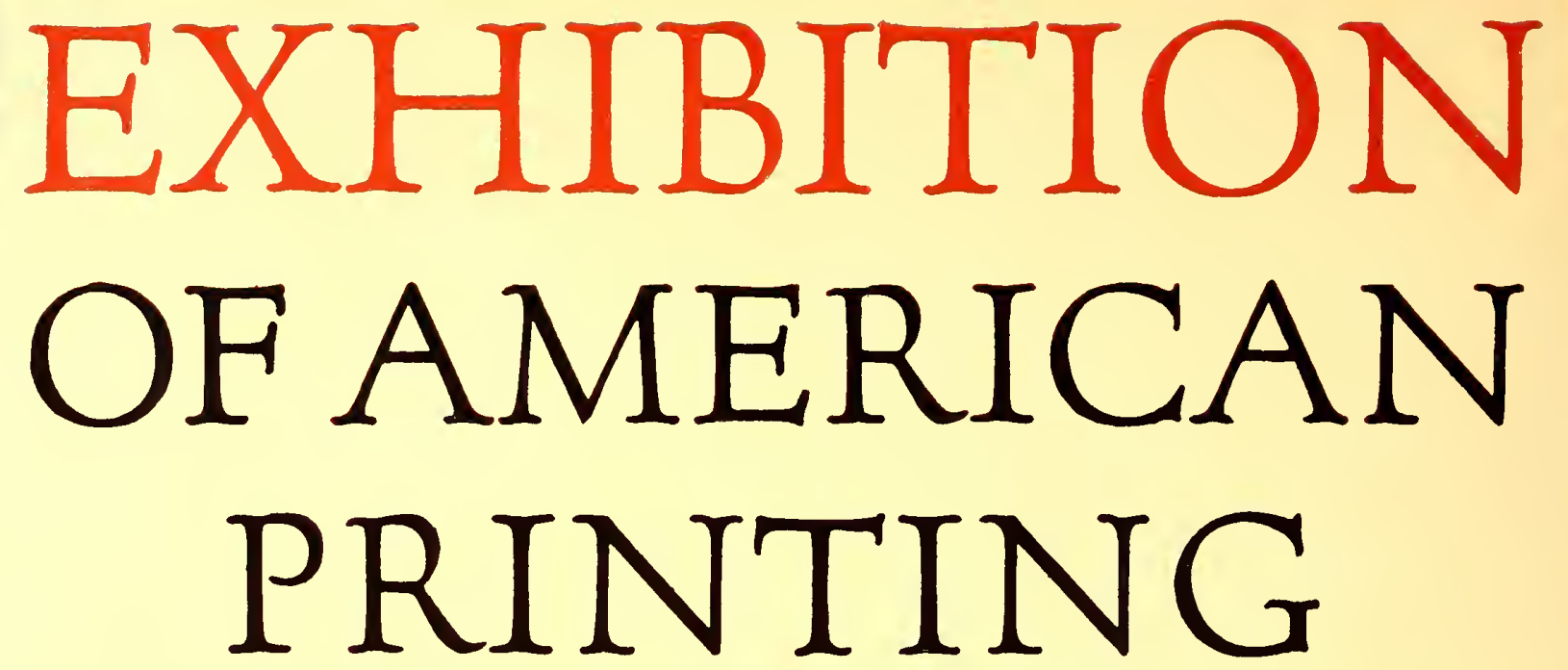

๘

UNDER THE AUSPICES OF THE

AMERICAN INSTITUTE

OF GRAPHIC ARTS

AT THE

NATIONAL ARTS CLUB

II9 EAST NINETEENTH ST.

NEW YORK CITY

MARCH 28 TO APRIL I4'MCMXVI

$$
\begin{aligned}
& \text { OPEN TO PUBLIC } \\
& \text { I0 TO } 6 \text { P.M. } 8 \text { TO IO P.M. }
\end{aligned}
$$




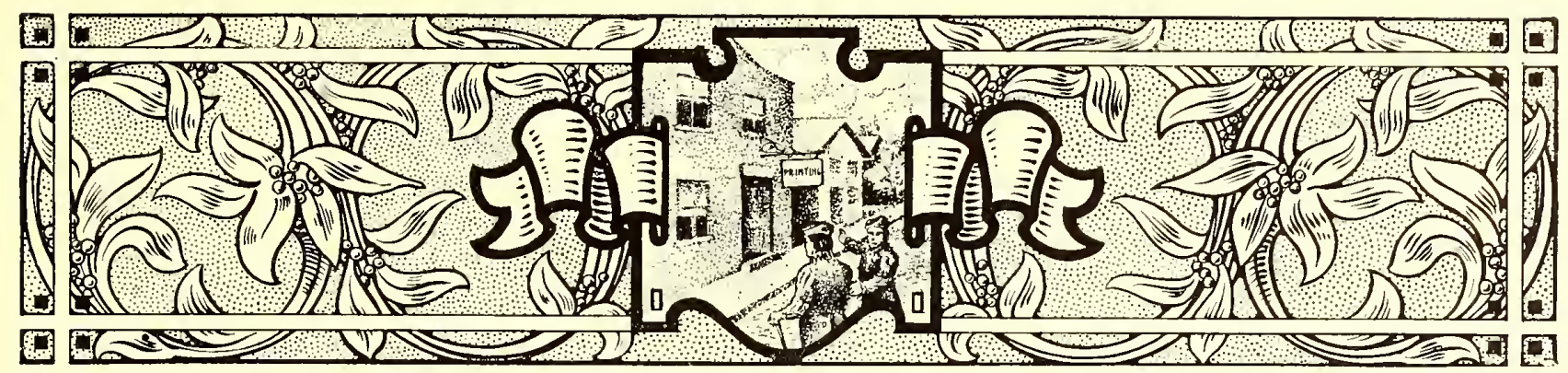

\section{POSTERS, CAR CARDS, WINDOW CARDS}

POSTER printing is a specialty in large cities, where plants are equipped for the cconomical and effective production of such work. However, consideration of the subject in this chapter will be confined to the interest it may have for the general commercial printer, he who is called upon at one hour to print a business card and at another to produce a window card, car card or other form of poster printing.

The type equipment of the poster specialist includes strong gothic and Clarendon faces, of a variety of widths that cnable him to make a full line of almost any word or combination of words. When such strong-printing capital letters are used, most of the lines should be full, as the general effect should be one of compactuess. A very little amount of spacing is sufficient. No extended reference will be made here to the conventional poster that carries these heavy types, as its arrangement is merely one that emphasizes in a plain manner the various important parts of the copy. Skill is necessary, but not the skill of an artist.

The wood-type equipment of the general commercial printer need not be elaborate, but it should be well selected. There should be a blending of styles in type-faces from the smallest size of metal type to the largest wood letter. The wood-type makers duplicate most of the standard job faces, so that harmony in this respect need be no idle dream.

Among poster printers a sheet $20 \times 39$ inches is taken as a unit and is known as a "one-sheet." "Four-sheet," "twelvesheet," etc., are terms designating the number of units or "onc-sheets" in the whole display. On the other hand, the commereial printcr's "sheet" poster is generally the full $25 \times 38$-inch paper, a "half-sheet" being $19 \times 25$ inches and a "quartershcet" $121 \% \times 19$ inches.
'The sizc of car cards-the advertisements used in trolley, elcvated and subway cars-is usually $11 \times 21$ inches.

The most common sizes of window cards-advertisements placed in store windows by courtesy of the merchants-are quarter-sheets ( $11 \times 14$ inches) and half-sheets ( $14 \times 22$ inches), the unit of which is the standard sheet of cardboard (about $22 \times 28$ inches).

Posters in their most attractive form are designed in plcasing combinations of decorative illustration, lettering and harmonious coloring. The printer with type alone cannot give the picture element, but he can give color and lettering.

What a poster authority has said of the pictorial poster can to some extent be said of the typographic poster: "The poster should be simple, clever, attractive, perhaps sparkling, spontaneous, appropriate, sometimes humorous, but in good taste, and should tell the story at a glance. It should not be elaborate in detail or labored; the designer should know where to stop. The coloring should be brilliant, yet simple; when many colors are used most of them are wasted, as the eye does not see them all. As detail in a poster is lost at a distance, it is unnecessary. The best posters have no background and not much lettering, as small lettering cannot be seen across the street, which is the test."

It is assumed that the typographic poster is viewed at closer range, as in its smaller sizes it is usually hung in stores and offices or posted in convenient locations that permit of easy reading; yet the printer who sets the work, as well as the man who writes the copy, should kcep before him the manner in which the poster, car card or window card is to be used. A person sitting on the opposite side of the car should be able to read the
A lettered poster by Harvey Hopkins Dunn that should be studied by the typographer 


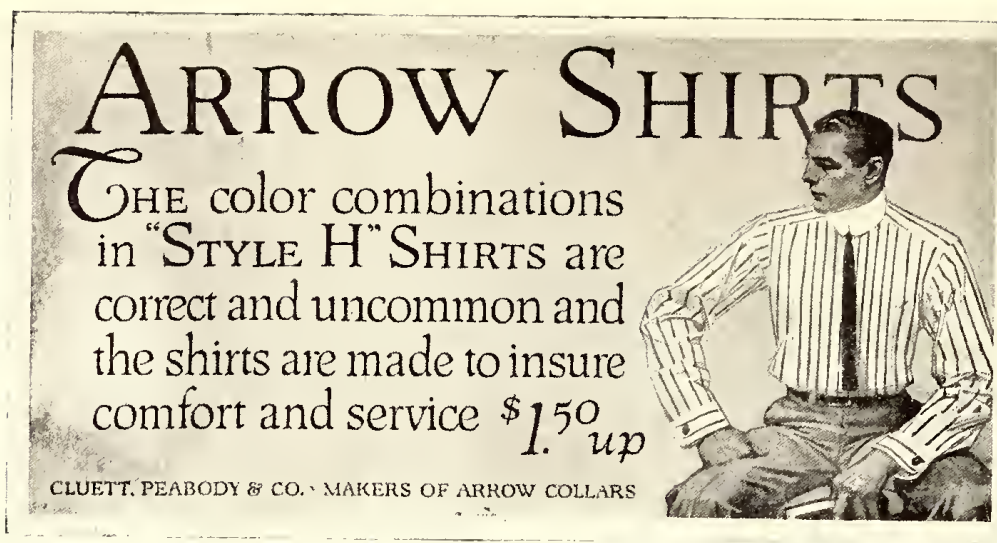

EXAMPLE 368

A lettered arrangement that has suggestion

\section{The Lightest Strong Suspenders Knothe Weve}

EXAMPLE 369

A few words of copy and strong contrasts

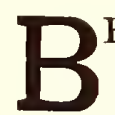

EFORE you get married have a policy of Life Insurance issued to present to your bride. Could you find a more suitable present, and one which she would appreciate more? Write at once to

\section{WARREN T. DIEFENDORF IoI5 Fulton Street, Brooklyn}

Mention Series E

EXAMPLE 370

A typographic style unique among insurance advertising in cars

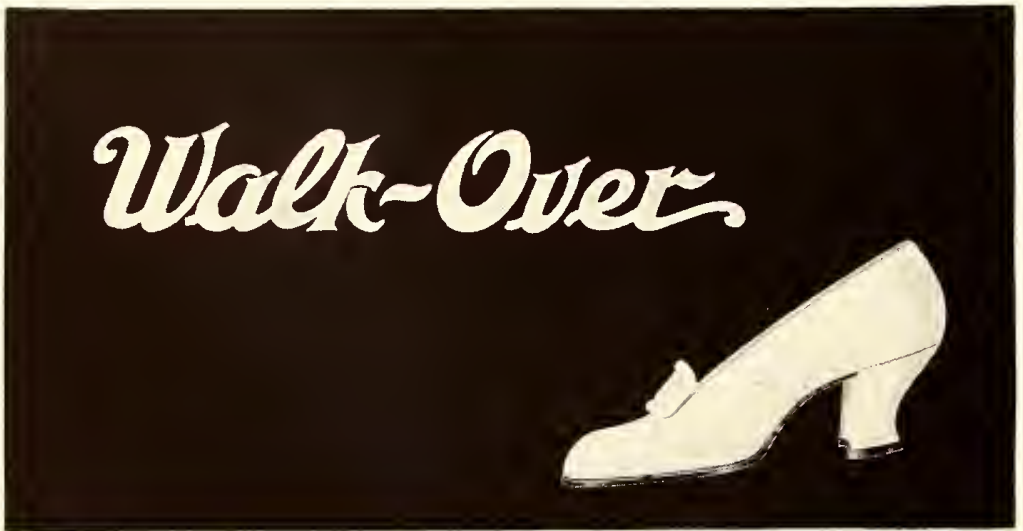

EXAMPLE 371

Simplicity that is worthy of adaptation car card, and the person passing a store window should find it possible to obtain the principal points of information from the window card. On store cards, such as used during special sales, the price should be prominently displayed.

Example 366 (Insert).-The possibilities of typographic effects in poster printing are to be seen in this examplc, arranged by Frederic W. Goudy. Forum Title, designed by him, was selected as the type-face. In order to obtain the larger sizes, the type was set in a smaller size, a clear proof pulled and a photo-engraving made. This poster measures up to the qualities outlined by the poster authority previously quoted. It is "spontaneous, appropriate, simple, clever, attractive."

ExaMPLE 367.-Althothis design is lettered, it should prove of great value to the typographer as a study of composition. In the production of this effective poster Mr. Dunn has given of his talent as an illustrator as well as of his skill as a letterer. The apportionment of blank space in the margins and at the head is pleasing, and it helps to make effective the black masses of lettering and the octagonal illustration. The border of thick and thin lines ties the design together.

ExAMPLE 368. - Most cards in urban cars are made up greatly of design and illustration, but in this one we find the illustration taking a minor position. The lettering is the main featurc, and it should suggest treatment with type that could be almost as effective.

Example 369.-The strong contrast of black, red and white in this car card could be approximated with bold, well-designed wood typc. The trade name is given most prominence, altho the remainder of the copy is also strongly presented. A suggestion of decoration is to be found in the ruled lines at the head and foot.

Example 370.--Seldom is copy such as this furnished for car cards, yet its conversational style probably caused it to be read more than other cards. As an advertisement it is an improvement over the common method of merely stating name and business. It presented opportunity to the printer to use types in a sane, simple manner, and he did so. A two-line initial letter starts the reading pleasantly, and the name in capitals has sufficient prominence.

Example 371.-At an exhibit of German modern-art posters the design that stood out most strongly was one which contained only a name lettered and an article illustrated. There was no detail to detract, and the effect was altogether pleasant. This shoe card is planned along similar lines, and the idea could well be put to further use.

Example 372 (Insert).--This is a presentation of a three-sheet poster which attracted the attention of the writer a few years ago because of its simplicity. For such effects as this, which carry but little copy, lower-case letters are appropriate. It is seldom, however, that the commercial printer is provided with so few words for his posters. Lower-case display, to look well, requires plenty of surrounding blank space, while capitals accommodate themselves to close quarters. 

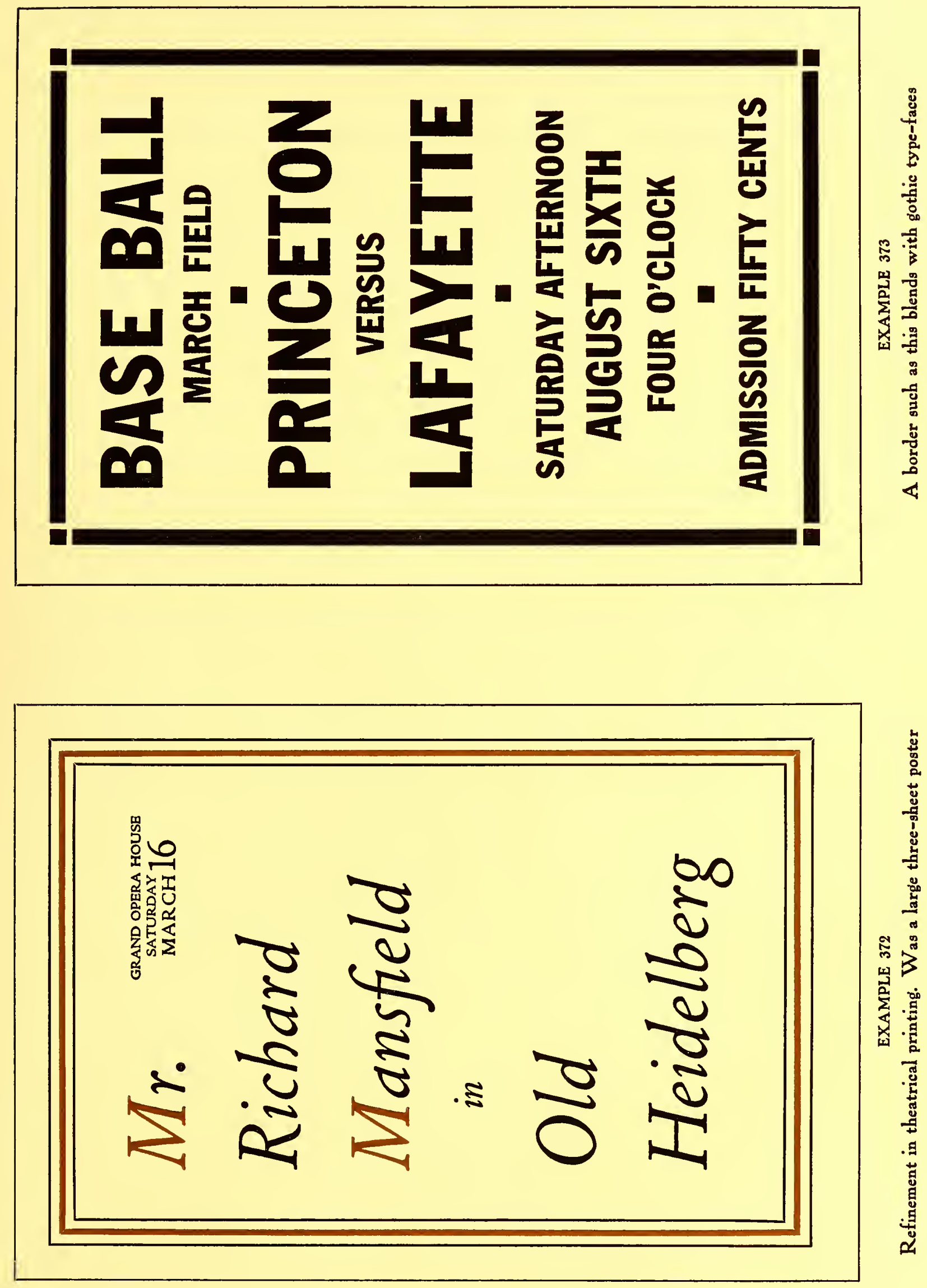

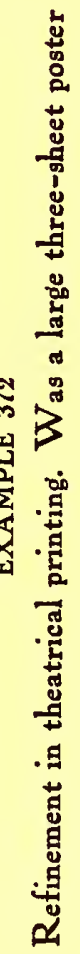



Example 373 (Insert).-The "Secession" style of border and ornament blends well with monotone type-faces without serifs, such as the type commonly known as gothic. As the wood-type equipment of most printshops very likely includes gothic faces, the style of treatment shown by this specimen may be produced successfully. A border such as this is easily procured, or can be made by the printer if he desires.

Example 374,-Printers seldom take advantage of the opportunities offered for unusual effects. This copy did not suggest anything to the compositor who first set it and the result was commonplace, with nothing to excite anything but ordinary interest. The fact that the birth of Franklin was to be celebrated should have been sufficient to suggest an arrangement such as is here presented, but it did not. Benjamin Franklin purchased his type in England, some of it at the old letter foundry of the Caslons; and what is more interesting than a poster announcement of a Franklin dinner set in the style of type-face that Franklin himself used?' This has been done in the example under consideration. Roman, italic, capitals and lower-case have been blended in the interesting manner in which this was done in the eighteenth century. The long $s(f)$ of Franklin's time is also used, to carry along the interest; it appears, as will be noticed, in all cases excepting at the end of words. A Caslon ornamental band is at the head and foot.

ExaMple 375.-This is another instance where the copy furnished a motif that could be developed typographically. Reproductions from the First Folio of Shakespeare's works were available and from them an initial and two decorative bands were enlarged to the desired size. The typography of Shakespeare's time was then studied and worked into the poster. The Caslon type-face is not exactly the same as that used in the seventeenth century, but there is sufficient similarity to make it suitable. Many persons of the present day will shy at the use of a single capital letter immediately following the initial, but that is the way it was done in the old days. Typographers should early begin to accumulate a library of books. They should frequent the second-hand bookstores, and occasionally purchase some old volume that shows the style of typography of fifty, one hundred or more years ago. The best printers do this.

Example 376.--It should be an easy matter to produce attractive window cards or paper hangers in this style. Selections from the many artistic and odd cover papers obtainable, supported by harmonizing color combinations, make possible any number of attractive effects. Only one size of type should be used, and the border should be one that reflects the character of the type-face. Plain rules for border purposes are more successful in obtaining harmony than is decoration. As most letters contain two widths of line, a rule border matching the wider line, or both lines, is pleasing.

ExaMple 377.-The Colonial style of type arrangement is here adapted to window-card purposes. The window card has the same adrertising reason for its existence as the paper

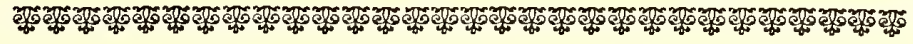

\section{The Los Angeles PRIN TERS' Board of Trade}

will obferve the $12 \mathrm{fft}$ Anniverfary of the birth of

\section{B. F R A N K I N,}

Patron Samt of the Craft,

At the Hollenbeck Hotel, at 6:30, of Tuefday, January 28 th.

$$
\text { स } \$ \text { स }
$$

$A^{s}$ a fitting obfervance the program has been falhioned with a view to the prefent-day needs of the fmall printer On this fpecial occafion every commercial printer and allied craftfman thould confider it his fpecial privilege to be prefent. Lay afide all excufes and gather on this occafion to do honor to the memory of THE GREATEST AMERICAN PRINTER All fupply falefmen can furnif b you with tickets at 75 cents each.

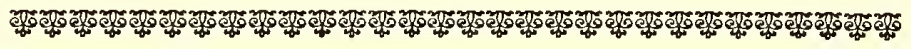

EXAMPLE 374

Type treatment that suggests Franklin's time

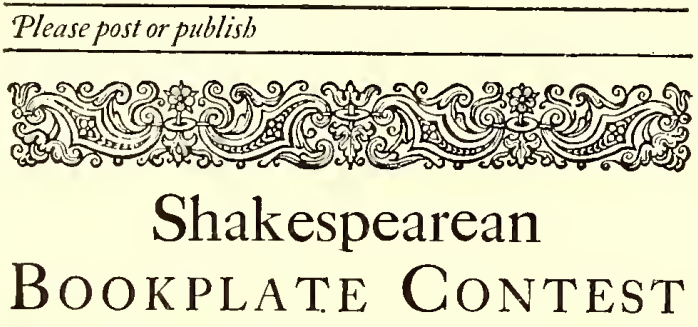

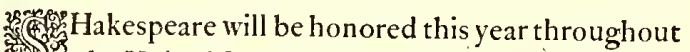
(t) United States. Schools, universities, and organizations of various kinds are planning fitting forms of observing the Sbakespeare Tercentenary. With the purpose of further stimulating interest in the works of the great poet, The American Institute of Grapbic Arts, in conjunction with the Shakespeare Birthday Committee of the City of New York, will conduct a Book PLAT E Contest. The prizes to be awarded should be an incentive, but the pleasure of designing a bookplate in the spirit of Shakespeare should be the chief stimulus.

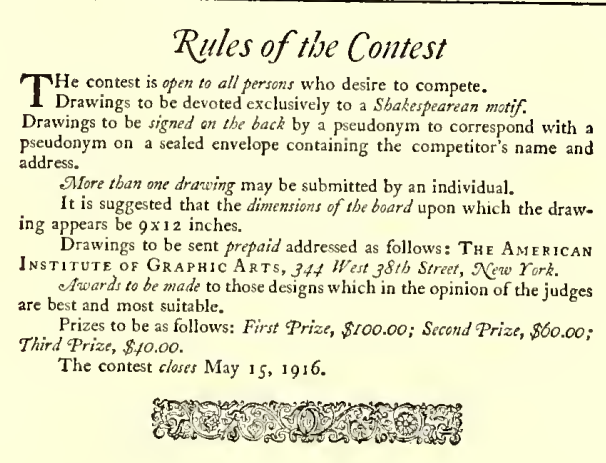

C O M M 1 T T E E

For the American Institute op Graphic Arts: John Clyde Oswald, President; J.H.Chapin, J.Thomson Willing. F о т тн в SH A K ZSpzare Birthday Commitrez: Henry Clews, Chairman; John DeWitt Warner, Treasurer; Mrs. James Madison Bass.

Poster in Shakespearean typography 
See the Merry Minstrels at the Crescent Theater

\section{every evening Now}

A simple typographic treatment that offers possibilities for attractive posters or window cards

poster, and is printed on cardboard to enable it to stand upright. The treatment of this eard is such that the word "Pinafore" and the decoration stand out most prominently, taking for granted that a person interested by the sight of this word will come close to the card and read it. Such an arrangement should not be intempted unless the copy is suitable. Forcing unsuitable copy in full-line Colonial arrangements results in illegibility and dissatisfaetion.

Example 378.-Sunday-school exeursions furnish copy for many window eards. The printer may appreciate this suggestion for an arrangement of such a job. It is sufficiently unconventional to attraet attention, at the same time providing a simple way of arranging the matter that usually comes in with such orders. The arrangement has merit from an advertising point of view, the information being given concisely and legibly.

It is probably true that the majority of printers have given no thought whatever to the arrangement and treatment of posters. It is even likely that there are job printers who feel that poster composition is beneath their dignity. In view of these eonditions, it is to be hoped that what has here been written regarding the poster will serve to create new interest in that line of work.

Years ago the author knew an old printer who had the reputation of being the best sale-

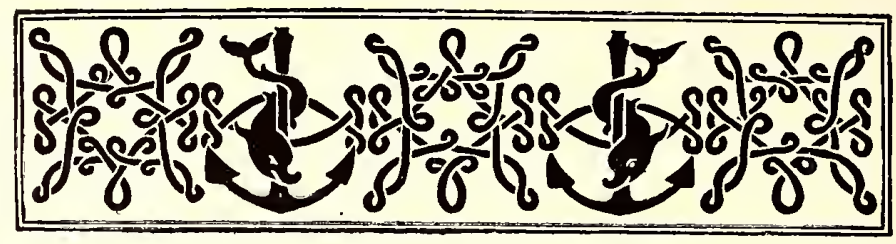

GRAND REVIVAL OF GILBERT \& SULLIVAN'S NAUTICAL OPERA

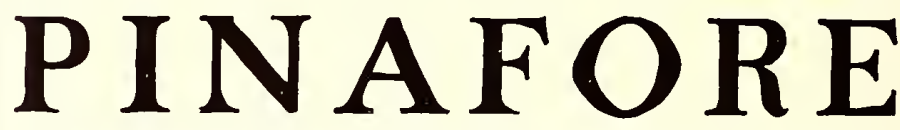

SING SING ACADEMY OF MUSIC DECEMBER THE TWENTY-SIXTH NI NETEE N H U N D R D FOUR

\section{EXAMPLE 377}

The Colonial style used on a window card

bill compositor in the county. His work was continea almost entirely to the sctting of posters announcing sales of farm goods, yet he did it so carefully and efficiently that residents of the eounty traveled miles to place an order with the eoneern for whieh this man worked.

Poster printing should not be attempted unless the equipment is such that the work can be done profitably. Lack of suffieient wood type will result in poor printing and makeshift arrangements. However. absence of equipment did not worry a certain printer who did business some years ago. He had no wood type at all, yet he aecepted orders for posters and, taking advantage of the craft eourtesies of those days, borrowed all the type lines from a eompetitor. It frequently happened that when the competitor desired to set up a bill he found that the type was mostly in the possession of the borrowing printer.

The large two-sheet and three-sheet posters look very big indeed to the printer in the small shop whose produet is confined to the output of his platen presses, yet poster printing is merely printing on a larger seale. The builder of the New York subways was onee asked how he found it possible to put through such a large undertaking. He replied that he knew he could build a cellar, and a subway was merely a multiplication of cellars. The printer who learns how effeetively to produce a small picce of printed advertising matter should be able, by developing and enlarging on his ideas, to prodnce good poster work.

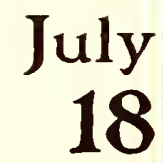

Annual Excursion St.Mark's Sunday School to

Meluscong

Fare
$50 \mathrm{c}$ on-the-Hudson by Steel Boat Line Leave Pier at 9 A. M.

EXAMPLE 378

Suggestion for an excursion window card 



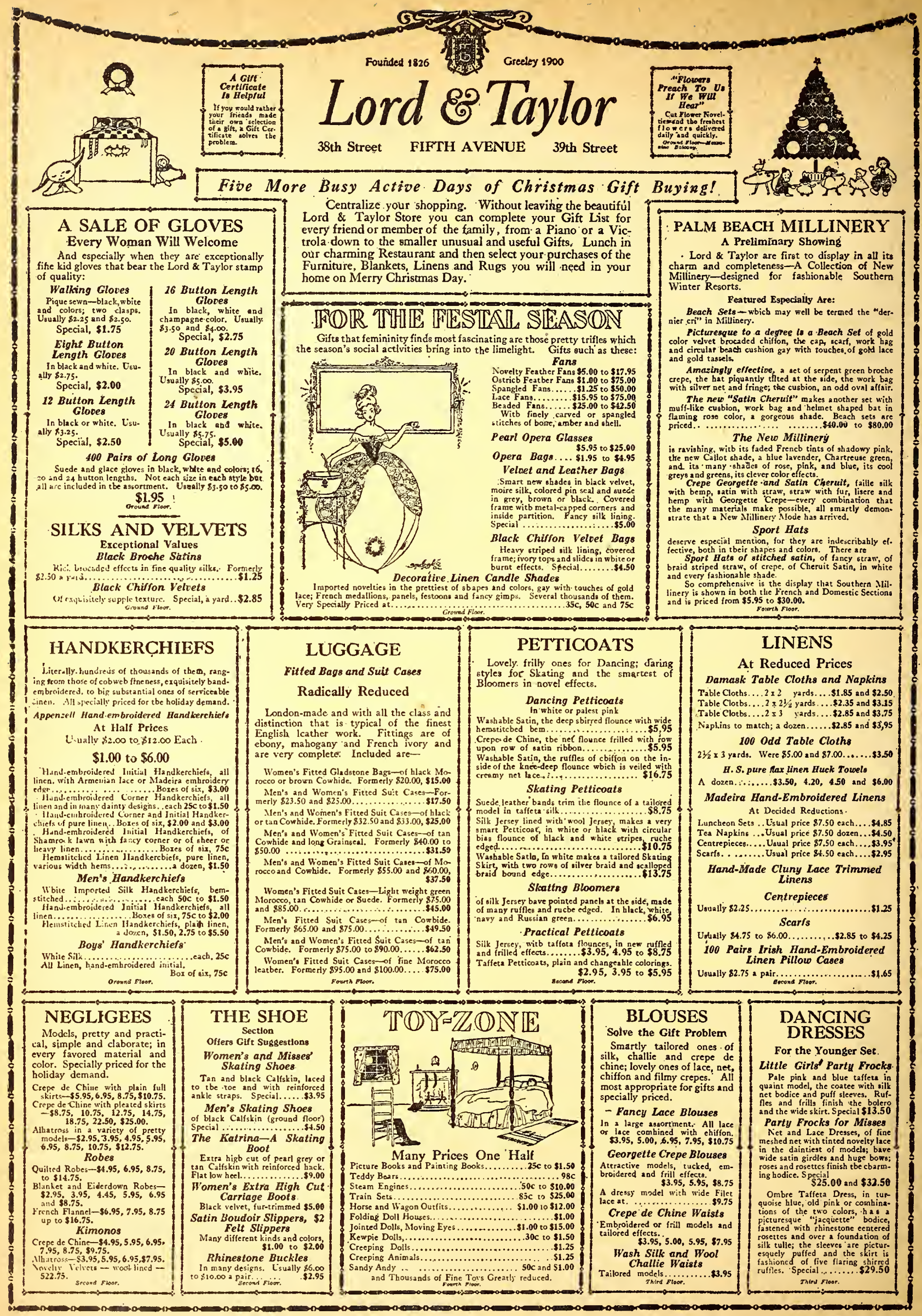

EXAMPLE 381

A city department-store advertisement of the good kind 


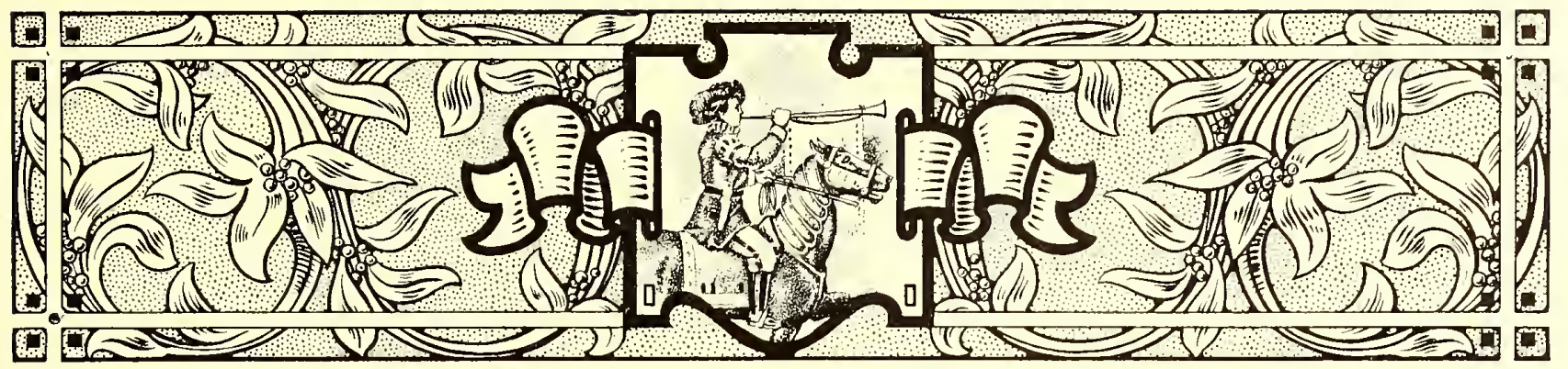

\section{ADVERTISEMENTS}

NO'T every business man can write an advertisement well.

Not every printer can set an advertisement well.

Of the poor advertisements that mar newspapers and periodicals, fifty per cent of the ineffectiveness should be blamed on those who write them and fifty per cent on those who set them.

In this chapter we are interested not in writing the advertisement, but in properly treating it typographically after it has been written.

Some day advertising typography may become so standardized that a compositor can be told in a few words just how he shall arrange it. Meanwhile as there is more than one way to set type for advertisements, we must for the present depend on the study of good type work, the advice of those who have theories, and our own judgment.

It is possible, however, to learn something about advertising typography by giving thought to the ways of the orator, who swayed human beings long before printing was invented. We have all listened to oratory in the church pulpit, the public square and the Chautauqua tents, and in halls on the occasion of political gatherings and organization conventions. Our most agreeable recollections are of those moments when we were so pleased and impressed with what the speaker was saying that we did not think of his manner of saying it. Probably the most successful printed matter is that which pleases and impresses without one's being immediately aware of the cause.

A good speaker will enunciate clearly and speak in a moderate tonc that can be heard.

A good typographic advertisement will be set in a legible type-face and in a sizc that can be easily read.

Print can be too small or too large, too gray or too black.

\section{TIMES BUILDING TIMES SQUARE}

Large, light rooms, with all modern equipments, to rent in the Times Building-the centre of New York's many activities. 2,050 square feet on a floor, making six or more rooms. Suit lawyers, physicians, real estate men, architects. Building open day and night. Elevators always running. Trains and cars in all directions. Subway station in building:

Renting Agent-Room 406. Telephone 1000 Bryant

EXAMPLE 379

Newspaper advertisement arranged without thought. See 380

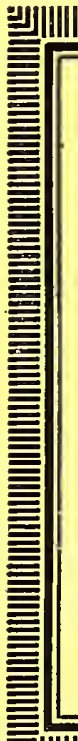

\section{Times Building}

\section{Times Square}

Large, light rooms, with all modern equipments, to rent, in the Times Building - the centre of New York's many activities.

2,050 square feet on a floor, Elevators. always running. making six or more rooms. Trains and cars in all direcSuit lawyers, physicians, real Trains and

estate men, architects.

Building open day and night. Subway station in building.

RENTING AGENT-Room 406

Telephone 1000 Bryant

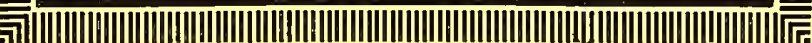

EXAMPLE 380

Easier to read and more pleasing to look at than 379
If a speaker is addressing an exclusive group of persons, he lowers his voice and talks in polite diction.

If he addresses a large crowd, many of whom are of less fastidious tastes, he raises his voice, perhaps using all his power, and most likely mixes with his English a little popular slang.

Thus advertising printing of the exclusive kind would likely be set in type smaller and in design more classic than that used for publicity matter that has wide and promiscuous circulation.

The typographer must keep in mind that while bluntness and forcefulness are liked by some, they give offense to others.

There are orators so eloquent and flowery that one is led away from the message by pleasure and admiration for qualities that should merely carry the message.

There are advertisements so attractive in decorative beauty that one sometimes forgets to read them.

And then there is the heavy-voiced orator who emphasizes every statement. He startles and he tires, and is as unsuccessful as the speaker who croons his audience to slcep with uninteresting monotones. How like such 
THERE are two ways to insure the best possible Terra Cotta construction, in appearance, in safety, and in economy.

One way, and except in certain circumstances the best, is to keep the Terra Cotta contract separate from the general contract, and engage the Terra Cotta Manufacturer to erect his own material.

The other way is to specify, "The General Contrartor shall engage an experienced Terra Cotta Fitter from the Terra Cotta Sub-Contractor to supervise and assist in the erection of the Terra Cotta".

It is perfectly evident that such a clause is to the advantage of every one concerned. The General Contractor employs an experienced man at regular union wages where he might otherwise employ an inexperienced man at the same rate.

An Atlantic Fitter works rapidly and efficiently and is paid only for the actual time at work. On days when for any reason there is no Terra Cotta work, he may be used to assist at other masonry work.

With such a man on the job the Architect and the Owner can be perfectly confident of the best possible results, and our interest is in line with theirs in knowing that the Atlantic Terra Cotta has been properly handled and properly set.

\section{Atlantic Terra Cotta Company \\ in Broadway, New York}

$$
\text { COPYRIGHT } 1916
$$

EXAMPLE 382

The conversational style of page advertisement

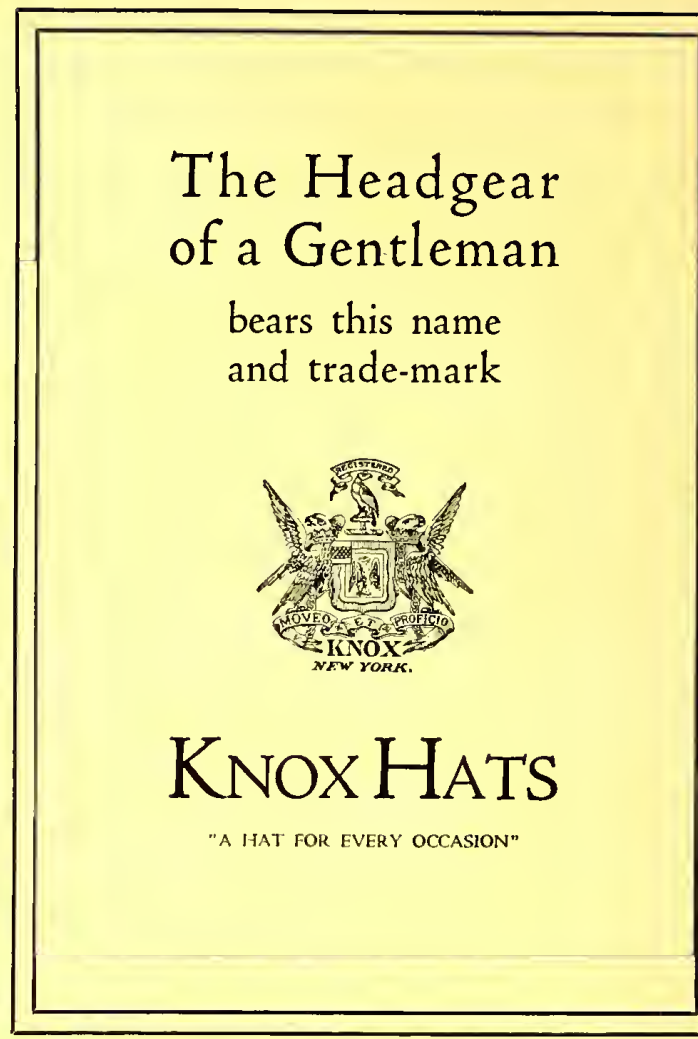

EXAMPLE 383

The name and the trademark depended on to sell goods

he started out to do was to make the message easy to read. He labored from the viewpoint of the reader and not from that of the advertiser or printer. The difficulty usually is that the merchant and typographer are too close to the details of their own daily occupations and fail to view the advertisement as does the prospective customer.

The important first sentence was emphasized by subordinating the type below. The smaller type is nevertheless casier to read than the same words as originally arranged. The border serves to catch the reader's attention, as in the newspaper this little advertisement dominated the page.

Example 381 (Insert). - The department-store advertisement as represented by this example is really a multiplication of small advertisements. It is necessary for the writer and printer to give attention in detail to each of the small paneled advertisements, but some one must assemble them into a harmonions whole. This is usually done by first making a layout in actual size. Such a layout as planned for the Lord \& Taylor page under consideration probably looked just as this advertisement would look if everything but the panel borders, headlines and illustrations were removed. Each panel was numbered, and the copy in each instance contained a corresponding numeral.

The style of lettering used for the firm name (Caslon italic) is a sort of trademark, as it is to be found on the store's stationery, on its building and on its delivery cars. The ornamental border, especially the festoon effect at the head, 


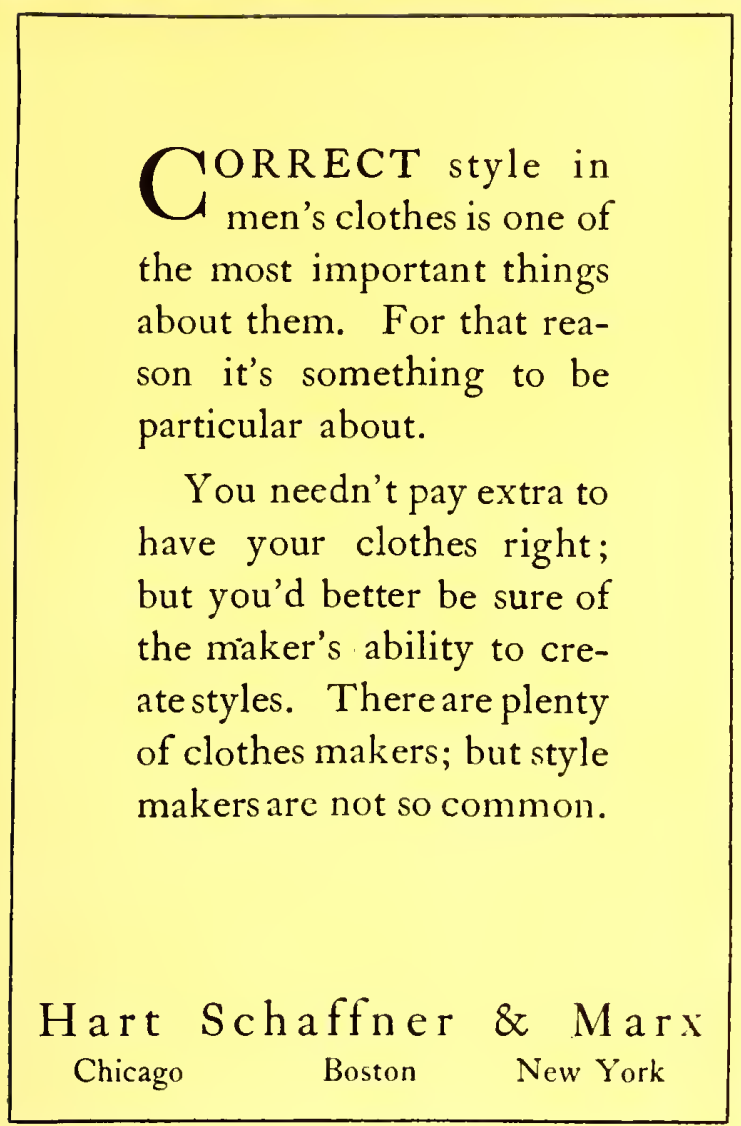

EXAMPLE 385
Interesting use of white space

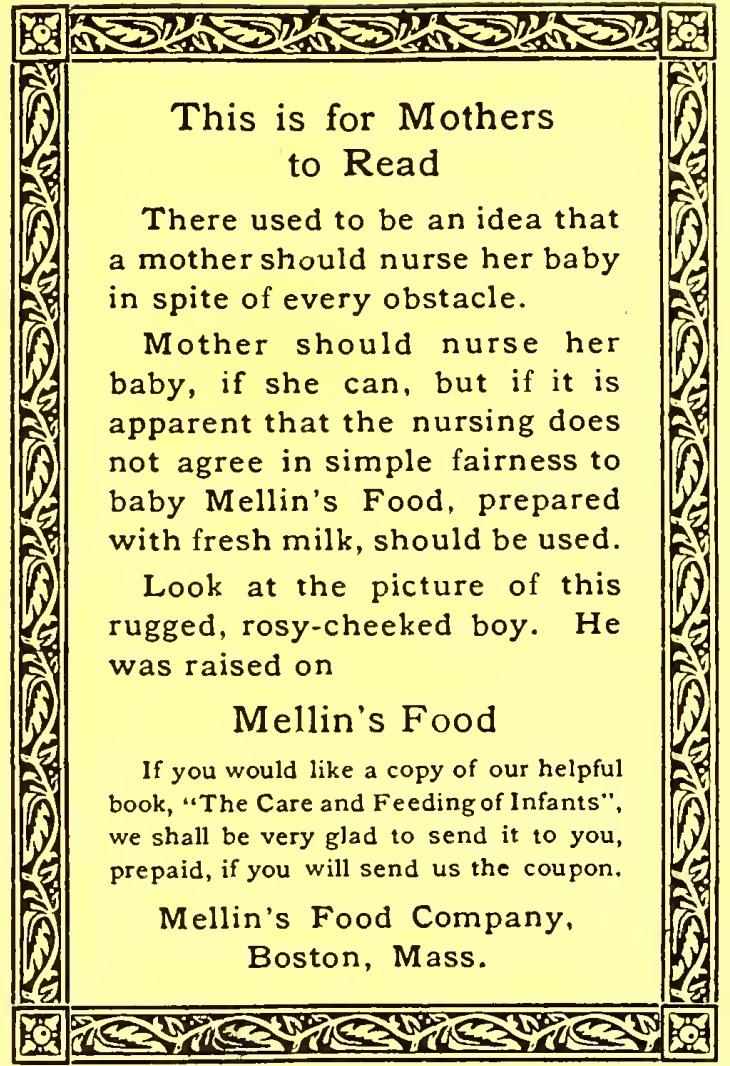

EXAMPLE 386

A bordered advertisement is used in all the newspaper advertising. It will be noticed that two of the panels have been accentuated with stronger borders, larger headlines and with decorative illustrations. They are so placed in the general group as to balance pleasingly. Prices are emphasized, but not as they usually are by department stores that appeal more to the class of people who for economical reasons find it necessary to take advantage of bargains. The names of articles in the Lord \& Taylor advertisement are set in a neat, bold typeface.

Example 382.-This is one of those easily read, conversational styles of advertisement set in Caslon Oldstyle. The first paragraph, in type a size larger than the rest, invites the attention of the reader. The ornament in the upper left corner adds attraction at the introductory point.

Example 383.-Like the house of Tiffany, the makers of Knox liats do not have much to say in their advertisements. The name and the trademark are depended on to sell the hats. Cloister Old-

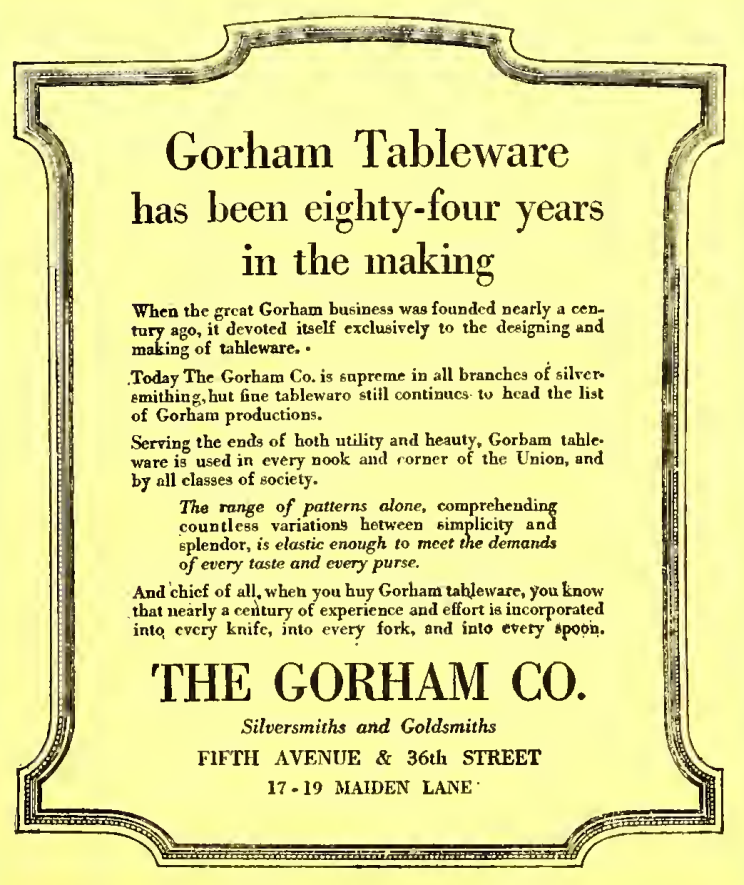

EXAMPLE 38 A study in advertising values style, the type-face, surrounded by liberal blank space, is effcctive.

Example 384.- The purpose of this advertisement is to popularize zine, and for this reason that word stands out so prominently. The rule band at the head and foot attracts the attention, and the Caslon type-facc makes the advertisement readable.

Example 385.-An easily read advertisement, due to the size and kind of type and the use of blank space. Hart, Schaffner \& Marx appreciate the value of good typography. The two-line initial at the head guides the eye to the beginning of the message. The signature at the foot is so placed that it is not forced on the attention, yct it cannot be missed after the two large paragraphs have been read.

Example 38ri-This arrangement of an advertisement shows a style liked by the Mellin's Food Company. The decorative border confines the attention to the reading matter it contrins, which is presented in Old-Style Antique, a dark-toned, interest- 

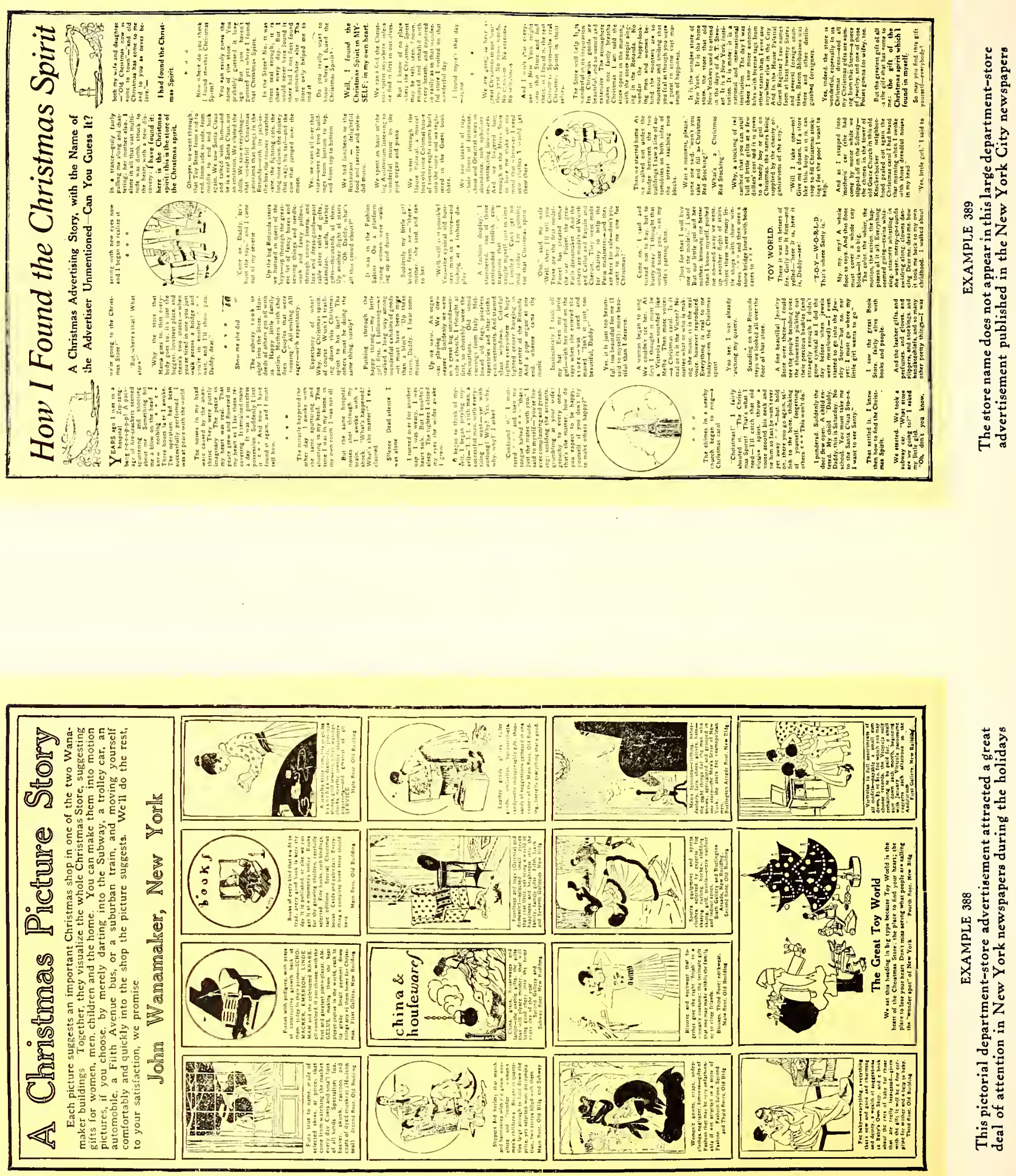

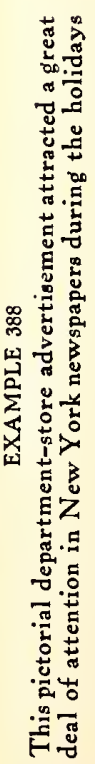




\section{Buy Your Christmas Presents at Home}

We have an attractive stock of

PIANOS

会会TOYS 基是

VICTROLAS

CABINETS

RECORDS

ROLLS

Etc.

DRY GOODS

MEN'S FURNISHINGS

RUGS, CHAIRS

CROCKERY
CLOCKS

WATCHES

RINGS

LOCKETS

FOBS

Etc.

\section{BARNES \& LEWISTON}

Near the Post Office

General Store

WELLSTON, MAINE

RALPH W. CURRENT

\section{PLUMBER}

Steam and Gas Fitter

REPAIR WORK

MY SPECIALTY

Ask for estimates on Steam and Hot Water Heating Plants. Arrange now for summer work at summer prices

My charges are fair and

my work is satisfactory

ON THE WELLSTON TURNPIKE

Phone 146
DAN SMITH

COAL

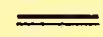

Full Weight and Best Grades

PLACE ORDERS NOW

FOR EARLY SPRING DELIVERY

EAT AT THE NEW

DEPOT

CAFÉ

Regular Dinner, 30 Cénts

W. MERZ, Proprietor

EXAMPLE 390

Four country-newspaper advertisements, showing slight variation in border treatment 



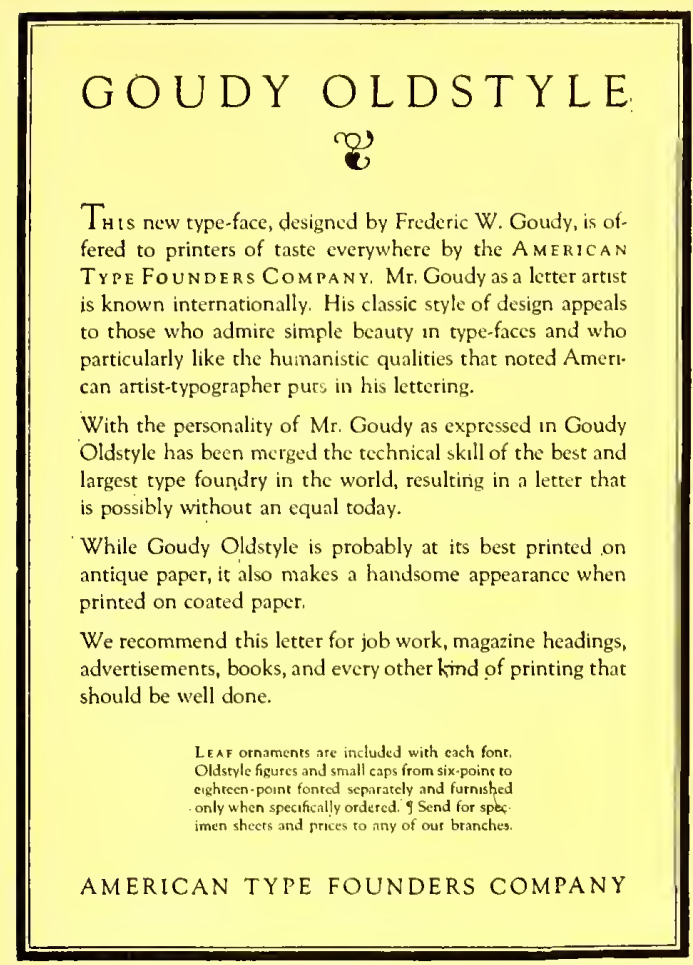

\section{A good-looking page advertisement that was easily read}

ing, legible type-face. The display lines are emphasized just enough to make them stand out from the main portion of the text.

Example 387.-The principal points in this advertisement are the name of the company (which is accentuated to catch the eyes of the many who know this house) and the three lines at the head (which are informative to those who may not know the Gorham company). This advertisement serves well as a study in advertising typography. Careless handling of it in the composing-room would have spoiled its effectiveness. The border has probably been used to attraet attention, yet it does not interfere with the reading of the advertisement, as the typographer has maintained a liberal margin around the type matter.

Example 388.- This is one of the many clever advertisements that are inserted in newspapers by Joln Wanamaker, and is different from most others because it is a pieture-story of the goods on sale. The type matter is secondary thruout excepting in the introductory panel at the head, which is displayed merely to eall attention to the style of the advertisement and to the name of the advertiser.

Example 389.- Few printers have seen a departmentstore advertisement just like this one. It does not eontain the name of the advertiser, and there is practically no display. It looks more like a story in a general magazine. A few circular illustrations are so placed as to relieve the monotony of the columns of text, and a deeorative piece is placed on both sides of the heading. The page is also made interesting by the use of space between paragraphs.

Example 390 (Insert). - The most difficult eopy to arrange well is probably that supplied eountry newspapers by their advertisers. There is seldom much to the copy, and it is almost always necessary to use display unsupported by the solid paragraphs of text that soften the contrast in advertisements that appear in eity dailies. Here are four advertisements different in size and representa-

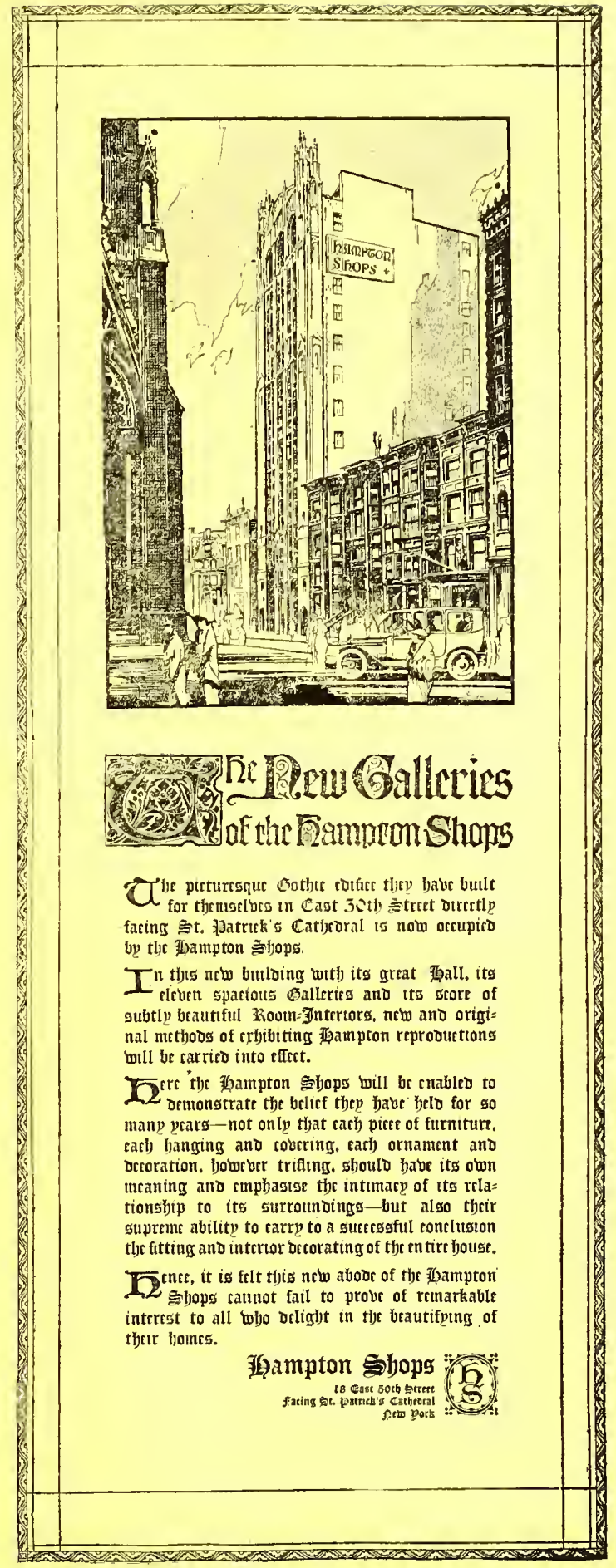

EXAMPLE 392

Typography and shape of this four-column advertisement suggested by the architecture of the tall building pictured

tive of small-town business. Some one has urged that fancy borders be not used in the small-town newspaper, and that the rules for borders be the same thruout. This advice is probably wrong, as it was tried in this instance and the effect was found to be monotonous and uninteresting. The same rule border is used around eael advertisement, but to obtain contrast an additional rule has been added to the coal advertisement and a holiday border and another rule to the general-store advertisement. These slight variations in border treatment add a great deal of interest to the page. Each advertiser is entitled to an individual hearing, 


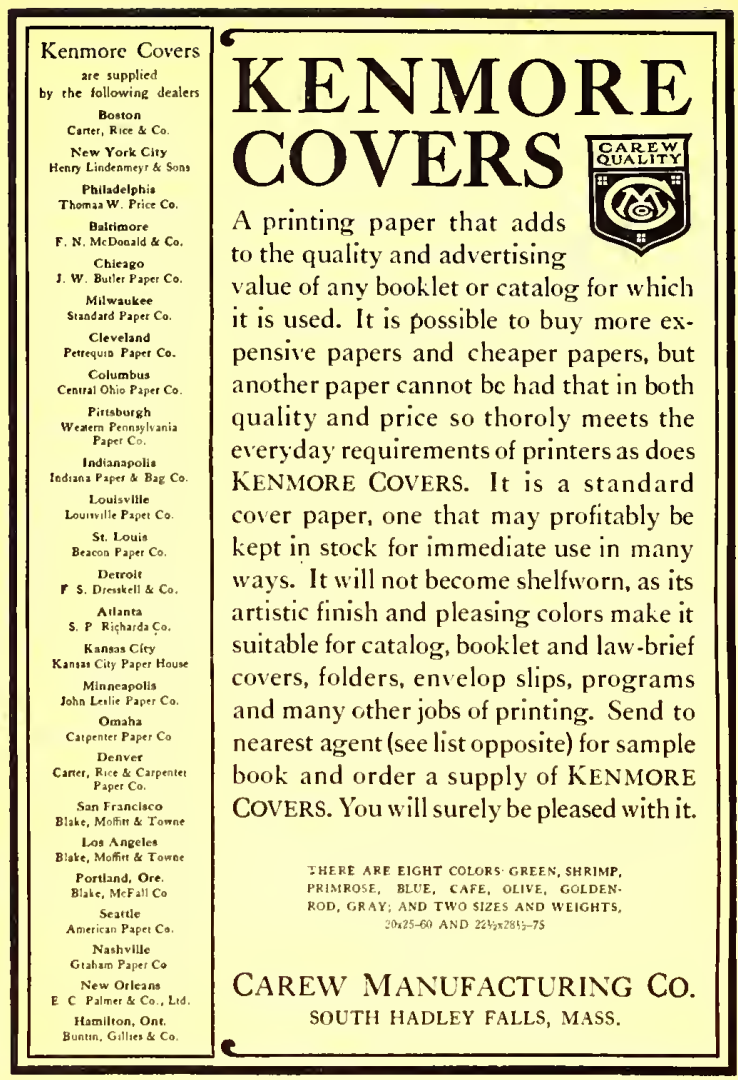

EXAMPLE 393

A page in which attractive typography was possible in spite of a long list of agents

and this is only possible when there is some distinct feature found in his advertisement alone. In the city newspapers each department store usually has a distinctive type-face which appears in no other advcrtiscment. In the small-town newspaper it may not he possible for the publisher to render such service, but an eff ort in the same direction can be made by varying the border treatment. The type-faces used in this example are Bodoni and Bodoni Bold. With the use of the Bold, emphasis is given at proper points in each of the four advertisements. In the largest one it is used for the name of the firm, in the smallest one it sets forth the name of the café, and in the other two advertiscments it emphasizes the name of the business. There may be another way to arrange the names of the articles in the general-store advertisement, but it is doubtful if any other arrangement would make reading easier. Typographers who are inclined to treat lightly the problems of the small-town printer should attempt to improve these advertisements.

Example 391.-The style of treatment of this tradejournal advertisement is influenced to some extent by the articlc advertised, yet there is no reason why this treatment would not be suitable for many advertisements of another kind. The heavy-and-light-line rule border is of a darker tone than the type page and for this reason adds color and interest. There is sufficient blank space between the border and type matter to allow for the text being read without interference. The capitals in the headings are letterspaced, the letterspacing not only giving them character, but making them more legible. The text matter is introduced with an initial that extends upward from the first line instead of downward as most initials are placed. This advertisement is of the conversational style, arranged for easy reading.
Example 392.- Some one has decreed that text types shall not be used in advertisements, but fortunately those responsible for the planning of this advertisement paid no attention to the decree. The advertisement was inserted in newspapers for the purpose of calling attention to the new building in the Gothic style of architecture erected for the Hampton Shops. Any one who has studied the details of a Gothic structure such as this or the Woolworth Building has felt the influence of the long, narrow lines found in Gothic architecture. The shape of this advertisement and the thin, pointed character of the text type used are in splendid harmony with the general idea.

ExAMPLE 393.- There was presented to the designer of this advertisement the problem of including in legible size a long list of cities and agents and yet reserving sufficient space in which to give due prominence to the text matter. The solution of the problem was the long, narrow panel at the left. While the entire advertisement is easily read, especially in its larger form, and probably has the approval of those who insist on legibility in advertising composition, there is yet something about it that will also interest those who maintain that typography should be built on art principles. The border, trademark and name of the article advertised blend in tone, while the remaining type matter shows a pleasing gray. Inserting the trademark in the space left by the shorter words of the heading makes the effect unusual.

Example 394.- This is one of a series of newspaper advertisements prepared for the Locomobile Company by T. M. Cleland. Planned to sell automobiles costing five or six thousand dollars, it naturally is treated differently

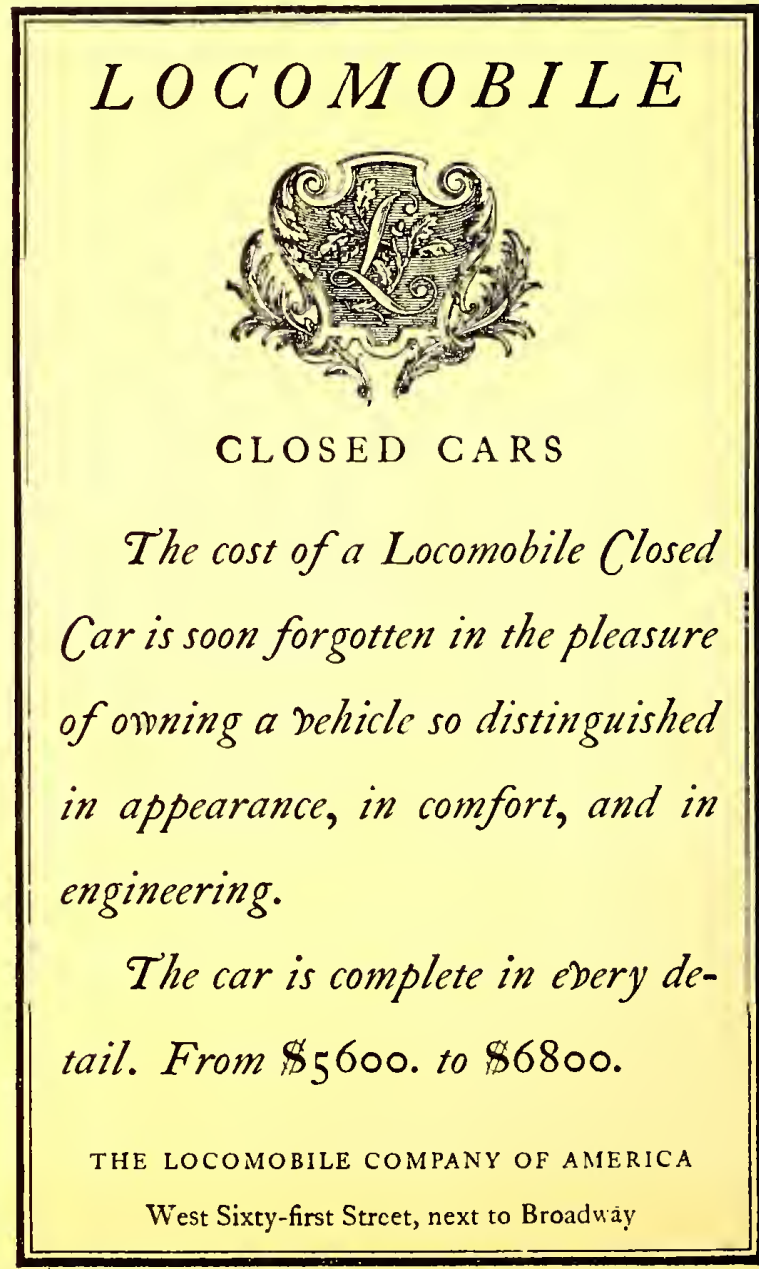

EXAMPLE 394

An advertisement planned to sell high-priced cars 


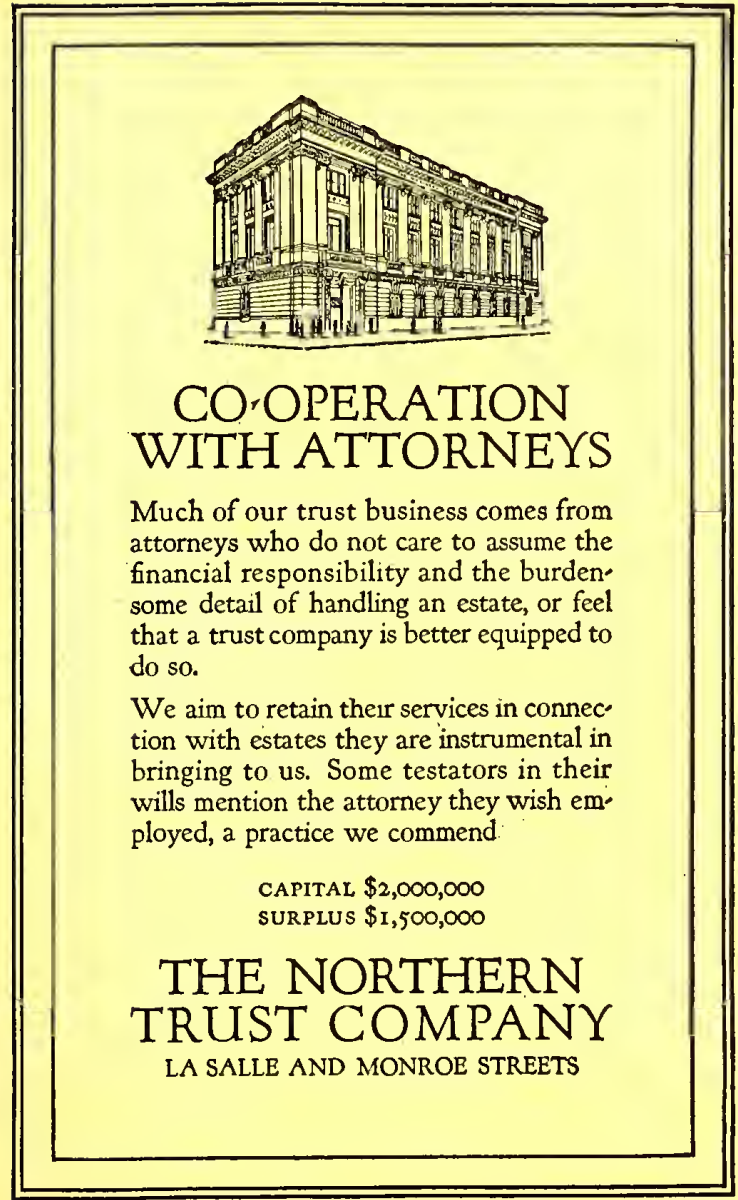

EXAMPLE 395

Roman lettering and Roman architecture

from an advertisement that would sell cheaper cars. The decorative crest is a factor in the effectiveness of this advertisement, and the italic with the swash capitals helps to give a touch of exclusiveness. It is an advertisement that will stand out on the average newspaper page.

ExampLe 395.-This advertisement has qualities similar to those of Example 392, the typography of which was suggested by the architecture of a building. Here we have an illustration of a building in Roman architecture, hence it is suitable that the type should be Forum, which is based on Roman carved lettering, and that the border should contain lines that suggest an architectural panel. Of course, this matter of harmonizing the plan of an advertisement with the architecture of a building can be overdone. An advertiscment is not necessarily a good advertisement because of such harmony, yet if an advertisement is readably presented, harmonious type selection and arrangement should add effectiveness.

Example 396.- This advertiscment in a way suggests Example 385, and in contrast with that cxample furnishes a study in the use of blank space. In the Hart, Schaffner \& Marx advertisement the margin is equal on both sides, and monotony is avoided by having the margin at the foot of the type group more than on the sides. In this Kodak page the text group is courageously pushed to the extreme upper right corner, and all of the blank space is assembled at the left and at the foot. The use of so much space is probably for the purpose of attracting attention, which it undoubtedly does. Nevertheless, it is possible that the advertisement would look better if the text group were treated as in Example 385.
The story of every child is a story of growth and change-

A change too gradual and subele for even the watchful eye of a mother to detect, or for memory to recall.

Only in pictures cas the story be told, and a record of the childish features and expressions kept for all time.

A good photograph now and then, will mean everything to you -and to them, in after years.

There's a photographer in your tocon. Eastman Kodak Company, Rochester, N. Y.

EXAMPLE 396

Uncommon placing of blank space to attract attention

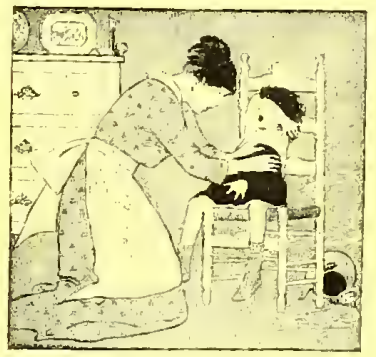

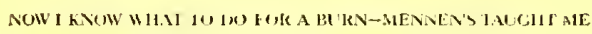

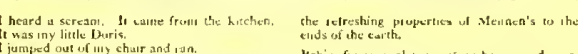

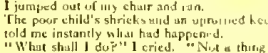

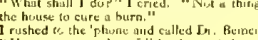

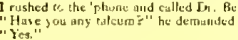
". Whes kind? "Mhennet's Bnrat

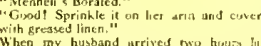
When my kusband arrived two hus the

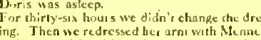

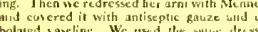

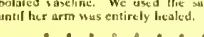

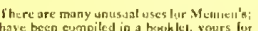
elids of the curther

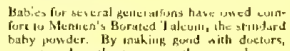

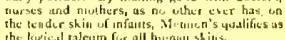

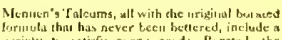

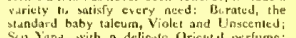

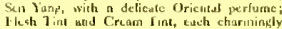

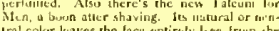

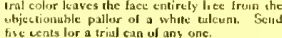
Buy Ialcums tor the Ismily by the tul

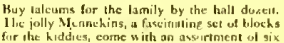

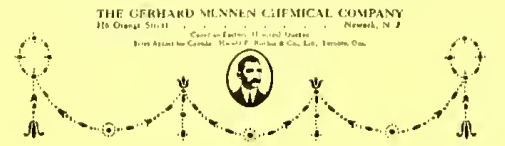

EXAMPLE 397

The modest display of a large magazine advertisement 


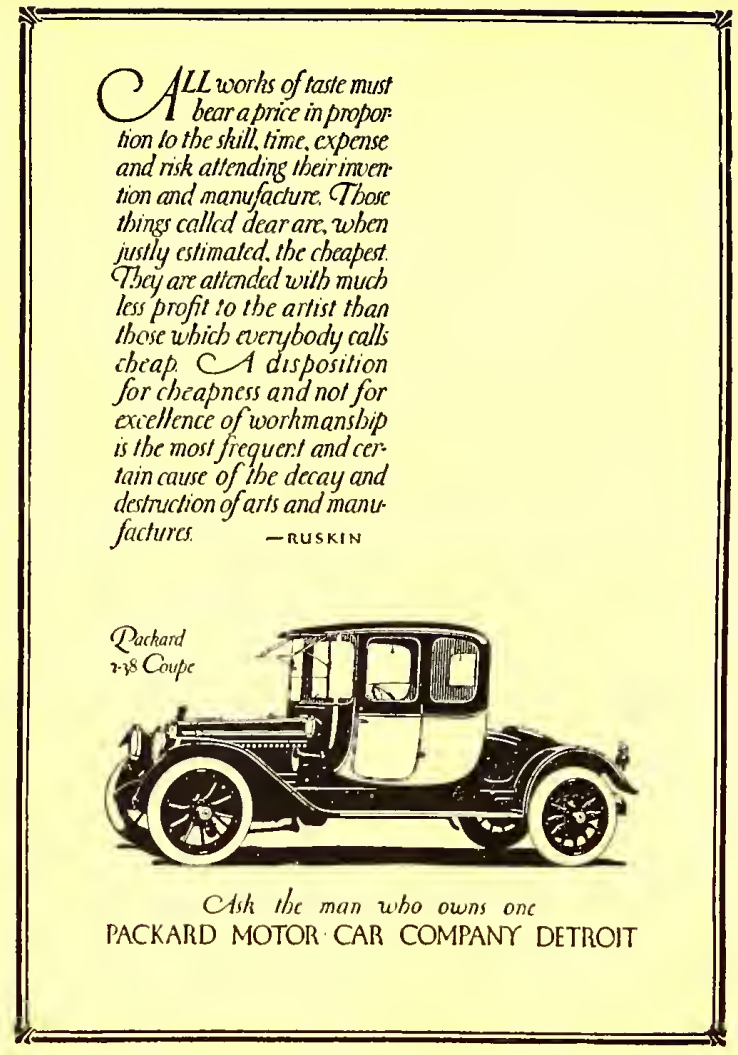

EXAMPLE 398

The blank space emphasizes the illustration

ExanpLa 397.-This advertisement has been reduced considerably, as it originally oceupied a large magazine page. For effectiveness the typographic treatment was depended on, and, as will be seen, it is unusuilly neat. The headline and the name of the company are the only suggestions of display on the page. 'The illustration. of course, is to catch the reader's attention.

Ex.M1'L 398.-Altho this is a lettered advertisement, it is a good eximple of blank spiace used to attract attention not only to the advertisement. but to the illustration, which here is really of the most importance. It should be noticed how the biank spice in the upper right portion clears the way for a view of the antomobile. Many advertisers are nsing a strip of white space in their advertisements, at the right or at the left.

Fximple 3:1:- The treatment of this advertisement proves that it is not abolutely neeessary to have the typography of country-newspaper advertisements as formal as that prescnted in Example 3:1). For general newspaper use Bodoni modern might have preference over the more interesting Cloister Oldstyle, ret a newspaper treated entirely in old-style type-faces would be likable. If this advertisement wore placed on the average newspaper advertising page, it would stand out strongly beeause of the blank space used around the type group, the restful and pleasing type-face and the dark-toned border.

Exiniple 400.- The manner in which this page of advertisements is treated should have suggestion for newspaper and periodical publishers who wish to make their classified-advertising sections more interesting. 'This page, from a trade publication (The American Printer), was set in eight-point type instead of the six-point that some publications usually use. It is a mistake to use type smaller than eight-point for matter that is supposed to be read. The expense and the time necessary to put in initials at the beginning of each advertisement are avoided by capi-

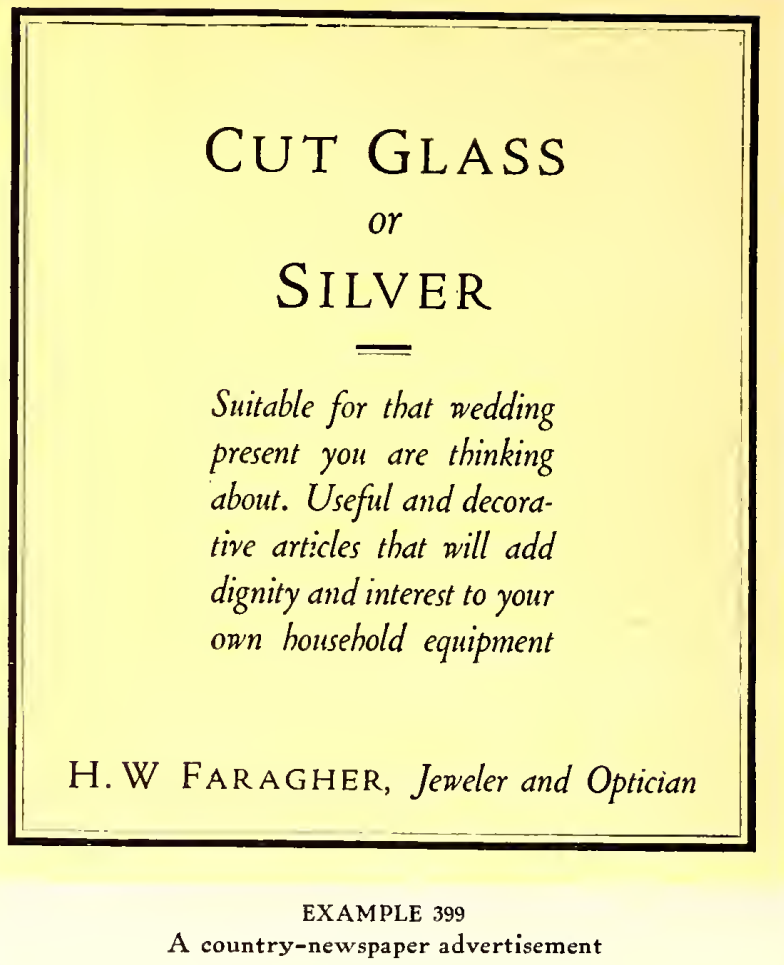

talizing the first word and setting it flush with the end of the line. Instead of using the stereotyped "Help Wanted" and "Situations Wanted" headings, lımman interest was introduced by phrasing each heading as a question, as would likely be done on a larger advertisement.

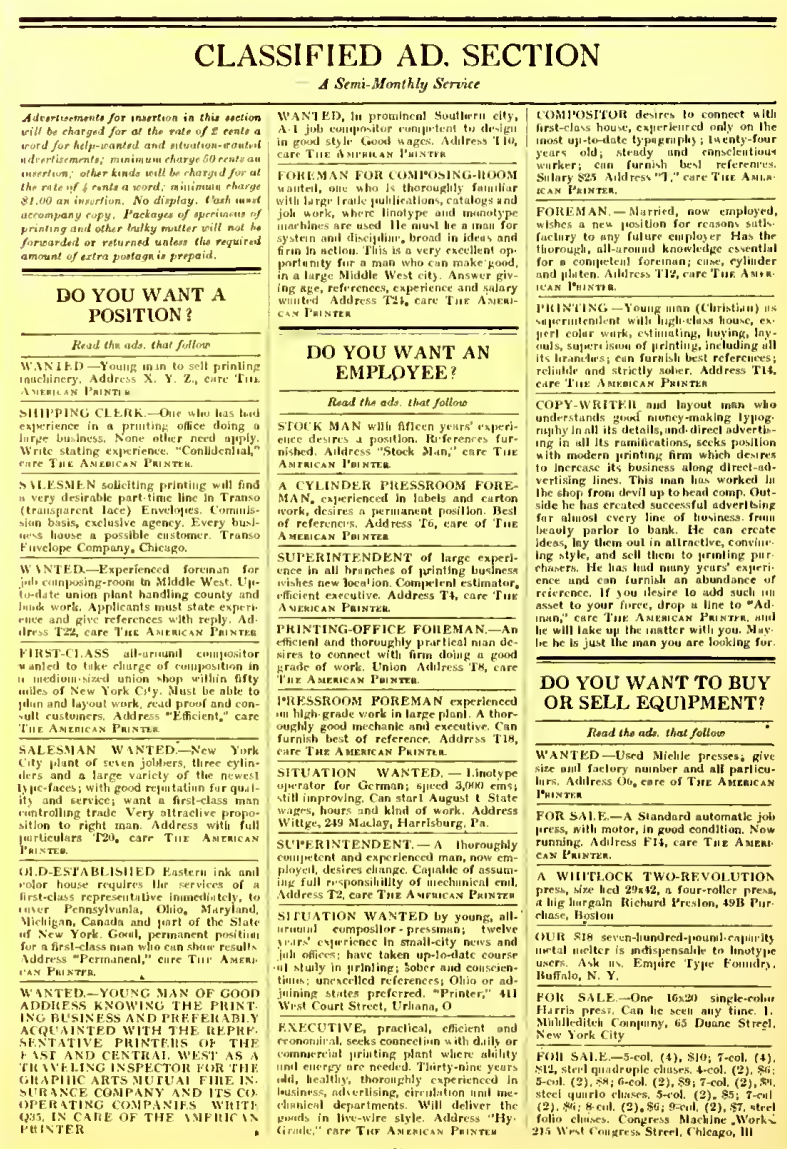

EXAMPLE 400

Suggested for treatment of classified ad. sections 


\section{THE CALDWELL PROGRESS.}

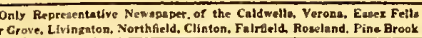

"Avoiding All Malice and Uncharitableness"....Grover Cleveland

Volume II. No. 19.

CELEBRATE BIRTHDAY

Members of Caldwell Club Have a Royal Time on

First Anniversary

SUPPER OF ROAST PIG

Splendid Solos, Side-splitting

For Guests Present

Last Saturday evening the Cals
well Club celebrated its first anuiser-
sary by giving a birthday part' in
honor of the ladies, and followink th
custom of the club the gentlemen of

If the wives, sisters or daughter's

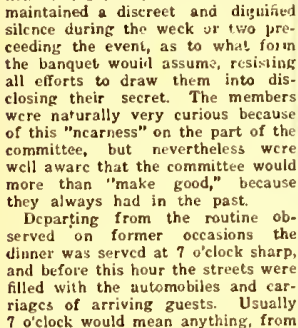

mittec had emphasized the impor
tance of starting the troublc prompt-
y there were few vacant place
when at 7.05 the eighty-five guest

atthough fully two-thirds of the th
liners would have called it turke

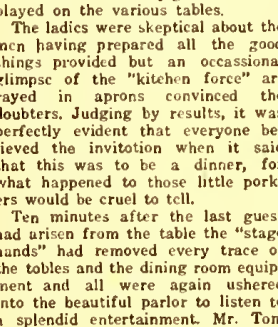

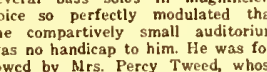

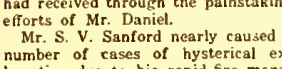

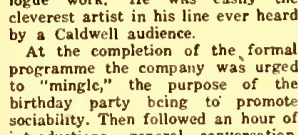

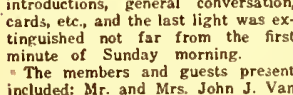

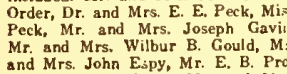

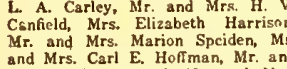

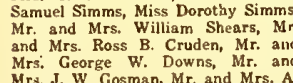

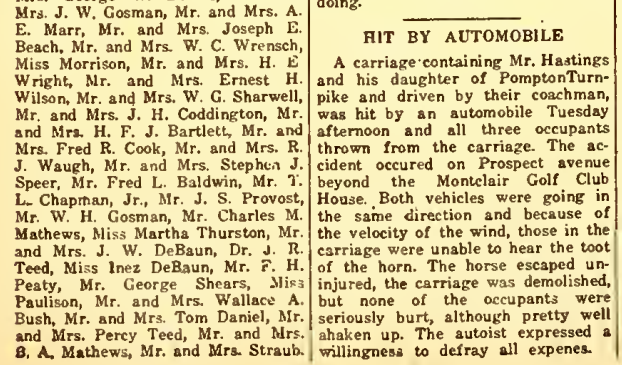

"HONEY GIRLS"

MAKE BIG HIT

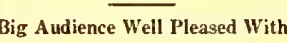

Unique Minstrel Show

CALDWELL, N. J., NOVEMBER 10, 1911.

5 cts. a Copy; $\$ 1.50$ a year.

BIG MAJORITY IN FAVOR OF A CALDWELL SEWER SYSTEM

Only Seventy-One Votes Cast Against the Proposition In a Total Vote of Three Hundred and Sixty Four---Both Bond Issues Were Carried

NO GREAT INTEREST SHOWN IN THE ELECTION

Howard and Block Chosen For the Council in Caldwell--Baldwin Library Wins Out-..-Oakes Mayor of Essex Fells

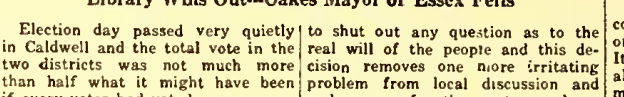
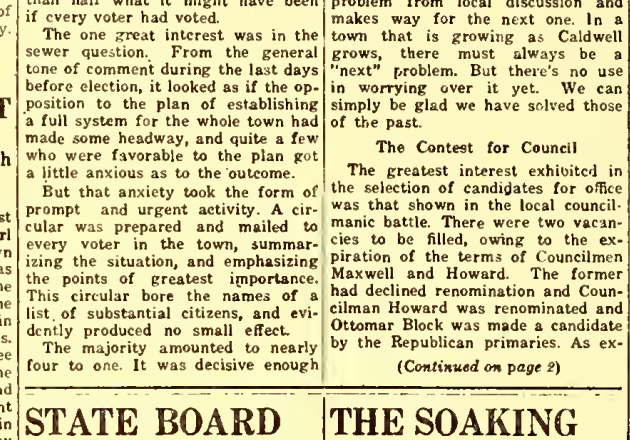

\section{STATE BOARD THE SOAKING}

CALDWELL'S BOARD OF TRADE HOUSES WILL

BE NUMBERED Boa the

Borough Council So Decides At Regular Meeting Last Monday They plan for 2 simple form of
organization whose work shall be carried on by a Board of ten Direct-
ors and seven Committees on subs
jects such as education, health, taxes.
treets and highways, legislation, ete. ACCEPT STREET DEEDS Many Other Civic Matters Were Careful Consideration
A meeting of all who wish to bc-
me identified with the permanent It looks as if Caldwell will tak APPROVES

The Action Taken at Last Falling Fast As Through Meeting of the Caldwell Fair Caldwell's Streets School District There Passed

AFTER A LONG DELAY THE HOST WHO SAID-.The School Board is Now Duly " Behold We Go To See the Field Authorized to Buy Land and Club's Minstrel Show :"

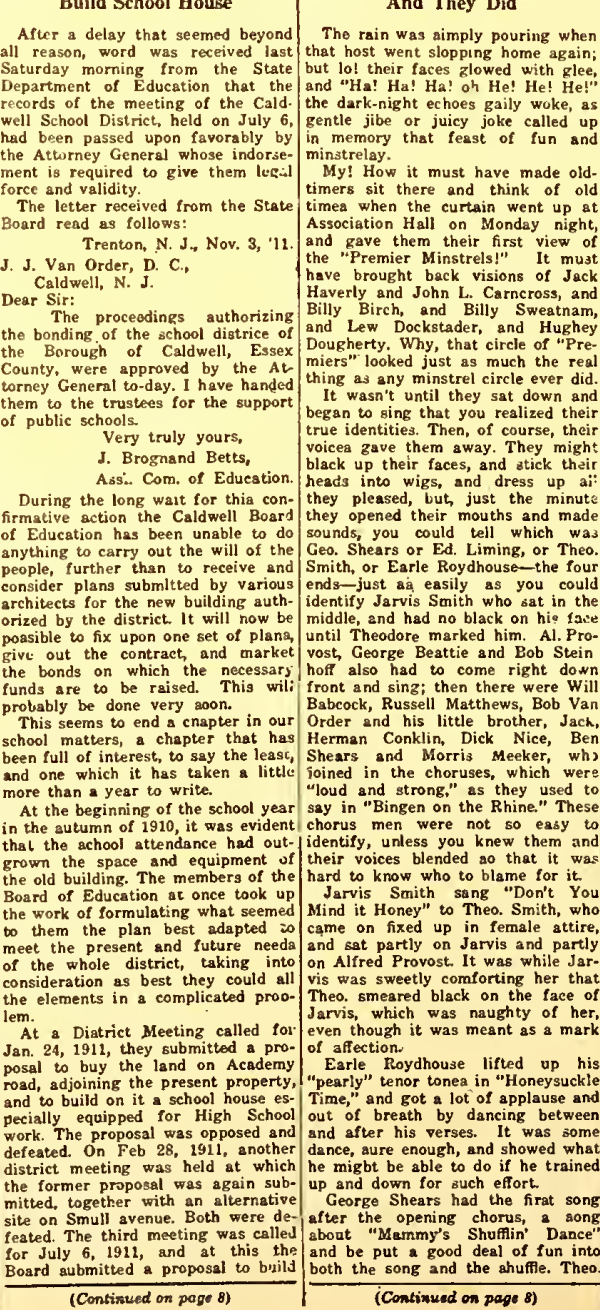$$
\text { " L }
$$

LORNA DOONE" NEXT TUESDAY

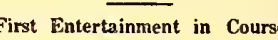

Under Men's Club Auspices
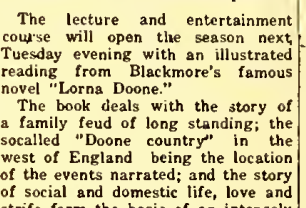
hired professional assistonts, and
with them went down into the Doane
country and took the pictures, with
which he illustrates his reading, on
the very ground where the scene of
the book is laid. The pictures, of which there a
two hundred all beautifully colored two
the
sele
and
rante and
ranks
mod
ent
is
pe
ev

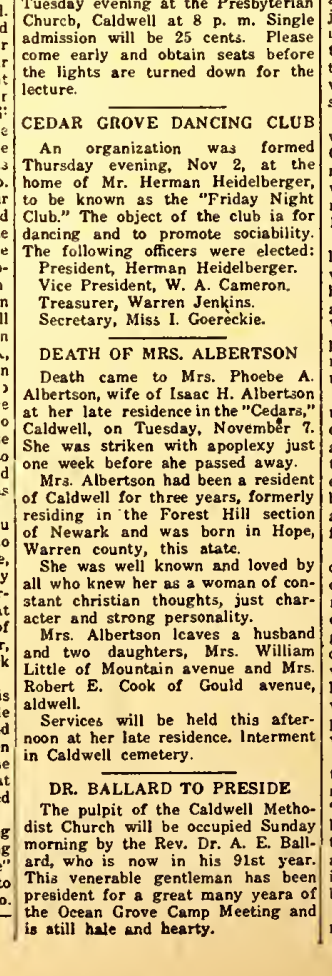
feels certain that those who hear Mr.
Armstrong on Tuesday evening will a pleasant memory for a long tume
to come. course tickets for the six numbers
may be had for one dollarar each from

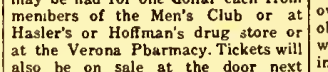

nother step in the profresessive lake
ny having the houses numbered. This

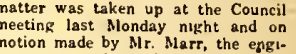
cer was authorized to prepare $a$
system of house numberning and sub-
nit it meeting. This has been under con-
sideration for some time and while dhe plan that will probably be adopt-
dd by the Councit will be somewhat map and in nature, us to make a
mape the houses and lots a urvey to be made of each and every
This would cost more than the
Council feels is necessary at this Mer, the proposed plan will cost ap.
poximately $\$ 50$. Then this is another step toward our free delivery.
Mr. Howard, chairman of the
specal committee to whom had been referred the commissoner's report
on the Park venue matter, made
veltal report revecommending to the
council that they concur in, and con. given considerable etrme to this situd
attion and eney elt that the report
as rendered was the farrest solutioy Deeds of dedication submitted by
F. Corbiere, bearing the dates of

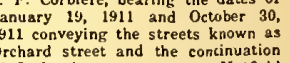
orchard street and the concinuation
of Orchard street west to Hatfield
street was accepted The clerk was

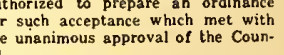
A communication was received from
o. Courter, in which he agreed to
ve the Borough the right of way
easement across his land on Or-

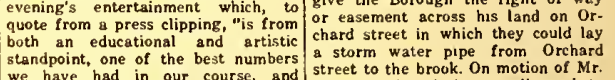

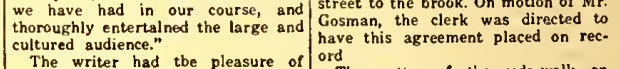

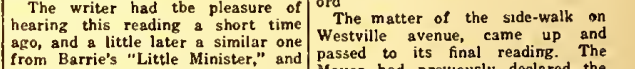
Mayor had previously declared the
meeting open tor the purpose of giv-

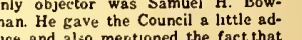
objecting to the the laying of of this sitede-
walk. Before Mr. Bowman had come a communucation trom one of of the ob-
actors who had signed this petitiolt, which it was stoted that in answer
to the notices which had been sent

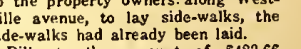
Bills to the smount of $\$ 483.66$
were ordered paid and the Mayor and
Cont

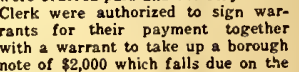
note of $\$ 2,000$ which falls due on the
17 h.
Mr. Maxwell, speakng for the Po. Me. Committee, reported that the ser-
cer Cos of the special police on Sunday
vices had been - discontinued for the present
and also recommended that Policeman Van Dyke should be authorized to

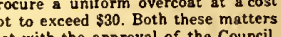
At the suggession of Mr. Marr, the
seter of auditing the Borough acat this time, with the suggestion that
thest arly part of December, thus enaan earlier date than had hereto-
. Mayor Espy brought the attention
the Council to the head-lights used 列 ding thas It seemed the general antages derived from these bril-
iant lights far outweigh the disadvantages which might be caused by The wit of the Council suggeated
The that in view of the fact that cars had "honey" warons since the lights had been instoiled that the warning which advantage. It was the general opinbe taken in the matter.
The meeting then adjourned to
meet the third Monday in November.

The neat typography and well-balaneed make-up of a suburban newspaper 


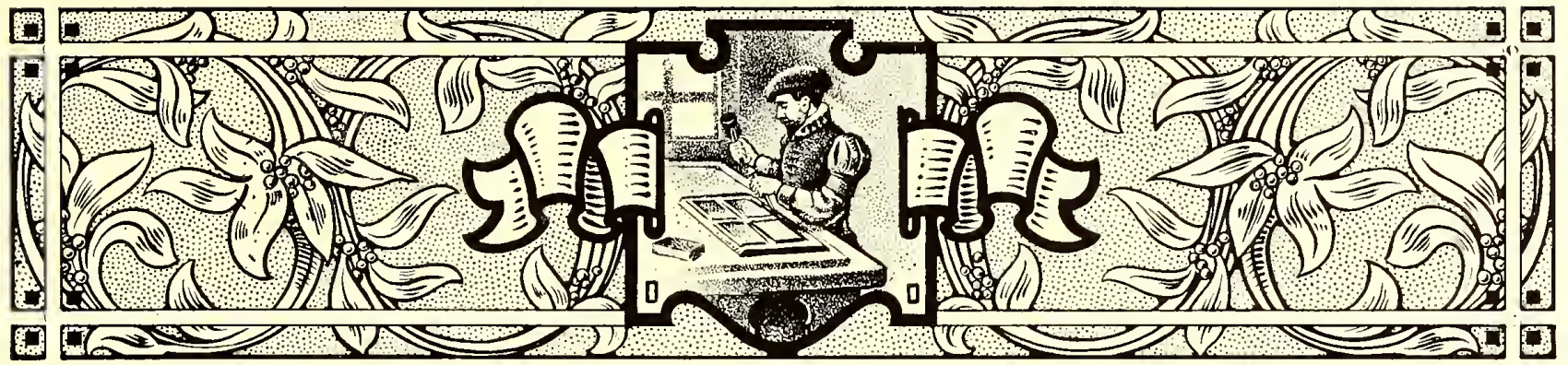

\section{NEWSPAPERS}

WE are all familiar witl the modeling clay with which children amuse themselves. They takc a portion of gray clay, mold it into some shape, and decorate it with small portions of red, yellow and blue clay. After they tire of their production they knead it with their fingers and lo! the bright colors disappear and there remains only the neutral gray.

The only way the typographical appearance of the average newspaper can be improved is by first reducing the glaring headlines and heterogeneous assortment of typefaces to a neutral gray. Upon this drab background the details of suitable and harmonious typographic form can be built.

However, it is easier to assert that the typography of newspapers can be improved than it is to improve it. In the early days of newspaper publishing the problem was a simple one, but today the newspapers of the large cities have liundreds of thousands of readers to serve, and much of the prevailing poor typography has resulted from efforts to present the news to these readers in a way that cditors assume will please them best, without giving any thought to technical defects in the type work.

\section{Numb. 1. OCCURRENCES Bofore, Thurday Sqw. 2sib. 1690.}

I

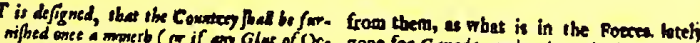

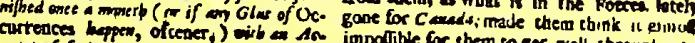

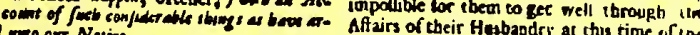
In order berenostice.

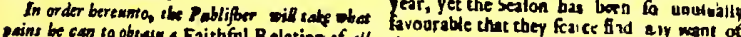
(wint sting

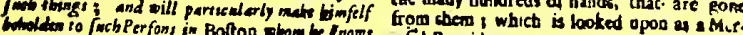

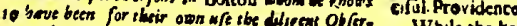

vers of fuch maters.

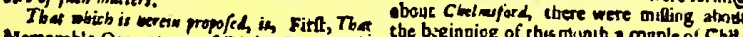

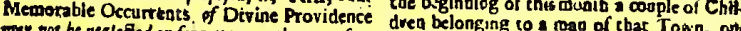

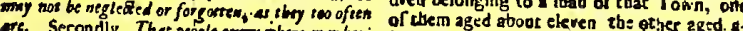

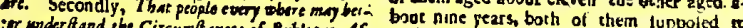

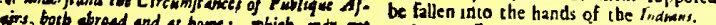

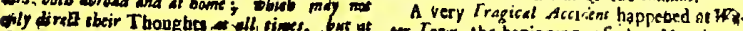

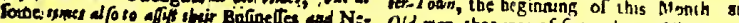
zotiatione Thirdly, That fomathing mog ki dme rowerd Marole Temper, but one tlat had lung tin-

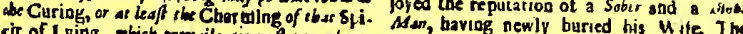

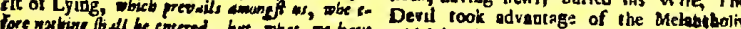

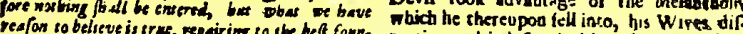

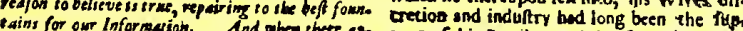

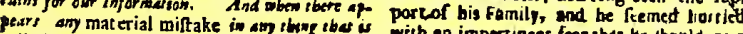
collicted, is $\beta$ ih $\Delta l$ be corrected in the perr.

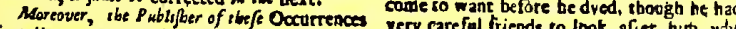

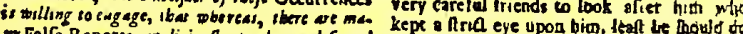

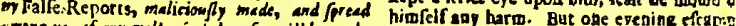

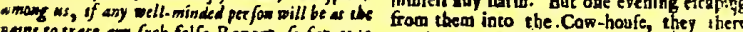

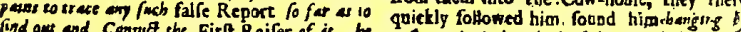
onil in sbus Paper ( unlefs juft Advice be given so a Ropriwhich they had afed to tye their $C$ alvers co ibe cons rary) expofe the Neme of fust given to wichalh he was dedd with bis feet heat couth

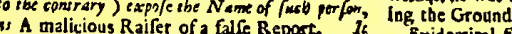

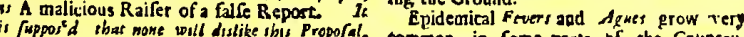
but fucts as intend to be guiley of fo willarous a common, in fome parts of the Cotinzry rotely anficted for theit imploy thens, iart

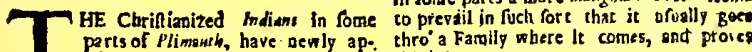
- pointed a day of Thanksgiving to Morial anto manty

The Smal-pux which tas heen raging in and pinching Necellities woder their late want atfons. after a meaner very Extraorditiary is Carb, \& for His glving them now a prof- now very mich atrated. It is I lbuglie that pett of a very Comfortable Harveft. Their far more lave been fitk of it then wete wils

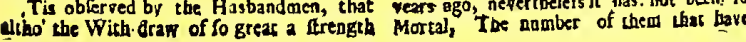

\section{The Bofton News-Letter.}

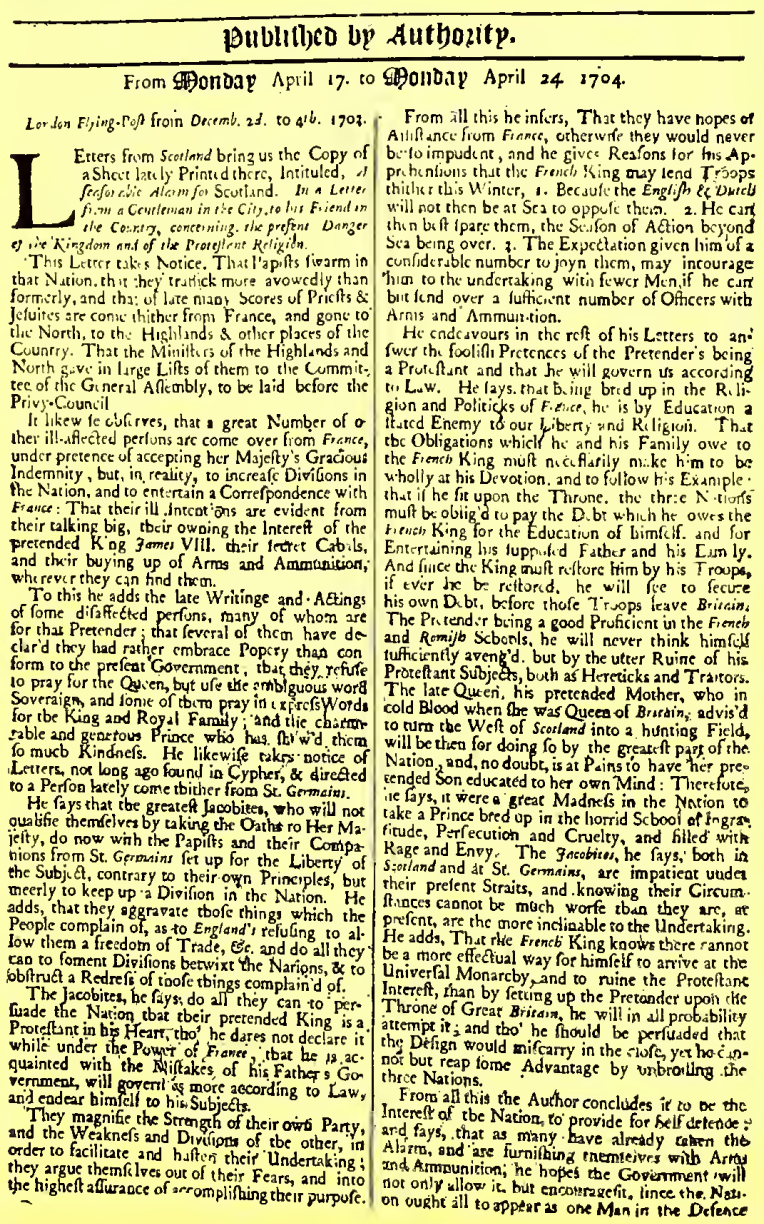

EXAMPLE 402

First number of the first American newspaper issued regularly 

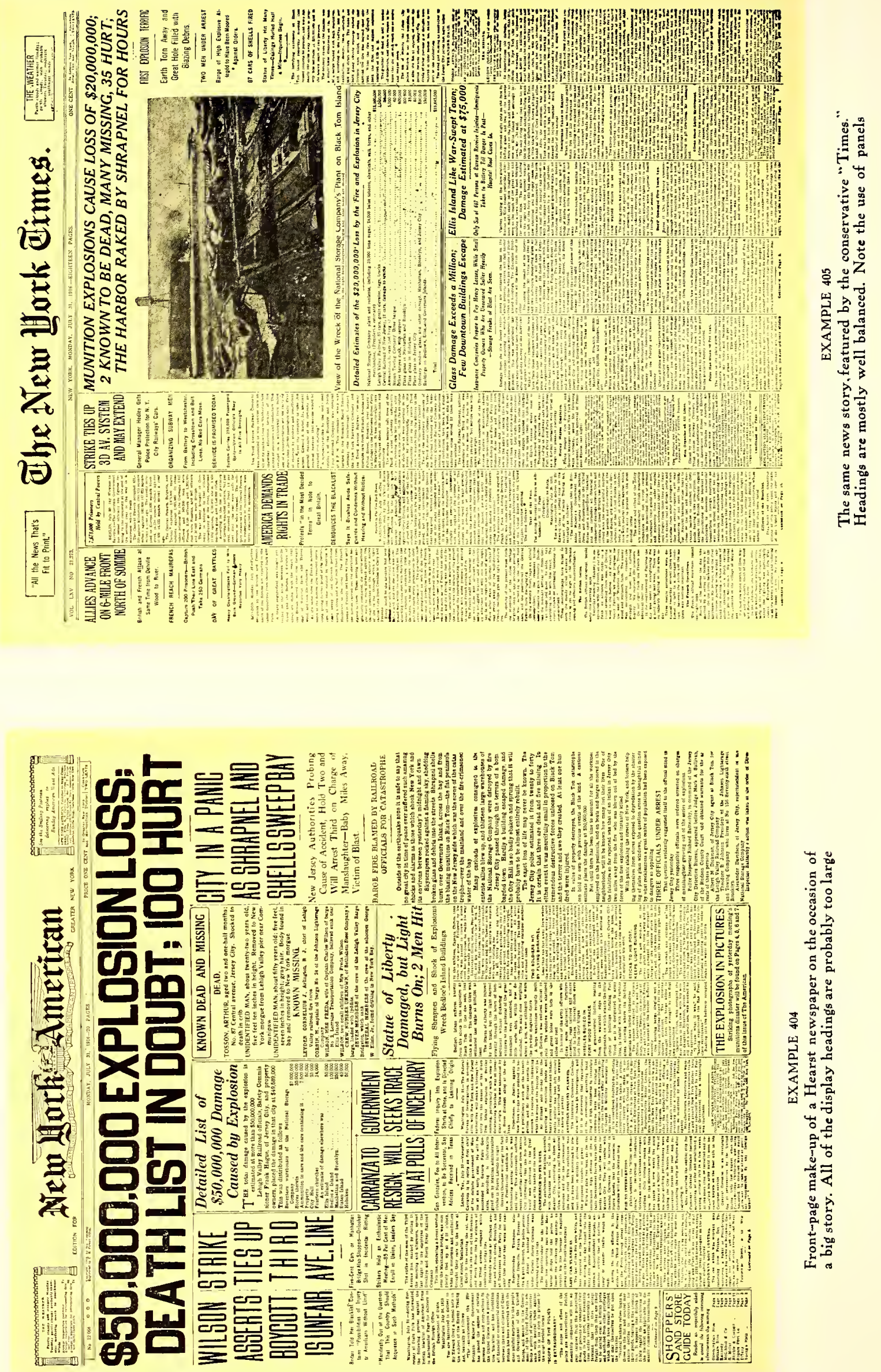
The ideal newspaper would probably be one in which the reader finds it easy to locate and read the articles in which he is interested, and in which the contents are presented in an orderly, good-looking, well-balanced and harmonious manner.

The Titse.-The name of the newspaper at the head of the front page should be distinctive in design, and it would probably add interest if the style of the letters composing the title bore some relation to that used at the time the publication was founded. Unfortunately, on most newspapers the headings are altered every time a new type dress is adopted.

For titles, most publishers of city newspapers seem to have a liking for English or German text letters. Such letters are doubtless good for the purpose, as they are different from any that appear elsewhere in newspapers. The New York Sun, as an instance, uses a black German text letter, altho on its first issue in 1833 the title head appeared in modern roman capitals.

It has become a practice to make use of the blank space on both ends of the title line, and in such spaces will now be found weather forecasts, slogans such as "All the News That's Fit to Print," and edition names. (See Example 405.) It was the custom at one time, and is today to some extent, to print under the title a quotation which defined the newspaper's editorial policy. (See Example 403.)

A type line under the title separated by rules on both sides contains the name of the city, the date, the volume number, and information regarding the price. (See Example 403.) Usually the rules have a double line, altho some newspapers use single rules for this purpose.

The Text.- The main desire of newspaper publishers, besides preparing the news, seems to be to have the matter set in the smallest size of type that can possibly be read. The large city dailies habitually use a seven-point typeface, which is the smallest that should appear on any newspaper. (See Example 406.) During the recent prevailing high cost of print paper some publishers began to use sixpoint in order to save paper, but they found that this move was a mistake. Newspapers are published to be read, and everything possible should be done to make the reader's task an easy one. Experiments by an educational body in England resulted in determining that ten-point should be the minimum size of type used for educational purposes. From this it will be seen that the seven-point type used on newspapers is too small and a cause of eyestrain.

The narrow width of the columns of newspaperstwelve and a half or thirteen picas-makes reading of the small type fairly easy, however. The eye has been tested scientifically and the discovery made that a person actually sees at a glance less than an inch of a line of type. Hence long lines require extreme side movements of the eyeballs or of the head. It is a mistake, as will be seen, to set editorials in a measure that extends over two columns, as is done on some publications.

Space between lines also helps the reader in locating the beginning of the next line, for which reason, and also to give them prominence, editorials are usually leaded. The beginning of an important article is sometimes leaded.

Lengthy excerpts or quotations are usually set in the same size of type but indented one em at the right and left ends of the line. (See Example 405, third column.)

Tire Headings.-The first newspaper continuously published in this country was a letter (see Example 402), and the items it contained were not set off with headings. As the quantity of news increased and newspapers became larger in size, headings were added. During the middle of the last century most of these were side headings joined to the first paragraph. When it became possible to print news promptly more attention was given to displaying the headings. As the Civil War developed, newspaper head- lines grew, and with the Spanish War came front-page headings of poster proportions.

Headlines not only advertise the contents of the text pages, but assist the reader quickly to absorb the news. As the reader cannot in these busy days read the entire paper, headings assist him in locating the items in which he is interested.

The error of using thrilling scareheads for comparatively unimportant events was madc evident when the European War started. Some of the publications had cried

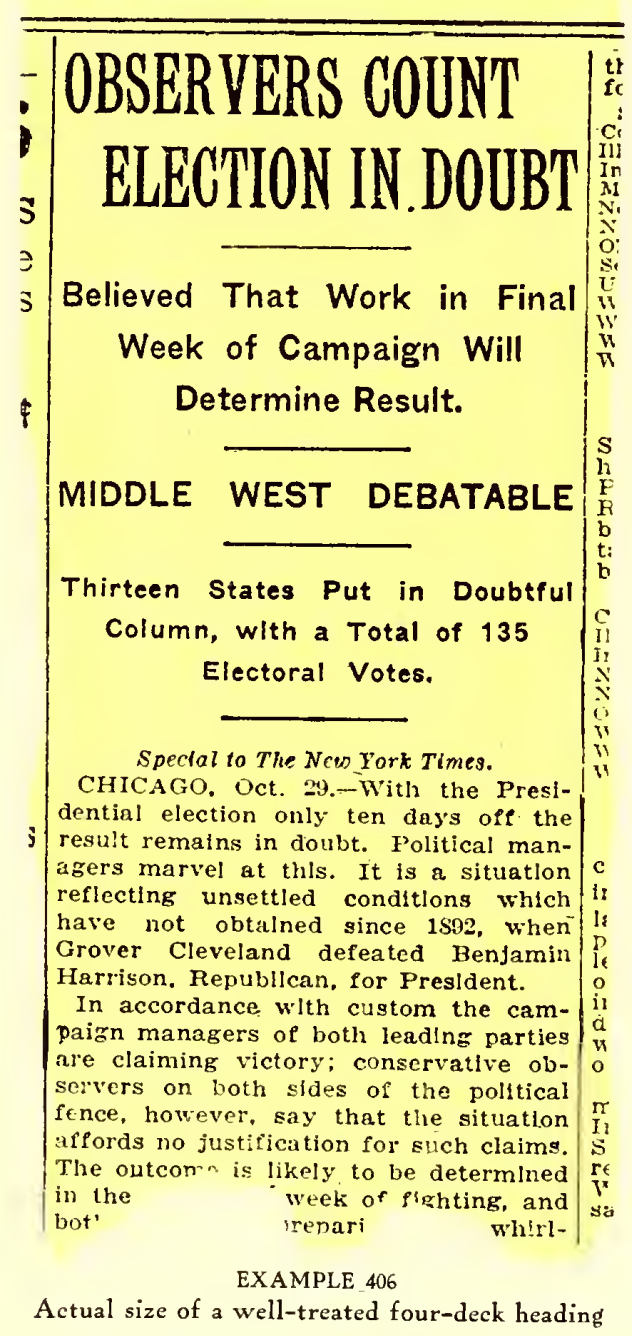

"Wolf !" so frequently that there was no emphasis left for a really big story.

Head-lctter type should not be intensely black, unless the reader is expected to read only the headlines. It is irritating to attempt to read the text matter in an article if strong black headlines continually glare at you. (See Example 404.) The head letter should be just a trifle darker in tone than the background of text type, or if liberal leading is possible a letter the same tone as the text is suitable.

Because of the narrowncss of newspaper columns it is necessary that type for headlines shall be slightly condensed, especially for the large lines. As few type-faces are legible in a condensed form, it is a problem to select a type-face for this purpose. Probably the most successful type-face of this kind has proved to be Latin Antique Condensed, a letter that has been in such use for a number of years. (See Example 406.)

It is, of course, best to have all type-faces harmonious in design, but the requirements of the newspaper are so unusual that in order to secure contrast this rule must be 


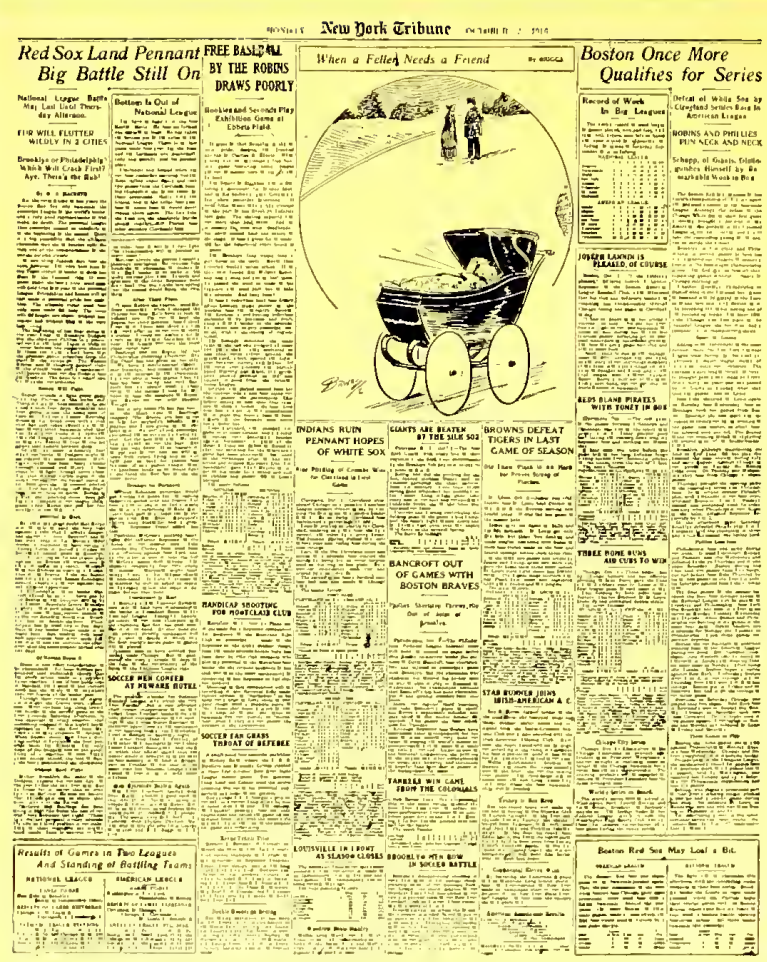

EXAMPLE 402

The sporting page of the New York

"Tribune," showing interesting make-up

violated. In Example 403 will be scen the neat and restful effeet that is possible by using thruont type that is harmonious, yct there is a monotony to the page that could probably be overcome by substituting, say, italic for roman in screral of the headings. On the page of the New York Times (Example 405) will be found hearlings in italic. Lower-case italic looks well used for the main lines of a double-column heading.

It is well first to harmonize the newspaper page, as in Example 1.03, and then add needed contrast, as in most newspapers attempts at contrast are so frequent that the result is eonfusing.

Paneled headings also add variety; specimens of such headings will he found in Examples 40.1, 407 and 408.

Restraint in the use of display headings by the New York Times, as compared with the noisy seareheads of the New York American used in reporting the same news, will be seen by comparing Example 405 with Example 404.

What is ealled a four-deek single-column heading. as used by the New York Times, is shown actual size in Example 406. Latin Antique Condensed is used for the first two lines and Newspaper Gothic for the other three decks. This heading as it stands is perhaps the most pleasing and legible of those used by metropolitan newspapers. A four-deck heading should present in the first deck the feature of the story; the first deek, and if possible every other deck in the heading, should contain a verb. The third deek is really the sccond in importanee, and. like the first one, is usually set in capitals. The size of the lower-ease used for the fourth deek is usually smaller than that used for the seeond. It would be a mistake to use eapitals for the sccond and fourth decks, as the result would be monotonous and illegible. The small section of text matter accompanying the head also shows a seven-point face on an eight-point slug, as used by the Times.

THE MAKE-IP. - In the make-up of a newspaper the sometimes derided "art tenets" should not be neglected. A good-looking newspaper has well-balanced headings, properly plaeed illustrations, and the various typographic details treated according to the requirements of good taste. Large display headings are usually alternated at the head of the page with small headings, which arrangement not only looks well, but enables the reader to peruse one heading without interference from another.

It is the practice of most good newspapers not to have advertisements appear on the front page, which is given over to the important news of the day. As will be seen by Examples 404 and 405 , the artiele of most importance, no matter how large the heading given to it, appears in the furthermost right eolumn, whence it is usually continued to the seeond page. Example 403 also shows how an important article ean be featured in the center of the page.

Interest and variety are also obtained by the use of a one-point rule around a portion of the news, as will be seen on Examples 404 and 405. The type matter on the inside is set elose to, but not against, the rule panel.

The editorials on most newspapers are to be found on the sixth pagc, and on the same page letters to the editors are also placed. There is a movement, begun by the Hearst newspapers, to have the editorials appear on the last page so that they may be read without the necessity of loeating them in the paper.

The sporting page has also eome to be an important feature of the newspaper. An attractively arranged sporting page is shown in Example 407.

It is eustomary to build advertisements from the lower right eorner of the page in a step or pyramid arrangement. (See Example 408.) This allows most of the text matter to appear at the left and in the upper portion of the page, and also makes it easy to give position next to reading matter as required by some advertisers.

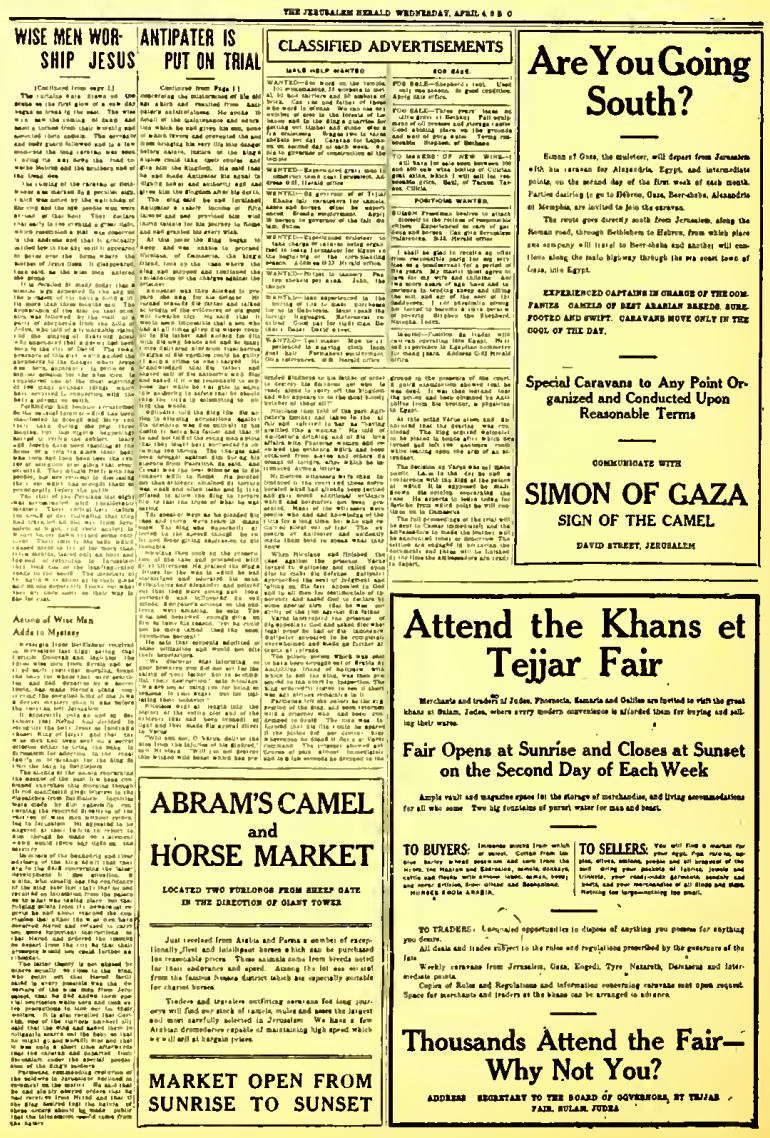

EXAMPLE 408

So-called pyramid make-up of a newspaper's advertisements. A "make-believe" newspaper 



\section{(9)( "Not at all," said Chipper.}

"Ain't there a vehicle?" said Mrs that I can ride anyhow." " "Hold on to my mane, and I'll help you They got up somehow and were close to the gate before it occurred to Mrs. Hairns
to ask what place it was, and to ask. hersel to ask what place it was, and

\section{"It's heaven." said Chipper.}

"“Oh, Lord!" said Mrs. Hairns, stopping I never done anything to get me into "True," said Chipper. 'Would you

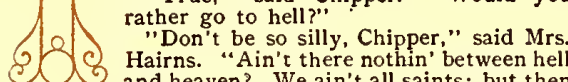
and heaven? We ain't all saints; but then gracious there must be a place for every-
day sort of people that don't set up to be "This is the only place I know," said Chipper: "and it's certainly heaven." "Belike there might be some kitchen
in it." said Mrs. Hairns. "You won't let on that I used to get a bit overcome once in a way, Chipper, will you?"

Chipper snuffed up a noseful of Mrs. Hairns s aura. "I should keep on the lee
side of St. Peter." he said. "That's Peter he added jerking his head in the direc tion of an elderly gentleman with a pair of keys of twelfth century design. The keys were more for ornament than use, apparently; for the gate stood wide it from blowing-to was covered with moss, and had evidently not been moved for centuries. This surprised Mrs. Hairns, on her in her childhood on earth that the gates of heaven were always shut tight. get them opened.

A group of angels stood in the carriage way. Their wings, purple and gold, helioirope and silver, amber and black, and all sorts of fine colors, struck Mrs. Hairns as lovely. One of them had a sword with a blade of lambent garnet-colored flame. Another, with one leg naked from the knee down, and a wading boot on the other, had a straight slender trumpet, which seemed yet was as handy as an umbrella. Through the first-floor window of one of the turrets of the gate Mrs. Hairns saw Matthew,
Mark, Luke, and John in bed with their breeches on according to the old rime. gate of heaven. Nothing else would have quite convinced her. Chipper addressed himself to Peter"This woman is drunk," said Chipper. "So I see," said St. Peter. "Ow. Chipper!"' said Mrs. "Hairns relooked at her, and she began to cry. The angel with the sword ot flame drew it flame did not hưrt and was wonderfully reviving. $\mathrm{I}^{\prime} \mathrm{m}$ afraid she's hopeless," said Chipper. "Her own children will have nothin "Whith her." "Tellus," answered Chipper.

What am I to tell them?" said Mrs. Hairns. The angels laughed. Peter roared can make puns. What's wrong with her?' "She's a liar and a thief." said Chipper "All the inhabitants of Tellus are and thieves," said the trumpet angel. liar and a thief," said Chipper.
"Oh!" said the sword angel, looking very. grave.
"'m only making it easy for you," said "I'm only making it easy for you," said
Chipper to Mrs. Hairns; "so that they shan't expect too much." "Then, to Peter: and walked on act dragging her up a hill with her husband three of his friends, their wives, eight children, a baby, and three dozen of beer." "Fancy your remembering!" said Mrs. "It was so unlike you, if I may say gotten it." " "I dessay it was silly of me," said Mrs Hairns apologetically,
PS (3)

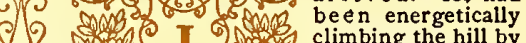
29 the little foot-tracks

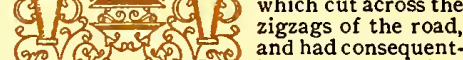
col toj "Is this the gate of heaven?". said the "It is," said Peter.

"The front gate?" said the bishop suspiciously. "Pou are sure it is not the
tradesmen's. entrance?"

"It is everybody's entrance," said Peter. "An unusual arrangement, and in my opinion an inconvenient one," said the angels. "Gentlemen," he said. "I am the Bishop of St. Pancras." "s dalmatic, putting his head out of one of the
turret windows, "I ani St. Pancras himself."

turret windows, "I ann St. Pancras himself."
"As your bishop, I am glad to meet "As your bishop, I am glad to meet
oou," said the bishop, "I take a personal you," said the bishop, "I take a personal
interest in every member of my fock. But for the moment, I must ask you to excuse me, as I have pressing business at court. By your leave, gentlemen"-and he shoulangels into heaven and trotted sturdily up the street. He turned only once, for a moment, to say: "Better announce me." and went his way. The angels stared after him quite dumfounded. Then the trumpet angel made a post horn of his trumpet, and first root-a-tooted at the sky and then swept the trumpet downward like the ray
of a searchlight. It reached along the street to the bishop's coat-tails, and the next blast swept him like a dry leaf clean round a corner and out of sight

The angels smiled a beautifully grave ing. "Ain't he a tease!" she said to Chip-

"Hadn't you better follow the bishop in?" said Chipper. Mrs. Hairns looked apprehensively yt Peter (she wias not afraid of the angels), and asked him might she go in. "Anybody may go in," said Peter. "What do you suppose the gate is for?" Mrs. Hairns. And she was ap-
proaching the threshold timidly proaching the threshold timidly
when the bishop came back. when the bishop ca

"I have been through the whole city in a very high wind," said the bishop; " and I can not find really heaven at all.

"Find what?" said Peter.

"The Throne, sir." said the bishop severely,

"This is the throne," said St.

Pancras, who was still looking out

his palms and his palms propped

" " This !". said the bishop.

"The city," said St. Pancras.
"But - but - where is He?" said the bishop

"Here, of course," said the sword angel. riedly, lowering his voice and looking apprehensively round from one to the other until he finished with the trumpet angel, who had sat down to take off his wading boot and shake a stone out of it.

"He is the presence in which we live," said the sword angel, speaking very harmoniously.

Pancras explained.

"What are you looking about for?" said the trum pet angel, standing up with his boot comfor table again. "Did you expect to see somebody in a shovel hat and apron, with
a nose, and a handkerchief to blow it with?" "you are profane. You are blasphemous. you are even wanting in good taste. But for the charity my profession imposes on me I should be tempted to question the word a gentleman. Good morning." his feet and walked away.
"Ain't he a curel" said Mrs. Hairns.
"But I'm glad there's no throne, nor no"But I'm glad there's no throne, nor nobody, nor nothin'. It'll be more like
Kings Cross." She looked at them rather per, indicating the trumpet angel.

\section{(4)} thing in the sword humber feel very They all looked back at her gravely; and she would have cried again, nnly she knew it would be of no use after the sword had touched her eyes; her tears were dried forever. She twisted a corner of her jacket - a deplorable jacket-in her restless fingers; and there was a silence; unbroken until the snoring of Matthew, Mark, Luke, and John became painfully audible, and mon little wooden beds, and at the fiyblown Illuminated text on the wall above them: 'A broken and a contrite heart, O Lord, hou wilt not despise."

"I wonder," she said, "would one of you "entlemen say a prayer for a poor drunken old charwoman that has buried eleven, and offer to go in."

Suddenly she sat down stunned in the middle of the way; for every angel threw up his hands and wings with an amazing outcry; the sword flamed all over the sky; horizon and filled the universe with ring ing notes; and the stars became visible in broad daylight and sent back an echo which affected Mrs. Hairns like an enordraft of some new and delightful "Oh mot siated spirit.

"Oh, not sich a fuss about me, gentle. queen or a the like" And she felt shyer than ever about going in. The sword angel smiled, and was going to speak to her when the bishop came back, pegging along more "Gentlemen," he said, "I have been thinking over what you said just now; and while my reason tells me that I was en-
tirely justified in acting and speaking as tirely justified in acting and speaking as tenable one, and your method ox express. its purpose I also find myself the victim of an uncontrollable impulse to act in manner which I can not excuse though to refrain is unfortunately beyond my powers of self-inhibition."

1

ND with that speech he snatched off his apron, made a ball his shovel hat, and kicked the hat into space. Before it
could descend, the sword angel, with wings cut of his the air whooping with ecstasy, and kicked it a mile who had no wings, but shot up by mere in a second and was shooting off with it when the trumpet angel collared him and passed it to the amber and black angel. By that time Mat-
thew, Mark, Luke, and fohn were out of thew, Mark, Luke, and John were out of above, where a football match was already in full swing between the angels and the saints, with Sirius for one goal and the sun for the other. The bishop looked in amazement for a moment at the flying scrum; then, with a yell, sprang into the air and actually got up nearly fifty feet, but was falling from that dangerous height when him later his hat was half-way to the moon: and the exultant shouts of the angels had dwindled to mere curlew pipings, while the celestial players looked smaller than swifts circling over Rome in summer.

Now was Mrs. Hairns's opportunity As her foot approached the threshold the houses of the. heavenly street shon friendly in the sunshine before her, and the mosaics in the pavement glowed like flower-beds of jewels. "She's dead," said the student from the left when I took hold of her to straighten her out; but it was only a spark She's \& dead now all right enough-I mean poor

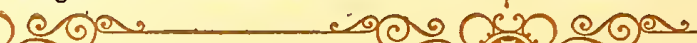
(c) 10 Cथ (C) (อ)

EXAMPLE 409 


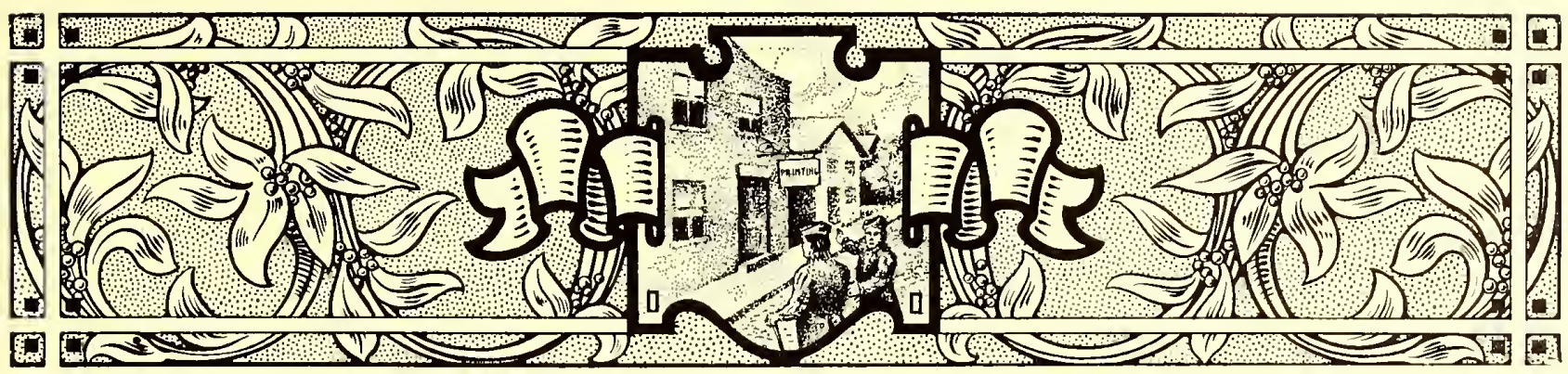

\section{PERIODICALS}

THE typography and the make-up of periodicals in the century last past were sedate and uninteresting to most Americans. As a consequence there came a change, and publishers endeavored to make their publications more attractive to readers. The letterer and the decorator were permitted to let their fancies run free over the magazine pages, and assuming that their readers had poor taste and weak eyesight the publishers of trade journals splattered their pages with ugly black circus poster type.

So long as there is poor printing (we read in the Good Book: "For ye have the poor always with you") there will be periodicals typographically poor. Yet, thanks to those who have trained themselves as typographic advisors, many American periodicals are now good to look at and at the same time easy to read.

We will consider the dimensions of the publication, the front cover, number of columns, the margins, type-faces

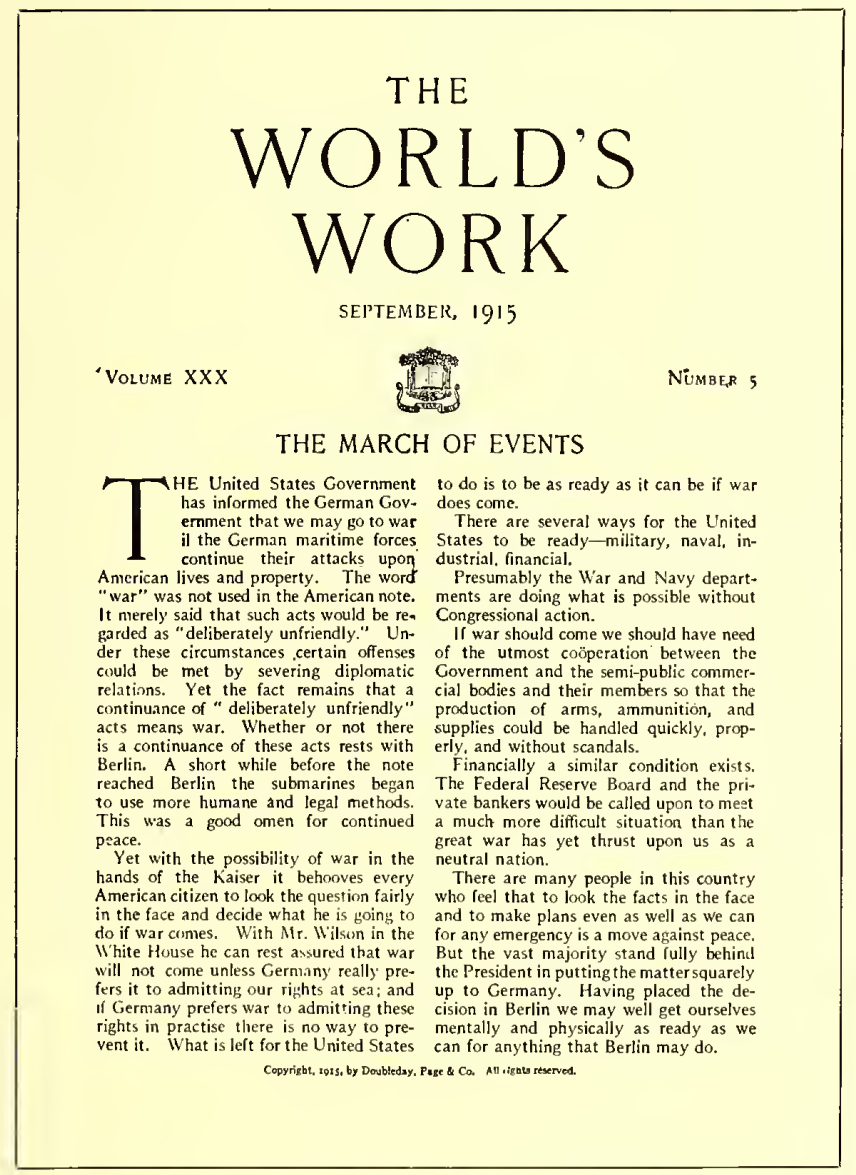

EXAMPLE 410

Dignity in make-up and type treatment. By Walter Gilliss for the text and for the headings, make-up of the illustrations, arrangement of headings, the captions, the editorial pages, features, and the advertisements.

The Dimensions.- Whim has much to do with the selection of sizes for periodicals, and precedent, or what the other fellow is using, has some influence also. Assembled and stood on end, several dozen periodicals gathered at random present the appearance of a platoon of "rookie" soldiers before they have been ranged according to hight.

Sixty-six business and technical publications were recently measured by the writer, and the dimensions of about half of them approximated $9 \times 12$ inches. The other half varied from $6 \mathrm{x} 9$ to $10 \mathrm{x} 15$ inches.

Examination of about two score of magazines revealed three groups of dimensions: $7 \times 10,9 \times 12$ and $11 \times 14$ inches. These dimensions are approximate, few magazines meas-

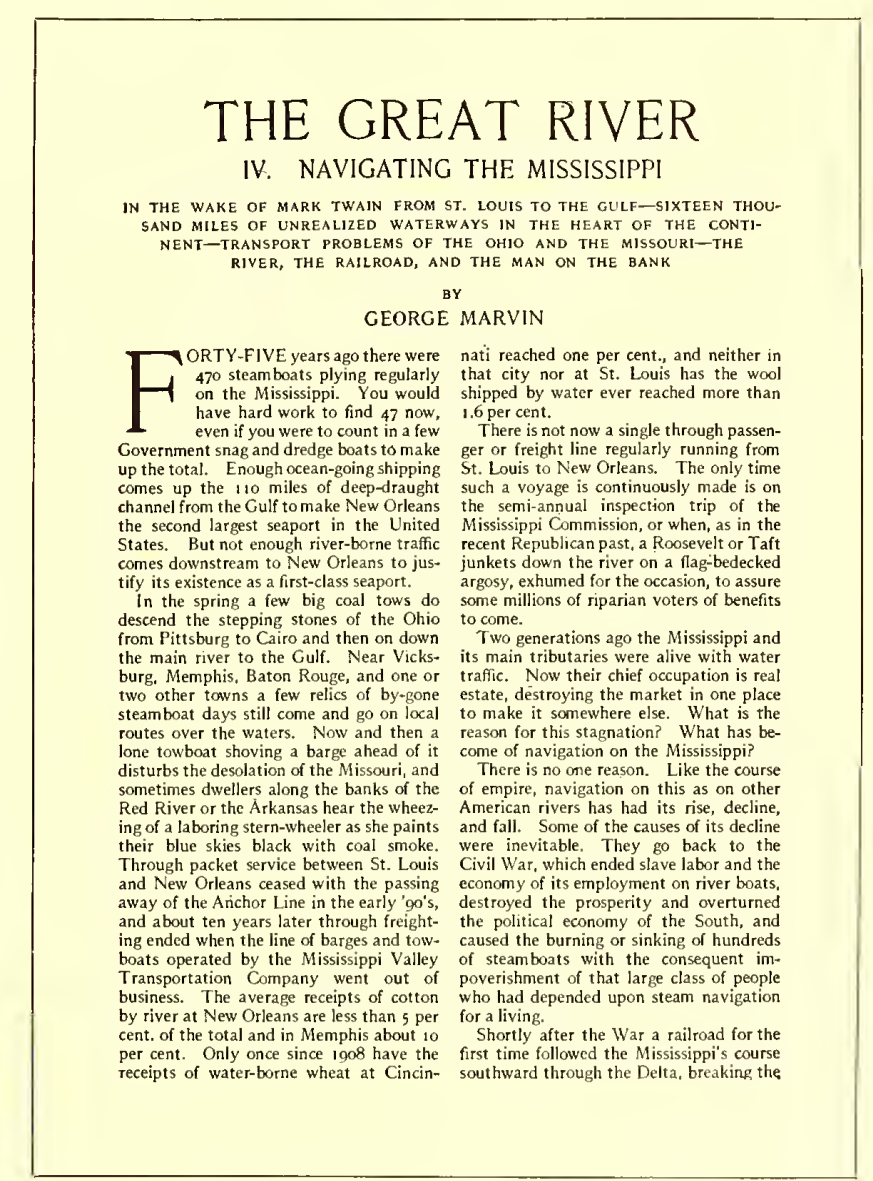

EXAMPLE 411

Harmony of the type-faces used for heading and text 


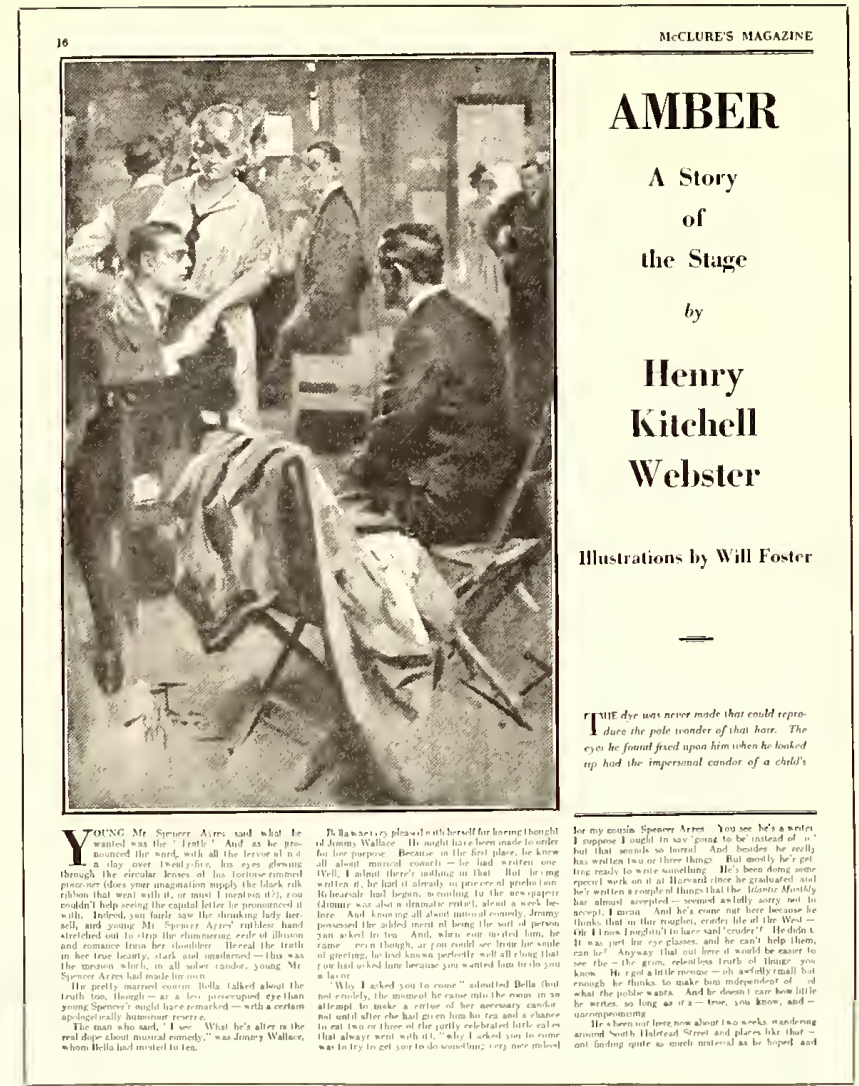

EXAMPLE 412

Advertising the story to the readers

uring exactly the same, the variations amounting to half an inch in some instances and several inches in others.

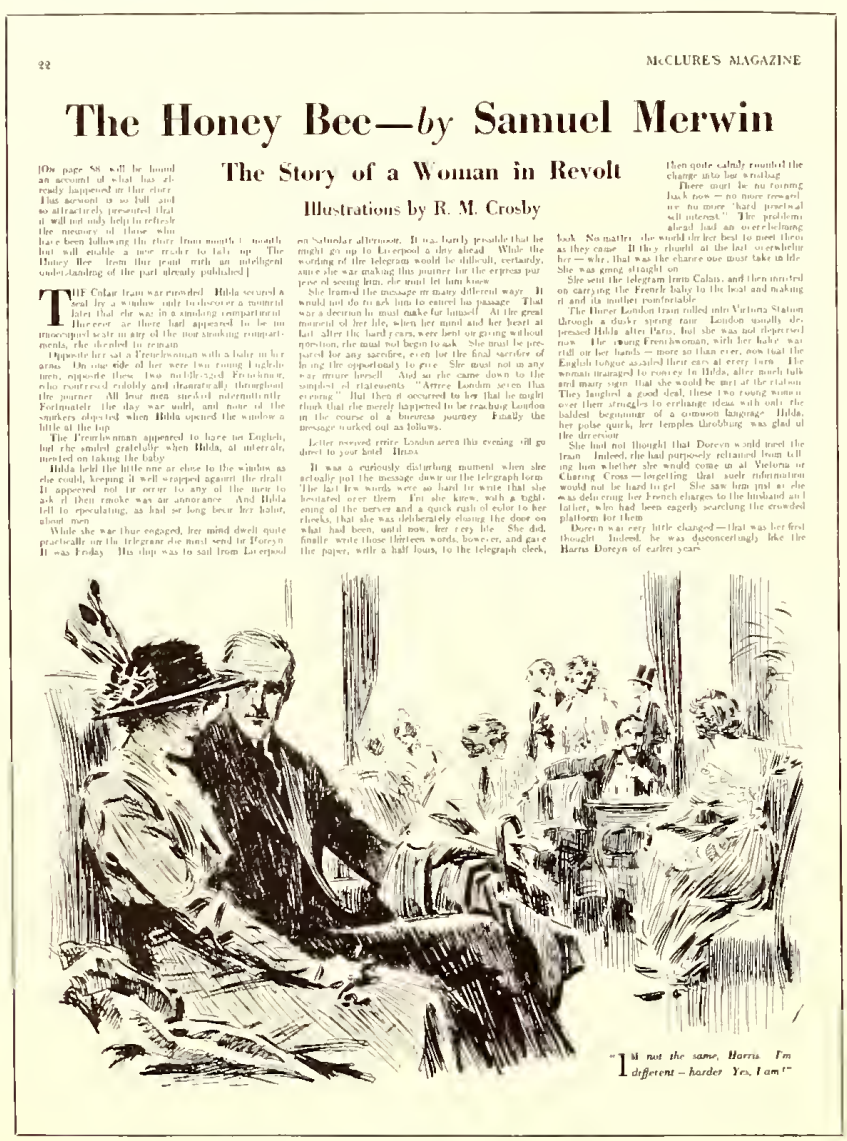

EXAMPLE 414

Style of make-up of these three pages suggested by Benjamin Sherbow

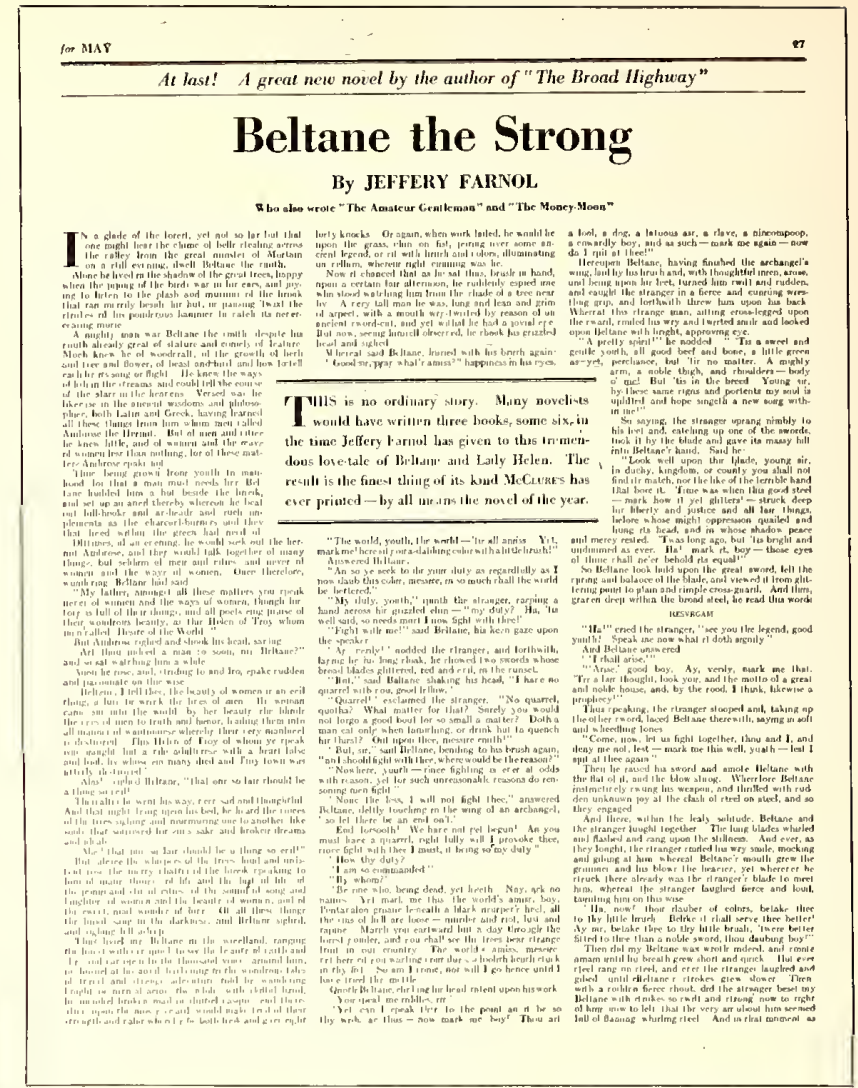

EXAMPLE 413

Interesting heading treatment and inserted feature panel

Scribner's is a type of the magazine in the $7 \times 10$ class (the actual measurement being a trifle minus); the Independent, of the $9 \times 12$ class (actual measurement $83 / 4 \times 12$ inches); and the Saturday Evening Post, of the $11 \times 14$ class, measuring exactly that size.

There has been a movement among magazines away from the smaller dimensions toward the larger, for the purpose of better displaying features and of enabling reading matter to be placed alongside of advertisements.

To a similar extent the business and technical publications have experienced reductions from the very large sizes that originally were probably inspired by the bigness of newspapers.

There are also a few small pocket magazines of the Philistine size that Elbert Hubbard made popular.

The Front Cover-C'Typography has little to do with the average cover of the general magazine in America. The foundation of the design is usually a painting, the subject being seasonable or otherwise appropriate. Lettering and decoration are added by an artist other than the one drawing the picture. In such cases the design is changed with every issue. Some magazines, the more conservative ones, use a design containing lettering and decoration only, and with each issue merely change such lettering as refers to editorial features.

The European custom of printing a paid advertisement on the front cover of periodicals has extended to America, and, while such advertisements will not be found on the general magazines, some business and technical periodicals have succumbed to the temptation thus offered for increased revenue.

When the front cover is sold, only an inch or so is retained for the title of the periodical. One publisher did stipulate that no color in the cover advertisement should come within two inches of the title; but even this rule is now disregarded on his periodicals. The time may yet come 

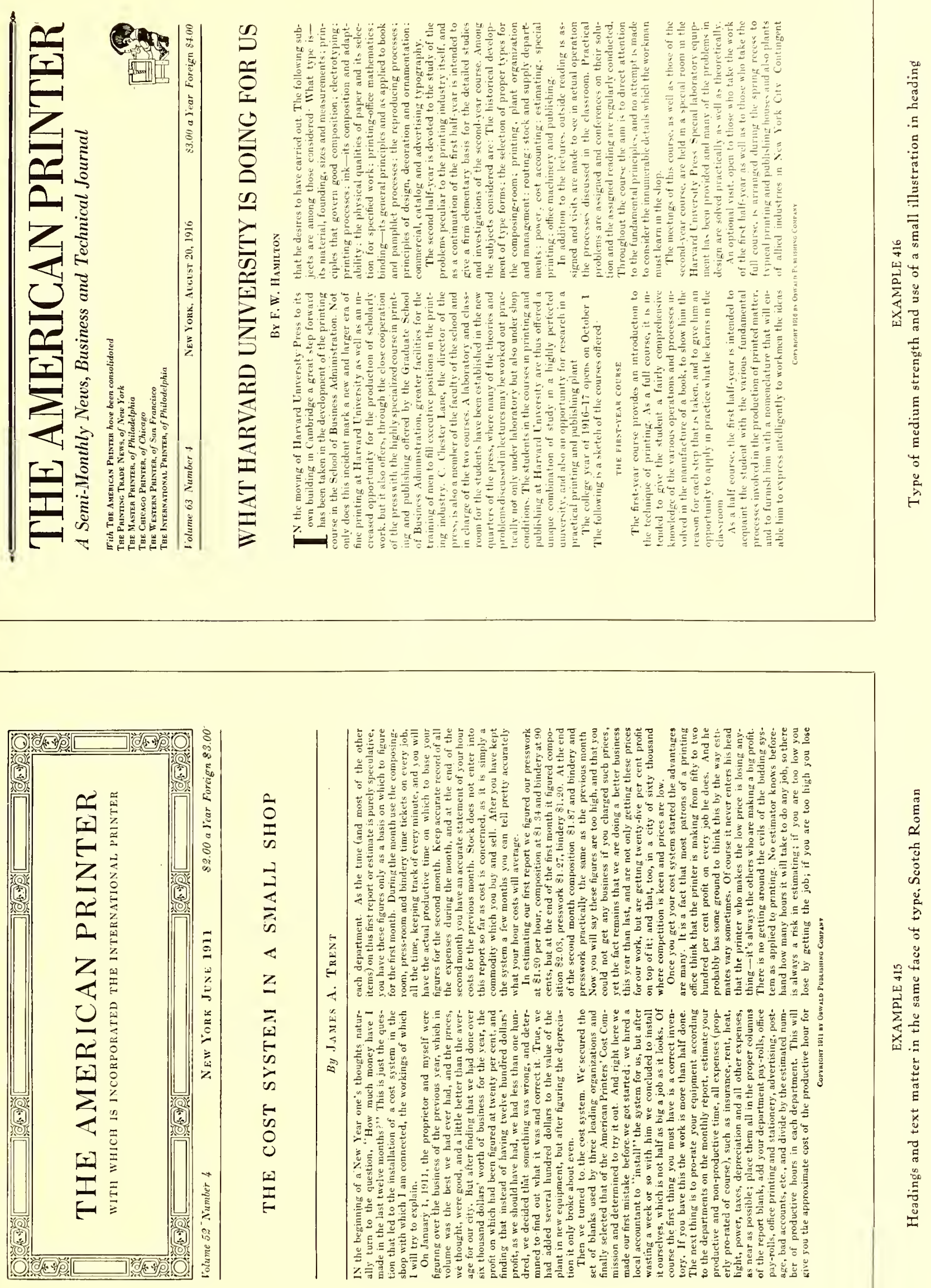

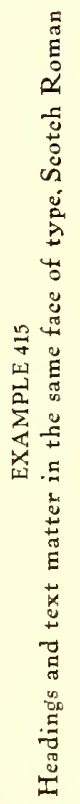


much as possible in the protecting shelter of Norwegian waters. When forced to go outside they trust to fog and darkness, when possible, to avoid the vigilance of the British fleet. Usually this course is successful, but sometimes they are conducted to Kirkwall or other British ports, where the cargo is purchased, and they return to try once more to beat the game. As iron is not a contraband

EXAMPLE 410-A

Section of text matter from the "World's Work"

(Monotype No. 22-E, 10-point on 11-point body, 10 set)

when the title of a publication will appear at the foot of the front cover in six-point.

$\Lambda$ weekly technical periodical in every issue has some appropriate view made into half tone and uses it inside a large panel under the title, and a photographic journal prints a reproduction of an artistic photograph on the cover, changing the subject with each issue.

Counms. - The number of columns to a page should be decided by the size of type used. Seven-point and eightpoint type should be confined in columns twelve or thirteen picas wide. 'Ten-point, clcven-point and twelve-point type can be read even if the columns are sixteen or more picas wide. However, no column in a book or periodical should cxcecl twenty-four picas. Neither should a column be unreasonably narrow.

Scicntific tests show that the eye is strained in the reading of wide columns. The column should be of such width that reading of the matter can be accomplished with only shight movements of the eyes to the right, after they have been focused at the beginning of the line to fit the size of type. When the column is too wide the head must be moved to the right and left with the reading of every line or the eyes may be injured from the strain and repeated change of focus.

A look over the examples of periodical pages in this chapter will show practically an acceptance of these requirements-three columns in the periodicals of large size and two eolumus in those of smaller size. For pocket magazines one column is naturally sufficient. In several instances (Examples 417 and 418 ) three columns instead of two would have bcen advisable.

Gutenberg, when he planned the pages of his famous Bible, arranged for two columns each about twenty picas wide, altho his type was large-about twenty points in size.

It is a great mistake to set, as some business publica-

Harum approached the deacon when he had a horse trade in mind, this broker had gone to the president of the company that owned the ship. After due deliberation and the tactical jockeying for position that marks trading in general, the owner had allowed he might take two millions cash for the vessel. This had been cabled to Norway, and the deacons over there had replied, in effect, that a million six hundred thousand was a tolerably tall price for a boat that had just cost but little over half a million. The dickering, oral and by cable, proceeded for a few days, until the price of one million eight hundred thousand dollars was

EXAMPLE 424-A

Section of text matter from the "Saturday Evening Post" (Monotype No. 20-A. 8-point on 9-point body, 83/4 set) tions do, six-point type in lines twenty-five or thirty picas wide. To require the reader's eyes, after being focused on such small type, to travel back and forth that distance is almost an invitation not to read the matter.

Tine Margins.- Blank space surrounding the printed pages in periodicals should be apportioned as it is in good books - the smallest margin at the binding side and increasing in amount in this order: Head, outer side, foot. Even when the total amount of margin is small it should be apportioned in this manner.

The rule can be stated in another way : the largest margin at the foot, with the type page inclining toward the bound side.

Periodical binderies do not always give the publisher good margins, even after he has planned for them. Unevenly cut paper, careless folding and inaccurate trimming will prevent the securing of desired results.

In measuring margins the rumning headings should be ignored if they are small, but in any event the printed page should have the appearance of being a trifle high on the leaf.

Type-Faces for the Text.-Type-faces for the text matter of most periodicals must be chosen for reasons different from those governing the selection of type-faces

taken into the lungs the animal would die. Thus as soon as a cetacean comes to the surface its breath is expelled and a fresh supply inhaled before it again goes down. The breath which has been held in the lungs for a considerable time under pressure is highly heated and, as it is forcibly expelled into the cold outer air, it condenses, forming a column of steam. A similar effect may be pro-

\section{EXAMPLE 422-A}

Section of text matter from the "Independent" (Monotype No. 20-A. 9-point on 10-point body, 93/4 eet)

for other purposes, because of the small size, usually eightpoint or nine-point.

Type-faces that are legible and good-looking in twelvepoint may prove illegible and ill-looking in eight-point. This is to some extent true of Caslon Oldstyle when printed on calendered surfaces. Such illegibility may be due to the hairlines, which almost disappear in the small sizes.

Commendable letters for periodicals that require small type-faces are the dark-printing kind represented by Century Expanded. Examples 422 and 424 are set in letters of this kind. (See also Examples 422-A and 424-A for type matter as actually used.)

As these types have short descenders the text matter is made more legible by separating lines with one-point leads or, in machine composition, by casting a face on a body a point larger (as in Example 424-A, which shows an eightpoint face cast on a nine-point body, and in Example 422-A, which shows nine-point on ten-point body).

French Oldstyle (especially Cadmus) is not only fairly legible in small sizes but good-looking. A representative of this style of type will be found in Examples 410 and 411 , and is shown actual size in Example $410-\mathrm{A}$.

Modern or old-style type-faces that are legible when printed on news paper or antique paper are sometimes not so when printed on calendered surfaces. A type-face such as Caslon Oldstyle was designed for printing on damp- 


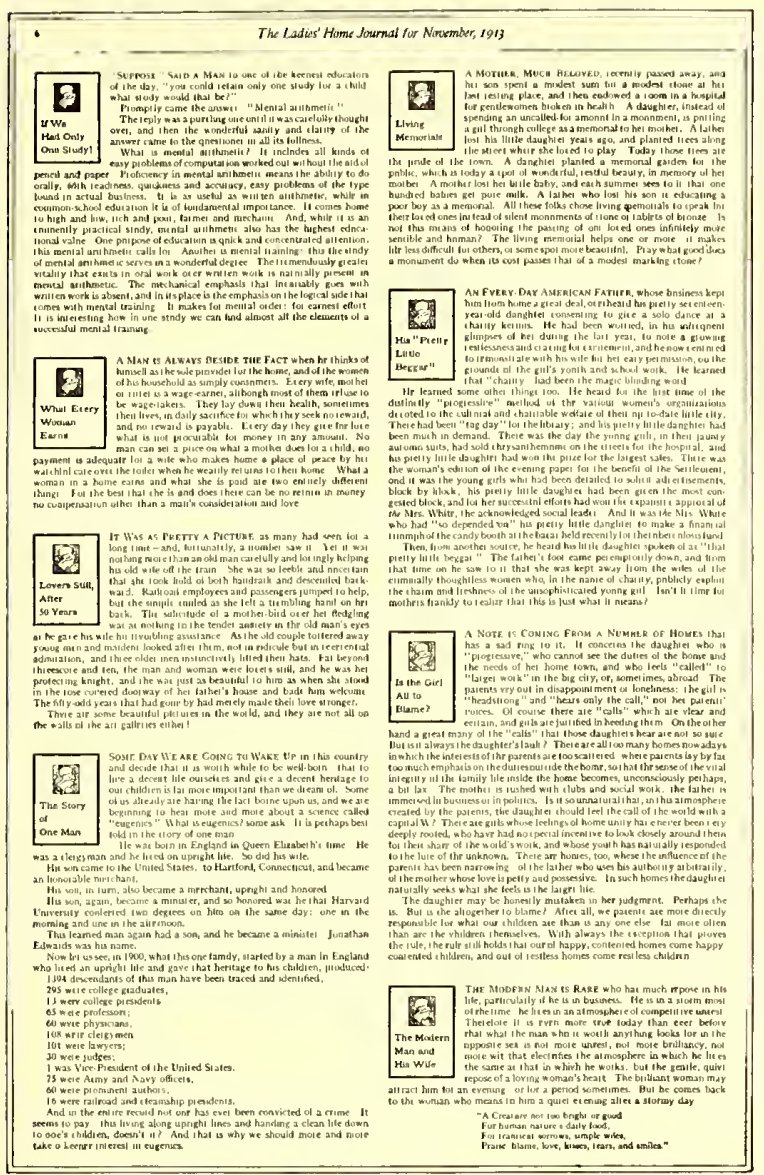

EXAMPLE 417

Box headings are conspicuous on this editorial page

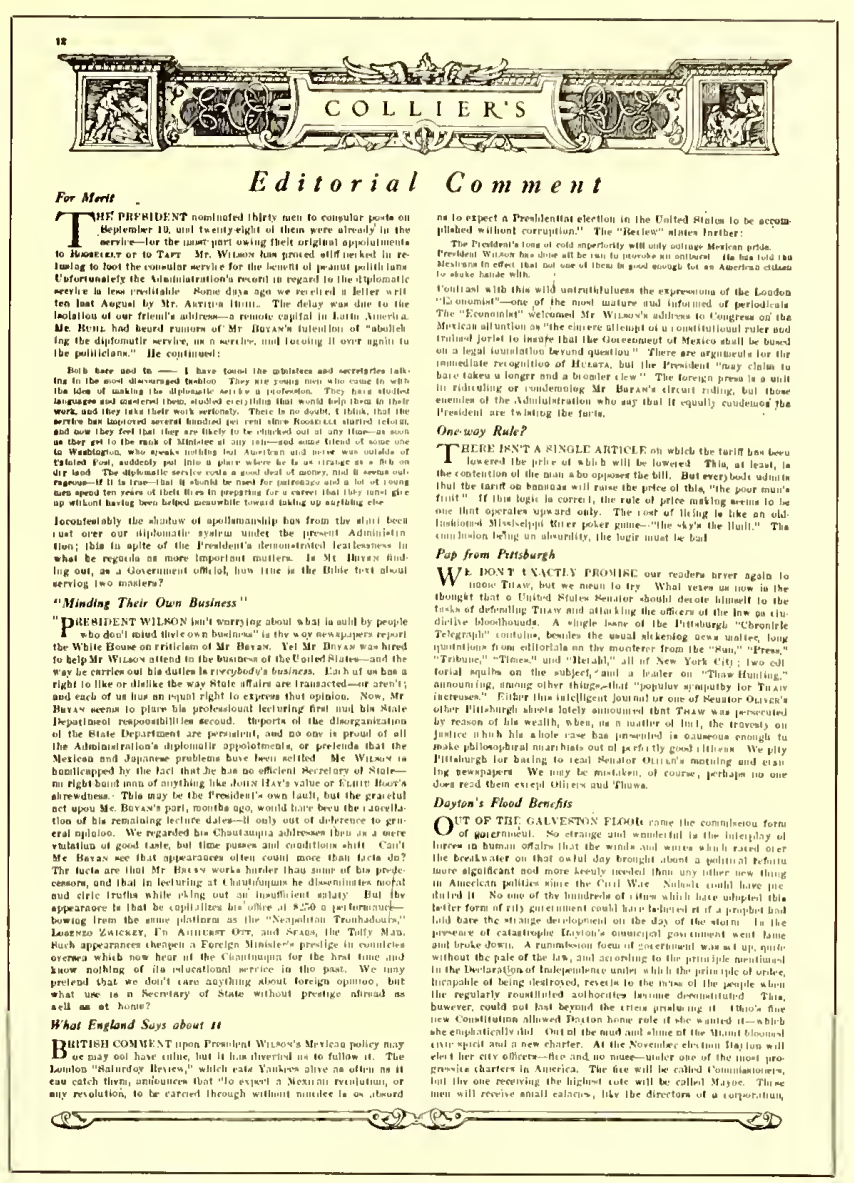

EXAMPLE 418

Another way to feature the editorials
SISTEM, the MAGAZINE of BUSINESS
EStid by A W. SHA
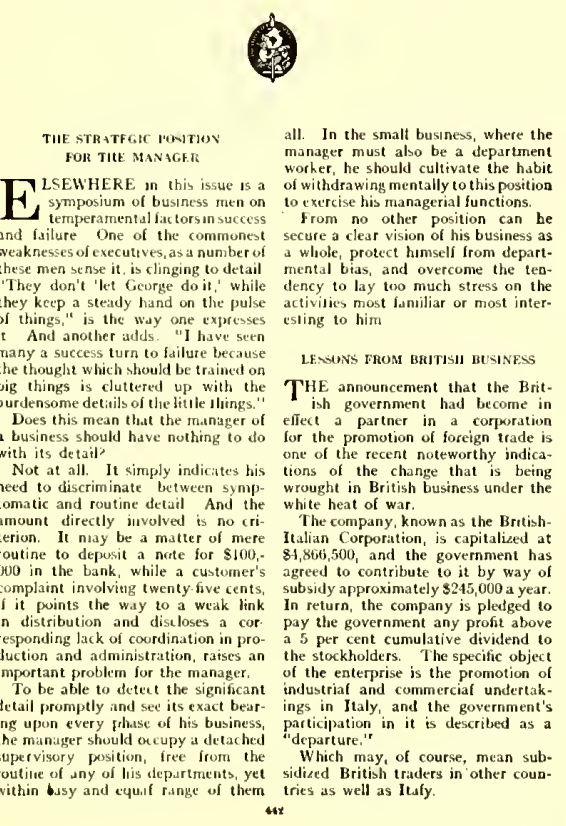

EXAMPLE 419

Excellent typography of an editorial page
Oceber, 1910 ADVERTISING \& SELLING PAg I0

And Now, Speaking Editorially:

Branded Goods on the
Rack

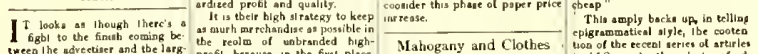

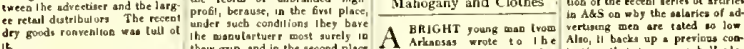

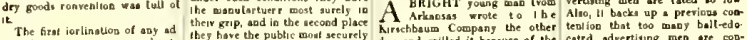

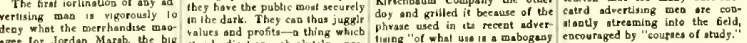

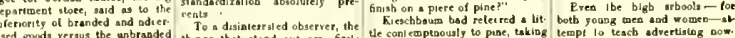

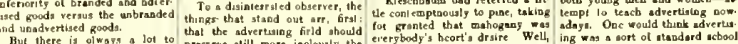

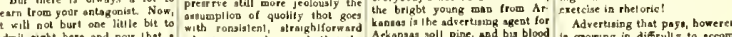

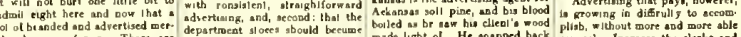
-

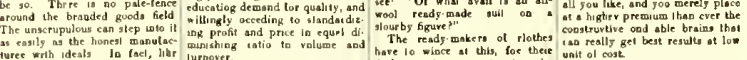

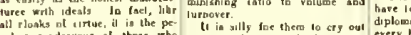

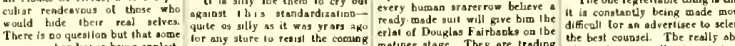

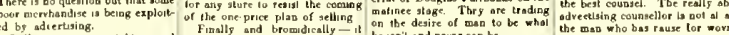

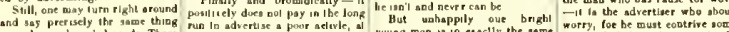

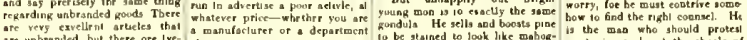

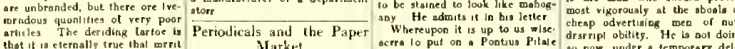

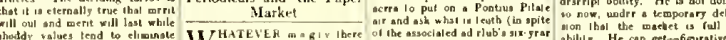

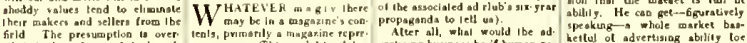

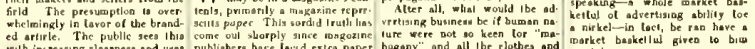

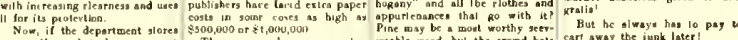

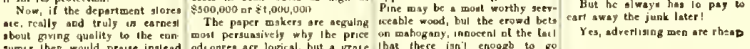

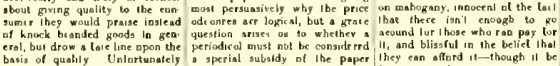

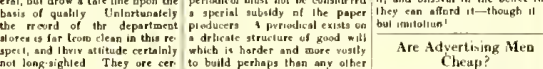

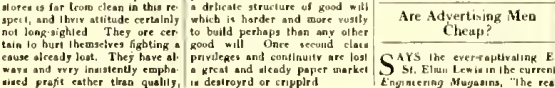

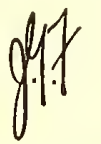




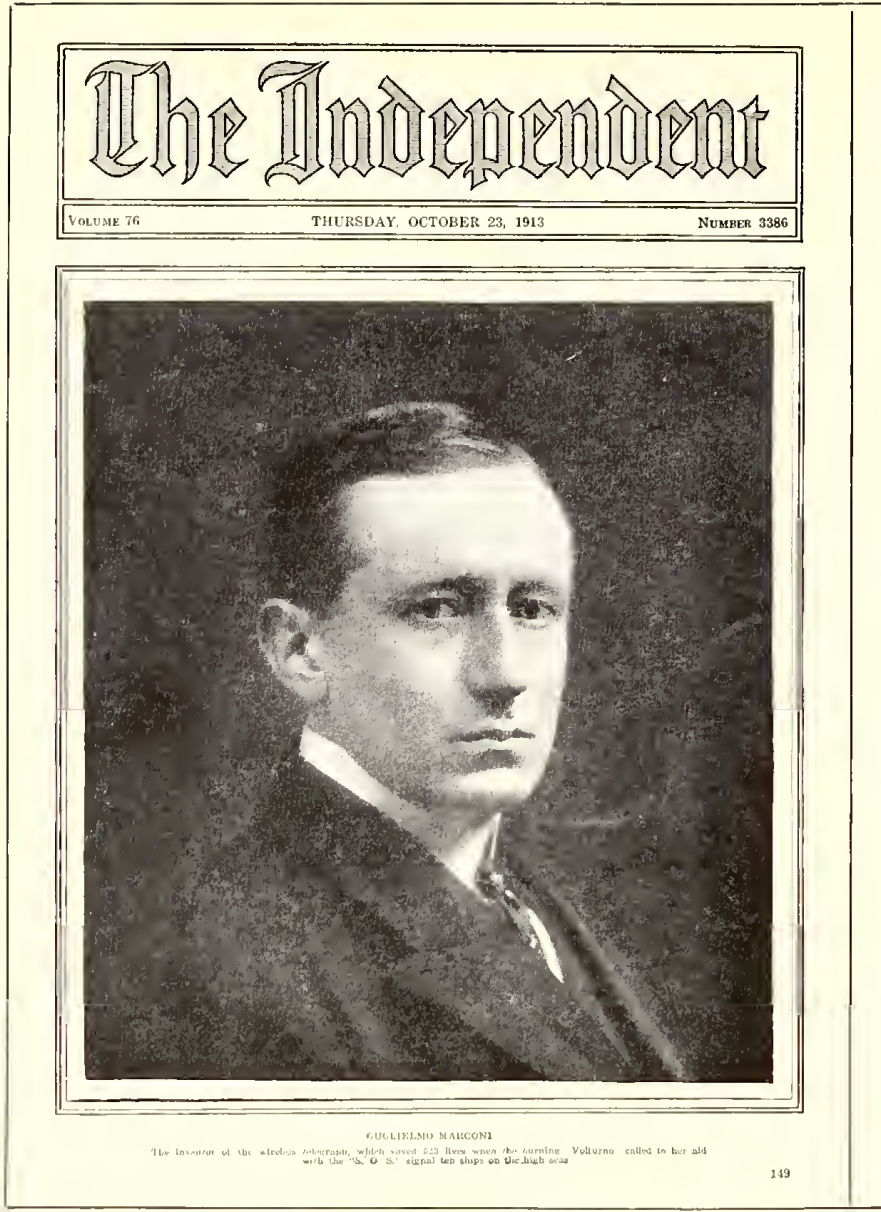

EXAMPLE 421

News photograph on the front page

ened paper of an unfinished surface, and it is no wonder that it does not appear at its best in small sizes on calendered paper.

It is absolutcly necessary that the text matter of a periodical be casily read, yet the type-face should not be sclected for that reason alone. It should be well formed and pleasing to look at, and, if possiblc, be a face that makes feasible some harmony in design between text type and head letter.

In publications that have text matter in eleven-point or twelve-point a letter such as Caslon Oldstyle would doubtless be satisfactory, and on small publications Old-Style Antique or Cushing Oldstyle render excellent service.

Scotch Roman, notwithstanding the fact that it contains hairlines, gives fairly good results, provided the paper is not highly calendered.

Ictters with hairlines when printed on calendered paper lack the little legibility that they otherwise possess. Many letters could be made more legible, especially those composed on machines, by cutting the matrices so that the print of the thin lines is a trifle stronger.

The chapter on "Type-Faces" should be read in this connection.

Trpe-Faces for the Headings.-An ideal condition in periodical make-up is one which makcs possible the use for headings of the identical design of type that has been selected for the text matter, as in Examples 410 and 411 , where a French Oldstyle has been used, and in Example 415, where Scotch Roman is the type-face.

It is not possible always to use the very same design of type-face for both headings and text matter. After a text letter has becn chosen for legibility or other reason, the

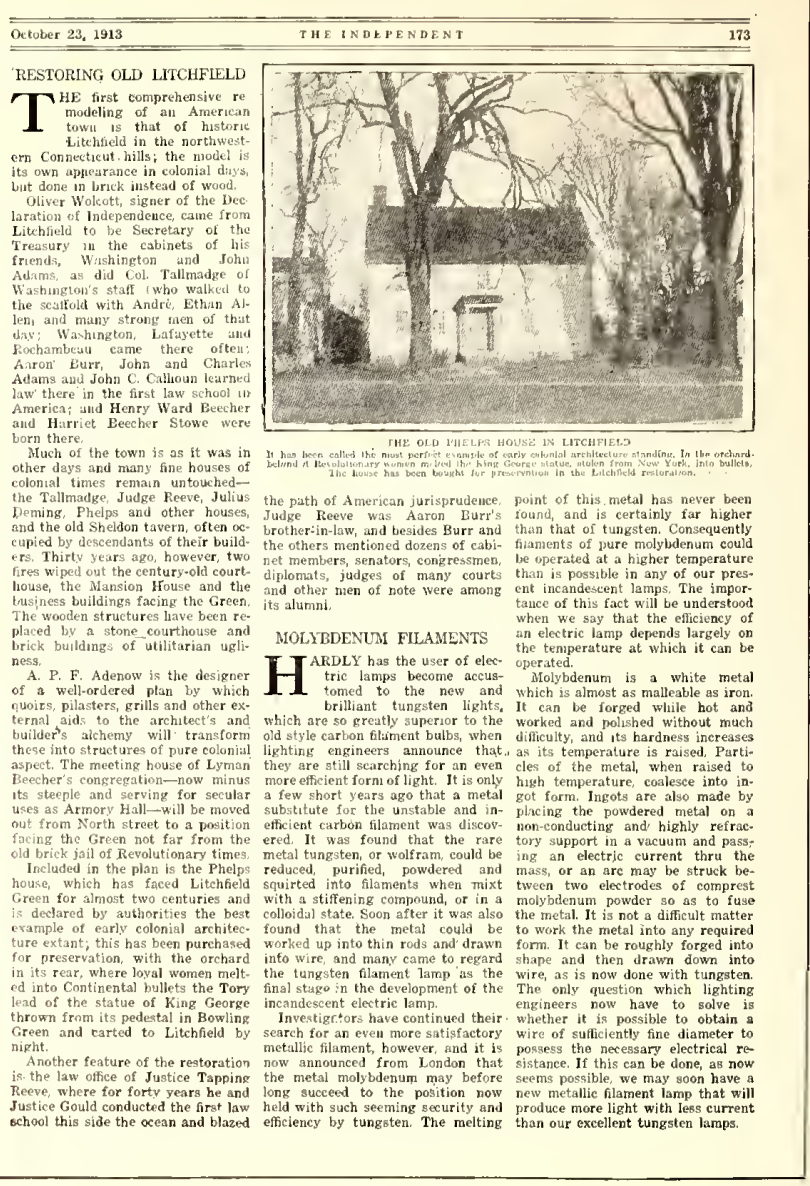

EXAMPLE 422

Fine specimen of typographic make-up

identical type in larger sizes may prove to be too plain for the sort of periodical on which it is to appear. And there are sometimes special rcasons, regrettable but unavoidable, an instance of which is this volume, wherein the text matter is in Scotch Roman (a modern letter with some relation to old-style) and the headings and captions in a type-face of old-style form. This combination is not ideal, and the explanation follows. In order that "The Art and Practice of 'Typography" conld be published at a price that would enable it to be widely circulated, the chapters, as soon as each was prepared, were first printed in The American Printer. The type-face used for the text matter and headings in that publication was Scotch Roman, hence it was felt necessary to use Scoteh Roman for the text of this volume. However, it was believed that a darker type-face of old-style formation would be more pleasing for the headings, and a Goudy letter was selected.

A modern type-face (Bodoni Bold) appears on the headings in Example 412, 413 and 414. Bodoni (not the bold) is also used for headings in Examples $41 \mathrm{G}$ and 427 .

Caslon Oldstyle is to be found used for both headings and text in Examples 420 and 430 . Old-Style Antique appears in Example 431.

The Saturday Evening Post for many years made use of an old-style letter for its headings that as a type-face was known as Post Oldstyle. The italic, outlined and filled in with gray-printing lines, is shown in Example 424.

A Gothic decorative letter is not out of place on a Christmas number of Collier's (Example 425), but is not recommended for general use on periodical pages.

Large, bold, black type-faces for headings in periodicals should be avoided.

Interest can be added, in the treatment of department 


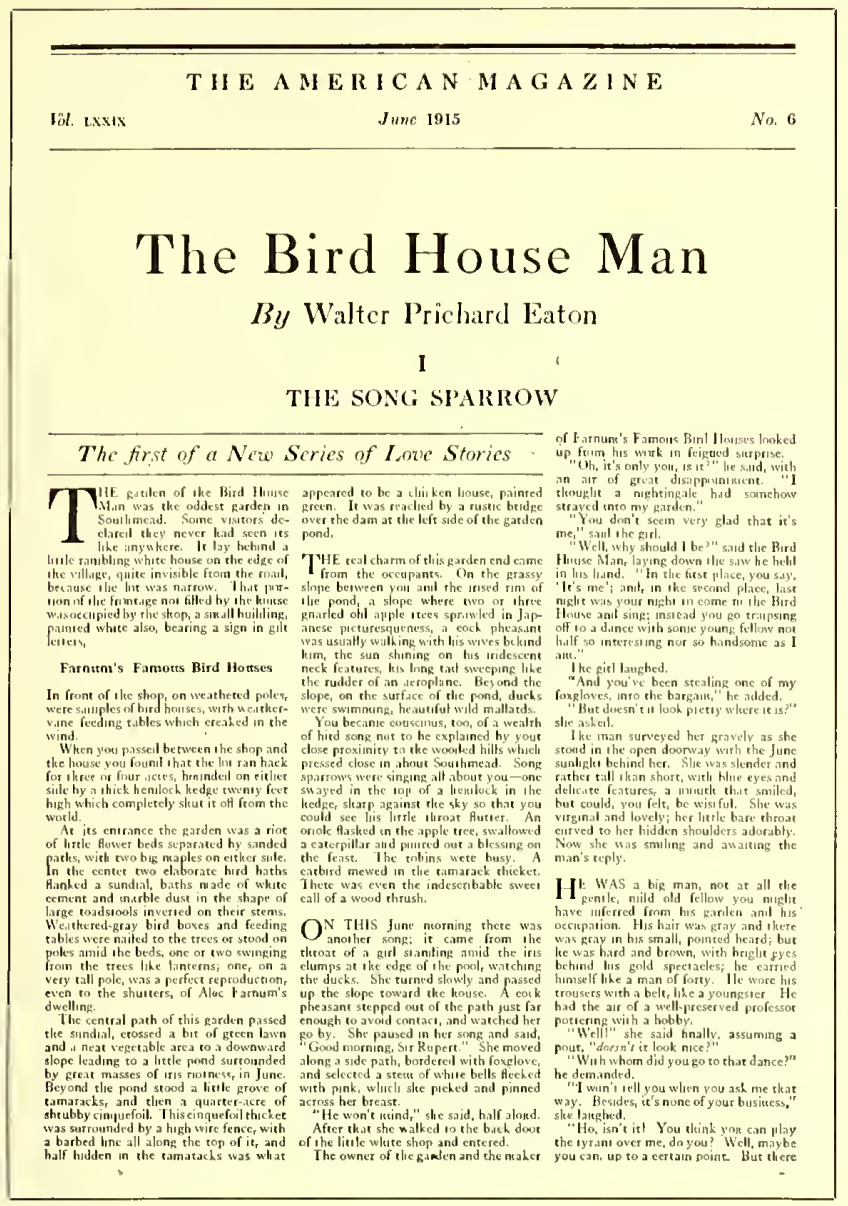

EXAMPLE 423
An attractive first text page By Lester Douglas

headings of technical publications, by using slightly deeorative panels, but such decoration should be light or slight, and not the commonplace sort sometimes found in illtreated job work.

Editorial and title headings in typographic treatment should blend with other parts of the text pages and not look, as some do, like quarter-page advertisements inserted in reading matter. Example 429 shows good treatment.

MAKE-UP OF THE Illustrations.-When planning to ase illustrations on periodicals both facing pages should be before the person doing the planning. The text matter of the two pages forms a baekground of gray, and the problem is to place illustrations, headings and initials in positions that will not only be well balanced but so assembled that one will not interfere with another.

Usually therc slould be some text matter between illustrations; they should be placed toward the outer side of the page (see Example 422). The center position is praeticable when there are three columns and the illustration is but a single column in width, or when the expense of running around may be incurred (see Example 424).

Illustrations frequently look better separated from the heading, as in Example 11 , than when joined with the heading, as in Example 412.

The same style of illustration should, if possible, be used on facing pages. Make-up that shows a line plate on one page and a halftone on the adjoining page is inharmonious and not so pleasing as when all illustrations on facing pages are of the same character. They should bc, say, either line like that in Example 414 or halftone like that in Example 412.

When an iliustration appears on a text page, initial let-

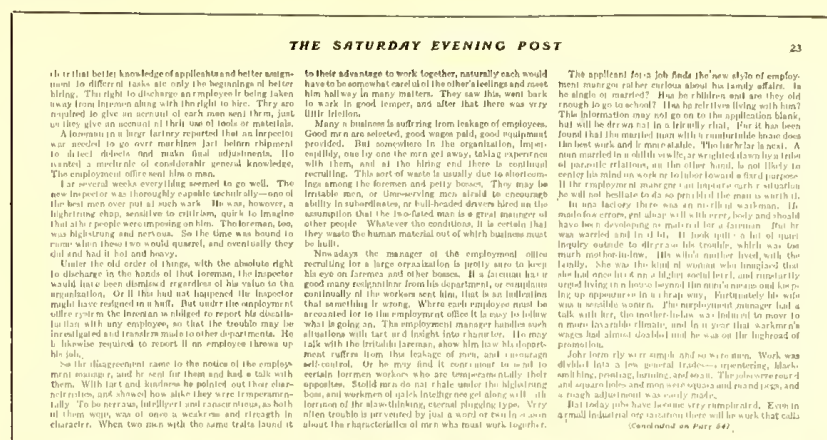

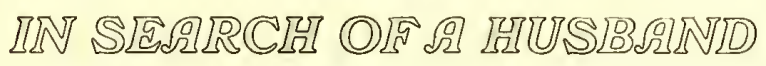

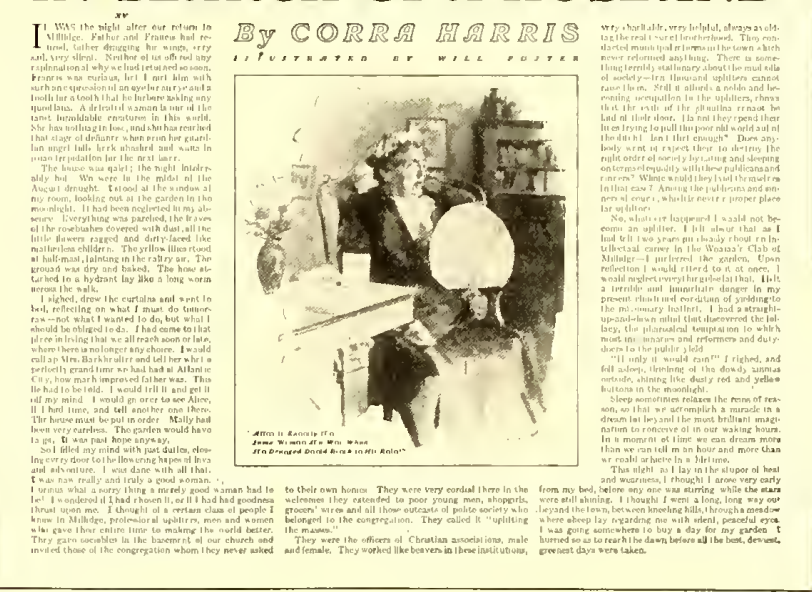

EXAMPLE 424

Illustration placed in center, necessitating running around

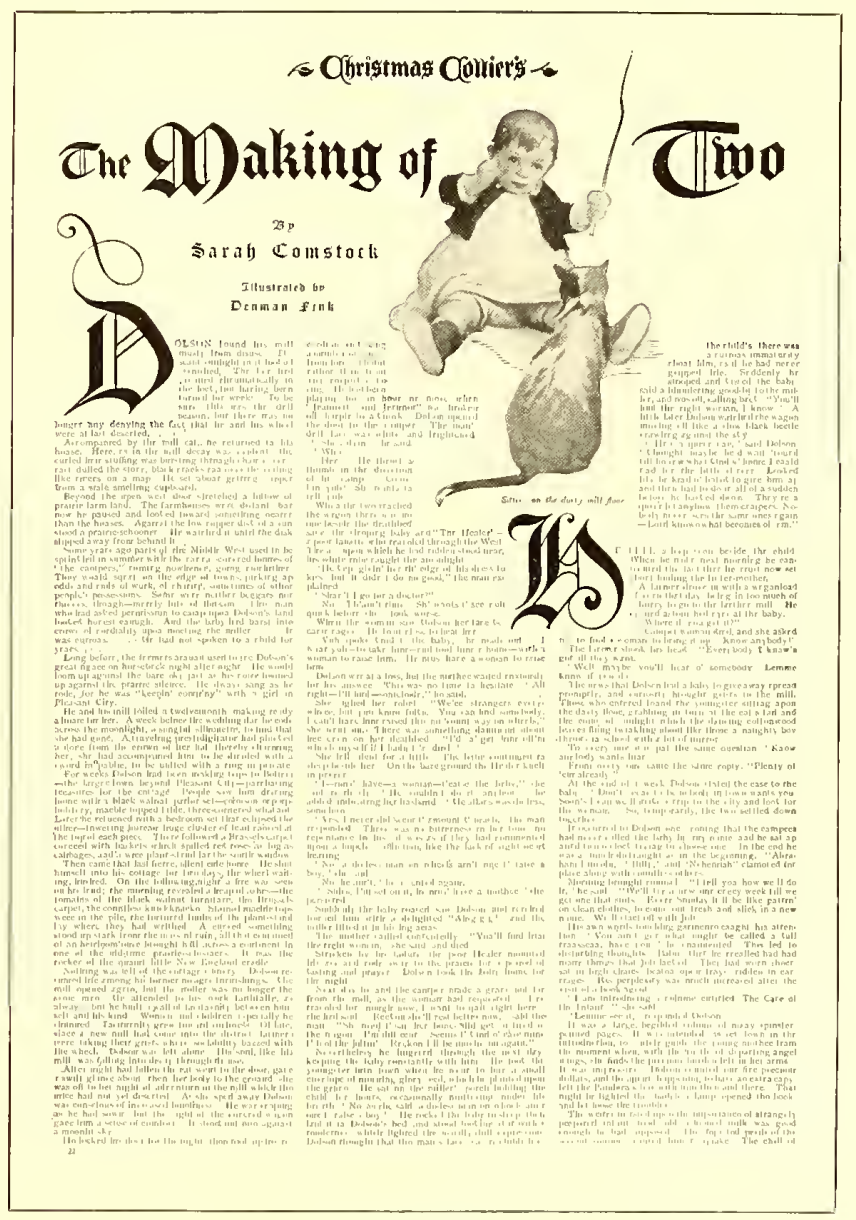

EXAMPLE 425

Feature page of a Christmas number 


\section{Convention Hearfaye.}

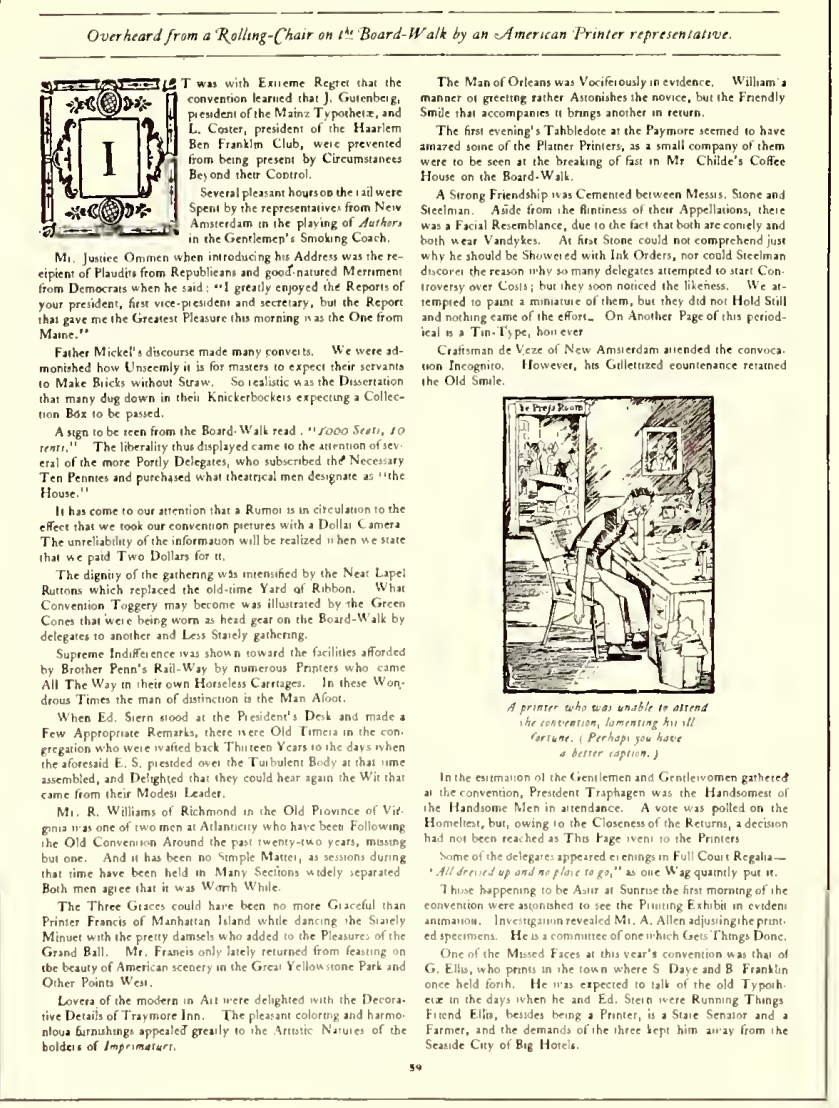

EXAMPLE 426

Convention feature page of a technical journal

ters should be plain and small, as in Example 414; but when no illustration appears the initial can be large, as in Example 411, or even decorative. For regular purposes initials as used on Examples 409 and 125 are inadvisable.

Pleasing usc of a vignette style of illustration is to be secn in Example 430. It lends interest to the first text page and at the same time illustrates the leading article.

The illustration in Example 129 is also effectively placed.

Armingenent of Hendngs.- Headings, in a way, advertisc or "scll" the contents of a periodical, and their arrangement depcnds on how far the editor or layout man wishes to go in advertising or "sclling" the contents. The American people have so much reading matter available that it is probably necessary in most instances almost to force them to read the various articles in periodicals. Eneyclopedias are read cven if there are no display headings and the type is in six-point, and there are periodicals that are read without urging; but it may as well be conceded that articles are read more when they are well advertised.

A well-advertised story will be found in Example 413 . The title is brought out prominently in a largc, bold type, as is the name of the author. The italic line above the title smacks of real advertising, as does the group of type inserted in the upper part of the text. The display in $\mathbf{E x}-$ ample 412 is frankly advertising in its appearance.

'The Saturday Evening Post heading (Example 42.1) is large, but there is no descriptive advertising, and there is little of the nervous fear of going unread so evident in Examples 412 and 413.

Calm, yet pleasing, treatment of headings is to be found in Examples 411 and 423.

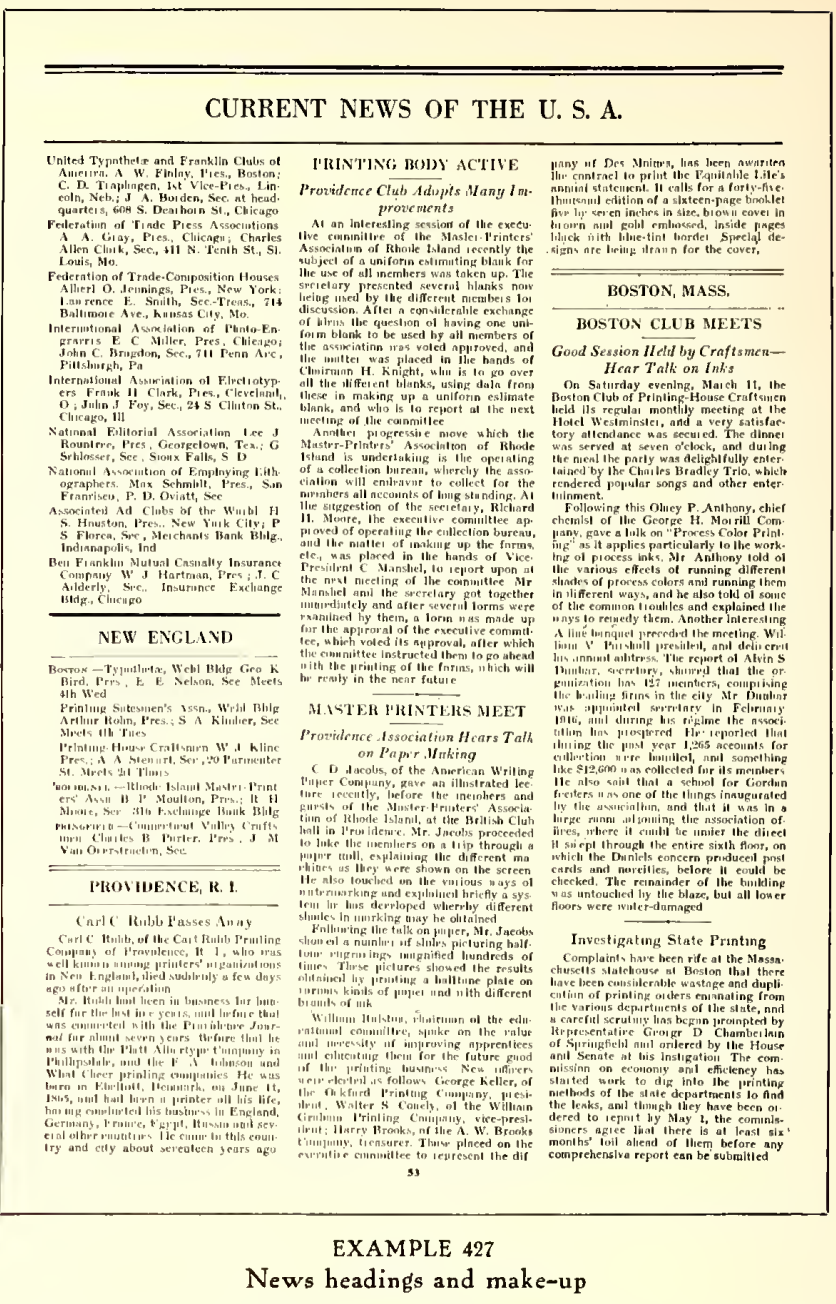

It is wcll to give attention to the presentation of article headings, but sometimes in the place where the heading should go there is so much noise and so much talking that, as a means of resting the nerves, the leaf is quickly turned or the periodical laid aside.

Periodical titles, as they appear on the first text page of each issue, are variously treated. The small, neat effect of Example 423 is commendable. It is in Scotch Roman and harmonizes with the article heading and text type. Titlc headings on a larger scale will be found in Examples 410, 415 and 416. Special lettering is sometimes pleasing, as in Examples 421 and 430.

The news department of trade and business periodicals requires numerous headings. Example 427 is suggestive. There the news articles are in narrow columns and have a newspaper style of heading.

Caslon Oldstyle looks well on any class of publication. Roman capitals and lower-case and italic may be used in the same line, as on Example 429.

The Captions.--It is customary to set captions centered under illustrations in a size smaller of the type-face used for the text matter and to arrange the caption in one or more lines no wider than the illustration.

When the caption is in two parts the first part is usually set in capitals and the second part in lower-case, both centered. The lower-case is sometimes roman and sometimes italic.

Seldom do captions receive the special decorative treatment that has been accorded them in Examples 412 and 414. Even two-line initial letters have been used with them.

The plain double caption in roman capitals and lowercase is to be found in Examples 421 and 422. A single cap- 


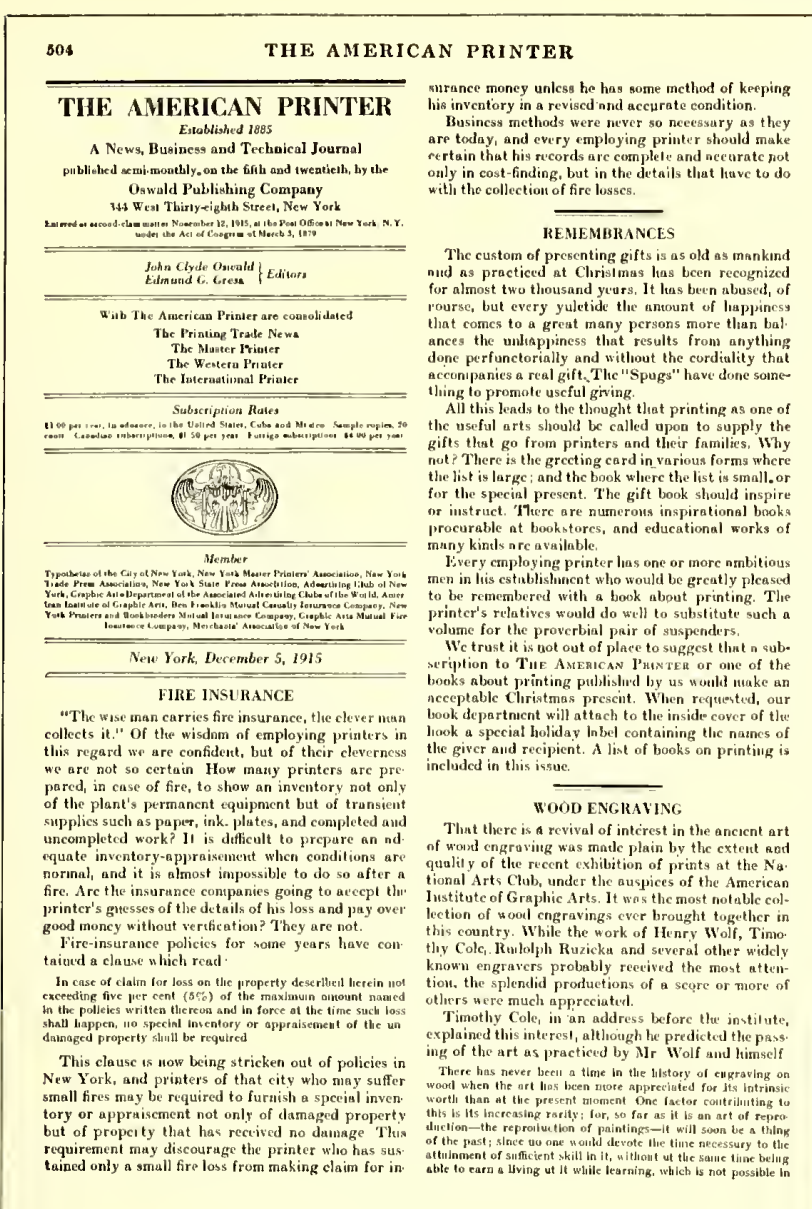

EXAMPLE 428

A conservative and readable editorial page

tion in italic lower-ease is shown inside a rule that surrounds the illustration in Example 42.t.

Arrangement of eaptions in lines of the same length, making a block of type (as in this book) is liked by many. However, the caption is to be read and its shape is not of more importance than its legibility. It is a mistake to arrange a caption in several lines of capitals and then letterspace some of the words to obtain the block effect. Such letterspacing advertises the effort as unsuccessful aud also disfigures the page.

The Editorial Pages.-In periodicals, editorial pages are treated variously. There is no standard style such as is found in most newspapers. All five editorial pages reproduced here, in make-up and typographic treatment, differ from one another.

The Ladies' IIome Journal (Example 417) has the title of each editorial in a small rule panel along with the publication's trademark, and the matter is set in two wide columns. The first clause beginning each editorial is composed in eapitals and small eapitals. The page is surrounded by a double-line border.

Collier's (Example 418) begins each editorial with an initial letter, followed by several words in eapitals, and the title in a dark-faced italic is set at the left end of the line. A decorative symbolic heading is placed above all.

System (Example 419) has a neat, readable editorial page, arranged in an interesting manner. The name of the magazine, of the editor, and the month and volume are neatly placed at the top, and the blank space that follows, occupied solely by the small black decorative mark, gives pleasure. Each editorial is introduced by a heading in small capitals and by an initial, which is larger in the first article.

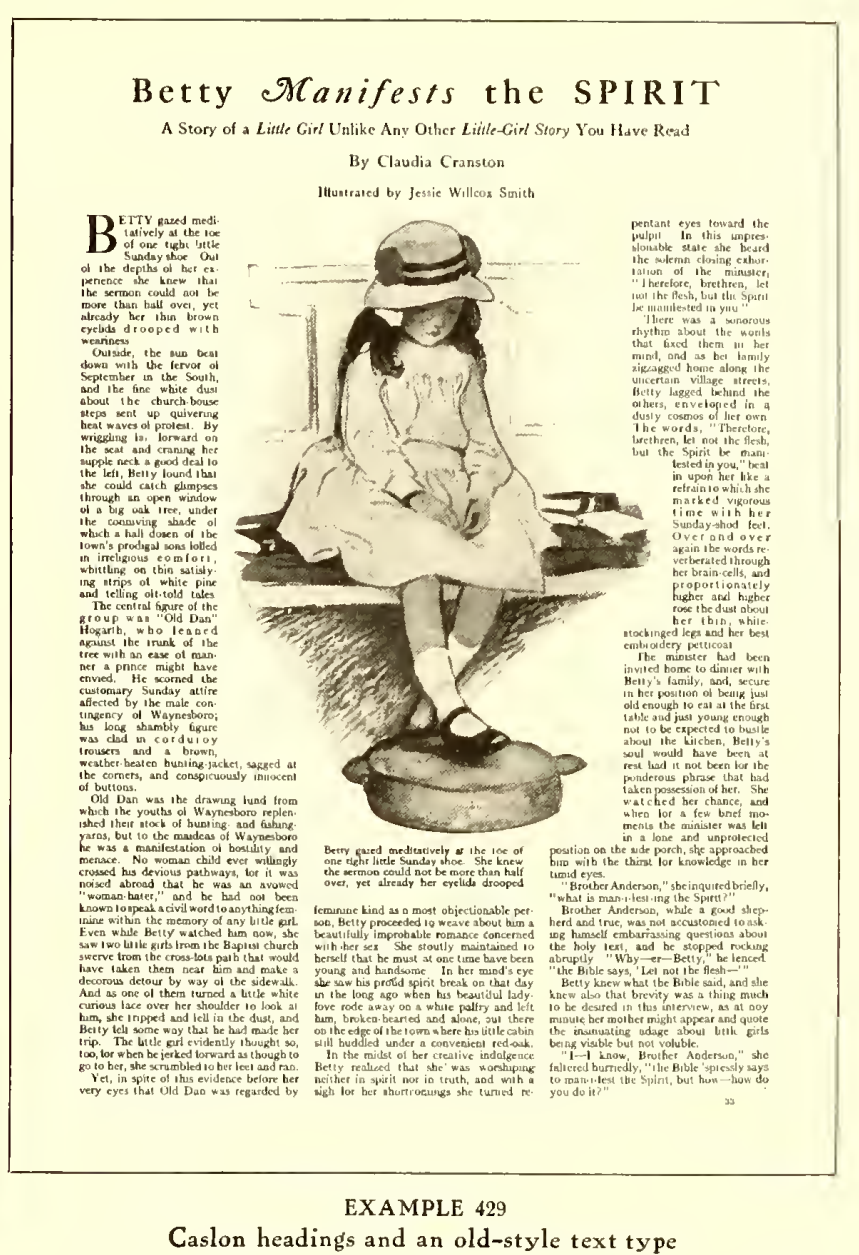

'The editorial page of Advertising and Selling (Example 420), by Sherbow, is unlike any of the others. Rules are used between columns, on both sides of headings, and above and below the page heading. 'The result is pleasing, and invites reading of the page.

The style of make-up of 'The American Printer editorial page (Example 128) was purposely patterned after that of the eonventional newspaper editorial page. The editorials of conservative metropolitan newspapers are probably read more regularly than any other part of the publications, and such reading has possibly been invited by the restful style of the typography. 'There is reason to believe that this somewhat old-fashioned treatment and its lack of affectation have really accomplished what was intended.

The editorial page should be unlike the other pages of a periodical, and these examples should assist printers and editors in determining suitable typographic treatment.

Features.-Typography can have much to do with the playing up of features in periodical make-up. An instance is the page reproduced as Example 426, which consists of what would ordinarily be the notes of the convention. In this instance the notes were written in a style that suggests the quaint diction of Colonial days. Some of the words of the text were capitalized, as was done in those times. In the page heading a few of the letters were tilted to give an irregularity caused in old eomposition by defective typefounding. Even the brass roles were nicked (brass rule was seldom in good condition in the old days). A crude initial of ancient vintage and an illustration simnlating an old woodcut added decorative interest. This page was a change from the routine style of the other pages.

The page from Collier's (Examplc 409, Insert) was 


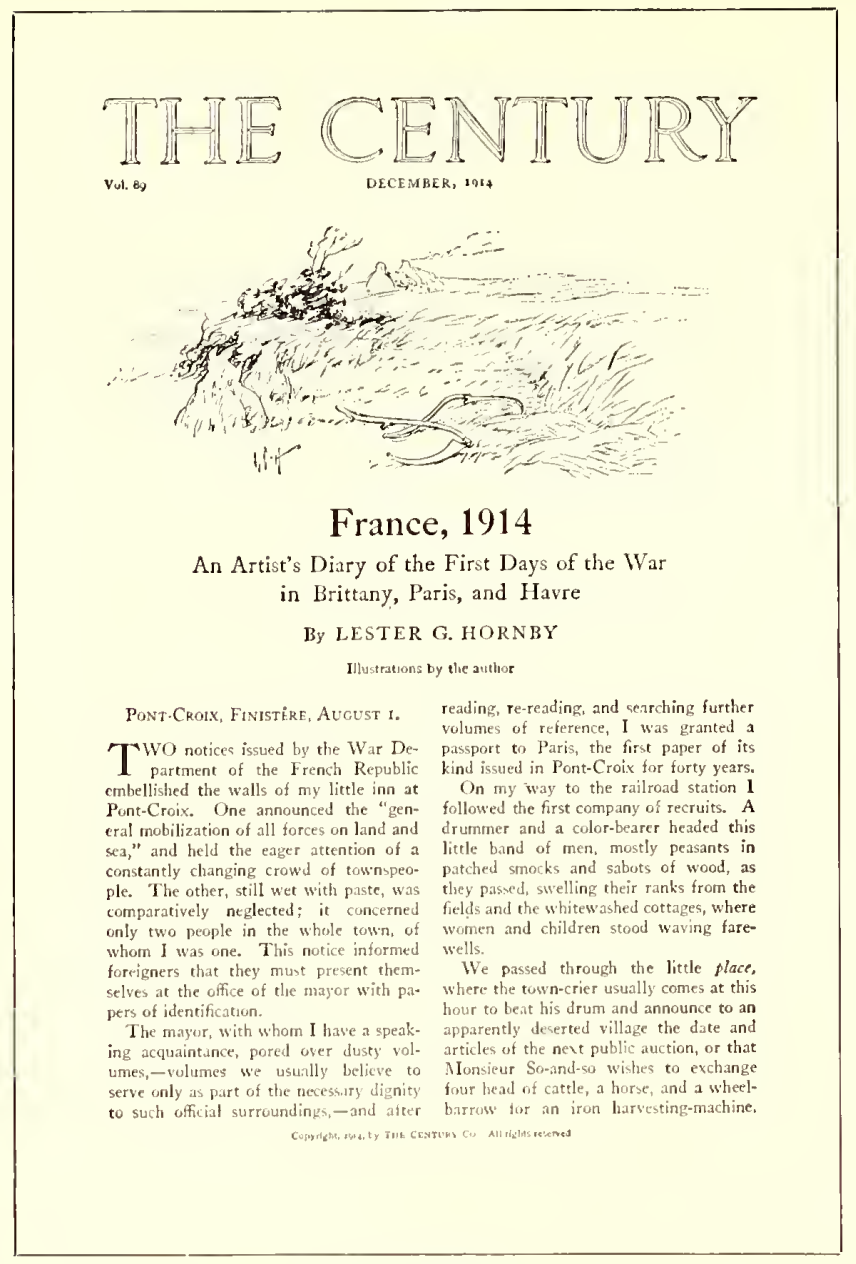

EXAMPLE 430

Caslon typography on a magazine. By Will Bradley

one of the features of a 'Thanksgiving number. Its decorative border suggests the treatment found in Books of Conmon P'rayer (sce page 27 ).

Christmas feature treatment is also found in Example 425 , also by Will Bradley. The text letter used in this $\mathrm{cx}-$ ample for initials and lieadings is hardly suitable for use generally in periodicals, but for occasional features it is not out of place.

Verse when used will usually look more interesting set in italie, especially when the italic has a decorative quality. One of the important general magazincs sets verse in Kennerley italic in a decorative panel broken into the text page at a suitable point.

Important parts of an article reprinted in an attractive panel on the same page would call attention to the article and invite reading.

A certain amount of restraint is necessary when planning typographic features for periodicals. Type-faces should be selected with knowledge and care, and seldom should large sizes be used. "Jobby" display effects are never in order on the text pages of periodicals.

Tine Advertisements.-The typographic details of the editorial section of a national periodical in the field of advertising were recently revised and made more pleasing. yet when made up and printed the work that had been done was so overshadowed and counteracted by the bold types on the advertising pages that the general result was disappointing.

It is useless to attempt good typography on periodicals so long as advertisements are inserted in text pages or occupy facing positions; that is, it is useless unless the periodicals set or reset the advertisements neatly in good taste as is done by the Curtis publications.

Advertisements should not be mingled with text matter. According to old-fashioned ideas, the reader buys a periodjcal for the text matter, and it is for him to determine whether or not he shall read the advertising pages. In some publications the text pages are yet to be found intact, altho preccded and followed by sold space; in others good resolves peter out as text meets advertisement toward the rear, and in others--a majority perhaps-advertisements dominate almost all of the text pages.

'Treatment of advertisements in periodicals need not necessarily be shy and timid; neither need it be blustering and noisy. Where advertisements are neatly treated and not unduly forced on the attention, readers are likely to give as much time to their perusal as to the text pages. A gentlemanly solicitor who talks clearly in low tones is more likely to sell goods than one who disturbs the entire office by his loud talk and boisterous demeanor. Apply this to the typography of the advertising pages.

Editorially, it is to be regretted that advertising must go "alongside of reading," but it is to be deplored that in so many periodicals, especially of the business and technical class, reading matter is seemingly written and placed for the purpose of accommodating the advertising.

The successful publication of a periodical, as of a newspaper, depends on liberal patronage from advertisers; yet these advertisers are best scrved when the publication is plamned with first consideration for the text features, and the advertisements are prepared to harmonize and not clash with the typography of the text matter.

THE S I LE N T PAR T NER
OPPORTUNITY-BLIND
AN'T you see more chances on this continent tban
anywhere else on earth? Why, man alive, you are
standing on the biggest opportunity in the whole
world-North America.
If you stop working and sit down and wait for an oppor-
tunity, some day your family will be compelled to bury
you, and this will be done in the very bosom of "Oppor-
tunity."
Tens of thousands of poor, uneducated aliens are com-
ing here from Russia, Southern Europe, and the frozen
mountains of the opposite world; and with all their buman
handicap, they are making good.
And still you stare in your opportunity-blindness, and
cry, "Will someone please pass me a soft snap?" Oh, you
boobl
THE TIGHTWAD

EVERY little town has a tightwad of its own. The tightwad is the only man that has to wait until be dies to have folks say nice thinks about him; and then he can't hear them.

He goes through life on crackers and half-rations. He does not live-he only pretends to live.

He can tell you just how many feathers there are in the lndian's head-dress, and he will squeeze this copper coin until its metallic cry can be heard all over the church. When he dies, the widow wears weeds a week or so, and then huys a basketful of worthless stock. And thus endeth the lesson of the tightwad.

\section{$\square$}

BUSINESS

TO some folks business is a frolic, fun; while to others it is a sad task.

Show me the man who calls bnsiness "fun," and I'U point out the fellow who has failed to grasp the true meaning of the word.

Business does not signify a frolic or a funeral. Business is business. It is not the extremes-it is the means. 


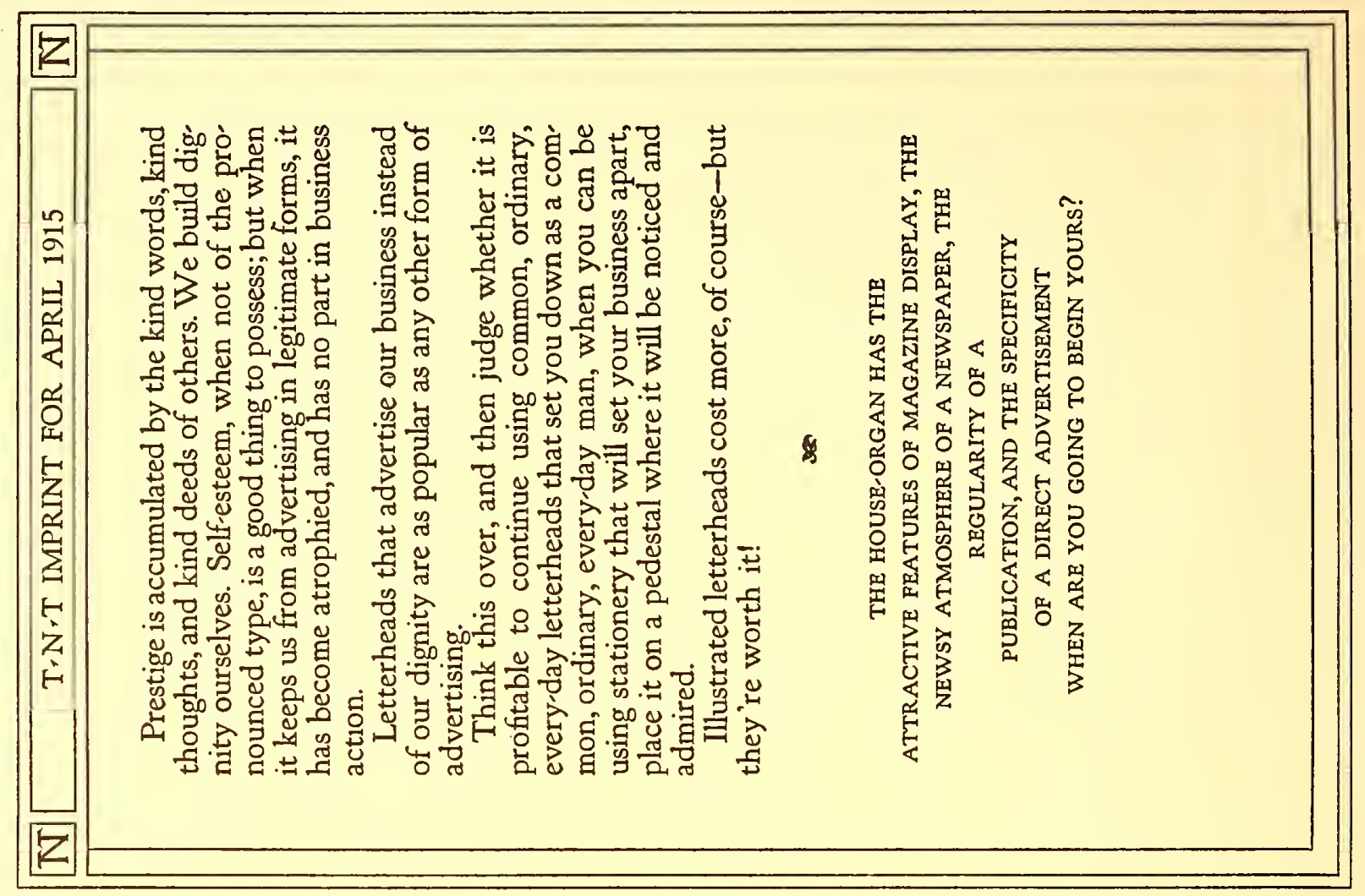




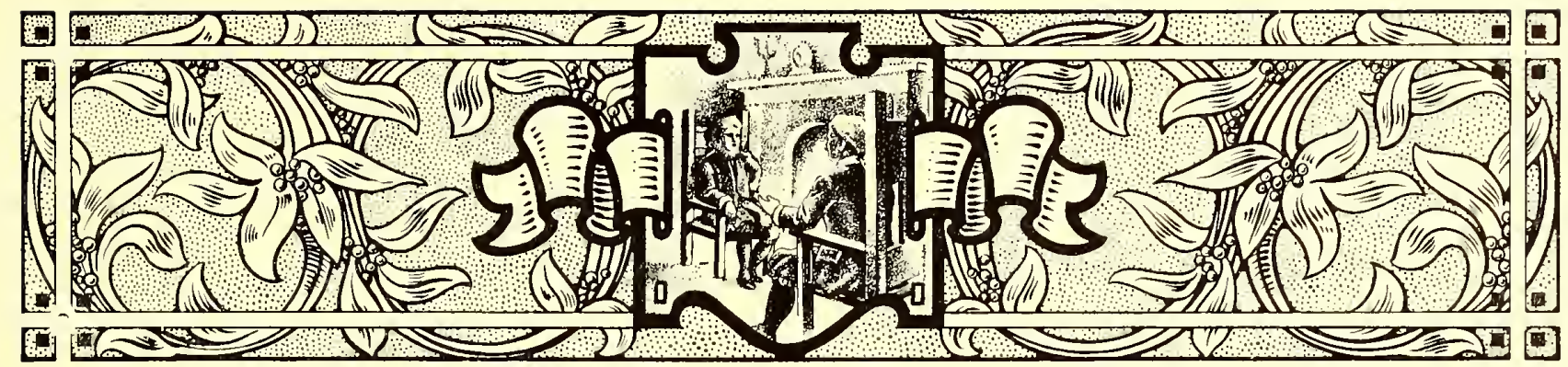

\section{HOUSE-ORGANS}

THE house-organ is the little brother of the periodical and newspaper. It is published most frequently as a means of communication between a business house and buyers of that house's product. Sometimes the publication is circulated only among the house salesmen or other employees.

Examination of more than one hundred house-organs revealed a condition that prevails in every department of publishing-lack of standardization in dimensions. The smallest house-organ measured about $3 \mathrm{x} 5$ inches and the largest $9 \times 12$ inches. The dimensions grew, from the smallest to the largest, by quarter inches and half inclies. There are many small pocket house-organs, some of which fit commercial envelops and others fit baronial envelops. If there is a favorite size for house-organs, it is $6 \mathrm{x} 9$, which dimensions are those of Examples 432, 436, 437, 441, 4.47 and 448 , illustrated in this chapter. Another favorite size is $7 \times 10$ inches, which are the dimensions of Examples 44.4 and 449. House-organs planned in the style of newspapers and containing four or eight pages are usually $8 \times 11$ or $9 \times 12$ inches in size.

A different stock is frequently used for the covers of house-organs, but equally popular is the self-cover stylethe first page of an eight- or sixteen-page form containing the cover design. The practices that govern the use of cover designs on periodicals apply to some extent to house- organs, althougl typographic covers are more often found on the last-mentioned kind of publication.

Example 141 shows a typographic cover in which most of the page is given over to a table of contents-not a bad idca when the contents are abundant.

Should a house-organ consist of only two or four leaves, it is unnecessary to give over the entire first page to a cover design, as the title could be treated as in Examples $436,438,439,448$ and 452 . If the cover page is to be lettered, it is well to have it treated in a style that will harmonize with the typography of the inner pages. See Example 435.

Seldom is there any reason for a house-organ to contain more than four or eight pages. Few of the more ambitious house-organs survive the first one or two issues, or are profitable if they do. A house-organ to be effective should be published regularly. Too many instead of being periodicals are "spasmodicals." There is more likelihood of a house-organ being published regularly if it be modest in plan and brief in contents. Printers err when they suggest elaborate and bulky house-organs to their customers. The smaller kind, neat and stylish in typography, attractive in make-up, good to look at and easy to read, are more desirable under average conditions.

The titles of house-organs are not usually as conven-

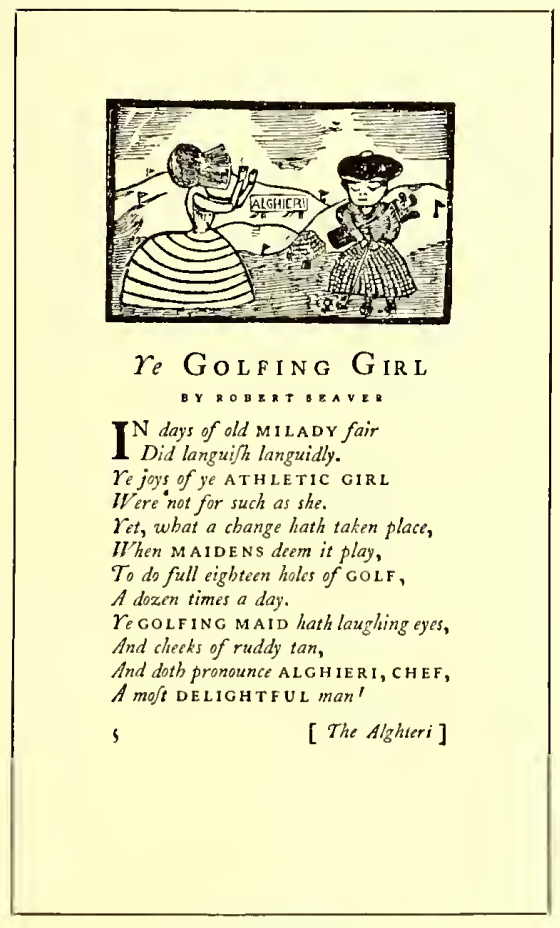

EXAMPLE 433

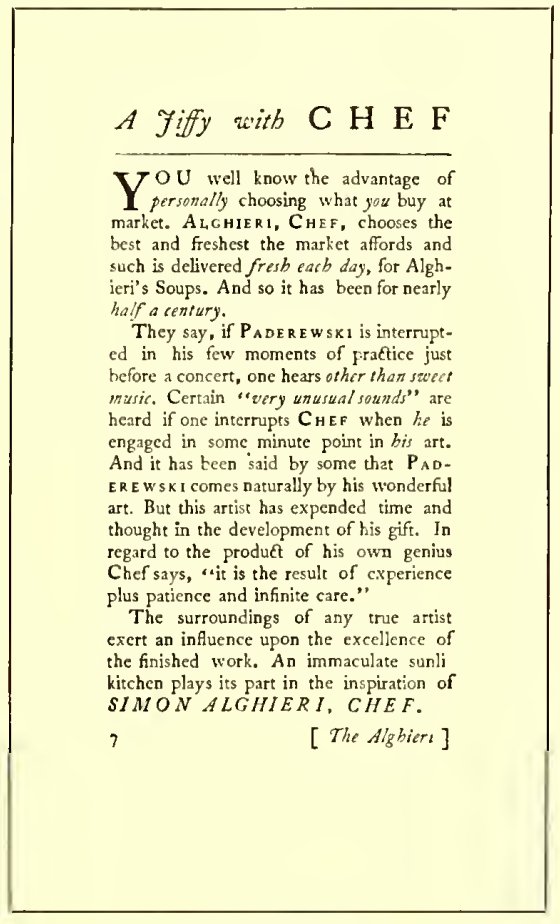

EXAMPLE 434

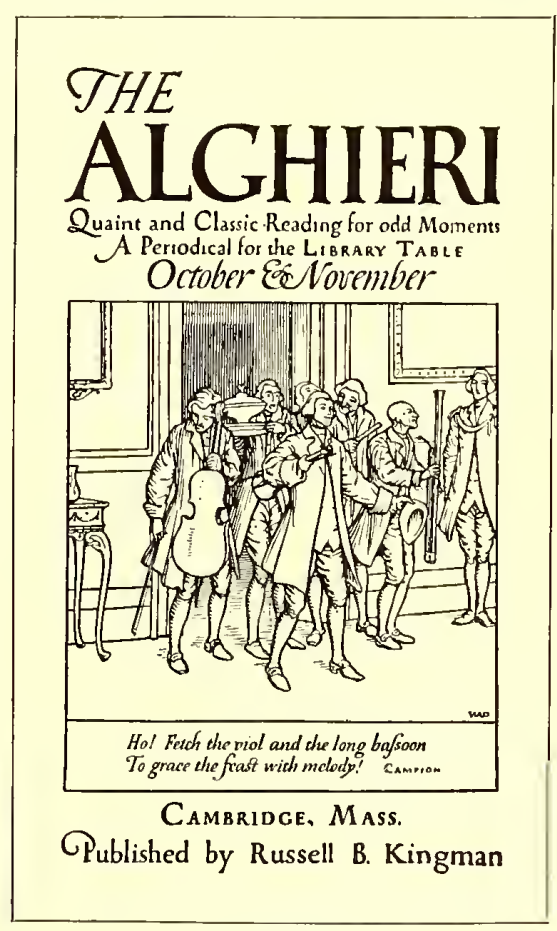

EXAMPLE 435

Pages from a quaintly-treated house-organ, by the Seaver Howland Press, Boston. Both type and illustration suggest the "good old days" 


\section{The Hampshire Service BULLETIN}

No $\cdot 1 \cdot 1916$

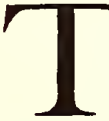

HE Hampshire Course in Salesmanship, which will be concluded with its next few issues, has brought us a great many friends-friends of the kind worth having. We think the course was.appreciated. It was our endeavor to make each booklet really helpful, and, if we may judge from the many good letters we received, our efforts were not without resúlt.

But there is much more work to be done. We do not want to stop here, nor do we want to feel that we are getting out of touch with the friends we have made. Our policy is an open one. We want the good will of the printer and the printing salesman - but we are willing to earn it - willing to show that we do not expect something for nothing.

Yet we do not hesitate to tell you that a generous amount of sentiment has crept into the work we have been doing. Each mailing of the Course would bring us many letters whose value could not possibly be measured by the amount of business they might represent. We have made many friends we should regret losing, regardless of the amount of Old Hampshire Bond they may or may not sell.

The Hampshire Service Bulletin will attempt to continue the work of the Course in Salesmanship, and perhaps carry it further, in broader channels, for the nature of the Bulletin will offer greater flexibility. As you may notice on the title page, the Bulletin will become an active expression of our idea of a partnership with those who sell printing.

\section{Brill Magazine}

THE OFFICE MEN MAY HELP, TOO

YOU, the office men of the elcetric railways, are doing a great-even a vital-work. There is-none of the personal contact with the public for you; you do not run the trams or collect the fares, and you may be hidden from the public eye, but the opinion the public at large bolds of your road, the favor it has for it and-what is more tangible-its patronage are largely dependeut upon the conduct of your work and the extent to which you serve the true interests of your company and yourself. It is fundamental to success to win the goodwill of your company's patrons and, sinee you do not come so often into personal contact with those patrons, you must make that effort through the platform men, by showing them a splendid example of courtesy and by encouraging them to work cheerfully and progressively for the welfare of the company-and themselves-and yourself.

Do everything in your power to assist in preventing the abuse of anything that has been provided by your company for your safcty and comfort and the safety and comfort of your fellou" employes

\section{THE TRUST OF SUCCESS}

$\mathrm{GACH}$ motorman and conductor is a stockholder in the Trust of 1. Success. The capital which he puts into this corporation is lis enthusiasm, his thoughtfulness and his industry, and the dividend which he draws are the notice of his " higher ups," promotion in position, and inereased salary. There are numbers who have risen from the platform to an office marked "private," but not one of these has gone up by chance- Each has been impelled by a desire to progress and has been forced to utilize his best thought and persistent industry. Each has kept before him the one hope that some day he would be included in the list of officers of his company, and with this constantly in view has put himself whole-heartedly into the battle

Don't follow your inclinations unless you first have reasoned out where they are leading you.

\section{CHANGES OF ADDRESS}

THOSE who receive Brill Magazine are requested to send in any ehange of address at the earliest opportunity. It will be more convenient in makiug up the mailiug list, if the new address is Publicity Department, The J. G. Brill Company.

\section{The Typographer}

Issued by the FREE PRESS fob Department, Easton, Pa.

Vol. 3. DECEMBER, 1904 No. 2.

\section{Poor Bill}

7 $F$ Shatespeare were alive today, Alas I be'd not he in it He couldn't make bis writing pay For jnet a single minnte.

He'd weet the coldest kind of bluff

For though be need to w rite good stnf

Jnst now he's not the caper.

I know, becaase I've written much,

Like Hamlet, only better,

And given it my finished tout

In every line and letter

A

And each my work dismisses

But jing a

And, say ! I've so mnch beart I'd bato

To see Will on his nppers,

The while we writers, up to date,

Would feast on wine-washed snp

1 could not find anch rare delight

Amid my wealth disporting,
While Will would have to go on nigb

$$
\text { -Nixon Waterman in Good Cheer }
$$

1 don't kare bow mach a man talt

\section{Colors in Printing}

(II) HE want of proper restrafnt in color printing has cansed many printer to hecome lost in the wilderness of color combination and effect.

Time was when the printer would lay in a stock of yellow, green, red, brown, blne, and varions other bnes and shades of ink, pnt ont a sign "Fancy Printine" ond commence to thro on cold make Noab's rainbow pale in comparison and the chameleon turn green with envy The red, white and blue effects are still with us, to tnra onr thoughts to the old days when the tri-colored poster announced to the village that Fourth of Jaly was a-coming fast, and Si Pleak, Esq., wonld deliver an oration, after selection by the village hrass hand

It is a relief to the eye to depart from 2ill th is and rest on the simple effects of the early printer, with their blect print, enlivened by a tonch of red. A intelligent handling of this combinatio

\section{Parish Tidings}

Published by the Luther League of St. John's Church, Easton, Pa. \begin{tabular}{lllll}
\hline Vol. I JANUARY & 1903 & No. 2
\end{tabular}

II

PY New Year

The year has 365 days in it. They are eeparate and distinct days. Each day the We mugt nse each day properly if the zear is to be spent well.

Onr congregation is nade np of individuats. The congregation's grow th and pendent po ine growth and developperfect the individuals, the more perfect the congremation. The more defective he individuals the more numerous will he the faults of the congregation.

Progress depends upon nnlty. Grndge, envy and jealonsy prevent unity, and therefore, hinder all progress and development.

Narrow mindedness, and its twin sis ter, bigoted individasilom, are frequently lond in me hero the charcubation are sare whon the are and

peeds he local or general. Individualiem should never appear in the churcb, regation or to a perso

The work of the Church at large is ependent upon the individual congregations connected with the synod. At a time should it be lo sight or-much  respo for the prostos of the ork nndertaken by Synod. Each conregation is morally hound to meet the bligations imposed on it by Spnod-and ertainly Christian congregations do not require a legal obligation hefore they aro willing to discharge it

The corner stone of the Chapel bein rected for the Church of the Good Sheprected for the Chark or the God saep4 lare A large congregation was present and hat the huilding rill proceed somewhat more rapidly in order that it way he ready for the congregation by Easter.

I

The Snndas School services Christma evening 


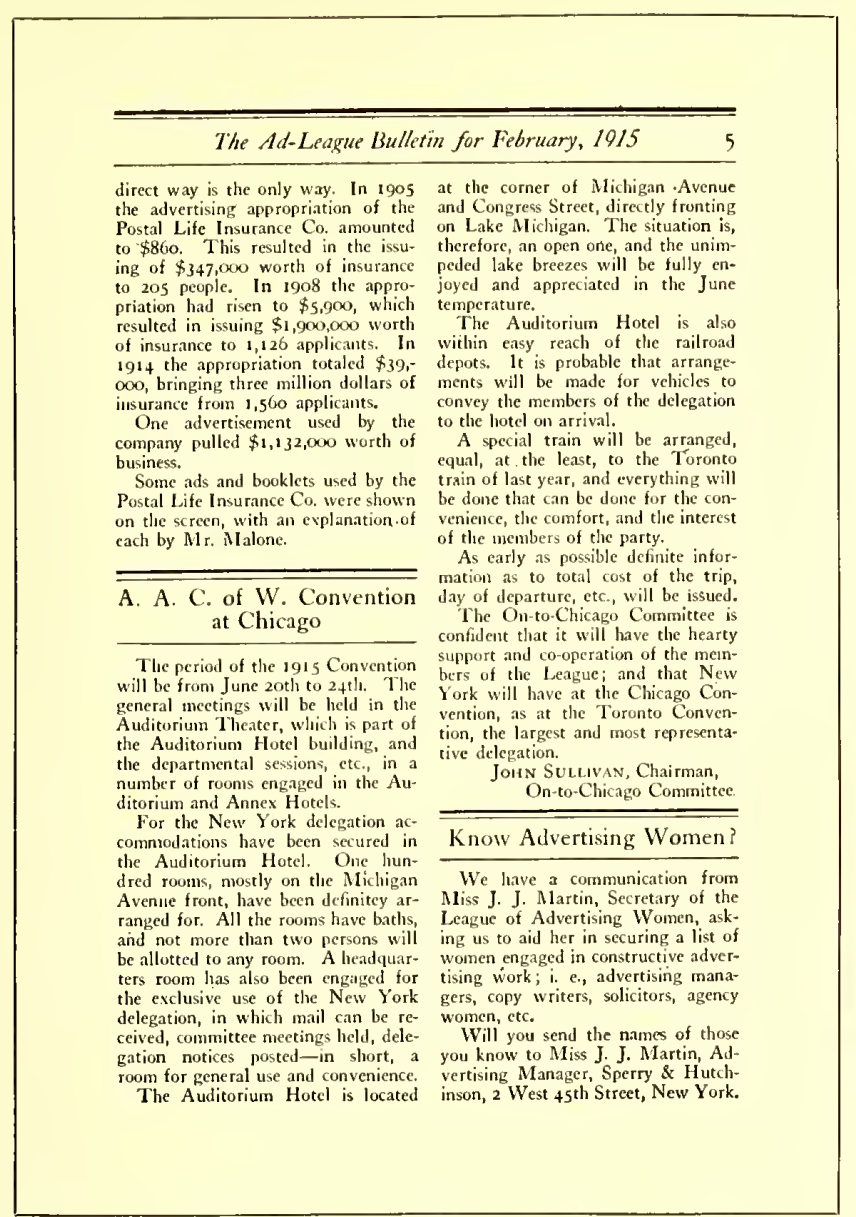

EXAMPLE 440

Attractive rule treatment of headings

tional and dignified as those of magazines and other periodicals, although those who have a liking for the conventional select the word "Bulletin," adding to it as part of the title a word which connects it with the business. Hence we have the "Linotype Bulletin," the "Hampshire Service Bulletin" (Example 436) and the "Ad.-League Bulletin" (Example 440). Printers, for their house-organs, use a variety of titles that include "Typographica," "Imprint" (Examples 432, $442,445,446,450$ and 451 ), "The Typographer" (Example 438), "Pica" (Example 448), "Type Talks" (Example 452), "Warde's Words" (Example 44.7). In other lines are to be found "Drug Topics," "Statler Salesmanship," "The Constructive Banker," "The Wallace" (Example 444), "Poor Richard's New Almanack," "Selling Sense" and "The Ambassador" (Example 455).

The number of columns that should be used in house-organs depends, of course, on the size of the page. One column is sufficient for the small pocket publication (Examples 433, 434, $435,445,446,453,458$ and 459 ). The page should be made

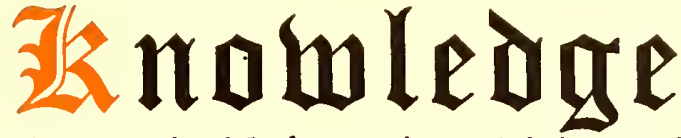

$A$ Journal of Information, Advice and Suggestion for the Direct-by-Mail Advertiser

P.UBLISHED BY THE DANDO COMPANY DIRECT-BY-MAIL PRINTING AND ADVERTISING 34 SOUTH THIRD STREET. PHILADELPHIA, PA. BOOK TWO FOR FEBRUARY, 1915

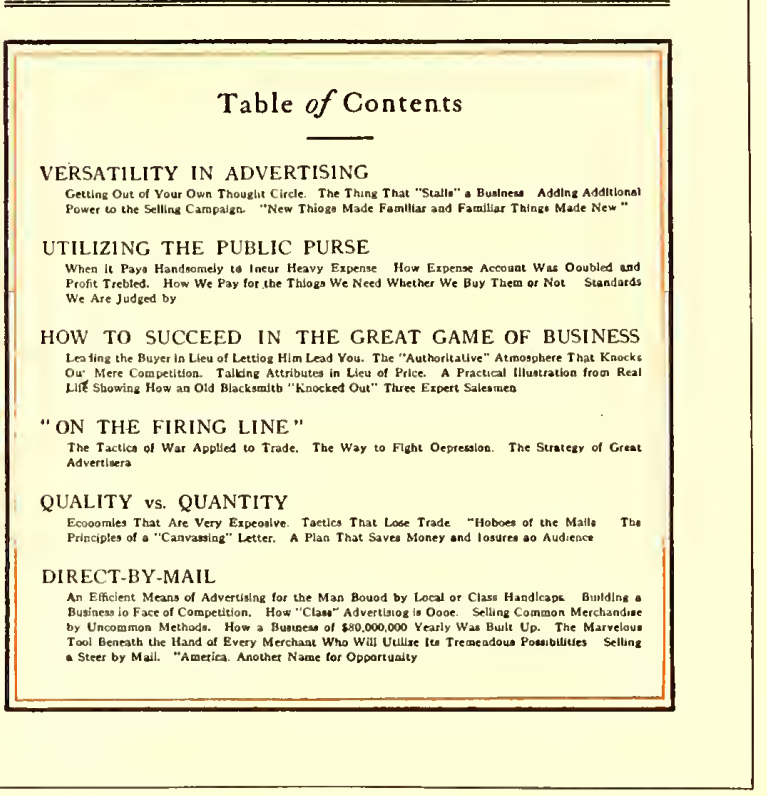

EXAMPLE 441

Contents outlined on the cover

up in two columns when the size is about 6x9 (Examples $438,439,440,444,448,449,450$ and 451 ). The purpose of more than one column is to make reading easier and not just to provide a narrow column. On some house-organs the columns are made so narrow that it is as difficult to read them as when they are very wide.

The margins on the houseorgans should be of the same proportions as on periodicals and booklets--the most margin at the foot, with the type-page inclining toward the head and binding side. In fact, such margins should be found on all printing in which there are two facing pages.

The type-faces used on houseorgans should be legible and at the same time good-looking. Caslon Oldstyle is suitable for house-organs as well as most other purposes. The Caslon style of type is used on Examples 433, 434, 436, 440, 441, $448,450,451,453$, and 455 . Other faces used on the houseorgans here reproduced are Kennerley Oldstyle (Examples $432,445,446)$, Old-Style Antique (Examples 442 and 447), Cloister Oldstyle (Example
EXAMPLE 442 Simple, effective typography 


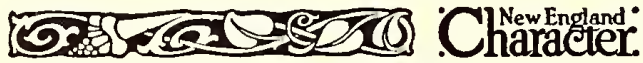

\section{Monuments of Clay}

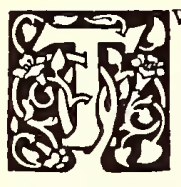

Wo thousand years ago a famous thinker said, "I had rather men should ask why my statue is not set up than why it is." There's an important lesson in these few words, and one that has a remarkable bearing upon success in business life. The moral marks the dividing line between that which is necessary and that which is unnecessary. Think for a moment how pleased you would be if your employer should walk through the factory or office and, after studying the result of your service, inquire of the manager or superintendent why you had not been promoted to do better work, or take a more responsible position.

On the contrary, think how uncomfortable it would be if you were holding a position of authority and your employer, after observing the way in which you handled yourself in it, inquired of your superior, "Why is that man allowed to retain such a position?"

It wouldn't take long to figure out that you were on the way to being "fired," for when a competent man is holding a position of authority, employers do not as.a rule find it necessary to ask why.

Think this over for a bit along these lines, for it all comes down to the principle of service. I heard a very interesting lecture a few-days ago in which the lecturer said, "They profit most who serve best" It seemed to me that there was a large amount of truth in the remark.

We are all employees in this world, in the sense that we are all serving some one, and the power of a man or woman increases in their capacity to serve the most people.

The president or general manager of a large corporation, or the sole owner of a big commercial concern does, as a rule, represent the very highest type of employee. He is the servant of the public. He has broad duties to fulfil. The lowest type of labor is the one that, as a rule, serves

$$
\text { (35) }
$$

EXAMPLE 443

Dark-toned typography by Griffith-Stillings Press, Boston

457 and 458 ). These and other good faces are available for house-organ purposes.

\section{Taylor VI.⿻ A POLICY TO ADVO.} ICATE CONSTRUCTIVE

Taylor PRICE-MAKING.

Printers ln carrying on our work we aim to meet one important limitation-that of cost. $\infty W e$ pre fer not to give exact quotations, though we do not decline to do so $\infty$ Our usual way is to planeach piece of work within reasonable limits of cost, though not neces sarily within the cheapest limits. (2) Enever try to 15 1 within limit 25. 35 of the "lowest

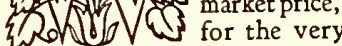
simple reason that in the long run we should almost certainly sac rifice every ounce of quality in the consummation of this object. Holding the point of view we

EXAMPLE 445

Rubricated typography by Taylor \& Taylor, San Francisco

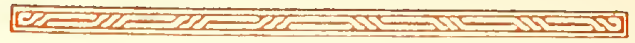

abruptly and looks pityingly at the bach. professional manner to join the ranks elor. "But you would not understand," in fact, she mentions in passing that she he continues regretfully, " you are only has practically decided upon the girl. a bachelor." "Then off be dashes on Surely, the "season of Brides " is al. a dead run. "Better get married," he most upon us - the sensom of largely in. fings back recklessly orer his shoulder. creased business for the dealer in silver. "Confound the idi" bachelor, boking unconforty around only by the attrectuens of him of hime as he catches the emused eyes of the passing maid. ". Unmistakably mad, poor chap."
But the madman is now floating busily
R. Wallace gift suggestions that are cerfin a Delft-trimant world utterly given to those an almost irresistible appeal to those who contemplate wedding tributes berause of their exquisite beauty and Truly this is a drying tome for bache lors - the open season, so to speal

Brides - Brides - Brides. Every paper he opens contains nothing buit pictures of Brides, and they are all so conwith $\mathrm{D}_{\text {hears people talking " }}^{\mathrm{N} \text { " } \mathrm{T} \text { y when one }}$ De "pors people talking "bard times" peres ways. They annoy him hugely, - these Each month has its opportunities for Brides. He forgets his coffee, and it the business man, and particularly in the with lim to the He carries their visions silver business - that's what interest ham from out a mass of correspondence. Here's June - synonymous with Bride They float alluringly around his deck and - and you know what Brides mean (if they are all so tantulizingly pretty, too, you have read the article on pages 5 and - these Brides. 6)-gifts. Your store should be the Trying tames, indeed. In the morn- distributing spot in your town. Scan the ong invitations greet han at breakfast. society columns of your local paper At nught, wherever he visits, a unother is engagements and announcements by the surs to take ham aside to tell him of dozen - every one of these means a wedthe day when she, too, was a bride. She ding soon.

gives him a bree synopsis of past wed- Fathers and mothers of these happy dings, then leads hiin up to the present. people are just anxious to thank you for augestion regarding gifts.

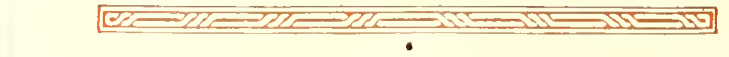

EXAMPLE 444

Suitable treatment for this silverware publication

What has been said in the chapter on "Periodicals" about the suitability of type for headings applies as well to house-organs. In most of the pages here reproduced it will be seen that the head letter is the same kind of type as the text letter or is harmoniously similar.

The treatment of display announcements or house advertising should be such as to carry out the purpose for which the house-organ is issued. If, as an instance, the publication is issued for the purpose of presenting the attractive wares of a stationery house, it would be well to devote half of the pages to illustrations, descriptions and prices of stationery supplies. Sometimes when the display announcements are as numerous as the text pages, an announcement is placed on the left page facing a text page at the right. When this is done, the typography should be neat in appearance; the type sizes should not be large, and the type itself not any blacker than, say, Caslon Oldstyle. Especially is it a mistake to use dark faces when illustrations of merchandise are a part of the page. Dark type-faces subordinate and render ineffective such illustrations.

A house-organ designed entirelydisplay announcements included-in the original Caslon Oldstyle by someone who knows how to get the best out of the type, would be ideal. The capitals, small capitals and lowercase of roman, and the capitals and 
First, how many savings depositors does this Bank have? Next, how many dormant balances are there among this number?

The answer to the second question got down to bedrock. It showed that only half of an immense number of depositors were really actual savers, and the other half - known by name and street address - were not visiting the Bank or using its facilities. Here was a list of thousands of names of real people-people who were already acquainted with the institution, had some money in it, and could be safely presumed to be favorably disposed toward increasing their balances if they were simply reminded of the fact.

The result was a common-sensed idea. It was decided to send a properly worded personal letter to each name on the inactive list, showing the advantages of contmued thrift and a good savings balance. This was repeated month after month. Results came fast. The expense was much lower than that required for a fancy scheme The effort went along the line of least resistance No outside stir was produced to lend credence to the belief that the Bank was hard up, and thousands of easily reached, but apathetic, customers became active and loyal supporters of the institution. In this case common sense hadn't a show against a painted novelty until some hard thinking settled the atmosphere

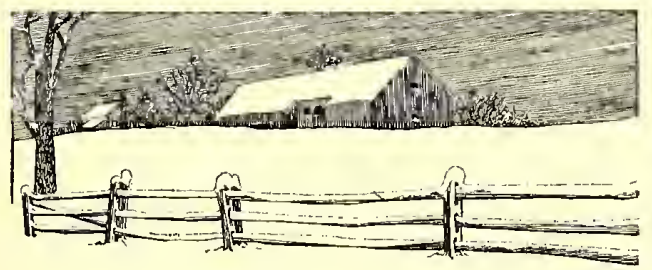

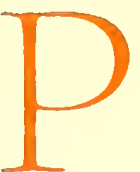
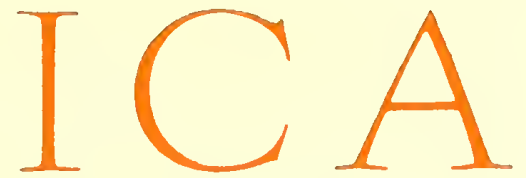

DEVOTED TO GOOD TYPOGRAPHY E THE ART OF ADVERTISING ISSUED BY EVERETT R CURRIER AEOLIAN BUILDING NEW YORK· NO 1 MARCH 1916

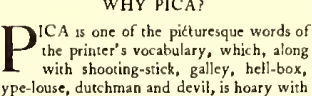
the craditions of the craft and more or iess familiar to those who
printing industry.

The word Pica, known to ornithologsts as
phe the Latin name of the magpie, came to occupy its present place in typography in a curious,
toundabout way Superficially, it would be
hard to discover any possible conne hard to drds nd any possible connetron be tion is fairly.plausible. Going back to the first centuries of printing we discover that the Ordinal, an early Engisish church calendar or liturgialo bol, was nickeffect of the blackletter page on white paper suggested a magpie's coat of feathers.
From this the word came to be employed to From this the word came to be employed to
dessignate the size of type as used in the Ordinal. destinate the size of type as used in the Ordinal.
It was one of that series of good old names - Brevier, Bourgeois, Long Primer, etcwhich served so long as handles for rype size beliore the point syssem was adopred Rendered obsolete by the point system as
the name of been retained widh of type pages or columns. Thus, while we now say "T welve-point Casion," for example, instead or "Pica Caston," if is easy see why "tweive picas wide" is preelerred to
"twelve twotve-poinsts wide." This then, explains the popularity and use fulness of this short but not ugly word, too good
an epithet ever to be dropped from the printer's vocabulary. Surely no word could more approthis leaAler represents. Do you know where so get a good posser, not he ordinary ground out mechanical posser prop-

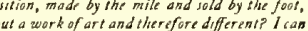
cill you, and further mark, I can supply the finished possers, execuled under my supervision. A fine design can casily be spoiled by carcless or by 100 meshanical reproducitus.

STANDARDIZATION IN PRINTING 11 VERYBODY connected with printing 1 Teels the need of greater standardization: and waste, the supply man because he is obliged carry too large and varied a stock, and the cusWer because he never knows what to ask for. We need a code of standardization in print10 govern the conduct of our daiky life. We can't expect to work out a code of standards thet will reduce the printing business ro a push-button basis. We can't hope to reach the stage where copy and paper may be shor opper and come out the other end if ansformed into perfect prining. We can not formulate specincations that will be absolutely automatic strong for that. The human equation is soo han we are at present. Standardization means the reduction of operations, of marerials, of tools and of space to the

EXAMPLE 448

A typographic house-organ

EXAMPLE 447

Easily read and pleasingly illustrated. By the Warde Press, Pittsburgh

lower-case of italic, can be manipulated so as to produce an abundance of typographic variety and interest.

While house-organs should be edited with the purpose of presenting useful technical and business information to customers, there should be sufficient light matter and features to maintain interest. Not unimportant is the typography of such features. In the make-up of all houseorgans are spaces at the end of articles that are available for feature purposes. Example 432 shows how one bit of blank space was made attractive by well-arranged small capitals, and in Example 450 similar use has been made of italic.

Articles of merchandise that are old-fashioned in their appeal furnish a motif for typographic treatment that can be made a feature. Examples 433 and 434 show Colonial typographic treatment, the use of italic and spaced small capitals, added to which is a feature page topped by an old-fashioned woodcut.

There is a suggestion of ancient rubricated books in the typographic handling of Example 445, appropriate for a printer who does typography especially well.

Borders around the text pages of house-organs can be made to act as features if they are designed with proper restraint, as was done in Examples 432 and 450.

Rules and decorative borders, ornaments and initials are not out of place on house-organs when used as they are in Examples 440, 443, 444 and 445.

When the house-organ is issued monthly an old-fashioned "almanack," with appropriate matter interpolated, makes a good feature, as in Example 4.57.

As a novelty, house-organs have been printed on blotter stock. The general treatment for blotter house-organs is

\section{The Edison Monthly}

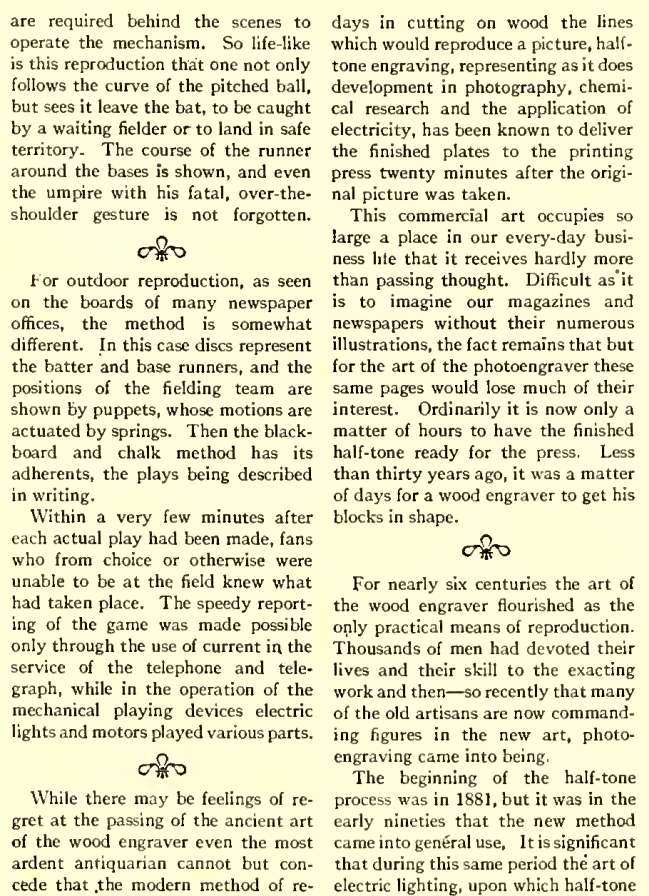

EXAMPLE 449

An editorial page of typographic neatness 


\begin{tabular}{|c|c|}
\hline \multicolumn{2}{|c|}{ JANUARY TI IMPRINT } \\
\hline 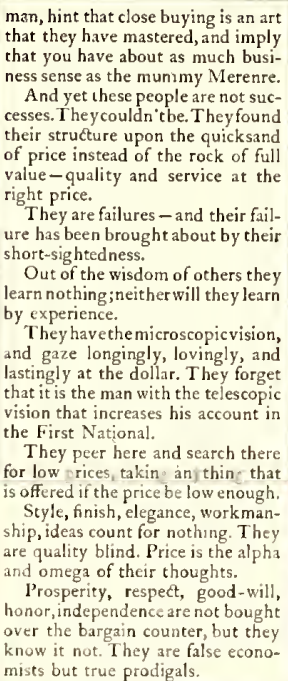 & 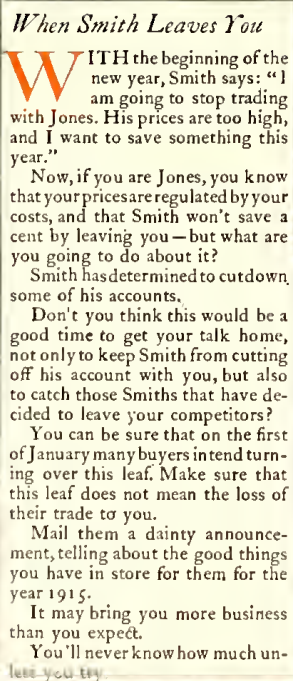 \\
\hline $\begin{array}{l}\text { camor afford much } \\
\text { affor }\end{array}$ & $\begin{array}{l}\text { Ie man who } \\
\text { good printing cannot } \\
\text { fanything else }\end{array}$ \\
\hline
\end{tabular}

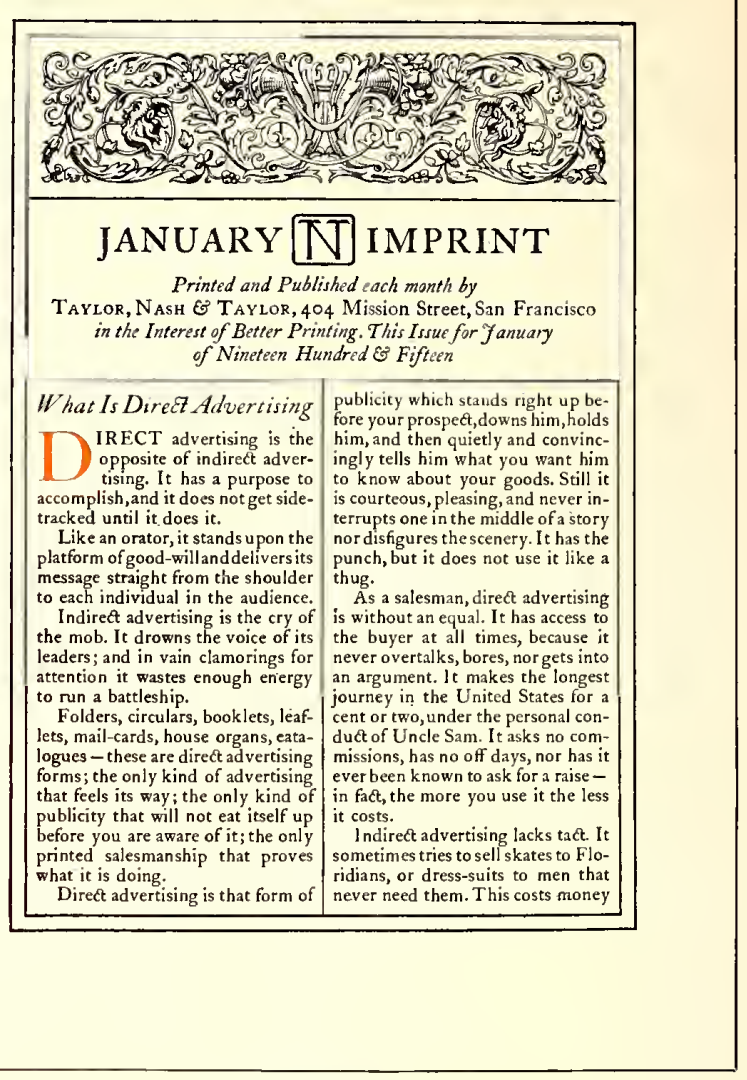

EXAMPLE 450

Attractive use of rules and italic

\section{TYPE TALKS}

A LINK OF REAL VALUE TO BIND YOU MORE CLOSELY TO EUGENE SMITH COMPANY QUALITY

\section{Warchful Waiting vs. Preparedness}

1 ERY thinking man has a pretty good idea of what business conditions in this country will be for a number of years to come. Prosperity is the promise of the future. We are enjoying unexampled prosperity while the rest of the world is suffering great economic hardships. Our domes. tic business is steadily growing in volume and the entre world is the market for our exporting.

Have you adopted a policy of "Watchful Waiting"? Are you going to sit tight and watch affairs develop and then go around among your friends three or four years from now and tell them exactly what you would have done if you had known what was going to happen - or are you a believer in Preparedness? Are you preparing now to get your share of the prosperity that is with us and that is coming to us in an ever-increasing volume? Are you Advertising?

EXAMPLE 452

A page in Cloister type
EXAMPLE 451

An elaborate house-organ title-page

16 Startitg In a Country Town

I The fence is a device of exclusiveness when there is no live stock about, and when people began tearing them away it was an indication that they felt and were less exclusive.

II And the brotherhood of man is just another term for co-operation.

\section{$\bar{z}^{*}=-x=0$}

IAn old lady in Marietta took a half interest in a business that was starting on a small scale. She was to pay ten dollars down and ten a month until one hundred dollars had been paid. The first payment was met. Then been paid. The first payment was met. Then Finally the other partner in the business proposed that she either pay up or release him after refunding her ten dollars.

"I "You see," the old lady explained, "I thought by the time the second payment was due we'd be doing enough business to meet my payments out of the dividends."

IY You can't fatten a cow on her own milk.

TThe element of risk-gambling-the willingness' to take chances-is back of more successes in business than efficiency, foresight or any other feature. "could have bought a half-interest in it for a song."

IAll great business men are plungers.

I Big institutions are big because they do things on a big scale, rather than that they do big things on a big scale because the institution big things on a big scale because the institution
is big. IThe reasons Americans are distinctively a
business people is that they are by nature care-

EXAMPLE 453

Use of paragraph marks. From Cottrell's Magazine
II We are continually meeting the man who 


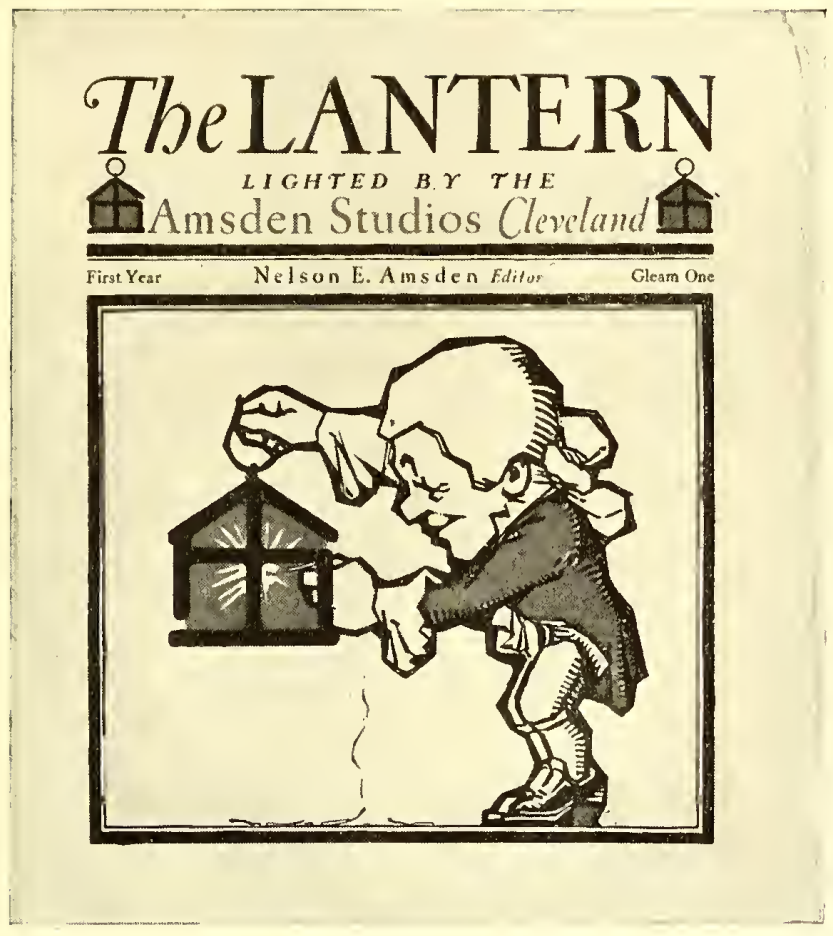

EXAMPLE 454
A good specimen of house-organ cover

not different from that of other kinds. The appearance of a publication is maintained and the matter is merely adapted to the dimensions of the blotter.

House-organs are sometimes successful when laid out in newspaper style for four pages about $9 \times 12$ inches in size. The text matter is planned for three columns, the text type being eight- or nine-point, such as is customarily found on machines. Headings are graduated on the newspaper plan according to their importance. Illustrations

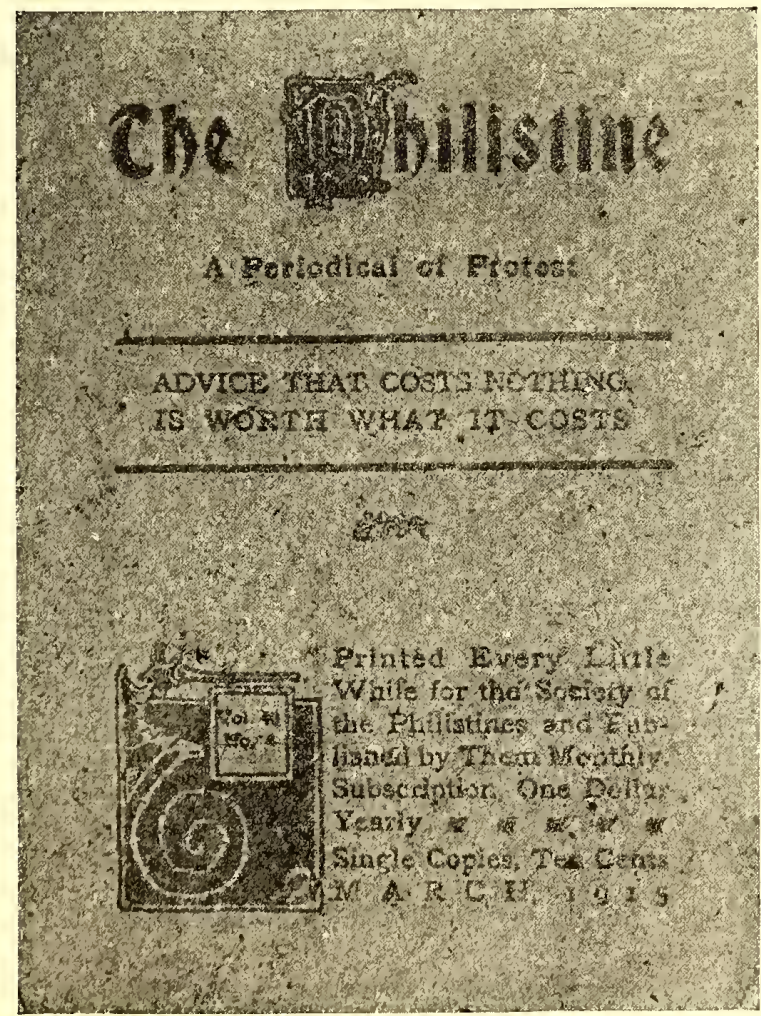

EXAMPLE 456

Cover of "The Philistine" issued about two months before Elbert Hubbard went down with the "Lusitania"

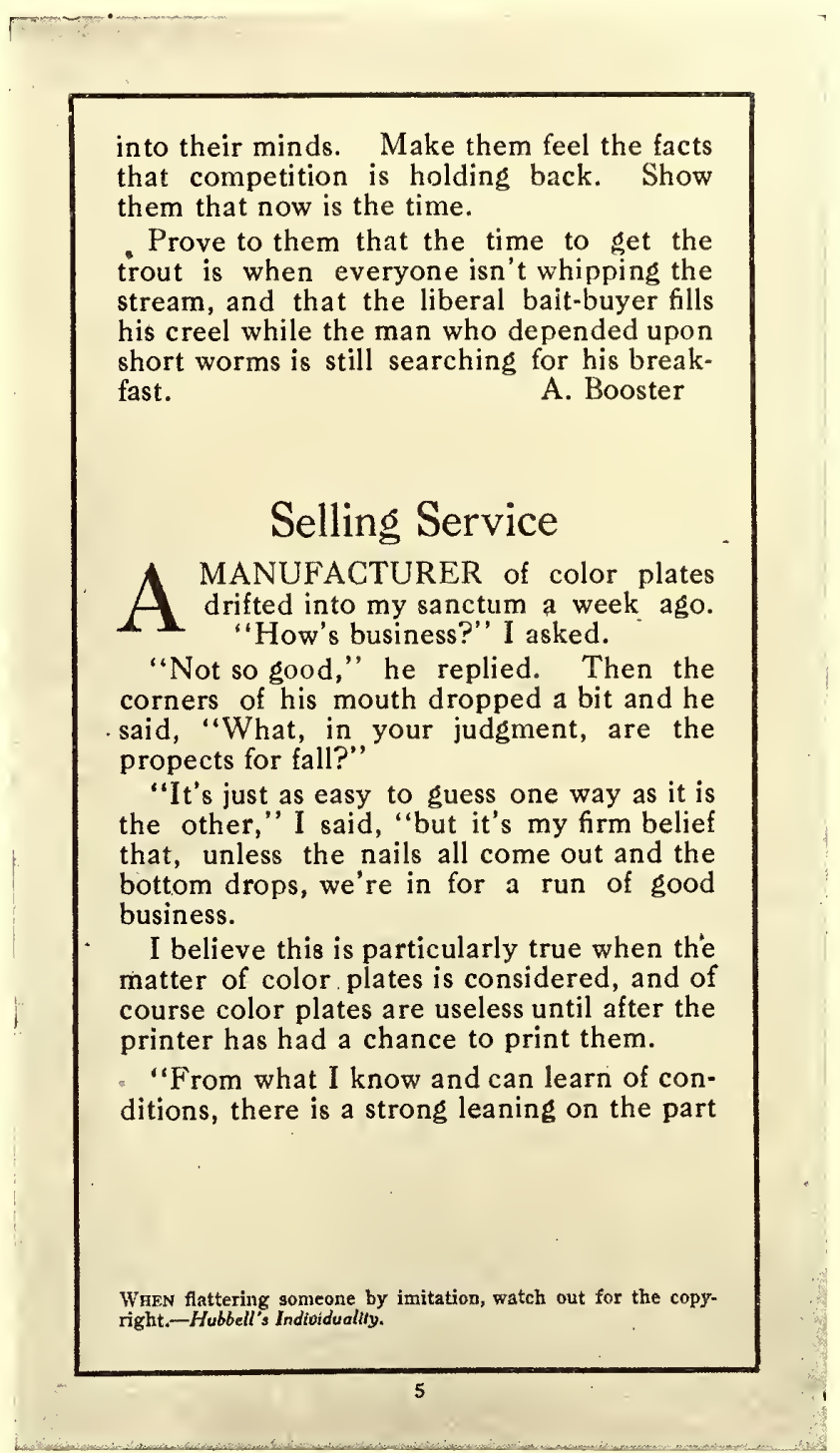

EXAMPLE 455

Blank space used to good advantage.

Text page from "The Ambassador"

are included at suitable points in such newspaper-like house-organs.

There is suggestion for a novel house-organ treated in old-time newspaper style in the reproductions of the first two newspapers published in Amcrica. (See Examples 401 and 402 of the chapter on "Newspapers.")

A western printer, who has found the house-organ to be effective in his business, expressed himself in these words:

Nowadays children are entertained as they are taught, and they learn unconsciously and much more readily than when stndy was made a task and a hardship. That is the principle we must embody in a house-organ-entertain and instruct simultaneously. Make your readers smile and enjoy themselves while they are learning the value of good printing, prompt service and square dealing. Create in them a desire to be as particular about their printing as they are about their company or the set of a collar, but keep them entertained and intercsted the while. Of course this can be overdone, so don't make the mistake of having too much outside matter, but keep to your subject in a tactful way.

The day is past when business secrets can be kept from the buying public. During the past ten years magazine and general advertising policies have educated consumcrs along entirely new lines, and now they insist on knowing why they pay special prices for specific articles. They not only want to know why, but what it is, where it comes from, who makes and sells it, and how. The sooner we tell them these things, just that mueh sooner will confidence be established and buyers of printing acquire a knowledge that will enable them to buy intelligently, to distinguish 


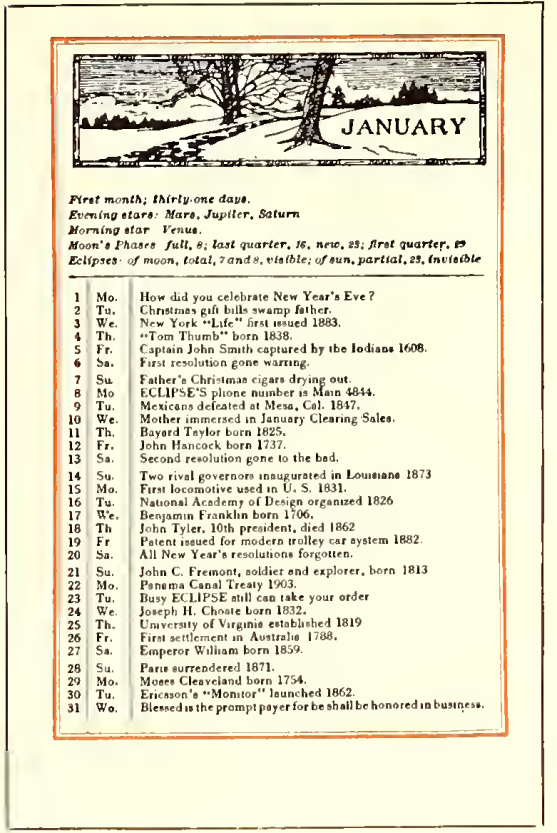

EXAMPLE 457

An "almanack" feature

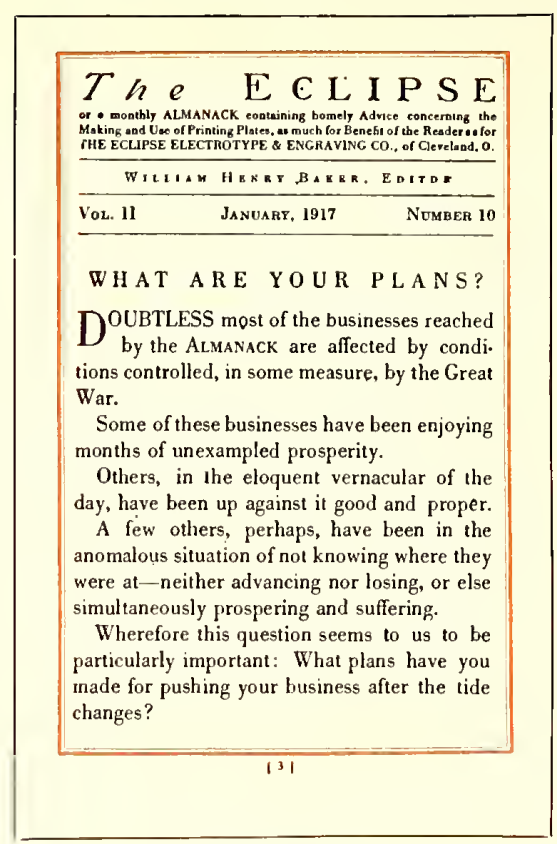

EXAMPLE 458

Bodoni typography

\section{The Co-opt-or}

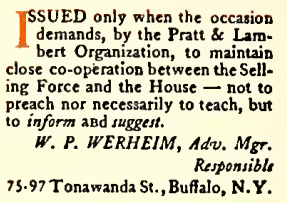

CTART the day right.

Read "A Cure

for Cold Feet"

- Page 8

March 24, 1915

Number 29

EXAMPLE 459

Cover of a small house-organ betwcen the economy in good service and the extravagance in poor service. In a house-organ there is unlimited opportunity for preaching the gospel of good service and for educating the public to the fact that that kind of service is the cheapest.

I consider the establishment of this confidence between the printer and eustomer one of the strongest pulling features of a house-oryin. I do not mean by that that one should open his hooks to the public, but give enough information to let your readers know that you are in a business that requires capital for its conduct, that it is a dignified business, that you give efficient scrvice, and that such efficiency costs you proportionately as much as it costs him. Having let your readers into this much of your busincss secrets, keep hammering away on your service and efficiency, but do it in a tactful way. Don't bore him. Entertain him. Remember the old proverb, "II who tries to prove too much proves nothing." So give it in homeopathic doses, but mighty regular onc's.

A feature of the house-organ as issued by a printer should be specimens of actual work. Small cover designs and pages from booklets and other specimens can be saved and collected from overruns and presented in the houseorgan. It would be better to use but one or two specimens in each issue than to overload the publication. Only creditable work should be included in this manner. If, say, a bit of four-color process work is produced, it should not be used as an exlibit merely because there is color in it, but it should be tested by answering these questions: Is it a good drawing? Are the colors properly blended, or is there an unpleasant predominance of red and yellow? Are the plates in good condition? Have they been properly printed? Unless the answer is affirmative, it would be better to include neat, modest black-and-white specimens.

Many house-organs are made ineffective by the anxiety of the business house issuing it to include everything pos- sible. A number of issues should be planned and eaeh should contain a limited amount of text matter and illustration. Many of those to whom the house-organ is sent also receive dozens of others, and examination and reading of the publication should not be discouraged. When there is too much of an abundance, the house-organ is either thrown in the waste basket or laid aside and never looked at again.

Loose inclosures should not be numerous. Attention is frequently taken away from the house-organ itself by the variety of envelop slips, calendars and blotters that are included in the mailing. There should be nothing but a return post card, and this should be clipped to the inside of the rear cover and not tucked in on top of the titlepage, as is too often done. Several return cards are reproduced (Examples 460, 461 and 462). When these post cards are planned the postal regulations governing their use should be investigated. It may be well to quote from the United States Postal Guide:

Post cards manufactured by private persons, consisting of an unfolded picce of cardboard in quality and weight substantially like the Government postal eard, not exceeding in size 3 9/16 by $59 / 16$ inches, nor less than $23 / 4$ by 4 inches, bearing either written or printed messages, are transmissible without cover in the domestic mails (including the possessions of the United States), and to Canada, Cuba, Mexico, Republic of Panama, and city of Shanghai (China), at the postage rate of 1 cent each, and in the foreign mails at the rate of 2 cents each, to be paid by stamps affixed.

Advertisements and illustrations may appear on the back of the card and on the left half of the face. "The right half of the face must be reserved for the address, postage stamps, postmark, etc.

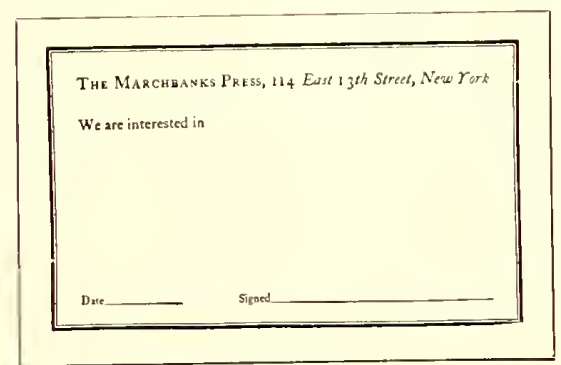

EXAMPLE 460

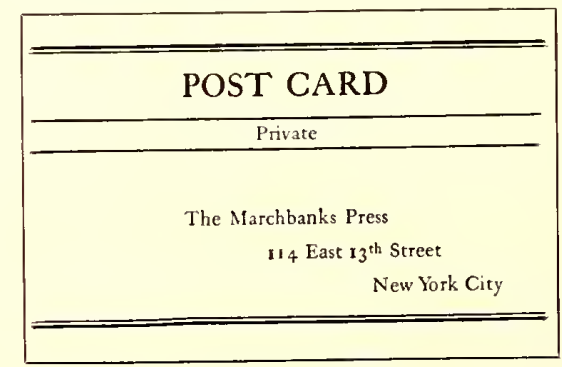

EXAMPLE 461
I have a job on hand as briefly follows:

but I haven't an idea how I can make it different!

Wander if yau can help me?

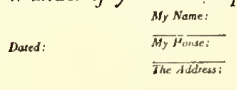

EXAMPLE 462

Suggestions for treatment of the return post cards that usually accompany house-organs 



\section{BOOKS E THE MAN}

A man is himself plus the books he reads, said an eminent divine, which statement is borne out by the experiences in 1722 of a great printer in America. This man halfstarved his body that his soul might have nourishment, and the wisdom of his action was proved in after years when the nations of the world paid homage to his greatness of intellect.

Caslon Oldstyle $47 \mathrm{r}$

\section{BOOKS \& THE MAN}

A man is himself plus the books he reads, said an eminent divine, which statement is borneouthy theexperiencesin 1722 of a great printer in America. This man half-starved his body that his soul might have nourishment, and the wisdom of his action was proved in after years when the nations of the world paid homage to his greatness of intellect.

Baskerville Roman

\section{BOOKS E THE MAN}

A man is himself plus the books he reads, said an eminent divine, which statement is borne out by the experiences in 1722 of a great printer in America. This man half-starved his body that his soul might have nourishment, and the wisdom of his action was proved in after years when the nations of the world paid homage to his greatness of intellect.

Kennerley Oldstyle

\section{BOOKS \& THE MAN}

Aman ishimself plus thebooks he reads, said an eminent divine, whieh statement is borne out by the experienees in 1722 of a great printerin America. Thismanhalf-starved his body that his soul might have nourishment, and the wisdom of his action was proved in afteryears when the nations of the world paid homage to his greatness of intellect.

Bodoni Book

\section{BOOKS E THE MAN}

A man is himself plus the books he reads, said an eminent divine, which statement is borne out by the experiences in 1722 of a great printer in America. This man halfstarved his body that his soul might have nourishment, and the wisdom of his action was proved in after years when the nations of the world paid homage to his greatness of intellect.

Caslon Oldstyle 47ı

\section{BOOKS \& THE MAN}

A man is himself plus the books he reads, said an eminent divine, which statement is borneout by the experiencesin 1722 of a great printer in America. This man half-starved his body that his soul might have nourishment, and the wisdom of his action was proved in after years when the nations of the world paid homage to his greatness of intellect.

Baskerville Roman

\section{BOOKS छ THE MAN}

A man is himself plus the books he reads, said an eminent divine, which statement is borne out by the experiences in $\mathbf{I} 722$ of a great printer in America. This man half-starved his body that his soul might have nourishment, and the wisdom of his action was proved in after years when the nations of the world paid homage to his greatness of intellect.

Kennerley Oldstyle

\section{BOOKS \& THE MAN}

Amanishimselfplus the books he reads, said an eminent divine, which statement is borne out by the experiences in 1722 of a great printerinAmerica. Thismanhalf-starvedhis body that his soul might have nourishment, and the wisdom of his action was proved in afteryears when the nations of the world paid homage to his greatness of intellect.

Bodoni Book 


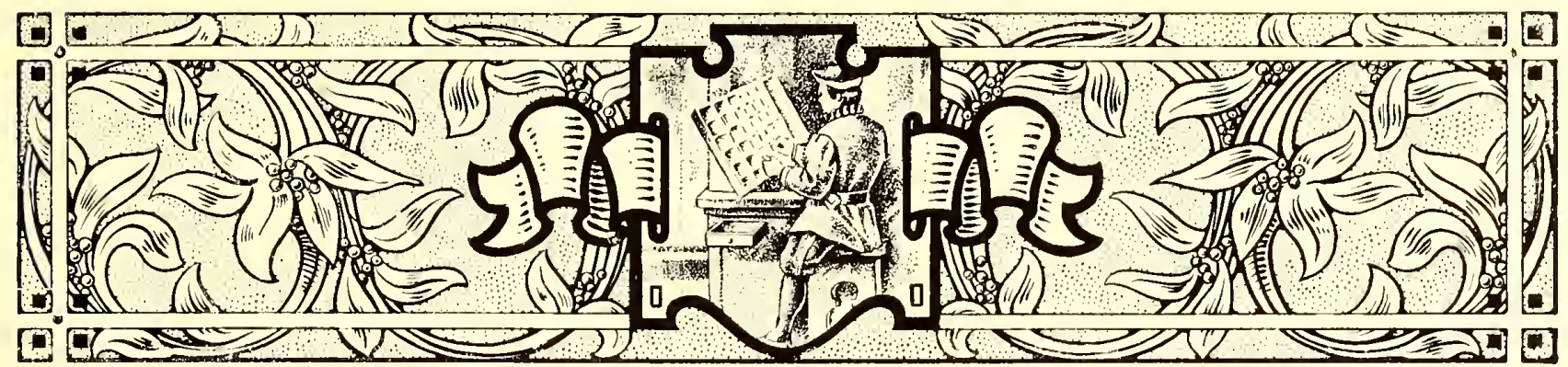

\section{TYPE-FACES}

TYPE-F ACES, at first aequaintance, are no more easily remembered than the faees of people we meet. Many persons look alike and many type-faees look alike, until we get to know them intimately and are able to distinguish their eharaeteristies. The average man or woman is unable to identify Caslon Oldstyle, Seoteh Roman, Bodoni Modern, or any specifie letter used in printing, altho there are those who have a vague idea of the existence of types known as "old-style" or "modern."

The faet that there are thousands of type-faees on the market adds to the diffieulty of reeognizing and naming them, and the situation is further involved by the praetice of eomposing-maehine makers in using only numbers to designate type-faees and by various typefounders giving different names to the same design of type. The speeial type-faces of private presses are usually given the name of the work on which they are first used.

\section{Six Representative Standard} Roman TyPe-Faces

Believing that such a serviee would be appreeiated by printers and users of typography, the author made a study of the thousands of Roman type-faces on the market, with the purpose of seleeting a half-dozen representative standard faees. It was felt that these type-faees should be legible and good-looking, and possess eharaeter; that their merits should be aeknowledged by authorities, and that the types should be eapable of wide servieeability on both book and job work.
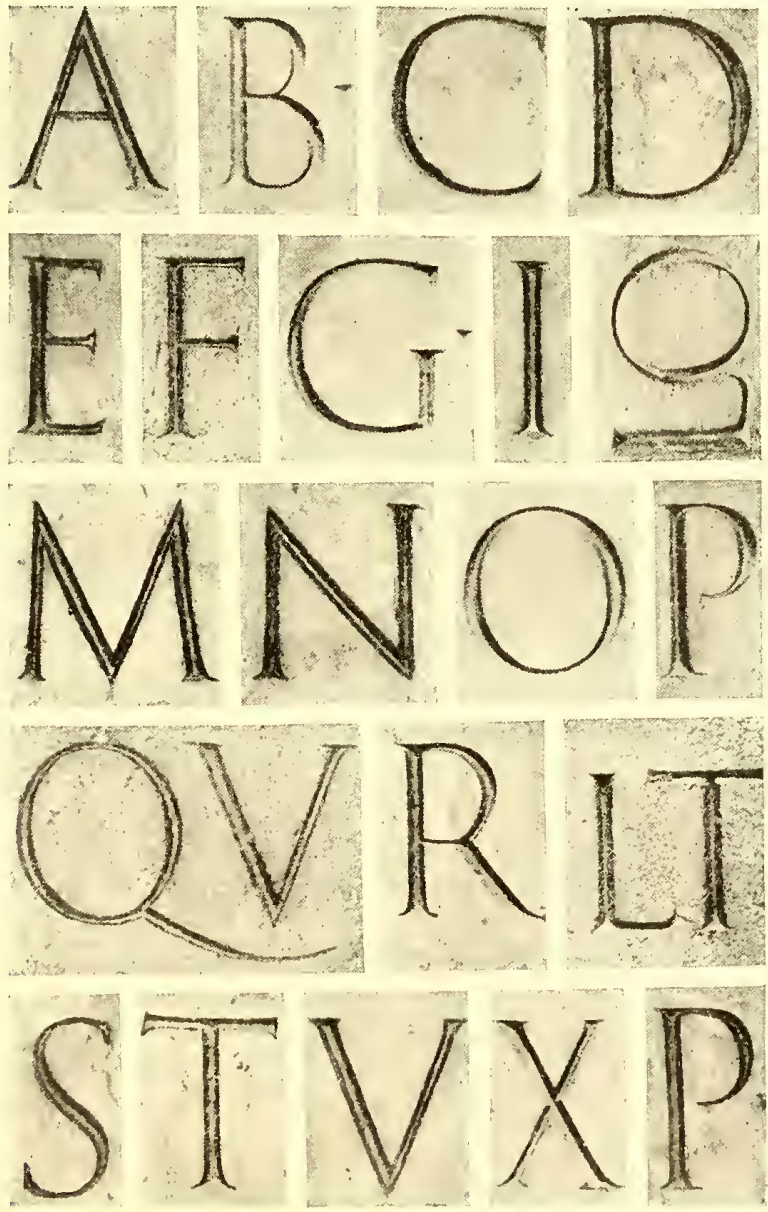

EXAMPLE 464-A

Roman alphabet from the inscription on the base of the Trajan column, Rome, about A. D. 114. From Johnston

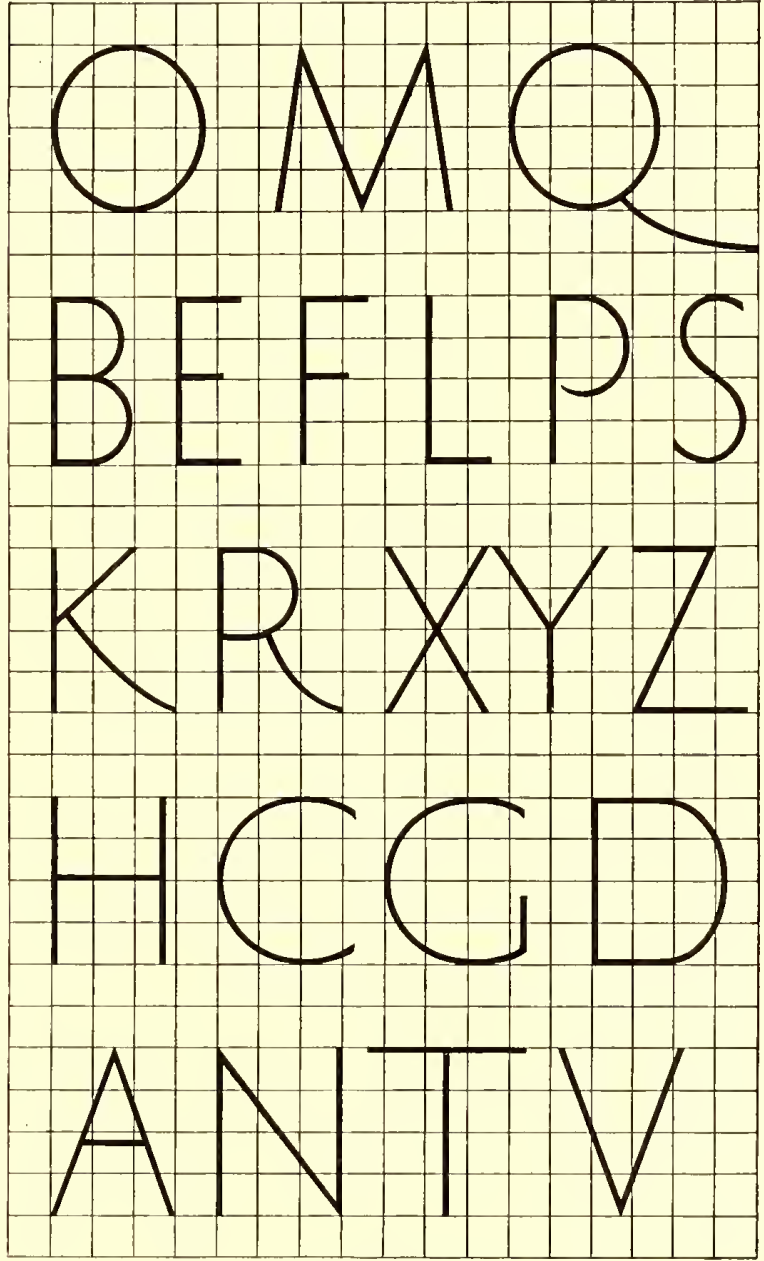

EXAMPLE 464-B

Proportions of Roman capitals as found in the Trajan alphabet, and a few additional letters 


\section{^A B C D E F GH I L MNO P QR S TVX}

Early Roman Pen-Made Capitals

- a B c J E FG I I MNOPGRST UX

Roman Uncials

c $a b c$ do e f g h líl m nop qrafstu $x$ Early Black Letter

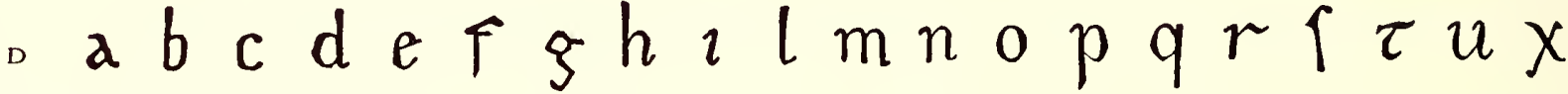
Caroline Minuscules, or White Letter

E $a b c d$ e f g h i l m n o p q r s t u $x$ Cloister Oldstyle

F abcdefghijklmnopqrfstuvw xyz

Joseph Moxon's Letters

G a b c d efghijklm nopqretuvw xyz

EXAMPLE 465

Evolution of Roman lower-case type-faces. (A) Pen-made Roman capitals. (B) Development into Minuscules or lower-case thru rapid lettering. (C) Black Letter or German Text developed from Roman Uncials. (D) White Letter, the open. legible Caroline Minuscules, on which Jenson based his Roman type-face of 1470. (E) A recent typer face closely modeled on Jenson's Roman types. (F) Joseph Moxon's letters of 1676. (G) Caslon's type-face of 1722

The face first seleeted-and without hesitation-was Caslon Oldstyle as originally designed. Scoteh Roman was the seeond seleetion, Cheltenham Oldstyle the third, Cloister Oldstyle the fourth. Bodoni Book the fifth, and Freneh Oldstyle the sixth. (All shown in Example 4i;7.)

Type-faees designed and eut for private use were not eonsidered in making these selections, as it was believed best to adhere to type-faees that are proeurable from most foundries and that are available for maehine eomposition. It may be well to inject here a warning that most so-ealled Caslon Oldstyles are not as good as the one seleeted ( $\mathrm{Ex}_{-}$ ample $4167-B)$; that Jenson Oldstyle is inferior to Cloister Oldstyle (Example $4: 7-A$ ) as a representative of the original Jenson type. However, good representatives of Seoteh Roman (Example 4(i7-D) are obtainable under the name of Wayside, of National Roman, ete.

\section{A B CDEFGH I K L M N P QRSTUVWXYZ}

abcdefghijklmnopqrstuvwxyz How it appears assembled

(A) Modernized Oldstyle, the Miller \& Richard type-face of about 1852

A B C D E F G H I K L M N O P Q R S T U V W X Y Z abcdefghijklmnopqrstuvwxyz How it appears assembled

(B) Century Expanded, the Benton "modern" type-face of I9or

Two standard type-faces that rate high in legibility, but that are colorless in the mass and lacking in the pleasing irregularities of form that characterized Roman ty pe-faces before the nineteenth century. The various qualities of legibility found in Modernized Oldstyle have been converted to narrower letter shapes and more "modern" form in Century Expanded 


\section{A B C D E F G H I J K L M N O P Q R S T U V W X Y Z abcdefghijklmnopqrstuvwxyz How it appears assembled}

(A) Cloister Oldstyle, representing the Roman type-face used by Nicholas Jenson, 1470

A B C D E F G H I J K L M N O P Q R S T U V W X Y Z abcdefghijklmnopqrsturwxyz How it appears assembled

(B) Caslon Oldstyle, as designed and cut by William Casion, 1722

A B C D E F G H I J K L M N O P Q R S T U V W X Y Z abcdefghijklmnopqrstuvwxyz How it appears assembled

(C) Bodoni Book, representing the "modern" type-faces of John Baptist Bodoni, 1768-1813

\section{A B C D E F G H I J K L M N O P Q R S T U V W X Y Z} abcdefghijklmnopqrstuvwxyz How it appears assembled

(D) Scotch Roman, representing the "modern" ty pe-face of Mrs. Henry Casion, 1796

\section{A B C D E F G H I J K L M N O P Q R S T U V W X Y Z} abcdefghijklmnopqrsturwxyz How it appears assembled

(E) French Oldstyle (Cadmus), the "Elzevier" of Gustave Mayeur, 1878

A B C D E F G H I J K L M N O P Q R S T U W X Y Z abcdefghijklmnopqrstuvwxyz How it appears assembled

(F) Cheitenham Oldstyle, the Kimball-Goodhue type-face, 1902

EXAMPLE $467 \rightarrow$

Six standard representative Roman type-faces, approved by authorities for both beauty and legibility, and selected by the author from the thousands of type-faces available for hand and machine composition

Selection of these faces was also made just as a person makes a wise selection of records for a Victrola-for permanency and investment. As standard records can be selected which will "wear" for a long time, so standard type-faces can be selected which will look well for many years. Good type-faces are like good music.

We will discuss these six faces.

Cloister Oldstyle.-Use in American printing of a standard type-face based on the Roman letter cut by Nicholas Jcnson about 1470 has been retarded by the fact that typefounders in this country some years ago used as a model Morris's interpretation of the Jenson face instead of going direct to the original letter. Jenson's face had been copied by Bruce Rogers, T. J. Cobden-Sandersoll, Frederic W. Goudy and others, and the fonts used privately, but for general use it was not until $191 \mathrm{t}$ that a creditable copy of the face was made available by the good judgment displayed by the American Type Founders Company in bringing out Cloister Oldstyle. 'This is probably the best rendition of the spirit of an old Roman typeface that a modern type foundry has made. If there is a fault, it is that the lower-case letters set a trifle too close. Jenson's face was not the first Roman type made, as is 


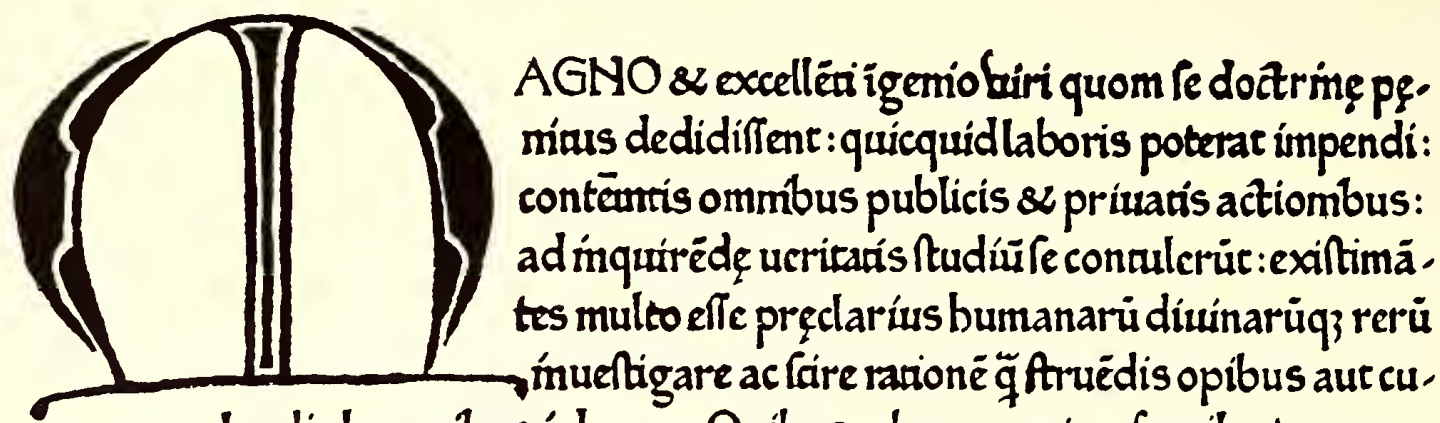
mulandis bonoribus ḿnberere: Quibus rebus quomiam fragilesterreneq 3 fune : $\&$ ad folius corporis prinent cultum nemo melior : nemo iuftior effici poreft. Erär quidez illi ueritaris cogmíione dignúfími quam faire tätopere cupiuerür: atqzita uceam rebus ommibus anteponerêr: Nam \& abiecilfe quofda resfamiliares fuas et renüriaffe umiuerfis uoluptabus conftat: ut

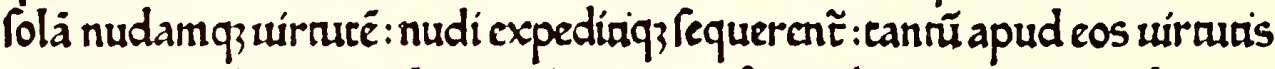
nomen er auctortess ualuit : ut ín ea omne fummi bomi premium ṕdicarêr . Sed neqzadeptifür ı̀ quod uolebăr : $\&$ operä fumul atqu índuftriā pdide, rür:quía ueritas ideft archanälümi dei quífecit ommá ḿgemio ac spriis

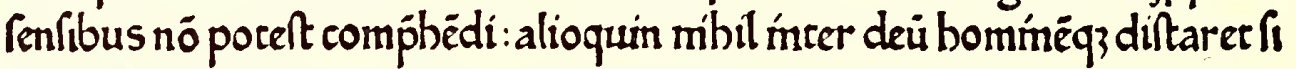
cöflla \& dípofitiones illus maicftaris eterne cogitario allequerẽ̃ buma. na. Quod qua fieri nó pouúc uc bommín nfe infir idon dirrima nnfroro. nnn eft paffus hommendeus lumē fapie ullo laboris effectu uagari per tenel aliquando: $\&$ norionem ueritaris $\pi$ nullä effe monttraret: \& erräráac u oftēderer. Verú quomiá pauci utun obuoluta moblcuro ueritas later: $e$ neis affertoribus eget: uel odio id, bomínum procliús mi uícia pari nc tudo pinixta é : rúria uero uoluptar ferunturmí p̈cepl : ac bonozespecie fä rédü efle his erroribus credidi ute mdocti ad uerã religionē. Que pro putanda ef $\tilde{q}$ illa oratoria ín qua $d$ argutä malicia úuuenes erudiebam

Type-face used in Italy by Sweinheim and Pannartz in 1465 . From DeVinne

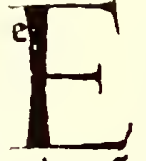

DEPOL nęmeá berus operam bac fabula feruus piger $\&$ curiofu ex fentẽtia fua. Edepol nę meá. tot uim cú maxía iniuria plenferit.Edepol $n \in c^{x}$ populo exprimiť. Deputat parui precii.qui. eam. qui deputat eam in re nullius precii có: defedi diem.nota accufatiuo cafu ufum effe. eto.memoriter $\&$ uigiläter feruus Miconiü dixit: ne uideret̃ negligétia uel obliuione $\mathfrak{f}$ efl. Miconiü bofpitê. bene oftendit fe memo deatur uere illufus cú operã dederit.I taq;i iep 8 inceptus:quafi ineptus. Adolefcens dic d demidẽ fr ipfum feruus imitať : \& eft uijuH tria manda ta funt inquirẽda:tria inquifita $f t$ bene tranfit a mimetico ad Diegematicon \& Quenğ effe arbitror.i.non $F$ pudebat federe an iterrogare. A noltro affin liter inducit feruus dicere $a b$ noftro affinec ct prius eft nofter focer uenit pro pampbili fi poetã monftrat locuturã p fonam. Quid bui nibil fciturus elt excurfurus piger. Parmenı

EXAMPLE 469

The Roman types of John and Wendelin of Spires. Venice, 1469. Greek letters were to be written in the line now half blank. From the original in Typographic Library and Museum, Jersey City, N. J. 
temporibus faluatoris noftri natiuitaté fuiffe:doctrinäq; quito decio Tyberii cxearis anno euangelica incopiffe. \$i quis ergo ab hoc tyberii anno ad fupenora fcandens diligéter $u C_{\beta}$ ad Darium prarum regem $\&$ reftitutioné templi perueniet quingentos.xlviii.annosinter Tyberiü. et fecüdum Darii annum interfuiffe comperiet. Secundus enim Darii annus fexagefim $x$ quint $x$ olympiadis primus fuit: Tyberii autéqntus decimus ducentifimx ac prim $x$ olympiadis quartus iuenitur.fta cétü ac triginta feptem olympiades interfuiffe manifefte uidentur:q numer rus quaternario auctus:quadrienniũ enim olympiadi attribuitur quir gentos.xlviii.annos effecit. In fecüdo auté anno Darii feptuagefimus hierofolymoßz et templi deftructionis fuit ut iudxorü hiftoria oftédit: Quod fi a fecundo Q Parii anno ad primã olympiadem percurras olym piades quidem. lxiiii.annos:cclvi, interfuiffe comperies. Quos quidem annos fi ab ultimo defolationis anno ac reftaurationis principio afcée dendo auferas ad quinquagefimú annum $Q$ zix iudxorum regis qua téporeIfraias $\&$ Oree prophetarunt omnino puenies. Ita prima olym' pias Ifaix temporibus fuiffe iuenitur. Inde autem a prima olympiade ufq; ad captiuitatem troix ut grxcorũ ipforum hiftorix fignificăt quar dringenti ac quinquaginta anni colliguntur:quem annorum numese a quinquagefimo $\Phi_{z i x}$ anno fimiliter auferendo ad tertium annum labdonis iudæorũ iudicis peruenies: (Ita troianæurbis deftructio reptë annis anteq $\$$ anfon hebrxos iudicaffet fuiffe oftéditur:quem corporis robore inuictũ fuiffe ut herculem g. a captiuitate troiana fi quadrigent $\&$ terrigenã cecropé deuenies. $\emptyset_{\mathrm{mn}}$ narrantur poft Cecropem fuiffe cor phxthontis icendiü:natiuitas Fricl myfteria: Eleufiniorï conftitutio:I ioue: Appollinis partus: Gadmiad t illi Dionyfus:et Minos:arculapius cropem omnes fuerunt. Quare om fuiffe confirmatur. $\$$ moyfe uero $u$ quingentos ac quinq; annos compr

The beautiful "White Letter" Roman type-face of Nicholas Jenson, 1470, from "Eusebius," the first book printed by him at Venice. The dot over the "i," small and slightly to the right, is found, also, in the manuscript specimen here inserted. From the original in the Typographic Library and Museum. Jersey City, N. J.

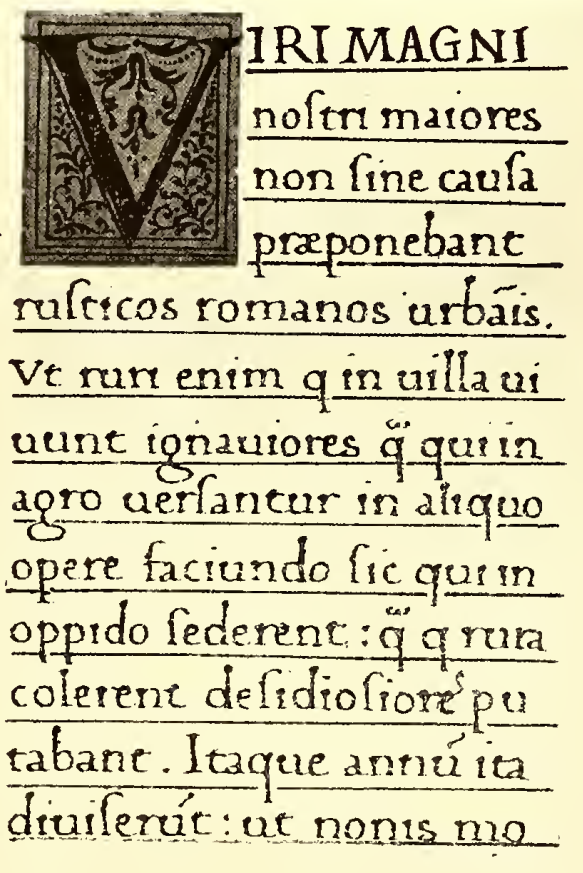




\section{P R AES T A N T I. VI R O}

IVRIS. VTRIVSQVE.SIN gulari cognitione ornato

FRANCIS C O. MOR A N D O

Aldus Manutius Paulli F

S. P. D

VMQVAM coruminftitu-

$N$ tum probaui, quieo animo fe ad litteras conferunt, ut, prae ter fuam utilitaten, nihil curent quo enim pluribus communicatur, eo nobilior eft Virtus. Accedit illud, quod fama nominis noftri \& propagatur friptis, \& perpetuo cuftoditur: qui eft uberrimus, ac practantiffimus litterarum fructus. quamobrem eo femper cogitationes meae fpectarunt, ut ea praestare poffem, quae fudiofis omnibus utilitatem aliquam afferrent, meumq. nomen pofteris etiam proderent. in quo Aui mei, Parentisq ueftigia cum fequar; fi me dignum utro-

$$
\text { A } 2 \text { que }
$$

\section{EXAMPLE 472}

Type-face used by Paul Manutius at Venice in 1566

sometimes supposed; others had previously been used (Example 169), but it was the first Roman type to meet the approval of those who preferred the Italian White Letter to the Gothic Black Letter.

Sweinheim and Pamartz were German printers who, in 1465 , began to print near Rome. Until this time the black Text letter sueh as Gutenberg had printed with ten years before was the only one used in typography, but book buyers in Italy wanted Italian lettering. The German printers attempted to cut an Italian face, but in appearance they did not advance far from Gothie lettering (Example 468).

PROBI AEMILII DE VIRORVM EXCELLEN

TIVM VITA PER. M. NICOLAVM IENSON

VENETIIS OPVS FOELICITER IMPRESSVM

EST ANNO A CHRISTI INCARNATIONE.

M.CCCC.LXXI. VIII.IDVS MARTIAS.

EXAMPLE 473

Cloister Oldstyle set in imitation of the Jenson title on page 14. Printed and zinc-etched, as was the original
A cinq heures précises, j’entrais à l'usi à gaz de la Villette. On dirait les ruines r lossales d'une ville de cyclopes. D'énorn et sombres avenues s'ouvrent entre les lou gazomètres alignés l'un derrière. l'autre, I reilles à des colonnes monstrueuses, trı

EXAMPLE 474

Type-face cut in 1693, now used by the National Printing Office, Paris. Notice slight projection on lower-case

"l," a decorative feature used by Gutenberg in his types

John and Wendelin of Spires, Germans, began to print at Veniee in 1469 with a type-face that was more Italian in character, yet it had Gothic characteristies. Nicholas Jenson, a Frenchman, who began to print in 1470 at

tamen ut frequentius pro Amyraldo, cujus ju-

tamen ut frequentius pro Amyraldo, cujus ju-

tamen ut frequentius pro Amyraldo, cujus ju-

tamen ut frequentius pro Amyraldo, cujus ju-

EXAMPLE 475

The first line is set in Cloister Oldstyle; second reproduced from Elzevir page opposite; third set in Cadmus; fourth in Caslon Oldstyle. These lines are zinc-etched

Venice, was more suceessful, and he gave to the world the fine Roman type-face that he used on his first book, shown, together witl a sample of contemporary lettering of similar design, as Example 470. More facts about Jenson will be found on page 14 .

GENESIS. Tranflat. B. Hierony. Creatio. C A P V T P RIM V M

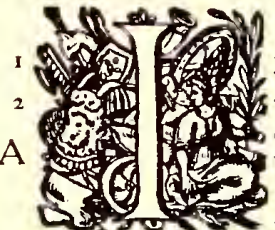
$N$ principio creauit Deus cælum \& terrã. $\quad$ Terra autem erat inanis \& vacua : \& tenebræ erant fuper faciẽ abylsi: \& Ipiritus Dei ferebatur fuper aquas. = Dixitq́; Deus, Fiat lux. Et facta eft ${ }_{4}^{3}$ lux. ${ }^{2}$ Et vidit Deus lucem quòd effet bona : \& ${ }_{5}$ diuifit lucem à tenebris. IAppellauitá; lucem diem; \& tenebras noctẽ. Factumq́; eft vefpere ${ }_{6} \&$ mane dies vnus. $=$ Dixit quoque Deus, Fiat firmamentũ in medio aquarum; \& diuidat aquas ab aquis. = Et fecit Deus firmamentum, diuifitó; aquas quæ erant fub firmamento, ab his quæ erant fuper firmamentũ. Et factum eft

EXAMPLE 476

Cheltenham Oldstyle, with the capitals a size smaller, set in imitation of the Plantin typography on page 16 


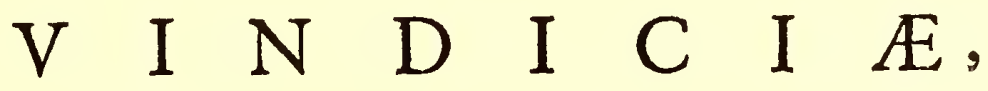 \\ Quibus fententia D. Arm IN II \\ D E \\ JURE DEI IN CREATURAS,}

\section{Defenditur adverfus}

\section{$\begin{array}{llllllllllllll}M & O & S & E & M & A & M & Y & R & A & L & D & U & M\end{array}$}

$C$ A P U T $T$.

Occafio \& Jumma bujus fcriptionis.

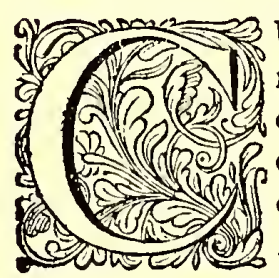

U M Thefium Gomari Examen magnam jam partem, mea cura, typis effet defcriptum, oportune mihi funt $a b$ amico oblatx, Mojis Amyraldi Profefforis Salmurienfis Differtationes Tbeologica quatuor: quarum fecunda qux de Fure Dei in creaturas infribitur, mex \& D. Arminii fententix oppofta eft. Iam cum avide perlegiffem, parum occurrit bonæ frugis : contra fodos paffim errores deprehendi. Inprimis vero illud difplicuit, quod immodico contradicendi fudio abreptus, etiam ea qux manifeltiflimæ funt veritatis vellicaret. Qua de caufa putavi, confeftim aliquid effe reponendum, \& propter argumenti fimilitudinem, Arminii opufculo quod in publicum exire geftiebat, appendicisinftar fubjiciendum : debere me iftud veritati divinx patrocinium, quxper noftrum utriufque latus impeteretur. Difputationi huic occalionem dedit Tractatus de Pradeftinatione, ab Amyraldo ante decennium Gallico fermone evulgatus : in quo cum Chriftum pro cunctis hominibus $æ$ qualiter mortem obiiffe contendat, aliaque nonnulla doceat qux Remonfrantium fententix affinia cffe videntur; id $\mathrm{Pe}$ trus Molineus Sedanenfis Profeffor adco ægre tulit, ut peculiari libello Tractatum illum examinandum fibi fumpferit. Ego vero Molinxani Examinus aliquanto poft cxemplar nactus, de dogmatis inter ipfos controverfis Sententian meam publice quoque, fed fupprefto nomine, dixi : in

EXAMPLE 477 Type-faces used by Daniel Elzevir at Amsterdam
in 1675. From "The American Printer" library didit, eum in profundam inferorum aby]fum demerfiffet, nulla babita ratione actionum ipfius feu bonarum feu malarum, tantum ut fummum juum in creaturas imperium oftenderet, debuiffe hosninem in ea feveritate non invitum acquiefcere, quia creatura creatoris eft, ex abfoluto jure atque indefinito. Ad quod Molinæus regeflit: Zus creatoris abfolutum ad injufta ufque non extendi, nec poJfe ab eo ufurpari in odio profequendo fuio opere, feu jufta atque infonte creatura. Nam praterquam quod injufta foret ejufmodi pana, Deum hac ratione bominem etiam redditurum improbum, \& ad fui odium atque murmura impulfurum.: eo quod fieri non polfet ut homo, qui nullum ex fuo erga Deum amore fructum perciperet, quamdiu Deus eum odifet ac in aternum cruciaret, aliter erga ipfum affectus effet. Ego vero hac animadverfione lecta, cum mihi non infirmis niti rationibus videretur, fed de Amyraldi mente fubdubitarem, dixi : Concedo accufationem iftam effe juftam, fi bac verba, in inferos demergere, Amyraldus de cruciatibus aternis intelligat, ut vulgo fieri folet, ó ipfe quoque innuere videtur. Sed frillis fignificare tantum vellet, Deum iure bomini vitam \&o ro eivas nofle adimere, ut $\int e c$ in quaper inf liguntur, ha foret. Ipfius auferre quod Jummum jus det, pro arl quam jufte I aternos crucia culpam prafu param infligi Deo ad Sodom

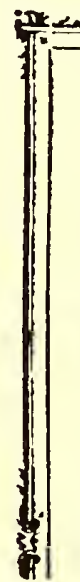

No. LX. $5^{8}$ GROS-ROMAIN.

CE font les hommes, dit Plutarque, de qui nous apprenons à difcourir, mais ce font les Dieux qui nous enfeignent à garder le

$$
\text { EXAMPLE } 478
$$

The Roman types of Fournier, the French founder, taken from his type book of 1766 

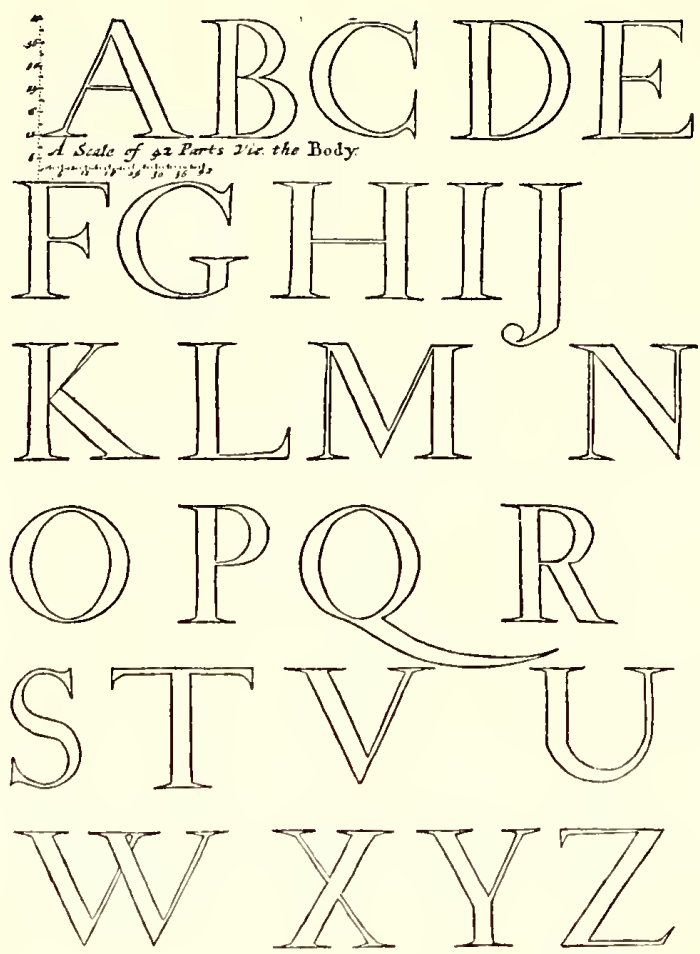

EXAMPLE 479

A capital alphabet drawn by Joseph Moxon

(1676) to a sealc of forty-two small squares

As time went on, printers and typefounders made changes in the Jenson design, but these alterations wcre not numerous (the cross stroke in the lower-case $c$ was

\section{A S P E C IM E N}

By W. CASLON, Letter-Founder, in lronmonger-Row, Old-Street, LONDON.

ABCD

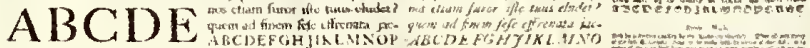

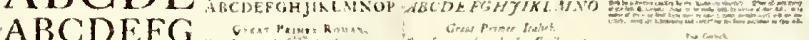
ABCI)FEGH

ABCDEFGH]JK

ABCDEFGHIKK

Quouffuc tan-

dem ibutere,

Carilima me

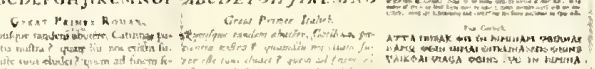

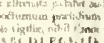

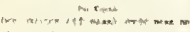

and

$+2$

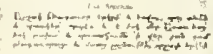

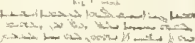

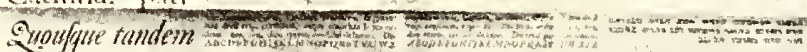

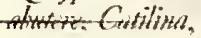

pationtin nofla?

Quoukque tandem

abutere, Catilina,

patientia noltra?

quamdiu nos etiam

शyoufgue tamiens a-

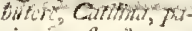

trientia meftra?" quam-

die wiss criam furvo

Quoufque tanders abu.

terc, Catilina, parientia

tam furor ifte ruas clu-

(1)

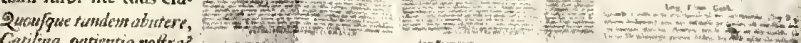

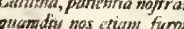
(wan

Writar

EXAMPLE 48

Earliest known specimen sheet of printing types, issued by William Caslon in 1734
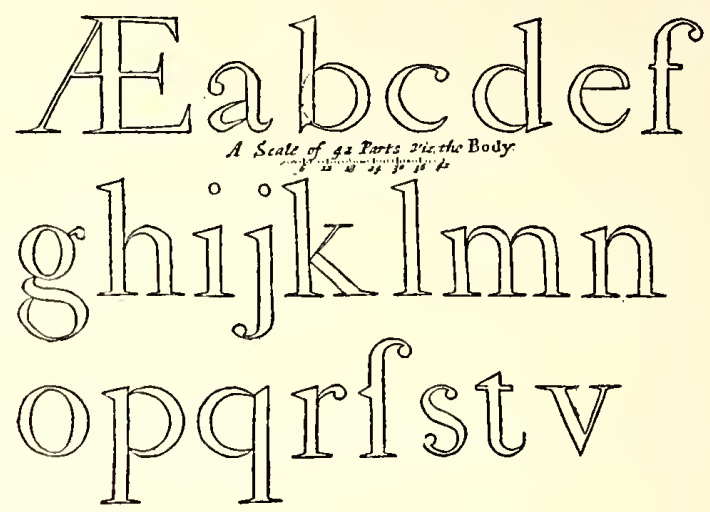

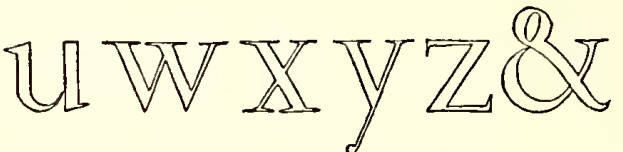
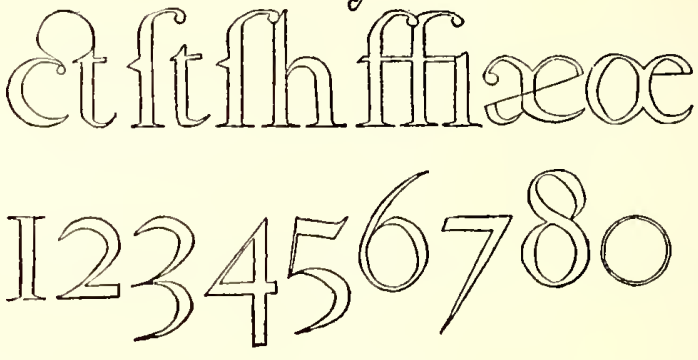

EXAMPLE 480

Moxon's lower-case alphabet, which he says was patterned after the letters of a Dutch punch cutter

one, Example 495), and fairly close resemblance to the Jenson types is found in the Roman types of Paul Manutius, 1566 (Example 472), Daniel Elzevir, 1675 (Example 477), and Fournier, 1766 (Example 478).

In selecting a page from Jenson's book, "Euscbius," to be photographed, the writer had great difficulty in finding one of sufficient evenness and clearness of print. It may be that Jenson, in his endeavor to enhance the "White Letter" effect of his types, used a minimum of ink, and, under thesc cireumstances it was perhaps more difficult for him to maintain consistent page color than it was for Gutenberg to do so with his "Black Letter" pages. Bruce Rogers's printing of his Jenson-like pages of typography would be a revelation to the old-time Venetian printer.

Jenson made his Roman letter in only one size, and that fairly large (about sixteen-point), so that the open design of the characters would admit white light from the paper background. When, some years later, he was required to print cheap devotional books, he cut and used a compact Black Letter Text type for the purpose.

There is now a movement away from the mechanical style of type-face, restricted in design by arbitrary craft rules, in the direction of the graceful, interesting yet legible faces represcnted by Cloister Oldstyle.

This type will be found in use in Examples 171, 240, $256,266,286,316,337,340,341,345,357,359,372$, 383,399 and 452 .

The Italic that accompanies Cloister Oldstyle is based on the Italic of Aldus Manutius.

Caslon Oldstyle.-This is a historic American typeface. It was used by that renowned American printer, Benjamin Franklin; it appears on eighteenth-century school books, and even our paper money was printed with it. It was the type-face used by John Dunlap, the Philadelphia printer, in setting up and printing the first pub- 


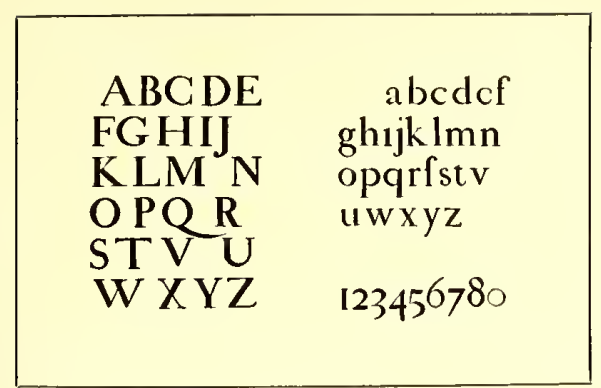

FXAMPLES 479-A and 480-A

The Moxon alphabets inked in

and reproduced in a smaller size

lished copics of the Declaration of Independence, a few hours after it had been passed by Congress, July 1, 177ii. (Sec facsimile that appears as a frontispicce to this book). It was one of these copics that was read to the Continental Army.

Today, nearly two hundred ycars after the first font was cut, Caslon Oldstyle has the approval of the good printers of America, who regard it, in its original form, as the best and most uscful Roman type-face available, as it is one of the few old faces the punches and matrices of which have been prescrved and placed at the disposal of all printers.

The Caslon foundry in England now casts the original letter as "Caslon Oldface." In this country, all typefounders make some sort of Caslon, and it may be procurcd practically in its original form, with long descenders, kerned $f$ and $j$, old special characters, decorated Italic capitals and all, from the American Type Founders Company, which has named it "Caslon Oldstyle 471" (Example 517).

Other foundries are preparing to furnish the letter more in its original form, and composing-machine makers are doing likewise. The monotype company, after cutting several faces in imitation of imitations of Caslon's type, finally copied the original fairly successfully, and this, as now obtainable, is known as Caslon Oldstyle No. 337. The linotype company is recutting its Caslons and is making a sincere effort to reproduce the original letter as closely as possible. Mechanical difficultics prevent an exact duplication in every detail of the Caslon type in machine composition, yet the companies that are attempting it show a spirit that angurs well for the future quality of printing in America.

Caslon Oldstyle is not at its best printed on a smooth, highly-calendered surface.

When properly composed and printed, it presents as a page a dark-gray tone, formed of a plcasant mixture of black ink and white paper; its letters show more of a contrast in thick and thin strokes than do the Roman types of Nicholas Jenson, and have more color and interest than the modernized old-styles of the nineteenth century. In the sizes above ten-point it measures up in legibility and beauty to the requirements of the best printers and other students of typography.

Caslon did not create an entircly new Roman letter, but with the elements that had already becn provided by Jenson and the type designers of Holland he did, with good taste and skill, build a type-face that is distinctive, legible and beautiful. The illustration of the evolution of Roman lower-case in Example 465 furnishes opportunity for study of this point.

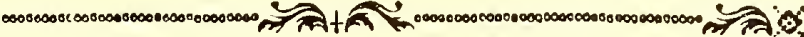

THE HISTORY OF PRINTING. 139

Double Pica Roman. I. Quoufque tandem abutere $\mathrm{Ca}$ tilina, patientia noftra? quamdiu nos etiam furor ifte tuus eludet? quem ad finem fefe effrenata jactabit audacia? nihilne te nocturnum præfidium pa

Double Pica Roman. 2. Quoufque tandem abutêre, Cailina, patientia noftra? quamdiu nos etiam furor ifte tuus eudet? quem ad finem fefe effrenata jactabit audacia? nihilne te nocturnum præfidium palatii

EXAMPLE 482

There were two slightly different faces to many of the Caslon fonts. From There were two slightly different faces to many of the Caslon fonts. From
he specimen pages in Luckombe's "History of Printing," published in 1770

The story of the designing of Caslon Oldstyle has bcen often told, yet a few brief facts may be of interest herc.

Typefounding and printing had deteriorated in England, and the product of the printing press was pathetically poor (the author was surprised, in examining important volumes printed in England about 1700, at the consistently poor work of typefounder, compositor and pressman), when, in 1720, William Caslon, an engraver on metal, was called upon to cut a font of Arabic characters, to be used in printing a New Testament for the poor Christians in Palestine and Arabia. At the same time, for use at the foot of the proofs of his Arabic types, he cut his own name in Roman, pica size. (This was at the time when Benjamin Franklin was working as a journeyman at Watt's printing office.)

The pica size, however, was not cast immediately. So far as is known, the size of Roman first to be cast by Caslon was that called "English" (about fourteen-point), which he cut in 1722. Additional sizes followed, and at about the period of his death, in 1760 , there were at least thirty fonts of Roman (pearl to five-line pica), nineteen fonts of Italic, ten fonts of Black Text, and various fonts of Greek, Hebrew and other alphabets, together with more than a half-hundred fonts of flowers and bands.

The fonts that have becn preserved to us, and that are purchasable, do not include all. There werc Tos. 1 and 2 faces in nonpareil, brevier, bourgeois, long-primer, smallpica, pica, english and double-pica (two-line small-pica). The No. 1 face in each case was a trifle larger than that of No. 2, and a third face, still larger, was made in bourgeois and long-primer. 
These faces were all sliown, in honor of the memory of William Caslon and as a tribute to the merit of the type, in Luekombe's "History of Printing," published by Adlard \& Browne, London, in 1770 (Example 182).

It is probably the smaller and lighter No. 2 faces that have been preserved to us in the ten-point (long-primer) sizes and under. The lighter, more open eighteen-point (great-primer) Italic (Example 517), so different from the Italic of the other sizes, is as Caslon made it. In some respects it is better than the Italic of other sizes.

While the general appearance of all sizes of the Roman is the same (and of the Italic also, with the exception noted), there are slight differences in details of design in the various sizes. For this reason, when Caslon Oldstyle is compared with the original letters, the comparison should be with the same size in each instance.

De Vinne, perhaps influenced by the prejudices and practices of ninetcentli-century typefounders, in one of his books points out as defects in the original Caslon types features that typefounders and composing-machine makers are today restoring to the face as used in America. The "defects" were supposed to be: "Too long a beak to the $f$ and $j$; unnecessary narrowness in the $s$ and $a$, and in some capitals; too great width of the $c, o$ and $v . "$

Typefounders and composing-machine makers have filled the type cases of the printers of this country with Caslons that have been improved (!), recut, modified, adjusted to "lining" systems, made bold, disfigured, sawedoff and ill-treated generally; and as they bring out good eopies of the original letter, it is to be hoped that, so far as possible, sale of the defective and offending type-faces and matrices will be discontinued.

William Caston died in 17tit; and the business was continued by William Caslon the second, and then by William Caslon the third. Mrs. Henry Caslon conducted the business in 1796, when was brought out the modernized Caslon (Example 181-B) that was probably the model for the type we know as Seotch Roman. 'This modernization was a concession to the demand for types in the new style that lad been designed by Giambattista Bodoni, an Italian typefounder.

The influence of Bodoni's ideas in type design was such that Caslon Oldstyle was not included in the 1805 specimen book of the Caslon foundry, and did not again appcar therein until 1860 , a year after the face lad been reintrodueed to America by a Philadelphia foundry.
The story of the revival of Caslon Oldstyle in England has been told in these words:

In the year 1813, Mr. Whittingham, of the Chiswick Press. waited on Mr. Caslon to ask his aid in carrying ont the then new iclea of printing, in appropriate type, "The Diary of I ady Willoughby," a work of fiction, the period and diction of which were supposed to be of the reign of Charles I. The original matrices of the first William Caslon having been fortunately preserved, Mr. Caslon undertook to supply a small font of greatprimer. So well was $M 1 \mathrm{r}$. Whittinghan satisfied with the result of his experinent that he determined on printing other volumes in the same style, and eventually he was supplied with a complete series of all the old fonts.

America took part early in the revival of Caslon's oldstyle types, for in 1858 matrices were brought to the United States by the Johnson Type Foundry, afterward Mackellar, Smiths \& Jordan, now the Philadelphia branch of the American Type Founders Company.

The first size made in this country was brevier, which was anmouneed in the "Typographie Advertiser," the company's house-organ, of January, 1859. Six months later thirteen sizes were shown, and in 1865 Caslon Oldstyle was made in sizes from pearl to six-line pica.

The decorative Italic types, known as Swash letters, were not until 1!1t: included in the American fonts, but these, redrawn by T. M. Cleland, are now proeurable.

Selection of Caslon Oldstyle, in 1892, for the text and advertisements of Vogue, the use of the letter by Will Bradley at the Wayside Press, in 189t; and the general old-style revival, influenced by the work of William Morris, of the Kelmscott Press, in England, were causes that led to the present popularity of Caslon Oldstyle.

This Caslon style of type-face is one of the few standard letters that has practically unlimited usefulness. Properly treated, it looks well on any class of printing, from a business card to the text and advertising pages of periodicals. It may be seen in action in this book by referring to Examples 18, 31, 6it, 65, 6ifi, 6 i7, 68, 81, 82, 86i, 96, 119, $121,126,127,182,133,131,135,138,150,151,167,168$, $169,172,178,180,188,190.191,195,203,215,221,222$, $223,224,225,228,230,231,232,236,239,245,246,247$, $218,219,250,260,262,248,274,282,281,287,289,290$, 292, 294, 294, $297,300,371,375,382,384,385,393,394$, $396,124,12 !, 130,133,431,136,438,139,140,441,448$, $150,451,453,455,159,460$ and 461 ; the frontispiece; upper speeimen, page 21 ; reproductions, page 23 ; insert opposite page 32 ; upper specimen, page 33.

\section{XVIII}

The Fifth $O D E$ of Horace, Lib. I.

Quis multa gracils te pucr an rofa, rendred almoft word for word wuthout reme, according to the Latin mcajure, as near as the language will permut.

W HA Thlender youth bedew'd with liquid odors Courts thee on rofes in fome pleafant cave, Pyrrha? for whom bind'f thou

In wreaths thy golden hair,

Plain in thy neatnefs? O how oft thall he

On faith and changed Gods complain, and feas

Rough with black winds and florms

Unwonted hall admire!

\section{XVIII.}

\section{The Fifth $O D E$ of Horace, Lib. I.}

Quis multa gracilis te puer in rofa, rendred almoft word for word without rime, according to the Latin meafure, as near as the language will permit.

$W_{c}^{\mathrm{H}}$ HAT flender youth bedew'd with liquid odors Courts thee on rofes in fome pleafant cave,

Pyrrha? for whom bind'ft thou

In wreaths thy golden hair,

Plain in thy neatnefs? O how of thall he

On faith and changed Gods complain, and feas

Rough with black winds and ftorms

Unwonted fhall admire! 
^ ABCDEFGHIJKLMNOPQRSTUVWXYZ

\author{
abcdefghijklmnopqrstuvwxyz\&
}

в ABCDEFGHIJKLMNOPQRSTUVWXYZ abcdefghijklmnopqristuvwxyz \&

c ABCDEFGHIJKLMNOPQRSTUVWXYZ
abcdefghijklmnopqrfstuvwxyz\&

EXAMPLE 484

The possible descent of Scotch Roman. (A) Baskerville Roman, based on Baskerville's letter of 1758. (B) Mrs. Caslon's "modern" Roman of 1796. (C) Scotch Roman, as we know it today

Bodoni Book.-When a representative of the Bodoni type family was selected for a place in the group of standard faces, Bodoni Book was chosen for its refinement and legibility. In its lower-casc, especially when printed on other than gloss-surfaced paper, it seems to have more of the qualities of the best types of the Parma printer than does Bodoni, the first serics brought out by the American Type Founders Company. Scientific tests have demonstrated that in the small sizes usually used for text purposes, type-faces with considerable contrast of hairlines and heavy strokes strain the eyes. The contrast found in Bodoni Book is moderate.

John Baptist Bodoni was born in Italy twenty years after William Caslon cut his first font of Roman letter. Bodoni's subsequent carecr as a printer and typefounder doubtless resulted from his entrance, when eighteen years old, to the printing house of the Propaganda, in Rome. He began his important work in Parma in 1768.

The print of his books is remarkable for clearness, and in both type-cutting and printing he was skilful to a high degree. His types are not quite so regular in design as the recent Bodonis, and were given additional character by being impressed firmly in paper that did not have the enameled surface so much in use in our day.

His type-faces were a change from those previously used-different from the type-faces of Jenson, the Elzevirs and Caslon. The change was principally in the serifs, which were straight, thin strokes; and the general charaeter of the letters was also distinctive. He used a few fonts in which the straight serifs were rounded by being filled in slightly at the corners, and these fonts probably suggested to Scotch, English and American founders the style known as "modern," as compared with the "oldstyle" faces in use before Bodoni's time.

The reader can compare for himself the resemblance of Bodoni Book to one of the text types of Bodoni as used in 1789. In order that the comparison could be fairly made, the Bodoni Book (Example 486) was printed on antique paper and etched on zine, as the original Bodoni page had been (see page 26 ). This type is not only lighter, but other details are different from a 1790 type of Bodoni (Example 487-A), which may have served as a model for the present-day type-face called Bodoni. Compare the capital $R \mathrm{~s}$, and notice that the cross stroke on the lowercase $t$ in the 1783 alphabet is low and distinct, while on the $\mathbf{1 7 8 9}$ page it is high and joincd with the upper end of the vertical stroke. The latter treatment prevails on many of Bodoni's types, as it does on practically all type-faces. Excepting for the straight serifs, many of Bodoni's types have some general resemblance to other Roman types of the scventeenth and eighteenth centuries.

In designing the present-day Bodoni, the typefounders gave it much of the "finish" in design that was given typefaces by Scotch and American founders during the nineteenth century. Typefounders seldom succeed in faithfully reproducing old type-faces, for the reason that they "correct the faults" of the old faces, and in doing so lose much of the humanistic spirit of the original. Were it not that the punches of some of William Caslon's types were preserved, we would not have the true rendering of this old-style that we now possess. Modernized Oldstyle represents the Caslon face corrected and improved as the typefounders of the nineteenth century thought it should be. Some American founders, however, are making excellent progress in reproducing the spirit of old type-faces, and it is possible that we may yet have a satisfactory copy of the famous "silver" types of the Elzevirs.

Bodoni types are shown in use on page 26, and in Examples $26,36,48,175,176,194,278,310,322,330,352$, $355,365,387,390,412,413,414,416,428,437$ and 158 .

Scotch Roman.-During the nineteenth century English, Scotch and American typefounders took Bodoni's type-faces, redesigned them more along mechanical lines, filled in the comers of his straight serifs so as slightly to round them, and gave to the English-speaking world what are best known to printers as the modern Romans.

Looking over the specimen books of the type foundries of the last century - those of Bruce, MacKellar, Smiths \& Jordan, and others-one marvels at the wonderful skill in the cutting of the hairlines and the general mechanical excellence of the modern Romans.

Because of their continued use on newspapers and in books of reference, these letters are in wide use today, altho there is a movement away from them.

The most generally used type-face on small city newspapers in America is the linotype company's Modern Roman No. 2 (Example 489). In the hand-set days this broad, open-faced letter was so made for the reason that it would stercotype casier than would the narrower letters. It was adopted by the ready-print and plate houses, and when the newspapers installed linotypes they natu- 
rally selected the same face, so that the type matter thruout the publication would match. The larger city dailies give more attention to the details of the faces they use for body purposes. If No. 2 is selected, or the leaner No. 1, modifications are frequently made in some of the letters or figures. The No. 1 Modern Roman is used by the New York Times (Example 406).

However, instead of the selection of a severe letter, such as the so-called Scotch-cut Modern Roman as a representative type-face in the group of six standard Roman letters, the more interesting Scotch Roman won the place. 'I'lis type-face was first made in America by $\Lambda$. D. Farmer \& Son, and the eiglit-point and ten-point sizes were used as body type by The Ameriean Printer first in April, 1902. In September of that year there appeared in that publication showings of the eight-point, ten-point, elevenpoint, twelve-point and fourteen-point sizes, with the statement that other sizes were in preparation. The name, "Scotch Roman," probably comes from the fact that Miller \& Richard, the Edinburgh typefounders, made a similar letter in sizes from eight-point to twelve-point. However, they call it "Old Roman."

Scoteh Roman is the link that connects the graceful old-style and the severe modern Roman. Compare it with the letter (Example 48 1-B) made at the foundry owned ly Mrs. Henry Caslon in 179mi, and notice the resemhiance. (As a further study, there is added an alphabet of Baskerville Roman, recently introduced to America.) Scotch Roman is also procurable under the names of Wayside Roman and National Roman.

Scotel Roman has heen used in Examples 38, 39, 77, $78,85,113,152.153,151,185,181,938,971,317,100$, $420,123,127,128$ and 111 .

Freneh Oldstyle.-This is the title by which is known among printers a style of type-face made, under the nime of "Elzevier," ly the Gustave Mayeur foundry of Paris in 1878 . Its design, M. Mayeur tells us, was suggested by types used in a book printed in Leyden by the Elzevirs in 11:31.

In 188 , Farmer, Little \& Co. of New York proeured drives of five sizes from france and began making the l'tter in America, naming it "Cadmus." The type foundry of Phelps, Dalton \& Co. of Boston had as early as 1881 made a similar and rather plcasing letter in capitals only, which it called French Oldstyle.

Theodore L. De Vinne was the first to use the Mayeur French Oldstyle in America. It was a favorite with Walter Gilliss, who adopted it in remodeling the catalogs and other printed matter used by the Metropolitan Museum of Art, New York.

The capitals of French Oldstyle are especially pleasing, and when this letter is employed they should be used in display with frequency. The irayeur letter would be

\section{A B C D E F G H I J K L M N O P Q R S T U V W X Y Z}

(A) Portuguese Oldstyle, cut about 1804. From De Vinne

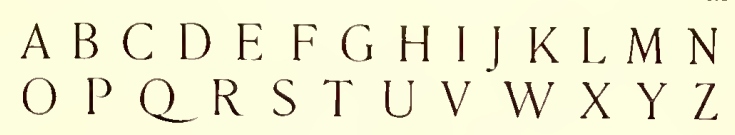

(B) Cadmus capitals, designed in 1878

A study of the French Oldstyle design of Roman capitals even more attractive if the proportions of its eapitals were nearer those of early Roman lettering (Example 464-B), as a re some other French Oldstyles.

French Oldstyle is tall and formed with liberal space between the strokes of the lower-case letters. It should always be leaded, as its open character and large lowercase demand that it shall not be crowded. Like Cheltenliam, it is best suited for pages that are narrow and long, such as the $12 \mathrm{mos}$ issued in the seventeenth century by the Elzevirs.

The Mayeur French Oldstyle has a slight resemblance to the type-faces found in the Elzevir seventeenth-century books (Example 475), but is a rather free rendering of those types. The capitals of the Elzevirs are more in the proportions of Jenson's (see Cloister Oldstyle, Examphe $4,7-\Lambda$ ), and the small letters $(o)$ of the lower-case are not so large in comparison with the tall letters $(l)$ as they are in French Oldstyle. The Mayeur letter also contains the shortened descenders and short-kerned $f$ of the nineteenth-century typefounders. In fact, both ascending and descending strokes have been shortened.

Examples 45, 183, 1 81, 217, 410, 411, and the Jacobi specimen on page 33 show French Oldstyle in use.

Cheltenham Oldstyle.--This extremely popular typeface was designed in America and here developed into the most numerous family known to typefounding-at least thirty serics. $\Lambda$ pamphlet issucd in 1905 by the Mergenthaler Linotype Company tells the story of its origin. Ingalls Kimball, director of the Cheltenliam Press, New York, was commissioned to suggest and supervise the making of a letter that would have both beauty and legihility. Cheltenham Oldstyle resulted, the drawings of which were made by Bertram G. Goodhue.

It was realized by the designers of this type-face that space between lines increases legibility, and experiments seem to show that the upper half of lower-case letters are easier to read than the lower half. For this reason the lower-case was then designed with long ascending strokes and short descending strokes. While the theory regarding the superior legibility of the upper half was announced as a new one, it had becn put fortl about 1882 by Dr. Émile Javal, a Parisian oculist. (See the demonstration in Example 508-G.)

The first announcement by the $\Lambda$ merican 'Type Founders Company of Cheltenlam Oldstyle in The American Printer, January, 1903, showed eleven sizes - eight-point to forty-ciglit-point. Claim was made that it was a "compact and legible book type," and that it would become the most popular job type.

Because of its lean formation and close set it has been frequently used for narrow booklets.

A Roman type-face entirely new in design would be a freak and unreadable in the mass. $\Lambda$ s a completed design, Cheltenham Oldstyle was different from others in use in 1903 , yet it is made up of features of Roman type design in rogue between the designing of Jenson's letter and Caslon's types. Study Examples 470, 472, 476, 477 and 478. Compare with the Portuguese capitals, especially $G, P, W$, in Example 4.85 .

Cheltenham Oldstyle has strength, readability, and a certain amount of beauty. Its capitals are awkwardly large in comparison with its lower-case. It is shown in use with smaller capitals in Example 476.

Because of the smallness of most of the lower-case and the close set of the letters, very little space is needed between words; yet, as used by printers generally, much of the legibility the type-face possesses is lost by wide spaeing between words, especially on machines.

Because the eye, as a rule, gives less attention to the lower part of a line of reading matter, the descenders 
were eut off almost entirely in the designing of Cheltenham. It would be as reasonable, beeause the eye usually sees only the upper part of a man, to amputate his legs. This amputation of the legs of type-faces by modern founders has maimed many other letters, notably Caslon Oldstyle as we most frequently see it.

The serif, whieh is supposed to distinguish modern types from old-style, is very small in Cheltenliam Oldstyle, and is more like the serif found in modern types. The general eharaeter of Cheltenham, however, is extremely old-style.

This letter has been used in the eomposition of Examples 35, 46, 47, 106, 122, 125, 209, 267, 273 and 350 .

\section{Development of the Ronan Type-Face}

In the beginning, Roman letters were in eapitals only (Example 464-A), and, earved on stone, were at their best about the beginning of the Christian era. 'The present soealled Roman, Italie and Text types are descended from them.

Use of the pen and brush in lettering and the tendeney to letter rapidly finally gave us the lower-ease type of today. 'The evolution is pictured in Example 465. " $A$ " shows the Roman eapital alphabet as made with the pen (eompare with the ehiseled letters of Example 4i:1-A). In "B" we have the result (known as uncials) of hurried writing of the Roman capitals, and one can see how the lower-ease letters were forming. At about this point in the development, the minuscules, or lower-ease letters, took two separate growths-one in the direction of the "Blaek Letter" or German 'Text types of today, and the other

et attonito quodam silentio, quam ulla loquendi copia prosequendas censeo, quibus certe Aula Hispanica beneficentissime pa. tuit, et in qua, tanquam in sua regia, sedem ipsae collocarunt. Et quidni eo confugerent mitissimae artes, ubi regium patro. cinium, et liberalitas eas ab invidia, et inopia liberabat, totque extabant exempla pro. pensae in doctos artifices CAROLI voluntatis? Cujus rei monimenta erant locupletissima Academia Matritensis regiis aedibus aucta: Valentina excitata: Hispalensis, Caesaraugustana, Barcinonensis largiter amplifica. tae; erant Carmonae, Selmae,Balliesterii Pa. risios missi, lautissimis ad iter, et commorationem impensis subministratis, ut quam modo in ipsorum operibus admiramur, graphidis, et sculpturae praestantiam asseque. rentur; erant laxata compita, ornata fora, instaurata templa, singulaeque urbium par-

EXAMPLE 486

Resetting in Bodoni Book of the 1789 Bodoni specimen on page 26. Like the original, this specimen was printed and then zinc-etched

\section{ABCDEGHIJKMNOPQRSTUW abcdefghijklmnopqrstuvwxyz}

(A) Types cut by Bodoni in 1790. From Bullen

\section{ABCDEGHIJKMNOPQRSTUW abcdefghijklmnopqrstuvwxyz}

(B) Bodoni as now made in America

EXAMPLE 487

Comparison of one of Bodoni's alphabets with a new type-face. Both are rough, having been zinc-etched

toward the "White Letter" of the Caroline Minuscules, which, as Roman lower-case, are now used almost exchsively in Ameriea, England, France and other countries in North and South Ameriea and Europe, the notable exception being Germany.

When Gutenberg began to print he used a black Text type designed after the bold lettering of the German manuscript books, and when Germans went to Italy to print they had difficulty in rendering into types the character of Italian lettering. Example $1, ; 8$ shows the efforts in this direction by Swcinheim and Pannartz in 1145, and in Example 1(i9, types by John and Wendelin of Spires, an improvement is noticed.

It remained, however, for the Frenehman, Jenson, to design and eut a letter that is the alpha of Roman typefaces (Example 470). Jenson was fortunate in the selection of a model, and it is interesting to include in the eorner for comparison a section of an Italian manuscript of the same century. Development of the Roman letter into the beautiful and legible form known as "Caroline Minuscules" was due to the encouragement of Charlemagne. Why it is called "White Letter" in eontradistinetion to "Blaek Letter" may be seen by comparing the light-gray tone of the Jenson page (Example 470) with the missal speeimen opposite page 14 . It may be well to explain that the seeming disfigurement of the capitals in the Jenson page is due to the custom that book decorators had of placing a stroke of vermilion over the capitals. In the reproduction these strokes came out black. Both the Spires and the Jenson specimens were reproduced from the original volumes in the Typographic Library and Museum at Jersey City.

Example 465 also shows, for comparison with the style of lettering known as the Caroline Minuseules, a type-faee lased on Jenson's letter of 1470 , following which are Moxon's and Caslon's lower-case alphabets.

The faithfulness with which Jenson's type-face was followed in the designing of Cloister Oldstyle may be seen by comparing the Cloister alphabet (Example 1.67-A) with the Jenson letters as they are found in Example 170. $\Lambda$ very interesting eomparison ean also be made of Jenson's capitals, on page 14, and Cloister Oldstyle, in Example 173. If a eomparison of present-day type-faces with very old faces is to have any value, the present-day type-faces should be printed on antique-finished paper dampened if possible. And if the old face is reproduced by zine etching from an old book the other type-face should also be zine-etched. Printing and zine etehing were resorted to in the ease of this example and in other instances in this chapter.

In some works reproductions of type-faces are valueless and misleading, for the reason that they have been retouehed by an artist, redrawn, or eut in wood. 
The influence of the Jenson style of Roman was seen for some ycars, but in 156; (Example 472) we find a change of form. The type is more condensed, and instead of a diagonal stroke on the lower-case $e$ there is a horizontal stroke close to the top of the letter. This style, as used by Paul Manutius in 1566, seems to have been maintained with little alteration in the work of Daniel Elzevir a hundred years later (Example 477) and two hundred years later in the types of Fournier, the French founder (Example 478 ). This style of letter was also used by Plantin, the Antwerp printer, in 1569 , and for the interest there may be in it the reproduction of a bit of his work (see page 16) should be compared with Example 476. This last-mentioned example has been set in Chel-

ABCDEFGHJKLMNOPQRSTUVWXYZ
abcdefghijkImnopqrstuvwxy
ABCDEFGHIJKLMNOPQRSTUVWXYZ
abedefghijkimnopqrstuvwxy
ABCDEFGHIJKLMNOPQRSTUVWXYZ
abcdefghijkimnopqrstuvwyz

Modern Roman as it is used on many American newspapers. Six-point, seven-point and eight-point Linotype Roman No. 2. A readable but not a handsome type-face

tenham Oldstyle. However, ten-point capitals have been used with twelve-point lower-case. It may be that the appearance of most reading matter would be improved if the capitals were a trifle lower in hight than the ascending strokes of the lower-case letters $b, d, f, h, l, l$.

The National Printing Ottice at Paris is using on some of its productions a type-face designed in 1 1693 by Grandjean. While it is greatly like other letters of that period, it has peculiarities, one of which is a slight dot on the left center of the lower-case $l$, a feature also present in the Black Letter of Gutenberg. and in the types of liust and Schoeffer (sec inserts opposite pages 7 and 12).

We have a key to the formation of the Roman types of the sercuteenth century in the alphahets drawn by Joseph Moxon, an English typefounder, and published in 1676 (Examples 479 and 180 ). 'These are here reproduced from Moxon's "Mechanick Exercises," as reprinted, under the supervision of 'Theodore Low De Vinne, by the New York Typothete in 1896. Moxon says these letters are copied from the letters of Christopher van Dijk, a punch cutter of Holland. As will be seen by the scale in the upper left corner of Example 479, he attempted to show how the shapes of letters were "compounded of geometric figures, and mostly made by rule and compass." Each letter was to be plotted on a framework of small squares, forty-two squares in hight and of a proportionate width. Passing up this idea as impractical, DeVinne said:

It is admitted that the characters are rudely drawn, and many have faults of disproportion; but it must not be forgotten that they were designed to meet the most important requirement of a reader-to be read, and read easily. Here are the broad hair line, the stubby serif on the lower-case and the bracketed scrif on the capitals, the thick stem, the strong and low crown on letters like $m$ and $n$, with other peculiarities now commended in old-style faces and often erroneously regarded as the original devices of the first Caslon.

The writer was curious to sce how these letters of Moxon's made up into type, and for this purpose had the outlined alphabets inked in and reproduced in smaller size (Examples 479-A and 480-A).

When William Caslon, in 1720, cut his first Roman letter he may have had Noxon's Roman alphabet before him. There are some resemblances, but that he did not slavishly follow the Moxon letters may be seen by comparing both type-faces (Examples 465-F and 465-G).

We could be more familiar with the types of Baskerville than we are, but now that the typefounders are reproducing them (Example 483) we shall come to a realization that they rival the letters of Caslon in beauty and readability. John Baskerville, the English typefounder and printer, spent six years and thirty thousand dollars in designing and cutting his first font of type. In 1758 he had cut eight fonts of Roman, but other printers would not buy his types, preferring those of Caslon. Two years later he attempted to sell his types and retire from the printing business. After his death, in 1775, his widow sold all his type and type-making material and they were removed to $\mathbf{K}$ chl, near Strassburg. There is a legend that the types finally reached lirance and were melted into bullets for the French Revolution. It is a pity that Baskerville's original punches are not available, like those of Caslon, so that printers of today could make use of the splendid type-faces that werc unappreciated in his lifetime. However, Baskerville Roman is a satisfactory reproduction of the types of John Baskerville.

Like Caslon Oldstyle, however, it should be printed on other than gloss-surfaced paper (Example 41;3), as then, especially in the smaller sizes, the good qualities of the letter are brought out and it is made more legible.

When Mrs. Henry Caslon, in 1794, "Bodoni-ized" the types of William Caslon the first, she was probably influenced as much by the types of Baskerville as by those of Bodoni. This is borne out by the comparisons in Example 481. In " $A$ " is shown an alphabet of Baskerville Roman as now made in America, and in " $B$ " Mrs. Caslon's Modern Roman. 'The third type-face (C) is Scotch Roman, one of the six sclected representative type-faces (Example $467-\mathrm{D})$.

John Baptist Bodoni madc some very good type-faces, but it is not difficult to lay at his door the responsibility for throwing typography out of gear for almost a century. Thru his influence and the desire of Scotch typefounders to improve on his work, the nineteenth century was inflicted with those stiff "Modern Romans" (Example 488 ) that in all their inhuman "perfection" yet abide with us and are still liked by Victorian persons of staid tastes. Many of our school children are being brought up on them, and in lighter form (Example 489) they are being fed to millions of Americans thru the homely typography of most newspapers. This double influence works for a lowering of typographic taste among printers and buyers of printing that for many years will keep the general standard of printing below what it should be.

'To return to Bodoni. This Italian typefounder's types, as a rule, were not so faultlessly finished as are the 


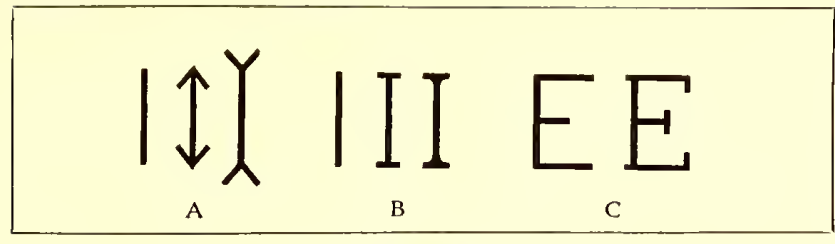

EXAMPLE 491

(A) Optical changes caused by adding $\mathrm{V}_{\mathrm{s}}$ at end of st rokes. (B) Appearance of vertical stroke altered by adding small horizontal strokes, or serifs, and by joining both with curved line. (C) Cross strokes or serifs added to $E$

recent types that bear the name. There may be seen in Example 487 the alphabet of a type-face cut by Bodoni in 1790, together with an alphabet recently cut in Ameriea. The Bodoni type of the American foundry is a clever copy of the original, vet there is in the copy much of the modernization of the Scotch founders of the ninetcenth century. Bodoni Book is a better-looking and more rearl able type-face.

The Scotch typefounders also attempted to improve the types of William Cas lon, and the result of their labors is known as Modernized Oldstyle (Example titi-A). This kind of type was first made about 1852 for Miller \& Richard of Edinburgh, Scotland. With EXAMPLE 495 (A) The diagonal stroke of the first Roman type-faces. (B) The lower cross stroke or serif extended to right on the Roman type-face of Jenson Caslon Oldstyle muknown. Modernized Oldstyle would be a rather satisfactory letter, but with Caslon Oldstyle procurable there seem to be no need of the Scotch letter. 'There was brought out in 188.4 by the MacKellar, Smiths \& Jordan Company a decorative Modemized Oldstyle under the name of Ronaldson Oldstyle.

\section{Characteristics of Roman Type-faces}

The Serif.- The serif is that portion of a type-face indicated by the small black sections in Example 4:12. It has a powerful influence in determining the character and style of a face of type.

As an experimcnt, we will make thrce vertical lines exactly the same length (Example 491-A), leaving one as it was first drawn, but on the other two adding $V$-shaped marks, bccause of which the character of the line is changed and the length seemingly affected.

However, the serif, when properly used, has a decorative quality and is to type what the capital is to the column and the eornice to the building in architecture.

After further experimenting with thrce vertical lines that we will now identify as capital Is (Example 491-B),

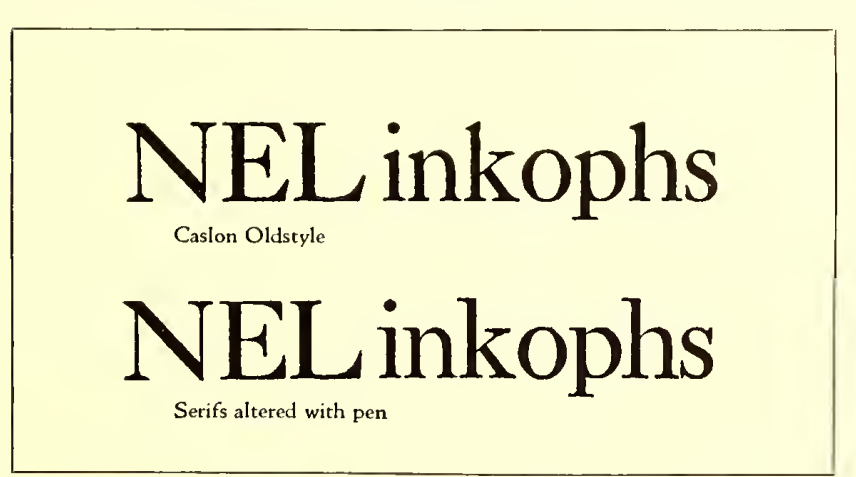

EXAMPLE 493

By altering the serifs, "old-style" type is changed into "modern." From Bullen
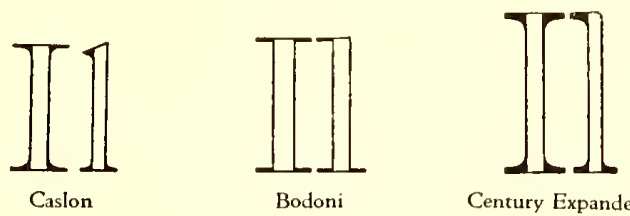

Century Expanded
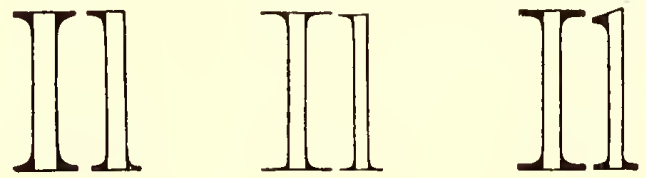

Scotch Roman

Madern Roman

Century Oldstyle

EXAMPLE 492

The black sections indicate the serifs, and show the differences in serif construction on several well-known type-faces. From Bullen

there can be no doubt that the serif is neeessary as a finishing stroke. The serifless $I$ suggests a man in the public streets without hat or shoes. The crudest manner of adding a serif is to place a small horizontal stroke at the head and foot of the long vertical line, but the sharp angles thus formed can be softened and one stroke joined to another by a curve, with the corner filled in, as is shown. These two illustrations of the scrif are merely for the purpose of introducing the novice to the subject. The fact that there are so many different faces of type is due somewhat to the manipulation of the serif-changes of length, thickness, direction and curve.

It is by the serif that in most cases old-style types are distinguished from the so-called modern Romans. An interesting demonstration of this was made by Henry $\mathrm{L}$. Bullen with Century Expanded, a modern Roman (Example 191). The first line shows the letter unchanged. As the serifs in most old-style faces project diagonally, he, in the second line, altered the modern serifs to conform to this idea. The third line shows Century Oldstyle as it actually appears in type.

There is, of course, more to a truc old-style face than mere change of serifs, and in the actual cutting of the types other minor alterations were made, as will be seen by study of the third line.

This process was reversed by Mr. Bullen, and in Ex-

\section{NELeinkophs}

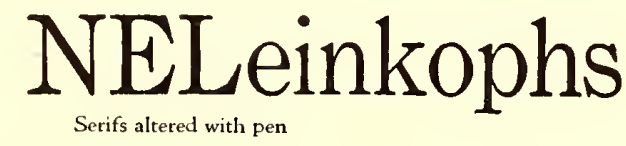

NELeinkophs

EXAMPLE 494

By altering the serifs "modern" type is changed into "old-style." From Bullen 


\section{ABCDEFGHIJKLMNOPQRSTUVWXYZ abcdefghijklmnopqrstuvwxyz}

In most Roman alphabets all vertical strokes are thick, excepting in M, N, U. Horizontal strokes are thin.
Diagonal strokes running down from left to right are thick and from right to left are thin, excepting Z, z.

ample 493 certain serifs of Caslon Oldstylc are in the letters $i, n, l, p, h$ made horizontal, and in the lctters $E$, $L, s$ made vertical. Modcrnized in this manner, Caslon Oldstyle resembles Scotch Roman (Example 484-C).

Thick and Thin Strokes.-The inbred good taste and instinct for beauty possessed by the Roman calligrapher which directed him to add the serif to his lettcring also

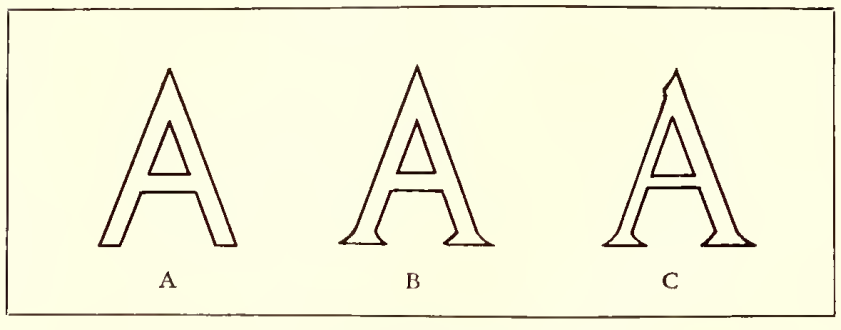

EXAMPLE 497

(A) No serifs or stroke contrast. (B) Serifs added.

(C) With serifs and thick and thin strokes

impelled him to vary the wilth of the strokes (Example Hil-A).

'The most uninteresting lind of lettering is that which is not only serifless but without contrast in the width of its strokes-lettering that is known to the printer as Block, or Gothic (Example 197- $\lambda$ ). Dignity and something of good looks are given to it by adding serifs ( $\mathrm{Ex}^{-}$ ample 497-13), yet it is not eligible for admission to the seleet society of pure Roman type-faces until the various

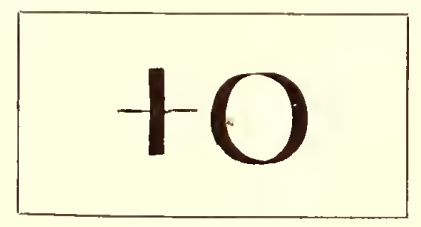

EXAMPLE 498

Vertical thick strokes were

made with pen held straight

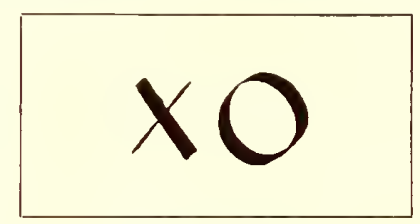

EXAMPLE 499

Diagonal thick strokes were made with pen held at a slant

strokes show, properly proportioned, a difference in thickness (Example 4:17-C). The difference should be at least as two to onc. It is about that in Cloister Oldstyle, but in Baskerville Roman (Example 1:mi) it is as six to one. When the difference in thick and thin lines is cxaggerated, as was done in the nincteenth century, the result is a caricature and type that is almost impossible to read, even in large sizes.

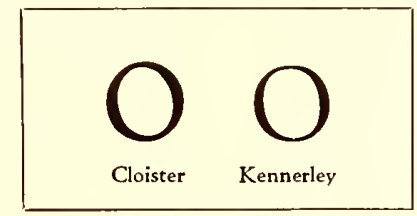

EXAMPLE 500

Heavy st rokes in the lower left and upper right part of curves
Generally the distribution of thick and thin lines in Roman letters, as shown in Example 496, is as follows: All vertical strokes are thick (excepting in $M, N, U$ ). Horizontal strokes are thin. Diagonal strokes running down from left to right are thick, and from right to left are thin (excepting $Z, z$ ).

When this rule is reversed, as was actually done by a nineteentli-century typefounder in a weird attempt at novelty, there is begotten a monstrosity. Good typography requires that basic principles be adhered to.

In the recent recutting of the Roman type-face of Nicholas Jenson, the founders went all the way back to his type for their models, and did not content themselves, as they did near the end of the last century, with copying Morris's type or the faces of other foundries. As Jenson based the design of his types closely on Italian manuscripts, we have in such a face as Cloister Oldstyle many of the characteristics of the pen-made letters, one of which is the position of the thick strokes on round letters. The thick strokes on the $O$, as an instance, instead of being vertical, are diagonal. 'This is due to the manner of holding the pen when lettcring. When held to write vertically and horizontally, the pen makes lines as in Example 498; when held at a slant, the pen makes thick lines diagonally as in Example 499. 'The Caroline Minuscules, upon which the lowercasc types of Jcnson were based, were written with a slanted pen.

In Example 500 are to be seen two well-known typefaces on which the slanted-pen thick strokes are used. In Example 501 are two faces that could be made by writing vertically. It was Mr. Goudy who reintroduced into type forms a characteristic of Jenson's Roman - that of having the lower serifs extend more to the right than to the left, as shown by Example 495-B.

Ascenders and Descenders. - Not a little of the beauty of Roman type-faces lies in the ascending and descending strokes, and one reason why our types are becoming more beautiful is that we are going thru a period of restoration - the long-missing ascenders and descenders are being given back to us, after an absence of many years.

What should be the length of these strokes? Edward Jolnston, in "Writing and Illuminating and Lettering," illustrates this point (Example 503), and says: "The lines in massed writing are kept as close together as is compatible with legibility. The usual distance apart of the writing lines is about three times the hight of the letter $o$. The descending strokes of the upper line must clear the ascending strokes of the lower line."

Bodoni, the Italian typefounder, had a system of measurement for the proportions of his lower-case letters: "Divide the body of the type into seven parts and let two at the top and two at the bottom be for the ascenders and descenders and the three in the middle for the other letters."

The ascenders and descenders, as found in Cloister Oldstyle and in the original Caslon Oldstyle, approximate the proportions given by Bodoni.

Half the letters of the lower-case alphabet-thirteen- 
are of the hight of the $o$, and we will call them the small letters. The letters with ascending strokes number eight, with descending strokes five (Example 502). Because the descending letters are only five in number, they are most frequently picked out for mutilation. This sawing off of a portion of the descending strokes cripples the letters just as the sawing off of a portion of a man's legs cripples his body. Not only is typography made imperfect by missing descenders, but, generally, the practice has worked toward the degeneration of type print, making it less easy to read, as the lines set too close together. When the descenders are of proper length they maintain a strip of blank space between lines, but when they are cut off the printer must add leads to recover the space-which he seldom does.

The printer and user of typography have been using false logie in favoring type-faces that have descenders cut off. They think they are getting more for their money when they obtain a normal twelve-point type-face on an eleven-point body, but as the one-point linear space must be restored by leading, there is nothing gained. Scientists, in the study of eye hygiene, have ascertained that a cer-

\section{a c e m n o r s u v W X Z bdfhiklt gjpqy}

\section{EXAMPLE 502}

Of the twenty-six letters of the alphabet, eight have ascending strokes, five have descending strokes, and thirteen have neither

tain amount of space between lines is necessary to save eyestrain, and the descenders are cssential in furnishing some of this needed space.

The descending curves of the lower-casc $g$ are a thing of beauty when allowed freedom (Example 50.1-A), but on the shortened plan they resemble a man cramped with rheumatism, in need of crutches.

Proportion of Letters.-One of the elements in the beauty of the ancient Roman stone-carved alphabet is the proportion of its letters. Goudy, drawing lettering and designing type-faces modeled after the inscription capitals of the Romans, has had a large influcnce in reviving good proportion in type. Cloister Oldstyle (Example 467-A), designed by L. M. Benton after Jenson's letter, is an excellent study of the old proportions introduced in present-day type-faces. How ever, there is no type that has the beauty of proportion to be found in the Roman capitals (Example 464-A) reproduced from an inseription on the Trajan column at Rome. The author has endeavored, in plain lines, to trace these capitals and show their proportions on a background of squares. It will be scen that the width of the letters $B, E, F, L, P, S$ is less than half their hight, and about half the width of $O, M, Q, C$, $G$ and $D$. It is this contrast in width as well as in shape that makes the alphabet as a whole so plcasing.

Comparison of the capitals of the six standard faces in Example 467 will show that "old-style" faces tend toward the old Roman proportions and that "modern" types, such as Bodoni Book and Century Expanded (Example 4titi-B), reveal an effort to make the eapitals as uniform in size as possible. Typewriter types are an example of what happens when this idea of uniformity is carried to its logieal end. It is really not necessary to throw Beauty out of the back door as Utility is admitted at the front. Both can live happily under the same roof.

As will be seen by Example 507, the lower-case letters are made up of a variety of curved lines, and vertical,

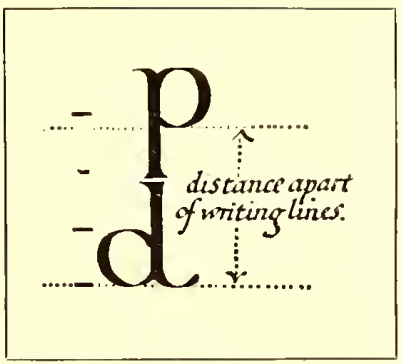

EXAM PLE 503

In good lettering, the descendind strokes are as long as the ascending strokes. From Johnston

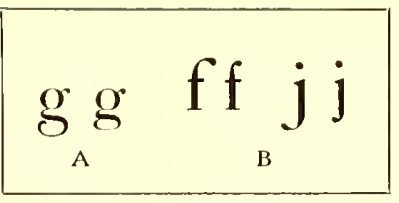

EXAMPLE 504

(A) How descenders are frequently cramped. (B) Compression of upper or lower prends of letters as found ends of letters as found in "improved" Caslon Oldstyle

horizontal and diagonal strokes, the purpose being the sime as that of having capitals of different widths, to make them when joined together in words readable and pleasant to look at. 'The word "minimum" is an example of unpleasant monotony in the repetition of similar forms.

\section{Legibility of Type-Faces}

Type matter should be casy to read, and this end is attained not only in the designing of type-faces but in the mamner of their use.

Many tests for legibility have been made in this country and in Europe, but none of them, so far as the writer knows, has considered the manner of printing the types and the character of the paper surface as factors in legibility, altho glossy paper has becn condemned because of its reflection of light, and cream-white paper preferred to bluc-white. There is shown as Example $4 ; 3$ a test made in the printing of the same type-faces on a hard-finished paper and on a soft-finished paper. The Caslon and Bodoni types are not only more legible on the soft-finished stock, but the character of the designs is brought out. 'The results of this demonstration should not be wondered at, as the original Caslon and Bodoni types were intended to be printed on soft-finished stock, and not on highly calendered coated paper.

Studies in legibility are presented in Example 508. As there are many details that count in the production of good-looking typography, so there are seeming trifles which go to make typography easily read. In "A" there are groups set in Cheltenham Oldstyle and Cloister Oldstyle. As Cheltenham is narrower in form and closely set, it is more suitable for long, narrow pages or columns. Cloister, on the other hand, conforms better to wider pages and columns. In lighter types (B) Bodoni Book and Caslon Oldstyle are similarly comparcd. For further illustrations of this point sce Examples 509 and 510.

One of the tests previously referred to proved Gothic (C) the most legible type-face. This unshaded, serifless type, which has long been popular on sales bills and for advertisements in some newspapers and trade publications, is not approved by those who believe there should also be character in type-faces, as it lacks the two essentials of typographic bcauty - serifs and contrasting thickness of strokes. Then, again, it is not as legible in the mass as in single lines.

While bold-face types, especially those with decided

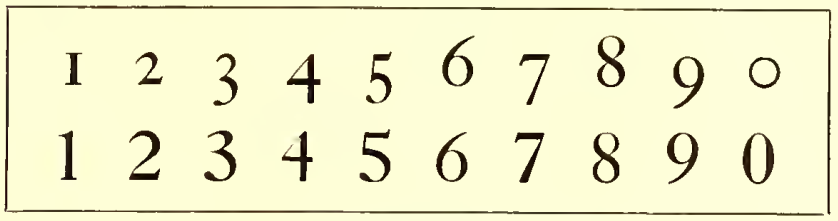

EXAMPLE 505

In the old-style Arabic numerals, five figures descended, two ascended and three did neither. The modern style is to have them of one hight 


\section{this and that}

\author{
EXAMPLE 506
}

The space between words in good lettering, according to

Johnston, is less than the width of letter "o" (lower-case)

contrasts in thickness of strokes, are legible when used in groups of two to a half-dozen words, they greatly tire the eye when used for entire pages of text. For this reason Bodoni Book is to be preferred over Bodoni for text purposes (D). The writer came to this conelusion when, during the reading of a book set in Bodoni, he found it necessary frequently to stop because of eye fatigue produced by the sharp contrasts and bewildering medley of light and shade.

It is generally conceded by authorities that lower-case types in the same size of letter are more legible than capitals (E) and should be used for headings and for display lines in advertising matter, where easy reading is essential.

Assuming that the largest possible face on the smallest possible type body results in legibility and allows more matter on a page, both users and makers of type have in many fonts caused the descending and aseending strokes to be shortened. The lower-casc letters $g, j, p, q$ and $y$ have been the prineipal sufferers, as they are the only ones with deseending strokes. 'The ascending strokes of letters $b, d, f, h, k$ and $l$ have been treated with more respect, and their principal ancestor, the Caroline Minuscule, would not have so much difficulty in reeognizing them.

'The left portion of section F of Example 508 shows what this practice has done to Caslon Oldstyle. It has also affected legibility by lessening the space between lines (see also Example 50!), and reading, already diffcult, is made still more so by the excess space that careless hand compositors and "speedy" maehine operators place between words.

Space Between Irords.--The eyes can, in the same space of time, read many more words if the words are narrowly spaced than if they are widely spaced. The early printers knew this and set type accordingly. When lowercase letters are widely spaced one letter must be read at a time (508-I). When words are widely spaced one word must be read at a time. $A$ person accustomed to reading reads by thoughts - groups of words or sentences. Even in the schools they are discarding the long-used method of teaching the $\mathrm{A}-\mathrm{B}-\mathrm{Cs}$, and instead of at first learning each letter separately, the child learns to know words by their formation and to read by word groups.

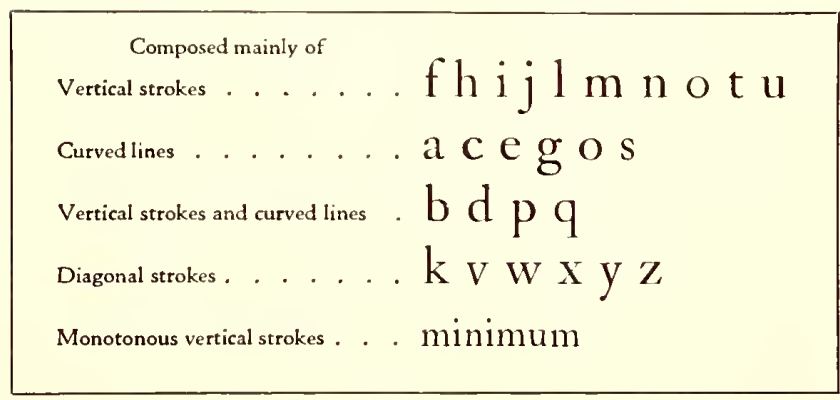

EXAMPLE 507

The lower-case letters grouped according to formation. As generally mixed in various combinations, distinctive word groups are formed. The word "minimum" is an exception
The present prevalence of wide spacing in the composition of books, eatalogs, pamphlets, periodicals and newspapers is a legacy from the ante-machine period.

In hand-sct days, job and book compositors, when they were called on to set so-called straight matter, were required to use great care in spacing. In the spacing out of a line the conscientious eompositor would remove thick spaces and insert thin spaces rather than add much extra space between the words. The newspaper compositor, on the other hand-he usually being a piece worker-seldom thin-spaeed, but liberally added space between words, especially on occasions when his "take" was to "meet" that of another eompositor. When machine eomposition was introdueed the spacing practices of the news-room hand compositor were passed along to the machine, with the result that today a page of machine matter set in the average careless way shows open spaees running irregularly down the page, resembling a trench map of a modern battlefield.

Close spacing and the resultant neat and readable appearance of the page are possible in machine composition, as many users of these machines are obtaining sueh results; but the general standard, due not a little to the demand for rapidity and somewhat to ignorance of the fundamentals of good typography, is humiliatingly low.

The design and form of the type-face, of eourse, determine the amount of space between words. Johnston tells letterers that "the average space between two words is less than the width of the letter o." Example 506 is illustrative.

A newspaper editor some years ago asked the hand compositors to thin-space, as there was a great deal of copy that day, whereupon the printers all laughed in ridicule of the lay notion that such a procedure would be of much use. That the request was not such an impractical one was recently borne out by an experienee of a periodical publisher, who, on the machines in his own shop, produced close-spaced matter. In an emergency an outside machine-composition house was called on to set a part of the copy. When the work of making up was completed, it was found that there were several galleys of matter that could not be used, altho there was no more eopy than usual. $3 y$ again referring to Example $508-\mathrm{F}$ it will be seen that in the left group spacing between words is lavish, while in the right group there is no waste of such spacing. Altho there is more space between the lines of the right group, it contains three more words than the left group.

In the lower part of Example 508 is the word "Typography" set in small six-point, and near the word is the lone letter $a$, same size. It is difficult for a person without excellent eyesight to identify the small six-point "a," but he can more easily and as quickly read the word made in the same size from ten letters. When the letters of the word "Typography" are widely spaced (even in larger size, as shown) they must be read one letter at a time, but when closely assembled they can be seen at a glance and read ten times as rapidly.

An experienced proof reader does not read a galley letter by letter, but recognizes a wrong type because the natural formation of the word has been broken.

Carrying the experiment further, place in "open formation" the words "Art and Practice of Typography," and they must be read slowly one word at a time, but group the words closely, as has been done in the lower left of the same Example 508, and the entire group of words can be read practically at a glance. Just as an illiterate person laboriously reads letter by letter, a young child beginning to read will see only one word at a time. While on rudimentary primers the words should be isolated, there is no necessity for wide spacing between words in text matter intended for adults. 
The narrow construction and close A set of this letter make it suitable for narrow measures such as this.

The tall and dignified appearance

B of this modern type fits it for a page not broad but narrow.
The round and easy old-style formation of this typeface is suited for wider measures, as narrow columns would likely result in awkward spacing.

This type-face, like the one used above, is round in design, yet the letters are not so closely set. It is proportionately suitable for lines this length. c LEGIBLE BUT PRIMITIVE

Strong contrast of thin and thick strokes

D of letters, such as in this type-face, has a tendency to make the reading difficult.

\section{SERIFS AND STROKE CONTRAST}

A type similar in design, but with the thick strokes not so heavy, giving less contrast, is more legible, and is less tiring to the eyes.

e type lines in lower-case more LEgIBLE THAN CAPITALS

Wide spacing between words and the shortened descending strokes of letters tend toward illegibility when the type

fines are set solid, as is unfortunately too

F frequently done both by hand and by machine. These defects are to be found in much composition of the present day, and the average page of typography will show that this example is not exaggerated.

Tho unnor nortion of a trus lino hac

G hoon found to ha agciarto road than the loxiar nortinn

H

SPACING OF CAPITALS WOULD MAKE THEM EASIER TO READ
Narrow spacing between words and long descending strokes of letters that preserve space between lines are aids to legibility, as the eyes easily move along the lines and read the words by groups. The page tone is also maintained. In fact the space used between the lines could, according to scientific investigation, be a trifle more than that provided by the long descenders.

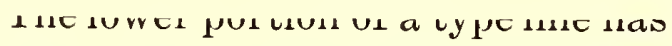

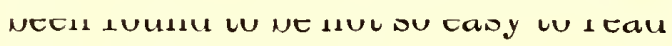
as wic uppes pus unil.

Spacing of lower-case letters usually makes them more difficult to read

$$
\begin{array}{llllllllllllll}
\text { Typography } & { }^{a} & \text { Typography } & \text { T } & \text { y } & \text { p } & \text { o } & g & \text { r } & \text { a } & \text { p } & \text { h } & \text { y }
\end{array}
$$

I
Art and Practice
Art
and
Practice of
Typography

Length of Lines.-This leads to consideration of the effect length of lines lias on reading.

The Board of Education of the eity of New York disqualifies textbooks in which the length of line is more than 100 millimeters (about twenty-four picas, or four inches). The maximum length of line recommended by the British Association for the Advancement of Science in 1912 is about the same. Professor Huey, in "The Psychol- ogy and Pedagogy of Reading" (1907), says: "There is a general consensus in faror of the shorter as against the longer lines, with a tendency to favor 90 millimeters as a maximum, some placing the maximum at 100 millimeters." Dr. Javal, the French oculist, who thirty-five years ago made tests in typography, belicres the maximum should be considerably below 90 millimetcrs (about 21 picas).

It would be well, in order to arrive somewhere in de- 
termining the proper length of line, to consider the size and kind of type that makes up the line.

The author asks consideration of Examples 509 and 510. The length of line is limited by authorities because the eye finds it difficult to read a long line of comparatively small type. Isn't it true that healthy eyes can read a line of type twelve inches long set in fifty-four-point Caslon Oldstyle, say, with the same ease as a line four inches long set in eighteen-point Caslon Oldstyle?

By the same reasoning, the line of twelve-point Caslon Oldstyle set three inches wide (Example 509,) is as easily read, after the eyes are focused on it, as the line of eighteen-point Caslon set four inches wide.

The author suggests, then, that the proper length of type lines be ascertained by measuring one-and-a-lialf alphabets of the lower-case of the desired type, as is demonstrated in Example 510.

Let us try out the top group-Caslon Oldstyle. (This type-face seems smaller, according to body sizes, than Seotch Roman, for the reason that its descending strokes liave not been cut off", while those of the Scoteh Roman group have becn shortencd; but of this more later.)

A lowcr-case alphabet-and-a-half of twelve-point Caslon Oldstyle (with long descenders) measures $171 \%$ picas in lengtl, as will be scen in Example 510. How it appears set in words in two lines of the same measure is to be seen in the upper part of kximple 509. According to the working out of the plan, $17 \%$ picas is the ideal length of line for books using this twelve-point type. By referring back to Example 197 in the chapter on "Books." the theory will be found borne ont in practicil use on a model book page.

Testing the lengtl of lines by reading (Example 50!!), it will be found, if the distance between the eyes and book is lengthencd as the sizes grow larger, that the line is short cnough not to necessitate a liunt for the beginning of the second line after the first is read.

'The optical disadvantage of using in one piece of printing type-faces of any great contrast in sizes may be proved by focusing the cyes so as casily to read the eighteenpoint size and then clanging quickly to the eight-point size, attempting to read the latter without again focusing the eyes to fit the smaller type.

There is a tcchnical as well as an optical reason for determining the length of line by measurcment of the types themselves. It will be seen by Example 50! that the copy adjusts itself to the various lengtlis of lines, or, in the vernacular of the printer. "works out line for line." If fourteen-point type, instead of twelve-point type, were set in lines measuring fiftcen picas in length, the compositor would have more difficulty in adjusting the spaces betwcen words, as these spacing points would number two less. This difficulty is usually solved by regrettable wide spacing betwcen words or more regrettable spacing between letters.

Testing types used on newspapers. selecting for the purpose the most used newspaper linotype face (sec lower part of Example 510), we find that the lengtl of line for six-point should be thirteen picas and for seven-point fourteen picas. As actually used in newspapers, the length of line is usually twelve and a half or thirtcen picas.

Approved Type Sizes and Space Between Lines.-.The type in the upper part of Example 509 also illustrates the sizes of type and the amount of space between type lines that investigators have determined are minimum for use on schoolbooks.

Dr. Cohn, whose findings in these matters have been practically indorsed by educational hoards and writers on school hygiene, stipulates that for first-year school children the vertical measurement of the lower-case $o$ should be at least 2.0 millimeters, with space between lines (meas- uring vertically between a lower-case $o$ in one line and a lower-case $o$ in the line above or below) of 4.5 millimeters. Twenty-two-point Caslon Oldstyle, with long descenders (not shown here), conforms to these measurements.

For the seeond and third years, the measurement of the $o$ should be at least 2 millimeters, with space between lines of 4 millimeters. Eighteen-point Caslon Oldstyle, with long descenders (as slown in Example 509), conforms to these measurements.

The fourteen-point size meets the requirements for the fourth sehool year-at least 1.8 millimeters, with spaee between lines of 3.(i millimeters.

After the fourth school ycar the type should measure not less than 1.1; millimeters, with space between lines of 3 millimcters, to which twelve-point Caslon Oldstyle, with long descenders, eonforms.

The descending strokes are sufficiently long in the eighteen-point size to maintain betwcen the lines of type the amount of spacing stipulated by Dr. Cohn, but in the fourteen-point size it was necessary to add a two-point lead and in the twelve-point size a one-point lead.

In comparing one font of type with another, it is not accurate to eompare, say, eleven-point with eleven-point. Not inf requently one type-face lias been pronounced more readable than another, when the preferred type-face was really a twelve-point face on an eleven-point body, with the descending strokes mutilated to allow for such an arrangement. The faces should be compared by the Cohn method given above.

'The panel inserted in Example 509 is illustrative.

'The thrce letters ( $I I d p)$ at the left are twenty-fourpoint "lining" Caslon; the three letters (IIdp) at the right are thirty-point Caslon Oldstyle No. 471. The economical printer too often prefers the "lining" fonts, as he does not necd to buy waste (?) metal. It is the same sort of reasoning that sees in the park spaces of the cities realcstate waste.

The laws of compensation in good typography require, where one point or two points or more are unwisely removed by shortening descenders, that these points shall be restored by leading. So where is the gain by mutilation?

\section{ItTALC TyPes}

Italic, the graceful, inclined, feminine type that is now mated witl most Roman types, was not known by Jenson or lis contemporaries. It made its appearance for the first time in 1501 on a book printed and published at Venice, Italy, by Aldus Manutius. In that volume, an edition of Virgil, Aldus gave credit for the cutting of the face to "Francia of Bologna," who has since been identified as the great painter and contemporary of Leonardo da Vinci.

The legend has been passed along for many years that Italic was fashioncd after the handwriting of the Italian poet l'ctrarch, but specimens of his handwriting do not bear tlie proper resemblance, and there are now those who scoff at the story.

How ever, the Aldus Italic is not, as one writer declares, merely an inclined Roman. As it has been reeut by the American Type Founders Company and mated witl Cloister, the recut Roman letter of Jenson, there is opportunity to compare Italic and Roman lower-ease, whieh is done in Example 515. It will be seen that, while there is a family resemblance, there are many differences other than that of mere inclination. Italic capitals, however, are inclined Roman letters, but it should be remembered that Aldus and Francia did not make or use Italic capitals, but that with the slanting lower-case letters Aldus used small Roman capitals. Example 513 slows how this was done, and this example, by the way, is a resetting in 


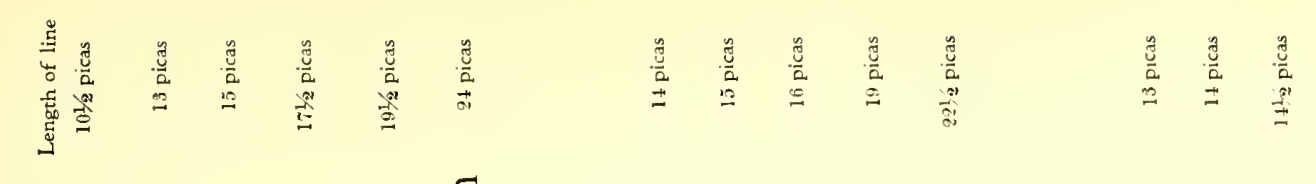
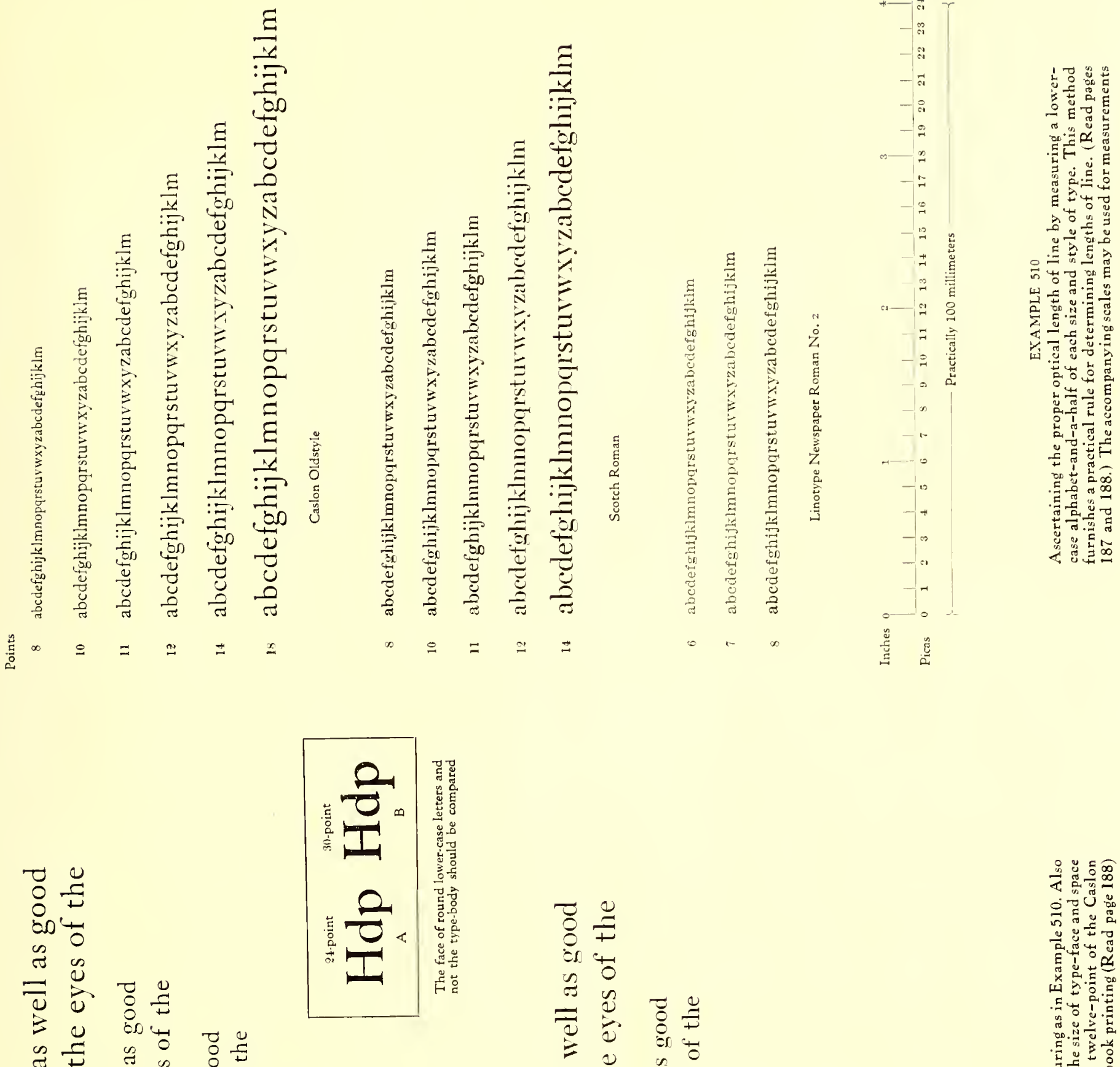

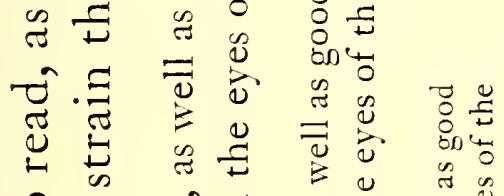

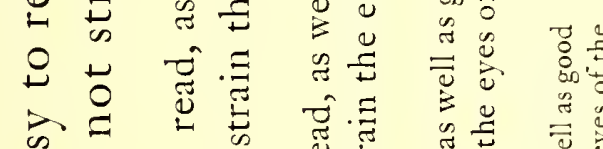

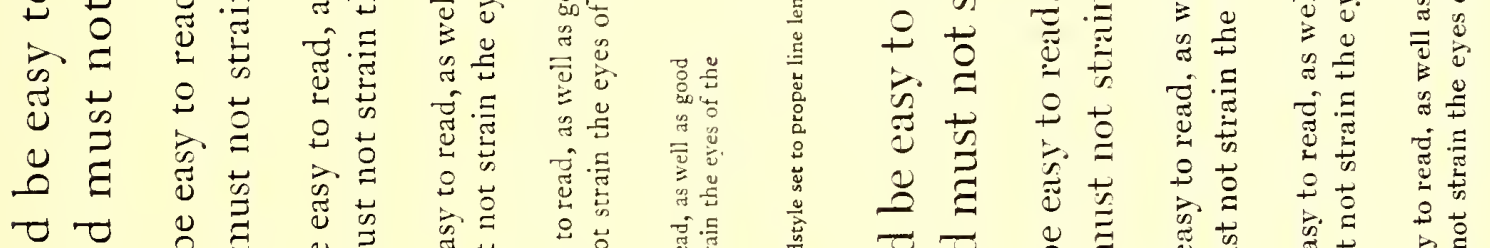

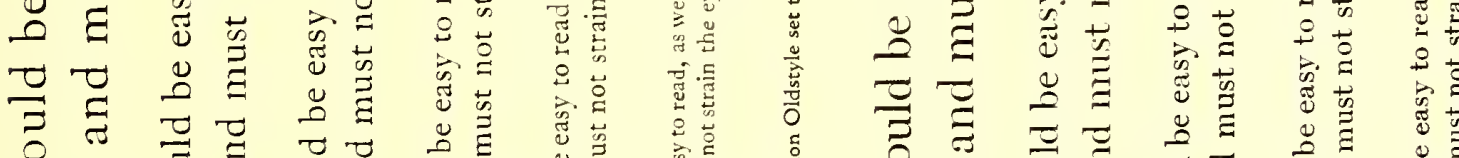

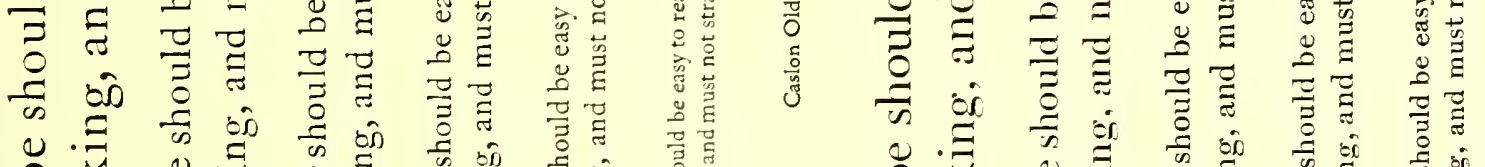

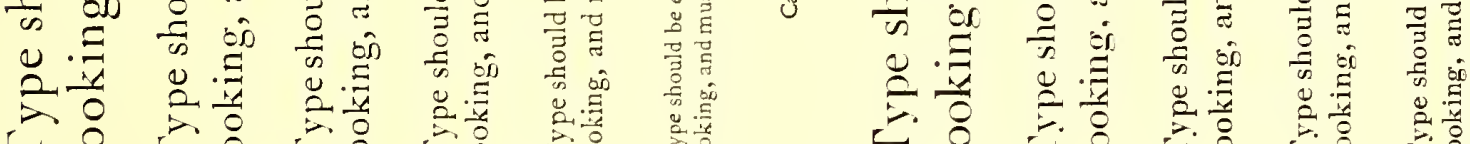

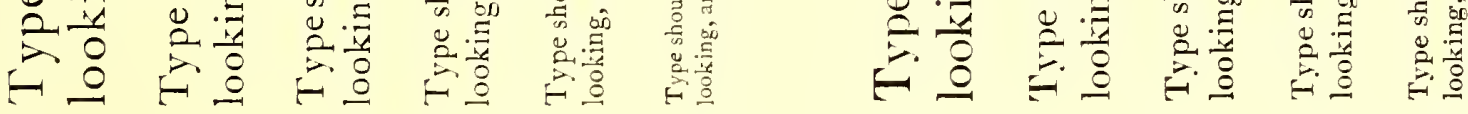

苛
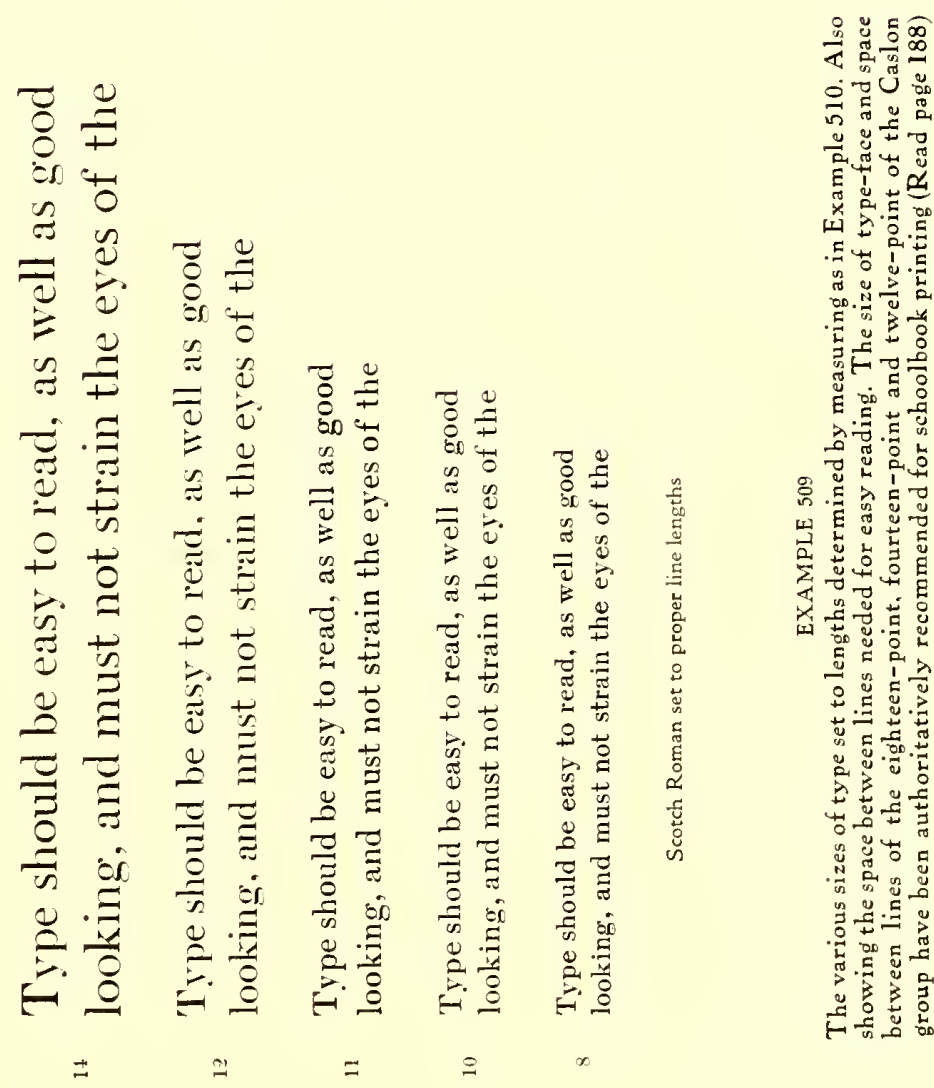

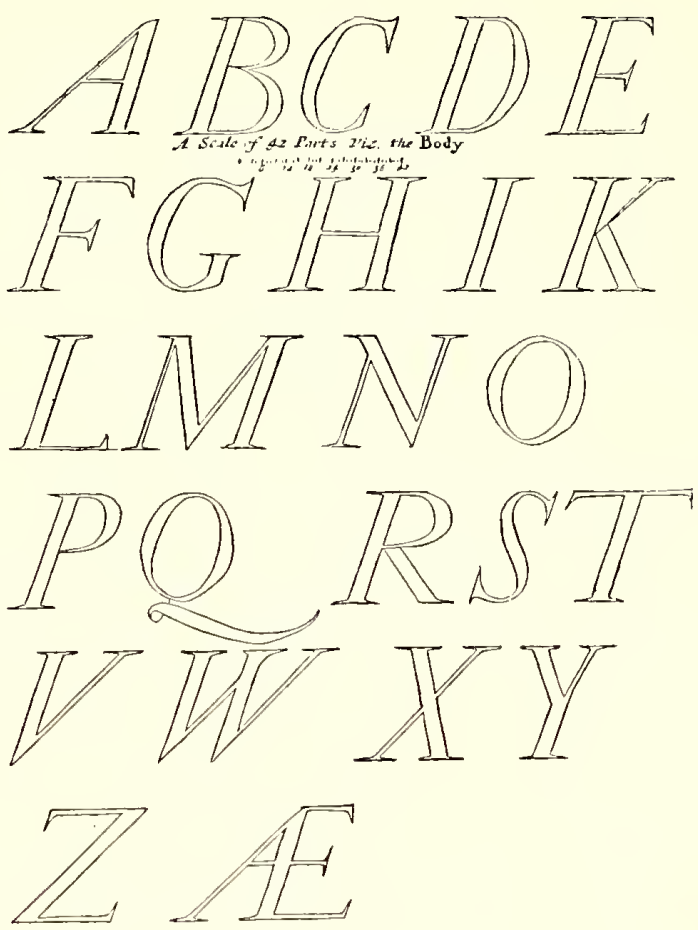

EXAMPLE 511

Moxon's Italic capitals of 1676

Cloister Italic and Roman small capitals of the Aldus page, reproduced on page 15 of the chapter on "The Spread of "Typography." In that chapter are included further facts about this famous printer.

Examples 511,512 and $51 \mathrm{t}$ are reproductions of Moxon's drawings (1676) of the Italic types of a Dutch punch cutter. 'They show the character of Italic used in the scventeenth century. The long $s$ of that time is included in Example 518, and Example 514 shows the decorated Italic capitals that we know as "Swash letters."

Swash Italic capitals and the old-style long $s$ are to be

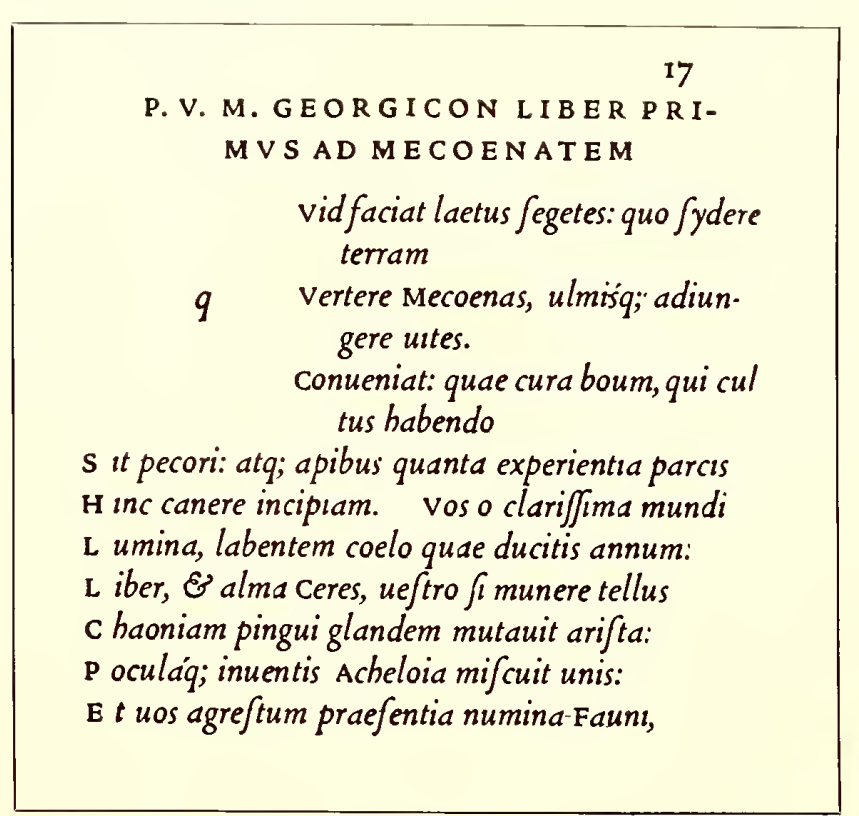

EXAMPLE 513

Resetting in Cloister types of an example on page 15 of this book of the original Italic types of Aldus and Francia

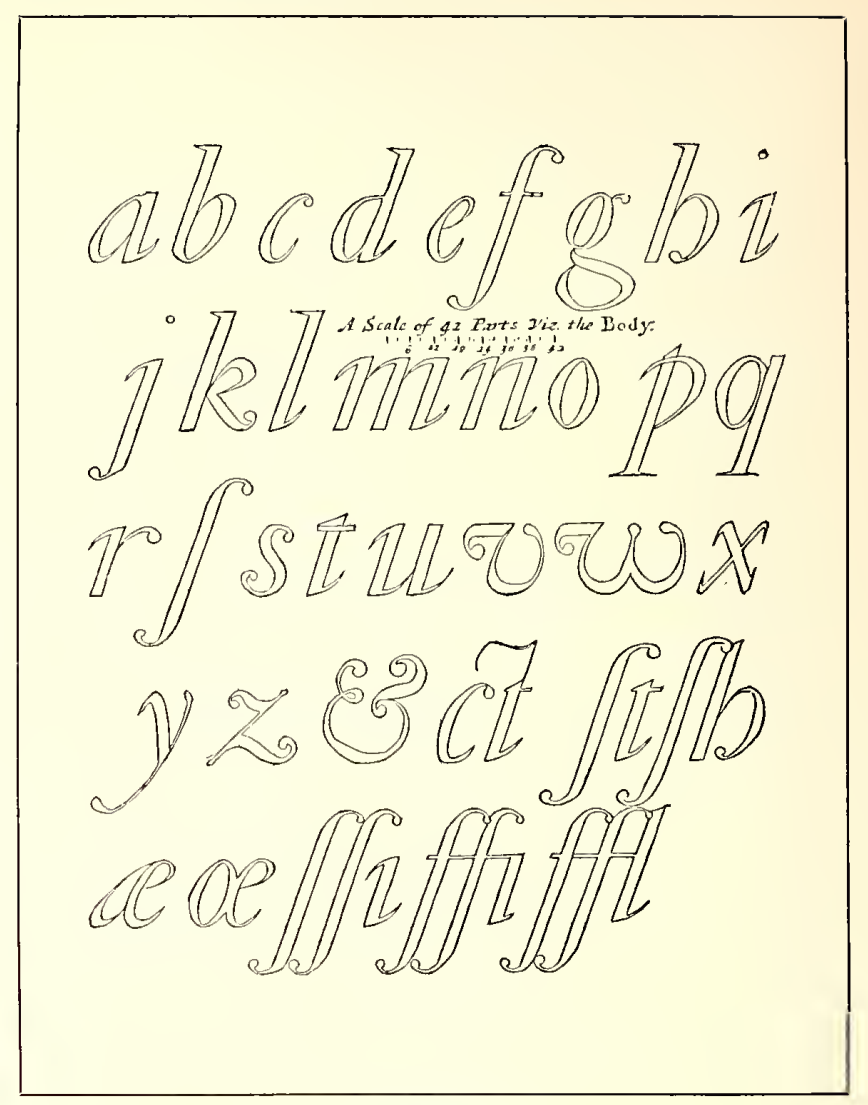

EXAMPLE 512

The Italic lower-case of Moxon, with long "s" (f)

had with Caslon Oldstyle. See Example 517. The Italie mates of a few of the present-day Romans are shown in Example 516.

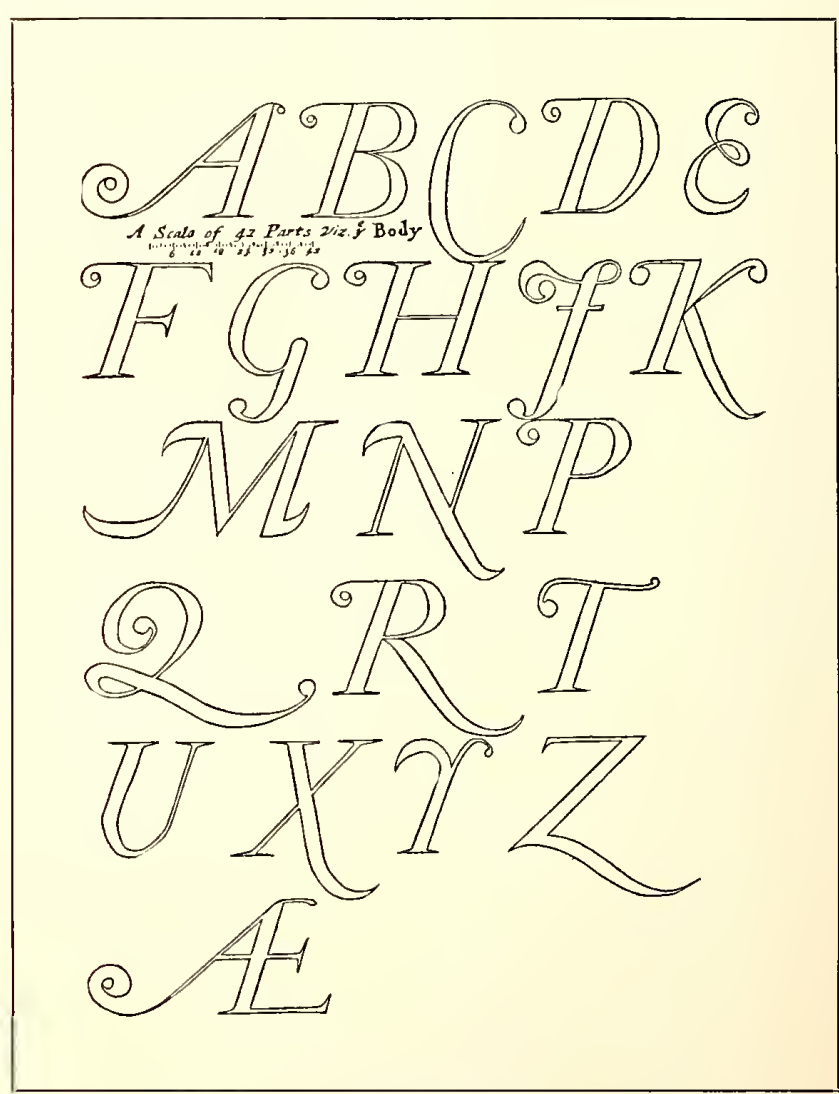

EXAMPLE 514

Decorated capitals, or Swash letters, as drawn by Moxon from Dutch sources 


\section{abcdefghijklmnopqrstuvwxyz abcdefghijklmnopqrstuvrexyz}

EXAMPLE 515

The first Italic was not made merely by inclining the Roman lower-case letters. Cloister Oldstyle (upper line) is modeled after onc of the first Roman types, that of Jenson, cut in 1470. Cloister Italic is modeled after the first Italic type of Aldus and Francia, 1501

Italic types, besides the instances previously mentioned, may be seen in use on pages $17,18,19,20,22,23,24,25$, 26,32 , and in Examples 45, 98, 100, 128, 138, 139, 114 , $152,158,168,169,170,171,180,185,191,215,222,223$, $224,232,210,215,240,250,2102,282,292,291,297,299$, $310,311,313,311,315,314,325,324,329,331,332,336$, $342,343,315,346,314,343,372,374,375,381,387,390$, $394,396,398,399,401,402,401,405,406,412,113,414$, $418,420,423,424,426,428,429,472,477,481$ and 183 .

Text Types

Gutcnberg and other German printers who followed him fashioned their type-faces after Black Letter, the formal writing of the German scribes, as Jenson fashioned his type-face after White Letter, the formal writing of the Italian scribes. The White Letter of Jenson grew into the Roman types that today are used almost exclusively in

\section{Mixed Typografic Alphabet} Cloister Italic

Jixed Typografic Alphabet Caslon Italic

Mixed Typografic Alphabet French Oldstyle Italic

\section{Mixed Typografic Alphabet} Scotch Italic

Mixed Typografic Alphabet Bodoni Book Italic

Mixed Typografic Alphabet Cheltenham Italic

Mixed Typografic Alphabet Kennerley Italic

Mixed Typografic Alphabet Century Expanded Italic

Mixed Typografic Alphabet Baskerville Italic

\section{Mixed Typografic Alphabet}

"Modernized Oldstyle" Italic

Mixed Typogrufic Alplubet "Modern Roman" Italic

\section{ABCDEFGHIJKLMNOPQ RSTUVWXYZ\&}

\section{abcdefghijklmnopqrstuvwxyz}

ABCDEFGHIJKLMNOPQRSTUVWXY\%

$$
\text { 1 } 234567890
$$

f fif fil fil fb th fk fl fi ft at ABCDEFGHIYKLMNOP 2RST'TUVWX'Z abcdefghbijklmnopqrstuvwxy:

$$
\begin{aligned}
& 1234567890
\end{aligned}
$$

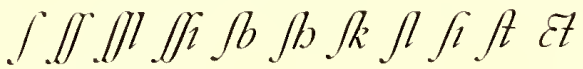

$$
\begin{aligned}
& A B C D E G K \mathcal{A C X} \\
& P R v \text { R w z }
\end{aligned}
$$

\section{EXAMPLE 517}

Complete Roman and Italic alphabets of Caslon Oldstyle with "Swash letters" and long "s" (f)

France, England and Italy and in our own country, while Black Letter developed into the German types that are almost exclusively used in the German Empirc. As this is being written, the Great War is being fought. America has just entercd it, and it is a coincidence that the comtries favoring. White Letter are on one side in the struggle and the countries favoring Black Letter on the other side. The years that follow the war may see, so far as general reading purposes arc conccrned, the gradnal elimination of the letter we know as 'Text and the largely increased use of Roman characters in the books and newspapers of all races. The Germans are alrcady favoring a Roman half 'Text in character (Example 521).

Text type, besides being known as Black Letter, is also called Gothic and Old English; Gothie beeanse of its preference by Gothic or German pcoples, and Old English beeause of its use by Wynkyn de Worde and other early printers of England.

Moxon, in 16:76, drew an alphabet of Text letter in both capitals and lower-case (Examples 518 and 519), and Caslon, in the eighteenth ccntury, cut a Text letter similar but somewhat thinner in form. Alteration in capitals works great changes in 'Text type.

Text letter in a variety of designs is used in Amcrica for special purposes-sometimes as headings of newspapers or for a line on stationery, but because it is generally considered illegible it seldom is given place, cxcept in German-language newspapers, on body portions of printed work.

The story of the evolution of Text type from Roman capitals has already been told on pages 5 and ; of the ehapter, "When Books Were Written," and under the 


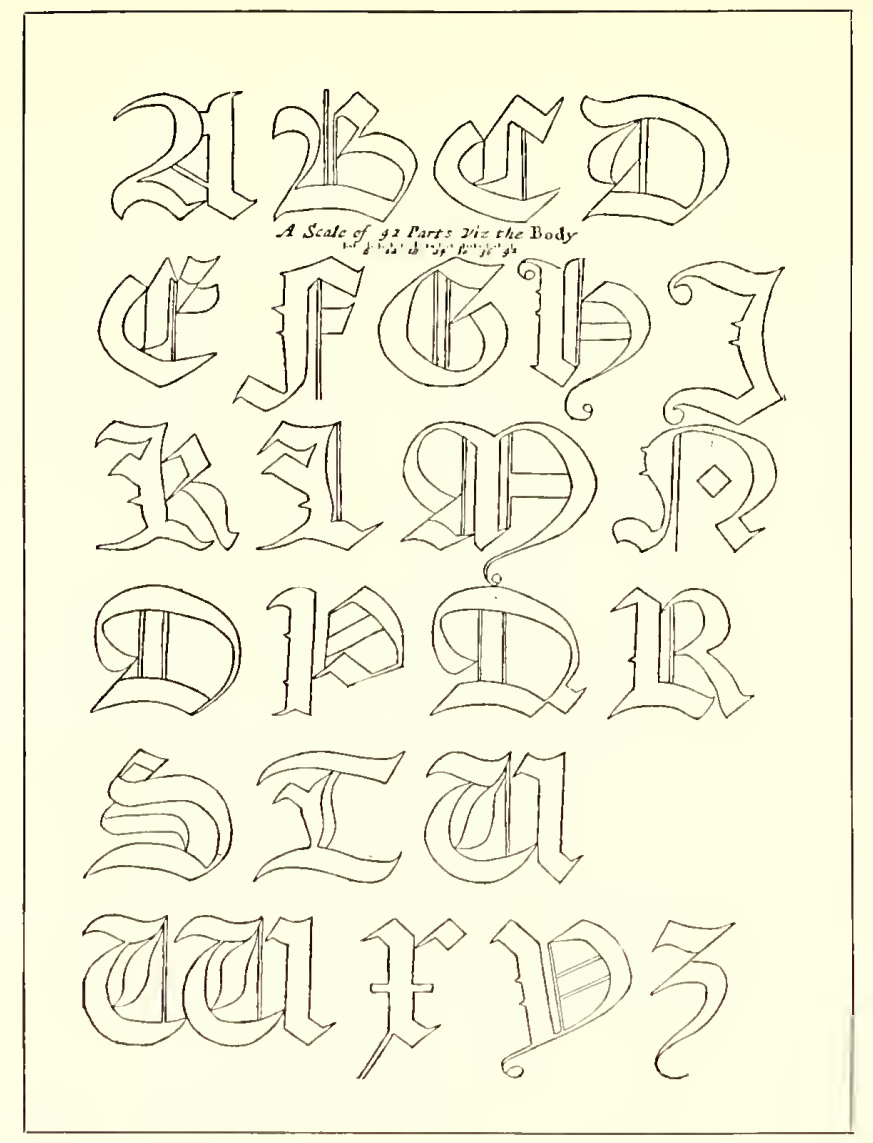

EXAMPLE 518

Text capitals and Text low

head, "Development of the Roman Type-Faee," in this chapter. It is illustrated in Example 465.

Text type maly be seen in use, even to a small extent, on pages 5, 7 (insert) $8,9,12,13$ (insert), 14 (insert), $16,17,18,27$ (insert), 31, and in Examples 19, 27, 32, $37,75,76,107,115,117,118,137,113,115,116,117$, $157,158,159,200,201,202,201,201 ;, 211,219,220,221$, 227, 298, 232, 233, 237, 211, 213, 211, 257, 277, 285, 287,

Mirico Iopografic :Mlphabet

IITiges Eprografic sllphabet

EXAMPLE 520

Two standard German type-faces,

the Fractur and the Schwabacher

\section{A B C D E F G H I J K L M NOPQRST UVWXYZ}

Eine Ergänzung zu diefer Schrift find die Verfalien zu der Carolingifchen Antiqua, welche wir jedoch nur auf befonderen Wunfch mitliefern
A

E $\mathrm{h} \Omega \mathrm{D} \quad \mathrm{C}$

\section{EXAMPLE 521}

The half-Gothic and half-Roman type-face now favored in Germany as the nearest approach to the Roman allowed by national prejudice of readers

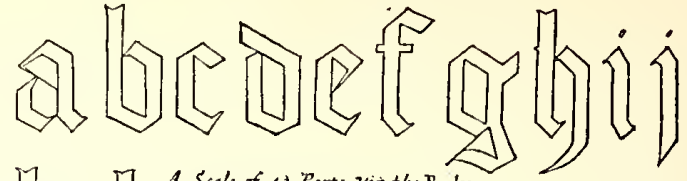

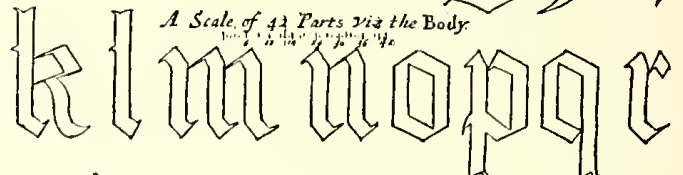
2) $\xi \hat{5}$ प $2900 \int_{0}^{2} \int_{0}^{10}$

EXAMPLE 519

$301,307,319,333,336,317,353,354,358,361,392,404$, 405,421 and 425

\section{Block Types}

The style of letter known as "Bloek," beeause of its plain, square appearanee, is more in use than it should be

Atlixed Tppografic Alphabet Cloister Black

Mlixed tppografic glphabet Caxton Black

Mired Tepografic Alpbabet Caslon Text

Mixed Typografic Hlphabet Tell Text

AHtixes Tupaunrafir Alplyathet Wedding Text

Flized Typografic Alphabet Church Text

STixed Oppografic ZAlphabet Washington Text

JHinco cypogiafir arpbat Cathedral Text 
(Example 523). It serves a purpose for very small sizes of lettering on lithographed stationery and on blank work, its capitals being more legible than regular Roman capitals in diminutive form; but its use on periodical and newspaper advertising, books and general job work is deplorable.

It is an unfinished Roman letter, as shown by Example 107. It is really not admissible to the company of the educated and informed until serifs have been added and a difference in thickness of strokes is visible.

Some American typefounder many years ago called this style of face "Gothic," and under that name this rather questionable type is widely known, probably better known than many worthier faces. It is possible, also regrettable, that it is the "best seller" of the type foundries' product. Over in Scotland and England the type is called "SansSerif" and "Grotesque"; in Germany it is known as "Block"; in France and Spain as "Antique." Examples showing use of "Block" type or "Gothic": $263,270,291$, $305,318,320,321,373,404,405,404$.

Poster artists of Germany and Austria have developed the "Block" type into a very strong letter of wide strokes, which, when printed in color, show forth color values attractively (Example 235, chapter on "Announcements"). This style of letter has been brought out in type form in Germany and in America. Alphabets of the American type (Publicity Gothic and Advertisers' Gothic) are shown in Example 524. As indicated by the titles, these types serve a special purpose.

Bold Types

There is a legitimate use for bold type-faces, especially in small sizes, on books of reference, schoolbooks, cata$\operatorname{logs}$, and similar printed work, but it is safe to wager that half the bold types in use, and almost all of the large sizes. conld well be dispensed with. When used to a great extent, the printed work on which it appears is unattractive. Bold type is to typography what the bass drum is to music: it fits in nicely for purposes of accentuation and emphasis; but who likes a bass drum solo?

However, a slight strengthening of lines sometimes serves special purposes well. Daniel Elzevir used a letter with slightly deepened strokes for the main line in $\mathrm{Ex}-$ ample 477.

Old-Style Antique has long been popular with good printers for typography requiring a darker tone than is given by Caslon Oldstyle; the so-called Caslon Bold will never really take its place.

Most of the standard type-faces referred to in this chapter are procurable in bold form. Cloister Bold. Caslon Bold, Bodoni Bold and Cheltenham Bold are included with a few other faces in Example 520.

\section{Ornanental Trpes}

Typography has its periods of abstention and fasting. which usually follow periods of revelry in decorative types in which good taste and dignity are not infrequently sinned against. After the typefounders of the nineteenth century had twisted, distorted, decorated, shaded and otherwise disguised the Roman alphabet until Jenson, Aldus, the Elzevirs, Caslon and Franklin would no longer recognize it, the users of printing, the printers and the typefounders became sobered and realized what they had done.

A period of fasting set in, but, recollections of the old typographic carousal wearing off, ornamental letters again began to appear. They were on different models, however - some of them very good-and were acceptable for informal typography (Example 527-C).

Some ornamental types of historic origin are based on

\section{ABCDEFGHIJKLIMNOPQ RSTUVWXYZ}

EXAMPLE 523

Block types, serifless and of one thickness of stroke

\section{ABCDEFGHIJKLMNOPQRST UVWXYZ \\ ABCDEFGIHIJKLMNOPQRSTU VWXYZ\&}

EXAMPLE 524

Modern-art poster type; the upper alphabet being known as

Publicity Gothic, and the lower one as Advertisers' Gothic

the eighteenth-century letters of Fournier, the French typefounder, and on those of English founders (Examples $527-\mathrm{A}$ and $527-\mathrm{B})$.

Types for Special Purposes

There are numerous other faces, many of them admirable, which for lack of space camnot be shown or described

\section{Mixed Typografic Alphabet \\ Mixed Typografic Alphabet}

EXAMPLE 525

McFarland (lower line), based upon the French Old-

style (upper line), the strokes having been made bolder

\section{Mixed Typografic Alphabet}

Cloister Bold

Mixed Typografic Alphabet

Caslon Bold

Mixed Typografic Alphabet

Oldstyle Antique

Mixed Typografic Alphabet Cushing Oldstyle

Mixed Typografic Alphabet

Cheltenham Bold

Mixed Typografic Alphabet Bodoni Bold

Mixed Typografic Alphabet Roycroft

\section{Mixed Typografic Alphabet}

John Hancock

\section{Mixed Typografic Alphabet}

Bewick Roman 


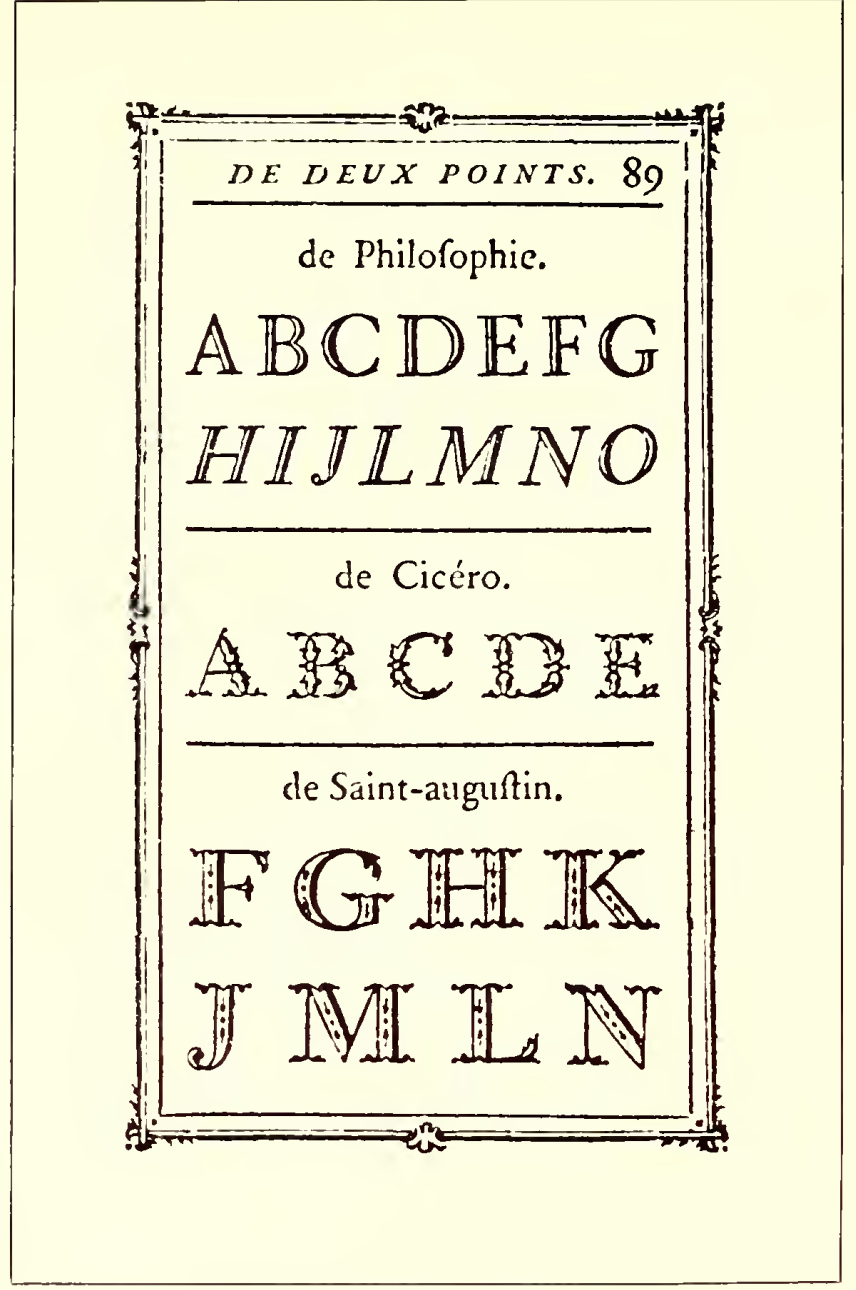

EXAMPLE 527-A

The eighteenth-century ornamental types of Fournier, the French founder

\section{IMNOPQRSTUV}

\section{$A B \mathbb{B} \mathbb{R} \mathbb{R}$}

\section{EXAMPLE 527-B}

Early nineteenth-century ornamental types of English founders

here. There are type-faces for special purposes, such as the imitation copperplate-engraving faces, made in English and French Scripts, Romans. Texts and Gothies; imitation typewriter faces, gray-printing "halftone" faces, such as wcre used for many years as a head-letter on the Ladies' Home Journal.

A dozen pages, were they available, could well be given over to exhibits of the privately designed types of the Riverside Press, Merrymount Press, University Press, Village Press and other notable printing offices.

\section{The Influexce of Goudy}

A liberal showing would be worth while of the various fonts designed by Frederic W. Goudy, who has done much in influencing type design during recent rears, but it will be necessary to be content with the exhibit of Kennerley, in Example 463, and other faces by Mr. Goudy in use in preceding chapters. Kennerley, the best known and most characteristic of the Goudy letters (19,11), is shown in Examples 187, 313, 329, 36.1, 395, 432, 445 and 446. Forum, made in capitals only, is to be found in Examples $20,229,334,360,360$ and 395 . Goudy Oldstyle is used in Examples 324 and 391. Camelot, which was Mr. Goudy's first effort at type designing (1896), appears in Examples 44 and 12\%. Pabst, another early effort of Mr. Goudy, but not so good in design as his later types, will be found in Examples 30, 100 and 214, and also used in this book for headlines, captions, title-page and cover labels.

Frederic W. Goudy is wielding a large influence over art work and typography in America. His style of lettering, decoration and type designing is now to be found on much of the good printing produced in our country. His type-faces are original; in their completed form they are not just like any one type-face previously used, but they revive details in letter forms that for many years had been considered obsolete by typefounders. Mr. Goudy is a humanist; he believes that type-faces should be more expressive of the art of the letterer than the skill of the typefounder. He is speaking:

Type must he finely and boldly designcd to be beautiful. In the majority of cases where these points are claimed for a type, it will be found that the claims rest on their perfect finish, exact lining or ranging, perfection of curve, precise angles, straightness of stem, or sharpness of serif and hair line. None of these points give beauty or legibility, altho they may be present in a type both beautiful and legible. Finish in the design of a letter is a merit only when it improves, but if made at the expense of design it constitutes a defect.

Ruskin's universal law, that "neithcr architecture nor any other noble work of man can be good unless it be imperfect," applies no less to our type designs. Types are made to use, and when spontaneous in design, the natural irregularities and deficiencies are signs of life and sources of beauty, giving credit to the designer for careful craftsmanship according to his ability. The demand for perfection is evidence of a misunderstanding of the true ends of art.

\section{Mixed 'Typografic Alphabet} College Title

\section{Mixed 'Typogroafice Alphabet Bodoni Bold Shaded}

\section{Mixed Typogirafic Alphaber} Caslon Shaded

\section{Mixed Typografic Alphabet Packard}

\section{Mixed Typogranc Alphabet Cheltenham Bold Shaded}

\section{Mirad Togpogreafice Alphar} Invitation Shaded 



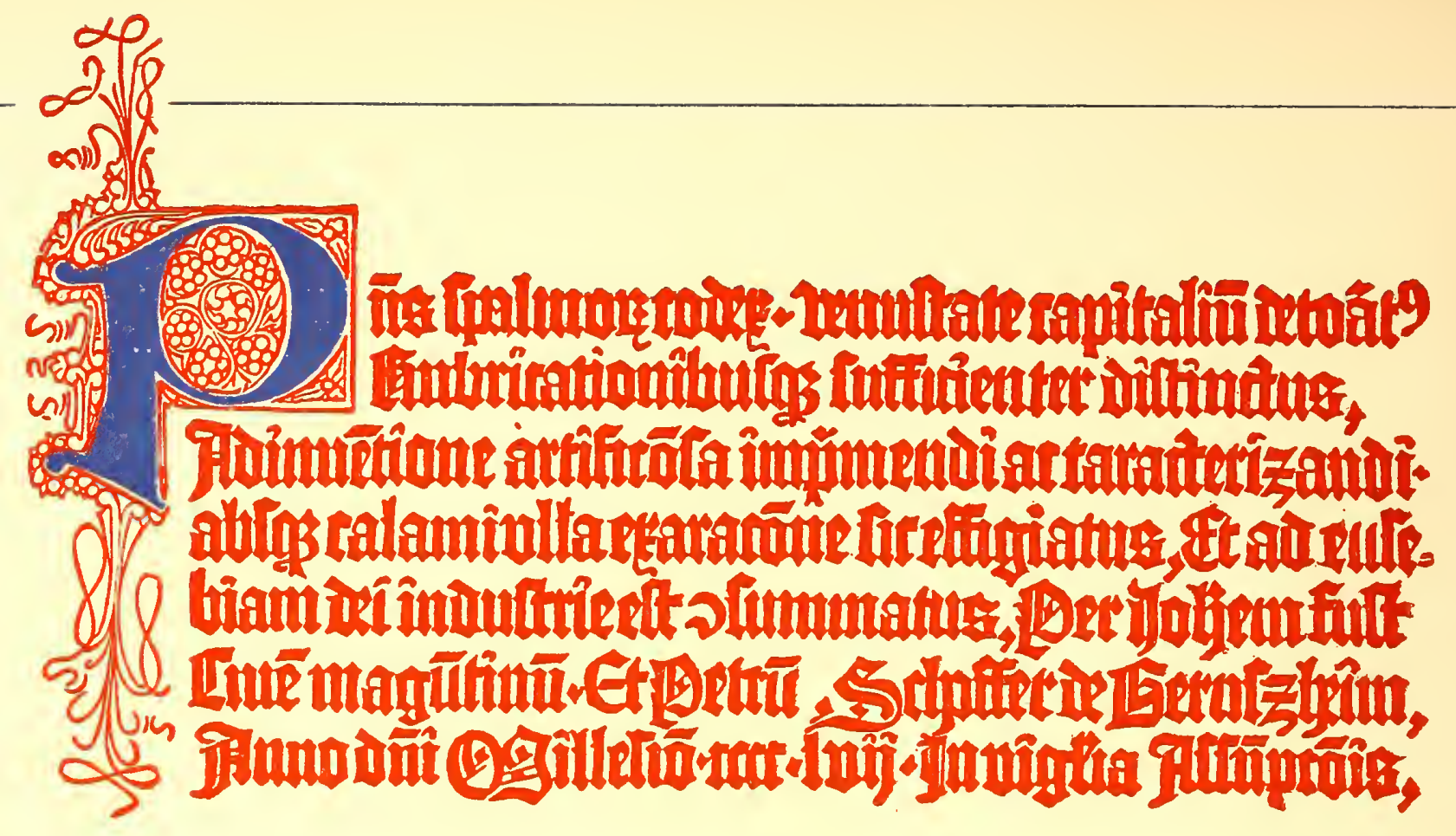

EXAMPLE 528-A

The first "imprint," as found on Fust and Schoeffer's Psalter of 1457

From DeVinne

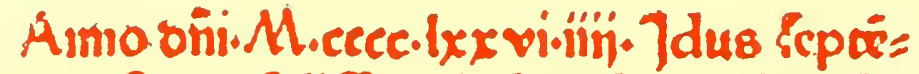
uris.Réuerédilfmoixpo pre acoño/sño Dietbero A repo Magritino Jn nobíli ur= to Oagücia R̂trmi'mpintone artínuétrice alünaq p̀ma!pñs Cleméunarï opus p̄ela

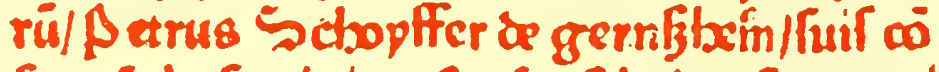

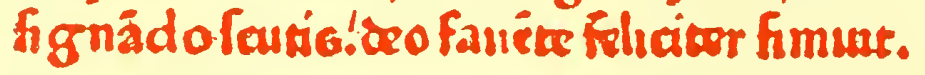

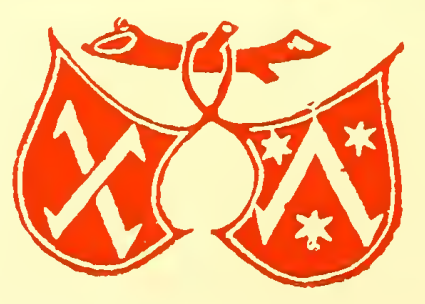

EXAMPLE 528-B

Colophon and imprint by Peter Schoeffer, 1476

From the original in the Typographic Library and Museum. Jersey City 


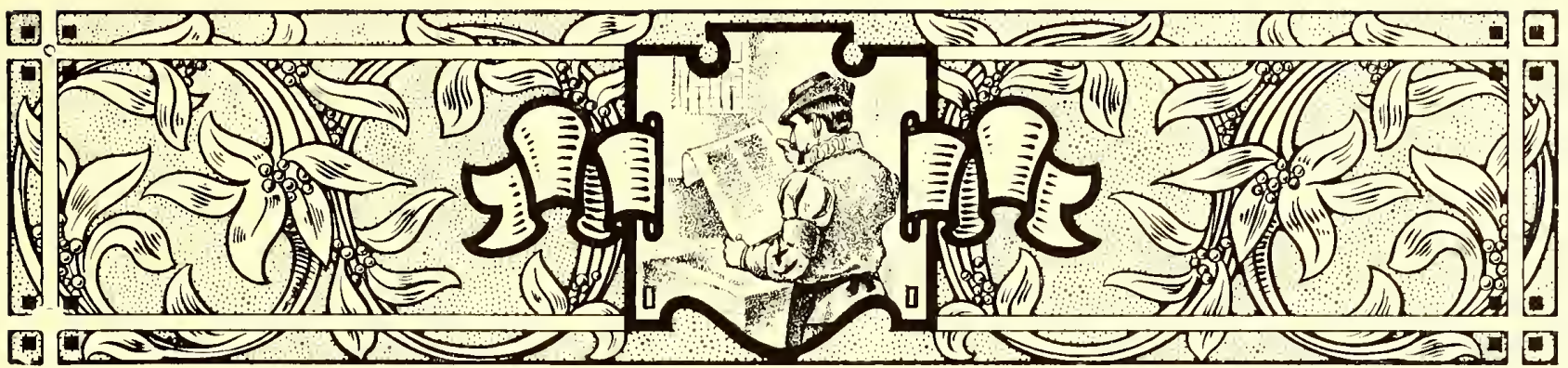

\section{IMPRINTS}

THE printer's name or device should, with all regard to good taste, be placed on every well-executed picce of work produced by him. That this is not more often done is due to neglect of advertising opportunities and to fear of the customer's objection. Why should not the printer mark his product as other craftsmen and manufacturers do? Each piece of elothing he wears, from hat to shoes, probably carries the name or trademark of its maker, as do automobiles, $\mathrm{pi}^{-}$ anos, watches, silverware and many other articles he owns. The maker's name and trademark are a guarantce of a eertain quality of product; in fact, they are absent only on cheap or imitative articles. If the printer is doing careless work and giving no thought to quality, he had better hide his identity, but if he is really producing good printing, as a duty to the craft of which he is a member he should "let his light shine before men."

If a commereial printer has not been in the habit of placing an imprint on his product, and he decides to do so, eustomers should tactfully be made acquainted with the imnovation. They probably stand ready to be convinced of its reasonableness. It may be an excellent plan for the printer to mail his customers an announcement to this effect: "The standard of quality attained by the Smith Printshop is such that it is due our customers and ourselves so to mark each piece of printing produced by us as to identify it as a product of the Smith Printshop. 'This we will do hereafter."
As a further precaution, all proofs receiving the $\mathrm{O} . \mathrm{K}$. of the customer should contain the imprint just as it is to be used, and on important large orders, where there is any doubt, permission should be obtained. There are instances where customers have refused to accept printed work for the reason that an imprint was placed on it.

It is only necessary to have printingoffice patrons become accustomed to the new order of things.

Joln Dunlap, who printed the Declaration of Independence for Congress, placed his imprint on it (see frontispicce of this volume). If some friend had suggested to Joln Gutenberg that he imprint his name on his work, the discussion that has since arisen as to whether or not he printed the "Bible of Forty-two Lines" would not have taken place.

The commercial printer's imprint should be unassuming and placed inconspicuously. Decorative imprints could be ised on booklet and catalog work, and in addition the decorative device should find place on every piece of the printer's own stationery and advertising matter, cven on the office door.

The use by printers of decorative devices dates back to one of the first printed books, the famous Psalter of $115 \%$. For a great many hundred years previous, pictures and devices in varions forms had been relied upon to convey information and to act as distinguishing marks for various purposes. Figures such as the white horse and the red lion, hung as signs

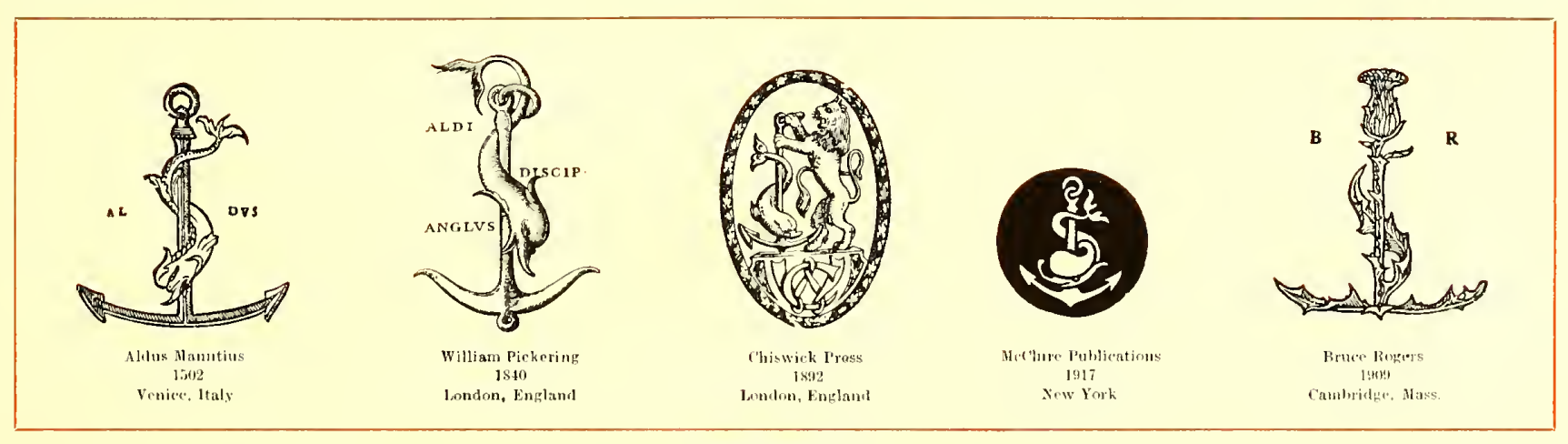

EXAMPLE 530

Aldus's anchor-and-dolphin device, and adaptations by modern printers 


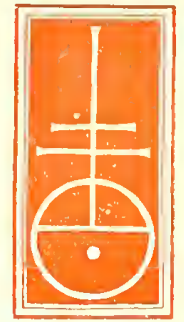

Sreciety of Printers 1481
Venice, Italy

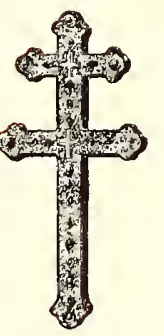

Ornumentul cross

of 670

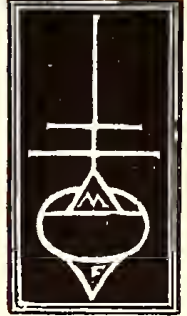

Francisens Madiis

$14 \$ 5$
enice, Italy

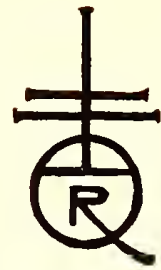

Elhert Huhhard 1896
East Aurora. N. Y

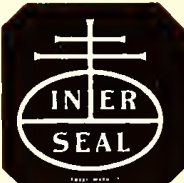

As a hise'uit lahel

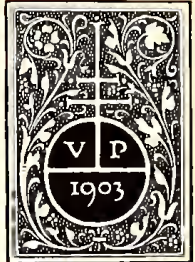

Frederic W. Goudy

Tew Yor

\section{EXAMPLE 531}

The most popular imprint-device as early used by printers, and modern interpretations

in front of taverns and public houses during the last two centuries, were ontgrowtls of the coats-of-arms of titled folk who in ancient times hung the family device in front of their estates as emblems of hospitality to the weary travelcr.

Emblems and devices seem always to have had place in human history. The sign of the Cross in the cleventh century led the Crusaders against the followers of the Crescent. The cross of St. George $(+)$ furnished inspiration for the English in their warfare with the Scots, who rallied around the cross of St. Andrew $(X)$, and the combined crosses of St. George, St. Andrew and St. Patrick now inspire the patriotic Britisher.

It would secm that printers could do better work if they were to sclect some device which would represent an ideal, and then attempt to live up to it.

While the Gutenberg Bible of Forty-two Lines, gencrally accepted as the first book printed with separate metal types, contained ncither device nor printer's name, the Book of Psalms, or P'salter, of 1157 , not only has the names of Fust and Scheffer and the date, but an imprint device which lias the distinction of being the first ever used on a book typographically printed. This famous P'salter was the product of Johann F'ust and Peter Schoeffer, who sueeeeded to Gutenberg's printing office. At the end of the book, printed in red ink, is the colophon of the printers (Hxample 528-A), a translation of which follows: "This book of Psalms, decorated with antique initials, and sufficiently cmphasized with rubricated letters, has been thus made by the masterly invention of printing and also of type-making, without the writing of a pen, and is consummated to the service of God, thru the industry of Joham Fust, citizen of Mainz, and Peter Schoffer of Gernszheim, in the year of our Lord 1157, on the eve of the Assumption."

The colophon contains a typographic error, perhaps the first to be made by a typesetter, the second word showing "spalm-" for "psalm-." On several of the Psalters still in existence (one is without it) the colophon is accompanied by the decorative device shown in Example 529, consisting of a pair of shields suspended from the limb of a tree. The significance of the eharacters on the shields is not definitely known. Humplreys, in his "History," asserts that the shields contain the arms of Fust and those of Schoffer. It is conceded that the shield on the left is Fust's and the shield on the right Schwffer's. In Rietstap it is found that one branch of the old German family

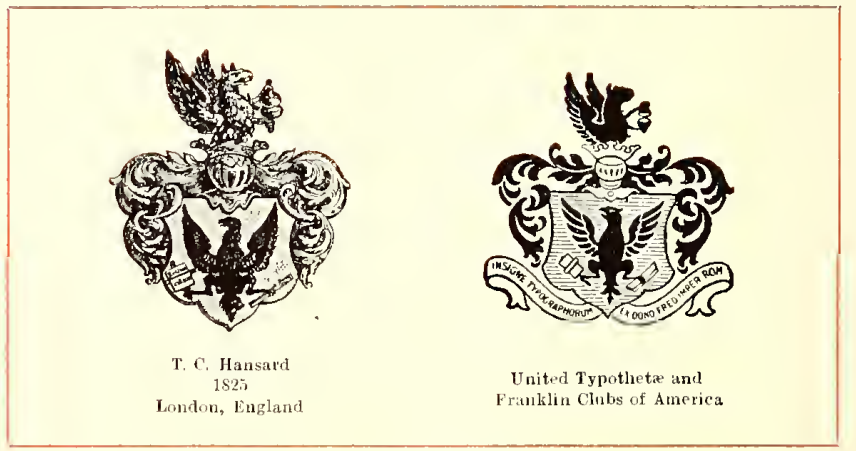

EXAMPLE 532

Arms supposedly granted the Typothetae, a society of master printers, by Frederick III

of Faust bore a coat-of-arms containing on a shield two crampons in saltirc (crossed). Bullen claims the character in the Fust shield is the Greek letter Chi $(X)$ and that in Schoffer's shield the Greek letter Lambda (A), and that they had some connection with secret societies to which Fust and his son-in-law Scheffer belonged.

Schœffer's device was used for many years by his descendants, Example 529 showing its use as late as 1747 by Peter Schœeffer, of Bois-le-Duc, in the Netherlands.

This device of $\mathrm{Fust}$ and Schoffer furnished inspiration to several printers of the same century, chief among whom were Michael Furter and Nicolas Kessler, whose devices

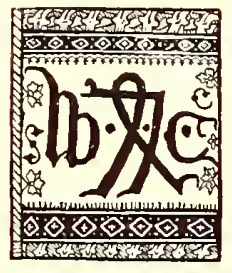

Willian Caxton Westminster, England
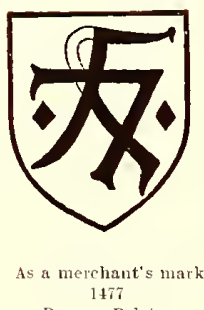

$1+77$
Bruges, Belgium

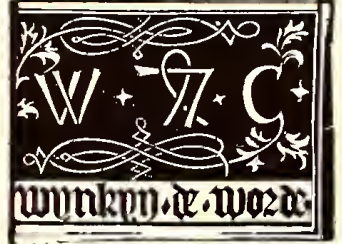

Wynkyn de Worde
$1+95$

London, Eugland

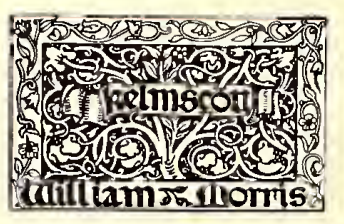

William Morris

Hammersmitl, England

EXAMPLE 533

The imprint-device of England's first printer, its probable derivation, and two notable devices evolved from it 

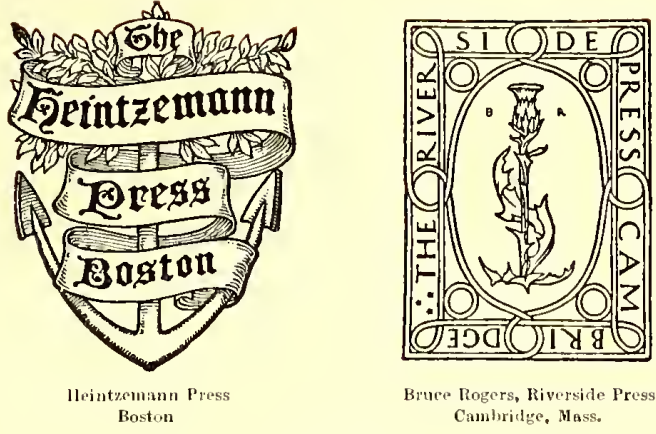

EXAMPLE 534

Two modern designs with ancient motifs

are shown in Example 529. Furter, who printed at Basel, Switzerland, in 1190 , was once credited with being the inventor of printing, thru an error in a book, the date of which was made to read 14t. (M.CCCC.XLIIII), instead of 1494 (M.CCCC.XIIII).

What is considered to be the most classic of all imprintdevices (Example 530) is that used by Aldus Manutius, the great Venetian printer, who introdueed the italic face of type. The device, an anchor, around which is twisted a dolphin, is said to be sympolic of the proverb "Hasten slowly." The anchor represents stability and the dolphin swiftness. The mark was taken by him from a book he had printed, "Reveries of Polyphilus," and was nised as the Aldus device for the first time in an edition of Dante of 1502 .

In a spirit of affection and regard for the famous Venetian, the device of Aldus has been adopted or adapted by several well-known printers. There is a nice scntiment conneeted with the use of this mark by William Pickering, the noted English publisher. In place of the "A L-Dvs", of the original, Pickering's adaptation contained a motto in which he announced himself as the English disciple of Aldus. The reproduction of the Pickering device shown is from a book published by Pickering and printed by Whittingham in 18.10 .

By 1892 we find a lion added to this device, as used by the Chiswick Press.

'The McClure Publications of New York have a conventionalized interpretation which shows the dolphin and anchor in white upon a black circular background (Example 530).

Bruce Rogers, at the Riverside Press, has most interestingly adapted the Aldus device. It seems that he always had a fondness for the thistle, the national flower of Scot-
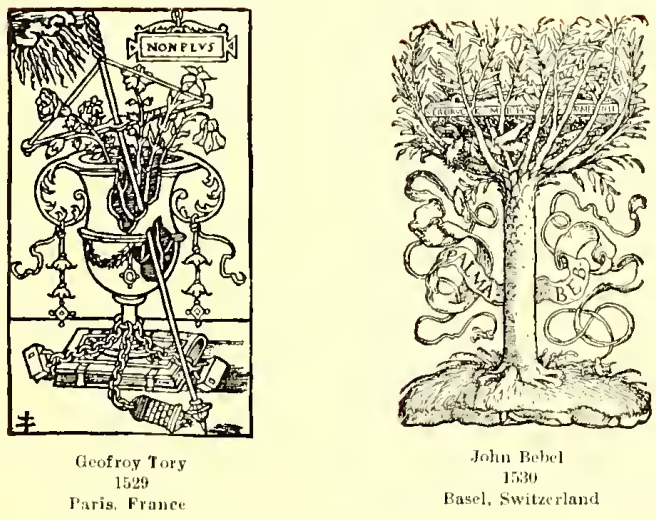

land, and when seeking a motif for his mark, naturally turned to it. When the time came for putting it into use, the first requirement happened to be for an Aldine page, so it was east in a form that would distinctly suggest the Aldus anchor and dolphin. (Compare the two designs in Example 530.) While on the subject of Bruce Rogers's device it may be intercsting to relate that later, when he desired to use it on a book modeled on French sixteenth-century work, he reshaped it as shown in Example 540, which carrics a suggestion of one of Robert Estiemne's marks shown with it. Rogers redrew his personal device, or that of the Riverside Press, to blend with the motif of the book on which it was to be used, a prae-

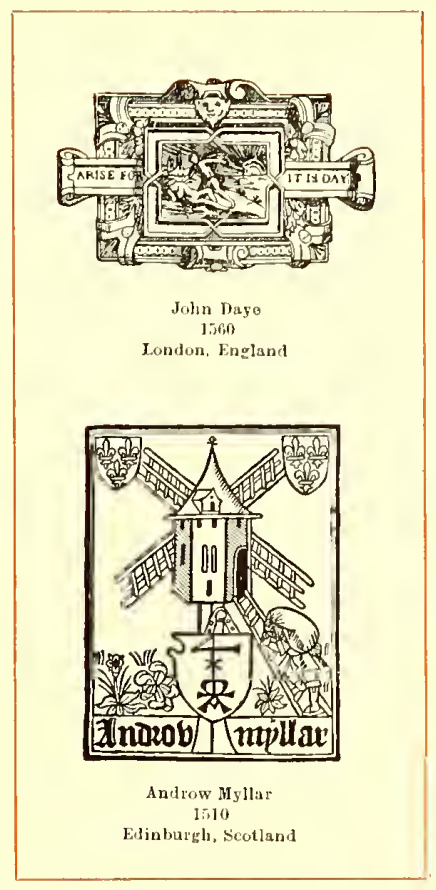

EXAMPLE 535

The pun, as found in two printers' marks tice that embodies the highest use of the printer's mark.

One of the most famous imprint-devices is that adopted by the Society of Printers of Venice in 1181 (Example 531 ), about the time of the death of Nicholas Jenson, who is supposed to have originated the design. Various explanations have been given of the significance of this device, the most reasonable being that the globc and cross refers to the millennium, when, according to prophecy. God shall reign upon earth. The globe-and-eross symbol was frequently embellished with supplementary characters having other religious significance. The mark of Androw Myllar (Example 535) contains a figure 1, which denoted the Supreme Being. People of antiquity frequently composed the name of the Deity in four lctters. The globe in the Venetian devicc probably represented the earth, altho the fact that the earth was round was not common knowledge in the early days. The theory, however, was accepted by the educated priest and layman long before Columbus sailed, as he thought, for India.

The double-cross in the Roman church today is associated with the anthority of an archbishop, and as a decorative form of the cross, extends back many centuries. The ornamental double-cross pictured in this connection was once the property of St. Waudru of Belgium, who died
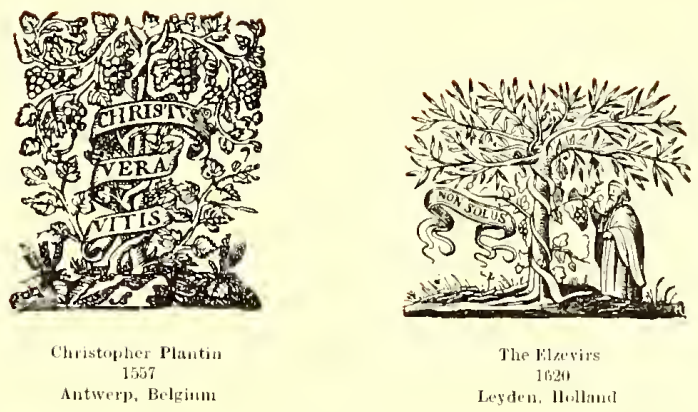

EXAMPLE 53

Devices used by notable printers of the sixteenth and seventeenth centuries 


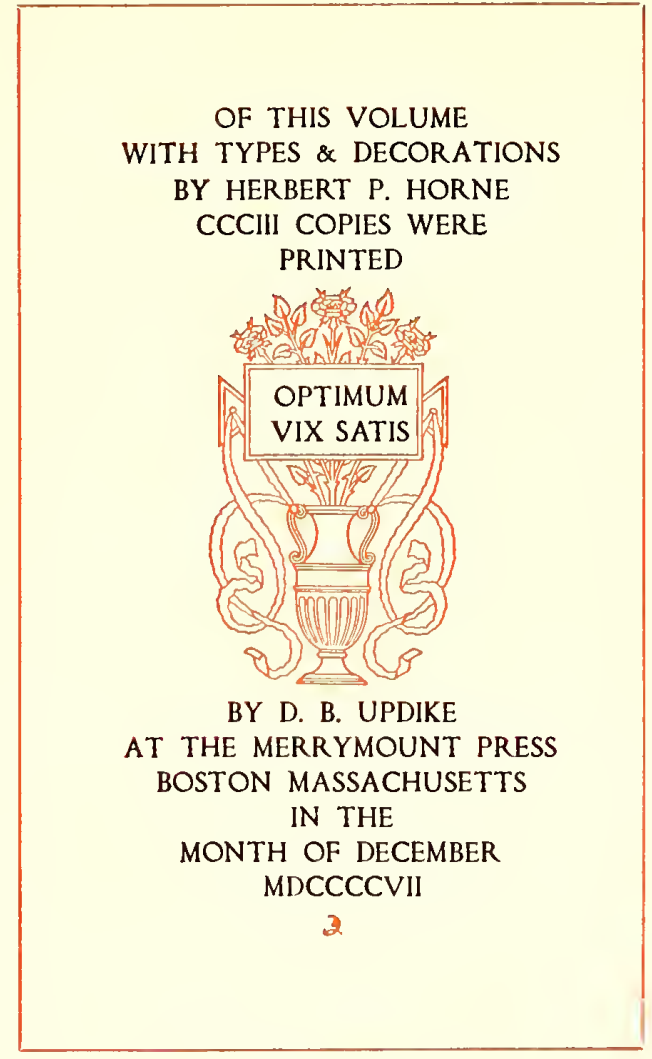

EXAMPLE 537

A colophon-imprint by D. B. Updike, from "Petrarch and His Masters," 1907

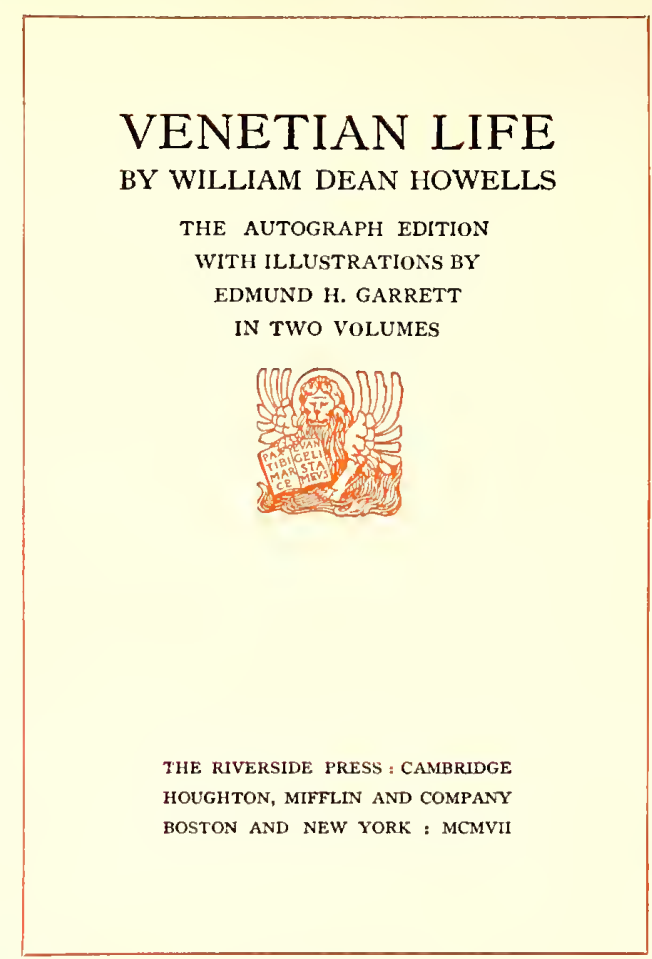

EXAMPLE 538

The Lion of St. Mark appropriately adapted by Bruce Rogers to a book on Venetian life

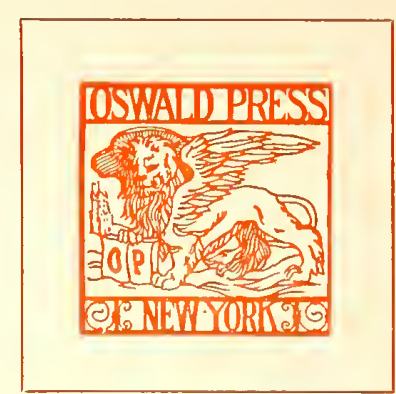

EXAMPLE 539-A

The Lion of St. Mark

as a printshop device

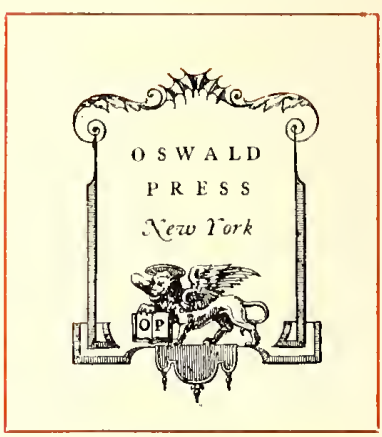

EXAMPLE 539-B

The Oswald Press mark designed by T.M.Cleland

in 1; 70 . The vircle as "the emblem of the perfect (the complete), and double cross the lines puncturing the circle the attempt to make a peror Lorraine cross was used by Geofroy Tory as a small mark on his wood engravings (see lower left corner of the Tory mark in Fixample 583i).

In further consideration of the cross-and-globe device it may be well to mention that an astronomical sign consisting of a circle with a cross alove it (t) was used by the Egyptians miny years before the Christian era. Such a sign is yet used astronomically and also to indicate the male in botany. Another astronomical sign bearing on the subject is that of a cross within a circle $(\oplus)$, by which the earth is indicated.

The cross-and-nlobe deviee of the Venetian Society of Printers has proved the most popular of any of the old imprints. When Elluert llubbard established the Roycroft Shop at East Aurora, N. Y., in 18:14, he adopted it as a

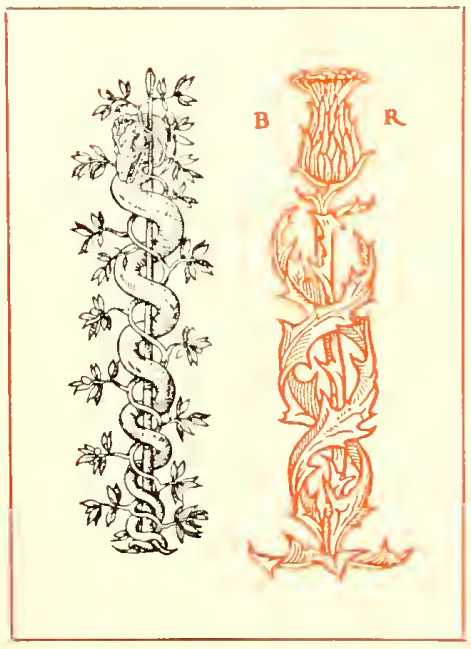

EXAMPLE 540

Robert Estienne's mark, and Bruce Rogers's adaptation of it workmark, placing an " $R$ " in the lower half of the circle in place of the dot. Lira Elbertus's interpretation of the device established the

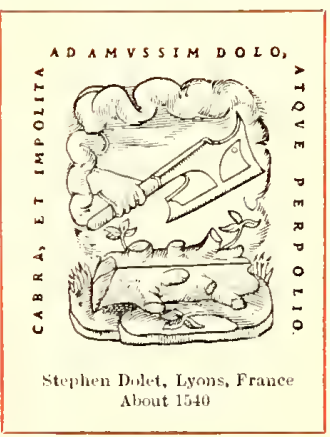

EXAMPLE 541

An appropriate mark for a printer to adopt fect article, to do perfect work."

When the advertising manager of the National Biseuit Company was looking about for a trademark this old device of the Lorraine cross and circle must have appealed to him strongly, and such is the power of advertising that printers may some day be accused of copying the design from this biscuit house.

The remarkable adaptability of the device is also demonstrated by the Griffith-Stillings imprint, in which it forms a part of a clever modern decorative design (Example 5.17 ).

Frederie W. Goudy incorporated the Venetian printers' device most interestingly in the decorative mark of the Village Press (Example 531).

The imprint-device of the Gould Press (Example 543) may have originated with the Venetian printers' design. It is an interesting variant.

These numerons uses by printers and others of the old circle-and-cross design suggest a paraphrase of an ancient proverb: "A good device lives forever."

William Caxton, England's first printer, used an imprint-device (Example 533) that in appearance resembles a rug, which it may have bcen intended to represent, as Caxton is supposed to have used this mark when the was a merchant at Bruges in Belgium. The characters eontained in the design have caused much discussion. The "V" on the left and the " $\mathrm{C}$ " on the right are generally accepted as the initials of Caxton. The center characters have been claimed by some to be the figures " 7.1, ," but the most reasonable explanation is that they form a trade device used by the merchants of Bruges. This explanation is seemingly confirmed by the discovery of a memorial plate to one Joln Felde, containing his trademark as a merchant, which trademark is very similar to the characters in the center of Caxton's imprint-device. The reproduetion of the Felde design shows that if the top stroke were taken away and a loop added the result would be Caxton's characters. 
Wynkyn de Worde, when he succeeded Caxton as England's printer, adopted Caxton's charaeters (probably a sentimental act) and in the device shown added his own name at the foot.

William Morris, in planning an imprintdevice for the Kelmscott Press, evidently made a study of de Worde's design, for there is rescmblance in shape and in the placing of the name at the foot

T. C. Hansard, on the titlc-page of his "'Typographia" (1825), uses a device which tradition tells us was granted by Emperor Frederick III of Germany to a corporation of master printers known as the Typothetæ. (See Example 532.) References by writers to the origin of this design are gencrally contradictory. The United Typothetx and Franklin Clubs of America, an association of cmploying printers, has adopted the device and uses it in the conventionalized form shown. The design in its original form tends to heraldic elaborateness. There is represented an eagle holding a copy guide in one claw and a composing stick in the other. Surmounting the design is a griffin (eagle-lion) grasping two ink balls. 'The Winthrop Press mark (Example 543) and other printers' devices have been inspired by this emblem, as the griffin copyholder and ink balls are familiar decorative forms.

In Great Britain the printer whose name would allow a pun has always been considered fortunate. John Daye, a London printer of 1560, had an elaborate device, paneled, in the center of which is a picture of a reclining man being aroused by a figure which, pointing to the sun, says, "Arise, for it is day." (Example 535.)

Androw Myllar, who printed in Edinburgh, Scotland, in 1510, used a device which portrayed a miller climbing to his mill (Example 535). The arrangement of his name in the lower part of the design suggests de Worde's, and the characters in the shields have meanings that may be determined by a study of the religious symbolism of the Middle Ages.

The imprints of some of the notable printers of the sixteenth and seventeenth centuries are interesting. The first mark in Example 536 shows one of the devices of Geofroy Tory of Paris from his "Champ Fleury" of 1529 . It consists of a broken pot filled with instruments and the Latin phrase Non plus (nothing more). 'The Lorraine cross in the lower left corner is interesting in connection

\section{Les mots francois felon lordre des lettres, ainfi que les fault efcrire: tournez en latin, pour les enfans.}

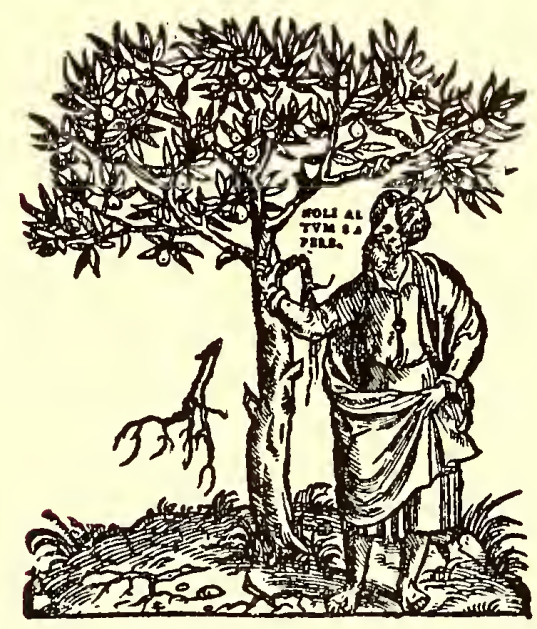

A P A R I S

De limprimerie de Rob.Eftiëne Imprimeur du Roy. M. D. XIIII.

Auec priuilege du Roy.

\section{EXAMPLE 536-A}

The printer's device and imprint here occupies two-thirds of the title-page. From a book by Robert Estienne, Paris, France, 1544

with the use made of it by the Venetian Society of Printers (Example 531). Tory, an accomplished scholar and noted wood engraver and printer, was, according to an epitaph written by a compatriot, "the first man to discuss seriously the art of printing," and "taught Garamond, chief of engravers." His work on the derivation and formation of Latin characters had considerable renown. He claimed, according to Fournier, that all the letters are
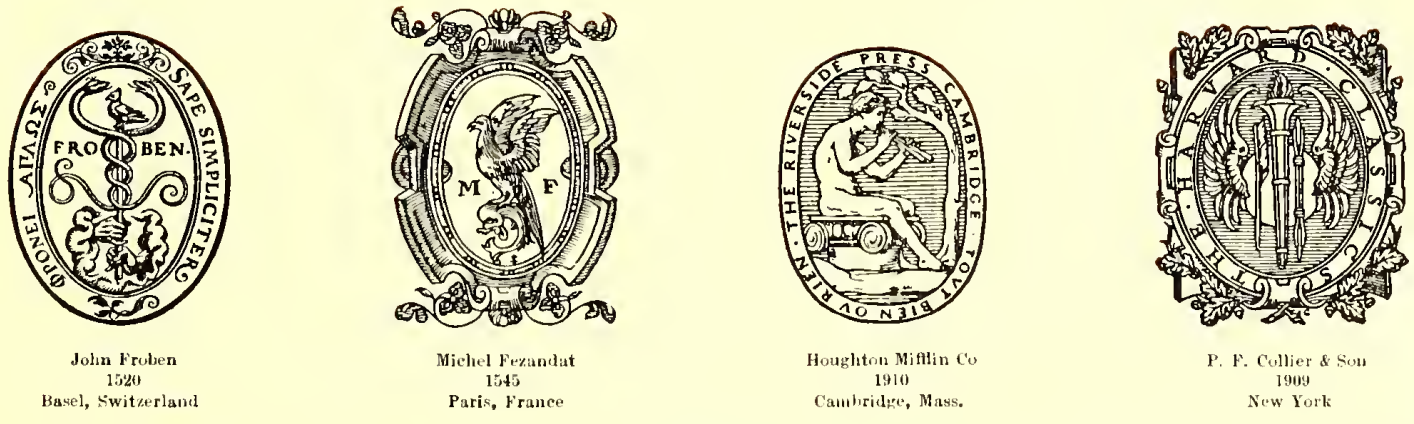

EXAMPLE 542

Use of the oval shape in the designing of printers' marks 


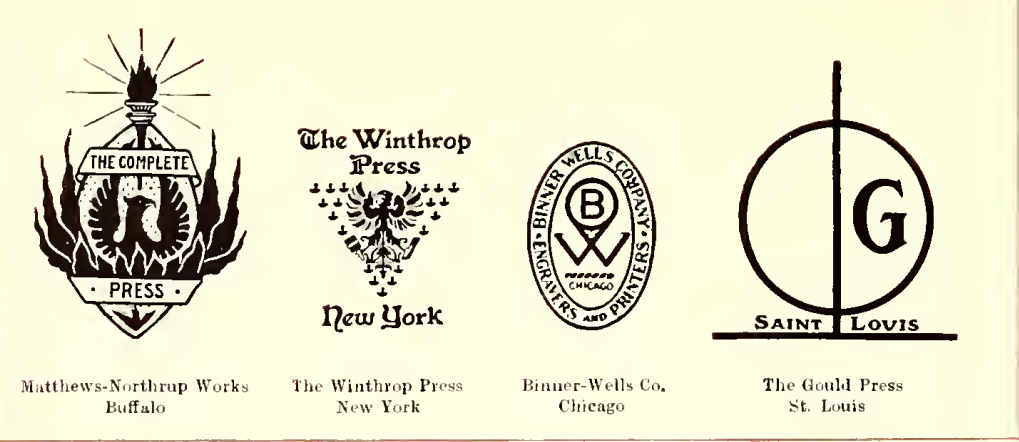

EXAMPLE 543

Modern imprints suggested by ancient forms

formed of $I$ and $O$. Proportions are arrived at by dividing a square into ten lines, perpendicular and horizontal, forming one hundred squares completely filled with circles, the whole giving form and figure to the letters.

The troublous times of the Reformation, during which John Bebel was imprisoned, may have had some influence on his selection of a device. It consisted of a tree, in the branches of which was a prostrate man, and over him was a large flat thing representing the platen of a printing press (Example 536). On the platen were words meaning "Do not press poor me to death."

Christopher Plantin, printer and publisher of Antwerp, Bclgium, whose famous printing office, preserved as a museum, was one of the shrines of worshiping printerpilgrims up to the beginming of the European war, cmployed a device which is emblematic of the saying of Jesus, "I am the vine."

A device used by the Elzevirs at Icyden, Holland, in 10.20, shows a tree with spreading branches. On one side of the trunk is the figure of a man and on the other a scroll with the words Non solus (not alone).

Robert Esticnne had a similar device in 15.t (Example $53(i-\Lambda)$. This device as shown is slightly reduced from the original, while those previously mentioned are greatly reduced in size.

John Froben of Bascl, Switzerland, who was a close friend of Erasmus, the philosopher and patron of learning, in 1590 used a device containing a staff surmounted by a dove and entwined by two serpents. (Example 5.12.) 'The legend, "Bc ye wise as serpents and harmless as doves," oceasionally aceompanied the design.

Sometimes these printers' marks were so large as to leave little room for the title-page proper, in contrast to which is the extreme modesty of Ulrich Zell of Cologne. Prussia, whose works are numerous and who is credited with starting the story of the invention of printing by Coster. Zell scarcely ever placed even his name on a book, yet his work may casily be identified.

The Heintzcmann Press device in Example 534 has an

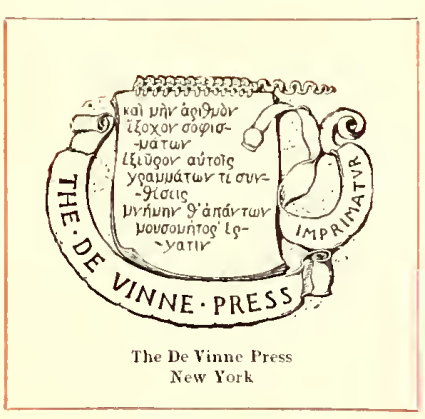

EXAMPLE 545

A mark that has to do with mythology antique appearance and its designer evidently received inspiration for his anchor, foliage and scroll from such devices as those of Aldus and Plantin. The Rogers-Riverside Press mark, too, has ancient motifs. The anchor-shaped thistle, as already stated, is based upon Aldus's device, and the frame suggests old designs in metal.

There is a suggestion of the pot device of Tory in the decorative portion of the Merrymount Press imprint shown as Example 537. This appeared at the end of the book as a colophon, the style in which the imprint is written fitting it for that position. It will be remembered that the printers of Italy usually had the beginning and cnding set in capitals to differentiate them from the body of the book. Elbert Hubbard used the idea commercially on his advertising booklets, as in Example 550.

Perhaps the device shown as Example 541 is a bit too suggestive for practical use by printers of the present day. Stephen Dolet's name, in its literal meaning, has something to do with an ax, hewing and cutting. Dolet was a scholarly printer of the sixteenth century who suffered martyrdom at the stake in 1546 .

The oval shape for imprint designs is not unpleasant, as will be secn by Example 542.

The Fezandat device was designed by Tory. The pheasant is a pun on the printer's name. The device as a whole is pleasing.

The Riverside Press device is classically Greek in motif. Pan and his pipes appear on many of the marks of this press in various designs. The one shown is from "Pan's Pipes," a Riverside Press publication.

The winged ball, torch and other symbolic decorative devices are blended pleasingly on the mark (Example 512),

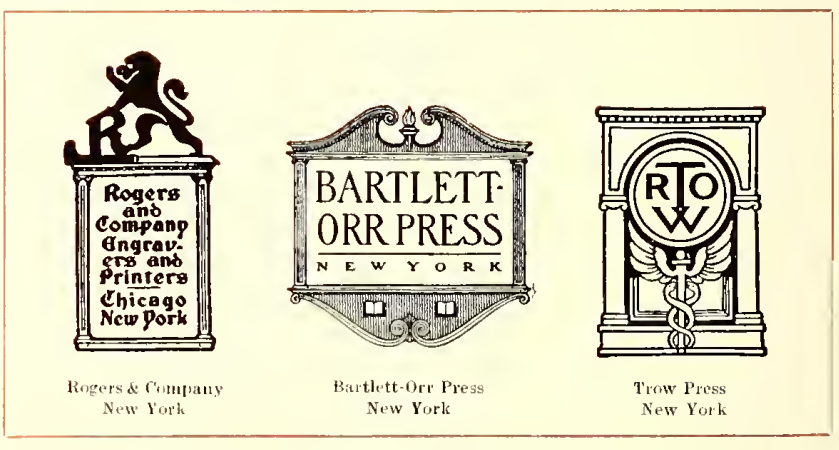

EXAMPLE 544

Printers" marks based on architectural motifs

which appeared on the title-pages of the famous Eliot six-foot shelf of books, "The Harvard Classies," 1909.

An interesting feature of some carly Venetian books is the use by printers of decorative devices designed upon the winged Lion of St. Mark. Recent adaptations of this device are the Oswald Press imprints (Examples 539-A and $539-13$ ) and the ornament on a title by Bruce Rogers (Example 538). 'The Lion of St. Mark is interesting in its significance. Tradition has it that long ago, when John Mark, the missionary companion of Paul, was traveling by way of Aquileia (Roman Secunda) for the purpose of

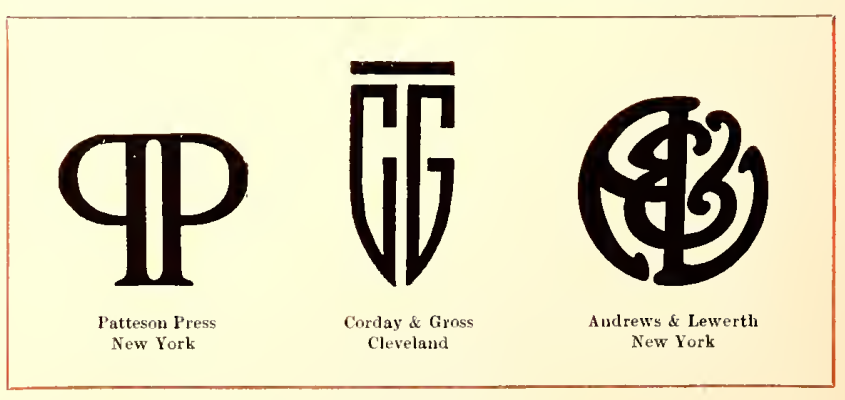

EXAMPLE 546

The monogram is an attractive form for printers' devices 


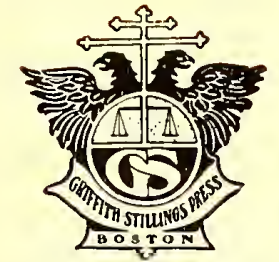

Griflith-Stillings Pres Boston
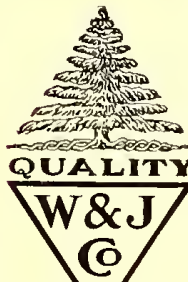

O

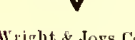

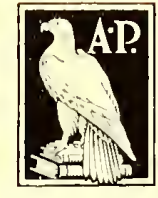

The American Printer New York

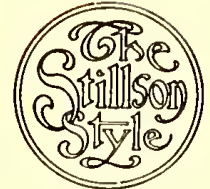

The Stillson Shop

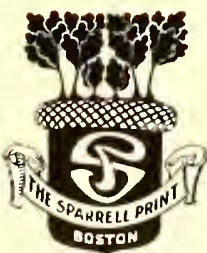

The Spratr Print

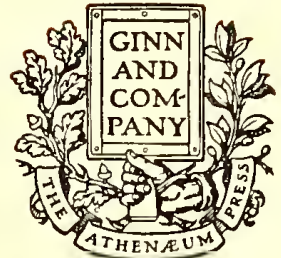

Ginn \& Company

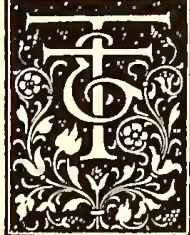

Taylor \& Taylo Francisco

EXAMPLE 547

Representative of the large variety of devices in use by American printers and publishers

preaching the gospel of Jesus, he found himself, after a violent storm, on one of the Rialto Islands that now form the city of Venice. In a dream an angel appeared saluting him (P'ax tibi Marce Evangelista meus) and announcing that on those islands his bones would some day find peace. In fulfilment of this prophecy, in the vear 829, several Venetians went to Alexandria, where the body of Mark had been buried, removed it surreptitiously, and took it to Venice. Such was the enthusiasm caused by this event that St. Mark supplanted St. 'Theodore as the patron saint of the city "IViva San Marco" was heard as the battle cry of the Venetians, and the winged lion, symbolic of St. Mark, became the glorious sign of the republic. In Venice today there are numerous statuary reproductions of the winged Lion of St. Mark, holding with one claw a book of the gospels. The exposed pages of the book usually contain the salutation of the angel. The story of St. Mark's vision and of the bringing of the body to Venice is pictured in mosaic work in St. Mark's Church, Venice, where his bones rest.

The four-winged beasts mentioned in the fourth chapter of Revelations are accepted as symbolic of the four evangelists, the winged lion typifying St. Mark.

Example 543 shows four designs with motifs taken from ancient sources. The Natthews-Northrup device of the mythical phonix rising from the fire is emblematic of immortality; the torch probably signifies the intellectual light resulting from the invention of printing. The Winthrop Press imprint has already been mentioned as having relation to the ancient Typotheta arms. The Binner-Wells design suggests that of Froben, by the shape and lettering between lines. The possible derivation of the Gould Press device from the Venetian master printers' emblem 'has been suggested.

The unique mark of the De Vinne Press (Example 5.15) probably pictures a page from a manuscript book. 'The legend eonnected with the Greek lettering is mythical and has to do with one Prometheus, who, while chained to a rock, tells of the benefits he conferred on mankind. A literal translation of the Greek at this point reveals the appropriateness of the quotation as used: "And further, I discovered for them numeration, most striking of inventions; and composition, nurse of the arts, producer of the record of all things."

Three imprint-devices, based upon architcetural motifs, are shown in Example 54t. In the Rogers design the architectural panel is surmounted by a silhouctted heraldic figure that adds much to the attractiveness of the device. A Colonial architectural panel frames the title of the Bartlett-Orr Press. The Egyptian winged ball, aspss and open book are well blended with the monogram circle that fits the Roman arch in the Trow imprint.

Initials in monogram form are frequently adopted by printers, and three such devices are shown in Example 5 k. Reversing onc of the initials is a favorite method when the nature of the letter allows it, as in the Patteson Press device. Fitting the initials to a general shape calls

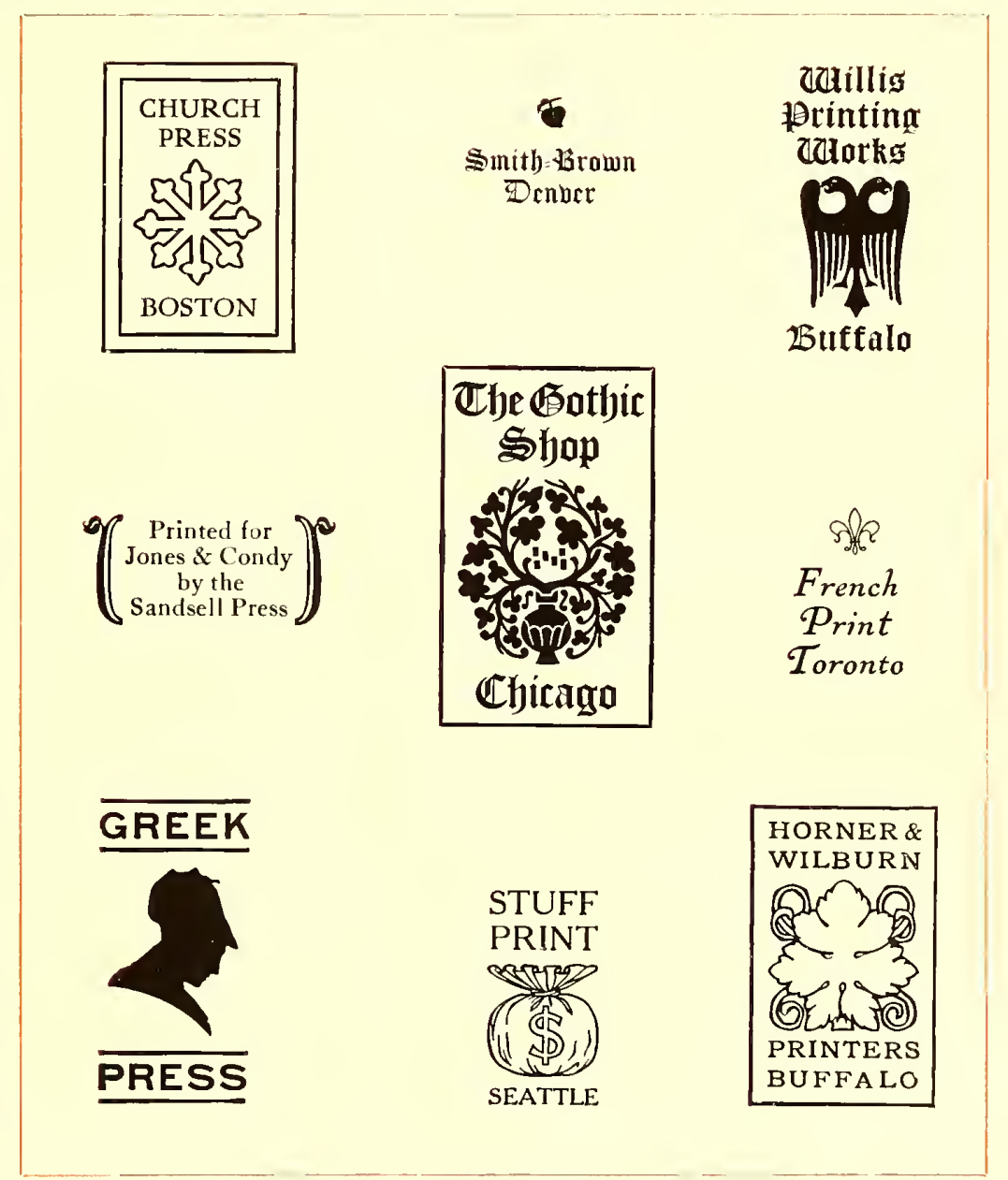

EXAMPLE 548

Decorative imprints constructed with typefounders ornaments and suitable type-faces 


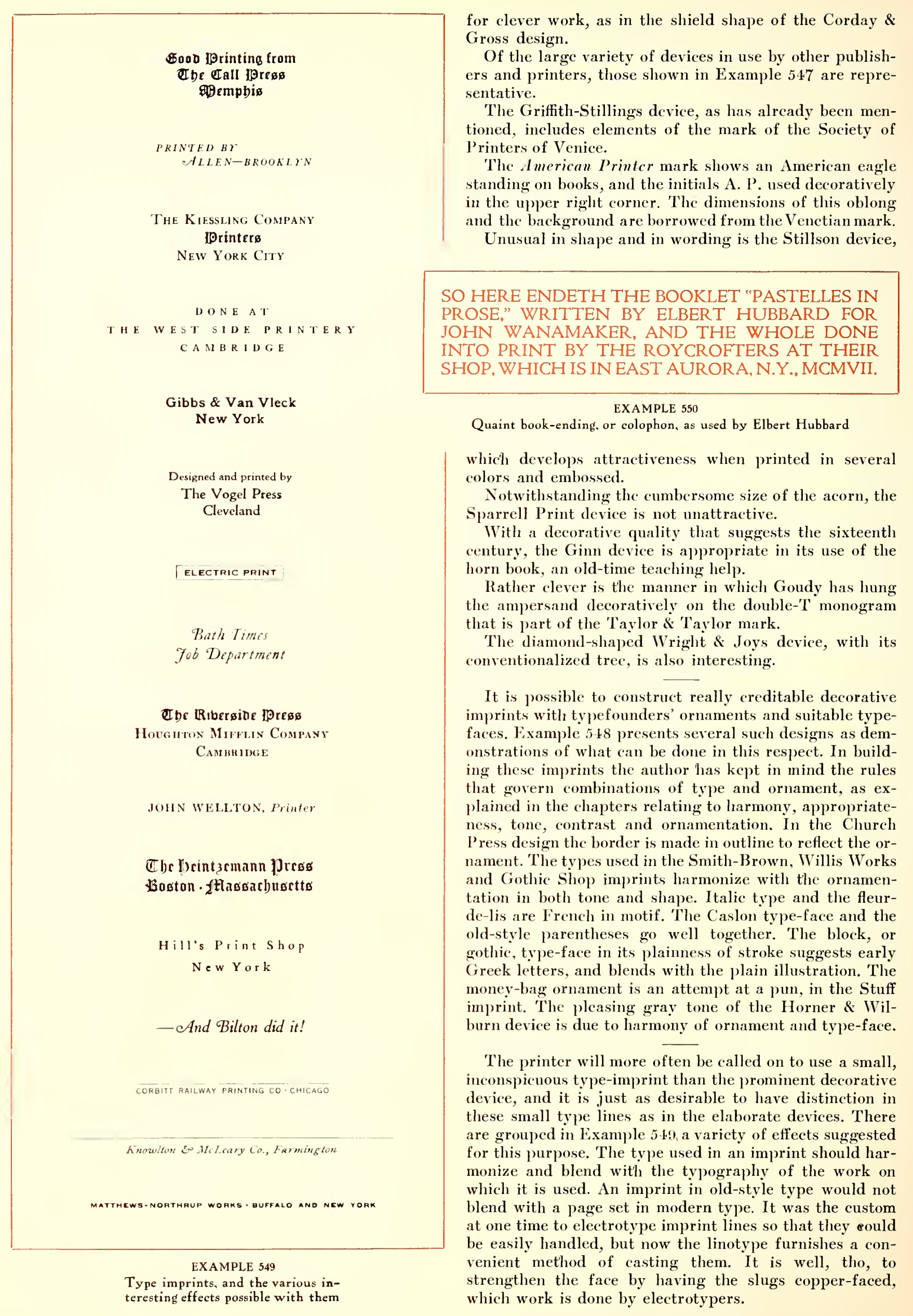




\section{APPENDIX}

Holiday Greetings 



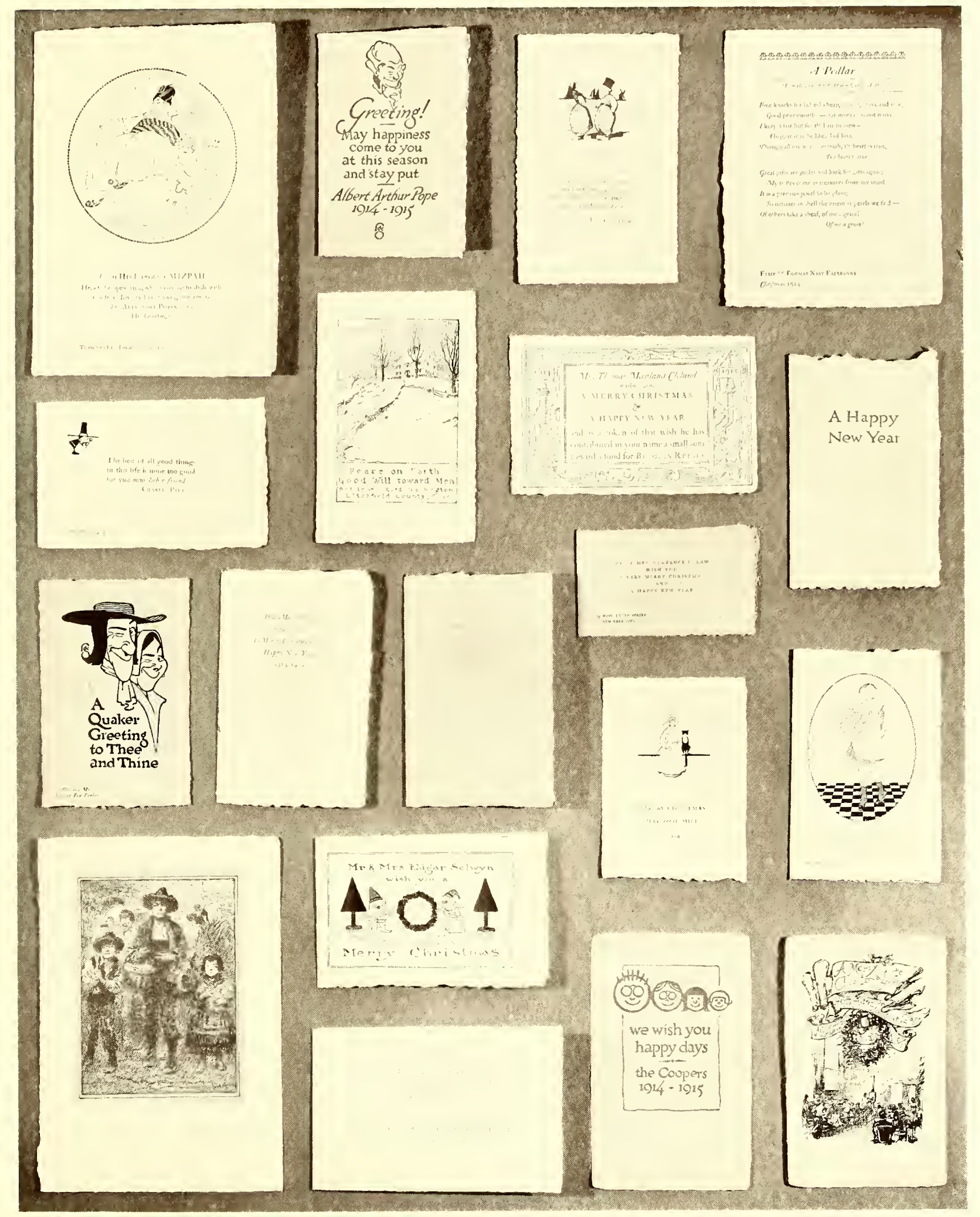

HOLIDAY GREETINGS furnish opportunity for expression of the art of printing. The more than one hundred specimens reproduced in miniature in this section (received by the editors of "The American Printer" from fricuds) contain many suggestions of typographic interest 


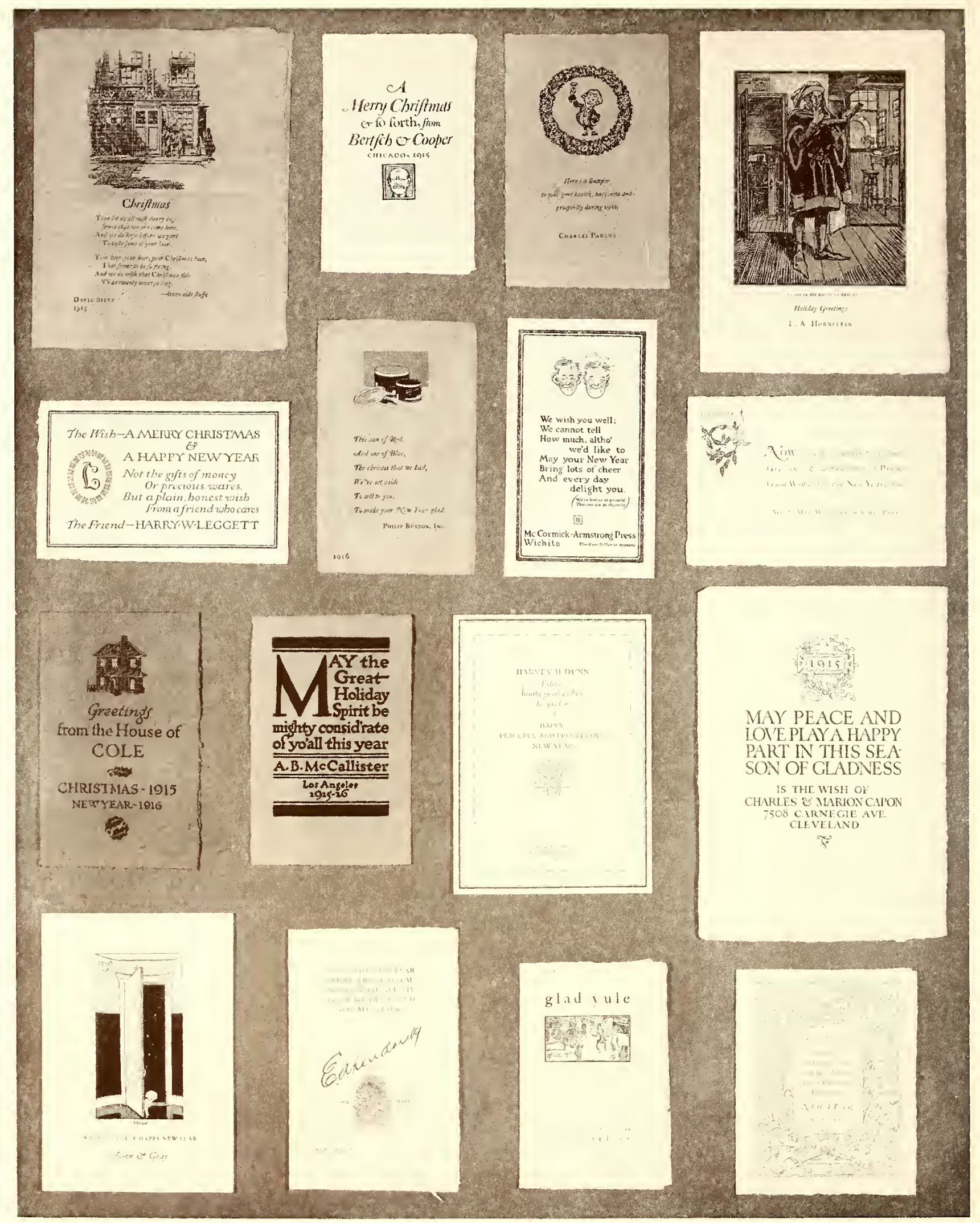

"Everybody in our house

wishes everybody in your house

a Merry Christmas

and a Happy New Year" 


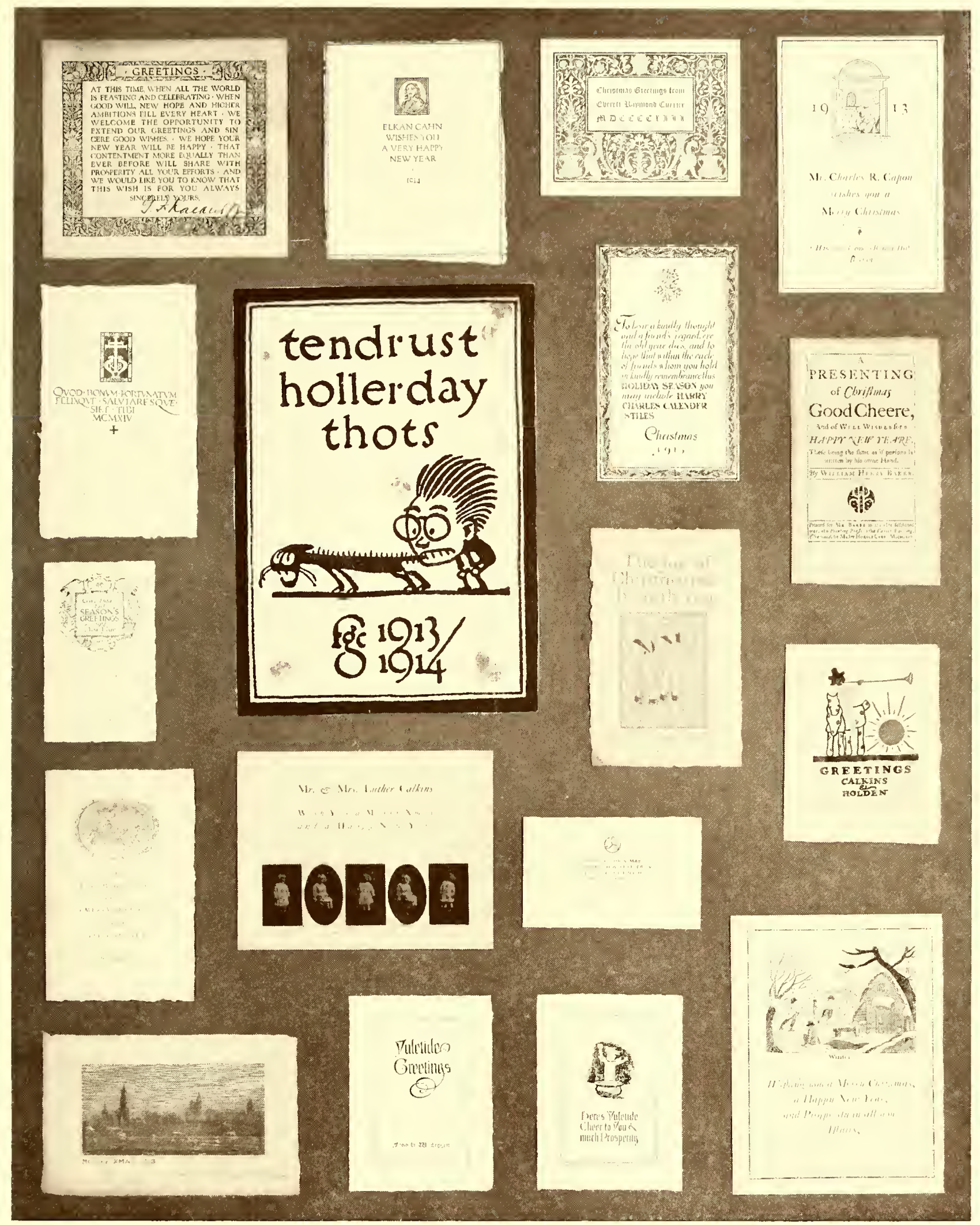

"Volumes of good wishes to friends of ours from friends of yours" 


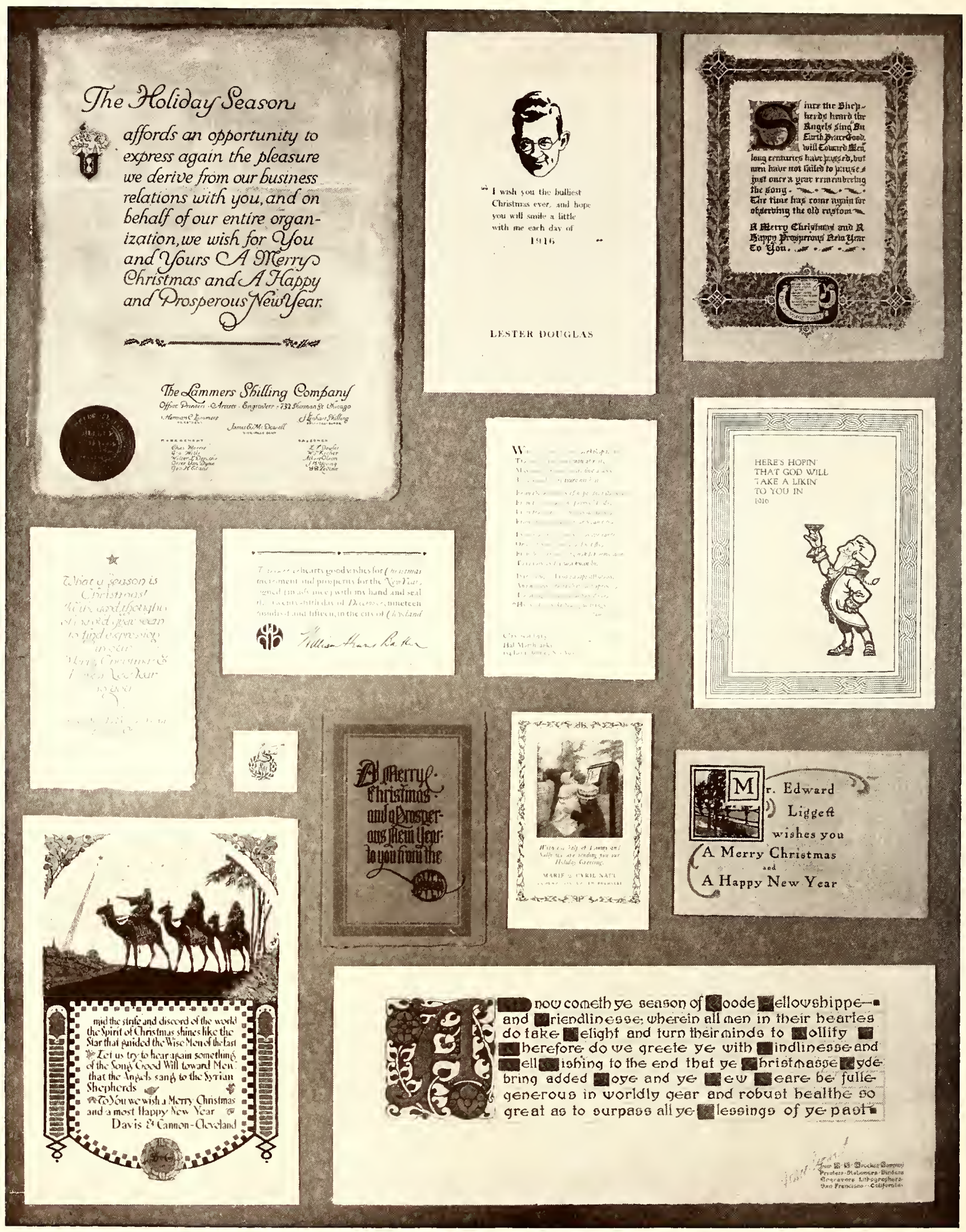

"Christmas :

A time for giving and for getting and forgiving and forgetting" 


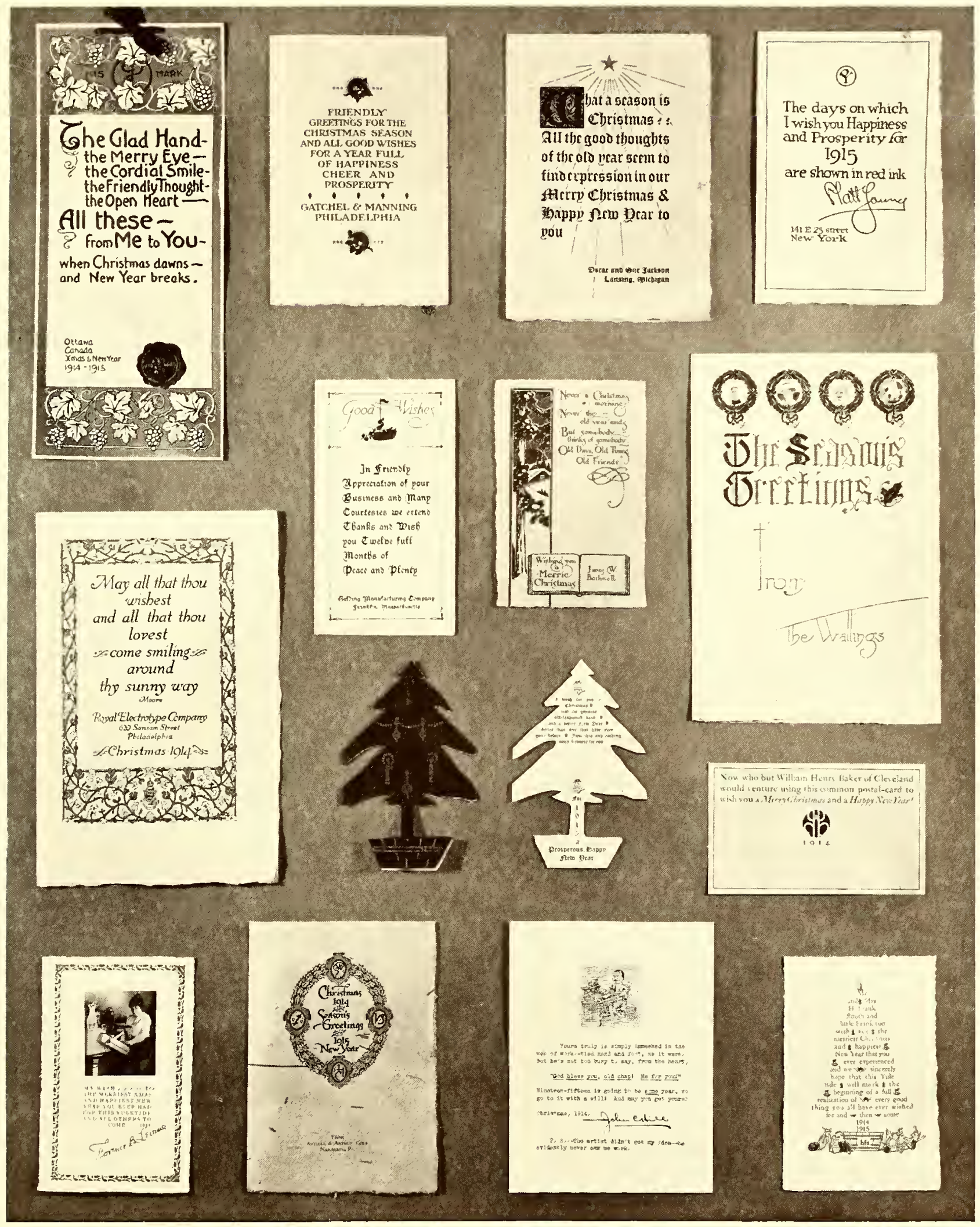

"May all that thou wishest and all that thou lovest come smiling around thy sunny way" 


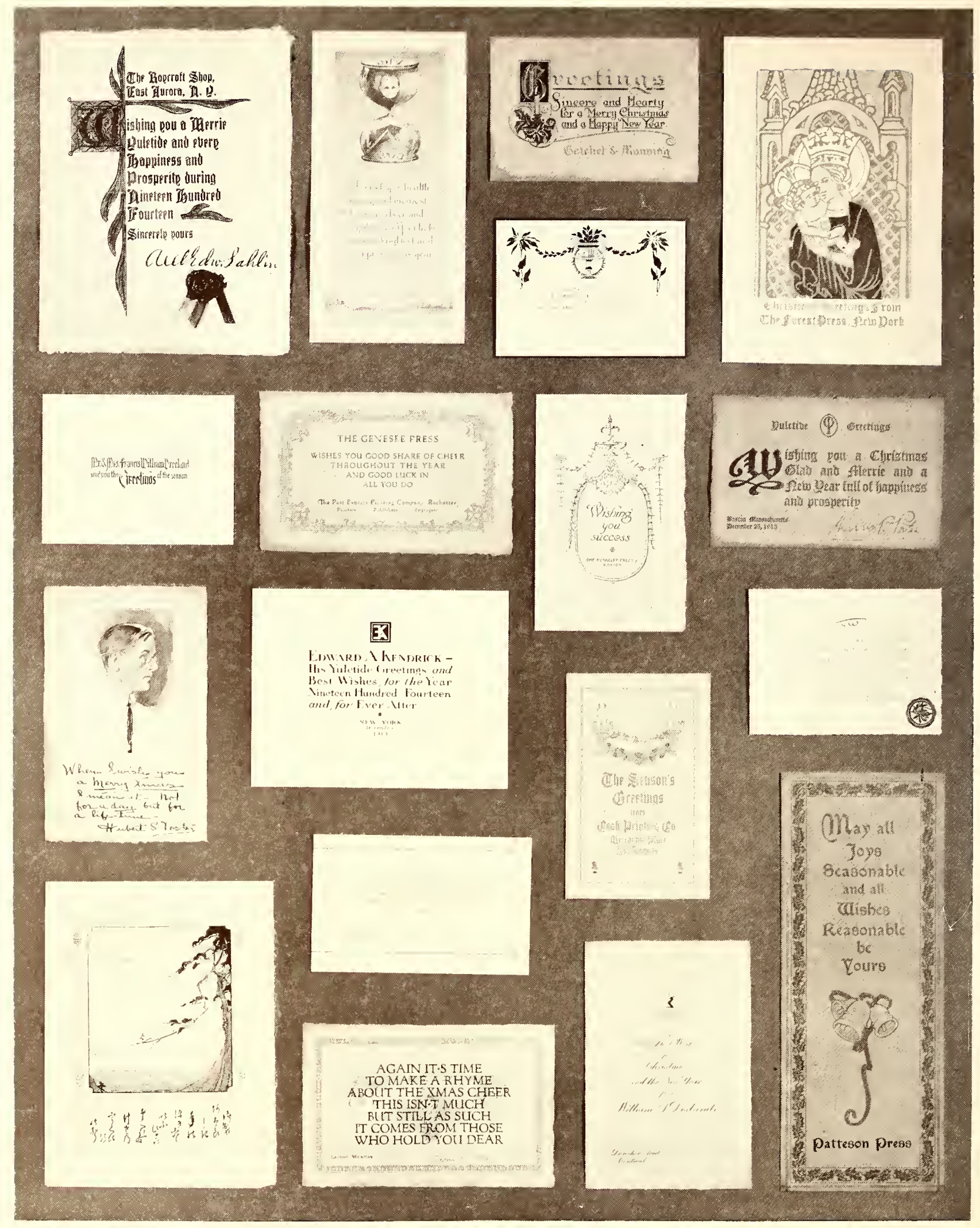

"At Christmas be merry

And thankful withal,

And feast thy poor neighbors,

The great with the small" 


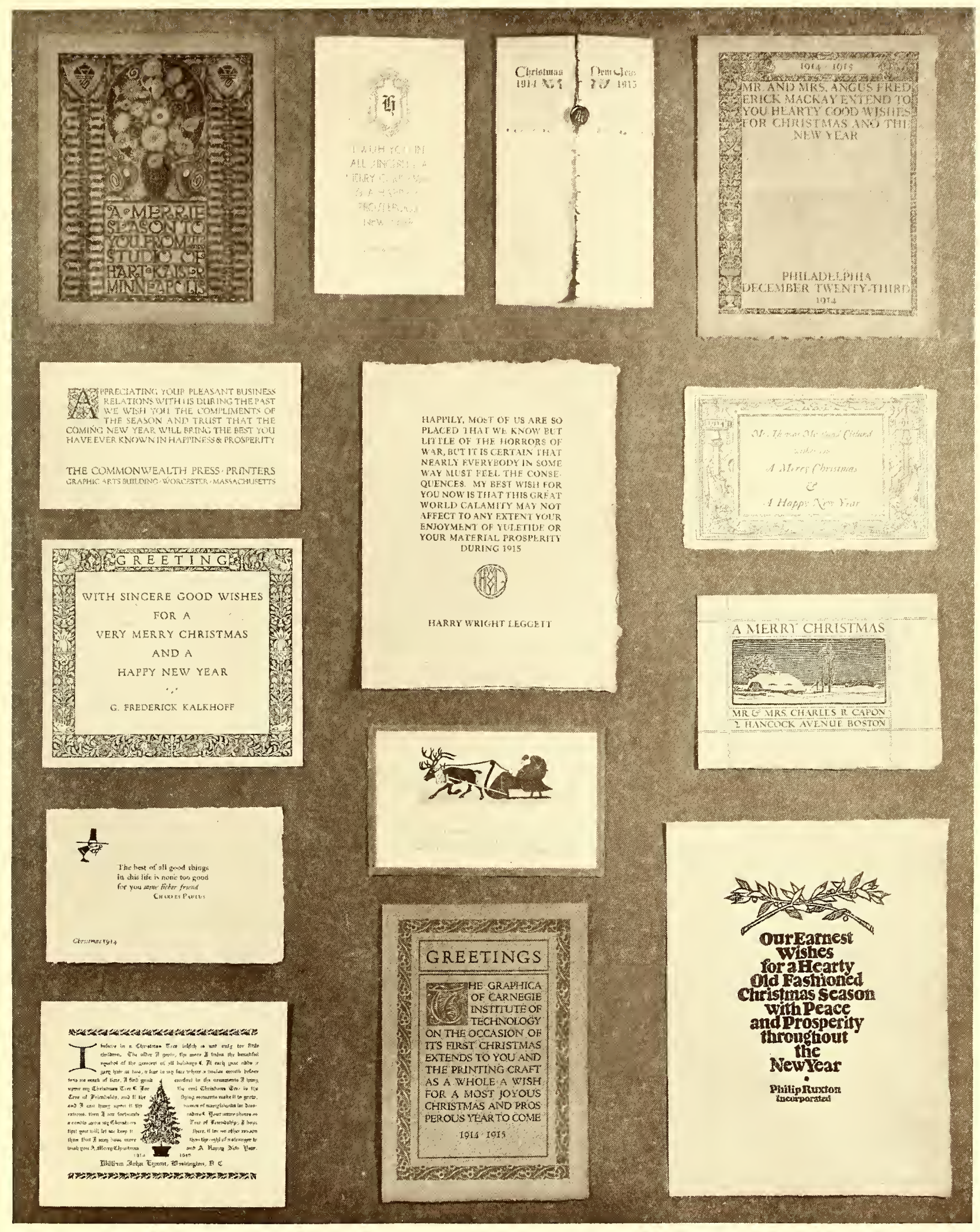

"GLORIA IN EXCELSIS

DEO

ET IN TERRA PAX

HOMINIBUS BONAE

VOLUNTATIS" 


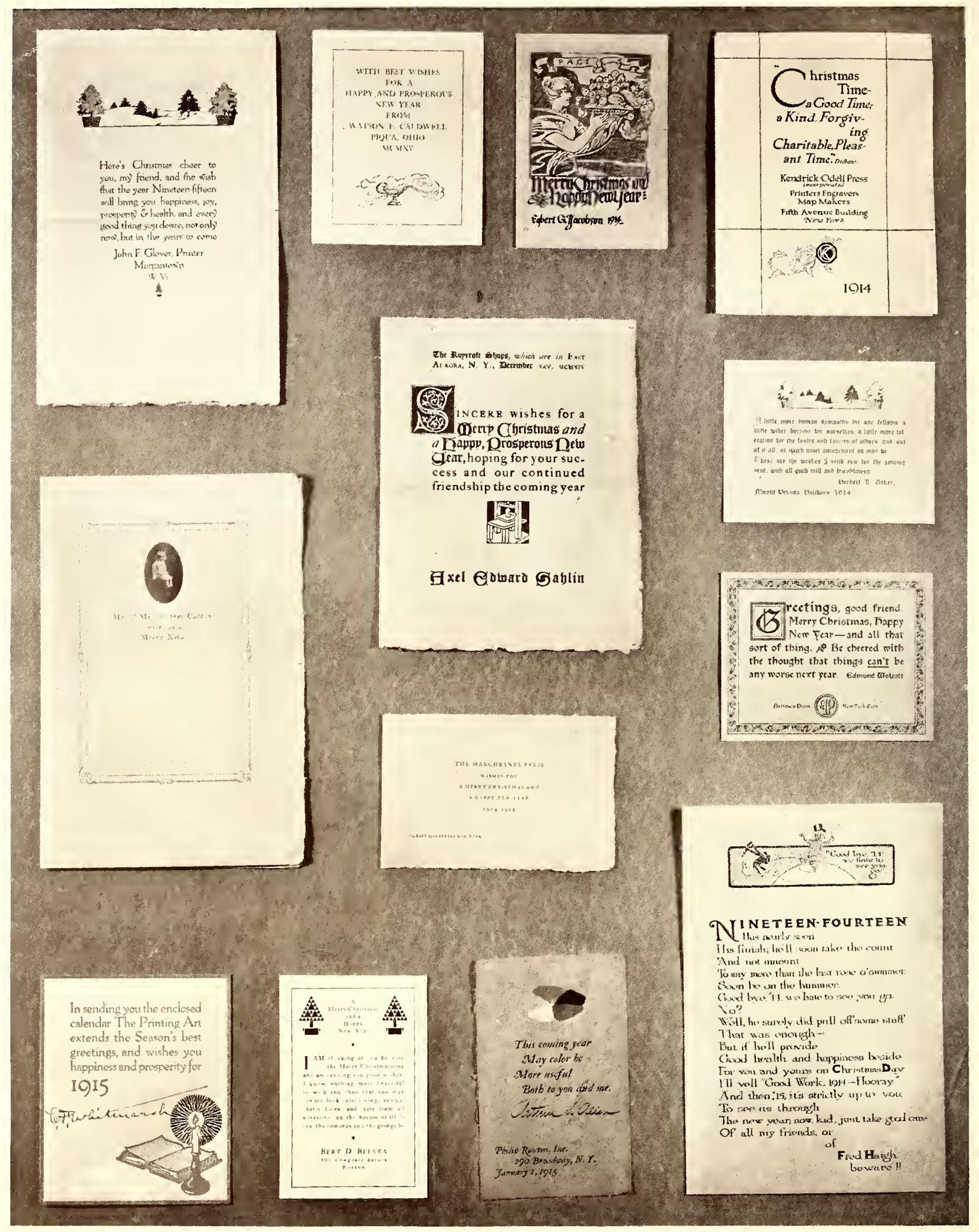

"Ule! Ule!

Three puddings in a pule -

Crack nuts and cry Ule!" 
. 

